\title{
The Diary of Heinrich Witt
}

Volume 2

\author{
Edited by
}

Ulrich Mücke

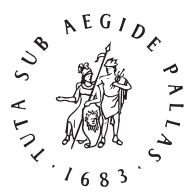

B R I L L

LEIDEN | BOSTON 


\section{[1] [2] Volume the second}

\section{Commenced in Lima October the $9^{\text {th }} 1867$}

Tuesday, $24^{\text {th }}$ of January 1843. At 10 Oclock a.m. I started for Mr. Schutte's silver mine of Orcopampa, my party was rather numerous; it consisted of course of myself on mule back with a led beast for change, the muleteer Delgado, his lad Mateo, both mounted, an Indian guide on foot named Condor, and seven mules laden with various articles for the mine as well as some provisions for myself, two or three fowls, half a sheep, potatoes, bread, salt, and sugar, also some sperm candles, and a metal candlestick. The mules carried each a load from eight to nine arrobes, besides four arrobes the weight of the gear and trappings. I may as well say en passant that I carried the above various articles of food because I had been assured that on this route I should find few eatables. I, accustomed to the ways and habits of the Sierra, saw nothing particular in the costume of my companion, nevertheless I will describe it, the muleteers wore ordinary woollen trowsers, and jackets, a woollen poncho over the shoulders, Chilian boots to the legs, shoes to their feet, but with only a single spur, on the principle that if one side of the animal moved the other could not be left behind; their head covering was a Guayaquil straw hat, underneath it Delgado wore a woollen cap, also round his neck a piece [_] jerga, for the purpose of blind folding his beasts when loading [_] a second piece round his waist the two ends of which [_] [3] and preserved his trowsers. The Indian's dress was still more simple: his shirt breetches were of the common bayeta, made in the country, the breetches were open at the knees reaching half way to the calves, thence to the ancles another piece of striped bayeta wrapped round answering for stockings, the upper part of the feet bare, the soles protected by sandals called "usutas" or "yanques", over his shoulders a small poncho, woollen, and another piece of coarse woollen stuff tied round his back, in which he carried some provisions and his pipe, la quena, made out of a hollow reed. Our road led over the bridge straight north towards the province of Cailloma, soon did we leave behind the houses of Yanaguara and Caima to the right, the road of Sachaca and Tiavaya to the left, then cultivation ceased and we found ourselves on the barren Arequipa surrounding plain, the way was not unknown to me. I had travelled it more than once in 1830 or 1831 when she whom I am so fortunate now as to be able to call my wife resided for several weeks in the quebrada or narrow valley of Yura, whither we were now tending. In this valley are some mineral waters of ferrugenous and sulphurous qualities of great efficacy - much frequented by the Arequipa

(C) KONINKLIJKE BRILL NV, LEIDEN, 2016 | DOI 10.1163/9789004307247_002

This is an open access chapter distributed under the terms of the prevailing CC-BY-NC License 
people. The dwellings around the sulphurous spring or bath owe their origin to an honest Gallego who for a long time was the exclusive seller of ices in Arequipa, he invested all his profits in building these houses, from the poor he exacted no rent, from those whose means could afford payment, a moderate one. I then by myself used to start from Arequipa on a Sunday morning at 3 or 4 Oclock reached Yura before breakfast, remained the day, again leaving at the same hour was back in Arequipa in good time for daily counting house work. The ride over this plain offers nothing of interest, both on the right and on the left it is bounded by chains of arid hills, the former not far off, the latter several leagues distant, before me the horizon unconfined, when approaching Yura the ground undulates a little in [_] [4] ascents and descents, there are some narrow passages and when these are left behind, the road divides; to the left it leads to Yura, to the right, which we took, to a few houses called Totora passing which we came to the quebrada of Yura; somewhat higher up than the baths, the soil is highly impregnated with salpetree, nevertheless Alfalfa grows plentifully. Two further ascents we had still to overcome, the second called "Sal si puedes", get out if you can, is very bad, steep and stony, irregular steps are cut into the rock, so that the mules had to climb up like goats; on the other side, a short descent brought us to the houses of the hacienda of Uyupampa built of the sand stone of the Arequipa quarry; without asking leave of any one I took possession of an empty room, had my mattress spread on the floor, dispatched a chupe cooked by my muleteer, and lying on my bed commenced reading Cooper's Bravo. The owner came in of course quite accustomed to such unceremonious entrances into his premises, he began to converse with me, he told me that he grew alfalfa, bred cattle, and sent for sale to Arequipa firewood, of which large heaps were piled up, the distance to be traversed nine leagues.

Wednesday, $25^{\text {th }}$ of January 1843. My breakfast was a drink of cold water, some bread and cheese, at half past six my party was on the move, immediately on leaving Uyupampa we turned abruptly eastwards, leaving to our right the snowy ridges of Chachani, the country through which we passed was as arid as yesterday's, not a vestige of cultivation or vegetation anywhere. After occasional ups and downs we came to a hollow road, undoubtedly the bed of a river, which must have rolled its waters many centuries back in this course, the traces of which in the sides of the rock were everywhere distinguishable. We followed the bed until it became too narrow for further progress, we then gradually ascended one of its sides, the ground cov[_] with the coarse grass of the cold mountain re[_] [5] not so tall as that in the northern parts of Peru, stunted trees grew here and there. Having reached the summit we found ourselves on a level road confined on the right by a ridge of mountains, the highest point of which goes by the name of El Rayo. Quinoal trees with their 
red trunks and particularly small leaves, which I had not seen since my visit to Mr. Pfluckers copper mine in Conchucos Altos, abounded here. I, certain of not losing my way rode ahead and at half past three Oclock reached the chapel called del rayo twelve leagues from Uyupampa a small yard in front, near it three huts covered with straw, their doors so low that I could not enter without stooping. Both chapel and huts stood empty and deserted; here I was overtaken by two Gentlemen, one a Curate, the other a miner of the neighbourhood, next came my Indian on foot, lastly the Muleteers with their train - we continued our ride and at a short distance stopped for the night on a plateau at a great elevation over the sea, this place was selected, for close by grew good pasture for the beasts, here were a few indian huts constructed of the branches of the quinoal trees found in plenty round about and covered with straw, only the door way, so low that I could not enter upright, consisted of stone. From the one I took possession of I ejected the inmates, giving them a small recompence in money, stretched my mattrass on the floor our common mother earth, so small were these huts that when my couch was spread there was hardly more than a foot and half space left uncovered all round. The temperature was chilly and I prepared myself for the cold expected next day, by taking out my warmest clothing, a chupe and Cooper's Bravo concluded the day.

Thursday, $26^{\text {th }}$ of January 1843 . When I arose at 5.30, it was a clear cold morning, the Indian population of the few huts consisting of some ugly old women with their babies slung behind them in a piece of common woollen stuff were already stirring, so were the muleteers loading [_] [6] beasts, which during the night to shelter them from the extreme cold they kept covered up with jerga and sheepskins. I watched attentively this intricate progress, in the first place they stretched a long piece of jerga from the neck to the tail of the animal smoothly on the back, on the middle they placed five or six sheepskins, some cut out in the centre, this done they folded back the jerga from both ends and on it they put the "lomillo" consisting of two pieces of thin board, sewed up in jerga, and connected together with narrow strips of the same stuff. Each board is placed on one side of the animals back, upon this the real "Aparejo" which consists of two flaps made of cane, sewed up, covered with jerga, and fastened to each, a duplicate on a large scale of the Lomilla, once more on this are heaped up two or three sheepskins. The whole heap, jerga, skins, and canes, no trifling weight, is bound together by a broad girth with an iron ring on one side, which is drawn as tight as the animal can bear. Then the load itself, usually one package on each side, this is secured to the Aparejo by long cords in a really artistical and indissoluble manner. My breakfast was some water and wine and sugar mixed, and dry bread. At 7 we started, rode through a wood of quinoal trees and ascending considerably, came to a stony plain, snowy 
mountains around us in every direction. Here as it often happened I had to wait a considerable time before the muleteers came up, this occasioned much delay, if I had been by myself I could no doubt have completed the journey in half the time I now consumed, but on the other hand being able to dismount so frequently whilst waiting the travelling was by no means fatiguing. The sun shone brightly, no clouds to be seen but the wind was cold. We descended to the mountain torrent which finds its way to the quebrada of Yura, crossed it and continued more or less over the same description of country, sometimes over pasture land, irrigated by rills of water, but on the whole over sand and stones. The road divides; to the right, it goes to Chichacay, this way was known to Delgado [...] not the recommendation of the Curate whom we [7] had met at Uyupampa, we took that to the left more beaten than the other. A new ascent led us to another plain, where utter desolation prevailed, sand, stone, and rock met the eye in every direction, high as was our elevation, still loftier mountains encompassed us, all arid, some snow capped, clouds had drawn up, and the wind blew piercingly cold. A long descent brought us gradually to a milder temperature, and when at 5 Oclock I rested on a stone, noting down some memoranda, the hills below lay before me divided by many patches of cultivation. At sunset we were at the bottom, and rode for some distance through fields of barley, potatoes, and beans. The place of (Urupampa) Yanque, twelves leagues from el Rayo, we left to our right, my muleteers thought better to stop for the night at Coporaqui two leagues further, and th[_] I started with my Indian guide leaving my party to follow at their leisure. We pursued the course of a rapid river, which flows into the valley of Majes, passed over a solidly built stone bridge, darkness soon concealed from my view the objects around me, but as long as I could clearly distinguish anything, I saw that every spot capable of tillage was brought under cultivation, the Cactusses were in full blossom, my thoughts reverted to my Altona botanical friends Semper and Knauer, who would have given much for such flowers as grew here wild the Pitajaya, a superior kind of Penca was among them, its flower is bell shaped, and of a light straw color, its fruit possesses considerably more flavor than the common tuna or prickly pair. An ascent, the last of this day's journey landed us in the village of Coporaqui I had some trouble in finding the Curate's house, once there, I was kindly received by the Curate, my friend from Uyupampa or Uchupampa who was there on a visit. I procured green barley for the animals, the owner of the house gave me a chupe to eat, and a large room where to spread my mattrass, in the course of this days ride I had seen many Llamas grazing on the mountains [8] also not a few indian women clothed in the usual dark colors, dark brown, dark green, dark blue; a jacket, petticoat, and poncho 
slung over the shoulder, resting on the back, the usual cradle or domicile of their babes, a broad brimmed hat made up the rest of their dress.

Friday, $27^{\text {th }}$ of January 1843. I rose at 5 a.m., my muleteers were loading their beasts, took a little hot wine and water with sugar and was on the point of starting, when my kind host, the curate, requested me to delay a while, and partake of a chupe and chocolate, together with my acquaintances from Uchupampa the Curate of Cayarani and the miner Carpio. We allowed the muleteers to go on before us, leaving at 7 a.m. we soon overtook them, immediately on leaving Coparaqui, we had to ascend and soon found ourselves in an extensive plain, here and there patches of snow; apparently this plain is from thirteen to fourteen thousand feet above the Sea level, and the highest point from Arequipa to Orcopampa, and but a trifle lower than the surrounding mountains. The descent was gradual and insignificant, shortly after the Curate left us, turning off toward Cailloma. At 12.45 Carpio and I stopped at the foot of some sandy peaks, snow capped which at a distance looked exactly like large white thatched house. Here the Tambo of Sani had been promised us but we saw no traces of it, now Carpio bade good bye; I sat down on the turf in utter solitude, no human being near me no cattle grazing on the Gentle hills before me covered with pasture which encompassed the sheltered nook where I was sitting. Fortunately the sun shone and it was not cold and till 3 Oclock I whiled away time reading some old German newspapers, which I had casually stowed away in my saddle bags; the muleteers came up and we continued our journey, I ahead with my Indian guide. We hurried over a barren sandy place, passed the lake Panhuanas called so, from the herons of this name which abound here, their white wings are edged with a [_] pink, and stopped for the night at the Estancia [9] Conchahuani, an agglomeration of a few miserable Indian huts surrounded each by a corral or enclosure of unhewn stones, to pin up the Llamas, the Indians' sole treasure. These hovels are of a circular form, their walls from three to four feet high, consist of common stones piled on each other, whence arises a low conical roof, thatched with straw. I crept into one of them, I say "crept", for in the place of a door they had merely a hole, inside, the floor is sunk two or three feet, so that a few rough steps are necessary to go down, what might be called the furniture, was a few sheep skins, and three or four stones to serve the purpose of a hearth, the smell within is very offensive, not only from the effluvia arising from the Indians themselves, but also from burning Llama dung for cooking with the only combustible to be found for the purpose in these regions, the smoke though it rises from the ground does not quickly escape through the crevices of the roof. For the remuneration of two rials the inmates yielded the place to me, I had my mattrass stretched, 
my candle lighted, a Chupe and Cooper's Bravo satisfied my physical and intellectual wants.

Saturday, $28^{\text {th }}$ of January 1843 . Once more I was up and stirring by 5 Oclock, this morning with a bad headache, owing to the close and confined air which I had inhaled during the night, it was soon however dispelled by the cool racy breeze of the morning. The beasts had been sent to some distance for pasture, before they were brought in and loaded, it was fully 7 Oclock when we started. The elevation of the place in which the Estancia Conchahuani lies and which is slightly overtopped by the mountains, which encompass it, is but little less than the highest point passed over on the preceding day. The ground was stony and broken as far as a plain called Las tres Estancias, where we were at 9 Oclock, for the next hour we had mountains on both sides, to the left of a calcareous nature of the most fantastic shapes imaginable rising frequently in pointed solitary peaks, to the right of [_] [10] brownish sand. At ten we reached the spot called Peñas blancas, soon after we crossed the river Molloco, the country surrounding not varying in (interest) aspect nor presenting anything of interest. We arrived at half past two at a solitary indian hut of the same name. I myself could have reached on the same evening the village of Orcopampa, hidden from our sight by an intervening chain of mountains, but the Indian guide Condor declared that he was too tired to move on any further, and for the laden beasts the distance was too great. Until darkness and with it, the cold night air came on, I remained outside, whiling away time in reading the Bravo, then I crept into my hut, similar to that of the previous night, with the difference that I shared it with the indian family, consisting of the man, his wife, and two children, they on their sheep skins, I on my mattrass.

Sunday, $29^{\text {th }}$ of January 1843. At half past 6 I was off again with Condor. Instead of riding over plains as hitherto, the road led along and between hills. At 7.30 I came to a fine pasture ground called "apo", then commenced the ascent over the mountain ridge, which goes by the name of La Pacheta, on the other side the descent was exceedingly stony. We crossed the river of Orcopampa, which flows through a narrow valley confined by hills and which further down falls into that of the valley of Majes, a clear proof that we were still on the western side of the Cordillera real, the village of Orcopampa is situated on its right bank, about one and a half league distant from the foot of the mountain we had left behind. The buildings of Mr. Schutte's establishment were close to the river. I rode up to the dwelling house but did not find him in; in his stead his clerk Mariano Valdez, a young man brought up in the United States, his wife, daughter of the Arequipa Saddler Julian Alcalá, and their little girl Amelia. Schutte was sent for, I found him little altered, he told me I had become grayer since our last meeting [_] Aug. 1838. I remained in Orcopampa 
till [_]turday Feby. 4 and spent the time in a uniform [11] manner. Schutte and I walked about the hacienda or smelting establishment, we rode to the mine el Manto about a mile English distant on the other side of the river, to a stone quarry, whence the mill stones used for grinding the ore are brought. We paid and received visits from the big wigs of the place - Mrs. Vera, her son the Governor, and the Curate, an elderly jocose man, conversation of course took up a great deal of our time, and when other occupations failed I had recourse to writing my diary and reading a North American Encyclopedia founded on the German Conversations Lexicon, which contains a vast deal of information. We used to rise between six and seven in the morning, breakfasted at $1 / 2$ past ten, and dined at half past six, there was no variety in the fare, mutton dressed in various ways and potatoes formed the staple, tea, a bottle of sparkling of Moselle pickles and preserved peas the extras, one with another, things might have been a little cleaner. Once or twice the Curate and the Governor came in and played a game of solo. The village of Orcopampa, or the plain of the "Males of Llamas" is a miserable place, built without any regularity. The inhabitants may number about 500, in the whole district including some other villages perhaps 3000, all Indians, with few exceptions, those residing in Orcopampa lived almost exclusively on the money expended by Schutte in the mine and the hacienda. The houses were built of mud or stone all thatched. Schuttes drawing room though dark was carpeted and papered but his bed room had little to recommend it, being a large dismal apartment with a small narrow window, admitting but little light, the floor of mud and uneven, the walls and ceiling once whitewashed, now so dingy that the original color was a matter of doubt, bedsteads made neither of wood nor metal were walled up of mud, a mud bench run all round the room, and two chairs of the old [_]abamba make, the wood heavy, the seats and back of leather completed the furniture - Living in Orcopampa was as [_] [12] be expected very cheap. Coca most indispensable for all Indian laborers varied in price, the arroba from $41 / 2$ dollars to 7 , a sheep from three to four rials, an ox of 4 years $5 \$$, of $56 \$$, a large bag of potatoes 11 rials, six eggs for a medio, a chipa, equal to a large bundle of dried unripe barley one and a half rial, a large sack of "Urcha" or dried llama dung a quarter of a rial, and a brazada or as much as a man can take up in his extended arms of the bushes growing on the plain from one and a half to two rials. Schutte's weekly expenses for 9 to 13 months was 7 to 8 dollars. The climate of the place was far from the healthy, owing to the great and sudden changes of the temperature, whilst I was there Fahrenheits thermometer varied in the course of 24 hours as much as 20 degrees say from $50^{\circ}$ to $70^{\circ}$ in the shade. It rains regularly, and even snows every day in the afternoon, evening, and part of the night - one night the fall of snow was very severe. In the winter the thermometer 
falls to $32^{\circ}$ and even lower, that is to say below freezing point and on certain occasions has risen to $78^{\circ}$. About 8 leagues further down, where the village of Andahua is situated, the climate is much milder, and seven leagues still lower at Ayo the temperature is such as to allow the growth of all kinds of tropical fruits in abundance. The process of amalgamation followed by Mr. Schütte was similar to that I saw in Huallgayoc, of which I have given a description in Volume $1^{\text {st }}$ page 663 to 671 . The number of hands employed varied according to the state of the weather, and the workmen's inclinations, in the mines there were from 60 to 120 ; on the hacienda from 50 to 80 . The ore extracted was of the kind called "de quema" which means that it required to be roasted before being ground, for this purpose there were three furnaces de "reverbero", two de taza, in the former the roasting took $3^{0}$ hours, in the latter from $5^{\circ}$ to 60 , the combustibles used were llama dung, and the brushwood before spoke of. There were two "Trapiches" or grinding mills moved by horizontal water wheels. Besides being de "quema" the ore had another quality, that of being (hot) which means [_] [13] consumes instead of amalgamating with the quicksilver. To remedy this defect, to the torta of 60 qts. certain quantities of melted lead, or slack Lime are added, the former costing $6 \$$ the quintal, the latter one rial the bag of two to three arrobes. The two last articles are totally lost in the process, but by their means the object is gained of making the ore and quicksilver amalgamate. In the "buitron" or patio there was room for eight tortas, one "tina" sufficed for washing away the earthy particles, which done, the pella remains. Schutte told me that the common ore yielded 30 to 40 , the picked from 80 to 150 marks the cajón of 60 quintals. The rate at which the Indians were paid, was as follows. The repasiles, that is to say, those who bring about the amalgamation by continually agitating the mass (for this Mr. S. occasionally employed horses) were paid two rials a day, and half rial's worth of coca. The "Atizadores" who fed and stirred the furnaces and the "molladores" who moved the ground ore whilst roasting, and who worked day and night, double the above named amount. The Pallares who picked the ores at the entrance of the mine, as well as the Maquineros who by pumping kept the mine clear of water, stood on the same footing as the Repasiles, the pay of the Barreteros was more complicated, they worked pr. tarea called in Orcopampa pr. Cajcha they had to loosen either by their picks, or by blasting 30 "capachos" of ores of which when paying them six were deducted for inferior quality, and two or three more as a costume of the place, for the remainder they received if common "breza" one rial, of escogido (picked) one rial and a half for the very richest "hachura" two rials, the Capacheros named in Orcopampa "Apires" were paid for ten capachos carried out and thrown down on the "Cancha" or place before the mine, three rials, and a medio of Coca. 
For an explanation of all these technical terms see my description of the [14] Hualgayoc Mines. The "Mayordomos" or Stewards both in the mines and Hacienda were paid from five to six dollars per week, which included besides the six days, though occasionally work was carried on on Sundays, in one week three nights, in the next four. The dress of the Indians in Orcopampa, was very scanty, they wore jerga breeches, without stockings, frequently no sandals, a common blue woollen jacket, now and then a jerga poncho over it, and a blue or black wide brimmed hat, the women generally blue petticoats and jackets. By Mr. Schutte's own account, he owed at this time, since his stoppage in 1838 , Augt.

to Antony Gibbs \& Sons

to Joseph Hegan \& Co.

to Naylors \& Co.

to Manuel B. dela Fuente

to myself

and this considerable sum of
$\$ 72,500$

35,000

15,000

28,000

19,000

$\$ 169,500$

he had no probability of ever paying off, for even the mine which he worked, was not his own, but the property of a certain Julian Garcia who was indebted to Schutte for $\$ 42,000$ which was to be liquidated by the product of the mine at the rate of $\$ 6$ the marc plata piña. In 18424649 marcs had been extracted - the new liabilities, which Mr. Schutte had incurred were the following, to Henry Reinecke represented by his heirs, $\$ 20,000$ - this loan was obtained for him solely through my wife's influence

with Reinecke

$\begin{array}{lr}\text { to Went, Leplatinier and self } & 10,000 \\ \text { to North American Hindman } & 4000 \\ \text { to a certain Robles } & 5000 \\ \text { to Thos. Mac Laughlin } & 4000 \\ & \$ 43,000\end{array}$

This was the state of pecuniary distress in which Mr. Schutte found himself in 1843 , now in 1867 , when I dictate these lines, he is a wealthy man, to what does he owe this marvellous change? It is not too much to say to my having placed at his disposal on Good Friday 1830 when [_] yielded to my wife's solicitations to form a partnership with [15] him, my fortune, my name, my signature, my credit. Based on this solid foundation, his mercantile daring, deterred by no obstacle, or risk, bade for the Huano Consignment to Germany and obtained from the Peruvian Gment. the contract of this lucrative business. Surely my 
wife and myself were entitled to some gratitude for these services rendered to Mr. Schutte, but we have made the sad experience that this virtue, if virtue it can be called, what is a mere duty, is no dweller in his breast, and has no place in his heart.

Saturday, $4^{\text {th }}$ of February 1843. At 11 Oclock I started on my return to Arequipa, over the plain abounding with low brush wood above spoken of, which served for fuel in Mr. Schutte's furnaces, to the foot of the mountains, a distance of 2 leagues I was accompanied by Mr. S. Not having overtaken my muleteers who had gone on before me I took an Indian guide and began ascending. It was noon, the sky hitherto cloudless and bright, became overcast, heavy clouds drew up and rested on the hills and mountains before me, all around, and when gradually rising, I came within their precincts, a pitiless hailstorm, cutting like needles, drove into my face. At 3 p.m. we reached the summit "la Pacheta". The weather cleared up, by five Oclock we reached the barren plain of Mollocco with a few Indian huts scattered over it at great intervals. My guide was not acquainted with the place where Mr. Schutte usually put up, and where my muleteers would stop for the night. It grew dark, the ground here and there was covered with snow; lengthways, and breadthways, we crossed the plain in fruitless search of the nights quarters, the anxiously looked for goal. Moreover, the Indian did not, or would not understand Spanish, I swore at and cursed him but to no effect, at last an old Indian woman pointed out the hut, and at 7 Oclock after an hour's most trying and annoying ride, we reached it, and I alighted; an hour later the muleteers arrived. At noon they had rested a while in the village of Huancarama, in the Orcopampa plain close to the mountains, there I had [16] passed them unseen. They carried the provisions with them, a sheep, potatoes, lard, cheese, salt, bread, a little cognac, and some cooking utensils. Delgado supplied me with a Chupe and though the smoke in the hut was almost insupportable I lying on my mattrass close to the ground could draw my breath, with the Indian family along side of me in the same manner as on the 28 Jany. I soon fell asleep.

Sunday, $5^{\text {th }}$ of February 1843. I awoke at 4 rose at five and was in the saddle at 6 , during the night the temperature had fallen below freezing point, and the whole plain of Mollocco even to Peñas Blancas was covered with ice and snow, the reflection from which shone upon by the sun, is injurious to the eyes, and sometimes causes a painful inflammation called "Surumpe" which is known even to end in blindness. Travellers to protect their sight against this brilliancy, most trying to the optic nerves, make use of blue or green spectacles, I had with me a pair made with iron wire given to me by Stubbs. When approaching the river Mollocco we saw a flock of Vicuñas, no doubt come down to take their morning drink, as soon as we came into sight, they started off with great 
rapidity, but when at some distance stopped and gazed at us, with much curiosity. The vicuña belong to the same species as the Llamas, Alpacas and Huanácos, but are untameable. Their brown wool is most esteemed on account of its great softness, however the amount exported is but small. At ten we were at Peñas blancas, passed the estate of Conchahuani, the lake of Panhuanas and at three reached, where the road to Cailloma and Orcopampa divides, onwards we had some hail falls not worth speaking of, whilst behind a fearful thunder storm was gathering. At four, half past we came to the Tambo of Sani which had previously escaped our notice, two houses entirely empty, even without an Indian to take care of them, stood well sheltered in a nook, and somewhat concealed at the foot of the yellowish Sandy peaks, before alluded to, of one of the houses we took possession, whilst part of the rafters of the other served [17] Delgado to cook my usual chupe with. In the work of destruction others had already preceded him. It was cold and the slightest exertion, even that of opening my saddle bags on the sack in which my mattrass was wrapped, or making my bed, fatigued me, which I attributed to the rarefaction of the air, on the great height on which we were, perhaps 13,000 feet above sea level. I therefore lay down, and crept under my blankets, as soon as I could, my little arrangements being finished.

Monday, $6^{\text {th }}$ of February 1843. My night's rest was interrupted by a mule pushing open the door, walking in, and regaling himself on some barley he found in a corner. At six we started, it was a very cold morning, the ground was hard and frozen. On leaving the tambo of Sani, we had to ascend and after a ride of a league and a half, came to where the road to Coparaqui and Chichacai divides, we took that to the latter place, which leads in a shorter direction to the same quebrada in which Coparaqui and Yanque are situated. Now followed descent after descent, the last one so stony and broken that I preferred dismounting and walking so far that when at half past eleven I remounted, I was actually downright tired and found riding a relief. Two leagues further on we reached a solid bridge of one arch, which spans the river, flowing deep below in its bed, it rests on the [?] rock, with both sides protected by balustrades. On the other the left side lies Chichacay, higher up the quebrada than the other two small towns already named. My muleteer took me to the house of an Indian Jose Maria Ramos where I alighted, and entered a rather large room, whence on my advent a man embroidering a girl's cap of velveteen with gold and silver thread, and a woman weaving a poncho made their exits, as soon as they saw me. I had the place to myself and plenty of time to observe all the arrangements therein which for curiosity's sake I here detail: the roof was thatched, the floor of mud, the walls whitewashed, all round ran a mud bench. One end [_] [18] the room was somewhat raised, and here were the prized things of the family kept. 
I particularly noticed the holiday dress and cap of the mistress of the house, with the poncho of her husband. Two tables covered each with a texture made in the country together with a wooden bench constituted what might be called the furniture; three engravings representing the Saviour's sufferings, and something in the shape of an altar, with a crucifix and two figures (angels) were the main ornaments, on a shelf round the wall were placed a bridle, a hat, a cap, a saddle and several baskets. After some rain and hail, the weather cleared up when I strolled about the place. I found it extensive owing to each house having an enclosure of ground entered by an arched gate way minus the gate. The land thus attached was cultivated and produced beans, barley and potatoes. The plaza large with a church and chapel; in the centre a "pila" fountain but without water. Delgado procured for his beasts a field with green barley for which he paid a dollar, he also took with him some grain barley for the remainder of our way. Before going to sleep I read Boccacio Decameron, "a gross work of a gross writer of a gross age". Quichua is the prevailing language between Uyupampa and Orcopampa, now and then some Indians, who speak and understand a little Spanish are met with.

Tuesday, $7^{\text {th }}$ of February 1843. This quebrada which besides Chichacay, Coparaqui and Yanque contains many such places is the same as that which further down forms the valley of Majes, and debouches at Camana, where the river flows into the Pacific Ocean. At the usual early hour, we were on the move, a heavy ascent lay before us, and the whole day's journey, thirteen hours from 6 a.m. to 7 p.m. was most uninteresting. The Muleteer now, his beasts not being laden, could keep up with me, and we rode at a fair r[_] te on the elevated Puna, (the Jalca of the north,) sometimes [19] covered with a little pasture, sometimes marshy, frequently stony. One of our horses became ill or tired, Delgado left it behind with his ayudante together with a supply of barley. The tambo Cañahua was a miserable solitary building, which however afforded us shelter for the night; an hour after our arrival, Matias appeared, with the tired animal, the mules were fed on the barley, brought by Delgado from Chichacay, I despatched my chupè, lay down on my mattrass and was soon fast asleep.

Wednesday, 8 $^{\text {th }}$ of February 1843. It was still pitch dark when we commenced this days journey, for several leagues we continued on the same elevated plain of which I spoke yesterday. When day broke I saw before me the lofty volcano El "Misti" and in the same direction, a little more to the right, the mountain chain of Chachani whilst to the left the sun gradually rose into a cloudless sky. Between seven and eight Oclock the descent commenced, the road turned abruptly to the right, and I after having taken detailed instructions from the Arriero as to the route, went ahead, using both whip and spur I put my mule 
into a trot, sometimes when the nature of the ground permitted it, into a gallop. The usual pace of travellors in Peru is the amble or the "paso llano" of the Natives. I had now the Volcano to the left the Chachani mountains to the right. Towards the Volcano side, the land gradually sloped downward to a deep ravine, from which El Misti raised its towering height, capped with snow and clouds. From the side I came which was from the north, the ascent appeared to me impracticable, so abrupt and precipitous did it look, whilst from the Arequipa or western, and from Eastern sides, it seemed less difficult, on the right side of the road, the ground gradually rises up to the peaks of the Chachani ridge, from which at short intervals descend deep fissures widening into gullies, which intersect the road, and lose themselves in the opposite ravine, at the foot of the "Misti". These gullies crossing the road were of course continually in my path, [20] besides my course was so impeded by large blocks of stone, everywhere lying around, as actually to form a labyrinth in which more than once I was on the point of losing myself. I was compelled to dismount and lead my mule, picking my way through, as well as I could. From a height called "la Pacheta" full six leagues from Arequipa, this town came first into sight, but surrounded as it is by a vast plain of sand it seems to dwindle into a comparatively small green spot presenting a much less pretty aspect, than when viewed nearer. Having overcome the stony and intricate descent I found myself in this same plain, overgrown with low brushwood, here and there a solitary house with generally a projecting broom in front indicating to the travellor the sale of Chicha. To my left deep below I had the river of Arequipa, cultivated on both banks. At the spot called "la piedra de Pijchu", I was stopped and asked whence I came, whether I brought any political news from Cuzco? These questions struck me as peculiar, and somewhat strange, when in the town I learned their purport. At $1 / 2$ past twelve I was in the village of Acequia Alta, where cultivation commences, I hurried through it, through Carmen Alto, Caima, Yanaguara, over the bridge and at half past one was in Rosita's house, tanned by exposure in the open air but not so much fatigued as might have been expected. I found Conradina in much better health than when I had left for Orcopampa. I received my letters, a few lines from Juan and a long and affectionate letter from my wife, from Enriqueta a whole page in french, in the composition of which I imagined she had received assistance, but was afterwards assured that it was solely her own work. On the night of the 28. Jany. a revolution had broken out in Arequipa, in favor of Gl. M. J. Vivanco, its prime mover was Gl. Guarda, whilst the subalterns who had fallen into his views and brought about the change were Verastegui, Lastre and Melch [...] l[_]rde, my wife's cousin, then Captain. Only one [_] was lost [21] that of the Sentinel on duty before Gl. Deustuas house. This latter and Gl. Nieto were sent 
to Islay, thence to Lima. General Guarda took the command, the officers of the troops stationed in Arequipa signed a declaration in which they repudiated the authority de facto of Gl. Vidal, and until the Congress, to be assembled, determined what was proper, they acknowledged the authority of Gl. Vivanco. This was the revolution, which lead to what was called Vivanco's directorio, upset in 1844 in the battle of Carmen Alto, gained by Castilla. Of the 3 officers mentioned above, Verastegui and Lastre were shot by order of Vivanco, not many months later, because as he pretended they were intriguing against him, Velarde sick of the ingratitude shewn him, made a vow never again to enter into a revolution and has kept it. \{For continuation of Peruvian politics see page 43.\} After dinner I spent some hours with Went with whom I took tea, at Rosita's on my return I found a tertulia among the assembled were the brothers Costas José Maria and Manuel, of whom I will say a few words. They are natives of Puno, in which department they possess property, and considerable influence, are in the habit of buying Sheep and Alpaca wool which they consign to Antony Gibbs \& Sons London. They might have been wealthy men had they not been such inveterate gamblers - at least they were so formerly, now (I write in 1867) they may have given up the habit and prudence come [with] advancing years. Josè Maria, the cleverer of the two has been for a long time in Paris, where for a few years [_] was Peruvian Consul. He is full of strange whims and fancies, so that at times one may suspect his eccentricity touches on insanity. His long absence has diminished naturally much of his influence in his native department, while Manuel from year to year [...] great strides in political importance. [_] 1854 when Castilla raised the revolut[_] [22] standard against Echenique, it was Manuel Costas who procured for him reinforcements from his department, as well as from Cuzco, where he has also many friends. Towards the end of 1861, when the election of the new Presidents took place he had the greatest chance of becoming Vice President if Castilla had not given all his influence to secure that dignity for Gl. Pezet, the successful Candidate. Then again he during Pezet's administration, was for so[_] time Minister for the Interior and President of the Council, within these last two months say Sept. and October 1867 it is asserted that he is intriguing against Prado's government but up to the present if there has been any result it is not known. In 1843 when I met them at Rosita's they were young men.

From Thursday, $9^{\text {th }}$ to Monday, $20^{\text {th }}$ of February 1843 . This second half of my residence in Arequipa passed away as pleasantly as before my excursion to Orcopampa. In Rosita's house, I was of course treated with great kindness, her two little girls became more attached to me day by day. In the mornings early I took a walk down the Vallecito or up the Love's walk more frequently. I rode 
about the beautiful environs alone or with Went. The battle field of Socavaya interested me greatly. I learned from Went, that Salaverri having passed the river at Uchumayo, was on his march on the left of the river with the object of gaining the Sierra, by way of Sabandia. When near the Pantheon, Sta. Cruz who was stationed in Arequipa the centre, whilst Salaverri had to make a long detour round the town, came on him whilst doing so. The Bolivian Cavalry was beaten back by Salaverri's [cuir] rasiers newly raised. According to some accounts it was the Bolivian infantry that decided the fate of the day - others assert Mendiburu through cowardice or treachery lost the battle for Salaverri, this Ma[_] Mendiburu [_] the same man who Nove [...] 1865 was Chief of the [23] staff of Pezet, and who acted such a doubtful part when Prado's army was on the march from Lurin to Lima. In this battle of Socavaya fell among others on Salaverris side Pedro Zavala a son of the Marques Valle Ombroso, in 1843 a cross marked the spot where he breathed his last. A brother of his, Toribio, was mortally wounded on the 2 May 1866 in the defence of Callao against the Spaniards, another brother José was shot in October 1867 whilst prefect of Trujillo by the malcontents of that city. To return to my occupations whilst in Arequipa - writing and reading always formed a part of them. I got hold of Watson's history of Philip II, one of the best works on this subject until the lamented Prescott published his, also of some historical German novels by Wilhelm Hauff in imitation of Sir Walter Scotts'. The one I read treated on on the war between Ulrich duke of Suabia and the Suabian Confederacy, assisted by the duke of Bavaria about the year 1519. The castle of Lichtenstien from which the novel takes its name lies now in ruins at Whitsuntide, they as well as a cavern close by in which the duke when pursued by his enemies took refuge, are visited by the Swabians of the vicinity. Paying visits likewise took up a great portion of my time, for the number of my acquaintance in Arequipa was very very great also many attentions were shown to me by the foreigners, especially by the Gallaghers, Went, and Harmsen. Two or three days that varied from the general routine I will now particularize.

Saturday, $11^{\text {th }}$ of February 1843 . I was invited to spend the evening at the Gallaghers. Besides himself, wife and lately arrived sister in law Miss Marie anne, and Patrick, the youngest brother, I met there Crompton, Johnson, Went, Marriott and Jack. We played whist which over we adjourned to the dining room, where we had a cold light supper, followed by whisky, hot water and sugar. We had some songs though none of the party could boast of much musical talent; even Mrs. Gallagher sported some ditties a[_] [24] which one song called the "old Maid" met with much applause, we were all very merry. Went got tipsy, Marriott half seas over, both had to be escorted home by their 
friends. I had not deviated from my habit of never taking spirits, so was both merry and wise. We broke up at one. The next day,

Sunday, $12^{\text {th }}$ of February 1843 , a pleasant ride to Tiavaya commenced the day. This village with its surrounding "chacras" and perales is one of the prettiest to be seen anywhere. The forenoon was taken up by paying many indispensable visits. I dined at Went's, the party consisted of himself, his wife, and little daughter Anne, his niece, Chavelita Ward, Crompton, Johnson, Jas. Gibson, and Stubbs, the two latter in Went's Office. The party was dull, for Went suffering from his previous night's excess, and always deaf, and his wife indisposed contributed but little to the general conversation. After dinner when we had sat down to Whist, they retired and left us to ourselves.

Friday, $17^{\text {th }}$ of February 1843 . Rosita, her intimate friend Josefa Bustamante, and I, started on horseback for a place called "el Huaico grande", about half way between Tiavaya and Uchumayo, on the right bank of the Arequipa river which waters these two places. We rode to the Huaico over the arid plain so often mentioned, and though none of us were especially acquainted with the road we fortunately hit on the right one. On approaching the river, cultivation begins, we passed the new farm of of Pedro Jose Gamio, son of L[?], then that of old Dr. Quadros called Cabeza blanca, and a little further alighted at the house of a farmer, known to the ladies. A few houses stand here abouts, with pretty orchards, producing figs, pears and peaches. We sauntered up and down, cut our initials on the bark of a fig tree, I alone attempted to visit the ruins of a bridge that once had spanned the river but desisted on finding the way over the bare rocks too dangerous. Soon after came Rosita's servant bringing eatables, [25] after him appeared a Bs. Airean, Gonsalez a friend of Rosita's. We breakfasted and returned, not to the town but rode to the farm of Doña Josefa Bustamante, there we dined and remained till the evening. The Bustamantes were very kind people, their farm, well kept and prettily situated, commands a fine view over Arequipa and the surrounding champaign.

Sunday, $19^{\text {th }}$ of February 1843 . Before breakfast I rode up to a spot called La Peña (the rock), one of the natural curiosities of the place, leaving the road to Socavaya and the Pantheon to my right, and to my left the cultivated fields of the very valuable farm belonging to the Goyeneche called Huasacacha. I descended after an hours ride into one of the many ravines or narrow valleys, sometimes covered with brushwood sometimes cultivated which form one of the characteristics of Peruvian Scenery, this ravine leads into another and in the latter after some search and difficulty I found the object of my excursion, a cave from 14 to 15 feet high, hollowed out into the bank of the river. From its summit there is a constant and thick dropping of water which forms a pool surrounded with the richest softest velvety green turf. From this pool the overflowing 
water finds its way to the river which courses through the middle of the valley. I recollected that three times during my former residence in Arequipa I had visited this spot. The first time shortly after my arrival in 1824, when I went there on horseback with Messrs. Robert Page, S. Lang, J. F. Johnson, S. Mardon, A. Von Lotten and various others, all except Page about my age, perhaps a year or two older, but as they had come out as supercargoes and were about to establish themselves in business whilst I was only a clerk they had a right to sit down and risk their money at cards, I left to myself had to amuse myself as I could. The $2^{\text {nd }}$ time though still a clerk I had gradually risen into consideration, and it was in the year 1825 I formed part of a picnick given by [26] Mr. and Mrs. Von Lotten, S. Mardon, D. Schutte, the Italian music master Bolognesi, and others. This Bolognesi is the father of the two Officers of the same name, so frequently mentioned in Peruvian politicks in the present days (1867). The $3^{\text {rd }}$ time probably in $183^{0}$, or beginning of 1831 , when the two Edwardses of Halifax (both now dead) lived with me, then chief of Gibbs house, with Jas. Jack and others, we had played Vingt-un the whole night, at day break we rode thither to refresh our fevered heads. From this incident, it might be inferred that perhaps I was then a gambler, not so, for never in the whole course of my life at one sitting have I lost or gained fifty dollars at cards, dice I have never touched. In the course of the twelve days of which I am treating the revolution did not progress much, in Arequipa Gl. Guarda was commander in chief as already said, and Jose Rivero prefect, whom I have known to fill various situations in the different branches of the administration. He is at once energetic and despotic, which latter quality has gained him the name of Solyman amongst the Arequipeñians; now in 1867 he is advanced in years. The Arequipeña Press was very busy with publishing philipics against Vidal and Lafuente, and as a specimen of the style then in vogue, (I may add now in 1867 it is not much improved,) I translate a few lines; the Author Don Mateo Paz Soldan is dead since: "General Lafuente that impure being, the Arimanes of all Republican guarantees, who has never made a step in his public career that has not been a blot on his reputation, the most incapable of all imbeciles and the most presumptuous of all ignorant men". In Cuzco where Vivanco was Prefect the public opinion could only show itself in his favor. Whilst to rouse the patriotism of the department of Puno, General Fermin Castillo had started thither, the same who only in the preceding October had fought for Vidal and Lafuente, and distinguished himself at the battle of Agua Santa. Mrs. Went of $[27]$ whose indisposition I spoke on Sunday 12 Feby., grew gradually worse and worse. On Monday $20^{\text {th }}$, the last sacrament was administered to her; the following night Dr. Gallagher and his wife were with her, on Tuesday the $21^{\text {st }}$ hardly had I risen when James Gibson came to tell me that she had breathed 
her last at 4 Oclock; and that Went wished to see me. I hurried to his house, and found the poor fellow lying on the sofa, his little daughter Anne with him, both in an agony of grief. I had known Mrs. Went, Juana Chocano, ever since my arrival when she was a young girl, she grew up I may say under my eyes. I liked her well and frequently showed her attentions. One morning when riding out with Went, he told me the difficulty he had had in obtaining the family's consent to the connection. The wedding took place in July 1832, during my absence from Arequipa. In April 1833, when I had removed to the Capital, the first letter I received from Went advised me of the birth of his little daughter Anne, now (1867) Mrs. Henry. In 1843 it might have been said I was present at her mother's death which took place whilst she was still young. This day,

Tuesday, $27^{\text {st }}$ of February 1843, I had fixed upon for my departure. Mr. and Mrs. Schutte had also decided, that Conradina should return with me to Lima, thus after breakfast, the muleteer with the light luggage having started previously, I bade good bye to my daughter and mounted my mule. Ascencia, a female servant whom I had to take with me, settled herself on another. Diego bestrode a third, he had to carry Conradina before him to the port, who up to the morning had been willing to go with me, at the last moment naturally enough, her little heart failed her at leaving her mother. It was a moving scene, she wept continually, and cried "no quiero no quiero". At last forcibly placing her on the saddle before the servant we left the patio, her tears and cries did not cease. It was a painful ride to me, not to hear her, I rode ahead. Of the road I had nothing new to say, by six [28] Oclock I reached the Tambo of La Jara, situated at the end of the descent from Piedra de afilar. I had a chupe prepared; about an hour later Diego, Conradina and Ascencia came up. After having taken dinner or rather supper, Conradina lay down beside Ascencia and both soon fell asleep. I slept also in the same room.

Wednesday, $22^{\text {nd }}$ of February 1843. The Muleteer roused me at 2 a.m. We set off in the dark, it was a pleasant and cool night, at breakfast 7 Oclock we partook of cold fowl etc. Conradina had grown more reconciled to the change and amused herself with counting the skeletons of mules and asses that had died on the way, parched up by the scorching sun, at Guerreros we rested again. At 2 p.m. we reached Islay, and alighted at Ward's house, here in a strange dwelling Conrada. recollected her mother, and tears began to flow, but when Ascencia who had remained behind came up, the child recovered her serenity, and was again contented and happy, so that I could venture to leave her, and dine with the Bowmans, Ward being absent. I met here Crompton and Captain Schroeder of the Swedish barque Lydia and stayed the evening.

Thursday, $23^{\text {rd }}$ of February 1843. Before 8 Oclock a.m. the Peru came to an anchor, we breakfasted at Ward's. I took the luggage on board, conversed with 
several acquaintances, called on Mrs. Bowman, who was always particularly civil to me. At 3 in the afternoon we embarked, Captain Pinnex assigned to Conradina and Ascencia berths in the lady's cabin, I occupied my old on in the forecabin, Ascencia soon grew sick, and lay down on the deck with Conradina by her side; they came neither to dinner nor tea. I was quite well for hardly the slightest motion was to be felt. The passengers numbered from fifteen to eighteen, amongst whom I will only specify Colonel Salvador Soyer, a frenchman of low extraction who had come to Peru either with San Martin or Bolivar, he conducted himself well, rose to the rank of Colonel and married a Miss Lavalle of Lima, a young lady of good family [29] now in 1867 both are dead. They left several children of whom the daughters are well married. I myself undressed Conradina, her maid being hors de combat from sea sickness.

Friday, $24^{\text {th }}$ of February 1843. I was hardly awake, when one of the Stewards came to tell me, Conradina was crying for me. When she saw me, she became quiet, whilst I finished dressing I left her in charge with Colonel Soyer who had taken a great fancy to her, she was with me the whole day on deck, took breakfast and dinner with us all, and behaved very properly, the maid was sick all day.

Saturday, $25^{\text {th }}$ of February 1843. Conradina made many friends among the passengers, and played all day long on the quarter deck. About noon we passed between the main and the isle of San Galan, at one, anchored opposite Pisco at a short distance hence lie the famous Chincha islands which contain the huano deposits. I did not go on there, not liking to leave my little charge. From the "Peru" the Custom house and Stores were visible, distant about a fifteen minutes walk from Pisco. This town I had seen various times, it consists of one long street parallel with the shore, it had several churches, and cultivation at each end. Some lady passengers came on board, consequently I had to vacate the berth in the ladies' cabin. I took possession of a sofa under the stern window. Here Cona. and I lay down soon after tea, but could not sleep. I rose dressed, read, looked after the little girl to prevent her falling off the sofa, thus passed the night.

Sunday, $26^{\text {th }}$ of February, Carnaval Sunday, 1843. At seven Oclock the Steamer came to an anchor in Callao Bay. The Captain of the Port came on board, with him I, Conradina and two military men, fellow passengers, proceeded to the Governor Gl. Jaramillo to communicate what political news we brought. At T. Conroy's I met Garland who was in Callao on account of his health, Juan and Herman Reincke, I left Conrada. with Juan and with [30] Reincke looked after the luggage, at 9 we went pr. Omnibus to Lima, where we arrived at 10.30 Oclock. In the Portal I bought a doll for my little girl. A few minutes later I was again at home, with my beloved family and thus my excursion to Chile 
and back was brought to a happy conclusion. A note of my expenses will be found under $\mathrm{N}^{\circ} 1$ and a few interesting extracts from Books under $\mathrm{N}^{\circ} 2$ in the appendix.

\section{Connecting Narrative}

From $26^{\text {th }}$ of February to $17^{\text {th }}$ of May

1843

My family, which as previously said consisted of my wife, Doña Berna, Juan, and Enriqueta, was now augmented by Conradina, a lively intelligent child, who soon became a general favourite. We placed her at the school, kept by Miss Dominiconi whither my wife took her in person, the first time, but she then wept and cried so bitterly, that my wife could not make up her mind to leave her, the following day she was quieter and remained. Gradually she became fond of the school and made fair progress in her education. Our acquaintances were numerous, our intimacies few. The "Limas" we continued to see frequently, still more so, the family of Charles Pflücker whose wife Doña Gertrudis was Mrs. Witts Comadre. She, the latter having stood Godmother to two of Mrs. Ps. daughters who died in their infancy. As I have just remarked that our circle of acquaintances was very extensive of course the number of farewell visits I had to pay was great, previous to my approaching departure for Europe. The course of time since then has brought about many changes. Thus of the four pretty little girls I have mentioned of the family of Julius Pflücker three have been married for some time, I say so in 1867. The fourth Miss Sophia must make haste to follow her sisters' example, if she wishes to escape the fate of single blessedness. The Le Moines, [31] the Boschs and the Limas left long ago - diplomates seldom remain permanently in one place. Others are dead, many have returned to Europe; of course during the period I am speaking about (1843), new faces appeared, Christian Hellman introduced to my family Herman Rodewald of Bremen, new clerk of Huth Grüning \& Co. This young man soon distinguished himself by his capacity, he became head clerk, then partner; with a competency not what may be called a fortune, he has retired to his native place where he is married. He was one of the few I became intimate with. Laurie, the well to do cashkeeper of Gibbs \& Co. who during the time of their huano business knew how to feather his nest, also then made his appearance in Lima. He and a companion named Cohen came from the United States recommended to my son Juan by one of the Bruhns of Baltimore (relatives of the Schuttes). They once or twice visited us but Cohen soon left, and Laurie when he had obtained his situation did not again come near us. Pole Jacobo Bistrownofsky, son of a Count, was another new acquaintance. 
He was an exile, having been implicated in the rebellion of 1830 against the Russian Government, in Lima he assumed the name of Santiago Flores, gained his living as a civil Engineer. Of him I had no great opinion and was glad when he ceased calling. Don Mno. Sierra, my wife's brother, returned from Guayaquil after a long absence occasioned by his close political connection with the Expresident Orbegoso. We were always on excellent terms (with him), but seldom saw him on account of the disagreeable character of his wife. Here again, Santiago OPhelan, Bishop of Ayacucho, a most worthy ecclesiastic, who in October 1831 had married Mrs. Witt and myself (the bishop lived in Lima, the cold climate of Ayacucho being too severe for one of his advanced age) we were always happy to see, and cultivated his acquaintance. Melchor Velarde my wife's cousin, spoken of above, as one of the [32] prime actors in the now prosperous revolution of Vivanco was at the time major in the Battalion of sharp shooters "Cazadores" of the President's guard, he commenced calling on us, and ever since then we had been with him on friendly, ultimately (1867) intimate terms. $\mathrm{He}$ is a man whose early education has been deficient but who possesses more than an average degree of shrewd common sense. His character is excellent, of irreproachable conduct and of honesty à toute èpreuve which is saying a good deal of a Peruvian Officer. Now (1867) he is not in active service, has a large family and a wife somewhat extravagant. Doctor Gallagher of Arequipa resided with us for several weeks, he was a great partizan of Vivanco, and had come to Lima no doubt with the view of advancing his fortune under the protection of that now prosperous chief, whether he succeeded or not I cannot say. Herman Reincke, Garland, who during these months suffered much from ill health, the monk Uria and Doctor Luna were our teatable habitués. Occasionally the theatre was a resort when a good opera was placed on the stage. Thus in one way or another time passed way pleasantly, I recommenced my Italian lessons under Dominiconi and worked hard to make myself a proficient in this language - my visits to Gibbs' counting house became gradually less and less, at first I still read the letters from the London house, but having no share in the business of course my interest in them decreased, nor could I expect they would be shown to me any longer, though I at the same time kept on the best of terms with both partners and clerks. I now opened my own set of books, drew out my will and my wife's, corresponded with Gibbs of Chile about the placing out of my funds in their hands, with C. W. Schutte on the matter of a small alpaca wool speculation, attended to my Consular business and in these various matters had [33] my time pretty well occupied, soon after my return Mr. Lembke returned to me the consular archives and with them an unpleasant letter which led me to imagine though as it afterwards turned out without reason that he intended supplanting me in Consulship. Then I had 
difficulties in finding someone to occupy my place during my absence and finally when I applied to Vivancos cabinet for permission to leave someone in my stead it was decidedly refused, because my commission from the Danish Gment. did not authorize me to do so, and the precedent I quoted to them that the previous administration had permitted me to leave Mr. Lembke to act for me they called an ill judged concession. I may mention finally that for some mornings before breakfast I took a bath in the bathing establishment of Altazar which not agreeing with me, I rode out once or twice to Chorrillos where I took a dip in the sea and at the same time called on Chas. Pflücker residing with his family there; of neither the one, or other bath have I taken any notice in my previous description of Lima in Volume the first, I will here therefore say a few words about them.

At the end of the second Alameda del Acho, avenue of the bull ring, on the right side of the river, where the high road continues to the valley of Lurigancho, lies on the left side a small property which consists of a dwelling house generally used as an inn, with a vineyard behind it, for grapes are its principal produce, and a long building opposite divided into ten or twelve apartments of which the first and the last are the largest. All contain a bath, hollowed out of the ground, filled with fresh water from an adjacent spring. Bath $\mathrm{N}^{o} 1$ is for men - it is built of bricks; from ten to twelve varas square, depth more or less a vara and a half, round it ran a platform with stone benches where the bathers undress; they used to jump in completely naked, in later times they wore a pair of loose pantaloons. The [34] other apartments much smaller except the last are for ladies and those gentlemen who wish to bathe alone, the last is about the same size as the first with incomplete arrangements for douche baths. These are the baths called Altazar most probably from the name of the original owner or constructor, they have also another designation, that of el "Puquio" (well). One morning I encountered there bathing Don Pedro Gonzalez Candamo, a man who has left a name of some note in Lima, on account of the large fortune he amassed. I was acquainted with him, but this morning more communicative than usual, he told me he was 41 years of age and that in his $23^{\text {rd }}$ year he came to Lima from Chile his native country possessing at the time $\$ 96,000$, he died in 1866 , worth from thirteen to fifteen millions of dollars. He was notorious for his parsimony, but a miser I think he could hardly be called, he was the ne plus ultra of selfishness, his conduct to his mother, and to the mother of his natural children proves that he was hard heartedness itself. As little did he know what was charity. On the other hand he was capable of great enterprises, for to him Lima owes the railways to Callao and Chorrillos, which gave him an enormous profit. He used to play at cards, seldom at hazard, he has told me that he lost considerably, all who ever played with him said he was quite a 
gentleman in his play. This is what no actual miser would have done, moreover he was very neat and clean in his dress. He left three illegitimate children, two daughters and a son Carlos, all of whom he acknowledged before his death and to whom excepting a few legacies he left the whole of his enormous fortune. Of the son Carlos all who know him speak in the highest terms, now (1867) he with his sisters, and young wife are enjoying themselves in Paris, the winding up of his father's affairs he had entrusted to an old Clerk Boza and to a young Hamburgher Arthur Von Heeren, with whom young Canda[_] [35] formed an intimacy when at school in Altona and for whom he sent immediately after his father's death.

Chorrillos originally a village of fishermen, lies distant from Lima about nine miles in a south easterly direction, situated on the high arid coast washed by the Pacific. It takes its name from a number of springlets of fresh water, which at a short distance from the place flow out of the base of the cliffs into the sea, this locality is called "Agua dulce" sweet water; chorro is Spanish for a gush of water, its diminutive "Chorrillos" has furnished the name as already said. The whole road from the Capital is more or less dusty and sandy, the cultivation rather scanty, owing to the scarcity of water. One leaves Lima through the Guadalupe gate and rides through the lane of Mattamandinga with farms on both sides, at the end of this lane another road crosses it at right angles, this place is called El Balconcillo, notorious for the robberies frequently committed there. We next come to the ruins of an extensive [buckhiln], further on to an open place with a cross, here the road branches cut into three, on the right to Miraflores, on the left to Surco, straight on to Chorrillos. Miraflores is rather a pretty village with a good deal of vegetation, which however according to general opinion renders it liable to the intermittent fever. The descent here to the shore for bathing is highly inconvenient and the sea much more boisterous than at Chorrillos. Surco, the other village a little inland with some fine trees and cultivation, is gradually falling into decay. Having left Miraflores to the right, another Chacra, el Pacayal where in 1838 Santa Cruz and Orbegoso dated many of their decrees, is passed, then one descends into a deep gully, el Barranco, over which a bridge leads and shortly after appears Chorrillos. In 1843 many of the fishermen's huts had gradually given away to handsome houses, built by the people of Lima. [36] The descent from the high coast to the beach was very inconvenient. Along the shore a number of miserable sheds made of matting, the floors covered with the same, and some big stones serving for seats, were for the use of the Bathers, for which they paid to the Chorrillano owners half a rial each. Men and women bathed together, but both sexes being clad in vestments made of a woollen stuff called Cubica all impropriety was removed. The beach shelves down very gradually; during the hot months a 
bath here is very delightful, timid ladies, children and infirm old men sometimes employ an Indian called el Bañador to take care of them in the water. Besides bathing gambling was the principal amusement in Chorrillos; in a house owned by the family of Elespuru, Antonio Cucalon kept a moute table, here one could also procure a room and a bed for the night. In the house of Doña Ignacia Palacios an amiable good lady of a respectable family gambling went on the whole day, and a great part of the night, in the evening her apartments were crowded. This poor old lady could not live without excitement, she died in Lima in 1866 at a very advanced age beloved and pitied by all. She had once been a rich woman, but her finances were found after her decease in the worst state imaginable; her two daughters, aged spinsters, live I may say now (1867) in penury. Chorrillos as already said, situated on the high coast, which forms here a small peninsula, leans towards the north east against a ridge of hills, which rise to the higher point known by the name of Morro Solar, which serves as a landmark for vessels coming from the south bound for Callao. In the village itself there is no trace of vegetation, a little inland are the estates of San Tadeo, San Juan and Villa, growing principally sugar cane. The above was the appearance of Chorrillos in 1843, now in 1867 it is greatly improved owing partly to the establishment of the railway, which facilitates commu[_] [37] cation and partly to the predilection of general Castilla for this place. The descent to the shore is now a wide paved road, as gradual as the nature of the ground will permit, a fine terraced walk called the Malecon is constructed, water to supply the town has been brought from a spring in the vicinity, the miserable cane huts for bathing have given place to neat, convenient, wooden buildings, floored and provided with two wooden benches and other accommodations, a small mole has been made, of no use as such, but it serves as a kind of break water so that the bathing ground is much more sheltered than formerly, and is so safe, that the Bañadores are no longer required. The whole front of the coast looking towards the sea, is occupied by handsome houses as various in their style of architecture as accords with the taste and fancy of their respective owners. There are at present two hotels, medical men, two apothecaries shops, one serving for the post office, and what is most extraordinary, owing to the unremitting exertions of Andraca the Prefect of Lima, the hazard tables are completely put down. The fashionable bathing season is during the hottest months of the year from January to April inclusive, but such is the high opinion entertained by the Limeños of the Chorrillos climate, that even without taking into account the tone given to the system by the bathing, not during one single month of the year, is the place without Lima residents. In the appendix $\mathrm{N}^{\circ} 3$ I subjoin a description of Chorrillos in verse, written by my friend Mr. Samuel Went. As said above, I arrived in Lima on 
Carnaval Sunday the two following days were devoted to the sports usual on this occasion, business and serious occupations cease, the pastime consists in men and women wetting each other to their hearts content. The balconies are lived with the fair sex of all shades of color, throwing water on the passers underneath, even on the patrols themselves on duty to [38] restrain, and keep within due limits the day's amusement. In the houses, the young people are at the same work, those who are a little more genteel use scented water. If four or five girls joining are strong enough to tumble a young man into a bath of water great is the delight; of course the young men retaliate in the same way. In the streets the black and the brown colored do not remain behind in the sport, with them the gutter water answers the purpose. The second half of the play consists in throwing egg shells filled with scented water at persons showing themselves in the balconies, these are sometimes thrown with such force as to wound the face or eyes. The Wednesday following - Ash Wednesday - all is silent and tranquil, all such as are desirous of distinguishing themselves for extraordinary devotion mark their forehead with a small cross of ashes. The next five weeks are lent time, many of the inhabitants of Lima keep their fast during this period which is to say that they never take breakfast, and on Fridays don't eat meat. On the $2^{\text {nd }}$ of March Enriqueta called my attention to a comet which I suppose had not been observed many days before we saw it. It was in the west, a trifle above the horizon, the nucleus very small, so small indeed that I could scarcely perceive it, but the tail was of extraordinary length, and occupied about one half of the heaven between the horizon and the Zenith. It was visible every clear night, it gradually drew towards the north, after the 20 March I make no further mention of it. Sunday April 9. Palm Sunday I witnessed the procession which crossed over the bridge from the suburbs of San Lazaro, the Cross covered up, and carried by one of the inferiors of the church opened the march. Behind it, a crowd of men and women, some of the formers as well as friars of the various Convents, in two rows with lighted candles followed an Anda or bier, carried by negroes, who could not be seen, for a cloth hung down, so as to cover them. On this Anda stood a wooden donkey on its back the Saviour [39] in effigy, above them, a canopy, and a little behind the mounted figure, a palm tree with palms looking close on the procession. He is represented $[\ldots]$ in a Jacket and [...] with a round hat, also a the figure whose purpose I did not know completed the personnel. In the train of this came another bier, separated from the first by rows of men, amongst whom were also friars, all carrying candles, on the second was the image of the "virgen de los dolores", another crowd and a few soldiers closed the procession. April 13. Holy Thursday. This day is devoted to many religious services, in the forenoon it is customary for the Archbishop to bless the oil, which is to serve 
througout the Republic for the christening of children, as well as for the last sacrament administered to the dying. Also he officiates at the ceremony of washing the feet of twelve poor men, who afterwards received a suit of new clothes, out of the funds of the Church. Their feet have been thoroughly cleansed previously so that the Archbishop's washing is merely a superficial act. I entered the Cathedral, which was so crowded, that I could not well see what was going on. I saw the supreme chief Gl. Vivanco with his staff in Gala Uniform, occupying the centre of the church. High mass was being said which over, Vivanco and suite returned to the Palace, Gl. Arrieta on his left, Gl. Pezet on his right, through two rows of soldiers. After dark, all churches are splendidly lighted up. In one is represented Christ in a reclining posture as if in the sepulchre, his hand and feet uncovered, reverently kissed by the devout, in a second, he is shown bending under the weight of the cross, in a third, tied to the scourging post. In all, before the high altar, a table is laid out with edibles, at it is seated the Saviour with the 12 apostles, Judas Iscariot, generally distinguishable by his red hair, and occasionally with an "aji" (pod of chilian pepper) in his mouth, is a prominent object. I need hardly say that this is the last Supper. On this day it is the duty of all Catholicks to [40] [...] though not stated [...] Testament Jesus stumbled under the weight of the cross, he [...] pelled to bear to Golgotha. Strictly speaking seven churches ought to be visited seven Ave Marias and seven padres nuestros repeated together with some other prayers, this walk can be abridged however by entering only one church and worshipping at seven shrines. The whole day is devoted to these religious exercises, however the churches generally commence being most crowded after dark, then they are brilliantly lighted up, and thronged with people, the sight presented to the beholder is very striking. My wife and daughter complied with this duty, Herman Reincke and I accompanied them in its discharge. On Thursday 27 Ap. /43 died Mr. Thos. Green with whom I was well acquainted, he was a good natured easy going man of the come day go day class, fond of cracking jokes and having friends at his house. But as usual with men of such character his expenses exceeded his income, solely derived from the sale of earthen and glass ware, thus if he did not actually outlive his income and suspend payment which I do not recollect, at all events he left his wife (he had not any family) without a farthing, she retired from the world. In 1829 and during my wife's absence from Lima in 1834 and 1835 I spent many a pleasant hour in his house. Thornely of Lang's Firm and Richard Humphreys, the wealthy iron monger, he had appointed his trustees, in the house of the former, on the $28 \mathrm{Apl}$. at half past seven a.m. a number of foreigners assembled, all in mourning. Coaches to Bellavista had been provided, as soon as we had arrived there the coffin on a bier was placed in the chapel where the burial service was 
read by Mr. Miller the English Consul [_] Thomas repeated the responses, this over the coffin was carried to the grave, into which it was lowered, at [41] the words ' $d[.$.$] dust', 'ashes to ashes' [...] of a portion [...] arth took place the$ grave was [...] and those present some [_] in number dispersed to their several occupations, in the [_] ares of which poor Greene I fear was soon forgotten. Wednesday May 3 at midnight died the Archbishop Arrieta, in his $75^{\text {th }}$ year. He was formerly a Franciscan Friar, and during life much respected. Luna Pizarro bishop in partibus succeeded him. Pizarro was uncle to the Minister La Torre whose sister Cipriana is wife of Vivanco. Friday $5^{\text {th }}$ May 43 the funeral was solemnized at eleven Oclock a.m.; first came friars of various convents with their respective crosses, next the coffin empty, the corpse in pontificalibus being stretched out on a bed, the face uncovered with the mitre on the head, was borne on a bier out of the Archiepiscopal Palace. Behind it, followed Bishop Pizarro, and OPhelan, bishop of Ayacucho, the canons, the clergy, and again friars. Part of the Battalion de la Guardia closed the procession, which moved slowly round the square "Plaza Mayor" stopping at each of the 4 corners, where an Altar was erected respectively by the 4 orders of Santo Domingo, San Francisco, La Merced, and San Agustin. At every time of stopping, the Friars knelt down, and prayed. The procession then entered the Cathedral, crowded with people; the corpse in the same position as before was raised on a stand before the high altar, mass was said and I left. In the afternoon the body coffined was conveyed for interment to the general cemetery outside the Maravillas Gate.

The Communication with Europe though perhaps more frequent than in the first years of my arrival in Peru was by no means regular, for as already said, when speaking on this subject during my late stay in Valparaizo, the steamers, which plied on the coast did not extend their trips as far as Panamá. Passengers [42] and correspondence came to, and returned from, Europe round the Cape in sailing vessels, amongst those who left Lima during the period I am writing about, was a German baron Leopoldt Von Winterfeldt, mineralogist by profession, he became acquainted with Mr. Charles Pflücker, whom he succeeded in inducing to invest some spare money belonging to Mrs. Pflücker his wife in opening a copper mine, at a place in the Cordillera called "Morococho", between seventeen and eighteen thousand feet above sea level, thither I accompanied the baron, and a younger brother of Juan Francisco Izcue, who was also interested in the undertaking, though in the commencement only. At the time the soil had never been turned by spade or plough, it was an interesting but cold excursion in the extreme, I much regret I have not kept the particulars of the trip. Mr. Pflücker commenced this speculation with ten thousand dollars, gradually he invested an enormous sum 
in it until he was requested by Gibbses partner of whose firm he was, to leave the establishment, because his attention was too much diverted from their business by his mines. Copper was found and extracted, but never did Pflücker succeed in smelting the ore so thouroughly as to produce pure copper, owing I believe to the great rarefaction of the air in such a great elevation as that of Morococho. He shipped the copper in a state called "regulus" in a condition when the metal is not entirely free from all heterogeneous particles. As long as prices remained good in England, notwithstanding the expensive carriage from the mine to Callao, its exportation did not actually give a loss, but when prices fell Pflücker could not continue shipping. At the present day he must be indebted for a large sum to Gibbses in London, which he will never be able to pay off. Thus this unfortunate casual acquaintance with Winterfeld [...] as [_] all his prospects in life, luckily a rather [_] active [43] silver mine was discovered close by, at a place called Tuctu from this he is now, (1867) a[_]d has been gaining a living for many years back.

The political news from Europe during this time, related mostly to the affairs of China and the East Indies, in connexion with England. The disgrace inflicted on the English arms in their invasion of Afghanistan was washed out by several subsequent victories, Cabul and Ghuzni were taken and the prisoners in the hands of Afghans were set at liberty. On the 22 Augt. 1842 a treaty of peace was concluded between England and China, the former represented by Sir Henry Pottinger, on board the Steam Frigate Queen, in the river Yangtze Niang opposite Nankin. The chief articles were the following; Art. $2^{\circ}$ China pays England twenty [_]illions of dollars in three years - Art. 3 the ports of Amoy Canton, Foochowfoo, Niugpoo and Shanghai will be opened, Consuls to reside there, equitable Custom house regulations will be made, Art. $4^{\text {th }}$ the Island of Hongkong is ceded to the English forever, Art. 8 as soon as the first six millions dollars are paid, the English military forces will be withdrawn from Nankin, from the great Canal and also from Chinhai; but Chusan and Kulangrov will be retained until the entire payment is made and steps taken for the opening of the ports. The huano trade was far from being placed on a solid footing, in the English markets the demand was irregular, consequently prices fluctuated. On the 15 March a fire of great extent took place in Valparaiso, destroying a great proportion of the houses on the left of the landing place. It broke out in the house of a certain Julian Lopez. The loss of property was estimated at two million dollars. Remains now to be told how the revolution in favor of Gl. Ml. J. Vivanco, of which we have seen the commencement page 20 of this volume extended over the whole republic, and ended in his being raised to the Presidential chair, which he occupied under [_] of director for about 18 months. At the time [44] of my arrival in Lima, end of Feby. Generals Vidal and Lafuente 
were at the head of Affairs; the one as President, the other as minister of Finance. However, already in the early part of March, they showed signs that their grasp of power was feeble, as soon as news had reached the Capital of the "Yungay", the largest man of war in the Peruvian navy, commanded by Panizo, having declared for Vivanco, a large meeting was convened of the principal civil and military dignitories on the 8 of March. At it, it was determined, that Doctor Don Francisco Xavier Mariategui should go to Islay to treat with the General. In pursuance of this resolution, he left in the Steamer on the $10^{\text {th }}$; the following day, Gl. Nieto set out to take command of the army, hitherto considered faithful to Vidal, but hardly had he reached San Juan de Matucana, when he received advices which he immediately forwarded to Lima, that Gl. Pezet commander in chief of the forces, stationed in Jauja, had declared agt. the Gment., and demanded that Vidal, being only $2^{\text {nd }}$ Vice President should relinquish his post to Figuerola the 1 Vice President of the Council of State. Lafuente immediately threw up his ministry. On the 15 and 16 of March the Council held two extraordinary meetings, Vidal resigned and Don Justo Figuerola was installed into power in his place. A new ministry was named, the members proposed, refused their nomination, all save Castilla, for war. At the time when Vidal and Lafuente retired from Office, there were about some $23,000 \$$ in the treasury, that such an amount, considerable for the time, should have been left unappropriated, arose from the following circumstance. Lafuente had agreed with some frenchmen to destroy the "Yungay" promising them $26,000 \$$ as their reward, the money was deposited in the Firm of Rowe, however the French Minister Le Moyne got wind of the affair, and prevented his countrymen from making the attempt, consequently the project fell through, $3000 \$$ expenses were paid to the men, [45] the remainder $23,000 \$$ went into the pockets of Vidal and his associate; the former in the last moments of his power conferred $5^{2}$ ascents in military rank on so many officers. On the 10 of March the Steamer from the South arrived, bringing news from Arequipa, Tacna and Moquegua; in the two last places Vivanco's interest was not in the ascendant - in Tacna Baltazar Caraveda had failed to bring about a movement in his favor, and in Moquegua Gl. Guarda had suffered a repulse - Gl. Torrico was said to be the favorite in those parts of the republic. Meanwhile on the 18 of Feby. Vivanco had named J. L. G. Sanchez his secretary general and appointed several individuals of less note to the heads of the different branches of his administration. On the $20^{\text {th }}$ of the same month he named himself by a decree Provisional Director of the Republic. Whilst these things were being done in the south, Figuerola undertook to keep order in Lima, and despatched his messengers to Pezet, they were met at San Pedro de Mamas by the vanguard commanded by Tomas Ortiz Alvarado, who sent them back to Figuerola, 
acknowledging the latter in his present position but requested that the troops in Lima should submit to Vivanco's authority. Two days previously, say the $17^{\text {th }}$ an attempt had been made to convene a cabildo abierto, it failed, for scarcely any one attended; had it happened otherwise, the ring leaders amongst whom I find the name of Juan Aliaga would in the then state of the public mind easily have directed the meeting openly to proclaim Vivanco's authority. Now arrived the news that Pezet in Jauja had on the 12 March given in his adhesion to Vivanco, stating as his proclamation said, he was compelled to do so by his officers and men, Castilla and Nieto at once threw up their respective offices. On Sunday night March $20^{\text {th }}$ the public declaration in favor of Vivanco was at length brought about in the Capital; at 5 Oclock [46] in the morning some troops were assembled in the Public Square, and, on command, huzzaed for him. The "Peruano" of the same day published a proclamation signed by several officers, amongst whom the following names were known to me; Norberto Elespuru, son of the General and son in law of the Doctor Benito Lazo; Elespuru's worthless character I have previously described page 641 Vol. 1; Vargas Machuca married to Maria Vermejo, niece of the worthy bishop Santiago OPhelan, a man mixed up in all civil dissensions, now in 1867 one of the many dissatisfied with Prado's dictatorship and succeeding presidency and José Zavala, whose melancholy death I have described page 23. In this document they recommended that the services rendered by the Generals Castilla, Deustua, and Nieto, should be recognized. Vidal retired from Lima to his estate, Lafuente disappeared. The Prefect Ignacio and the Intendente Rivas resigned their offices, Doctor Luna concealed himself, not considering his insignificance a sufficient shelter. On the same day the $20^{\text {th }}$ the "Notables" of Lima assembled, and elected J. Rufino Echenique prefect of the Capital, on the $22^{\text {nd }}$ he being the only constituted authority in the place, passed polite notes to the diplomatic and Consular Corps informing them of the change in the Government of the Republic. On the $21^{\text {st }}$, Pezet's vanguard arrived, the General himself also made his appearance, and was recognized as Comandante militar. Lafuente embarked on board a French man of war "L' Ambuscade". On the $6^{\text {th }}$ of April the great man of the day made his entry into Lima through the Maravillas Gate, accompanied by a few Curassiers, the Scholars of San Carlos, and a number of the Plebs. He repaired to the Palace then to the Cathedral to render thanks for his safe arrival. Without loss of time he appointed his ministry, J. L. Gomez Sanchez of the Interior, Felipe Pardo [47] of Foreign Affairs, Manuel Guarda war, P. A. de la Torre of Finance, and Andres Martinez worship. Great reforms were to be introduced in all parts of the administration, the army to be reduced, and economy the order of the day, the Ministers' stipend to be $\$ 4000$ annually, 
the Supreme director himself instead of $\$ 48$,ooo would be satisfied with $\$ 24,000$. A committee was named to revise the old Reglamento Comercial (commercial regulation). All this sounded well, but General La Puerta (now ${ }_{1867}$ President in Prado's absence) in a call made on my wife, remarked to her, that Vivanco talked too much, and performed too little, this is the general opinion of his character. The more he was known, the more experience proved its correctness. I was introduced to him by Doctor Gomez Sanchez, on whom I had called on a matter connected with my passport - I found him good looking; dressed in black, as he was seated he rose on my entrance, shook hands, some conversation followed about my wife and daughter, Lima and Arequipa; as soon as he was silent I made my bow, and retired, our interview lasted some two or three minutes. The oath of fidelity, which he insisted on being taken by all the civil and military employés was the great stumbling block, the "Vocales" of the Supreme Court demurred to it, for some time. Many considered adverse to him were banished, I will only mention Generals Vidal, Castilla, Nieto, Frisancho, Bermudez and La Puerta - M. A. Alvarez of the Supreme court, a particular friend of ours, threatened with banishment, submitted at last and took the obnoxious oath. On the 7 April, a te deum was celebrated in the Cathedral, on the same day the Comercio Nacional made a loan of $\$ 50$,000 at $2 \%$ monthly to the Gment. The "Peruano" of 10 May, contained a decree of the Supe. Director, countersigned by Sanchez, [48] Guarda, and Latorre, convoking a Congress to amend the Constitution; notwithstanding so many intended amendments undoubtedly for the good of the country already two conspiracies had been formed against him, but discovery prevented their being carried into effect.

\section{Voyage from Callao to Europe - Journeys through England, Ireland, and Scotland, and voyage across the German Sea to Altona, from 18 May to} Decr. $21^{\text {st }} 1843$.

More than a year had now elapsed since I, notwithstanding Hayne's advice to the constrary separated from Gibbs' establishments; this sacrifice of my pecuniary interests I willingly made to my uncontrollable desire of revisiting my native place, and of again shaking hands with the friends of my childhood and youth, after an absence of twenty years. My intention was to take the route to Europe via Panamá, but notwithstanding my diligent inquiries, I could hear of no vessel sailing direct for this port, a Mr. Hunter, an Englishman whose chance acquaintance I had made and who had formed a similar plan left for Paita, where he expected sooner or later to meet with 
a conveyance for Panamá; to me this seemed too uncertain. I therefore decided on returning round Cape Horn, and the "Vicar of Bray", Brig, Captain George Seymour, having just arrived consigned to Gibbses I took my passage in her, if I remember right for $\$ 300$ to London; Hayne spoke highly of Capt. Seymour, he recommended me to him, and I may at once say in anticipation that it would have been impossible to be treated with more kindness and more attention than I was by Seymour [49] during the passage. He was an Irishman, part owner of the "Vicar of Bray", and I may add much superior to the ordinary run of merchant Captains, though on the other hand when in later years he acted the Gentleman the Captain often peeped out. After some time he retired from a sea faring life, established himself in business as a ship broker and having married the daughter of a large ship owner did for some time a very extensive business under the firm of Seymour, Peacock \& Co.; in the years 1861 and following, his firm ranked very high on the London Exchange. Great was my astonishment, when the news of his having suspended payment in 1866, came to my ears. After the repeated customary delay, the 18 of May was peremptorily fixed upon for the vessel's sailing. For the last fortnight I had been paying my farewell visits, which numbered more than two hundred, many of course, no more than a moment's look in. Part of my luggage with a good many books, of which by the way, I did not make great use whilst in Europe, I had previously sent by a Russian vessel the "Helios" direct for Hamburg. On the 17 May in the evening P. J. Gamio junior, oficial primero in the Ministry of Dr. Gomez Sanchez brought me my Gment. Passport, at 11 Oclock when our usual visitors were gone my wife and self retired to rest. At one I was again up wrote a few words in my diary and finished packing up, at 3 Oclock I again went to bed.

Thursday, $18^{\text {th }}$ of May. I rose at the usual hour, after breakfast I had still a few parting calls to make. On my return my wife's eyes and Enriqueta's gave clear proofs that they had been weeping, I sat down with them quietly having requested Juan to let me know when the coach was ready to start from Gibbses. He called me at 12, I embraced Mariquita, Enriqueta and Doña Berna but our little Conradina who had not gone to school, and who under the guidance of Domeniconi was together with Francisca and Carlos Pflücker amusing herself with blowing soap [50] bubbles asked me Papacito te vas al Callao, I answered in the affirmative, and hurried away to conceal my emotion. At Gibbses I had of course to say adieu to Mrs. Hayne, who to my great annoyance entered immediately into a discussion on a point of etiquette which had arisen between herself and my wife, she complaining that Mariquita on her (Mrs. Hayne's) last return from Chile had merely sent her card, instead of paying her a visit. I ran back to my house, for the purpose of arranging the dispute but my wife insisted 
that she was in the right. On my return to Mrs. Hayne, she had drawn out a statement of the affair in English, which I requested Juan to translate to his Mother, when I was gone, but I doubt if this weighty matter was ever arranged between the two ladies. I now found myself in Gibbses dining room, where a small party were assembled waiting to accompany me to Callao, some in the meanwhile were refreshing themselves with ale, bread and cheese. An omnibus was at the door ordered by Hayne, and paid for by the house, in it we left. By we I mean Cristoval Armero, John Hayne, C. Pflücker, Dominiconi, Dr. Luna, Frederick Schutte, Herman Reinke, Miller, clerk of Gibbses, Juan and myself. In Callao of course we went to Conroy's, Mr. Thomas Conroy being Gibbses Agent. From there, at 4 Oclock on board, where I had two private conferences, one with Juan my son, whom I endeavored to persuade that his conduct towards Doña Berna, his mother and Enriqueta was not as affectionate as it ought to be, and that he should alter his deportment, I doubt whether my representations made any impression on him at the time but in later years when his repeated voyages had taught him the difference between the affection and love of his family, and the interested friendship of strangers, he showed the kindness and goodness of his disposition also to those nearest to him. The second conversation was with Dominiconi who disclosed [51] to me that he was not married to his reputed wife Doña Enriqueta, whom he had introduced to the Lima society as such. He begged me not to mention to his friends in Rome, to whom he gave me letters of introduction, that he was married. In the Cabin were many good things on the table. Champagne in abundance, "a good voyage" was drunk, I returned thanks, thence on deck, in time all left, to some I had managed to say adieu but had in the end to tear myself away being overcome by my feelings. Vicente Gonsalez and I at last found ourselves alone; this young man was the youngest son of the rich Gonsalez of Trujillo, deeply in love with his cousin Emilia Orbegoso, [her] father considering him too young to marry had sent him on this trip to England, his brother in law Iturregui had recommended him to me in a most particular manner. He was an excellently well disposed youth, not particularly clever but good natured and good principled. On his return from his travels he married his early love. He was elected deputy to one of the many congresses which have sat in Lima, now 1867 he lives in England, father of a grown up family. Captain Seymour came on board, anchor weighed, we took tea, at 9 Oclock I went to bed. The Captain had been good enough to cede to me his own berth.

Friday, $19^{\text {th }}$ of May 1843 . Got up at 8, felt sick, lay the whole day on the sky light, took nothing but a little arrow root.

Saturday, $20^{\text {th }}$ of May 1843 . Equally poorly in bed all day, threw up the little soup and arrow root I had taken. 
Sunday, $27^{s t}$. A little better, for breakfast a little tea, a potatoe with salt, went on deck, lay on the skylight. Still the fine Peruvian climate, a good S.E. Breeze. At noon lat. 15.33 Long. 81.32. Dined and took tea in the cabin, gained a game of chess from Don Vicente, feeling squeamish turned in. [52]

Monday, $22^{\text {nd }}$ of May. Up at 9, breakfasted on deck, potatoes and tea, walked a long time with the Captain, then lay down on the skylight, read Miss Flora Tristan's work on Perú "Les Perigrinations d'une Pariah". Going along with the trade wind nicely. Gained several games at chess from the Captain. Don Vicente and I did not go below till 9 Oclock, when I went at once to bed.

Tuesday, $23^{\text {rd }}$ of May. The morning like yesterday, the day fine, the wind fair, at noon Lat. $18^{\circ} 50^{\prime}$. Long. $84^{\circ} 18^{\prime}$ gradually the wind dried away to nearly a dead calm.

Wednesday, $24^{\text {th }}$ of May. Began Josephus' history of the Jews; found it very tedious, continued playing chess a good deal being very costive I took one of the pills prescribed by Dr. Gallagher. The little wind there was came from the S.W. instead of the S.E. as hitherto. I had some talk with the second mate. He told me he had been twice shipwrecked, once in an old vessel, at some distance from Cape Finisterre when the bowport was stove in by a floating block of wood, in about 20 minutes the vessel sunk, all escaped in the long boat save a sailor and a lady passenger, another sailor died afterwards from thirst. At the end of two days they were picked up by a Spanish vessel and taken to Malaga, they had no more than one wine glass of water every 24 hours. The second time of his being wrecked happened between Dublin and whitehaven, when again one of the crew was drowned. The first mate who all his life time had been employed in long voyages had never found himself in imminent danger. Lat. 20.11.

Thursday, $25^{\text {th }}$ of May. When I went on the deck at 9 , we had a nice breeze and beautiful weather, in the afternoon the wind fell nearly calm, a heavy sea from the west, consequently much rolling.

Friday, $26^{\text {th }}$ of May. Rain obliged me to remain below, I grew very sick, and vomited, the weather thick with [53] little wind. Our meal times were as follow: breakfast about 9 Oclock, dinner at 2, tea 6 more or less. The Vicar of Bray was a temperance vessel, neither the Captain, Mates, nor men taking spirits or wine. Had the whole night a fine northerly breeze which continued on

Saturday, $27^{\text {th }}$ of May with rain, which obliged me to remain below, afterwards I laid down on the skylight and commenced reading Gibbon's splendid work "Decline and Fall of the Roman Empire". Noon Lat. 23.55' In the evening bad weather came on, which with a few interruptions persecuted us for more than eight weeks. I was playing chess with the Captain when he had to run on deck, a heavy squall with a rain from the N. requiring his 
presence there. The vessel began to toss about wofully, I hurried to bed where I remained till

Tuesday, $30^{\text {th }}$ of May morning, suffering dreadfully from sea sickness, vomited frequently, could not avoid spitting out continually a nasty tasting nauseous saliva collecting incessantly in my mouth, spent a very bad night from Sunday to Monday, when we were lying to for some time, and the rudder, knocking continually against the rudder case, made a deafening noise. The weather was wild with occasional squalls, when we were under double reef topsails and foremast stay sail. Sunday afternoon, there was a vivid flash of lightning, the reflection of which penetrated to my berth, it was accompanied by a loud clap of thunder. On Monday, the wind veered more to the South, and we were several points out of our course, making by far too much Easting. Sunday noon Lat. 25.10 Long. 84.30; Monday Lat. 26.30 Long. 83. On Tuesday the sea having subsided I got up but was so weak, that Mr. Sawyers first mate had to assist me on deck, here I took a light breakfast but feeling again sick, I only overcame it by lying down on the skylight. Whilst [54] talking with Gonsalez I happened to mention my little granddaughter Conradina, the bare mentioning of her name had such an effect on me, that I felt my eyes full with tears. Enveloped in my big cloak I remained stretched out on my usual retreat the skylight till past 8 OC, admiring the beautiful starlit sky. I then went to bed, but the Captain coming to my berth and conversing with me about his family I kept awake listening to his conversation, in the course of which he told me, that his parents were still alive, and resided in Bray, County Wicklow where his father carried on a small business in coal, lime and timber, he invited me after our arrival in England to spend a few days with his family, which I gladly accepted. Capt. Seymour was about this time 30 years old, had served his time on board the vessels of the large ship owners of Lpool. T. \& J. Brocklebank. He had been five times to the East Indies, three to the Mediterranean, and this was his fourth return voyage from the west coast. When Captain of the "Maipu" Brocklebank's swift sailing craft, he had made two quick voyages to Lpool., one from Callao in 84 days, the other from Valparaiso in 89. He was an orthodox protestant, in Politicks, consequently a true Orangeman, thoroughly detesting O'connel and his gang; "Orange and blue loyal and true" - "White and Green, not fit to be seen". The first two colors mark the Orange party, the latter the papist. It was late before I fell asleep somewhere about midnight.

Wednesday, $33^{\text {st }}$ of May. Got on deck at 9 O.C., a strong breeze from the west, our rate seven and a half knots pr. hour, course Sh. by Wt. A number of Cape pigeons were flying about. These are the last words I wrote in my pencil memoranda, hence forward sea sickness prevented me putting either pen or pencil to paper. I had to request Mr. Gonsalez to keep a short diary for us both. 
Though he had never [55] been at sea before he hardly suffered at all from sea sickness, on the contrary I saw him always moving about with an English Grammar in his hand. It was a dreadful time which I spent from this day till the 19 of July, exactly seven weeks. We had to content with frequent contrary gales, which obliged us either to lie to, or to be under storm canvas, which comes nearly to the same thing, in both which cases the motion of the vessel was so annoying, sometimes rolling, sometimes pitching that I could not otherwise but seek for some relief by lying in my berth, where many a time I had to remain from 60 to 70 hours, but even then not without occasional fits of vomiting. My berth, though the Captain's, had the great disadvantage of being very dark, the little light being admitted through a small bull's eye, so that it may be easily conceived how heavily such 60 to 70 hours hung on my hands, when at the utmost I could read only an hour's time every day by snatches just when the rolling of the vessel allowed the rays of the mid day sun to fall upon my pillow. The remainder of this time I had to while away as well as I could, talking with the Captain or Gonsalez which was a treat, dozing, sleeping, thinking till thought became fatigue, ciphering in my head till this even lost its interest. The manner in which I spent my time when the weather or the motion of the vessel allowed my rising was not much better. At about 8 Oclock the first mate used to come to my berth to wind up a small chronometer, the large one which cost 60 guineas being wound up only once a week, every Saturday afternoon at [_] Oclock I awoke usually and asked him how the weather was etc.? A few minutes afterwards, the boy José, a Peruvian from Tirana not far from Iquique, appeared with a tumbler of water to clean my berth, [56] an indispensable necessity never omitted under any circumstances. At ten Oclock breakfast, at first of arrowroot boiled in water and slightly sweetened, afterwards of tapioca, preferred from having more flavour. If the weather and the vessel's motion would permit of my going on deck I did so, at about 2 p.m. So the best of my recollection. We were near the Cape before my fellow passenger and I ventured on deck, when obliged to remain below I rose still later, when dressed reclined on the sofa until the Captain got up, which varied from four to 5 Oclock p.m. When too ill I remained where I was, and my dinner was brought to me, but when able I crept to the after cabin, the meal finished I returned to my couch lying there until 12, 1, 2 and 3 in the morning, conversing not usually my forte, for the lamp or candle placed on a distant table did not cast it's rays far enough to enable me to read on my sofa. Sometimes but not often the vessel's motion allowed me to sit up and to read or play at chess from tea time till I turned in. We were fortunate enough in not suffering from very intense cold; as I have just said, about the latitude of the Cape I first managed to get on deck, well covered up in the Captain's or Mate's peajacket, gloved, and 
my hat tied closely over my ears. I then used to walk 2 or 3 hours, when the days grew longer even 4 or 5 daily which exercise did me good removing the costiveness which troubled me in the beginning of the voyage. To remedy this I took a dose of castor oil which had its effect, but by the Captain's advice I had no more recourse to medicine but relied on a change of diet eating ship biscuits and drinking ale which combined with the exercise produced a healthy state of the digestive organs. Our dinners were very good, fresh meat always unless by way of a change or relish salt beef or pork was preferred, as long as the poultry lasted they constituted our daily dinner with potatoes, then the ducks, after which the [57] pigs and sheep, the latter lasting the whole voyage. The potatoes were less frequently placed on the table, when absent boiled rise was the substitute. We had always a good soup and pudding, the latter either rice, sago pumpkin macaroni or plum, the last generally reserved for Sundays. Pea soup, tripe, pease pudding (nautically dog's body) and fritters were our Saturday's fare. The Vicar of Bray being a temperance vessel the use of liquor was interdicted to the crew as well as to the Captain and Mates, as long as the cold weather lasted the Captain and first mate took their glass of ale and porter together with Gonsalez and myself at dinner, but when the season grew warmer they discontinued it, though we passengers did not. The Crew which had excellent salt meat pork, and ship biscuits ad libitum got tea or Cocoa instead of rum, and when the weather was particularly cold and the work hard, two nights I saw porter given them, a tumbler full each. At first the dinner hour was two O.C. gradually $3,4,5$, because the many weeks when the weather was particularly cold and bad, the days short, the sun, not over the horizon till 8.30, had set again at 3 p.m., and particularly whilst there was any danger the Captain never went to bed till between 4 and 8 in the morning, consequently he slept during the day. No one could have been more attentive to the ship's safety than he was, during the whole time the crew also was kept in excellent order. Frequently in the day time the sun was not visible, but then if the stars could be seen observations were taken in the night; either by their means or by dead reckoning he or the fist mate always ascertained the exact position of the vessel. Towards myself Captain Seymour was always particularly kind, sometimes I could not help contrasting his treatment with that received on board the "Wanderer", when I first sailed for the west coast. A poor "dependiente" then I was [_]bbed and of no account, now treated with the first [58] consideration, it was but natural to see in this difference the influence of the possession of more or less money. The first mate (Thomas Sawyers) was of a respectable family in Whitehaven, his father a collector of the Customs in Rochester, he was very gentle and quiet, he pleased me much. The Captain I thought treated him rather too harshly on account of his being as he said too 
indolent and negligent. Mr. Young the second mate was a common sailor but a good fellow, as second mate he had a handle of Mr. to his name. Mr. Sawyers dined with the Captain and passengers. Young, Duffy, the steward, and the boy José Montal sat down together after we had done. Gonsalez' black servant José took his meals on the floor. Duffy was a Catholic and an Irishman under an engagement to Father Mathew, the great temperance Apostle, to abstain from all liquor which of course he would not break. The remainder of the crew consisted of the Carpenter, Steward, four men before the mast, three boys or apprentices, the above Duffy, the $4^{\text {th }}$ apprentice, had taken the place of a steward dismissed by the Captain about a fortnight before leaving Callao. The Captain's pay I learned was $£ 8$ per month, $2 \%$ of the freight of the produce, $5 \%$ on that of the money and $1 / 2$ on the passage money the ship providing for the passengers. The first mate received from $£_{4.10}$ to $£_{5}$ a month, the second mate about $£_{3.10}$, the Carpenter generally ten shillings more than the second mate, the men before the mast $£ 2.5$ monthly, the boys a few pounds annually. The Vicar of Bray measured 281 tons register new measurement she has on board 6000 quintals of Nitrate of Soda and nearly 1800 bales of wool each 80 lbs. She stood in, ready to go to sea with spare canvas spars etc., provisions for the voyage out and home, and the usual advances to the sailors exactly $£ 6000$. She was built in Whitehaven A.N. [?] for 12 years at Lloyd's at $10 £$ pr. ton, which included the masts and [...] [59] but exclusive of the copper sheathing and sails. She was insured at $70 \mathrm{pr}$. cent out and home. When speaking of the weight of the copper sheathing, the meaning is so many ounces to the square foot, the heaviest used is 32 ounces, the lightest 16 . During my voyage I got through the following works: Guy Fawkes by Harrison Ainsworth, this novel treats on the Gunpowder plot and gives a good historical account of this horrible conspiracy, which was to have exploded on the $5^{\text {th }}$ of Novr. 1605. I do not like the Author's style, though this story is written in a much more sober and less pretentious manner than that of the notorious Jack Shepherd. The two Admirals by Cooper, the N. American Novelist, which marred, like most of his writings by his ridiculous Yankey prejudices, as if the States and those born there, were without doubt superior to the English and England, however pleased me much. The scene is laid on the Sh. Wt. coast of England, during the reign of George II about 1745. The hero is a young Virginian, whose character is but loosely sketched, but the two friends and Admirals Oakes a staunch supporter of the Hanoverian dynasty, and Bluewater a Jacobite in the innermost recesses of his heart, are exquisitely drawn. The Lord of the Isles' a scottish story of the reigns of James I and II, a very stupid work, a tissue of improbable events poorly written. "The old Manor House" not much better but in a different way, the events of the tale are few and spun out to a great and tedious length. 
The life of William III by G. Ryan, an out and outer Irish Orangeman, quite a party book but none the worse for that. William landed from Holland at Torbay Novr. $5^{\text {th }} 1688$. The life of Dr. Benn. Franklin partly by himself, and some of his essays, this is a sweet little book in a plain unaffected style, replete with common sense. "Two years before the Mast" or a voice from the Forecastle by K. H. Dana junr., which gives a plain unvarnished account of a sailor's life during a voyage of two years from Boston to California and back 1839 to 1841, and finally "Count Fathom", by Si[_], disgusting account of an accomplished villain [6o] [?] up with a number of unlikely events described sometimes in a licentious, sometimes vaunting style.

The following is a translation of the notes written by V. Gonsalez, for the greater part by my direction, until the $19^{\text {th }}$ July.

Wednesday, $37^{\text {st }}$ of May. Lat. 28-54 1/2 Long. 83-10.

Thursday, $1^{\text {st }}$ of June. Lat. 31-4 1/2 Long. 83-2.

Friday, $2^{\text {nd }}$ of June. Lat. 33 Long. 83 . From 10 a.m. till

Saturday, $3^{\text {rd }}$ of June at 6 a.m. a strong gale from the S.E. impeding our progress. Lat. 34-40 Long. 81.45.

Sunday, $4^{\text {th }}$ of June. Lat. 35.20 Long. 82.15.

Monday, $5^{\text {th }}$. Cloudy day, no observations. From 8 p.m. till

Wednesday, $7^{\text {th }}, 5$ p.m., lying to, a strong gale from the S.E. In the night from Tuesday to Wednesday a large ship with all sail set and a fair wind came straight upon us, the Captain on deck at the moment, had merely time to set sail. The Vessel then passed us at a short distance and was soon out of sight.

Thursday, $8^{\text {th }}$ of June. Lat. 37-46 Long. 82-50.

Friday, $9^{\text {th }}$ of June. Lat. 40-28 Thermometer at noon on deck 49.

Saturday, $10^{\text {th }}$ of June. Lat. 41-27 Long. 82-5.

Sunday, $11^{\text {th }}$ of June. Lat. 42-31 Long. 81-38.

Monday, $12^{\text {th }}$ of June. Lat. 45-12.

Tuesday, $13^{\text {th }}$ of June. Lat. 48-12.

Wednesday, $14^{\text {th }}$ of June. Lat. 50-10 Having now made sufficient westing from 2 p.m. the Captain endeavored to shape our course to the South East.

Thursday, $15^{\text {th }}$ of June. Cloudy, no observations.

Friday, $16^{\text {th }}$ of June. Do. Wind contrary S. E, lying to till

Saturday, $17^{\text {th }}$ of June 8 p.m. head E. 1/4 N. Lat. 53-20 Long. 84-4.

Sunday, $18^{\text {th }}$ of June. Fair wind since 4 a.m. Lat. 53-43 Long. 79 .

Monday, $19^{\text {th }}$ of June. Calm till 8 p.m. when a strong foul wind obliged us to lie to. Lat. 54-4 Long. 78-5.

Tuesday, $20^{\text {th }}$ of June. Lying to. Thermr. noon on deck $38^{\circ}$, in the water $32^{\circ}$. Wednesday, $23^{\text {st }}$. Very little wind. Lat. 54.14 Long. 78-5.

Thursday, $22^{\text {nd }}$. Head wind Lat. 54.30 Long. $76.23 \mathrm{~N}$. 
Friday, $23^{\text {rd }}$. Calm, cloudy, no observations. [61]

Saturday, $24^{\text {th }}$ of June. It snowed for the first time, Lat. 55.26 Long. 14.30.

Sunday, $25^{\text {th }}$ of June. A pretty heavy snow fall in the late. of the Cape $55^{\circ}$ 57 . The opinion as to the best time for doubling the cape varies considerably, no doubt according to each Captain's experience. Captn. Seymour is of opinion - in which I agree - that for it, the middle of summer is the most favorable, that is to say from Nov. to Jany., were it only for the long days, when darkness lasts a little more than 2 hours, whilst with us it continued for 17 , so that for fear of striking against icebergs we had always to shorten sail, when it grew dark, even though the wind was fair, of which fair wind we certainly had but a small allowance. It was a dreary sight, to see the sun even at noonday only a few degrees above the horizon say $8^{\circ} 15$ without any perceptible strength, and the sky of a pale sickly blue, so different from the deep azure of the tropics.

Monday, $26^{\text {th }}$ of June. From aloft but not from the deck the Isle of Diego Ramirez was visible. At 1 p.m. it bore E. about 38 miles distant, it was a fine sunny day, but the wind blowing strong from the N.E. impeded our making any progress. Lay to from 5 p.m. till

Thursday, $29^{\text {th }}$ of June at 4 a.m. when we had drifted considerably to the South. Lat. 58-30 Long. 64-31. We passed the Cape, 42 days after leaving Callao. The cold was very great, the oil in the binnacle lamp (bitàcora) froze, several times consequently the light went out. At 8 O.C. p.m. in the evening whilst I was lying in my berth the Captain and Gonzalez playing at chess, the former heard the man at the helin singing out - ice ahead. He immediately ran on deck and as he told us afterwards, there was a large mass just ahead of us, he added that we were actually in danger, for if he had not taken the precaution of shortening sail every evening, we might have run slap upon it the wind blowing fresh 6 to 7 knots breeze from the N.W. and if we had struck we certainly should have gone to the bottom. As it was, there was merely time to wear and [62] and turn our sail to the enemy, our distance from him being no more than a ship length.

Friday, $30^{\text {th }}$ ofJune. Wind fair, but at about 10 , we had a field of ice, extending before us from E. to W., at first the Captain thought of running again to the West, but on nearing the ice he observed a very narrow passage, left open, through which we just managed to scrape, when I went on deck, at 2 p.m. we had left the danger behind, but to the south of us I saw various masses floating upon the water, rising considerably over the level of the sea, they were of a shining white color. In the evening little wind, however, we stood our course $\mathrm{N}$. At noon Lat. 57-44 Long. 64-31.

Saturday, ${ }^{\text {st }}$ of July 1843 . At Noon Lat. 56-32 Long. 63-52. Therm. on deck 43, in the water 33 , little wind, course $\mathrm{N}$. 
Sunday, $2^{\text {nd }}$ of July. Lat. 55, 57 Long. 61-45. Strong breeze. We saw to windward a ship steering our course, believed to be the Royal Admiral, which with, the Philip Capt. Hill sailed twelve days before us from Callao for Lpool. We left her now astern.

Monday, $3^{\text {rd }}$ of July. An abominable day, contrary wind from N.E. Therm. on deck 32 in the water $35^{1 / 2}$.

Tuesday, $4^{\text {th }}$ of July. Lying to, wind N.E., head west.

Wednesday, $5^{\text {th }}$ of July. Do., do., Lat. 55.25 Long. 59.30 Therm. on deck at 9 1/2 a.m. 33, at 3 p.m. 43 .

Thursday, $6^{\text {th }}$ of July. A strong fair wind from the west, course N. Lat. 54.27 Long. 57.25 Thermometer at 3 p.m. 36 , the same in the water.

Friday, $7^{\text {th }}$ of July. Beautiful day, the wind and our course the same as yesterday, Lat. 51-40, Long. 56-30. The sun set at 4 p.m., the days were now growing longer. The Capt. went to bed at midnight, a good sign proving that the extreme dangers of our passage were passed. We were now abreast, Eastwards of the Falkland Isles of which I extracted the following description from Purdys Atlantic:

The group consists of nearly 90 islands lying between Lat. $5^{1}$ and $5^{2}$ 1/2 S. and 57.20 and 60-40 W. The two main Islands are now called the East and West Falklands. The western is the [63] Gran Malvina of the Spaniards, and the eastern la Soledad of the French, Falkland sound which separates them, is from seven to twelve miles broad, and contains many Islets, its harbours are safe and commodious. The eastern Island has a beautiful harbor Berkely Sound, called by the Spaniards the Bay of Acarrun, of easy access, where excellent water may be procured, also fine beef, excellent vegetables, and plenty of the finest antiscorbutic grasses. Though the eastern Island appears more valuable, yet of the western it was said long ago by the late Admiral Gower, "that the country abound, with long segy grass, and food consisting of Geese, ducks, widgeons, teal, etc." "We brought many pigs and rabbits to the Island which increased greatly, many beautiful pebbles were found on the beach. The mountains produce fine crystals which after being in the hands of a lapidary, appeared little inferior to precious stones." The western Islands are extremely high and may be seen $5^{0}$ miles off, the tops are entire rocks, the lower parts rich and productive. They contain fine lagoons abounding in wild fowl, there are likewise many rivulets, where water cresses, wild celery, and scurvy grass, are to be met with in plenty; and the banks produce excellent turf for fuel. On the side of the grand Island to the south and a few miles in the interior natural curiosities are met with, in the shape of huge amphitheatres, large caverns, etc., in which some beautiful stalactites have been found, which sufficiently indicate the presence of [?]. The climate of the eastern isle is temperate, the Thermometer 
never falling below $26^{\circ}$ not rising above $75^{\circ}$, its general range in winter is from 30 to $5^{\circ}$ in summer $5^{0}$ to 75 , the weather is rather unsettled, but the showers whether of rain, snow, or hail, are generally of short duration. Ice is seldom found above an inch thick. Thunder and lightning are of rare occurrence, fogs frequent, but disperse towards noon. These Islands are generally supposed to be the Pepys land of Cowley 1584. Sir Richd. [64] Haykins in 1594 called them Virginia and Maidenland, in honor of Queen Elizabeth. In 1639 Captain Strong gave the name of Falkland to the Frail between the two large Islands, which was afterwards extended to the whole group. In 1706 they were visited by the French from Sn. Mateo, whence the name of the Malvinas. In Feby. 1764 the French under Mr. de Bougainville attempted to establish a colony in Berkely Sound but the court of Spain claiming the Islands, the french establishment after a two year's existence was withdrawn amounting to 150 persons. In 1766 the English took possession of the western Island, and formed a settlement at Port Egmont, on the north side, until 1774 when they ceded it to Spain, who made no use of the Islands, but as a place for the transportation of Convicts. In Nov. 1820 Commodore Jewitt of the frigate Heroine took formal possession of the Islands in the name and by the authority of the British Gment. They were however unoccupied till 1825 when Louis Vernet a German obtained a grant of them from the Bs. Airean Gment., and settled there. The Eastern Island was made over to him as his settlement forever. In Oct. 1831, he was found happily situated in Port Louis, with his wife, superintendant, some slaves and a number of individuals from various nations, altogether about one hundred, subsequently Mr. Vernet left, but his superintendant Mr. Brisbane remained. Towards the end of 1832 or beginning of 1833 these islands were again taken possession of by the Commodore of H.M. ship Clio Mr. Curlew. Under order of the British Gment., a small party was left at Port Louis under a Mr. William Dickson, but on the 26 of Augt. 1833 he and 3 other principal persons along with Mr. Brisbane, were murdered by eight Gauchos and Indians, who then plundered the houses, pillaged the place, and drove off with their booty up the country. At the beginning of 1834 Ltenant. Hy. Smith was appointed [65] governor of the Islands accompanied by a small party as a nucleus of a future colony. The old settlement at the head of Berkely sound was fixed on as head quarters. It was estimated at that time, [_] head of fine wild cattle and 500 wild horses were roaming over the excellent pasturage of the eastern island. Small men of war have since been sent there, for the protection of the new settlement.

Saturday, $8^{\text {th }}$ of July 1843. Fine day and a fair wind. Course N.E. Lat. 48.59 Long. 54.30. At 10 p.m. the wind abated and changed to the Northward, our course E. Thermometer $34^{\circ}$. 
Sunday, $9^{\text {th }}$ of July 1843 . Lying to, from 4 a.m. to 4 p.m. when the wind became again pretty fair, cloudy, no observations, course N.W.

Monday, $10^{\text {th }}$ of July 1843. The wind increased gradually, since Sunday Midnight it blew a strong gale from the S.W., our course was N.E., we thus had the wind right aft. Just before retiring to my berth, I went up on deck, where I could scarcely stand. The night was terrific, to see the vessel in a fine moonlight night, with few sails set, surging through the water or rather through the mountains of waves at ten miles an hour, leaving behind her a foamy wake, moreover the sea as far as my sight could reach, was covered with the white crests of the billows stirred up by the gale. Towards the morning of

Tuesday, $17^{\text {th }}$ of July 1843 the wind slackened. Our rate was now no more than about 5 knots till midnight, when the wind blew right against us until

Wednesday, $12^{\text {th }}$ of July at 4 a.m. It then came again round to the right quarter, and increased to a fresh 8 knots breeze, the day was beautiful. Thr. on deck $44^{\circ}$, Lat. $43^{\circ}$ Long. $54^{\circ}$. The night fine, the Captain and I walked the deck till near three a.m. The aspect, which the Vessel and sea presented was similar to that of Monday night but on a scale more moderate. Capt. Seymour and I from our respective beds conversed till near day break. Without having [66] had a wink of sleep I rose for breakfast on

Thursday, $13^{\text {th }}$ of July 1843 which I had not done for many weeks. Mr. Gonsalez kept his bed with a swollen face. Towards morning the wind fell calm, and continued so till 5 p.m. when it went right ahead to the N.E. Lat. 42.50 Long. 44.12. Here about the problematical Island of Isla Grande is said to be situated L. 44 S. Long. 43 West. According to Purday it was discovered by an Englishman La Roche in the year 1678, but since then has not been seen again, though many navigators have gone in search of it. On the other hand signs of land such as small sea fowl, beds of weeds, and the change of the dark blue color of the deep sea to the pale green, which color denotes that the sea can be sounded, have been observed. Besides this, the same La Roche discovered another Island in Lat. $55^{\circ} \mathrm{S}$. far to the East of Cape Horn which was afterwards seen by Captain Cooke in 1771 and called by him Georgia.

Friday, $14^{\text {th }}$ of July. Day cloudy, in the morning a light breeze from the E., our head N. $1 / 2$ E. Lat. $42^{\circ} 35^{\prime}$ Long. $431 / 2^{\circ}$ the wind increased, and our course improved to the N.E. until

Saturday, $15^{\text {th }}$ of July 2 a.m. calm for the whole day. Lat. $41^{\circ}$ Long. $42^{\circ}$ Therm. on deck $45^{\circ}$, fine weather, wind during [...]

Sunday, $16^{\text {th }}$ of July. Since daybreak our course N. 1/2 E. [...] Lat. 40-37 Long. 42-17 Therm. $46^{\circ}$, a beautiful day. Captain Seymour when in Callao promised us that he would treat us to a bottle of Champaign at dinner the first favorable 
occasion, in celebration of rounding the Cape, the weather being propitious, the promise was now fulfilled. In the evening the wind increased rapidly so that on

Monday, $17^{\text {th }}$ of July we had to reduce our canvas. I went on deck for a few minutes where I vomited a little which I had not done for 19 days; not from not having felt nausea but because I had managed to keep on my back either on my bed or on the Sofa. Lat. $38^{\circ} 47^{\prime}$ Long. $42^{\circ} 56^{\prime}$. The wind going to the N.E. we had to lie to till

Tuesday, $18^{\text {th }}$ of July 8 a.m. the wind shifted to the N.W., later in the day to the W., course N.E., the very rough [67] and agitated state of the sea caused the motion of the vessel to be so unpleasant, that I was obliged to keep my bed. Lat. 37.25 Long. $431 / 2$.

Wednesday, $19^{\text {th }}$ ofJuly1843. Fine, fair wind, course E. by N.Lat. 36.40 Long. 37.11. Thursday, $20^{\text {th }}$ of July 1843. Fine, fair wind, Lat. 35.51 Long. 36-4, Therm. 62.

Friday, $27^{\text {st }}$. Cloudy, fine, fair wind _ Therm. 58 .

Saturday, $2^{\text {nd }}$. Day fine, fair wind Lat. 34.40 Long. $32-40$ Therm. 58. During these last four days everything had gone on so nicely and favorably, that I flattered myself we had passed all the disagreeables of the voyage, I threw aside my big cloak, for many weeks my inseparable companion during day and night when I had it thrown over all my other bed clothes, notwithstanding which in the neighbourhood of the Cape my feet used to feel like ice. I had my bed clothes taken on deck and aired, I examined my trunks, pistols, books, some of which had got a little wet. I looked over all the letters the Captain had on board -327 in number, which he had to deliver to the first pilot who came on board in the Channel. For each single letter the Post Office charges eight pence, and allows two pence to the Captain and one penny to the pilot. I began to make a copy of the [Vicar] of Bray, drawn by Mr. Sawyer - see appendix $\mathrm{N}^{\circ} 4$. $[\ldots]$ out my Italian books and vocabularies, in short I thought of turning over quite a new leaf, but I had reckoned without my host, for in the evening of this day it began to blow fresh, the wind shifted from the S. to E.

Sunday, $23^{\text {rd }}$ of July then to N.E. our head to W. under storm canvas. The pitching was almost insupportable. I parted company with my dinner, and was as sick as sick could be, of course turned into my place of refuge, my berth, at 6 p.m. the wind came round to the N.W. when the vessel resumed her night course N.E.

Monday, $24^{\text {th }}$ of July. In bed, on account of the dreadful motion of the vessel, the Captain having all sails set, slashing along with a strong breeze, and a press of canvas through a highly agitated sea, Lat. 30-52 Long. 30.50.

Tuesday, $25^{\text {th }}$ of July. The same as yesterday. I, in bed, [68] we steered N.E. 8 knots an hour until 3 p.m. when the wind veered to South, our course nearly due North. Lat. 28-10 Long. 29-13. About here there is no variation of the 
Compass, all the way from Callao hitherto the inclination to the E. that is to say if per Compass our course is N. we are really sailing N. with one or two points Eastwards. From here the inclination is to the west, increasing till we reach England. The cause of the variation of the Compass is still undiscovered. It varies continually, the degree of variation can be ascertained by taking the bearing of the sun and its setting, it being exactly calculated, where this luminary sets in the different latitudes. Purdy makes on this the following interesting observations; It is now well known, that the magnetic needle has a diurnal as well as an annual variation, from about 2 a.m. it verges to the west, until 2 p.m. it gradually returns to the E. until 8 or 9 p.m. when it becomes stationary, until next morning. In 1821 the mean variation was by observations of the royal society Somerset place London $24^{\circ} 11^{\prime} 18^{\prime \prime}$, in $2224^{\circ} 9^{\prime} 55^{\prime \prime}$ W., in $182324^{\circ} 9^{\prime} 4^{\prime \prime} 8 \mathrm{~W}$., in 1824 to midsummer $24^{\circ} 9^{\prime} 33^{\prime \prime} \mathrm{W}$., in 1834 under $24^{\circ}$. The Compass of 360 degrees is divided in 32 points, consequently one point is equal to $111 / 4$ degrees. Besides the variation the Compass is subject to an aberration, arising from a peculiar state of the atmosphere, aurora borealis, lightning, the local attraction of the ship, Iron, etc. The dip of the needle is a certain degree of inclination towards the earth which it acquired with its magnetic virtue. This property was discovered about the end of $16^{\text {th }}$ century by an English Compass Maker Robt. Norman; at a certain distance from the Equator either N. or S. it varies but little from an horizontal position, but depresses one end on receding either way from the parallel, the N. end when nearest to the N. pole, the S. end when nearest to the South pole. For instance at $10^{\circ} 57^{\prime} \mathrm{N}$. Long. $23^{\circ} \mathrm{W}$. no dip whatever or horizontal [69] at the Equator or rather at $0^{\circ} 11^{\prime} \mathrm{N}$. Long. 16-13 W. dip $17^{\circ}$, on the Equator itself at $0^{\circ} 11^{\prime} \mathrm{N} .17^{\circ}$ in London $70^{\circ}$ in Baffin Bay Long Bay nearly $86^{\circ}$ which dip is at most perpendicular, $90^{\circ}$ being fully so. At the time Purdy wrote these observations, the exact position of the magnetic pole had not been discovered.

Wednesday, $26^{\text {th }}$ of July 1843 . It now really appeared, that fine weather had set in, the sea being smooth and of course the motion of the ship such as would allow me to rise. I was up early and breakfasted with the Captain and Gonsalez. I occupied myself with writing, learning Italian, walking the deck, reading in the evening, and playing at chess; on such a day as this life on board was not unpleasant, the time slipped away fast enough. Wind from S.W., course N., 7 or 8 knots an hour. Lat. 25.9 Long. 28.49 Thermr. 62.

Thursday, $27^{\text {th }}$ of July. A pleasant day like yesterday, the wind not quite so fresh, however a nice rate of 5 to $6 \mathrm{knots}$, in the afternoon the wind S.E. here we caught the trade wind, which lasted till 7. of Augt. At 10 the Capt. changed the course from N. to N.E. to give a wide berth to the Island of Trinidad and Martin Vasrocks to our westward. Lat. 22.22 Long. 28.45 Therm 62. 
Friday, $28^{\text {th }}$ of July. Since day break, our course was again north, the day as pleasant as yesterday, Lat. 20.16 Long. 28.10 Ther. 68. I threw aside my underneath heavy clothing, also my silk shirt, the whole moring was spent in writing; it was almost a pity to remain below with such a beautiful day on deck. The Cape pigeons, our companions from the Tropic of Capricorn in the Pacific to the same tropic in the Atlantic had now begun to leave us, we had again reached the Tropics in the same latitude as Iquique. The island of Trinidad is situated (see Purday) in Lat. 20.31 S. Long. about 29.18 to 29.21 W. It is about 6 miles in circumference, the land is very unequal and at best no more [70] than a cluster of rocks with some shrubs in the valleys. The N. side is quite barren, to the south all the instertices of the rocks are filled with ever greens, there is also an abundance of sea fowl and many wild pigs; it is surrounded by sharp rugged coral rocks over which a surf is continually breaking. There is water enough for its few miserable inhabitants. On the west side there stands a stupendous arch, a natural passage made by the sea, through a high bluff about $800 \mathrm{ft}$ in height it is $40 \mathrm{ft}$ in width, nearly 50 high, and 420 in length, the depth of water about 3 fathoms. On the same side are two remarkable rocks, the one the "monument" called in 1700 by Dr Halley "the Ninepeen" cylindrical in form, $850 \mathrm{ft}$ high, with large trees on its top; the other at the south end, the Sugar loaf, of a conical form $1160 \mathrm{ft}$ and when it rains hard with a beautiful cascada of a fall of more than $700 \mathrm{ft}$. The Martin Vasrocks, the Eastern most Lat. $20^{\circ} 29^{\prime}$ $24^{\prime \prime}$ S. Long. $28^{\circ} 48^{\prime} 19^{\prime \prime}$ are three high barren rocks which when approaching Trinidad from the E.ward on its parallel will be seen at the distance of 8 or 9 leagues from deck. The central one is the largest, they are nine leagues from Trinidad, the distance between the entrances is 3 miles, they are steep and inaccessible. We continued during the night in the same manner, rate 5 knots, wind E., E. by S., E.S.E., course due N. Hitherto not much has been said about my companion "Don Vicente Gonsalez", a young man of some 26 years, the same who on board the Steamer in Huanchaco on 26 Ap. 1842, took me to Iturreguis house, and the next day up to Trujillo. He was pleasant and quiet, not particularly clever. He took great pains to learn English, but made no very great progress, his object in visiting Europe was to see something of the world, to purchase a cargo of french, and English goods, for Trujillo, for which purpose he had a letter of credit of Iturregui on A. Gibbs \& Sons, for $\$ 40,000$. His instructions were to stay from 4 to 6 months in England, the same time $[\ldots][71]$ and two months in Spain and Italy. Capt. Seymour was also anxious to acquire the Spanish language in which he succeeded pretty well. I observed that my frequent vomitings produced costiveness, this I attributed to the bile being thrown up, some time must elapse for the fresh supply requisite for the digestive process to be secreted, and return to its usual channel, to enable the bowels to discharge their functions with due regularity. 
Saturday, $29^{\text {th }}$ of July. We continued during the night on the same N. course, going from 5 to 7 knots per hour; when I was called in the morning, the motion was greater than on the preceding day, however I rose at $8 \mathrm{a} . \mathrm{m}$. I found when going on deck that we went through the water from 7 to 8 knots, our course N., a fresh wind from the E. to E.S.E., which did not vary through the day. Lat. $17^{\circ} 38^{\prime}$ Thermr. $72^{\circ}$. I occupied myself in the morning with making out the capt.'s specie manifest; he had on board almost exclusively in Gold and silver bullion, rather more than $3[5] 5,000 \$$ worth; about 7 tons in weight, with a few hard dollars in addition. After dinner I began a letter to my wife, after tea I felt squeamish, the vessel's motion having increased. I kept off sickness by removing from the aftercabin to the fore cabin, where it was less felt. During the night we went on in the same manner, at $2 \mathrm{O}$ clock for about $1 / 2$ hour we ran at the rate of ten or even more miles, the wind increased so much as to make the Capt. take in some of the light sails.

Sunday, $30^{\text {th }}$ of July. No observations. We ran fast through the water, there was so much motion that though I managed to have my hair cut by one of the sailors, to shave, and to write some lines I was at last compelled to lie down. It was a cloudy day, and rather squally, our rate from 8 to 9 knots, the motion was so strong as to compel me to recline the whole day on a sofa in the fore cabin. Towards night the wind moderated a little, I finished Smollet's Humphry Clinker, in my opinion [72] the best of his novels, but occasionally disfigured by obscenity and licentiousness. At noon Latitude $14^{\circ} 42^{\prime}$ Long. $28^{\circ} 5^{\prime}$.

Monday, $37^{\text {st }}$ of July 1843 . Fine day, sun shining brightly, our rate a little less than yesterday, wind more aft., motion less, and then though not quite well, I managed to remain on deck; till dinner time I wrote my diary, and to my wife, passing the time nicely. Lat. $11^{\circ} 43^{\prime}$ Long. $27^{\circ} 50^{\prime}$ Therm. $76^{\circ}$, how different from the weather a month ago!

Tuesday, ${ }^{\text {st }}$ of August. Our wind the same, E. by S. to E.S.E., course N. by E., weather fine, heat perceptibly increasing, even before breakfast it was hot on deck, at this meal we had two flying fishes fried; rather dry, but good. Yesterday the dead lights were taken off from the windows of the After cabin allowing the entrance of plenty of light and fresh air; they were fastened down ten or twelve days after leaving Callao, Lat. $8^{\circ} 44^{\prime}$ Long. $27^{\circ} 3 / 4^{\prime}$, Therm. $78^{\circ}$. At noon a vessel passed us, standing to the south, about a mile off. The sailors took down the strong sails replacing them with old ones, an economy always practised in latitudes, where fine weather prevails. I finished an odd volume of Tracts and Horus of the Irish peasantry - written apparently by a Protestant in a pleasing style, and giving an interesting account of the catholic Irish lower class, about 25 or 30 years back.

Wednesday, $2^{\text {nd }}$ of August. At 7 Oclock I took a pleasant salt water bath in a large tub on deck. The day hot, Lat. $5^{\circ} 44^{\prime}$ Long. $27^{\circ}$ Therm. $78^{\circ}$. Gradually the 
heat became so intense that for the day, I dispensed with my coat, waistcoat, and cravat, the wind moderate, on deck some time after tea till past 8 , the moon shone clear and bright.

Thursday, $3^{\text {rd }}$ of August. Bathed again in the morning, the thermometer both in the air and in the water stood at $75^{\circ}$. At 12 O.C. Lat. $3^{\circ} 17^{\prime}$ Long. $27^{\circ} 52^{\prime}$ Thermr. 79. A beautiful day, but little wind. At 4 Oclock a vessel was sighted from aloft, going our course, distant perhaps 20 miles.

Friday, $4^{\text {th }}$ of August, The day fine but sultry, the wind light at 12 Lat. $1^{\circ} 41^{\prime}$ Long. $28^{\circ} 3^{\prime}$ Therm. $79^{\circ}$. The following was my [73] mode of living for some time: I rose at 7 or 7.30 , sometimes a bath, sometimes not, walked the deck for exercise, learnt my Italian Vocabulary till Breakfast, generally made a good meal, cold meat, bread and butter and an arrowroot boiled in water slightly sweetened. The interval between breakfast and dinner 1.30 was occupied with writing and drawing, finished my sketch of the "Vicar of Bray" appendix $\mathrm{N}^{\circ} 4$ in pencil, commenced translating Botta's history of Italy into Spanish. When the table cloth was laid I went on deck till summoned to dinner between 2 and 2.30. After dinner whilst the second party were dining I stayed on deck, reading, walking or lying down. When the cabin was clear I returned to it and wrote till dark about 5.30, then till tea time, patrolled the deck again, after tea ditto with the Captain till 8, then read for a couple of hours, finishg. with Chess till 12 or 12.30. By this time, quite well I was pleased with my way of living, and did not find it insupportable; cut off, as it were, from all intercourse with the world. There was nothing to ruffle the temper save the occurrence of foul winds and calms and being free for the time from many of the major and minor ills of active life. Captain Seymour gave me for perusal his description of an excursion from Iquique into the neighbouring Nitrate of Soda and Silver districts, which pleased me so much, that I asked him to allow me to take a copy, which is affixed in the appendix under number 5 ... I need scarely add that my request was very willingly acceded to.

Saturday, $5^{\text {th }}$ of August 1843. Wind and weather like yesterday's, we were again in the Northern Hemisphere, which I had left more than 19 years ago, how changed since then my situation in life, my plans, my views. I may say almost everything relating to me was altered. I, when I revolved these things in my mind, was filled with feelings of gratitude to God for having disposed events in such a manner, as to enable me to gain a competency sufficient to support myself [74] and family in such a way as accorded with my ideas. In the early part of the day I bathed. At noon our Lat. was $8^{\circ} 4^{\prime} \mathrm{N}$. Long. $28^{\circ} 18^{\prime}$ Thermometer $81^{\circ}$, the moon being in her first quarter, the evenings on deck were beautiful in the extreme; the sea as smooth as a mirror, the wind of course light. Having passed the line, we had per promise two bottles of Champagne 
at dinner a fourth was to be drunk on the coast of England being made, which would within 30 days be, according to a bet of a bundle of cigars Captain Seymour proposed to Mr. Sawyers he declined taking it.

Sunday, $6^{\text {th }}$ of August 1843 . Exactly like the preceding day. Every one clean, shaved and in sprucer attire than had been or wont for some time past sat down to breakfast. Therm. $78^{\circ}$ Lat. $1^{\circ} 54^{\prime}$ Long. $281 / 2$, our course was attired to N.E. by E. which was done to avoid, or rather to counteract a strong current, which runs here towards the west and North West, and a proof of which was our having made in the last 3 days $38^{\prime}$ west longitude, though our course had been always N. by E., this current coming round the Cape of Good Hope in a $\mathrm{N}$. Westerly direction, to the bight of Benin, sweeps all through the Southern Atlantic, to the north of Colombia, where following the trend of the land it rushes into the Gulf Stream, which (see Purdy) like an immense river wends its course eastwards between Cuba and Florida, northwards between Florida and the Bahamas setting thence nearly parallel to the American coast, in a N. N.E. and Easterly direction. Gradually losing its impetus, it falls to the southwards on the meridian to the west of the Azores or Western Isles, and is finally lost in the Sargossa or weedy Sea. The length of the gulf stream may be estimated at more than 3000 miles from the Mexican gulf. It's velocity varies from $11 / 2$ to $31 / 2$ miles pr. hour, its narrowest breadth is in the strait of Florida between Cape Florida on the west, and the great bank of Bahama to the East, a distance of 3[_] [75] to 36 miles, it gradually widens, and its limits in breadth I make out to be to the South, in Long. $73^{\circ} \mathrm{W}$. Lat. $35^{\circ} \mathrm{N}$. and W. to the north in Long. $60^{\circ}$ W. Lat. $411 / 2 \mathrm{~N}$. a distance of about 390 nautical miles.

Monday, $7^{\text {th }}$ of August 1843. A fresh breeze with the same beautiful weather, I extracted from the Lpool Times of 20 Sept. 1842 the following description of the Great Britain, Iron Steamer, then being built in Lpool.: "She is built entirely of iron, with the exception of the floor parts of her decks, and the flooring and ornamental parts of her cabin. She is $324 \mathrm{ft}$ in length aloft, or upwards of one hundred longer than our largest line of battle ship, her extreme breadth 51 " (on this point Capt. Seymour was of opinion, that $51 \mathrm{ft}$ of breadth was a misprint for 81 feet, it being the general rule for vessels built in such a manner, to make the utmost breadth one fourth of the length) "her depth of hold $32 \mathrm{ft}$, her register 3200 tons. She has four decks, the lowest of Iron for cargo. She can accommodate 360 passengers, each with a single bed without a sofa being made up. The principal Saloon is $108 \mathrm{ft}$ long, 32 wide, $83 / 4$ high. She has sufficient stourage for 1000 Tons of coal and 1200 Tns of measurement goods, 3 boilers capable of containing 200 Ts of water, heated by 24 fires, four Engines each $25^{\circ}$ horses power, 1400 tons of Iron have been used in their construction. Her mode of propulsion is by the newly improved Screw Propellor patented 
by Smith of London, she will be fitted with 6 masts, low as compared with her size." I finished another novel called Gretun Green, though rather amusing if not so interesting as the old Manor house, is in reality poor stuff, also Roderick Random by Tenollet which 20 years ago I denied the ne plus ultra of a fine novel, I now considered far inferior to Walter Scott's and Bulwers novels; even to Dickens writings and Le Sage's Gil blas I give the preference.

Tuesday, $8^{\text {th }}$ of August. No alteration, fine weather, good breeze, the rolling of the vessel increased a little, the crew having completed mending the sails, took down the short top masts and put up the long ones. At noon Thermometer $80^{\circ}$ Lat. 6.30 Long. 27.33.

Wednesday, $9^{\text {th }}$ of August. Thermometer 81 ${ }^{\circ}$, Lat. 8.14 Long. 27.13, the wind [76] decreased at 2 Oclock, heavy showers of rain, then a calm for an hour followed by a little wind. We were now in the Variables.

Thursday, $10^{\text {th }}$ of August 1843. Till noon little wind, then a light breeze, heavy showers, intense heat, Therm. $82^{\circ}$ Lat. $9^{\circ} 33^{\prime}$ Long. $26^{\circ} 32^{\prime}$, calm in the evening and night as well as

Friday, $11^{\text {th }}$ of August. The sky clouded with occasional rain, no wind, at noon a breeze sprung up, too much however from the North, obliged to steer E. by N. The Captain told me his object was [...] make northing, only as much easting or westing as the winds forced him. For about a week I slept on a sofa in the after cabin, on account of the heat frequently with no more covering than a cotton night shirt. Patrolling the deck after tea time in company with the Captain, enjoying the fine moonlight night I found almost a luxury after the day's great heat.

Saturday, $12^{\text {th }}$ of August. No change, about 7 Oclock a.m. when I took my bath, the sun shone out, it was a really hot day, at 12 Oclock to the North a vessel in sight Ther. $82^{\circ}$ Lat. 10 1/2 Long. 26.50. After dinner I occupied myself with making an abstract in Spanish from Botta's history of Italy, which I submitted to V. Gonsalez for correction. This was more or less an employment for a fortnight. At six on deck, in the horizon the clouds were shaped like mountains, Mr. Gonzalez compared them not inaptly to the Andes bounding the plain of the sea which I had never seen quieter, not the slightest sign of a wave, nothing but a long undulating movement caused by the Ocean's swell. I threw a bit of wood over board where it formed numberless circles spreading farther and farther, until entirely lost, exactly as if the mighty Atlantic's waters were those of a fish pond, of course the vessel did not obey the helm but veered about in all directions. After tea on deck, a fine starlight night. Jupiter shone so brilliantly as to be reflected in the water, I could distinguish Mars also with his red light. 
Sunday, $13^{\text {th }}$ of August. At 8 Oclock, a light breeze from the N., enough to ripple the water, our rate about 2 knots an hour [77] no bath this day, that the newly painted bulwarks might not be [_]oiled by the overflowing from the tub. Therm. $82^{\circ}$ Lat. $10^{\circ} 33^{\prime}$ Long. [_] ${ }^{\circ} 15^{\prime}$. At 2 p.m. two vessels in sight, at 4 I could see them without the aid of my glass, at 5 we tacked N. by E., both vessels approached fast, showing N.A. colors we hoisted our English, the smaller ship a schooner crossed our Bow and went on her course southward. Capt. Seymour supposed her bound for the Brazils, the larger one, a fine vessel, seemed inclined to speak to us, the Captn. ordered the yards of the mainmast to be squared, those of the foremast remained as they were. This pretty manoeuvre I had never seen before - the result was that the sails of the foremast filled by the wind in the usual manner propelled the vessel forward, whilst those of the mainmast backed (as it is called), swelled in contrary direction, or towards the stern. Thus the two influences being exactly opposed, neutralized each other, and the vessel remained stationary, or nearly so. This is called lying to - but very different from the lying to in a strong gale, under storm canvas. The Vessel's head was east all the time. At 6.15 Oclock the American passed our stern, closed by. The Capt. hailed her with "Ship ahoy" - N.A.: Hello! - Seymour: where are you from? - from N. York - where are you bound to? - Canton - How many days out? 26 - N.A.: where are you from? - Seymour: Lima. Then Capt. Sey. gave the N.A. some directions regarding the winds he was likely to meet - Seymour: where did you lose the N.E. trade? in $13^{\circ}$ - Seymr:: your long. $27^{\circ} 20^{\prime}$ Seym.: $26^{\circ} 50^{\prime}$ any news? N.A.: nothing fresh, where are you bound to - Seym.: London - How are the English getting on in China - N.A.: I believe all is settled - Sey.: a pleasant passage to you - thank you - the same to you. The Fanny Pratt (such was her name) continued her course and we ours, N.W. with a nice breeze.

Monday, $14^{\text {th }}$ of August. The day like the preceding, a cloudless sky and great heat Ther. $83^{\circ}$ Lat. $10^{\circ} 45^{\prime}$ Long. $27^{\circ} 50^{\prime}$. At noon tacked E. by N. [78]

Tuesday, $15^{\text {th }}$ of August 1843 . Bathed in the morning. The day clouded, at noon a drizzling rain, the heat less than the preceding day. To the south a barque in sight, she hoisted colors not distinguishable, the Capt. imagined her dutch or French, gradually we gained on her. At 10 a.m. a fair breeze, our course good N.W. by W. believed we had caught the trade, a mistake. I finished Tom Cringle's log originally published in Blackwood's magazine, where I had read the greater part of it. The Author is Mr. M. Scott, I found it amusing with a graphic description of the West Indies, the life there, and various encounters between English Men of war and Pirates and Slavers. I considered it too highly colored, and written for effect. 
Wednesday, $16^{\text {th }}$ of August. A cloudy day, not so rainy as the preceding; Lat. $12^{\circ} 3^{\prime}$ Long. $29^{\circ}$. In the middle of the day a heavy shower came on, which lasted the whole afternoon, evening, and night, for several hours it was accompanied with a fresh breeze, which carried us along at the rate of 5 knots per hour. At sun down half past six a vessel appeared in sight, ahead of us.

Thursday, $17^{\text {th }}$ of August. At 6 a.m. the breeze ceased, calm till nearly noon, when we sighted a vessel coming up with a fair wind, on reconnoitring her with a spy glass, Capt. Seymour made her out to be the same bark, seen on Friday. She hoisted her ensign, the Swedish flag, blue with a yellow cross, and took it down, and run it up again half way. This Capt. Seymour considered a sign of distress and though favored with a fresh breeze from the west, just sprung up, we stood about and went to meet her. It was pretty to see how with the same wind the Swede ran to the Northward, and we to the Southward. She passed us close by to the westward, when Capt. Seymour after having hailed her, asked the Captain if he wanted anything to which was answered "Bahia" evidently showed the question was misunderstood - it was repeated, the answer was nothing. Capt. S. was greatly provoked at the loss of time and abused the other roundly, "a d-d Dutch lubber" was one [79] of the rhethorical flourishes, which struck my ears. The vessel was the "Halcyon", she continued her course, we ours, having turned about and at 4 p.m. we had passed her considerably. Lat. $12^{\circ} 57^{\prime}$ Long. $28^{\circ} 34^{\prime}$. Later on, rain with squalls, which lasted during the night, and continued till

Friday, $18^{\text {th }}$ of August blowing nearly right aft. Our Course north, the day cloudy and rainy, the heat less, the bark out of sight, probably we had left her behind. It was too cloudy to get a sight. Towards evening the wind abaled, until at 9 p.m. it was a dead calm. I finished my rough abstract in Spanish of the $3^{\text {rd }}$ volume of Botta's excellent history of Italy from 1789 to 1814 . During the night there was not a breath of wind. Duffy fearing lest some water might enter the Cabin had shut the Stern windows, consequently the heat was excessive, I suffered more from it than during the whole voyage, I awoke the next morning with a bad headache.

Saturday, $19^{\text {th }}$ of August. The Captain and Mate attributed my headache to my having exposed myself on deck to the Sun's rays, with only a silk cap on. In this opinion I did not agree but thought it was caused by my having eaten too much and taken too little exercise; this day I ate little and drank no beer, took a great deal of exercise on deck, which measures made me quite well. At about 8 a.m. a light air reached us, at 10 we had at last caught the trade N.E. which blew at the rate of 7 to 8 knots the whole day and night, sometimes more sometimes less, our course to the westward. Lat. at Noon $15^{\circ} 32^{\prime}$ Long. $29^{\circ}$. The Thermometer in the Cabin below the skylight $82^{\circ}$. 
Sunday, $20^{\text {th }}$ of August. At 3 Oclock a.m. the $2^{\text {nd }}$ mate called the Captain up, with information that a vessel was in sight. When I went on deck she was distinctly to be seen, we hoisted our ensign, she did the same, we then ran up some signal flags according to Capt. Marryat's instructions, she changed her course a little and [8o] approached us, Capt. Seymour believing her to be the Philip, took in sail and waited for her. At 11 a.m. we were so close that Capt. S. could speak to her Captain through his trumpet. She was the Georgina, Capt. Wilson, from Valparaiso to Lpool., 75 days out with 6500 [qls] of Nitrate of Soda, no light freight and $\$ 30,000$, she was to the windward and as Capt. S. said, kept the wind from us, we therefore stood out a little more to the W., to get clear, and then gradually went a head, The Vicar of Bray's number in Captain Marryot's code of signals $8^{\text {th }}$ edition was 3281 , in the $2^{\text {nd }}$ list of merchant vessels, which number expressed by the following flags: $1^{\text {st }}$ at the top dark blue with a white ball which is the distinguishing signal of the second list, secondly below this flag another divided vertically, the one half white, the other red for number 3 , thirdly a flag with horizontal stripes, dark blue white in the middle and dark blue, the figure 2 , fourthly a flag blue with a yellow square, for 8 , fifthly a flag white with a blue square figure 1 . About this time we were abreast the Cape Verde islands, which according to Purdy are situated between $14^{\circ} 48^{\prime}$ and 17.12 Lat. N. and $17^{\circ} 12$ and 22 long. west. Their names are Sal or Salt Island, Bonavista, Mayo or isle of May, Santiago, Fogo Brava, San Nicolas, Raza, Santa Lucia, San Vicente and San Antonio. Alcalá says these Islands were discovered in 1446, by the Portuguese, to whom they belong, that Santiago and San Felipe are the only two inhabited, the Capital is Porto Praya in the former, most of the inhabitants are Africans, the sole export is salt. Thermometer $80^{\circ}$ Lat. $17^{\circ} 37$. Long. not ascertained.

Monday, $27^{\text {st }}$ of August. A clear day, a strong breeze, our rate from seven to eight knots. The Vicar lay over a good deal, the motion was greater and more disagreeable than we had had it for many weeks past. The Georgina continued to windward without any change in our relative positions, the temperature was considerably cooler, though the Thermometer in the midday stood at $80^{\circ}$ Lat. $19^{\circ} 36^{\prime}$ Long. $32^{\circ} 5^{8}$. [81]

Tuesday, $22^{\text {nd }}$ of August 1843 . Wind, weather and course like the preceding day - the variation of the Compass 1 point west, our direction by Compass nearly N.W. The Georgiana still to windward about 3 to 4 Leagues distant. At midday Therm. $78^{\circ}$ Lat. $21^{\circ} 30^{\prime}$ Capt Seymour was a little disappointed, that we had not made more latitude, as he was not anxious to make more westing, he had the sails braced up more and going thus closer by the wind our course was by compass nearly due north. By these means our rate was not so fast through the water but we did not make so much westing, the Captain remarked, that 
the ship did not sail at her usual speed, owing to the seaweed and barnacles fouling her bottom, and also to some of her coppers being [_]bbed off by the ice when rounding the Cape. At $3 \mathrm{O}[$ [] k p.m. sighted another vessel, but which running before the wind was soon lost in the distance, by her build the Capt. took her to be a spanish ship.

Wednesday, $23^{\text {rd }}$ of August. At noon lat. 21-6 1/2 Long. 36.38 Therm. 81.

Thursday, $24^{\text {th }}$ of August. Wind, weather and course the same as the previous day. Arrow root all consumed as well as the rice, the vegetables at dinner in smaller proportions, and less variety in the puddings, one day bread, the next flour with raisins, few and far between. In the evening the wind fell to almost a dead calm.

Friday, $25^{\text {th }}$ of August. A beautiful day of which the Capt. availed himself to paint the vessel outside and varnish the quarter deck, the main skysail was also set again, which had been down for the last six days. The Georgiana still in sight to windward, and right astern at a greater distance than the Georgiana another ship. We had now entered the Sargossa or weedy sea, but so far only a few bits of weeds had been seen, the Capt. said in his late passages he had seen but little. Therm. $80^{\circ}$ Lat. 27.52 Long. 37.18.

Sunday, $27^{\text {th }}$ of August. In the Variable, though with but little wind [82] which compelled us to tack several times to improve it. The day was beautiful the $102^{\text {nd }}$ since we left Callao and though so long a time had passed we still had good dinners to wit. We dined this day on preserved beef soup, preserved fowl, preserved vegetables, mashed potatoes, salt beef, plum pudding and a bottle of ale. Thermr. 80 Lat. 29.10 1/4 Long. 38.13 1/2.

Monday, $28^{\text {th }}$ of August 1843 . At about 6.30 the sun set most splendidly, hardly had the fiery ball touched the superficie of the ocean, when it was immersed in the same, whilst for some time the clouds just above were of the richest golden hues imaginable, reflected in the sea which lay expanded like a mirror, or rather like a mass of molten lead unruffled by the shiniest air, only broken by the slow heaving of the ocean into large masses, some of dark blue, others of a milky white color, which varied according to the gradual rising and falling of the swell. Also the pale light of the moon and of Jupiter was reflected in the Sea, altogether the evening was most beautiful, a description of which I have attempted to give but faintly, not possessing the talent to describe. I remained some time on the deck enjoying the beautiful evening, interrupted in my meditations by occasional questions of Mr. Gonzalez for one or other English word. I reflected that those stars which looked down on my insignificant self, had gone through their invariable course for thousands and thousands of years, and for thousands and thousands more would still roll on, whilst countless generations would pass away and leave not a trace behind "Oh! God is great and we, how small, little, and insignificant." Nothing is more true than "life 
is a dream". I have lived half a century and this time nothing! A mere breath, a dream, such were the thoughts evoked by the splendid and yet solemn scene around.

Wednesday, $30^{\text {th }}$ of August. The whole night was a dead calm, at 8 a.m. a light breeze sprung up just sufficient to curl the water, the day was very fine, certainly warm [83] but hardly too hot, and the ocean broken into myriads of small waves, the top of each shone upon by the sun glittered with an uncommon brilliancy. Of our companions the Georgina was scarcely visible, and the schooner at about 9.30 a.m. was perhaps two miles before us right ahead. The Captain sent the first mate on board in a boat, rowed by four of our men to buy some provisions, it took 35 minutes to reach her, his reception little pleased him, he could only obtain some rice and fariña as a gift and a quarter box of bad cigars, bought from the Capt. Fariña is the root of the Mandioca or Yuca dried, and ground on which the Slaves in Brazils are mostly fed. The Schooner was Prussian from Memel called the Dundee, 32 days out from Bahia with sugar, bound for lowes in the Isle of Wight for orders. We were now in the Horse latitude which name the Captain told me was derived from the circumstance that frequently English vessels with horses on board for the West Indies overtaken by uncommonly long calms were compelled to throw them overboard for want of water. At midday the Thermr. stood at $82^{\circ}$ Lat. $30-9$ Long. $38^{\circ} 34^{\prime}$. At sunset a flight of birds passed us, shaping their course to the S.S.W., their size was that of the Cape pigeon. They flew in the figure of a wedge. Again a splendid evening, the moon in her first quarter shed a mild silvery light over the scarcely ruffled surface of the Ocean. About 10 p.m. a breeze sprung up which continued till

Thursday, $37^{\text {st }}$ of August 2 Oclock a.m. when a sudden heavy rain came on, followed by a calm, which however did not last long, for the wind freshened to a 5 knots rate, course W. by E., variation 1 1/4 point. The schooner 3 or 4 miles off; for some days we were abreast the "Canaries" which islands according to I. Purdy are situated as follows

Lat.

Palma

Tenerifa

Fortaventura

Los Salvages

[84]

Ferro

Gomera

Gran Canaria

Lanzarota $28^{\circ} 38^{\prime}$ to $28^{\circ} 43^{\prime}$ $28^{\circ} 17^{\prime}$ to $28^{\circ} 28^{\prime}$ $28^{\circ} 4^{\prime}$ to $28^{\circ} 45^{\prime}$ $30^{\circ} 8^{\prime}$ to

$27^{\circ} 44^{\prime}$ to $27^{\circ} 47^{\prime}$ $28^{\circ} 5^{\prime}$ to

$27^{\circ} 45^{\prime}$ to $28^{\circ} 13^{\prime}$ $28^{\circ} 58^{\prime}$ to $29^{\circ} 25^{\prime}$
Long.

N. $14^{\circ} 45^{\prime}$ to $17^{\circ} 53^{\prime} \quad W$.

N. $\quad 16^{\circ} 15^{\prime}$ to $16^{\circ} 39^{\prime} \quad W$.

N. $13^{\circ} 48^{\prime}$ to $14^{\circ} 45^{\prime} \quad W$.

N. $15^{\circ} 54^{\prime}$ to ${ }_{-} \quad$ W.

N. $17^{\circ} 5^{6^{\prime}}$ to $18^{\circ} 9^{\prime} \quad$ W.

N. $17^{\circ} 7^{\prime}$ to

N. $\quad 16^{\circ} 30^{\prime}$ to $15^{\circ} 50^{\prime} \quad W$.

N. $13^{\circ} 30^{\prime}$ to $13^{\circ} 32^{\prime} \quad W$. 
I expected we should be in a few days opposite Pato Santo Lat. $33^{\circ} 3^{\prime}$ Long. $16^{\circ}$ $18^{\prime}$ and Madiera Lat. $3^{\circ}$ 37' Long. 16.38'. In the middle of the day a fine N. A. Brig crossed our bow. For dinner an excellent dolphin hooked by Duffy in the morning, it was served with good preserved oyster sauce.

Friday, $7^{\text {st }}$ of September 1843 . Several ships passed us, we gradually left behind us the Dundee and again neared the Georgina. Course N.E. by E. by compass, equal to N.E. by N. Lat. $32^{\circ} 57^{\prime}$ Long. $37^{\circ} 42^{\prime}$, no more sea weed. I occupied myself in making an abstract of the English history from Goldsmith's Compendium. A N.A. vessel some a few miles astern.

Saturday, $2^{\text {nd }}$ of September. All our companions, the Georgina, The Dundee, and the other vessel, were out of sight, a fresh wind from the South, our Course N.E. by E., we were going at the rate of from 8 to 9 knots per hour. Though the motion was not very great, it made me feel a little squeamish and compelled me to leave off my task, and take refuge on the sofa. The sea came in at the windows of the after cabin, and the dead lights were again put on, Therm. $80^{\circ}$ Lat. $35^{\circ} 261 / 2^{\prime}$ Long. $35^{\circ} 10^{\prime}$ a plank of the Bulwark was stove in, Course by Compass E.N.E. $1 / 2$ E. equal to [abt.] N.E. $1 / 2$ N.

Sunday, $3^{\text {rd }}$ of September. The same as the previous day, felt better in the middle of the day; we had run 203 miles or $81 / 2$ knots pr. hour Lat. $27^{\circ} 45$ Long. $32^{\circ} 13$, Thermometer 78 . We altered our course to make if possible some of the Azores at night, which are situated as follows:

\begin{tabular}{|c|c|c|c|}
\hline Formigas & uninhabited & Lat. $37^{\circ} 16^{\prime}$ & Long. 24.54 \\
\hline Sta. Maria & pop. 4500 & Lat. 36.54 & Long. 25.5 \\
\hline $\begin{array}{l}\text { Sn. Miguel } \\
{[85]}\end{array}$ & pop. 80,000 & Lat. $37^{\circ} 45$ & Long. 25.10 \\
\hline Terceira & 30,00o Inhabitants & Lat. $38^{\circ} 38^{\prime}$ & Long. $27^{\circ} 12^{\prime}$ \\
\hline San Jorge & 11,ooo Inhabitants & Lat. $38^{\circ} 29^{\prime}$ & Long. $27^{\circ} 50^{\prime}$ \\
\hline Graciosa & 8ooo Inhabitants & Lat. $39^{\circ}$ & Long. $27^{\circ} 57^{\prime}$ \\
\hline Pico & 22,00o Inhabitants & Lat. $38^{\circ} 26^{\prime}$ & Long. $28^{\circ} 27^{\prime}$ \\
\hline Fayal & 17,00o Inhabitants & Lat. $38^{\circ} 30^{\prime}$ & Long. $28^{\circ} 41^{\prime}$ \\
\hline Flores & 7000 Inhabitants & Lat. $39^{\circ} 33^{\prime}$ & Long. $31^{\circ} 8$ \\
\hline Corvo & $75^{\circ}$ Inhabitants & Lat. $39^{\circ} 41^{\prime}$ & Long. 312 \\
\hline
\end{tabular}

Variation of the compass about $21 / 2$ points West Purdy. We were abreast of Europe, Gibraltar being situated in Lat. $36^{\circ} 6^{\prime}$ Long. $5^{\circ}$ 19', Cadiz $36^{\circ} 32^{\prime}$ Long. $6^{\circ}{ }_{17}$, Cape St. Vincent $37^{\circ} 2$ Long. $9^{\circ}$, Lisbon $38^{\circ} 42^{\prime}$ Long. $9^{\circ} 8^{\prime}$

Monday, $4^{\text {th }}$ of September 1843 . At day break we were in sight of Fayal and Pico, when I went on deck about 8 Oclock, I could distinguish the two islands, 
with the aid of my glass, about 60 miles distant. I made a sketch of them

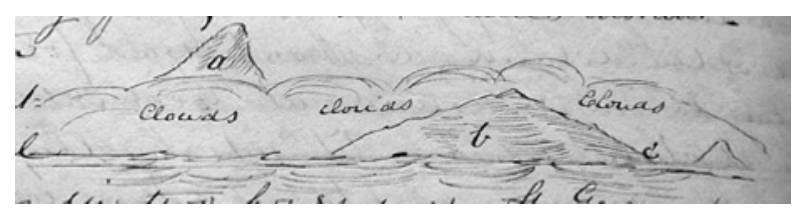
a. the island of Pico the mountain just above the clouds b. Fayal round its point c. the harbor. In two hours more St. George opened on us, like the other two, on our Starboard side. At 5 p.m. Flores and Corvo were distinguishable to the North. The sea became smooth and the wind abated, course E. 1/2 N. to E. by N., at noon Thermometer $76^{\circ}$ Lat. 39-7 Long. $29^{\circ} 2^{\prime}$. The following account of the Azores or Western Islands is taken from Purdy: They were discovered by Joshua Vanderberg from Brugges, about the middle of the $15^{\text {th }}$ century, soon afterwards, they were taken possession of by Enrique of Portugal, who called them the "Azores" or isles of Hawks. They were destitute of inhabitants and every animal except birds. The climate is delicious, the air generally clear and serene, the soil prolific. The cultivated parts the lava, once a stream of fire, are planted with oranges, lemons, and vines, the land formed from the decomposition of volcanic substances is sown with Indian Corn beans and wheat, there is still much waste land fit for cultivation, the coasts are steep and rocky. These islands have been and still are, much subject to [86] eruptions and earthquakes; their exports consist in fruits to England, corn, pulse poultry and cattle to Portugal, also vegetables, [...] to Russia and N. America. The residence of the Governor is Angra in Terceira, the Bishop lives generally in Sn. Michael, which Island contains 80,000 inhabitants, its city of Porto del Gada is the chief seat of commerce, it is like the remainder of the Azores. The production of volcanic eruptions, at present externally at least extinguished but supposed still to burn internally and invisibly of which the "calderas" or fountains of boiling water are evident symptoms. In the early part of the year 1810 (the flames were first seen in the night of Feby. 11) a most awful and tremendous explosion of smoke, flames, cinders, ashes, and stones of an immense size, issued from the sea, at a distance of half a league from the shore; at the western end of the island, a shoal was formed, on the 13 June it began to smoke, and at noon on the $18^{\text {th }}$, the crew and the Captain of the British Sloop of war the "Sabrina" observed the mouth of the crater, just showing itself above the surface of the sea. On the $20^{\text {th }}$, they set out on a cruise, leaving the volcano about $150 \mathrm{ft}$ high, still raging and increasing in size, on the 4 of July they returned, found a complete island formed and perfectly quiet. The Captain and several officers landed, they found it very steep from 200 to 300 feet high, but the ground was so very hot beneath their feet, that they were obliged to return, they took formal 
possession of it and hoisted the English Union Jack. Its form was nearly circular, its circumference about a mile, its appearance that of a crater, the cliffs on the outside as walls steep within and without, in its middle a large basin of boiling water, from which the smoke etc. issued. Subsequently this islet fell by degrees into the sea, by the middle of October, no part was visible above water, but a dangerous shoal remained. In Feby. 1812, smoke was observed still issuing out of the sea west of the spot. Before the existence of the shoal was known the big Swift [87] with all her crew was lost on it. Fraya Bay, in the island Terceira on the eastern side, is described as the largest and safest port in the Azores. The island of Pico derives its name from the remarkable peak or volcanic mountain which stands on it, and which, where the southernmost point of Fayal is in a line with it, appears thus:

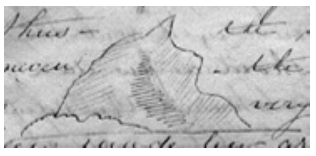

The sides of the mountain are neither very steep, nor uneven, the summit terminates in a small sugar loaf so very regular that one would think it had been made by art, (from the Vicar we did not see it. H. W.). "Its height above the sea level, 7043 Eng. ft. A view of Pico from Purdy:

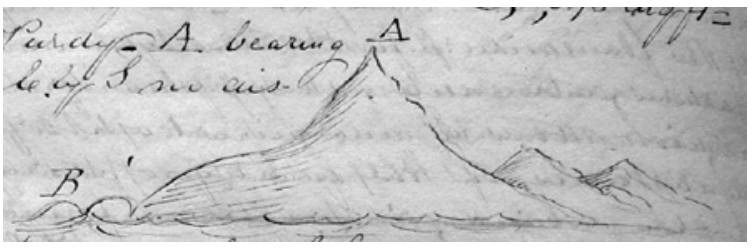
A. bearing E.S.E. by compass, B. E. by S., no distance given." The chief town of Fayal, is villa Orta, on the S.E. side, with 5000 inhabitants, opposite which is good anchorage, except that it is open to the winds from $\mathrm{N}$. to N.E. and from S.E. to S.W., that from S.E. blowing right in is very destructive, and thus vessels anchoring here should always be ready to start. A view of Fayal from Purdy: A. bearing N.E. by E. $1 / 2$ E. by compass, $B$. E. by S., no distance

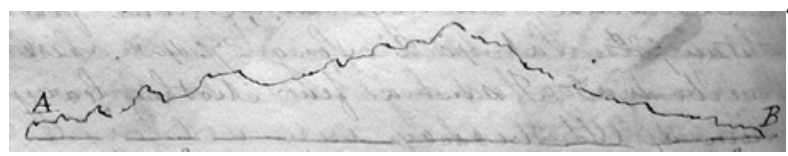
given. St. George 3 leagues from Pico, 8 from Graciosa is a long narrow island, about 9 leagues in length, and one in breadth. On the $1^{\text {st }}$ of May 1808 a dreadful volcano burst out about the centre of the island. On the $3^{\text {rd }}$ a crater was formed in size about 24 acres, its fire had nearly subsided on the same day, but in the evening of the $2^{\text {nd }}$, another small one had opened, the earth was rent in every direction, the whole island seemed convulsed. On the $5^{\text {th }}$, and succeeding days from 12 to 15 [88] small volcanoes broke out from the rents or chasms in the earth, throwing out a quantity of lava, which ceased about the $11^{\text {th }}$, on this day the large volcano again broke out, sending forth prodigiously large stones and an immense quantity of lava, which like a perfect river of fire (seen from Fayal) 
flowed into the sea. On the 5 of June its force began to fail, and in a few days after, ceased entirely. About 60 individuals of whom a few died, were scalded by flashes of steam, numbers of Cattle shared the same fate. The Island rich in herds, corn, and wine, was nearly ruined, supplies were sent from Fayal. Graciosa the most fertile of all the Azores takes its name from its beauty, and fertility in corn, fruit, pastures, and cattle, it supplies Terceira and several of the other islands with a large part of its produce. Its extent is only $81 / 2$ miles, but the quantity of its cereal crops is incredible; the same abundance in its wines, fruits, and vegetables, its only scarce article is wood. Corvo and Flores present nothing remarkable; the latter resembles a large lizard lying on the water, the former a tortoise.

Tuesday, $5^{\text {th }}$ of September 1843. We exchanged signals with a large ship, but owing to the great distance between us, we could not understand each other. Our course E. but owing to the wind having lulled, our progress was not much. Therm. $78^{\circ}$, Lat. $40^{\circ} 2^{\prime}$ Long. $27^{\circ} 46^{\prime}$. Here my straw hat was blown overboard, I saw a few Mother Carey's chickens behind the stern of the vessel.

Wednesday, $6^{\text {th }}$ of September 1843. We saw again the vessel of the previous day, supposed to be a Londoner, together with two others. Almost a dead calm, the weather most beautiful, not too hot, Therm. at noon $78^{\circ}$ Lat. $40^{\circ} 39^{\prime}$ Long. $27^{\circ} 12^{\prime}$. The Captain had now put his crew on Watch by Watch, the meaning of which is explained by the following: A ship's company is always divided into two watches, the one, the Starboard, the right hand side headed by the Capt. whose stead the $2^{\text {nd }}$ Mate takes, the other, the larboard, "the left" headed by the $1^{\text {st }}$ Mate. [89] The day and night are divided into seven watches; the first from 8 a.m. to 12 , the $2^{\text {nd }}$ from 12 to 4 p.m., the $3^{\text {rd }}$ from 4 to 6 p.m., the $4^{\text {th }}$ from 6 to 8 p.m. (the two are called dog watches, and are instituted, in order that the night watches fall one night on the one, the other night, on the other half of the crew), the $5^{\text {th }}$ from 8 till midnight, the $6^{\text {th }}$ from midnight to 4 a.m., and the $7^{\text {th }}$ from 4 till 8 a.m. During the night the one half of the men is below, whilst the other is on deck, unless something particular makes it necessary that all hands should be called up, whilst during the day, from daybreak to sunset, or from 6 to 6 all are on deck, occupied someway or other, but as a kind of reward for good conduct, and when nothing of importance is required to be done, half of the crew is allowed to remain below, also in the day time, when it is their turn, this is the meaning of the expression "watch by watch". I whiled away time by walking the main deck full 1250 times the distance 40 of my feet, equal in all to 16,125 varas, or $21 / 4$ leagues of 6650 varas each.

Thursday, $7^{\text {th }}$ of September 1843 . The calm and fine weather continued, more than 20 dolphins were caught before breakfast, with a baited iron hook. There were hundreds around the ship, they are an exceedingly voracious fish and 
rapid in their motions, great enemies of the flying fish, their length is from 12 to 16 inches. Having heard and read so much of their changing their color and of the beautiful hues they exhibit when dying, I viewed them with much attention, it was true that their color changed a little from gray and white into a greenish and ultimately into a brownish shade, but the great beauty of the reported changes must be looked for in the imagination of the beholders. The Grains, the instrument with which the Captain and Mr. Sawyers tried in vain to spear these dolphins, ("dorados" in Spanish) consisted of a large pole [90] with five hooked prongs at one end, one in the middle surrounded by the four others, the other end of the pole was loaded with lead so that as soon as a fish was speared it turned up throwing the prongs with the prey trains fixed out of the water. Close to the leaden extremity, a ring was fastened through which a line was passed, which allowed the weapon to go a great depth into the water when cast and by means of which it was pulled up again. Therm. $78^{\circ}$ Lat. $41^{\circ} 3^{\prime}$ Long. $27^{\circ} 10^{\prime}$. When on deck at 6 p.m. we saw several shoals of flying fish fly out of the water, they appeared to skim only the surface and after a short flight plunged again into the deep; these risings out of their native element are to escape their enemy, the dolphin.

Friday, $8^{\text {th }}$ of September 1843 . Therm. $76^{\circ}$ Lat. 42.34 Long. $23^{\circ} 8^{\prime}$. At abt. 4 p.m. a great hubbub on deck excited my attention, the man at the helm told me, that all on a sudden the wind had taken the ship completely aback, shifting from W.S.W. to N., varying from half west to half East; we made an east course by compass, with as much northing as possible, the yards were braced up sharp, and we went at the rate of 8 to 9 knots per hour, by 7 Oclock, the wind abated a little. To the N.W. an English Man of war was visible. The temperature being so much cooler, I changed my drill trousers for cloth. The sky was so cloudy, and the deck so wet, that every one called it a second edition of the Cape, though on a more moderate scale.

Sunday, $10^{\text {th }}$ of September. The temperature was now changed in an extraordinary manner, it was actually cool, and during the night, I found blankets quite necessary. We had during the evening a fresh breeze, which continued till morning. Therm. $68^{\circ}$ Lat. $43^{\circ} 20^{\prime}$ Long. $20^{\circ} 2^{\prime}$, about opposite to Cape Teneriffe, which lies in Lat. $42^{\circ} 54^{\prime}$. The vessel we had last seen, was not a Man of war, but a large ship, which gained on us, the wind died away gradually to a ca[_] [91] at day break.

Monday, $17^{\text {th }}$ of September 1844 . A fine sunny day, Therm. $66^{\circ}$ Lat. 43.2 Long. 19.26. A quantity of fish was caught of a kind unknown to all on board, color black, eyes prominent, length about 15 inches, we had one for dinner, with preserved oyster sauce, we found it very good: for the first time since leaving Callao we had no pudding, sugar having become scarce. 
Tuesday, $12^{\text {th }}$ of Septermber. I awoke early at 6 a.m., I did not hear the rudder thumping in the rudder case, a good sign! I inquired the reason, and was told that a breeze had sprung up in the night from N.N.E., not exactly in our favor, however we made progress to the Eastward, at the rate of 7 to $71 / 2$ knots per hour. The yards were braced up and our good ship jumped about in fine style. At noon Thermr. $66^{\circ}$ Lat. $43^{\circ} 27^{\prime}$ Long. $18^{\circ} 2^{\prime}$, to the N. of Coruña. At a later hour I felt a little squeamish, which increasing towards evening drove me to bed at 9 Oclock.

Wednesday, $13^{\text {th }}$ of September. Wind, weather, course, and motion like yesterday. At noon Therm. $68^{\circ}$ Lat. $43^{\circ} 12^{\prime}$ Long. $15^{\circ} 30^{\prime}$ Capt. Seymour said our distance from Lizzard Point was $620 \mathrm{~m}$. In the afternoon the wind shifted to the westward and we made a good course, without much motion.

Thursday, $14^{\text {th }}$ of September. At noon the wind was from the S., we made on the Starboard tack the same course, which the preceding day we had made on the Larboard. Looking from the poop or helm forward the Starboard tack means that the wind comes from the right, then the weather side (Barlovento in Spanish) and the vessel leans over to the Larboard, then Lee (sottovento) side, and vice versâ. At 1 Oclock p.m. the wind came suddenly from the N.E. having gone round the Compass in less than 24 hours, our course N.N.W. at 4 p.m. we tacked and at 5 p.m., the wind came from the N. We went E. by N. a good course, at the rate from 5 to 6 knots pr. hour, one thing with another [92] it was a most disagreeable, cold, wet, cloudy, boisterous, squally afternoon, however our course was fair, with a fresh breeze. At 2 p.m. the sun came out, we ascertained our position to be in Lat. $44^{\circ} 13^{\prime}$ Long. $13^{\circ} 34^{\prime}$. It blew strong towards night, which of course I passed badly, the sofa on which I slept in the after cabin being to windward, every time the ship rolled I slided against the board, put to prevent my falling out, and as it was rather thin it bent when I came against it with any degree of violence. Hence forward I slept again in the Capt.'s berth, which I had occupied during the first part of the voyage.

Friday, $15^{\text {th }}$ of September 1843 . The sea was high and the wind strong. Therm. in the Cabin at $67^{\circ}$, peajackest and Sou'westers (tarred or oiled hats with broad brims behind, resting on the back to prevent the rain running down the neck) again appeared. Our course between E.N.E. and N.E. by E. by compass. The Capt. wanted the wind to come a few points more free, that is to say, to turn more to the westward so as to enable him to weather Ouessant Anglice Ushant, the N.W. Cape of France, Lat. $48^{\circ} 28^{\prime}$ Long. $13^{\circ} 16$ ', without tacking. By lying down I kept from vomiting, but did not feel quite well, I finished Alessandro Verris "Notte Romane", a splendidly written work, it represents the Author as conversing with many of the great men of Antiquity, such as Cicero, Cesar, Pompey, etc., 
whose shades are supposed to be assembled in the tombs of the Scipios, close to Rome, which tombs were discovered about 1780 , and were afterwards visited by this Author. I read also the life of Sappho, and that of Erostratus who set fire to the temple of Diana in Ephesus, the night when Alexander the Great was born, by the same Author. These two last works of Verri I consider inferior to the Notte Romane. At noon we were in Lat. 45.3 Long. 11.10, 360 miles from Lizzard Point. At sunset it rained, which calmed the sea a little, by degrees it went down so that

Saturday, $16^{\text {th }}$ of September was a very different day from the previous [93] the weather was [mild], the sea smooth, and the wind [_] ed to a calm, our course about N.E., at noon Therm. $68^{\circ}$ Lat. $46^{\circ}$ Long. $10^{\circ} 10^{\prime}$. A scarcity of ink began now to be felt. At midnight a light air sprung up from the south, afterward from the S.S.W. which lasted during the night as well as

Sunday, $17^{\text {th }}$ of September 1843, a pleasant mild day, with little rolling. Our progress slow, at the rate of 4 knots pr. hour, with a fair wind to the E. by N. by compass variation full two points, at noon Ther. $68^{\circ}$ Lat. $47^{\circ} 16^{\prime}$ Long. $8^{\circ} 59^{\prime}$.

Monday, $18^{\text {th }}$ of September 1843 . A most beautiful day, as far as the weather was concerned, the sun shone out brightly, not a cloud to be seen, and the sea just rippled, but as regarded the wind, we were badly off, there was hardly any, and the little there was, blew right out from the British Channel. The Capt. told me, we were more or less 150 miles from Lizzard Point. We saw continually passing vessels, so that I ceased to notice them. We were at this time considerably in the Chops of the Channel, the sea had changed from the beautiful blue of the Ocean, to the dirty green of the shoal water. About this part of the entrance of the Channel the so called Rennel's Current, running across the mouth is sometimes perceptible "Occasionally (see Purdy) it is of considerable breadth and length, Lat. $49^{\circ} 51^{\prime}$ Long. $5^{\circ} 10^{\prime}$, it sets frequently athwart the entrance to the N.W. and W.N.W. at some distance west of the island of Ushant, and Scilly; a prevalence of the westerly and S. Westerly winds in combination with a current, that commonly sets into the southern part of the bay of Biscay, causes an accumulation of water in the Bay, which seeks to escape by setting to the N.W. or W.N.W. Though a certain amount of northerly indraught is always to be allowed for, with the tide of flood, on approaching the Scilly Isles, the Current sometimes will be scarcely felt. According to Capt. Seymour, the Current comes from the Atlantic, from the west along the north of Spain, until it reaches the land, it then runs a- [94] long the coast to the N. and N.W. across the Channel, part to the west of Ireland, and part into St. George's channel, sometimes at as much, as one mile pr. Hour." At noon Lat. $48^{\circ} 6^{\prime}$ Long. $7^{\circ} 39^{\prime} \mathrm{Th}$. $67^{\circ}$. Mr. Sawyers went by the Captain's orders on board a brig, for which we had waited, she was the Caroline from Uckermünde in Prussia, laden with grain 
from Hamburg to Newcastle, which having discharged, she was on her way thence with Coals to Algiers, from Algiers, she was to proceed to Alexandria; the Mate brought from her Captain a loaf of sugar, a cask of beef, a canister of oil, and some potatoes. He brought back also a Newspaper "The Pictorial Times" of 12 Augt. which contained the News that Espartero, the Regent of Spain "el Principe de la Victoria" had fallen from power, and taken refuge on board the English man of war "the Malabar" on the $28^{\text {th }}$ of July, whence he had gone to England, he was upset by Generals Narvaez and Concha. Espartero was at this time about 50 years old, the youngest of ten children of a carpenter, sickly in early age, his father destined him for the church, when the French invaded Spain in 1808 he exchanged the Student's gown for the soldier's uniform; in the expulsion of Napoleon from Spain, he went to Sh. America and in 1824, after the capitulation of Ayacucho, he returned from Peru to his own country, a Brigadier with £8o,ooo [?] gained at the gaming table. Before leaving Arequipa he proposed to one of the many sister's of my wife's mother, daughter of Agustin Velarde, a respectable burgher who like many of his townsmen united the pursuits of trade and farming, Espartero's offer was declined by Miss Velarde, on account of his inveterate propensity for gambling. In 1825 he married into a wealthy family; in 1833 when Ferdinand died, he took a decided part in politicks, opposing himself to Don Carlos. He was often defeated by Zumallacarregui, the Carlist Commander, but when the tide of victory turned in favor of the Cristinos he was made Regent of Spain. The Queen Mother and the Minister [95] on the [...] Espartero as the leader of the so called "high party" with his secretary Linazo, on the other, were far from agreeing, a storm of revolutionary fury rose, caused in a great degree by the Queen dowager, Cristina, having signed some political measure, to which he was opposed. It was calmed only by the former ceasing to exercise any power in state affairs. In Oct. 1840 Espartero became in consequence the head of the regency. Since then he governed Spain until as before stated he was up set by the revolution of July last. In Germany on the summit of the Teut- or Grotenberg $1200 \mathrm{ft}$ above the level of the sea in Westphalia, a colossal statue of Herman, who defeated the legions of Varus, was to be erected by subscription among the Princes of Germany. The figure of the hero was to be $45 \mathrm{ft}$ in height raised on a circular temple of solid sandstone $100 \mathrm{ft}$ high as a pedestal, to be made of plates of copper, hammered and fixed upon a framework of iron bars. The sculptor, who has been named to carry out the design, is a certain Bandel. As far as I know the project has not yet been executed (1868).

Tuesday, $19^{\text {th }}$ of September 1843 . During the night and morning, we continued the same course about E.S.E., at Noon Therm. $68^{\circ}$ Lat. $47^{\circ} 5^{\prime}$ Long. $6^{\circ} 25^{\prime}$ only 134 miles from Lizzard Point, 61 miles from Ushant; at 4 p.m. a number 
of porpoises from 4 to $5 \mathrm{ft}$ long, gambolled round the ship. At 6 p.m. Duffy our Steward, a fine hearty Irish lad and José Montel a disagreeable sulky little peruvian boy from Iquique, put the tea things on the table, securing them by the means of a frame work made of wood called a fiddle fastened on the table, at which time I used to go on deck remaining there, till summoned to tea. After tea I went again on deck, and stayed till 8 Oclock after which hour, the time till midnight (bed time) was spent in reading and playing at chess, varied now and then with conversation. At 6 p.m. we had a very thick fog, at 7 we could hardly see twice the vessels distance, [96] a situation fraught with some peril in a part where numerous vessels were passing.

Wednesday, $20^{\text {th }}$ of September 1843. At 4 a.m. we tacked again, at 8 Oclock I went on deck, found the weather thick, the water smooth, the wind fair, and our course E. by N. at 10 a.m. 31 miles from Ushant, just ahead. At noon Therm. $70^{\circ}$, Lat. $48^{\circ} 20^{\prime}$ Long. [?]. We tacked again, and hove the lead, which brought up, 68 fathoms deep, a little brown sand and shells, at 4 p.m. another tack, head N.W. 18 miles from Ushant, the weather thick and foggy.

Thursday, $27^{\text {st }}$ of September 1843. Before 6 a.m. I was awakened by Mr. Sawyer's telling the Capt. that a Man of war was in sight, I went instantly on deck, and found her close by, with a pilot boat a little astern of her. The Capt. signalized, showing the Vicar's name, which being done the Thunderer, 74 guns, with 1130 soldiers on board went on her way, for such we afterwards learned was her name. From the Pilot boat a launch with 3 men came on board the Vicar, after some haggling I agreed with them to land Mr. Gonzalez and myself at Penzance for $£_{4}$ each, they trusting to our generosity for any further gratification we might be disposed to give. We got our luggage and each with a trunk, a carpet bag, cloak and hat box, at about half past nine Oclock, left the Vicar, after having spent on board 126 days minus a few hours. She was then about 60 miles to the N.W. by compass of Ushant. The launch took us to the Pilot boat, which on her main sail had painted 9/S in black, the figure 9 denoted her number, and the letter $\mathrm{S}$ that she belonged to the Scilly islands; when we had jumped on board the boat, the launch was hoisted up on deck with great care by the men with their hands alone, the opening in the bulwarks was then closed with a thin plank, the launch, when on deck occupied more than a fourth part. The pilot boat measured about 30 tons with one [97] mast not far from the vessel's head, this mast had an enormous spanker boom with its corresponding sail, which was called the main, above it the Gaff topsail, and before the Gib, the flying Gib; they tacked with the greatest ease in about a minute's time, these boats sailed as close as five points to the wind, whilst the Vicar could go no nearer than 7; and 
many vessels only 8 points. There were 30 pilots belonging to the Scilly Isles, licensed by the board in Trinity house, which board sent 3 examiners for that purpose, but the number of boats was at the time, no more than 12. Seven men formed a crew, but on board ours, there were six only, all elderly men, save one, who was about 30 . As soon as we were on board, the "Agnes" for that was her name so called from the name of the island she came from, "St. Agnes", I wrapped myself up in my cloak, and sat down in the Stern Sheet of the launch. At 12 Oclock we had dinner on deck, it consisted of a plate full of boiled salt beef and potatoes, both very good. We ate freely using our fingers. We finished nearly a whole bottle of Claret, Capt. Seymour unaware that the pilots were temperance men had supplied us with rather too large a stock of wine. At one Oclock we had six vessels in sight, one outward bound, the Vicar, and one close to her, on the same tack, a heavy sailing Brig with timber, probably from Canada, the Man of war and another pilot boat $\mathrm{N}^{\circ} 25$ from the Islands. We stayed on deck until 6 p.m., when we went below; the cabin was much more roomy than I expected, but rather low, in an adjoining little bit of a hole were two jugs of tea on a table, (Capt. Seymour had also furnished us with both tea and sugar as well as bread) and salt beef, we returned on deck and remained there till seven, when we again went below. A Candle was set on the trunks and after having rested a short time I turned into one of the berths which I did not too scrupulously examine, feeling certain I should not find it over clean. During the day we had [98] steered more or less to the North. I had hardly lain down, when we tacked and stood to the East South East, I covered myself up and was soon fast asleep.

Friday, $22^{\text {nd }}$ of September 1843. I rose at seven, when dressed went on deck, at 8 we breakfasted below, tea, bread, and salt pork. All yesterday's vessels had disappeared, there were now three in sight, two large full rigged ships, probably Dutch Vessels bound for Batavia, and a schooner beating up the Channel. The weather was fine, the sky was clear, the wind pretty fresh, but contrary. We went at the rate of 5 knots pr. Hour, head north, at 12 steering N.N.E. we saw St. Agnes' light house, Lat. $49^{\circ} 53^{\prime} 38^{\prime}$ Long. $6^{\circ} 19^{\prime} 23^{\prime}$, just ahead of us, about 6 miles distant. Gradually the land itself became visible, and also very many desolate rocks extending to the westward; at some distance further in the same direction against a single dangerous rock, the waves were dashing and foaming, a light house was about being built on it. St. Agnes is the most westerly of the Scilly Islands, nearly three miles in circumference, with a population from 250 to 300. At 3 miles distance from it, we tacked with our head to the S.S.E. but in about an hour's time we again tacked, with our head to N.E. by E. by Compass. I must not forget to state that at noon we had our dinner as yesterday improved by 
a nice flour pudding. Gonzalez went below to take a long siesta and I also lay down in the bottom of the launch, at 4 Oclock when I looked up, we were close in among all the Islands. Next to St. Agnes to the Eastward, follows St. Mary's, the largest of all, about nine miles in circumference with a town of the same name; behind St. Mary's to the North lies Sampran the smallest island of the six, consisting merely of a large field with five or six inhabitants. St. Mary's runs out to the Eward., in a point where is situated the anchoring place, then succeeds somewhat in the back ground from St. Mary's about N.E. Frisco and Briars, and again in the same line with St. Mary's various rocks and finally St. Martin, the Eastermost inhabited Island, at the east head of which a pill [99] is erected to warn the Navigator of the dangerous [...] tones half way between St. Martin and the Landsend covered at half tide and close to which a light ship is stationed (visible to us when the sun went down). To the east of St. Martin there is another uninhabited Island, the round island. The Scillies belonged formerly to the Duke of Leeds, after his death the duchess sold them to a Mr. Smith, of whose arbitrary measures our Pilots complained bitterly. These islands, rocks with a fertile soil on them, are fruitful. Potatoes at the period of which I am writing cost only $2 / 6$ the hundred weight, they produce however not sufficient grain, flour must be imported from England. Some kinds of fish are found here, in great abundance. The lobsters and crawfish taken, are sent to the London market. There are no Catholicks in the Islands, the inhabitants whether of the Established Church or dissenters with the exception of a few in Frisio were followers of Father Mathew, of course the Pilots must be included also in the number, this beneficial measure was brought about by a baptist minister, some five years previously. When I lay down before seven Oclock feeling squeamish the wind was very light.

Saturday, $23^{\text {rd }}$ of September 1843. I was roused before six Oclock with the words "we are in the bay of Penzance" when I went on deck we were close in on shore. Certainly the view was delightful and presented the most pleasing appearance, the whole Bay open to the South, more or less, sketched all round. Instead, of the high barren gray or brown looking west coast of South America, nothing but undulating hills covered with green fields, \{After the departure of Mr. George A. Coleman on the $6^{\text {th }}$ of March 1868 , these Extracts were continued on the $11^{\text {th }}$ of the same month under my direction by Mr. George Barker [Cipher of George Barker]\} [100] with trees, with white houses, with churches and high chimneys, belonging to the steam engines at the entrances of the [_], peeping out through them. At the North West side of [_] Bay is situated the Town of Penzance, of which the "History of Mounts Bay" 1831 says, "that perhaps without exception it can boast of a warmer climate than any other in England". Following the bend of the Bay on the Eastern side, stands the town of Marazion, 
which, according with the said book, though well sheltered from cold winds by a considerable elevation of land to the N., is far less eligible as a residence for Invalids than Penzance, being exposed to the S.W. winds. From Marazion the Bay extends to the S.E. and S., and abreast of the same, about in the S.E. corner lies a mountain or rather rock, with a Castle on the top, which looks exceedingly beautiful and which gives to the whole Bay its name of Mount Bay. This Bay (I follow in many instances the above named book) is situated at the most western extremity of England and is formed by an irregularly curved outline of several miles in extent, the southern and western points of which form the Lizard and Lands' End. When we left the Pilot boat and entered the Launch, Mr. Gonzalez's hat box was wanting; he was sure it must be onboard, the pilots said, it was not to be found, and Gonzales had to go without it, which small loss annoyed him greatly. At about 7 1/2 we landed - the pleasure I felt on being once more on English ground was inexpressible. Our luggage was taken to the Custom-house officers' room, who hardly looked at it, and our pilots then showed us to the Union Hotel, where we washed, shaved, dressed and had an excellent breakfast of tea, eggs, muttonchops, and bread and butter. We then presented ourselves at the collectors of the Custom-house, where some formalities had to be gone through with our passports; after that we strolled about the town, looked into the principal church, ordered our dinner for $61 / 2$ and set out [101] on a long walk. The impression this place made upon me and Mr. Gonzales was pleasant in the extreme. It is a bustling, lively place; the houses, for the greater part built of granite stones stuccoed and the roofs covered with slate, some of 3 stories high, and others, outside of the town with porticos and flower gardens in front; also the maid servants, blooming girls with fair complexions, decently dressed in printed Cotton gowns pleased us much, so different from the abominable Lima Zamba wenches, and notwithstanding their large feet and absence of bosom, they might be called good looking. The Church was a new building and extremely neat and pretty inside, with beautifully painted windows, the exterior built in an antique gothic style. We left the town, the further we went the more we were pleased with the beautiful weather, the green fields, the shady walks, the rich foliage and here and there a park-like gentleman's estate. We first walked in a northern direction and after some time turned to the right, passing a flour mill and crossing a splendid green field we emerged in the high road, which, running close to the Beach, leads to Marazion. We followed the same, soon reaching this little town and leaving to our left two small villages and various smelting Establishments. In Marazion we took a lunch consisting of ale, bread, cheese and pickles and had ourselves rowed over to the Mount St. Michael, on the top of which the castle is built. An old lady showed us, together with another man 
and his wife, not first rate people as to gentility, over the different apartments. Every thing was kept in the best state of preservation; in one room we saw some old Canvasses, the dining saloon, now called the "Chase room" was ornamented with a frieze, representing various modes of hunting, the wild bull, the stag, the ostrich and rabbit. The walls were adorned with the arms of the different members of the St. Aubin family, at the upper end were the royal arms with the date [102] of 1644 and at the opposite end were the aims of the Godolphin family. The roof was superbly decorated with a profusion of carving in English oak. Two chairs were pointed out to us, the one said to be 300, the other 500 years old. There was also a beautiful window of stained glass, representing our Saviour and various religious subjects. The Chapel was of the Ghotic order, with stained windows and several curious specimens of scriptural pieces of ancient sculpture in marble. This mountain is isolated at high water, at low water it can be approached over a kind of causeway formed by pebbles and shingles; it is about 400 Yards from the shore of Marazion, fm. its base, more or less a mile in circumference, to the summit of the tower, whither a winding narrow staircase of 62 steps leads from the Chapel, the height is about 250 feet. The ascent is neither steep nor difficult; just below the entrance to the Castle stood a battery mounting 11 Guns. From the summit the view was as extensive as it was beautiful. At the foot of the rock lies a village containing about 250 Inhabitants, an artificial barrier is formed by two granite moles, which stretch out from the Mountain into the Bay and afford a safe anchoring place. The owner, at the time, of these Islands, was, Sir James St. Aubin. Shortly after Christianity first gained a footing in Cornwall, this hill was dedicated to religious worship, and as it was believed that the Archangel Michael was fond of preaching among those rocks, it obtained its present name. On the summit of the mount, a projecting stone, probably the remnant of a stone [lanthorn] still goes by the name of St. Michael's Chair. In after times the castle has often been taken and retaken in the course of civil wars in England. Henry de la Pomeroy held it out for Richard Coeur de León, against his brother John Lackland. In the reign of Henry VII, Lady Catherine Gordon, wife of Perkin Warbeck, took [103] refuge there, until she was obliged to submit to Lord d'Aubeney. At the time of the great rebellion it was strongly fortified by the King's adherents, and was taken after an obstinate conflict by the troops under Colonel Hammond. We were rowed back from this rock, in the crevices of which numberless wild rabbits were gambling about; to Marazion, whence we returned on foot to Penzance. When we approached the town heaps of ore and some structures, which we believed to be steam engines, and which we saw at a short distance, induced us to deviate a little from the high road. We came to 
the entrances of the mines, small circular holes in the ground, boarded round, just large enough for a man to descend into them by means of a ladder. Many people were at work, they allowed us to look at every thing, and gave ready replies to my enquiries, nevertheless neither from them, nor from a fellow traveller on the following day, did I obtain sufficient information to satisfy my curiosity. I learned that on ladders, the one fastened to the other, the miners descend into the bowels of the Earth to the depth of 120 fathoms and even in one instance to that of 240 . The wages they receive are more or less $45^{\mathrm{s}}$ weekly, the ore is brought to light by means of winches; to the west of Penzance, as far as Land's End, it contains mostly tin, with a small admixture of sulphur whilst to the east of the same place, its principal component part is copper, with some tin. In the former district blasting is mainly resorted for detaching the ore, whilst in the latter, this is brought about by manual labour with pick-axes. The ore when above ground is either crushed between two iron cylinders or pounded. The copper Ore was in 1843, and is still in 1868, shipped for smelting to Swansea, whilst the tin ore, after having been heated to make the sulphurous particles evaporate, is [104] is smelted on the spot. On other points I could obtain no satisfactory answers, such as how the winches were put in motion, whether the Ore was brought to the surface through the same aperture into which the miners descended, whether the engine served to keep the mines clear of water, etc. When we reached Penzance, we walked over the building where meat was offered for sale. It is large and airy with glass windows and a handsome cupola in the centre; upon long rows of tables, very cleanly kept, all kinds of meat were spread out. The Town Hall, a Catholic, and Wisleyan Chapel, were also pointed out to us. At six o'clock we had a nice dinner at our Hôtel, fried fish, beefsteak, vegetables, apple-pie and 2 bottles of porter. Having done ample justice to these good things, we again strolled out and were surprised at the many people whom we met in the streets; it was Saturday night; the labouring classes, which had received their weekly pay, were laying in their provisions for the Sunday. Fish, fruit and shoes covered the stalls; also bread, cakes, cheese, butter and other provisions. Well pleased with this day's work, Gonzalez and I took our tea and wrote our respective diaries till midnight, when I had to settle the Hotel Bill not without some dispute with the waiter on account of the servants' perquisites.

Sunday, $24^{\text {th }}$ of September 1843 . We rose at 5 , packed up our traps and had hardly time to swallow a cup of coffee, when the impatient mail coachman in his official red coat with gold lace summoned us our seats, which we took outside. There was but one passenger inside, and in the course of the day we had a continual change of travellers. At first, the morning was rather cool, 
but by and bye, when the sun rose it became a delightful day, it was not the scorching heat of the tropi[_] [105] sun, it was the genial warmth of the northern sun on a fine autumn day. For 2 miles we followed the road, by which, on the preceding day, we had come from Marazion, then leaving this to our right we drove on keeping rather from the sea, on the hard, well kept turn-pike road. The country around was very pretty, Church steeples peeped through the thick foliage, the land, undulating without rising to the height of hills, well cultivated; green and yellow fields, divided, not as in Peru, by the ugly dead mudwalls, but by live green hedges. As far as Truro there was an abundance of mines with heaps of Ores and engines. At a place called Hayle's Copperhouse, so denominated because in former times a large smelting Establishment stood there, now (in 1843) there was an Iron foundry, a stout talkative gentleman got up and took a seat near me. I soon entered into conversation with him, he told me that the Cornish-men were on the whole an industrious people, we met many of them on the road. Both men and women in their Sunday dress looked clean and decent. In some swampy ground, where I saw turf being cut, my English companion told me that in the rivulets formed by these cuttings small particles of tin are found, which the poor people collect and the tin so gained is known in the trade by the name of "River tin". Lead mines are also found in this vicinity, and a ton of lead contains sometimes from 60 to $80 \mathrm{oz}$ of silver. Hayle was the first place of some importance which we came through, it lies on the bank of a small river which at the time was so shallow that several vessels were lying high and dry. Without noticing many villages through which we drove, I will only mention the names of the following Cornish towns we passed to the Eastward of Hayle: Camborne, which is a comparatively new town, consisting of one long [106] street, inhabited almost solely by miners, Redruth and Truro, these two with a rather more antique look about them. In Truro the coach stopped for half an hour to change horses, as far as here we had come with two only, now two more were added, also the guard in red, like the coachman joined us and Gonzales, our talkative friend and myself took a nice breakfast. Next followed the town of Bodmin, which had of late risen in importance; the annual assizes, which were formerly divided between Bodmin and Launceston were now held exclusively in the former place. Shortly after leaving Bodmin we passed a country church picturesquely embowered in a group of stately trees, then the road ascending a trifle we drove for a considerable time over a barren height which, though covered with verdure, formed a striking contrast to the rich cultivated lands through which we had passed ever since Penzance, and which recommenced when we neared Launceston. From this high lands two low mountains, the highest in Cornwall, lying to the north east are 
visible, they are called the Router, and the Broad Willy, both in reality of little elevation. Lammerton had a pretty appearance; in the centre of the town upon a low hill stand the ivy-covered ruins of an ancient castle, its eastern outlet is encumbered with a heavy vaulted gate, similar to those which from the times of my childhood, I recollected as part of the fortifications of Hamburgh; the massive solid doors which originally shut up both ends of the vault were no more. A little to the eastward of Lammerton we crossed the bridge which spans the river Plym, separating Cornwall from Devonshire. Our talkative companion, who, be it said en passant, murdered the Queen's English with his [107] provincial pronunciation, (for instance cold was to him "cauld"; a flea, a flag; meen, mine) made us observe that from Penzance onward, and even passing the boundary, all buildings were constructed of granite, he called our attention to two handsome edifices, the one a large Almshouse, the other an Asylum for lunatics. In one of the Cornish towns through which we had passed, (I cannot recollect in which) stood a column erected to the memory of Richard Lander who had died on a journey of discovery in the interior of Africa, raised by a subscription amongst his townsmen. The column was not finished, for the money collected had not been sufficient for the purpose. Devonshire is called the garden of England, and though a long day's drive, outside the coach might well have blunted my enthusiasm, yet I continued to admire the beautiful scenery all around. This country is more woody and hilly than the preceding one, we had to our left a fine park, belonging to the Duke of Northumberland, filled with deer; drove through Oakhampton, and about 7 o'clock alighted at the New London Inn in Exeter 120 miles from Penzance. At a short distance before reaching this town the high road was lighted up by gas, so were the streets, and also the saloon, where we sat down to a good dinner. We then took a stroll, walked up and down the high street; it being Sunday the shops were shut, Gonzales admired the wide foot pavement, I was surprised to see respectable ladies promenading by themselves without male companions; and, on the other hand, of that class of females which is the pest of the London thoroughfares, I saw no trace.

Monday, $25^{\text {th }}$ of September 1843. It was as late as 8 o'clock when we appeared in the general saloon to take our breakfast, which being dispatched, we started [108] for a ramble. Soon did we find ourselves out of town, where rows of pretty uniformly built houses stretch far into the country, each with its well kept flower garden in front; further on we came to gentlemens' country seats, surrounded by parks tastefully laid out, abounding in tall and stately trees, some of them concealing the owners' mansion, from which almost invariably a velvet lawn encompassed by gravel walks, slopes down to the enclosure of 
the property, with a brick wall, an iron railing, or a green hedge, separating the same from the highway. Owing to the nature of the ground the prospect we had was nowhere extensive, but whithersoever our sight reached we saw undulating hills, cultivated fields, pleasure grounds and rich pasture, all intersected by roads. The fresh green of the English champaign is a feature in the landscape admired by all foreigners, and certainly Gonzales and I were no exceptions to this rule. When we returned to town, and walked up the high street, other objects attracted our attention, Gonzales had never previously been out of Peru, whilst I had been absent from Europe full nineteen years. He wondered at the crowded streets, at the shops, behind the plated glass windows of which the rich manufactures of England and France were displayed in elegant profusion; I, at the stupendous cart horses, which, powerfully built, in size small Elephants, long thick hair hanging down their strong legs and covering their fetlocks walked along, step by step, obedient to each sign, as well as to the voice, of the driver, no weight seemed too great for their strength. With pleasure did Gonzales and I look at the pretty females, high and low, at their white complexion, and red cheeks, but at the same time their [_]graceful manner [109] of walking and the long tails of their dresses sweeping over the pavement did not escape our censure. We entered the Cathedral, a fine Gothic building surrounded by trees, and railed in. Divine service was being held, in the mean time we walked about the extensive aisles, and though generally I am a creature but little impressive yet on this occasion the majestic structure of the interior, and particularly the deep swelling tones of the organ awoke in my heart religious feelings in which I willingly indulged for a few moments. Service over, a gentleman accosted us very politely and on my espressing the wish to be shown the church, he handed us over to a woman, who acted as our Cicerone. This Cathedral was commenced in the reign of Edward the Confessor, and was finished in the $14^{\text {th }}$ Century. The many stone effigies, statues, and monuments that fill the interior bare date from the $11^{\text {th }}$ to the $16^{\text {th }}$ century. With the help of the sketch herewith, I shall endeavour to give a description of this Cathedral, which being the first I saw after the lapse of so many years, interested me more than probably it would have done at any other time. Its shape is that of a cross, which (this I add in 1868) is that of all Christian Churches except of those which go by the name of "Basilicas"; the materials used in its construction are mainly stone, exquisitely worked and polished, also some marble. The exterior is adorned with many rough looking stone statues of saints and patriarches each in his respective niche. o.o.o. Represent the three entrances, the one in the middle, in front of the nave or widest passage, the two side doors in front of the two aisles, both of the same width, but somewhat narrower than the 
nave, from which they are divided by two rows [110] of black marble columns represented by dots in my sketch, above the middle entrance is a handsomely stained glass window, the same at the other end, opposite the two side entrances. As far as the organ g.g. the interval between each two columns is open, whilst, from the organ to the altar screen, k.k. splendidly sculptured in stone in the antique gothic style, each two columns are connected with each other by a low stone screen of curious workmanship. Above the organ 13 remarkable passages from holy writ are represented in stone; at the time of the commonwealth they had been plastered over, but the plaster being scrubbed and washed off they now look again almost new. i.i. represent the altar; the space between the altar screen, h.h. and the organ g.g. is taken up by pews for the congregation, $\mathrm{K}$ the

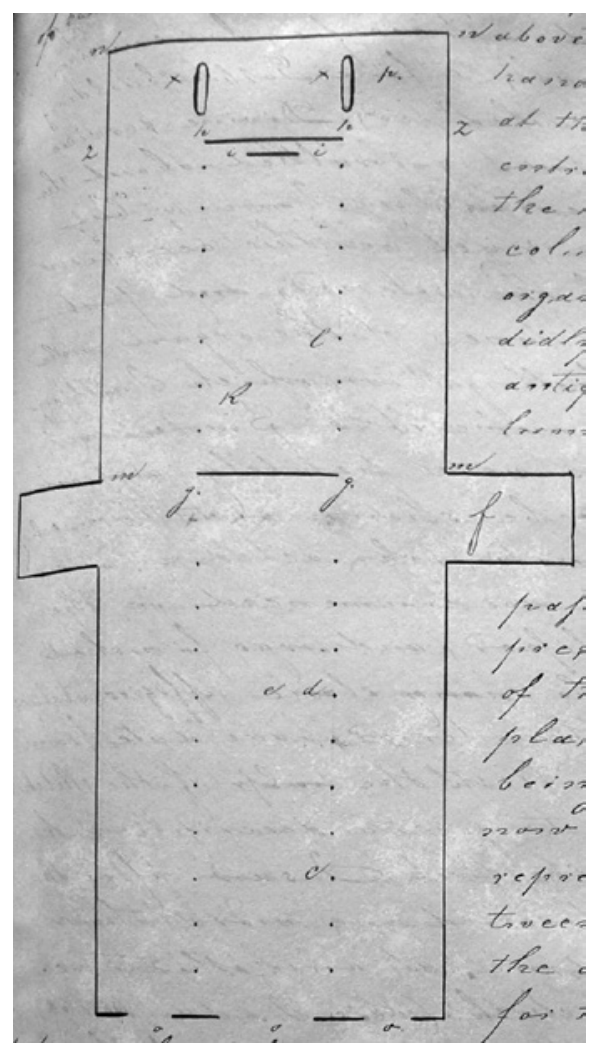
pulpit on the left side, opposite $L$ the bishop's seat, laid out with red velvet, and crowned by a strangely worked steeple of dark foreign oak. On the right side of the nave stands the baptismal font of white marble, marked c, a little further up on the same side a stone monument, on the top of which lie stretched out, likewise cut in stone, a knight in full armour, one of the noble house of De Courtnay, and his lady. Alongside of them, inlaid in black stone, (the pavement of the Cathedral, consisting of flag stones) is the effigy of another [111] Knight, their son. In the wing $\mathrm{f}$. are the two most ancient tombs; no monument nor statue, of the two first Bishops of Exeter, who flourished in the $11^{\text {th }}$ century. The two aisles are divided each in two unequal halves by iron railings, with their respective doors m.g. and m.g.; further up the aisles there are two similar rails z.h. and z.h. which lead to that part of the Cathedral, which goes by the name of "Lady's Chapel" because in the time of the ancient faith it was especially devoted to the adoration of the Virgin Mary. The monuments x x, each with a reclining statue of a Bishop or Templar executed in stone, divide the Chapel 
into three parts; in that to the right - $\mathrm{p}$ - is a statue of one of Sir Josuah Reynolds' pupils, sculptured by Chantry, also a portrait of a General in bas-relief with a sailor on one, and an Indian on the other side by Flaxman, both of white marble. The ceiling of this Cathedral is not one sole vault, but divided into a considerable number of small vaults, each between two columns, and the corresponding pillars in the walls. Similar to the monument of the De Courtraey's and to those in the Lady's Chapel, of which I have taken particular note, many others fill the Cathedral; below rest the mortal remains of him whose stone statue reclines above. Having satisfied our guide with a few shillings we left the Cathedral, and then entered a banking establishment to change our foreign coins, but were shown to a jeweller close by who paid us the Spanish Dollar at the rate of $4 \mathrm{~S} 1 \mathrm{~d}$, the Peruvian Ounce or Doublon at $£ 3.2 .7 \mathrm{1} / 2 \mathrm{~d}$ each. Our next visit was to a shoemaker, Gonzales standing in [112] great need of a pair of shoes. We were shown to the parlour which pleased us much on account of its neatness, it was carpeted; there was a Sofa, a fire place, clean and bright, the mantlepiece with a few nicks-nacks, all pretty and comfortable. Gonzales having obtained what he wanted, we continued our walk, now directing our steps towards the bridge, before we reached it we turned to the left, and soon came to an ancient [_]vy covered wall. Entering under an open portcullis we found ourselves in front of the session house, the exterior of which does not require any particular notice; we marched on, descended some steps, passing through the lower part of the town; and crossing a bridge were soon again in the open country, now on the grassy banks of the gently flowing Ex. Here a tree, there some houses, children playing about, nursery girls taking care of their babes, the whole a pretty rural scene. Having followed the course of the river for a short distance we emerged into the high road which skirts the town. We tramped along merrily in high glee with the beautiful surrounding country. We reentered Exeter by the east end of High street, and not yet satisfied, finally strolled towards the apparently aristocratic part of the town in the south east Corner. Here there was no bustle, no shops; all quiet, like the west end of London. Here I found crescents and squares, of which latter, though generally well known, I as a faithful recorder will give a description. What is called in London, and all over England, a square, is an open place generally a quadrangle, now and then oblong, for instance Jorrington square in [113] London. Four rows of uniformly built houses form the four sides, and thus eight streets, two at each corner, lead to the square. Before the row of houses is a wide sidewalk of flagstones, then the paved carriage road, and in the centre, an iron railing, (to which only those who live in the square are allowed the key) enclosing a shrubbery, a gravel walk, and a lawn. At six o'clock we were back at 
our Hôtel, dined, made a few memoranda, and retired to rest at an early hour completely fatigued.

Tuesday, $26^{\text {th }}$ of September 1843 . We were up betimes, and again took our seats outside the coach. It was a pleasant clear morning, but even had it been raining, our cash had run so low that we could not have afforded to pay for inside seats. The country we drove through pleased me still better than that to the west of Exeter; it was more woody, the apples trees were bending under the weight of the fruit. Devonshire, it is well known, is famous for its cider, the fermented juice of apples. The first place of importance we passed was Collumpton, on the other side of which a fellow passenger pointed out to me on a hill a column erected by the inhabitants of Wellington in honour of their reno[?]ed namesake the "Iron Duke", and accordingly called Wellington's monument. When we approached Beambridge, as far as which place the Western railroad from London was completed at the time, we saw many people working on the line which was to run to Exeter, and further on. A hill called the "white ball" was laying right in the way but [114] this obstacle, I was told would easily be overcome by cutting a tunnel through it. At Beambridge, about 21 miles from Exeter we left the coach, and availed ourselves of the railroad. A railroad, and every thing belonging to it were things I had never seen before and the details which I am about giving may appear trivial (now in 1868) when there is scarcely any one in the civilised world who is not acquainted with these iron roads, but the object of my writing is to narrate what I thought and felt at the time, what were then the impressions made on my mind, not what I think and feel on the same subjects in 1868 after a lapse of a quarter of a century. The terminus at Beambridge was a large building with a wooden platform in front. The passengers descended and the luggage being taken down, a porter accosted me, politely asking whither we went; on my answering "London" he stuck to each of our four packages a paper with London on it, and assured me that I need not trouble myself any further about them, that in London they would be safely delivered to me, I however prefered following them until I had satisfied myself where they were stowed away. At the office where an individual was busy selling tickets, I took ours for the $2^{\text {nd }}$ class, the state of our finances not allowing us to travel by first. The engine was at the head of the train to which were attached 4 or 5 first and as many $2^{\text {nd }}$ class carriages. The formerly prettily painted outside, had stuffed seats and glass windows, whilst the latter of a more ordinary apperance had no [115] glass to their windows and wooden seats. Gonzales and myself paid £1.10 each besides 8 for our luggage consisting of 2 trunks and 2 carpetbags. The officers of the Great Western Railway were dressed in dark green with red lace and are not 
allowed to accept any gratification from the passengers. After a delay of some minutes we steamed off, we made sometimes a mile in 2 minutes and occasionally went still faster; nevertheless, so much had I heard in Town of the velocity of railway travelling, that at first I was disappointed. Objects at a distance remained in sight longer than I had expected they would, on the other hand all objects close by, as for instance, a tree, a bush, the enclosure which rails in the line to prevent cattle from straying on it, labourers in the fields, guards stationed along the road, their arms outstretched in various directions, no doubt, to give certain signals to the engine driver, all these seemed to rush by, but when another train coming from an opposite direction, passed ours like a flash of lightning, then only could I form some idea of the wonderful rate at which we were travelling along. I noticed that each time before we came to a station and also when we again started the speed diminished, also an extremely shrill steam whistle made itself heard serving as a signal for various purposes. However what I most admired was the construction of the road itself; railroads require to run as level as the nature of the ground will permit. Every ascend, slight as it may be decreases the speed of the train, and needs a greater power of steam; therefore over valleys [116] viaducts must be built and through hilly ground either cuttings are made or if the height is too great tunnels are bored through. Between Beambridge and London we passed through many cuttings and tunnels; the embankments of the former, if steep are propped up by masonery work, if slanting this support is not required and in this latter case they were invariably covered with green turf, many bridges span the cuttings, for without them the communication between the two sides would be interrupted. The tunnels are like enormous tubes running under the earth, there is total darkness, so much so that holding my hand close to my nose, I could not see it; it is certainly a strange feeling to be rattling along in this manner, the noise of the train reverberating from all sides increases tenfold; the burning cinders flit through the air and then again in a second or two you are once more in bright daylight. The longest tunnel through which we passed is the Box Tunnel, over three miles long, into the same 3 or 4 apertures are cut from above to admit light and air. Of the country I could not see so much as from the top of the slow going coach; however Somersetshire did not appear to me to be behind Devonshire in careful cultivation of the land. Wellington was I think the first place in this country through which we came, a book called the Railway Guide gives the names of the different stations, which it would be superfluous for me to repeat. We saw Clifton at a distance, and stopped at the Bristol station. Bristol was and still is in 1868 one of the most important railways [_] unctio[_]. [117] Before we started the train was moved backwards and forwards for some time, and when we left it consisted of more than 20 carriages, 
one engine before, another behind. Next we came to the Bath station, at Swindon there was a delay of [_]o minutes; the saloon with the bar for refreshments was splendidly filled up with gilt framed looking glasses and stuccoed pillars. Gonzales and I bearing in mind our nearly empty pockets contented ourselves with 3 cakes a penny each and a bottle of brown stout containing two tumblers costing one shilling. At Reading a large edifice was in progress of building, I thought it was intended for a Royal palace, I learned that it would be a jail. Further on we passed a handsome asylum for lunatics, still nearer London we had at a distance a view of Windsor Castle with the Royal Standard floating from the tower, a proof that Queen Victoria was there. Lately she had been on visits to King Louis Phillip in Paris and King Leopold in Brussels. It was somewhat past six when we arrived at Paddington station London 171 1/2 miles from Beambridge. The terminus similar to that at Beambridge but of course on a much larger scale. Omnibuses, at that time also new to me were waiting; we were hurried into one of them and the luggage was put on the top. Hardly had we moved on and I had exchanged a few words with Gonzales in Spanish, when from the other end of the vehicle some one addressed me with the words "Pray Sir is your name not (Mr.) Witt?" On my answer in the affirmative the repl[_] was "and my name is Charles Crawley", it [_] in fact Mr. [118] Charles Crawley to whom I am indebted in a very great measure for my more or less prosperous mercantile career (see connecting narrative pages $337 / 8$ of previous volume) and as it may be easily imagined we had a great deal to talk over. He was coming to town from an estate of his near Oxford where he was then living, I am not certain whether at the time he had already separated from the firm of Antony Gibbs \& Sons and from their branch establishment on the West coast; at all events the old firm of Gibbs Crawley \& Co. so well known in Peru, Chili, Bolivia and Equator was changed some years later to that of William Gibbs \& Co. On our long drive to the bank I took but little notice of the objects around; we drove along through everlasting rows of houses, at first with small gardens in front of them, the streets splendidly lighted up with gas. I recognised Oxford street, Holborn, Snow Hill, Newgate street, Cheapside and Poultry. Close by at the Bank the Omnibus stopped, all [_] to alight, but as I not knowing where to take up our quarters for the night, had arranged with a fellow traveller to accompany him to the "Bull Inn" Aldgate, we had to enter another Omnibus which put us down at the door of the inn. From its locality at the East end of London we might have taken a warning that it would be a low place; which it turned out to be, now it was too late and here we cast anchor, after having been on our way 131 1/2 Days from Lima to London. The bedrooms we were shown to were miserable, the dinner which we took with our companion in the Coffee room was pretty fair. Gonzales was eager to 
see something of London, we strolled out together and I still recollecting the whereabouts [_] the city, took him to where [119] I expected to find old fish street hill, but this had disappeared, there was no more the descent to old London bridge; new London bridge had been built a little higher up the river during my absence. The handsome king William street on a level with the bridge leads to it, whilst steps descend to the Thames streets both upper and lower.

A note of my expenses from Lima to London will be found in the Appendix under $\mathrm{N}^{\circ} 6$.

Wednesday, $27^{\text {th }}$ of September 1843. After having breakfasted, and before the office of A. Gibbs \& Sons was open, Gonzales and I took a walk. All we had seen in Exeter was again brought before our admiring eye, but every thing enlarged, augmented, and improved. Gonzalez regretted the time, which in his opinion we had lost in the Provincial town. The cart horses were still taller, the carts still heavier laden, the streets still more crowded, the shops presented a still more splendid display. The foot pavement (trottoir) of flag stones still wider, all was a scene of life and activity such as can be found in the city of London only. On London bridge we stopped for a few minutes, for a moment we looked at the endless files of foot passengers, of carts and other carriages passing from one side to the other. Then we threw a view up the river where numberless small steamers were plying in all directions, then another look down the river where a forest of masts met the eye; both on land and water the bustle was alike. Gibbs' office was at the time in Lime street, a narrow street, leading from Leadenhall to Fenchurch street (in 1824 when I left their counting house, it was in Winchester street, Austin friars) Mr. William Gibbs the head of the house had not yet come, [120] we were received by the two head clerks Mr. Wm. Parish Robertson, who attended to the correspondence and Mr. Dankaerts of Dutch descent, who had the sales department under his charge. Mr. Wm. Parish Robertson and his brother Joseph Parish Robertson are known in the literary world as authors of letters on Paraguay and of Francias reign of terror. They were if I mistake not natural sons of one of the Parishes of Hamburgh. Joseph became in later years if not downright crazy, at all events a lunatic in religious matters, he died at Boulogne. Mr. William I saw many years later in Lima in rather reduced circumstances; afterwards he was employed by the English holders of Mexican Bonds to make some arrangements with the then Mexican Government. With his arrangement they were satisfied but not with the sums of money he said he had been obliged to spend in order to obtain his object; since then he has also died. From Gibbs' we drove to Mrs. Dakin $\mathrm{N}^{\circ} 41$ Finsburry square to whom Mrs. Pfeiffer of Lima had given me a letter of introduction. Pleased with the looks of two bedrooms and a sitting room 
we secured them at once. Finsbury square just outside the city, has a cheerful aspect and is situated where the City road begins which, with its continuation, "the new road" forms the northern boundary of London proper. Cabs were also new to me they had taken the place of the old hackney coaches, to which they are certainly superior. They are smaller, not so dirty as their predecessors were, and are driven much faster. We now returned to Gibbs', Mr. William Gibbs was in the office; he had become grey headed since I had seen him last in 1824, but was [121] quite as active and lively as then; he asked me a thousand questions relative to his establishments on the West coast and I gave him all the information I could; he then asked us to dine with him in the afternoon. Having still some time to spare Gonzales returned to the Bull Inn to take our luggage to Mrs. Dakins whilst I started by myself to make a few calls. First I went to the office of my old chum Theodor Elmenhorst of whom frequent mention has been made in my previous extracts, after leaving Donner's counting house he [_] established himself in London where he was doing a small business. His office was in Mark lane, I did not find him, instead of him his cousin Christian Donner an agreeable young man one of the younger sons of J. C. Donner of Altona. Next I went to Henry Kendall's at the time Peruvian Consul in London, formerly the head of Naylors Kendall \& Co. of Lima; also to John Robins, a gentleman who having been one of the British merchants who first settled in Lima had returned to his native country after a comparatively short absence with a moderate fortune. Both were polite and expressed the wish that I should spend a Sunday with them in the country, for both lived out of town and had only their offices in the city. However as neither fixed a day I looked on these invitations as mere "façon de parler". At a later hour we drove in an Omnibus to the West End and were put down in a street not far from Hyde Park street, where ( $\mathrm{N}^{\circ}$ 371) Mr. Gibbs resided. On this drive I observed that many streets in which the thoroughfare was stopped a new pavement of wood was being laid down; this [122] was at the time preferable to stone pavement, mainly because it diminished the deafening noise which the carriages produced; it was however again abandoned after the experience of a few years, because many accidents happened owing to the horses having no fast-hold on the slippery wood especially on rainy days. At Mr. Gibbs' we were shown upstairs to a comfortable and neatly furnished parlour where we found himself, his lady and young Mr. Henry Gibbs son of the late Geo. Henry Gibbs. I took Mrs. Gibbs down to the dining room where the dinner was plain and good, servants in livery attending. When Mrs. Gibbs had retired we remained a short time over our wine, speaking spanish in consideration of Mr. Gonzales; upstairs coffee was handed round, then Mrs. Gibbs herself presided at the tea table. At 10 o'clock after a good deal of conversation well pleased with the reception we 
had met with, we walked home though the distance was very considerable. Mr. Gibbs had pleased me, he had been very agreeable and even communicative; of Mrs. Gibbs I formed no decided opinion, neither to her advantage nor to her disadvantage; she has a slight impediment in her speech which is rather against her. Mr. Henry Gibbs was a well educated young man who had seen a good deal of the South of Europe.

Thursday, $28^{\text {th }}$ of September 1843. At Gonzales' desire we had this morning coffee at breakfast instead of tea as usually, also bread and butter, dry toast and one soft boiled egg for each. I again went to Elmenhorst's Counting house, this time I found Theodore at home, a stout, sober [123] and even serious man with spectacles, instead of the cheerful youth whom I had known 20 years back; he embraced and kissed me which mark of friendship I would have willingly dispensed with; he was friendly but not so warm hearted as I expected to have found him. He talked a great deal of business he was doing especially in Colonial produce and added that it was his intention shortly to return to Altona there to join his brother in law Warnholtz under the paternal firm of Elmenhorst Bro. His elder brother Jean, poor fellow, my fellow traveller in the first months of 1823, was already in his grave. At Gibbs' I wrote to my wife and other persons on the West Coast. I then drove in Omnibus to Cunningstreet Pentonville, to the north of the new road, there my dear little English aunt, as we used to call her, lived in $\mathrm{N}^{\mathrm{o}} 37$ with her daughter Frances. I believe her son Diedrich was at the time in a Counting house in Liverpool. Of course Mrs. Willinck looked also somewhat older, it was particularly about the mouth where I observed the change, she had lost her teeth, otherwise she had borne up pretty well and her liveliness as well as her kindness was unaltered. Frances was a tall rather good looking girl, the house they lived in was small but all I saw neat and clean. They showed me to the parlours, the walls of which were adorned with many portraits, both of the Cresswells and the Willincks. Amongst others I found there a "silhouette" of my sister Betty which I examined for some time tears filling my eyes. In the course of a long long conversation which we had come to speak of my sister Maria and then I could not help crying outright. They gave me for Lunch some porter bread and cheese and I left, [124] not merely pleased, nay delighted with my dear relations. Gonzales and I took our dinner in a Chophouse, it consisted of a large plate of excellent roast beef with potatoes, bread and a pint of Porter, its cost including the waiter fee $2 \mathrm{~d}$ was $15 \mathrm{~d}$ 1/2 each. At a later hour I once more entered an Omnibus and now drove to the north east through the Bishopsgate street and Hackney to Stoke Newington; Theodore Elmenhorst and his wife, formerly Constance Heyne, occupied there some apartments in Church street. Theodore had asked me to take tea with them, Constance still very pretty was kind and agreeable, now and then 
Theodore flashed out with some of his old merry sallies, and upon the whole I spent a pleasant evening. He accompanied me a good deal of my way home and not without some trouble I reached my lodgings.

Friday, $29^{\text {th }}$ of September 1843. In the course of the forenoon I made an arrangement with Mr. Wm. Gibbs in virtue of which, if I made any consignments to his Establishments on the Westcoast of South America, the usual Sales commission of $71 / 2 \%$ should be reduced to $5 \%$; on purchases made for me through A. Gibbs \& Sons they would charge $21 / 2 \%$ (by the bye exorbitant) and on any funds left by me in their hands, they would allow me $4 \%$ per annum interest. Discount in London was at the time 11/2 to $13 / 4 \%$ and Mr. Gibbs showed by his books that he had £15,00o unemployed. I have already alluded to the wood pavement about being introduced in London, this day I looked at it more attentively. It consists of small logs of wood rammed into the ground and placed in diagonal lines; to fill up the interstices a cement was poured over them which in course of time became as hard as stone. [125] I was told that to make a trial cannon balls had been fired at this pavement, the wood had been shattered to splinders the cement had remained unimpaired. With Mr. Dankaerts I went on Change which was held in the Excise office, whilst the new Exchange was being built; the old one which still existed when I left and which dated from Queen Elizabeth's time had been destroyed by fire during my absence. On Change Mr. Wm. Gibbs introduced me to Mr. Grüning, partner of frederick Huth \& Co., an elderly not to say an old man. Elmenhorst took me to shake hands with George von Dadelszen and with a Mr. [T] ürk. Von Dadelszen was the same who whilst I was at Donners in Altona was established in London under the firm of G. M. von Dadleszen \& Co. and with whom in 1823 on my first arrival I lived for a short time in his lodgings at Clapham; now he was fast going, if he had not already, gone, to the dogs. He smelt of spirits, and his red nose gave clear evidence of his propensity for drink. [T] ürk I hardly recollected, he was the brother of the widow of Wm. Wall (see $1^{\text {st }}$ vol. page 534) and as I understood was manager of the house of Coleman in London. Betty Wall to whom he had written of my expected arrival was, he told me, very anxious to see me; she was governess in the family of Mr. Ferand M.P. At 5 p.m. Gonzales and I went to Mrs. Willincks who had invited us to dine with her; there were besides herself and Frances, Robert and Maria Cresswell, old Mrs. Dubois and John Cresswell. In the first volume page 453 I gave an account of how Robert and Maria looked in 1814, now they were an elderly bachelor and elderly spinster, they lived in Landmans street; the office of proctor once occupied by Messrs. Cresswell and Adams having now descended to junior members [126] of the family. Robert was Counsellor in the Insolvent debtors' court, and freely spent his moderate income. They had not forgotten their old "I say Henry", and necessarily had I 
to attend to Miss Maria though more willingly would I have listened to what my aunt or frances said. Mrs. Dubois was a very respectable old lady, the sister of Mr. Edward Dubois my aunt's brother in law. She lived with Mrs. Willinck whom she paid £10o per annumn which was a great assistance to my aunt's income, which by dint of strict economy and good management sufficed for the wants of the family. John Cresswell, son of Richard, and consequently frances' cousin, a surgeon by profession was engaged to her, and the marriage was to take place as soon as his pecuniary circumstances would permit. We had a nice dinner, a boiled leg of mutton, a roasted goose (Michaelmas goose), fruit pie, pudding, wine, and beer, after coffee had been handed round, Frances and Gonzales sat down to chess; Mr. Dubois, Maria, Robert and John to cribbage; my aunt and I talked over old times and thus the hours slipped away pleasantly till 10 1/2 o'clock when we left.

Saturday, $30^{\text {th }}$ of September 1843. In Gibbs' office I draw out a note of some manufactured goods to be purchased by them and to be shipped on my account for sale to Gibbs Crawley \& Co. of Lima. It was Mr. Dankaerts who had to attend to this order of mine. I also met in the office General William Miller, well known in Peru. He was paying his farewell visit as he was on the point of sailing for the Pacific, the British Government having appointed him Consul General in the Sandwich Islands. Afterwards I called at the Counting house of Huth's $\mathrm{N}^{\circ} 10$ Morgate street, where I made the acquaintance of old Mr. Frederic Huth, the founder [127] of this highly respectable firm. I had some conversation with him and he communicated to me divers political news. In Tacna general Nieto had brought about a rising against Vivanco's authority, he had been joined by Torrico living as an exile in Bolivia. Dr. Justo Figuerola had been proclaimed by them as the legitimate president. These were the first glimmerings of that revolution which overthrew in the following years Vivanco's Directory by the victory near Carmen Alto. In Ireland, the repeal of the Union was loudly asked for, but of course resisted by the British Government. In Spain Genl. Narvaez favored by Doña Christina the queen's mother governed the country, but as Isabela II would soon became of age, better times were expected on her ascension; in which hopes alas! the Spanish nation has been woefully disappointed. In Greece great discontent prevailed, owing to the incapacity of King Otto, and the injudicious preference given by him to his Bavarian country men. In the streets I met Mr. Jules Rousson whom in 1825 I had known in Arequipa as a dashing French super-cargo; he was now in London on a, to my judgment, foolish errand, the object of his visit being to be paid by General Espartero then in London for losses caused to him by Espartero whilst holding command as a Spanish General in Peru. About 20 years later I again saw him in Lima, where he was very poor and died in the employ of Candamo as ticket 
seller at the Chorrillos railway station. Gonzales and I learned that this evening Drurylane Theatre would be opened for the season; we therefore decided on going thither and by 7 o'clock found ourselves at the end of a long queue of human beings who had assembled before the entrance. The doors were thrown open, there was a violent rush, a light squeeze and thanks [128] to our bodily exertions we obtained good seats in the pit. The interior appeared to me less large than I had expected, in length I thought it did not surpass the theatre of Lima, in width and height it certainly did. It was tastefully painted white, pink and gold and brilliantly lighted up; one large Gas chandelier hung over the pit whilst 28 smaller ones were ranged round the two first tiers of boxes. Besides two boxes on the level with the pit there were 3 tiers of boxes and above them 2 galleries. The boxes were divided, not as is the case in Lima, by high partitions, so that each forms a small room by itself, but by partitians not much higher than the seats themselves, so that the whole audience had the appearance of one single fashionable party; I say fashionable, for it was the custom and I believe is still in 1868 to go to the play, at least to the first two tiers in full dress. When the curtain rose the stage was occupied by the greater number of singers and actors, who, the entire audience standing up, sang "God save the Queen"; a conventional mark of loyalty which pleased me much. The Opera, performed in Italian was the Siege of Rochelle, which a few days before my leaving Lima I had seen there under the name of Clara Rosenberg, so mutilated and curtailed however, that had it not been for some remarkable scenes, for instance that where Michael tells his travelling adventures and that at the end between the same and Montalban, I should hardly have recognised it. Of course in London the Orchestra was much more complete, I not relishing much the overpowering noise of the drum, the scenery and dresses handsomer than those in Lima, but as to the singing itself I am certain that Sissa, the tenor, La Pantanelli, contraalto, and La Rossi, soprano, in Lima were at all events equal if not superior to those who sang the same parts in London. The opera [129] was succeeded by a Ballet, the Peri which to be sure surpassed everything I had seen before of the kind. All was splendid, enchanting; however the two scenes which struck me most, were the one, whilst Achmed the hero was asleep the clouds opened and the host of the Peri, young girls prettily dressed in white with small light blue bodices did homage to their queen, acted by Carlotta Grisi a handsome young woman and first rate dancer, she jumped down, if I may make use of the wood jumping, which conveys no correct idea of the grace of her aerial movements. She presented herself before Achmed, who aware of all this in his dream became of course enamoured of her and tired of his former favorite Sultana (Miss O'Bryan also an excellent dancer), after overcoming many obstacles was at last united to his beloved; the other, the last when the Queen and her Peri 
appeared enveloped in what might be called celestial glory. Of the dancing no description can be given, one must come, see, and wonder, the strict bounds of decency were no doubt transgressed more than once, one of the great feats of the female dancers is to stretch out one of their legs in a direct horizontal line and then of course the eye of the looker-on could wander farther than proper. We were home by 1 o'clock. Bouquets of course were thrown to Mademoiselle Albertassi one of the singers and Mademoiselle Grissi.

Sunday, ${ }^{\text {st }}$ of October 1843 . For a considerable time I was occupied at my lodgings with writing my diary and then started in search of my very [_] friend Mrs. Grautoff whom I have frequently mentioned in my first volume [130] when she was Miss Marian Charlton. In King William Street I entered an Omnibus which took me to Camberwell Green. All this neighbourhood I well recollected from former times, close by there then was the pretty Camberwell Grove, whether it was still in existence in 1843 or still is now in 1868 I do not know. From Camberwell Green I struck off to the village of Dulwich where at a public house I enquired for Mrs. Grauthoffs cottage. The Inn keeper told me that she had left but could not tell me whither she had removed. I continued my walk and addressed a lady and gentleman with the same question, when the lady was so obliging as to write on my card not only Mrs. Grautoffs address, but even the details of the route which I was to take in order to find her. I had still to walk a considerable distance before I reached the Dartmouth Arms. But the country through which my way lay was so delightful through shady lanes along green hedges, pretty cottages everywhere, sometimes a gentleman's mansion with greater pretensions, then again a country church, in one word the whole scenery so rural and so much in accordance with my taste that I felt no fatigue and almost regretted when after waiting a few minutes at the said public house I had to enter the Brighton and Dover train, which after about 15 minutes put me down at Croydon. Here all was bustle for a fair was going to be held the 3 next days; there were booths, swings and crowds of people. With some trouble I found the house of Mr. de la Fossé where Mrs. Grautoff and daughters lodged, but was told to my great [regret] that they had gone out and would not be back [131] for 2 hours. Now I had nothing better to do than to take the first train back which stopped at the London bridge station. On this the borough side alterations had been made similar to those on the city side. Tooley street which in 1824 was on a level with the bridge now lay considerably lower and steps descended to it the same as opposite to Thames streets. Gonzales and I dined in the City on cold meat pies, it being Sunday, nothing hot could be had in the Chop houses. At Mrs. Dakins we took tea with her, her daughter, her son, clerk at Sir John Lubbocks \& Co. and a fellow lodger. I concluded the day in a 
quiet manner at my aunts, my cousin pleased me, I commenced addressing her Frances instead of the stiff ma'm as I had done hitherto.

Monday, $2^{\text {nd }}$ of October 1843. One of the junior clerks of Gibbs' was at the time Ventura Marcó del Pont, son of Manuel Marcó, a Buenos Ayrean to whom and his partner Ambrosio Ybañez, my first principal in Arequipa Mardon, was consigned with the "Bristols" cargo in 1824, as it will be found detailedly explained in my first volume. A few years later Ventura obtained a situation in Gibbs' house in Lima and afterwards joined his uncle José as clerk, who under Gibbs' auspices had established himself in Paris; when his uncle died, he succeeded him and now in 1868 is doing there a fair business under his own name. This Ventura accompanied Gonzales and self to the London dock into which the "Vicar of Bray" had arrived on the previous day. Capt. Seymour was not there, Mr. Sawyer the mate was very busy discharging the bullion; we therefore merely collected our luggage, got it landed [132] and then walked with Marco to the Tower of London to see the many curiosities which it contained. One of the yeomen who keep guard here, dressed in the old fashioned style (of) a frockcoat, red and yellow, much embroidered and with many puffs, well known by the vulgar name of beefeaters showed us and some other visitors over many parts of the building; he was very attentive but had the defect common to all "concierges" to hurry over his job as quickly as possible, so that one has no time carefully to examine the many objects which deserve attention. The tower, as everybody knows, lies just outside the city to the east close to the river, its most ancient part called the white tower was commenced by William the Conqueror and concluded by his son and successor William Rufus; a few years previous to 1843 a fire had destroyed part of the tower with an enormous quantity of stands of arms; now barracks were about being built on the spot. The tower had occasionally been used as a Royal residence but during the middle ages, even down to the middle of last century its principal object has been to serve as a prison for Royal and noble personages. Many a foul and dark deed has been committed within its precincts and its records, faithfully kept if kept at all would present a frightful array of secret assasinations and public executions. A few steps guarded by a strong Portcullis lead down to the Thames; this is the traitors' gate, of ill repute where the supposed delinquents used to be landed and received by the Reeper. Our cicerone pointed out to us the window of the garret where the two sons of Edward IV were put to death by order of their uncle Richard III, also the so called Bell Tower where Queen Elizabeth was [133] kept not a long time previous to her accession, in "durance vile", by her sister Mary; he showed us the prison cell in which Sir Walter Raleigh passed 12 years of his life, another small apartment, where those condemned to death 
used to be confined before their execution; the spot where these executions took place, the very block (this in the so called queen Elizabeth's armoury) on which much innocent perhaps also some guilty blood has been spilt, the Church where the remains of the beheaded used to be interred, finally some instruments of torture. Willingly did we turn from these gloomy objects to the crown jewels shown to us in a well secured apartment. There were many crowns with abundance of pearls, diamonds, and precious stones, for instance that of Ann Boleyn, that of George IV, that of Queen Victoria, divers sceptres, the most remarkable of which was one of Ivory, that of Ann Boleyn, further the gold baptismal font in which Queen Victoria was christened, an enormous tankard, a dish, a tray, and similar articles all of massive gold and exquisite workmanship. Our beefeater told us that the value of the treasure kept in this apartment was 3 million Pound St'g. One hall was filled with ancient armour, helmets, cuirasses, belly-thigh and leg coverings made of iron or steel, some tastefully inlaid with gold, then there sat on their wooden horses covered with a panoply of iron the effigies of the Kings of England, each in his own full armour, a grand sight indeed. Queen Elizabeth on her palfrey in a dress similar to that which she wore in St. Pauls when giving thanks to the Almighty for the victory over the Spanish Armada. Outside the tower our attention was directed to guns and mortars, remarkable either for their antiquity or for being trophies taken from the enemy, for instance French guns which date from [134] the battle of Ramillies (23 ${ }^{\text {rd }}$ of may 1706 , Duke of Marlborough) and that of Waterloo ( $18^{\text {th }}$ June 1815 Duke of Wellington) two guns taken at St. Jean d'Acre, one gun and remnant of 2 standards, taken by the French from the Knights of Malta and retaken by the English. Of course there were a thousand other curiosities fully worth my notice, but they made no impression on my memory owing to the above given reason. In the office, Mr. Wm. Gibbs detained me a considerable time with many questions relative to his correspondents on the West coast, in reply to which I gave him all the information I could. I then hastened to my lodgings where I found 2 notes, one from Mrs. Grautoff, the other from Mr. de la Fosse, both inviting me to dine with them. I now shaved dressed and made the best of my way to London bridge terminus where I entered the train which put me down at the Croyden station; then an hour's walk took me to Mr. de la fosses country house; here I was shown to a [snug] comfortable parlour cheerfully blazing fire. After a few moments Mrs. Grautoff entered and addressed me in a most affectionate manner, she was dressed in black silk, from her cap hung down silk pink ribbons, very becoming to her fair complexion. Notwithstanding her age, she was rather more than fifty, she looked extremely well, and the delicate bloom of her cheeks made me suspect for a moment that she had rouged a little; quite as likely it might have been her 
natural colour. Next appeared Mr. de la Fosse, a plain insignificant man, dealer in Coffee and Tea of $\mathrm{N}^{\circ} 22$ Fenchurch street, then Mrs. de la Fosse, by no means to my taste. During the few hours I was in her company I noticed clear marks of her overbearing temper, finally fond young ladies came in, a Mrs. Harrison rather pretty, Mrs. Grautoffs two daughters Caroline and Ellen, tall and pleasant [135] girls not as handsome as their mother, and a niece of the de la Fosse's. At dinner Mr. and Mrs. de la Fosse occupied respectively the two ends of the table, on one side sat I between Mrs. Grautoff and Mrs. Harrison, opposite the three girls. Dinner was plain, of wine we had Hock, Sherry and Port. Mr. de la Fosse and I sat but a short time over our wine and soon joined the ladies. Whilst tea was served I of course addressed myself especially to Mrs. Grautoff and had a long conversation with her. When we spoke of my family she expressed herself in the most feeling terms, my sister Maria she mentioned with tenderness, my mother with gratitude; of herself and hers she told me that she had sold her Dulwich cottage and that for some time to come she intended to live in lodgings, now here now there, just as her inclination might prompt her, that her son Albert was still at College, that her sister Fanny with her husband Mr. Goldermann, immensely rich, was travelling about the Continent undecided where to take up a fixed residence, and that her brother Bernard, married to an Irish girl had not prospered in life; he was at the time not far from fifty, just then out of employ and in search of a situation in a counting house. The Brighton and Dover train took me back to London and about 11 o'clock I was again in Finsbury square.

Tuesday, $3^{\text {rd }}$ of October 1843. The thermometer which hung in the shade at the top of the stair case in our lodgings ranged during the day from 61 to $67^{\circ}$ fahrenheit, I usually rose at about 7 o'clock, before and after breakfast Gonzales and I occupied ourselves with our diaries and about 11 I was in the habit of starting my daily wanderings. The visits to the shoe-maker, to the tailor Hall, 89 London Wall, to the stationers Royston \& Brown, 40 and 41 Old bread street, always took up some of [136] my time; this day I called on Mr. frederick Huth and on Mr. Edward Sieveking in their respective offices, both grey headed men; the latter, much the younger of the two, about 55 years of age, cousin of my friend Henry Sieveking of Altona, who had sent me a few introductory lines to him, received me very politely and expressed a wish to see me at his house; however as we had but few objects of common interest to converse about I remained but a short time. Not so with Mr. Huth who kept me very long, but instead of inquiring about his partners on the West coast as I had naturally expected, he on the contrary let them pass in review before me. Of Christian Hellmann he spoke in very laudatory terms though he complained of his bad handwriting; he would nevertheless leave the concern at the expiration of the 
contract then in force for 5 years, for having made some money he must make room for others. Joseph Cullen, Hellmann's favorite whom he was anxious to make a partner, Mr. Huth said was unfit for such a post, because he was without education without manners and of low extraction, his father being shoemaker in Liverpool, however to humour Hellmann he had not objected to the very high salary paid Cullen, on the other hand Hellmann's reluctance to see Hermann Rodenwald made a partner Mr. Huth styled a flagrant injustice. George Hellmann of Tacna, Christian's nephew he had separated from the firm of Huth Grüning \& Co. in April last, because he had been found guilty of negligence and unable to defend a bad sale if once made; however he having established himself on his own account in Tacna, Huth's agency had not been taken from him. Bartholomew Browne, Mr. Huth informed me occupied a subordinate situation in the Valparaiso house; and though he had the sales department [137] under his charge he had to consult with Mr. Ward as to the extent of credit to be granted to a purchaser "never will he again reside in Lima as partner of frederic Huth Grüning \& Co.", these words of the old gentleman, referred of course to Browne's imprudent conduct at the time of Salaverrys revolution in 1835 . Gonzales and I dined at our usual shop, then crossing London bridge and walking up the river close to its bank, at the shades wharf we went on board a small steamer which passing under Southwork, Black friars and Waterloo bridges landed as close to Westminster bridge on the Surrey side, fare $4 \mathrm{~d}$ each. At a short distance from the last mentioned bridge, the foundation of another had just been laid, viz. of the Suspension bridge for foot passengers. A short walk brought us to a temporary building, Batty's circus, which as the play bill said was Astley's Royal Amphi-Theatre, so renowned in former years. When we entered an offensive smell greeted our olfactory nerves, originating either from the enormous Gas-chandelier suspended over the circus in the middle of the pit, or from the many horses which constitute, in fact, the principal actors in this theatre. The first piece was the "Conquest of Granada"; the scenery was on the whole pretty and in accordance with the age and place, when and where the events were supposed to have occurred; but here and there the painter might have been more sparing in the use of Gay and Brilliant colours. The stage was illuminated with all kind of lights, Blue, red and green, then there was a numerous array of men and horses. There came some warriors in glittering armour, swords were brandished, lances tossed, banners waved. There was the fiery steed denominated the silver star, which bounded in, [138] holding a sword in its mouth which it presented to the hero, just at the moment of his greatest need; all was very fine and grand, but a little common sense, never expected and seldom found in pieces like this, would have been a very acceptable ingredient. We next had some rope dancing, the best part of 
which consisted in that done by a little girl apparently 4 or 5 years of age who had made her exit from a flower pot wheeled about on a wheel-barron by a boy not much older than she. Then followed an Equestrian performance in the circus, very good; one horse was so well trained as to pick up from the ground a handkerchief and gloves and to present them to his master. The entertainment concluded, with a piece called the Forest of Bondy founded on the well known story of the Dog of Monlargis, which discovers the assassin of his murdered master. The principal actor, much applauded, was a beautiful well taught dog. We left at a very late hour, not over well pleased, for what we had seen had certainly been far from first rate, by 2 o'clock in the morning we reached home.

Wednesday, $4^{\text {th }}$ of October 1843. The whole forenoon was taken up in Gibbs' office with writing my own correspondence and with examining jointly with Mr. Gibbs and at his request the accounts of many of his South American correspondents. At 4 p.m. Bernard Charlton called by appointment, we walked to the more than once mentioned London bridge terminus where we entered a Greenwich train, I paying is for a return ticket. I find in my original diary of which the present is a condensed [_] I hope improved copy that I praise the comfort afforded by the stuffed seats and backs as well as by the closed glass windows, a proof that this [139] was the first time I availed myself of first class carriages. In Greenwich, Bernard and his wife Louisa, they had no children, occupied a very small house with 3 furnished rooms, which he had rented. We had for dinner a leg of roasted mutton, potatoes and greens, apple and raspberry tarts, fruit, ale and sherry. A girl attended, but I soon found out that she was the daughter of the owner of the house, who on account of my presence was good enough to act as servant. I should not have recognised Bernard if I had met him in the streets, so much had he altered since 1815. In 1823 and 24 he had been absent from London as Clerk to Stieglitz \& Co. of St. Petersburg, where he told me he had been well pleased, but was obliged to leave owing to the severity of the Russian winter. Next he had gone into partnership with Augustus Grautoff, brother of his sister's husband, their business had been to import straw from Switzerland used for the making of straw bonnets, this trade, trifling as it appears, he assured me was lucrative, but Grautoff's temper was such that he could not bear it and they separated. Hereupon he had entered as a clerk to George Clark, manufacturer in Manchester, also Consigner to the West coast, to Huth, and Templeman \& Bergmann. There, bad health had been the cause of his throwing up the situation, finally he had gone to Berlin to put up some machinery, whence he had returned the very day of my landing in Penzance. Much as I liked Bernard I could not help suspecting that some way or other the fault of his remaining nowhere stationery any length of time, must be partly his own; notwithstanding his at the time no doubt poor circumstances, he was 
very plesant even gay, and now and then flashed out his dry caustic humor, an heirloom of his father. Our conversation was in English, Bernard was an excellent German scholar, perhaps his accent a little foreign. His wife tried to make herself agreeable, yet I did [140] not admire her. To any observation of mine, she had a particular manner of saying $\mathrm{Oh}$ ! as if incapable to give a rational reply. I was home at an early hour.

Thursday, $5^{\text {th }}$ of October 1843. Gonzales and I walked to the London docks to look after our luggage, which, landed from the "Vicar of Bray" had been deposited in the Custom house stores. Long had we to wait till it was the turn of our luggage to be searched and what a search this was! Every article to the very bottom of each package was taken out, placed on the floor and looked at. My large box with books and pistols I left in Bond to be reshipped for Hamburgh, whilst the remainder not subject to any duty was permitted to be forwarded to our lodgings. Whilst there General Espartero, who by the English is considered an extraordinary man, followed by a small group of gapers and admirers paid a visit to the stores, which are certainly very extensive; the Dock itself was so crowded with shipping that one's sight could not pierce the forest of masts and cordage. After dinner Gonzales and I accompanied by Dankaert walked to the Surrey Zoological Gardens, situated as the name implies at the right or Surrey side of the river, a little westward of the well known Elephant and Castle public house. When we reached the gardens the sun had just set, the moon soon rose and the evening though a little cool was very agreeable. The area which the gardens occupy is tastefully laid out; more or less in the centre stood a round building, the roof consisting of the thick glass, it continued many strong iron cages with their savage occupants, tigers, lions, leopards, etc. Other cells were spread all over the grounds each with some animal or other, however the uncertain moonlight prevented our having a distinct view of them. On a platform a complete Orchestra diverted the perambulators until the firing of a gun gave the [141] signal for the fire works to commence. All now rushed to rows of benches, ranged of course in the open air, in front of a large sheet of smooth water, first appeared at the opposite end a Hindoo temple in a fiery light, it was a beautiful sight, but so rapidly did it fade away into darkness that it scarcely left any impression on my mind. Then some dark objects just visible by means of a blue light came moving on upon the surface of the water, they exploded, a steeple, a tower, all on fire stood before you, a balloon rose and the entertainment closed with a figure representing Brittannia; all this as well as a hundred fiery tongues shooting through the firmament, stars of all colours sparkling momentarily in the moonlit sky altogether reflected in the still expanse of the water below, was in fact a beautiful spectacle. At 8 o'clock 
we walked home, better pleased than with anything we had hitherto seen in London. Mrs. Dakins treated us to a cup of tea and we retired to rest.

Friday, $6^{\text {th }}$ of October 1843. Immediately after breakfast Mr. Henry Marriott called on me; he was the elder brother of Frederic Marriott of Arequipa, who had given me a few introductary lines, which on a previous day I had left for him at one of his stores. He made me an offer of his services with peculiar earnestness; told me that he had 3 ironmongers shops in the city, that he was on the point of retiring from business and that his private residence was in the wilderness, near Hampton Court. In Gibbs' office I was told that Mr. Wm. Gibbs had had on the previous evening a fainting fit whilst driving home and that he had therefore not come to the city; at Mr. Jennigs, bookseller in Cheapside I purchased Dr. Lardner's valuable Cabinet Encyclopaedia. This shop was a few houses to the eastward of Bow church, which church has the peculiarity that its clock with a dial-plate on each side [142] sticks out horizontally into the air, very convenient for all passers by, there is also a saying, that, such Londoners only, as are born within the sounds of its bells are the true "Cockneys". At the western extremity of Cheapside, turning to the right in Aldersgate street stands the new Post office, a large massive building, the solid and plain columns without any ornament, I suppose of the Doric order, which form the outer Portico and support the inner hall, appear to me particularly well adapted for a building like this, the sole object of which is the convenience of the public. Behind the post office stands the Goldsmiths Hall; in Hatton Garden lived Mr. Johnson the assayer of the mint to whom I had a letter from his brother John Frederic of Arequipa, this, he not being at home, I left with the servant and then continued my walk through pretty streets and squares to the north of City road, till I reached Cummings street where at my aunts I remained a considerable while, they showed me a printed book containing the genealogy of the Willincks, a copy of which fell at a later period into my hands. Gonzales and I used to take our dinner in a chophouse in Cornhill opposite the new Exchange then in progress of construction, our plain meal over we drove in an Omnibus as near as possible to Madame Tussaud's Waxwork exibition, Portman's square. The saloon was opened at 7 o'clock precisely, the impression on entering was striking. The saloon brilliantly lighted up with gas was filled with wax figures, life like effigies of the persons whom they represented, each in its proper attire, some in gorgeous and costly costume. Along the side wall stood at short distances fluted gilt columns, the intervals between each two hung with dark red drapery occupied by small groups of from 2 to 4 figures. Two principal groups filled the centre of the saloon; the one consisting of Queen Victoria, many members of the Royal family and some of the nobles of 
the land. The other [143] of the Emperor Napoleon, Alexander I of Russia, Frances I of Austria, Frederic William III of Prussia and many other high personages of European celebrity. It is superfluous to add that their dresses were dazzling and that they were decked with orders and stars. At the extremity of each of the two passages, between these principal groups and the side walls was a large pier glass and in the recess between the 2 glasses sat King George IV in his coronation robes. For further particulars I might refer to the catalogue which enumerates all there was to be seen, however I think that a succinct account of what pleased and interested me most will not be out of place. Immediately on the right were the Princess Royal and the young Prince of Wales, children of Queen Victoria in expensive babies dresses lying in their costly cradle, close to them stood a Chinese mandarin with his favorite mistress, he in a many coloured gown which for the variety of its hues put me in mind of a Harlequine's dress, pea-cock feathers stuck out from his cap and 3 or 4 of his fingernails of uncommon length attested his high rank; both moved their heads. Louis XVI of France looked a good natured man, as he was, the Queen Marie Antoinette had a majestic mien; her two little children, the boy the unhappy Louis XVII so cruelly treated by the monster the shoe-maker Simon, the girl, afterwards married to the Duke of Angoulème, before her Francis I and Henry IV of France, both in armour, stood near each other, the former a handsome man in the prime of life, the latter at an advanced age with a grisly beard. Queen Victoria and the Prince Consort, standing before a Bishop and exchanging rings did not answer my expectations, for the latter at all events has always been considered a handsome man which in my opinion he was not, as I now saw him. Lord Brougham and Sir Francis Burdett were placed near each other, I was struck with [144] the very remarkable turned-up nose of the former as well as with the intelligent face of Mr. C[u]nning. Leopold King of the Belgians still as Prince, was undoubtedly the handsomest man in the whole company. Queen Caroline, George IV's unfortunate Queen, her hair hanging down in numberless ringlets, was represented in a melancholy attitude, and pleased well. Old King George III, Pitt on the one, Fox on the other side, I recognised at a glance. His sons stood there, handsome men as they were. Queen Elizabeth, the haughty imperious woman, Mary queen of Scots pretty with downcast eyes and the 3 Reformers, Luther, Calvin and John Knox, formed an interesting group, Luther's square massive face is always easily known. In 2 other groups of British statesmen, amongst whom Sir Robert Peel, Daniel O'Connell and Palmerston were the most distinguished, I discovered no features indicative of the great intellect which some of them no doubt possessed. The looks of Mrs. Siddons, the famous tragic actress, as Queen Catherine, were splendid and majestic; Sir Walter Scott had the appearance of 
an honest benevolent farmer; Voltaire with his abominable sarcastic grin, a small three cornered hat in his right hand, and paying his respects to an old french Coquette was very characteristic. Madame Saint Amarante, who fell during the French revolution a victim to one or the other of Robespierre's evil passions, dressed in black, a black veil covering her face, lay on her couch resting her head upon her arm; her bosom and body heaving as if she were asleep. This figure is almost too life-like. The "non plus ultra" of the whole collection were, Frost, the Chartist leader, sitting at the deck, pen in hand; Mrs. Tussaud herself an elderly lady, spectacles on her nose, and William Cobbett, also spectacled, sitting on a bench and gazing at the two principal groups of the saloon; all three were dressed in common clothes and it is asserted, which I by no means disbelieve, tha[_] [145] visitors have addressed them thinking they were alive. For an additional sixpence we were admitted to the [_] room of horrors, not so very horrible after all; here you see the wretch Marat in his bath in a reclining posture, his hideous features in the agony of death, the black blood gushing from a deep wound in the neck. There were busts of Robespierre, Fouquier-Tinville, Hebert, also of Ravaillac; further full-sized figures of notorious English murderers, such as Greendere, Courvoisier, Hare, Burke, with a most vulgar expression of face and others. It will be remembered that a comparatively modern verb "to burke" has been introduced into the English language, founded on the atrocious and peculiar manner in which the last named used to murder his victims. Burke was hanged in 1829, his accomplice Hare escaped by turning King's evidence. In a frame, and under glass, was shown the identical shirt worn by Henry IV, when stabbed by Ravaillac, a large blood stain on it. The two last rooms were filled with curiosities relative to Napoleon and are highly interesting, there were his carriage and his toilette case, both taken after the defeat of Waterloo; the toilette case was empty, but its many compartments gave evidence of the various articles it contained when complete. The camp-bed in which the Emperor slept during his 7 years residence at St. Helena, a coffee cup there used by him, his cloak worn at Marengo, his sword worn in Egypt. A Diploma of a knight of the Legion of Honour, rolled up, Napoleon's signature outside, one of his teeth, etc. etc. It was a pity I had no time to look at all these things with the attention they deserved, I had remained too long in the other rooms and at 10 o'clock the exhibition closed and all visitors were requested to leave.

Saturday, $7^{\text {th }}$ of October 1843. This forenoon was devoted to a visit to the Zoological Garden, one of the most [146] interesting, if not the most interesting, of the many objects which the great metropolis presents to the curious traveller. Gonzales and I walked to Cumming street, whence with my aunt and cousin we drove in an omnibus to Regent Park, where we alighted. 
I gave my arm to Mrs. Willink, Gonzales to Frances, the conversation between the two latter must have been equivalent to nil, for the beau, notwithstanding his efforts, had made but little progress in the English tongue, and the belle did not understand a word of Spanish. We passed through the park and entered the garden which, similar to that on the Surrey side of the Thames, surpasses it by far, in extent, and in the number of animals collected here; many of them very rare and procured with great difficulty. These are of course the principal attractions of the Garden, but even without them, its green fields, traversed by wide well kept gravel walks, the fine trees, bushes, and shrubs, not a few of which brought from foreign climes, would suffice to form a pleasant promenade. The wild beasts are kept in roomy cages secured by strong iron bars, whilst those of milder nature, especially the herbivorous, are allowed more liberty. The latter have their pasture grounds, slightly railed in and their comfortable huts, not to say houses, to which they retire for rest. In one cage were 5 or 6 beautifully spotted leopards, the size of the full grown one about that of a big Newfoundland dog, 3 or 4 of them, young whelps, were tumbling and playing about like so many kittens, the motions and the look of the lot clearly showed that they belonged to the feline family. The tiger, striped, not spotted, is much taller than the leopard, one of these ferocious beasts incessantly paced its cage up and down, the make of the forelegs, and especially of the paws, denoted that in them lay its enormous strength. A big lioness in a cage by herself constantly moved about somewhat like the tiger, but in a more restless manner, not with [147] the quiet self possession of the others. Another lioness somewhat smaller occupied a cage in company with a lion, the latter was very lazy, did not stir at all, sometimes yawned awfully. The head and face usually given to the Lion in the imperial arms of the United Kingdom drawn as their supporter on the one - the Unicorn on the other side - give in my opinion a fair idea of the original I then had before me. Of the Elephant I find in my original diary a rather queer description, I said that the one in the garden, a fine tall specimen, looked more like a condensed mass of mud than a being of flesh and bone. With a young one we amused ourselves by giving it some bread, which it picked up with the trunk and then threw it into its mouth, a vast receptacle placed below the trunk. A Rhinoceros, very lazy would not stir, its hide is of the same colour as that of the Elephant, its so-called horn, in fact no horn, is a thick somewhat round shaped hard bony substance, which protrudes a little above the nose. There was a Hyena, an ugly restless animal, of a dirty light fawn colour, with nothing of the beauty and majesty of the tiger, lion or leopard, it belongs, I should say, rather to the dog or wolf, than to the cat species. Of dogs there was a fine collection, also 2 brown bears; 4 Giraffes interested me above all. They are of a fawn colour with brown 
spots. Their forelegs and tall neck give them in front the extraordinary height of 15 or more feet; whilst behind they fall off so suddenly, that their hindlegs do not measure above 5 feet. They were so tame, as to bow down their long necks and to take anything from the visitor's hand. Of Camels there was but one, certainly no beauty, it had only one hump. The Ourang-Outang was sick, and lying down covered with a blanket; when it stretched out one of its forepaws, it bore some resemblance to the skinny hand of an old woman. Of monkeys and baboons (neither the one nor the other ever quiet), [148] there were great numbers; likewise of parrots, continually screaming. One or two macaws (the Huacamayos of Central America) 2 ostriches, 1 cassnary, extensive collections of eagles and vultures, etc. etc.; two water-rats bigger than any cat I had ever seen, likewise young aligators, artificially hatched in the Garden, much resembling lizards, the difference between the two lying in the shape of he head; further 2 or 3 snakes; the rattle-snake did not choose to make its appearance, I need hardly say that there were hundreds and hundreds of other animals, which however escaped my notice or faded from my memory. The foregoing will give an idea, though certainly a very insufficient of the wonders of the zoological gardens. Three manners of conveyances, an omnibus, my legs, and a railway train, carried me to Croyden station, not far from Mrs. Glovers, with whom Mrs. Grautoff and daughters lodged. I had hitherto been under the impression that they had lived with the de La Fosse's, this day I learned that the two families were very intimate, but that the de La Fosses stood far too high in society to let apartments. We were by ourselves, had a nice dinner and much pleasant talk. Mrs. Grautoff was particularly agreeable, of the two daughters, the younger, Ellen, pleased me better, the elder, Caroline, was too quiet. By train I returned to London and on foot to my lodgings.

Sunday, $8^{\text {th }}$ of October 1843. Windsor was the goal of our this day's excurtion, an Omnibus took us to the Paddington, thence a train to the Slough station, due west from London. A mile and a half's walk through a pretty country took us to Eton college, a large plain brick building, we crossed a yard where many youngsters were at play, walked about the park, passed a bridge and found ourselves in Windsor. There I engaged a fly for 12s to drive us through the park to Virginia waters and back. From one of the entrances of the castle a long avenue called "the long walk", runs in a straight line for $23 / 4$ miles to a colossal equestrian [149] statue of George III. It is formed by two double rows of trees, and lined with soft green turf, the extensive park, 30 miles in circumference, spreading on each side. At a very short distance from the Castle, to the left of the avenue, stands a cottage called "Frogmore Lodge", where at the time the Duchess of Kent, Queen Victoria's mother, resided. At the extremity of the avenue a smooth lawn gradually ascends, and on the summit large granite 
stones and blocks are piled up, apparently by nature, but in reality by human hand. In one of them the following inscription is engraved, "Georgio tertio optimo patri Georgius Rex", and on the top of the pile stands as above said a colossal equestrian Statue of George III, it is of bronze, the King in imitation of ancient statues rides without stirrups, the ancient Greeks and Romans as it is well known, used neither spurs nor stirrups. Here the road branches off to the right, and to the left; we continued our drive in the latter direction through he beautiful park, sheep, red and fallow deer, grazing unmolested and undisturbed under the shade of its stately trees; we passed several neat cottages, occupied by the keepers, also the Palace, though it went by the humble name of Cottage, in which King George IV passed many of his later years, where he fell ill, and whence he was removed to Windsor Castle, there to die. The Marchioness of Conyngham used to be his constant companion, whilst the Marquis contented himself with living in one of the outer buildings. Of the latter a few still remained in 1843, used for the Queen's and Prince Albert's hunting studs. Our driver told us that some of the dwellings forming part of George IV's luxurious establishment had been pulled down by order of Adelaide, Queen dowager of William IV, who, as well she might, had been scandalized at the immoral conduct witnessed by these [150] walls. Further on we came to Virginia Waters where we had to alight. This part of the park owes little to nature, nearly all to art, and the exquisite taste of George IV. Virginia water is a broad river dug out 12 to 20 feet deep, some rocks are thrown into it for the purpose of forming a cascade which however is insignificant in the extreme, there stands a cottage in the Chinese style, where King George used to angle; there are artificial Italian ruins, a bridge spans the river, green fields extend all around covered by groups of young and old trees, the whole is very pretty, and the nation must have had to pay dear for its sovereign's hobby. When we were there 2 threemasted yachts were lying at anchor, the one belonging to the Queen dowager, the other to Queen Victoria. We drove back more or less the same way we had come, we passed a Palace once inhabited by the Duke of Cumberland, the hero of Culloden; we saw at a distance a column erected to commemorate this victory, also a tower called the Belvedere. As soon as we had alighted in Windsor we directed our steps toward the castle, situated at the top of a low gradually rising hill. It is built throughout of grey stone, and its exterior, though extremily irregular is imposing for its plain solidity. It was during the reign of William the Conqueror that an extensive fortress was erected here, which by his successors has been enlarged, improved and altered, until it has become what it is in our days; as late as $1824 £_{300,000}$ were voted by Parliament for further improvements, and in 1843 it was in a state of excellent preservation. The state rooms are shown to the visitors amongst whom Gonzales and myself 
were on this occasion; the haste with which we were hurried through them, was to say the least of it, very annoying to me, who like to examine things leasurely. We passed through the guard room, filled with ancient armour, through the St. Georges or great banqueting [151] hall, through the ball or grand reception room, furnished and fitted up in the style of Louis XIV! time overloaded I may say with gilt carvings, through the Queen's audience room hung with superior Gobelin tapestry representing the story of Esther and Mordecai, we may have careered through many other saloons but of them no recollection remained with me. The chapel is within the precincts of the castle some distance down the hill; it was opened for divine worship when we entered, but also here we were not allowed to remain long, for hardly had I stopped for a few moments to examine the cenotaph of Princess Charlotte, when a verger told me that the service was about commencing. Gonzales and I left and wended our way to the north terrace (commenced under the reign of Queen Elizabeth) whence we enjoyed a beautiful prospect over the country, green fields spotted with trees, Eton college and the Thames lay before us. This view brought back to my mind a similar one from the terrace of St. Germain en Laye where I had been in 1824 when present at the betrothal of Louis Stanislaus Macé, who had been my fellow pupil in 1815 at Mr. Jay's. We continued our walk to the east and south terraces which owe their origin to Charles II. Crowds of people were listening here to the music of 2 military bands and waiting for the appearance of the Queen, who after all this time disappointed her loyal subjects. From the terraces the ground slopes down gently and the space between them and the castle is filled up with flower beds, intersected by gravel walks with a pretty sheet of clear water and with four bronze statues. In front of the castle stands an imitation of the famous (why?) Warwick vase. If Gonzales had now done as I wished him to do, we might have reached London by daylight where we still might have got something to eat, but to him it was impossible to withstand any longer the cravings of [152] an empty stomach, though already in the forenoon we had recruited our strength with some bread and cheese, and I thus allowed him to take his dinner by himself, which, consisting of partridge, some ale, bread, and waiters fee, cost him $4 \mathrm{~s} / 9 \mathrm{~d}$. In the dusk we walked to Slough where [_] arrived before 7 o'clock, as the train for London would not start for $3 / 4$ of an hour, we had nothing better to do than to enter the Coffee-room at the station, sumptuous splendid and correspondingly expensive; for tea and toast we were charged $4 \mathrm{~s}$, besides $6 \mathrm{~d}$ for the waiter. The train, then the Omnibus, carried us to the bank, but a short distance from Finsburry square. Mrs. Dakins treated us to tea and we retired to rest still at an early hour.

From Monday, $9^{\text {th }}$ to Thursday, $12^{\text {th }}$ of October 1843. The greater part of the forenoon of these days I stayed at home, occupied with writing; I merely went 
out an hour or so to stretch my legs. Once I went to the Baltic Coffee house to look for Bernard Charlton, such Coffee houses were, and probably still are, very convenient for gentlemen who have no fixed residence in the city. For an annual payment of 5 Guineas, Bernard might remain in the Coffee house as long as he chose without being under any obligation to take refreshments, he could receive his friends, messages and letters were left there for him, he had the daily newspapers at his disposal, and pen, ink and paper for his correspondence, without any extra charge. Another day I called on Miss Maria Cresswell in "Doctors Commons", she was very kind, had some lunch brought in, called Douglas Dubois one of her sister Harriet's sons from the office, and did all she could to make herself agreeable, the sprightliness of her sister Frances was however not be found in her. The third forenoon I paid a visit to Mrs. Johnson a [153] pleasant old lady 78 years old of age, living in Newgate street with her son in law. She spoke in very affectionate terms of her son Frederic of Arequipa, told me that her son the assayer was absent in Cornwall and made herself a little ridiculous by dilating on the grandeur of the Johnson family. The fourth forenoon Mr. Wm. Gibbs detained me a long time with a repetition of his enquiries relative to his correspondents on the West coast. The evenings I spent much to my liking; on Monday I took tea with Elmenhorst and his wife in Stokenewington, a Mr. Preller an agreeable man, intimate with Theodore made the fourth to our little party. On Tuesday I took a plain dinner with Bernard Charlton in Greenwich, his wife looked better than I had at first thought she did, she had fine dark eyes and a well shaped nose, her complexion was rather dark she being of East Indian extraction. On Wednesday I dined by invitation at Mr. Edward Sieveking's Stamford Hill the first house outside the turnpike gate, I drove thither per omnibus. The party which met was rather numerous, consisting of Germans only, and German was the only language spoken. There were a Doctor nearly blind and his lady, both elderly people, a young clergyman, Elmenhorst and wife, Mr. Preller, Christian Donner, Mr. Sieveking's son Gustavus, and some others whose names I do not recollect. To all them I was introduced as Mr. Witt of Lima and as may be expected questions about Lima, Peru and South America in general were not wanting. When we went below to the dining room Mr. Sieveking took the Doctor's wife, the Doctor, Mrs. Elmenhorst and I, the lion of the party, Mrs. Sieveking. At dinner, which was nice and genteel, not over abundant, I sat to her left, the Doctor to her right. Two servants in black attended. The general conversation was animated, I talked a good deal to Mrs. Sieveking, daughter of Senator Meyer of Hamburg and thought [154] her a very agreeable lady. After dinner the time passed quickly away with coffee and tea, with looking at books and prints and chatting; the party broke up at 10 o'clock. The Doctor and wife 
who lived at Camberwell 7 miles off gave me a seat in their coach and put me down in Finsburry square. Thursday evening I was present at a public meeting in Covent Garden theatre convoked by some members of the ultra liberal party. Mr. Edward Sieveking, who in politics inclined to radicalism had received a ticket of admission, which he was good enough to give to me. After having waited for a short time before the doors of the theatre, I pushed through the crowd as soon as they were opened, and secured a seat in the pit in the $3^{\text {rd }}$ row from the stage. The interior of the theatre resembled that of Drury lane; it was crowded from top to bottom, even on the stage several rows of benches, placed amphitheatrically were occupied by spectators, and between them and the footlights stood 4 armchairs destined for the orators and a table covered with green cloth at which 2 secretaries were seated. The first who appeared was Mr. Villiers M.P. chairman, who said a few words in a plain distinct voice, the object of which was to extol the merits of Mr. Pattieson and to run down Mr. Thomas Baring, both candidates for a seat in the House of Commons in lieu of the recently deceased alderman Mathew Wood, well known at the time of Queen Caroline's trial, it need hardly be added that the former of the two was liberal, the latter the conservative candidate. Mr. Villiers next introduced to the audience Mr. James Cobden who was received with shouts of applause, so was the next orator Mr. John Bright. After them spoke Mr. Fox and when he had had his say, Mr. Villiers again made his appearance and in a few words requested the audience to meet again in a fortnights time. The speeches of the 3 orators were of course all on the same side, they were of an inflammatory nature [155] and full of abuse of the aristocracy and oligarchy. The corn laws were called hideous, grinding, etc., also the duty levied on foreign-grown sugar was touched upon in severe terms, many sarcasms were flung against an expression which one of the Conservatives was said to have made use of, viz. that the anti-corn law principles might do in theory, but not in practice. Such expressions as the merchants and traders of the wonderful town of London, the enlightened constituency of the city, no monopolies and the like, drew down thunders of applause, cries of hear, hear resounded, handkerchiefs and huts were waved, the entire audience to whose intellect the orators well knew how to adapt themselves, was in a state of great excitement, Cobden spoke in a quiet jocular manner, whilst Bright, who at the end grew hoarse, ranted not a little; the former said in plain terms that the anti corn law league intended to prosecute criminally every one who at the present London election could be proved to have received or to have offered a bribe, the latter went so far as to give to understand that the Government was upon the whole a superfluous encumbrance; to Mr. Fox I Iistened but little. At a late hour the meeting broke up, as to myself I entirely lost myself in the intricate streets between Covent 
Garden and the Strand, however as soon as I had reached this last named great thorough fare I of course knew my way and reached my lodgings without any further trouble.

Friday, $13^{\text {th }}$ of October 1843. When last in Arequipa, Mrs. Gallagher gave me some introductory lines to her parents Mr. and Mrs. Dr. Robertson residing in the Chatham; in order to pay them a visit I left London on this day and embarked at $101 / 4$ on board a steamer for Gravesend from a wharf immediately below London bridge on the city side. Where the extremity of the former bridge had been stood in 1843, and still existed in 1863, a handsome [156] Hôtel; somewhat further down the river on the same side is the Custom House, the narrow space between it and the water filled up with terraces. It was a fine day, the sky azure blue, the sun shone out, however, over London city hung a thick yellow fog, on the river all was life and activity. Boats plied from the one shore to the other, steamers steamed up and down, sailing vessels came up with a fair breeze, whilst others, the wind being but slight, could creep downwards with the help of the ebbing tide. For some distance along both banks was moored vessel to vessel in one continuous row, gradually this dense mass grew thinner and thinner, and I saw on both sides well cultivated fields, the right, the Kent side, woody and hilly, the left, the Essex side, flat and apparently marshy; towns, villages, now and then Gentlemen's country seats succeeding each other at short intervals. At 1 1/4 we arrived at Gravesend where an omnibus was waiting for the passengers; I took my seat outside. After an hour's drive through an open, in England never barren country, we entered the town of Stroud, consisting as far as I could judge of one long street. When approaching the "Medway" I saw opposite, rather picturesque, the old Cathedral and the ruins of the Castle of Rochester. We crossed the bridge and found ourselves in the "city and borough" of said name. A long straight street traverses it as well as the town of Chatham without any visible division between the two places. Chatham lies close to the Medway, which flowing in a N.E. direction falls into the Thames a short distance farther down, Rochester is situated a little inland. In Chatham I alighted at the Robertsons, who received me with great kindness, a bed room was assigned to me, we immediately sat down to lunch and soon after to diner, which was very good, perhaps a little better than usual on my [157] account. In the evening many visitors came in, Mr. and Mrs. Dickinson, elderly people, very intimate with the family, their daughters, their son in law Mr. Whittle, employé in the Dockyard, Mr. Tiper assistant surgeon, an old bachelor Major Seward, who having served as officer of Marines on board the Flagship in the battle of Navarino $\left(20^{\text {th }}\right.$ October 1827$)$ had been, of all officers on board the only one who escaped without being wounded or killed; there might have been a few young folks whom I did not take notice of. Till past 
1 they made me play short whist with Dr Robertson, Major Seaward and Mr. Whittle, all better players than myself, and though I do not find it mentioned, no doubt I rose a loser. Willingly would I have escaped to the young people who amused themselves with a round game, and afterwards with dancing, but this I found impracticable.

Saturday, $14^{\text {th }}$ of October 1843. The house in which the Robertsons lived was small, on the ground floor were the dining room and the surgery, half way up the stairs a bedroom for the boys, on the first floor the drawing room and the room given to me, and probably on the $2^{\text {nd }}$ floor the bedrooms for the remainder of the family. This family was numerous, there were the Doctor, called so by courtesy, for he was but a surgeon, attached to the dockyard, a pleasant shrewd elderly gentleman whose favourite amusement seemed to be playing at whist, his favourite occupation intriguing and canvassing for the political party to which he belonged, the Conservatives; next his wife, perhaps older than he, pleasant but rather limited in intellect, their two daughters, Elizabeth and Emma, both plain, with large mouths and noses and small eyes. Emma, the younger, who in later years married on the west coast Mr. Thos. Renny could however boast of a fine complexion, and a handsome bust, both did their best to make [158] themselves agreeable and I liked them well. Finally there were two boys, Tom and Ned, and their cousin William Shaw born in Sierra Leone. Besides these already mentioned I knew of the Robertson family, the eldest, Isabel, Mrs. Gallagher; the next Mary Ann, Mrs. Went, the doctor Archibald, and Patrick, for some time clerk at Gibbs', and he who many years later died in the capacity of British Consul in Callao, was, I suppose either Tom or Ned, children in 1843. After breakfast I went out for a stroll; the house was a corner house, on the south side of the already mentioned long street which, in 1843 extended $33 / 4$ miles from the western extremity of Stroud across the bridge to the eastern extremity of Chatham. On the west side of the house ran up a somewhat steep street to a high ground, behind or to the south of the town; from this commanding spot I had an extensive view over the surrounding country dotted over with many wind mills, turning my eyes to the northward, there lay before me the town, the river Medway and the opposite shore where a village called Frindsbury was distinguishable. I walked for some time on this height, descended to the main street and returned to the Robertsons. Here, the mother being unwell and in bed I chatted with the daughters until the father came back from his visits to his patients, and it still being early in the day we two then started on a round to the many interesting objects to be seen in Chatham. On our walk the doctor pointed out to me some fortifications thrown up at the time when Napoleon's invasion was apprehended and which were now falling into decay. We first came to the barracks a little out of town in a 
north easterly direction, they formed a row of solid brick buildings, a gravel walk in front of them which some of the red coats, for punishment were smoothing by means of heavy iron rollers. Trees [159] and shrubs were about being planted, lawns laid out which in course of time would soften a little the heavy appearance of these piles of bricks and mortar. The Krompton barracks for the artillery-men formed a square three sides of which were occupied by the buildings, the fourth by a garden or park railed in. I observed over the door of each barrack figures which denoted the number of soldiers in each, in a similar manner in the interior each saloon was numbered for the same purpose. We entered here the office of Sir Frederick Smith chief of the corps of artillerymen and Engineers. Dr. Robertson was a crony of his, for it was he whom the Conservatives, also the Government were anxious to bring into Parliament, after the present member Mr. Byng, a radical, would be raised to the house of Lords on the death of his father which was shortly expected. On application to a clerk in military dress, a sergeant showed us over the model-room, which pleased me much, there were models of [_]dges, pontoons, roofs, all kinds of carriages used by [_] my, of cannons, and even of fortifications. On a table stood the model of a fortified town, with the besieging army, showing how the latter makes its approaches and opens its trenches, there were Congreve Rockets, consisting of Iron tubes more than a foot long, and filled with the powder. There were many relics from the "Royal George" which went to the bottom in Portsmouth harbour in the year 1782, viz. 2 large pieces of the main-mast, part of her cable, 4 muskets which by the action of rust had been united into one compact mass, various implements, a piece of leather, etc., all brought to light in 1839 by means of an apparatus of which on a later occasion $\left(27^{\text {th }}\right.$ October 1843 in the Polytechnic Institution) I saw a model on a diminutive scale. In 1843, and I suppose in 1868 the same law is still in force, foreigners were not admitted [162] \{one sheet cut out\} into any British Dock Yard without a special license from the proper authority; however, accompanied by the Doctor I found no difficulty, only in the book kept for the purpose of entering the names of the visitors, I had to write mine as Henry Witt merchant of Edinburgh. Once within the precincts all I saw excited my admiration; everything was carried on, on a scale and in a manner worthy of the first maritime power. Now in 1868, the era of iron-clads, even the strongest wooden vessels, three deckers with 100 guns or more, are out of date, nevertheless [if in] after times these my extracts should ever be read, [_] short description of what I then saw, may perhaps be looked upon as a strange and curious account of olden times; I therefore proceed. There were 8 or 9 slips on which as many men of war were in various stages of construction; they were under roofs provided with glass windows, which roofs, formerly made of copper, consisted of thick brown 
paper, tarred and printed, this being both lighter and cheaper then the previous material. The "Trafalgar", a handsome 3 Decke $[. .$.$] apable of carrying 100$ guns, was nearly finished, she had Nelson's bust for a figure head, the Admiral's cabin was on deck, her length 200 feet. The "Watt", when concluded, would be the largest man-of-war steamer then in existence. The "James" was to be constructed as an experiment on the plan proposed by Lord Alex Cochrane, viz. a steamer capable of moving backwards and forwards without the necessity of turning, her length 189 her breadth no more than 29 feet. Of other vessels the Reel had just been laid. All these vessels when brought to a certain point, would, as I was informed, be left unfinished for 6 or 7 years, so that the timber becomes perfectly dry. Considerable quantities of timber were kept in Depôts formed by the waters of the Medway, which Depots were impregnated with the solution of a certain mineral, the name of which has escaped my memory. The timber having remained there a certain length of time [163] is then said to be cayenned, (I believe the proper term is Kyanized) and is considered to be impervious to the dry-rot, also sails treated in the like manner do not rot though folded up wet. Under another very extensive roof all kinds of boats were about being built. Until 1843, or thereabouts, the planks of which boats were made, used to be placed lengthways, thus place the inner coating broadways, thus, III the outer coating crossways thus, ' $\mathrm{WII}$ and between the two coatings common oil paper, a greater strength was obtained by these means. Here was a boat belonging to the Queen's yacht, also a life boat, the former painted outside black with a gilt line, inside green with a similar line, the seats and grating of mahogany; in the latter the life boat, all seats were hollow, besides which, there stood in the middle a hollow case, more or less in the shape of a coffin. By means of these cavities filled with air, a life boat is always kept buoyant, and cannot be submerged, the rowers who work such boats are usually lashed to their seats so as not to be washed off by the surging waves. Next we came to the smithy, still within the dockyard, all walled round. Here the fabled stories of the "Cyclops" of old came to my mind. I thought of Virgils "Illi inter sese multa vibrachia tollunt". Forty or more fires, each a forge, were burning; one of the "Cyclops" sooty as he was, otherwise a handsome and intelligent man, showed us round and explained everything. Bellows were no more in use, instead of them 2 fans, put in motion by a steam engine, created a current of air carried through numbers of pipes to each forge respectively, a valve easily graduating the quantity of air wanted. The same engine put in motion two enormous hammers, the one weighing $700 \mathrm{lbs}$ fell down upon the iron placed on the anvil with a weight of $51 / 2$ tons, 130 times a minute. This was brought about [164] by a machinery, the working of which passed my comprehension; the other hammer, named the Hercules, was 
without such machinery, the weight with which it came down was somewhat less, and 2 or 3 seconds intervened between each blow. Our conductor told us that the iron when thoroughly heated, or rather melted, becomes of a snowwhite colour; I may however observe that, when about 2 months later I saw liquid iron in the great cannon foundary of "Low Moor", the liquid mass was of a light rose colour. Outside the smithy some neatly-finished anchors, just concluded, were lying; one of them weighing 8500 lbs Much more work had the same engine to do, it turned steel borers which with great ease bored holes into and through iron; it cleaned the Dock of the residue of water, it lifted beams and carried them to the saw-mill, where again it moved many saws, cutting the beams with the greatest nicety into planks of every thickness. The sweepings and remnants of timber, here of no further use, were swept together into large heaps, and disposed of by public sales monthly. Convicts were employed to work in these establishments, they were dressed in jackets, waistcoats and breeches of light brown ordinary cloth, with white and gray striped stockings, an iron ring round one of their ankles which did not prevent their walking. Gangs of them moved about with hardly any guards attending them; the dockyard being walled round, as said above, there had been few examples of their making their escape. On board the convict ship, an old manof-war called the "Fortitute", the convicts seemed also to be but slightly watched. A Mr. Bly, assistant to Dr. Robertson, accompanied me over this vessel where everything was kept as clean as could be desired. When this vessel had her complement of convicts on board, which was but seldom the case, one ward was alloted to each 24 of them, thither they went to take their meals and rest. They [165] slept in hammocks slung against the ceiling; each ward was provided with 3 tables, to each table belonged 8 jugs, 8 plates and 8 spoons ranged on the shelves around. The windows towards the sea as well as those which looked into a passage in the middle of the vessel, paced at night time by a sentry, were of course well secured with iron bars, the doors with strong padlocks. Close to the "Fortitude" was moored the "Wye", used as a hospital to which Dr. Robertson was attached as physician. This vessel was somewhat smaller than the "Fortitude", and if possible still cleaner, or at all events better aired. In the centre burned a cheerful fire; each sick man, of course a convict, lay in his iron bed stead on a mattress, with pillow, sheets and a blanket, a chamber pot standing on a form within his reach. The convalescents were cleaning the deck. Dr. Robertson had here his own neat cabin, so pretty that his family was in the habit of paying him there an occasional visit to divert themselves. Not a few men of war were lying at anchor in Medway "in ordinary" as it is called, which means that part of their masts, their yards, sails riggings etc. are taken down and kept on shore in good order ready for immediate use 
in case these vessels are wanted for active service. Shortly after our return home we sat down to dinner; messengers had been dispached to various friends to play a rubber, fortunately only Major Seaward came and thus as no table could be made up we passed the evening in conversation.

Sunday, $15^{\text {th }}$ of October 1843. With Miss Elizabeth and the boy Tom I went to Rochester Cathedral, there to attend divine worship. This church as far as my poor judgment goes is only remarkable for its great antiquity. Miss Agnes Strickland in her excellent work "Lives of English Queens", says in her biography [166] of Matilda of Scotland, Henry I's first queen: "There is a statue of Matilda in Rochester Cathedral which forms the pilaster to the west door; that of King Henry her husband forms another. The hair of the Queen depends over either shoulder in two long plaits below the knees. Her garments are long and flowing, and she holds an open scroll of parchment in her hand. Her features are defaced and indeed so completely broken away that no idea of what manner of countenance she had can be gathered from the remains." My companions knew nothing of these statues, and they not being pointed out to me escaped of course my notice. Here in the same manner as in Exeter Cathedral and Windsor Chapel, only in a small part of the building divine service was held, the organ partitioned it off from the other part. A Doctor Alcock preached, and, what happens seldom to me, with sermons delivered by Divines of the Anglican Church, I was pleased with what he said; he insisted upon the indisputable truth that faith alone does not secure our salvation; good works are indispensable to obtain this end. Service over, we called on the parents of young Sawyers the "Vicar of Bray's" first mate; we stayed a few moments with the mother an old lady and then walked home, not along the long street, mentioned more than once, but on the high ground which extends to the back of Rochester and Chatham, a well kept gravel road and then the steep lane alongside Robertson's house took us home. In the drawing room we found several visitors, Capt. Seymour, old Mr. Sawyers, Collector of the Custom House, a particularly fine looking old man, his son the mate, also the Dickinsons. When the visitors were gone, Capt. Seymour, who stayed for dinner, with Miss Emma, I with Miss Elizabeth and the boys [167] started for a walk, between the two first named much flirtation was going on. We were rowed over to the opposite, the left side of the Medway, walked as far as the pretty church and the church yard of Frinsbury, thence coming back we passed the entrance of an underground canal or tunnel which unites the Medway with the Thames and of which barges are in the habit of availing themselves, making thus a short cut instead of going round the Peninsula formed by the confluence of these two rivers. We then kept close to the river's bank until we reached Stroud, passed the bridge and returned to the Robertson's through the long tiresome street. 
Here a good dinner with Champagne awaited us, and this being Sunday, no Whist-day, we conversed until Seymour left, and the inmates of the house, I amongst them, retired to their respective bedrooms.

Monday, $16^{\text {th }}$ of October 1843. After breakfast Doctor Robertson and I walked to the parade ground to see the soldiers muster, who are sent off in small pickets to relieve the guards posted all over the Dockyard, arsenal and other important points in Chatham. There were but 200 of them and they looked extremely neat and clean in their scarlet jackets, blue pantaloons and white gloves. The major, the adjudant and the Commander, General Sir Thomas Wilshire, this latter in military undress, were on horseback. Sir Tho. Wilshire who had distinguished himself in the Afghanisten war, looked a hale, strong though elderly man; he was a martinet and had a quick eye as Dr Robertson assured me. Of these two qualities he gave me evident proof during the short time we were on the ground. Nothing escaped him. "Major, do not go so near, they can hear you better at a distance" to a young officer, a High- [168] lander in his splendid national dress, though without a kilt, "move a little further down, further down"; to a sergeant, "your hand is too low, keep it higher up"; then again, "Good God Almighty, what are you about", such and similar expressions kept all on the "qui vive". The whole small body went through its usual exercise. It passed in review before the commander whom all respectfully saluted, the officers with their swords. From the parade, the Doctor and I went to the Hospital-ship, where, whilst he visited the sick, I amused myself in his cabin with reading the "Lancet" a medical periodical from which I learnt that the death usually called death by old age or from natural decay, is caused by the ossification of some part or other of the human frame. On Saturday last, time had not sufficed to show me all the establishments of the Dockyard. This day I visited a room where models of nearly everything used in the yard were kept, neatly and carefully arranged; another saloon where lead was melted, at first in large square pieces which were reduced to any dimension required by being placed between 2 iron cylinders turned by steam. These cylinders turning round, the mass of lead was dragged through and came out slowly at the other end exactly of a thickness equal to the distance between the cylinders; again another saloon where leaden pipes or tubes of great diameter were reduced to tubes of any diameter, this was also done by steam. There were iron moulds of great thickness perforated all through, the one wider, the other narrower; through them the leaden pipes were pulled, an iron rod in the middle preventing the aperture from closing, and thus every process diminished [169] the diameter, and naturally increased the length of the tube; another building $1 / 4$ of a mile long, which served solely for the purpose of making rope. In one story the hemp was carded, in another spun, and twisted into twine, which passed at once through hot pitch, in the 
$3^{\text {rd }}$ story the twine was wound upon numerous reels and in the $4^{\text {th }}$ twisted into ropes. The wheels on which the hemp was spun as well as the reels were moved by steam. It may be that there was still more worth seeing, however I was satisfied and even more than satisfied therefore willingly did I consent to our returning home. On this our walk back I was called upon to admire the handsome front of the Melville hospital for marines and soldiers; somewhat later I, accompanied by the boy Tom, looked into Fort Pitt, which as well as Fort Clarence formed part of the fortification constructed in the beginning of the century and above spoken of. The fort which I saw was in a miserable state of dilapidation, its moat without water and in all probability that which I did not see was in a similar ruinous condition. Dr. Robertson who had called on Sir Frederic Smith brought the news that on the $14^{\text {th }}$ Daniel O'Connell, his son, and a whole gang of Irish patriots had been arrested on the charge of sedition, conspiracy, and other misdemeanours; they had however been admitted to bail and again set at liberty. At the early hour of half past seven we went by invitation to the Dickinson's a family apparently of some fortune. There were old Mr. Dickinson 80 years of age, still active and lively, his lady, his son and 3 daughters, Lydia, Charlotte and Harriet. The first named a nice sprightly girl; the second about 24 years of age very agreeable but suffering from such an extraordinary weakness of her neck, that she could not hold up her head [170] and was therefore obliged to be always in a reclining posture. To please the company she rose from the sofa and played a little on the piano her sister holding up her head all the while. The third, Harriet, was likewise ailing. Further a certain Mr. Piper whom I had already seen before; Major James an invalid who had retired after 30 years active service, an agreeable straight forward man, and his lady with some elegance in her manners; finally the Robertsons and myself. We took tea below, then upstairs I was pinned to the card-table with Mr. Dickinson, the Doctor and Major James. At 11 o'clock we went down stairs to partake of a nice supper and wound up with dancing in the neatly furnished drawing room. I danced a quadrille with Miss Elizabeth, another with Mrs. James and got through them better than I expected, whilst on the other hand I did not distinguish myself in a waltz with Miss Lydia, though in Peru and also in my youth before I left Europe I had always been looked upon as a good waltzer.

Tuesday, $17^{\text {th }}$ of October 1843. At 10 o'clock the omnibus was at the door. I bade good bye to the Robertsons, thanked them heartily for the kindness with which they had received and treated me during my stay with them, mounted the coach and drove off for Gravesend where the steamer "Blackwall" was awaiting the passengers. This vessel belonged to one of the 4 or 5 Companies, which at the time were running steamers between Blackwall and Gravesend 
and which, as is usually the case with rival establishments, did their utmost to outstrip and even to ruin each other. Hardly was I on board when I was joined by Mr. Henry Marriott with whom until we landed at Blackwall I had much pleasant talk. He pointed out and named to me the various places situated on both sides of the [171] Thames, but as they can be found on the map of the Thames \& Medway in my possession it is superfluous to repeat them. I will merely note a few particulars which he communicated to me; thus for instance the village Purfleet derives its name from the circumstance that at the time when England was threatened by the invincible Armada, Queen Elizabeth took her station on the spot where the village now lies and turning her looks towards the fleet lying in the river exclaimed "Oh my poor fleet!" thence "Poorfleet" changed in time to Purfleet. Between low and high water in the river Thames the difference is from 10 to 12 feet. On both banks of the river I observed some poles; on those Mr. Marriott informed me the colliers bound for the London market are fastened until there be room for their admittance in the pool which is the name given to that part of the port of London, situated between London Bridge and Blackwall and then they are allowed to enter in the same succession as they have arrived. On the same, the north side I noticed a large Government building, where under a heavy penalty all merchant vessels before entering the port, must deposit all gun powder which they have on board, and which is returned to them on their leaving. Blackwall is the name given to a small Peninsula on the north side of the Thames. It is renowned for the very splendid vessels, especially steamers which are constructed there. A railroad runs thence to London, on a viaduct formed by a continuation of arches, on a level with the roofs of the houses on both sides. It crosses Broad Street and the "Minories" and terminates at the southern end of London Street Fenchurch Street. The train is not pulled along by a locomotive; at first it runs down an inclined plain, then it is moved along by means of a cable running on wheels and in conexion with a stationary steam engine along side [172] the road. There was also a galvanic apparatus which made known in a second or in still less time to the London station when the train had left Blackwall and vice versa. A similar apparatus was also used between the Paddington station and Slough, for the purpose of sending important messages to the Queen at Windsor. This in my opinion must have been a near approach to the electrick telegraph invented a few years later. At the London station I took a cab which passing the, to me well known house in London street $\mathrm{N}^{\circ} 17$ where my uncle and aunt lived in former years, put me down at Mrs. Dakins, with whom and some of her friends I took dinner and tea.

Wednesday, $18^{\text {th }}$ of October 1843 . This day I had fixed upon for a perambulation all over London, and right well did I carry out this, my intention. I started at 
10 and walking eastward soon came to an agglomeration of crooked streets and dirty houses, all about being pulled down, for a broad road was to be cut right through from London docks to Islington. Further on in the same direction I reached Whitechapel, far east, though not yet the farthest east of the great metropolis; thence through the Minories, well peopled with descendents of Abraham, to Trinity square in the neighbourhood of which, $\mathrm{N}^{\circ} 3$ St. Georges street I easily found Capt. Seymour's lodgings and settled my accounts with him. I now turned my face westward and 'ere long was again within the boundaries of the city. I called on my stationers Royston \& Brown, New broad street on Mr. Robins, Jeffreys square, Mary Axe, on my bookseller Robert Jennings Cheapside, on Chubbs, the famous lock-maker, St. Paul's churchyard, where I made a small purchase; then through Holborn part of the great artery which under various denominations runs from the western to the eastern [173] extremity of London, I entered Halton Garden to the north of this immense thorough fare, here at Mr. Hamiltons $\mathrm{N}^{\circ} 73$ I paid my bill for some cutlery bought of him and destined for my family in Lima; next at Mr. Chamberlain's the optician, Broadstreet Bloomsbury I purchased glasses for my eye-glass, and recrossing to the south I soon was lost in the intricacies of "Seven Dials" and its vicinity, the abode of misery and poverty. Emerging thence I came to Leicester square where in 1823 with my good friends, Sieveking and Reincke many a time I had made my Sunday repast at a French "restaurant". Here two panoramas were exhibited to the public, the one of Edinburgh the other of Coblentz, each with its respective environs; I, recollecting the pleasure which 20 or 30 years back such sights had given me, entered, but as I might have well known before hand, now I was rather disappointed. A little further west the handsome parts of London opened out to me, the fine street called the Haymarket, St. James' Street with its many Club-houses; in the Albion and in the Conservative Clubhouses, I looked in vain for the brother of Mrs. Lima of Lima, to whom she had given me some introductory lines; at the one end of St. James' street stands or at least stood in 1843 the tasteless St. James' Palace, at the other, its northern extremity, St. James' street debouches into Piccadilly. I continued my walk along this broad splendid street, had to my left the Green park, passed to my right Apsley House, the Duke of Wellington's mansion, also on the same side Hyde park and then turning to the left came to Sloane street Knight's bridge, where Mr. Edward Dubois and family lived. Mrs. Dubois had of course changed since I knew her as Miss Harriet Cresswell, but considering the many [174] years elapsed since, she had kept up remarkably well, her family consisted of 3 young men, none of whom was at home and her daughter Emma, the eldest of all, a very agreeable, talkative, lively, and as the Willinck's assured me, talented young lady. Both mother and daughter received me very kindly, and when I was 
leaving I fortunately met at the street door Mr. Dubois, now an elderly greyhaired man, judge of the Court of Requests; but the few words I exchanged with him, gave clear evidence that advanced age had not dimmed his intellect nor damped the wit and humour so many flashes of which I had witnessed in his younger days. Having still time to spare I strolled about in the Green park and St. James' Park, had a look at Buckingham Palace at the west end of the latter, where the Queen resides when in London, and emerging at the south east corner of the same Park stopped for a few moments before Westminster Abbey, before Whitehall and the new houses of Parliament, then in progress of construction. Parliament street and Whitehall brought me to the Strand, at the western extremity of which I noticed a high column still surrounded by scaffolding to serve as a pedestal for Nelson's statue, also Northumberland house; a stone lion over the gateway, the equestrian statue of Charles II at Charing Cross, further on Somerset house with its numerous public offices, and finally rested for a while at a genteel Chophouse in Fleetstreet just outside Temple Bar where I took my dinner. I started afresh at about 7 o'clock, struck due north, recrossed Holborn and following the wide and long Grays Inn road came out in the new road at an open place called King's Cross, already to the ast of Cumming street, but I, believing that it was to the west of this street walked a great distance eastward [175] until I found out my error, and then had to retrace my steps. It was past eight when I arrived at my aunt's where I took tea, both Mrs. Willinck and Frances were as agreeable as they always had been, they showed me an interesting collection of medals and old coins, gave some porter, bread and cheese for supper and it was past midnight when I came home, probably somewhat fatigued.

Thursday, $19^{\text {th }}$ of October 1843 . Till 4 o'clock in the afternoon I was at home occupied with writing; I then walked to the Chophouse in Fleetstreet where I had dined on the previous day, and here regaled myself on boiled cod; potatoes and oysters sauce. By six o'clock I was in the Chinese exhibition Piccadilly, a collection well worth seeing and very interesting, in as far as it gives some idea of the Chinese way of living. Those objects which were kept in glass cases were of most value, as for instance 3 enormous statues bronzed or perhaps gilt over, in a sitting posture, the legs crossed, representing Buddha whoes reign over the world has passed by; Buddha who now does reign; and Buddha whose reign is to come; in another case 3 Mandarines with a servant; again 2 priests together with a gentleman in deep mourning, dressed in common coarse greyish sackcloth, and his servant; a soldier with his matchlock and a Tartar; some literary gentleman occupied with smoking and reading; some ladies wrapped up like the men in ample loose gowns so that of their "contours" nothing could be seen, the sleeves wide and hanging; another case of larger 
dimensions represented a Chinese room with a table, some china-ware, and various gentlemen standing about; another case containing a tra $[\ldots]$ full [176] and splendid costume, his gown stiff with embroidery and some boys representing females; another with a barber, a cobbler and a blacksmith; in another case might be seen the exterior as well as the interior of a Chinese shop with the counter and the vendors behind. There were besides many models of vessels and "pagodas", all kinds of utensils, China-ware, porcelain, many lacquered articles, engravings, books, manuscripts, coins, beautiful butterflies, dried fish and reptiles, shells, etc. etc. There were finally some figures hideously shaped and worked out of distorted roots; altogether I repeat what I have said in the beginning, that it was a very interesting exhibition. A book which I then bought and still have gives a detailed description of what I saw here. When walking home a fog was falling so thick and palpable that I actually felt it when breathing, I therefore took a seat in an omnibus and was home by 10 o'clock.

Friday, $20^{\text {th }}$ of October 1843 . This was a busy day with me, already on my first walk through the city I observed three things which I thought worthy of being noted in my diary. The first, placards stuck on the wall stating that Mr. Robert Grant, partner of Howard Grant \& Co. $\mathrm{N}^{\circ} 13$ Old Jewry chambers of London had absconded, taking with him a cheque of $£ 1000$ which had been delivered to him for the purpose of paying a bill; a reward of $£_{50}$ was offered for his apprehension. The second a square shaped cart drawn by one horse, to which was attached behind a wide broom which swept the streets, and the dirt thus collected was by means of an ingenious contrivance raised and thrown into the cart. The third, deal boxes of an enormous size culted on wheels and drawn by [177] horses, plastered all over with large placards printed in enormous types on coloured paper, the $[\ldots]$ object of which as well as of others like them, stuck on the wall was that of blackening the political character of Mr. Thomas Baring the conservative candidate for the City and of extolling the merits of his rival Mr. Pattison, who was recommended to the electors of the City as their proper fit representative in Parliament. These placards said for instance "Baring - Bread - Tax"; "Pattison, plenty"; also: "religious persecution" - Baring's party; another recorded the various occasions on which Pattison had voted for liberal or rather radical measures whilst Baring had invariably opposed them. I learned that at Guildhall the show of hands had been in favour of Pattison and to me it appeared evident that his supporters the radicals exerted themselves much more in his favour than the Conservatives did for their candidate. By the Blackwall train from London street station I went $2^{\text {nd }}$ Class, which gives no seats, only standing room, to the West India Docks, fare [_]d where I alighted and remained nearly two hours, walking about in every direction and enjoying the spectacle of incessant activity which these docks present. They are large 
artificial basins dug into the earth at a short distance from the Thames, whence they receive their supply of water through small canals. Their sides are lined with either brick-work or stone and they are provided with enormous stone gates, which, easily moving on iron hinges, when open give admittance to the vessels desirous to enter the docks, when shut serve as bridges over which to pass from one side to the other. I need hardly say that these docks were crow[_]d with vessels, and that there was a continual loading and unloading that there were large sheds and store houses, which I [...] bye [178] I did not enter. I wondered at the enormous masses of timber [piled] up here, at the tremendous logs of mahogany wood. I observed waggons laden with square pieces of wood ready for the pavement of the London streets, large tin canisters with preserved potatoes about being shipped and I do not know how many other things, the one effacing the impression which the previous one had made on my mind. At the entrance stands the bronze statue of Robert Millegan upon a granite pedestal; to him the Commerce of London is principally indebted for the construction of these docks and in 1809 the directors and proprietors erected this statue in honour of him. To the south of these docks stretches into the Thames a small Peninsula opposite Greenwich, it is called the Isle of Dogs and in 1843 when I visited it on the present occasion, it was partly occupied by streets partly covered with green fields. I now walked back for a considerable distance towards the city along the Commercial road, which runs parallel with the Blackwall railroad, a little to the north of it; many streets turn off from the same towards the Thames, all of which are spanned over by Arches, the fundaments of the said railroad. Turning to the left I came through many dirty nasty streets of that part of London called Wapping, inhabited almost exclusively by sailors and the lower classes of society. I emerged near a handsome rotunda to which light is admitted through a glass roof; inside are two handsome wide flights of stairs, which uniting into one, descend to the Tunnel (see appendix $\mathrm{N}^{\circ}$ 8) under the Thames, one of the wonders of the world, or to speak correctly one of the greatest works undertaken and completed by human ingenuity and perseverance, Brunel was the engineer who planned and executed it. The [...] culties which he had to overcome [179] were enormous, more than once the water broke in from above and destroyed a great part of what already had been done. The tunnel is 1200 feet long and consists of two passages running parallel to each other and separated lengthways by a row of arches. The tunnel is lighted up by gas which jets out of small iron columns with two branches, placed under each second arch, whilst the intervening one is occupied by a table or stall, on which numberless trifles are sold, I bought there two medals which give a very fair idea of the tunnel. Its side walls as well as the ceiling are built of brick, whitewashed. The former, the 
walls, are not straight but have more or less the shape of an egg, thus which shape I am told contributes vastly to the strength and solidity of the structure. A strange feeling, a sensation of awe crept over me when I considered, that whilst I was pacing slowly from one side of the river to the other in apparent safety, volumes of water were rolling and vessels of all sizes and dimensions were sailing above me. As a speculation the tunnel has not answered, on the contrary it is a losing concern, as a thorough fare it is by no means used so much as it was expected it would be. The toll paid is but a penny. On the other the southern side there are flights of stairs and a rotunda similar to those on the northern bank. I was now in Rotherhithe, an Omnibus took me for $6 \mathrm{~d}$ to Deptford and thence I walked to Greenwich. Before entering Greenwich hospital I walked for some time round the four massive piles forming that, which once inhabited by royalty, under the reign of William and Mary became what it is now, a refuge for infirm and maimed sailors, who have served in the navy and also for such who on board of merchantmen have been wounded in a battle against their countries enemy; [180] the famous Duke Humphrey of Gloucester one of the uncles of Henry VI laid the foundation to the palace, Henry VIII completed it, Queens Mary and Elizabeth were born within its precincts, whilst Charles II pulled down part of the old structure and commenced a new palace on its site. In front of the Hospital is a long terrace whence two flights of stairs lead down to the river's bank; here I stopped for some time, never tired of the prospect before me, the Thames alive with sailing vessel, steamers and boats. An invalid came up to me and offered me his services, he took me to the dining saloons where supper was laid out on long tables. Each 4 men had a plate with a loaf, a piece of cheese, and four jugs, what their beverage was I forgot to enquire. In a long passage they were allowed smoking. I went upstairs where long passages traversed the building, at one end blazed a fire round which many of the old men were sitting, a few reading, the greater part conversing. On each side of these passages are the bedrooms, some of which I entered. Four sailors occupied one room, their beds were of wood, similar to berths on board a ship, each man had his chest below his bed and the walls were often hung with wood cuts and cheap engravings. On Mondays and Fridays the Chapel and Painted Hall are open to the public, and I had thus by chance come the right day. I must suppose that the former contains nothing of great interest for in my original diary, of which the present, as said more than once, is a corrected transcript, nothing is said of the same; on the other hand the Painted Hall pleased me much, its walls are adorned with many naval pictures of which I liked best that which represents the death of Nelson in the cockpit on board the "Victory" in the battle of Trafalgar, fought the $21^{\text {st }}$ October 1805 ; in a glass case Nelsons uniform worn by him at [181] the 
battle of the Nile $1^{\text {st }}$ of August 1798 is shown; there are also statues of famous naval commanders, not British, such as one of Columbus, another one of a Dutch hero, probably either van Tromp or Ruyter. At the time Greenwich hospital, certainly superior to the royal residences of St. James' Palace, Buckingham Palace and Hampton Court, gave food and shelter to 2700 Invalids, the Infirmary is in a separate building. Well satisfied with what I had seen I entered Greenwich park and again recollections from former years came upon me, I remembered the smooth lawn, the stately trees, the tame deer and stags, the hill with the Observatory famous all over the world. Slowly I walked on, the park has a gentle ascent and at the other end opposite to Greenwich a gate opens to the high healthy ground called Blackheath; here also I trod well known ground; from this heath several shady lanes radiate down to the lower land around; in one of them my uncle had a cottage in 1815, a short time previously or after his marriage, thence my acquaintance with this neighbourhood. Easily did I find my way to Bernard Charlton's lodgings, he had not yet come from town, his wife of course was at home, and with her, whom on nearer acquaintance, I found to be a very pleasant lady I took a walk up to the Blackheath. On our return Bernard had come, we dined, conversed pleasantly, which was always the case in Bernard's company and by train I returned to London.

Saturday, $27^{\text {st }}$ of October 1843. This day was a day of great excitement in the city. The polling for the new member of Parliament commenced. The city of London is divided into 26 wards, consequently there are besides Guildhall the principal station 26 places, one in each ward [182] where the electors give their votes, these are called polling booths. Every hour, even every half hour the two parties, the radicals and conservatives published the state of the poll. Already at an early hour the Radicals were ahead of their opponents with a majority varying from 100 to 300 . At 12 1/2 the Conservatives gave the state of the poll as follows Baring 3013, Pattison 3003, whilst at 4 o'clock the poll closed with the majority for Pattison of 200 and odd as per his party's statement, of 100 and odd according to that of the conservatives. With one of the brothers Boidenx, both clerks of Gibbs' I went in search of the office of Robert Sims, plate glass factor who had removed to Aldersgate street. After some conversation he promised to let me know at an early day how much he would charge for 6 glasses which I required. Two for Pio Tristan and four for my house in Lima. At a later hour I went per train to Croyden there to dine with Mrs. Grautoff. When I arrived at her lodgings she and her daughters had gone out for a walk, I therefore looked in at the de la Fosses, living not far off in a pretty rural spot called Addiscombe lane; they also being out I hastened back to the Grautoff's with whom I spent a very pleasant evening. Mrs. Grautoff was again Marian Charlton of old whom 
in the times of my childhood I had looked upon as my dear sister. Her daughters had not yet shaken off the reservedness which I noted on the first day of my acquaintance with them, and which as the saying goes is the characteristic of the English young ladies, though to be sure Frances Willinck, Emma Dubois and also the two Robertsons were entirely free of it.

Sunday, $22^{\text {nd }}$ of October 1843 . By invitation I was to spend this day with Mr. Henry Marriott [183] at his Swiss cottage near Hampton Court. I did therefore all I could to have an early breakfast at Mrs. Dakins. Nevertheless when I came to the wharf close to London bridge the steamer which was to take me up the river had just left. A waterman advised me to make the best of my way to Gracechurch street, so I did and was just in time for an omnibus which for $8 \mathrm{~d}$ conveyed me to the Vauxhall station of the Southwestern or Southampton railroad. Thence I steamed through a part of the environs of London hitherto unknown to me to Kingston upon Thames station where again an omnibus was ready to take me up and to put me down close to the rivers edge. Hardly had I been there a few moments when Mr. Marriott descried me from the opposite side. He called a waterman and I was rowed over. Mr. Marriott was a grey-haired off handed man without much ceremony; in the course of the day I easily found out that he was a little purse proud also that his rough corners had not been so well rubbed off by means of intercourse with foreigners as those of his brother Frederic in Arequipa. As an example of his coarseness I may mention that in my presence he told his wife, by the bye neither pretty nor agreeable, that she knew of business as much as a cow. The remainder of the family consisted of a daughter, a black-eyed young lady of about 26 , his son, a disagreeable lad, and a little blue-eyed grand daughter. Towards me he was very friendly, showed me over his pleasure grounds, not large but prettily laid out and separated by a private gate, which he made me note particularly, from a meadow belonging to Hampton court. Having satisfied himself that I was a Protestant he proposed to go to church in Hampton Wick to [184] which I acquiesced. The daughter and grand daughter went with us, and the son rowed us over, for Hampton Wick as well as Kingston upon Thames lies on the right side, Hampton court and Marriotts cottage on the left side of the river. The church was small, unadorned but neat, the sermon insipid, Mr. Marriott had of course his own pew. Come home we sat down to a substantial lunch; Miss Marriott asking me many questions regarding the death of her brother Albert in Guayaquil, to which I was unable to give any satisfactory reply. Lunch being over Mr. Marriott invited me to have a look at Hampton court park and palace, to which of course I did not object. The palace is a plain, large quadrangular brick building, without the slightest pretention to architectoral beauty; there are small niches in the wall which are occupied by statues of roman emperors, 
made of baked clay of a brown colour. This Palace was originally built by a Cardinal Wolsey who presented it to Henry the $8^{\text {th }}$ in the vain hopes that this splendid gift would reinstate him in his royal master's favour. If I am not much mistaken the last sovereign who made it his permanent residence was William III. In the interior the walls of a long row of spacious saloons were hung with numerous paintings, when walking through them Mr. Marriott yawned awfully, whilst I occasionally stopped before one or the other painting which I thought might possess greater merit than the rest; however I also was glad when we were again in the open air. Nature as it presents itself in the country is to me a source of delight of which I never tire; with pleasure did I look to the blue sky above; to the high trees around, to the green grass below. The 2 lions of the Park [185] the mazie and the old vine with its stem of extraordinary thickness, I did not see on this occasion. This being the first time that a picture gallery, of which I visited so many in the course of the following year, came under my notice, I will say here once for all, that, though in my original diaries many pages are filled with my descriptions of them, I shall not do so in my present extracts, for as I have never been a "connaisseur" of the fine arts and may hardly call myself an "amateur", anything I could say would only be either a barren nomenclature or a tedious description. The catalogues which are everywhere sold on the spot will serve to fill up these chasms in my narration. Mr. Marriott, never lost the main chance out of sight; when looking at his promises we came to his coach house where he immediately offered me his coach for sale asking £10o. I did not like the shape and refused the purchase, sure, it was not worth the money! We dined, had coffee and tea and pleasant talk till it was time to leave. I was rowed across the river walked to the Kingston station and returned per train. Hitherto during my stay in London the weather had been extremely favourable to my excursions; in the morning a little chilly, Fahrenheit's thermometer ranging from $50^{\circ}$ to $52^{\circ}$ whilst in the middle of the day it was very pleasant, now for the first time when I alighted from the train at Vauxhall station, it rained and there was thus such a rush to the omnibuses that they were immediately filled inside. I under my big cloak had now to walk home, which considering the distance, was no small job. On enquiring my way from a person, he, after having given me the necessary information, tried to enter [186] into conversation, he told me that he was a Johanite which means that he was a follower of Johanna Southcott that he was expecting the millennium, but did not know when it would come. I walked on and left him talking his nonsense.

Monday, $23^{\text {rd }}$ of October 1843. The entire forenoon I was at home, I finished my correspondence to the Danish Government, Copenhagen, which, with a request to forward it, I enclosed to Mr. Fletcher Wilson, Danish Consul General 
in London. I arranged some samples of manufactured goods brought with me from Lima, and commenced copying the genealogy of the family Willinck. Past 5 I went to Mr. Robert Cresswell, barrister in the Insolvent Debtors Court, and his maiden sister Maria, who in Godliman street Doctors Commons, kept house together. They had invited a small party to meet me, no doubt to celebrate my return to England after such a long absence. Few as we were, we were rather too many for their small parlour: besides the host and hostess, rather prosy, Mr. Edward Dubois and wife, their daughter Emma and their 3 sons, Edward, Douglas and Theodore, of whom the latter two came in after dinner, all full of life and fun, the father and daughter perhaps the cleverest; next my aunt and my cousin Frances. I have often said how very fond I am of the former, also Frances I like though I think her to be a little dogmatical and too prone of making a show of the knowledge which she possesses; Miss Dubois, Mr. Dubois' sister, an excellent old lady, Dr. Adams, formerly old Mr. Cresswell's partner when proctors in Doctors Commons, a good old man who had borne up well against the inroads of time, but had acquired a disagreeable habit [187] of drawling out his words. Dr. Pratt, a pleasant man who in the capacity of tutor to a young nobleman had travelled over a great part of the continent and finally myself. We went below to dinner, where I was seated between Mrs. Willinck and Mrs. Dubois with both of whom I kept up a rattling conversation. Of the good things placed upon the table I particularly noted a hare, brought up entire, so very different form the manner in which this kind of game is dressed in the north of Germany. When the ladies, that is to say the three sisters had retired, we gentlemen remained over our wine rather longer than it was exactly considered genteel in 1843, perhaps the older members of the party recollected the conviviality of Coram street and were loath to act in direct opposition to the example set there by old Mr. Cresswell about 30 years back, when Mrs. Willinck and Mrs. Dubois were still Misses Frances and Harriet Cresswell, when Miss Maria was the prim thin girl just come from the boarding school, when the barrister Robert was a wild college lad and when I was at Mr. Jays! When we had rejoined the ladies I began talking with Emma and Frances, but to my regret was soon called off to the whist table where I had to sit down with Dr. Adams, Mr. Dubois and sister. Before the party broke up about 10, punch was handed round and I left highly pleased with the kindness which all had shown me.

Tuesday, $24^{\text {th }}$ of October 1843. With Bernard Charlton I went to the Catherine Docks. In order to be admitted to the wine vaults a particular permission is required, which Bernard had obtained from a friend of his. We were also allowed to taste the sherry of various casks as if we in- [188] tended to make a purchase; it is truly interesting to see the enormous quantity of casks and 
barrels which lay piled up here, narrow passages left between them, dimly lighted up by solitary lamps hanging from the ceiling; our conductor, Bernard and I also carried lamps, just as I had done in the mines of Peru South America. On our return Bernard was good enough to accompany me to several shops in which I made purchases for my own use. For dinner I was again invited out, Capt. Seymour had spoken of me and of my long stay on the West coast to Mr. Southey, wool stapler, who it seems was anxious to learn something about S.A. wool, about the sheep, the shearing, the washing, etc. etc. and it was for the purpose of obtaining this information that the invitation was given. In an omnibus I drove to the Angel public house, city road and walked to his residence $\mathrm{N}^{\circ}{ }_{23}$ Compton Terrace Islington. Mr. Southey was a pleasant elderly man and most willingly did I tell him all I knew on the subject which he had so much at heart but I fear that my answers did not entirely satisfy him. There were besides him and myself Mrs. Southey, rather vulgar, 2 Misses Southey's, nice girls, two other young ladies, Captain Seymour, two other captains and another gentleman. At dinner I sat to the right of Mrs. Southey to my right one of the young ladies with whom I conversed very agreeably, also upstairs after dinner Capt. Seymour and I had a long chat with one of the daughters. We left at 10 .

Wednesday, $25^{\text {th }}$ of October 1843 . This day I devoted entirely to my aunt and cousin. With them I went in the forenoon to two bazaars, the one in Soho square, the other called the Pantheon in Oxford street; both were pretty well filled, not crowded with visitors; the Pantheon finished [189] in 1834 was the handsomest of the two buildings. To it as my aunt told me idle folks were in the habit of resorting, looking upon it as a convenient lounge to while away their leisure hours, the other, that in Soho square, was more frequented by actual purchasers; in both establishments hundreds, nay thousands of articles were exposed for sale, all tasteful and pretty; here were no solid manufactured goods, such as piece of cloth, a piece of white or printed calico, no cutlery, not even valuable silver or gold articles, no rich jewerly, nothing of the kind, on the contrary, amongst a few useful things many which may be called superfluous, lacquered and China ware, toys, all kinds of fancy articles and ornaments for ladies, children's dresses, etc. etc. I laid out some money for my family in Lima and bought a trifle which I presented to Frances. In Cumming street, John Cresswell, my cousin's cousin and her future husband joined us. We had a homely but excellent dinner, cod and potatoes with oyster sauce, roast beef with Yorkshire pudding. When it was time to go to the theatre, Cresswell procured a cab. He took his seat near the coachman, we other 3 inside. We drove to the Haymarket theatre where we obtained front seats in the first tier of boxes. The interior of the house was small but neat and prettily painted. 
Four small comedies were represented, the principal parts in which were acted by some of the best performers then on the London boards. In the first piece called Louison, Madame Céleste did the heroine; she was a good looking young French woman, a great favorite with the audience, perfect master of the English language but not without a very strong foreign, otherwise pleasant accent. The second the Queensberry fête [190] was extremely well performed, Charles Mathews as a country clown spoke so dreadfully provincially broad that I could hardly make out what he said. Mr. Strickland and Mrs. Glover as a super animated beau and belle of the old school could not possibly be better, whilst the famous Madame Vespes rather disappointed me. In the third piece "I would be an actor", written by Charles Mathews for himself, he was almost the only actor. He appeared in three different disguises, firstly as a choleric old man, secondly as a Welsh gardener, thirdly as a French lady and finally, what he actually was, a fine young gentleman. The last play, "The railroad trip" was full of improbabilities not to say impossibilities, but amusing owing to its very absurdity. A young gentleman of the Scilly (silly) Islands comes to London and has been ordered by his father to go to Birmingham in search of his sweetheart, but he knowing nothing about railroads is packed off for Bristol by a friend of his rival. This mistake gives rise to many laughable quid pro quoes but at the end all is wound up to the satisfaction of the parties interested and in the last act no less than 3 couples are made happy. We amused ourselves well, and past midnight drove back to Cumming street all 4 inside the cab, my aunt on her daughters lap. The expenses of our little party in the course of the evening were defrayed by me.

Thursday, $26^{\text {th }}$ of October 1843 . In the forenoon I called upon Mrs. Sieveking, Stamford hill and Mrs. Elmenhorst Stokenewington, to pay them my farewell visits, both had gone out. I dined at a chop house and past six o'clock drove with Dankaerts one of the two head clerks of Gibbs', of whom I have already spoken previously, to his lodgings in Kent road. He was an agreeable unpretending man and stood high with his employers, who when several years [191] later they established a house in Rotterdam for the sale of Guano, placed him at the head of it. His wife appeared a good kind of woman, and of his daughters, 6 in number, the eldest, a grown-up girl, played the Piano and sang a little; as yet she was no great proficient however half an hour or so passed away pleasantly enough listening to her. We had tea, afterwards a light supper, the oysters were excellent.

Friday, $27^{\text {th }}$ of October 1843 . With Gonzales I made a call on Mr. Hy. Kendall who received us politely, but contrary to my expectation, did not invite us to dine with him; we learned here that the "Antonia" had arrived from the West coast bringing letters from Lima down to the $1^{\text {st }}$ of July and from Valparaiso 
to the $12^{\text {th }}$ of the same month. In Gibbs' office I received my correspondence, consisting of a kind letter from my dear wife, of a few lines from Juan and Enriqueta and of a letter from C. W. Schutte in which he gave a fresh proof of the ease and "nonchalance" with which he breaks engagements previously entered into. Before I had left South America we had arranged that he would sell to me all his Alpaca wool, besides $5^{0}$ qq already paid for by me, now he wrote me that he had sold the surplus to Mr. Frederick Marriott. The political news from Peru was of importance, many of the Generals banished by Vivanco, see Page 47 of this volume had returned from Valparaiso to Arica and Tacna, where they were joined by Torrico and San Roman who brought with them some aid from Bolivia, probably money and arms. Torrico and Nieto who had stood opposite each other at Agua Santa, I do not venture to say that they had fought against each other, for to fight is a precept seldom found in a Peruvian general's catechism, now acted in unison for the purpose of upsetting Vivanco. In Tacna [192] a few soldiers declared for the chief magistrate, whom this crowd of Generals thought proper to proclaim. Their choice fell upon Dr. Justo Figuerola, he being the $1^{\text {st }}$ Vice President of the council of State. Torrico had actually rebelled against Figuerola's authority when he brought about the revolution of the $16^{\text {th }}$ of August of the previous year and Nieto had ignored him when siding with Vidal; but little did it matter to them to act in opposition to the principles previously laid down or to make use of a homely phrase to eat their own words. Of Menendez, the President, and Vidal, the $2^{\text {nd }}$ Vice president of the said Council of State, not the slightest notice was taken. Torrico was named by his colleagues General in chief of the Peruvian army; Fermin Castillo with a few soldiers marched against him, but before any blow was struck his own troops abandoned him and joined the files of the enemy. In order to crush this rebellion which bore a threatening aspect, Vivanco had despatched towards Islay General Guarda with about 800 men. Very naturally all interested in the trade to the West coast looked forward with great anxiety to next advices from that quarter.

At a later hour I went to the Politechnic Institution, Regent street. When I entered, I was completely bewildered; there were all kinds of engines moving, spinning, whirling, whizzing, buzzing; I looked and stared but did not comprehend, even when my cousin Frances, whom I met here with a friend of hers Miss Trumpel, did her best to explain to me what she herself knew of the matter, my mind was but slightly illuminated; for my intellect is particularly obtuse with regard to every thing relative to mechanics. Besides these engines there were models, drawings, statues and many other objects which filled the ground floor and the $1^{\text {st }}$ story and which are [193] detailedly described in the pamphlet I bought. A bell rung, my female companions, 
myself, and many others rushed to a saloon where several rows of forms placed amphitheatrically were immediately filled and then all listened with the greatest attention to a lecture on Electricity delivered by a professor and illustrated by interesting experiments. The electricity was produced, not as I had seen on other occasions by the common electric machine but by a steam engine, how I cannot tell; the electric fluid, once produced, the lecturer led, by means of brass wires which served as conductors, to any point he listed. Various times a continuance of sparks, which issued from the conductor emitted a beautiful white rather blueish light, another time the light led through a tube ran lengthways and was of a purple colour, this the professor called and compared to the Aurora boreales; again this wonderful fluid ignited shavings and gun powder; the prettiest experiment of all was that when the electric fluid was conducted to an upright post from which many strips of paper were suspended. When the fluid reached them these strips began to move, they rose until they stuck out horizontally, in which position they remained as long as they were under the electric influence. The lecture being over we returned to the saloons, which in my diary are called very irreverently the shows rooms, where our attention was directed to a coining apparatus, which appeared to me no great matter. It struck of zinc medals with the profiles of Queen Victoria and Prince Albert. Next came the diving process which I much admired, there was an artificial well filled with water more than 6 feet deep. A man appeared dressed in Indian rubber clothes, his head incased [194] in a big metal helmet, fitting close round his neck and provided with two large glass eyes, and a hole in the top into which through a flexible tube air was pumped from above. He remained under water for sometime, when he came up and uncovered himself he looked rather exhausted. This over a cryer proclaimed that the diving bell was to be lowered into the well and invited anybody present to go down in it. I was the only one who accepted the offer for which I had to pay a shilling. The bell made of wood was large enough to hold six persons with seats around, in the flooring on which the feet rested there was a round hole, in the upper part were several thick glass windows and a hole with a tube inserted for the same purpose as above explained when speaking of the diver. We, one of the establishment and myself, went down to the bottom in a moment and were up again almost as quickly. I did not feel the slightest difficulty in breathing and talked with the same ease as if I were in the open air. The sole disagreeable feeling which I experienced was a pain on the tympanum caused by the condensed air pressing against it. With me the pain ceased in a few moments after I had left the bell, others, I was told, had suffered from the same cause for several days. It was also shown in what manner the "Royal George", so long an obstacle to navigation in Portsmouth harbour was removed by means of 
explosions. A small wooden vessel was lowered to the bottom of the well, then the diver went down and placed below it a charge of gun powder well secured against the water, this was ignited by means of a fusee, in a few seconds the explosion took place, the vessel was blown to pieces and the fragments floated on the surface. This experiment was repeated with the only difference that the gun powder was ignited by electricity and [195] then the explosion took place instantaneously with the same result. Again the bell rang, again there was a rush to the lecture room and again in a trice all seats were filled. The dissolving views were to be exhibited. The wall opposite the spectators was covered with a large sheet, on the white surface of which, probably by means of an apparatus similar to the Camara obscura, the childrens toy, vivid images of well known rural scenery, ruins or towns were thrown, in colour and size facsimiles of nature. Whilst looking steadfastly on the picture before you, it gradually faded away and as gradually another took its place. The entertainment closed with the Hydrogen magnifier, exactly similar to that which poor Alexander Simpson, of whom I spoke on page 204 of the preceding volume of these extracts, showed to me and many others in Lima in the year 1838. A flea of the size of a $10^{\text {th }}$ part of an inch, appeared on the white canvas 55 (?) feet long; its outlines ceased to be distinctly marked, its colours grew dim. The animalcules in a drop of water hardly visible, if visible at all to the naked eye, became 4 feet long, and the water tiger, the most ravenous and the largest amongst them made fierce war upon the smaller fry. Finally the reflections of the portraits of the Queen and prince Albert were thrown on the wall, placed in a handsome frame which actually looked as if it were raised on the surface. At 5 1/2 o'clock the exhibition closed. I took my dinner in a Chophouse in the Strand whence walking leisurely and stopping at every chop-window, I reached Mr. Edward Dubois' house in Sloan street exactly at $71 / 2$. The family with the exception of the two youngest sons who upstairs were busy studying law was about taking tea in company with a Mr. Webster, an intimate friend [196] of theirs. I joined them, we had a lively conversation, 2 quiet rubbers and a light supper. It was about midnight when Mr. Webster and I bade good bye, he walked westward to Kensington, I eastward to the city. It was a raw windy night, I was glad when an Omnibus overtook me, I got in and was put down at the Bank a short distance from Finsbury square.

Saturday, $28^{\text {th }}$ of October 1843 . I fetched Bernard Charlton from the Baltic coffee house and with him walked to the street called Long Acre which is the proper place in London for the purchase of carriages, just as Billingsgate is for fish or Covent Garden market for flowers. Per chance we came at once to a respectable and first rate coach builder called Haulditch, but desirous as I was 
to purchase a coach for my wife, the prices which he asked were so exorbitant that I could not make up my mind to close the bargain. He asked for

a Half-coach or Chariot with 2 seats, of course

4 wheeled

Guineas 170

Plated harness and saddle for 1 horse

Guineas 12

Plated harness and saddle for 2 horses

Guineas 28

Packing and shipping expenses etc.

$£ 220=$ Guineas 210

$£ 10 \quad £ 230$

which at $45 \mathrm{~d}$ with freight, Insurance, duty and charges in Lima and Callao would come to almost $\$ 1700$ rather too heavy a sum. On my return I called on Mr. Henry K. Marriott, not at home, and upon Robert and Maria Cresswell with whom and some friends of theirs I lunched; on Mr. Edward Sieveking and on Theodore Elmenhorst, the object of which calls being to bid them good bye. I likewise said farewell to all the members of Gibbs' counting house, where I provided myself with money and letters of introduction. Finally I dined at my aunts and spent there as usually a pleasant evening; besides Mrs. Harriet [197] Dubois, my aunts inmate, there was another Mr. Edward Dubois, cousin of him of Sloane street, 70 years old, wonderfully active and lively for his age. In 18[_] he had been in Lima and was fond of talking of what he had then seen and experienced in South America. I left at 9 as I had many things to do and to arrange before I went to bed, for the next morning I intended to leave for Liverpool.

Sunday, $29^{\text {th }}$ of October 1843. I rose soon after daybreak, some gas lamps were still burning in the streets, they gave a dim and dismal light in the grey and foggy of the morning; I myself went in search of a cab, I found one, the windows drawn up, the driver inside fast asleep, he came to the door, my trunk and carpet bag were put in and after having said goodby to Mrs. Dakins, who by the bye had taken care to give me an early breakfast, and to Gonzales up for a wonder, I drove off for the Liverpool terminus Euston square. The streets usually teeming with life, were quiet and deserted at this early hour; a few stagglers loitered here and there of rather disreputable appearance, their looks give evidence that they had not enjoyed the sweets of a quiet night's rest; milkmen with their clean metal pails also showed themselves to satisfy the first daily want of a large proportion of the London population. I was at the station 20 minutes to 8 o'clock, saw my luggage stowed away and took my seat in the $2^{\text {nd }}$ class carriage, fare to Birmingham $£ 1.1 .0$, a jolly farmer-like looking man was my companion all the way. Immediately on leaving Euston square 
we descended a slightly inclined plane similar to that on the Blackwall line, when [198] we were on level ground we had one engine before, another behind the train. On we sped through a well cultivated level country, here and there a little woody with pasture grounds and Corn fields, with humble cottages and gentlemens' seats, with villages and towns. The railroad guide gives the names of the different stations at which we stopped. In Wolverton we were allowed 10 minutes to stretch our legs and to take some refreshments. The train arrived at Birmingham at $121 / 2$ o'clock but instead of continuing the journey at $1 / 4$ to 2 o'clock as the railway guide indicated we did not start till $23 / 4$ o'clock after the arrival of the mail train from London. In the meanwhile I together with some fellow passenger partook of an excellent dinner in an adjoining Hôtel, cost 2 including waiters fees, and then strolled about in the neighbourhood not venturing far for fear of being too late for the train. Probably I only saw the outskirts of Birmingham, the houses had no respectable appearance and the streets sufficiently wide to be sure, were altogether empty, perhaps because it happened to be a Sunday. When leaving Birmingham I found myself on the Great Junction railway; the $2^{\text {nd }}$ class carriages had glass windows which could be pulled up, so that excepting the outward appearance and the seats not being stuffed they were but little inferior to those of the first class. I was tired and soon fell asleep notwithstanding the infernal noise made in another carriage by two intoxicated sailors belonging to the Royal navy. Darkness came on and I arrived at the station in the centre of Liverpool without having even observed that for the last 2 or 3 minutes, the [199] train had passed through a tunnel under the very streets of the town. It was 7 o'clock, 11 hours since my departure from London, now in 1868, the distance of 200 miles, which by the circuit through the Trent valley is increased to 210 is done by express train in 5 hours and a quarter. I drove to Stork's Hôtel, Queen's square, and having shaved and dressed I went out in search of the house of Mr. Reimers, in former years confidential clerk of my uncle in London, his direction was $\mathrm{N}^{\circ} 12 \mathrm{St}$. James' road, but all my enquiries for him were in vain. The streets well lighted up were filled with decently dressed people returning from evening service. On my return I took some negus bread and cheese and withdrew to my bedroom occupied by a four-posted spacious high bedstead, curtained, of mahogany or cedar as is almost invariably found in every respectable English house.

Monday, $30^{\text {th }}$ of October 1843 . I rose at about 7 o'clock, rather too early for the waiters of the Hôtel none of whom as yet were stirring. Two hours later I obtained a light breakfast consisting of a cup of coffee, two soft boiled eggs and buttered toast. At 10 I sallied forth to make several calls. I first went to see Mr. Samuel Bright, the head of Gibbs Bright \& Co. № 8 Brotherton Buildings, St. John's street north. In 1823 in Gibbs Counting house in London I had seen this 
gentleman for a moment when on his return from Hamburgh where he had served as a volunteer in some firm or other. He was on his way to Bristol and Liverpool. Shortly after that period he established the house of Gibbs Bright \& Co. in the latter place, of which ever since he had remained the chief and had extended the [200] business of the firm far and wide; 15 or more clerks were at work in the different offices. Mr. Bright about my age, perhaps a year or two younger, I found to be a very active bustling man with bright black eyes and beautiful white teeth. He received me with great kindness, we had a long conversation, and in his private office he placed a desk and writing materials at my disposal for the time of my stay in Liverpool. He introduced me to his partner Mr. Shutte, the very reverse of him, fair complexioned and quiet. Both pleased me well, Mr. Shutte invited me at once to dine with him. Next I went to Coleman and Stolterfoht with whom Mr. Reimers was head clerk. Reimers had always been a thin poor looking creature, now he had not changed for the better, he stooped as if bent down by the weight of years. Though I told him that on the previous evening I had been in search of his private residence, he did not make the slightest insinuation that he should like to see me there. Mr. Stolterfoht, many years back of the firm of Stolterfoht \& Evers of London, was civil; I have only to say of him that he belonged to the sect of Unitarians. My cousin Dietrich Willinck, clerk with them, was called and presented to me, he seemed to me a good youth but not of brilliant intellect. He was born in 1824, a few months after I had left England. From Coleman's office I directed my steps to that of J. C. Jack (John Jack, "Juan Doble") of Arequipa (see Page 103 Vol. I), he was not in, so I left my card. My last visit was to Samuel Lang (page 104 Vol. I) exactly the same as I had known him in Arequipa and Lima, consequential and pompous but kind at heart, with much interest did he enquired after my wife. At a somewhat later hour I drove in a cab called in Liverpool a car to Mr. [201] Shutt[e] Queen Ann street. His family consisted of his wife, agreeable, but delicate in health, his son and 3 grown up daughters, somewhat like the Robertson's of Chatham, but rather better looking and more refined in manners. We sat down to a plain good English dinner at which we were joined by Mr. Shutte's brother. Dinner over, this latter, the 3 young ladies and I drove to an undress concert given in the lecturing room of the Collegiate Institution. The saloon, not large, was well filled, the ladies in undress, that is to say their bonnets on. The Shutte's observed that they did not see any particularly handsome face, my opinion agreed with theirs but of course I did not give utterance to it. The director, the singers, the musicians all were English and although I am no judge of music I believe that they executed their respective parts in a very creditable manner. The performance consisted of part of Händels Messiah. We drove home, had tea and I left past eleven. 
Tuesday, $37^{\text {st }}$ of October 1843. This being Market day in Manchester, the principal business day during the week, Mr. Bright had to go thither and I thought well to accompany him as I might perhaps find some articles suitable for the Lima market. My samples I took with me; at 8 3/4 o'clock Mr. Bright and I met by appointment at the railway station, the same as that at which I had arrived the previous evening when coming from Birmingham. We of course went first class Mr. Bright paying for both of us. Immediately on leaving we entered a tunnel emerging from which we found ourselves outside the town in the open country. We passed Par Moss and further [202] on Chat Moss, both places as their names indicate originally mosses or swamps, which in course of time had been partially drained and put under cultivation, however as the soil was poor much Peruvian Guano had of late been used as manure. Mr. Bright informed me on this occasion that Guano was gradually getting into consumption, that the stock in England was small and that the price at which it was selling varied from $£ 10$ to 12 per ton, thus the prospects for this article looked cheering; however fears were entertained that the Peruvian Guano might be interfered with by a similar article discovered of late on the West coast of South Africa, whither Glasgow merchants had despatched a considerable number of large vessels; these apprehensions I may say now in 1868 were but partially realized, for the quality of the African Guano turned out to be inferior to that from Chincha Islands and its quantity being small it was soon exhausted. Chat moss, I suppose derives its name from a circumstance which Harrison Ainsworth mentions in his novel Guy Fawkes, where, he says, that master, afterwards Sir Humprey Chatham who was implicated in the Gun powder plot, took refuge here with some of his followers, whilst some royal troops sent in their pursuit, were drowned or better said suffocated in this swamp. On our arrival in Manchester we took a car, here of a peculiar construction, square, entered from behind like an omnibus and so small that there is only room for 2 persons sitting face to face. We alighted at Mr. Robert Yates' who was employed by Gibbs' to effect their purchases in Manchester. I showed him my samples and whilst he went out to see what he could do for me and whilst Mr. Bright made his calls on the Correspondents of Gibbs Crawley \& Co. [203] on the West coast, I accompanied by one of Yates' clerks went to see some of the wonders of Manchester, that is to say the extensive manufactories. We first visited a spinning and weaving mill owned by Messrs. Sterling \& Beckton, who had in their employ about 1500 persons the greater part of whom females. The machinery was immense, all of course put in motion by steam. I witnessed the different processes through which the raw Cotton wool passes till it turns out the Grey Cloth ready for sale. The first thing done is to clean 
it, then joined so as to form a thin consistent thread it is wound round itself and put up in rolls, next it is divided into loose skeins, called rovings which are taken to the spinning machines or self acting mules which is the technical term. If I recollect rightly the warp is made of a stronger texture than the woof, and in the looms, of which there were 1200 in this establishment, the woof is thrown into the warp by means of the shuttle, so that the warp and the woof, crossing each other produce the texture of the Gray Cloth; to each 2 looms one girl attended. We next went to the printing house of Messrs. Wilson Bros. in the town of Salford, which situated on the other side of the small river Irwell is an integral part of Manchester. The Grey Cloth after being bleached by means of acids, which process I did not see, is singed, that is to say it is passed over hot irons rollers, which just take off the small rough particles which stand out from the cloth. The white cloth is now ready for the printing machine where it receives its colours and designs; the designs are engraved on large brass rollers and to me it would seem that the engraving of the designs is the most arduous task of all. They are first drawn in black on these rollers and then [204] by manual labour neatly cut out with a pointed steel instrument (graver?). Of copper rollers there were in this establishment to the value of $£_{30,000}$ and the engravings on them were worth $£_{10,000}$ more. When the cloth is printed it is passed through a solution of Madder in order to heighten the colours, through a solution of Cow-dung for the purpose of fastening them; some colours are heightened, not by madder, but by chemical means. The last operation consists in drying, pressing, and calendaring the printed Cloth. The third manufactory I went to was that of Engines belonging to Messrs. Roberts \& Co., this was still more wonderful than the preceding one, but to me still less comprensible; hardened steel put in motion by steam is here the great operator, it cuts and perforates iron with the same ease as if this metal were but a sheet of paper. A large quantity of machinery lay ready for shipment to France. In these various establishments walking up and down stairs was done away with, all persons employed there as well as we the visitors, placed in a box, were hoisted up and let down, I suppose by the agency of steam. On our return from the factories we passed the Infirmary which we did not enter, it is a large, handsome, but irregular edifice. In 1843 one wing was still wanting for its completion. The Collegiate Church we did enter, it is a very ancient building, Sir Humphrey Chatham, if not actually the founder of the College, at least endowed it with great revenues, owing to which liberality he and his successors had a Chapel in the Church for their sole use; however no monument is erected to commemorate Sir Humphrey's merits, probably because for a short time he mixed himself up with the gunpowder plot. The family of the Chathams has 
become extinct. [205] It was in the Collegiate Church that the famous singer Madame Malibran sang for the last time in her life, it was on the occasion of a musical festival, which being over she fell ill and died shortly after. An old woman who served as our Cicerone showed us the spot where she had been interred; 2 months later her friends had her exhumed and carried to her native country. Having reached Mr. Yates' office he told me the prices at which he could purchase and I gave him some trifling orders. Mr. Bright and I returned by train to Liverpool where we arrived in the dark. We took a car, stopped for a moment at my Hôtel, where I ran to my room for some clean linen and shaving apparatus and drove to Mr. Brights dwelling house in West Derby 3 miles off. As soon as I entered the Hall, I saw at a glance that everything in this house was carried on in style. I was shown to my bedroom, but had no time to shave before dinner, which was very disagreeable, for one feels rather awkward in having a long beard when in the presence of ladies seen for the first time. We were only Mr. and Mrs. Bright, a lady acquaintance of theirs and myself. A servant out of livery attended, all was nice and good, Mr. Bright, talkative and pleasant, but the ladies not handsome and rather reserved. The latter perhaps they considered necessary to give me an idea of their belonging to the Liverpool aristocracy. If I remember right Mrs. Bright is the daughter of the Major. When fruit was placed on the table, the children came in, six in number. Also at tea, the ladies preserved their prudish demeanour, I was therefore not sorry when at $10 \mathrm{1} / 2$ o'clock I could retire to my bedroom. [206]

Wednesday, $7^{\text {st }}$ of November 1843 . It was a clear cold morning. When I went below to the pleasure ground around the house, all was covered with hoar frost, the orchard, the flower garden, the kitchen garden, also the small meadow which produced sufficient grass for the keeping of Mr. Bright's horses; this gentleman soon joined me; together we entered the green and hot houses in which he, being a great flower fancier, took a particular interest. On our return to the parlour breakfast stood on the table, all at once three maid servants came in, I was surprised at their sudden entrance and had no idea what it meant, they knelt down, the male servant knelt down, Mr. Bright, the ladies, and a governess who now made her appearance did the same. I of course followed their example and then the master of the house read aloud a good and appropriate family prayer. At breakfast Mrs. Bright and friend were as frozen as they had been on the previous evening, the children meanwhile joined us. Breakfast over Mr. Bright went out to give some necessary orders and Mrs. Bright thought proper to follow his example and to leave me by myself. This was surely no mark of good breeding; when the omnibus came to the door I sent her word by the servant that I should be glad to see her to bid her good bye. In town I spent the whole forenoon in Mr. Bright's private office occupied 
with writing to Mr. Yates of Manchester and to Messrs. Gibbs Crawley \& Co. of Lima about the consignments which I intended to make to the latter place. Towards 6 o'clock I drove to dine with J. C. Jack No 3 Bedford street, south. He was very much the same as in former years [207] perhaps a little more refined in his manners than he then was. His wife, daughter of a Scotch clergyman, tall, rather good looking and extremely fair, pleased me well, she conversed in freely and frankly without an iota of the foolish primness of Mrs. Bright. The fourth who sat down with us to dinner was her brother Mr. Church, just returned from the East Indies whom many years later I again saw in South America, when after the death of Charles Jack he took charge of the establishment of the Jack's in Arequipa. The $5^{\text {th }}$ was an insignificant Miss Grant from Manchester, a boarding school girl with heavy unprepossessing features. Jack lived in style like Mr. Bright, but as to the rest, here I found myself quite at home. We talked and chatted, Mrs. Jack taking an active part in the conversation as if we were old acquaintances.

Thursday, $2^{\text {nd }}$ of November 1843. After having finished the little work I had still to do I went out with Mr. Bright, first on board of a fine large 4 masted steamer the "Great Western" from New York, to the consignment of Gibbs Bright \& Co. Previously she used to run between New York and Bristol, but this not answering she was placed on the New York Liverpool line. Now that the winter was coming on, she was to be laid up for some months. Next Mr. Bright took me to the Exchange rooms which form 3 sides of a quadrangle, their façades fronting inwards, whilst the fourth the South side is occupied by the town hall. In the centre of the square stands Lord Nelson's monument. Finally we visited the Custom House which is a fine extensive massive building, as far as I could judge somewhat [208] smaller then the London C. House. One of its wings was appropriated to the General Post office. The long room is similar to that in the London Custom house and answers the same purpose; here as well as there it is occupied by a number of officials all employed in the Customs. Mr. Bright was of opinion that both the house and the room were constructed on too large a scale for the business done in them, because too much time was lost in going from one office to the other. Close to the Custom House is the Cunning dock, in 1843 there were in all 9 docks extending down the river Mersey on its right bank. The graving docks are used for repairing vessels; these having floated in are left high and dry after the water has been let out, and then the workmen employed have no difficulty in doing the work required. The docks were of course well filled with vessels and there was bustle and activity in every direction, however not quite so much as Capt. Seymour and mate Saywer had led me to expect in speaking on board the "Vicar of Bray" about the business done from the port of Liverpool. I again dined at Mr. Bright's at west Derby, it 
was a counterpart of the other evening. I did my best to make myself agreeable, and at all events succeeded, in so far as to elicit from Mrs. Bright a few words more than she had previously favoured me with. At 10 o'clock I drove home in a car fare $4 \mathrm{~s}$.

Friday, $3^{\text {rd }}$ of November 1843. The whole forenoon was taken up with conversing with Mr. Yates and writing to Lima, for the letters had to be ready this evening, thus I lost the opportunity of seeing the Duke of $\mathrm{B}$ [orde]aux which I have [209] much regretted ever after. This personage was at that time in Liverpool and had taken a fancy to visit the "Great Western". Mr. Bright as Consignee of the vessel had to receive him, and he asked me to accompany him, which I refused, being too busy at the moment. I dined at my hotel together with my cousin Diedrich Willinck and after dinner we went to the Liver Theatre, Leiver, I learned from Diedrich is a name given to a particular class of stork and as everybody knows what a pool is, here we have the derivation of the name of Liverpool. The house was small but prettily fitted up; the boxes were empty, the pit rather filled. The first piece represented was the stranger, the translation of Kotzebue's [Menschenhass und Reue], a Mrs. Gordon acted Mrs. Haller and a Mr. Phelps the stranger, both did it very well, and one or two scenes between them actually affected me. At the close when all is made up between the two and Mrs. Haller throws herself at the strangers feet, or into his arms, English decorum does not allow him to pronounce the words "I forgive you". The second piece was called "Mariette", similar to Louison which not long before I had seen performed in the Haymarket theatre London. The last the waterman was a pretty petite piece, all the actors acted very creditably and one with another I was well pleased with all the three performances; only the songs in the waterman, much applauded by the audience were by no means to my taste.

Saturday, $4^{\text {th }}$ of November 1843 . During the short time of my residence in Liverpool I usually rose at about 7 o'clock and till 10 both before and after breakfast wrote my diary in [210] the coffee room, which done I went out and regularly paid my first visit to Gibbs Bright \& Co.'s office. This morning one of the clerks a Mr. Fox accompanied me to the steamer's office, where I took my passage on board the "Prince" to leave this evening for Kingstown in Ireland, thence we walked to George's pier close to which the steamer was moored. To the right and left of this pier, that is to say up and down the river, are the docks previously spoken of. In this part of the town I noticed many extensive and high brick buildings used as stores, a great part of which were owned by the Duke of Bridgewater. I learnt that of late twice an attempt had been made to set fire to these latter. The Mersey at Liverpool is twice, perhaps three 
times, as wide as the Thames at London bridge, but in 1843 the traffic upon its waters could bare no comparison to that on the Thames; of course crafts of all descriptions were in motion up and down, across from one side to the other, but their number was much less than what I had been accustomed to see on the rival river. On the opposite the Cheshire side in 1843 there were but a few villages, in 1863, when I was last in Liverpool the town of Birkenhead had sprung up and has since been growing in importance with gigantic strides. Fox and I next visited the town-hall, a beautiful building, "a magnificent structure in the Grecian style", as the handbook descriptive of Liverpool says. On the landing place on the first floor stood the statue of Canning, the saloons used when the mayor receives company were splendid, they consisted of a suite of drawing rooms, of the dining and small and large ball rooms; in one of them hung the portraits of George III, George IV and the Dukes of York and Clarence. We ascended a winding stair-case to a platform surrounded [211] by a stone balustrade, from which a high cupola rises, this again surmounted by the statue of Britannia. A thick fog rested over the town, yet over the river side where the view was pretty clear I was well rewarded for the trouble which I had taken in climbing up so many steps. The town-hall forms as said above the south side of the Exchange quadrangle; from it, Castle street runs down due south as far as the Custom House, it is divided into two halves by St. Georges church, whence the 3 principal streets of Liverpool, Church street, Lord street and Wall street, stretch in one line to the South east. In front of the Town hall branch off from Castle street, to the west Waterstreet to the east Dale street. With arranging my papers, packing up my trunk and port-manteau, the former of which I left in Liverpool, and settling my Hôtel bill, when I found the perquisites I paid were as follows

Waiter 8 meals

Chambermaid 6 nights at $6 \mathrm{~d}$

Boots 6 nights at $3 \mathrm{~d}$
$3 s$

$3^{\mathrm{s}}$

1s $6 \mathrm{~d} \quad 7 \mathrm{~s} 6 \mathrm{~d}$

I was fully occupied till it was time to drive to St. George's pier head and at 20 minutes to 7 o'clock I found myself on board the steamer "Prince". This was the first sea voyage I made on board a steamer and I therefore noted some details overlooked by me on later occasions. The dining saloon, of a good size, was below the poop, a fire place in the middle divided it in two halves, each half occupied by a table with benches around. Light was admitted from above through two skylights in the shape of cupolas. The berths around the saloon, from which they were separated by prettily painted 
panels did not open into it by sideways. My berth was $\mathrm{N}^{\circ} 14$, a lower one. The number of passengers [212] Dining saloon on board the steamer "Prince"

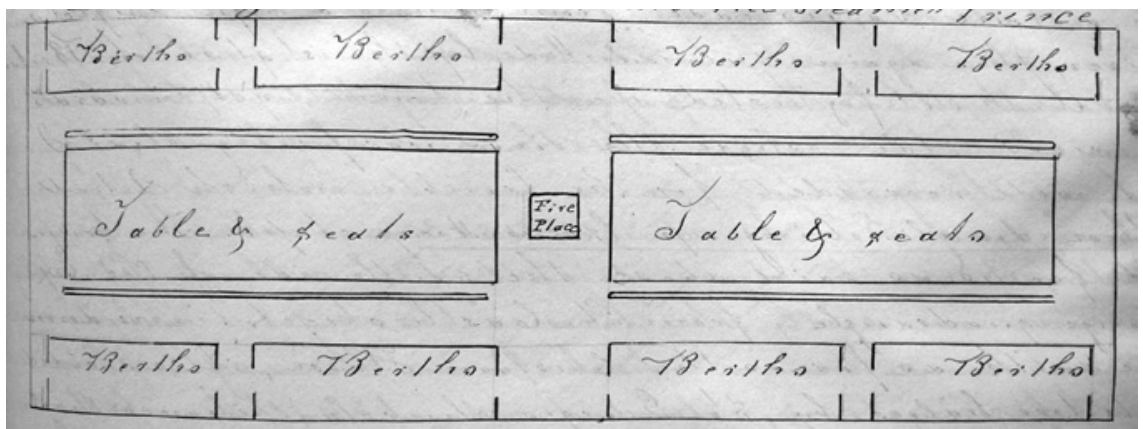

was perhaps sixty. At about $71 / 2$ o'clock the tremulous motion and the sound of revolving paddle-wheels proved to me that we were under steam; somewhat later tea, coffee, fried fish and cold meat were placed on the table to which I did ample justice, for I had had no dinner; whilst thus occupied a gentleman came from above and brought the news that there had been fire on board but that it had been fortunately extinguished before doing any material injury. It was a clear moonlight night but so cold that, although I ventured on deck more than once, I soon again took refuge below. I observed on the Cheshire side several lighthouses which had a steady light, whilst the light of that on the rock not far from the mouth of the river was a revolving one. I read in a paper that the trial of Daniel O'Connell and accomplices had commenced, the grand jury consisting of 23 individuals had been empannelled and this jury was to decide by mere majority whether the Bill was to be found or ignored, that is to say in other words, whether the accusation of the said persons was to be brought before the petty jury or not. A gentleman with whom I entered into conversation attempted to show to me how the knight on the chess board can move over all 64 squares without touch- [213] ing one square twice, he succeeded with 63 squares. When he was gone I myself tried to solve this problem but in vain; thus time passed away till 11 1/2 o'clock when I retired to my berth and slept soundly without awaking till

Sunday, $5^{\text {th }}$ of November 1843, a quarter to six o'clock, when the steward called us all up. Quickly were we on deck, the "Prince" was just entering the capacious basin which forms the asylum harbour of Kingstown, situated about half way between Dublin and Bray. The two piers which constitute the sides of this harbour, constructed entirely by the hand of man, extend into the sea like two arms stretched out to the assistance of the forlorn mariners, many of whom I was assured had found refuge when threatened by destruction within their protecting precincts. The entrance to the port of Dublin is dangerous owing to 
a bar across the mouth of the river Liffey. The day had just broke, turning my eyes seawards I saw the light still burning in 3 pharos, the one to the right on Kingstown pier, the second right before me, on the summit of the hill of Howth. The third to the left at the extremity of a long mole built far into the sea from the town of Dublin. Hardly had I stepped on shore, port-manteau in hand when I saw the ragged boys of whom I had so often read in Irish novels, when I heard the rich brogue, the vernacular "my honey"; English was spoken around me, but it was not the English of old England, it was the English of Green Isle. Also the vehicles called jaunting cars, many of which were in attendance were of a peculiar Irish construction. They were 2 wheeled, uncovered and drawn by one horse, the seats were placed sideways [214] and had room for three persons, who of course sat back to back; between the seats was a kind of hollow, called the well, serving as a receptacle for luggage and other objects. The seat of the driver, one of the boys in tattered clothes already mentioned, was a little higher, and this he occupied when the side seats were filled, otherwise he preferred standing on the very low step used to get up. I engaged one of these cars and told the boy to drive to Sea Point, the name given to the house where the Seymour family lived, but omitting to add near Bray, my driver took me to another Sea Point to the north of Kingstown, whilst the Seymour's Sea Point lies to the south. Here, that is to say at that Sea Point which was not my destination, the houses were closed and owing to the early hour nobody was as yet stirring. After having waited a little some peasants appeared who soon put us on the right way. The high road on which we drove was good in itself, but dirty and muddy, owing to the rain that had fallen of late. The peasants whom I met did not look so tidy and neat as those of the same station in life whom in England I had so frequently noticed with pleasure and satisfaction. The women wore bonnets and were wrapt up in their dirty cloaks, invariably torn here or there. Also the clothes of the men were full of holes; hardly did I see a coat, a jacket, a pair of trowsers, a pair of breeches which did not require mending. Of handsome faces I saw none, neither male nor female, and this made me jump at the conclusion, perhaps too hastily, that Daniel O'Connell's favourite phrase of the finest peasantry on the globe, was one of his many expressions, not to be taken too literally. On the other hand, in vain did I look for the wretched miserable hovels with the description of which all Handbooks treat- [215] ing on Ireland are filled, the cottages on the road side had on the whole a pretty decent appearance and there was hardly a single one that was not provided with its chimney. We passed through several villages, I only recollect the name of Loughlinstown with large almshouses, of little Bray with a new church, finally we came to Bray itself. On the left side of a shallow river of the same name, the boundary between the countries of Dublin and Wicklow. We drove 
through one long street, crossed a small bridge and a little further on stopped at the door of the Seymour's. It was now about $71 / 2$ o'clock, as yet none of the family had risen, but on sending up by a servant girl the few introductory lines given me by the Captain, I was immediately shown to a comfortable bedroom on the first floor. From its windows I had a pretty view, to the east as well as to the north east the sea, a little more to the north a few small vessels anchored in the river, the bridge somewhat higher up, and then to the left pretty cultivated green fields with a few trees here and there. I had just time to shave and dress when I was called to the parlour below, where the family was assembled for breakfast. I had to introduce myself and was received with extreme kindness. The short time which this meal lasted did of course not suffice to enable me to form an opinion of the different members of the family, in order however, that here after I may not have to break the thread of my narrative I will resume here in anticipation the observations which I made regarding them during my 7 days stay at Sea Point. They were all kind hearted, frank and hospitable, the father rather above sixty was broken both in body and mind. He [216] did not appear at breakfast, rose late, walked with the help of crutches and could not attend to his business, the retail sale of iron, slate, coal, lime etc. etc. which he left to the management of his eldest son Robert and his clerk Cumming; none of those about him treated him with the respect which in my opinion is due to the head of a family, nevertheless he seemed to be happy and enjoyed his meals and particularly his whiskey punch, both at dinner and supper. Mrs. Seymour was an active delicate woman of no refined education, but with a sound good heart. Her strong Irish accent was very remarkable, for instance the child was the cheild, the island the oisland, in the word wind she gave the poetical sound to the i and so on. Of the eldest son Robert I saw but little, he was for the greater part absent in London, when at home he was civil and polite to me. The daughters were three in number Alicia, Ann and Charlotte, respectively about 30, 26 and 20 years of age. The first and last of the three had prominent eyes and I believe I do them no injustice if I call them plain, they resembled their brother Robert, whilst Ann and the captain were more like their mother. Alicia took the head of the table and kept up a lively conversation with me, Peru, its inhabitants, their customs, etc. were the points regarding which she, as well as her sisters, appeared anxious to obtain ample information. Ann, who of late had been dangerously ill, was better looking and less talkative than her elder sister, she said that she had a passion for foreign languages and tried to learn both Italian and Spanish. Of French all three knew a little. Charlotte the youngest had taken it into her head that it became her to be a little snappish and though this to be sure is no amiable propensity yet I did not like her the worse for it. [217] Alick Cumming, who had been 17 years in the 
employ of Mr. Seymour, was a pleasant unpresuming man. When we rose from breakfast I already found myself quite at home with my new acquaintances. Miss Alicia told me that they never treated any one with ceremony and that they expected to be treated in the same manner. With Cumming the clerk, and Mr. Robert Beddy, a cousin of the Seymours, in 1843 clerk in a mercantile establishment in Dublin, now in 1868 married and long established in Lima, I went to see one of the many Martello towers, of a round shape which in the beginning of this century, when a French invasion was apprehended were constructed round a considerable part of the western and southern coast of Ireland. On the east side they did not extend further than Drogheda, that close to Sea Point was numbered 2, the higher numbers succeeding south and westward. In 1843 these towers served as temporary dwellings for the men belonging to the preventive service. From the Martello tower we walked down to the beach whence we counted not less than 15 sail standing down the St. George's Channel towards the Atlantic. We next entered the Park, or as it is called here Demesire, of a gentleman lately deceased whose widow, like so many other Irish landlords, instead of attending to enjoying her fine property at home preferred spending her income on the Continent, but notwithstanding her absence, everything was in good order and seemed to be well taken care of; the tastefully laid out plantations, the well filled hot houses, the handsome substantial mansion. It was now time to attend divine service; Mrs. Seymour, the 3 daughters and I, went to the protestant church in Bray which was but [218] poorly filled; the Lord of the manor, Earl Meath and his lady, were present in their own pew, the hatchment with the family arms hanging on the wall above them. The preacher spoke so indistinctly that I could hardly make out half of what he said, but what I understood did not make me regret that the remainder was unintelligible to me; we returned through a handsome garden belonging to a large Hôtel owned by a certain Mr. Quin. When I expressed my surprise that such small and apparently poor place as Bray could sustain such a splendid establishment, the answer I received was that the daily intercourse between Dublin and Bray was considerable and that in the summer months, the season for sea-bathing, there was such an influx of strangers and particularly of Dublin people into Bray, that not only the Hôtel was crowded but also many private houses were let to give them accommodation. On our reaching home the young ladies insisted on showing me their sanctum sanctorum i.e. the pantry, where on a clean deal table some cream, butter, cheese and cakes stood very enticingly and, nolens volens, I had to partake of these good things. To show me some of the natural beauties for which the county of Wicklow and the adjoining southern part of that of Dublin are famed, was the next object of these excellent people and though a November day is not exactly the proper 
time for a tourist in search of the picturesque yet I was much pleased with this days short excursion. A jaunting car with a powerful trotting horse stood at the door. Miss Alicia and I occupied one of the side seats, the two younger sisters [_]e other. We first drove to little Bray where at the church door a number of Gigs, jaunting cars and other carriages were waiting. The preacher, Miss Alisia informed me, [219] was far superior to him whom we had heard in the morning. From little Bray a mile or so to the northward we came to a piece of high ground, close to which a Mrs. Roberts had her property called Mount Eden. From this elevated point the eye ranges over a pretty extensive plain richly cultivated and studded with noblemen and gentlemen's country houses, peeping from between the surrounding trees, now alas! in the sere arid yellow leaf; it is confined to the left or north by Killiney Hill, to the right or south by Brayhead. This prospect brought to my recollection the view over the Valle of Tiavaya near Arequipa, from Carlos Santos' house, however with the difference that in Peru the background is formed by a ridge of arid grayish hills, in Ireland by the vast expanse of the sea. Close to Brayhead the town of Bray and the bridge were clearly distinguishable, and from this headland a chain of low mountains stretches inland to the south west. The highest points of which are the little Sugar loaf 1120 feet high, the large Sugar loaf $1551 \mathrm{f}$, and the Douce $2384 \mathrm{f}$. Just behind mount Eden or speaking more properly to the north west rises the low mountain called Shankhill 912 feet high and a little more to the westward there is a remarkable passage between the mountains which goes by the name of the "Scalp". Having made myself perfect master of these localities and enjoyed the scenery all around, we drove back to Sea point through the pretty village of Enniskerry. Dinner awaited us; the all gentleman appeared but not at the head of the table which seat [_] honour was occupied by Miss Alisia. A Mr. Alfr[_] Sutheren, a baker by trade, brother of the apprentice Sutheren on board the "Vicar of Bray" sat also down with us. Dinner was wound [220] up with whisky punch of which all partook except myself. We then adjourned to the drawing room, had tea and the evening slipped away imperceptibly, all talked, laughed and were merry. Before retiring to rest at about 11 o'clock spirits, wine and a light supper were brought in but I persevered in my regime of abstinence with which I have fared so well up to the present day $\left(18^{\text {th }}\right.$ June $1868,53^{\text {rd }}$ anniversary of the battle of Waterloo).

Monday, $6^{\text {th }}$ of November 1843. In the forenoon I wrote my diary in the parlour where the young ladies were at their needle work. When I had finished and was on the point of taking a walk by myself, they told me that Cumming would immediately be ready to accompany me. In a gig, he taking the reins we drove to the Park of Viscount Powerscourt somewhat to the south of Sea point, within its walls we crossed a meadow bounded on both sides by hills covered with trees, 
mostly oaks, the foliage of which, now in the fall of the year displayed various tints, from light green to dark brown, next we came to a waterfall, the prettiest which I had seen till then. The Dargle further down called the Bray precipitates its waters from a considerable height over a perpendicular rock, for a time they foam and froth, then glide away smoothly. The "Glen of the Downs", the beauty of which consists in the sides of the hills being covered with wood from the very base up to the summit did not call forth from me such an enthusiastic praise as my companion had expected. Another part of the road which they call "the wild part" certainly brought to my mind scenery of a similar kind though on a much larger scale which I had so often seen during my travels in Peru. Here, as well as there, the ground produced a moist pasture, here and there were barren rocks, between them occasional patches [221] of cultivated land, here as well as there tiny rills of water trickled down the mountains side like so many silver ribbons; but now the dissimilarities: here the grass is short, smooth and velvet like, there hard, often coarse and high; here we drove on a well kept high road, there I rode along a narrow sometimes dangerous bridle path; here we were at a small elevation over the sea, there I was 8,10 or more thousand feet above its level; here we were within hail of civilised man, there the nearest miserable hut of a poor Indian in the lowest stage of civilization was one, perhaps several leagues distant. In the evening we had whist, Mr. Seymour and I against Alicia and Charlotte; the two ladies played a pretty fair game, but the old gentleman the very reverse, not only did his memory fail him but it seemed to me as if his intellect were a little impaired.

Tuesday, $7^{\text {th }}$ of November 1843 . This day and the next I devoted to a visit to Dublin. An Omnibus started regularly at certain hours from Quin's Hôtel in Bray to the Capital 12 miles distant; I just missed it and had to take a jaunting car cost 2s. As regards the road the observations I made on the preceding Sunday suffice; but, when entering Dublin I was surprised at the breadth of the streets and the regularity with which the houses were built. Counting the underground area and the ground floor, they were invariably 4 stories high; the larger ones had frequently the ground floor of stone, otherwise bricks were the material everywhere employed. A considerable proportion of the smaller houses had a very narrow front, merely the street door and one window, 2 windows in each of the upper [222] stories. I passed Stephen's Green, a large square, one mile in circumference with the statue of one of the George's (George II) in the centre and alighted at Gilbert's Hôtel in Westland row, close to the Kingstown railroad station. I left here my cloak, toothbrush and comb, the only luggage which I had carried with me, and strolled out without having formed an exact plan whither to go. Chance led me to the end of a street, where two handsome buildings front each other, Trinity college and the Bank of Ireland, formerly the 
Parliament house; I then sauntered along the right side of the river Liffey not so insignificant as I had thought it was; it divides the town into two pretty equal parts and is spanned by 7 bridges, that nearest the sea being called Carlisle bridge. I walked as far as the place called Ringsend where the Liffey falls into Dublin Bay, all the way down it is walled in by massive quay built of free[_] stone. Small steamers were running up and down and other vessels, none of large size were lying at anchor. On my return I passed Carlisle bridge and on the opposite, the left side found myself in Sackville street, I believe one of the finest streets in all Europe; even in London I had not seen anything like it. It is uncommonly wide, about half way on the left side stands the post office, in front of it a Column 130 feet high with Nelsons statue on the top. At the other extremity the Rotunda, a public building used for balls, concerts and similar festivities. Having dined in the Hôtel I went at $61 / 2$ o'clock to the theatre in Hawkins street, it was a small house but pretty. Fra Diavolo a well known opera by Aubert was represented, a Mr. and Mrs. Wood sang the principal [223] parts, he was good looking man, she whom I had heard as Miss Paton in 1823, never pretty now more than 40 years of age had become decidedly ugly. She sang well, but such were her grimaces when opening the mouth, that the best thing one could do was to shut ones eyes when listening to her. Her first husband Lord Lennox had treated her so badly that she had claimed and obtained a divorce; she then became the wife of Mr. Wood, repentance came over her, because Lord Lennox was still alive, entered a convent, got tired of it after six months, rejoined her second husband and reappeared on the stage. The second play was a comical farce called the "Tiger", a slang term applied, as every body knows, to a boy servant. In the Hôtel I had a poor bed on a stretcher.

Wednesday, 8 $^{\text {th }}$ of November 1843. Ten minutes to nine I started from my Hôtel with the object of taking a long walk through Dublin; the plan of the town in my pocket and often in my hand, I carried out this my plan to my entire satisfaction and returned to my room $10 \mathrm{~ms}$. to 4 o'clock; 7 hours had I been on my legs and to my surprise did not feel fatigued. Stephens green, Merrion square and Fitzwilliam square, are fine, large, open, and unquestionably healthy places. In William Street I found out the firm of Messrs. Ferrier Pollock \& Co. with whom Robert Beddy was clerk; he showed me all over the establishment, and never before had I seen such extensive warehouses. Messrs. F. P. \& Co. were merchants who purchased all descriptions of manufactured goods at first hand and then sold them to the shop-keepers all over Ireland; there were from 12 to 15 large rooms, each appropriated to a different article, thus for instance in the first there were [224] grey and white cottons, in the second, printed calicoes, in the third, woollens, in the fourth, silks, in the fifth, haberdashery, in the sixth, perfumery, and so on. 50 young men were employed in the different branches 
of the business. When I passed the castle yard, the soldiers were mounting guard, there were but few of them, but their uniforms very pretty. The infantry in scarlet, which, it is well known is the colour of the greater part of the English army. The dragoons likewise in scarlet, the hussars in blue jackets with red facings and gold lace, their pantaloons red; the riflemen in dark green with black and red lace. When I reached the College I boldly entered and presented Mr. Beddy's respects to a Mr. Dobbs who had charge of the library; Mr. Dobbs hardly recollected Mr. Beddy's name, nevertheless kindly allowed me to go all over the library-room, which I did very leisurely. Its walls were of such height, as to reach to the ceiling of the second story; round a long table reaching from one extremity of the saloon to the other sat several gentlemen in perfect silence, some reading, others writing; the books were placed all round in excellent order on shelves in separate recesses, between each two recesses on a stand the bust of a sage from ancient or modern times. I crossed the river over King's bridge which derives its name from the visit paid to Dublin by King George IV, and found my way to the Phoenix Park, where the first object which attracted my attention, was the so called Wellington's testimonial, an obelisk 210 feet high, not unfitly styled by George IV an overgrown mile stone. On each of the 4 sides were engraved the names of 7 victories gained by the Duke, in all of course 28 . Within the park was the Zoological garden, with a small but choice collection of animals, the Dromedary and the Llama grazed in [225] company, the hyana was a beautiful sp[_]ad, the elephant uncommonly small; there were a jackal and a puma or South American lion, many of which latter I had seen stuffed, hanging round the walls of the buildings in the Estate of Angasmarcas, (see Page 706 of previous vol.) of alligators there were a few young ones, also some snakes. After leaving the park and walking along Barrack street I soon lost my way, and emerged into the long Prussia street, which led me to the circular road; this, as the name implies is a high road encircling the town. I passed the villages of Phibsborough and Blessington, and through Dorset street reentered Dublin, which on this the left side is superior to the quarter on the right side, both as to the regularity of the streets and the beauty of the edifices. Sackville street brought me to Carlisle bridge which I crossed, hurried to my Hôtel, paid my bill and was just in time for the 4 o'clock train for Kingstown. Dublin abounds in handsome public buildings which the guide book enumerates and describes, I will only mention a few of them which pleased me best: The Custom House with the adjoining dock; for the Corn Exchange close by, I looked in vain; the Bank of Ireland, opposite to which a rival establishment the National Bank under the auspices of Daniel O'Connell was about being built; Trinity college, the pupils of which sauntering about in the vicinity I easily recognised by their black silk gowns and black square caps. The four courts of Justice. Whilst I 
quietly paced around them, weighty matters were discussed within its walls, thronged as the papers of the next day informed the readers, with an anxious crowd. The grand jury found the Bill [...] Daniel O'Connell and his accom[226] plic [...] tside all was quiet and nothing gave the slightest indication of what was going on at the distance of a few steps; the post office and the Kings Inn. For $8 \mathrm{~d}$ the train took me to Kingstown, $2^{\text {nd }}$ class, thence a jaunting car for $4 \mathrm{~s}$ to Sea Point. The Seymours whose party had increased by the arrival of the eldest son Robert, the captain and Gonzales, were at the dessert, but Miss Alicia, always kind, immediately got me some dinner. Afterwards we had tea, whist and much conversation, it was past midnight before I retired to my bedroom.

Thursday, $9^{\text {th }}$ of November 1843. Capt. Seymour showed Gonzales and myself all over his father's establishments, he took us to the garden and to the beach, to the small counting house and to the stores filled with the different articles in which Mr. Seymour traded, even to the hay stacks; all was well taken care of and in good order. At a later hour we drove to Viscount Powerscourt's property; we alighted and entered that part of the park which "par excellence" is called the Dargle, perhaps originally, as one of the young ladies suggested, the dark glen; it is a pretty picturesque spot. The foot path leads through a wood, on both sides hills thickly covered with trees; now in their autumnal livery; between them the Dargle tumbles its waters over a rocky uneven bottom, it foams and frets against the obstacles in its way, forming a continuation of diminutive waterfalls, which to borrow a term from the mighty North American rivers might be called miniature "rapids". Now the river comes to light, now it loses itself beneath the foliage and then again appears, a cliff rather precipitous whence one looks down perpendicularly to the river below goes by the name of "the Lover's leap". A drizzling [227] rain came on which drove us to the car and home. Ann read Spanish to me, after dinner I taught Charlotte chess; we had tea, whist, spirits and then to bed.

Friday, $10^{\text {th }}$ of November 1843. After breakfast Gonzales taught Miss Ann Spanish, she him English, I amused myself with reading Levers novels Charles O'Malley. The Captain, Gonzales and I then drove to Kingstown but instead of taking the direct road took another nearer the sea, we passed the foot of Killiney hills which have furnished the stones used in the constructions of the Asylum harbour. On one summit stands an obelisk, from another whither we ascended, on a clear day the bay of Dublin to the north, bounded by the peninsula of Howth, to the south that of Bray confined by Bray head, are visible; but on this day the cloudy atmosphere concealed nearly the entire surrounding country. Close to Dublin is situated a place called Clontarf, thither O'Connell had called his last monster meeting to assemble in November, which however 
had been prevented by the Government. Leaving the Killiney hills to our right, we came to the village of Dalkey in front of which lies the Island of the same name, between them and the main is a safe and deep anchorage, often sought by vessels in stormy weather before the asylum port was built. Between Dalkey and Kingstown an atmospheric railroad had just been concluded, not yet open to the public; trial trips on the same were said to have been satisfactory. I did not understand all its details but the main principal is that along the railroad is placed a thick wide iron tube from which all air is extracted, into it a piston is introduced which meeting no resistance in the vacuum moves on with great velocity and carries along with it the train to which it is attached. [228] The difficulty lay in the circumstance that the iron which connects the piston with the train must necessarily tear through a soft substance which solders up the upper part of the tube and which to close with such rapidity as to prevent the introduction of air had until then been found impossible. In later years many attempts have been made to overcome this difficulty, but in vain, and finally the atmospheric railroad has been abandoned. In Kingstown we paid visits to some acquaintances of the Captain's who do not require any particular notice; it rained like yesterday. After dinner I again taught chess to Charlotte and played two games with the Captain, he gained one, I the other, I giving him a castle. An Irish barrel of grain weighs $280 \mathrm{lbs}$, an English quarter $480 \mathrm{lbs}$, an Imperial bushel 6o lbs, a Liverpool bushel 70 lbs.

Saturday, $11^{\text {th }}$ of November 1843. In the course of the forenoon the Captain, Gonzales and I went down to the beach to see the vessels employed in fishing come in from their station, which at the time was in the Irish sea and St. George's channel, nearer to the Irish than to the English coast. They had been out 2 days and 2 nights and came back laden with herrings; some men were still occupied with disentangling the fish from the meshes of their nets, others already effecting their sales; the purchasers threw the fish into large sacks and drove off with them in their carts, the maze of herrings equal to 5 long hundred, 127 fish, was sold at 10s. One of these vessels had on board 200 mazes, thus no less a quantity than 127,000 herrings. We next walked up to the Martello tower, where an intelligent man of the preventive service showed us all that was worth seeing. The tower built of stone and cement was 40 feet high, at its base, the wall measures 12 feet in thickness, a few [229] feet higher up, where the door is to which a few steps led us, the thickness gradually decreases to 9 and 8 feet and at the top to 7 . The door is sheeted in iron impenetrable to musket ball. Inside on the level with the door is a small room with a fire place and a stand of arms, below a magazine with balls and shells (and in time of war with powder), also with a tank for keeping rain water. A winding staircase in the wall itself leads up to the flat top upon which stood an eighteen pounder 
which could be turned in every direction. Already in 1843 when nobody had as yet the slightest idea of the extraordinary progress which in later years Messrs. Armstrong, Whitworth, Blakely and others would make in the construction of cannons, it was well known that these towers could not withstand cannon ball fired at them from the distance of a mile. Balls fired from the smooth bored cannon of the time would kill a man at the distance of 3 miles but would no penetrate a thick wood board. After dinner I bade good bye to this kind hearted people, of whom I may say I liked Miss Ann best, though she paid me the poor compliment to say that every English word I spoke had a certain foreign twang or accent, which however by the bye I do not believe to be the case. At 6 o'cl. I took the omnibus from Queen's Hôtel to Kingstown where without further delay I went on board the steamer "Merlin", fitted up in the same manner as the "Prince" in which I had come from Liverpool. We were soon under the steam, the sea was tranquil but the cold such that I remained below; at midnight I turned in.

Sunday, $12^{\text {th }}$ of November 1843 . I rose at $81 / 4$ o'cl. without having suffered from sea-sickness. After breakfast I went on deck, we were just [230] entering the Mersey. We passed several light-ships, of course anchored, on the Cheshire side a dangerous sand bank on which the remnants of a steamer, stranded there several years back were still visible, further on, the Rock light house, then still on the Cheshire side close to which the steamer kept, the villages of New Brighton, Egremont, [S]eacombe, Woodside, Birkenhead and Tranmere. For the building of a large new dock about this neighbourhood heavy sums had already been subscribed by Liverpool merchants, and only an act of Parliament was wanting to commence the work. Our large steamer the "Merlin" remained in the middle of the river, whilst a small steamer landed us at St. George's Pier. I walked to my Hôtel in Queen's square, afterwards to Shuttes' whom I found at their early Sunday dinner, and in the evening searched in vain Jack's house in Bedford street, for not knowing that there were 2 Bedford streets in Liverpool, I went by chance to the wrong one where Jack did not live. The "Callao" had arrived at Liverpool in 84 days from Callao. With regard to Peruvian politics I learned that Vivanco's star was in the ascendant, the revolutionary movement in Tacna mentioned page 127 had failed for the moment and the disputes between Vivanco and general Balivian, president of Bolivia which threatened a rupture between the two Republics had been amicably settled; 2 Merchant vessels had made an attempt to load Huano clandestinely at the Chincha Islands, the "Vistula" and the "Prince of Wales"; the former had been caught and was likely to be condemned, the latter had escaped.

Monday, $13^{\text {th }}$ of November 1843. In Gibbs B. \& Co.[_] office I read my letters from Yates of Manchester and Edward Alexander of Glasgow. The former had 
[231] purchased some goods for me destined for the West coast, the latter invited me to pay him a visit, and he did so in such a friendly manner that I determined to take a trip to Glasgow before going to the Continent. Having answered both letters I called on Diego Power of Arequipa, who told me that he lived happily and contentedly in Liverpool, whilst his son Abel, 22 years old looked sad and melancholy. Power jointly with Atherton tried to gain a little money by making occasional consignments to Arequipa and Tacna. In the evening I took tea with Mr. and Mrs. Jack, spent there some pleasant hours and left about $101 / 2$ o'clock. Such a dense fog filled the streets of Liverpool that it was literally impossible to distinguish anything at the distance of 2 Yards, I only heard but did not see the people who passed me in the streets and with difficulty did I find my way home.

Tuesday, $14^{\text {th }}$ of November 1843. On this day the trial of Daniel O'Connell and his accomplices commenced in Dublin before the special jury consisting of 12 individuals all of whom must be unanimous in declaring them guilty before they are considered as such. In Gibbs Bright \& Co.'s office I met a Mexican just arrived from London with a letter of introduction from Antony Gibbs \& Sons. Mr. Bright being absent I had to serve as interpreter between him and Mr. Shutte. I also accompanied him and a clerk of the house in search of a private apartment which we soon found to his entire satisfaction. Together we walked to the St. James' burial ground, a little outside the town; having originally been a slate quarry it lies in a hollow and the entrance through a large archway is cut out of the solid rock, the burial ground is tastefully laid out and filled [232] with tombstones and monuments. One of the many who have found here their last resting place is Mr. William Huskisson, who having filled the situation as secretary for the Colonies in the Loderich and Wellington ministries was, as it is well known killed accidentlly in his $60^{\text {th }}$ year at the opening of the Liverpool and Manchester railway on the $15^{\text {th }}$ September 1830; his statue is erected here to commemorate the services rendered by him to his country. A handsome chapel is annexed to the burial ground; thence we walked on to the Asylum for the blind, a highly beneficent institution sustained by voluntary subscriptions. More than 100 blind men, women and children were occupied in various manual labour, we entered divers rooms, where we found some knitting, others weaving, making baskets, shoes, boots, twine; men and boys were employed in a rope walk, in fact none were idle. All visitors are expected to purchase something, I bought for $18 \mathrm{~d}$ a small rug to be placed under a tea urn. At 2 o'clock we together with other visitors went to the Chapel and took our seats on benches placed in front of the organ; between the organ and us sat 25 to 30 blind men and women who sang most beautifully psalms and hymns accompanied by the organ played by a blind man. This lasted till 3 o'clock 
when we went below to the school room where boys and girls were occupied with reading, I say "reading" by means of the touch, the characters not letters of the alphabet, but characters similar to those used by short hand writers are somewhat raised upon the paper which lay before the children, and alternately one line runs from the left to the right the other form the right to the left, so that without any danger of losing itself, the finger passes [233] over these characters. By the touch they are distinguished and some of the children read aloud fluently enough. The clerk and I dined together at the Angel inn, Dale street and in Gibbs Bright \& Co.'s office I wrote till $71 / 2$ o'cl. when all left. In my hotel I passed the time reading daily papers lent me by Mr. Bright. In the Punjaubs the whole family of the late famous ruler of this country Runjut Sing who died in 1839 has been murdered and a boy 10 years of age has been raised to the throne, this had happened in March and would in all probability lead to the Punjaub falling under the protection of the English East India Company, which is tantamount to an annexation to the great British Indian Empire.

Wednesday, $15^{\text {th }}$ of November 1843. In the office I finished my letter of instructions to Gibbs Bright \& Co. commenced on the previous evening and treating on the shipment of my goods to Callao, I also wrote to my wife in Lima, for the "Robert Finny" was to sail to the West coast in a day or two. At 11 o'clock I went with Mr. Shutte to the Exchange room, a spacious saloon, the ceiling sustained by the columns; a secretary paid by the members of this establishment is attached to it, his duty is to keep every thing in order and to note down on a slate all mercantile and shipping intelligence which he can collect, for the immediate information of subscribers, then to copy the same in a book kept for the purpose. Nearly all London, a few provincial and some French papers were to be found here; annual subscription three Guineas. Up stairs was a smaller more private room similar to the London Lloyd's where Insurance business was transacted. We also went to the Custom house, passed through the long room and entered [234] several smaller offices, where I had not been before. By myself I walked to Atherton's buildings, Dale street where, at the desire of Diego Power, I called on Mr. Atherton, but regretted having done so, for he received me in a cool and stiff manner. At Mr. Wm. Jackson's, whom in $1825 \mathrm{I}$ had known in Arequipa as Clerk of Dixon Price \& Co. and who was now the head of the same firm in Liverpool I fared better, he was polite and conversative, also Mr. Reimers in his office had thawed since I last had seen him; he was sorry, he said, not to have introduced me to his wife. I paid a visit to the village of Everton, whence, being situated on high ground, one has a pretty view over the town to the river, also to the Necropolis, which, notwithstanding its high sounding name, is nothing but a common burial ground. The rain 
which came on prevented my walk to the Zoological Garden. I dined at the Angel inn and in Mr. Bright's office finished my long correspondence for Lima.

Thursday, $16^{\text {th }}$ of November 1843 . My cousin Diedrich Willink breakfasted with me, he took me to an elegant shop in Church street, fitted up in the style of the London bazaars where I laid out some money for my family in Lima; I did the same in Davenports store filled with beautiful glass and earthen ware; for Dr. Mariano Cossio, then judge of one of the inferior courts of justice in Lima; now in 1868 a man of importance, member (vocal) of the supreme court, I bought a terrestrial and celestial globe; at McIvers office I took my passage to Glasgow on board the steamer "Admiral"; with Mr. Stolterfoht, at my aunts request, I had a long conference regarding her son Diedrich with whom he expressed himself well satisfied; I bade good bye in Gibbs B. \& Co's office and had just 2 hours to spare to [235] take a trip in the steamer to the Cheshire side; but unfortunately something of my trunk broke, a joiner came to mend it and this detained me too long. At 4 o'clock, accompanied by Diedrich I drove in a cab to the Clarence dock, somewhat down the river, which only steamers are allowed to enter. I went on board the "Admiral", here the saloon or State room was fitted up more elegantly than those of the "Prince" and the "Merlin", it was carpeted, adorned with pretty paintings, looking glasses and provided with a handsome fire-place; the panels were made of solid, carved polished oak, the tables of the same material, the Companion ladder was a convenient stair case, the sky-light painted. At 51/2 o'clock Diedrich left me; at 6 we got under weigh. We kept close to the Lancashire side and Liverpool illumined by innumerable gasslights presented a pretty appearance. In the state room the various small tables were joined together, so as to form 2 long ones and the passengers sat down to tea, the tea service was of white China with gilt edges, we had fried fish, cold fowl, cold turkey, etc., etc. The cold prevented me from going on deck, I took up a Glasgow paper and saw that Santa Ana the Mexican President was incommoding the foreigners living in his republic, just as the Peruvian Government used to do with the foreigners residing in Peru. He had published a decree prohibiting foreigners to sell by retail, unless they were married to Mexican women or had been naturalized; but the decree did not say whether naturalization was eo ipso the consequence of marriage. At 10 o'clock I lay down on a sofa which I had chosen for my berth, but as the motion of the steamer made the bed clothes fall off, I climbed up to an upper berth in which I slept soundly, though on

Friday, $17^{\text {th }}$ of November 1843 I was told in the morning [236] that the passage had been a rough one. At breakfast about 40 passengers, amongst whom several ladies, assembled; it was near 10 when we past on our larboard side the Peak of Arran. Both to our right and our left we had a high coast which continued 
after we had entered the wide mouth of the Clyde, but the fog or rather the rain came down so densely that it was impossible to distinguish anything, which to me was certainly a great disappointment for I had promised myself much pleasure from this trip. I had thus nothing better to do than to while away the time with reading a novel which I found lying about in the State room. At about 2 o'clock I observed some movement amongst the passengers; they went on deck, I followed their example, the sun had broken through, we were opposite a place on the left bank called Gourock and a few minutes later we came to an anchor in Greenock harbour; Greenock is the port of Glasgow, as seen from the steamer it appeared to me to be an old fashioned town, there was much life and activity, on the slips vessels were building, in the river vessels were at anchor, there were docks, quays and a custom house, all denoted that it was a place of mercantile importance. Opposite on the right bank of the Clyde I descried a row of white houses along the river, this place is called Helensborough, a little higher up on the same side lies Dumbarton Castle. Goods were landed, all passengers went on shore, and, I being left by myself, the Captain advised me to have a look at the largest "whale" on the globe by which he meant the largest wheel. I landed, again it rained but I nothing daunted walked on; after some enquiries I found the factory of the Spinning Company, where a gentleman was so obliging as to show me the enormous waterwheel which put in motion the whole machinery, [237] it measured 70 feet in diameter was made partly of wrought partly of cast iron. A high house was built over it, to keep it under cover and a winding staircase led round it to the top. I learnt afterwards that this manufactory, in which only Cotton thread was spun, was a losing concern. On my return to the steamer I was told that she would not start until 5 o'clock and as by that time it would be dark and I consequently precluded from distinguishing anything, preferred going by rail to Glasgow, where I arrived "sin novedad" as the Spaniards say. We passed Port Glasgow, Bishopstown and Paisley, the last mentioned a large but dirty town. At the Glasgow station I engaged a cab, here called Kaddy, which took me to Georges Hôtel, Georges square, the weather continued as unfavorable as it had been since the early morning and on my drive through the town I could only notice many elegant shops well lighted up with Gas. In my Hôtel I took a good dinner consisting of boiled rabbit and commenced making a few memoranda in the coffeeroom, when I was interrupted by some gentlemen who like myself had come passengers in the "Admiral". A party was formed round the blazing fire, free trade was the first question that was discussed, next the merits and demerits of french and English silks and finally we descended to a comparison between french and English boots all giving the preference to the former. At 10 o'clock I took my night candle and retired to my bedroom. 
Saturday, $18^{\text {th }}$ of November 1843. I was well pleased with the George Hotel; the house itself was large the coffeeroom handsome and well fitted up, the staircase wide and carpeted, [238] my bedroom spacious, my bed clean and soft. The Duke of Bourdeaux on his late visit to Glasgow gave the preference to this Hôtel, nevertheless in the general estimation it ranked lower than its rivals', the "Star", the "Royal" and the Wellington, all in the same square, here were also the counting houses and stores of several of Gibbs Crawley \& Co.'s correspondents, of Messrs. Henry Montieth, Thos. Shields \& Co. and Adamson \& Logan. In the middle of the square similar to those in London an iron railing encloses some shrubs or trees, green lawns with gravel walks between them; within this enclosure stand three statues, the one of Sir Walter Scott in the centre on a high stone pillar; the second in the western corner on a granite pedestal, that of James Watt of bronze by Chantry; the third, not far off, that of Sir John Moore, likewise of bronze and of colossal dimentions on a pedestal of Aberdeen granite. Sir Walter Scott the great novelist, in my opinion surpassed by none, equalled by few, was born in Edinburgh in the year 1771 and died in 1832. James Watt, the well known improver of the steam engine was born 1736 in Greenock and educated in Glasgow, died in 1819. Sir John Moore, the military hero, a townsman of Glasgow was born 1761. He commanded the English army on its disastrous retreat through Galicia; on the $16^{\text {th }}$ of January 1809 when the French army was close upon him near Coruña, he turned at bay and repelled the pursuers, he himself fell but his army effected its embarcation without being further molested. At 10 o'clock I went in search of Mr. Edward Alexander, agent of Gibbs Crawley \& Co.'s establishments on the West coast. He was in his office $\mathrm{N}^{\circ} 7$ Montrose street, being managing partner of the house of Corbet Alexander \& Co. and I found him to be quite as agreeable a man as I had anticipated judging from the pleasant [239] tone of the many letters written by him, which I had read in the course of my 12 years connection with the said firm. His age was about 50, his features prepossessing, his head rather bald; he introduced me to his partner Mr. Alexander Corbett, to his brothers Matthiew and Walter, all three pleasant, agreeable people, also to his 3 sons, John, George and Edward who were employed in their fathers business. We had some general conversation, talked a little about my own business and then started for a long walk through the town. The more I saw of Glasgow the more I was surprised, I had expected to find a dirty smoky place with narrow streets and high houses but found almost invariably, for I except the old part of the town in the east, wide streets with broad foot pavements, some of flagstones some of asphalt, the houses of sand stone built with much regularity, the greater part 4 or 5 stories high. These high houses are inhabited by various families, each occupying one story, or as called here a flat. Smaller houses of which there are 
but few are tenanted by families who prefer living by themselves. The middle of the street or as they say here the causeway was to be sure badly paved and owing to the late rains, dirty and full of pools of water. The same as in London the west end of the town is considered the genteelest part and the further west, the greater the gentility, the wider the streets. I observed entire rows of houses, all built in the same plan and the exterior of each house similar to that of its neighbour. In later years I saw the like in Westbourne Terrace in London. Glasgow is rich in churches, Kirks as they are called here; there are those of the Presbyterians who predominate in the whole of Scotland, of Episcopalians, of Catholics, also the Chapels of the Dissenters. St. Georges church dis- [240] tinguishes itself by the lightness and elegance of its structure; the Cathedral was founded during the reign of David I in the year 1123 and was dedicated to St. Mungo on the $3^{1^{\text {st }}}$ of May 1197. It is the only church built in the medieval gothic style which has escaped the destructive fury of the over zealous reformers of the $16^{\text {th }}$ century and in which divine service is still performed. In 1843 this church was much dilapidated, many windows were broken and on the north side the walls were propped up with large beams; at the principal entrance the floor inside was 5 to 6 feet lower than the outside, the tombstones blocking it up to this height. Round the church is a common burial ground; $\mathrm{Mr}$. Alexander pointed out to me the gate which Sir Walter Scott describes in his Novel Rob Roy as the place where his hero and Osbaldistone met; it was of little height and in 1843 gave entrance to the Charnel house. Close to the Cathedral stand the Infirmary, a handsome modern building, and another house solely destined for the fever sick; on the other side of the Cathedral the Barony church, which insignificant in itself, is as the guidebooks say, only remarkable as being the parish church of the largest parish in Glasgow, viz. of the barony of Garbals on the left bank of the river. "Darnleys cottage", an old house, with these two words painted over the street door, in which Darnley, Queen Mary's husband is said to have resided, and a few steps further, at a street corner, a painting representing one of the victories of Wallace over the English, are the objects which next attract the visitor's attention. A little south of the Cathedral lies the Necropolis or general burial ground upon a hill particularly arid and stony, belonging to the charitable institution called the merchants house, the sides of the hill are cut out into terraces which are crowded with tombstones and monuments; by [241] chance I came upon a tombstone on which the name of Hugh McCulloch who died in 1842 was inscribed; I had known him in Callao, where under the name of Luis Macala, for he considered his own name too jaw-breaking for the Peruvians, he had been established as port agent. The most prominent monument is a pillar with the statue representing John Knox on the top; not far from it, the statue of a certain McGiver who some years 
previously had distinguished himself by writing a series of papers against Catholicism. Mr. Alexander told me that it was the intention of the Directors to excavate the hill so as to form catacombs, as soon as the surface were filled with the dead. The exchange room requires no description it being similar to that of Liverpool. Behind the Exchange follow the Bank and the Custom House a small building close to the river, which, contrary to my expectation, for I was under the impression that Greenock was the port of Glasgow, was crowded with large vessels, as far up as the first bridge called Glasgow bridge; this I learned from Mr. Alexander was due to the care which the authorities, called the Clyde-trustees, had taken to deepen and widen the river, so that, at high water, vessels drawing 17 feet could and did come up, the natural consequence of which was the decline of Greenock, just as Port Glasgow had declined when Greenock rose in importance; quays lined the river's sides and sheds were constructed upon them for the storing of merchandize. Under the name of Bazaar was known in Glasgow the market, where cheese, eggs, butter, poultry, vegetables etc. were exposed for sale, this for a certainty much inferior to what I had seen in Liverp'l. answering the same purpose; as little could the Argyle arcade bear any comparison with the [242] Burlington Arcade of London. I dined "en famille" with Mr. Alexander, wife, daughter and 3 sons. The dinner was plain but good, everything pleasant and comfortable, we had tea and at $10 \mathrm{I}$ retired, well pleased with the kindness and hospitality shown to me. The Scotch low-land accent with which the family pronounced the Queen's English grated harshly on my ears, for instance to the a in father and glass was given the sound of the a in the word ale. Neither Mrs. Alexander nor her daughter pleased me much, the latter however improved on closer acquaintance, she became in later years the wife of my friend F. A. Eck; in Lima they have visited me, in 1856 I paid them a visit on their estate called Hollybush house in Ayrshire, all which will be chronicled in these my extracts should I live long enough to carry them on until those times, which, I confess, I think rather doubtful. (3 July 1868)

Sunday, $19^{\text {th }}$ of November 1843 . Between 7 and 8 o'clock in the morning when I was in the habit of raising, Reaumur's thermometer stood at 8 ; the weather was foggy if not rainy, the days short, the sun low above the horizon and its rays if ever they pierced the thick clouds, without warmth; what else could I expect in the middle of November and in $56^{\circ}$ North latitude? Glasgow lies $55^{\circ} 50^{\prime} 35^{\prime \prime}$. At 11 o'clock the eldest son, John Alexander called on me and together we went to the cathedral, the interior of which required repairs just as much as the exterior. Part was occupied by scaffolding, part by the congregation, it was the first time that I attended at the Presbyterian Divine service, it is different from that of the anglican church, the Lords prayer was said but once, some psalms were sung without the accompaniment of the organ, for there was none, another psalm 
was read; the clergyman in a black silk [243] gown, pronounced a short prayer and then delivered, not read, a long sermon. Behind the pulpit was a painted window, the sole ornament which I noted. I recollected the years of my youth when I so frequently listened with great attention to the excellent practical moral lessons, which in the reformed french church of Altona the clergyman Gabain taught to a devout audience. Both preachers, he in Glasgow and Gabain in Altona were of the Calvanistic creed, but great was the difference between their respective sermons, in Glasgow it was dry and unimpressive, whilst in Altona Gabain spoke to the heart, he rivetted the attention of his audience and knew how to inculcate his sound moral precepts. Service over, young Alexander took me to his fathers house, I entered reluctantly for I knew how strictly in Glasgow the Sabbath is kept, nevertheless I had some lunch and then started with the 3 sons on a walk to the other, the southern side of the river; we passed a wooden, the accommodation bridge, a little higher up than the Glasgow bridge, and found ourselves in that part of the town which is called the Barony of Garbals. In extent it is inferior to the part on the right bank, not so in the regularity of the streets, the magnitude and the material of the houses. At a short distance a hill called Camphill was visible behind which lies the village of Langside where in May 1568 Mary Queen of Scots was defeated by the Regent Murray, whereupon she fled over the border to her "dear sister" Elizabeth, there to find a prison and a scaffold. The brothers Alexander pointed out to me on the north side the monster vent, that is to say the chimney belonging to Messrs. Charles Tennent \& Co. manufactory of chemical preparations, the most [244] extensive in Great Britain; its height is not less then $45^{\circ}$ feet; also on the south side where we were an Iron foundry which worked continually Sundays and working days where the fires burnt day and night; close to it passed a railroad on which the Iron was brought from the Iron mines, of which, as well as of Coal mines there are many in the neighbourhood. This railroad is spanned by an arch over which runs the Greenock railroad, also at the same elevation by an aqueduct through which flows the Paisley canal. On our return over the Glasgow bridge, built of Aberdeen granite, which stone never turns black, though ever so long exposed to air and weather, my attention was called to the handsome stone warehouses as well as to the small Corn-exchange on the left bank. At the corner of my Hôtel the brothers left me, I dined by myself in the coffee room where I remained until it was time to go bed, there were some of my fellows lodgers besides myself, reading, talking, sipping hot water and spirits and whiling away the time as well as they could. I entered into conversation with one of them a well informed gentleman from the south of Ireland, a catholic and repealer. 
Monday, $20^{\text {th }}$ of November 1843. In the forenoon Mr. Edward Alexander took me to the counting house of Messrs. Paterson, Jamison \& Co. one of the most valued and faithful correspondents of Gibbs' on the West coast, and to whom I had penned many a letter whilst with that firm; I do not know when they had commenced consigning to Gibbs Crawley \& Co. but in 1868 they still continued doing so to William Gibbs \& Co., G. C. \& Co.'s successors. Mr. Paterson had died some time ago, his son in law Mr. John Jamison, now the principal man of the firm was even more kind and civil towards me then I had expected he would be. He could not conceal his satisfaction with Gibbs' [245] management of his affairs and only complained of the temporary stagnation of business in Valparaiso. Mr. Jamison invited me to dine with him, we had a very long talk together, he showing me all kinds of patterns and goods. He accompanied me to Mr. George Young who hardly recollected me and with whom I therefore did not remain long. At the hour fixed by Mr. Jamison I went to his dwelling house No 247 Brandon place, George street. His first wife, Mr. Paterson's daughter, having died, he had married again, and his present wife was a very agreeable handsome young lady; I of course had to take her to the dinner table and sat to her right, to my right Mr. William Jamison, John's brother, a nice man, there was also a Mr. Kerr, partner of the firm, rather insignificant. Everything was excellent and I spent the hours as agreeably as I could wish until it was time to retire; the gentlemen present being interested in the trade to Peru they very naturally asked and I had to answer many questions about that country in general and especially relative to Huano, which produce at that time commenced to attract the attention of agriculturist's and traders to Peru. Mr. Wm. Jamison and I left together and as it was still early introduced me to the Glasgow club, where many gentlemen were assembled sitting round the fire, smoking and discussing a question, which at the time excited the most lively interest all over Scotland, caused differences between the most intimate friends and even divided members of the same family. Until then it had been the custom in the Presbyterian church for curates (Scotch "ministers") to be appointed by corporations, Lords of the manor and similar men of influence, they owing thus their situations to patronage, those who adhered to this system were called intrusion- [246] ists, whilst the non-intrusionists or freechurch people, who were the seceders, insisted upon the curates being elected and paid by their flock.

Tuesday, $27^{\text {st }}$ of November 1843 . Contrary to my custom it was as late as 10 o'clock when I appeared in the coffee room, I quickly despatched my breakfast consisting of a cup of coffee, an egg, toast and butter, and hastened to Mr. Alexanders office who was ready to take a walk with me to the Botanical 
Garden which lies far west outside the town. Everywhere new handsome buildings were springing up, we passed the small river Kelvin over a recently constructed bridge and notwithstanding the unfavourable state of the weather, it was clear to me that the country hereabouts must be very pretty in spring and summer; at the distance of about 12 miles to the northward I distinguished a low range of hills which may be considered as the basis of the High-lands; somewhat further north are Ben and "Loch-Lomond" romantic scenery well known to the readers of Walter Scott's novels. In the Botanical garden John Alexander soon joined us and as he was something of a botanist we remained here a considerable time, both in the open air and in the hot houses filled with rare and valuable exotics. I dined at Alexanders who had invited his two brothers and Mr. Corbett to meet me, dinner was exactly similar to that at Mr. Jamisons, soup, fish, two roasts, pastry fruit and hot water and spirits after the wine. I sat near Mrs. Alexander but could not elicit any interesting conversation from her. After dinner I showed to the party my drawings of Lima costumes, which amused them much, then Mr. Alexander brought out a beautiful edition of Walter Scott's work with splendid engravings, which I had to admire rather longer than agreeable to me [247] for I should have preferred to approach the piano, where Miss Alexander played and sang very prettily.

Wednesday, $22^{\text {nd }}$ of November 1843. Mr. John Alexander was good enough to accompany me this morning on a stroll to the east or old part of the town, here both the causeway and the foot pavement were narrower; the streets more crowded than in the west, there were also some houses with old fashioned gables of this shape $\mathrm{Fr}_{\mathbf{2}}$. An open place where the Highstreet from the north, the Trongate St., which is the continuation of the beautiful western Argyll street from the west, Saltmarket from the south, London street from the south east and Gallow gate from the East, join, is called the new cross and here the country people used to meet on Market-day which is Wednesday, not so much for transacting business, as for chatting and gossipping. At the end of high gate stood an Archway with a steeple and a clock, the only remnant of the old jail or toll booth. Going from the new cross westward we had in Trongate street to our right the old Exchange for the East enders, in front of which a statue of William III, and the Town Hall, to the left Tronchurch. Tron is an old Scotch word which means to weigh and Trongate was the place where in times long past by, merchandize was publicly weighed. From the Cross through London street we came to a large open place, called the Green, along the bank of the river, a green turf with a few trees, an imitation of the London parks. On our return we passed through St. Andrews square with a church of the same name, once the most fashionable part of the town; when the "beau monde" migrated westward it became the central point for stores and warehouses, in 
1843 it commenced being the abode of operatives. When we had reached the office Mr. Alexander the father went with me on another excursion. Gibbs Crawley \& Co. of Lima [248] had written of late that Cotton bagging was scarce in that market, accordingly we tried to find a suitable parcel, but not meeting with one to our liking, I left my order with Mr. Alexander for the purchase. Next we called upon Mr. Wm. Falconer the manufacturer of Poncho Cloth, a quiet unobtrusive man; for several years he had resided in Hamburgh, was a citizen of that free town and spoke a little german. Thence we wended our way to the University's buildings, consisting of two quadrangles, the one of which with a somewhat monastic appearance, turrets and irregular small windows. To the west of the University stands the Hunterian museum, an extremely elegant building. The renowned Dr. Hunter left the museum to the trustees of the college, its original cost was £100,ooo, in later years many valuable additions have been made to it. The saloon of the ground floor was filled with stuffed animals of all descriptions. Quadrupe[ds], birds, fishes and reptiles, many of which I had seen alive in the Zoological gardens of London and Dublin. A boa constrictor devouring a deer was got up life like; an antler probably of an antediluvian stag I much admired on account of its enormous size; monster births of cats, pigs, sheep, deer, etc. might be curious and interesting to the natural philosopher, to me they were disgusting; for instance the bodies of two animals had grown together presenting thus 8 legs with one head and vice versa one body with 4 legs and two heads. On the walls were hung up weapons from the South Sea Islands, also a Roman and a Chinese shield. We hurried through the anatomical saloon, because Mr. Alexander had no mind for the objects which it contained, I however took my time to examine with much attention two skeletons, one of a man, the other of a woman; the woman has 12 ribs, large and small on each side, the man only 11. The legend accounts for this difference by say- [249] ing, that God the Almighty when creating Eve took one of Adams ribs for that purpose. Here I saw likewise for the first time an Egyptian mummy, preserved in a box, which dates as many centuries back as the mummy itself. The lid was taken off and the bondages around the embalmed body were rather in an imperfect state of preservation. Upstairs were vast collections of minerals and shells, which interested me but little, also paintings, some of which were said to be master pieces, but true to my resolution expressed on Page 185 of these extracts, I refrain from describing them. The collection of coins and medals is very valuable and only inferior to that of Paris, of manuscripts and old printed books, dating mainly from the $15^{\text {th }}$ century there were many, and willingly should I have pored over them for some time, but the cold in these unhealed large saloons, made itself so sensibly felt that Mr. Alexander and I soon thought proper to leave. The next two hours 
which together with John Alexander I spent in the institution for deaf and dumb, afforded me as much rational enjoyment as ever before or after I have experienced in the course of my long and multifarious wanderings. Many are under the impression, I at least was one of the number, before visiting this charitable establishment, that the deaf and dumb are stupid, bad tempered and ill disposed. Here however I was convinced of the contrary, the children whom I saw looked healthy, happy and cheerful and to some of them it would be unjust to deny a good deal of intelligence. The first thing done was to teach them writing, when they knew the written letters, the second step was to teach them how to represent each letter by certain positions of the fingers, and as soon as this was accomplished, words which define objects, perceptible to the senses of the deaf and [250] dumb, such as, ear, eye, hand etc. were written down and were shown to them on their bodies. On a large paste board all kinds of objects, houses, trees, stones, animals, etc. etc. were painted and these were taught them in a similar manner. A little girl apparently of the lower class was called in; I mentioned to the master one of the objects painted on this paste board, he spelt the word to her by signs of his fingers and immediately the girl pointed out the object on the board. So far as this went I did not find any great difficulty in the teaching but how the children learnt the meaning of abstract words, such as, beauty, crime conscience etc. passed my comprehension and nevertheless this the master, a model of patience and perseverance who had already spent 17 years of his life as teacher in this establishment, had brought about. I requested him to ask his pupils of the first class (10 or 12 in number) what was vice. He wrote the question on a black board hanging on the wall and then each child, boy and girl wrote the answer on its slate. One wrote, "it is hateful to God", another, "There is no man without it", and all answers were more or less to the purpose and written in a fair hand. With the definition of beauty, which was my next question, they did not succeed so well. A pretty, clever little girl pointed out South America on the map; a little boy, fair headed and very sharp answered in writing on the slate every question asked him by the master. "Where is Malta?" - "In the Mediterranian" - "What is Malta?" - "An Island" - "What is an island?" - Also to this, his answer was satisfactory. Again "Where is Scotland?" - "In Great Britain". "Where is Great Britain?" - "In Europe". "Where is Europe?" - "In the world". "Where is the world?" - "In the universe". "Where is the Universe?" - "You should not go any further"! (Excellent!) "What countryman do you think this gentleman is?" referring to me [251] "I believe this gentleman is neither English, Scotch, nor Irish, but I do not know from where he is". Then the master by tapping on the table attracted the attention of all 10 or 12 in number. I blew my nose, he asked them what I had been doing. Each child wrote his answer on a slate; one wrote "the 
gentleman having taken his napkin out of his pocket wiped his nose", I clapped my hand, again all were writing "The gentleman stretched out his arms and slapped his hands, as if to amuse a child", "the gentleman clapped his hands", the third was at a loss not knowing the word clap. The fair headed boy wrote a long answer in which he said that I looked like a minister and when he was asked what kind of minister, his reply was that there were ministers who counsel the Kings and Queens and others who preach. The little girl above mentioned cast out 2 pair of gloves at $2 \mathrm{~s} 6 \mathrm{~d} 1 / 2$ each and multiplied a certain number by 15 ; the boy had to calculate what was the $10^{\text {th }}$ part of 150 , he did it wrong, whereupon he pointed to his head as if he meant to say, how stupid of me! and then he did it right. Finally to the masters question whether they loved him when he punished them, the boy answered "I do not love you at the time you punish me, but afterwards when I see that you teach me and do me so many other kind things I love you". The girls reply was too long for me to recollect it entirely, she said something about it being the master duty to punish them. All the questions which the master put to them were asked by means of signs made with the fingers and with the greatest rapidity, in the same manner the children conversed with each other and even with a little girl who was neither deaf nor dumb. Before leaving the establishment the master showed me the bed and the washing rooms, all kept in the nicest order, the children $\left[25^{2}\right]$ were clean and well dressed. In the evening I went to the theatre with George and Janet Alexander, the house was extremely empty, in the first tier we were the only ones, even at half price it filled but sparingly, only the $6 \mathrm{~d}$ gallery was crowded and noisy as usual. Richard III was performed, Mr. Henry Betty as Richard ranted and roared to his heart's delight, however not without an occasional sprinkling of really good acting. The farce of a Roland for an Oliver, Miss Alexander, who as an only daughter and pretty girl had a right to have her whims, declared to be beyond endurance stupid, and consequently we left as soon as the curtain rose.

Thursday, $23^{\text {rd }}$ of November 1843. Together with Mr. Geo. Alexander the youngest son I visited the North town and county jail near Market lane; the South jail is in the West corner of the Green. In both prisons together were confined about 500 malefactors, men, women and children, mostly for thieving, the term of their confinement varied from 10 days to 2 years according to the gravity of their offence, whilst such as were guilty of more heinous crimes were conducted to the Perth Penitentiary or transported. The North jail consisted of various separate buildings 4 to 5 stories high, one of which recently concluded was built on the most approved plan, so as to render it more airy and consequently more healthy than prisons usually are. There was in the middle an oblong yard covered with a sky light; inside round each story 
ran a gallery or corridor and into it opened the doors of the respective cells destined for the prisoners. Each prisoner occupied a cell by himself, spacious enough, and this solitary confinement was the principal punishment; shackles and handcuffs were not used as a general rule, they were only imposed as an extra chastisement upon those prisoners who were refractory and otherwise unmanageable; all such as had learned certain trades, as for instance [253] shoemakers, tailors, carpenters, weavers, worked in the jail at their own trade, women also wove or knitted whilst the remainder who were otherwise useless were occupied with picking oakum. 10 Hours in the day they had to work for the benefit of the establishment, any overtime they were allowed to employ on their own account as the Captain who showed us round told us, there were a few who made a little money for themselves. The two sexes were of course kept separately in two different buildings. The keepers of the males were men, those of the females, women. There were children as young as 11 and 12 years of age and generally, I was told, boys entered the career of crime at an earlier age than girls. On the sick-list there were only 3, a proof of the good care which was taken of them, cleanliness pervaded the whole establishment. For breakfast they had oatmeal porridge, for dinner at 1 o'clock p.m. a substantial soup, a little meat and a loaf for each; I tasted the bread and found it of very good quality. They had a play ground wherein to stretch their legs and run about, nevertheless in course of time many became stiff in their limbs, and this it was observed, happened more to men than to women. I saw an example of it in a young man who being an incorrigible thief had been confined a second or third time and thus been in the jail nearly 4 years consecutively; he walked stiffly and with difficulty. The education of the prisoners was as well attended to as their bodily health; they were taught writing, reading and cyphering, useful and religious books were likewise placed at their disposal. The men were dressed in a suit of clothes of ordinary cloth, of a light brown colour, the women in striped Gingham. The whole establishment had more the appearance of a large factory than of a prison, the clanking of chains which some look upon as a necessary accompaniment of a prison was nowhere heard. We [254] thanked our conductor for his kindness and attention and then directed our steps to the manufactory of Corbett Alexander \& Co. who make only Cotton platillas and blue cotton checks. I find in my original diary two descriptions of the manufacturing of these articles; the one attempted by myself, the other drawn up by Mr. Edward Alexander; but neither the one nor the other is quite clear and intelligable for which reason I do not reproduce them here. Before parting Mr. Geo. Alexander showed me the bridge of one handsome arch, over a small rivulet, "Molindinar", leading to the Necropolis. The Glasgow people have given it the name of "the bridge of sighs"; I suppose in imitation of the famous bridge 
of the same name in Venice. I dined in my Hôtel and in the evening paid a visit to Mrs. Jamieson a most agreeable lady, her husband was not at home, I remained with her nearly 2 hours.

Friday, $24^{\text {th }}$ of November 1843. With Mr. Edward Alexander I went to see what a certain somebody called the "Happy family". This person had collected in a very large cage a great number, the advertisement said 100, animals inimical to each other, the pursuers and the pursued, such as cats, rats, monkeys, ferrets, hawks, pigeons, owls, a raven, a dog, rabbits, guinea pigs, magpies, starlings, etc. These no doubt by means of some drug he had reduced to a state of apathy and lethargy, so that they lived together and even jostled against each other without the one taking any notice of its neighbour; it was clear to me that they were under the influence of some somniferous agent and thus the show was by no means to my liking. Thence we walked to the warehouses of Messrs. Broadfoot Brond and Thomson where we took a long time in picking out $5^{\circ}$ Pieces of Silk Hkfs. to be shipped by Alexander on my account to Gibbs of Lima. I dined once more at Alexanders', we were quite by ourselves and I was glad that the lady of the house had not put [255] herself out of the way on my account. We had broth, a boiled leg of mutton with potatoes and turnips and two kinds of pastry. After dinner Miss Janet asked me to look over with her some books with engravings, we became better friends than we had been hitherto, I was however more and more convinced that she was not without those little defects which are consequent on being a spoiled child.

Saturday, $25^{\text {th }}$ of November 1843 . This being the last day of my stay in Glasgow Mr. Jamieson had invited me to breakfast with him, we were himself and his wife, both very nice people, his three sons from his first marriage and I; their babe Catherine 10 months old was also brought in to be shown to me, of course her parents' darling. I made here the acquaintance of young Mr. Patterson, brother of Mr. Jamisons first and of Mr. Kerr's present wife. At a later hour Mr. Edward Alexander who never tired in his kindness towards me went with me to the Asylum for the blind, which establishment owed in a great measure its highly advanced state to Mr. John Alston, a merchant and banker of Glasgow, whom we met at his office in the Asylum. He presented me with a printed report on the state of the establishment, a marble bust of his stood in the office, a portrait of his was hung up in the schoolroom. Eight blind girls some of them grown up were on the point of leaving the room but Mr. Alton called them back and told them to sing; they did so very prettily knitting all the while and one of them playing on the organ. They were dressed in dark gowns with blue and white aprons and a silk Handkerchief over their neck; they looked healthy but rather more sad than the deaf and dumb whom I had seen two days ago. Bibles with raised letters, the usual latin type were print- $[256]$ ed in the establishment; 
all the time running from the left to the right, in both which points the plan adopted here differed from that in use in the Liverpool Institution. One of the girls read aloud with fluency, following the lines with her finger, she hesitated once or twice but only for a second. Arithmetic was taught but though one of the girls made an addition of several sums in my presence and I was referred for further particulars to the report above alluded to, which describes the means employed to impart the science of cyphering to the blind children, I could not comprehend the whole process, each girl had a metal board, perforated with a number of holes of a pentagon shape and a small metal pin differently pointed on each side, if inserted in the corners of the pentagon it represented the uneven numbers 1357 9; turned round the opposite end upwards and inserted in the middle between two

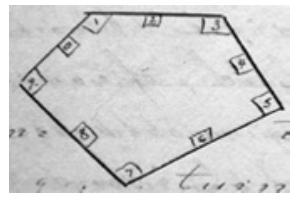
corners it represented the even numbers $2468 \mathrm{o}$, so far all was intelligible to me, but in what manner the casting up, deducting, multiplying and dividing was done remained an enigma to me. The girl most advanced told me she knew how to calculate interest. Geography was also taught here. On the terrestrial globe what represented the land was raised a little over the remainder which constitutes the sea, and on the land, towns rivers and mountains were again raised a trifle and thus by the touch the children were enabled to distinguish these various parts. The master assured us that the children made very fair progress in Geography and that a few had even some idea of latitude and longitude. Of boys I saw but four who were idling about I was told it being Saturday many of the boys had been allowed to go out; it was also scrubbing and cleaning day, for which reason all the apartments were not shown to us. In the same manner as in the Liverpool insti- [257] tution blind men and women were at work at their respective trades. Out of the fibres of the Cocoa nut strong rugs for cleaning the feet in dirty weather were being made, an occupation I had not seen in Liverpool; the proceeds of the various articles made here sufficed for the maintenance of the blind. A few young girls even sewed their own dresses. I now bade good bye to Mrs. Alexander in her dwelling house (Janet had gone out) to the other members of the family in the office, settled my bill in the Hôtel and hastened to the railway station where I took a first class ticket for Edinburgh, and hardly had I taken my seat when Mr. Alexander, the father, came to give me the last shake of his honest hand. That part of the river up to Glasgow bridge where vessels are moored is called Broomielaw or lew meaning a hill covered with Scotch broom with which shrub in former times the hills on both sides had been covered. From Argyle street Buchanan street runs straight north to a place called Port Dundas situated close to a canal which commencing to the west of Glasgow and ending to the west of Edinburgh 
unites the Clyde with the Frith of Forth. In Port Dundas all goods sent from Glasgow to Edinburgh and vice versa are shipped and landed. In the battle of Langside the bakers of Glasgow rendered material assistance to the regent Murray, in consideration of which he permitted their mills to be driven by the river Kelvin tax free and this privilege they still enjoyed in the year 1843; besides nobody was allowed to put up a bake-house, unless he was a baker's son, had married a baker's daughter, or paid $£_{150}$ for the license. Mr. Alexander the father told me that he had ceded to his sons his interest in the Corbett manufactory and that he contented himself with the income which he derived from the agency for Gibbs' establishments on the west coast, in which branch of his business he expected $\left\{[\ldots]\right.$ a plan of Glasgow i [...] ppendix $\left.\mathrm{N}^{\circ} 38\right\}[258]$ his eldest son John would succeed him in course of time. I installed myself smugly in the left corner in the railroad carriage and had thus a pretty view over the undulating and well cultivated country to the north of the railroad. Close to Linlithgow I noted the ruins of a castle, a little further on we came through the dale of Almond and crossed the river of the same name. We passed through several tunnels over much rocky ground and past 3 o'clock arrived at the terminus in Edinburgh, whence an omnibus conveyed me to an Hôtel in Princes street, a few houses to the westward of the Register office, which as the guide book says, is more or less the centre of the town; nevertheless I found here but few lodgers and after I had taken possession of the room given to me I started for a walk. Darkness came on, but what I could distinguish of the town seemed to me very different from anything I had seen in other places. Walking eastward through Waterloo place, then skirting Calton hill in the direction of the London road it seemed to me that nowhere had I seen in such a short space a similar accumulation of monuments and public buildings, whilst turning southward towards the north side of Cannongate I was not a little surprised when I observed that the houses in that street 4 to 5 stories high, did not reach up to the level where I stood. Somewhat further down I crossed the north bridge with a massive stone parapet on each side; it put me in mind of London bridge but with the difference that whilst below London bridge flows a mighty river, the North bridge in Edinburgh is built across a street, the said Cannongate, and here I saw houses actually 10 stories high, the one half reaching from the bottom of Cannongate up to the bridge, the other half from the bridge upwards. In Edinburgh as in Glasgow each flat or story is generally occupied by a different family thus the houses [259] are lighted up from top to bottom; the streets are of course illumined with gas and thus standing on this bridge I saw lights in every direction, below and above, before and behind; to the right and to the left, a strange sight altogether. At 7 o'clock I went to the theatre a few houses distant from my hotel. The ticket to the pit costs $2 \mathrm{~s} 6 \mathrm{~d}$. The house rather smaller 
than that of Glasgow was prettily painted and this evening well filled. Miss Helen Faucit was the great attraction, she acted the heroine in a Drama by I. Westland Marston called the "Patricians daughter"; her acting was excellent and on more than one occasion she drew tears from many of the spectators. The plot of the piece is simple, Mabel the Patrician's daughter (Miss Faucit) and Mordaunt, a young man of low extraction but richly gifted by nature are enamoured of each other, Lady Lidia, Mables aunt is opposed to their marriage on account of Mordaunt's ignoble birth, intent on separating the lovers she intrigues, she calumniates, she invents and tells falsehoods; at last she obtains her object and this so effectually that, when after some years Mordaunt has risen in life and has become Sir Edgar, it is he who refuses Mabels hand. This is too severe a blow, the poor girl conscious of her innocence, her spirits fail her, her health declines and she is gradually sinking into an early grave. Now remorse seizes upon Lady Lydia who discovers and explains all her machinations. Mabel prevails upon her father to pardon Sir Edgar the insult offered to him when declining the alliance with his daughter. The two lovers meet. Mabel throws herself into the arms of Mandaunt, whether to live or to die is left to the imagination of the audience, for at the same moment the curtain drops. The drama was succeeded by a poor ballet and by an amusing Burletta called the Loan of a lover. At 11 o'clock I was in my Hôtel.

Sunday, $26^{\text {th }}$ of November 1843. In the coffee room [26o] there was only one gentleman taking his breakfast besides myself. Over north bridge I went to St. Gile's Church in High street, in the cemetery lie buried the mortal remains of the famous reformer John Knox. Only a small part of the interior of the church was occupied by the congregation, they sat on rows of benches with narrow desks for placing the bible and prayer book upon before them, in front a plain pulpit below which a desk for the clerk. The church was without any ornament, without an organ, exactly the same as in St. Mungo's of Glasgow. I must correct here an error then made: in the Presbyterian divine service the Lords prayer is not said a single time (Page 242 I said erroneously it was read once). The sermon treated on the transfiguration of Christ, but without grounding upon this fact any religious or moral lesson. Service over I passed through the yard formed by the Exchange buildings and then leisurely sauntered down High street and Cannon gate until I reached Holyrood house. Of the various "lions" on this route pointed out by the guide book I merely noted at the extremity of this latter street the ungainly fabric of Cannon gate Church, the Cannongate court room and jail neither of which three buildings present anything interesting except perhaps their antiquity. On the other hand the extraordinary height of the houses 5, 6 even 7 stories crowned with a gable, the windows small and narrow, not infrequently the panes broken and 
a female head sticking out from the uppermost flat, also the plaster in many places fallen off, so as to lay open the irregularity of the stones underneath, all this did not cease to occupy my attention; though I must say that my guide book is rather too grandiloquous when it speaks of "the stupendous height of many of the houses, and the air of antique majesty which pervades this street." [261] On both sides branch off from Cannongate various lanes, closes as they are called, steeply descending and inhabited by the lowest classes of the Edinburgh population. I passed Holyrood house on my left and soon came to Salisbury crags, a hill which presents its abrupt side to the town which lies to the westward. I ascended this hill from the opposite side and enjoyed from the summit, the day being, considering the season, pretty clear, a fine and extensive view. To the south where the prospect was not impeded by Arthurs seat, higher then Salisbury Crags, I had before me well cultivated fields, here and there a farm house, now and then a clump of trees, just at the foot the dark masses of the coal Depôt for the Dalkieth Railway. Turning my look westward where low hills prevent a distant sight, Edinburgh itself was spread out before me, it is true that smoke and fog lay over it like a canopy, but not so densely as to conceal the castle with its fortifications, which though on a low hill is always a prominent object, nor the many steeples, of the names of which I was as yet ignorant. Nearer to the Crags are the suburbs with green patches between and at the very basis Holyrood house. Continuing the circuit to the North west, the modern part of the town with many monuments appears in view, behind it the waters of the Frith of Forth and at the very verge of the horizon the northern banks of this Bay; still more to the right Calton Hill covered with statues. To the northward the town regularly built in that direction gradually loses itself in the surrounding country which to the eastward is seen to be confined by the frith, here at its mouth so wide as to resemble the open Sea. Leith, with its pier, Portobello, the northern banks of the firth a mountain covered [262] with snow shone upon by the western sun, a few islets, on the south side a hill in the shape of sugar loaf, were distinguishable. A long while did I contemplate this beautiful panorama, then descended and again ascended a hill called Arthur's seat by a path partly lined on one side by a solitary wall, the remnant of a chapel once dedicated to St. Anthony, the summit 822 feet over the sea is level, it was covered with smooth grass, slippery owing to the late rains, the wind from the S.E. blew so furiously that I kept my footing with difficulty and took shelter behind some rocks, here however I did not remain long for the weather changed for the worse and the view hence differed but slightly from that from Salisbury crags. I scrambled down on the south side where there was hardly a beaten track, reached the bottom in safety, followed for a few minutes the road leading to Doddington, turned off to the left, crossed the Dalkieth railroad, 
then round the corner of Gihbet Yoll, through Leonard street, close to St. Pauls church, through Pleasance street, St. Mary's Wind into High street already known to me by forenoon's visit to St. Giles. In all these streets particularly in St. Mary's Wind, the high houses, many storied, gabled, gave evidence of the antiquity of this part of the town, the remainder of the day I stayed at my Hôtel dining, reading, writing and when in bed I blessed my stars that I was not at sea for the blast beat furiously against my windows.

Monday, $27^{\text {th }}$ of November 1843 . Black in his excellent little book called the economical guide of Edinburgh lays down two walks through the town, which he recommends to all visitors who are desirous that no object of interest escape their attention. These 2 days' excursion I completed in one long forenoon [263] walk from 91/2 to 41/2 o'clock. Princes street divides Edinburgh into two halves, the one to the south or looking down the street towards the castle, to the left, the other to the right or to the north. The former I most delighted in for the sake of its old fashioned appearance, however so often did I pass thither and hither that the very afternoon when I tried to put to paper what I had seen, my recollections were none of the clearest and thus it will not be surprising if the description which I am now about to give will be a little confused. Through North and South Bridge streets I came as far as Nicholas street and square, passed the college or university, a large quadrangular building, opposite to which the Royal Infirmary and Surgeons Hall, surrounded by so high a wall that barely any part of them is visible. On the same, the East side of St. Nicholas street the Surgeons Hall of which the guide book says, "that in classic elegance few buildings will be found to surpass this handsome structure". I retraced my steps and when on north bridge descended a number of steps leading to the inferior not to say infernal regions. The "Marbles", which name is given to the vegetable, fruit and fish market, close by the shambles, both the one and the other are wanting in cleanliness, so much required where provisions are exposed for sale. A gradual ascent again brought me up to Prince's street, which as already said is the demarcation line between the two parts of the town. I walked on westward, passed on my left Scotts monument, which surrounded by scaffolding, was not yet concluded; a little further on, on the same side the Royal Institution, one of the handsomest modern buildings of which Edin- [264] burgh can boast. Articles of Scotch manufacture were exhibited here gratis to the public, I entered but what I found here was but little, and for the little there was, extravagant prices were asked. Behind the institution was an earthen mound, an accumulation of rubbish and earth dug out when the modern part of the town was commenced being built. Sir Walter Scott calls it very properly a "deformity", but in 1843 it served for a convenient 
communication between the North and the South and as such I availed myself of it. I climbed down one of those narrow closes yesterday spoken of and everywhere the same monster houses, 9, 10 stories high greeted my sight. St. Giles' church forms the north side of Parliament square, opposite, south stands the library of the advocates and writers of the signet, to the east The Parliament house, to the west the court of Exchequer, in the centre an equestrian statue of Charles II with the ridiculous inscription "invicto monaicae". A few steps further westward I came to the County hall, of the exterior of which the guide book speaks in the most laudatory terms, comparing it to some of the most renowed antique temples in Athens. On the ground floor, opposite to the entrance to the quadrangle formed by the exchange buildings, is the council chamber where the magistrates of Edinburgh were in the habit of holding their sessions; in a separate office I obtained without difficulty a ticket for admission to Crown room in the castle. On my way to the castle I passed to my right Bank street at the end of which a fine building, the Bank of Scotland, separated by Princes gardens from Scotts monument, further on to my left Victoria Hall an edifice which, little as I understand of architecture, [265] pleased me much, on account of the light and airy style of its construction, its noble spire is 241 feet high; the foundation stone was laid by Queen Victoria on her last visit to Edinburgh, and its object was to serve for the meeting of the general assembly of the Church of Scotland. By this time I had reached the castle on castle hill, I passed over a draw bridge, then under a low arched gateway, soldiers were lolling about everywhere, guns thrusting their muzzles out of their embrasures, sentries on their posts, a main guard, a little further on, barracks, wall above wall and notwithstanding all this apparatus of precaution nobody prevented me from entering, I went wheresoever I listed and there was hardly a nook or corner into which I did not pry. The regalia are of course the object which visitors must see above all, they were kept a few steps up a winding staircase in a low vaulted room and consisted of the Crown, sceptre, the sword of Justice and its scabbard. Chambers in his "Walks through Edinburgh" says about them: "Their essential littleness excites wonder at the mighty circumstances and destinies which have been determined by the possession or want of possession of what they emblemize and represent", and again, "the period of the crown's disuse seems to have been the epoch from which we may reckon the happiness of our monarchs and the revival of our national prosperity." It was last worn by Charles II a preface to the disasters at Worcester. The regalia were with difficulty though successfully saved from the clutches of the republicans and regicides at the time of the Common wealth; on the $26^{\text {th }}$ of March 1707 they were deposited in the Crown room in an iron 
chest, secured with 3 strong locks; the keys to them being lost the box [266] was broken open in October 1817 by order of the Prince Regent and the said Regalia were found in it and besides them the High Treasurer of Scotland's mace of office made of pure silver. In this crown room four other valuable jewels were shown to me and to the other visitors, they were bequeathed to George III by the Cardinal of York, the last male descendant of the Stuarts, who died in Rome in the year 1807 , and consisted of:

1. A golden collar of the order of the Garter, presented by Queen Elizabeth to King James VI.

2. The St. George, or Badge of the Order probably appertaining to this collar.

3. The St. Andrew, the image of the Patron on one side, the badge of the thistle on the other; below a fine miniature of Queen Ann.

4. A sapphire ring, the coronation ring of Charles I.

Outside the castle is the Esplanade with a handsome bronze statue of the Duke of York; from this elevated point, I had a fine view over the town below, which wheresoever it is seen from always presents a picturesque appearance. Hardly had I walked on a few steps when I was accosted by an elderly lady with two daughters, they were strangers like myself, being from Perth and I had exchanged a few words with them in the Crown room; she asked me why I had not visited that room in the castle, in which Mary Queen of Scots had given birth to James VI, the first of this name of England, I answered that I had not been aware that such a room was in existence and when she told me that at present it was empty and afforded no other attraction, I did not think it worth while to reenter for the sake of it. The street North Bow took me from George's bridge, which spans Cow gate deep below, to the Grass market, in the centre of which a cross formed by the stone pavement marks [267] the very spot where in former times the socket stone of the gallow-tree was sunk. Previously to 1785 criminals were hanged here; on the $8^{\text {th }}$ Sept. 1736 , the murderers of Porteus (Sir Walter Scott in the first chapters of the Heart of Mid-Lothian gives a detailed account of the storming of the toll-booth by the populace and of the murder of Porteus, the governor) suffered on this spot capital punishment and were carried to the place of execution along the North bow, the street through which criminals used to be conducted thither. On the West extremity of the Grass market stood an insignificant building, the Corn Exchange and its S.W. corner where the West Port leads into it is the place where Burke and his accomplice Hare committed their atrocious murders in the year 1829. From here I ascended a steep street running due South and found myself again on the very spot where I had been an hour before, say, close to Harriots Hospital, a queer quadrangular building with a tower at each corner and these towers adorned or rather disfigured by small turrets in the shape of pepper boxes. 
George Harriott, the jeweller of James VI, the jingling Georgie in Sir Walter Scotts novel "the Fortunes of Nigel" founded this Hospital which is destined for the reception, maintenance and education of poor and fatherless boys, flower beds and gravel walks surrounded it. To the east of this Hospital stands Gray friars Church a serious looking building. Opposite to Harriotts and over the way, another Hospital that of George Watson, a plain building for the children and grand children of ruined merchants of Edinburgh. A fine avenue skirts the grounds belonging to this latter Hospital, I followed this to the eastward, looked into St. Georges square and Ruccleuch place, genteel quarters in the olden times, then [268] wending my way westward through another pretty avenue I had to my left or South, green meadows and Hope park, to my right the Merchant Maiden Hospital, in fact I was outside the town, turning to the right I reentered the same and walking along Leven street, Knox street, Earl Grey's street and Lothian road I emerged at the western extremity of Princes street where are the two churches of St. Cuthbert and St. John, the former an oblong barn with an airy steeple, the latter an episcopalian church built in the so called gothic style, embellished as the guide book says by the graces of internal and external architecture of the English Church. I here crossed Princes street and through Charlotte street entered the modern part of Edinburgh, which by the regularity of the houses, the width of the streets and foot pavements as well as by the few people whom I met, reminded me of the West End of London. At the extremity of Charlotte street I passed Charlotte square with the really elegant St. George's church, then through Randolphs Crescent and Randolph's cliff I came to Dean's bridge 106 feet over Leith water, I crossed it and was again in the open country. A handsome episcopalian Church called the Trinity church was to my left, to my right I had some nursery grounds, I reentered the town through St. Bernard Cresecent, recrossed the water and came to Murray place, that part of the town which is most celebrated for the architectural magnificense of its buildings with which I confess I was highly pleased, though a certain Dr. James Johnson speaks of the new town as being beautifully monotonous and magnificently dull. House rent in this West end of Edinburgh was in 1843 no more than $£ 140$ to £16o per annum. Forres street took me from Moray place into Queen's street with its pleasure grounds, then Castle street from Queen's street into George's street, really beautiful. [269] Georges street runs from East to West; at its western extremity lies Charlotte square with St. Georges Church already mentioned; it is first crossed by Castle street, next by Frederick street and where this intersects Georges street stands the statue of William Pitt, the third cross street is Hannover street and at its point of intersection the statue of George IV and where Hannover street debouches into Princes street it is fronted by the Royal Institution. 


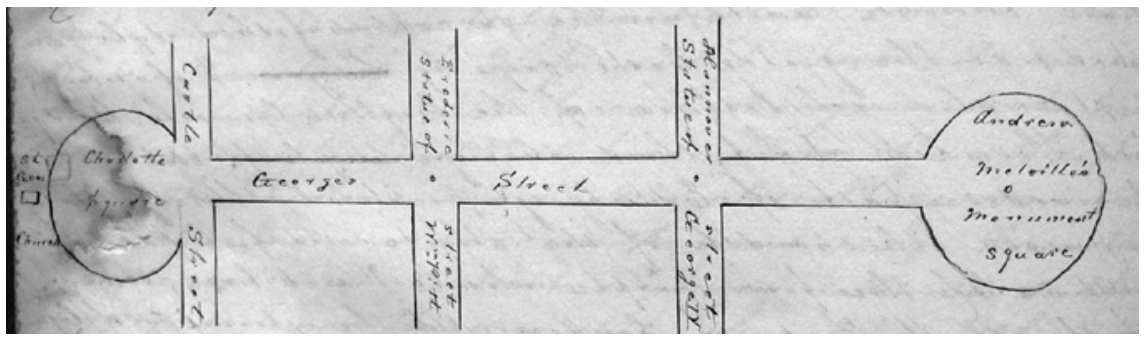

Following Georges street to the east I passed to my right the Assembly house and further on, on the same side the Physician Hall and opposite, St. Andrews church; the former being kept too far back, the latter brought too much forward, the observation has been made that the impudence of the Church and the modesty of the physicians have spoiled one of the finest streets in the Europe. At the Eastern end of Georges street we arrive at St. Andrews street and square with Melvilles monument, which consists of a handsome column 136 feet high and Melvilles statue 14 feet high on the top. The shaft is fluted in imitation of Trajans column in Rome. Taking the north side of St. Andrew's square I came to York place with another handsome episcopalian church, that of St. Paul's, and finally hurrying through Broughton, Catherine and Leith streets I came out in Princes street opposite the Register office a few steps from [270] my Hôtel. The remainder of the day I remained in the coffee room, passing the time as on the previous day. O'Connel's trial before the Special jury was to commence on the $25^{\text {th }}$ of January in Dublin.

Tuesday, $28^{\text {th }}$ of November 1843 . The economical guide had two other walks in store for the visitor of the capital, and I in my capacity of curious stranger followed the directions given. Accordingly on leaving my Hôtel, that of McQueen's in Prince's street I walked up this street eastward, passed to my left the Register office or Deposit of public records which faces the North and South bridge streets, a little further on, on my right the theatre, a very plain building and when entering Waterloo place the stamp and post office. Here Calton Hill, covered with monuments opens to the view. It is of insignificant height, and a wide commodious flight of stairs leads up to it. Across the street the eye rests on the heavy somewhat castellated jail with the Governors house behind it, to the eastward of the jail stands another prison, "Bridewell"; to the westward a burial ground, in one corner of which a tower, erected to the memory of David Hume the great historian. A second flight of stairs leads to the summit of the Hill, immediately to the left I was struck with an elegant monument in honour of Dugald Stewart Mathematician philosopher, political economist and professor in the university of Edinburgh, he died in 1828. A few steps on I came to the two observatories, the old one a misshapen building, the new one a handsome edifice; next, to the monument, a clumsy one as my 
original diary says, to the memory of Dr. Playfair who like Dugald Stewart was a mathematician philosopher and professor of the Edinburgh uni- [271] versity also geologist and secretary of the Royal society in Edinburgh, he died in 1819. The object of a high column with a winding staircase inside, which leads to the platform at the top surrounded by an Iron balustrade is to record to posterity Nelson's immortal deeds (as if ever they could be forgotten); I climbed up, more or less the same as that from Salisbury crags, and though the weather was rather hazy, the prospect which I enjoyed here, rewarded me for the trouble I had taken. Close to this column stand 12 columns, part of the national monument not concluded for want of funds, it was to have commemorated the heroes fallen at Waterloo. The steel engravings in my possession give a good idea of some of the most interesting edifices and monuments of Edinburgh. I may here refer to the view from Calton Hill, to Calton Hill itself, to the high school at its foot with its handsome façade, to Prince's street and to Burn's elegant monument. A few steps from the national monument Dr. Forrest had opened a Gallery of Sculpture to which the admission cost 1s. I was much pleased with the statues, nearly all colossal, here exhibited, and thought that its a pity that such a good sculptor as I considered Mr. Forrest to be threw away his talent and labour upon a stone of a pale yellow colour found in Scotland, instead of using marble. Close by another exhibition cost me another shilling, it was the observatory which was well worth seeing, two panoramas were shown the one a moving one, Edinburgh and its environs, the other of the Thames tunnel, both were excellent paintings true to nature. Also a Camara obscura which owing to the thick weather did not work well, finally a microscope, which I was told [272] on some occasions magnified 12,000 (should that be a mistake?) sometimes 4000 times. The dust from the wings of a butterfly, a human hair, a bit of human skin, a fly's leg, a bee's sting and other minute objects were placed under it, augmented to stupendous size. Interesting as all this was I was still more pleased with an orrery, the first I had seen in my life. A girl, to judge by her dress rather of the lower class explained to me the motions of the planets in such a clear and intelligent manner as really to surprise me. I felt ashamed at my ignorance as I am sure many other gentlemen would have done. I was told that on a clear night some telescopes kept there were at my disposal for surveying the heavens without any extra charge. I descended the two flights of stairs and thence down a footpath to a lower part of the town; a little further to the east I came to Holyrood house, in former times the abode of Scotch royalty. It is a quadrangular castellated building, a gravel court in the middle, round the four sides of which a piazza; sentries walked to and fro. On my entering, a little girl showed me to the ruins of the chapel, the floor was covered with many tombstones, devices and inscriptions 
cut into them, below mouldered the bones of many a great lord, many a knight, many a priest. A tower in one of the corners was pointed out to me as having some historical interest, on account of an event which had happened here to Queen Mary, but the particulars of which have escaped my memory. Close to the east wall I was shown the spot where Mary and Darnley stood when they were married. In the South East corner is a vault into which I looked down through a well locked railing, I distinguished human bones, which the guide book says are those of [273] Scotch monarchs, David II, James II, James V and Darnley are particularly enumerated. The girl who was my cicerone assured me that in Cromwells time the Republicans had broken into this vault for the sole purpose of robbing the coffins, which they sold in the town. In the narrow passage which leads from the chapel to the palace report says that Rizzio lies buried. The [_]rl now handed me over to an elderly woman, like her[_] a domestic of the Duke of Hamilton hereditary keeper of the palace. He, the Duchess, together with their son the Marquis of Douglas, and the Marchioness were shortly expected for the accouchement of the latter. The woman conducted me to what was once the ball room, now the picture gallery, 150 feet long 27 feet broad and 21 high, round the walls of which hung 106 pictures, representing as many Scotch Kings and Queens. It was in 1745 when the last ball was given here by Charles Edward the Pretender. In present times this room is only used when those scottish peers are elected who are to sit in the House of Lords of the United Kingdom. The suite of state apartments which Charles X of France and his family occupied in 1830-33 are in the same story, also the Hall of state where George IV held his levees in 1822, but neither the one nor the other presented at the time anything worth noticing, some are hung with Gobelins, others with scarlet paper; the furniture, merely put in to hide the naked appearance of the not carpeted rooms was of ordinary quality. A short winding stair case leads to the interesting apartments of Queen Mary. Here the bed of Charles I, the state chairs of Queen Mary and Darnley, also some needlework done by her were shown; further on her bed-room the same which she occupied, her bed with dark scarlet curtains, which remained in the same state as when she last slept in it; in this bedroom is a door [274] to the private staircase through which the murderers of David Rizzio entered on $9^{\text {th }}$ March 1566; he, the Countess of Argyle two other persons and the Queen were supping in a very small cabinet adjoining the bed room, when the conspirators appeared and dragged him out. In this small cabinet, Darnleys armour boot and glove are shown, another door leads from the bedroom to her dressing room, and outside the bedroom a dark-looking spot still exists where the corpse of Rizzio, transfixed her 56 wounds, is said to have laid the whole night; close [_] some dusky stains said to be of Rizzio's blood. An extremely pretty miniature portrait of Queen Mary is shown and I bought a seal purporting to 
have the impression of her signet which is still in my possession. After leaving Holyrood house I walked along the foot of Salisbury crags and had the pleasure of discovering the cottages which are immortalized by Sir Walter Scott in his Heart of Mid-Lothian as being the dwellings of Dumbre Dikes and David Deans. I retraced my steps to the palace and then leisurely ascended Canongate, here amongst others I noted Murrays house, no doubt once the property of the famous regent of this name, built in 1618 and easily to be recognised by its old fashioned balcony; and again on the right side, where the Netherbow expands into High street the miserable looking house of John Knox the reformer. Something in the shape of a pulpit was stuck against the wall of this house and again in this pulpit, a wooden statue, no doubt representing the renowned preacher. This worthy would, I fear, have turned round in his grave if he could have imagined that his effigy had recalled in a stranger's mind the idea of a statue no doubt, idolatrous in his sight. I refer to the small wooden bust's which here and there are affixed in Lima against the street corners, their hands clasped, their eyes [275] turned towards heaven and which go by the name of "animitas" or little souls, a small tin plate box is fastened on their chest, this has an aperture into which the devout are expected to drop their mite, that masses may be said for the eternal welfare of their departed friends. I rested for a short time in my Hôtel and then started afresh. I took a north easterly direction on the road to Leith, however on reaching Leopold place I turned off along Hill side Crescent and the Royal terrace; the streets are built here with great regularity and symmetry, like those in the new town whither I crossed over. I passed through Layfield square, Broughton place, Broughton street, until I reached Bellevue Crescent of which only that side where St. Mary's church stands was completed. I continued my walk till I came into the open country and returned through Huntley and Brandon streets making excursions right and left thus paying visits to the royal Circus place, to the garden in front of the miserable Custom House and to Queen street Gardens. After having dined in my Hôtel I went to the theatre where Bulwer's "Lady of Lyons", a trifle called state secrets and a pantomime founded on the well known Opera of Don Juan, were represented. In the first of these 3 pieces Miss Hellen Fawcitt as the "Lady of Lyons" was again the great and I may say only attraction. Claude Melnotte acted by Mr. Edward Glover did by no means come up to Miss Faucitt's exquisite performance. In the "State secrets" Mr. Murray the manager of the theatre acted a tipsy tailor to perfection. The pantomine was so senseless that I left soon after its commencement; with the playing of the orchestra [276] I was well pleased and was at home $113 / 4$.

Wednesday, $29^{\text {th }}$ of November 1843 . In the coffee room I had a conversation with a gentleman whoes face was well known to me but where and when I had seen him last I could not recollect for the life of me. On inquiry Ilearned from the 
waiter that his name was Hunter and that he had been in the East Indies, now it became clear to me that it was he whom I had seen in Lima in May last, and with whom I had deliberated on the proper route for Europe; I went round the Cape in the "Vicar of Bray", whilst he had sailed for Payta where he had availed himself of an opportunity for Panama and then across the Isthmus had taken the steamer in Chagres. Having fixed on the following day for my departure from Edinburgh I secured my seat for Selkirk in the Defiance coach and paid my last visit to my favourite haunt the old town. I descended many steps into Cow (here pronounced Co) gate, spanned over in one arch by the South bridge, then following this street eastward came to Holyrood house which I passed and ascended Arthur's seat. Here I remained but a few minutes, so violent and cold did the wind blow; I descended on the east side, came to pretty lanes, passed through a handsome park called Duddingston house belonging to Lord Abercorn, further on through a small village East Duddingston and to a long row of houses which goes by the name of Willington place, for the greater part manufactories of chemical preparations, with their smoking vents rising high into the air. By this time I had reached the shore of the Firth of forth, a long pier stretched into it, opposite a similar one was in course of construction, when finished the two would form a kind of dock for the miserable village of Fisher row. Walking [277] through its one long street I came to Musselburgh an old fashioned place, the Esk, a shallow river (the 3 bridges are built over it, one of wood, 2 of stone), divides it into two parts; on a sign board I saw painted the following to me unintelligible words: "Everything is bought which is taken in here". From Musselburgh I retraced my steps as far as Willington place and ere long found myself in Porto bello, a modern and better looking village than Musselburgh, the houses of sand stone; hence I continued my walk close to the shore, the high road running parallel with the rail road on which, not steam, but a fast trotting horse was the locomotive power. I entered Leith from the east side and as it is so often the case, also here the East end seemed to be the least fashionable part, here were narrow streets and high houses, whilst towards the west wide regular streets and houses built in the modern style were inhabited by the more aristocratic population, several bridges, one of them a draw bridge, cross the Leith waters, and the railroad, already mentioned, terminates at the quay, in the vicinity of which are the custom house, sheds, docks of no great size, slips on which vessels were building, and one with another signs of commercial activity. In the bay which was enlivened by many sails of small vessels, I descried an island, perhaps Grummond, with a Church steeple, another a very small one called Inchkeith with a lighthouse. From Leith I returned to Edinburgh along the high road called Leith Walk, lined on each side by a handsome row of fine houses. I reentered the town by 
Hoddington place, left Gayfield square to my right and then turning to my right walked in a straight line as far as Ainsli[e] place, all these streets are [278] built with great regularity and have really a stately appearance. I measured their width with my steps and found the foot pavement to be $31 / 2$ to 4 Yds wide exclusive of the area railed in before the houses where a few steps descend to the kitchen, the "causeway" about 22 Yards wide. I noted in Broughton street, visible from York place, the neat Gothic front of the Roman Catholic chapel, and in St. Andrews place in front of the Royal bank, a plain building, the statue of the Earl of Hopetown, standing alongside of his horse. The rest of the day I remained in my Hôtel; I observed in the streets of Edinburgh a much greater proportion of good looking females than in Glasgow, plaids were quite the fashion, both in the ladies gowns and shawls, mostly red and green checkered with an occasional admixture of other colours. In appendix under $\mathrm{N}^{\mathrm{o}} 7$ will be found my Hôtel bill.

Thursday, $30^{\text {th }}$ of November 1843. At 5 1/2 o'clock I was called by boots, at $61 / 2$ I sat well wrapped and muffled up on the box of the "Defiance" coach alongside the coachman; of course it was dark and the street gas lights were still burning. We passed over north bridge and were soon out of town. It was a cold sharp morning and willingly when about half way to Selkirk did I avail myself of the coachman's offer to take a seat inside where I found but one passenger an elderly decent looking lady, as much a stranger as myself in these parts of the country. The dark at the commencement of this day's journey, then the cold which made me feel uncomfortable, afterwards my riding inside and finally an occasional nap which I could not resist indulging in, all together prevented my paying so much attention as I was in the habit of doing to [279] the objects and country around, but what I noticed appeared to me void of interest and very different from the pretty country through which I had passed in September last from Penzance to London; here were no neat village, only some straggling houses at which we stopped to change horses. Afterwards Mr. Rodger confirmed the unfavourable opinion so hastily formed by me of these parts of the Scotch low lands; he told me that they were hilly and more adapted for pasturage than for tillage. About 7 or 8 miles from Edinburgh we passed beneath the Dalkeith railroad, which for a considerable length runs over a beautifully arched viaduct; further on we came to the river Gala which we passed over and entered the comparatively speaking modern town of Gallashiels, which was fast rising into importance owing to the manufactories of woollen shawls, tweeds and plaids. In population and size it had already surpassed Selkirk, the county town of Selkirkshire. We had to cross the Tweed and Ettrick, the latter an affluent of the former. On our arrival in Selkirk 38 miles from Edinburgh Mr. Rodger was already waiting for me and 
we immediately drove off in his gig to his farm Bridgelands 1 mile off. His wife received me in a most friendly manner, she gave me some breakfast and then permitted me to retire to my room, where till 4 o'clock I was occupied with reading and partly answering a number of letters, which had accumulated here for me; one of them was from my wife dated Lima $28^{\text {th }}$ of August. At 4 o'clock we dined, Peter a brother of George Rodger made the fourth of the party. We had tea, a good deal of conversation and when I was left by myself I continued writing correspondence till 1 o'clock. George Rodger, a Scotchman had many years previously been a [280] clerk in the house of Gibbs Crawley \& Co. in Valparaiso where he had risen to be junior partner; he soon tired of the West coast and preferred retiring with a small fortune to his native country where now in 1843 he was living on his own property which had been his father's. He was married to a second cousin of his, Margaret Robertson, a tall rather good looking lady about 26 years of age; he had two children, George 18 months, Agnes 4 months old. His farm he told me did not yield him more then $3 \%$ on the capital invested in it; he also made consignments of manufactured goods to the West coast in which of late he had been successful; when required, he visited Gibbs' manufacturing friends for which he received £10o p.a. besides travelling expenses and finally he purchased Guano from A. Gibbs \& Sons which he retailed in his neighbourhood. He assured me that he was well satisfied with his lot. I learned from him that the stocks of Guano in the hands of Gibbs \& Meyer's were inconsiderable, that the demand for the article was brisk and that the price varied from 10 to $12 £$ per ton according to quantity.

Friday, ${ }^{\text {st }}$ of December 1843. It was as late as 9 when I made my appearance at the breakfast table. This meal over Rodger told me that his one horse gig was at the door, we mounted he took the reins. The weather though not so raw and disagreeable as on the previous day, was cold enough to make me rejoice every time when we had to alight and to walk a little, so as to warm my stiffening limbs. The country hilly intersected by the Yarrow and the Ettrick would no doubt have been pretty if seen in a more favourable season, but now in December, though no snow had as yet fallen and the ground had still preserved a little verdure, the [281] leafless trees, sad and rigid marred every landscape. The Ettrick has I $\mathrm{m}\left[\_\right]$[say] a classical [...] on its banks lived the [_] known James Hoggad who under the name of the Ettrick shepherd contributed so largely to the delightful "noctes ambrosianæ" in Blackwood[_] magazine; this river after having received the waters of Yarrow puts in motion the mills of several newly established manufactories of woollen goods. We crossed the Ettrick, then the Yarrow and on the right bank of the latter river soon came to the Bowhill an estate belonging to the Duke of Buccleuch who possesses considerable property in this neighbourhood. His lands extend from the 
German Sea to the Atlantic Ocean, all across the Island, and in 1843 his annual

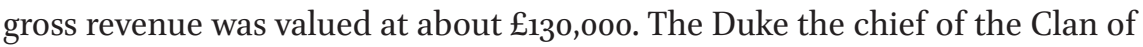
Scots (I do not know whether he is the same who bears the title in 1868) was an excellent man, much beloved by his tenantry, in politics a conservative and consequently conservatism prevailed amongst the people living thereabouts. The garden was prettily laid out and kept in good order, we drove through a stately avenue of tall beech trees, through which squirrels peeped out with their merry eyes, and alighted at the door of the mansion, a plain looking building, which the house keeper would not allow us to enter, because the Duke and the Duchess were expected within a few days. Behind the house was an artificial sheet of water and in the background a range of woody hills. We had a few words talk with a man who had under his charge some bee hives, he told us that a hive gives annually about $50 \mathrm{lbs}$, half wax, half honey, the honey comb was worth is $6 \mathrm{~d}$, the liquid honey which trickles out 1s. The [?] further on still within the precincts of Bowhill we [ca]me to the ruins of an old Castle called Newar[_] castle of which only the four bare [282] walls with small and large loopholes were still standing, the roof [...] in. We recrossed [_] Yarrow, to its left bank where Rodger showed me [_] house where the famous African traveller Mungo Park was born, his younger brother in 1843 a man more than 70 years of age lived not far off at a farm called Fowlshiels. We then drove into Selkirk to the post office to ask whether any letters had come for us. In the market place of this town stands a statue of Sir Walter Scott. On our return to Bridgelands we rested a little and soon started afresh for a walk over the farm; they were busy taking in turnips mostly used here for fattening sheep and horned cattle. Rodger showed me one turnip grown on a field manured by Guano, another from a field where the common manure had been used; astonishing was the difference in size the former being 4 or 5 times as large as the latter. Rodger and I entered the cottages of two of his labourers; not a little surprised was I at the cleanliness and neatness which prevailed in both, in the one only the wife, 6 months married, was in, she was repairing her fire place and even in this dirty occupation she looked clean, in the other 3 children were at home, bloomimg girls, the eldest 10 or 11 years of age taking care of her younger sisters, they read fluently and spelt correctly. Also Mrs. Rodger and her two babes, whom we met in the fields, looked extremely neat and tidy. After dinner conversation flagged a little, each of us took up a book when we were interrupted by a call to the kitchen, where 5 lads from one of the neighbouring factories had walked in, 4 of them wore a white cassock or shirt over their clothes and a paper bonnet on their head, the $5^{\text {th }}$ in his usual dress. They recited some verses in a singing tone of which I unders[_]d but little, one of them was Galoshin the greater warrior, an order on his breast; he and one of his 
companions quarrelled, [283] they drew their wooden swords, they fought, the latter was killed and fell to the grounds, then approached the $5^{\text {th }}$ the doctor, who had travelled from the bread to the cheese, from the poker to the tongs, he had seen geese walk with pattens, and after having narrated some further nonsense of this kind, he approached the dead man and brought him to life. Finally all shook hands, made friends and marched out after having received a few pence as a remuneration for their performance. Neither Mr. nor Mrs. Rodger could tell me the origin of this strange custom, it is only in the month of December and until Christmas that this liberty is taken by the young and permitted by the old folks. Before and after dinner Rodger was in the habit of saying grace, in the morning and in the evening he read prayers and a chapter from the bible, when the servants were present; whilst the bible was read they took their seats but during prayers they, as well as Mrs. Rodger knelt down and hid their faces on the chairs and sofa.

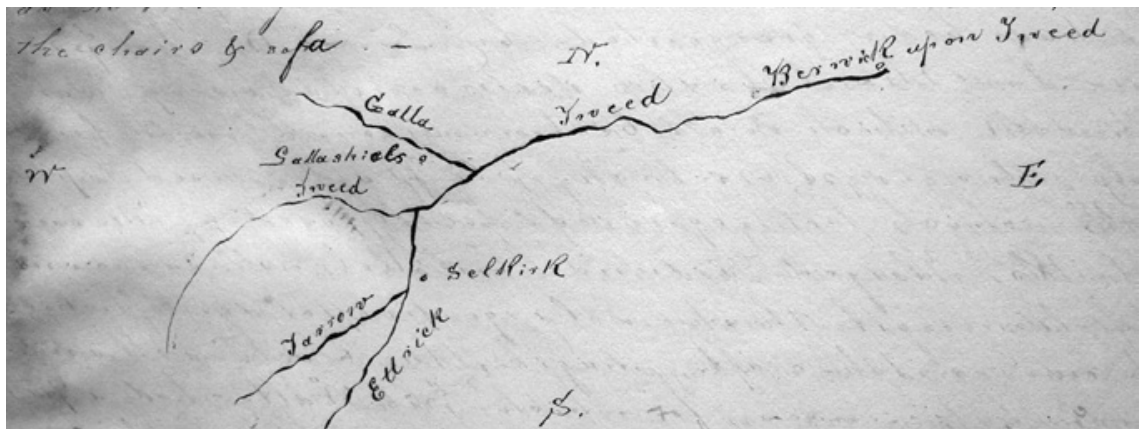

Saturday, $2^{\text {nd }}$ of December 1843 . Immediately after breakfast Rodger and I were again seated in the gig, this day our route lay over an undulating country on the right or south bank of the Ettrick as far as Abbotsford, the beautiful seat of the late Sir Walter Scott, owned in 1843 by his eldest son Walter, [284] Colonel in the East India service. The Tweed flows at the back of Abbotsford, 4 miles distant from Bridgelands, 3 from Selkirk. It is built in the gothic style; the steel engraving in my possession gives a faithful idea of it. We did not alight at the principal gate seen in the engraving, but drove round the left corner to a small side door, where an old woman said to be 90 years of age, the widow of Sir Walter's trusty forester Purdy, whose portrait hangs somewhere in the house took care of our horse, whilst an elderly decent woman apparently English showed us to the various apartments occupied in his lifetime by the, in my opinion, greatest of all novelists, only to his bedroom visitors were not admitted. In the drawing room was a set of ebony chairs and a large desk in which Sir Walter had kept a collection of curiosities; this furniture beautifully carved and made in Ceylon had been property of George III and had been 
presented by George IV to Sir Walter. In the library room stood a very convenient desk which could be turned round, with four slanting sides, upon which Sir Walter used to place the books which he required for reference. The number of books ranged around on shelves was considerable, amongst them a large proportion which treated on witch-craft, magic, the black art and other occult sciences, for which Sir Walter had particular predilection; our guide said that these were books in all languages, to which assertion however I do not give implicit belief. The windows of this room were handsomely painted with the arms of the different branches of the clan Scott to which Sir Walter belonged. In all these coats of arms I noted two stars and one crescent [285] or two crescents and one star. In the study we saw his writing desk shut up, but when opened, we were told it occupied much space, so that a great many books and papers could be placed upon it, sitting at this desk the wonderful man wrote the greater part of his works; before it stood a very convenient leather arm chair with springs in the seat, which the guide said had been much used by him, however another armchair, also in the study had its red velvet seat completely worn through so that it would appear that this had been his favourite; nor should I wonder at it for its back was made out of the only beam which has been preserved from the house in which William Wallace was made prisoner by the English and it is well known what a true scotch patriot Sir Walter was. In a glass case were preserved his hat and usual suit of clothes; of the great many curiosities of which he was such an indefatigable collector. I will enumerate only a few, such as two tremendous keys of the old tollbooth (prison) in Edinburgh, Rob Roy's long gun and pouch, Andreas Hofer's rifle, a pistol of Claverhouse's, two pistols of Napoleon's, Tippo Saibs slippers, a Malay crease, a dreadful dagger in this shape two french standards brought home battle field of Waterloo, French number of South sea Island weapons, which must inflict a fearful gash, by Sir Walter himself from the cuirasses from the same field, a a genuine Scotch clay more, highland shields and one Persian shield. From this study a stair case leads up to the bedroom, so that Sir Walter at any hour of the night or early in the morning could go down to his work unobserved by anyone. Many an hour given to sleep by the rest of mankind, he was in the habit of devoting to his literary labours, nor could [286] he have otherwise written so much as he has done, for he was greatly addicted to field sports, also fond of seeing his friends with him whom he entertained with great hospitality; and even now and then he did the duties of a forester, for not a few trees in the grounds around the mansion were planted by his own hands, and these various, not literary occupations, must necessarily have taken up much of his time. We remounted our gig and drove to the small place of Melrose not far off where we left the gig 
and walked to the ruins of the abbey of the same name close by. The abbey was founded in the year 1135, its present ruinous state must be attributed not only to the lapse of time but also to the hands of man, for little was held sacred by the republicans in the time of the Commonwealth. A boy whose strong Scotch accent was hardly intelligible to me showed us round and called our attention to the handsome carved work of some of the stone pillars and arches, also to some stones along the walls hollowed out, in which in all probability the Holy water used to be kept. The ground was covered with tombstones under which lay the mortal remains of many Scotch Lords and Ladies, some members of the family of the Pringles still known in the neighbourhood are interred here. On the spot where the high altar stood, the heart of Robert Bruce is said to be buried, likewise the body of the famous Douglas who fell in the battle of Otterburne. In a large hall a row of niches are hollowed out in the wall; no doubt each monk had here his separate seat, whilst one above this row seems to have been occupied by the superior of the convent. Some of the old arches are built up with comparatively modern masonry which spoils the antique look of the whole, a churchyard sur- [287] rounds this ruins. Rodger and I tried hard to find out a spot whence the view of the building is taken as drawn on my steel engraving, but in vain, there are, to be sure, two wings, but to us it appeared impossible that they can be seen at the same time with the main building as it is there represented. From Melrose abbey a four mile's walk on the high road brought us opposite to a park on the other the north side of the river belonging to the Earl of Buchan just where the Tweed turning suddenly, first to the south and then again to the north forms a peninsula. Within this park, in front to where we descended to the waters edge is a hill with a statue of William Wallace on the summit. In the lifetime of the present Earl's father a suspension bridge facilitated the communication between the two banks; now there was none and so we had to be rowed over. On application to the gardener a girl accompanied us to open the gates of the park and showed us the ruins of Dryburgh abbey; the park was kept in excellent order, the gravel walks swept clean and neat, the lawns shorn close and even, the tall stately trees grew high, their bo[_] spread far and in the midst of them stood the ruins of the abbey. Only part of the eastern wall of the nave remained, close before it must have stood the high altar of which there was no vestige left, thence a row of firs intermingled with the stumps of a few pillars 2 or 3 feet high runs westward, a green sward covered the ground, these few pillars I consider to have divided the nave from the aisle, on the north or left side of which a few arches were still entire, my steel engraving gives a good idea of them. In this aisle are interred Sir Walter Scott, his wife a french lady, and his grandmother; no monument is raised here to his memory; [288] a mound of earth covers the mortal remains 
of this great and good man, an iron railing encloses the grave. The steel engraving shows a monument with an urn on the top, this was not there at the time of my visit. The south or right aisle was in a much better state of preservation, some members of the Haliburton family, related to Sir Walter, lie buried here. In one corner, where the roof was not fallen in the Earl of Buchan had erected a statue of Sir Isaac Newton; on this side of the abbey were the refectory and the kitchen, where the chimney had stood was clearly visible. A staircase partly crumbled to pieces led up to the dormitory, the wall of which with its windows was still in existence, whilst the floor was gone. This my visit to Dryburgh Abbey though less famed than that of Melrose afforded me great pleasure. Rodger and I returned the same way we had come, had a glimpse of some huntsmen who were out with the Duke of [Buccleuch]'s hounds, met a few small Highland cattle returning from Melrose where it had been market day, remounted our gig and arrived at Bridgelands in the dark; we had our dinner and a quiet evening.

Sunday, $3^{\text {rd }}$ of December 1843. Sundays in Scotland are, as every body knows exclusively devoted to rest and devotion. After having taken an earlier breakfast than usual, Rodger and I went to church in Selkirk; both the exterior and interior of this building were plain and unadorned. The minister Dr. Campbell, who had filled this place for 30 odd years and who by the by had an annual income of $£ 250$ preached. Once during service the Lord's prayer was cited, hymns and psalms were sung, unaccompanied by the solemn tones of the organ, for such an instrument there was not. Also in Selkirk some of the parishioners had seceded from the old established Presbyterian church [289] and gone over to the so called Free church. I returned by myself to Bridgelands, for Rodger waited for his wife with whom he again repaired to church at 1 o'clock. The whole day long I occupied myself with reading and writing. At 9 p.m. Mrs. Rodger read to her husband, to myself, to two female and one male servants, a very good sermon, which treated on a subject, which though a trite truth cannot too often be brought before us. "Every moment we may be stricken by death, therefore we ought always to be prepared to die". After a sermon Mr. Rodger read a chapter from the bible.

Monday, $4^{\text {th }}$ of December 1843. Accompanied by Rodger I walked over the farm, where as already said above, it was the time for taking in turnips, this vegetable grows only a little below the surface, and can thus be easily gathered; three women were occupied with it, they cut off the thin root which penetrates a little deeper, as well as the leaves (called here the straw) also eaten by the cattle, then men came to load them on a cart and took them to the farm where they were spread on the ground merely covered with straw and kept for the winter. These women as well as some girls who were picking stones, Rodger 
paid at the rate of a penny per hour. The low land plaid is an indispensable part of the clothing of a low land farmer and countryman, it consists of a woollen scarf white and blue checkered 3 Yds long $11 / 2$ broad with a pouch at one end and is thrown over the left shoulder, originally it was only worn by shepherds; in the right hand the farmer carries his stick. Rodger told me that Sir Walter Scott's statue in St. George's square, Glasgow, has the plaid thrown over the right shoulder, in opposition to the costume of the country. To dinner came in their gig Mr. and Mrs. Robertson, Mrs. Rodger's father and mother from K[e] lso; Peter Rodger the "pro- [290] curator fiscal" of Selkirk living close by on his farm of Bridgeheugh joined us. Mr. Robertson an elderly tall and thin but hale gentleman was agreeable in his conversation; but all when conversing with each other spoke in such a broad Scotch accent that I soon got tired of listening to them, and thus, much of what they said escaped me. I learned from Mr. Peter that in England in criminal cases a Grand Jury consisting of 23 members is empanelled which decides by mere majority whether a true bill is to be found against the accused or not, in Ireland it is the same, as it was lately the case on occasion of the State trial of Daniel O'Connell and his accomplices; in Scotland it is the Sheriff and not the grand jury who decides the point. In England and Ireland the petty jury, consisting of 12 jurors must be unanimous in their sentence of the guilt or the innocence of the accused, whilst in Scotland there are 15 jurors to the petty jury and the majority decides.

Tuesday, $5^{\text {th }}$ of December 1843. In the forenoon I accompanied Messrs. Robertson and Rodger on their walk over the farm, during which the former, an old experienced farmer, gave much salutary advice to the latter, as yet a neophyte in agricultural pursuits. At a later hour the visitors left and I spent with the Rodgers a quiet day. I have already had occasion to mention that there were two female servants; to look at them was a real pleasure, so clean and neat were they in their appearance, their dress consisted of a print gown, an apron and a cap, from under which their hair fell down in pretty ringlets. They worked hard, nevertheless their wages were small $£_{5}$ in summer and 2 Guineas in winter, out of which they had to pay for their clothes. In the morning they had their porridge made of oatmeal boiled in water with a little [291] salt, much like the german [?] Grütze. Their dinner at 12 1/2 o'clock was not only earlier but also inferior in quality to that of their masters. In the evening they had their tea; on Monday morning their mistress gave them their allowance of sugar and bread for the whole week, "Bannocks", a bread made of pease and second rate wheat flour, they had at discretion. I myself liked porridge and with milk ate it always at breakfast, at which meal we had besides, honey, ham, tea, eggs, toast and bread and butter. Rodger at Bridgelands and his agents in Leith and Berwick were at that time selling Guano to the agriculturists at £11.5.o per 
ton, which price in the latter case, after deducting expenses and commission left him but a small profit of 3 s; he bought from Gibbs at $£ 10$ with 14 days credit. An English acre is equal to 4840 square Yards, a Scotch about $1 / 5$ less. The farms in the neighbourhood of Selkirk are measured by English acres and the annual rent per acre varied from $£_{1}$ to 3,30 to 40 s was about the average. If a farm was sold, the price paid was generally 27 years' purchase; that is to say if the acre was let at $£_{2}$ it was sold at $£_{54}$.

Wednesday, $6^{\text {th }}$ of December 1843. This day I had fixed upon for my departure, we therefore breakfasted earlier than usual and at a little past nine Rodger drove me in his gig or rather car, for it had fair seats, two before and two behind to Gallashiels 6 miles off. We passed the Ettrick then the Tweed before their junction, and being thus on the north side of the latter river had a pretty view of Abbertsford seen from behind. It was a cold morning and at our arrival at Gallashiels the weather was so unfavorable, that when about 10 o'clock the coach arrived from Edinburgh on its way to New [292] Castle, I could not make up my mind to take a seat outside, the inside was full. Rodger wrote a few lines to the coach proprietor in Edinburgh, requesting him to reserve an inside seat on the next day, which done we drove back to Bridgelands.

Thursday, $7^{\text {th }}$ of December 1843. At the proper hour Rodger and I were again in Gallashields, I bade good by to my good friend and kind host and took my inside seat, which the coach proprietor had kept for me in conformity with Rodger's note of yesterday. There were besides myself a Scotch elderly lady who left at Melrose and two Englishmen, probably travellers for manufactories, the younger with an ugly swollen face told us he was from Leeds, with the other, a man about my age I had much conversation, about Napoleon and Wellington, Tories and Whigs, Miss Ellen Faucit and Miss O'Neall and on many other topics. For some time we remained on the north side of the Tweed, we crossed recrossed and again crossed it, passed through Melrose, St. Bosswell and [Jed] burgh, this latter an ancient town, frequently mentioned in the border wars; we observed its vicinity the beautiful ruins of its abbey, also a somewhat fortified building, probably the jail. As far as here the country had been hilly and well cultivated, though lacking the smiling farms and pretty villages which are to be found on the other side of the border. On both sides of the frontier we drove over an uneven moory country, covered with grazing sheep, a toll-gate called the Carter Car is the point of demarcation between Scotland and England. A thick fog concealed all objects around us, everything looked gloomy, the road was heavy and muddy and slowly did we move on. At 20 minutes past 3 we stopped at a village, 12 miles from the border called Horsely, where for dinner 20 minutes were allowed [293] us, and these we three inside passengers made good use of in discussing a good pea soup, a fine leg of mutton and an apple pie. 
A little further on the guard pointed out to us a tower, which he said was that of Otterburne, a hamlet in the valley of Reedsdale, famous in Scotch history for the defeat there inflicted upon the English; Sir Walter Scott in a note to the $10^{\text {th }}$ verse of the $2^{\text {nd }}$ canto of his "Lay of the last minstrel" says: "The famous and desperate battle of Otterburne was fought the $15^{\text {th }}$ of August 1388 betwixt Henry Percy called Hotspur, and James, Earl of Douglas. Both these renowned champions were at the head of a chosen body of troops and they were rivals in military fame, the issue of the conflict is well known; Percy was made prisoner and the Scots won the day, dearly purchased by the death of their gallant general, the Earl of Douglas, who was slain in the action." He was buried at Melrose, beneath the high altar. "His obsequye was done reverently and on his bodye layde a tombe of stone, and his launer hangying over him". Froissart Vol. II Page 165. It is hardly necessary to add that Sir Henry Percy (Hotspur) was the son of the Earl of Northumberland; and not only he but also his brother Ralph fell in this battle, into the hands of the Scotch. Soon after it became dark our conversation flagged and all three fell asleep thus though the moon rose and it was a clear night I saw but little of the road. On both sides grew rows of trees; we drove through several villages, left to our right some extensive barracks and at about 8 o'clock stopped at the Twif Hôtel in Collingwood Street, Newastle upon Tyne. By a strange coincidence the number of the room I occupied was 22 the same number of the room which I had had in Glasgow and [294] Edinburgh Hôtels. I strolled through the town and by chance came to the apparently modern part, where the streets were straight and wide, the houses large and regularly built. Inside of them I heard the piano played, I saw family parties return home and these incidents, trifling as they were, brought back to my memory my Lima home and family, I thought of Enriqueta, how sweetly she used to sing and play, of my wife, with whom after having paid a visit or having been at the theatre I used to return to our house, where a good cup of tea was awaiting us in our snug "salita". Am I not a fool said I to myself to have abandoned those quiet comforts and enjoyments, and to be now running after new faces and new scenes? A line recently read occurred to me: "a man alone in a desert feels less solitary and forlorn than when left by himself in a large town where nobody knows nor cares for him", and I thought the writer was right. By and by more cheerful ideas came to my aid, I pictured to myself the pleasure which I would experience when revisiting my native place and shaking hands with my old friends after such a long absence; at a later hour, when in bed, Warren's Diary of a late physician in hand, his harassing stories engrossed all my thoughts and attention and finally sleep made me forget the past, the present and the future actual and imaginary sorrows and pleasures, reality and fiction. 
Friday, $8^{\text {th }}$ of December 1843. Newcastle on Tyne is a queerly built town. In no shop could I obtain a pocket map of the same and I therefore walked about without a certain plan, allowing chance to guide my steps. In the old part of the town, near the river the streets are narrow, running up and down hill and in many instances flights of steps lead from one to the other, there are lanes in [295] nothing superior to the Edinburgh closes, the houses are built in the old fashioned style, and often one story protrudes over the other. I crossed the bridge to the South bank, here everything had a suburban appearance. In all directions did I see wind mills turning their sails, vents or high chimneys emitting volumes of smoke. I turned back, when on the bridge looking down the river innumerable small vessels lay before me, the hum of busy human kind reached my ears, however active and bustling as the scene was it bore no comparison with what I had seen in London, Liverpool and Glasgow. Turning my eyes northward, I saw on the summit of a hill a handsome large building which was the court house, close by the old castle, miserable narrow lanes lead up to it and under a low arch-way which formed the entrance old clothes were offered for sale. The close, a long street by the river's side like the Upper and Lower Thames streets in London seemed to me of some importance, many narrow lanes lead down to it, these were filled with shoemakers' shops and their ware. Of the modern part of the town I had already formed a correct idea on the previous evening, now in daylight I observed that many houses were to be let, others stood unfinished, others were in progress of building. Not far from the bridge is the Exchange, which I was told contains a beautiful readingroom; round it runs a "piazza" in which fish was sold. Where Collingwood and Mosley streets meet stands a handsome church, that of St. Nicholas. The market is a splendid building and for the purpose which it is intended for, perhaps one of the most adequate in Europe; it measures in length 190 of my steps or about $130 \mathrm{Yds}$, in width 140 steps or $93 \mathrm{Yds}$, it is well ventilated and consists of 5 rows of stalls and shops with wide [296] entrances at each end, a skylight covers the whole roof and large windows run lengthways; not only meat, poultry, vegetables, fruit and other provisions, except fish, which I did not observe, but also books and toys were offered here for sale. The county jail is a large walled in building; on an open spot, where various streets meet, not far from Eldon square, a high pillar is erected with a statue of Earl Grey on the top. From Newcastle eastward a railroad ran to Shields, on the South side the railroad to York was about being made, however only finished from York to Darlington. At 2 o'clock I left Newcastle by coach, in which I had taken an inside seat. An elderly woman well acquainted with the neighbourhood was my only companion, we passed the bridge, drove through the suburb on the south side and when in the open country I was well pleased with its 
appearance, it is hilly, partly woody and generally well cultivated, there were high chimneys, machinery close to the coal pits and red tiled houses. I found here some resemblance with Cornwall, there are tin and lead mines, here coalpits. We drove along the extensive park of the Earl of Durham, further on, on the same, the left side, we had a fine antique looking castle, called Loomley Castle, belonging to the Earl of Scarborough, in it, my companion informed me, William the Conqueror had resided for some time. We passed through the small town of Chesterbroach and in the ancient episcopal town of Durham stopped only the few minutes required for changing horses. The streets are narrow, the houses high; I had a glimpse of the fine massive abbey of the same name, also of the surrounding country, which it is said is very pretty, and the little I saw of it, certainly was. It soon grew dark and at 6 o'clock the coach stopped at Darlington, 34 miles from Newcastle. After a few moments detention in a handsome [297] coffee room I steamed on by train, first class, the weather was too cold for travelling second. Ten miles from Darlington lies York; an omnibus conveyed me from the terminus of this latter place to the "Black Swan" a comfortable Hôtel. I took tea and passed the evening reading the "Standard" newspaper; the "Times" is however the paper which is generally found in public houses all over the United Kingdom.

Saturday, $9^{\text {th }}$ of December 1843. I had the good luck to find at the booksellers not far from the Hôtel the guide for the city of York together with the map of the place, which saved me a great deal of time, always lost, when one strolls about at a random in a strange place. The Minster is the object of greatest interest in York, on my way thither through the narrow streets I was struck with the tranquillity which reigned here, hitherto I had visited Capitals, commercial and manufacturing towns, now I found myself in the sedate and quiet residence of one of the highest dignitaries of the Anglican church. The gate of the Minster stood open, I entered, and as prayers were about being said, I joined the very scanty congregation which was assembled in the choir, consisting of a few ladies and gentlemen. The clergymen in their white surplices and several boys attending in their white robes had a very Roman Catholic like appearance. The usual episcopalian service without the lithurgy was read, in a to me disagreeable routine manner and tone; no sermon was preached. It was now 11 o'clock and a verger offered his services to me to show me round. The guide book gives of course a detailed description, however a few words about this beautiful wonderful edifice, will I think not be out of place. The central tower is of an extraordinary height, its columns measuring, if I mistake not, 200 feet, when standing under [298] it I could not but admire its elegance and loftiness. To the eastward of this tower, is the stone screen, the western face of which is, as the guide books says, "covered with a super-abundance of niches, canopies, 
brackets, pinnacles, crockets, statues etc." In its centre is the arched doorway which leads to the choir and on each side of this doorway, outside, are niches in which stand the statues of 15 English Kings, from William the Conqueror to Henry VI, seven to the north, 8 to the south. Above the screen the large organ. The choir was destroyed by the fire, which on the $1^{\text {st }}$ of February 1829 was lighted by the madman Jonathan Martin; thus everything here was new, such as the beautiful wooden carving, the ceiling, the stalls, the throne opposite etc. The altar stands, as it is always the case, at the east end of the Church, behind it, the altar screen, close to it I observed an extremely old arm-chair, in which several of the Saxon Kings are said to have been crowned. Behind the altar screen follows the so called Lady's chapel. In the upper part of the eastwall is a famed stained window, of which the guide book, quoting the words of a certain Drake, says, "that it may justly be called the wonder of the world, both for masonry and glazing". My conductor told me that this church with the exception of St. Peters in Rome was of greater length from East to West then any other in Europe, my guide book gives it 524 feet, whilst it states that Winchester Cathedral measures 554 feet, consequently my informant was wrong. The great central tower already spoken of, stands where the nave is crossed by the transept which runs of course from north to south. At both extremeties of the transept are beautifully painted windows, from its northern end a hall or vestibule leads to the Chapter house which I much admired. I was glad to see that in the opinion which I had formed of the beauty of its architecture I was borne out by Dr. Whittaker, who pronounces the [299] Chapterhouse to be "the most perfect specimen now remaining of the early florid gothic style of architecture, introduced in the reign of Henry III". Seven fine arched windows occupy as many of its sides; the eighth side is of solid masonry, below, the entrance gate, above, the wall covered with tracery corresponding with the patterns of the windows. The inside circumference is taken up by canopied stalls for the Canons who constitute the Chapter. The dignitaries of the York Archiepiscopal seat meet in this Chapterhouse if anything of importance is to be transacted, all their documents are dated hence, though for convenience sake, after first having assembled here, they remove to the vestry; here also each new dignitary takes his oath when sworn in. At the time of this my visit to the Minster the whole western part was separated from the rest by temporary brick walls, behind which labourers were at work repairing the injuries done to the church by a fire which broke out on the $20^{\text {th }}$ of May 1840 and which owed its origin to a casualty; the floor was likewise still undergoing repairs, having been broken to pieces by the ceiling falling in on occasion of the conflagration of 1829. Under a part of the Cathedral is the Crypt, a low arched vault, eight steps lead down to its first level, four more further down to its centre, my guide book 
says that these vaults are supposed to be remnants of the Original church, built partly in 642 by King Edwin, partly by Archbishop Thorne in 1067, and upon which in later times the present Minster was erected; of it the most ancient part is the South Transept, the foundation stone of the same being laid in 1227 . The material almost exclusively employed in its construction is stone, only the greater part of the carving of the ceiling and the interior of the choir are of wood. The deanery garden whither [30o] I went next was very insignificant, a few grass plots with gravel walks between them. The Minster library is of little importance, consisting of about 8000 Volumes, the greater part on theological subjects; they are ranged on shelves in a rather small room, to which on four days of the week, this being one of them, the public was admitted. The greater part of the town is surrounded by a rampart very low and narrow, paved with flagstones and then in an excellent state of preservation; it has its bulwarks, embrasures and 5 gates, here called bars which go by the names of Bootham Bar, Goodramgate Bar, Postern Gate, Walmgate Bar and Micklegate; the woodcuts in my guide book give a faithful idea of them; outside the rampart runs the Foss navigation. The castle is situated in the South corner of the town, a ticket was required to obtain admittance to it, but this I had not the means of procuring. The whole area is enclosed by a lofty stone wall, "within are four radiating double prisons with eight airing courts and the Governor's house in the centre", also the County courts and the ruin called Clifford's Tower. The river Ouse an affluent of the Humber divides the town into two parts, joined by a bridge, close up to which a few vessels were at anchor. Parliament streets and Samson square were filled with stout men, whom by their looks I supposed to belong to the well known genus of Yorkshire farmers, the foot pavements were occupied by their female relatives. At 2 o'clock all were gone, probably this was market day and they had come to town to make their purchases. All kinds of things, not only provisions, such as meat, poultry, venison, particularly large quantities of hares and rabbits, fruit, vegetables, but also shoes, manufactured goods, tinware etc. were exposed for sale. At 2 o'clock I returned to my Hotel, drove in an omnibus to the railway station and steamed off. [301] It was a gloomy foggy day. The road over a level country offers nothing of interest and about 5 I found myself in Scarborough Hôtel in Leeds 34 miles from York. A large coffee room was crowded with travellers who gradually left by different trains, I started by myself, went into the street, but so dismal was the weather, so poorly were the streets lighted up, that I quickly returned. I then took my tea, read the papers and retired to rest at an early hour.

Sunday, $10^{\text {th }}$ of December 1843 . Boots called me at six, I was up in a moment; on the previous night I had packed up my trunks which I left at the Hôtel and only took with me my comb, my tooth brush, a few clean shirt collars and my 
big cloak. I walked through the dark foggy streets over which the still burning gas lamps threw a sickly light, before 7 I was at the coach office, I took an inside seat for Bingley and off we went. The mist was so dense that I could not see further then the width of road, occasionally I distinguished some trees, a solitary house or entire rows of houses, nothing clear, all shadowy. At Bradford 10 miles from Leeds the well known thriving dirty manufactoring town we stopped to change horses, the guide and coachman went into a public house to take their breakfast, I remained in the coach and took out my inseparable companion the Diary of a late physician. The more I read of this book the greater was the interest which I took in its heart stirring stories, the more did I admire the author's vivid descriptions of misfortune, of guilt and misery. Six miles further on lies Bingley, here I alighted at the Kingshead inn, where at first I was shown to the taproom but on my asking for breakfast the travellers' room, very comfortable was got ready for me and a substantial breakfast consisting of tea, [302] hot muffins, buttered toast, and excellent fried ham, was placed on the table; the "Morning Herald" was handed me for perusal. The landlady a decent elderly woman told an errand boy to show me the way to Hardon Grange, the property of the Ferrands' with whom Miss Betty Wall, the intimate friend of my sisters lived as Governess. When out of town the road descends a trifle towards a small river the Broad Ayre, which further on falls into the Ouse, having crossed it, I followed the road which turning off from the river leads alongside the Park walls of Hardon Grange overtopped by fine tall trees. The iron gate of the park stood wide open, I walked in, passed the near Porter's lodge, the door of the mansion was open, nobody noticed me and some time elapsed before I could make myself heard. At last a servant came and on my enquiring for Miss Wall, his reply was, that she had been expecting me, he showed me to the dining room and after having waited for a few minutes my old friend entered - she seemed much affected - she looked at me for some moments, I at her and I hope that the impression which I made upon her may have been more favorable, than that she made upon me. She was near 50 years of age but looked older, she had lost some of her teeth, wore a cap and the hair which was visible was certainly not her own. She hurried me through the library and drawing-room, elegantly furnished and fitted up. I could merely glance at the statues, the beautiful carpets, the comfortable armchairs, on one of which a large white Greyhound was resting itself, the looking glasses, the piano, the tables covered with books and so many other trifles, which are never found wanting in the houses of the English gentry. Miss Wall's apartment upstairs looked very plain in comparison; here we had a long talk for very naturally we had much to say to each other. When she had concluded her narra- [303] tion it had become clear to me that she was not happy in her 
present situation. It is true that under her paternal roof she had not lived in affluence, but her family was respected in Altona where they led a quiet life. Miss Wall in her youth had enjoyed all the pleasures and diversions which her and my native place afforded to young folk, she had received an excellent education, by which, as nature had endowed her with a strong intellect, she had profited well, and thus in a small town like Altona, she had the reputation of being one of the cleverest young ladies of the place. Here in Hardon Grange she not only felt, but was made to feel, that she was an inferior, in wealth, rank and station to her employer Mrs. Ferrand, of whom she said that she was a pleasant lady; "but", added she with some bitterness, "rather than call me, the Governess, to the drawing room to keep her company during her long autumn evenings, when Mr. Ferrand is absent, she prefers passing them by herself, whilst I am also alone in my room, after little Sarah, called Lilla, whom I have under my charge has gone to bed". Miss Wall gave me the following rather intricate account of the family of the Ferrand's. Mrs. Ferrand, she who had engaged her as Governess, was the guardian in Chancery for her cousin Mr. Ferrand's two children, a boy and a girl, the latter, the little Sarah already mentioned. Mr. Ferrand's true name was not Ferrand, he had adopted it in accordance with the will of the previous owner of this estate, who had left it to the family who now bore the name of Ferrand on condition that they should change their original for this name. At the time of my visit Hardon Grange was owned by Mr. Ferrand's mother, who was represented to me as a bad and wicked woman, with whom the Ferrand's of Hardon Grange had no intercourse, but from whom Mrs. F. had nevertheless rented the estate [304] which she sublet to sundry tenants. Mr. Ferrand, about 32 years of age was 3 years younger than his cousin, he was a member of Parliament, in politics a Tory, a great defender of the agricultural interest and a great speechifier at county meetings. On a certain occasion, I do not recollect the exact date, when he made himself disagreeable in the House of Commons, Sir Robert Peel gave him a set down which made an extraordinary noise in the political world, and which I think will still be remembered by such as have not yet forgotten the parliamentry transactions of that period. Of her own family Miss Wall told me that in 1834 her father Daniel and her uncle Isaac had liquidated their business, had paid all their creditors but had remained what might be called penniless; both had died and to her mother, who then was living with her brother Fritz on a farm not far from Flensburg in Schleswig her father had left BM 3200, which would come to her on her mother's death. She had been Governess with many families, also for a short time with her relation in Altona Mr. Chal. Semper, after the death of his first wife, his character she did not admire, though she could not but do justice to his clear understanding and his extensive knowledge 
both theoretical and practical. Little Lilla came running now and then, a lively young girl; she laid down on the ground, stretching out her limbs, resting her head on a low pillow when I enquired for the reason of this strange posture, I was told, that the medical man of the house was of opinion that continual sedentary occupations might have an injurious influence upon the little girls frame and that therefore it would be advisable for her to take some of her lessons whilst lying on the ground. We were still conversing when a pencil note was brought up from Mrs. Ferrand to the effect that she would be most happy to see Miss Wall's friend at luncheon. Accordingly when [305] the bell rung we went below. Mr. and Mrs. Ferrand, we two and the 2 children sat down together, hot roast beef, vegetables, a little pudding, sherry and Porter stood on the table. I partook of these good things, and conversed freely quite at my ease. Mrs. Ferrand pleased me, she was rather good looking, particularly well shaped and nothing haughty. Mr. Ferrand appeared a good straight forward man, not over bright in conversation. Luncheon over Mrs. Ferrand wished me a pleasant passage and a favourable west wind, a hint, that I should not see her again. Miss Wall and I returned to her apartment; I should like to have seen something of the park and the neighbouring country, which looked pretty, as far as a momentary ray of the sun would allow me to judge of them. But the fog was so thick and heavy that any excursion was quite out of the question and I wondered that I could find my way to Bringley without losing myself. It was half past four when I bade good by to my dear friend. In the Hôtel I remained in my comfortable room, wrote, read and went to bed.

(After the departure of Mr. Barker on the $30^{\text {th }}$ Aug. 1868, these Extracts were continued on the $4^{\text {th }}$ Septr. 1868 , under my direction, by Mr. G. M. Graham.)

Monday, $11^{\text {th }}$ of December 1843. The hotel, or Inn, for its exterior was such as rather to deserve the second name, in which I had taken up my quarters for the short time of my stay in Bingley, was both comfortable and reasonable. The travellers' room I had to myself; the previous evening after taking tea I had a good bed, and this morning an excellent breakfast, and 4 besides 1 which I gave to the maid, were the total of my expenses. The usual charges in the hotels in which I had lodged in the course of this journey, were as follows:

For the bed-room in England

[306]

For the bed-room in Scotland

For breakfast in both countries

For Dinner in both countries

For Tea in both countries

To the servants in both countries
2S

2s 6

$2 \mathrm{~s}$

$3 \mathrm{~s}$

2S

Waiter 6d Maid 6d Porter $3 d=1 s$ 3d 
Total, per diem, without Wine, beer, or spirits: 10s 3d in England, and 10s 9d in Scotland. At 7 1/2 o'ck. the coach passed, and I took an inside seat for Bradford; the fog, which had so much annoyed me the previous day had cleared away, and I was enabled to distinguish something of the surrounding country. To the left of the road it gradually sloped down towards a valley, through which a river flowed; on the opposite side it gradually rose again, and all, intersected with [live] hedges, was covered with cultivation; even the present winter season some fields had not lost their verdure, and from under the now leafless trees houses looked forth here and there. In Bradford the coach stopped at the "Bowling Green" hotel, where I alighted and breakfasted. Carts, waggons, and coaches moved to and fro, and gave evident proofs of the great activity which pervades this manufacturing town. At 10 o'c. I started again in a coach for Halifax, no more than 8 miles distant from Bradford. Nowhere, in the course of this my journey through England had I come through a district more populous than this appeared to me: Coal-pits, Iron Mines, Quarries of Lime, and other stones came near the very sides of the road, lined by almost uninterrupted rows of Factories and houses. Halifax had the appearance of an old town. As soon as we had arrived at the "White Nart" Inn, I asked my way to "Pie Nest" - the well-known establishment of the great wool manufacturers J. Edwards \& Sons. It lies about 1 1/2 miles distant from Halifax, on the left side of the high-road to Manchester, and, leaving my cloak at the Inn, I walked out thither. I entered the dwelling house, whence a servant showed me [307] to the detached counting-house. Hardly had I here mentioned my name, when old Mr. F. W. Cronhelm - the head clerk - jumped up from his desk, and received me with a cordiality which left no doubt upon my mind that he was really glad to see me. The two young Messrs. Edwards - Henry and Joseph - were also very kind. Mr. Cronhelm was busy writing to "Intermedios" per "Highlander" and "Hebe", and I availed myself of this opportunity to let my wife hear from me. The two Messrs. Edwards took me to their garden, and made me admire their hot-houses, pine-apples, etc., they introduced me to their sister, a rather plain, but not disagreeable young lady, also to their father and mother, excellent old people, the former still ailing from the effects of an apoplectic attack. They and their daughter took their early dinner at 2 o'c., the two sons and I joined them, looking upon this meal as our Lunch. I then remained with the old people conversing with them in the most friendly manner until dark, when two horses were brought to the door - the one for Mr. Henry, the other for myself. I, never a good horseman, and accustomed in Peru to the convenient saddle, to the soft "Pellon", and the easy amble of mule or horse, had great difficulty to keep my seat on a slippery English saddle whilst the horse was trotting and cantering; nevertheless I managed not to fall off. We rode to Mr. Henry's dwelling, "Craven 
Lodge", distant from "Pie Nest" a mile, from Halifax 1/2 a mile. Here I had to take up my quarters for a few days, the whole family having insisted upon my staying with them, and orders being already given to the hotel in Leeds for the transmission of my luggage left there. The drawing-room into which I was ushered was furnished and fitted-up with taste and elegance; the lady of the house, who soon made her appearance, was young, rather good-looking, and very agreeable. Three children - Henrietta, Henry and Churchill, [308] respectively four, three, and two years of age also came in, and engrossed, as is always the case, much of their parents' and the visitor's attention. The lastborn was as yet kept in the back-ground. Mr. Joseph Edwards, Mr. Cronhelm, his son Edward - also employed in the Establishment - the host and hostess, and myself, sat down to dinner which was excellent. Of wine, we had Bucellos, Rock and Champagne, after dinner Sherry and port; before we rose Mr. Cronhelm gave proof that he had done ample justice to these good things. At the tea-table Mrs. Edwards presided, I sat near her, chatted with her, and found myself quite at home. When the visitors had left and Mrs. Edwards had retired, her husband and I withdrew to his private room, the only one in the house in which he allowed himself the pleasure of smoking; here we remained till midnight conversing on many topics, on politics, on business, the Lima mercantile Establishments, etc. He was at the time rather less than thirty; he wore spectacles, had a rather long nose, his whiskers reddish; he was fond of field-sports, of horses and dogs, and not a little proud of his Captaincy in the Huddersfield and Halifax Yeomanry Cavalry, raised about 7 months previously for the suppression of riots - not uncommon occurrence in the manufacturing Districts. In my bed-room I found a fire blazing, even a clean night-shirt laid on the bed; surely I felt delighted with the hospitality shown to me.

Tuesday, $12^{\text {th }}$ of December 1843 . I was called at $71 / 2$ o'c. and rose immediately. Looking out of my window I could distinguish but little, owing to a dense, almost impenetrable fog. In front of the house were a lawn and a few trees; further on in the same direction the ground sloped down towards a valley through which a small river - the Calder - wended its way. At 9 Mr. Henry, who had already been at work in "Pie Nest", his wife and I, sat down to a breakfast [309] quite in keeping with yesterday's dinner. With my hostess I had an animated conversation; she told me that she was a Londoner, that her maiden-name was Koster, that she had been educated in France, that she was fond of dancing, that before her marriage she had waltzed with every body, but that since her marriage she did so only with her husband and brother. After breakfast Mr. Henry and I rode to "Pie Nest" - no pleasure to me for a certainty. Whilst the horses were being saddled for Mr. Joseph and myself, for our visit to Messrs. Edwards' Mills I called upon the old couple in their dwelling-house; 
in the drawing-room I found the younger daughter Henrietta - about 17 years old - at her embroidery frame; upon my entering she left off her work and conversed with me until her parents and some visitors came in, when the conversation became general, and I, of course, was less attended to. The mills were about 4 miles distant; our road thither led through a pretty country well studded with houses and factories. To the left, or to the south, we had the valley of the Calder: a canal, first flowing parallel with this river then turns to the right, or northward, which we crossed by a bridge, this bridge being again spanned by a beautiful arch over which the Halifax and Leeds Railway passes. Further on we had on the same - the left side - another, called the Ripperton river; the valley gradually narrowed, the hills from both sides seeming to meet. The scenery must be beautiful in the summer-season, even now in winter it had its attractions. We passed a large village - Sowerby Bridge - rapidly rising in importance, owing to the manufactories which were daily springing up in its vicinity. A little further on, the mills were situated, and Mr. Joseph was good enough to shew me all over the premises. As far as I could judge, the different processes which the [310] raw wool has to go through before it turns out as a finished texture are similar to those which I had seen in the Cotton mills of Manchester. The raw wool after having been cleaned and teased, that is to say pulled asunder, so as to render it more loose and less compact than it is in its original state, is conveyed to the first spinning machine, whence it comes out in the shape of rolls or tubes about one yard long and of the thickness of my finger: in the next spinning machine these tubes are joined and twisted together, and re-appear as Woollen yarn. The yarn of which the warp is woven is stiffened with Size, which answers the same purpose as the flour or starch used in the Cotton Mills, here, the same as there, the weft is thrown into the warp, stretched out in the looms by means of shuttles, and the fineness or coarseness of the various fabrics - $\mathrm{Fa}[\mathrm{x}]$ uelas, Cien hilos, Dos Frizas, Bayeta de Pellon, Flannel or floth, depends upon three conditions: firstly the quality of the wool employed; secondly the fineness or coarseness of the yarn, and thirdly upon the greater or less rapidity with which the texture moves. This last expression requires explanation. The warp is rolled over a cylinder, and is pulled on gradually whilst the shuttle throws in the weft; a weight is fastened to the warp on the side opposite to that whither it is pulled, and naturally the heavier this weight is the slower the warp moves on, and the more blows the beam gives which knocks each thread of the weft against the preceding one, consequently the more frequent those blows are upon the same spot the closer the texture becomes, whilst on the other hand, when the weight is diminished, the warp moves on quicker, the less blows the beam gives upon the same spot and the more open is the texture. The Loom having done its work, the respective 
textures which it produces undergo [311] various finishing processes, the last of which one of the heads of the establishment superintends in person. The manner in which the wool is raised upon the Bayetas de Pellon is considered a secret, and even I was not admitted into their "Sanctum Sanctorum" where it was done. All descriptions of Bayetas and ordinary cloths are dyed in the piece, fine cloths in the yarn. Woollen yarn cannot be spun without the use of oil which prevents the minute particles from flying about and injuring the lungs of the workpeople, and it is for this reason that Woollen are more healthy than Cotton manufactories. In Messrs. Edwards' establishment the men looked upon the whole in good condition, also the women and children, of whom many had even rosy cheeks. Another mill lay still further on. Mr. Joseph and I walked thither, and the manufacturing seemed to be exactly like that at the other establishment. Messrs. Edwards make use of water-power, not of steam. Mr. Joseph and I re-mounted our horses, but mine - a mare - became so frisky, that I dismounted and did not venture to trust myself again on her back; the weather was fine, and with pleasure did I walk home. In "Pie Nest" I looked in upon old Mr. and Mrs. Edwards and their two daughters, and in Craven Lodge Mr. and Mrs. Henry and I dined by ourselves; the dinner was plain; however, as on the previous day I had said that I preferred Champagne to every other wine a bottle was again brought out. In politics Mr. Henry Edwards was a decided conservative; in his demeanour he had something aristocratic, not to say haughty; to me however he was invariably kind and obliging. His wife I liked better than I had ever done any other lady after so short an acquaintance; she herself nursed her children. After dinner Messrs. Cronhelm, father and son, came, with them I walked to the Halifax [312] chess club of which they were members; there were but few gentlemen the greater part having to attend at a free trade meeting in the Odd Fellows' Hall where Messrs. Cobden and Bright were expected to harangue. Mr. Edward Cronhelm and a certain Mr. Forbes - who was absent - were considered the best players of the Club. I gained two games from Mr. Cronhelm Sr. and four from another member. About this time Mr. Staunton, the English, and M. St. Amand the French Champion were playing a grand match in Paris for $£ 100$ - besides other considerable sums being staked upon the result. He who first gained 11 games was to be declared the victor. Mr. Cronhelm had received a letter from a friend of his in Paris - a Mr. Wilson, Mr. Stauton's second - stating that Mr. Stauton had won nine games, M. St. Amand three, and two drawn, and that notwithstanding his favourable appearance, he was by no means certain of the final issue. Mr. Staunton he added was strong in the attack, weaker in the defence; the writer confessed that he himself was nearly knocked up. The last game had occupied no less than 13 hours, including $1 / 2$ an hour for a miserable dinner. Two months later, 
when in Altona, I heard that Staunton had gained with great odds in his favour. On our way home we met the above mentioned Mr. Forbes, who told us that $£ 1400$ had been subscribed as the Halifax mite toward the $£ 100,000$ required by the anti-Corn Leaguers for the purpose of keeping up the necessary agitation. During my absence my portmanteau had arrived from Leeds. In bed I amused myself with Warren's "Ten thousand a year".

Wednesday, $13^{\text {th }}$ of December 1843 . When I rose the ground was covered with hoar frost. It was a cold morning, gradually however the temperature became milder. With Mr. Henry I walked to "Pie Nest", where, after having paid a short visit to the good old people Mr. Joseph accompanied me to various outhouses and other buildings - all forming [313] part of this large property - which I had not seen before. We went first to a house which Joseph and his lady were to occupy after their marriage which was to take place in a year's time. This had been previously inhabited by his eldest brother John, then, after John's death, by the second brother Charles, and this latter as well as his wife, having also died, it was now to fall to the share of the youngest, Joseph. I may just mention here, that John and Charles, long before their marriages had lived with me in Arequipa in the years 1830 and 1831, which I suppose I have already related in my diary of that period. The out-houses and grounds were filled with colts, dogs, Vicuñas, Alpacas, Pheasants and other animals, all well taken care of. We also visited the stores where the Wool, and others where the Baizes were deposited, the Establishments where the various Fabrics were milled, where the nap was cut off the cloth, and where other labours were in progress. Mr. Joseph and I next walked to town to call upon Mr. John Waterhouse, who, 2 or 3 years before had been in South America. He belonged to the highlyrespectable firm of Messrs. S. and J. Waterhouse, like Messrs. Edwards \& Sons, one of the oldest and most valued correspondents of Gibbs' establishments on the West Coast. He was not in, and I learned from Mr. Joseph, that being sometimes subject to epileptic fits, he had almost entirely withdrawn from business, and only attended to his duty as a magistrate, occasionally also to Scientific pursuits. His brother Samuel, married to a Miss Charlotte Edwards, was the active man of business, we met him and he invited me to dine with him on Saturday next. These two brothers, John and Samuel, were the sons of old Mr. John, whose entire left side had been recently paralized by a stroke of apoplexy. Their uncle Samuel was a dried-up old bachelor. The firm had given up the actual manufacturing of cloth, and even let their Factory, [314] having found it more profitable to purchase the cloth of the small makers and merely to give it the last finish. Mr. George Pollard of Halifax, who held some vaut in the Cavalry Yeomanry Corps, gave this evening the first Ball of the season to which he had invited all the Edwards, and Mr. Henry being very intimate with 
him, assured me that I might accompany them without a special invitation. Mr. Joseph lent me a suit of black clothes which fitted me pretty well. At 9 o'c. we drove to the party in Mr. Henry's commodious and capacious coach. Having deposited our cloaks we were shewn to ante-room where tea was handed us. In the adjoining Ball room Mr. Henry introduced me to Mr. and Mrs. Pollard, he an agreeable young man, she good and genteel-looking but rather thin. About $6 o$ persons were assembled, the greater part of course, young folk; dancing had already commenced, waltzes and quadrilles alternately, to the latter I did not venture to stand up, and had therefore no opportunity of dancing, either with Mrs. Henry or with the two Misses Edwards - for neither of them waltzed. For the waltzes Messrs. Edwards were so obliging as to find me partners one of them was Miss Julia Rawson, no doubt of the family of the Rawsons, the great Baize manufacturers and rivals of the Edwards. All, with the exception of one who couldn't keep time, knew how to waltz, and thus I think we twirled about to mutual satisfaction. Miss Norris, to whom Mr. Joseph was betrothed, was without doubt the prettiest girl in the room; he introduced me to her and I danced with her the waltz before supper, this consisted of ham and cold fowl, jellies, cakes, all kinds of Wine and Champagne "ad libitum". I did not lead Miss Norris to the table, but finding her standing alone in a corner, for there was not room for all the ladies to sit down, I held [315] her bouquet and plate, and tried to make myself agreeable, in which perhaps I was not altogether unsuccessful. When the ladies had retired the gentlemen sat down Mr. Pollard at the head of the table, I between Mr. Henry Edwards and Mr. Rawdon Briggs, an elderly pleasant man, an agriculturist, uncle of Christopher and Nelson Briggs of Lima. Our host, after his and his wife's health had been drank, delivered a speech interrupted by applauses and cheers, in which he expressed his hopes that his fellow-townsmen would shortly follow the example he had set them this evening. Dancing re-commenced; I waltzed again with Miss Norris and then stood up with her for a Spanish country dance, called here a Saraband but which, as few of the dancers understood the figures, soon changed into a waltz. I even made bold to ask her for a fourth dance; but this she refused. Beauties there were none, but many pretty faces. The ladies were generally dressed in white, some in lace, few in coloured dresses; jewellery I observed but little. Mrs. Henry Edwards wore a beautiful crimson-velvet dress with a broad trimming of rich Honiton lace. The gentlemen were in their usual black attire, with white kid gloves, many with white cravats and white waistcoats. The party broke up at 3 o'c.; only Mr. Henry, two other intimate friends and I remained for an hour or so with Mr. Pollard; the other gentlemen sipped their brandy and water, I contented myself with a glass of negus, with which beverage several bowls had been replenished in the course of the evening. The conversation turned 
exclusively on the Yeomanry Corps, and on some misunderstanding which had arisen between the Halifax and Huddersfield Divisions. Mrs. Henry had driven home in her own carriage at 2 o'c., her husband and I followed her [...] in a fly. Once home I immediately hastened to bed. I may add that I had been extremely well pleased; not only those with whom I was already acquainted; but [316] also other gentlemen entered into conversation with me in a very polite manner. With an elderly spectacled lady I had also a long talk, and was not a little surprised to meet here a Mr. Armitage with whom on the $24^{\text {th }}$ Octbr. I had dined at Mr. Southey's, London (see page 188, Vol. 2).

Thursday, $14^{\text {th }}$ of December 1843. After having breakfasted at the unusually late hour of 10, I walked to "Pie Nest" and made my customary call to Mr. and Mrs. Edwards, enquired for the health of the young ladies after last night's fatigue, and had a long conversation with the elder of the two, Miss Priestley Delia, who was very desirous to hear from me how I had been pleased with the entertainment at the Pollard's, and especially how I had liked the young ladies. An hour or two later I went with Mr. Joseph to Halifax, where we called upon Mr. John Waterhouse Jr., who had promised to accompany us to an Iron foundry in the neighbourhood. We found him - sickly-looking - and his father and mother - very old people - at their early dinner; they insisted upon our sitting down and taking something, which we did. A fly was called, and Mr. John Waterhouse, Joseph and I drove to the Low Moor Iron Foundry, one of the most considerable in the United Kingdom, and distant 4 miles, on the road to Bradford. As soon as the premises came in sight they presented a splendid, striking appearance; furnaces were blazing; liquid iron flowed along in streams; red-hot iron bars, like so many fiery tongues, were hurled about. We were in the Cyclopian regions. The first process consists in filling an enormous furnace with the exact proportions of iron ore, lime stone - without which no fluxion can be brought about, and coke. This mass is lighted, the heavier metal sinks to the bottom, whilst the lighter parts remain on top; then the furnace is tapped, which means that a hole is made into it, through which the dro[p] or refuse escapes first; this [317] when cold is sold on the spot for 2 a ton, and is used for making and repairing the roads; next another opening is made in the furnace somewhat lower down than the first one, through which the liquid iron runs along a gentle declivity into long moulds made of sand, which as soon as they are filled are covered up with the same substance, for otherwise the Iron exposed to the action of the air would immediately oxidize. This stream of metal in a fluid state looks beautiful, it is of a rosy hue, and emits thousands of sparks. The glow and heat which emanated from it were such as to prevent my near approach. When the iron becomes cold the moulds are broken, but the metal in this stage (called "Pig iron") is not yet maleable: to 
render it so it is refined two or three times in different furnaces, and placed, in a white-hot state, under immense hammers, which, falling upon the mass with their enormous weight, give to it the shape of cakes. (Its is very interesting to see how the furnaces are supplied with Coke, a small cart filled with this fuel by some ingenious contrivance moves up an inclined $\mathrm{p}$ [_] in, when it reaches the top it is emptied into the open mouth of the furnace, and the truck runs down again). When the pig-iron has been sufficiently refined or freed of the carbon it contained, and by these means has become maleable, the next process is to shape it into bars, and this is effected by placing the metal, red-hot, between rollers or cylinders: $1^{\text {st }}$ between a pair the widest apart, next between another pair less far apart, again between others still closer together, so that every time the iron is put in between the rollers and again pulled out it has become longer and thinner. These red-hot bars the operatives take hold of with large pincers, and [_] about with the greatest ease and "nonchalance". We [_] present when a large mould for a cannon was filled with molten iron; the cannon first turns out quite solid, [318] then it is bored or drilled by means of a gigantic steel auger of the required diameter, the cannon moving slowly lengthways, whilst the fixed borer revolves on its axis and scopes out the hole. A powerful steam-engine puts everything in motion; the bellows or rather large air pump which serves to fan the fire, the cannon in i[_] a slow progress just described, the revolving borer, the huge hammers, shears and knives, which latter instruments cut the iron like paper, and many other machines impossible for me to examine on so cursony a visit. The touch-hole is drilled by manual labour, the same is employed in cleaning the outer surface, and in paring off with chisels any extraneous matter still adhering to it. The cannon which we saw cast was a 64 pounder, and its weight from 3 to 4 tons. Cannons are sold by weight; in 1843 the price was $£ 12$ 10s a ton. It was as late as 5 o'c. when we had finished; we had now to walk fully a mile in the dark, over a muddy road, to a public house where the Fly had stopped; we got into it, passed another furnace where balls were being cast, put down Mr. Waterhouse at his abode in Halifax, and reached Craven Lodge by 7 o'c. Here Mr. and Mrs. Henry and a cousin of the former (Mrs. Priestley Salisbury) were by this time at their fruit, but Mrs. Henry notwithstanding my strenuous objection, had some broiled mutton prepared for Mr. Joseph and myself. At 7 o'c. we drove to a circus provisionally erected for the performance of an equestrian Co. In the dress-circle ours was the only box occupied, whilst the cheaper seats were pretty well filled. The horses were neither well trained nor managed the equestrian [...] thing particular, the jokes of the clowns, though [_] and stupid, elicited nevertheless some laughter, the only person who excited my admiration was one who 48 times consecutively threw somersaults, or "saltos mortal[_] [319] in the air, touching of course, every 
time he came down, with his feet, the spring-board from which he rebound'd and then went up again. The performance concluded with what the Bill called "Studies of Antiquity". Several men made their appearance dressed in fleshcoloured "Tricot" which gave them the appearance of complete nudity, with the exception of a piece of gaudily ornamented cloth wrapped round their loins; three horses were then let forth, one man stood on the back of each, two others upon the shoulders of these three men, and a sixth again on the shoulders of the two, so that his head formed the apex of this living pyramid. It was past 11 o'c. when we drove home, took tea, and retired to rest.

Friday, $15^{\text {th }}$ of December 1843. In the course of this forenoon I had some conversation with Mrs. Henry Edwards and her sister in law, Miss Delia, when I was much amused with the manner in which these ladies, who belonged to the old manufacturing families in Halifax of long standing in the town, look down upon those whom they call "parvenus"; there was a feeling of superiority which they could not conceal; "the Yeomanry Ball on the $3{ }^{\text {rd January promises }}$ to be very amusing, for we shall meet there all kinds of folks". In this sentiment, expressed by Mrs. Henry, Miss Delia coincided. At a later hour Mr. Joseph introduced me to his sister Charlotte, the wife of Samuel Waterhouse jr., she received us in her drawing room, tastefully and elegantly furnished, and was as agreeable as all the ladies of this family are; afterwards I accompanied Mr. Joseph to Mrs. Norris' whom we found at home with her two daughters, the younger of whom, Mr. Joseph's betrothed - the same with whom I had danced so often at Mr. Pollard's ball - when we left, shook hands with me in such kind and hearty manner, as if we had been very old acquaintances. In "Pie Nest" I looked in at old Mr. and Mrs. Edwards, and then went with [320] Mr. Cronhelm to take pot luck. In his house, called "Crow Wood", all was plain and unostentatious. A servant girl attended. I could not help thinking it was a hard case that Mr. Cronhelm, an old man and a drudge in the Establishment for many years, was obliged to live in such a homely manner, whilst Henry and Joseph Edwards - young men - had already the means of indulging their expensive habits. Besides Mr. and Mrs. Cronhelm - a very taciturn, insignificant lady - their son Edward, and myself, there sat down to dinner, 3 young chess friends of the son, Messrs. Forbes, Layland and Walsh. The absorbing topic was Chess, and I came off tolerably well, if it be considered that my antagonists were accounted the best players in Halifax. I won two games from Edwd. Cronhelm, 1 from Forbes, lost 2 to Forbes, and one drawn with each of them.

Saturday, $16^{\text {th }}$ of December 1843 . Our breakfast party was more numerous than usual: there were Mr. and Mrs. Henry Edwards and myself, Mr. Cronhelm and his two sons, Edward and William, the latter Wool-stapler in Halifax and 
Serjeant in the Yeomanry Corps. In "Pie Nest" Mr. Henry took me to the wool stores, and the manner in which the nap is cut off the cloth was explained to me. At a later hour, together with old Mr. Edwards, I walked up and down his garden for a long time; we conversed on many subjects, and I liked the old man very much, he was so mild and unpretending, whilst his sons were not altogether free from a little purse-pride. The remainder of the forenoon I passed in company with Mr. Henry; we walked to Halifax, first to the coachmaker's, Piercey, with whom I came to terms about a chariot which he was to build for me; it was to be of a deep claret or maroon colour, inside to be lined with white silk, and to cost, (including two plated harnesses, the one for one horse and the other for two) £207 placed in Liverpool. Mr. Edwards promised me that he would carefully look after it whilst it [321] was building. Halifax was, at the time, an old dirty place with narrow streets and narrow footpavements: the houses were generally built of stone found in the neighbouring quarry cut into the shape of large bricks; occasionally one story protruded over the other. The Infirmary was a plain building, 4 substantial columns forming a porch at the entrance. The market place was nothing but a large open space, well stocked with provisions, abundantly with game. The Piece-Hall was a large quadrangular edifice, with a handsome piazza running all round; in it manufacturers of Halifax and the neighbourhood had their offices, and here, especially on Saturday - market day - they sold their Fabrics by sample. Mr. Henry and I returned to Craven Lodge, and at about 6 o'c. drove to the dinner-party at Samuel Waterhouse Jr. In the drawing-room in which, on the previous day, Mrs. Waterhouse had received me, the following company was assembled; the host and hostess Mr. Samuel Waterhouse Sr., John Waterhouse Jr., and a Mr. Haigh; Dinner was announc'd and Mr. Samuel Waterhouse Jr. requested me to take his lady to the dinner-table, where the place of honour was assigned me, as will be seen by the following tableau.

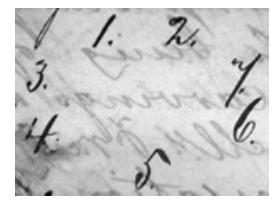
$\mathrm{N}^{o}$ 1, myself. $\mathrm{N}^{\mathrm{o}} 2$, Mrs. Samuel Waterhouse, $\mathrm{N}^{\circ} 3$, Mr. John Waterhouse, No 4 , Mr. Hy. Edwards, $\mathrm{N}^{\circ} 5$, Mr. Saml. Waterhouse Jr., No 6, Mr. S. Waterhouse Sr., $\mathrm{N}^{\circ} 7 \mathrm{Mr}$. Haigh. The carving-knives and forks were placed before me, but fortunately, when I declared my incapacity to carve, my neighbour to the right was good enough to save me the trouble. With Mrs. Waterhouse - good looking, but very delicate - I kept up such a lively conversation about Dublin, Edinburgh, York, Newcastle, and I dont know what, that actually I found no time to eat my fish, also with Mr. John Waterhouse I talked a great deal. We gentlemen remained but a short while over our Wine. Up stairs, coffee and tea were handed [322] round, the lady of the house played 
and sang, and my conversational powers were once more put in request both by Messrs. Samuel Waterhouse Sr. and Jr. The party broke up at 10 o'c., I much pleased with the kindness which had been shewn me.

Sunday, $17^{\text {th }}$ of December 1843. After breakfast Mr. Henry Edwards and I walked, Mrs. Henry Edwards drove to the Episcopal Church in Halifax, an ancient stately building. A numerous congregation was assembled, a seat in the pew of Mr. John Waterhouse Jr. was allotted to me, but unfortunately a pillar just before me prevented my understanding anything of the sermon. Service over, Mr. Waterhouse and I walked to his father's place just out of town, called "Well-head," where, with the old gentleman, and his equally venerable lady, we took an early dinner. He shewed me his scientific books, and many instruments; a telescope, thermometer, barometer, etc., he took me to the garden and hothouses, and across the fields to "Pie-Nest", where I remained some time, and I then bade good bye to the excellent people of this place, for I had fixed upon the next day for my departure. Once again in Craven Lodge, Mr. Waterhouse, Mr. Henry Edwards, and I, adjourned to Mr. Henry's study which he called the Oak-room, the panels being of oak, and the room otherwise adorned with carvings in the same wood. Here we were joined by Mr. Frank Rawson and the time glided away in conversation; Mr. Waterhouse was in my opinion rather prosy, and too fond of indulging in scientific dissertations. After tea, and when the visitors had retired, the servants entered; they, as well as Mr. Henry and I, knelt down, whilst the lady of the house read an appropriate prayer in a clear distinct voice.

Monday, $18^{\text {th }}$ of December 1843. We were astir at an earlier hour than customary. We breakfasted. I bade fare well to my most amiable hostess, who before parting, desired [323] that I should go to the Nursery and kiss her four pretty children, which I of course did with pleasure. Mr. Henry and I then drove to "Pie Nest", where I neither saw the Cronhelms - who had gone home to breakfast - nor the two daughters, for they, as Miss Delia was shortly to marry an Irishman named Clark, had gone per rail to Manchester for the sole purpose of making purchases, a proof that Halifax was not well provided with fashionable female articles of dress. By $1 / 2$ past 10 we were at the Sowerby Bridge Station, where I took leave of Mr. Henry Edwards. At 11 o'c. -20 minutes behind time - the train arrived, and I took a first class seat for Leeds, 32 miles distant by train, 16 by high road. The weather was thick and disagreeable, very different from the mildness of the previous afternoon, owing to which I could distinguish but little of the surrounding objects, we passed the Wakefield station without my observing it, also that of Normanton where the York line joins, arrived in Leeds, and took an omnibus for the Scarbor[s'] Hotel. As soon as I had secured an apartment I started anew in search of Mr. John Cronhelm, 
a young solicitor to whom his father had given me a few introductory lines. At his office in Boar Lane I found only his lady, who being already informed of my probable coming received me with particular politeness, and offered herself as my guide anywhere I should like to go. We went to the parish church, a pretty edifice with handsome stained-glass windows, also to the market place, where to my surprise, the stalls though well supplied with provisions, were neither covered nor walled in. On our return Mr. Cronhelm had come in from Court, he was an agreeable young man, and immediately proposed to go out with me in order to shew me what was worth seeing. The entrance to the reading-room pleased me; two wide flights of steps, one from each side, lead up to a tasteful rotunda resembling [324] those on both extremities of the Thames Tunnel. The Cloth hall, extensive, and of an oblong figure -128 yards long by 100 wide - had no pretension to architectural beauty, it contained no less than 2640 stalls on which the manufacturers in the neighbourhood, (for the greater part hand-loom weavers) laid out their cloths, generally in an unfinished state, which the merchants and great manufacturers were in the habit of purchasing for the purpose of giving them the last finish. On each stall were inscribed, in large letters, the owner's name and residence. Tuesday was market day in Leeds. At the Counting house of Messrs. Marshall \& Co. (one of the most extensive spinners of Cotton thread in the kingdom,) we were refused admittance to the Factory, where about 2 acres of ground, roofed over, were covered with spinning-jennies. Leeds like many other English towns, has its west end, where the streets are wider, and the houses built in a more modern style, than either in the centre or east end. It was now dinner hour. We went to Mr. Cronhelm's residence, one of a row of neat houses, each with a grass plot in front. On entering I was struck with the air of comfort which pervaded the whole dwelling; Mrs. Cronhelm, now dressed in a black velvet gown, appeared more to advantage than she had in the morning, her features, sharp and marked, were not very pleasant. Dinner was plain, this meal over the lady played the Piano, I won two games of Chess from Mr. Cronhelm, and at 10 o'c. returned to my hotel.

Tuesday, $19^{\text {th }}$ of December 1843. At $71 / 2$ a.m. when it was just dawning, the gas lamps still burning, and the factories lighted up from the top story down the basement, I drove in an omnibus to the railroad station, where I quickly installed myself in a snug corner seat, first class. Like yesterday, the atmosphere was thick, and concealed much of the level country through which we steamed [325] along to Hull, or rather Kingston-upon-Hull, 55 miles distant, and where we arrived at $101 / 2$. Here I took up my quarters in the "Minerva Hotel", opposite the docks, which were crowded with shipping. I hastened to the office of Mr. Wm. Ward, to whom Messrs. Gibbs Bright \& Co. had given me a letter of 
introduction. He was not in, but his clerks gave me some letters which had been waiting here for me, two from Captn. Seymour and one from Gibbs Bright \& Co. with samples of goods shipped on my acct. to Callao at "Robert Finnie". I wrote a few lines to Antony Gibbs \& Sons and then strolled about the town, mostly in the neighbourhood of the docks, here passengers were landing and embarking; bales of enormous size, probably containing Twist and Cotton Yarn, were being conveyed on large trucks to the vessels; similar bales thrown down from the stores to the street. Vessels were in progress of construction, the quays lined with capacious substantial sheds filled with merchandize, steamers plying up and down, in short all gave evidence of an active trade, and nevertheless I learned afterwards that, as at the time the northern ports of Europe with which Hull principally trades commence being blocked up by ice, this was by no means the most busy season of the year. Hull also did business with British-America, whence cargoes of Timber were imported, and these, strange to say, sometimes found their way to Manchester, although one might suppose that this latter place could be supplied more cheaply from the nearer port of Liverpool. Close to the Dock stood the statue of Wilberforce; in another street called "Low Gate" was the statue of King William III, here also boots, shoes and books were exposed for sale, of the latter I bought a few to have something to read on my passage to Hamburgh. I returned to the office, and Mr. Ward accompanied me immediately to the exchange and reading-rooms, both buildings of small dimensions. Hull lies on the north side of the Humber, which, over 32 miles further up, is formed by the junction [326] of the Trent and Ouse; its distance from the sea is 22 miles; by the small river Hull the city is divided into two parts connected by bridges, the smaller part being an island formed by the docks, the Hull and the Humber; in the vicinity of the docks and shipping the streets were narrow, dirty and full of people; Hull has also its west end, the more fashionable district, where Mr. Ward resided; he made me enter his house, take some refreshments, and pressed me to remain a few days with him, but as after this day's steamer, there would be none before Saturday, which could not arrive in Hamburgh sooner than Monday - Christmas Day - I adhered to my original intention of leaving this day, and having said good bye to Mr. Ward went with my luggage, carried by Boots, to the steamer "Hamburgh", under Hamburgh colours, and bound for Hamburgh. The whole crew was German with the exception of the Captn. - Brown - and the stewardess; also the passengers were, for the most part, Germans. The steamer was capacious but not so well fitted up as that on the Liverpool and Glasgow line. At 6 o'c. we had tea and cold meat. At a later hour an interesting conversation was entered into by a Frenchman who called himself Baron Maurice, and who could hardly make himself in English, and a Mr. Behrens from Bradford, (an agreeable 
young man, a jew belonging to the rich family of Behrens of Manchester and Hamburgh,) on the subject of Wellington, Napoleon, Ney and similar political topics. At midnight we all turned in.

Wednesday, $20^{\text {th }}$ of December 1843. I rose at 8 o'c. after a good night's rest. We breakfasted, Captn. Brown at the head of the table. The sea was smooth. The steamer glided through the water imperceptibly, without the slightest motion. Of seasickness there were no symptoms. I walked the deck with one of the passengers (Seemann), conversed with Behrens, who by the bye spoke French fluently, won some games of drafts from him - for chess-men there were no on board, read and passed the time pleasantly enough. We dined at 2, and from 5 to 8 [327] when the tea was placed on the table, four of us viz. Behrens, Baron Maurice, Dieseldorf and myself, played whist. The Frenchman was by no means disagreeable, of course much wedded to Paris, extolling the amiable qualities of French ladies in general, and of the Paris "grisettes" in particular. Dieseldorf was a jew, partner in a Berlin firm. The other two passengers were Livesson, traveller for a Bradford house and Pierson - a young Englishman - clerk in a Hamburgh establishment.

Thursday, $27^{\text {st }}$ of December 1843. At 9 o'c. I went on deck; the sea was as smooth, the weather as calm as on the previous day, the little wind there was in our favour. Heligoland, to our left, we had already passed unperceived by me; further on a fire-ship was at anchor, several vessels waiting for a fair wind, next came to our right the Island of Neuwerck which belongs to Hamburgh, and whence a pilot came off to us. A steeple embowered in trees points out the site of the village called Dose, next come in sight a beacon, the Cuxhaven lighthouse, the town itself with a wooden mole stretching out from the shore, amongst the houses one surpassing the others in size, (probably an hotel), also a church, and several vessels at anchor. We stopped here for a few moments allowing the necessary time for some passengers, as well as to another pilot, to come on board. From Cuxhaven, both westward and eastward, the coast is very low; to the westward sandy, to the eastward covered with verdure, here and there a tree appearing. At 11.30 the right, or Holstein side, of the Elbe was not yet in view; I felt happy beyond measure. I was now to re-visit - after an absence of 21 years - the scenes of my childhood and youth. I thanked the Lord for having blessed my labour and endeavours toward the acquirement of a fortune which might be called a competency. I walked the deck with rapid strides; I sang; I would have jumped about like a child if I had not known that so many eyes were upon me. The weather became thick, a drizzling rain fell; we [328] passed to our right the town of Otterndorf; opposite, on the Holstein side, Brunsbuttel; further on, the mouth of the Stör with the fortress of Glückstadt; we passed between the Island of Poggen Sand and a sand-bank. At 2 o'c. we 
sat down to dinner, our party much increased by the Cuxhaven passengers, amongst whom were the captain and mate of an Italian vessel which had recently been wrecked upon one of the many dangerous shallows at the mouth of the river. We stopped opposite Stade for a few minutes, when we returned on deck Wedel was already left behind, and now every object I beheld was familiar to my memory. Not for a second did I take off my eyes; there was the old Sühlberg whither I had so often resorted to catch butterflies, with a new Inn on the summit; there were Baur's magnificent Park with the ruined Castle, a temple, and the hot-houses, Godeffroy's Garden, and Dockenhude, Nienstädten and the Devil's Bridge. My anxiety increased every moment, one country house follow'd the other, each surrounded by its park, some known, others new to me. The second and first Windmill I recognized at a glance, then Rainville's garden, in another moment the house at the corner of the Elbstrasse and the Quäkerberg - where my father and mother had died - came in view. Donner's new warehouse was the next remarkable object. A boat came off from the shore for the mail-bag, I hurried into it with my luggage, the steamer continuing its course to Hamburgh, and in another minute I landed at the landing-place called the "Holzhafen" in my dear native place, after an absence of 21 years, less 1 month. It was on the $20^{\text {th }}$ Janry. 1823 when I had left home for a tour through Germany in company of Jean Elmenhorst, long since dead and gone. Indescribable are the feelings which at that moment made my veins throb and my heart beat. [329]

\section{Residence in Altona, including an excursion to some places in Holstein from 21 Decr 43 to $28^{\text {th }}$ of May 18 [_].}

Continuation of Thursday, $23^{\text {st }}$ of December 1843. I stepped on shore; I looked round; nothing was new to me; nothing had chang'd, but all appeared to me small, poor, insignificant. The porters who carried my luggage shewed me to the counting house of Sieveking \& Schuster close by; before entering I cast a glance towards the houses of Elmenhorst, Reincke, and Donner, a few paces higher up the street, which had been the scenes of my youthful labours and pleasures. When I opened the street door Schuster came out of his office; he had become grey-headed; I did not recognize him nor he me, but hardly had I mentioned my name when he gave me the most cordial possible welcome. His partner Henry Sieveking - my best friend - was not in; he, Schuster told me, was at a dinner-party given by his mother, old Mrs. Sieveking, to celebrate the bethrotal of her grand-daughter, Sophia, the younger daughter of Ernestina and Lucas Willink, with young Löhmann, son of the opulent Conrad Löhmann of 
Glückstadt, who (the son) owned the druggist's and apothecary's shop, which well remembered by me with the sign of the Lion, was in my childhood the property of Dr. Schmeisser. I at once decided upon joining the party, I shaved and dressed, and while I was thus engaged another gentleman - Charles Semper - came in, he, though an intimate friend of mine, was not more clear sighted than Schuster had been, he did not know me nor I him. After having paid my respects to Mr. Schuster, Semper offered to take me to Mrs. Sieveking; we ascended the street called Van der Smissen's Allée, the joy and delight which I felt are not be described, I greeted every stone, each tree as an old acquaintance. At the corner of the street just named and the "Palmaille" stands the handsome house which my grandfather had built in the beginning of this century, which in 1823 had [330] belonged to Mrs. Sieveking, and which during my absence, she had sold to Semper; he requested me to step in, and introduced me to his wife (L[_] Reincke), but such was my flurry that I took no notice of her personal appearance. Mrs. Sieveking lived at the time in one of a fine row of new houses, the property of her wealthy brother old Fritz Baur. The servant showed me up stairs to an ante room, and hardly had I sent in my name when Henry Sieveking came running out eagerly, unfeigned pleasure depicted on his countenance. We entered the dining saloon where a large party sat round a well-spread table; he presented me to his mother, and to old $\mathrm{Mr}$. C. H. Donner, my former principal, now graced with the title of "Conferenzrath" upon which he prided himself not a little. Both had not much changed, and both were very friendly to me. One of the guests invited not having come, a seat was by chance vacant, and this I occupied between Johannes, the youngest son of Fritz Baur and a Miss Löhmann, sister of the bridegroom, neither goodlooking nor young, nevertheless I entered into a spirited conversation with her. I observed that here the custom was to place the viands on the table that the company might see what they consisted of; then the servants removed them to the side-board, carved the meat and handed the plates round so that every guest helped himself to what he preferred. I ate nothing and merely took 2 or 3 glasses of champagne. Donner asked me to take wine. After dinner, whilst coffee was handed round, all stood in small groups conversing with each other; the gentlemen retired to the smoking room; only Sieveking and I remained with the ladies; the gentlemen re-appeared and at about 10 o'c. the party broke up. Here, by a mere chance, I was unexpectedly introduced to the "elite" of Altona society; I renewed my old, and made new, acquaintances, all of whom shewed to me quite as much attention as I had any right to expect. Mr. Fritz Baur, a gentleman of nearly [331] 75 years of age and head of the ancient firm of J. H. \& G. F. Baur well known and highly respected in the whole mercantile 
world, talked with me for a long while, enlarging upon the recently projected Altona Kiel railway, to which he was decidedly opposed, as it often happens that men of the old school are not partial to novelties, new enterprises, or new doctrines. This railway, I say so in anticipation, was quickly constructed, and not only became an indispensable link of communication between the Baltic and north of Germany, but also turned out to be a profitable enterprise to the original undertakers. C. H. Donner had become stouter, he was robust for his age (nearly 70), had doffed his antiquated black suit of knee breeches and silk stockings, and was now dressed in the modern fashion. To me he was pleasant, but true to his character, availed himself of the first opportunity to remind me that I had once been his clerk, which by the bye, I had never forgotten. It was and still is the custom in Altona, as also in Hamburgh, after a dinner-party, for the guests to address each other with the words "gesegnete Mahlzeit", which translated literally means "blessed meal", but which may be interpreted better with the words "May what you have partaken of do you good"; after my long absence I did not comply with this ridiculous custom, when Donner came up to me saying "Well don't you wish a "blessed meal" to your old principal"? The Rev. Mr. Koster, curate of the neighbouring village of Ottensen, to which parish the west end of Altona belonged, was also one of the guests, he was a very old man; 1816, on the holy Thursday, he had confirmed me in his church. Of the same generation as the three last named gentlemen was Mr. Stuhlmann, many years back established in Rio Janeiro; in 1843, together with Mr. Lübbes, chief of the firm of M. Mathiessen \& Co. in which they had of late admitted as partner Theodore Reincke, one of the nephews of the latter. Stuhlmann came up to me to shake hands. Of my contemporaries, there were only Sieveking and Fritz Warnholz, both frequently mentioned in my previous diary during [332] the years 1819 to 1823 . Warnholz, after having lost his first wife, Maria Elmenhorst, had married Augusta Reincke; he was the partner of Elmenhorst Brothers, which (at the time of my leaving Europe) insignificant firm, he had raised through his exertions to great respectability, he was now, in 1843, a very active member of the Municipality (in German "Kammerei Burger"). To a later generation belonged the bridegroom Mr. Löhmann, his intimate friend Dr. Calisen, young Johannes Baur, and probably some others who escaped my observation. Of the ladies, the hostess Mrs. Sieveking, occupied the first place, she was a lady in every sense of the word; to me she was kind, motherly and affectionate. Her daughter Ernestina, the bride's mother, I liked well, having been acquainted with her from my childhood; I learned afterwards that she was not much admired by her townsfolk, because she was too fond of criticising her neighbours' conduct and proceedings. Her husband Lucas Willink was, if I mistake not, at the time absent in Norway. Her former governess now her mother's companion, Miss Götz, 
very clever and very ugly, had somewhat improved her looks by a set of false teeth. Henry Sieveking's wife Theresa Reincke was a pretty young genteel lady; her sister Augusta, Mrs. Warnholtz, seemed a good-natured person. The bride Sophia Willink very fair, and her elder sister Caroline of darker complexion, were not much to my liking; I missed in them that sprightliness and vivacity which had pleased me so much in my late young English female acquaintances. Augusta Baur was the youngest daughter of the rich Fritz Baur, and strange to say, not yet married, nor did she ever contract marriage in after life; on this occasion I saw little of her. When we got home Sieveking and his wife retired to their bedroom. I went to that assigned to me.

Friday, $22^{\text {nd }}$ of December 1843. My friend G. H. Sieveking lived at the time in a small house on the right or northern side of a street called Klopstock street which, from the western extremity of the "Palmaille" further on, changes into a high road, and runs towards Flottbeck and Blankenese. Opposite, on the South, or the left side of the street, was a large garden [333] inclosed by a wood paling belonged to a handsome house, presented, shortly after the evacuation of Hamburgh by the French, to Count Blucher Altona - then President of the town - by the grateful Altona people, for his prudent conduct during the disastrous period when Hamburgh, occupied by the French, was blockaded by the Russian army in the winter of 1813 to 1814 . At a later period the Count sold this fine property to the rich Jew Gumpel of Hamburgh, who in 1843 was the owner. On the ground floor of Sieveking's house there were the sitting room looking toward the street, the adjoining dining room, and a small apartment, with a window to the yard and garden, comfortably fitted up as a bed room for myself. Below were the cellar and kitchen, above the bedrooms. The family consisted of himself and his agreeable young wife Theresa, a Miss Petersen, a young woman who assisted Mrs. Sieveking in her household affairs, and 4 children, George Henry, the eldest 11 or 12 years old, Peter Johannes, Theresa and Charles, the youngest, still teething. Now in 1868 I may say what has become of them; the eldest is married and partner in his father's business; the second, who went to several universities and whom in 1855 I saw in Göttingen, has a lucrative situation in one of the mining establishments of Ossa \& Escobar Copiapo in Chile; Theresa is married to a Mr. Behn a widower with several children, one of his daughters has become young Henry's wife; and the last, the delicate child in his nurse's arms in 1843, is at the present moment a promising young lawyer, likely to follow ere long his eldest brother's example. I breakfasted with the family at 8 o'c., merely a cup of coffee and some bread and butter, as is the custom all over Germany; at a later hour, at least in the northern seaports of that Country, a more substantial $2^{\text {nd }}$ breakfast or lunch follows. In 1843 the general dinner hour in Altona was between 3 and 4, so as to allow time and 
appetite for tea and supper. After breakfast I opened the case which I had left in the London Custom house to be re-shipped to Altona, and then went with Sieveking to his Counting house in the Elbstrasse where Schuster lived, and where I had been received the previous evening. I was surprised to perceive that [334] Sieveking and Schuster had no clerks, even the copying of their letters not by press, but by hand, was done by themselves; they employed merely a man something in the capacity of an English porter, but rather superior, who kept the office clean, went on errands, took letters to the post, presented bills for acceptance, etc. Old Johann Julius Reincke - a most excellent man - receiv'd me with particular kindness; I saw his eldest son Edward who had not much altered during my long absence, also his youngest daughter Wilhelmina, the only unmarried one, an agreeable young lady. From Reincke's house I wended my way, first to Mrs. Elmenhorst's, then to Miss Schluers' lodgings, both of whom were very glad to see me. The latter of the two, who had been housekeeper to my maternal great grand-father Lucas Oven Beets - nearly 80 years of age, by means of pecuniary help from her friends, could just make the two ends of the year meet; she of course lived very secluded and had her apartment up two flights of stairs; she however enjoyed good health with the exception of gout in her hands, and was satisfied with her lot. Mrs. Elmenhorst, better off in the world, lived in a genteel manner; she had preserved her vivacity, and still some remnants of the beauty of her younger years. With Sieveking I called upon Mrs. Theodore Reincke to congratulate her on her birthday, she - named Thusnelda, daughter of Dr. Stintzing - was very pretty and of reputed ability; her husband - a plain man - had no lack of intellect. Chocolate and cakes were handed round. Many visitors came in, amongst whom Mrs. Knauer with whom, when Emily Reincke, I was so desperately in love before leaving Europe; she had grown older and stouter, but had retained that kindness, good-nature and modesty, which had always been her great attractions. With Warnholtz and Theodore Reincke I drove to the Hamburgh Exchange in a cab, which goes here by the name of "droschka", a Russian word, for it was at the time when the Russians entered Germany in the year 1813, that these vehicles first came into use; the fare charged by them was from 8 to 16 shillings currency according to distance. The Hamburgh Exchange is a [335] handsome solid quadrangular (see appendix $\mathrm{N}^{\circ}{ }_{13}$ ) edifice which was erected during my absence; owing to its isolated situation and the volume of water kept continually pouring over it, it escaped from the dreadful fire which, from the $5^{\text {th }}$ to the $8^{\text {th }}$ May 42 , consum'd all the houses in the vicinity and of which I gave an account Page 758 of previous volume. The interior area, without any partition whatever, is roofed over; round it runs a wide corridor. Here all the merchants of Hamburgh and Altona assemble daily -Sundays and holidays 
excepted; every merchant has his own place, which is occupied by one, two and sometimes four members of the same firm. These generally remain at their places unless they are called away by some particular business, the brokers on the other hand are always on the move and you see them running about from one end of the Exchange to the other. It is on Change that almost all sales are effected of produce, bills of exchange, and public funds. This going on change has become so general a rule that not appearing at the regular hour is looked upon, and really is, a sign of the house having suspended payment. Between 1 and $11 / 2$ o'c., the extensive area gradually fills up, and becomes crowded. At $11 / 2$ a bell rings, and the sworn brokers quote the rates of exchange of the day; whoever enters after 2 o'c. has to pay a fine of 4 currency to the porter. Up stairs overthecorridorareseveralsmall roomstowhichonlysuchmerchants-generally those of the highest standing as pay annually $24 \mathrm{CM}$, are admitted. On Change I spoke amongst others to Johannes Limpricht, (an excellent man) my playfellow in childhood, my companion in many a party during my youth; he was much stouter than when I had seen him last, but otherwise unaltered. In 1843 he and his younger brother Bernard were established in Rio under the name of Limpricht Bros., and did a very good business; Johannes resided in Hamburgh, Bernard in Rio. Daniel Schutte had worn his years extremely well, and had not lost his smooth and insinuating way of talking. C. H. Donner saluted me and introduced me to his son Bernard, whom I had left in 1823 as a child in London, and who now, his father's partner, [336] was a tall thin man with long nose and big whiskers. Sieveking presented me likewise to George and David Knauer, both men of good common sense and sound heart, but not of very refined education. David, the younger, was a wine merchant in Hamburgh; Geo., the elder, husband of Emily Reincke, was established in Altona, he had a share in a Tobacco manufactory which gave him a sure and handsome income; he was also owner of several vessels which he used to send to Brazil and the West Indies on his own acct., thence to bring back colonial produce. I learned that of late, much money had been lost in coffee. I returned per omnibus to Altona, fare 4. Mr. Stuhlmann, the same whom I had seen the previous evening, and who is graced with the title of "Justize Rath," the lowest of the many empty distinctions which the Court of Copenhagen dispenses to the predilect of its liege subjects, alighted with me from the omnibus and I accompanied him to the door of his house; one of the pretty row of buildings in a chaste and modern style which - owned by Fritz Baur - stand on the spot where in 1823, I had known the residence of the agent Becker with a large pleasure ground attached; each of these new houses has a pretty garden in its rear and a fine view across the "Elbe" to the Hanoverian side. The tenants of them in 1843 were Conrad Count Blucher Altona; the lawyer Stuhlmann, (once 
my guardian); the "Justize Rath" Stuhlmann; Mr. Fischer, partner of Hayne and Fischer, (the former of these two my fellow-clerk at Donner's), with his motherin-law Mrs. Dankert; Consul Hildebrand, married to a daughter of Fritz Baur; George Baur, Fritz Baur's $2^{\text {nd }}$ son and partner; old Mrs. Sieveking and Bernard Donner. Of all these just named, now in 1868, I know only George Baur to be living, of Consul Hildebrand I have not heard anything, the remainder dead. Dinner at Sieveking's was very plain, rather different from what I had been accustomed to at Mr. Henry Edwards' in Craven Lodge. The meal over I called upon the two Misses Finck - aunt and niece - the elder, Betty, who after my sister Betty's death had taken charge of her baby, my nephew Charles Ropsy, [337] she was much the same as when I had left Altona, Jeanette, the younger, who when I last had seen her was a young girl, now stood before me, a person of respectable age - say about 36 - her large mouth was hardly made up for by her fine rosy cheeks. I remained with them a considerable while conversing on many topics mutually interesting. At a later hour I went by invitation to the Knauers', who at the time lived - and still live in 1868 - in the Elbstrasse, a short distance higher up than my paternal home, but on the opposite, the south side of the street. I met there Warnholtz and wife, Mr. Stuhlmann, mentioned more than once, and Mr. Lübbes, brother-in-law of old Mr. Reincke, and consequently uncle of the many brothers and sisters of this family. Soon I found myself as much at home as if I had never been away. Mrs. Knauer called me at once Witt dropping the formal Mr., and took me to the Nursery where the younger children were asleep. We had tea, whist till $1 / 2$ past 9 and then a light supper. The family consisted of Mr. and Mrs. Knauer, he about 47 years of age, she perhaps 5 or 6 years younger, and 7 children, viz.: George, 19 years old, in the Counting house of Elmenhorst Brothers; William, 2 years younger, in the office of Hayne and Fischer; Maria, a good-looking robust girl of about 15; Emily, a year younger, not so pretty as her sister, but gifted with a clear and sharp understanding; Julia, still a child; Hermann and Edward infants. I will add what has become of them now after a lapse of 25 years. George is established as a merchant in Hamburgh in partnership with a former clerk of his father, and does an excellent business; he married the lovely daughter of Johannes Limpricht, and after her untimely death, re-married. William, a bachelor, is in partnership with his father, and makes himself useful in the civic affairs of the town. Maria married Arthur Donner who with his two elder brothers Conrad and John, are successors in the firm of their deceased father J. C. Donner; their profits are not great and Arthur with his wife and a numerous family live in a retired manner. Emily made a rather unfortunate marriage, she, when travelling with her father and mother, became acquaint'd [338] in a hotel in Paris with a Swiss gentleman then established in Rio called Gänslie, who - not bad man, 
but completely incapable of getting on in the world - has tried many things and has never succeeded, so that though I believe her parents render her some pecuniary aid, she has been compelled to exert herself for her maintenance by educating, jointly with her own two daughters, one or two other young girls from Spanish America who were placed under her charge. She lives generally in Paris, paying occasional visits to Altona. Julia has become the happy and blooming young wife of Mr. Kochen, sole proprietor and manager of the long established firm of L. F. Lorent am Ende \& Co. of Hambh., for Hermann his father has bought a small estate on the frontiers of Silesie, where he lives as an agriculturist. Edward, after having been in a Counting house in Brazil and at J. V. Campo's in Lima, is now - October 1868 - still in this city without a fixed occupation.

Saturday, $23^{\text {rd }}$ of December 1843 . The previous volume page 425 and following, contains an exact description of Altona and its vicinity, I will therefore confine myself to saying that, while this day driving an omnibus to Hamburgh, the impression made on me by that town Altona was by no means favourable. The streets, the houses, everything appeared to me small, paltry, even mean. I did not see one single shop elegantly fitted up; even the public buildings, such as the Town House, the churches, the theatre, the Foundling Hospital, were not in the least remarkable for architectural beauty. Only the "Palmaille" was lined on the southern side by an almost entire row of handsome private residences, whilst on the opposite, the northern side, fine houses formed the exception, smaller and poorer ones being the general rule. Having crossed the suburb of St. Pauli, the omnibus entered the old Hanseatic free town of Hamburgh by its western, called the "Millern Gate", whence two streets in a straight line, the first and second "Steinweg" or stone way, run eastward; they are sufficiently wide, but the houses old-fashioned; the majority of the population of this quarter is Jewish. At [339] their eastern end I turned off to the left through the "FuhlenTwiete" - hardly at all superior to the "Steinwege" - until I reached, in the street called the "Hohen Bleichen", the Counting house of Messrs. Feldmann Bohl \& Co. to whom I had an introductory letter from Messrs. Antony Gibbs and fam. London. Mr. B[ö]hl, a tall thin man, was very polite, he expressed himself however in such a manner as to afford me little hope that I should see much more of him during my stay in Altona; one of the sons of George Henry Gibbs of London was a clerk with him. This Mr. Böhl belonged to one of the old respectable families of Hamburgh. When a young man he entered the office of Anthony Gibbs \& Sons, shortly after I had left in 1824; how long he remained there I cannot say, but I know that when he established himself in Hamburgh on his own account the Gibbses always favoured his firm. Feldmann Böhl \& Co. were their guano-agents in Germany and have continued to be their 
correspondents. Alfred, the $3^{\text {rd }}$ son, is in 1868 junior Partner of Wm. Gibbs \& Co. Lima. On my later visits to Hamburgh I became well acquainted with the family. Thence I bent my way to the Esplanade, which had been built since the great conflagration; it is a very wide street, three avenues formed by four rows of trees, the broadest in the middle, run lengthways, on each side a carriage road, then good foot pavements, and houses constructed in the modern style but generally with flat roofs. In 1843, this fine street was disfigured by a number of small booths which filled the greater part of the avenues and served as a temporary refuge for many of the poorer classes who - their dwellings having been destroyed by the fire - had as yet been unable to find new ones. Mr. Daniel Schutte lived here, but was not in when I called. The neighbourhood of the old "Jungfernstieg" - "Virgin's path" - had also suffered greatly on those fatal days of May 1842. The river "Alster", which forms here a beautiful basin of water, had been somewhat confined by massive stone quays; on its western side the new "Jungfernstieg" had been constructed, consisting of one row of houses only on the off side of the river. The old "Jungfernstieg" on the southern side of this street of water was not yet completed, but [340] fine buildings were fast springing up, amongst which Streit's hotel was remarkable for its great size. The blackened walls of the much frequented coffee house called the "Alster Pavilion," had not yet been removed. On the eastern side the roadway was only planned, nothing had been as yet commenced; the fourth or north side is occupied by the Lombard Bridge, with a pretty, rural wind mill on it. I have visited many places, large and small, in Europe and America, but in no town have I found a spot so much to my taste as that of which I have just given an outline, not however as it was in 1843 , but as in later years, when the streets which form the quadrangle were concluded. A few steps further on to the Eastward I came to the church of "St. Peters" - bereft of its beauty - the elegant airy steeple had become a prey to the flames, an ungainly stump had remained. Not far from this was a large open place, the site of what was once the Church of St. Nicholas. The ruins left by the conflagration had all been cleaned away, but the reconstruction, though handsome and lofty houses were being erected in every direction, was not yet completed. Pipes for the purpose of sewerage were about being laid, and the lighting up of Hamburgh by gas was projected, and soon after carried into effect. Per omnibus I returned to Altona. Dinner at Sieveking's was plain, consisting merely of soup, roast meat, and vegetables; after the meal a cup of coffee; no tea at a later hour. I assisted my friend in arranging the christmas tree for the evening, the real christmas eve on the $24^{\text {th }}$ being celebrated at old Mr. Reincke's, Sieveking's children received their presents on this day the $23^{\text {rd }}$. A large tub is filled with earth, in it a small fir tree is placed, and its branches are adorned with numberless small wax candles and gilt sweetmeats; this, in 
the centre of a room well lighted up, forms the principal object of attraction, around it the presents are laid out on tables. This room had been kept shut - to the children at least - for several days, and now it was opened when old Mrs. Sieveking, Ernestina, her two daughters and Löhmann came, [341] Sieveking giving the signal on a trumpet. Then the children rushed in, joy and surprise held them speechless for a few moments, each one searched for and found his present, even I had not been forgotten; for me there were some extremely handsome engravings, illustrative of well-known German songs and ballads, which accompanied them in print. The party was joined by Edwd. Reincke, Mrs. Knauer and her two daughters, and Lohmann, with the latter of whom, after the presents had been sufficiently examined and admired, I drove to Warnholtz's house where the same scene was acted anew for his children. Here I met old Mr. Reincke, Mr. Lubbes, old Mrs. Elmenhorst, Theodore Elmenhorst, and his agreeable and pretty wife Constance Heyne with their numerous children, also a Mr. Romund, Warnholtz's uncle. The old people together with Theodore Elmenhorst sat down to cards, whilst the greater part amused themselves with Warnholtz's "Camera obscura". On my return to Sieveking's his relations had not yet left. I shewed them the presents which I had destined for Elizabeth Bobertag, and my drawings of Lima costumes. Supper was handed in on a tray and towards 11 o'c. the party broke up. I like Lohmann who is a wellinstructed man.

Sunday, $24^{\text {th }}$ of December 1843. Christmas eve. Soon after breakfast two sons of Cristoval Armero of Lima, Ricardo and Julio, who were at a boarding school in Flottbeck called upon me, they, as boys generally do, complained of the master, of the treatment they received, etc. When they were gone I started on a long round of visits. I commenced with the Sempers; Charles, his wife and Mrs. Warnholtz were up stairs in the large saloon arranging the Christmas presents. When old Mrs. Sieveking owned this house, many a pleasant evening had we spent there when she used to give small dancing parties to the young folk of Altona. Afterwards Semper took me to the drawing room, everything was genteel and bespoke affluence. Behind the house stretches a well-kept garden, a postern at the end of which opens into Van der Smissen's allee, crossing the same you find yourself at the entrance to Sempers large factories where woollen yarn is dyed. With this yarn he provides many [342] markets all over Europe, much is sent to England where it goes by the name of Berlin wool, even from Turkey he receives orders, and the business is a very lucrative one. My next call was on Theodeore Elmenhorst and his wife, whom on my departure from London I had left residing in Church street, Stoke Newington. They now lived with Otto Heyne in the Elbstrasse, in the house former occupied by the old Mr. and Mrs. Heyne. Only Constance was at home, she also was 
busy with presents for her children, named Mimi and Margaret (twins), Otto, at school in Meimingen, Theodore, Walter and Percy. Mimi became the wife of Ferdinand Reincke, whilst Margaret, many years later, married a Mr. Vogler, first confidential clerk, then junior partner of John Henry Schröder \& Co. of Hamburgh. My old principal C. H. Donner; my fellow clerk Nopitsch, book keeper and correspondent at Donner's; Conrad Donner nephew; Bernard, son of old Conrad Hinrich - all had gone out, and I contented myself with leaving my card at their respective dwellings. Old Mrs. Baur, a very respectable lady of nearly 70 years of age received me in a very friendly manner, she was the widow of a younger brother of Fritz Baur, who, notwithstanding his limited capacity, had, owing to his station in life and his considerable wealth, been favoured by the King with the tittle of "Etats-Rath", and been raised by his townsmen to the dignity of Senator and even burgomaster. The widow lived in style in a large house in the "Palmaille", and was much beloved on account of her charitable acts. I found her busy writing invitations for a dinner party to be given on the $4^{\text {th }}$ Janry; on my return home there was one for myself. My last visit was to [lawyer] Stuhlmann, who took me to his study, and I stayed with him a considerable while. After having taken an early dinner at Sieveking's, we drove at 4 o'c. to the house of Johann Julius Reincke, the progenitor of an extremely numerous family; in the 2 rooms below were assembled he himself, his brother-in-law Lübbes, his sons and daughters with their wives and husbands, his unmarried children, and grandsons and grand-daughters, ad Libitum. We were shown up stairs to the saloon where, once more, presents [343] were laid out, hilarity and good humour prevailed. Sieveking had a basket brought in which contained my presents all labelled, they consisted of:

2 Cuzco paintings, very handsome, for Mr. Semper.

2 Silver "plata piña" Lions for Mrs. Warnholtz.

1 straw cigar case for Mr. Warnholtz.

1 small china crape shawl for Mrs. H. Sieveking.

1 pair of Gloves made by the Indian for Mrs. H. Sieveking.

1 small China crape shawl for Wilha. Reincke

1 large scarlet and white crape shawl for Mrs. Knauer

1 Cigar case for Mr. Knauer

1 Cigar case for Edwd. Reincke.

As far as I could judge, all were pleased with my having remembered them; of course the crape shawl were liked best, and that for Mrs. Knauer, in reality a beautiful piece of workmanship, was much admired. When she shook hands with me to give me thanks, she was evidently affected, and had not probably 
altogether forgotten the times of our youth; I had some conversation with her, when she confessed to me that she had not been able to keep up the studies of her juvenile years, which she attributed to the manifold duties her large family entailed upon her, also to her many social connexions; my own opinion was at the time, and still is, that her husband was in great measure the cause of her neglect, he placed no great value on female accomplishments and merely required a thrifty and active housewife, as well as good-natured companion, all which he had certainly found in his wife. After the distribution of my presents, Mr. Lübbes, who is an [_]llent and kind uncle to the whole family, had another basket brought in with his presents, which were likewise handed over to the interested persons. Numerous as the family of the Reinckes is, I may say here, that to none of the various individuals, male and female, of which it consisted, an improper or vicious action can be imputed in the course of their lives. The men were good citizens, kind and loving husbands, and affectionate fathers. In their intellectual capacities there was of course some inequality: Charles Semper and Theodore Reincke were superior to the rest, the former [344] of the two fond of banter, rather positive in his ideas, and difficult to be dissuaded from what he had once considered right, was much respected, but perhaps not generally liked. When, a few years later, the political troubles commenced, he and Theodore Reincke took a very decided course as friends to the SchleswigHolstein and enemies to the Danish question; repeatedly both, but particularly Reincke, were elected deputies to the various congresses which met, and warmly defended what they considered just. Reincke, accustomed to frequent public speaking, acquired the habit of a pompous delivery, with which even his private conversation was tainted, and which I much disliked. Here, to be sure, I speak in anticipation, for in 1843 he was still at the outset of his connubial commercial and political career. The other brothers were not distinguished by any remarkable ability; in their characters there was of course some variety. Knauer was fond of his garden and hothouses, of a good dinner, a good bottle of wine, and a game at cards. Warnholtz aimed at distinctions; from the King he obtained the Dannebrog Cross and rose to be Burgomaster, he belonged to the conservative party. Sieveking and Edwd. Reincke followed, in politics, the example of Semper and Theodore Reincke, but always in their wake; the former, like his sister, was fond of finding fault; Edward, with whom I had lived in 1823 and 24 at the same lodgings in London was wonderfully exact and precise in all he did, even in the smallest greatest trifle; he was a lady's man from youth to old age, always a bachelor, because as he told me he could not afford to maintain a family; after his father's death he gave up business and became Treasurer of the Altona Saving's Bank, for which situation he was particularly adapted. Of the ladies, Thusnelda was the most clever; her features were 
regular and handsome, but her figure was against her, she was short and with a propensity to corpulence. Theresa, Mrs. Sieveking, was the genteelest, her appearance was quite that of a lady. Louisa - Mrs. Semper - plain, had no doubt improved and learned much by her daily intercourse with her husband, who, as already stated, was a well-informed clear-head [...] [345] of Augusta - Mrs. Warnholtz - I took little notice. Wihelmina, the youngest, unmarried, was an excellent rational woman of nearly 30, she kept house for her father and her brothers and did so to perfection. Hardly had a y[_] elapsed when she became the happy wife of a Mr. Andersen who was the principal of a College and boarding school. Emily, Mrs. Knauer, the eldest was kindness personified, not only her younger sisters, but all her female friends of whom she had many, when in trouble, looked up to her for advice and assistance which they were sure to find. New to me were the young lawyer Lübbes and his pretty wife from Flensburg, both nice people; also the three younger brothers of the Reinckes, Otto, Ferdinand and Johannes. Otto was a fine talented young man, probably the drudgery of his little profitable business, the retail sale of cloth, to which he was far superior, was the cause of his depressed spirits. Ferdinand, his junior by several years, was frank and gay, still a clerk in the office of Elmenhorst Bros.; Johannes, a lad, as yet insignificant. When the hubbub at old Mr. Reincke's was over, we went to Knauer's, there to witness the same scene of present making, with the difference that here the children also presented each other with some trifle, like the rest hung up on the branches of the Christmas tree, by the side of which the father stood and called them over one by one. I received a small purse which Mrs. Knauer said she herself had knitted for me. In Semper's house the Christmas scene was once more enacted. His mother, his sister Eliza - who was rather deformed - and the Elmenhorsts formed the party. I looked in at old Mrs. Sieveking's, to whom and her daughter Ernestine I presented 2 "peveteras" each, (peveteras are small columns of virgin silver - "plata-piña" - about 5 or 6 inches high and inch square). This busy day I wound up at Mr. Reincke's, where, Knauer at the head of the table, we took our supper of carps and crucians, of which all ate heartily, I excepted. At 11 o'c. I was at home.

Monday, $25^{\text {th }}$ of December 1843. Christams day. At an early hour I went to the Knauer's, Mr. Knauer having proposed to me to accompany him to his country house in Eppendorf, before we started [346] he shewed me all over his extensive premises, consisting of the spacious and comfortable dwelling house with the adjoining tobacco manufactory, and the large warehouse which (many stories high, like all the warehouses in the "Elbstrasse") is built at the very edge of the waters of the Elbe, so that lighters can moor close alongside, into which merchandize is easily let down or hoisted up from them. Knauer's carriage stood at the door, we mounted, he took the reins; we drove down the 
"Elbstrasse" through the Pinas gate, then up a small ascent and, turning off to the left, crossed the suburb of St. Pauli leaving Hamburgh, which we did not enter, to our right; we soon came to some avenues which in[_]ght us to the village of Harvstehude on the right bank of the Alster; leaving this behind us, we alighted a few steps further on, at the country house of David Knauer, the bachelor, a great flower and plant fancier like his brother. The orange trees, each in its tub filled with earth, which in the summer are taken into the open air, now kept in the Conservatory, made certainly a fine show and Mr. David prided himself upon them, not without reason. Having remounted our carriage, Geo. Knauer and I soon arrived at his country seat in Eppendorf, a convenient building, large enough for himself and numerous family; the garden stretches toward the Alster, from which it is separated by a low lying meadow. The trees, the grass-plots gave unmistakable evidence of the wintry season, whilst the hot houses - pleasantly warm - were filled with all kinds of choice plants and flowers. Knauer had to look after many things, he had many orders to give, when he had done we walked to his mother's house which was locked up, also to that of his brother Henry, his partner in the tobacco business, him we found at home, and after a short visit returned to Altona. I dined at old Mrs. Sieveking's quite "en famille", present were the lady of the house - Ernestina was not visible - the 2 grand-daughters, Löhmann, Henry, his wife, children and myself. Encroaching old age had in some measure damped the vivacity of the hostess, the two young ladies nature had not [347] endowed with this gift, and thus the party would have been rather dull had it not been for the occasionally interesting conversation of Löhmann. From Sieveking's I had to go to old Mrs. Elmenhorst's where Christmas presents were again distributed. I found there Mr. and Mrs. Warnholtz, Mr. and Mrs. Theodore Elmenhorst, with 5 children, the apothecary Siemsen, who had been married to Theresa Elmenhorst, with his present wife, and his daughter by the first marriage, Malvina, the orphan child of Jean Elmenhorst, and Gretchen Donner, whom it would have been impossible for me to have known again; she had become old, grey-head'd, and deaf. Two parties formed, I first played with the younger an easy game [_] cards called "Schenk-Grabüsche", then with the elder at Whist. At supper I filled the place of honour between the two old ladies, Mrs. Elmenhorst, and her sister Gretchen.

Tuesday, $26^{\text {th }}$ of December 1843 . The holidays being over, my friends returned to his usual daily avocations. At Sieveking's we all rose at candle light, 8 o'c. being the breakfast hour. At 9 Sieveking used to repair to the Counting house, at $121 / 2$ to 'Change in Hamburgh, we dined between $1 / 2$ past 2 and 3 , at 4 he returned to his work, whence he did not come back before 7 or 8 o'c. The weather continued mild but mirky, the streets were extremely muddy, 
the trees leafless, nature was asleep. In the course of the forenoon I walked to Hamburgh where in the Böhmcke strasse - a not very genteel quarter - I found the lodgings of Mr. Christian Gräpel, a tall, lean, rather swarthy man; he had not much changed during my absence though his bushy black hair had turned greyish and his teeth were gone. Having been unfortunate in his business, he had, thanks to his connexions, obtained a situation in the excise office, upon the salary of which he contrived to live. His wife, a Miss Donner, had died, and his many children had gone out into the world to seek their fortunes. Julius, engaged in some mercantile pursuits, was a married man in Banff in Scotland; Cæser farmer in Illinois; Christian a medical practitioner in the vicinity of Hamburgh; Adolphus doing a thriving apothecary's business in Flensburg, his sister Susan was with him; finally Hans and Henrietta, (the former married to a Miss, the latter to a Mr. [Reutorff]) were settled in Wisconsin. Thence I went to [348] Mr. Daniel Schutte's in the Esplanade with whom I conversed on many subjects of interest to him and to me, time slipped away so rapidly that I had to call for a "droschka" in order not to be late for Sieveking's dinner which was already on the table when I arrived. At 6 in the evening I paid a visit to the widow of J. C. Donner, who still had preserved some traces of her former good looks; her two sons, successors in their father's business, Jean married to a Miss Storjohann, and Conrad, the husband of a Miss Silvester, were agreeable young men, of course I had known them as boys. At a later hour I joined the family party of the Reincke's who, in the winter season, met every Tuesday evening at their father's. The sisters sat all on the sofa knitting and chatting whilst in the adjoining room, the gentlemen were playing at "l' hombre" and whist. I took Mrs. Semper to supper and sat between her and Mrs. Knauer, the latter of whom called to my recollection some passages from former years which I thought would have been obliterated from her memory. We broke up at 11.

Wednesday, $27^{\text {th }}$ of December 1843. This day I once more devoted to the renewal of old acquaintances. I called upon Mrs. Jette Gottig, who, when Miss Rohde, was the belle "par excellence" in our little dancing parties previous to my departure from Europe, she - about my age - was still pretty, and conversed more agreeably than any of the Altona ladies with whom I had hitherto come in contact, her husband - probably because there was something wrong in his business - had absconded a few years after their marriage and nothing was known of his whereabouts. For several years her friends had made an annual subscription for her, but this she now refused to admit any longer, because she said that she could gain her livelihood by giving lessons on the piano. My next visit was to a very different person, Miss Hannchen, J. Willink, of whom I will say nothing, because the less said of her the better; she resided in the village of Ottensen in a large comfortable house, not finding her at home I 
left my card and then perambulated the [349] dirty roads of this place until I emerged on the highway to Flottbeck. I entered Rainville's garden and strolled to the Pavilion in the left corner whence the prospect over the wide "Elbe" to the Hanoverian side is always beautiful, even in the most unfavourable season, from side to side it measures nearly 3 miles, but the very large islands on its left bank make it appear much narrower. Mrs. Gabain, the widow of the much beloved and respected Calvinistic clergyman of that name, I still found wonderfully robust and agile for her age, which she told me was 79. I was home for a supper, consisting of apple soup, bread and butter, and cold smoked tongue, when my host and hostess had retired to rest I amused myself with the perusal of an interesting diary written by my nephew Charles Ropsy during his journey through Italy.

Thursday, $28^{\text {th }}$ of December 1843 . I determined upon paying this morning a visit to the young Armeros in the boarding school at Flottbeck. At pages $430 / 1$ of the first volume of these extracts I have given such an exact and correct description of the road which leads thither that it would be useless to reproduce it here, and I will therefore content myself with saying that, notwithstanding its bad state, caused by the wet weather, I much enjoyed my walk. Wheresoever there was a gap in the almost interrupted row of villas with their parks and enclosures, I stopped and admired the view over the wide river, alive with steamers, large and small sailing vessels, then I walked on again; sometimes I was lost in deep thought and thus, almost imperceptibly, I reached the spot, about 3 miles distant from Altona, where the sombre lane spoken of page 431 volume 1 , turns off to the right; following the same I easily found the boarding school, the present director of which, Dr. Cramer, was on the point of transferring the establishment to a Mr. Döse; he was busy packing up his trunks and boxes, however for quarter of an hour he conversed with me and gave me some account about the young Armeros; Ricardo he said, had at first been literally untamable, by and by he succeeded in conquering his violence, but upon the whole he did not appear much satisfied with the two boys, nor did I myself [350] find that they had made much progress, German they spoke fluently, of French they knew more than of English. I returned to Altona the same way I had come, however when at the second mill, I descended to the river's bank, walked along the pretty, clean villages of Neumühlen and Ovelgönne (see page 427 volume 1), reached the spot where we used to bathe; I recollected the first day when I was dipped into the river by Mr. Ropsy, then quite a child, a little further on, the well-known garden of C. H. Donner and the pond with the swans came in sight, here the path ascends and I had to run up the long ladder-like steps so as to regain the turn pike road, this I crossed and entered the village of Ottensen. Miss Hannchen Willink was at home, 
after some friendly altercation we agreed, that, hereafter we should call each other by our christian names, and "You", not the familiar "thou". Then will be remembered that she was (in 1868 she is still living) the cousin of my mother, the sister-in-law of C. H. Donner who had been married to her sister, and at the same time sister-in-law to [...] Henry Sieveking, his sister Ernestina being the wife of her brother Lucas. After a few words conversation she led me to an inner room, where Donner sitting on the sofa, was apparently quite at home. There were two young girls, whom Hannchen told me she had under her charge, but regarding whose birth and lineage scandalous rumours were afloat, over which I prefer throwing a veil. I left along with Donner, he, on our walk, complained of the Sievekings just as they had complained of him; he, being one of the two guardians of Charles Ropsy, said that he was by no means pleased with his ward's journey to Italy, and added that he had contributed considerably to the education of the young man, which "considerably" I afterwards learned was decidedly false.

Friday, $29^{\text {th }}$ of December 1843. Some visits still remained to be paid; My cousin Nelly Hugues, now Mrs. Dr. Kramer, had not yet returned from a journey to her brother Theodore, the Calvinistic clergyman in Celle. Albert Schmidt I did not find in, whilst his brother Gustavus was at home [...] [351] In 1823, the year of my departure from Altona, he was studying at the University, now he was a physician, but with a poor practice. His wife, Emily Schwartze, was particularly agreeable and lively. They had no children. Another call I made upon E. F. Mutzenbecher whom I had known upon the West Coast as partner of Huth Grüning \& Co., but whom ill-health had forced to retire from business; he suffered from epilepsy and notwithstanding this horrible malady he had found a wife whom he introduced to me, her appearance was that of a servant girl, in him she had met with a husband, in her he had met with a nurse. I was back in Altona just in time to go with the Sievekings to their mother's, there to dine. A young Dr. Sieveking, son of Edward of London who, many years later became physician to the Princess of Wales, and Miss Malchen Sieveking, another relation of the family, made up the party, this latter was a very remarkable person, she having devoted all her life and time to charitable pursuits; in Hamburgh she had established several beneficent institutions for the poor to which she attended with indefatigable perseverance; of late she had been called to Copenhagen for the purpose of founding similar establishments, and had been received by the Queen with particular kindness and distinction. During her stay there she had written a diary which she read to us, upon the whole it was interesting, but occasionally traces of vanity were discernible. The evening I spent at a party at Sempers, besides many members of the family, I found there Fischer, apparently a clever man, who had been a clerk at Donner's after 
my leaving, also his wife Ellen Dankerts, and his partner Otto Heyne. Semper did not like card-playing, therefore the time passed in animated conversation, in which however I could take little part, as it turned mainly on town topics. The Altona Kiel railroad was the engrossing subject, and they gloried in being able to carry out this undertaking, not only without the assistance of, but even in opposition to the first families of the place, such as the Baur, Donner and Hesse. Semper and Arnemann were the Directors [352] Theodore Reincke, President of the Committee; which may be considered as the Legislative, the Directory as the executive power. 18,500 shares of 100 "species" each had been issued, of which the town of Altona had taken 4000, Semper and Arnemann 100 shares each. The "species" was a silver coin worth about 5 s 6 1/2 each; in later years these species, on account of the excellent quality of the silver, have nearly all been remelted. At supper I took my seat between Mrs. Semper and Mrs. Theodore Reincke, the former plain, the latter pretty, both agreeable.

Saturday, $30^{\text {th }}$ of December 1843. Sieveking introduced me to his cousin George Baur, son and partner of his father Fritz, he was an agreeable young man, my junior by about 8 years, and originally brought up for the law, but when his elder brother Henry, whom his father had selected for being his partner, declared his disinclination to continue the mercantile career, the second son George was called from the University to take his elder brother's place. With Sieveking I went on 'Change where I made the acquaintance of Mr. Kedenburg, for whom his partner, Mr. Paulsen, Danish Consul in Valparaiso, had given me a letter of introduction, afterwards I called upon Albert Schmidt, who together with his brother Gustavus, had been from my tender childhood until I left for school in England, my best beloved playfellows, when he entered the counting house of Peter Keetmann, and I that of Donner, we saw less of each other, but always remained on the best terms; I not only liked but respected him; in 1843 he was subject to a dreadful infirmity, he had a weakness in the spine which rendered his legs powerless; with the aid of his servant he could walk a few steps, otherwise he sat the whole day on the sofa, his chairs were set on castors so that whenever he wished he could roll himself about the room which of course was boarded, not carpeted. I wondered at his equanimity, nay at his good spirits. He took an interest in everything that was going on and had fortunately many friends who visited him; though he could not make himself useful to his partner Mr. Möller he had still an interest in the business carried on under the [353] name of Schmidt and Müller. I dined in Altona "tete á tete" with my old principal C. H. Donner, he received me in his study, when a servant in livery announced with a low bow that dinner was on the table. The cooking was excellent, everything in the French style. Our conversation did not flag for a moment. I left at 8.30 p.m. 
Sunday, $37^{\text {st }}$ of December 1843. Mr. C. A. Nopitsch came to see me early in the morning. He was the same which he had ever been, a drudge in Donner's office; he lived and died in his capacity of book-keeper and correspondent. At a later hour Sieveking accompanied me on various calls which I had to make. First we went to Mr. Lübbes' an elderly, really good and kind-hearted man, a bachelor, in bad health, with a broken constitution. Next, to the brother of Sieveking's mother Fritz Baur and his lady, the wealthiest people in Altona; she was not bed, but chair ridden and could not move without assistance; he, a small spare man, more than 70 years of age and in every respect the very reverse of his commercial rival C. H. Donner; this latter, tall and now getting stout, was domineering, authoritative, ostentatious and ambitious, he continually strove for distinction and increase of riches, all that he possess'd he owed to his own exertions. Baur, on the other hand was mild, unpretending, unobtrusive, and perhaps too economical, considering his large yearly income, his station in life, his business; part of his fortune he had inherited, and merely followed in the footsteps of his father. It was generally supposed that with more energy he might easily have widely extended his mercantile transactions. The third visit was to Mr. Bockelmann, sickly, very polite and gentleman like in his manners. He was a complete stranger to me, and I only paid him my respects because he took a great interest in the welfare of my nephew Charles Ropsy, whose most intimate friend was young Bockelmann. Donner I was told was desirous that Ropsy should commence his diplomatic career in a Government office in Copenhagen, but Ropsy preferred trying his luck in Wurtemburg, this intention he ultimately carried into effect, but alas, not long after a fatal disease (consumption) put an end [354] to his life and all his plans. Henry, the eldest son of Fritz Baur, was the $4^{\text {th }}$ whom I went to see. Though he had obtained the title of Senator, he was in fact a miserable creature; he was so shy that in his own house he always remained in the back-ground, with great difficulty could he utter a connected sentence and nevertheless those who knew him intimately assured me he was not without some capacity; he had married a Miss Wattenbach, a clever sprightly lady who undoubtedly ruled the roost. Stuhlmann the merchant was the $5^{\text {th }}$ upon whom I called, pleasant but somewhat prosy; I heard once an observation made of him, that he was fond of threshing straw, not a bad simile to convey an idea of his insignificant and empty conversation. At Warnholtz's, with whom I closed my round, I met a physician, Harmes by name, whom I had not seen since 1814 - when he and I were pupils together in the $1^{\text {st }}$ class of the Altona "Gymnasium" or College, he seem'd glad to see me, and gave me a kiss, which I would willingly have dispensed with. At Sieveking's Ferdinand Reincke dined with us, and time hung rather heavily on our hands until about 8 o'c., when I went to Knauer's to spend 
there new year's eve. The party assembled was very numerous, for though the Sempers, Sievekings, and Theodore Reinckes were missing, who passed the evening with their respective parents, also old Lübbes apprehensive that a glass of wine too much might injure him, their absence was made up for by old Mr. Reincke, old Mrs. Elmenhorst, Theodore and Constance, Burgomaster Behn and various others. Two card tables were laid out, whilst by far the greater part, amongst whom Mrs. Knauer and myself, played at round games, 10 fishes for a German shilling, less than an English penny. I amused myself very well; all were in great glee. When supper was served the gentlemen conducted the ladies to the table according to the gradations of rank and age; I took Maria, the eldest daughter of the house. The substantials being consumed, a bowl of punch was placed on the table, singing commenced, and every glass taken increased the joviality of all present. At 1 we broke up, many wished to remain longer, but the old folk wanted to get to their beds. [355] Knauer, Warnholtz and I accompanied the Burgomaster Behn to his house, Knauer and Warnholtz me to mine, Knauer hallooing out in a stentorian voice when opening the street door "a happy new year to you all". It was 2 o'c. before they reached their homes.

1844

Monday, ${ }^{\text {st }}$ of January 1844 . I commenced this new year with a headache, result of the previous night's excess, therefore to rid myself of my pain, instead of going to Church as I ought to have done, I, accompanied by Henry, the eldest boy of Sieveking, took a walk about half way to Flottbeck; though the wind was high the sun was out, and the bracing air did me good. The officers of the civic guard, Sieveking among the number, waited in the forenoon upon Conrad Count von Blucher Altona, to whom as representative of his Danish Majesty, under the title of Supreme President of Altona, they had to deliver their congratulatory addresses. I also had once more a round of visits before me, however as some of those whom I went to see were not at home, of others an account has already been given, I will not enumerate them all and only say that at the widow's of J. C. Donner a good lunch was spread to which young Emil Hesse, one of the sons of the rich jew Isaac Hesse, also 2 clerks from the counting house, Conrad Donner, Gretschen Donner, Warnholtz and wife, and myself, sat down. Having made good use of our knives and forks, some of us rose and repaired to old Conrad Hinrich's who actually held a levee, so many people went and came; even Mr. John Henry Schröder of Hamburgh, the father of Bernard Donner's wife, paid his respects to the old gentleman. At old Mrs. Sieveking's I saw some new faces, viz.: Blacker, the widower of Line 
Becker, this latter often mentioned in the previous volume; also Dr. Kramer, husband of my cousin Nelly Hugues, whom I must confess, I was very far from admiring: he appeared to me to possess neither great intellect, nor knowledge, and nevertheless he was pertinacious and fond of laying down the law; he was brought up a lawyer and though his practice was not very considerable, yet his gains added to the interest on the small fortune inherited by my cousin, enabled them to lead a retired life. Again at old Mrs. Elmenhorst's, some acquaintances [356] whom I believe I had never thought of since I left Altona, made their appearance, for instance Gustavus Wall and Wm. Stoppel with his lady. I made an attempt to see my revered teacher of the college, Professor Claussen, but his house was closed and I could not gain admittance. At 4 o'c. I went to dine with Theodore Elmenhorst, we were only the family, and Otto Heyne, the brother of Constance, Mrs. Elmenhorst. I spoke of him page 415, Vol. $1^{\circ}$; he had now become an agreeable gentleman, and had lately lost his youthful wife, an English lady, of whom all who had known [_] spoke in high terms; his last-born, twins, Mrs. Bernard Donner had taken charge of for the present. Theodore and Constance having lived for some time in London had brought an English nurse with them to Altona, their children had not yet forgotten their English, and their house was the only one where I observed a little of that English gentility to which I am so partial. Soon after dinner Mr. Johann Julius Reincke, also Mr. and Mrs. Wm. Gossler, joined us; this Mrs. Gossler - Betty - daughter of J. C. Donner, was a little child when I left; she had become a good-looking, rather corpulent lady, to me entirely devoid of interest. Her husband was pleasant and lively, a partner in the great Hamburgh firm of Berenbergh Gossler \& Co. We played cards, supped, and broke up at about 11.

Tuesday, $2^{\text {nd }}$ of January 1844 . When walking to Hamburgh to pay a visit to my cousin Mrs. Kramer, I did not as hitherto go through the centre of the town but immediately on entering the gate the "millern Thor", turned off to the left and ascended the ramparts by a gentle incline; these ramparts which surround Hamburgh towards the west, north and east, (the south side being bounded by the river) are very broad, as there is room enough for a wide carriage road and pretty walks for foot passengers, through grass plots, flower-beds, and shrubberies. Here and there a monument is erected, one in the northeastern corner to the memory of a certain Mr. Repsold, who, as chief of the firemen, had distinguished himself on many occasions by brave and valient deeds. The ramparts are encircled by a wide deep wet ditch, fed by the waters of the "Elbe". Half an hour's walk [357] over the ramparts brought me to another gate, the "Damm Thor" where I descended. My cousin could not receive me, she being indisposed. The evening I spent at Mr. Johann Julius Reincke's in the usual 
Tuesday party; I have in my possession a handsome lithographic engraving which gives a good idea of this family circle.

Wednesday, $3^{\text {rd }}$ of January 1844 . When I awoke it blew a complete hurricane, the ground was covered with snow, winter had set in. I spent a quiet day and for the most part was occupied writing in Sieveking's Counting house.

Thursday, $4^{\text {th }}$ of January 1844. In the forenoon I called upon Theodore Arnemann who is considerably younger than I, and I had hardly been acquainted with him before my departure from Europe. He had now succeeded his deceased father in his mercantile pursuits. At 5 p.m. I, together with Sieveking and his wife, drove to Mrs. Baur's, the widow, who gave a large dinner party to celebrate the betrothal of Löhmann and Sophia Willink. We entered the room where the cloaks are deposited at the same time with lawyer Stuhlmann, his wife and stepdaughter, Caroline Testorff. The latter my friends had extolled to me more than once, and I was therefore glad to make her acquaintance so unexpectedly; she had been living for some time in Bordeaux where her father and mother had resid'd and she had thus acquired something of the French manners, which became her well, she was also good-looking, not to speak of a rather large mouth. The lawyer Stuhlmann, after having led a gay life in his youth had married, in the autumn of his age, Caroline's mother, the widow Testorff. Up stairs the company was assembled, consisting, if I recollect aright, of the lady of the house, her companion Miss Bertran, Mrs. Sieveking, Ernestina, her 2 daughters, Miss Götz, Löhmann, his friend lawyer Callisen, Consul Hildebrand from Hamburgh with his wife - a Miss Baur - Mr. Fritz Baur, his daughter Augusta, his son Johannes, the merchant Stühlmann, Ed. Reincke, Senator Gähler - wry-necked - whom I now saw for the first time since my arrival [358] and the already mentioned Stuhlmanns. The folding-doors were thrown open, dinner was announced, each gentleman selected his lady, I offered my arm to Caroline Willink, and in twos and twos we proceeded to the dining room. Dinner of course was excellent. I ate little and drank sparingly. To my left sat Miss Testorff; both, with her and Miss Willink I sustained an animated conversation, of the two, Miss Testorff had no doubt more "savoir vivre". After dinner the gentlemen retired to the smoking room, only the widower Stühlmann, Sieveking and I remained with the ladies; conversation however slackened, and I rejoiced when the smokers re-entered and came to our rescue. Tea was served. I chatted with one and the other. With Miss Testorff I looked over some illustrated Leipsic papers published in imitation of the London illustrated News, and at 10 oc. the guests retired.

Friday, $5^{\text {th }}$ of January 1844. In the course of the forenoon I called upon Mr. Claussen, whom the King, in consideration of his great services at the Altona College, where he had been teacher for not less than 55 years, had recently 
honoured with the title of "Etats Rath" (Counsellor of State) and had at the same time I suppose permitted to withdraw from active life on a pension. Mr. Claussen was now nearly 82 years of age, his aspect was venerable, and excepting a slight difficulty in hearing he was in possession of all his faculties. During the period that I was a pupil in the College from Easter 1809 to Midsummer 1814, he occupied the second rank under the name of rector, and taught Geography, German literature, English, and Latin; he also gave private lessons in the Danish language. Of all his colleagues whom I had known, Director Struve, Professor Feldmann, sub-rector Lilie, Mr. Ropsy French master, Mr. Bunssen drawing master, and Mr. Kroymann, master of writing and arithmetic, he was now in 1844, the only survivor. With him and his lady - also of an advanced age - I remained more than an hour, very well pleased. In Hamburgh my cousin Mrs. Kramer was visible, she was extremely glad to see me, and almost smothered me with kisses which I received but did not return; she insisted upon my dining [359] with her to which I willingly agreed. On 'Change I conversed with many of my acquaintances, amongst whom with Henry Schaar and Herrmann Dreyer, the former, by many years my senior, had been clerk in my father's office, and was now a respectable broker of clover seed and other grains. The latter, exactly of my age, had been my playfellow in our childhood; he was a thorough merchant, a great arithmetician and whist player; in 1827 I knew him in Lima as agent for the Rhenish West India Company, and in 1844 he was partner and principal man of the firm of Oswald \& Co., also one of the members of the Hamburgh Commercial Tribunal, a clear proof of the great opinion entertained by his fellow merchants of his capacity for business. I returned to Kramers. My cousin was extremely affectionate and still looked pretty well; what I disliked in her was a propensity to find fault with every person whose name came on the "tapis", and this she did in so positive a manner as to preclude the possibility of contradiction. Her husband the Dr. pleased me rather better than he did on a former day, he insisted upon our calling each other "thou", which I could not gainsay. They had one pretty little daughter, Maria, 10 years of age, their second daughter Cornelia had died in 1842 immediately after the great fire. Another little girl, Louisa Hintze, they had adopted as their own so as to have a companion for their daughter. Dinner was very good, but attendance we had literally none. Kramer had only one servant who was both cook and maid of all work. In Altona I was present at a party given by Warnholtz in celebration of his wife's birthday; there were all the Reinckes and Elmenhorsts. I played 2 rubbers of whist and Vingt-un with the young folk, but the whole was dull and insipid.

Saturday, $6^{\text {th }}$ ofJanuary 1844 . Sieveking introduced me to the rich Isaac Hesse, who, I now heard for the first time, had abjured Judaism and been baptised; his 
daughter Mary ran in and out, probably with no other object than to have a look at the new importation from South America, meaning my humble self. Mrs. Hesse was not visible being occupied dressing for a large party to be given in Hamburg [36o] by the Senator Merck in celebration of his jubilee, 50 years having elapsed on that day since his first arrival in Hamburgh, a poor unknown boy from the south of Germany. At a later hour we repaired to a dinner party given by the lawyer Stuhlmann, probably once more in honour of Löhmann and his bride. I will not enumerate all the persons present as they were more or less the same whom I had met on previous occasions; there were however some new faces, to wit the architect professor Hansen, a music master, Marxen, invited for the sole purpose of accompanying Miss Testorff on the Piano whilst she was singing, also Henry Stoppel, my fellow pupil in the College, now a lawyer of some repute, who addressed me at once with the confidential "thou" of olden times. Lawyer Stuhlmann the landlord, was particularly polite towards me; he apologized for not having requested me to take his lady to the table, and added that as Sieveking had done so, while I had led Mrs. Knauer, he supposed this had been preconcerted between ourselves, which imputation I of course disclaimed, and expressed a hope that another time I might be more fortunate. Whilst at dinner I had a very long coversation with Mrs. Knauer, she gave an account of how her marriage had come about, and how, ever since, she had been living in Altona with her husband, family, friends, and acquaintances. To me it appeared that, at the commencement of her wedded life, the want of polish in her husband and his family had not passed unobserved by her, however in course of time one gets accustomed to everything, and the kindness and good nature of Mr. Knauer could not be surpassed. Dinner over coffee was hand'd round, Miss Testorff herself superintending the making, then the gentlemen retired to the smoking-room, and I, not to be left alone with all the ladies, had to follow their example though rather against my inclination. I will here note a few points in which, on such occasions, the customs of the north of Germany differ from those of England. In the latter country Port and Madeira are generally left till after dinner, whilst, in the former these 2 wines are handed round immediately after Soup; Rhenish wine, champagne and some sweet wine such as "Malaga" make their appearance between [361] the courses whilst each gentleman has a bottle of Bordeaux wine standing before him. In England the viands are carved by the host, and each guest serves the dish placed before him; not so in Germany; there at dinner-parties at least, everything is left to the servants, who carve and hand round, the guests helping themselves or refusing as they choose; the table-cloth is not removed and both ladies and gentlemen leave the table at the same time. It is a great desideratum to have an 
equal number of both sexes, so that every person may have a partner, and as in Altona the fair sex preponderates, single gentlemen, such as Ed. Reincke, the merchant Stuhlmann, and I - then by myself - were in great request.

Sunday, $7^{\text {th }}$ of January 1844. I paid a visit to Dan. Schutte at his lodgings in the "Esplanade" Hamburgh. We conversed a long while then he accompanied me over the picturesque Lombard Bridge which separates the 2 beautiful sheets of water called the inner and outer Alster to a handsome new street called St. George on the Alster, this street consists of only one line of houses divided from the river by a carriage road, foot pavements and a row of trees. Here Hermann Dreyer and Johannes Limpricht lived, the former had gone out, the latter I found at home together with his young wife, Miss d'Albert, both very nice people, short and stout, I believe they were fond of good cheer; their house which was their own, and built according to their design, was very convenient, prettily furnished, and commanding a fine view over the river to the country beyond, the Lombard Bridge and the new Jungfernstieg. Johannes and his younger brother Bernard had formed a mercantile establishment in Rio under the firm of Limpricht Bros. and did a profitable business, Bernhard resided in Brazil, Johannes in Hamburgh. I dined in Altona at C. H. Donner's, the party was small, consisting of him, his sister-in-law Hannchen Willink, his sister Mrs. Elmenhorst, Theodore Elmenhorst and wife, Wm. Heyck and wife, the architect Hansen, Otto Heyne, a Miss Rosenberg daughter of the old drawing-master of former times and myself. Wm. Hayck, now a physician, I should not have recognized, so different did he look from the fair headed, curly [362] locked mild boy, the playfellow of Johannes and Bernard Donner. Dinner, wine, attendance, everything was in style, a plate of oysters placed before each guest, then a glass of hock, both before soup, were an innovation much to my liking, whilst tables were arranged and at about 11 the party retired.

Monday, $8^{\text {th }}$ of January 1844. In the evening I went to the Altona theatre in company with Semper, 3 sisters Reincke and their husbands. The Altona theatre was an insignificant building, its inside painted without taste, and generally speaking the actors were $2^{\text {nd }}$ or $3^{\text {rd }}$ class; of this inferiority they gave a proof in the performance of a silly farce which they represented. The main attraction was the so-called "tableaux vivants", or more properly speaking, the imitation of statues or groups of statues by human beings placed exactly in postures similar to those of marble sculpture. Those parts of the body which were to represent nakedness were covered with flesh-coloured tights; the females were upon the whole enveloped in a superabundance of drapery. The performers stood perfectly motionless on a large platform which slowly moved round in from 2 to 4 minutes, so that the spectators could see the group from all points, a strong light fell exclusively upon them, the rest of the house being darkened, 
and the "tout ensemble" had thus a very fine effect. A Mr. Müller, who in previous year had on account of his great strength, acted the part of a stage Hercules and who now called himself Professor, was the chief of the Company which he carried with him; in such groups where more persons were required than he had at his disposal, some of the Altona actors lent their assistance; he himself was an athletic, well-shaped man, perhaps a little too corpulent, and in his flesh-coloured "Tricot" - a cloth wrapped round his loins - was in my opinion, a not very proper object to be stared at by young unmarried girls, of whom there were not a few in the house. The statues represented were, "The fight of the Amazons", sculptor Trick. "Ariadne" on a panther, the property of Bethmann of Frankfort sculptor Dannecker. "Tatius and Romulus", David. "Vulcan", Thorwaldsen. "Vulcan and Venus", Flaxman. "Rape of the Sabines", an antique. "Jupiter [363] and the Muses", Flaxman. "Herrmann and Thusnelda", Schadow. "The Gladiator", an antique. "Mars and Amor", Thorwaldsen. "The Wrestler*", an antique. The "river-god", Thorwaldsen. "Ajax and Cassandra", an antique. "The murder of Abel*", Javise. "The fright of Cain", Canova. "The burial of Abel", Thorwaldsen. "The rape of Hylas," Solm. Those marked with an asterisk were represented by Professor Müller himself. "Hermann and Thusnelda" was most applauded, they appeared covered with hare skins in lieu of the skins of wild beasts. I was informed that Professor Müller had given similar exhibitions, the performers in a state of actual nudity, in the neighbouring village of Eimsbuttel, (entrance fee 1 "Louis d'Or"). They had very properly been suspended by order of the police. I ended the day at Semper's, where a nice little party had united, all were in high spirits, because a decree had arrived from Copenhagen fixing the spot where the terminus for the Kiel Altona railway was to be erected. The directors, Semper and Arnemann, determined that a subscription ball should be given in Rainville's hotel to celebrate this happy event.

From Tuesday, $9^{\text {th }}$ to Friday, $12^{\text {th }}$ of January 1844 . The cold increased. It snowed occasionally and masses of drift Ice appeared in the Elbe. On Friday the weather was beautiful, the sky cloudless, and the hard ground all covered with snow was glittering in the rays of the bright though powerless sun. A long walk down the Flottbeck road afforded me a healthy and pleasant exercise. Tuesday evening I spent at old Mr. Reincke's where the family circle was complete with the exception of Sieveking and his wife which latter, always delicate, had been taken ill with cramp in the stomach and consequently was confined to her bedroom for several days. On Wednesday I was at Kramer's in Hamburgh to witness the distribution of the Christmas presents which had been postponed till this day owing to my cousin's absence. I need hardly say that the children were as happy as could be. I met here two ladies who in their youth were in 
great repute for their good looks, Malchen Hänckel married to a Mr. Kirchner, a tea-dealer, and her elder sister Augusta, the wife of Mr. Augmordt, the director of an insurance Compy.; the ladies [364] were very nice persons, of the husbands I know little. Kramers, who were very kind to me, gave me a bedroom in their house and I therefore remained with them till next morning. In their political opinions they were ultra conservatives. He was opposed to the slightest change in the Hamburgh constitution; she, in her household affairs wanted everything to be carried on in the same manner as it had been the custom in her mother's life time; neither progressed with the spirit of the age. On the following morning I paid a visit to Mr. Kedenburg, to whom I had a few introductory words from his partner in Valparaiso Mr. Paulsen; he was very polite, took me to his wife, and made me lunch with him. I also called on Mr. Henry Bachmann, a most uninteresting individual; I knew him many years previously on the West-Coast when he consigned himself with a cargo to Gibbs Crawley \& Co.; his partner Mr. Brandt was out of doors beating up for subscriptions to an Insurance Coy. which they were endeavouring to form. Friday I was invited to an evening party at the Counsellor of State's Claussen. On my first entering I did not know a single one of those present; gradually I became acquainted with a few of them. The gentlemen sat by themselves in one apartment, smoking, taking tea, and conversing on topics of general interest. The ladies in an adjoining room occupied with their knitting or needlework. The girls sang and played the piano. There was no card playing. At a later hour the supper was announced, and the guests, divided into small parties, each occupying a table. I procured a seat near Dr. Stintzing, a very intelligent man, and some of the younger folk, and I amused myself pretty well. I made an arrangement with one of the teachers of the College, Professor Frandzen, that on my return from my journey to Eutin and Kiel, he should give me lessons in Latin.

By the preceding it will be seen that the three weeks, more or less, which had elapsed since my arrival in Altona, were spent by me in an almost uninterrupted series of diversions, nevertheless I found time to occupy myself with reading and writing, and now and then to repeat my calls on some of my excellent female acquaintances, for instance old Mrs. Sieveking and Mrs. Knauer, both of whom treated [365] me with great friendship, and conversed on their own private affairs with an openness very gratifying to my feelings.

Saturday, $13^{\text {th }}$ of January 1844 . I rose at $1 / 2$ past 4 . As soon as I was dressed I ran to Knauer's where I found father and mother and the four eldest children, of course by candle light, at their coffee of which I partook, and as soon as Knauer was shaved, we got into the carriage which stood at the door, his own as well as the horses. This vehicle was of the kind called a "chaise", open, with 
2 seats, one altogether uncovered for the coachman, the other occupied by Knauer and myself was provided with a leather covering like that of a gig, which, drawn from behind, reached over the head; another, a leather apron covering the feet came up as far as the chest, the small space between the two could, when the cold was very piercing, as it was on this day, be closed by means of a wooden frame work with glass windows, which, joined to the cover from above, was fastened to that from below; thus the cold could only penetrate through any small casual chink, and therefore, as both Knauer and I were well wrapped up besides an extra protection for our feet and legs consisting of a woollen sack lined with sheep for myself and another sack filled with chopped straw for him, we felt but little of the inclemency of the weather, the only effect I experienced was an irresistible drowsiness caused by the action of the cold on my eyelids. We drove down the Elbstrasse, then turning to the left, we came to the open place before the town house, when the clock struck six. Day did not break until we were far out of town, we passed the large pond called the "Diebsteich" or Thieves' pond and stopped for a moment at the village of Langenfelde where the Custom house officers ought to have examined our luggage, none however appeared as no doubt the cold kept them within doors. Langenfelde was one of the points of the Danish Custom house line which encircled Altona, for this latter place being a free port, many articles which passed from it into the Danish territory - the Duchies included - were subject to the payment of import duties. At 9 o'c. we reached the "[Binsen] Mill" where we breakfasted on sausages and an excellent beverage made of hot beer, eggs and sugar. We next arrived at [366] the small town of Barmstedt, the market place was adorned with rows of trees and in its northern corner stood a statue roughly carved out of stone, representing a knight on foot of gigantic size armed with helmet, shield and sword; in many towns in the north of Germany such statues are found, they go by the name of "Roland's Pillars", but their origin and object are very doubtful. It is well known that Roland or Orlando was one of the famous champions of Charlemagne, and lost his life in the disastrous retreat through the defile of Roncesvalles; but, that the Saxons, the sworn enemies of Charlemagne, should have erected statues in honour of one of his warriors, is certainly not probable. Learned men are of opinion that such a statue merely denotes the jurisdiction which the town possessed and exercised over its inhabitants, and that "Roland" is merely a corruption of Rügeland, "rügen" in German meaning, to blame, to chastise. My own belief is that nothing certain is known regarding them, they exist and nothing more can be said. Further on we came to the town of Bramstedt on the small river "Brame", which at Itzehoe falls into the Stör. We continued our drive and arrived at Neümunster, a town of more importance than either Barmstedt or Bramstedt. 
We made here our dinner of good chicken broth, a Mr. Rencke kept us company; he and his brother were the proprietors of a large cloth manufactory and I was surprised to find how well he was acquainted with all descriptions of wool, he like the Edwards of Halifax observed that the Buenos Ayrian wool had a great defect, namely that of being mixed with many small thistles. On the other side of Neumunster we had to our left the lake of Bordesholm and arrived in Kiel at about 5 when it was quite dark. The Chaussé or Turnpike road which we had followed the whole distance from Altona to Kiel, about 12 German miles, runs along the somewhat elevated sterile ridge, which separates the western, extremely fertile part of Holstein, from the eastern, which though the nature of the soil is more sandy, is however well cultivated, produces much grain, and abounds in lakes, beech-forests and fine scenery. We alighted at a certain Mr. Possat's in whose house Knauer, who regularly every year about this time used to visit Kiel, had two small rooms, a sitting and a bed room [367] at his disposal. To obtain for me an apartment a servant was despatched to several hotels, but none provided with a stove, indispensable in the present season, was to be had, and I therefore willingly accepted Mr. Possat's offer to occupy a room in his house in the uppermost story, or rather in the loft, which had however a bed and a stove. Since a long series of years it had been the custom, and I believe it is still in 1868 , that every year between the $10^{\text {th }}$ and the 18 January, which period goes in Kiel by the name of "Umschlag" or "turning over the leaf", many of the landed proprietors of Holstein, a few from the southern parts of Schleswig, and some merchants meet there for the purpose of settling their money transactions. Knauer for instance found in this place many small tobacco dealers whom he had provid'd with the article during the year and who now paid their debts. Farmers made their appearance to pay their rents, to cancel or renew their leases; landed proprietors came to pay the interest they owed on their mortgages; to liquidate such mortgages, or to contract new loans. Add to those whom their business brought to Kiel, others who went thither to meet their friends, and thus the great influx of strangers at the time of the "Umschlag" is easily accounted for. Whilst Knauer went out to see his friends I called upon Mrs. Lilie, the widow of the sub-rector, an elderly lady whom I loved with almost filial affection. She was a native from Brunswick and as her name, Chaufepié, denoted, of French extraction, probably a descendent of those French refugees who at the time of the revocation of the Edict of Nantes abandoned their country for religion's sake. When I was born she was living in the house of my parents as a companion or assistant to my mother; at a later period, probably when the losses suffered by my father during the war obliged him to retrench our expenses, she left us and obtained a similar situation in Hamburgh with Mr. Schmidt, partner of Adamy \& Schmidt, whose wife had 
just died, and where she took charge of his two boys Albert and Gustavus, often mentioned in my diary. When the two Schmidts grew up she had again to look out for employment which she easily found at my grandaunt's, Mrs. Bernard Willink, and there she became acquainted with and married the sub-rector [368] Lilie, a widower with 2 sons, Jacob and Philip. This gentleman requires a passing notice. He was a man crammed with book learning, but more shy and diffident than any other person whom I have ever known; in the College he seemed to be afraid of his own pupils. He had not the slightest idea how to conduct himself in society, and in his own house he was continually studying and writing, but as his wife assured me he invariably destroyed what he had written, wanting the moral courage to publish it. He died in an Asylum for lunatics and left his widow in circumstances far from affluent, nevertheless nothing could damp her spirits and liveliness, and on this occasion, not having seen me for several years she received me with the kindness which I had anticipated. Her son Ernst, about 30 years of age, was teacher at the Kiel University with the title of "Colloborator". Knauer called upon me, and together we went to the Assembly rooms called the "Harmony". They were crowded with gentlemen, nearly all smoking, some walking about and conversing, others playing l'hombre at high stakes, none at hazard. Knauer, himself a smoker, exchanged a few words with his acquaintances, whilst to me the dense smoke soon became unsupportable. Up stairs were large saloons occasionally used for balls, now tables were spread to which 2 to 300 people sat down, Knauer and I of the number; we supped on Oysters and Rhenish wine, he never permitting me to pay my share of the expenses. We walked home at about 11 and I was glad to find a fire burning in my bed-room stove, for the cold was severe.

Sunday, $14^{\text {th }}$ January 1844 . When I rose at $1 / 2$ past 8 the windows of my bed room were frozen over. I breakfasted on a cup of coffee and some "zwieback" a kind of hard biscuit much used in the Duchies, and then took a run in and outside of the town. Kiel, well known for its University lies on the western side, towards the southern extremity of the long bay which enters from the Baltic in a southerly direction, inclining a little to the westward. From the town a pretty wood called "Dusternbrook" extends along the bay on its western side toward the north; here are public gardens, bathing establishments and country houses, all deserted and shut up in the present season. Across the bay now frozen over, a few vessels lying immovable in the ice, a [369] tract of land most carefully cultivated and rich in all kinds of produce named the "Probstei" stretches along the Baltic. Within the precincts of the town is a sheet of water, in this season of ice, the inner "Kiel" which communicates with the Bay. The town itself was in 1844 of little extent, the houses generally small, the castle and the University 
buildings without any architectural beauty. Hardly had I come home from my stroll when Hermann Willink jr. called, he, the son of H. Willink Sr., my mother's cousin, was nearly 40 years of age, good-looking and agreeable; a slight impediment in his speech and the consequent disinclination to mix in the great world had perhaps contributed to his choice of agricultural pursuits, at the time he worked a farm near Luttenburg and was doing well. With him I went to Mrs. Lilie's where I met his father and mother, and we drove together to a small farm called Stift, part of the large estate of Seekamp belonging to Count Schaak, this the father Hermann Willink had farmed, distant from Kiel about 1 German mile. The route thither lay for some time along the Bay, then crossed the Schleswig Holstein Canal at the lock of Holtenau. A little to the north of the Canal already in the Duchy of Schleswig lies the farm of Stift, where we alighted and where Mr. Willink gave me a hearty welcome, him and his wife I had not seen since summer 1822 when they were present in Raguth at the wedding of my sister Maria; their house was small but kept very neat and clean. On entering the hall there was on the right the sitting room well scented with tobacco for both father and son were inveterate smokers, they receiving abundant supplies of the weed from the younger son Charles, partner of Schön at St. Thomas. This good son did not limit himself to these gifts, acceptable as they were; towards the end of the year a letter arrived regularly in which he told his father that if he had any difficulty in paying the rent due about that time, he need only apply to Knauer who would immediately furnish him with the funds required on his, Charles' a/c. Close to the sitting room was the bed room of the old folk, on [...] side the dining room and another apartment arranged for [_] ann jr. and myself. Carpets were a luxury little known herabouts, the rooms [370] were always boarded. After dinner we paid a visit to the daugh [...] enrietta, who lived close by, and though only on the new year's eve she had been confined, by the by of her eighth child, was well enough to receive me, she was married to a Mr. Feddersen, land steward of Count Schaak. On our return we supped and soon went to bed. I will add here that as old Herrmann had never prospered in life his children had been educated at the expense of C. H. Donner, the boys in the boarding school of Mr. Köhncke in Nienstädten, the girl in Donner's house as a companion and friend of his daughter Betty, in 1844 a great lady at the Court of Copenhagen.

Monday, $15^{\text {th }}$ of January 1844 . Notwithstanding the great cold of the weather the 2 Messrs. Willink and I soon after breakfast started for a walk to the neighbouring estate of Knoop. The mansion was a stately building and the pleasure grounds attached were laid out with so much taste that even in the present winter season I could easily form an idea of the beauty of the scenery on a fine summer day. At the Knoop lock we passed over the Canal to 
Holstein side. This lock was under repairs, for it was the custom to postpone the necessary labours on the canal till winter, when the navigation was stopped by the ice, however the cold was now so severe that it was found necessary to warm the atmosphere by means of fires lighted in large stoves, to enable the artizans to proceed with their work. We returned over the Holtenau lock where the canal flows into the Bay; at the eastern extremity of the Bay the small fort of Friedrichsort is discernible. The Schleswig Holstein Canal, which joins the Eider near Rendsburg, is 18 feet broad and deep enough for vessels, drawing 10 feet. Its greatest height is at the Flamhude lake, between which lake and Rendsburg there are three locks, and the same number between the lake and the Holtenau lock. We were home in time for dinner, which meal here in the country is taken at an early hour. Afterwards we called on Mrs. Feddersen, whose husband's acquiantance I now made. In Stift the father Willink shewed me over his small establishment, his cow house, his barn and other buildings. The tonne is the measurement used here for landed property, it is equal to [371] 24 [_]then" or roods, each of [?]6 square feet. The rent of a "tonne" varied in [_] from 5 to $7 \$$ currency annually.

Tuesday, $16^{\text {th }}$ of January 1844 . The weather had become less cold, so that Herrmann Jr. and I, well wrapped up as a matter of course, could return to Kiel in an open carriage without any inconveniences. Having made my toilet I went to my dear Mrs. Lilie, well known in our family by the name of Mame, which, in my infancy, was the way I pronounced the word "Mamsell", the German corruption of the French word "Mademoiselle", and an appellation given to the female companions of the mistress of the house in respectable families. She invited me to sit down with her, her son, and a friend of his, to their homely dinner, which I did with pleasure. [Young] Lilie as assistant teacher at the university had an annual salary of CM 700 and his mother had a similar income from various charitable institutions, so that with great economy they could just manage to meet their expenses. The room in which I was received was very fairly furnished. The next visit which I paid was to Mr. Louis Pelt, an acquaintance of mine, an intimate friend of Henry Sieveking, old Mrs. Sieveking's protegé, and now professor of Theology in the University; he was a man of excellent character and sound learning, but his personal appearance was much against him, he was short and thickset with an uncommonly black beard, his wife who by him had only one daughter was pretty and very agreeable. I wonder how they ever formed the match. I finished the day in the theatre, small, its interior tastefully painted. An Opera called the "Tailor Cacadu" or the 3 sisters of Prague was performed, the most stupid and insipid play which I have ever seen. The amusement was corresponding. It was nihil. 
Wednesday, $17^{\text {th }}$ of January 1844 . This was a pleasant dry morning, cool, not cold. Merrily did Knauer and I roll along on the hard ground of the well-kept turnpike road. Just outside Kiel we passed through a village called Dorfgarten, lying opposite the town on the eastern side of the bay and in due time drive at the small town of Preetz, 2 German miles distant. Whilst Knauer was attending to his business I strolled about, and the only thing worth noticing which I observed was [372] a row of houses, enclosed by a wall, the gate of which stood open. This was the Convent, not to be confounded with a Roman Catholic Nunnery, for though it was inhabited by females, called "Ladies of the Convent" not Nuns, they were at liberty to go in and out as they pleased. The information which I obtained regarding this institution is the following; at the birth of a girl in the family of the Holstein nobility, her parents undoubtedly of the Lutheran creed could by paying in a certain sum to this Convent, secure for their daughter in after life, if unmarried, a shelter, that is to say some furnished rooms in this Establishment, also when her turn came she would receive some pecuniary annual aid. The money paid in was lost if the girl married or died. Count Raventlow had a house within the precincts, he was at the time the head of the Institution under the name of "Probst", which clerical title, though the Count by no means belonged to the Church, may perhaps be rendered by the English word Dean. The weather being pleasant I walked on the high road for a German mile until Knauer overtook me in the carriage and 1 mile further on we reached the town of Plöen, very prettily situated in the middle of a lake which it divides into two unequal halves. Here Knauer and I separated, he continued his journey in his own carriage, whilst I hired another to convey me to Eutin. Whilst it was getting ready I walked about the town, the houses have generally old fashioned gables; a large building dignified with the name of Castle stands upon a low hill, in front of it is an avenue of large trees and from this elevated spot I had a pretty view over the lake and town below. The carriage brought to me was a common vehicle, uncovered. Eutin is 2 miles distant from Plöen, the road thither leads through a pretty, partially woody country, abounding in lakes, which as already said, form the main feature of Eastern Holstein. I alighted at the Inn kept by Ranniger called the "City of Hamburgh". Having dined boots shewed me to the house of my brother-in-law, the architect Limpricht. He had removed from the house where he lived with my sister in Jany. 1823, when I saw my dear Maria for the last time, and now occupied a house at the very outskirts of the place, that next to his being that [373] of his son-in-law Mr. Bobertag. Limpricht had become a little grey-headed but otherwise not much altered, his second wife was, in my opinion rather coarse, even her pronunciation betrayed her want of education, but on the other hand, everything she said gave evidence of her sound common sense, and above all the quality which I 
admired in her was her great love of her step children, she making an exception to the general rule of step-mothers. When I entered she held in her arms Elizabeth's first-born, little Hans, 10 months old (in 1868 a clergyman of the German Lutheran congregation in Hull) and nursed him tenderly. Elizabeth, the eldest child of my sister, born in 1823 , was thin and slender, pale with black hair and eyes - she said they were green - her nose ugly, her mouth rather large but adorned with a fine set of white teeth, occasionally a slight blush tinged her cheeks which became her much, just as had been the case with her mother. She was very well educated, for when my sister died, though she was then only 9 years of age, a good foundation had already been laid. At first she was a little timid, by and by she lost her shyness and talked without reserve. She was much pleased with the present which I brought her from Mrs. Grautoff consisting of babies' clothes, also with the portfolio and the brooch which I had bought for her, the former in Liverpool, the latter in Glasgow. Her husband named Paul Bobertag, a native of Silesia, a few years older than she, rather plain, but agreeable in his conversation, was teacher in the Eutin College, he was well versed in the sciences to which he had dedicated himself, for instance Mathematics, Chemistry, and the different branches of natural Philosophy, but in Classics he was not very proficient, and of modern languages he knew little. Johannes, the eldest of my 2 nephews, was a fine strong fellow, 19 years old, he was brought up for the law and was shortly to leave the College, where he had reached the highest class, for the University of Kiel. Henry, 2 years younger was a nice open-hearted lad much addicted to Chemistry and Physics; his complexion was darker than that of his sister and brother and he was by no means bad looking. The youngest of them all, Herrmann, half brother of the others, was a round-faced boy resembling his mother, not much to my liking. We took our supper [374] at 8 o'clock, conversed a great deal, and at 11 I retired to the bedroom which had been fitted up for me in the house.

Thursday, $18^{\text {th }}$ of January 1844 . Limpricht's house was large, the rooms pretty nice furnished, all boarded, none carpeted, he let part of it when opportunity offered. Bobertag's house was much the same, only smaller. In both I saw some furniture which I remembered having seen in my parent's house in the "Elbstrasse", for instance a clock with a cupboard below, two clothes presses, mine, but of course never reclaimed by me, handsome engravings, also some pretty drawings by my two sisters in coloured "crayon" by my elder sister, amongst which a faithful likeness of my uncle Diedrich in London, and in Sepia by my sister Maria who excelled in the portraying of animals. A thaw had set in, the road had become very muddy, and I thus unable to take the long walk which I had proposed, contented myself with a stroll through the Ducal Park which, bordering the lake, is of small extent, but contains many avenues of tall 
stately trees. In its centre stands a poor irregular edifice constructed of brick with a yard in the middle which goes by the name of the Palace and which is occupied by the Duke, usually residing in Oldenburg, when he pays a visit to Eutin. The outhouses built in later times according to designs of Limpricht have a more tasteful appearance than the main pile. At dinner the whole family met at Limpricht's. In the afternoon I paid a visit to Mrs. Tramm and the two Misses Willink, sisters of Hermann Willink of Stift; they were ladies of a certain age, being cousins of my mother, though several years younger. The eldest, Mrs. Tramm, was a good farmer's widow, and nothing further; of the two others, both unmarried, Nancy, the elder was by far the more agreeable; in her younger days, she, without being handsome, looked rather interesting, and though she did not speak her own language grammatically, yet she had felt or pretended to feel a great "penchant" for Göethe's works and similar literature. Since I had seen her last she had altered in an extraordinary manner, whilst her younger sister Betsy, a poor insignificant creature, was the same as she had been 20 years ago. With the family of Limpricht they were on bad terms, for at the time of his second marriage [375] Nancy had expressed herself touching his bride in disparaging language and her words, talebearers, who are never wanting, especially in small places, had not failed to carry over to the party interested. Towards evening I spent several hours with Elizabeth and Bobertag who joined us, when he came from the College, in a very confidential conversation.

Friday, $19^{\text {th }}$ of January 1844. It grew colder, the ground was hard, and thus I could take a walk in the environs. I made a circuit of the lake, passed the village called Fissau, crossed the Pulverbeck wood in which some pretty walks are laid out and returned to the town at the extremity opposite to that from which I had started. In the evening a subscription ball was given at which Bobertag, Mrs. Limpricht, Elizabeth, Johannes and I were present; Limpricht and Henry did not go, the former still suffering from the gout, the latter because he was not yet confirmed. I, not having anticipated such a fete, had been under the necessity of borrowing a dress coat and trousers from Bobertag. We were accompanied by a young girl called Reinecke, the daughter of the music master Reinecke of Altona with whom my nephew Charles Ropsy, after his father's death had been placed by his guardians, she lived as a companion of a young noble lady whom she was principally instructing on the piano at an estate 1 or 2 miles distant called Sierhagen, belonging to the family of Von Plessen[_]. Notwithstanding the cold she had made light of coming so far in an open carriage, for if I mistake not it was her first appearance at a public ball and she was of course in very high spirits; she looked pretty enough only her dress much stiffened gave her a promontory-like appearance. Elizabeth in a rose-coloured silk and 
cotton dress with a silk shawl, once her mother's, the brooch which I had just presented to her and the filigree silver earrings which previously I had sent her from Peru looked very genteel. The weather was unfavourable, it hailed and snowed, consequently the three ladies and myself went to the ball in a coach lent by an acquaintance, whilst Bobertag and Johannes walked. The ball room whitewashed, lighted up by a chandelier and several branch lustres [376] (the candles I believe were stearine), floored not carpeted, was well filled, about 100 persons were present, the fair sex preponderating. Bobertag introduced me to the Directors who afterwards did not take any further notice of me. Upon the whole I found here less good breeding than in Halifax. At the Waterhouse's many gentlemen observing that I was a stranger accosted me and entered into conversation, whilst here though many enquired who I was, not one addressed himself to me. The dances were limited to 2 Cotillons and various kinds of waltzes. To the latter I stood up more than once, but though in Lima I was considered a good waltzer, and also in Halifax I managed to whirl round to the satisfaction of my partner, here I did not succeed, not being acquainted with any of the different steps. About midnight we sat down to supper, some in an adjoining saloon, others in the ball-room, everybody asked for what he liked and paid for it before leaving at the counter. A bottle of Champaigne which I asked for cost $[\mathrm{CM}] 6$, but it was poor stuff. We drove home at 4 o'c. This Ball was given by the Eutin aristocracy which consists of the Ducal employés, Teachers at College, clergymen, lawyers, medical men, and some burghers of the higher class. When the little shop keepers and artizans met in the same locality, then of course those of this evening stayed away.

Saturday, $20^{\text {th }}$ of January 1844 . This day being fixed upon by me for my departure, Johannes and Henry came to my bedside before they went to College to bid me good bye, to each of them as well as to their brother Herrmann I presented 3 Dutch Ducats. At breakfast the Bobertags joined us. Last night's party was discussed, Miss Reinecke returned to Sierhagen, I paid my farewell visit to the 3 sisters Willink and on my return requested Elizabeth to read some English to me which she did with a very fair pronunciation, she even understood difficult passages from Lord Byron's "Corsair". At about 11 a Mr. Rüder came to the door, he was a gentleman bound for Hamburgh like myself, and I had arranged with him to take a carriage on joint a/c. As far as Lubeck our conveyance was an open vehicle but though it froze the cold was not severe and the weather rather agreeable. I bade good bye to my kind relations [377] and we drove off. The cross or country roads until we reached the turnpike road were very uneven, for the deep ruts formed during the recent thaw had been hardened by the frost. Our route lay through a level country, sometimes woody and abounding in lakes and ponds. It was $31 / 2$ when we arrived in Schwartau, a 
town of modern appearance. Whilst Mr. Ruder attended to his business I passed the time in the room of an Inn, the floor of which was strewn with Sand, the landlord smoked and an old woman, perhaps his mother, spat incessantly. In all such Inns which can lay no claim to the name of Hotels, the vernacular "Patois" of the country - Low German - is always spoken; I of course understand it, but much regret that I cannot speak it. We entered Lubeck through the "Holsten Gate" which had once been the scene of carnage and desolation, for it was here where, in Oct. 1806, the French troops commanded by Bernadotte stormed the town to which Genl. Blucher had fled with a small part of the Prussian army defeated at Jena; now the handsome houses of the suburb and the fine avenue of tall trees leading to the Gate betokened many years of uninterrupted peace and tranquillity. We crossed the bridge over the "Trave", a Custom house officer very politely enquired whether we had with us anything subject to excise, and on our answering in the negative allowed us to pass without searching. It was now 1/2 past 4, the Diligence or stage coach started for Hamburgh at 4.45, I had thus a quarter of an hour to spare which I made use of to take a run through a few of the streets. I was struck with the antiquated style in which some of the houses were built; the top story was frequently used as a granary, not divided into apartments, towards the street its facade was shaped into a queer looking gable-end, and more than once this gable consisted only of a wall having nothing but an open space behind and serving as a finishing ornament for the building. The ramparts, like those of Hamburgh, were laid out in walks. When we left it was dusk, and ere long darkness concealed all surrounding objects. We were only 4 in the comfortable coach, with one of them Mr. Rüder entered into conversation on the intellectual character of the [378] Eutin and Hamburgh society; on this they dilated to such a degree that I soon got tired of it and fell asleep. The coach stopped at a place called am Berge the last town in the Lubeck territory, then in Oldesloe, Arensburg, Wandsbeck and finally entered Hambrugh through the "Stein-Thor". We alighted not far from Dr. Kramer's house, thither I went with my luggage and found my cousin and her husband just on the point of saying good by to a number of friends who had spent the evening with them. It was 11 o'c. and I, much fatigued hastened to the bedroom which had been placed at my disposal.

Sunday, $27^{\text {st }}$ of January 1844 . Hardly had I done breakfasting with my cousin when I was called upon by Mr. Franz Pini, a young man who was engaged for one of Huth's establishments on the West Coast and who had been recommended to me the previous night by Mrs. Mahncke, formerly Miss Lotte Zeller; at his request I gave him a few introductory words to my wife. I next paid 2 visits, the one to Johannes Limpricht who, being indisposed, received in his bedroom, the other to my excellent friend Albert Schmidt, 
who notwithstanding his dreadful malady, was so cheerful and pleasant that I readily remained with him more than an hour. The weather was agreeable, the Alster partly frozen, the hard ground, the roofs, the trees and shrubs on the ramparts covered with snow, all glittering in the rays of an unclouded sun, afforded a pretty winter landscape. On my return to Sieveking's in Altona I was met by the news that Hermann Reincke, for whom I had procured a situation in Gibbs house in Lima, had written his family that he was about leaving his present post and joining Lembcke at the beginning of the year, for 12 months as a clerk with $\$ 1000$ salary, then as partner with one third interest in the concern, $12 \%$ per annum being allowed Lembcke on his capital. This annoyed me not only because I had flattered myself that in course of time Reincke would have been promoted in Gibbs' employ, but also because at the time of my departure from Lima I was on very bad terms with Lembcke. Mrs. Theresa Sieveking was rather better in health than when I had left for Eutin, however not well enough to accompany her husband and myself to a large dinner party given by Mr. Fritz Baur in honour of Lohmann and his bride. In this house everything corresponded of course to the great wealth of [379] the owner. The viands, the wine, the china and glassware, the attendance of the servants, all was excellent in a superlative degree, but I, true to the rule which I had laid down to myself and which I strictly carried through to the end of the convivial season, was very abstemious both in eating and drinking. I took Ernestina Willink to the dinner table, to my left sat Mrs. Hildebrand of Hamburgh (Sophia Baur), a pretty young lady, I conversed with both but especially with the former, who gave me a long account of the reasons of her husband's absence in Norway, of her wish to join him there, of the dislike which her mother and brother had taken to him and so forth. After dinner, time passed in the usual manner and I will only mention that I became acquainted with 2 clever and agreeable men, Dr. Lappenberg, and Professor Ulrich of Hamburgh, both sons-in-law of Fritz Baur; they having once got hold of me they did not allow me to escape and much had I to narrate to them about Peru.

Monday, $22^{\text {nd }}$ of January 1844 . At an early hour Miss Gotz was with us solely for the purpose of complaining of the opinion which I had expressed in my conversation of the previous day with Ernestina, to the effect that she ought to join her husband in Christiania, and this, coinciding with her own ideas, she had made the best of, in a controversy with her mother, who was averse to her journey to Norway. I of course begged Miss Gotz to present my apologies to old Mrs. Sieveking for my having been the cause, certainly against my will, of some annoyance to her. In the forenoon I occupied myself for several hours with examining a large case which in 1823 I had left in charge of Mr. Lucas Willink and which had been remov'd to the loft in Sieveking's house. At 5 o'c. I once 
more repaired to a dinner party given by Mr. Geo. Baur. Here the guests were less numerous, and the whole arrangement less splendid than the previous day at his father's; nevertheless everything was very nice and I was much gratified with being in the company of such pleasant people as old Mr. Baur - in whose favour I rose rapidly - Mr. and Mrs. George Baur, Mrs. Stuhlmann, Caroline Testorff and others. New faces were Mr. Fiedler and his nephew, clerk at Baur's. My partner at dinner was Miss Augusta, the youngest and only unmarried daughter of Mr. Fritz Baur. [380] After having taken tea, Sieveking and I went to the railroad ball to which I alluded on the $8^{\text {th }}$ Janry. and which was given in the Rainville's Hotel. The subscription was, for a single gentleman, CM 6; for a gentleman with one or two ladies 10 CM, supper included. When we entered the large oval saloon which many years back had been added to the main building, dancing had already commenced; the saloon was brilliantly lighted up with many chandeliers, the walls were tastefully decorated, the orchestra consisting of 24 musicians was directed by a certain Behrens from Hamburg, and the whole scene was very animated. I and the friends of my youth without whom, more than 20 years back, no dancing party could have been given in Altona, were now of course considered as old folks, and contented ourselves with looking on, Ed. Reincke however excepted who still stood up now and then and danced with much more grace than the young people, who kept excellent time but danced rather wildly, even the French quadrille, where gentility and a kind of sobriety are required, became a romping dance in the hands of the Altona youth. I myself made several attempts, but though Mrs. Theresa Sieveking had endeavoured to teach me the waltzing step then in vogue, I by no means distinguished myself. We went to supper at midnight. I sat at the foot of the table, near me Mrs. Knauer whom I had handed in, then Warnholtz, Mrs. Constance Elmenhorst, Edwd. Reincke, and Miss Testorff; opposite at Mrs. Löhmann, with whom, though I had never seen her before, I kept up a spirited conversation to the great delight of her neighbour Caroline Willink, next to whom followed a Mr. Andersen from Norway, Mrs. Warnholtz and Theo. Elmenhorst. All agreed in declaring the supper very good, also the champaigne, of which Warnholtz and I ordered each a bottle. I was home by 3 o'c.

Tuesday, $23^{\text {rd }}$ of January 1844 . In the forenoon I commenced removing my few chattels, consisting of my clothes, books, etc. to Rainville's Hotel where I had rented 2 rooms. This hotel, so frequently mentioned, then just outside the town, was prettily situated surrounded by an extensive park gradually sloping down to the beach of the Elbe; from my sitting room I had a fine view over this park and the river to the opposite - the Hanoverian - shore. This room occupied by the King of Denmark on his latest visit to Altona, was [381] 
handsomely papered and carpeted, and the furniture though not new, quite as good as I had any right to expect. The adjoining bedroom looking toward the yard was not carpeted, otherwise comfortable. I paid 50 [CM] monthly which included hot water for breakfast. Bread, wine, tea, milk, candles and coal I had to purchase myself, and when I dined at home, which was but seldom, I got a nice dinner for which I paid at first $[\mathrm{CM}] 11 / 2$, which price I, at the instigation of my cousin Mrs. Kramer - who considered me very extravagant - reduced subsequently to $1[\mathrm{CM}]$. On the 13Jany. I have mentioned that Altona being then a free port, many articles imported from that place to the Duchy of Holstein were subject to duty. Rainville's Hotel lay outside this line of demarcation, and thus I had to pay duty on some writing material which I happened to have with me. At a later hour I called on old Mrs. Sieveking to enquire about the health of her grand daughters after last night's ball, and here I learned that Donner and Count Blucher-Altona were endeavouring to procure a situation in the Altona Lottery office for Lucas Willink. I may say in anticipation that nothing came of it, and only note this circumstance to give an idea of the low ebb at which Lucas' finances must have been at the time, for a place in the lottery office was always looked down upon as not very creditable. The evg. I spent in old Reincke's family circle.

Wednesday, $24^{\text {th }}$ of January 1844 . I finished removing to Rainville's and settled with Mr. Schwob, the best master of the French language in Altona, to give me 1 lesson weekly. At 5 o'c. I went to dine at Warnholtz's. This was a plain quiet party, very different from the fetes at the Baur's. We sat down as follows, Warnholtz at the head of the table, he was a kind, amusing, talkative host; to his right Mrs. Arnemann who was accounted a strong-minded woman and a patroness of the fine arts; I did not admire her for to me she appeared masculine, not to say coarse, and as to her patronage, I discovered afterwards that she was fond of having young artists in her train doing homage to her beauty; next to Mrs. Arnemann, Ed. Reincke, a vacant seat for Otto Reincke who was prevented from [382] coming by his occupation as one of the Directors of the alms houses, Jean Donner, Mrs. Warnholtz - both quiet people - Mr. Stammann, brother of Mrs. Arnemann, an architect - Mrs. Semper, whom I liked well, for though she could not be ignorant that her husband was fast rising in his native place and rapidly becoming one of its most influential men, she had - to use the vulgar phrase - "no nonsense about her", and she was kind and affable to everybody, my chair was placed next to hers, and finally came Mrs. Stammann, a pleasant, rather pretty, woman. Semper and Arnemann were not present, having too much on their hands as railroad Directors. I enjoyed myself well, and as soon as dinner was over, drove off to Hamburgh, where Albert Schmidt had invited me to spend the evening with him and some of his friends - all bachelors 
and men who, like the greater part of young Hamburgers, had led a very gay, if not dissipated life. They were, Tornquist, manager of the house of Leers \& Co. - Kreep, successor of Schlingemann - Mönch, an excellent fellow whom I had known in former years, and Adolphus Müller, Schmidt's partner, the most worn out man upon whom I have ever laid eyes; less than 20 years later he committed suicide, tired of the world where he found nothing worth living for, such a total wreck had he made of his physical and mental capacities. We had a rubber at whist, a nice supper, lots of champagn, and cheerful conversation. I rather passed the bounds of moderation of which I had made a rule, and did not reach Kramer's house before 12.30. The Doctor had been waiting for me which I much regretted.

Thursday, $25^{\text {th }}$ of January 1844. The streets of Hamburgh were nearly impassable. In that part of the town which had been destroyed by the great fire, new houses were being built, and there the dust and small particles of brick, as well as the remnants of the late ruins, mixed up with the melted snow, had formed a deep mire through which I had to pick my way when I went in search of a master in the Italian language, who however when at last I had hunted him up, told me, that he was too busy to spare me an hour. More fortunate was I with the Danish master whom I found in the person of a Dane named Birk who was employed in the Altona [383] mint and who agreed to give me three lessons weekly at the rate of $1[\mathrm{CM}]$ per lesson. I dined this day at $\mathrm{Mr}$. Henry Baur's, who though a Senator, was an insignificant little man, his wife on the contrary was a very superior lady. Present were his father, his mother - so paralytic that she had to be carried across the street in a sedan-chair and was moved about the house in an arm-chair - Henry Sieveking and wife, Mrs. Henry Baur's sister, the wry-necked Mr. Gähler, and some others. All these dinner parties were so much alike that the description of one will suffice for the whole. An equal number of ladies and gentlemen was the "sine qua non", next in importance was the excellence of the dinner itself, which over, coffee was serv'd, then came the withdrawal of the gentlemen to the smoking room, on their return tea, sometimes a game at cards, and the break up between 10 and 11. This was the first night of my sleeping in my new lodgings; when I entered the fire was burning in a small iron stove, candles were lighted, and there was an air of comfort pervading the place. Before going to bed I amused myself with the perusal of a pamphlet giving an account of a "Crim Con." Trial instituted in 1807 against Dr. Woolcot, better known by the name of "Peter Pindar", who after a close investigation, had been pronounced, "Not Guilty".

Friday, $26^{\text {th }}$ of January 1844 . I was so contented with my new rooms that I remained at home the whole morning. I went to the Hamburg Exchange with Sieveking, and here, as ex-partner of Gibbs Crawley \& Co. had to listen 
to a long narration of Mr. von Leesen who, some time back, had made an unfortunate flour consignment to the Lima house. I dined "en famille" at old Mrs. Sieveking's - where Mrs. Theresa did her best - though unsuccessfully - to teach me the Jäger step in waltzing. At an early hour I went home and read there Dr. Schleiden's interesting a/c of the great conflagration in Hamburgh from $5^{\text {th }}$ to $8^{\text {th }}$ May 1842.

Saturday, $27^{\text {th }}$ of January 1844. Mr. Birk, my Danish master, gave me my first lesson; he came a little past 8 and remained till nearly 10, I liked him well. The forenoon was taken up with my writing a long letter to Mrs. Grautoff. I dined at Kramer's in Hamburg whose [384] turn had now come to celebrate Löhmann and his bride's betrothal. These two, Caroline Willink and her mother Ernestina, Fischer, Otto Heyne's partner, his wife and mother-in-law, Mrs. Dankert, and I, formed the Altona part of the company. Mr. and Mrs. aufm Ordt, Mr. and Mrs. Kirchner and 3 lawyers were the Hamburgh guests. I conversed much with Fischer who was allow'd to be a man of considerable parts. I may however mention that C. H. Donner, whose clerk he had been after my leaving, observed of him that he - Donner - would be a very clever man if he knew all that Fischer believed he himself knew; also Theodore Elmenhorst assured me that though Fischer was never at a loss for an answer to any question put to him, he had invariably found on reference to printed authority that Fischer's answer was incorrect. When the Hamburgh people began playing cards, we from Altona drove home.

Sunday, $28^{\text {th }}$ of January 1844. In the course of the forenoon I called upon several of my kind Altona friends, of whom on this occasion I will only mention old Mrs. Elmenhorst with whom I left for perusal a manuscript which I had found amongst my papers, it was a cash book written in 1796 corresponding to a club of which my father and mother, Mr. and Mrs. Isaac Wall - both couples recently married - C. H. Donner, his sister Maria, (Mr. Elmenhorst) and several others, had been members at the time; she very naturally took great pleasure in looking over these reminiscences of days gone by. At 4 o'c. I walked to Hamburg and drove with Kramers to Wandsbeck, there to dine with Mr. and Mrs. Kirchner, this latter my cousin's most intimate friend. Wandsbeck is a village belonging to Holstein; the noble family Schimmellmann are proprietors of a large mansion there, which goes by the name of Schloss or "Castle", the park which surrounds it is not very extensive. In 1844 the village was filled with Hamburghers who had taken refuge there after the great fire. Instead of the ancle deep sand of former years, a well-kept turnpike road led thither, which passing through the suburb of "St. Georg", was lined with houses nearly up to the very entrance to Wandsbeck. The country about is flat and uninteresting. At Kirchner's we were by ourselves, everything plain and unostentatious. 
Mrs. Kirchner though an agreeable woman, had however a very broad [385] Hamburgh accent, and she, like my cousin and many other ladies, particularly of Hamburgh, not of Altona, made use of sundry queer German words certainly not to be met with in any dictionary.

From Monday, $29^{\text {th }}$ to Wednesday, $37^{\text {st }}$ of January 1844. These were wintry days, the wind blew high, it rained, snowed and hailed alternately, and large masses of ice floated up and down the river, through the midst of which small sailing vessels, which convey to the Hamburgh and Altona markets Turf, Fish, Vegetables, milk and other necessaries, with difficulty threaded their perilous way. The greater part of the time I stayed at home occupying myself with reading and writing. Monday evening till late at night I studied Virgil's "Æneid”, and had some difficulty in understanding it. On the following day I took my first Latin lesson in Professor Frandtzen's house, to whom I read and translated from this author. On the same day I had a Danish and a French lesson. At 9 a.m. I breakfasted on tea, bread and butter. Monday and Tuesday I also dined at home; the dinner hour I had fixed upon, was between 4 and 5. On Tuesday evening when returning from the usual family party at Mr. Reincke's, just before entering Rainville's Park, I saw suddenly before me in the dark night a blue light, and whilst I was wondering what it could be, a loud clap of thunder rolled over my head, and this accounted for the phenomenon, for thunder and lightning may well be called a phenomenon in the midst of winter in our high latitudes. On Wednesday I, together with my cousin Nelly, and her husband, went to a dinner party, which, if I mistake not, Mr. Kedenburg gave in my honour. Many guests had been invited, of whom I will merely enumerate Mr. and Mrs. Fischer, the clergyman Geffcken with his lady, Mrs. Fischer's sister, and Mr. Vivanco (Spanish Consul) with his wife. At dinner I sat between the latter and Mrs. Fischer, Mrs. Vivanco had still the traces of very great beauty, but as I was neither acquainted with nor introduced to her, I had no reason to enter into conversation with her; however Mrs. Fischer my right-hand neighbour, her husband next to her and I rattled away in fine style. In the smoking room Mr. Vivanco addressed me in Spanish and I had a long talk with him in this language. Up stairs Mrs. Vivanco, [386] a young man apparently a relation of hers, Dr. Kramer and I played right amusing rubbers at short whist and by 11 o'c. the party retired. Both at Kedenburg's and the other day at the Kramer's, though the whole arrangement was very fair, yet it cannot be compared to the gentility and elegance which prevailed in the first Altona circles which I frequented. I was much amused with my cousin and her husband who were in the habit of finding fault with every one; she harped upon want of education and accomplishments, he upon want of gentility. 
From Thursday, $7^{\text {st }}$ to Wednesday, $7^{\text {th }}$ of February 1844. The weather was agreeable, the cold not severe. In the daytime Reaumur's thermometer ranged from 1 to 3 degrees above freezing point, whilst the Frost during the night and early in the morning kept the ground hard and prevented the snow from melting; thus the bracing air gave tone to the system, strength to the nerves, and elasticity to soul and body. More than once the Devil's Bridge, near Flottbeck, was the goal of my rapid walk, on other occasions I strolled more leisurely over the Hamburgh ramparts, always in good health and buoyant spirits. The study of the three languages to which I had devoted myself took up much of my time. For the French master I translated Schleiden's description of the fire of Hamburgh into French, in which translation Mr. Schwob very rarely discovered any grammatical errors, but the real French idiom I was far from possessing. In Danish I contented myself with reading aloud to my master so as to acquire the correct pronunciation; I made easy translations and learned the vocabulary by heart. In Latin, besides the Æneid, I translated Sallust's Conspiracy of Catilina to professor Frandtzen. On the $1^{\text {st }}$ Febry., Mrs. Semper's birthday, I went to her in the forenoon to present my felicitations; dined at Sieveking's with three of his brothers-in-law, Otto, Ferdinand and Johannes, of whom Ferdinand was about leaving for London where he had succeeded in obtaining a situation in a counting house. In the evening I again repaired to Semper's where a numerous party had assembled, all the Reincke's with some of the grown up children, Semper's mother, his sister Eliza, his brother Wm. the Hamburgh apothecary, Mr. and Mrs. Arnemann, Mr. and Mrs. Theo. Elmenhorst with their twin-daughters, a few [387] other intimate friends, and finally myself. Some of [...] going gentlemen sat down to l'hombre, by far the greater part played Bouillotte which I suppose was a round game then much in vogue, and the [_] remainder - I of the number - tried to make ourselves agreeable where we could. Towards 10 o'c. a nice cold supper was laid out in three different rooms to which no less than 37 sat down. I procured a seat at the table of the ancients between Wilhelmine Reincke and Mrs. Knauer, who was this evening particularly good-looking. In the course of our conversation our midnight walk on the $11^{\text {th }}$ May' 22 through the dark Palmaille to the equally dark Rainville's Garden came on the "tapis". Both Mrs. Knauer and I after a lapse of 22 years agreed in qualifying this nightly excursion as improper, she added that Maria Elmenhorst and she had always kept it secret from their mothers, nevertheless another 20 years later, in 1863 , when she was a grandmother I heard her relate it to her married daughter. On the $2^{\text {nd }}$ Feby. I went in the evening to Knauers', who, on Fridays were always at home, and with whom I met a few of the usual friends, also a number of little girls on the point of leaving who had been celebrating little Julia's ninth birthday. On the $3^{\text {rd }}$ Feby. 
C. H. Donner gave a large dinner party in honour of the espousals of Lohmann and bride, at the same time it serv'd as a reconciliation party with the family of Sieveking, the members of which had not partaken of his hospitality for the last 15 years. We were the following, old Mrs. Sieveking, Ernestina, Löhmann, his bride and her sister, Henry Sieveking and wife, Mr. and Mrs. Knauer, Mr. and Mrs. Warnholtz, Mr. and Mrs. Theodore Elmenhorst, Bernard Donner and wife, old Mrs. Elmenhorst, Hannchen Willink, Arthur Donner, Chamberlain Von Bille, Danish Minister in Hamburgh, Mr. Paulsen, Lieutenant in the Danish Navy, and myself. The reception saloon, the dining room, the smoking and card rooms, all were splendidly and elegantly fitted up, on the walls hung valuable paintings, marble busts stood here and there, amongst others those of the King (Christian 8) and the Queen in two niches in the card room; the lighting up was brilliant, the lustre over the dining table was much admired, so [388] were the [_] silver dish covers. On the other hand the wines were certainly inferior to those at Fritz Baur's, and the dinner itself, of which I never take any notice, was, I was assured, nothing particular, consisting of insubstantial made up French dishes. I always manag'd to amuse myself at these parties. At dinner I sat near Constance Elmenhorst, afterwards I chatted with Bernard Donner and Ernestina, and finished the evening with a few rubbers with old Mrs. Elmenhorst, Mrs. Knauer and Henry Sieveking. Sunday $4^{\text {th }}$ Febry.: In the morning several friends called upon me; Edward Reincke and Henry Sieveking tasted some Port which I had bought, I read to them Extracts from my Diary of 1823, and we talked over the time we then had spent together in London. In the forenoon I paid a few visits and dined at Semper's whose acquaintances belong to a different circle from those whom I had met the previous day at Donner's; amongst others I found here the Arnemanns and Fischers. The principal topic of conversation was the carpet which the Altona ladies intended to embroider as a present for Count and Countess Blucher Altona, who, on the $1^{\text {st }}$ May, were to celebrate the $50^{\text {th }}$ anniversary of their wedding, which is known in Germany by the name of "Golden wedding". On Monday evening owing to Ferdinand Reincke's departure for London on the ensuing day, the members of his family assembled at their father's house instead of on Tuesday, which was the customary day. Old Johann Julius was in the habit of sitting down to cards with the first of his sons-in-law, who came in, whilst the ladies - all sisters, except Thusnelda Stintzing, Theodore's wife - sat round the table, conversing, sewing, and embroidering. By and bye the other gentlemen, (amongst whom Lubbes, old Mr. Reincke's brother-in-law,) made their appearance, they conversed by themselves, addressed a few words to the ladies, at 9.30 went up stairs to a light supper and broke up at 10.30. On the $6^{\text {th }}$ Feby I went to see Mrs. Ahl, formerly Betty Matthiessen, an old acquaintance of mine, but not finding her at home, 
her husband - a wine merchant - received me and gave me, in a rather prosy manner, some account of the Mathiessens, the oldest of them - Conrad - had died, the second Wm., who has not prospered in his profession as a lawyer, led an easy life upon the inter[_] [389] of the property left by his father and had married one of the Rohdes. Adolphus, after making a large fortune in Mexico in business, was travelling about in Europe for pleasure; at the time he was in Altona on a visit, having left his pretty wife Elvira Rohde with their sickly child in Pisa; the youngest brother, Otto, was doing well in St. Petersburgh as a sugar refiner. I dined in Hamburg at a restaurant where I took half a bottle of porter, which owing to its bad quality, did me much harm. In the evening at old Mrs. Sieveking's, Henry, Edward Reincke and I amused ourselves with making out the lists of the guests to be invited for the ball on the $19^{\text {th }}$. On the $7^{\text {th }}$ Febry. I again dined out on the occasion of Theodore Elemenhorst's birthday, who then completed his $43^{\text {rd }}$ year. It was the same story over again, the only variation being that we had a little music; Mrs. Arnemann and Arthur Donner sang very prettily, whilst Mrs. Elmenhorst accompanied them on the piano.

On the preceding pages I have given such ample details of the manner in which I spent my time whilst in Altona, that I not only consider it superfluous, but I even think it would be a tedious task if I were to continue making so scrupulously exact a copy of my original diary as hitherto. It will have been seen that not only my friends and relations, but also new acquaintances, overwhelmed me with attentions and civilities, and these did not cease nor even diminish whilst I was with them. All the Reinckes treated me as if I belong'd to their family. Henry Sieveking, his mother and sister, as well as the Kramers in Hamburg, did not flag in their kindness; also the Baurs, with whom I was but little acquainted when I left in 1823 , were now very polite; of C. H. Donner I cannot but say the same. My social intercourse was thus extremely agreeable and at the same time my lodgings at Rainville's were so comfortable that more than once I should have preferred staying at home to going out into the cold wintry night for the purpose of keeping an engagement. In Latin and Danish I made rapid progress, not so with French, which language I never could master completely, though up to a certain point I found no [390] difficulty in learning it. Notwithstanding all my efforts, I could not meet with an Italian master to my satisfaction, and at last abandoned my search for one. When at home, and not studying the above mentioned languages, I of course amused myself with reading. I finished James' "False heir", a milk and water story, as all novels of this author are - in my opinion at least, and commenced Eugene Sue's "Mystères de Paris", which, just then published, roused universal attention. My original says it "treats of the very refuse of Paris society, of murderers, robbers, thieves, [_], but is nevertheless written in decent expressions and is very interesting". 
Henceforth I intend to select merely one day or the other which may require particular notice - omitting, as a general rule, the description of dinner parties, to which I was so frequently invited that at last I actually grew sick of them.

Friday, ${ }^{\text {th }}$ of Fe bruary 1844. I partook of potluck at my old friend's Dr. Gustavus Schmidt; we were only he, his wife, his poor paralytic brother Albert - who is an excellent man, and myself. Mrs. Schmidt pleased me much, she was chatty without the slightest affectation, and apparently gave utterance to whatever was uppermost in her mind; also like my cousin Nelly and some of her friends, she occasionally made use of words which, though German in sound, were surely not so in grammar, the A which in German as everybody knows ought to have a clear ringing sound, she pronounced nearly as deep and broad as the Danish a a.

Saturday, $10^{\text {th }}$ of February 1844. I received letters from Lima dated 13/14 Octr. p. "Minstrel Boy" to Liverpool. Mr. La Torre, Vivanco's Minister of Finance, previously mentioned, had died. Frederick William Schutte, the youngest of the three brothers, after the failure of Pflucker's silk-worm speculation which Schutte superintended, and of which I gave a detailed account page 792 and 3 , Vol. 1 of these Extracts, my wife wrote me was making desperate love to Doña Paula Benavides, the widow of Evaristo Gomez-Sanchez, no doubt with the idea of marrying her, however nothing came of it. The weather was so windy and the ground so wet that I felt little inclined to leave my lodgings, but having received an invitation from Mr. Ahl to spend the evening with him I could not well stay away. Mrs. Ahl [391] when Miss Mathiessen was a particularly nimble girl, now she had become stout and felt such a weakness in the legs that she could not walk any distance; in conversation she was the same as in former years, lively and full of quaint sayings. Her brother William, I found to be very insignificant, his wife pleasant, her sister Mrs. Jette Gottig very agreeable, but I having at old Mr. Reincke's particular request bought a pair of spectacles and used them this day for the first time, discovered that over her, time had not passed so tracelessly as I had previously imagined. Adolphus had become very stout, he spoke in a rather positive manner, and was listened to with deference, no doubt because he was the richest man in the family; since he had retired from business he had devoted himself to all kinds of study, Medicine, Astronomy, Chymistry and Natural Philosophy. We had tea, whist, and abundant substantial supper; only a maid servant attended, the room was not carpeted. I learned here that Arnemann had bought the large property on the south side of the Palmaille belonging once to Count Blucher Altona for $[$ Bco. M $]$ 150.00o. Kiel-Altona railroad shares stood nearly at par.

Sunday, $11^{\text {th }}$ of February 1844 . For the first time I called on Mr. Schutt, who like me, lived in Rainville's Hotel where he occupied a suite of apartments. He 
was a bachelor of about 60 and well-known in the first circles of Hamburgh. He very seldom dined at home. His business was that of agent of Schön Willink \& Co. of St. Thomas and some other firms. Of the dinner party at Kramer's in Hamburgh, I will only say that I met an old acquaintance, the rich André Souchay of Lubeck, whom Nelly, his and my cousin, branded with the epithets "close" and "effeminate". Contrary to the usual custom the gentlemen remained the whole evening by themselves in the smoking room, and as I remarked to my cousin that such a long absence appeared to me rather ill bred, she imposed silence by saying "That's the way with us north Germans", and her husband still worse, laid down the law observing that "ladies and gentlemen have nothing to say to each other if together any length of time", both which sentiments, I decidedly denied.

Monday, $12^{\text {th }}$ of February 1844 . Late in the evening I went to Semper's, [392] he had not yet come in from his railroad business, but as soon as he appeared we sat down to Chess; at which we played 4 games, I won 3, 1 was drawn. When I left, Mrs. Semper had already retired to rest, the more I knew of her the better I liked her. I was particularly pleased with her not making the slightest distinction between her own and her step children.

Wednesday, $14^{\text {th }}$ of February 1844. I looked out in Hamburgh for an acquaintance of my youth frequently mention'd in previous pages, Philip Lilie a clerk in a Hamburgh counting house. If we had not mentioned our respective names we should not have recognized each other; he received politely but so chillingly that I at once decided upon dropping his acquaintance. Again a dinner party. This day at Warnholtz's. At Whist I was generally one of the worst if not the worst player but the stakes were usually very low -1 the point. Altona-Kiel railway shares had risen to 102, those of the Gluckstadt branch to 106. In the London Times I found quotations of some South American loans raised in London Peruvn. $20 \mathrm{c} 201 / 2 \%$ - Columbia ex Venezuela, which signifies Bonds of the Columbian loan excluding the responsibility of Venezuela which Republick after the division of Columbia had made a separate arrangement with its Creditors $121 / 2 \%-6 \%$ Chilian at from 103 to 105 .

Thursday, $15^{\text {th }}$ of February 1844. A fine winter's day. As far as the eye could reach all was snow and ice. I dined "en famille" with Henry Sieveking and spent the evening at his mother's, where I was fond of passing my hours, for a certain gentility, not to be found everywhere, prevailed in this family.

Friday, $16^{\text {th }}$ and Saturday, $17^{\text {th }}$ of February 1844 . Do not require very particular notice, the temperature had become mild, it thawed, the ice and snow rapidly melted away, both on shore and in the river which now presented hardly any obstacle to the passge of small vessels which sailed up and down. The one evening I spent at Knauer's, the other at Semper's playing chess. 
Sunday, $18^{\text {th }}$ of February 1844. Johannes Limpricht had invited me to his house, and this being the first time that I dined with him I'll [393] say a few words about the party. The guests were 18 in number, and as far as I could judge of them all nice people. Of the three sister D' Albert, the one married to Senator Gossler (brother of William Gossler, husband of Betty Donner, J. C. Donner's daughter) was beyond question the best looking, but to my taste not quite so agreeable as her younger sisters, the wife of Johannes and that of Dr. Löhrs, both were lively and full of conversation. Another lady whom I must not pass over in silence was Mrs. Witt married to a certain Mr. Witt who had been many years established in Bahia, her eyes and hair were jet black, she was full of animation, more so than the generality of ladies with whom I was acquainted in Altona and Hamburgh, and her whole appearance and demeanour suggested the idea of her being born in the southern hemisphere; my cousin Kramer believed that she was a native of the Island of St. Croix in the West Indies. At Limpricht's everything in the house testified to the good taste of the owners, there was not the display of wealth as at Fritz Baur's or C. H. Donner's, but all was genteel, and one thing was in keeping with the other. The party broke up at 11. Mr. and Mrs. Witt put me down in their carriage not far from Kramer's where I occupied for the night the room which they had been good enough to place at my disposal. I, as was then my habit, read in bed before going to sleep; this kept my cousin and her husband so uneasy that the latter rushed in more than once to see what I was doing, and when I observed their disquietude I put out the candle. During the night a fire broke out somewhere, the ringing of the fire bell and the rattling of the engines made a frightful din which kept me awake for some time.

Monday, $19^{\text {th }}$ of February 1844. Through the dirty streets of Hamburgh and the muddy roads across the suburb of St. Pauli I walked from Kramer's direct to the house of Mr. Lubbes in Altona who on this day, the first day of carnaval, was in the habit of giving a lunch to a large number of his acquaintance to which repast I also was invited. There were nearly all the male members of the Reincke family, the architect Hansen, a more elderly gentleman, various young lawyers, Callisen, Tams and others, likewise Otto Lange who had been my school fellow in the Altona [394] College, and whom I particularly recollect as one of the six who were instruct'd twice a week by Rector Claussen in the Danish language; he and I used to sit together, and frequently did he divert my attention from what we were about by his untimely chat; he was exactly of my age, tall, not over clever but goodnatured; we now called each other "thou" and soon were as good friends as we had been thirty years previously. It is the custom in Altona to regale oneself on Carnaval Monday with a particular kind of biscuit, hot and buttered which goes by the name of "Hedewig" - a 
corruption of "heisse Wecken" or hot rolls. To partake of these was the pretext for this meeting, though I need hardly say that everyone present did ample justice also to the many good things which covered the tables. I myself followed the example set to such an extent, that I had of necessity to lie down and sleep a little before I was ready to drive with Henry Sieveking and wife to a ball old Mrs. Sieveking gave this evening. We were among the first arrivals, but during a long conversation with Mr. Isaac Hesse and the lawyer [Lemfert], the saloons gradually filled; two were prepared for the young folk, one for the elderly people, the fourth saloon for the card players. I once more tried my luck at Waltzing, but though the ladies had endeavoured to teach me the steps then in vogue I did not succeed. I managed somewhat better in the French quadrille with Mary, daughter of Isaac Hesse, and in the Cotillion with Mrs. George Baur. Supper was laid out on a number of small tables, after which dancing recommenced and the party broke up at the early hour of 1 o'c. It appeared to me as if this dance had not come off with the spirit and animation which generally prevail, or should prevail, in such parties.

Tuesday, $20^{\text {th }}$ of February 1844. The thaw continued, the Elbe was almost free of ice, and large vessels came up the river favoured by the then prevailing Westerly wind. In the evening the family circle at Mr. Johann Julius' was much reduced. Many of its members stayed away for various reasons.

Wednesday, $27^{\text {st }}$ of February 1844. It snowed the whole night, and in the morning the snow lay ancle deep. I was invited to dine with Fischer, the party consisted of only 12 persons, Fischer and his wife, the clergyman Geffcken and wife (Mrs. Fischer's sister), Kedenburg and wife (Geffcken's niece), [395] an uncle of Mrs. Fischer, Otto Heyne (Fischer's partner), a Mr. Wiebel, teacher of chymistry in the Hamburgh "Gymnasium", Mrs. Dankert and myself. These were people whom I was not in the habit of meeting, and I was therefore well pleased with the novelty which this little party offered in new faces.

Thursday, $22^{\text {nd }}$ of February 1844. It had frozen during the night and in the forenoon many people were out in sledges enjoying the clear sky and bright sunshine. At Henry Sieveking's there was hardly one in the house who was not indisposed. In the evening I went to a concert given by nonprofessional singers and musicians in a large saloon in the first floor of the building in the "Lange Strasse" which in former years had served as the Post office. A Dr. Mutzenbecher was the founder of this musical society, which in 1844 was in a state of great perfection. Handel's Oratorio "Jephtha" was performed, the greater part in recitative, with an occasional air accompanied by instrumental musick.

Friday, $23^{\text {rd }}$ of February 1844 . It was a cold stormy day with the wind from the south west beating against my room windows. Towards the afternoon it 
veered round to the east, the sky cleared up and the cold increased perceptibly. At 8 p.m. Reaumur's Thermometer stood at between 7 to 8 . At 10 o'c. 11 degrees below freezing point. I dined "en famille" with old Mrs. Sieveking and spent the evening at Kramer's in Hamburgh who had invited for the occasion a few of their intimate friends. The ladies sat in close array round the tea table, knitting, sewing, embroidering, and gossiping among themselves, whilst the gentlemen kept aloof talking over the affairs of the town. For me to break through this rule and to address any of the ladies would have been considered a strange innovation. We played Whist and had a cold supper. Two lines of omnibuses plyed in 1844 from 8 in the morning till $91 / 2$ evening, each line four times an hour - the one every full quarter, for instance at 12, 12.15, 12.30, and 12.45 - whilst the other started in the intervals between each quarter. The one had its stand at the west end of the "Palmaille" and went straight through Hamburgh to its eastern Gate the "Stein Thor", the other from the Palmaille St. in Altona, turning in [396] Hamburgh to the left and finishing its route at the same "Stein Thor" whence they returned to the Altona stand, moreover during Exchange hours one or two extra omnibuses were put on, fare 4 currency.

Saturday, $24^{\text {th }}$ of February 24 1844. This was the most wintry day I had yet experienced during my present residence in my native place. It snowed continually, and the flakes, driven by the easterly wind with such violence into one's face as to cut like needles, fell so densely, that they precluded any distant view; the Hanoverian shore for instance, was completely shut out from my sight as if a thick fog lay between us. In Hamburgh labourers were busy clearing the streets from the snow which was being carted away. In Altona when in the evening I went with Theodore Reincke to Mr. Von Bockelmann, the snow in some places lay in deep drifts, into one of which I fell up to my knees. I found Mr. Bockelmann in his house looking on at a game of chess played between Professor Jones, teacher of that noble game, and a certain Doctor. I myself played a game with each, the former by far my superior, was of course the winner, whilst the doctor, though I believed he played a little better than I, was not so fortunate. It was I who gained.

Sunday, $25^{\text {th }}$ of February 1844. It was a fine day. The sun shone merrily into my windows. There was no wind and thus in the course of the morning the road to Flottbeck and further down to Blankenese was enlivened with sledges, generally only large enough for one or two persons sitting inside well wrapped up; a rich bear, tiger, or similar skin, spread over them, the gentleman driver behind on a somewhat elevated seat reining in the horse, by rule a fast trotter with tinkling bells and well caparisoned, some sledges with an outrider. The Elbe was completely filled with Ice being impassable to vessels, however as yet no foot passengers ventured to cross. After breakfast I studied Latin for an 
hour and then started to make a number of calls. Everywhere I was received with particular kindness and was favoured with several invitations, some of which I could not accept because I was previously engaged. [397] At Mr. Isaac Hesse's I was introduced to his lady, of whom it was well known that she wore the breeches, and who, on account of her affectation and her grand airs she liked to give herself, was often nicknamed the "Countess Amalia". Having returned to my lodgings I had a visit from my fellow lodger Mr. Schutt whom I had already mentioned, and from Simon Post whom I had known in South America, where he had managed the house of Schutte Post \& Co. in Valparaiso, and having retired from business was in Hamburgh for the purpose of settling the affairs of the partnership. I dined at Theodore Reincke's who celebrated the $2^{\text {nd }}$ anniversary of his own and the $23^{\text {rd }}$ of his father-in-law's wedding. He lived in a very small house, and there was not one room large enough

(On the $16^{\text {th }}$ of January, I requested Mr. Graham, who had been with me since $4^{\text {th }}$ of September of last year (see p. 305) not to return to my office, he had made himself so disagreeable on every occasion, that it was imposible for me, to bear any longer with him. Mr. Charles Duval took his place on the $3^{\text {rd }}$ of February 1869.)

to accommodate the guests whom he had invited. We therefore sat down to dinner in two separated apartments. In the one, Theodore at the head of the table, to [_] right, Mr. George Knauer, Mr. Lübbes, old Mr. Reincke; at the foot opposite to Theodore, his wife Thusnelda, and his father in law Dr. Stintzing, and then on the sofa opposite the three Gentlemen, Mrs. Knauer, myself and Mrs. Stintzing. In the other room the younger folks were served, all was plain and homely, but the three ladies particularly agreeable, as I have always found them, contributed much to my enjoyment. I left at 10 p.m. when the temperature was really cold, and the snow lay considerably deeper than in the morning.

Monday, $26^{\text {th }}$ of February 1844. A thaw had set in, and the streets overflowed with snow water. For the evening I had received an invitation from the two Misses Finck, Betty and Jeanette, aunt and niece. Besides the hostesses and myself, there were William Mathiessen with his wife, a miss Nissen, an elderly spinster, [398] and the wife of Doctor [Sensen] verging towards old age and rather hard of hearing, whom I [reco]llected, when Miss Gretchen Voss, daughter of the opulent brewer as one of the friends of my Sisters. Mrs. Mathiessen was undoubtedly the most agreeable of this small party. We had tea, Whist, and a nice cold Supper. It was an inclement night when we separated at about eleven o'clock, and I pitied Mrs. Mathiessen who had to walk through pools of melted snow to her house in the Pin[_]berg road almost out of the town. I have already mentioned that my Danish master had a situation in the 
Altona mint; from him I learnt that by order of the Danish Government, they were at the time busily employed in melting the excellent coin which in pieces of 4 and 12 Shillings had long been current in the Duchies under the name of "Grob courant", which may be given in English by "Solid Currency", and in recoining the same into coins corresponding to the Danish "Rigsbank's" money, or money of the Imperial Bank in Copenhagen. This measure was extremely unpopular in the Duchies, and was perhaps one of the many motives which caused the first rising in 1848 . One Rigsbank dollar was equal to $96 \mathrm{Rbks}$ Shllings or 30 Shillings currency, and each dollar was divided into pieces of $3^{2}$ Rbks Shillings $=10$ Shs cury., $16 \mathrm{Rbs}=5$ Shs and 8 Rbks $=21 / 2$ Shillings currency; there were also double Rbks dollars of 6o Shs currency equivalent to the ancient species. One mark fine silver rendered 18 1/2 Rbks dollars if coined into pieces down to 8 Rbks Shillings, but if coined into pieces of 4 Rbks Shs or $1 / 4$ Shs currency then more alloy was added, so that 21 Rbks dollars became the product of one mark fine silver.

Tuesday, $27^{\text {th }}$ of February 1844 . The weather had again changed, it froze, and the ground was hard, I dined "en famile" at the Kramer's in Hamburg. Only Miss Schlüer had been invited to meet me. Kramers lived upon a plan which I did not much admire, they saw much company, and went out to many parties. Whilst at home they lived very economically; they kept only one servant girl who did all the work in the house, even cooked and washed; of course she could not attend at dinner, and for this purpose they had a certain Miss Alvina who was a Jack of all trades, she served as a kind of Governess to the two children Maria and Luisa, she assisted my [399] cousin in the house keeping affairs, sat down with them to dinner but did not consider herself superior to menial services, thus for instance she jumped up from table at every moment to clear away the plates and dishes, and put clean ones in their place. Now, my plans would have been quite the reverse, I should have lived more comfortably by myself, and on the other hand shown less hospitality to my friends. The evening I spent as usually on Tuesday's at old Mr. Reincke's, but many members of the family were wanting; in the winter season colds and catarrhs frequently prevent ladies from going out at night.

Wednesday, $28^{\text {th }}$ of February 1844. It froze hard, the Elbe had become one solid mass of ice, and the peasants from the opposite shore came over without any danger with their provisions for the Altona and Hamburgh markets; some on foot, others on horseback, still others in sledges. I dined at old Mrs. Jean Donner's, to celebrate the birthday of her third son Conrad. A certain Borgen, a Dane, Otto Reincke of the same age as Conrad Donner, (his birthday had fallen on the previous monday) and I were the only strangers; the remainders were members of the family, Old Mrs. Donner, her second son, Jean and his 
wife (a Storjohann), her third son Conrad and his wife, (a Silvestre) and her daughter Betty, the youngest of all the children with her husband, Mr. William Gossler of Hamburg. Of the ladies nothing is to be said; to me, they appeared extremely insignificant, they hardly opened their mouths; the Gentlemen on the contrary, agreeable, particularly Mr. Gossler, merry and jovial. After a short sojourn in the smoking room I played whist till 9 p.m., when I had to hasten to a most magnificent ball given by Mr. Isaac Hesse; the furniture and everything was splendid: the rich sofas, chairs, and arm-chairs, the soft carpets in the receiving rooms, the dancing saloon being boarded, the heavy curtains, the large chandeliers, the brilliant illumination, the abundant refreshments, the choice supper, the excellent wines, the first rate music, all harmonized with each other, and gave evidence of the wealth of the host, and the good taste of the hostess. He was a good natured rich old Jew with whom I was on the very best terms, she a Jewess but a stylish lady who did certainly everything in her power to make herself agreeable to all present, not a single one of the guests did she neglect, though their number was between 130 and 150. This evening Count Conrad Von Blücher Altona the President of Altona was the highest in rank, he was a man who in his younger years had been good looking; he was now of a very [400] venerable aspect; on the following day he completed his $80^{\text {th }}$ year. Mr. Hesse introduced me to him, he recollected my family and made some inquiries about them; his partial deafness and the noise made by the dancers and the music prevented however any further conversation. Present were amongst others, the British, French, and Brazilian Ministers resident in Hamburg, the representative of Great Britain being Colonel Hodges, a Danish count Holk, a Swedish countess Arangel, many of the Hamburg moneyed aristocrats; the Schröders, the Von-Halles, the Heynes, the Gumpels and others who were unknown to me. Some Hanseatic Officers whose uniforms brought some variety into the monotony of the habitual black dress coats of the gentlemen. There were likewise some of my acquaintances of Altona; but I regret to say that those excellent girls Wilhelmina Reincke, the two misses Willink, Miss Bocklemann, Miss Bertha Stintzing and others could not compete with the Hamburghers in their rich and expensive toilet, nor in the air "du grand monde" in which those of the great rival town certainly surpass them. Thus, they were always the last [_] to be led to dance, the last to be taken to the supper table. This last observation however did not apply to the Misses Hesse, daughters of the giver of the fête, to Miss Carolina Tesdorff, educated in France, nor to Mrs. George Bauer, and Mrs. Bernard Donner, whose respective husbands were partners of firms well known in the whole mercantile world. Mr. Daniel Schutte quite a lady's man, still an active dancer, and acquainted with all the Hamburghers, appeared at home, and made 
himself very useful. The reverse was the case with his ex-partner Mr. Post, who a few years older, and of a more sedate character, seemed almost lost in this world of Strangers. I amused myself much better than I had expected, it is true that I met with a rebuff from a young lady, one of the daughters of Fritz Bauer, married to Consul Von Hildebrande, who not many weeks previously had been my neighbour at a dinner-party, and had then been conversing with me very freely and pleasantly. This evening, when I addressed her, she hardly vouchsafed an answer, whilst when the Brazilian Chargé d'affairs drew near her a few minutes later, she was all smiles and graces. On the other hand, I had the good luck to lead to the Supper table Mrs. George Bauer, a lady both agreable and of the élite of the Hamburg and Altona Society. Supper was laid out on various small tables, round that at which Mrs. G. Bauner and I sat down [401] our companions were Mr. Daniel Schutte, Mrs. Von Halle, Mr. Shutt, old Mrs. Schröeder, Mr. Von Heeren, Dr. Abentroth, and Mr. George Baur. I ate nothing as was my custom and took only one or two glasses of Champagne. At the request of Mrs. Hesse, Mr. Schön of Hamburg, partner of Ch. Willink in Saint Thomas, a very handsome man gave the health of Count BlücherAltona which as the papers would say was drunk with rupturous applause. I must not omit mentioning that I was also introduced to Mrs. Von Heeren, a malaga lady with whom I conversed a short time in Spanish; she told me that she was by no means displeased with Hamburg, that she knew sufficient of German to be able to order her servants, and that otherwise, French carried her through everywhere. Of the Climate, she most complained; in 1855 when I visited Hamburg in company with my wife, we became more intimately acquainted with her. Since then she had died. Her son is Arthur Von Herren whom in 1868 we saw so frequently in our rancho in Chorrillos, and who has lately married one of the immensely rich daughters of the deceased Don Pedro Gonzales Candamo of Lima. Amongst the many ladies who graced this fête, I observed not real beauty, neither a single woman well shaped; of pretty faces there were not a few. After supper, dancing recommenced, and I left before the party broke up. It was a mild moon-light night and together with my fellow lodger Mr. Schutt, I returned to my rooms in Rainville's hotel, at half past nine p.m. the cold had been severe, Reamur Thermometer having stood at $13^{\circ}$ degrees (Below zero).

Thursday, $29^{\text {th }}$ of February 1844. This was as already said, the birthday of Count Blücher-Altona; the Hamburg Senate as a mark of their respect and esteem, sent to Altona the military band of the Hanseatic corps; early in the morning it took its place opposite the Count's residence in Palmaille, and played and sung very prettily; I listened to it with pleasure, was however not so completely absorbed by the performance as to become insensible of my cold feet, which 
a consequence of the frozen ground on which I stood, drove me home before the conclusion. At a later hour, dressed in my consular uniform, I waited on the count to present my congratulations to him. When I entered, the Clerical body was just leaving, and I found only a few officers with him and his lady. Both received me very politely; the Countess whom I addressed in French, spoke of my poor dear mother in the most laudatory terms, nothing than which she well knew could have been more gratifying to me. The Count who completed his $80^{\text {th }}$ year was [402] still sufficiently robust, though a recent fall from his horse had affected him greatly, his lady though younger than he, looked rather older; on her forehead she wore a black plaster to conceal a [large] scar caused by her giving herself a severe blow against a beam and which would not heal. She moreover was toothless which seems to prove that in 1844 the use of artificial teeth was not so general as it is now in 1869. Chocolate, wine and cakes were handed round, of none of which I partook, and retired after a stay of about ten minutes. I rested a while in my lodgings and then started to congratulate old Mrs. Elmenhorst who on this day entered her sixty ninth year. She was very active and lively considering her age, to me always very kind. I found with her Senator Siemsen who was a relation, perhaps the father of the Apothecary Siemsen who had been married to Mrs. Elmenhorst youngest daughter Theresa, and who after Theresa's untimely death had taken a second wife. There were also two clergymen Horn and Nieman, this latter very old and brokendown, finally Miss Matilda Wedekind, who though a stranger to me, said that she well knew who I was. On my return home I felt rather indisposed; a short nap did me no good. Nevertheless being invited by Theodore Elmenhorst I went to his house where a numerous party was assembled to celebrate his mother's birthday. We were, Theodore and his wife, his mother, C. h. Donner, his uncle and God father, Mrs. Jean Donner, the widow of Theodore's uncle Jean; Bernard, C. H. Donner's son and his wife, Betty, Mrs. Jean Donner's daughter, and her husband Mr. Gossler, Warnholtz, whose first wife had been Maria, Theodore's sister, with his second wife Augusta Reincke. The above mentioned apothecary Simpson and his wife; Arthur Donner, Mrs. Gossler's brother just returned from Tondern where he had paid a visit to his eldest brother Otto, an officer in the Danish' navy, and finally Otto Heyne, brother of Mrs. Theodore Elmenhorst. As far as here, it'll be seen, all were members of the family, whilst Mr. George Knauer and Mr. Preller of London, Mr. Harzen a broker in articles of "vertu", and myself had been invited as being intimate friends. The Dinner was sumptuous, but I felt so unwell, for one moment I was shivering with cold, at others my head was burning, that I could hardly eat anything, and drank nothing. My neighbours Mrs. Simpson on the one, Mrs. Jean Donner on the other side were very uninteresting, but fortunately 
close by sat Mr. [403] Harzen a very pleasant man, and with him I conversed a good deal; in the smoking room I listened to an interesting discussion which he and Mr. Siemsen had on the subject of the Hamburgh and Altona temperance society of which Mr. Harzen was a most active supporter. I learned that to the members of this society the use of Brandy and similar Spirituous liquors was prohibited but wine was allowed in moderate quantities only. On a previous occasion I have already spoken of the carpet which 30 ladies of Altona were at the time embroidering for a present to count and Countess Blücher on the anniversary of their $5^{0^{\text {th }}}$ wedding day which would take place on the first of May next, this was the usual topic of the ladies conversation and this evening was no exception to the rule; the thirty ladies who had united for said purpose were considered, and considered themselves the very cream of Altona society, with Mrs. Stühlman, Mrs. Bockelman, Mrs. Böhn, and Mrs. Arnemann, as the directresses of the work. This exclusiveness had of course given rise to some rivalry, and another union of thirty ladies with Mrs. Gustavus Wall and Mrs. Doctor Hayck had formed itself with the object of embroidering the back of two arm-chairs, gold and scarlet, likewise to be presented to the noble couple on the first of May. When I reached my lodgings I felt poorly, went to bed and covered myself up well. A party given by the members of the Club called the museum, in Rainville's Hotel, and a ball given by the civic guard in the theatre, were further proofs of the affection borne by the Altoners to their President.

Friday, ${ }^{\text {st }}$ of March 1844 . When I awoke, I felt pretty well; only my throat was a little inflamed; I therefore remained at home all the day, busying myself with studying the three languages to which I had again dedicated myself, and with reading and writing.

Saturday, $2^{\text {nd }}$ of March 1844. My throat continued more or less the same; thus I did not stir until it was time to drive to a dinner party to which Mr. Daniel Schutte had invited me. He being a bachelor, gave it in the excellent Streits Hotel in the Jungfersteig; the guests were received in the two Saloons, and in the dining room the dinner was laid out in such good taste and abundance so as to leave nothing to desire; in no respect was it inferior to what I was accustomed to in the private houses of my wealthy friends. Numerous servants attended, dressed in black dress-coats with white cravats and white gloves. When dinner was announced, Mr. Schutte took me by the arm to show that the party was given in my honor; I was of course placed to his right. I believe we were 24 in all, of whom I will enumerate those whom I recollect: Mr. Post from Valparaiso, Mr. Hüp[c]ken from New York, Mr. Wohler partner of the great [linen] house of [Kramsta] in Bohemia; Mr. Richard Godefroy son of [404] Peter Godefroy, Junr. and intimate friend of Henry Sieveking, who established in London with a Mr. Simpson had been of late very unfortunate in business. 
Mr. Shcön; Mr. [T] ogmus, a Hamburgher who had been a General in the Egyptian Service; Mr. George Hesse, eldest Son of old Isaac, Mr. Newman (an Englishman); his partner who spoke German to perfection; Hermann Dryer, one of my playfellows in my childhood; Mr. Schmidt whom like Dryer I had known in Lima in 1827 when agents of the Rhenish West India Company, now married and established in Hamburg under the firm of Schmidt and Helwick; Mr. Oswald with whom in 1827 when he was supercargo of the "Princess Luisa" I made my first voyage from "Quilca" to "Callao", now a merchant of some consideration, Prussian Consul General, and decorated with an order; and Mr. Witt from Bahia, whose acquaintance I had made at Johannes Limpricht's. The conversation was general, animated and agreeable, several toasts were given, the first by Schutte himself to the health of the wives of the Gentlemen present, when emptying his glass, he turned towards me with a meaning look which I well understood. At a later hour, some sat down to cards, I left and went to my cousins where as said more than once, I had a bedroom at my disposal. Whilst waiting for her and her husband who had gone out, I amused myself with reading some translation (German) of Custine on Russia, which at the time made much noise in Political and literary circles; this Custine was son of the general who was guillotined at the time of the French Revolution. At the dinner party, I learned a sad piece of news; Mr. J. H. Berkemayer the clever little humpbacked-man, Hamburg Consul in Valparaiso had been obliged to stop payment owing to various unfortunate speculations, and on the following day, he committed suicide.

Sunday, $3^{\text {rd }}$ of March 1844. The weather had completely changed, the temperature was mild and a thaw made the streets almost impassable for foot passengers, I therefore took a Droschka to make several calls, on my good palsied friend Albert Schmidt, on his brother the Doctor and his wife, on Johannes Limpricht and family, on professor Wür[m] and family, formally his wife was miss Hermine Specter, all these were very nice people, the two latter distinguishing themselves moreover by more than common intellectual capacity. Hermann Dryer I did not find at home, and was received by his wife, a vulgar looking disagreeable woman from Hanau. Thence I hurried to old Mrs. Sieveking in Altona where I dined with the family. We were the old lady, her companion Miss Götz, her daughter and two grand daughters, her son Henry, his wife, three of his children, Löhmann and myself. I neither expected nor found [405] great amusement. After dinner Henry and Löhmann tried do divert those present by reading aloud some little pieces written in the Jewish and Berlin dialect, which pretended to be very witty and clever, but which I at least could not much admire. Towards 9 p.m. I went to a so called "musical soirée" at the lawyer Stühlmann's, the party was small but select. I have already 
had occasion to say that both Mrs. Stühlmann and her daughter Carolina had seen much good society and made of course excellent hostesses. Carolina's singing accompanied on the piano by Mr. Marzen was no great thing. However her playing as well as that of Marzen and the singing of Arthur Donner pleased me well. I was at home at about midnight.

Monday, $4^{\text {th }}$ of March 1844. Some Steamers came up the river; with great difficulty they broke through the ice already loosened by the thaw. Kramer in Hamburg gave a great dinner party, I was present but have little to say of it. At dinner my neighbour was Mrs. Kyrchner a nice woman, there was old Mrs. Langhans who had known me thirty years back, in the abominable smokingroom, the smoke produced by the inveterate cigar-smokers was so dense as to make my eyes water.

Tuesday, $5^{\text {th }}$ of March 1844. A quiet day, in the evening I went to old Mr. Reincke's, Mrs. Semper near her confinement, and her husband were not present; their places were taken by Mr. and Mrs. Theodore Elmenhorst. George Knauer had received a letter from Hermann Reincke of Lima dated November $15^{\text {th }}$, in which he informed him that he had actually left Gibbs's and joined Lembcke.

Wednesday, $6^{\text {th }}$ of March 1844. In the course of the forenoon I had two pleasant visits; the one from Albert Schmidt, who induced by the fine weather had ventured to come so far; he was accompanied by a servant who lifted him out from the carriage and again placed him into it; the other from Mr. Bockelmann, who, poor gentleman, had his nose gradually eaten-up by a cancer. He told me he had transferred the weekly meeting of chess players at his house from Friday to Saturday, and invited me to dine with him on Sunday next. I was occupied the whole day long with bringing up my ledger and Journal, and read some chapters of "Les mystères de Paris", until two in the morning.

From Thursday, $7^{\text {th }}$ to Saturday, $9^{\text {th }}$ of March 1844 . The weather on Thursday and Friday was beautiful, the Elbe was nearly free of ice, and for the first time I ventured into the garden of Rainville's Hotel which ever since my arrival had been blocked-up with snow. I thought of former years; of my rambles in these shady walks when a boy and a young man; I recollected how my mother and sisters were in the habit of enjoying themselves on a fine summer evening, promenading in the avenue nearest to the Elbe distant from the turmoil of the frequenters of the hotel [406] and Coffee-rooms. At the Eastern extremity of the garden, labourers were now at work felling trees, fore here the inclined plane was to be constructed, the object of which was to connect the AltonaKiel Railway with the Elbe. On the beach, large hewn stones brought down from the quarries of Perna, were lying about to serve for the quay which was to be built. On Thursday evening I went to Semper's to play at Chess, this time I 
lost two games and gained but one. Mrs. Semper was an excellent step-mother, often did I find her playing with Semper's children by his first marriage, Otto, Charles, and Elizabeth, all of whom she treated with the same kindness as if they were her own. On Friday, early in the morning she was happyly delivered of a little boy, in the evening of this day, I supped at Knauers where the party assembled was rather numerous, more than usually so. Saturday evening I spent with Mr. Bocklemann and lost two games at chess to Mr. Jones, who it must not be forgotten was a professional teacher of this noble game. I received a letter from A. Gibbs \& Sons enclosing a private one from Mr. William Gibbs couched in the most flattering terms. He offered me a situation in his London house with a salary of one thousand pounds and a promise to be the manager of the concern whensoever he might be absent. I refused the proposal for it appeared to me that as Mr. Robertson was about to leave; I was merely wanted as a head-clerk, which did not answer my purpose at the same time, in my answer I gave Mr. Gibbs to understand that I was not desinclined to reenter his South Amcan. establts.

Sunday, $10^{\text {th }}$ of March 1844. I made a number of calls: firstly on Mr. Post at Straits in Hamburg, and then on many of my Altona friends. I dined at Mr. Bocklemann with the exception of the wry-necked Mr. Sähler, Theodore Reincke and wife, the remainder were strange to me, Viz.: Mrs. Bocklemann whom I was requested to take to the table; Mr. Ernest Pöel, Editor of the "Altona Mercury"; his sister; Mr. Bocklemann's unmarried sister; his two daughters; his young son; and a Mr. Reimarus from Hamburg. Though as will be seen this circle was different from those in which I was in the habit of moving, yet, here as well as there all had to be gone through with in the same manner. At diner the conversation was sometimes general, but more frequently, those sitting close to each other conversed in a low voice, and it was the particular duty of the gentleman to make himself agreeable to the lady to his right. I must confess that I often spent the time to my great satisfaction when placed alongside of a pleasant neighbour. Ladies and Gentlemen rose simultaneously, then formed themselves in small knots, standing, taking coffee, and wishing each other the "blessed meal", which may be given in French by "Bien vous fasse", then followed the Gentlemen's withdrawal to the smoking room, a costume which went always against my grain. On the gentlemen's return to the ladies, tea was served, and finally the "l'hombre" and whist [407] were ressorted to. I made the observation, that in the houses were the inmates were actually or at least considered themselves in mental culture superior to the generality of the families, card playing was eschewed also in the Reincke's family, Theodore and Semper, undoubtedly the cleverest of them, were not friends to this pastime. 
Monday, $17^{\text {th }}$ of March 1844. The weather grew disagreeable, it rained, thawed, and the South west wind blew against the window of my room so violently that I could hardly keep myself warm, notwithstanding my comfortable iron stove, and the considerable daily consumption of coal. With my cousin Nelly and her husband, I drove to Mr. and Mrs. Wür[m] who received us in two rooms barely large enough for the guests whom they had invited to dine with them; these were: Clergyman Geffcken and wife; Mr. and Mrs. Doctor Petersen, the Doctor, like Professor Wür[m], teacher at the Hamburg Gymnasium; a certain Dr. Bermann and wife; another young Doctor, Dr. Schleiden who kept a large boarding school and hislady, Mrs. and Miss Campe; Mr. Richard an architect; and Otto Speckter who had of late accompanied Mr. Mutzenbecker, the expartner of Huth's establishment in South America, to England and Scotland. We had a good dinner, which was served in a spacious room in which afterwards tea was taken. I had a long conversation with Otto Speckter and Mr. Richard who had resided long in the United States. With the other persons present, I hardly became acquainted. I may however mention that Mrs. Campe was if I am not mistaken the widow of the well known publisher and bookseller of the firm of Campe and Hoffmann who in his excellent book "Kynderfreund" (Children's friend) first brought to the notice of the German public, Defoe's popular novel of "Robinson Crusoe". Here, in the same manner as on the previous day, cards were not required to kill the time.

Tuesday, ${ }^{\text {th }}$ of March 1844. In the morning I went in search of, and found out the dwelling of an old woman, Catharina Trillken, who had served in my paternal house, and been my faithful nurse during the first years of my existence. She had always been a favourite with my mother, and it gave me now great pleasure to find her and her husband Joachim, by trade a well digger, though much advanced in years, apparently in easy circumstances, they told me that during the summer he earned always sufficient for his and his wife's maintenance during the whole year. They occupied a small house for which they paid an annual rent of seventy two marks currency, and which contained two rooms, the smaller of which I did not enter, in the larger one where the good people received me, stood a comfortable bed, a stove, a table, chairs, and a cupboard with drawers underneath; outside was a large hearth, and I even noted white earthenware, plates, cups, and saucers ranged on the shelves. On the previous day their daughter Hanchen, married, and looking very decent, had called on me. The remainder of [408] the day I stayed in my rooms, did not even go to old Reincke's family party. I finished "Les mystères de Paris", the last chapters of which are in my opinion very tame, and void of interest when compared with the preceding ones. 
From Wednesday, $13^{\text {th }}$ to Friday, $15^{\text {th }}$ of March 1844. The weather became milder, steamers came up and went down the river, even for a short time when the wind blew from the north, sailing vessels by means of tacking could go in both directions. I was at home the greater part of this day; but hardly a day I think passed over without my calling at Henry Sieveking's with whom and his most amiable wife, I was on very intimate terms. On Wednesday I drove to Hamburg, to a merry evening party at Albert Schmidt's; his brother Gustavus and I were the only married men, the remainder were nine old bachelors fart livers, two of whom had been trading up and down the Western Coast of Africa, had undergone many dangers and hard ships, and seen a good deal of savage life; thus when supping and taking punch, it will be easily conceived that the stories related did not always keep within the bounds of strict decency. After supper we had tea and short whist at rather high stakes. Friday night I went to supper at Knauer's, when returning, the streets were again covered with snow. The shares of the Altona-Kiel railway which when I arrived stood at $90 \%$ had risen to 110 . The sellers were principally the town of Altona for whom Warnholtz as a member of the Municipality, the Danish Government for whom C. H. Donner, and the town of Kiel for whom J. H. and G. F. Baür were the agents; the orders for purchasing came mainly from Berlin and Saxony. A Branch from Glückstadt was to join the main railway at Elmshorn, the inscriptions of which were already at six and half premium.

Saturday, $16^{\text {th }}$ of March 1844. This day I had fixed upon for giving a large dinner party, from the very first moment that I arrived in altona, not only my old friends, but also new acquaintances had treated me with such kindness that I could not otherwise but make some return for the many attentions and civilities which were shown to me. At first I intended to confine myself to my more intimate friends of my own age, and some younger folks, but Sieveking and his wife assured me that those of maturer age, such as C. H. Donner, Fritz Baüer, the Stühlmann's and others, would willingly come, if invited. Consequently the number of my guests was to be thirty, and I settled with Messaw the o[_] of Rainville's Hotel, to furnish me with a good dinner at six marks per head, w[_] of course excluded, but including candles, fuel, coffee, tea and cards. With Sieveking and Theresa I had arranged in what order the guests were to sit, and I had then nothing else to do, but to write their names on cards which I placed before each seat, and to expect my friends in the [409] receiving rooms which Messaw had placed at my disposal, and from which a few step lead down to the large oval saloon in which the late Railroad-ball had been given and where now the dinner table was laid out. The following were prevented from accepting my invitation, Lawyer Stühlmann being engaged at a party in Hamburg; Old 
Lübbes because the bad state of his health required the strictest diet; Lawyer Lübbes, for a similar reason. Kramer, who could not absent himself from a weekly club; Hermann Dryer whose presence at a meeting of the Hamburg "Tribunal of Commerce" of which he was a member, was indispensable; Post who had started for Bremen on the previous day; and a Mr. Bush who like myself lodged at Rainville's, and to whom and his lady, an Englishwoman, I had paid a long visit on the previous evening, because on account of his great obesity, he did not like to be pinned to his chair for any length of time. At the same moment Mr. Stühlmann the merchant, George Baür and Edward Reincke sent excuses, being prevented by sudden indisposition. The first who made his appearance was Senator Hesse who was desirous to have a long private chat with me, the next were Fischer, Sieveking and young Gibbs, after whom the remainder dropped in, in rapid succession. Doctor Gustavus Schmidt, and Warnholtz came, when we had already sat down, of all present C. H. Donner was the highest in rank, he bearing the title of "counsellor of State" (Etats Rath), next to him in rank was old Fritz Bauer, geheime Conferenzrath, coun[s]ellor of secret conference \{Conference (Conference Rath) Whilst Fritz Bauer older than he by several years and of a higher standing in the mercantile world was his inferior in rank being only cons[el]lar of $\}$; to these two I addressed myself requesting them to lead the way which they did, Donner keeping always a pace ahead of his Companion whom I assisted when descending the steps. I had arranged that I should sit on one side in the centre of the table with Baür on my right, when C. H. Donner, should front me. However, as these two kept inseparable, I placed Senator Hesse to my right; at one end of the table, Sieveking took his seat, at the other Theodore Reincke in lieu of his brother Edward; the following give an idea of how we were ranged. (See next page.) I of course conversed a good deal with Senator Hesse, also with young Gibbs, son of Mr. George Henry; C. H. Donner was particularly agreeable, old Fritz Baür afterwards confessed to Sieveking that he had been much pleased. I took with C. H. Donner a glass of wine to the health of his daughter Mrs. Zarthmann, he one with me to the health of my wife; Knauer gave my health, Arnemann my wife's, somebody else, my daughters's, I ought to have stood up and given my thanks, but could not muster sufficient courage to do so. At about eight o'clock I looked significantly at the two old gentlemen opposite, they understood my meaning and rose [_] by all. Sieveking told me that their early breaking up had been a good saving to my [_]rse, for several of my friends had made up their minds for a long carousel [_] for a consequent swelling up of my wine bill, which intentions were thus frustrated. With difficulty could I make up two whist tables; to the one sat down Johannes Limpricht, Theodore Elmenhorst, Gustavus Schmidt and Schuster, [410] when Schmidt and J. Limpricht left 
for Hamburg, Theodore Reincke and I came in for one rubber, which over I ceded my seat to Daniel Schutte who had been playing at "bouillote". The other table consisted of Kedenburg, Hesse the Senator, Shutt and Fischer; Hesse and Schutte's places were taken by Knauer and myself at a later hour, towards eleven oclock all were gone. Daniel Schutte was the last. I flattered myself that this party had given general satisfaction and that all had been pleased. The dinner certainly was good, the cost was the following:

30 Dinners at

$11 / 2$ bot. Madeira at

$11 / 2$ bot. Port at

18 bot. St. Julian at

6 bot. Markebrunner at

6 bot. Sauterne at

18 bot. Champaigne at

Extra illumination
6 [CM]

3.0

3.0

2.8

3.8

3.0

5.0
180.0

4.8

4.8

45.0

21.0

18.0

90.0

10.0

[CM] 373

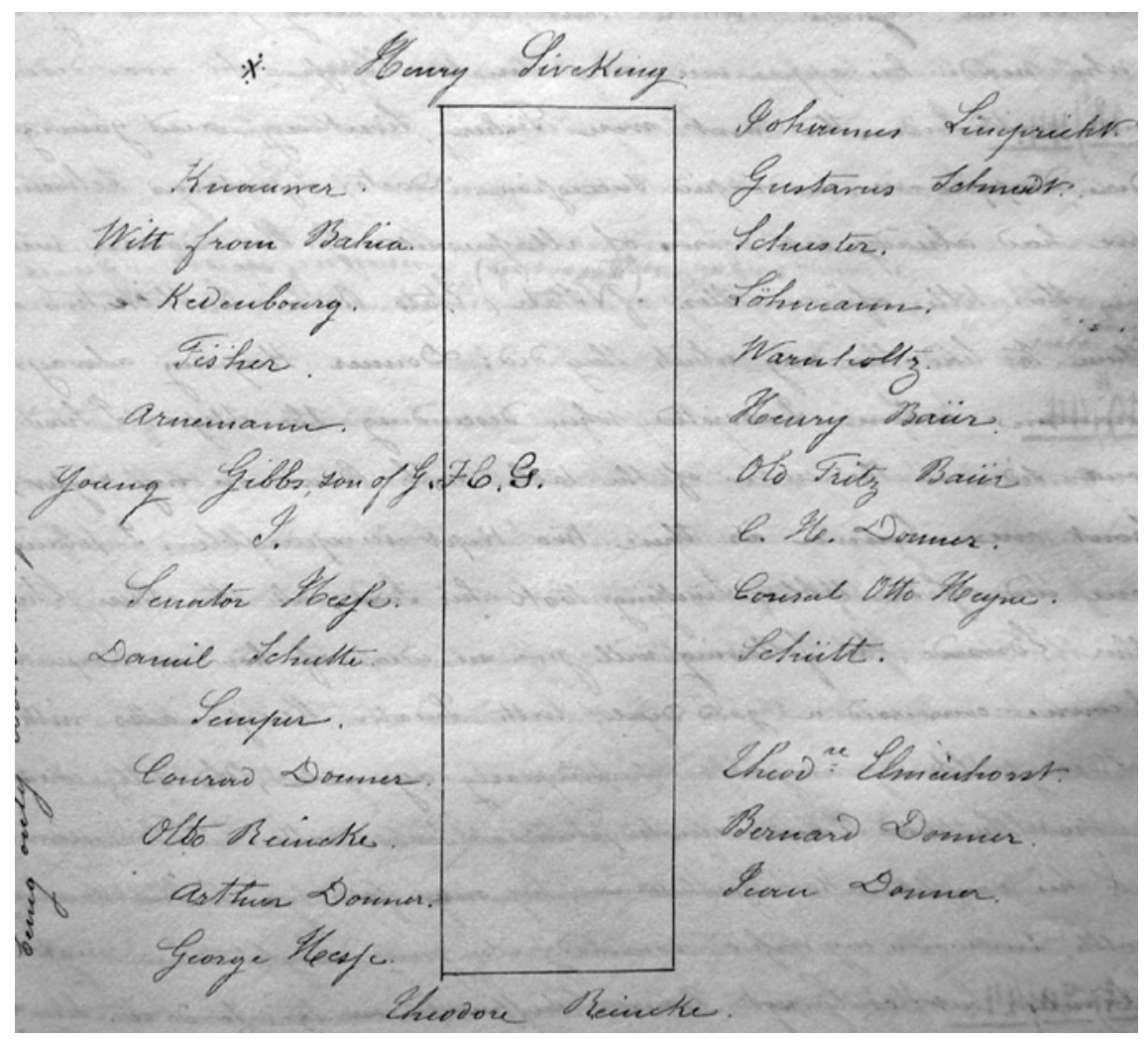


The Old King of Sweden Bernadotte Duke of Ponte-Corvo had died and been succeeded by his son Oscar.

Sunday, $17^{\text {th }}$ of March 1844. Accompanied by Semper I paid a visit to [_] astronomer Professor Schumacher whom I recollected as a guest at C. H. Donner previously to my departure from Altona in 1823, he received us unshaved and wrapped up in his "robe de Chambre", he was what [_] may call chess mad and having been [411] informed that Semper and I were fond of the game had expressed the wish that we should call upon him, he showed us several very interesting problems and read a part of a letter written to him by Monsieur Deschapelles who he said was at the time the first Chess player in Europe. Until then I had been under the impression that Messrs. Saint-Armand and Staunton of whom I spoke page 312 of these extracts were considered as such but of them Monsieur Deschapelles spoke rather disparagingly in his letter. I dined at the Senator's Henry Baür. There was amongst the guests a young medical man, Doctor Sieveking from London whose evident good opinion of himself, and self-sufficiency made him altogether distasteful to me, he was the youngest son of Mr. Edward, the cousin of Henry Sieveking's. His mother was also a native of Hamburg, but he was English by birth. Many years elapsed before my hearing again of him, until 1864 when he appeared in the Newspapers as one of the Physicians of the Princess of Wales called in at the sudden birth of her first born; a proof that he has risen high in his profession.

Monday, $18^{\text {th }}$ of March 1844. I dined at Henry Sieveking's, and supped at his mother's, in both houses I was quite at home, and was looked upon as if I belonged to the family. Old Mrs. Sieveking treated me like a son, Ernestine and Henry I knew since the days of my earliest childhood. Löhmann was a very well informed man, but the two young ladies were rather too taciturn to suit my taste.

Tuesday, $19^{\text {th }}$ of March 1844. A fine sunny day of which I availed myself to take a stroll through Rainville's Garden. The engineers who directed the construction of the inclined plane committed dreadful ravages amongst the stately trees which had once formed the fine avenues of "[Sl]avenshoff"; not one of them was left standing, one house had come to the ground, another was shortly to share the same fate. I wrote an official despatch to that Department of the Copenhagen Ministry, which was called the "College of Commerce" and the Consulates, and to which at the time I was instructed to address myself. The purpose of my note was to communicate to the Danish Government all that I knew of the Political disturbances in Peru and which I extracted from the various letters written to me by my family. In the evening I was at old Reincke's. 
Wednesday, $20^{\text {th }}$ of March 1844. Mr. George Baür had invited me to dine with him - him and his lady I liked above all, there reigned in their house an air of gentility and exquisite good breeding not to be found everywhere else, also the persons whom I found with them I did not meet generally in the houses of my other acquaintances, and thus no invitations were accepted with greater pleasure by me than those which I received from Mr. Baür. It is true that at dinner, Mrs. Baür who sat to my right was so much taken up by her neighbour on the other side, [_] Heyne [_] whom she seemed to be on very intimate terms [412] that she did not show me all the attentions which I might have expected, however as Ernestine sat at my left, I did not complain.

Thursday, $27^{\text {st }}$ of March 1844. The commencement of spring. Though the ground was covered with snow, the sun shone merrily which induced me to fulfil the promise made long ago to William Mathiessen of paying him a visit. He lived a good distance off at the North east extremity of Altona in the Pinneberg road, a prolongation of the Old Johannes Street. This part of Altona was quite new to me, it had sprung up during my absence, and many houses of bricks and stuccoed over were about being built. Mathiessen's house was small, but enjoyed a fine view over this surrounding country. He received me in his dressing gown, his young wife dressed plainly and decently looked very well. Mathiessen lived upon the interest of a small capital inherited from his father, and as his detractors said, did nothing but buy needles and thread for his wife; at all events he appeared happy; some might call him a Philosopher others a man without ambition and energy. The agency of his rich brother Adolphus who employed him in placing money on interest gave him just now a little more to do than usually. After an hour's stay with them Mathiessen accompanied me to the new Cemetery situated still further out of the town, and which I had not seen before. It was laid out regularly, divided by gravel walks (into compartments) and planted with evergreens. Thence we walked over the open ground which confined Altona to the North, we reached the projected Railway where labourers were at work levelling the ground. It comes from "Langefelde", where it crosses the high road from Altona to Kiel then leaves to the right a well known public house called the "Ha[hn]enkamp", cuts off the Eastern end of "Koning's street", and terminates on the Northern side of the Eastern extremity of the "Palmaille" where the terminus was to be built. Thence, rails across the road place the railway in communication with the more than once mentioned inclined plane of which in March 44 the outlines were nearly discerneable. On my return I met George Knauer and Mrs. Arnemann with whom I entered the large property just purchased by Mr. Arnemann from the Jew Gümpel, it was extensive and though Mr. Arnemann had counted upon part of it being 
absorbed by the great improvements then in progress in the neibourhood yet even without that part it will always be considerable.

Friday, $22^{\text {nd }}$ and Saturday, $23^{\text {rd }}$ of March 1844. Nothing worth noticing occurred; I concluded Warren's splendid novel called "ten thousands a year", sorted various papers which I had found in the large box left with Sieveking, I destroyed most of them but preserved fragments of my diaries, my letters to Maria from Woodford wells, and letters from my two sisters to myself. I also commenced a great undertaking, which by the by I did not conclude, viz. that of making the abstracts in Italian of Allen's and Dahlmann's L [... of Denmark, the former written [413] in Danish, the latter in German.

Sunday, $24^{\text {th }}$ of March 1844. I was occupied with my Italian abstracts of the history of Denmark until it was time to dress and to make a few calls. at Bocklemann's I found the family in a more than usual state of excitement, for the daughter Francisca had just come home from the principal Lutheran church, where she together with one hundred and sixty girls and boys high and low amongst whom besides herself Bertha Stintzing, and one of the daughters of Mr. and Mrs. Blacker (formally Leny Becher) had been confirmed by the "Probst", the title given to the highest clerical authority in Altona. I went to dine at Mr. Isaac Hesse's, where I was received by the eldest daughter Mary, a young lady rather plain, but extremely well shaped and agreable; gradually appeared Mr. Hesse and Lady, their two sons George and Emil, Mr. Gähler, Daniel Schutte and Mr. Behrens from Dantzig, a Frenchman from Hamburg, a little grey-haired man, and young Spaniard whose acquaintance I had already made at the ball. Mrs. Hesse though always polite and civil, was it would appear less friendly to me than to the other guests. The Gent[m]. (Frenchman and Spaniard) spoke German fluently, nevertheless a great deal of the conversation was carried on in French, perhaps because Mrs. Hesse was glad to have an opportunity for showing with what ease and fluency she and her daughter spoke this language, in which accomplishment the Gentlemen were certainly not equal to those ladies.

Monday, $25^{\text {th }}$ of March 1844. An invitation from Dr. Gustavus Schmidt from Hamburg prevented me from being present at a dinner party given by Sieveking. I looked in at Streits where I found Post just returned from Bremen and about leaving for Hull; he told me that in all probability he would return to Valparaiso, and again take charge of Daniel Schutte's establishment in that place. Of the various people I met at Schmidt's Dr. Löhrs and his wife, sister of Mrs. Johannes Limpricht pleased me best, both were very gay and conversative. Three card-tables were formed, two of whist, one of "'hombre"; at one of the former I sat down with Mrs. Gustavus Schmidt, Mrs. Löhrs and a Mr. Palm. By chance we two gentlemen were partners the whole evening and gained 
every rubber. The ladies losing jointly not less than one hundred and forty two points, fortunately for them however at no higher stake than 2 Sh currency the point. A warm supper was served next, I sat close to Mrs. Gustavus Schmidt. Then a bowl of Punch was brought in and we separated at midnight. at this hour of the night the streets of Hamburg were almost deserted, the watchmen being the only human beings to be met with; I slept at Kramer's.

Tuesday, $26^{\text {th }}$ of March 1844. Dinner parties did not cease, this day one was given by Mr.Theodore Arnemannin celebration of hislady's birthday. Arnemann lived at the time in the same house in the Palmaille which, about the year 1808, was occupied by [414] my father, mother and family. The interior arrangement had undergone little change when going up stairs, a door faced you which led to a room which in my parents time on account of its brown paper-hangings went by the name of the brown room. Here my father used to sit, and made me, though only a boy of nine or ten years of age, study very hard. When, there is little doubt, I laid the solid foundation of all I learned in later years. In this room the Gentlemen invited assembled. Next to the left were two rooms, the one like the brown room looking towards the Paillmaille the other adjoining the same, towards the garden. The former which had been my father's bedroom was that in which the ladies of the party were received; the other my mother's bedroom, was Arnemann's private office. To the right of the brown room were two others corresponding to those of the left side. The one towards the street was called by us, the yellow, also the best room, because it was opened only on grand occasions. That close to it, but with no communication towards the garden was my paternal grand mother's dormitory. These two rooms Arnemann had made into one divided by a slight partition which this day had been removed, and in the Saloon thus formed the dinner for twenty persons was laid out. Some of the guests were my Altona acquaintances, Knauer, Warnholtz, etc., etc., besides these a few Hamburg relations of Mrs. Arnemann, the remainder unknown to me. I led Mrs. Constance Elmenhorst to the table and my neighbour on the other hand Arnemann's married sister being not only a stranger to me but also very hard of hearing, I devoted myself exclusively to my fair partner. When coffee was handed round Theodore Elmenhorst and I took hold of Mrs. Arnemann who as I have previously mentioned was a somewhat eccentric woman, Semper joined us and we had a long, merry, and even boisterous chat. Mrs. Arnemann was in high spirits, and as I by chance alluded to Mühlenbeck, an Estate, which once the property of my grandparents, had lately fallen into the hands of Arnemann, there was no end to the stories which she had to relate of the adventures befallen her there. With this conduct of Mrs. Arnemann, some of her female friends were rather displeased, and very properly so, for she as hostess ought to have remained with, and attended to them instead of 
laughing and talking with the gentlemen. When we broke up at about 11 p.m. it was such a mild night that I had no inclination to go to bed. With Heyne I promenaded for a while on the good pavement in front of Baür's new houses, then by myself walked as far as the Nobies gate, and returned to my lodgings at midnight. On this and the previous day the open place around the town house, and some of the streets leading to the Nobies-gate were occupied by two or three rows of miserable booths in which as well as in some of the neighbouring streets, articles of little value such as toys, cakes, ginger bread in abundance and ordinary manufactured articles were exposed for sale. This constituted the Altona Fair held every three months, a diversion for children otherwise [415] of no importance.

Wednesday, $27^{\text {th }}$ of March 1844. In the first volume of these extracts I gave an account of my childhood, I have stated that for five years and three months I frequented the Altona College called the "Gymnasium", more than once had I undergone a solemn examination which at the time used to be held once a year in the large saloon of an adjoining building called the "Hörsaal"; it was thus very natural that I should like to see how such things were now managed. Accordingly at about 9 a.m., I accompanied Professor Fransen my latin teacher to one of the College rooms where the pupils of the first class or the "Selecta" were in the habit of taking their lessons, this room was nearly the same as when I left in midsummer of 1814; only the large lecturing desk for the teachers had been altered a little and the small desk before the larger one had been removed. Director Eggers opened the solemnity with a small Latin speech. Professor Klausen did not remain long. Director Eggers and professor Franzen were the examiners, Probst Paulsen was present, I the only visitor. They commenced with the pupils of "Selecta" of whom there were no more than nine or ten; they appeared to be between 18 and 19 years of age, and some affected the dress of the German students, long hair falling on their shoulders, the so called German coat, the shirt collar flapping over, and a little bit of a cravat round their neck. In greek they translated Theocritus, in Latin Tacitus. Of this I was able to judge, and some did it well. Birck examined in Danish. Next came the pupils of Prima in the same number as those of Selecta, in age two or three years younger, they translated Homer and Virgile, the later quite fluently and correctly. Schwalb examined in French which language they pronounced fairly and translated well; the last were the pupils of Secunda, ten or twelve boys between ten and twelve years of age. I was astonished to see the progress which they had made both in Latin and Geography. At about eleven oclock all was over. In the afternoon the examination of the lower classes was to follow. I was told that the "Gymnasium" was about to be remodelled; the class of Selecta was to be abolished, and the five classes of which the College was now to consist, were to 
be called: Prima, secunda, tercia, cuarta, quinta. Towards the evening I drove to the Thalia Theatre in Hamburg which had been much recommended to me, and in which higher comedy and farce were generally represented, whilst the principal Theatre of the town was dedicated to Dramas and Tragedies. The play acted had the title of "Doctor Wespe" (in English "Wasp") which was not much to my liking, though the performance was good, and two actors from other theatres had joined their efforts to those of the Hamburg Company. The interior of the house was built in a light and elegant manner, fitted up and painted prettily and tastefully. The space allotted to the pit [416] was unusually small, whilst the stalls between the pit and the orchestre were occupied by many rows of benches, there were two tiers of boxes each with large balcony in front, above the gallery; the admittance varied from six shillings the lowest for a place in the gallery, to twenty four shillings for a seat in the stage boxes.

Thursday, $28^{\text {th }}$ of March 1844. The weather was fast improving, snow and ice had disappeared, at 2 p.m. the thermometer in the open air and in the shade stood at $12^{\circ}$ Reaumur equal to 59 Fahrenheit. The sun shone, and with my windows open I enjoyed the view over the gardens to the Elbe alive with sailing vessels and steamers. I dined at Mr. Stühlmann's the widower. It was one of the usual parties which requires no particular description. At dinner I sat between Mrs. Theresa Siveking and Miss Carolina Tesdorff; regarding the latter I find the following observation which I copy "Verbatime": Miss Tesdorff liked to carry her nose rather too high, I found out how to pull her down, I needed merely to take no notice of her, then she, fearing that she was neglected, came to, made the first advances and was very agreeable.

Friday, $29^{\text {th }}$ of March 1844. In the course of the forenoon four young men, pupils of the Gymnasium College who were about leaving the highest class "Selecta" for the University, had according to custom to deliver their farewell speech, in the Saloon called the "Hörsaal". Thither I went at about 10 a.m. the Saloon was very plain, it was white washed. At one end stood the two Cathedras, the larger nearest to the wall for the professors, the smaller before the other for the pupils; both painted white with gilt edges. On the walls hung on one side the portrait of King Frederick $V^{\text {th }}$, on the other that of King Christian VII. In front of the Cathedras were placed several benches and chairs pretty well filled, mostly with ladies. Here I took my seat. The open space between these rows and the Cathedras was occupied by two groups, the one consisting of Count Blücher-Altona, the Burgomaster Böhn and the "Probst" Paulsen who formed the directory of the College. In the other group opposite I observed the professors of the College including the Director Eggers, also Mr. C. H. Donner. The pupils were all neatly dressed in black with white kid gloves, each holding in his hand the Manuscript of his speech and to which 
he refferred occasionally when memory failed him. When the musical band placed on the gallery opposite to the Cathedras had ceased playing, the first ascended the smaller Cathedra. His name was Phillipe Henry Schwartz native of Altona. In his Latin speech which he pronounced very distinctly and of which I understood something, he treated of the advantages which the fatherland derives from the Altona College, this is the subject prescribed in the will of a Mr. Schröeder who many years back left a certain sum of money annually to such pupils as the teachers should consider worthy of the reward, on condition as already said of his dilating in his speech, on the advantages according to the population of the Kingdom $\mathrm{f}[\mathrm{rom}]$ the Education given in the Altona [417] College. Towards the end of his speech, he in the same manner as his three companions pronounced a very short allocution to the Directory of the College, to the teachers, to his fellows students, and to the audience which was considered as the representative of the town of Altona expressing his thanks to some and saying farewell to all. The second was George Frederick William Worsmann of St. Pauly who in a neatly turned, well delivered, but rather superficial speech in German explained what was required in order to render a certain event in history of particular interest to the reader. The third, Otto Kallsen of Altona, in Greek Yambieks indistinctly pronounced and probably understood by nobody showed the relations between different arts. The allocution was fortunately not in Greek but in German verse. The fourth and last, Samuel August John Vezin of Kiel, attempted to show in what the practical mind so necessary for a Scholar actually consists. He spoke too hurriedly to be well understood. Each time between the different speeches the music played for a few minutes, and as soon as Mr. Vezin had descended from the Cathedra, Mr. C. H. Donner rose and delivered a few words, the purpurt of which I could not make out on the spot. Afterwards I learnt the following: at the death of the much beloved burgomaster Gähler which occurred during my absence, it was mooted to erect a monument to his memory. Some Altona people were of opinion that it would be more advisable to lay out the money subscribed for this monument in a manner which they believed would have been more agreable to the Burgomaster if alive. Accordingly it was determined that the sum collected should be placed at interest, and such interest be laid out for the assistance of poor and clever young men on their leaving the class of "Selecta" for the University. C. H. Donner subscribed most, and therefore it was resolved that the teachers of the College having fixed upon the young man whom they considered worthy of this pecuniary aid, it was Donner who should publicly communicate to him this pleasant piece of news. In 1844, the choice had fallen on young Vezin, and C. H. Donner informed him in a few words that for the next three years he could count upon five hundred 
marks currency annually. On my return to my room I stopped for some time in Arnemann's lately acquired property, and wondered at the rapidity with which the Railway Engineers progressed in their work, regretting at the same time the indispensable destruction of so many fine trees, once the pride and Glory of the adjoining garden of Slavenshoff and Rainville's. Some of the trees were of such magnitud and so deeply rooted that it was found necessary to blow them up with gunpowder. Last Sunday, there had been a general strike of the labourers on the Railway; the Danish Dragoons were called in to quell the disturbance. Sixty of the working men were discharged, and to those who remained [418] their wages were raised; they now received eighteen Shillings per diem. New branch lines were spoken of, and likely to be carried out: the one already spoken of between Elmshorn and Gluckstadt distant two German miles, cost 6oo,oo CM, another from Itzehoe to Hackelström, one and a quarter German mile north of Elmshorn cost 500,000 CM; a third from Itzehoe to Heide, a fourth from New Münster, one of the principal points on the trunk road to Rensburg, and the last from this latter place to Flensburg, for which last mentioned 8000 shares of one hundred species each, or 3,000,000 CM. were required, and a considerable number of shares were said to be taken. The shares of the original trunk Railway stood at 113. A Russian Polish loan of $35,000,000$ Bo. Mks. paying $4 \%$ interest was contracted in Berlin at $86 \%$, in which several Bankers of Hamburg were said to have taken a share. The evening I spent at Knauer's. The famous sculptor Thornaldsen born in Ireland in 1770 ( $29^{\text {th }}$ of November $)$ died suddenly on the $10^{\text {th }}$ of March in Copenhagen. De Pradt, one of Napoleon's famous diplomatic agents is also dead.

Saturday, $30^{\text {th }}$ of March 1844. As it was my custom on Saturdays, I went in the evening to Mr. Bockelmann's where I lost a game at chess to Mr. Jones, who was teacher of mathematics in Hamburg. Mr. Bockelmann paid him for coming out to see him, and as the old gentleman passionately fond of the game was too weak in his head to play himself, he was of course very glad if any one came in to play, and he could enjoy himself by looking on. When I was on the point of leaving at 8 o'clock, Mr. Petersen a young Astronomer under the care of Schümacher entered to take my place, at Kramer's in Hamburg one of the customary evening parties had assembled, of which I need not say anything.

Sunday, $3^{\text {st }}$ of March 1844. With Dr. Kramer and little Mary I went to Saint Catharine's church, the interior of which was very plain and unadorned, perhaps too much so for a place of Divine Worship; two rows of massive high square pillars built of brick and whitewashed divided the church lengthways into three passages, the middle, the wider one, the Nave, the two lateral ones somewhat narrower, the aisles. At the east end of the nave stood the altar, at the western extremity the organ. On the right handside looking towards the altar 
was the pupilt. A few paintings representing probably Hamburg burgomasters or Senators hung against the pillars, the light was admitted through several high round windows consisting of innumerable small panes, a few of which I observed to be painted. Round the walls whitewashed like the pillars ran the gallery, totally empty on this occasion, probably because the preacher's words could not be heard well from there. Below, the area occupied by pews and chairs was crowded with devout listeners. Under the pulpit sat three senators in black with old fashioned white ruffs round their neck. The Clergyman's attire did not differ materially from that of the Senators, his sermon which treated on the subject "that sufferings formed" the true Christian [419] pleased me well, the repeated singing out of the prayer book seemed to me very tedious and two interruptions I thought very improper, the one caused by a woman who was eagerly collecting the price of each seat, the other caused by the "Klingbeutel" or tinkling purse, which was the name given to a purse or small bag with a narrow opening, into which all present threw a small coin, seldom I believe more than one Shilling. The object of this collection for the poor was praiseworthy, but not so in the manner in which it was made; the bag with a small bell attached to it whence the name, was fastened to the end of a long stick, provided with which a man dressed in black, probably belonging to the vestry, visited each corner of the church, and I doubt whether a single one of the numerous congregation escaped without the "Klingbeutel" being presented to him. At 10 1/2 service was over. I called upon and lunched with Mr. Kedenburg, dined "en famille" with old Mrs. Siveking and closed the day playing at chess with Semper who was gradually getting too strong for me; this evening I lost two and gained one game. It was a beautiful moonlight night, when I returned to my lodgings not a human being was stirring. Instead of retiring to rest, I went to the small balcony in the eastern corner of Rainville's garden where leaning on the railing, I admired for a long while the wide expanse of the river over which the moon nearly in her full threw a wide streak of silvery light. There was not a breath of wind, and thus the waters motionless were hardly ruffled by a solitary boat rowed across. Here I stood thinking of times long past by, of my mother and sisters who were no more; of my childhood and youth, then also of my good wife and family on the other side of the Atlantic.

Monday, $1^{\text {st }}$ of April 1844. I had a visit from Mr. Henry Pflucker of Hamburg who was at the time considered the black sheep of his family. He asked me for one hundred dollars against his order on his brother Julius in Lima, which I however in polite terms refused doing.

Tuesday, $2^{\text {nd }}$ of April 1844. The weather was so pleasant that Messow, the owner of Rainville's Hotel considered the time had come to place the small 
tables and chairs kept indoors during the winter, in the large open place behind the hotel in expectation of the guests who were to come. The Evening I spent at old Mr. Reincke's.

Wednesday, $3^{\text {rd }}$ of April 1844. A quiet day and lovely weather similar to that of the preceding days. In the garden I met old Mr. Reincke with his daughter Wilhelmina surrounded by a number of little girls, his grand daughters and their friends. He told me that old as he was and though he had come thither hundreds and thousands of times, he never tired of the prospect from this spot. Maria Knauer was the eldest of the young girls, she was just budding into womanhood and though she could not be called beautiful, [420] her fair blue eyes like those of her father's being too prominent, and her teeth having a somewhat yellowish tinge, yet she was rather pretty, and at all events a nice creature, the Spaniards say "no hay quince, malos". I received letters from my wife and Juan dated 4 and $26^{\text {th }}$ of December, the latter answering mine of September 26 from London which must have reached Lima in sixty days (a very short time in 1844). Also from Mr. William Gibbs a letter came to hand in reply to that written to him by me, he said that my wife's desinclination to live in London was a sufficient reason for my refusing the offer which he had made me and added that many difficulties were in the way to my filling $\mathrm{H}[\mathrm{e}] \mathrm{yne}$ 's place in Lima in case he were to leave, as I had suggested.

Thursday, $4^{\text {th }}$ of April 1844. Though the weather was fine there was a little more wind, the water of the "Elbe" had a Brownish colour and the waves sometimes were white crested. Warnholtz, who with some of his children took his coffee in the garden, told me that he had just disposed of 25 shares of the Altona-Kiel Railway on account of the town of Altona at the high rate of $118 \%$. At five o'clock I went with my fellow lodger Shütt to dine at C. H. Donner's; four ladies having been prevented from coming by indisposition, the party was small. Viz.: old C. H. Donner, his son Bernard Donner and wife, Dr. Hayck, architect Hansen, Schutt and myself. The usual great variety of wines was not served, we had merely Bordeaux, madeira, which bottle Donner ordered to be placed before me though I drank only one glass, excellent red champagne and first rate claret. Both the host and Mrs. Bernard Donner were very polite towards me. The health of Theodore Elmenhorst and wife Constance was drunk, this being the fifteenth anniversary of their wedding-day. We drank also to my wife's health. With Bernard Donner I had a long yarn in the Smoking room, and we wound up with whist at a rather high stake. It was long whist, but the tricks were counted double, the rubber itself was seventeen points, besides which many extra points were paid such as three or four aces, four honours, seven or more trumps in one hand. I lost fifty six points at four shillings $=$ fourteen marks currency. 
Friday, $5^{\text {th }}$ of April 1844. (Good Friday). Shortly after breakfast Mr. Schutt came to thank me for the fourteen marks gained by him last night, which I had sent him by the waiter. Probably he wanted to while away an hour or two, because this being a close holy day he had nothing to do in the Hamburg mercantile world. I will not give him the epithet of a proser, but at all events he was a great talker, sometimes very tedious. The weather was fine, and I therefore started at half past twelve oclock for a long walk projected long since; the wind blew sharply from the coast, but as I walked westward I had it on my back and was not inconvenienced by it. Shortly after leaving Rainville's I crossed the field on the [421] other side of the Flottbeck road over to Ottensen, and came to a lane which in my childhood went by the name of Philosopher's path. Now the carriage-road running alongside was less muddy than formerly. The superfluity of branches had been cut away and the whole had lost its sombre appearance; whether the name had remained, I cannot tell. Imperceptibly ascending I reached a spot a little elevated above the surrounding country. Here stood in 1844 and stands probably now in 1869 a mill, that of Roland, a country house of a round shape with its surrounding garden, in 1844 the property of architect Hansen and close by a deep gravel pit, all objects recollected from former years. I looked round me; to the east I discerned the few steeples of Altona and Hamburg, thence to the right or southward the first and second mills and many country seats with their parks on the south side of the Flottbeck road conceal the Elbe and the Hanoverian shore: to the westward, distant half a German mile more or less, is the Flottbeck wood, in 1844 Jenisch's property, whilst close by in the same direction I had before me the village of "Ottmarshen" partly concealed by trees, leafless of course at this season of the year; still more to the right, drawing towards the north some red tiled houses looked rather garish in the clear sun light, and other villages; finally a few scattered windmills near Altona closed the circle. Jumping over ditches, breaking through hedges, crossing fields, now and then forced to turn aside by a recently ploughed piece of ground, I made my way in as straight a line as I could towards those red roofs which had attracted my attention, and which I reached in about half an hour. On Inquiry I was told they were the village of "Barenfeld". The appearance of some of the houses, the large panes of glass, the curtains at the windows, all denoted that the owners were Hamburg and Altona people; also the thatched houses of the peasants looked very comfortable. Owing to this being such a close holy day few people were at work, all whom I saw were neatly and cleanly dressed, here and there boys were playing in the streets, a girl, prayer book in hand coming from church. Three roads I saw now before me; that to the north leading to "Shenefeld", that to the west to Blankenese by way of Gross-Flottbeck and Osdorff, that to the South to Klein Flottbeck. I chose the middle one. In 
gross Flottbeck the houses did not stand quite so close to each other as in Barnfeld, also to judge by appearances they were less occupied by town people. I noted one building with a square steeple of which I had a faint recollection from my childhood; then it was owned by the family "Goverts", now by a certain Von Bullow from Mecklemburg. Passing behind the Flottbeck wood and the School house, where I had visited the two young Armero's on December $21^{\text {st }}$ last and following a long carriage road with hedges on each side arrived at the village of Osdorff, whence the high road leads to Weddel, whilst turning to the left reached after a few minutes the village of "Dockenhude". The fields and meadows on both sides of the high road which I had come, were just tilled, ready to receive the seed; others [422] were green with the young grass and new corn an inch or so high. I may mention here that it is the custom in the north of Germany, perhaps also in some other countries, though of this I am not certain, to sow twice a year, once a little before the winter sets in, this is called the winter corn, and was now above ground; the second time at the first beginning of spring; this goes by the name of summer corn, and is naturally harvested a few weeks later than the former, the winter corn. At Dockenhude, art has done much to improve and embellish nature; nature has given nothing but a few sandy downs, called here "Berge" or mountains. Art has transformed them into tasteful plantations and adorned them with comfortable houses. As the soil is poor fir trees and birches grow most easily, though on some spots where the ground is improved by manure, more noble trees can find the nourishment which they require. The first hill which came in sight was the Crow mountain "Krähenberg" with Mr. Ross' country house and garden: opposite on another hill, Klünder's property. I passed between the two and wended my way to the Sühlberg, where thirty or more years back I had been in the habit in company with one or two of my playfellows of catching butterflies; then it was in a state of nature, now an inn stood on the summit, surrounded by a garden still in its infancy. When I expressed to the owner my surprise that the rooms of his house were uncommonly low, his reply was that the wind blew sometimes with such violence as to expose higher structures to the risk of being overthrown, "and therefore" he added "I preferred building my house in the humble manner in which you see it". Far down the river where it increases so much in width as to convey an idea of the open sea, by means of a spy-glass, the steeples of the town of Stade can be seen from the Sühlberg in the opposite direction, further to the east than Hamburg, like Städe on the Hanoverian shore, the steeples of "Lüneburg" are said to be distinguishable on a fine day. Between these two extremities, I descried "Haarburg" opposite Hamburg; the deep inlet between the islands, called the Köhlbrand right in front of Altona, the villages of Altenwerder, Möorburg, Finkenwerder, and others until exactly 
vis-a-vis to where I stood, the wide Elbe between us, my eyes rested upon the steeples of Neustadt, the small river Este taking its source not far from "Buxtehude" falls into the Elbe close to a place called the "Kranz" whither travellers cross over from Blankenese. On the Holstein side, the view presents nothing of interest, a few sandy uncultivated hills, then a sandy plain stretching as far as "Wedel" close to the river, and "Uetersen" more inland. To the East on the contrary nothing prettier can be seen than the village of Blankenese lying before me with its tortuous streets winding up and down, between the hills on the sides of which it is built, in 1823 the houses were all thatched, but since then two conflagrations have taught the Blankenese people the danger of straw roofs. In 1844 nearly all the houses were of brick and tiled. On the other side of the village the hills which formed the northern shore of the Elbe are covered with trees, shrubs, and bushes in great variety, which completely confine the horizon in this direction, those nearest belong to Fritz Baüer's noble park, an artificial ruin, a temple and similar structures peep through from between them. Besides Baüer's, the garden of Godefroy, Parish, and other wealthy Hamburghers extend to the village of "Nienstädten", no demarcation is distinguishable, an extensive woodland lies before the beholder and all this be it borne in mind, brought about by the hand of man, for originally these sandy downs were either entirely barren or overgrown with weeds. I took a plain dinner, cold veal, potatoes, pancakes, and two glasses of white Bordeaux wine cost five shillings each. I had a long conversation with the landlord who told me amongst other things, that in Summer on Sundays when the weather was fine sometimes one thousand people visited his Inn on the "Zuhlberg", the greater part from Hamburg, per steamer. At 4 p.m. I started again, descended the Zuhlberg, walked leisurely through the village of Blankenese, noticed two little girls who [423] having made some incisions in the roots of a birch tree allowed the juice to drop into two small bottles, and assured me that this liquid was a most wholesome beverage, then entered Klunder's garden where a bed of multicoloured roses attracted my attention, and finally visited Fritz Bauer's garden. The principal gate was opened only to the owner, his family and friends, whilst visitors like me anxious to see it had to address themselves to the porter at the smaller gate where they were requested to inscribe their names in a book kept for this purpose and to pay a few shillings for admittance which money thus collected was laid out for the benefit of the poor of Blankenese. Bauer's park covers a very extensive area, it includes three or four of the already mentioned sandy downs which by dint of labour, and at an immense cost have become what they are now, a delightful and valuable property. The upper part is a piece of level ground where the dwelling house which is a pretty building stands; near to it are the out-houses and stables, shrubberies around, with 
grassplots between; thence fine avenues interspersed with [Sylverio] huts, a Chinese pagoda, an artificial ruin, and a temple of which latter I had a glimpse from the Zühlberg, lead gradually to the lower grounds, partly occupied by large hot-houses, and finally to a massive quay constructed of big square sand stones floated down from the quarries of Perna, with an equally soled iron balustrade along the same. The object of this quay is of course to defend the property against the inroads of the Elbe which at the time I was there was however separated from it by a broad belt of sandy and stony beach. I had no time to remain long, for it was getting late, and I was still far from home. I now took the high road to the village of "Nienstädten", passed many country seats belonging to Cesar Godeffroy, Oswald, Anderson, and others; that of Richard Godeffroy is nearest to the village; the spot where it stands is called the "Bost"; and here the well known and famous Philosopher, Scholar, and Statesman Hugo Grotius resided for sometime, so at least the landlord of the Zühlberg informed me, and it is most likely that he was right for I see in Grotius Biography that after his second banishment from Holland, and before queen Christina of Sweden called him to her court, he lived for sometimes in Hamburg about the year 1633. From Richard Godefroy's country house the distance to the village is small. "Nienstädten" is of some importance, to its curacy ten villages belong, on the right hand side of the high road is the fine country seat of Richard Parish, next to it the well known inn of Jacob much frequented in the Summer season by the town people, then the road runs so near the brink of the hill as to leave very little room for plantations, whilst on the opposite side one country house succeeds the other. Arnemann of Altona owned in 1844 that which in previous times was the boarding school of Köhncke, not far from it dwelled the physician Dr. Valdemar Nissen, brother of my playfellow Fritz Nissen. On the same, the [424] left side is situated the picturesque looking cemetery. On its gates I read the following most appropriate inscriptions: the one, "They rest from their labours"; on the other, "their works follow them". Shortly after having passed Jacob's hotel the road descends from the ridge of hills which I had followed since Blankenese, to an open piece of ground on a level with the Elbe where an insignificant bridge denominated the Devils bridge spans an equally tiny brook. On the other side the road ascends again, and runs in a straight line to Altona. Of this part of the environs of my native place I have given so good a description in the first volume page 432, that I need only refer to it. There abouts I met Mr. Schwab my French master and the young Spaniard whose acquaintance I had made at Hesse's, accompanied by the latter I arrived at about eight p.m. at my lodgings, rather tired, exclusive of the short rest on the Zuhlberg I had been on my legs almost eight hours. The evening was beautiful, the temperature was mild, and the sharp east wind of the morning had lulled. 
We took tea together and at 9 p.m. I went to sup at Knauer's, at whose house notwithstanding it being good friday their usual friends had assembled. Maria and Emily half grown-up girls were sent to bed at nine oclock much against their inclination.

Saturday, $6^{\text {th }}$ of April 1844. In one of the Pavillons or coffee houses in the Hamburg Jungfersteig where I entered to take a cup of chocolate I read in a German newspaper that a number of protestant Clergyman in the North of Germany were about forming a union under the name of Gustavus Adolphus union for the ostensible purpose of assisting poor protestant communities, but in reality with the object of presenting a firm front and a decided opposition to the encroachment of Catholicism, another paper was opposed to this union. The writer styles Gustavus Adolphus, to whom Walter Scott in his legend of Montrose gives the appropriate epithet of the bulwark of the Protestant faith, a foreign conqueror, and added: "these are not the times for the revival of the union and the leagues of the thirty years war", whilst the third paper mentioned the rumour of a Tilly union about to be established in opposition to the Gustavus Adolphus's union under the protection of the Government of Bavaria, which country in 1844 took lead in the defence of Catholicism. The evening I spent at Bucklemann's where I had the good luck to gain a game of chess from Mr. Jones through a gross oversight of his. Mr. Petersen whom I had seen already on the preceding Saturday was also present. He was almost as good a player as Mr. Jones and much more agreeable being less conceited.

Sunday, $7^{\text {th }}$ of April 1844. Easter Sunday. The fine weather continued, I walked to Hamburg, and as I sometimes did, immediately on entering the gate, turned off to the left ascending the rampart which surrounds the town but instead of remaining on the higher part I descended towards the wide ditch filled with clear and limpid water which encircles the rampart; at a small elevation [425] above this ditch, a pretty walk which runs along the same is laid out. I followed it and emerged at the "Dammthor", here I crossed the wide street which leads out of town. In the Esplanade I looked in at Daniel Schutte's whom I did not find at home, and continuing my walk towards the Lombards bridge with the inner Alster on the one, the outer Alster on the other side, I passed through the Ferdinand's gate, to the pretty street called Saint George on the Alster, where several of my friends lived. Mrs. Mahncke was not in, Professor Wür[m] and lady were particularly agreable, also Mrs. Johannes Limpricht was very friendly towards me. I dinned at Kramer's. We were only my cousin, the Doctor, their daughter Maria, the adopted Child Luisa, and Alvina, the Jack of all trades, of whom I have already spoken. Little Luisa was indisposed, she therefore remained at home, whilst we others, Alvina of course excepted took a walk to the Botanical garden which lies just outside the Dammthor to the left, and 
gradually descends towards the fosse, the waters of which, as I had already observed in the morning, were extremely clear and clean. In 1844 the Botanical garden had not been long established; it was however tastefully planned, and likely to become of some importance, for the Hamburghers took a great interest in it. My cousin and Mary returned home, Kramer and I continued our walk. There is outside of the Dammthor a wide open place from which several roads, I believe five in number diverge like a fan towards the villages around the town. Kramer and I took that most to the right, which is by far the prettiest. We had to our right the outer Alster in shape like a small lake, its banks lined with villages and country houses, to our left a row of villas each with its garden, and hardly one similar to the other. Full half an hour's walk brought us to the village of "Harvstehude"; here a large building well recollected by me from former years as a much frequented hotel served now as an asylum for foundlings, for the town house in Hamburg having been destroyed by the great fire, it had been found necessary to appropriate the original foundling hospital in the "Admiralitats Strasse" to the use of the Municipality, and the foundlings had to make their exit; but certainly they had not been the losers by the change. At "Hasstenhude" we turned to the left and walked home by a road parallel to that which we had come, but at a greater distance from the Alster. It went by the name of "Am-Rothan-Baüm" literally "at the red tree", more correctly at the red turnpike. Here the country had entirely lost its rural character, houses stood in uninterrupted files, many of [426] them public houses were filled with guests; the good burghers of the middle classes were enjoying themselves with their families. They sat in the open air taking their coffee and beer, and smoking their pipe or cigar. We were back at seven o'clock, took tea and discussed about the long journey which I intended to make in the course of the year, I left at about half past eight o'clock. When I crossed the suburb of San Pauly, the many public houses with which this suburb of rather ill repute abounds, resounded with the noise of revelry; music was heard, dancing and drinking were indulged in everywhere. I went to bed at an early hour.

Monday, $8^{\text {th }}$ of April 1844. (Easter Monday) At Eleven o'clock several of my friends assembled by appointment in Rainville's garden. I joined them and together we started for a walk to Jacob's public house in Nienstädten, two open carriages accompanied us for such as might get tired. We were old Mr. Reincke and his brother in law Mr. Lübbes, Mr. and Mrs. George Knauer, their four eldest children, Mr. and Mrs. Warnholtz, Whilhelmina, Edward, Theodore, Otto and Johannes Reincke, Mr. and Mrs. Sawyer, Lübbes, a Nowegian gentleman called Mr. Gade, a little boy Charles, a protégé of the Reincke's, and myself. Leisurely did we walk along, the ladies leading the way, the gentlemen following, I conversing with the one or the other. A short distance before reaching Flottbeck 
we entered the nursery garden of Messrs. Booth who did an extensive and lucrative business in seeds, plants, and trees with which they not only supply the many country seats about Hamburg and Altona but also shipped them to various parts of Europe; the hot houses were extensive, well arranged and filled with exotics. Further on when we came to the Devil's bridge, Edward Reincke and I turned off to the right, walked through several pretty gardens with tasteful walks, nice houses, stately trees, and verdant lawns, always in sight of the not far distant Elbe. A pond which I recollected as forming part of the property of the family Roosen looked not quite as melancholy as ever. Further on, Edward and I came to a country seat now owned by the rich Fritz Baür, who, he himself told me in the evening, had purchased it at the death of his brother John Henry for CM 40,000 and now valued, but probably overrated it at $\mathrm{CM} 300,000$. We joined the party at Jacobs where Mr. Lübbes had provided a plain substantial lunch consisting of beefsteaks, chops, vegetables, fruit, bread, cheese and wine. These good things being dispatched, a few of our party were too lazy to renew their walk amongst whom only one lady, Mrs. Warnholtz; the others, by far the greatest part resumed their march. Mr. George Knauer recommending his lady to my particular care, we directed our steps through the garden of Richard Parish to that of Richard Godefroy. I offered my arm to Mrs. Lübbes, a [427] nice and pretty woman, when Mrs. Knauer saying that her husband had put her under my care, took hold of my other arm. After some jokeing, Mrs. Lübbes [?] her right, and we then proceeded. Twenty two years previously I should have been in raptures, now I was in a quiet state of mind, "Tempora mutantur et nos mutamur [in illis]". Agreeable as my companions were to me, yet my real enjoyment did I derive from the splendid weather, the fine country, and the beautiful frequently varying prospects. It was half past three oclock when we were back at Jacobs. I left Mrs. Knauers with her brothers, and hastened as fast as my legs would carry me to my lodgings at Rainville's where I arrived perspiring all over, but in time to dress and to be at a little past five o'clock at Mr. Fritz Baür's where a party of more than thirty persons were invited to dinner. When I entered I distinguished only a few of those present. I paid my respects to the host and hostess, to the Senator Mr. Henry Baür, to Professor Uhlrich, Fritz Baür's son in law, and to a few others. Shortly after, dinner was announced, when as it was the custom, two by two, the host with the lady highest in rank leading the van, we went up stairs to the dining room. I gave my arm to Miss Augusta, the youngest daughter of the house, at table Caroline Willink sat to my left. Everything was in the first style as it was to be expected in the house of one of the wealthiest merchants in Hamburg and Altona. When we had risen, I had an occasion of exchanging a few words with old Mrs. Sieveking, Mrs. George Baür, and Mrs. Henry Baür, her 
sister Miss Wattenbach, the two Messrs. Hildebrand, both sons in law of Baür, M. Fiedler of Prague and others. In the smoking room Consul Hildebrand took hold of me and I rejoiced when I could shake him off; cards were played, to which I did not sit down, but preferred talking, sometimes with the ladies also with old Mr. Baür. We separated at half past ten o'clock.

Tuesday, $9^{\text {th }}$ of April 1844. When at home I was continually occupied, I wrote my diary, studied Latin and Danish with assiduity, translated German into French [_] my Italian abstracts of Allen's and Dahlmann's Danish histories and when I had a few moments leisure amused myself with light reading. I had finished Eugene Sue's "Mystères de Paris", and Warren's "ten thousand a year", and I now perused Bulwer's "Devereux". Not a day passed without my looking in at Henry Sieveking's. This evening I spent at old Mrs. Sieveking's in company of the family, Löhmann, told me that Altona-Kiel R.W. shares stood at 122, Gluckstadt Altona a shade lower, also that the Itzehoe people had relinquished their idea of a direct line from Itzehoe to "Hackelshorn", a place on the trunk road from Altona to Kiel, and they would resume probably the original plan of bringing their line into communication with that from [428] Altona to Glückstadt via Elmshorn, from Itzehoe it was to be continued to Heide.

Wednesday, $10^{\text {th }}$ of April 1844. In the evening I drove to Hamburg, where I called at Kramer's for the latch key of the street door which they were kind enough to let me have. My cousin told me that the election of a new Senator had just been concluded, and that the choice had fallen upon Mr. Haller, a Doctor in law, who himself baptised, was the son of the highly respected Jewish merchant M. J. Haller. In Hamburg a considerable proportion of the inhabitants are of the Jewish persuasion, probably several thousands in number, and all these were in great glee at the triumph gained by one of their blood. From Kramer's, I went to Dr. Gustavus Schmidt, who had invited a few friends to celebrate the birthday of his brother Albert, who born like myself in 1799 completed on this day his forty-fifth year. We had tea, cards and supper; whilst at this meal the company was kept in a continual roar of laughter by a sharp war of words carried on between Mr. Müller and a Miss Kosegarten. He, partner of Albert was a bachelor who lived a very dissolute life, she an elderly unmarried lady, and rather plain, was very pert, and never at a loss for an answer. She had taken a great dislike to Mr. Müller, neither did he admire her; thus many good things, sometimes bitter enough were said on both sides to the great amusement of the company.

Thursday, $11^{\text {th }}$ of April 1844. Iawoke with a headache, probably the consequence of the bad quality of the Schmidt's wine. When returning to Altona I walked up the rampart on the south side of the gate, at the corner where it turns eastward, and from the highest point called the "Stintfang", one has a pretty view over the 
Elbe, and especially over the harbour crowded with shipping. I felt so unwell that at home I had to lie down several times; nevertheless I managed to go to old Mr. C. H. Donner whom I congratulated on his birthday. He was seventy years of age, and invited me to return to dinner which I did of course. With a few exceptions the party consisted of Donner's nearest relations, he and his sister Mrs. Elmenhorst who sat at the head of the table, Hannchen Willink, his sister in law, old Mr. Gräppel, his brother in law, Bernard Donner his son and his wife, Jean and Conrad Donner as well as Theodore Elmenhorst, all three his nephews, with their wives, Arthur Donner, another nephew, the two little daughters of Theodore Elmenhorst and Malvina daughter of the deceased Jean Elemenhorst, these three Donner's nieces in the second degree. Beside these Mr. and Mrs. Warnholtz, Mr. and Mrs. Fischer, Mr. and Mrs. Dr. Hayck; she a daughter of Läwätz, of the firm of Läwätz and Koch, a Miss Reutorff engaged to marry Hans, son of old Gräpel now in the United states, architect Hansen, Sch[utt] and myself. I thought of taking Mistress Bernard Donner to the table, but Fischer was too quick for me, and thus I had to be satisfied with Mrs. Warnholtz [429] who is little communicative, and I therefore looked for conversation to my left hand neighbours Bernard Donner and Doctor Hayck. Fischer gave the health of C. H. Donner who returned thanks, and in his turn proposed the health of young Hans Gräpel and of my wife. The smoking room, tea, and whist filled up the time until we broke up.

Friday, $12^{\text {th }}$ of April 1844. I was again quite well, and spent a quiet day at home, in the evening as I always did on Friday went to Knauer's.

Saturday, $13^{\text {th }}$ of April 1844. The weather was a little more cloudy and windy than on the previous days, however the temperature had become already so mild that I hardly found it necessary to light the fire in the stove. I had three visits in the course of the day: the first from a certain Hertzbruch, the second from young Mr. Bocklemann, the $3^{\text {rd }}$ from the young Messrs. Gibbs. Hertzbruch when I was in Donner's counting house was there in the capacity of light porter. He was a little humpbacked, clever, and cunning fellow, already then he was fond of playing at the lottery, after my departure he played so deeply and lost so much money, that in order to make up for his losses he saw no other course open before him than to embezzle the money given him to pay the Broker's accounts. Then certain that this would be found out he forged Donner's signature upon a cheque on the banker Stresow, the cheque was paid, but the forgery discovered before twenty four hours had elapsed. Hertzbruch was of course turned out of his employ but not criminally prosecuted by Donner, he told me that he now kept a small shop and gained his living but no more. Young Bocklemann was a particular friend of my nephew Charles Ropsy, who he told me had a predisposition to consumption, but he hoped 
the Ropsy's stay in Italy might crush this malady in the bud, which however, I say so in anticipation has alas! not been the case. The young Gibbs were the sons of the late Mr. George Henry, Henry just arrived from England, Anthony who had been for some times in Böhl's counting house in Hamburg. They came on horseback in company with a countryman of theirs, and were in a great hurry for they wanted to Gallop to Blankenese and be back to Hamburg, I do not know in how a short time. In the evening at Bocklemann's I found Mr. Jones and Mr. Petersen playing at chess, the former gained after a very hard fight. I then sat down against Mr. Jones and when he had to leave at half past nine oclock, I, thanks to the advices given me by Petersen, had certainly some advantage over my antagonist. Then Petersen and I tried our respective strength and though there was no time to conclude the game, mine stood a trifle better than his when we ceased playing. We walked home together, and it being a starlight [430] night, our conversation turned upon Astronomy. When he attempted to give me some idea of the immensity of the universe he told me that lately an astronomer had calculated the distance at which a small star in the constellationof the Swan is from the earth; he had found out that nine thousand of years are required before the light which emanates from that star, can reach our globe, whilst I find in a North American Encyclopaedia that the light travels at the rate of two hundred thousand English miles per second. Such numbers may well be pronounced but not comprehended.

Sunday, $14^{\text {th }}$ of April 1844. I had two visits in the course of the forenoon, the one from professor Frantzen, my teacher of the Latin language, another from Krammer whom at his request I accompanied on a walk along the bank of the Elbe through the villages of "Ovelgönne" and "Neumühlen" well described in the previous volume pages 427,428 . More than once did we stop to look at the lively scene which the river presented filled with vessels of all sizes, some impelled by wind others by steam. Joannes Limpricht had invited me to dine with him. In the omnibus in which I drove to Hamburg, the only passenger besides myself was a young servant girl so neatly dressed, and so very pretty that I could not resist saying many tender things to her, to which she knew well how to reply, and I was not a little annoyed when the coach stopped and put an end to our sweet colloquy. When I entered the drawing-room at Limpricht's I found more than twenty persons assembled, the greater part of whom were strangers to me, the move being made for dinner, I looked out for Mrs. Löhrs one of the few ladies with whom I was acquainted, but not finding her, the last who remained, a plain lady fell to my share. I did not know who she was, neither was I acquainted with the other lady on my left, when Johannes who observed how awkwardly I was placed, rose and introduced us to each other; the one to my right was a Mrs. de Voss, whose maiden name was also de Voss, a relation to 
the Altona brewer of the same name, the other wife of Doctor Baetcke, cousin of Miss Emily Baetcke, who was Governess at C. H. Donner's when I was clerk in his counting-house. The ice once broken, we went on flyingly, and I had not the slightest reason to be dissatisfied. I observed that two nosegays were placed before a gentleman and a lady who sat about the middle of the table and was told that the young couple thus distinguished were a Doctor Meyer and a Miss Stiech actress in the Hamburg theatre whose betrothal had lately been made public. Dinner was excellent and Champagne in abundance. In the smoking room I conversed a long while with Johannes and his brother in law, an agreeable man, Mr. D'Albert, Director of the Bergedorf Railway. Finally [431] I played whist with Dr. Meyer against his bethrothed Miss Stiech a nice, not particularly good looking young lady and Mrs. Dr. Löhrs, my favorite. We laughed, joked, and thought little of the game. Also Kramer had had some friends at dinner amongst whom there were many young folks. They had represented charades and amused themselves well.

Monday, $15^{\text {th }}$ of April 1844. I dined out again; this day at Mrs. Dankert's, who lived in one of the handsome houses of Fritz Baür's in the Palmaille. She was the mother of Mrs. Fischer and of Mrs. Geffken the wife of Mr. Geffken, Clergyman in Hamburg, there were also my cousin, Kramer and several of my altona friends. Everything went on in the customary manner and I think it would be needless again to go over this so often trodden ground.

Tuesday, $16^{\text {th }}$ of April 1844. From eleven to one oclock I was in the "Horsaal". Director Egger[st] introduced to the Public in Latin speech which I did not understand, two new teachers of the Altona Gymnasium, Professor Bendixen who was to be the second, professor Brandes who was to be the fourth. Director Egger[st] and Professor Fransen remained in their respective situations of first and third teachers. The two new professors replied in German, Bendixen had a prettier delivery, Brandes a better German pronunciation. Their Stipends were not large, the former received from the Government $\mathrm{RB}[\mathrm{k}] 1250$ and 200 more for teaching Danish, equal to $\mathrm{CM} 2718$, Brandes $860 \mathrm{RB}[\mathrm{k}]$ equal to $1612 \mathrm{CM}$. The evening I spent at old Mr. Reincke's.

Wednesday, $17^{\text {th }}$ of April 1844. There was in the Hamburg theatre an exhibition of flowers which though the pretty enough, disappointed me in as far as I had expected a more extensive and brilliant display. Albert Schmidt had invited me to dine with him but as the hour fixed was half past three, I had still some time to spare, which I employed in perambulating some parts of the town of Hamburg little known to me. The theatre is situated in Dammthor Street to the right of which turns off the Esplanade built after the great fire. Between the row of houses which forms its Northern Boundary and the fosse around the town there was in 1844 and there is still perhaps now (1869) a pretty walk following 
which I came to the Lombard bridge, further on, on the rampart I passed the monument erected to the memory of Professor Büsch a well known Hamburg author, but thence instead of passing through the Ferdinand's gate to the pretty street called St. George on the Alster I kept close to the town in a south easterly (and afterwards southerly) direction. Labourers were busy demolishing the remnants of the old wall, a little further [_] I had to my right a new building (a prison or detention house), it was [_] [432] that the wall and ditch behind the same put a stop to the devastation of the great fire in may 1842, it ceased for want of Combustible. Sparks and fiery flakes were carried over by the wind to the suburb of Saint George, and fears were entertained for its safety. Fortunately they turned out groundless. Proceeding, I left to my right the Mary Magd[elan] Convent, an institution for poor females, opposite a monument erected in honor of Adolphus IV Count of Shaunburg. Formerly the convent, and in after years the monument stood on the spot now occupied by the new exchange. Adolphus IV of Schaunburg was Duke of Holstein and on July $22^{\text {nd }}$ 1227, gained the sanguinary battle near Bornhoved, a small village two German miles North of Segeberg against Waldemar (the Victor) King of Denmark. King Waldemar himself commanded the centre of his army, his nephew Otto of Lunebürg the right, his son Waldemar the left wing. The Dithmarschers were in the [river]. Opposite to the Danish King fought the Holstein Duke Adolphus with his Holsteiners, and three hundred heavy Cavalry, sent to his assistance by the Emperor of Germany, to the left of Adolphus, Albert Duke of Saxony, to his right Henry of Schwerin, and Alexander Von Saltwedel Burgomaster of Lübeck. In the beginning, the day went against the Duke, but the sudden passing over of the Dithmarschers to his side gave him the victory; this defeat of Waldemar was of great importance to the Duchy of Holstein. Had he been victorious the Duchy would have become a Danish province, now it remained part of the German Empire, and though in later years it fell again under the dominion of Denmark, it always belonged to Germany. The King of Denmark was duke of Holstein just as before the accession of Queen Victoria to the British throne, the King of England was [Elector] of Hanover, and the Danish language never passed the Eider. After the battle of Bornhöved, Dithmarschen became free, hardly acknowledging the Spiritual Supremacy of the Archbishop of Bremen, whilst Adolphus received as [feif] from Germany; Holstein, Stohrmarn, Wa[g]rien and the town of Hamburg which already at that time enjoyed many privileges. Lübeck was an Imperial town which means that it acknowledged no other superior but the Emperor himself. Duke Albert of Saxony as his share of the booty received Ratzeburg and the Castle of Lauenburg. Adolphus reigned from 1202 to 1239 when he abdicated in favor of his two sons. Continuing my walk I passed the "Steinthor" to my left, further on to my right a handsome building 
the Johannes convent, an establishment similar to that of Mary Magdelane, then again to my left the terminus of the Bergedorff Railway which though built of brick only, had a tasteful exterior. On the other side a [_]ble looking large house, Röding's museum, a collection of all kinds of insi[_] trifles which such an important commercial town as Hamburg should [433] be ashamed of. By this time I had reached the Deich-Thor close to the Elbe, a small branch of which forms the small upper harbour, the object of which is to receive the long narrow and flat bottomed boats which come from Magdeburg and other towns on the upper Elbe bringing fruit and other articles to the Hamburg market, outside the gate a series of dikes extends a great distance up the river for the protection of the low lying land against the inroads of its waters. I remained inside the gate, crossed a small wooden narrow bridge to an islet used exclusively for the storage of Pitch and tar. Another similar little bridge took me back to the town, and a well kept gravel walk with houses on the one, a channel of the Elbe not wider than a respectable ditch on the other side, brought me to another gate the "Brook thor" whence a solid bridge leads to the island called the "brook". Here were in 1844 an Iron foundry, the extensive cane manufactory of a certain Meyer and a few dwelling houses. At the Eastern extremity of the brook, the upper Elbe Steamers were in the habit of anchoring. It was now three oclock and I made the best of my way to Mr. Albert Schmidt's, I returned to the city, and striking right through some very ugly streets narrow with high and gabled houses which put me in mind of the old town of Edinburgh I emerged in the large open place where the St. Nicolas church, destroyed by the fire, had stood. Here the modern part of the town commences. Some houses were concluded, others in progress of construction, and of others the foundation was just being laid. Albert and I were by ourselves, he was such an excellent man that I always felt great pleasure in his society. The last hours of the day I passed at Semper's, gained two and lost one game at Chess. Semper told me that in former years he had some times gained BM 100,00o a year, now the profits had fallen off. His dyed woollen yarns were in demand all over Europe and he continued to receive orders from Germany, Denmark, Sweden, Norway, England, and the United States. In France the importation was prohibited. Altona Kiel Railway shares stood at 130 .

From Thursday, $18^{\text {th }}$ to Saturday, $20^{\text {th }}$ of April 1844 . The weather was beautiful, nature had shaken off its winter lethargy, everything was reviving and budding afresh, some leaves had not yet burst through the delicate brown capsules which surround them, others freed of all restraints and fully developped spread a faint green tinge over some precocious plant, tree or hedge; I went into the fields and heard the merry singing of the lark which rose higher and higher in the air until it was lost to my feeble sight. I went into the gardens and listened to 
the melancholy music of the nightingale carefully concealed in a neighbouring bush. Daylight lasted until half past seven oclock. On friday I dined with my cousin [434] in Hamburg to try Sirop-Klöse, plain flour dumplings with treacle which however were now not so much to my taste as they had been in my childhood. In the evening we went to Professor Wür[m] who on Friday's was in the habit of receiving company. Clever people were always to be found in his house; on Saturday evening I went to Professor Schumacher, where the chess club had met, I played with Mr. Jones, and the omnibus in which he returned to Hamburg saved him from a defeat. When he and Mr. Bockelmann were gone, I sat down against Mr. Peterson. I had the advantage of a Knight and a Bishop, but lost the game because he brought down the pawn and made a queen.

Sunday, $27^{\text {st }}$ of April 1844. My Cousin Nelly and I had fixed upon this day to pay a visit to Mühlenbeck, a country seat three german miles from Hamburg which in the beginning of the century had been the property of our maternal grand father and of which we still retained a faint collection, however as it rained in the morning, Kramer came to tell me that they had thought more prudent to put off our excursion to another day; thus I spent the Sunday in the usual manner. I made many calls, and dined at old Mrs. Sieveking and her family. In the evening we went to the Altona Theatre where she had secured seats for all of us in the first tier. The house, old and dirty, was crowded and the actors strengthened by some from the Thalia Company, performed very fairly. Three vandervilles were represented, the waltz from Ghisella was well danced by a French girl, Miss Bertin.

Monday, $22^{\text {nd }}$ of April 1844. I received letters from my family in Lima the last date of which was January $\mathbf{1}^{\text {st; }}$; in politics, changes of importance had taken place, of which I shall give a more detailed account on a later occasion. Here I will confine myself to say that General Don Ramon Castilla after having defeated General Guarda near San Antonio close to Moquegua was fast gaining the advantage over Vivanco; he had made himself master of the Departments of Puno and Cuzco, and was marching upon Ayacucho. In Lima Domingo Elias with Joaquin Osma as his secretary placed his reliance on the National Guard which with five hundred men brought from Ica, amounted to two thousand five hundred armed men. Mistress Baüer the "Etats Räthinn", had a few friends at dinner, amongst whom Mrs. Lawätz and her young daughter who squinted a little were the only new faces to me. I took the latter to the dinner table but did not succeed in eliciting much interesting conversation from her. Her silence was however made up for, by [...] bour on the other side, Mr. Otto Lange of whom I have already said that he and I when children, frequented together the Altona Gymnasium, now he was a lawyer without practi[_]. [435] 
Tuesday, $23^{\text {rd }}$ of April 1844. The Evening at old Mr. Reincke's. Altona-Kiel Railway shares had declined, they were at 126.

Wednesday, $24^{\text {th }}$ of April 1844. I went to see the opera "Norma" represented in the principal Hamburg Theatre, the interior of which was plainly but tastefully decorated, there were three tiers of boxes besides the gallery, the pit was divided into two halves, the cheaper one nearer the entrance, the other, the Parquet or Stalls immediately behind the orchestra, the seats were divided by iron arms, so that each formed an armchair by itself; the house was empty. Miss Evers who sung as Prima-Donna was younger and thinner than the Pantanelli of Lima, thus her Norma was less majestic but quite as pleasing as the Pantanelli's. Mrs. Fehringer as Adalgisa sang certainly quite as well as the Rossi, but was not so pretty by far. She was too fat, too short, and too old. On the other hand, Wurdar's Roman Proconsul was far superior to Sisa's. I amused myself well. The Pantanelli, Rossi and Sisa were Italian singers who in 1840 and following years as contra alto, soprano, and tenor, delighted the Lima Public.

Thursday, $25^{\text {th }}$ of April 1844. Immediately after breakfast I walked to Hamburg, and found Mr. Daniel Schutte at home. He told me that very soon he intended setting out on a long journey to his manufacturing friends, he thought of visiting E[lb]erfeld and the neighbourhood, of ascending the Rhine as far as Switzerland, and of returning by way of France and England to Hamburg. He also communicated to me the piece of news that Mr. Simon Von Post was engaged to a Miss Castendyck, a step daughter of his cousin residing in London; this no doubt was true, but at the last moment the young lady changed her mind and poor Post had to go back to Valparaiso without her. In Altona I was present at an Oratorio "Samson" by Handel which was sung in the principal Lutheran church, the proceeds were for the benefit of a charitable institution. With the exception of Miss Bornett from the Hamburg stage all singers were amateurs, amongst the Choristers, I recognised several of my Altona acquaintances, whilst the solos were exclusively sung by Hamburgers. Beneath the organ the scaffolding was erected for the musicians both vocal and instrumental. The audience was very scanty. At six o'clock I went to dine at Mr. Isaac Hesse's and was much surprised to find there the President Blücher-Altona, for as Mr. Hesse had invited me in the morning when passing by on horseback, I of course had expected to meet but [_] intimate friends. Besides the Count Blücher, there were Otto Donner, eldest son of the deceased Jean Donner, Mr. Newman, Arthur Donner, a Miss Bertha de [Jongh]; the sons and daughters of the house, [436] a young gentleman whom nobody introduced to me, and myself. When we went to dinner, the count of course offered his arm to Mrs. Hesse, I followed and took Miss Mary, the stranger Miss de Jongh. I had unwittingly committed a great blunder, for the young man was count Schemmelmann, count Blücher's 
grandson, and the owner of much landed property. I ought to have given him the precedence and should have done so if I had known him. Whilst at dinner Mrs. and Miss Hesse had to show so many attentions to their noble guests, that they found no leisure to bestow any on such an humble individual as myself, and probably I should have fared better than I did with miss Mary, if I had taken miss de Jongh. Count Blücher was agreeable and affable; his great deafness was however an insuperable impediment to a fluent conversation with him. After dinner I had some talk with Otto Donner, Lieutenant in the Danish Navy, married to a Miss King, a young Danish lady residing in "Tondern"; a sister of his wife was engaged to marry young William Hesse. Otto Donner had seen much of the world both in the Navy and as a captain of merchant vessels he was now employed in the preventive service. In 1848 at the time of the first rising of the Schleswig-Holsteiners he took part with his countrymen. After the peace of 1849 he entered the Prussian service in which he gradually rose to the rank of Rear admiral. At a later period he fell into disgrace, and now in 1869 when I am dictating these lines, he after the loss of his wife lives upon a pension, a hypocondriac in the village of Reinbeck, three German miles from Hamburg. I likewise conversed with Count Schümmelmann, an insignificant young fellow. His mother Fanny Blücher he told me had died. He had been travelling about in the East and had hurried back to Altona to be present at the anniversary of his grand parents's fiftieth wedding-day. His uncle Gustavus Blücher and lady were daily expected. When the Counts were gone we sat down to whist, unfortunately old Hesse was my partner. He knew no more of the game than I, and nevertheless found fault with my playing in a very annoying manner. Mrs. Hesse played "Grabüsche" with Arthur Donner, Mrs. Bertha de Jongh, a pleasant young lady of at least twenty five years of age, was the daughter of old Mr. Hesse's sister, the widow of Mr. Jongh Hamburg broker, in 1845 she became the wife of Mr. Daniel Schutte.

Friday, $26^{\text {th }}$ of April 1844. When I removed to Rainville's in the beginning of the year I placed into an unlocked drawer a bag with a small but choice collection [437] of gold and silver coins and medals which I had brought with me from South America and which I now thought might be an acceptable present to the Antiquarian society of Copenhagen, the secretary of which, Mr. C. C. Raffen, had lately entered into correspondence with me, I therefore went to the drawer to have a look at the coins, and was not a little surprised when I found the greater part of them missing. I immediately mentioned the circumstance to my landlord Mr. Messow. He assembled his waiters, had their rooms searched, and within half an hour brought me some silver coins found in the room of the second waiter which I, on comparing them with a list in my possession, knew and declared to be mine. Two policemen were sent for who 
took the culprit to Mr. Hilmers, the chief of the Police, in whose presence he immediately confessed his guilt. I also went to Mr. Hilmers and begged him not to be too severe with the thief, as I having left the drawer open was in some manner, blamable. Mr. Hilmers replied that this did not depend upon him, and when I met him at Knauer's in the evening he told me that I had little chance of recovering the lost pieces as the money changers who had them would not give them up until they received what they had paid for them, and the money found upon the waiter was trifling. My loss consisted of six gold onzas, eight half gold onzas, four quarter gold onzas, one guinea and several medals. The carpet embroidered by the ladies for Count and Countess Blücher-Altona was shown to the public at Mr. Bocklemann's; in the centre were the Counts arms, otherwise it was not much to my taste. A large silver urn which the artisans of altona intended to present to the noble couple was also exhibited, it was beautifully worked. Towards the evening the fine weather induced me to take a walk towards that part of the town where the railroad was to come in from the North, and I was much pleased with the progress made. The Engineers had likewise been hard at work at the inclined plane, but their labours had a result certainly not expected by them. When digging at the foot of that continuation of hills which were covered by the plantations belonging to the gardens of Rainville's, Slavenshoff, and Arnemann's, late Gumpël, they not taking into consideration the nature of the soil uncommonly loose and sandy or carrying on the excavations too far, had undermined its basis, the consequence of which was that the upper strata in Rainville's Garden suddenly gave way. The ground rent in many places, and fissures differing in width and length became apparent in Rainville's garden. This was of no great importance for the whole mass of the garden gradually descending filled up the cavity formed below, and a few days work at a small expense $[. .].[438]$ the inequalities which had arisen. Not so more to the East, where everything was to be solid and immovable and therefore in order to prevent the possibility of any further movement of the ground it was found necessary to build at the [front] a brick and mortar wall of an extraordinary thickness and this effectually stopped the further descent of the ground.

Saturday, $27^{\text {th }}$ of April 1844. It blew a cold wind and the Elbe, yesterday like a mirror, looked this day rough and threatening. I felt so unwell that I did not go to Bocklemann's but spent the evening pleasantly with Sieveking and his wife.

Sunday, $28^{\text {th }}$ of April 1844. Though I was much indisposed I went to Semper's to be present at the Christening of his last born child. The party assembled was very numerous; besides the Clergymen and their wives of whom I shall speak further down, I met there all the members of the Reincke family who are not a few, with the exception of Mrs. Theodore Reincke lately confined and 
Warnholtz and his wife in whose house the measles had made their appearance, further Semper's mother, brother, sister; Otto Heyne, Theodore Elmenhorst, his wife, who were the nearest relations of Betty heyne, Semper's first wife, Mr., Mrs. Fischer and myself. At the time of my departure in 1823 there existed in altona two congregations of the Calvinistic persuasion, the one which called itself French; the other the Dutch. In course of time their number decreased so much that they thought proper to unite. The Church belonging to the Dutch was demolished, and dwelling houses were built on the spot, whilst the Church of the so called French congregation, in reality they were all Germans but of french extraction, served both to the one and the other alternately. One Sunday the service was held in French, the next in Dutch. Semper was one of the French Calvinists, and thus his child was baptised by the french pastor of this Church Mr. Reusher. He placed himself before a small table upon which stood a basin with tepid water, opposite to him Mrs. Sieveking with the baby in her arms, to her right miss Elisa Semper, to her left Mr. Fischer, these three being the sponsors, the remainder, as well the Children and the Governess, ranged themselves as well as they could. The Clergyman read a very fair discourse and then Christened the child with the name of Richard Wilhenn pouring three times the water over his head in the name of the Father, Son, and Holy ghost but without making the sign of the cross as it is the Custom with Roman Catholics. Shortly after, dinner was announced, and we went up stairs to the large Saloon where it was laid out for [_] less than 34 persons. I took my seat between George, the eldest son of Semper [_] fourteen or fifteen, and Theodore Reincke who this day made himself most [439] agreeable. Dinner was excellent and abun[_] both as regards the dishes and the wines; many toasts were given, nor [_] Semper omit to propose my health. I neither went to the Smoking room, nor played at cards, and went home at ten o'clock jointly with Sieveking and Theresa his wife.

Monday, $29^{\text {th }}$ of April 1844. I had an unexpected visit from Philippe Lilie with whom I went to the garden which gave evidence that the merry month of May was close at hand; all shrubs and many trees were covered with a young tender and fresh foliage, trees were still behind hand. To watch them and to note their daily progress and development was my great delight. The fissures in the ground which existed on Friday last, had increased in size, and I also observed one or two new ones. I amused myself with reading Chevalier's Pamphlet on the possibility of [_] a Canal through the Itshmus of Panama, and at a later hour went to the "Turnhalle" where I listened for some time to the rather indifferent singing of a few male amateurs. I was at home at half past ten o'clock.

Tuesday, $30^{\text {th }}$ of April 1844. In Latin I had made some progress since I commenced taking my lessons from Professor Frandsen. Virgil's Enæid I now 
understood very easily, Horace's Odes I could manage with the assistance of the explanatory notes in my edition, but Tacitus was as yet a hard nut to crack, for the notes being only critical, threw no light on the meaning of the text. My cousin Nelly accompanied me to one of the China and Glass ware stores in Hamburg where I bought as a present for Henry Sieveking on his birthday, a china ware tray white with gilt edge and twenty four plates corresponding to it, likewise as a wedding present for Löhmann and Sophia Willink two cut glass fruit baskets. The former cost $\mathrm{CM}_{48}$, the latter $\mathrm{CM}_{3} 6$. With Kramer I went over a large hotel just finished and thrown open to the public for inspection. It was called "San Petersburg" and being situated in the "Yungfernstieg" the greater part of its apartments had a fine view over the Alster and its neighbourhood so frequently alluded to by me; from nine to half past ten oclock I was at old Mr. Reincke's.

Wednesday, ${ }^{\text {st }}$ of May 1844. At last dawned the first of May, the day so long expected by the good altonaers who made a complete holiday of it, intent upon celebrating the fiftieth anniversary of Count and Countess von BlücherAltona's wedding day. At four o'clock in the morning an instrumental, at half past seven o'clock a Real Serenade was given to the noble couple, at neither of them was I present. I breakfasted with Sieveking and at ten o'clock started to see $[\ldots]$ going on. Before the Count's residence the civic guards both on foot and on [440] Horseback drew up; the former about [_] hundred men strong were divided in two Batallions, the first commanded by Mr. Koch, the second by Mr. Meiners, their uniform consisted of short-tailed blue coats with black facings lined with red laces and white pantaloons. The Cavalry, the green guard, was much reduced in number from what I had known them in my childhood, when there were two respectable corps: one the yellow, another the green guard, now they were about sixty in green jaquets and grey trowsers with a black stripe along the seam. When the Count and countess appeared at the window they were received with some huzzaing. He delivered a short speech of which I could not hear a single word, emptied a glass of wine and withdrew, a few minutes later, he accompanied by his son Gustavus, his nephews, the young Von- $[\mathrm{Q}]$ ualen his grand son, Count Schimmelmann and some military men, amongst whom I recognised Edward Reincke as aide de Camp of Colonel Koch, walked up and down the lines, and then retired to his house whereupon the guards also marched off. I hastened home, dressed and at noon went to old Mrs. Sieveking's to congratulate her for she completed on this day her sixtyeighth year; she was not in, having gone to present her respects to Countess Blücher. Thither I now directed my steps. The receiving rooms up stairs were crowded. The Count to whom I went up was very off-hand, I made my bow and with difficulty squeezed my way to the Countess's apartments, where I found 
several ladies of my acquiantance; I remained but a short time. In an outer room the presents were laid out. There were the carpet so often spoken of, the arm-chairs from the rival ladies, the silver urn from the artizans, the Gold spoons from Salomon Heyne, a silver tureen from C. H. Donner, a large cut glass basin for flowers upon a silver stand in the shape of a vine from Fritz Bauer, a screen from Koch, partner of Lawätz and Koch, a beautifully embroidered red velvet portfolio with a congratulatory address from the Jewish community, etc., etc. Many people had come to Rainville's garden to look at the arrangements made for the grand dinner. I myself whiled away the time as well as I could until half past four when the receiving rooms, the same which Messow had placed at my disposal when I gave my dinner party, became gradually filled with the guests, at last the crowd was such that one could not move, even the ladies had to stand, and an order was given for the Gentlemen to withdraw. I did not obey, and it was well I remained, for Fischer who had gone out, could not get back through the crowd; and thus Mrs. Arnemann whom he had [_] as his partner for the dinner, had to go by herself, following the stream; as soon as the Count, Countess, and suite arrived, all descended to the oval shaped [441] dining room in which I also had given my party, but to which on this occasion a provisional tent was added. Both the one and the other were well decorated with orange trees, arms, banners, and flags. Three hundred and fifty three persons sat down. The following small sketch will give an idea of how the tables were arranged: (a) represents the tables, (b) the spot where the musicians sat, close to them a number of young men all amateur singers who formed a club known by the name of "Liedertafel", or the board of Songs $(++)$ represent the seats of the Count and Countess, at the same table near and opposite to them sat their nearest relations

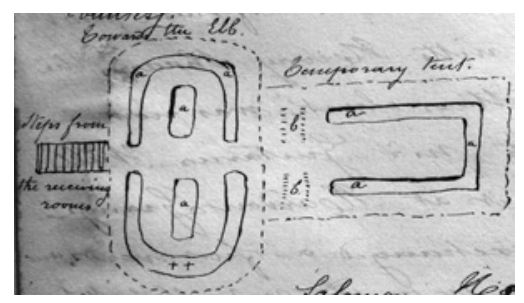
such as their son Gustavus, his lady and children; their brother in law KammerJunker von Qualen with lady, who was the countess's sister, their sons, the Count Schemmelmann; also such of the guests as were considered the aristocrats of Hamburg and Altona, Salomon Heyne, Fritz Bauer, C. H. Donner, Senator Hesse and lady, Count and Countess Holk, etc., etc. Another table at which George Knauer, one of the comittee for the arrangements of the fête, presided, was occupied by him, Mrs. Behn, her husband, merchant Stuhlmann, Mrs. Knauer, Mrs. Arnemann, Semper, Mrs. Warnholtz, Mrs. Fischer, Mrs. Dr. Hayck, Sieveking, and myself. I was in very good spirits, and amused myself extremely well. Mrs. Arnemann, Fischer, and Behn always lively were particularly agreeable this day. Mrs. Knauer was always 
good, kind and amiable whilst Mrs. Warnholtz and Mrs. Hayck were taciturn and insignificant. I ordered some bottles of Sauterne, the other gentlemen, the Champagne. Mr. Behn a clever man was "Etats Rath" and Burgomaster and ought in my opinion together with his wife to have had a seat at the first table instead of the old fool of Hesse who owed all the considerations which he enjoyed solely to his Riches. Between the courses the young singers under the direction of Mr. [Marxen] placed themselves in the middle of the saloon and sang prettily. All present joined in the chorus of the song in honor of the Count and Countess, the band played of course with few interruptions. Towards the end of the banquet Knauer rose and gave the health of "the count and countess" in a clear and distinct voice. The Old Count read his reply which was rather long, far from fluently, from a paper before him. [B]arbeck another of the committee gave the health of the "Count's and Countess's children and grand children", to which Count Gustavus replied in a pretty speech, and gave the toast "to the welfare of Altona", next came Hirsch's "toast to the ladies" in poor doggerel verse; and finally Clergyman Nevers, "Mr. [442] and Mrs. Von Qualen", who likewise celebrated the anniversary of their fiftieth wedding day. At about nine oclock the Count rose, and the party broke up. With Mrs. Knauer and Otto Heyne I went to old Mr. Lubbes who had rented for the Summer a small house belonging to Rainville's garden fronting the Floatbeck road, here he had given this day a dinner to the younger members of the Reincke family. We joined them, and after having taken tea, I returned to the banqueting hall where many ladies and gentlemen were still enjoying themselves. Knauer was busy in the midst of them, not sparing his Champagne. I renewed my acquaintance with Henry Shaar, the younger brother of that Shaar who once my fathers clerk, was now a broker in various descriptions of grain; also with Mr. Gustavus Wall cousin of Betty Wall to whom I had paid a visit at Hardon-Grange (See pages 301 to 306). With Henry Stoppel the lawyer I exchanged a few words and concluded the busy day with a long conversation with old Mr. Nopitsch, when I was in Donner's counting house he was bookeeper, first and corresponding Clerk, in which capacity already then he had been with C. H. Donner, I do not know how many years, now in 1844 he was still in the same employ and when he died several years later he was still the same, C. H. Donner's bookeeper and first clerk. It was midnight when I went to bed.

Thursday, $2^{\text {nd }}$ of May 1844. Nelly Kramer, and I were in truth good friends, nevertheless there were often some bickerings between us, thus for instance one day she read me a long lecture on my great imprudence and negligence in leaving open my drawer with money in it, on another occasion she blamed me for not having my shoes so neat and clean as in her opinion they ought to be. A third time I had to listen to a severe sermon on the heinous offense which I had 
committed in showing some, (which my cousin considered) marked attentions to Miss Tesdorff which might endanger the young lady's "good repute". I for my part retorted upon her by representing that she acted certainly very foolishly when speaking in such disparaging terms of the Peruvian ladies of whom she neither did nor could know anything. Notwithstanding such disputes we never separated without being on excellent terms, and this day we agreed to make an excursion to Mühlenbeck on Sunday next. In the evening I went to the Hamburg Theatre where I secured a seat in the third tier of boxes, but the height at which I found myself above the stage and the pit was such as made it impossible for me to remain there. I did not feel any giddiness in the head, but a certain uneasiness in the [443] whole body especially in the legs as if they would break down under me, and I therefore descended to the pit where I got a seat. A small Drama called Christopher and Renata or the two orphans was well performed, but did not interest me much; next appeared on the stage two young girls of thirteen and fifteen years of age called Maria and Theresa Millalleno who played some pieces on the violin in a masterly style. Finally Mrs. Feringer sang two little songs, and Mrs. Brüning recited a poem pretending to be very droll and funny, but which seemed to me very stupid.

Friday, $3^{\text {rd }}$ of March 1844. This evening Mr. and Mrs. Knauer had their last usual Friday party; on the following day, they intended to remove to their country house in Eppendorff.

Saturday, $4^{\text {th }}$ of May 1844. I played at chess at Bocklemann's but convinced myself that I had no chance against such players as Messrs. Jones and Petersen who actually studied the game, whilst I merely made my moves on the impulse of the moment, without being able like them to foresee all their consequences.

Sunday, $5^{\text {th }}$ of May 1844. When I arrived in Kramer's in Hamburg, they had gone to church to attend the service held on this day, the second anniversary of the great fire of 1842. They having come home, Kramer and I walked, whilst Mrs. Kramer, Mrs. Pauli a friend of hers and the two little girls drove to the Railway terminus, whence the train for Bergedorff started at half past twelve oclock. We occupied the preference seats in the Coupé, the name given to the first division of the first class carriages with glass windows in front. The terminus lies close to the Deych-Thorr, which gate as its name implies leads to a continuation of dykes constructed for the purpose of protecting the low land which lies behind them against the waters of the Elbe; this river centuries back extended in width as far as the foot of the sandy hills, now at a considerable distance inland, and I well remember that when a child, a certain hill was pointed out to me, behind which about the year 1402 "Stortebecker" the famous pirate of the Northern seas, used to moor his fleet. In course of time the land between these hills and the present bed of the river had gradually been 
redeemed, and converted into fruitful meadows intersected by ditches for drainage. The high road to the Duchy of Mecklennburg before railroads were known, led from the "Steinthor" through the suburbs of St. George, the villages of Hamm and [444] Horn, replete with country houses, through "Shiffbeck and Steinbeck" on the sandy summit of those hills once the boundary of the Elbe to Reinbeck and so on, a route well known to me in the years of my childhood, when every year during the summer holidays, my parents with us children paid a visit to our grandparents at "Raguth". The railroad to Bergedorff ran along the lowland which about a mile in width and three miles in length goes by the name of Billwerder. The high land and the Bille of which we had an occasional glimpse, were to our left, to our right the dykes and the villages of Moorfleth and Allermöhe, in twenty five minutes we reached Bergedorff two german miles distant. This town belonged half to Hamburg, half to Lübeck, and had a poor appearance excepting however some gay and gaudy hotels lately built in the vain expectation that the Railway would bring thither a great concourse of strangers. This had not been the case, and the hotels turned out to be losing speculations. From Bergedorff our walk to Rainbeck leading for the greater part through a wood, was very pleasant. On approaching this last named village on the other, the Northern side of the Bille, here a narrow rivulet, we had again before us a thick and extensive wood which encircled a large rather clumsy building, the castle or "Schloss" with a short steeple, and a few houses alongside. To our right we had a deep hollow, fresh in my memory from former years, for distinctly did I remember how on our annual drive to "Raguth" our four horses with the cumbrous travelling carriages used to toil up this heavy ascent from the Bille, to which we now descended, crossed the bridge, and entered the public house of "Jahncke" which I had not forgotten either. Here our small party took a plain dinner: Beefsteacks, pancakes and a bottle of wine, which though labelled "Sauterne" turned out to be Moscatel, and was of such a quality as to give me the belly ache. Our next move was to look out a carriage to continue our journey to Mühlenbeck, but as none was to be got, we had nothing to do but to remain where we were, and to postpone our visit to Mühlenbeck to another day. Kramer had predicted in Bergedorff that this would be the case, and had been of opinion that we should there hire a carriage, but Nelly had insisted upon the walk, and thus there was now no end to Kramer's exultation. He and his wife had some words on the subject, not very pleasant to be listened to by the bystanders. Whilst the ladies remained in the inn, Krammer, the two little girls and I strolled about in the vicinity through the wood, along the Bille, and through the garden of [445] a certain Doctor Vogel, which, once this gentleman's hobby horse, was now falling into decay. Though occasionally a drop of rain fell, yet upon the whole the weather was mild and agreable; the 
meadows now in the early spring were covered with the most delicate green, the fruit trees also the black thorns stood in blossom, whilst the oak, like the beech, the indigenous forest trees of the North of Germany, was still leafless. We walked back to Bergedorff the same way we had come, and whilst waiting for the train which did not start till half past seven oclock took a cup of tea in an hotel called Frascati. Hardly had I entered the Coffee room, when that at the slough's station on the road from London to Windsor recurred to my mind, this in Bergedorff was fitted up, and decorated in a very similar though not quite so elegant a style. The owner of the Thalia theatre in Hamburg had the lease of the Frascati hotel and had as yet been a loser by it to a considerable amount. As soon as I had alighted at the station in Hamburg, I hurried off to the pig market near the "Steinthor", whence an omnibus took me the great distance to the western extremity of Altona for the small fare of four shillings currency. Sieveking had invited a few friends, of course I was one of them. The party was rather dull and broke up at half past ten oclock, when I with Löhmann went to a Subscription ball given at Rainville's in honor of Count and Countess Blücher. When we entered, he and his lady were on the point of retiring. The Company was much more mixed than that of the late dinner party, owing to the low rate of subscription, three marks Cury. for each Gentleman. A great many of them were strangers to me. There were however several ladies with whom I was acquainted. I conversed with the one and the other, and when they were gone I also retired, it was past two o'clock in the morning. In my sitting room which for this night I had given up to Messow, some Gentlemen were still playing at cards and smoking. The music from the ball room was heard in my bedroom. Nevertheless after such a busy day as this had been it is not be wondered at that I soon fell asleep.

Monday, $6^{\text {th }}$ of May 1844. I purchased in Hamburg a punch bowl of Bohemian glass, dark red and gilt which I intended as a present for Henry Sieveking's birth-day.

Tuesday, $7^{\text {th }}$ of May 1844. Towards the evening I enjoyed the spectacle of a thunderstorm, thick black clouds drew up from the South, they rose gradually; overshadowed by them, the Elbe looked dark and [446] threatening, whilst in strong contrast, the sails of the vessels seemed as white again as usual. The sky became totally overcast, the thunder rolled at the distance, it came nearer and nearer, it grew louder and louder. Sometimes the lightning cut in zigzag through the heavens more frequently the whole sky was suddenly lit up as if a dark shrowed were removed, an instant later all was dark again. Now the thunder rolled over our heads, one or two loud claps resounded, the rain poured down, the sky cleared up, and nature resumed its smiling aspect. 
Wednesday, $8^{\text {th }}$ of May 1844. At 10 a.m. I had to appear in the town house before two magistrate Messrs. Gähler and Olde, with both of whom I was acquainted. The latter had been one of my fellow pupils in the Gymnasium, but on this occasion he addressed me with Mr. Witt, and I him with Mr. Counsellor of Justice ("Justizrath"). Both questioned me on the subject of the theft committed in my room and discovered by me on the $24^{\text {th }}$ of April last. Olde then drew up in a clear manner a summary account of my deposition and read it to me. At home I took my lessons and Mr. Schwalb, my French master, was still with me when the first of my friends whom I had invited to dinner arrived. They were: Albert Schmidt, Gustavus Schmidt and lady, and whilst I was finishing my lesson, my fellow lodger Mr. Schutt kept them company. By and by my other Friends made their appearance, we walked about in the garden, looked at the labourers on the Railway and wondered at the rents in the ground which I observed to Semper were increasing from day to day. His reply was that no doubt in the upper part of the garden the whole hill was giving way, but that further down near its base there was no trace of any damage being done. Semper as Railroad director made this assertion, yet I thought it rather hard to believe; at half past five we sat down to dinner in one of the pavilions behind the Hotel in the following order. I at the head, to my right Mrs. Gustavus Schmidt, Sieveking, Nelly, Semper, Mrs. Siveking, Kramer, the two little girls, one empty chair for Edward Reincke who had not come, Albert Schmidt, Wilhelmina, Gustavus, Mrs. Semper, and again I. The dinner and wines were very fair, the conversation general and animated, and all were well pleased as far as I could judge. Mrs. Schmidt above all, pent up in Hamburg between her four walls, did not tire of expressing her admiration at the beautiful view before us. [447] Dinner over we retired to my sitting room, where coffee was served, some went again to the garden, others did not; at a later hour candles and tea were brought in, the Hamburghers left at nine o'clock, the Altonaers half an hour later, the cost of this small party was CM 69 .

Thursday, $9^{\text {th }}$ of May 1844. I had again to appear in the town house where justice Olde delivered to me against receipt CM 139.6, one gold ounce, two half onzas, and a small gold chain of little value, a silver watch, and a gold ring which the delinquent said he had not bought with my money, the judge kept in deposit. Business done, Olde recollected old times and put me in mind of having been together as very little children at the primary School of Mr. Bartels. From the town house I hurried to Semper's where a considerable party had assembled to go over his very extensive factory for dyeing woollen yarns. His grand mother had carried on this business on a very limited scale, he had inherited it from her and extended it in an extraordinary manner within the last twenty years. Until lately he had been in the habit of purchasing the yarn 
partly in England, partly in Holstein and Saxony, but now he had established a spinning factory in the Elbstrasse close to Donner's dwelling house. The machinery moved by steam had been made in England. As far as I understood the process was the following: the wool in its raw state is sorted, washed and carded, then taken to the preparing frames of which there are seven or eight. Here the wool is drawn out; it goes from one frame to the other and every time turns out longer and thinner. Next it is removed to the spinning wheel and spun into thin thread. These threads by another machine are twisted together and the white yarn is ready. In the establishment of the Carolinen Strasse where Semper possessed a row of large buildings, the white woollen yarn was dyed, washed, and dried, and one of the foremen told me that they produced not less than 1050 different colours and shades. Here also the yarn ready for exportation was deposited. Whilst we were there, parcels were made up for Perth and Trieste. The Steam Engine in the Elbstrasse likewise pumps-up the water from the river, and sends it on to the factory of the Carolinen Strasse situated considerable higher up than the level of the Elbe. Semper's mother still kept the retail shop in the Gross Mühlens strasse, where I left my friend Semper in 1823, already then intent upon devising new colours and occupied with Chemical preparations. At five oclock we returned to Semper's [448] dwelling house where the greater part, not all, partook of his hospitality in the same saloon and around the same table where we had been feasted on the $28^{\text {th }}$ of April. I led upstairs the Governess, a very pleasant young lady, and conversed much with the children. After dinner I did not feel well, and was uncommonly quiet. To please old Mr. Reincke, Semper, Elmenhorst and I sat down to play whist, we had daylight until eight oclock.

Friday, $10^{\text {th }}$ of May 1844. The weather continued mild and I let off lighting the fire in my stove. This day I devoted to a visit to the Altona mint. Mr. Birk, my Danish master employed in this establishment showed me round; in a furnace, the pure silver and a small proportion of Copper which serves as alloy were melted. A working man took this liquid mass of a reddish colour out of the furnace with an iron ladle provided with a very long handle and poured it into a mould with a lid which shut easily. This mould was likewise of iron, very narrow and of great length. At the very moment when the liquid was taken out of the furnace, some charcoal dust was strewn upon it in order to prevent the copper from oxidizing, for this metal, as well as Iron, in a melted state oxidizes on the slightest exposure to the air (see what I say on the Subject page 317, $8^{\text {th }}$ line), whilst the noble metals silver and gold do not oxidize. As soon as the liquid cooled and consequently become harder, the lid was opened, and another man with a pair of tongs took out the silver which now appeared in the shape of long and very narrow bars. These bars were taken up stairs and 
passed through various Iron cylinders where by the repeated pressure they became thinner and thinner until they had the thickness of species dollars. The weighing of such dollars occupied many other workmen; the dollars which were too heavy were filed off, those too light were remelted. The next operation was that of stamping these round disks with the dies. The machinery used for this purpose was not working but it appeared to me to be an old fashioned one and quite out of date. Each dollar had to be placed under the die by a man and again taken out when stamped. There was another machine made somewhere in the interior of Germany for the purpose of coining smaller coins which worked with more ease and rapidity. Out of a narrow tube filled with disks to be coined, a pair of tongs took them out one by one, placed them under the die, and when stamped shoved them aside. The last process was that of giving the edge and then the coin was finished. Species dollars contained $7 / 8$ pure silver, 1/8 alloy; also Danish ducats contained 7/8 pure [449] gold and 1/8 alloy. The manner [_] which the silver with its alloy before being coined is assayed, was explained to me; the assayer makes out of ashes two small cups or bowls very porous and of little weight, into them he puts small pieces of the Silver to be assayed and which are weighed in a pair of scales so exact and [nice] that a bit of paper of this size $\square$ affects them. Next the two cups with their contents are exposed to the action of fire in a small furnace heated with charcoal. The alloy, be it copper, lead or any of the inferior metals, evaporates and enters into the pores of the cups, this being done the silver is reweighed and naturally the deficiency in weight which now appears shows the quantity of alloy originally contained in the silver. Having left the mint, I walked down the Berg Strasse until I came to the public-house called the Hahnenkamp, which strange to say I never had visited before, I entered, took some bread, butter, and a glass of wine. Looking Eastward I saw before me the steeples of Altona, to the South the last houses of the Pailmaille and the steeple of ottensen, Westward the village of this name, Nortward the red roofs of Langenfelde and in the immediate vicinity green hedges and green meadows filled with buttercups and every where the loveliness of the present month of may. Close to the inn runs the Railway, walking along the same I met Semper, the Railway director, with two engineers. They showed me the third class carriages that were to be employed; certainly far superior to second class carriages in England, and quite as good as those by which I had travelled between Liverpool and Birmingham. It is true that the seats were not separated, so as to form each a seat by itself; nor were they stuffed, as little as the backs; but on the other hand these carriages had glass windows which could be pulled up and let down. Having dined at home I took in the cool of the evening a walk along the meadows which line the 
Railway, skirted the Hahnenkamp, and striking off into a foot path to the right, emerged into the Pinneberg road where the Mathiessen's lived, and with them I spent the remainder of the day.

Saturday, $17^{\text {th }}$ of May 1844. It was my birthday, I completed my forty fifth year, I gave thanks to my Creator for the blessings bestowed upon me in the course of my life, and prayed for the continuation of this divine protection for myself and family. Whilst I was breakfasting and studying my Horace, suddenly the door opened, and who should enter but Sieveking, his wife and children, a moment later Knauer, his wife, William [450] Maria and Emily, likewise Wilhelmina Reincke, appeared. Taken by surprise as I was, I could not but express my regret that my good friends should have inconvenienced themselves on my account at such an early hour for it was only just past eight oclock, and Knauer in particular had already come in from his country house in Eppendorff. Little Charles Sieveking presented to me a garland of flowers; his sister Theresa, a nosegay; Wilhelmina Reincke a pair of velvet slippers embroidered by her; Mrs. Sieveking and Mrs. Knauer a large travelling bag embroidered by them, on one side my arms, on the other a fancy pattern. I was much affected by these evident signs of their friendship for which I thanked them most sincerely. The travelling bag is still (1869) in my possession, but has gradually descended to the ignoble purpose of serving as a deposit of my soiled linen. I must say a few words about my arms; my family never had any, but when the Edwards in Halifax made me the offer to have a carriage made for me under their own inspection, and asked me for a design of my arms to be painted on the panels, I did not like to say that I had none, and thus when I came to Altona invented them and had them engraved (See appendix $N^{\circ} 9$ ). Soon however I became ashamed of this childish vanity and never used them again. I obtained from Mr. Cronhelm a design of the (crest) of the witts of England (see appendix $\mathrm{N}^{\mathrm{o}} 10$ ). My visitors remained but a short time, together we went to the garden where some of the fissures in the ground had so much increased in magnitude as to threaten the safety of the small pavilion and the balcony in front of it. Hardly had I resumed my studies when Ernestine Willink, her two daughters, and miss Götz came to congratulate me. Ernestine gave me an insignificant and valueless memorandum book. Whilst I was taking my lesson at Frandsen's Edward Reincke called leaving his card, also George Knauer Junior. A few moments after my return the door opened once more for Kramer, Nelly and the two children. Kramer had composed some congratulatory verses which the two children recited alternately and delivered to me a written copy of them which I have affixed (in the appendix under $\mathrm{N}^{\circ}$ 11). I dined at Sievekings with Edward Reincke and handed to the former the presents which I had purchased. 
As stated previously, he was exactly one year younger than I, Warnholtz two years. When we were at the second bottle of champagne, Semper and his wife came and presented me with an extremely pretty embroidered velvet portfolio which now (in 1869) is still to be found on the table in my drawing room in Lima. Immediately afterwards a parcel was brought in for me containing an embroidered sofa cushion from [451] Mrs. Warnholtz from whom I surely had not expected anything. To celebrate her, Mrs. Warnholtz's, husband's birthday, old Mrs. Elmenhorst had invited a few friends. Mrs. Semper and I went thither merely with the object of congratulating Warnholtz. Towards eight oclock I went to old Mrs. Sieveking's where I knew I was to meet with a large party, but I had not the slightest idea that I should find there my niece Elisabeth with her husband Bobertag, who had arrived the previous night at Kramer's request, and of course with the cognizance of old mistress and Henry Siveking. Not less surprised was I when I saw Mr. and Mrs. Limpricht, Mr. and Mrs. Gustavus Schmidt. They were solely invited because they were my intimate friends, for never before or after did they, as far as I know, again put their feet into Mrs. Siveking's house. I suppose we were at least fifty persons. After tea was served, the young folks represented charades, the first was Wittelsbach, the first syllable of which "Witt" was made so clear that my old acquaintances could not fail to recognize me at once. There were two rocking horses each mounted by one of the performers the one of which had a long [surtout] coat drawn up high, his hat pulled down, and some money was continually dropping out of his pocket. This referred to an old story. Many years back perhaps in 1821 or 1822 , Semper and I took a ride on the Flottbeck road. I had put in my pocket a quantity of Shillings to pay my tailor's bill. There was a hole in my pocket and when I came home, my money was all gone. For a long time this mishap had been an excellent Joke to my friends, and now they recollected it immediately. The second Charade "Sommer nachts traum" (Summer night's dream) was prettily done though I could not distinguish it well. Afterwards cold refreshments also champagne were handed round. Knauer gave the health of Sieveking and myself, I, that of Mrs. Siveking. Before we separated somewhat past eleven oclock young Nopitsh and Arthur Donner sang very nicely, and the party though it did not go off with "grand éclat," was however more animated than it was generally the case at Mrs. Sivecking's. The whole evening I was on the move, talked with all the ladies, and endeavoured to make myself agreeable, but whether I succeeded, that is another question. Mrs. Johannes Limpricht was the prettiest of the ladies, although she looked wearied, my niece Elisabeth personally known to few made a favourable impression upon all. She was pronounced to be good looking and genteel. She 
also brought me an embroidered cushion as her present. It was twelve oclock when I returned home fatigued to be sure but grateful [452] to my friends for the extreme kindness they had shown to me.

Sunday, $12^{\text {th }}$ of May 1844. I rose before six oclock. The birds chirped and twittered in the garden, it was a fine sunny morning though the moisture on the one side of the windows proved that the night had been cool. I was occupied for more than an hour with my diary in which I gave an account of the previous day's festivity, then looked in at Sieveking's, and drove in an omnibus to Kramer's with whom Elisabeth and her husband had taken up their residence during their short stay in Hamburg. In the street called Vorsetzen or quays, we embarked for Haarburg on board the small, fast iron Steamer the "Primus". At the same time with us another party from Altona, Mrs. Sivecking, Ernestina, her two daughters, Löhmann, his sister and his fat brother stepped on board. The deck was crowded and notwithstanding the current of air occasionned by the Steamer's rapid motion through the waters, not a few complained of heat. The passage which lasted three quarters of an hour was very pleasant, turning my eyes towards the Northern Shore whence we came, furthest to the East, the fertile "Vierlanden" were hardly distinguishable, more westward the church steeple of Steinbeck, then the sandy hills spoken of (page 444 of this volume) were clearly visible; Also the low land of Billeverder, the Suburb of St. George and Hamburg itself stretching along the shore with her five or six steeples, that of St. Peter, such an elegant structure before the great fire now a misshapen ruin, that of St. Michaels remarkable on account of its great height. From the western extremity of Hamburg the ground rises perceptibly the suburb of Saint Pauli, the connecting link between the two towns presented itself, the houses interspersed with trees, then Altona, Semper's corner house, the row of fine white buildings belonging to Fritz Bauer and the foliage of the Paillemaille I could clearly discern. Next came the sandy chasm where the inclined plain descended towards the Elbe. Some solitary clumps of trees, Rainville's garden and hotel, and continuing in the same direction, the ridge of hills covered with wood which runs as far as Blankenese was gradually lost in the distance until at last Fritz Bauer's Country house in the surrounding park was nothing but a white dot in the midst of a green spot. The Hanoverian or Southern side presented a different aspect. The various Islands which fill up the entire width of the Elbe as well as the Shore of the main land itself lie low and are protected by dykes behind which the peasant houses, some agglomerated into villages [_] isolated are partly visible, gaily painted, generally green. The following Sketch gives an idea of this part of the country and shows the course which we took (See next page). At the very moment when [453] we landed at Haarburg a little boy fell into the water and was drowned. 


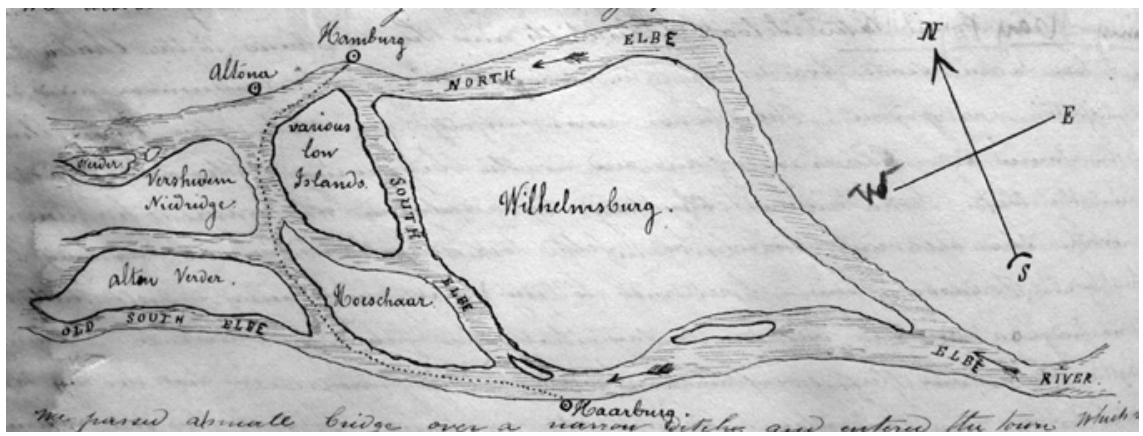

We passed a small bridge over a narrow ditch, and entered the town which was and is still in 1869 of little importance. I noted however a small fort, low walls and a few large buildings, such as the post office, the Custom House, and two or three hotels, a short avenue of poplars took us to a sandy hill (Schwartz berg), a small distance out of town in a Westerly direction, on the top of which is a public house surrounded by a garden tastefully planned. During the winter 1813/14 when the French under Davoust were blockaded by the Russian army commanded by General Berningsen a battery was planted on this hill, for Haarburg was like Hamburg in the hands of the french. In 1844 there were still two or three guns probably more for show than for use. From this elevated point the prospect was very extensive. Towards the North, the scenery just described lay before us, to the South a level country sandy and barren stretching towards the well known Lüneburg moor, just before us eastward, Haarburg with its steeple, behind the same, the steeple of the village of Wilhemsburg. The last named island was of a swampy nature and Davoust during the siege in order to facilitate the military communication between both towns had a wooden bridge built across, the materials for which he took from the owners of course without paying for them. I may however observe that in 1815 when after the second occupation of Paris by the allied troops France had to pay to the victors the heavy sum of I believe two thousand millions of francs, some partial compensation was made to those who had suffered by Davoust's exactions. At each extremity of the bridge there was a ferry as there is still in 1869. After the peace of 1815 , the Hanoverian Government in order to protect the interest of the (Hanoverian) Haarburg Skippers had [_] destroyed and the materials disposed off by public sale. In later years a good chaussée has been constructed across the Island. We took a plain lunch, strolled about [454] in the neighbourhood and at about 4 p.m. returned to Hamburg in the same steamer. A few hours later I took Elisabeth and her husband to the Thalia theatre where I had taken seats for us in the parquet; Lucia de Lamermoor, an opera by Donizetti, was given. The house was empty, nevertheless Elisabeth soon complained of closeness of air and in the beginning of the second act, she 
swooned. We took her to the lobby, and by applying cold water to her temples and nostrils she recovered soon, but felt too unwell to remain by longer. She and her husband drove home, I returned to my seat and amused myself pretty well. I am no judge of music, but will say that the frequent recurrence of drums and kettle drums and the overpowering noise they made were not to my taste. This night there was no room for me at Kramer's, and I therefore returned to my lodgings at Rainville's.

Monday, $13^{\text {th }}$ of May 1844. Accompanied by Kramer and Gustavus Schmidt I went to the Hamburg Johanneum, a College which enjoyed a very good reputation, far and wide. It was a plain building consisting of the principal in the center and 2 wings in this shape $\square$ (the dots represent the railing towards the street). The building in front was destined for the upper classes, where the higher branches of knowledge were taught in a manner similar to that adopted by the Professors in the German universities. This went by the name of the Gymnasium. In one of the two wings, the rudiments of a classical, in the other those of a mercantile education were imparted to the pupils. In some apartments the Chemical apparatus, and the zoological museum were about being arranged, as yet they were closed to the public. However, to us as strangers, they were opened, they contained so far as I could judge nothing of very particular value nevertheless it was sufficiently interesting to look at the various objects. Up-stairs was the library of about two hundred thousand volumes kept in excellent order; any Gentleman might sit down, ask for a book and read it there on the spot. Such as were known and specially recommended to the librarian were allowed to take books home with them. There were manuscripts of great antiquity, in one book, the lord's prayer was printed in one hundred and fifty different languages. On my return to Altona I went with Theodore Elmenhorst and Fritz Warnholtz to the Country house of C. H. Donner who had invited us to dine with him. This country seat lies at a short distance out of town and in a very pretty spot indeed, like all the gardens from Altona as far as Flottbeck, it covers the hill side from the flottbeck road down to the bank of the Elbe. It is laid out in terraces and splendid shady walks descend [455] gradually from the top to the bottom. The dwelling house which stands on the level ground at the foot of the hill was in 1844 a plain modest building, in later years as I have mentioned in other parts of these extracts, C. H. Donner's son and successor, Benhard, had it pulled down and constructed in its stead a building of such size and pretensions that the lower classes used to call it Donner's Castle. When my companions and I arrived we were told that Mr. Donner and his guests had gone out into the garden, we went in search of them, and the whole company was introduced to the Sanctum Sanctorum, the museum, an octagon built on a plan given by the architect Godfrey Semper 
(a younger brother of Charles). The inside was painted with glaring colours in imitation of the walls of Pompeii, the principal treasure which it contained was the three graces sculptured by Thorwaldsen out of one block of marble, they are of human size and completely naked. Their arms are entwined, and Donner told me that in Thorwaldson own opinion in this entwining of the arms he had shown his greatest art. The two figures which stand each on one side turn their looks towards her in the middle; all three though of stone are really lovely creatures. On a later occasion Mrs. Zarhtmann, Donner's daughter observed to me, Thornwaldsen's graces are those of nature, Canova's those of a saloon. There was also Thornwalsen's shepherd boy, considered like the three graces, a Chief d'œuvre, but not so much to my taste; besides a large urn of marble upon which are sculptured in bas relief a number of "amourettes" some fluttering about, others in a cage, very pretty indeed. There was a colossal bust of Thorwaldsen himself (in marble) sculptured by Bissen and many small statues in alabaster and terra-cotta, copies of famous antique statues, such as the Lascoon, the Venus di Medici, the Gladiator, etc., etc.; they cost but little in Italy. Having duly admired these beauties of art, we heard the Dinner bell ring and sat down to a nice pleasant dinner in the following order: Donner at the head, to his right Clergyman Paulsen, Jessen a Naval Danish officer, Schutt, a young Mr. Schroeder from Amsterdam, at the bottom of the table Bernard Donner and Warnholtz, round the corner Schuster, I, Elmenhort and Knauer; Elmenhorst was in good spirits full of fun and jokes, and contributed much to my amusement. After dinner when Bernhard Donner and I were spinning our yarn sitting before the blazing fire (a proof that the weather was cold) he told me amongst other things that he knew for a certainty that the house of Barings in London had made in one year a clear gain of $£_{360,000}$. The names of the three W[s]. N. Amican. houses which stopped payment at the time of the last comercial crisis in 1836 are: [456] Wilson, Wegan and Wilde.

Tuesday, $14^{\text {th }}$ of May 1844. Kramer had fixed upon this day to shew to their Eutin guests the beautiful country which extends from Altona as far as Blankenese and though the weather was unfavourable, for it threatened to rain at every moment, and the heavy clouds were only prevented from discharging their contents by the violence of a cold wind which chased them across the sky, the plan was carried out, and accordingly at about ten oclock, they without the Children arrived at my lodgings. After a short detention we continued the drive along the Flottbeck road. Elisabeth and her husband were much delighted with all they saw. At Booth's nursery garden we alighted, and entered the hot houses well worth seeing; the Orchids [or air-] plants, which extract all their nourishment from the air without requiring either earth or water, and of which there was a great variety, interested me mostly. We remounted and stopped 
again on the other side of the Devils bridge, near the melancholy pond (see page 426,) and being sheltered here against the cold wind by the surrounding trees, had a pleasant walk round it [...]. It was too cold to sit in the open air, and we therefore took our lunch within doors. Having refreshed ourselves, we set out on foot ordering the carriage to wait for us at the entrance of the Bauer's property. We walked though the parks of Richard Parish, of Peter and Cesar Godeffroy, which are all laid out with great taste. They abound with trees of all kinds: Birches, poplars, oaks, beeches, horse-chesnuts, Lime-trees, firs, pines, etc., etc. Between the two last named lies an extremely pretty small valley known by the name of the "mill-dale"; a mill pond, a few houses, and some trees arranged by nature in such an artificial manner as to present a most picturesque little landscape. In the garden of Cesar Godeffroy we noted particularly an artificial ruin, an excellent imitation of the originals of which I saw so many in my later travels through Italy. We finally visited Bauer's park which I have described on a previous occasion (see Page 422). A little fatigued, we were not sorry to have the carriage at hand, and in it we drove through a sandy high road to the "Köster-Berg", the sandy hill or down which lies furthest to the west, here was a public house. The weather had become so cold that the ladies preferred remaining inside. I ran down to the beach and scrambled up again, then Bobertag and I ascended to the top of the house where a telegraph was established, not a majestic Electric one, as we can boast of in 1869, but one consisting of large moveable boards which being turned one way or another signified some letters, words or phrases. There were nine such telegraph stations between Hamburg and Cuxhaven, the principal object of which was to communicate ship news: this on the "Köster-Berg" corresponded [457] Eastward with that in Hamburg, Westward with that in Schulau, about one German mile further down the river. Thence the next was that in Stade on the Hanoverian side. It was near 6 p.m. when we drove home. On passing Arnemann's country house in Nienstädten I got off, because I wanted to pay a visit and to say good bye to Mrs. Arnemann who within a few days intended to leave for Karlsbad in Bohemia. She sent for Doctor Waldemar Niessen of whom I had preserved but a faint recollection, he was now forty five (44) years of age, and had been practising as Physician in Nienstädten for the last twenty years. The lady, the Doctor and I conversed very pleasantly till half past eight, when I had to start again. I walked fast as it was and is my custom, and reached Altona in time to spend the remainder of the evening at old Mr. Reincke's.

Wednesday, $15^{\text {th }}$ of May 1844. Johannes Limpricht was desirous to contribute his share to the amusement of his niece and her husband during their stay in Hamburg, and had thus made us the proposal which we accepted with pleasure to accompany him and family in an excursion to Rainbeck. at ten 
oclock we, that is to say: Bobertag, Elisabeth, and I, Joannes Limpricht, his wife, his mother in law Mrs. d'Albert, and his two eldest children Henrietta and Hans (Anglicé Jack) started from the Bergedorf Station per rail, and reached Bergedorff in twenty five minutes. We took a little broth in the Frascati Hotel and then drove on a "Stuhlwagen" to Rainbeck. The Stuhlwagen is an uncovered two horse carriage with four seats, one behind the other, each wide enough for two grown-up persons, the first seat occupied by the driver. The carriage road which passes through the Village of Wentorf is by no means as pretty as the walk through the wood which I took with the Kramers when last here. In Rainbeck we put up at Jahncke's, breakfasted and strolled-out to the Wild Koppel, a wood fenced in, originally no doubt a game preserve. The weather being mild, very different from that on the previous day, Mrs. Limpricht proposed to walk back to Bergedorff, which we did and I for my part enjoyed myself. Mrs. d'Albert was still in the prime of life, Mrs. Limpricht a pretty young lady, and Elisabeth an innocent creature; sometimes I gave my arm to the one, sometimes to the other; a harmless snake called the "Blindworm" crossed our path, and as may well be imagined called the attention of all of us for snakes in the neighbourhood of large towns are a rare sight. In Bergedorff we refreshed ourselves with Seltzer water, and returned per train to Hamburg. The owner of the Thalia theatre was [458] not as I said (page 444) the proprietor, but merely the lessee of the Frascati Hotel, and so considerable had been his losses that in order to annul [...] ten years lease, he preferred paying a fine of CM 20,00o. On our arrival in Hamburg the whole party, some in a Droshka others on foot went to Limpricht's dwelling house where I met his brother augustus, whom though intimate with him in my childhood and youth, I should not have recognised, his voice however was familiar to me. He was one year younger than Johannes, but looked much older. In 1822 when he left for Newcastle on tyne he was a good looking very genteel young man, but alas, now his gentelity was gone [_] his reddish nose gave evidence not to be mistaken, of his propensity to the bottle, the fatal comforter of all those who drown the consciousness of their troubles and cares in the fumes of spirituous liquors. He had married a woman below his sphere in life, who had borne him seven children. Whether he has always been in a dependant situation, or done business on his own account I did not learn, but that he had not prospered in the world was a certainty. His two eldest boys, Bernhard the third brother partner of Johannes intended to take to his house in Rio-Janeiro. We had a nice dinner; soup, turbot, Chickens and dessert. We finished the day in the Thalia Theatre where Johannes had taken seats in the balcony. The house was crowded, the purport of the first play was to bring on the stage the caricature of an English Gentleman Mr. Peading. The second was the "Vocation" (Der Beruf) a girl presented herself to Monsieur Voltaire, 
and told him that she wished to go on the stage, to which he replied that she had no vocation for it. To prove to him that he was mistaken in the opinion he had formed of her, she represented without being recognized, three different parts: that of typsy peasant boy, that of an old female fortune teller, and that of an elegant young Marquies, Miss Hermann acted this part to perfection. The third, a farce was Mr. Hamplemann in search of lodgings, in which the actor Mr. Hassel who appeared this evening on the Hamburg stage for the last time, acted Mr. Hamplemann, a Frankforter speaking in the Frankfort dialect, quite different from that used in Northern Germany and this was the point. I thought it very stupid, but the audience was well pleased, and the laughter of Augustus was so loud, his mirth so boisterous that Elisabeth as she afterwards confessed to me, was actually afraid of him. At the door of the theatre we separated. I had spent an extremely pleasant day.

Thursday, $16^{\text {th }}$ of May 1844. (Ascension Day). I awoke with a bad headache which made it impossible to me to attend to my usual studies which by the bye I never neglected [459] when I was at home by myself. Before my departure from South America, Mr. John Hoyle of Trujillo, had made me a present of a box containing Huacos, that is to say old Indian earthenware, pots and other vessels some representing animals, and all more or less curiously shaped. They are found in the burial grounds of the ancient Indians who, ruled by the Incas, inhabited Perú before the Spanish Conquest. This box had arrived, I opened it in Sieveking's house, found the contents without breakage, and decided upon presenting it to the Antiquarian Society of Copenhaguen. At a later hour I drove with Sieveking and his wife to Knauer's country house in Eppendorff. We walked about the garden which I did not much admire. It is not large, lies rather low, has a stagnant pond, and extends towards the Alster from which it is separated by a meadow lying still lower, therefore it must be necessarily damp, besides being exposed to the cold north wind. The hot houses are well taken care of, and contained many valuable plants, they were the hobby-horse of Knauer, an intelligent flower fancier. My headache did not leave me. I felt dull and stupid, and had no inclination to exert myself, the consequence of which was that at dinner I had for my partner the least interesting of all the ladies present, say: Miss Bertran (Mrs. Bauer's Companion), moreover my seat was at the very bottom of the table as will be seen by the following enumeration of the guests: Mr. Knauer and Mrs. Bauer, the widow of Burgomaster and counsellor of State of the same name (Etats Rath) at the head of the table, next to her Lawyer Stuhlmann, Semper, Mrs. Henry Sieveking, Otto Reincke, Maria Knauer, myself, Miss Bertran, Dr. Callisen a lively young Physician, Wilhelmina Reincke, Edward Reincke, Carolina Tesdorff, Burgomaster and counsellor of state Behn, Mrs. Knauer, Theodore Elmenhorst, Mrs. Semper, old 
Mr. Reincke, old Mrs. Elmenhorst and again Knauer. Everything was excellent with the exception of the red Champagne that was not to my taste. I was down in the mouth, and did not enjoy myself. After dinner we again walked about in the garden, but the cold night air soon drove us in. Maria Knauer presided at the tea table; she and her sister Emily though not exactly pretty looked very engaging. They were plainly dressed in white with a light blue ribbon round their waist. Semper and his lady had the kindness to offer me a room in their house for the short time which I still intended to remain in Altona before my departure for Denmark and Norway. Messow had warned me to leave the apartments which I [46o] occupied in his hotel, and which he had let to me for the winter only, and now that the summer season approached he required them. Towards 10 p.m. we returned to Altona.

Friday, $17^{\text {th }}$ of May 1844. The weather was again so cold that I had the fire relighted in the stove. I was quite well and remained at home the whole day writing to Lima, and bringing up my diary.

Saturday, $18^{\text {th }}$ of May 1844. The eighteenth of May 1843 I left Lima (Callao) in the "Vicar of Bray", how quickly the time had passed[!] The foundation stone was laid to the Railway terminus, which as mentioned more than once was to be built on the Northern side of the western extremity of the Pailmaille. Many people crowded round to see the ceremony. In a corner of the wall a little below the surface a cavity was made into which a sand stone hollowed out and containing various documents relative to the Railway was placed, and covered up with bricks and mortar. The Directors Semper and Arnemann each laid one brick, then the latter delivered a short speech in which he gave a succinct account of the many difficulties with which the entreprise had had to contend, also various dates such as that of the first meeting, that of the arrival of the Royal concession etc., etc. He next proposed the health of the King of Denmark, then drank to the welfare of Altona, both which toasts were received with applause by the surrounding multitude. Before, during, and after the laying of the foundation stone, the members of the Liedertafel sang the verses, a copy of which will be found in the appendix (under number 12). All this being over, the Directors, the members of the committee, the singers, and many others, I of the number adjourned to Arnemann's garden over the way, where under a tent a cold collation was served, also the workmen were treated with wine, bread and butter, and kept it up until seven o'clock. I went back to my lodgings at six, dined, and began packing my trunks.

Sunday, $19^{\text {th }}$ of May 1844. I rose at as early an hour as half past four oclock. When I had finished packing I ran to Sieveking's to swallow a cup of Coffee, then returned to my lodgings where the porters were already waiting. One large case filled with such things as I least required I sent to Sieveking's ware-house, my 
books to his dwelling house; my wearing apparel to Semper's, who as already said had placed a bedroom at my disposal. It was the large saloon up-stairs which during the winter season had served as a dining hall and Ball room. It had a Balcony towards the garden and thence a view towards the Elbe similar to that from my lodgings at Rainville's, but mo[_] [461] confined. The garden behind the house extends so far down that a postern gate at the bottom was merely separated by the width of a Street, Van der Smissen's allée, from the extensive factory building in the Carolinen Strasse. Semper's family consisted at the time, of himself, his wife, seven children, Otto, Charles, Elisabeth, George, Edwin, Augustus, and Richard, the three first were the Children of his first wife Betty Heyne, a young lady (Miss Emily) Mrs. Semper's companion, and many female servants. Though Semper was already a rich man and his wealth yearly on the increase, as yet he had no country seats, no carriage of his own, not even a male servant, the family lived in a plain manner, economy prevailed, not parsimony. He spent his money well without launching out into any extravagance. In the forenoon I paid many farewell visits, it is unnecessary to specify the families to whom I bade good bye as this would be a mere repetition of the names which have so often recurred in these my extracts in the course of the last five months, suffice it to say that on this the last day I experienced the same friendship and kindness as had been shown me during the whole time of my residence in Altona. Mrs. Bauer, the widow, went so far as to express her regret at my having removed to Semper's, for she would have been glad said she, if I had gone to live with her. We dined at 3 p.m. I then played at chess with Semper, gained three and lost one game, and spent the evening in his and his wife's company.

Monday, $20^{\text {th }}$ of May 1844. At Semper's everything was early. At half past seven breakfast was ready, coffee, Bread, and butter, at 2 p.m. the plain dinner was served; after dinner a cup of coffee in the garden. In the forenoon I called at the Counting houses of C. H. Donner and of Mathiessen \& Co. represented by Messrs. Stuhlmann and Lübbes. Both houses promised me letters of introduction and credit to Copenhaguen and Norway. In the forenoon I spent more than an hour with Arnemann who laid down to me the route which he advised me to take through Norway. Whilst with him, we had a thunder storm, tremendous rain, vivid lightning and thunder at the distance. As soon as it cleared up, I walked out to Donner's Country house, he was sitting in the dark by himself admiring the storm as he said; Bernhard came, and I remained with them for more than an hour. A party of Gentlemen assembled at Semper's merely for the sake of conversation, not to play at cards to which manner of killing the time my host was by no means partial. We were Mr. George Bauer, Dr. Hermes a Physician, Dr. Van [462] der Smissen, a Lawyer, apothecary 
Simpson, a Mr. Wichers, employed at the Railroad, Mr. Poel, Editor of the Altona Mercury, Warnholtz, Schuster, and myself. We separated at eleven oclock after a plain supper.

Tuesday, $2{ }^{\text {st }}$ of May 1844. The morning was fine, but at 1 p.m. a thunderstorm again burst forth. The lightning was incessant and at half past nine oclock when Semper and I went to Mr. Reincke's, the rain had not yet ceased. This evening for the first time after her confinement Mrs. Theodore Reincke was present, so was Mrs. Lawyer Lübbes whose husband had left for Karlsbad in company with Mrs. Arnemann. I said in my original diary that these two ladies as well as Mrs. Henry Siveking may challenge comparison with thousands of others. I learned that in Norway in the course of one year 700,00o Barrels of herrings had been packed, each Barrel containing 800, and consequently $560,000,000$ of herrings were caught in one season.

Wednesday, $2^{\text {nd }}$ of May 1844. This day to my great regret, Professor Frandsen gave me his last lesson (Latin), my French and Danish masters I had dismissed a few days previously. In the course of the forenoon I took leave from some of my Hamburg acquaintances, and then drove out in an omnibus to Eppendorff where I had to walk a short distance to Knauer's country house. Mrs. Knauer was by herself; she showed me all over the house and garden which latter I was to day quite as much pleased with as I disliked it on Thursday last, a proof how externals influence one's mind and opinion. On Thursday the weather was raw and cold, this day it was mild and pleasant, then I felt unwell, now I was in good spirits, then I did not care for my companion, now I had an agreable guide to call my attention to everything which she thought might please me, to the cattle grazing on the meadow, to the red roofed village of Uhlenhorst on the other side of the alster, and thus I repeat I did not think that the garden was so very bad. Nevertheless even Mrs. Knauer confessed that it was a damp spot and that in the first year she and her family spent there the summer months, they suffered much from fever and ague but gradually they had become accostumed to its climate. At about four oclock Knauer arrived with his two daughters. We dined in the open air, I played with the girls, I swung Maria in the swing and she did the same good office to me. At seven oclock the carriage was ordered, it was a beautiful evening. We drove along the alster and they put me down at the Dammthor. I remained an hour with my cousin Nelly, and on my return to Altona was so totally lost in my thoughts that instead of taking the straight road across St. Pauli, I kept too much to the right, so that I [463] entered the town by its Northern extremity, and did not reach Semper's till eleven oclock.

Thursday, $23^{\text {rd }}$ of May 1844. Donner whom as already said I had asked for letters of recommendation and introduction, furnished me with a letter of credit for B. Mk. 30,00o on Copenhaguen and Christiania. At my booksellers 
Wendeborn I purchased some books which I intended for presents to Wilhelmina Reincke and Emily Knauer, the birthday of both of whom fell on the $26^{\text {th }}$ instant., namely, for the former "Rückert's poems", for the latter, "the Bewitched rose" by Schultz. I dined at George Bauer's with various pleasant people who were in the habit of meeting round his hospitable board now in the fine season when we had daylight till a late hour, the abominable smoking room was done away with, and after dinner both ladies and Gentlemen used to adjourn to the garden there to take the coffee, and the Gentlemen to smoke their cigars in the open air. When we reentered the house, there was so little inclination for cards that no whist table could be formed. We separated at ten oclock.

Friday, $24^{\text {th }}$ of May 1844. I paid a visit to Rainville's garden where the rents so often mentioned had increased in size and number. In the course of the day I finished my abstract with which I had been occupied for sometime, of Chevalier's pamphlet on the possibility of cutting a canal through the itshmus of Darian. Professor Frandsen paid me a visit to bid me good bye, towards the evening Semper and I commenced a game at chess, but were interrupted by some friends who were in the habit of passing Friday evenings in his house, namely: Mr. and Mrs. Fischer, Mr. and Mrs. Theodore Reincke, and Otto Heyne. Again we had no card playing, and the conversation turned mainly on the all absorbing theme of Railways. Bitter complaints were made of Arnemann's arbitrary conduct and want of correctness in his capacity as first of the AltonaKiel Railway directors. The shares of the Copenhaguen-Roeskilde Railway were up to $112 \%$. 7000 shares of the Railway planned between Apenrade and A[ar] ösund about eight German miles long were brought into the Hamburg and Altona market by Lawätz, and found immediate purchasers at a premium of $21 / 4 \%$, of which $21 / 4 \%$ one per cent went to the Apenrade projectors, one cent to the Lawätz who had disposed of the shares, and a quarter per cent to the broker through whose medium the sales had been effected. The amount of each share was one hundred species dollars, but the Apenrade people had introduced this particular condition that the person who took the original share even if he sold it afterwards, remained responsable for the payment of [464] all hundred per cent - in the Altona Kiel Railway, his responsability did not extend further than forty per cent.

Saturday, $25^{\text {th }}$ of May 1844. This day was for the greater part taken up with farewell visits. In the morning I went to the police office where I presented the bailiffs who had assisted in discovering the thief who stole my collection of coins with five N. 2/3 or currency marks $9 / 11$. Afterwards I walked out to the second mill where my cousin Nelly had gone for the day in company of her own and some other children. I dined with Sieveking and family and before going 
to bed had a desperate chess mach with Semper; we played for four hours. Railway's shares were quoted as follows: Hamburg-Bergedorff 116 1/2 to 117 1/2, Altona-Kiel 125 1/2, Hamburg-Berlin (hitherto projected, not yet commenced) 128 to 128 1/2. Gluckstadt-Elmshorn 122-122 1/2.

Sunday, $26^{\text {th }}$ of May 1844. (Whit Sunday) I drove to Kramers who celebrated this day the anniversary of their wedding. When I bade them good bye, both kissed me, which token of their affection I would willingly have dispensed with. I called on Herrmann Dryer, Johannes Limpricht and others. From the first named who was in every respect well acquainted with the laws and customs of Hamburg, I learned that the value of all the houses in the town was fixed by certain persons appointed for the purpose by the municipality, and the value was calculated by the rent which actually each house paid, or if inhabited by the owner himself, should have paid if let. The Saving bank was only permitted to lend money on mortgage as far as half the value of the mortgaged building and the interest was three and a half per cent currency on Banco. Money of minors could only be lent on mortgage up to two thirds of the value of the mortgaged building, interest four per cent currency on Banco. The owner of a house who had mortgaged his property up to two thirds of its value, and still required more money, might have to pay five and a half or still a higher interest currency on Banco for the obvious reason that he gave less security to the lender, and consequently had to pay a higher interest. Hamburg levied no transit duty, only an import duty of half per cent and an export duty of one eighth per cent Banco on Banco. Before the great fire, these duties were paid currency on Banco. The loan which the town was obliged to contract after this dreadful disaster amounted to thirty two millions Banco marks at an interest of $31 / 2$ per cent. Whilhelmina Reincke's birth day was celebrated at Semper's. The Children sat at a separate table and huzzaed, lastly when toasts were given it was too cold to remove to the garden after dinner, and thus the smoking room was again [465] resorted to, where we remained an uncommonly long time, for my part I should have preferred the society of Mrs. Theodore Reincke, Mrs. Lawyer Lübbes and others. To please old Mr. Reincke, his son Theodore, Semper and I sat down to Whist with him whilst in the neighbouring room the younger folks sang and played the piano very prettily.

Monday, $27^{\text {th }}$ of May 1844. (Whit Monday). In the course of the forenoon I continued my calls and brought up to the day my mercantile books. I dined with C. H. Donner in his Country seat. The weather was cold and windy, but in his beautiful garden we were well sheltered against the Northern blast. There were but a few friends, and the time passed quickly and pleasantly, the two ladies, Mrs. Bernard Donner and Mrs. Dr. Hayck soon disappeared and we Gentlemen played at cards. 
Tuesday, $28^{\text {th }}$ of May 1844. At last I concluded my farewell visits. Rainville's garden actually looked ruinous, the hill was giving way more and more, in some places perhaps as much as twelve feet. The hotel and other buildings suffered nothing for they stood higher up on hard and solid ground. We dined at two oclock, Semper for my sake had invited Sieveking, wife, and children to join us. I received letters via Panama and England from my wife and from Charles Pflücker dated 23 and 24 of February. Schuttes affairs in Orcopampa looked black, his silver mine yielded but little ore, and both he and his wife were suffering from ill health. The money which I had left in Chile and in Lima was placed (of course on my risk) at a fair interest, say: nine and ten per cent. Henry Reinecke who had died in Guayaquil had in his will appointed me and his wife (Executors testamenti), Spanish (albaceas). My health was drunk amidst the loud cheers of the little ones. Dinner over, a droshka came to the door, I thanked Mrs. Semper for the very friendly reception which she had given me, shook hands with her and Mrs. Siveking, kissed the Children, and accompanied by Semper and Sieveking, drove to the Danish Post-Office in Hamburg, whence the stage coach, called here "Diligence" started for Lübeck at five oclock precisely. [466]

Journey from Altona through part of the Holstein and Schleswig over Alsen, Fühnen, Sealand, to Copenhagen, Christiania, and Trontheim, and back to Altona, from $28^{\text {th }}$ of May 1844 to $24^{\text {th }}$ of August 1844 .

\section{Continuation of}

Tuesday, $28^{\text {th }}$ of May 1844. My fellow passengers were a female neither pretty nor genteel, who left us at Ahrensburg; a Frankfort Gentleman apparently travelling for some mercantile establishment on his way to San Petersburg; a young man whom I soon discovered to be partner of one of the Ganslands of Lübeck, he had seen a good deal of the Northern countries, and now together with a young girl to whom he was engaged, and her mother, a one eyed elderly lady, had spent the Whit holidays in Hamburg. Conversing with them, I learned that in the Kasan church in San Petersburg, many trophies of war are preserved, such as colours and standards taken from the enemy, the keys of the gates of conquered towns, also Davoust Prince of Eckhmühl's Marshal's batoon. The priests of the Greek church called "popes" are allowed to marry, but not a second time should they lose their first wife. We left Hamburg through the Steinthor, drove to the suburb of Saint-George, and reached Wandsbeck (see page 384) at half past five. After some minute's stoppage we drove on; to our right we had a small wood and lake, and continued our journey as far as Ahrensburg through a very flat country; 
some fields were lieing fallow, others under cultivation gave hopes of a fair crop; here and there a farm house, also one or two villages through which we passed. All along the road, which was well kept, stood at a short distance from each other, small white painted stones, numbered from one onward: their object was to prevent the carriages from driving outside the two lines formed by them, so that they must necessarily keep on the high road or "Chaussee". Ahrensburg is three miles distant from Hamburg, and before the door of the post office I noted one of these small stones, with the number 286. Ahrensburg like Wandsbeck has its antiquated castle. On the other side of this town, [_] country quite as flat as before, is more woody. Meanwhile the evening had become fine, the wind had lulled, and the setting sun shed a mellow light over the whole landscape; besides a few villages, also the Estates of some Gentlemen [_] noblemen lay in our way, and by nine oclock (p.m.) we arrived at the town of Oldesloe, six miles from Hamburg where we stopped again ten minutes. [467] It grew dark, I took off my spectacles, settled snugly in one of the corners of the carriage, and soon fell asleep. We passed through the towns of $[\mathrm{H}]$ amberge and Hansfelde, entered the town of Lübeck by the Holstein gate and at eleven oclock precisely concluded this day's journey. From the post office a porter carrying my luggage took me to the "Hotel du Nord" in the "Breiten Strasse" or Broad Street where I was shown to a confortable room. I reperused the letters which I had received from Lima and went to bed. When speaking of miles, German, not English are to be understood.

Wednesday, $29^{\text {th }}$ of May 1844. I rose at six o'clock, hot water for shaving, a cup of coffee with bread and butter, which constitutes the early breakfast all over Germany were brought to my room. I wrote my diary till eight and then ordered a "Lohnbediente" or "Commissionaire" to show me what was worth seeing in the town. These commisionaires are very useful members of Society, and are to be met with in all towns of some importance, on the continent; for the remuneration of a Prussian dollar per day they accompany the stranger over the town, showing the curiosities, and communicating to him all the information which they themselves posses. Of the old fashioned style in which many of the houses in Lübeck are built, I have already given the description (page 377) and shall therefore not add anything to it. The Commisionaire told me that there were ten Churches, viz.: the Dom or Cathedral, St. Mary's, St. Peter's, St. James, St. Egidius, St. Catherine's shut up; one for the Catholics, one for the Calvinists, that of Holy Ghost rather small to which a charitable institution is annexed, and finally that of St. Laurence outside of the Holstein gate. We first directed our steps to the Cathedral. It has at the western end, two pointed steeples which strange to say do not stand straight, but incline towards 
one side, at the Eastern end another steeple of less height. It was originally built in 1170 by Henry the Lion, duke of Saxony, who constructed the western part as far as a spot where now a cross stands, the Eastern half was added at later period. Inside, along the walls of this cathedral, many chapels are constructed, which are nothing but small compartments separated from the aisles, as well as from each other by iron railings similar to such as on my later travels in the South, I saw in Catholic Churches. These chapels served in former times as burial places for noble families, and are filled with marble sarcophagi. The Sexton, a respectable looking old man who soon joined us, informed me that the [468] body is enclosed in a wooden coffin, round which a leaden one, and then the marble sarcophagus. One of these chapels belonged centuries back to the noble family of the Guzman of Spain, and had by inheritance become the property of the Guzman of Altona, who in 1844 derived no other benefit from it but the honor, and the expenses of keeping it in repair. Since 1804 all interments in these Chapels were prohibited, and since 1830 when the cholera raged, this prohibition extended to the entire church. With the Duke Peter of Plöen who was somewhat deranged, the only exception has been made, and he found his last resting place in his ancestral Chapel. The entire floor is covered with tombstones, many of which are adorned with the effigy of the occupant below, and none without his name. This cathedral measures in length four hundred and thirty three feet. The pulpit rests apparently upon a fine Statue of Moses. A handsome painting of Hans Hommeling a disciple of Albert Dürer with the date of 1471 is shown here; it represents the history of Christ's life. The Sexton called my attention to many other curiosities, but though he spoke in a slow and distinct voice, and I listened to him with great attention, when I brought it to paper, I could not recollect anything further than what I have noted. St. Mary's church has a less sombre appearance than the Cathedral; it contains many things worth looking at. There are the pulpit and high altar, both of marble, the large organ, a Chapel called brief Chapel, because in former times valuable papers and documents were deposited in it; in the same stand two granite Columns each cut out of one block, thirty six feet high, further the astronomical clock made in the year 1405 , maker's name unknown. It shows the date of every day in the year for more than a century, say from 1753 to 1875 , also the phases of the moon for the same period; it is adorned with the zodiac and other astronomical circles. When the clock strikes twelve, twelve figures representing the apostles step-out of a door, make their reverence to our Lord Jesus Christ with the exception of Judas Iscariot who shakes his head, and then walk out of another door. One of the most interesting objects in this Church is a chapel, round the walls of which is painted the "death's dance," the dance commences with a figure of death playing the flute; next, death carrying a 
coffin and leading the pope by the Hand; death follows the Emperor, death again, the Empress, and so on; the representations of the different stations of life; a figure of death between each two, down to the Virgin and the baby in the cradle whilst death carrying [...] in his hand closes the dance. The great merit of this painting is that though the figure of death appears over and over again, it is painted every time [469] in a different atitude. The painter's name is unknown, it is not Holbein who was born in 1495, and the Painting was finished probably in the year 1463 . Originally a verse in low German, appropriate and quaint, was written below each figure, however in the course of time, the verses became not only illegible but unintelligible, and thus in 1701 they were replaced by verses in high German. At the time I bought a small pamphlet giving the particulars of this painting, but unfortunately now in 1869 I cannot find it amongst my papers. In the charitable institution close to the Holy Ghost church in 1844 one hundred and thirty six poor of both sexes were comfortably housed and maintained, each had a small wooden cabin for him or herself, and a large saloon heated in winter, was for the use of all. A large room which went by the name of the Merchant's company answered I suppose the object of the exchange of other commercial towns, for it was here as my commissionnaire told me, that the merchants were in the habit of meeting. It is adorned with very curious workmanship in carved wood representing various passages taken from the Bible. Lübeck once the renowned head of the Hanseatic league has lost much in importance; its two rivals, Bremen and Hamburg, have left it far behind in wealth, size, and population. It is surrounded by a wall which however like that of Hamburg, has been converted since the peace of 1815 into a pleasant promenade. Four gates lead out of the town; the first, the Mühlen thor which looks towards Ratzeburg, the second the Holstein Thor, two bridges, one over the ditch which encircles the whole town, the other over the trave lead to this gate, which in 1844 consisted of two heavy solid vaults, under which one has to pass before entering the town. Vessels come up the trave as far as this bridge, whilst under its arches only boats can pass higher up the river. Outside of this gate is the Schnekenberg, a hill of small height, round which a path winds up to the top. I ascended it, and had thence a pretty view over the surrounding country, which when first seen by me in its wintry garb (page 373) pleased me, how much more now when in the merry month of May, nature had put on its holiday dress. The third gate is the Burg-thor, and the fourth the Hüxter thor. Lübeck is situated at the junction of several small rivers with the Trave, as will be seen by the sketch herewith. The Trave on the left side of which Lübeck lies, takes its origin in the Warder-lake, close to Segeberg, passes this town, Oldesloe and Lübeck, and throws itself into the Baltic near Travemünde. The Wakenitz comes from the Ratzeburg lake, 
passes [470] Hornsdorf, and unites its waters with those of the Trave close to Lübeck near the Dankwark bridge. The Stecknitz joins the Trave with the Elbe a canal commences at Lauenburg on the latter river, and forms its junction with the Stecknitz near Alt-Möllen, and this river disembogues itself into the trave near the Holstein gate. The third affluent is the Schwarta[u] which comes due North from the Barkauher lake close to Ottendorf, and falls into the Trave below Lübeck.

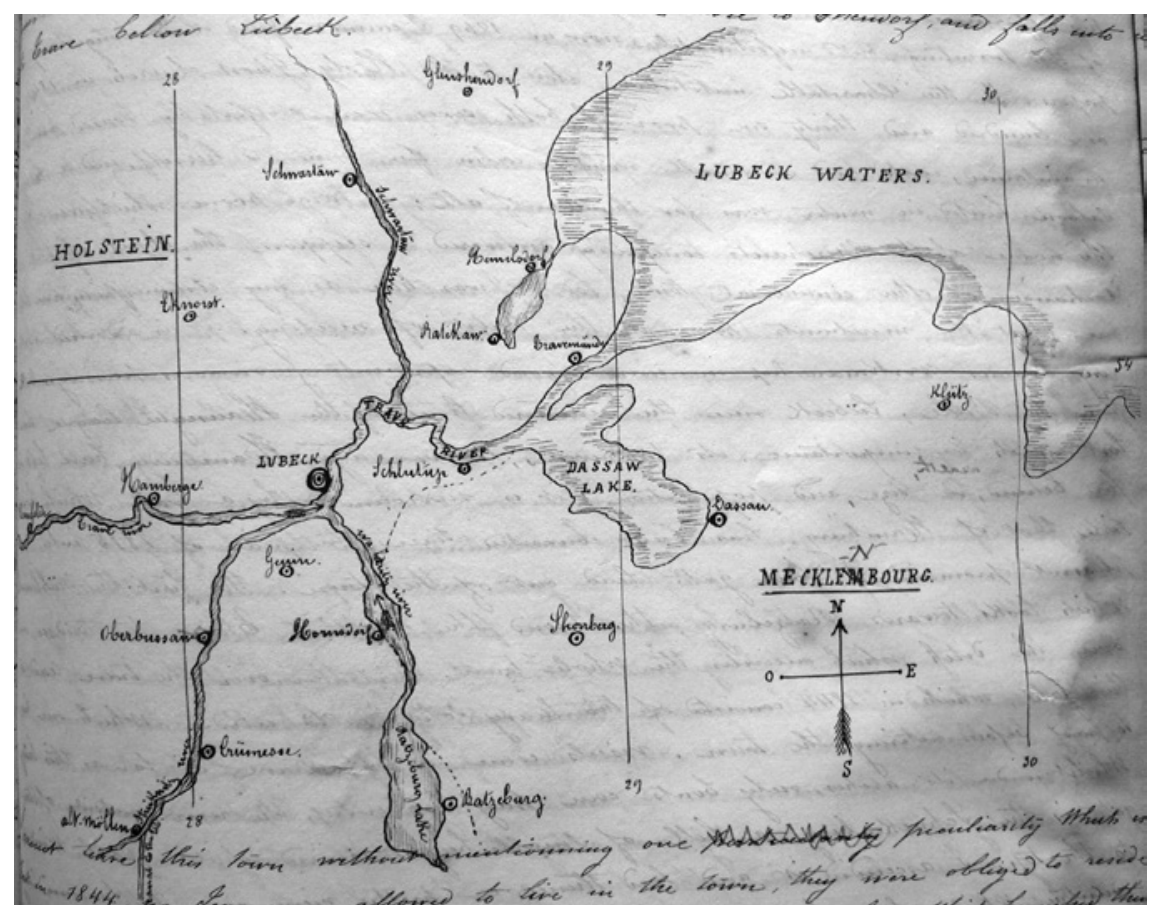

I cannot leave this town without mentioning one peculiarity which is that in 1844, no Jews were allowed to live in the town, they were obliged to reside in the village of Meisling not far distant. In 1855, the law which banished them thither was still in force; whether it exists still in 1869, I cannot tell. Towards two oclock I left Lübeck in a comfortable carriage which cost me no more than one mark eight Shillings currency, and drove to Travemünde a bathing place much frequented in the summer season, two miles distant. I left the town through the Burg-Thor, a heavy vaulted structure of strong masonry, like the two at the Holstein Gate, crossed the Wakenitz, passed the churchyard prettily adorned with trees and shrubs, and continuing my way through a [471] dense wood, reached the bank of the trave where it had formed a wide basin, the waves of which were stirred-up by the strong wind. I was ferried over without alighting from the carriage. Thence forward the country, flat with few trees, 
was rich with waving cornfields; a considerable village Schlutup I saw at some distance to my right, and Travemünde itself when it first came into sight with its steeples and red roofed houses presented a smiling aspect. a fair was being held, the streets were crowded, shoes and boots were the most prominent articles exposed for sale. In the bay, few vessels were at anchor, amongst them a Swedish and a Russian Steamer, the latter just arrived from San Petersburg with many high personnages on board. A row of houses, nearly all hotels, at the first of which I stopped, stands close to the sea-shore, in front of them an avenue of trees. Whilst my dinner was getting ready, I walked along a solid quay built of blocks of stone held together by massive iron cramps. I passed a Telegraph, a light house, and a signal staff, and having reached the utmost point, turned round the corner, and came to Behrens-Bathing Hotels, extensive and well kept buildings, surrounded with pleasure grounds indispensable during the season for the amusement and recreation of the bathers; all was as yet shut up for seldom strangers come to Travemünde for the luxury of bathing before the month of June. After a good and cheap dinner, I started for Eutin in a Stuhlwagen drawn by one horse. For some time we drove through sandy cross roads all hedged in as it is the custom in the whole of Holstein until we reached the Chaussée or turn-pike road from Lübeck to Eutin near the village of Ratkau, but as it was under repair by order of the Danish authorities, we could not remain on it, and had again to betake ourselves to badly kept country roads. The country was altogether uninteresting; the driver lost the way more than once, the horse got tired, I suffered a little from the cold notwithstanding being wrapped up in my big cloak, but at last arrived at about nine oclock in Eutin, where I alighted at my brother in law Johannes Limpricht's who received me in the most friendly manner imaginable. I took a few cups of tea, conversed a little, and hastened to bed.

Thursday, $30^{\text {th }}$ of May 1844. The country in the neighbourhood of Eutin as well as the entire North Eastern corner of Holstein is rich in lakes and woods which form the main features of the many pretty landscapes which meet the tourist's eye at every turn. Bobertag, though a native of Silesia had however lived here long [472] enough to have become p [?] the Natural beauties of the country of his adoption, and he felt a pleasure in pointing out to me every spot and prospect, which he thought I might like well. Accordingly, this day the weather being fine though the wind blew cold from the North East, we started soon after breakfast from his house, the very first in the town when entering from the Lubeck road, the second was that of his father in law; in front the park belonging to the ugly Ducal mansion spoken of page 374. On first leaving the town, we walked for a short time westward to the little Eutin Lake, then more or less retracing our steps, we ascended a small tower built in the centre of his 
garden by a wealthy Dyer, from the summit we saw the fine country around lying below us, panorama like, to the South quite in the foreground Eutin itself with its one steepled church, to the southwest the small Eutin lake whence some level ground brought us to the village of Neudorf, the Majenfelde-mill, and the village of Quisdorf due West, continuing in the same direction we soon reached the pretty Bentin wood more than two miles in extent, the space between the same and where we stood was occupied by a woody and hilly country, thatched and tiled houses peeping through here and there. In the North west the new mill forms a pretty "point de vue", before it the Jägerhof, or Hunter's farm, behind the Princes wood encircling the Keller lake, a small part of which could be seen. Due North lies the village of Fissaw, to the North East, the N. Western extremity of the large Eutin lake, on the other side of which the Oxen and Fir-wood draws Eastward, to the S. East the Pulverbeck wood, and finally the Pheasants islands in the lake take us back to Eutin and close the circle. Having satiated our sight we descended and continued our walk, passed the New mill, skirted the northern bank of the Keller lake, rested at a fisher's hut whence another fine prospect presented itself, across the lake to the village of Sielbeck; in another direction some distance off, the town of Plöen with three steeples, also the Grem's-mill between the Keller lake to the west, and the Diek lake to the East, the malente wood and the village of Malente which enjoys a certain reputation, the poet Voss having laid there the scene of his poem "Louisa"; behind Malente, Neversfeld, then cultivated fields until some woods confined the horizon. We returned through the princes wood, south of the Keller lake, to Fissaw where we rested and took some refreshments, started afresh and going here and there out of the way when Bobertag had to point out to me something or other, which he imagined might please me, we reached Eutin a little after three oclock. In the College he showed me the library and when we had come [473] home, we sat down to dinner. At [_] p.m. we went to the Clergyman Müller's where we met several friends of his, whom I should not wonder he had invited to do me honor. With the exception of Bobertag and Elisabeth, all were titled persons, for in Germany the ridiculous custom prevails that the [_] of titled persons are addressed in the same manner, the syllable "inn" being added to the husband's title. This "inn" answers to the English "ess", but with how difference that the genius of the former language permits the addition of this syllable to any title such as "Colonel", "Lieutenant", "court architect", "Professor", etc., whilst the English idiom allows the "Ess" to be added to certain names only, for instance: "Princess", "shepherdess" and others, but not "General" "Doctor" etc. The names of the Guests were: Reverend M. Müller a native of Bremen, his lady from the neighbourhood of Rizebüttel, Lieutenant Colonel Frisius and his lady, Mrs. Professor Meyer from the Duchy of Saxony, 
a noble Miss von Schleiden, a Mr. Auditor, a Mr. Secretary, two insignificant girls, Limpricht and wife, Bobertag and wife, and myself. The Supper was to be sure substantial and abundant; we had fish, roast, veal and potatoas, salad and preserves; for Desert a cake, crawfish, sweetmeats, bread, butter and Cheese. The wine, Bordeaux was not of the very best quality. By and bye the Gentlemen took out their cigars, both ladies and Gentlemen sang, forfeits were played, all were merry, and it was one oclock when we separated. I must say that upon the whole all were pleasant people, perhaps they were without the highest polish of the most refined aristocratic society, yet none was without good breed, and it was easily to be perceived that with one or two exceptions they had had a good education and learned something. The Lieutenant Colonel told me that the Duchy of Oldenburg to which Eutin belonged, and the Kingdom of Hanovre had not yet joined the German custom-house league. For the army of the confederation, Oldenburg and Eutin had to furnish three thousand men, the three Hanseatic towns two thousand in all: five thousand under an Oldenburg General formed a brigade. How all this is changed now in 1869!

Friday, $3^{s^{s t}}$ of May 1844 . Fortunately for me the vacations of Whitsuntide lasted the entire week, thus Bobertag freed from his professional duties could devote himself to me, and accordingly this day at ten oclock we again set off on an excursion on foot, first to Fissau, then over a rather sandy plain to the village of Sielbeck which lies to the North East, a few steps furhter on we entered a beautiful wood consisting principally of tall stately beech [474] trees, which gave a delighful shade, and through them peeped here and there the blue surface of the Ugley lake. On its Eastern extremity, completely surrounded by trees, stands a solitary house the "Forester's house near the white field", we rested here a little, and in the open air took a plain breakfast, black bread, butter and Cheese, half a bottle of white French wine, and so[_] ham for Bobertag, for all which we paid no more than one mark currency. It was a lovely spot. We continued our walk through the wood all round the lake measuring three quarters of a German mile in circumference. Its character especially on such days as this when owing to the quietness of the atmosphere, its glassy mirror was not ruffled by a single wave, is that of perfect tranquillity if not melancholy. The trees reach to the very water's edge and form a complete green leafy wall nowhere broken except on a place where a small white painted balcony named the "Anglers bridge" projects a little over the lake. Here we sat down, and soon were lost in our thoughts, mine took a long flight even to the banks of the Rimac. We started afresh, two small deer crossed our way running fast over the ground, ancle deep, covered with the brown leaves of last Autumn, and soon were hidden between the foliage. A very short ascent brought us to a small height on the summit of which stood the hunter's mill. Now we had at our feet 
the great expanse of the Keller lake, at its western end the Grems-mill, and at some distance the prince's wood where we had been on the previous day. We kept the Northern side of the Keller lake, along a shadeless road, and came to the Village of Malente; close by is a small hill with some new plantations still in their infancy. However each height in this neighbourghood affords some fine prospect or other, and this made no exception to the rule. By three p.m., over some woody grounds, we reached Grem's mill lying on a brook which unites the two lakes of Keller and Dieck's. Here we were joined by Limpricht, his wife, Elisabeth, Johannes and little Hans, who had come out thither on a Stuhlwagen. Some refreshments were taken in an inn, I contenting myself with three glasses of buttermilk. This inn was built in a kind of gully between two heights, on the one side the Mill-Berg, on the other the Barn-Berg. On the former we sat down for some time; to the South East the Bentin Wood was clearly distinguishable, thence a little to the left, a gay looking house with red tiles which went by the name "on the Red Sand", the Princes wood, the Keller lake, the hunters pavillion, the sandy road to the North which Bobertag and I had just walked over, and then immediately before us the mill buildings, behind [475] which the Barn-Berg, and part of the Diek lake; at some distance Westward, the three steeples of Plöen, and finally to the South West the Kreutzfeld wood. We walked about here and there, paid a visit to the Bahnberg and drove home at about seven o'clock. We then took a light supper, and I retired to rest at half past nine; it was not yet completely dark.

Saturday, ${ }^{\text {st }}$ of June 1844. I passed this day in a very quiet manner; I paid a visit to Mrs. Tramm and her two sisters Nancy and Betsy whom I mentioned page 374, when I was last in Eutin. With Bobertag I took a walk through the Ducal park, dined at his house with his father and mother in law, and conversed on many topics of greater or less interest till ten oclock, when it was time to go to bed. Elisabeth had everything prettily and neatly arranged in her house, though necessarily on an economical plan. Though I cannot entirely agree with the "Holstein Tourist", a book to which I refer occasionally, in the praises which it lavishes on the natural beauties of the park, yet I do not deny that its fine trees, its long avenues, the pavilion, the cottage, etc. pleased me now in the Summer Season, far better better than they had done at the time of my previous visits to Eutin in the winter of 1823 and again in the winter of 1844 . But when the same author raises his voice in defence of the Ducal mansion called a castle, then I must put in my protest, for nothing can be more ugly that this irregular pile, not a single wall stands in a straight line. Symmetry is not thought of, and the small glass windows in leaden frames are fit for a poor peasant's cottage, not for a Ducal residence. The tourist entered Eutin from the same side as Bobertag and I did on the $30^{\text {th }}$ of May, and expresses himself on the following terms 
(See in appendix $\mathrm{N}^{\circ}$ 12A) from "on approaching", as far as "Burghers' dwellings". This is all very well as far as it goes, except the bürgher dwelling's, some of which looked far from respectable, on the contrary, they were not much better than miserable huts.

Sunday, $2^{\text {nd }}$ of June 1844. At half past six oclock in the morning, Limpricht and his wife, Bobertag with Elisabeth and myself left Eutin for Plöen and its environs. Our conveyance was a Stuhlwagen drawn by two strong horses. We were provided with cloaks and great coats for the morning was cloudy. However the sky soon cleared up, and we had fine weather all day. We drove through the villages of Neudorff, Quisdorf, and Mayenfelde, over a well kept road confined by the customary hedges on both sides. We alighted at the village of Bosau still within the Duchy of Eutin lying so close to the lake that [476] the churchyard is washed by its very waters. Whilst the boat was getting ready to carry us across the lake, we amused ourselves with deciphering the inscriptions on the tombstones, many of them of very ancient dates, with which the Church yard is filled. There are no stately monuments, all are low and humble memorials of those who sleep below. A stone was shown to us which, tradition says, had been used as a baptismal font more likely as an altar many centuries back about the time when the holy Vicelin introduced Christianity into this country, inhabited I need hardly say by the Wenden a fierce Pagan nation. Henry the Lion granted the village of Bossau to the holy man after he had become Bishop of Oldemburg, in 1149 he built the church which still exists, constructed of big stones and mortar. Vicelin's disciple Helmold who wrote a history of Holstein resided likewise in this village as curate. The boat in which we embarked though small for it could carry no more than forty tons of Corn weighing each $224 \mathrm{lbs}$ had two masts with their corresponding sails, one man rowed, the other was at the helm. The passage across lasted three quarters of an hour. The Castle of Plöen on a small height formed the most prominent part of the landscape. When approaching the opposite, the Holstein side we were struck with the fine Groups of tall trees along the shore, they belonged to the estate of Nehmten, the property of Mr. Von Kronstern, where we landed, and walking about in the park, we were much pleased with the fine broad walks, with the towering trees, with the good order in which every thing was kept. The dwelling house was a plain extensive building, wooden stairs led up to it from the garden; we ascended and enjoyed hence a very pretty prospect of the trees which lined the lake, just sufficient had been cut away to leave an opening or "Vista" opposite to which the steeples of Plöen as if placed in a frame work were visible. Turning the eye in a different direction, there was the Plöen castle, the intervening space was filled-up with a handsome grass plot, a small sheet of water, a large meadow, and the expanse of the lake. Bobertag, Elizabeth, and I rambled about 
at our leisure through this beautiful property, and came to a large square formed by the dwelling house and other buildings such as: the Barns, the Granaries, the Stables, and cow houses, in the centre grew two fine rows of Linden trees, thus . Meanwhile the carriage had come round the lake by land, we all remounted, and continued our way over a country road, sandy, hedged [477] on both sides, and planted with young fir trees. To the left, we had an occasionnal glimpse of the Stöck lake, passed through the pretty large village of Gliesdorf, and reached the Estate of As[_] which belonged to the count of Ahlfeld, formerly to the noble family of the Rantzaw. We alighted at an inn where we had to wait full an hour for a poor dinner, buttermilk, a few good pancakes, bad veal chops and a bottle of abominable wine. Aschberg was not kept in such an excellent order as Nehmten, nor were the walks as broad and cleanly swept, but the trees, oaks and beeches quite as stately as those on the neighbouring estate. In Aschberg a shady avenue ran along the borders of the lake, thence another to the dwelling house, and a third from the dwelling house to the park gate. In the last mentioned a number of peasants in their holiday dresses on horseback, their hats and horses adorned with flowers were running a match for a ring hung-up on a cord stretched across the road. They did the best they could, but instead of coming on at full gallop, they were hardly able to put their horses to a counter. If I may believe the Holstein tourist, as many as twenty villages belonged to this Estate. We left Ashberg at four oclock (p.m.), to the right we had the Plöen lake, to the left a dense wood, before us a little to the left the town and castle of Plöen surrounded by woody heights, somewhat to the right a few white spots were discernible, they were the houses belonging to the estate of Ruhleben ("quiet-life") owned by Messrs. Parish, merchants of Hamburg. We now crossed the lake over a natural causeway which divides the same in two parts, the large and the small Ploen lake; two small brooks which unite them are famous for their fat eels. We alighted at a "Schloss Garten" which similar to those already described is rich in tall trees and shady walks; hence we went to the terrace before the castle in front of which lies the large lake. Walking around the building, we had a different view, just below and before us lay the town of Plöen with hilly gardens to the left and behind the town, the small lake surrounded by green meadows. The Ducal mansion looked somewhat better that it had done when I saw it in January last, it can never be a handsome edifice but at all events some improvements had been made, it was stuccoed all over, and the small window panes were gradually making way for large ones. It is two stories high, besides the ground floor, seven gable-ends, a window in each, constitute the finishing ornament of the roof, five on the main pile, one on each wing. [478] The carriage waited for us in the market place, we remounted, but got off again 
when we were outside of the town, in the public garden of a certain Lange; the [_] was to take a cup of Coffee, the real object, to ascend a small height within the precincts of the garden whence the prospect surpassed all we had seen during the day. Here was nothing grand or sublime, there were no large rivers, no towering mountains, no brawling torrents, no thundering cataracts, the whole landscape wore the impress of a smiling and peaceful tranquillity. Towards the North the view was impeded by an eminence higher than the station which we occupied, commencing then to the North East the eye rests first upon a small lake, the Schön lake divided by a narrow itshmus from the Keller lake between which and the Diek lake called by our landlord [_], the Grem's mill was just distinguishable, from this lake, a continuation of woods extends behind the Plöen lake lying to the South of us; succeed Ruhleben, Bossaw, the sandy plain to Nehmsten, Aschberg, the buildings of these two estates partly concealed by the thick foliage, a small hill called the Parnassus, and finally Plöen itself; an islet in the Plöen lake, and a pavilion at the extremity of a peninsula stretching into its waters must not be omitted to be mentioned. In the West and North West, more small lakes can be seen, through which the Swentin winds its course to the Lanker lake, thence to the Kiel Bay. A strange echo was pointed out to us. I placed myself near the house and halloaed against the hill where we had stood; the sound returned not directly to me but obliquely to another spot some yards distant, where it was clearly heard by a person that stood there. The girl who attended us in Lange's garden was a native of the Probstei, a fertile tract of land extending East of the Kiel Bay along the Baltic. Thither if I mistake not one of the ancient Dukes of Holstein transplanted a colony of industrious Dutchmen who carried with them not only their careful cultivation of the soil, but also their particular dress which the Probstei people have preserved to this very day. The girl was clad in this peculiar manner, but as I expected to see more of these people in my travels through Holstein I did not take any note of it, which I much regret, for I saw none of them afterwards. We remounted our carriage for the last time, and returned to Eutin where we arrived after nine Oclock. The second son of Limpricht, Henry, had just returned from a pedestrian excursion to Segeberg. In my portfolio of engravings will be found one of the Ugley lake, one of Grem's mill, and a third from [479] the prospect of Lange's garden.

Monday, $3^{\text {rd }}$ of June 1844. The College was reopened. Bobertag had to attend to his duties as teacher, Johannes and Henry [_] as pupils. I dined with the three sisters Willink; Nancy, carried on the conversation, I may say exclusively, her two sisters hardly venturing to put in a word so completely had she established her dominion over them. For the evening Limpricht had invited a few friends. Mrs. Limpricht, a busy and thrifty house wife, arranged everything 
very nicely. The lady of highest rank who made her appearance was the "Geheime Räthi[?]" (Secret Counseller a very high title of the many which the King of Denmark was in the habit of granting), Mrs. von Prangen; at supper I had the seat of honor at the head of the table between her and Mrs. Müller, the Clergyman's wife; besides these, there were present Reverend Mr. Müller, Miss Lindemann and brother, an elderly spinster, name unknown, a Miss Encke also of a certain age who gained her livelihood by teaching piano and singing, a Lieutenant Von Holstein, the Mr. Secretary whom I had seen the other day at Mr. Müller, Bobertag and Elizabeth. After tea had been handed round some of the Gentlemen took out their cigars. Then after a good deal of general conversation, a game of forfeits in which all took their share was played, which though not particularly interesting made the time pass pleasantly enough till supper was ready. When Mrs. Müller gave the health of each of the party in "extempore" rhymes which were sung by all present to the one or the other well known popular tune, this was very clever and amusing. We separated after one oclock. The table service was the same which had once been the proprety of my parents. It was white with a pretty border of green flowers, at the death of my mother it was divided between my two sisters. The half of my sister Betty was smashed to pieces someday when the shelf upon which it stood, gave way. My sister Maria's half was sold at her death when Limpricht bought it in, and in 1863 it was still in the possession of Elizabeth. I also found several engravings from my parents' houses in Limpricht's rooms; one representing the human soul under a figure of an eathereal body wafted heavenwards, below the words

"O death where is thy sting?

O grave where is thy victory!"

two engravings representing well known scenes from Shakespeare plays viz: the one, the last in Romeo and Juliet. When Juliet in the vault [480] has not yet recovered from her lethargy, Romeo has emptied the phial with poison, and the friar descends the steps, a lantern in his hand; the other, King Lear [...] of his slain daughter Cordelia lieing before him frantic, tearing his hair, below these words:

"Howl, Howl, Howl, Howl,

$\mathrm{Oh}$ ! ye are men of Stones.

Had I your eyes and tongues,

I'd use them so,

that heaven's vault should crack.

Oh She's gone for ever!"

The two last engravings published probably at the time when the question for the abolishing of slavery was first mooted in the British Parliament, represented the cruelties committed by white people on the unhappy negroes. 
In both, Limpricht's and Bobertag's houses, paintings by my two sisters adorned the walls of the rooms. Here follow a few items of some interest, Jaques Lafitte the well known French Banker who it may be said put Louis Philippe on the throne of France died in Paris at the age of 77 years. Both the Emperor of Russia and the King of Saxony were on their way to pay a visit to the queen of England, whilst the crown Prince of Denmark who afterwards became King under the name of Fredrick VII was enjoying himself on a trip to Scotland. Crockford the notorious owner of one of the hells in St. James, London is dead, and gone to where he is to give an account of his actions in this sublunary world.

Tuesday, $4^{\text {th }}$ of June 1844 . I made my preparations for my departure on the following day, my intention being to travel on foot, first to Hermann Willink's farm near Lutjembürg and thence to Kiel to which place I forwarded my trunk by post. To the reverend Mr. Müller and Lady, very agreeable people I paid my farewell visit. Bobertag, a great friend of natural sciences showed me his Physical apparatus in the college, and made several pretty experiments. The North magnetic pole is ascertained to be situated in latitude seventy and longitude one hundred West from Paris. The whole family supped at Limpricht's where I had much to relate and many questions to answer relative to Peru, the West coast and my family. [481]

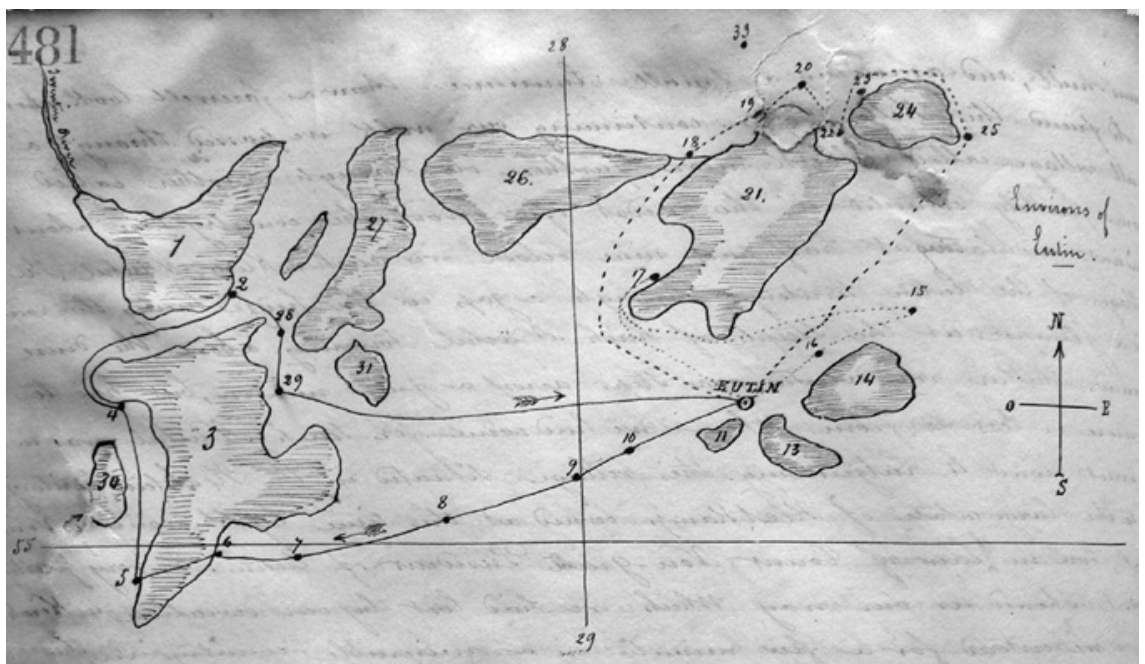

1. Small Ploen Lake

2. Town of Plöen

3. Large Plöen Lake

4. Estate of Aschberg

5. Estate of Nehmten

6. Village of Bossaw

7. Village of Small Neudorf
8. Village of Thürck 9. Village of Quisdorff 10. Village of Neudorf 11. Small Eutin Lake 12. Town of Eutin 13. Large Eutin Lake 14. Sielberdof Lake 
15. Village of Sielbeck

16. Village of Fissaw

17. House (am Rathen Sand)

18. Grem's mill

19. Village of Malente

20. Village of Krummensen

21. Keller lake

22. Small village of Gremsmüllen

23. anglers bridge

24. Ugley lake

Walk on $30^{\text {th }}$ May ...... Drive on $2^{\text {nd }}$ of June

Wednesday, $5^{\text {th }}$ of June 1844 . I bade good by to my kind relations, and at eight oclock started on foot accompanied by my guide a very decent fellow who spoke high German, called Becher; he carried a small bundle with some clean linen and the necesary brushes, also my big cloak. I myself, stick in hand wore my Liverpool made great coat [yclept], "wrap rascal". Our destination was Lutjemburg due north from Eutin. The weather was pretty fair, the sky cloudy, and looked as if it were going to rain. We passed the Keller lake the waters of which were so violently stirred up by the wind as to give some idea of the Ocean. We walked through Sielbeck, could descry [482] the Grems-mill, and ascending a small Eminence threw a farewell look upon our old friend the Keller lake. Continuing our walk we passed through a small village called [Sell] book-moor, further on through another called Kibitzhorn prettily situated in the midst of a wood. The country here about is somewhat undulating, at half past nine oclock we reached Klein-Nüchel, the low village of the Eutin territory, through a gap in the hedge lining the road we had a glimpse at the steeple of Kirch-Nüchel towering above the dense wood around. Thither we directed our steps across a green meadow, but had to return more or less to from where we had come for Kirch-Nüchel was not in the direct road to Lutjemburg. This village situated in the Holstein territory belongs to the large estate of Klet Kamp owned at the time by the Count Von Brockdorf, son in law of Count Vongrate, President of Eutin. A very pretty young girl showed us our way which we had lost by our deviation to Kirch-Nüchel; we entered for a few minutes a miserable country inn, the room to which we were shown was not boarded, but bricked, it was filled with beds, and the landlord was shaving; my guide took a dram, I a tumbler of buttermilk. We ascended a low hill, whence on a clear day a large extent of the surrounding country with the steeples of Lübeck, Eutin, and Plöen is visible, this day the atmosphere was so hazy that we could only see the steeple of the last named place as well as a tower town built on the shore of the Baltic which served as a land-mark for such vessels as are bound 
for the port of Neustadt, a place which does a considerable trade in all descriptions of grain. I may observe that all the church steeples which I had seen in this part of Holstein taper into a point, whilst those which I noted in England on my drive from Penzance to London are square-built, and truncated; the latter have a more solid, the former, a more elegant appearance. Close to the Kirch-Nüchel church, the Von Brockdorfs have erected a small chapel to serve as their family burial place. Our road led sometimes over the land belonging to Klet Kamp, sometimes over that of the estate of Helmsdorf owned by Mr. von B[_]ald. We then came to the village of Flehm, further on we had to our left the Sand-Krug or "Sand Public house", and to the right the steeple of the mansion of Klet Kamp, whither two extremely well kept roads turned off from the high road. The next village on our way was Högsdorf forming part of the estate of Helmsdorf which extends nearly as far as Lutjemburg itself. The road ascends a little. It was now about one oclock, the sun came out and to [483] the right the eye swept over rich cornfields intersected by green hedges with a sheet of water, no doubt a bay formed by the Baltic at the verge of the horizon. It was a quarter to two oclock when [_] arrived at Lutjemburg where we entered a public house to rest a little. We took some raw ham, bread, butter and cheese, my guide a tumbler of beer, I one with butter milk. After half an hour we started afresh, crossed the market place and just outside of the town found many people occupied with putting up a high pole. On inquiry we learned that as it is the custom in the North of Germany a wooden bird was to be placed on the top, at which the country people were to try their skill shooting with cross bows. Half an hour's further walk brought us to the farm of Frederickshof which my relation Hermann Willink had rented for the Landgrave Von Hessen. At the first view it made an agreeable impression upon me, the dwelling house was not large, but had a comfortable appearance, consisting merely of the ground floor with a few windows in the roof, in front a row of lime trees, opposite a large stable, between the two buildings a well kept grass plot, on each side of which, so as to complete the quadrangle, the granary and cow houses in this manner had expected gave me the most and took me to his snug sitting . Herrmann as I

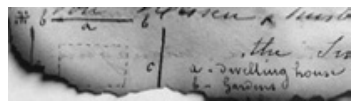
hearty welcome room; the floor was boarded, not carpeted, the walls were papered and the furniture, sofa, table, chairs, cupboard etc. though not of mahogany were neatly made of varnished common wood. After having rested a few minutes, he showed me to my bedroom where I had to clean myself thoroughly, for I was dust all over. We then strolled out together first to a small eminence close by, called the "Pielsberg" upon the summit of which the Landgrave Von Hessen who is the owner of the large estate of Panker of which the farm of Fredrickshoff is a part, 
has constructed a building which goes by the name of Hessenstein, it is of an octagon shape, below a comfortable room with stained windows, upon the same a tower of considerable height. To the platform on the top a stair case of a hundred steps leads, which of course we ascended, and had thence a very extensive prospect over woods and lakes, over greenfields and hedges, over windmills, villages, and the Baltic at the distance. The Landgrave Von Hessen was son of Luisa sister of Christian VII King of Denmark and of Prince Charles von Hessen, a descendant of Prince von Hessenstein who was an illegitimate son of Frederic Prince of Hessen, husband of Princess Ulrica who succeeded Charles XII on the Swedish throne. The Prince of Hessenstein purchased [484] various estates which jointly form the estate of Panker on which the present Landgrave, Danish field marshal, born in 1771 resided. He had at the time an annual income of $\$ 60,000$ of 3 CM each, say: $\$ 20,000$ as Danish Prince, 20,000 as Hessian Prince, and 20,000 from his estates. We descended and entered a garden or park which belongs to the castle of Panker. Close by the father of the present Landgrave had erected a monument in honor of the founder, the Prince of Hessenstein of whom a handsome alabaster statue stood in the already mentioned Octagon room. We sat down on this monument, and then walked home. The evening was delightful; on a bench before the house Herman and I took tea - we conversed on thousands of subjects, and at half past ten went to bed, I rather fatigued I confess. Hermann was an agreeable man, well educated and well instructed; it was a great pity that he had a slight impediment in his speach. He told me that he paid for his farm an annual rent of $\$ 1400$ besides 40 odd dollars yearly taxes, and was obliged to keep everything about the farm in good repair.

Thursday, $6^{\text {th }}$ of June 1844. The slender stem of a vine which grew outside of the house, was introduced into my room through a small hole made in a window frame and its leaves covered the entire inside of the window which looked very pretty. The weather continued splendid; at all events for a tourist like myself, but the farmers began to complain of the want of rain for they were apprehensive that the dryness which they had experienced for some time might destroy the young corn. When my host came in from his daily avocations, he invited me to walk with him as far as the neighbouring estate of Clamp which as well as Schmoël, both owned by the landgrave, were rented by a Hamburgher called Trümmer. Hoenfelde is the name of the fourth estate belonging to the Landgrave. It was a very pleasant walk through cornfields and woods which latter are in this vicinity quite as plentiful as about Eutin. About half way we sat down on a rustic bench with the extensive view before us; to the North East and North West, we saw the Selenter lake, next to that of Plöen the largest in Holstein, the Estate of Neuhaus, the property of Count von 
Hahn, the Villages of Giekau and Emkendorf, situated in a rich well cultivated and somewhat hilly country. At the verge of the horizon we could distinguish the waters of the Kiel bay. Mr. Trümmer was a well educated man, not so two other gentlemen whom he employed in the management [485] of the estate. At noon, we took pot luck with him, broth with forced meat dumplings, fried fish, potatoes, butter, and a bottle of French wine; Hamburg papers were lying about from which I learned various news which will be found further down. We remained a considerable while, then returned home and before taking tea Willink showed me all over his farm, and communicated to me many particulars relative to farming, some of which I immediately noted down. He was in the habit of cultivating his farm in the following rotation: the first year a field lies fallow, the second wheat or rye is grown, the $3^{\text {rd }}$ year Barley, fourth and fifth Oats, the sixth, seventh and eight grass, the ninth it lies fallow again. Wheat and Rye are sown in this neighbourhood in the month of September and are called winter corn; all other descriptions of grain with the exception of Rape seed, likewise beans, pease, potatoes are sown in Spring, say in march; thus Barley and oats are summer corn, rape seed is sown both in Winter and Summer and goes accordingly by both names. This seed requires the richest soil and exhausts the strenght of the ground to such a degree that I have heard of land owners who prohibited their farmers from cultivating this grain. To sow a "tonne" of land with rapeseed, only $1 / 32$ parts of a tonne of seed is required, and it usually produces ten tonne, in extraordinary years twenty, consequently it gives 320 and even 640 fold. Rapeseed is enclosed in a pod whilst other grains are not, and these latter give usually no more than eight or ten fold. The first crop in the year is that of grass, made into hay about the month of June, the last, that of Potatoes in the month of October. The tonne is a measure which is of different weight, viz.: Pease 240, Wheat 230, Rye 200, Barley 190, oats $150 \mathrm{lbs}$ Holstein weight. The Hamburg Tonne is a trifle larger than the Holstein. When I was with Willink the prices of a tonne placed in Lutjemburg were: Wheat ten, Rye eight, Barley seven, and Oats five mark currency. The Tonne is likewise a measure of land, it is equal to 240 squares "Rutten" or "roods", the rood equal to sixteen feet. An estate consists of farms, villages, woods and lakes; the lakes and fields are let to the farmers, the woods and the game, the owner of the Estate preserve for his own use. When the houses in the villages and a piece of land belonging to each house which is called the "Huffe", are let to the villagers, those villagers are called sometimes "[Huffner]". The huffe varies in size, here abouts it measures sixty tonne more or less. The labourers on the fields received for three months in the year seven Shillings currency daily, other three months eight, and again nine, and even twelve [486] according to the length of the day and the work to be done, making an average of about nine Shillings daily, all 
the year round; they must find themselves. On the other hand the overseer of the farm, and he, whose business is to attend to and take care of the horses, are better remunerated, and are found by their employers; Willink paid his forty Dollars currency each annually. The dairy contributed considerably to Willink's yearly income; he kept it very neat and clean, particularly the tubs painted red in which the milk was preserved, he had ninety cows, two bulls, only ten calves, at present all the cattle was kept night and day in the fields. The cows were milked twice a day and gave about three hundred bottles of milk each time. The cream is made into butter, the milk into cheese worth from one and a half to three shillings currency a pound. The butter Willink sent for sale to Mr. George Knauer of Altona who charged him no comission, and paid him the proceeds annually in the first days of January; at the Kiel "Umschlag" (see page 367 ) the price of butter in altona varied from seven to nine Schillings per pound. Willink also grew on his farm flax and hemp, both which were spun in the Winter season by his female servants who in the Summer attended to the dairy. The flax was woven into what is called home made linen, by small wavers of the vicinity who then returned the linen to Willinck. The hemp was spun in Lutjemburg into rope of different thickness. The garden abounded in all kinds of fruit, strawberries, goose-berries, currants etc., etc., even the pig stye I was shown to. Its grunting inmates, when sufficiently big and fat were like every thing on the farm converted into money. The prices of eggs ranged between three to seven [_] two Shillings currency. Remains to be noted the news which I had gathered from the Hamburg newspapers. On the thirtieth of May the court of queen's bench in Dublin found guilty Daniel O'connel and his gang. O'connel himself was condemned to twelve months imprisonment and to a fine of one thousand pounds sterling, moreover he had to give bail for keeping the peace for seven years, he himself for five thousand pounds, and two other persons for two thousand five hundred jointly; his accomplices to be imprisonned for nine months each, fined $£$ fifty, and to give bail each for himself for one thousand pounds, and two other persons for five hundred pounds jointly; tranquillity in Dublin had not been disturbed. It was rumoured that the Russian Government intended to construct a railway from San Petersburg to Odessa two hundred and [fifty] German miles long. That from Altona to Kiel fourteen German miles long cost B. Mk. 5,400,000 say eighteen thousand shares at one hundred species dollars [487] each calculating that the Russian would in proportion cost no more than the Holstein, the cost would run up to B. Mk. 96,00o,ooo.

Friday, $7^{\text {th }}$ of June 1844. After breakfast Willink and I walked out together; he attended to his fields labours whilst I soon left him, and climbed up the Hessenstein for the purpose of forming a correct idea of the towns, villages, and estates situated around this central point. Though the atmosphere 
was far from clear and heavy dark blue and black clouds in the South west of the horizon threatened a thunder storm, nevertheless I succeeded to my satisfaction and the following is the result of my observations: due East lies the village of Bleckendorf, thence a little to the right I clearly distinguished the town of Lutjemburg, between it and the Hesseintein, the farm of Frederickshof. The country in this neighbourhood is undulating and presents a pretty variety of hills and dale; drawing further southward, the red roofs of Clamp and the Selenter Lake were visible; somewhat nearer the estate of Neuhaus, between the church and the village of "Glekau"; to the South West, cultivated fields and woods filled up the entire space, until my eyes rested upon the waters of the Kiel bay glittering in the sunshine and opening into the Baltic which further on forms a bay on the other side of which Eastward the land of Oldenburg was dimly distinguishable. On this side of the bay a narrow ridge of land separates the Baltic from a Salt lake called the "Never inner lake", round which the houses and a [_] of the estate of Neversdorf owned by Count von Holstein are clustered and thence fields and woods bring us back to our starting point, the Village of Bleckendorff. At the foot of the Hesseinstein stood a public house whence a straight avenue of newly planted lime-trees lead to the mansion of Panker. In this extensive landscape the only living objects that I could descry, were Willink accompanied by his faithful dog, some field labourers, a few horses pulling two or three carts loaded with manure, and sheep grazing. Having sufficiently enjoyed this beautiful prospect, I descended from my elevated post, strolled about in a pretty wood of oak trees and after a long search discovered the monument which is erected in the Landgrave's garden to the memory of Prince Von Hesseinstein. It consists of three high granite steps on the top of which stands a small pyramid (granite) with the following inscription in gold letters, on one side: "Hic quiescit Fredericus G[uill]ermus Princeps de Hesseinstein natus 27 feb. 1735, denatus 27 Julii, 1808 " - on the other side: "Illustrimo Viro Principi Hesseinstein Frederici I Sueci[æ] regis, Landgravii Hessi[æ], filio [po]suit hoc monu- [488] mentum amicus hoeres Carolus Landgravius Hessia Electoralis"; note that the Landgrave calls the Prince of Hesseinstein, an illegitimate son, not illustrisimo, but illustrimo which in reality has no meaning. I sat for some time on one of the steps, and looked at the large building before me stuccoed and kept in good repair, surrounded by the garden and plantations. I reached Frederickshoff by a round about way, and after dinner started afresh accompanied by Willink. The sky was overcast, we had even a shower of rain, however we did not allow ourselves to be deterred and visited the various spots which Willinck had determined to point out to me, for he was proud as well he might be of the beauties of the neighbouring country. We crossed the yard in front of the mansion of Panker, passed various out-houses and a public house 
which I mention solely on account of the quaint verse which was written in low German above the street door. It runs as follows: "In der Ohle Liese; da gait dat nah de ohle wiese, de wehrt, de supt dat Beste ann segt prost min lewen gäste" which means: "in the 'old Bess', the old custom prevails, the landlord drinks the best there is and says, your health my dear guests". Continuing our walk, we had an occasional view of Lutjemburg to our right, and of Neversdorf to our left. The farm of Stöss belonging to this estate lay in our way, across the same through fine avenues and a straight road cut through a wood, we emerged upon a bridge which spans a small brook. Behind us, we had now the wood through which we had just passed, to our right low lying meadows, the garden, the pavillon and the irregular buildings of the estate of Neuhof belonging to Mr. von Buchwald; to our left, similar meadows, the Never lake on the further side of which, the previously spoken of narrow ridge of land which separates it from the Baltic. Towards the North this ridge appeared to me barren and sandy whilst its Southern part was occupied by some houses named Hassberg. We made a small excursion to the Pavillion of Neuhof, returned the same way which we had come as far as the farm of Stöss. Here the Count von Holstein had chosen for himself and family a burial place which in my opinion is the most picturesque which I ever have seen, and if it depended upon me, in a similar spot should I wish my bones to rest. There was originally a mound of earth probably one of the many tombs of ancient Warriors, Saxons or Wendish which are found in the north of Germany, and which go by the name of Tomb of the Hühnen, a corruption, no doubt of the word "Huns". This mound had been deepened, [489] vaulted, and the interior bricked all around. On one side it was closed by an iron railing, behind which by a wooden door, which we managed to push open a little, the Old Count, Countess and one of their daughters were interred there, we however could only distinguish one coffin. On the summit of the mount covered with smooth grass stood a plain black cross shaded by a few tall oak-trees. At Stöss we left the high road, and across fields, hedges, and ditches again reached Frederickshof. The last part of our walk Willinck called the short cut, however I confess that I arrived somewhat fatigued. A few cups of tea refreshed me, and once more we got on our legs in the beautiful evening of a long summer day, we rumbled about in the surrounding woods to my great delight; towards eleven oclock, I retired to rest.

Saturday, $8^{\text {th }}$ of June 1844. I bade good bye to Willink, thanked him for the kind reception he had given me, and at eight oclock left on foot for Kiel, due West from Frederickshof with a guide who carried my cloak and bundle. A strong wind blew from the West which prevented the rain from falling, though the sky was clouded the whole day long. We crossed the Pielsberg, and through foot paths and by roads with which my guide was well acquainted and which 
are far preferable to the beaten high road, we came to Emkendorf, a village of some importance. All about here, dark red seems to be the favourite colour of the peasants; the doors, gates, the windows, the frame work of the houses, the banister of bridges, etc., all were painted with this dye. Further on we passed a large brick building, a school house belonging to the villages of Gleschendorf and Emkendorf. Two pretty little girls, brown haired, a rarity in this country of light complexion and flaxen hair trudged along before us through a corn field, merrily and briskly, not as [sc] hakespeare has it, creeping like snail unwillingly to school. We had to our left the village of and the Selenter lake, behind us the Hesseinstein as our land mark. [Dransau] and Pülsen were the two next villages, a school house about half way between the two. On the other side of Pülsen, our way led us close to the Selenter Lake, the waves of which were white crested, so strong did the wind blow. A little further on the light blue and white colours with which the Banisters of a small bridge were painted, gave evidence of our having crossed the limits of the large estate of Salzau, the property of the rich count Von Blume. The first village in this estate which we passed, is called Pratjan; a fine well kept avenue ran from there in a straight line to the mill and inn of Salzau. We entered the latter to take our breakfast: Sausages, bread, butter, and cheese, butter milk for [490] myself, a drann for my guide, the furniture in the room was of mahogany but the floor boarded and strewn with sand as it is the custom. I walked about in the garden and park of Salzau for an hour and a half. Art had done much, nature little; the fine woods of Beeches and oak trees, also the abundance of fir and pine, of alders, of Lime trees, Hazelnuts bushes, etc., which had pleased me so much in the neighbourhood of Eutin and Lütjemburg were wanting. Groups of stately trees, fine avenues, well kept grass plots which stood in need of the care bestowed upon the lawns of English parks, a rustic bridge from a pine covered eminence to another across a road planted with lime trees and leading to Selenter lake, also hot houses and a kitchen garden, finally a sheet of water behind the garden were the principal objects which attracted my attention, however one with another, the whole landscape was not to my taste, tame and flat. The Count's dwelling house, not unlike a palace, was an extensive edifice with two wings, on the façade of the main body the Count's arms were cut in large dimensions. Other houses such as stables, barns, etc. formed the sides of the quadrangle, and a grand solid gate opened into the same. But the road leading up to it did by no means correspond: instead of a fine straight avenue, it was a crooked way round the corner which brought me to the entrance. On the other side of Salzau we passed a pretty building, the Counts manège, to the right appeared the Passader lake situated in the Probstei so frequently mentioned. My guide told me that the revenue of the piece of land so called 
served for the maintenance of the convent in the town of Pretz (see page 372), the chief of which is named the "Probst", whence this name of "Probstey". Descending a trifle we arrived at Charlottenthal where Count von Blüme had established an extensive distillery; the buildings belonging to the same were in excellent repair. Next after having passed a pleasant wood we came to the Village of Schlesen close to the Dobersdorfer lake; the village of this name lies on the opposite side. Keeping the lake to our left, and following a path through a corn field, we came to a tile Kiln, then to Tockendorf which we did not enter, for just before, we turned off a foot path over the fields which brought us to Schönho[rst], Shönkirchen, and finally to New-muhlen on the banks of the Swentine which river takes its source in the Lanker lake a little to the south of the town of Pretz. From this point round the bay by land to Kiel, is still a considerable distance which I was too fatigued to walk. I therefore here in Neumuhlen paid my guide, and engaged a boat man to carry me over to the town. Opposite to Neumüllen which is on the right side of the river, lies Wellingdorf, and at the mouth Ellerbe[_] [491] the Swentine was so shallow, that my boatman moved his craft by pushing a long pole against the bottom, but as soon as we entered the bay into which the swentine falls, he hoisted a small sail and the spray flying over the boat, the strong wind carried us quickly across; the whole passage lasted an hour and a half, the fare was not more than eight Shillings cury. Of course Kiel presented now a different aspect from what it had done in January [_] then the fine wood of Düsterbrook stood leafless with its rigid branches, now it was covered with the fresh green of spring; then the bathing establishments were shut up, now they stood open, and the country houses were inhabited. The largest villa was that of the merchant Klötz of Kiel, the most extensive garden, that of Countess Rantzau which adjoins the garden of the castle. The Castle itself is an irregular building: more eastward than Düsterbrook the red roofs of Holtenau were visible and at a great distance in the same direction the small fort of Frederickshort. I put up at Brandts Hotel whither I had directed my luggage from Eutin. I was tired, my feet pained me, nevertheless after having dined I went to see my old friend Mrs. Dr. Lilie, took tea and had a long chat with her and her pleasant son Ernest. Next I called upon Mr. Pelt, Professor of Theology; he was busy in his study with several students and lead me to his wife, one of the nicest women of my acquaintance. I conversed with her quite "a mon aise" until her husband joined us again, took tea and walked back to my hotel. Notwithstanding the great exertions of this and the previous days, I could not sleep soundly, probably the great quantity of tea which I had taken kept me awake.

Sunday, $9^{\text {th }}$ of June 1844. I was in the habit of rising early, for the morning hours were the only ones which I had at my disposal to keep up my diary to the 
day. Having paid my bill, I strolled about the town. Also here as in Lübeck some houses have those curious gable-ends which I described (P. 377), however not one gable did I observe which stood free in the air merely sustained by iron bars, an open space behind, of which I had seen a few in Lübeck. I went to church for the purpose of hearing the Probst Harms, a clergyman who enjoyed a great reputation amongst his followers and adherents in religious matters. He stood at the head of those who, called "Supernaturalists", look upon faith as the Keystone of Christianity in opposition to the rationalists who as the name implies, subject every dogma of the Christian belief, to the touchstone of reason. Young [492] Ernest Lilie, Old Hermann Willink, Wife, and son Hermann were enthusiastic in their praises of Harms, whilst Mrs. Dr. Lilie and Mr. and Mrs. Fedderson looked upon him as a fanatic. Thus in the [v]ery centre of families, all Lutherans, different religious opinions prevailed. Hardly had I entered the Church, when Hermann Willinck Senior called me, and ceded to me a seat in his pew, next to his wife. I confess that I am not Physiognomist which may be the reason that I found nothing striking or interesting in the reverend $\mathrm{Mr}$. Harms' features he was a man of about seventy, and having lost his teeth, his smile was far from pleasant. After the singing of some hymns accompanied by the organ which is in my opinion a superfluous part of the Divine service Harms mounted the pulpit. He had no paper in his hand and spoke apparently "extempore", though he had no doubt studied his sermon at home. His pronunciation was very bad owing to his being a native of Ditmarshen, a part of Holstein where the lower classes, and Harms was of low extraction, do not pronounce correctly for instance the German Evangelium he pronounced Evangeilum, Lazarus he said Laazarus, giving the two a's, the broad Danish sound; the end Syllable of the German verbs (en) he accented distinctly, whilst it should be run over quickly erlangen, instead of erlangn. His gesticulations, not graceful, were impressive, and the entire sermon was delivered in a clear and intelligible manner, but on the other hand I think there was no necessity of calling a bad woman a Wh..., he might well have found another term of the same meaning without this gross sound. The text of his sermon was the well known parable of Lazarus which Harms thought proper to call a stranger because it did not chime in well with the text of the previous Sunday, all which texts are fixed upon before hand by a superior Clerical authority; on this point, that is to say on the text being a stranger as he was pleased to call it, he dwelled for about half of the time of his preaching, and the other half, he dilated on the obvious and thread bare truth that a rich man who does not make a proper use of his riches will be punished and that a poor man who bear his misfortune with meekness and patience will be rewarded in the next world. From the expression in his text that there exists a deep chasm between Heaven and Hell, 
he drew the inference that the damned will be damned for ever, and suffer in Hell for eternity. A horrid idea surely not in consonance with the opinion [493] which I have formed of an all merciful father. I was pleased and diverted, not edified as I had been in my youth when listening to the reverend Mr. Gabain. The famous or notorious John Knox may perhaps have preached somewhat like Harms. Divine service over, I drove with Mr. and Mrs. Willink to their farm of Stift, but the high road being under repair, we had to take a somewhat different route from that we took in January last. We passed the villages of Brunswick and Wyck and when we reached the Holtenau lock where we had to pass the canal to the Schleswig's side a vessel was just passing through, thus we had to wait till the lock was reshut, and I now obtained a clear view of the manner in which by opening and shutting the locks a vessel can be lifted up or lowered. At half past twelve we arrived at Stift, a farm forming a part of the estate of Seekamp, the property of Count Schack of Schakenburg nearTondern. A row of Lime trees stood before the dwelling house which however did not look so neat as that of young Willinck's in Fredirickshoff. The dining room boarded, was strewn with sand. At 1 p.m. we took a plain but excellent dinner. Shortly after whilst we were at our coffee Feddersen, married to Henrietta, the daughter of Hermann Willink, came in, they lived close by. Feddersen being landsteward of the Count, he was an agreeable man, and Henrietta, an old friend of mine from early youth, looked very genteel, but like her mother had the ugly habit of finding fault with almost everybody whose name turned up in the course of the conversation. When they were gone, Mr. Willink and I took a walk to the neighbouring estate of Knoop belonging to Count Baudissin which now in the month of June fully answered the expectations which I had formed of it in January last (see Pe. 370). We continued our walk to the Knoop lock, thence along the Canal reached the Holtenau lock, and over fields and hedges returned to Stift. A stroll through the garden concluded the day. We supped at eight oclock and at half past nine, when day light had not yet entirely faded we retired to rest. Besides Mr. and Mrs. Willink, the inmates of the house were Miss Caroline, the latter's companion, a good kind of creature; a young Holstiner, Schmidt, who at a low salary assisted Mr. Willink in his agricultural pursuits; a young Dane from Odenssee who was placed under the charge of Mr. Willink for the purpose of learning husbandry, he I suppose had to pay a trifle for his board. The maids who worked in the dairy had to rise in the Summer season between one and two oclock in the morning. [494] Stift is smaller in extent than Frederickshoff, it measures three hundred Tonne, Frederickshoff four hundred Tonne, but the soil being considerably better, both farms paid the same rent of $\$ 1400$ annually. Beeches are indigenous in the Southern part of Schleswig as they are in the North Eastern part of Holstein where they abound 
most; next rank oak, [_], Elms and lime trees; firs and pines are scarcer. Of ash trees which give a good fire wood not so compact as that of beeches and oaks, I observed some new plantations, horse-chestnuts and alders are met with here and there, maples may be called a rarity, the hedges consisted mainly of Hazelnuts and yoke-El[_] (German "Hagebuke").

Monday, $10^{\text {th }}$ of June 1844. In the forenoon Mr. Hermann Willink and I took another long walk through Holtenau to the mouth of the canal where some neat buildings for the Custom House officers, also a Custom House store not much used, were erected. Two vessels were unloading timber but if I compare the quantity piled up here with the masses of the same material which I had seen in England, it was really not worth speaking of. In the afternoon we again strolled about in the neighbourhood, then paid a visit to the Feddersen's with whom we took tea and supped. Feddersen had a large family, a young lady from Hamburg miss Prömmel who attended to the education of the children, was a pleasant young lady, and Henrietta gave clear evidence of the good education which she had had, and of the good society she had seen whilst living in C. H. Donner's house, but the more was I displeased with the manner in which she expressed herself about the companion of her youth Betty Donner, now Mrs. Von-Zahrt[_] in Copenhagen, whom she accused above all of pride. It was half past ten oclock when we returned home. From Mr. Herrmann Willink I learned many particulars of the lives of his cousins, sons of Diedrick Willink, Johannes and Jacob who died in America, and Abraham who died in Altona. To judge from what he told me, and what previously had come to my knowledge, of the cousins Willink, none of them had prospered in the world; only two, Herrmann and Deidrich have had male descendants. Deidrich, son of the latter born in 1824 is at present date (1869) unmarried and clerk in a mercantile establishment in London; no great thing for a certainty! Herman's two sons are: Hermann already mentioned, a bachelor and excellent man, and Charles, one of the first merchants of Hamburg, partner of Shön and father of a large family. This is the only one who keeps [495] up the name.

Tuesday, $17^{\text {th }}$ of June 1844. Besides the light usual breakfast, my kind host insisted on my taking more substantial fare before I started. At eight oclock I bade them good bye, my stick in one, my bundle in the other hand, I walked as far as the Holtenau lock, having passed which I turned off to the left towards the lower part of the village of Wyck and the beach along the Kiel bay. Further on I reascended, passed through new plantations of young trees belonging to a certain Eckhard, and through the beautiful wood of Dusterbrook to the Brandts hotel in Kiel, where I was shown to the same room which I had previously occupied. It was now only ten oclock. At one oclock I went to dine with my dear Mrs. Lilie who was inconceivably active and lively for her age, 
for I suppose she could not have been less than sixty eight years old. Her son Ernest and his friend Doctor Baumgarten, an oriental Scholar who delivered lectures in the University on the Old Testament, sat down with us. The young men, both complete gentlemen were fanatics in theirs religious belief, but had the good sense to conceal their opinions. They left at two oclock and when they returned at four p.m., we walked out together. My companions took me in a Southerly direction where new houses in the modern style were about being built. Further on, we came to a small eminence covered with a pretty, the Wickburg, wood. This hill and the continuance of it young Lilie made me observe are the cause why the Eider does not fall into the Kiel bay; the Eider which has its origin in the Einfelder lake to the South of Bordesholm flows due north, but meeting here with this impediment, turns off to the left or Westward and as every body knows disembogue into the German Sea. We descended towards the beach where the Railroad works were in progress, a church yard had had to make room for this [_]ovation, corpses had been desinterred and reinterred, which, as well might be imagined, had given rise to many bitter complaints. At the time it was not yet determined where the terminus was to be constructed, some were of opinion that the inner Kiel, a sheet of water inside of the town should be filled up, others that its waters which emitted an offensive stench should find their subterranean vent under the castle Garden into the bay. We walked on, passed through the pretty village of Dorfgarten, and came to a public house, at a place called the Whilhelms- [496] [_] (William's hill), where Mrs. Lilie who had come over in a [_] waited for us with tea. Everything was nice and pretty, I only regretted the expense which these good people who had no superfluity of money were incurring for my sake. Young Lilie, a really intelligent man, pointed out to me a group of trees where three or four centuries [_] judgment was pronounced by a council assembled there in the open a[_] and till this very day, a small brook has preserved the name of "Voll R[_] bach" (full Councils brook). Across the bay, we returned to Kiel, Mrs. Lilie and Baumgarten left us, and with young Lilie I made some enquiries for the first Steamboat to Flensburg not far from which town Fritz Wall to whom I intended paying a visit, lived on his farm. Lilie pointed out to me several ancient buildings belonging to Old Holstein noble families, on the wall of one of them noted the name of "Peter Margareta Rantzau," and Lilie told me that in the $15^{\text {th }}$ or $16^{\text {th }}$ centuries it had not been unusual in noble families to give to their male children a female name. A small church called the Convent church was all that remained of the convent founded by Count Adolphus IV of Schaunburg, who had retired thither in the prime of Life after his victory over Valdemar King of Denmark near Bornhoved (See page 431). Another building, now a school house was remarkable because in one of its 
apartments, the peace of 1815 was signed, the principal condition of which was the cession by Denmark of Norway to Sweden.

Wednesday, $12^{\text {th }}$ of June 1844. At 10 oclock, my thermometer at the open window stood at $151 / 2$ R. $=691 / 2$ F. At a later hour I paid a long visit to Mrs. Pelt born in Frankfort on the Oder, a lady both intelligent and good looking. She confessed to me that she disliked the drudgery connected with the duties of what is called a thrifty house wife, knitting for instance she could not bear, for it was a mind killing and time consuming occupation. Woven hose, she said was quite as cheap and durable as knit stockings, in which, however, she was mistaken. At one p.m. I went to dine with Mrs. Lilie and the two Gentlemen mentioned yesterday. Afterwards, I again called upon Mrs. Pelt, and with her husband the professor, a gentleman who expressed himself in such a deliberate and slow manner as one seldom meets with, I took a walk out of the town. We followed a foot path which led us to the Village of Brunswick situated to the north of Kiel, then keeping to the right, we passed through the nice [497] garden of Eckard and that which is known by the name of the Royal nursery, the object of the latter is the growing of young trees to be sold to the various great estates in Holstein. In the wood of Dusterbrook we found Mrs. Pelt and two other ladies, the wives of Professor [Chalybeius], a latin translation of the German word "Stählen" (of Ste[a]l), and of Professor Scherk who were sitting in the open air before a public house. With them and their two husbands who soon made their appearance we took tea, enjoyed the fine weather, the pretty view over the bay to the other side and an animated agreable conversation. The Professors were inquisitive men, and I had to answer many questions regarding South-America. The whole party walked back to Kiel along the fine avenues which lead thither from the wood, and the remainder of the day I spent in Pelts house. I showed to him and his wife, my drawings of Lima Castums, Mrs. Pelts showed me her Album; we conversed on many topics, eat a little cake, drank a glass of wine, and at about 10 p.m. I returned to my hotel. I must not omit to mention that R.R. shares had experienced an extraordinary decline since my leaving altona attributable it was said to a decree recently published by the Prussian Government prohibiting the sale of Rail-road Shares on credit, as well as the sale of not-Prussian Railway shares within the Prussian territory, without permission of the Government. The Altona Mercury of June 11/44 quoted Hamburg-Bergedorf at 95, Altona-Kiel 100, GluckstadtElmshorn 100, Copenhagen-Roeskilde 94. On the $24^{\text {th }}$ of May the King of Denmark conceded permission for the construction of a railroad from Kiel to Eckenförde and Schleswig, there to join the trunk road from Rensburg to Schleswig, and Flensburg.

Thursday, $13^{\text {th }}$ of June 1844 . The temperature was colder than yesterday inside my room with the windows shut the thermometer stood at the same point as it 
had done in the previous day with the windows open. I spent the greatest part of the day with Mrs. Lilie and her son, and with Mr. and Mrs. Pelt. I dined with the former and passed the evening with the latter. Young Lilie and I conversed a good deal on serious matters, and I was surprised and pained to find that such a young man as he was, had formed a very bad opinion of his and my fellow creatures, an opinion worse than what human kind, bad as many men certainly are, deserves; as his experience in the world must necessarily have been limited, I should attribute [498] his gloomy views solely to his religious fanaticism. His mother was of a very different caste. She was educated at the time of the first years of the French Revolution, a period when Deistical theories were the fashion in many parts of Europe and her religious opinions had in some measure been tinged by them. On one occasion she made to me a very proper observation, "Ernest and Baumgarten think so much of Jesus the son, that they forget God the father". Mr. Pelt, a learned theologian shaped his path between the two extremes and Mrs. Pelt I think rather inclined towards Mrs. Lilie, than towards the son. In the forenoon young Lilie accompanied me to the University where in a room very plainly furnished and whitewashed I listened to a lecture delivered by Professor Waitz on Danish and Norwegian history in the $10^{\text {th }}$ and $11^{\text {th }}$ centuries. 16 students amongst whom I recognized young buckleman, by no means dressed in an out of the way manner, their long hair falling over their shoulders, sat on benches with narrow writing desks and writing materials before them. Some of the young men noted down the Professors words, others only listened. I observed that both benches and desks had names cut into them, nearly quite as much as was the case in the altona Gymnasium in the time of my youth. The Professor entered at 12 precisely, walked up to his lecturing desk, and commenced his lecture without further preamble; as soon as it struck one, the Students shut up their portfolios and gave evident signs that they wanted to be released. The Professor took the hint which was not to be mistaken, closed his book and walked out. The students distinguished themselves by the colour of their respective caps, the red caps were the mark of the aristocrats, who included the scions of the Nobility and the sons of such men as occupied high Stations under Government. The Republicans with few exceptions sons of the middle and lower classes in society, wore white caps. A small knot of tipplers had chosen the green cap for their badge. After dinner I took a walk by myself, passed the village of Brunswick, but instead of keeping to the right as yesterday with Pelt, I struck off to the left, came to an open ground where the young people of Kiel exercise themselves in Gymnastics, further on, to a meadow which serves as a drilling ground for the Soldiers, and reentered the town at its North-Western extremity where I observed several fine streets and buildings. The high road planted with trees leads thence to the town of Schleswig. 
Friday, $14^{\text {th }}$ of June 1844 . Though the previous night had been cold and raw, this morning was pleasant, and the sky cloudless. At 6 a.m., I with my [499] trunk and big cloak was on board of the Steamer bound for Flensburg, situated to the North West of Kiel, and a few minutes later the anchor was weighed. As long as we were in the Kiel bay the water was smooth and the shores on both sides presented pretty prospects. To our right we had the Villages of Ellerbeck and Schrevenborn, to the north of which the fertile Probstey. Here the land turns Eastwards and the increased motion of the vessel gave evidence of our being exposed on that side to the waves of the open sea, some of the ladies gave sign of distress, sea sickness made itself felt. By this time I had taken a survey of my fellow passengers, they were: a Mr. von Bust owner of landed property in St. Thomas, his wife belonging to the noble family of the von Moltke, her grown up step son and step daughter, several little children and servant girl, this party kept aloof from the rest; Mr. William Hesse of Altona, son of old Isaac and engaged to a Miss King, sister in law of Otto Donner's wife; two young men, Lange, a Mr. Edlefsen with a moron look about him, his sister of apparently twenty eight or thirty years of age with whom I gradually became acquainted, and myself. On our left side or Westward we were more or less under the shelter of the Coast during the whole voyage. Having left Kiel and Dusterbrook behind us, the red roofs of Holtenau came in sight, then some woods extending as far as Frederickshort which I now learned for the first time answered no more the purpose of a fortress, though the walls were left standing. Here abouts, the course of the Steamer altered to the North West, on our Larboard side we had the high Coast of Duchy of Schleswig, the Estate of Danish Neuhoff, a light house and another estate called Buch. The weather had completely changed, the wind blew strong from the west, and the cold was such that nearly all the passengers went below, I managed to remain on deck, however. When opposite the bay of Eckenförde, also I feeling some nausea, had to go below. The Cabin was neatly furnished with sofas of Mahogany wood, stuffed with horse hair, the panels prettily gilt. The weather grew worse and worse, at eleven oclock we entered the Flensburg bay. To our Starboard side we had the Island of Alsen. The wind from the west blew right into our teeth with such force that the Steamer made hardly any progress. Partly reading, partly sleeping, then eating a good beefsteak, I whiled away the time until half past one, when I returned on deck. The waves of the bay were violently agitated and white crested, [500] more so than the Atlantic had been, when I was for some days and nights on board of a Pilot boat which landed me in Penzance in September last. On both sides of the bay the shore was formed of high sandy hills here and there covered with wood. On approaching the town, the country became somewhat prettier, but could by no means be compared with that of 
Kiel bay. The villages, the Country houses, the bathing establishments, the woods were wanting. Instead of them humble farms and solitary peasant houses stood close to the beach, at the foot of the ridge of sandy hills. About a mile before reaching the town, on our left, or Southern Side through a dense wood, an opening was cut at the end of which vista the steepled castle of Glucksburg was visible, further on to our right or northern side appeared the Village of Collundt forming part of the extensive property, the "Copper mill". Flensburg, which lies westward of the Southern extremity of the bay, when seen at a short distance presents no striking features, the hills around are covered with Wind-mills. The water is so deep that we anchored at a short distance from the shore, close to a narrow short wooden mole where we landed. It was now half past four, three hours and a half after the time fixed for the Steamer's arrival. So long had the wind kept us back, hardly had I put my foot on shore when I was accosted by a man, the carrier from the village of Satrup who delivered to me a letter from Fritz Wall residing at his farm in the village of Obdrup. Wall in answer to a letter in which I had expressed my desire to visit him, advised me, to avail myself of the conveyance which this carrier would place at my disposal and so I did. This man whom I afterwards found out to be a humorist, and who fully answered the description which Professor Arndt gives of the Holsteiners, as men who are fond of their slow jokes and quiet fun, showed me to an hotel kept by a certain Doll. Whilst my dinner was getting ready, I strolled about the town. I saw not much of it but what I saw gave me no great idea of the beauty or regularity of its buildings, the houses were upon the whole similar to those which formed the ugly part of my native place, only two edifices made an exception, viz: the house which had belonged to the late wealthy merchant Christiansen, and the branch bank of the Rigsbank or Imperial bank of Copenhague. This establishment, I mean the branch bank, the Schleswig-Holsteiners looked upon, whether with justice or not, I cannot say, as the bane of the two Duchies, not long ago I had read a paper which spoke of it as the hated stranger upon which each patriot (that is to say) all such as [501] were opposed to everything Danish looks with detestation. A certain Tiedemann who called himself a thorough patriot had put up another bank in Rensburg in opposition to the said branch bank. My luggage came to the inn and whilst I took my dinner Mrs. Doll who still preserved the traces of former beauty kept me company and conversed with me pleasantly. Now my Satrup carrier called with his carriage, a miserable small Stuhlwagen with two seats, and filled with luggage, one seat was for him who acted as driver, and myself, the other behind us was occupied by Miss Edlefsen, my fellow passenger and her half sister, a Mrs. Petersen who lived in the village of Obdrup close to Fritz Walls place. All this weight was pulled by a single miserable looking horse; 
of course he could not move along quickly. The weather continued cold, and the drive was by no means a pleasant one over a barren and wild tract of land called the heath. When we approached the village of Obdrup the country improved a little; there was more cultivation and occasionally a wood showed itself. Water however was completely wanting, and the landscape could not bear the slightest comparison with the beautiful scenery which delighted me in Holstein. Here abouts that part of Shleswig which is called Angeln commences. It is the true cradle of the Anglo-Saxons whose descendants at present are to be found all over the Globe, this small unknown nook has also given its name to England. At half past eight oclock we stopped at the door of Fritz Walls house in Obdrup, two miles from Flensburg, and on the South Side of the bay; its exterior was far from neat and comfortable, much inferior even to that of Hermann Willink at Stift. Fritz, his mother and wife, a Miss Schwedler of Altona with which latter of course I was not acquainted, gave me a friendly welcome. We took tea, I had to answer to thousands of questions, and after a light supper I retired to the bed room which had been arranged for me. Fritz Wall, three or four years older than I, had preserved the round full face of his childhood, also the smile or rather the smirk which always played around his mouth was still there as in former years. When a youth he did not smoke, now the pipe never out of his mouth, his outward appearance was altogether that of a farmer, not to say of a peasant. His mother seventy three years of age was an excellent woman, his wife though [502] still in the prime of life had lost her teeth. She seemed to me a good creature. They had two sons William and Ernest, and a very young man Thornsen was kept in the house as their teacher with a salary of two hundred CM annually; for such a small remuneration certainly no great acquirements could be expected; the furniture denoted poverty, perhaps only economy. Drawings of Fritz and his sister betty adorned the walls.

Saturday, $15^{\text {th }}$ of June 1844. All in the house were early risers and at half past six or seven oclock a slight breakfast, bread, butter and coffee was taken. At 10 a.m. Wall and I walked along a high road hedged in on both sides, to the village of Satrup of more importance than Obdrup, where we paid a visit to the reverend Mr. Edlefsen, curate of the village and father of the young lady who had been my fellow traveller from Kiel. Mr. Edlefsen was a man of seventy three, lively, agreable, and with fine clear blue eyes. I learnt afterwards that in his religious opinions he differed widely from the ultra-Orthodoxy not to say mysticism of Mr. Harms of Kiel. His lady, a native of Copenhagen was occupied with cleaning unripe gooseberries, and though I was a complete stranger to her, did not allow herself to be interrupted by my visit in her homely occupation. The house, the drawing room and the study, everything looked more comfortable 
than at Walls. Having returned to Obdrup, we dined at noon after which meal a general siesta was taken, and at 3 p.m. Coffee was served. At a somewhat later hour Doctor Hansen the Physician, and Mr. Yungclausen first assistant at the Aphotecary's, a native of Altona, came over from Satrup to pay us a visit, both were nice young men. Tea was served, we walked through the garden, looked at the dairy, played several rubbers at long whist, and concluded the day with a light supper. At 11 I retired to my bed room. I was surprised at the laziness of the teacher Mr. Thornsen; this being Saturday, he had no lessons to give, and thus the whole evening, he was with us smoking, looking at our playing, and doing nothing. Also Fritz it appeared to me did not overwork himself, on the contrary; whilst his wife was attending to all the duties of a good house wife, I saw him doing nothing but smoking his pipe. He was in his assertions as positive as he used to be in his youth, otherwise, he was good natured and extremely fond of his two boys. In this neighbourhood the country is parcelled out into small pro[503] perties owned by farmers and substantial peasants, there are no large estates as in Holstein. Wall had paid for his farm which measured 165 Tonnen CM 50,00o. He grew little corn, but his principal income he derived from his dairy, the work of which establishment was done by male servants. He had at the time forty seven cows, of which two had not yet calved, each cow gave daily five and a half "Kannen", or eleven large bottles of milk, he made weekly $240 \mathrm{lbs}$ of butter, worth from seven to nine Shillings currency. The inside of the tubes in which the milk was kept was painted red, and varnished which I thought a great improvement upon what I had seen in Fredrickshoff and Stifft, for in this manner they could be easily kept clean, other farmers had these tubes made of thick coloured glass. Wall told me of the strange custom which prevails amongst the peasants of Angeln: when the Goodman grows old, and his strength fails him, he retires from active life, and makes over to his eldest son his dwelling house, and nearly all his property. He himself withdraws to a small house close by, keeps a little land for himself and receives a small sum annually from the son, and thus the old people live without cares, and without ambition until they are gathered to their forefathers. The daughters and the younger sons received each a trifling sum of money from their eldest brother. The former hardly ever remains unmarried, the latter must work their way in the world as well as they can. Frequently he, who is now the head of the family becomes a little embarrassed in his money matters in consequence of the payments made to his brothers and sisters, then the Old father goes in search of a girl in the neighbourhood who may have the money required to put the son right again, and a match is often made without the young people being much acquainted with each other. Nevertheless unhappy [matrimonies] are seldom heard of. The weather continued disagreeable, cold, windy and rainy. 
Sunday, $16^{\text {th }}$ of June 1844. At seven o'clock thermometer stood in my room with the windows shut at 12 Reaunur $=59$ Fahrenheit; certainly very low for a summer day. At about ten oclock, Wall and I walked to Satrup to return Dr. Hansen's visit. He lived in a comfortable house and treated us, though so early in the morning , to cakes and bordeaux wine. Mr. Yung Clausen insisted upon our accompanying him to the Aphotecary's Mr. Blume to whom and his lady he had spoken about me. Their [504] house was perhaps the best in the place, a Palace in comparison. Mr. Blume was occupied and did not make his appearance, but as regards Mistress Blume I was actually astonished to find in such an out of the way place as Satrup a lady so handsome, not to say beautiful as she was. She had black hair and black eyes, a clear complexion a handsome nose and mouth and fine teeth, her father was Mr. Salomon, a merchant of Kiel. We remained half an hour, and I was glad to hear that we should meet her again in the evening. This being Sunday, our dinner at noon was particularly good, it being over, Wall, Thomsen, the boys, and I took a walk and I was confirmed in the opinion which I had formed of the Country at first sight, it was very flat. There were corn fields, meadows, pasture grounds, and a wood here and there, very different from what I had seen in the North East of Holstein. At half past four we drove to the reverend Mr. Edlefsen's in Satrup, where a small party was assembled. It consisted of Mr. and Mrs. Edlefsen; their son, now a very different man from the moron character which he had seemed to be when on board the Steamer; his sister Caroline, a modest young woman; a second married sister on a visit from Itzehoe; a half sister Mrs. Oetersen already mentioned; a Miss Moorhagen from Flensburg; Wall, his wife; Yung Clausen, and myself. We took tea, I conversed with the one and the other, I showed them my drawings of Lima Costumes which I had brought with me. Whilst thus occupied Mr. and Mrs. Blume entered, and joined us. Card-tables were set out, Old Edlefsen, his son, and Wall played L'hombre, Mrs. Blume and I against Yung Clausen and Miss Moorhagen long whist at very low points. My partners presence fully made up for the tediousness of the game. Supper was substantial, roasted veal with all kinds of vegetables, and a nice cake with Lemon Sauce. Old Mr. Edlefsen offered his arm to Mrs. Wall, I mine to Mrs. Blume with whom I confess I conversed very agreeably. Dishes and plates being removed, singing commenced in which the old man notwithstanding his advanced age, and the young people, especially Miss Caroline who had a pretty voice, took an active part. For the first time in my life I heard a Danish song which sounded prettily. We broke up at eleven, much too soon in my opinion. When we drove home Mrs. Wall evidently nettled at the marked attention which I had paid to Mrs. Blume, observed that this lady was very coquettish, and that she knew how to make use of her fine eyes. [505] Now and then, though 
extremely seldom, Danish words were introduced in the German spoken in these parts of Schleswig, to the South of Flensburg bay; for instance Old Mrs. Wall born and breed in altona who knew nothing of Danish, frequently made use of the expressive Danish word "sysle" (to be busily occupied) to which she gave a German termination and called it "Süsseln". In my room at midnight thermometer stood at 11 Reaumur $=56$ 3/4 Fahrenheit. Altona-Kiel R.W. shares had risen again to 115 .

Monday, $17^{\text {th }}$ of June 1844. When I left Obdrup between six and seven in the morning, the whole family of the Walls were already up to bid me good bye, the young house wife was always in the habit of stirring at the early hour of five, but this day even Old Mrs. Wall had risen before her customary hour. Fritz had placed his Stuhlwagen at my disposal. He himself accompanied me, and at Satrup through which village we had to pass, Doctor Hansen joined us. The character of the country was similar to that already described, here and there it was a little undulating, and everywhere rich corn fields gave evidence of the fertility of the soil; we passed through several villages, the names of some of which escape my memory. I remember Hunsbye, its church steeple was of a particularly pretty shape, pointed, of wood and resting upon a base partly of bricks, partly of big stones; also Gremencrüp abounding in storks, upon the roof of one of the peasant's houses I observed six nests of these birds; and thirdly Munkbroadrup which called my attention because the church was without a steeple. When approaching the hamlet of Glucksburg, the high road on both sides was lined with fruit-trees, and through a fine avenue we drove straight up to the inn where we alighted, took a little bread and butter and some wine which went by the name of Madeira, and started on foot for the purpose of visiting the Castle and park of Glucksburg. This castle is an ugly cuadrangular white washed building bathed by the waters of the lake. Its four corners are disfigured by little turrets resembling pepper boxes; on one side a narrow bridge leads to the gateway, the façades of the three other sides finish in old fashionned gable ends, in the middle is a square yard. A wood consisting mainly of beech-trees surrounds the lake, and stretches frequently to the very water's edge. Both the wood and the park are intersected by walks and avenues. We crossed the vista of which I had a glimpse on passing by in the Steamer. On one side we had the Castle, on the other, the [506] Flensburg bay. Further on we came to an artificial dyke which separates a small fresh water lake on the left from the bay, which forms here a small inlet on the right. Doctor Hansen told me that some years back when he was a practitioner in Glucksburg, he used to go thither in the dusk of the evening, and sometimes succeeded in killing an otter. These animals have their dens in the fresh water lake under the roots of trees; there the water is too deep for them to catch the fish, and towards 
evening they cross over to the salt inlet where the water being shallower, they are sure of their prey. Having passed the dyke we entered another wood, where Doctor Hansen pointed out to [...] bubbling spring which he said contained many particles of iron. The weather was cold and windy, the sky was clouded, and the view to the violently agitated bay and the other shore was dark and gloomy. On our return to the hamlet we noted the preparations for a fair to be held on the following day; one booth was about being erected for a set of ropedancers, who if the hand-bill was to be believed had had the honour to perform before high and mighty personages in Copenhagen, Stockholm, Saint Petersburg, etc. Another booth was intended for the exhibition of wild beasts, most extraordinary animals to judge by the bill, entrance $4 \mathrm{Sh}$. Cy., servants and children half price. At 12 oclock we drove on again, wheresoever the houses and hedges afforded some shelter, the wind could be borne, but when we crossed a small neck of land to a peninsula on the utmost point of which lies the small place of Holdness, the wind was insupportable, on our arrival at the inn in Holdness and on inquiring whether I could be ferried over to the opposite side I received at first a decidedly negative answer, however on addressing myself to the landlord, a, to judge by his looks, drunken fellow, he said that generally towards the afternoon the wind lulled, and accordingly I determined upon remaining. "Noes" means in Danish a point of land, however the vulgar availing themselves of the similarity of the sound between "nase", the German for nose, and "Noes", gave to Holdness a ridiculous derivation. They said that a traveller involuntarily took hold of his nose less it might be blown off by the high wind which invariably prevails in that neighbourhood. Wall had a letter which a person in Satrup had requested him to deliver to a [young lady] who lived in Holdness whose story ran as follows: She was born in St. Thomas, educated in Copenhagen, and on a passage across [507] when 15 or 16 years of age had been seduced by the Captain of the vessel. A son, the offspring of this intercourse, her father had taken care of, for some years, but shortly after her marriage with a Mr. Hansen who had been kept in ignorance of her "faux-pas", the father had returned the child upon her hands; then all came out. Mr. Hansen sued for, and obtained a divorce; his lady left him, and now lived with an aunt of hers, the wife of a Custom house officer Mr. Schmidt. We had heard much of her great beauty, therefore Dr. Hansen and I determined upon accompanying Wall on his errand. Mrs. Hansen was certainly a beautiful [_] woman of about twenty one years of age, neither she, Augusta, nor her aunt, a pleasant lady spoke German, and I therefore conversed with both in English, to which the younger one replied in the same tongue which she pronounced fairly, the Elder one in Danish, this I managed to understand so, so, but on our leaving when I begged permission to return in the evening in 
case I should be detained, her answer in the same language was unintelligible to me. Both ladies were neatly dressed, a Danish translation of "Les mysteres de Paris" was lying on the table. We paid another visit to a Custom-house officer Mr. Folk with whom, his lady, his grown up daughter and younger children, Doctor Hansen was well acquainted. The daughter bore a striking resemblance to Maria Knauer. She had the same fair hair, the same blue, somewhat prominent eyes, the same small, a little curved nose, only as regards the mouth, my new acquaintance could not bear comparison with Miss Knauer. I now took leave from Wall and Doctor Hansen, they returned to Satrup, I walked to the beach where a ferry man assured me that for the moment it was impossible to cross over. I went back to the inn, dined, learned some Danish vocabulary and to while away the time noted down as exactly as possible the different objects which I could see from my window. Here at its mouth, the bay widens considerably. To the right at a distance I just distinguished the Island of Alsen, on the opposite, the northern side. The shore gradually slants down towards the water, it was generally cultivated, here and there a sandy patch of land, close to a wood a few red roofed houses and a brick [Kiln]. Somewhat inland the two steeples of Broacker's church were Clea[_] and between the inn or ferry-house, and the bay, not distingu [...] where I was at my window, the space was filled up with some pasture [508] ground hedged in on which two cows were grazing. On the other side of the hedge a road led to the beach. Time began to hang heavily on my hands. When at about five, the ferryman came to tell me that the wind had so much abated as to permit my embarking with safety, my bill amounted, including the fare across to no more than twenty sh Currency which paid to my hostess, a pretty nice woman, very different from her beastly husband. The boat which carried me and my luggage, had one mast, two sails, and its crew consisted of two men. The waves were still agitated and white crested. However the weather was fast improving, the clouds disappeared, the sun came out, and for the first time to me the Flensburg bay presented a cheerful appearance. In about 10 minutes I reached the opposite Northern side where I landed close to a few houses called Brunsness, I addressed myself to the postmaster who only spoke Danish and who no doubt did not scruple to take in his German brother. I had been told that the distance from Brunsness to Grovenstein was no more than one full mile. He insisted on its being two, and made me pay one species for a Stuhlwagen drawn by two horses with a Danish postillion. I found myself now on the Peninsula of Sundervidt, and was well pleased with the appearance of the Country; it is a trifle more hilly than Angeln, somewhat woody, and was under excellent cultivation. The peasants' houses built of yellow bricks looked respectable and comfortable. Broacker with its two steepled churches is a considerable village. 
Also Eckernsund which stretches along the beach of a narrow inlet from Flensburg bay is of some importance. I had to wait a short time till the ferry boat came from the other side, it took me over in a few minutes and another short drive brought me to Gravenstein, a place famous for the excellent apples produced in the neighbourhood. I had my luggage taken to an inn, and started immediately for a walk. The sun set past eight oclock but in these high latitudes, the twilight lasts so long that for more than two hours before it became quite dark I could stroll about in the environs which looked more park-like than any other country hitherto visited by me. The roads were beautifully kept and lined with fruits and other trees. I came to the mansion or Schloss, a large pile without any arch[itec]tural beauty; this is more or less its shape: from a small balcony behind the main buil wall [_] had a pretty view over the lake which on two sides is hedged by wood small neat town of Gravenstein. belonging to the mansion

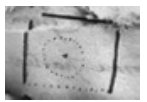
, the third side is occupied by the In the other direction lies a farm [509] or Castle. I took another road which led me to a wood, then to a large saw mill close to the beach opposite Eckernsund, and by ten oclock was back in the inn, highly delighted with my ramble. Though the floor of my room was strewn with sand, everything was neat and clean; I ordered tea, had a long chat with the landlord a Norwegian who spoke German very fairly. During the war with England he had been a sailor, made prisoner, and kept for several years on board of a pontoon in Chatham, without ever being allowed to go on shore. The servant, a pretty young girl also spoke German, but the jargon of "boots" a mixture of low German with Danish I could hardly understand. The following sketch I copied from my landlords map.

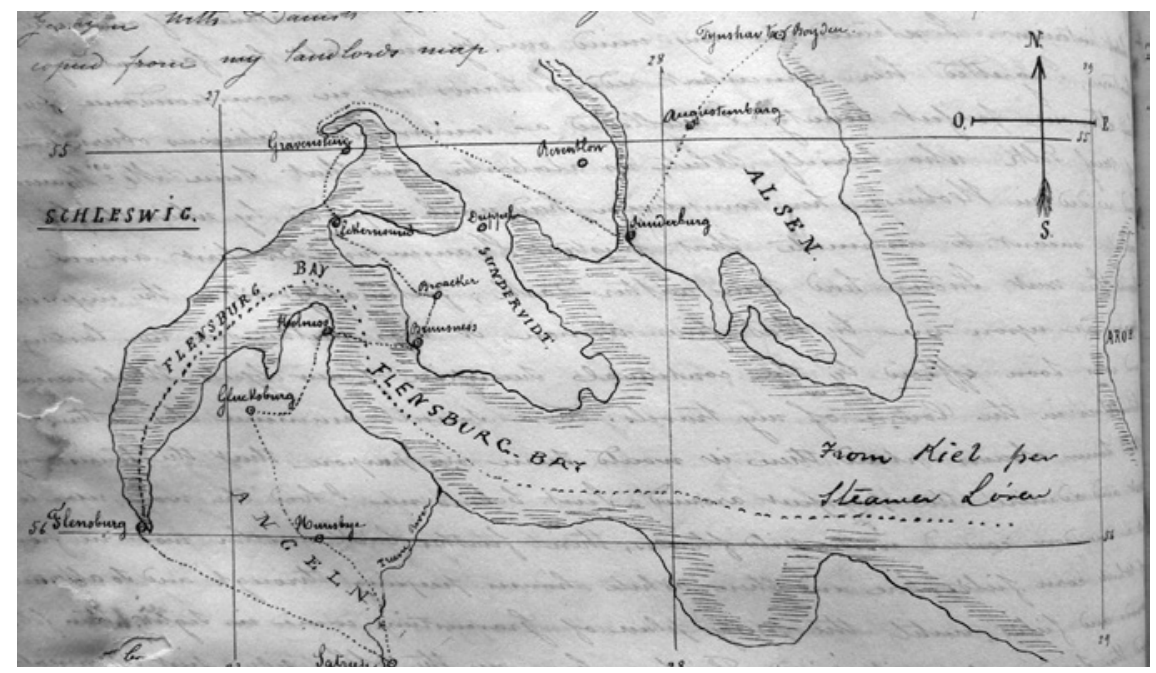


The tract of land comprised between the Canal and Eckernförde bay, is called, Danish, "Woldt" (Anglice "Forest"); between Eckernförde bay and the Schley, Swansen; between the Schley and Flensburg bay, Anglen, and the peninsula to the North East of Flensburg bay, Sundervidt. It was in this neighbourhood that in the war between Prussia and Denmark in 1864 the Danish erected the well known "Duppel fortifications" which though of great magnitude and valiantly defended, were entirely destroyed and [_] into pieces by the superior Prussian artillery.

Tuesday, $18^{\text {th }}$ of June 1844. The weather had cleared up and the wind had ceased, [510] the thermometer stood in my room, windows shut below 10 Reaumur. The first hours of the day from $41 / 2$ to $61 / 2$, I occupied myself with writing my diary, broke my fast with a good cup of Coffee and sweet biscuit and then started for another long walk. Outside the town, I turned into an avenue which led me to a wood, this I entered, crossed and recrossed it in every direction and enjoyed the delicious shade afforded by the thick foliage of beeches and oaks intermingled with firs. Here and there seats and benches were placed for the weary wayfarer, and I must confess perhaps to my shame that all the while my imagination was haunted by the image and round contours of Mrs. Hansen. I recalled to my memory every circumstance of our yesterday's short interview, I retraced in my mind one by one all her fascinating features, I regretted her somewhat reddish hands not in correspondence with her otherwise perfect beauty. I recollected a somewhat malicious observation of Miss Folk who herself white as alabaster said that since Mrs. Hansen had resided in Holdness, her complexion had much improved, by which the fair critic meant to insinuate that mistress Hansen on her fist arrival from the west Indies had been rather dark; fortunately, vivid as the impression was made upon me by that fine woman, it was neither deep nor lasting and was soon effaced by the continual succession of new objects which presented themselves in the course of my travels. On a small eminence close to the wood stood some chairs placed there it would seem on purpose that the tourist might rest and admire the prospect around. Just behind me I had the wood, near to it a meadow covered with wild flowers, then further back another wood in front of which corn fields, here and there white houses peeping through and so alternately woods and fields, until the pretty place of Gravenstein came in sight; then followed the Sund where it joined Flensburg-bay; on the other side, just discerneable the shore of Sundervidt, next, more or less opposite to where I sat, the red roofs of the town of Eckernsund whence a continuation of woods and fields similar to those on this side, drawing round the North-Eastern extremity of the Sund again joins the wood behind me. The waters before me were hardly rippled by a slight breeze. Two small vessels lay at anchor, a boat 
came rowing across, at my feet I descriyed a rye field, then a sand or marl pit where a [_] was occupied with loading his cart and driving thence to the large building which I had seen on the previous evening, and thought to be a Sawmill. The whole landscape was lighted up by a cloudless sun and with [511] difficulty did I at last tear myself away from this beautiful spot. I crossed the high road, entered the park of the castle, and soon found myself in a forest, where the ground was strewn with the branches, twigs, and leaves torn off by the strong wind of the preceding days. This forest extended so far that I had to return without reaching its boundary. I then skirted the lake until I came nearly opposite to the small balcony where I stood last night. Now I had in front of me the castle, on one side of the lake the thick wood, on the other the neat Gravenstein. When back in my hotel, I took a stroll through the garden, and on observing a bathing house, asked for the key which was of course given to me, but the water still saltish was so very cold that I jumped out quite as quickly as I had jumped in. Now it was high time for me to leave, and the landlord's Stuhlwagen brought me to the shore of the narrow strait of the Baltic which separates the Island of Alsen from the Duchy of Schleswig. The Country through which we drove was similar to that of yesterday. The road lay round the Sund, and the double steeple of Broacker remained in view nearly till the very moment that we touched the Baltic. The Strait is so very narrow, that the town of Sonderburg situated in the Island of Alsen when seen from a short distance does not seem to be separated by the sea from the main land. A boat took me across, I deposited my luggage in an hotel and at my request was shown to a quadrangular building called the palace, built of bricks and in a very ruinous state. Here all the members of the Augustemburg family have been interred for centuries back. I entered with my guide into a rather decayed church or chapel on the walls of which the arms of the house of Sonderburg were cut in stone. Above the door leading to the apartment in which the Coffins were deposited, were represented in alabaster the last Duke of Sonderburg, John the younger with eight princes, and his second spouse Isabel with six princesses. I was rather disappointed, for the lantern carried by my guide certainly did not suffice to dispel the obscurity which surrounded us. In the first chamber stood the coffins, all adorned with gold and silver of two of the Holsteinbecks, now called Glucksburg, as well as those of the Sonderburgers, from the time when the first Ernest-Gunter until then merely Duke of Sonderburg came in possession of the property of Augustenburg. In the second were piled up the Coffins of the family of Sonderburg before it became united with the Augustemburg. I felt glad when I was again in the open air, and then took a walk along the beach, about the country [512] and through the town which has two churches, one street long and wide with several smaller ones, a 
few large edifices, and an abundance of small houses. I amused myself with reading the names painted over the shop doors, with few exception they terminated in Sen, which corresponds to the English "Son", and the German "Sohn", and clearly showed that I was fast approaching a country where Danish is the native language. There were Jansen's, Hansen's, Clausen's, Bendixen's, Ohlsen's, Nielsen's, Asmussen's, Danielsen's, etc. Both, town and country people, were upon the whole of a fair complexion and light hair. I observed but a few who looked darker, no doubt of Foreign extraction. I again engaged an open carriage to carry me to Fynshav on the Eastern shore of Alsen. We were hardly outside of the town when the road rose a little and the whole Island lay before me, it is generally level, here and there a little undulating, well cultivated and the rich corn fields are intersected by hedges interspersed with an occasional small wood. The high road was excellent, every peasant was obliged to keep a small part of it in good repairs at his own cost. From the North a small bay penetrates into the island, on its opposite Eastern side, lies the Castle of Augustenburg, an artificial dyke crosses the bay, and a straight avenue of Lime and Horse Chestnut trees leads up to the Castle, a handsome building. Through a wide gateway we entered a spacious yard; in front was the Duke's Palace, on both sides other houses such as those inhabited by his suite, the manège, stables, etc. The Duke, brother to the queen of Denmark (spouse of Christian VIII) a great amateur of fine horses, was standing at the door, and looking with complacency at some beautiful animals mounted by smart jockeys. I having alighted, and not knowing whither to go perceived two gentlemen whom I addressed in German. One of them who, I afterwards learned, was the Sub-Inspector, very politely offered himself to show me round. We walked through the park, rich in beautiful trees. It extends as far as the bay, my companion told me that there were pheasants, stags, deer, and hares in abundance. In a large cage a small Eagle wounded by my guide and then caught, was preserved. Eagles of that description appear in the Island in the beginning of Spring from the South, whither they return in autumn; during this short residence they are very preju[_] to the hares which they carry off and devour. On my mentioning to my companion that I was from Altona, he told me that a townsman of mine lived at the Duke's, and he insisted upon taking me to him. [_] [513] was Bahrt, first Inspector in the Ducal service. I remembered him as a fellow pupil in the class of Selecta in the Altona College. He also recollected my name but received me so coolly that I remained but a short time. He was now a married man with family, and he had been with the Duke more than twenty years. I bade good bye to my polite companion, remounted my carriage and continued my drive to a few houses called Fynshav on the shore of the Baltic. It was now five oclock. I easily obtained a boat and was 
rowed to two larger vessels provided with sails, at a short distance from the island. One of the two with two men on board was on her way to Fyen; I stepped into it. Far to the East this last named Island was distinguishable at the verge of the horizon in the shape of a dark line, so was the island of Aroe to the South whilst the woody shore of Alsen was still clearly visible. There was hardly any wind, the sails flapped against the mast, and by dint of rowing was I carried across to Boyden in the Island of Fyen. The passage was a tedious one, and I, well wrapped in my big cloak slept the greater part of the time. It was past eleven when I landed at Boyden in Fyen. Two Custom house officers immediately presented themselves, who very politely and superficially examined my luggage; in the public house to which it was carried, the landlord was the only one who spoke a little German. Now for the first time I found myself in a thoroughly Danish country. The travellers room was filled with men who had just returned from a horse fair in Faaborg, and I was surprised at their high stature. Professor Arndt observes that, of all the inhabitants of Northern Europe, those of Jutland and South Sweden are the tallest, and that those of Sealand and the other Islands are shorter and of a darker complexion; if he had seen the fine specimens of Fyenmen I think he would have altered his opinion. In the same manner as in Graveinstein, I had in my bed a down mattrass and a down cover[_]. At 11 1/2 the North Western sky still preserved the reddish tint produced by the sun which had set in that quarter, and without artificial light, without moon or star light, I could clearly distinguish the hour which my watch indicated.

Wednesday, $19^{\text {th }}$ of June 1844. At half past five the landlord called me; whilst I was still in bed the servant girl, very fair, brought me a cup of coffee, I then rose, and left Boyden in a Stuhlwagen roughly made of boards with two seats, one for myself, the other for the driver who was [514] a Danish postillion. With him I tried to enter into conversation and as is always the case when one commences to speak a Foreign language I succeeded better in expressing myself than in understanding what was said in reply. To the North of Boyden the Sea forms a bay which for some time remained in sight. The aspect of the country was in every respect less pleasing than either in the Duchies or in the Island of Alsen. The road, confined on both sides by barren stone walls, not by bushes and hedges, was out of repair, there was a scarcity of trees, the peasants' houses which we passed, looked less neat and comfortable, the soil less carefully cultivated. At the gate of Faaborg which is but a small town, a Custom house officer addressed me in German and allowed me to pass on without searching my luggage. My postillion took me to an inn, probably the best in the place, where I was shown to a room which had just been left by another traveller, and still about being being cleaned by a servant girl. The sky was clouded, it rained, 
and at 12 oclock the thermometer stood inside my room at ${ }_{13} R .=61$ Faht. I was called to dinner, and went below into a large low fairly furnished room where the landlord who spoke a little German received me as if I was a friend of his, not a stranger who paid for his board. We two sat down together, and in his Company I spent a pleasant hour; we had excellent broth with bread dumplings, Fried fish, mutton chops, and a bottle of Bordeaux wine. He accompanied me to the house of Jorgen (George) Ploug, Swedish Consul, who not being at home we went to his mill a little outside the town, where he was superintending the building of a new house. I should have recognized him anywhere, his features were not the least altered; he had only grown older and stouter, he had a pipe in his mouth and his teeth were schockingly dirty, a brush for a certainty had not come near them for a number of years. The good natured and good tempered Clerk at J. J. Reinckes in Altona in 1822 had in 1844 ripened into the burgher of weight and importance in the small town of Faaborg. He invited me to take up my residence with him, but on my declining his offer he did not insist, and having exchanged a few words in Danish with his wife, which I did not understand, he observed that the fresh paint of the only room he could place at my disposal, might be injurious to my health. Together we walked to a small farm of his close by, where the walls of the principal room were hung with the portraits of his ancestors painted in oil. Within the precincts of the Garden lay the highest hill in the whole Island of Fyen two hundred feet above the [515] level of the Sea; from its summit we saw before us the Baltic dotted with many islands, and this view Ploug did not hesitate to compare with the far famed natural scenery of Switzerland. "Why," said he, "is Switzerland praised up to the Skies? because at one glance one sees Land and water, water and land, and have not the same here before us?" In 1844 I had not yet visited Switzerland and thus was unable to gainsay him; but at present in 1869 having visited that country twice I may assert without running the risk of being contradicted that a more ridiculous comparison than Ploug's was never made. The beauty of the Alpine Scenery consists in the contrast between the towering snow capped mountains and the rich valleys below, between the glaciers and the fresh green vegetation round their icy bases, it consists in the flower enamelled meadows with their neat "châlets", it consists in the elegant villas and hotels surrounded by the gardens, parks, and woods; it consists in the placid lakes whose mirror like surface reflects the objects around, it consists in the rushing cascades, the one dissolving itself into tiny rills, the other precipitating volumes of water. All this, and much more does the traveller in Switzerland see and admire, but what did Ploug and I see from the mole-hill upon which we stood? the Sea and an Island, again the Sea and an island, and once more the sea. In a like preposterous manner did Ploug discover a similarity 
between the small woody island of Bjórnóe (Bears island) and the island of Ischia in the bay of Naples. The island of Lyoe has an historical name, it was here that Waldemar the conqueror or Victor, King of Denmark who had probably gone thither for the sake of hunting, was surprised and carried off by his enemy the Duke of Schwerin. He was kept prisonner for three years and finally released on hard conditions to the thorough fulfilment of which he bound himself by a solemn oath, but hardly had he recovered his liberty when he applied to and obtained from the Pope the cancelment of this oath, whereupon to revenge himself on the Duke of Schwerin and his other enemies he levied a numerous army and invaded Holstein where (See Page 432) he was defeated near Bornhoved in the year 1227. We returned to the mill, paid a visit to Ploug's counting house and being impeded by the high wind to take a walk along the quay as we intended, closed the day with a light supper at a mill in Company with Mrs. Ploug a relation of her husband. She was a very insignificant woman, much inferior to the interesting ladies Mrs. Pelt, Mrs. Blume, and Mrs. [?] whose acquaintance I had made lately. The Children were Elisa, Petra, and [516] Simon Hampel which latter had been the name of Ploug's father, their respective ages nine, Eight and seven. Ploug spoke to me a good deal about the business he was doing, and about the great credit he enjoyed, he showed me letters of Baur's, Donner's and Reincke's of Altona which were written in a very polite and friendly style, he told me that he had a large establishment in Odensee of which a certain Reichardt formerly his clerck had charge. In his political opinions he was an ultra-Dane though he would not confess it. Lately some differences had taken place in the town of Schleswig where deputies from the Duchies had met, between the majority who spoke German and a few who made use of the Danish language which latter had withdrawn; the King had published a decree favouring the former. This had been very ill received by the whole Danish population and numberless petitions had been presented to the King requesting him to revoke this obnoxious Decree. Ploug himself had collected many signatures to this effect. This and similar disputes which occurred daily between the two heterogeneous parts of the population of Denmark, the inhabitants of the Duchies who with the exception of a few living in the most Northern part of Schleswig speak German, and the inhabitants of Jutland and the islands who speak Danish, were the precursors of the rising of the Schleswig-Holsteiners in 1848. As long as Christian VIII reigned, his wise and temporizing policy prevented an outbreak, but hardly had he closed his eyes and been succeeded by his son Frederick VII when the flame burst forth, which was quenched in the blood shed in the battle of Idstedt on the 25 of July 1850 . After this overthrow the Schleswig-Holsteiners uneasy and dissatisfied bore the Danish Dominion for fourteen years till 
november 1863, when the death of Frederick VII and the consequent extinction of the Royal Oldemburg branch in the male line revived their hopes to form an independant principality ruled by the Duke of Sonderburg augustemburg, the eldest son of him whom I had seen in the Castle of augustemburg, this latter (the father) having previously renounced his rights. Then as everybody knows Prussia and Austria interfered, the Duchies were conquered in 1864, and incorporated with the Kingdom of Prussia in 1866. In the appendix under number 14 will be found a pretty genealogical table of the house of Oldenburg. I learned from Plough that in 1843 the island of Fyen had produced from 6 to 700,000 tonnen of grain, the average value of the Tonne [_] from seven to nine Marks curry. 21 Tonnen Danish are [517] equal to one English last of forty quarters. 24 Tonnen (Danish) make one Hamburg last. Herewith a Scketch of the Southern part of Fyen which gives an idea of the small islands lying in front of Faaburg.

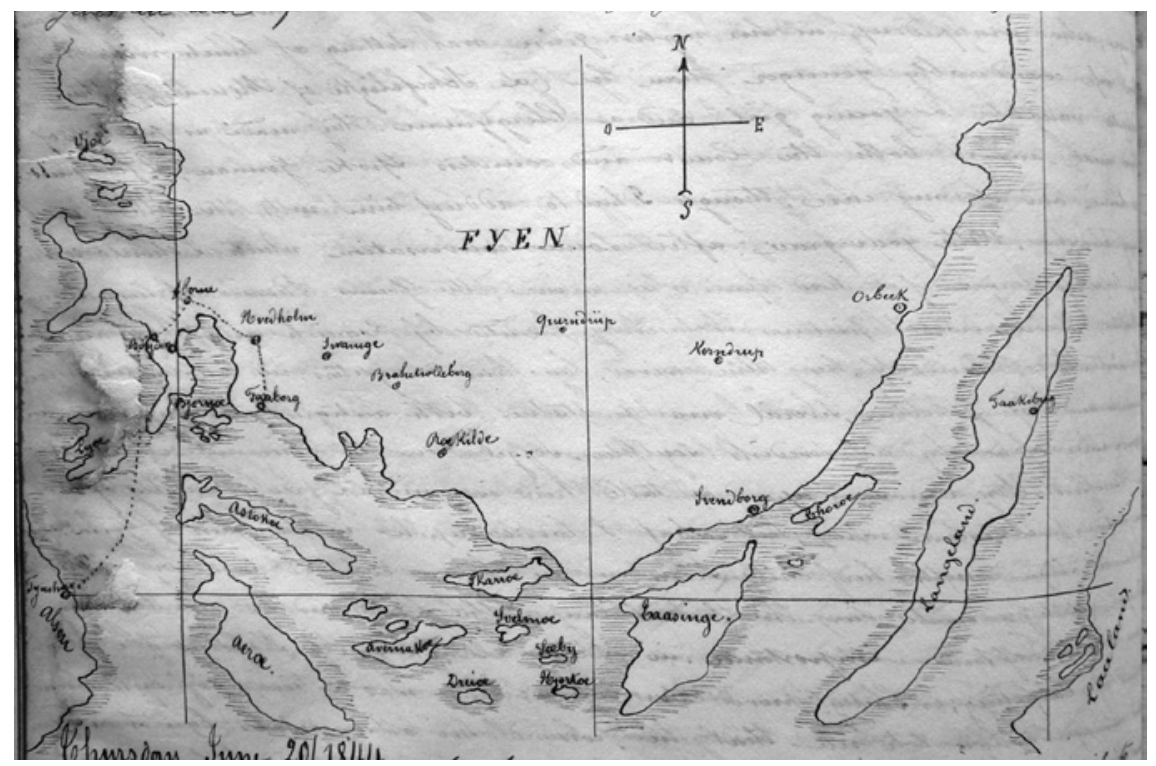

Thursday, $20^{\text {th }}$ of June 1844. Also here it was the custom for the servant girl to bring the coffee and sweet biscuits to the traveller early in the morning whilst he was still in bed. Ploug called, he showed me his granaries filled with Rye, Barley, and Rape-seed. All grain before being shipped are usually dried either by artificial heat or by the heat of the sun. By this process they loose in weight but fetch a somewhat better price, because being dried they are less exposed to become heated on board and to spoil in consequence. Ploug likewise showed me his stock of wine which he had for sale. Bottles made in Denmark cost two Shillings Currency each, in Germany they stood in much cheaper but the high import duty of two Rbk. Sh. per bottle rendered their importation impossible. 
We lunched at the mill and then drove out in a carriage half covered called a chaise. Our first visit we paid to the Count of Bille-Brahe residing in his estate of Hvedholm, a short distance out of town on the road to the Boyden. The main building of an ancient Structure and irregular, stood in front, [518] on both sides the customary out-houses, stables etc. formed a large yard, behind the main pide or dwelling house, another smaller yard. Having sent in our names we were admitted and received by the Count, seventy two years of age, who wrapped up in his night gown was sitting at lunch with his third wife, considerably younger than he (a Schefelizki of Mucat[_]), their adopted daughter a young girl, and a Clergyman. They made us partake of their meal and as both the Count and the countess spoke German, I felt quite at home and at my ease, though I had to address him with the title of excellency and her with your grace. After some conversation which I should willingly have prolonged if it had depended upon me, the Count showed us his many collections, in one room pictures exclusively painted by Danish artists, in another the portraits of himself, his three wives, sons and daughters, in another numerous Danish and Foreign coins, several marble statues both antiques and $[\ldots]$ an amor and Psyche by a Swedish sculpter, Sergel, on the stair case the bust of a Bacchante by canova, upon a table laid in with a great variety of lava, an antique Etruscan vase, but what I looked upon as the Gem of gems, was a small virgen with her child Jesus, cut in brown coloured wood by Albrecht Durer, nothing could surpass the delicacy of the workmanship. His 1[_]y was likewise of some importance. In short all I saw, if I except the total want of carpeting, evidently proved that the Count was a man of taste, education and money. Ploug told me that he possesed two other estates Egestor in Fyen and Svaneholm in Zealand (Danish Sjalland) his gross income was calculated at 25 to 30,000 Species annually. His second name of Brahe he had adopted from the last descendant of the famous astronomer Tycho-Brahe who left him all his property on condition that he should bear his name. We now bade good by to the Countess, Ploug kissed her hand, I merely shook hands. The Count accompanied us to the door; we descended into the park, had a look at the stables, cow-houses and the dairy, which latter establishment was superintended by a holstein woman with a splendid row of teeth in her mouth. Hvedholm had at the time 120 cows, the poultry yard stocked with many turkeys, geeses, fowl, etc., was of a size larger than many a garden in Hamburg or Altona. There was a fine pond in the middle and the house for the birds to roost in was clean and airy. We remounted our carriage and drove to the village of Horne which curacy as well as that of Swannige, forms part of the Counts domain. In the church over the altar stood a beautiful picture [519] painted by Eckersberg in 1812, it represented the Saviour calling the little ones to him. On 
the right side of the picture is our Lord in a sitting posture with a finger of the right hand lifted-up, with the left arm he takes hold of a boy eight or nine years old who clings to him full of confidence, behind him is the "varonil" face of Saint Peter, two others apostle stand in the background, on the left side three beautiful women each with a child in her arms. They listen with attention to the words which proceed from our Saviour's mouth. Two of the Children, little angles in beauty, full of innocence, stretch out theirs hands, whilst the third, a babe takes no notice of what is going on round him. An elderly woman behind the three is the last figure on the canvass Page 185 of this volume I promised the readers of these extracts if ever they should find any, which I much doubt, that I should never inflict upon them the tedium of a description of paintings, I hope they will excuse this one deviation from the rule then laid down. The graves in the Churchyard of Horne were mere rustic mounds adorned with flowers and shrubs. In the midst of them rose a splendid mausoleum not of marble but stuccoed, it belonged to the family of the Count Bille-Brahe. The Verger opened it to us, the light fell into it through three windows in the shape of crescents, the interior was occupied by four large sandstone coffins, the inscriptions in gold letters on the two on the left say that in them lay the mortal remains of the Count's two first wives, the two others still empty were destined for himself and his third wife. From Horne we drove to the village of Svannige. On the road I observed peasants cutting turf, and the soil appeared to be of a swampy nature; we entered into a peasants house and I was much pleased with the air of neatness and comfort which prevailed. Ploug, an ultra patriot in his feelings, assured me that the peasants of Fyen were more civilized and educated than those of Zealand; they know that they are free-man. whilst to the benighted minds of the Zealanders, this Divine truth has not yet dawned, these were more or less Plough's words. A little girl with wooden high heeled shoes usually worn here, with a Lantern in her hand showed us to a tumb of the old ancient Pagan warriors of Fyen similar to the Hunen graves previously spoken of (See page 488/9). The entrance formed by big stones four or five of my paces long was so narrow that I could hardly squeeze myself through and so low that I had to stoop considerably, the grave itself was high enough for me to stand up-right in it with my hat off, it measured in one [520] direction fourteen, in another nine of my feet. Both the walls and the ceiling were formed of enormous stones. The bones which once rested here, had probably been removed long ago. A Schoolmaster had charge of the keys of the church of Swannige, which Ploug was desirous to show to me. We went to the schoolhouse where a number of girls and boys all cleanly dressed were occupied writing on theirs slates and imitating the models before them. The complexion of some of them bore out Professor Arndt in his above noted observation as to 
the darker color of the inhabitants of the Danish Islands. One of the girls accompanied us to the Church. Hardly had we entered it when my attention was attracted by an exquisite bas relief in bronze on the wall, which had been presented by the Count of Bille-Brahe, it was modelled by Thorwaldsen, when it was cast, I did not learn, it measured in height about three feet, and represented one of the deeds in Danish history on which the Danes pride themselves. There stood the fine figure of John of Rantzaw, King Christian the third's general in full armour, spurred, a plumed helmet on the head. He listens attentively to a tall man, barefooted, wrapped in a loose gown, kept together by a cord round his waist, the schoolmaster Hans Matzen just escaped from prison who relate with energetic gestures the details of a plan formed by the Lübeckers, which he had by chance overheard. The features of both men are noble and impressive, not so those of the Secretary who notes down on a tablet Matzen's statement. Behind John von-Rantzau an old warrior was visible, also an [esculchon] with the arms of that noble house, in the back ground the Danish flag with the Daneberg cross. This occurred in the year 1535 when the Lübeckers had landed in Fyen under the pretence of replacing on the throne of Denmark King Christian II who having made himself odious to his Subjects by his despotism and cruelties, had been disposed by his paternal uncle Frederick I, Christian III father. John of Rantzau doubted for sometime Matzen's veracity and only allowed himself to be persuaded when the latter vouched with his head for the truth of his assertion. He then took his measures, and in the battle which was fought in consequence at [Oxne]burg near Asens, the Lübeckers were totally defeated. The Church itself was kept clean and in good order. Above the altar hung an old painting of the Crucification renovated by order of the Count but preserving its original ugliness. Altar cloth was of red velvet with golden fringes, on the same, in golden letters, the initials of the Count's [521] name P. B. B., Preben Bille-Brahe with an embroidered golden crown over them. This seemed to me rather out of taste and I learned with satisfaction that a repetition of such and similar vainglory in the house of God, had been prohibited by the Superior Ecclesiastic authority. We drove back to the mill where dinner was waiting for us, Ploug had invited a young Faaburger who spoke German to meet me. It seemed strange to me that the roasted veal as well as the roasted chicken was served without vegetable whatever, instead of them stewed french prunes and cucumber salad. Dinner over Ploug and I walked to town to a club where the comercial and agricultural aristocracy of Faaburg and its environs including the Count Bille-Brahe met to plat at L'hombre. I stayed but a few minutes and then walked out of town to the Cemetery so prettily laid out that it might serve for a promenade. The greater part of the graves were adorned with shrubs and flowers, and the few 
monuments there were, were plain and unpretending. I also visited the quay which was of inconsiderable length. The trade of Faaburg is confined to the export of grain, there were only six vessels in the port. In my room in the inn I wrote my diary, but was interrupted for sometime by a female servant who entered under some pretence or other. Her business was to take care of the cattle, of course her hands were coarse and large, and her features common, but her complexion was such as the ladies of the highest rank in this and other lands, would have envied. Her face, forehead, and neck were as white as the driven snow, and her rosy cheeks glowed with the bloom of health and youth.

Friday, $23^{\text {st }}$ of June 1844. The Sky was clouded, it even rained and this unfavourable state of the weather prevented me from enjoying the many prospects which Ploug assured me this day's drive would have afforded me if the day had been clear and which he did not hesitate to pronounce equal to any he had seen in Switzerland or Italy. At a very short distance out of town we passed a building which the Faaburgers used for their balls, concerts, and similar social parties. Ploug told me that a wonderful equality reigned in the Faaburg society the families of Shoemakers and tailors were in the habit of meeting on an equal footing with those of the higher classes; and even with those of the nobility they beheaved he said with the greatest propriety, and the most critical eye could not have found any blemish in theirs manners. I did not venture to express my doubts on the subject, for Ploug gave me to understand [522] that it was he who had in a great measure contributed to this astonishing Republicanism in the small world of Faaburg. The first estate at which we alighted belonged to the Baron von Holsteen, but the exterior of the house and the garden were so common place, so much like hundreds of the same kind which I had seen that they did not make the least impression on my mind, so much so, that when only twenty four hours later I attempted to give a description of them on paper I had not the slightest recollection. Thence we drove to Brahe-Trolleborg owned by the Count von Reventlow, husband of a von Sch[i]mmelmann, sister of the Count of the same name who had married the daughter of Count Conrad von Blucher-Altona. The principal building was old, irregular and ugly, it was connected with the Church in which the baptismal font adorned by the Genius of Thorwaldsen was the sole object of interest; the four sides of the font were sculptured in bas relief, the one represented Saint John in the act of baptizing Christ, the second, the virgin with the two children Jesus and Saint John the Baptist, the third our Saviour calling the little ones to him, and the fourth, three angels, Faith hope and Charity. The outhouses were built in an elegant modern style, the park was extensive, laid out with taste and had a small lake in the center. Whilst walking about in it, we met a Gentleman whom Ploug was well acquainted with, his name was Khrön 
and he was the Doctor of this estate. He was an extremely lively man, spoke much and in a loud voice, but so clearly did he pronounce his Danish, that I understood the greater part of what he said, and to my own astonishment, was not at a loss for a single answer to the many questions which he made about South america, and this in Danish too? He made us lunch with his lady whose Danish was less intelligible to me; the conversation touched by chance on the marriage of a servant girl of the Count which had been celebrated a few days previously, and on this occasion I learned the particulars of some customs prevalent amongst the Fyen peasants. All those who are invited to a wedding, and at this of a servant girl, not less than $18 \mathrm{o}$ had been present, sent dishes of every kind to the house of the bride's father where the banquet takes place, the day of the wedding itself they even make presents of money. When the couple to be married drive to church, on their going, the carriage with the bride takes the precedence, on the return, that of the Bride groom. [523] Both the Doctor and Ploug were ultra Dane and consequently anti Schleswig-Holsteiners in their political opinions, they complained bitterly that the German population in the Duchies was doing its utmost to suppress the Danish and spread the German tongue. The town of Hadersleben, they told me was ultra German, the peasants in the neighbourhood ultra Danes, and the latter had convoked a meeting of the friends of Denmark to be held on the $4^{\text {th }}$ of July upon a hill called Shambings Banke for the purpose of resisting the "intrusive Germans". Ploug intended to be present at the meeting. we returned to the mill, dined, and the evening I spent with Ploug, his wife, his sister, and the young Faaburger of yesterday, called Voigt. We three gentlemen played whist with a dummy, whilst Mrs. Ploug was knitting her stockings. The Tonne which is the land measurement in Fyen is equal to 1400 square Ells, each Ell 28 Holstein inches.

Saturday, $22^{\text {nd }}$ of June 1844. The weather had cleared up. At 10 a.m. a Stuhlwagen belonging to the Royal Post stood at the door of the house of old Mrs. Ploug, my friend Ploug's mother. we lunched with her and then mounted our carriage, the first seat was occupied by the postillion in his uniform, a red jacket with yellow cuffs and yellow facings, the second by Ploug's sister Mrs. [Toxvardt] and her two little daughters, the third by Ploug and myself, behind us the luggage was stowed away. The goal of our this days journey was Odensee, the Capital of Fyen five Danish miles distant, lying due north from Faaburg. Our drive took us right to the island. The country flat and fairly cultivated was uninteresting, only the lake of Arveskor near Brahetrolleborg broke its general sameness. I have already observed that this island is poor in trees, some of them still grew in the vicinity of Faaburg, but the more we drove north the scarcer they became. We passed through no town only through several villages, of which that of [Sunderbracky] about half way was the most important, it is 
situated on the banks of the largest river of which Fyen can boast which is but a small placid rivulet called Odenseaa and which passing through the capital falls into the bay of the same name. The churches in all these villages were without steeples, theirs roofs were pointed, finishing at each end more or less in this manner odensee which we reached at two oclock is a town with a population of about twelve thousand souls. The houses upon the whole were small and a few larger ones owned by some of the wealthy inhabitants such as Foxvaerdt the brewer, Richard the enterprizing merchant [524] and others formed the exception. At Richardt Ploug had a bed room with two beds for himself, this he had the kindness to offer to me for the night, and I willingly accepted it instead of going to an hotel as I had intended to do. The rooms in which Richard and his family lived were prettily furnished, and had they been carpeted, I should not have found any fault with them. In the counting house all was bustle and activity, and Ploug assured me that no firm in Odensee did as much business as his. In a large store on the ground floor many articles, Colonial produce and manufactured articles excepted were being sold. Ploug, good patriot as he was, now accompanied me to show me what was worth seeing in Odensee, but which in reality was equivalent to nought. We first went to the garden which belonged to the building called the Palace of the Viceroy of Fyen, who at the time was Christian VIII's son by his first marriage, Frederick heir presumptive to the throne. He was absent on an excursion to the highlands of Scotland; his spouse, a princess of Mecklemburg Strelitz who it was well known led a most unhappy wedded life, was on a visit to her family. The garden was small, had two or three fine avenues and a pretty vestibule filled with Rose bushes, now covered with flowers, which we were told was the favorite haunt of the Princess. Our next visit was to a garden a small distance out of town in which I found nothing worth noticing. Our third was to the principal church, that of Saint Canute, the only one in Odensee with a steeple, the inside was kept clean and was adorned with some paintings and statues, round the high altar were those of Saint Canute, Moses, the Apostles and the Evangelists. Two very ancient coffins were pointed out to us which it was said contained the mortal remains of Saint Canute and his brother, both murdered at the foot of an altar, in another, not in this Church. All that was shown to us was not worth the Rbk. dollar with which Ploug remunerated the verger. At seven p.m., Ploug and I went by invitation to a friend of his Mr. Hansen who took us to the roof of his house where the weather having become fine, and the day clear, we had an extensive view over the surrounding flat country and the bay. In a garden which extended to the bank of the Odensee Mrs. Hansen, her daughters, her son, and some friends were waiting for us with tea, or as the Danes more properly call it (Tea water, "Thee vand"), with various kinds of cold 
meat, shrimps, radishes, bread, butter, etc. All were kind and civil towards me and I managed to get on pretty well with my broken Danish. The river was alive with boats, most [525] of them rowed by young ladies, all enjoying the beautiful evening. Our party was also rowed over to the other side where Mr. Hansen had a larger garden; here the young folks and I amused ourselves with a swing. Ploug and young Hansen rowed us as far as a bridge which connects the two halves of the town and at nine oclock, we gentlemen went to a club where we sat down to whist. They played here the game of five points, without honors, the tricks they did not mark with markers as is done everywhere-else, but both tricks and games were chalked down on a slate, it was past eleven when Ploug and I retired to our bed room. The $22^{\text {nd }}$ of June is, as everybody knows the longest day in the northern hemisphere. Odensee lies in latitude about $551 / 2$, and thus, the interval between the cessation of twilight in the evening and the break of dawn in the morning was extremely short, if any at all.

(See Sunday 23 page $5^{26}$ ).

Monday, $24^{\text {th }}$ of June 1844. Thermoter 16 Reamur $=68$ Fahrenheit. In the forenoon I had some conversation with Mrs. Foxvoerdt who having lived several years in Lübeck spoke German fluently and with Mrs. Richardt who was now somewhat more lively that she had been on the previous evening. With her husband I chatted a good deal; Ploug and he besides being the principal if not the only bankers in Odensee, did much business in all kinds of grain, which is the most dangerous article one can have to do with, because as the fluctuations in the price depend only on the vicisitudes of the weather, it is beyond the reach of the most prudent and experienced merchant to make any reliable calculation as to the future state of the market. About 2 in the afternoon the mail Coach, "diligence" came through from Middelfahrt. This carriage was divided in three parts, I with two Danish gentlemen occupied the foremost immediately behind the horses, my companions were agreable men, but unfortunately my imperfect knowledge of the language precluded the possibility of my deriving any pleasure or advantage from their conversation. The country presented not the slightest variety, it was exactly like those parts of Fyen which I was already acquainted with. At about five oclock we reached Nyborg apparently a strong fortress. We passed the first bridge over a Ditch, next under a strong vaulted gate, over a second bridge through the second gate, over a third bridge, and then through the town, once more under a gate and over a bridge to the quay close to which the steamer was moored ready to receive us. We stepped on board, a few minutes later, were under weigh. The number of passengers was perhaps twenty, some German Jews, one of [526] them with his very handsome young wife an English Jewess, the remainder all Danes amongst whom I observed a particularly pretty young lady. Her 
fingers and ears glittering with diamonds, rather out of place I should think on a journey by sea and land. This fair one accompanied by her sister was the mistress of Count Ahlefeld of Laaland. Nyborg seen from the water side presents a pretty appearance. It lies at the western extremity of the bay which penetrates into the land from the great belt. As soon as we were outside of the bay, we kept for a short time close to the shore, along a narrow neck of land, on the other, the western side of which the bay was clearly seen. We then stood across the great belt towards Corsöer, leaving the island of Sprogöe to our left - before the coast of Fyen was out of sight, that of Zealand was in sight. We entered the bay of Corsöer through a rather narrow passage; the bay encircled by hills covered with vegetation and gradually slanting down towards the water's edge, is large, the town itself with some windmills in its vecinity lies to the South in a narrow neck of land between the belt and the bay, a few vessels, and few they were indeed, considering the wide expanse of this beautiful sheet of water were anchored close to the shore, under the shelter of the very houses. A coach similar to that in Fyen was waiting for us at the mole, we mounted, and off we drove. When in Fyen I noted the inferiority between this island and Holstein and Angeln as regards fertility of the soil and the apparent neatness and comfort of the peasant houses, now it seemed to me, as if there was again a falling off between Fyen and Zeeland. The Sunset at 9 was a glorious sight. At $91 / 2$ we stopped at Hagelsee for a cup of Coffee, thence forward, though my seat in the middle between two gentlemen was rather inconvenient I managed to go to sleep. I awoke then a few minutes at Ringstedt, where we were at $121 / 2$ oclock, and at four in the morning we arrived at Roeskilde, ten miles from Corsöer. My fellow travellers continued their journey to Copenhagen, even the pretty Danish Lady did not look so enchanting as she had done in the afternoon, a night passed in a stage coach is a formidable destroyer of good looks. I alighted at the inn where the coach stopped, a bed room was pointed out to me and I went to bed.

(See Tuesday June 25/44 page 528).

Sunday, $23^{\text {rd }}$ of June 1844. In the Course of the forenoon Ploug, Richard and I went on board some Vessels anchored in the Canal which connects the Odensee with a small bay to the Westward. I did not ascertain at the time for what reason this Canal had been dug and why instead of [527] doing so, the Odensee itself which flows into the bay to the East had not been deepened. At four in the afternoon Ploug returned to Faaburg during the three days which he and I had now been together, he had shown me great kindness for which I felt very grateful to him. We have not met since; if I am not mistaken, he was obliged to stop payment some time after, and died a few years ago. I dined with Richard and family. Here in the same manner as in Faaburg no vegetables came on the 
table, the roasted fowl was served with pickled gherkins and sweet conserves after which first rate strawberries with cream and sugar and finally a good cup of Coffee. The weather had become beautiful, Richard and I took a drive in an open carriage round the town. The Country was in every respect like that I had come through on my way from Faaburg. As a peculiarity of the peasant women's dress I have merely to note their wooden slippers and their uncommonly wide brimmed hats made of paste board painted and varnished. Richardt and I got off our carriage near a small wood in the centre of which was the ball room of the Odensee people say a circular piece of ground where the trees had been cleared away and which was boarded, round it wooden seats for the lookers on, as well as for the musicians and a box raised a little above the rest for the Chamberlain von-Benson, a wealthy landowner in the neighbourhood who had presented the town of odensee with this rustic saloon. Of course it could be only of avail when the weather was dry and fine. When this was the case, on sundays or holidays a flag was hoisted on an elevated building in the town, and the young folks then flocked out to the wood to enjoy the pleasure of a dance, so they had done this afternoon. The space was divided by a rope into two parts; the smaller one for the Children, the larger one for the grown-up people, the fair sex were dressed in printed calico gowns, a shawl over their shoulders and a straw bonnet on their head. There were many pretty faces, no beauty, and not one handsome figure. The men all in black, wore generally dress coats, a few, frock coats and had their hats on. Cotillons and waltzes were the only dances. I suppose that those who met here were of the middle classes and that the Faaburg Republicanism had not yet been introduced into the Odensee Society. The Chamberlain Von Benson with his family, in his box, looked-on; so did the bishop and the Curate of St. Canute. To these two Gentlemen Richard introduced me; they had the attention to speak slowly and distinctly, and thus enabled me to understand what they said, and to converse a few words with them. After our return, Richard [528] and I went to sup at a certain Mr. Maar. Supper stood already on the table when we arrived; it consisted of cold meat, shrimps, a splendid lobster, anchovies, etc. etc. The drinks were Bordeaux wine and a bowl of punch. To me it was a very tedious party, the conversation was carried on all in Danish which I could not follow. Near me sat Mrs. Richard, extremely taciturn. Perhaps she disliked to hear her native tongue mutilated in such a dreadful manner as I did. The lady of the house and her daughter were always on the move attending to the wants of their guests, a custom by no means to my taste. Many toasts were given: the health of Mr. Richard, of Mr. Maar, of the ladies, of the stranger (that was I), and finally Mr. Richard who I think was the great man of the feast (Mr. Maar being but a broker), broke-up the repast with the words: many thanks for what we have enjoyed, again a habit far from genteel, at least in my opinion. 
(See Monday $24^{\text {th }}$ of June, page 525 ).

Tuesday, $25^{\text {th }}$ of June 1844. When taking my cup of Coffee and eating my customary biscuit I amused myself with reading the Danish newspapers: an English steamer "the Manchester" on her way from Hamburg to Hull had been wrecked at the mouth of the Eider upon a sand bank called the "Ricoën", all hands on board had been lost. A war had commenced between France and Morocco. The Cathedral in Roskilde is in great repute on account of the many high and noble personnages who are interred within its precincts. Thither I accordingly went. It is a very large and plain building built of brick, whitewashed outside and inside, with three steeples, two high ones at its western extremity, one low one at the East end. Hardly had I entered when so many objects of interest, vaults, Coffins, Sarcophagii, [?], statues, presented themselves that I was at a loss whither to turn first. The interior measures in length 272 , in breadth 82 , in height 82 feet; the walls are generally seven feet thick, those of one of the waults below thirteen feet; the Ceiling is supported by sixteen brick pillars, each nine and a half feet in diameter. In vain did I look for a square central tower like that in York Minster, which I had there so much admired, and of which I said a few words page 297. The organ is on one side of the nave and the high altar about two thirds down the nave is of so small dimensions as to have almost a ridiculous appearance; it looks more like a large Cup board than anything else, also the wood carvings round the same representing scenes from holy writ thickly gilt are of no great beauty. One Chapel was occupied by four coffins covered with black velvet richly adorned [529] with Gold and silver; one of them was still hung with garlands, though the flowers were faded. This was that of the last king Frederick VI, who the faithful and stupid ally of Napoleon I lost Norway to Sweden by the peace of Kiel in 1814, but was nevertheless much beloved by his subjects; the second was his father's Christian VII, who like his brother in law George III of England was crazy during the last years of his life; the third Coffin was that of Prince Frederick the humpbacked, son of Frederick V by his second wife Juliana Maria; the fourth, that of a Prince of Hesse George Philipstahl Brachfeldt. Of Christian VII, my original diary makes no mention, whether this is an oversight of mine, or whether really he is not interred in this Cathedral of Roskilde, I cannot tell. Marble Sarcophagii enshrine the mortal remains of Frederick V, of Frederick IV and his queen, and of Christian $\mathrm{V}$ with his spouse. On each side of that of Frederick V stand two colossal marble statues representing Denmark and Norway bewailing the loss they have sustained; Widervild was the Sculptor. The Coffin of Christian IV covered with black velvet with silver and gold ornaments, stands in a vault below, on the lid lies the Sword worn by him at the battle which he gained in Feemern over the Swedes in the year 1644. The cenotaphsof Christian III and Frederick II of marble and alabaster distinguished 
themselves by their magnitude, each costs 2,000,000 mark currency. The bones of these two Kings lay below in their respective coffins. Upon that of the latter are sculptured in bas relief some of his deeds which contributed mostly to the glory of his reign, amongst them, the Victory over the Ditmarshers in 1559; his motto which was a very strange one, also is to be read here, it runs thus: "Meine Hoffnung zu Gott allein, treu ist 'Wild-pret', which means in English: my trust is God alone, faithful is Venison (this was the name of a favorite dog of his). Not long ago excavations had been made in the chapel which contains these two cenotaphs, and two tombs of bricks well preserved were discovered. They are those of Christian I, of extraordinary length and that of his spouse. Christian I, the first Danish King of the house of Oldenburg was in size a giant, he measured not less than six feet, ten and a half inches. In the same chapel on a granite column finely polished three marks are made. The one uppermost indicating the stature of King Christian I, the second a little lower that of the Czar Peter I, the third considerably lower, more or less my height, that of Frederick VI. [530] Behind the altar the dust of her who was once the renowned Margaret, the queen of the three Scandinavian Kingdoms, who died in 1402, is inclosed in a threefold coffin, the first of wood, the second of lead, the third again of wood covered with black velvet adorned with gold and silver, and round [?] last the marble Sarcophagus upon which the marble statue of the queen lies extended, her head reclining upon a cushion of marble, and on her head a marble crown gilt, her features are handsome, but severe. Four pillars sustain a lower ceiling above the choir, these four columns are hollow and contain the bones of four remarkable persons; the one, those of Harald Blaatand who was assassinated in the year 991 by Palnatoke; the second, those of Margaret who, widow of Magnus Barefoot King of Sweden, married Niels, one of the many sons of Svend Estridsen; the third, those of Svend Estridsen himself who died in 1076; and the fourth, those of a bishop William who must have been a very holy man for it is said that his bones just visible through a Chink in the pillar have worked extraordinary miracles. The entire floor of the Cathedral is covered with tombstones upon which the figures of many Knights, abbots, Bishops, etc., also ladies are sculptured. One of these figures is a strange one; it represents a skull and the upper part of a skeleton a snake like a collar winds round the neck and bites into it. The legend runs as follows: in the year 1504 a young rich Canon left the country and placed in the hands of his daughter a considerable sum of money instructing her to divide it amongst the poor in case he should not return; but she, instead of obeying his mandate had a beautiful Gold necklace made out of the money which the first time she wore it, changed into a snake, and this snake devoured everything she ate, so that in a few days she died of hunger. The tombstone of Saxo Grammaticus is without inscription. Having 
seen all that was to be seen in this mansion of the dead, I returned to my inn, dined, and then took a walk into the country. The weather was beautiful, the larks sang merrily rising higher and higher into the cloudless sky. Roskilde lies at the southern extremity of a bay formed by the Cattegat; its entrance from the north is long and narrow. The land around is flat, more or less cultivated. At the mole which is of small length five or six vessels were unloading theirs cargoes, mostly timber. I came to a pretty village, to a cemetery so tastefully laid out, so well adorned with trees, shrubs and flowers that it might answer the purpose of a promenade. I was back in time to continue my journey by the "diligence" which arrived from Corsöer at [531] six p.m. I had only with me one fellow passenger who spoke a little German; the road from Roskilde to Copenhagen, four Danish miles, was kept in good repair, the country presented the same character as on the western side of Roskilde, villages at the distance here and there, their churches without steeples. Half way is a public house "Roskilde Kroog" where the coach stopped for a few minutes; thence the road was lined on each side with trees. About half a mile from Copenhagen on the right hand side lies the small village of Walbye, the inhabitants of which place have monopolized the butter and cheese trade of the whole island and supply the Capital with these two necessaries of life. A small wood extended from Walbye to the Royal Palace of Fredericksberg at the time the residence of the widow of Frederick VI. On the left side of the road now Country-houses and gardens succeed each other, they go by the name of "Werterbro", and may be called a suburb of Copenhagen. We entered the Capital over a small bridge, and under a vaulted gate a custom house offr. in red uniform jumped up and accompanied me to the post office where he opened my luggage apparently for form sake only; another Employé showed me to the "hotel d'Angleterre in "Kongens-ny-torv" (The king's new market) where I obtained a large, badly furnished room in the back part of the house, that towards the Street being filled with strangers. I went into the street, at half past ten, it was still daylight. The Kongens ny tow is of an irregular shape, and was haunted by the plague of all large towns, public women. Of course, I could not yet form an idea of Copenhagen however the first impression it made upon me was a favorable one, the streets are long, wide, and straight, but the houses upon the whole inferior to those which I had seen in the west end of London, in Dublin, Glasgow, and the new town of Edinburg, and to those about being built in the part of Hamburg destroyed by the fire of 1842 .

Wednesday, $26^{\text {th }}$ of June 1844. The first thing I did after having breakfasted was to purchase a new hat, then a map of Copenhagen provided with which and having looked in the directory for the domiciles of the various people to whom I had letters of introduction I was enabled without the aid of a 
commissionaire to find those whom I intended to call upon. The first visit I paid was to the von Zahrtmann's, who lived in the first story (bel etage) of a fine house in Brede-Gade (Broad street), one of the best streets of Copenhagen. A Servant in livery opened the door, I sent in the letter [532] which C. H. Donner had given me for Zahrtmann and of which on account of the strangeness of its contents I have affixed a copy under $\mathrm{N}^{\circ} 14$ in the appendix of the first volume, I was immediately shown in, and received with great politeness. He was an agreeable gentleman of fifty and odd years. He said that he still recollected me, and that I had not much altered. A few minutes later, his wife Betty Donner entered with the words: "now we must have a good look at each other". At first sight I thought she had much changed, but looking at her attentively I soon remembered the features of her youth. She was a tall, well shaped lady, her face was not exactly pretty but far from plain, her nose long, her eyes green but her complexion fair and a pleasant smile always played round her mouth. Her station in life, her money, the excellent education which she had received and her clear intellect, contributed to make her an accomplished very agreable lady "du grand monde". She and her husband moved exclusively in the highest circles of Copenhagen society. In our childhood she and I had been very intimate, I refer to pages 440 and 447 Vole. the first. They told me that they had a very busy week before them; next friday was the queen's birthday, and on monday they thought of setting out for Altona there to remain for some time with C. H. Donner. Nevertheless they asked me to return to dinner which I with pleasure acceded-to. Mr. Von Zahrtmann advised me to pay my respects to Mr. Von Blume, who was the Chief of the Department, called in 1844, that of duties and Commerce, to which as consul I belonged. His house was in Anna Pladen a fine street to the east of Brede-Gade. He not being at home I left my card, hence I directed my steps to another part of the town called Christianshavn, upon the island of Amages which by a narrow strait of the Sound is divided from Kjöbenhavn, both parts being connected by several bridges. I crossed Kongens-ny-torv, had to my left the Holm or Royal Dock yard, in front the exchange, passed a bridge called Knippel-bro, and reached the counting house of $\left.\mathrm{C}_{[}\right]$]sten Noe \& Co. to whom Siveking of altona had given me a few introductory lines. The head of the establishment being absent, the clerk delivered to me a number of letters which had accumulated here for me from Lima, London and Altona. Almost at the very extremity of Copenhague in this direction in Prin[ssens] gade lived Mr. Garlieb my immediate Chief, a Subaltern of Blume; also he had gone out. I now returned, and with some difficulty found out behind the Exchange, the dwelling of Mr. Adolph to whom Mr. Reincke [533] whose clerk he had been for four years, had given me a letter of introduction. He received me very kindly and presented me to his mother and 
wife. With all three I managed to converse in Danish. Adolph's large Store extended to a Canal which receives its waters from the strait, and is deep enough for vessels drawing sixteen feet. Mr. Adolph accompanied me to the Exchange built under the reign of Christian $V$ who I was told brought over from Sweden at the time of his hostile invasion of that Country the sandstones used in its construction. Above each window on the ground floor, a human face is cut in the stone, none alike; also between each two windows on the ground floor and the first story the stone is cut into the figure of a human being with head, but without arms and legs. The steeple on the top of this building is of small height and curiously shaped, four large dragons cast in lead are made to support themselves on their breasts, their bodies and tails raised into the air, the bodies leaning against each other, the tails entwined finishing in a point upon which a weather cock is placed; the heads of the Dragons are turned respectively towards the four points of the compass. The ground floor is occupied by shops and stores, a passage connects the Exchange with the "National Bank". Up stairs is a bazaar filled with many tables and stalls where numberless articles are exposed for sale. Close to the bazaar are two other rooms, one for the Merchants, the other for the underwriters, a third serves as a reading room, a fourth for public sales. This latter is built in a circular form and has the same singularity as the whispering gallery in Saint Paul's of London, namely, words pronounced in very low tone of voice close to the walls are heard distinctly, exactly opposite. We then left, he made me observe a long row of large and handsome buildings which serve for public offices, connected with them are the stores for the provisions for the Royal fleet. Behind the same is an extensive sheet of water, which by means of a canal corresponds with the Straits between the town and Amages. This strait forms the beautiful port of Copenhagen. The arsenal joins the just mentioned stores, and close to them stands the splendid palace of Christiansborg, which seen from its principal entrance over a stone, called the marble bridge appears to the greatest advantage. It is built of sandstones and bricks. On both sides of the manège are the stables, one of which we entered and I was much pleased with its great cleanliness. Every horse had its own name written on the table hung against the wall. The palace with the buildings already mentioned and a few others, lies on an island formed by the strait, and by the canals which run round it; five bridges lead thence to [534] Kjobenhavn others to Christianhavn. A few vessels lay at anchor in the already mentioned canal on both sides of a small bridge called Holm-Bro, but by far the greater part which of course as regard their number can bear no comparison to those which crowd the part of London, in the strait itself between Knippel-bro and the Custom house. Near five o'clock I returned to the von Zahrtmann's, we dined by ourselves. Mr. and Mrs. von 
Zahrtmann (who now appeared in a different dress from that they had worn in the morning) their two elder daughters (the youngest was still a child), and myself. Dinner consisted of soup, fish, meat, and pudding, the wines were Bordeaux, Madeira and Malvoisur. The table-service both Earthern and glassware was first rate, the spoons and forks of massive silver, a servant in livery attended, all the rooms were carpeted, and the furniture was elegant; everything bespoke the wealth and the good taste of the owners. The conversation was animated and unbroken, however on the part of the lady rather superficial. She touched on a hundred different subjects, immediately dropped them and passed on to something else. Henrietta Feddersen had warned me that I should hear a great deal about the Nobility and the Royal family, this was not the case, but on the other hand Mrs. von Zahrtmann might well have shown a little more interest for her Altona acquaintances. She did not even allude to my dear mother and sisters which pained me much, neither did she inquire after the Limprichts of Eutin only about Charles Ropsy she wished to hear something from me. Zahrtmann I clearly perceived was the master in his house, though he owned his entire advancement in the world to his marriage. When we had taken our coffee their own carriage stood at the door, a coachman and a footman in livery on the box. We drove in a Northern direction to that part of the town called "Osterport". as soon as we were outside the gate many country houses came in sight, in every respect inferior to the elegant [villas] in the environs of Hamburg and Altona. To the right we had a pretty view over a cultivated plain to the Sound where various vessels were distinguishable, also an Island with the famous "tre Kroner" (three crowns) battery. Von Zahrtmann told me that on the Sea Side Copenhague is so well fortified, that from that quarter it may be considered to be impregnable, not so on the land side. In September 1[_] 7 when the English demanded and finally obtained the delivery of the fleet, they disembarked to the North of Copenhague near the village of Vedbeck, thence surrounded the town, and from the landside bombarded it so successfully that within three [535] days the Governor was obliged to capitulate. A little further on to the left is a pretty [wood] through the foliage of which appeared a white large building, the residence of Prince William landgrave of Hesse-cassel married to Princess Charlotte, [_] King's sister and whose son Frederick married to alexandra, daughter of Nicolas I, Emperor of Russia was in 1844 considered as the presumptive heir to the crown of Denmark. These hopes however vanished when at a later period alexandra who already was suffering from consumption died. Whilst Mrs. Zahrtmann with her second daughter "Mimi" paid a farewell visit to the French Minister, Zahrtmann and I got off the carriage and walked about for a considerable while in the pretty wood. We conversed on many topics; he of course defended [_] what the King 
did and had done, but imputed to him want of energy. He said that all true Danish patriots must bewail the great influence which the two brothers of the queen, Princes of Holstein Sonderburg-Augustemburg, both Anti Danes have upon his mind, and consequently upon his actions. On our return to town we called on the widow of Commodore Christian Leonard Donner a Danish Lady whom I recollected from former years. She received me with politeness, we took tea, and at about eleven oclock walked home, Von Zahrtmann hastening to give his arms to his lady, so that I had to offer mine to the eldest daughter Elisabeth.

Thursday, $27^{\text {th }}$ of June 1844. I was in the habit of rising at six oclock, the first three hours of the day I devoted to my diary, then went out. "Kongensny-Torv" was as already mentioned an irregular open place, that is to say its corners did not run at right angles; in the centre stood an Equestrian Statue of Christian's IV, perhaps of bronze, perhaps of lead bronzed over. Under the horse's feet writhed a figure with a snake in its hand representing Anarchy or discord, on one side of the pedestal were the Danish arms, at each corner, a human figure of more than natural size, the meaning of which I did not learn. The four sides of the place were occupied by the academy for arts and sciences called Charlottenburg, the military college, the theatre, the main guard house with three cannons in front, two of the principal hotch, that "d'Angleterre" and that "du Nord", and by several private houses. Mr. Blume to whom I made my first visit detained me but a few minutes, and referred me to my immediate Chief Mr. Garlieb; Mr. A. F. Möller upon whom I called next received me with unfeigned politeness, he was a talkative old man who overhelmed me with questions; my third visit was to Mr. Garlieb, I remained with him a [536] considerable while. We talked on many topics, and I flattered myself that I made a favorable impression on him. I told him amongst other things that it would be advantageous to his majesty's service, if power were $\mathrm{g}\left[\_\right] \mathrm{n}$ me to name vice Consuls in Peru, and this he promised he w[_] attend to. I also begged him to send me an escutcheon with the Danish arms, and the Danish flag. From Garliebs I walked to Adolphs, went up stairs, where I stayed for a short time with his wife and some ladies mutilating the Danish language in a frighful manner, I was however understood and could understand. On Adolph's return, he accompanied me to the Museum of Northern antiquities, which, in its kind the first in Europe, occupies several apartments in the Christiansborg palace. Mr. C. C. Baff [...] the Secretary having gone to some watering place in Germany, it was a Mr. Thomsen who very kindly showed and explained the different objects to a number of curious visitors, and when Mr. Adolph had introduced me to him, he more than once directed himself to me in preference. The Archaeologists divide the times of our Pagan ancestors into 
various periods. The most remote, that during which utensils and weapons were made of stones, next comes the period when Copper, and much later that when iron was used. Mr. Thomsen showed us specimens such as hatchets, knives, daggers, etc., made (in the different periods) of the three different materials; Gold ornaments and Gold chains, the links of which used instead of money in the fourth and fifth Centuries were objects of great curiosity, also other gold ornaments such as not many years back were and perhaps still are worn by the peasant woman in some parts of Sweden, Norway and Iceland. A few bones said to belong to one or two of the martyred Eleven thousand Virgins, once great relics, now afforded much amusement to the by-standers, not better fared some sacred vases which dated from the time when Catholicism prevailed in Denmark. With Mr. Adolp I looked in at the exchange, and was surprised that whilst the building was crowded with merchants who attended to their business, women and children were allowed to go in and out. By myself I paid a short visit to Mr. Paulsen brother of the Danish Consul in Valparaiso; I saw him and his wife, an elderly lady, and to judge from appearance, they were not very well off in the world. I again dined at the von Zahrthmann's; at the request of Mrs. Zahrthmann I had brought with me my drawings of Lima Costumes, which both he and she had the good breeding to run over at a gallop. A Chamberlain Mr. von Oxholm dined with us; every thing was [537] as stylish as on the previous days. The conversation was carried on, both in the German and Danish languages, von Oxholm and I left at six oclock. Then I called on old Mr. Möller who took me to a public garden much in vogue at the time called the "tivoli"; it was a large park a short distance outside the town on the Roskilde road. The first thing which presented itself on entering was a theatre in which a farce was being represented, it ridiculed the rage for the unity of the three Scandinavian Kingdoms, or the Scandinavian mania, then in great fashion; the piece was called the Scandinavian brothers, Clown Harlequin and Columbine were the principal performers. Close to the theatre was a shop for refreshments in which we took tea, the next a Restaurant, in the third articles of fashion were sold, then followed a large saloon in which 2 orchestral bands were playing alternately, also "Montagnes Russes", a circus for Equestrian performances. In short nothing was wanting to attract the multitude; the entrance money was only one Rigsbank mark or five Shillings Currency, so that notwithstanding the extensiveness of the place, it was well filled, and of course the society mixed; the generality was of the middle classes with a sprinkling of females of easy virtue and peasants of Amager. The women of this Island still preserved the peculiar dress of their Dutch ancestors, who first introduced thither the careful horticulture which continues to flourish in Amager up to the present day. 
Friday, $28^{\text {th }}$ of June 1844. In the course of the forenoon I made several calls on which I do not dilate. The collection of paintings in Christianborg Palace to which I devoted one or two hours shall not be described either, in obedience to the rule laid down by me (page 185 of this volume). I dined at my hotel; twelve or fourteen persons sat down, amongst whom three flensburg ladies and a bearded Frenchman. German and a little French were the languages used at table. We had for dinner soup, roasted veal with potatoes, fowl with pease, salad, and stewed green goose berries, dry sweetmeats, bread, butter, and cheese; each person had half bottle of Bordeaux wine placed before him. I ordered a bottle of Madeira which lasted me the whole time I was at the hotel. The evening I spent in Adolphs company; the first he did was to order a boat in which we were rowed the whole length of the port measuring a full english mile from its South Western extremity Lange Bro (long bridge) to the Customhouse at its North Eastern point. Adolph assured me that the shipping is here well sheltered against every wind. The port was not crowded but could not be called empty either, the vessels looked as lost upon the vast expanse of the water, some also lay concealed [538] in the canals which from the strait run into Kjobenhavn on the one into Christianshavn on the other side. Solid stores of large dimensions owned by private persons are built on both banks, the Custom house stores, other edifices belonging to the Government, the Dock yard, etc. all are constructed on a great scale. In the same manner the palaces in the town, Christiansborg, Amalienborg, and others are rather too grandiose for a Kingdom, the population of which hardly exceeded two millions of souls. If this was my opinion in 1844, what should I [_] have said in 1869 when after the dismemberment of the Duchies [_] the population has decreased nearly one million. Opposite to the Custom-house, that is to say on the East side, a few men of war were at anchor. [_] they are not in active service as it was the case with these vessels, they were kept under cover of a red tiled roof, the top of each mast was covered with a cube, probably of iron, for they were connected with each other by an iron chain which serves as a conductor of lightning. The three bridges, namely Knippel-Bro, Langer-bro, and that near the Customhouse are draw-bridges. To the North of Langebro on the Kjobenhavn side were the public baths. On our return to Adolph's house tea was ready, together with cold meat, raddishes, bread, and butter. Adolph himself was a very amusing man, he, his pretty little wife, her still prettier female friend, all were very nice people and I liked them exceedingly. At ten oclock candles were lighted, at eleven adolph accompanied me home.

Saturday, $29^{\text {th }}$ of June 1844. Early in the morning I made the acquaintance of Counsellor of State ("Etats Rath") L. N. Hvidt director of the Rigsbank or 
Imperial bank. He had the reputation of being a very active man, already at half past eight oclock I found him in his office. At a later hour I was to have an audience from the King; accordingly at about ten oclock, dressed in black with a white cravat, and white kid gloves I presented myself at the Royal Palace of Amalienborg where the porter instructed by von Zahrtmann, one of the Royal aide de camps, immediately admitted me, and showed me to the ante-room where von Zahrtmann dressed in Naval uniform, and other courtiers in red with Epaulets, orders, Chamberlain-keys and others distinctions, were conversing. At half past ten the King came from the Country lodge Zorgen [Fri] in a close carriage drawn by six horses, he did not pass through the ante chamber. Menials passed through carrying large Portefolios, other [539] officials dressed in red, went in and out. As soon as the aide de camp of the week, a von Blucher, nephew of the Count, president in Altona, entered, von Zahrtmann introduced me to him, he then withdrew. Young Gustavus Blucher, son of the Count came up to me; I had known him in my childhood and we had a long talk. At half past eleven the other Blucher, the aide de camp, came out from another room and showed me in. The King, Christian VIII stood a few paces from the door, he was dressed in red uniform various orders on [...]. I think he was at the time a man near sixty years of age, rather good $[\ldots]$ was a little twisted and without teeth. I made a bow somewhat more profound than is generally my custom. His first words were: "you are our Consul in Peru?" "Yes your Majesty." "I doubt not but you take good care of our interests?" "At least I endeavour to do so." After this preamble we conversed in a superficial manner on various topics about the ithsmus of Panama, about [_] Danish trade in Peru, about imports and exports, etc. I did not feel in the least embarrassed, on the contrary, I even offered his majesty the box with Peruvian antiquities which Hoyle, of Trujillo had presented to me, and of the arrival of which I had been informed by Noe \& Co; the King referred me to Mr. Thomsen. About 10 minutes elapsed, he slightly inclined the head, I made another bow, opened the door and withdrew. This was the audience which I had from the King. The Royal Palace Amalienborg forms the entire circle of amalia Place, which divides into two parts the beautiful Amalia street running parallel with Brede-gade. This is a really fine Aristocratic looking, but little frequented part of the town; the houses are large and Palace-like, the streets wide and straight terminate at an open piece of ground covered with grass and intersected by avenues, which is called the Esplanade. In the centre of Amalia Pladzen stands an Equestrian bronze statue of Frederick V erected to his honor by the Asiatic Company. The street which crosses Amalia Place runs in one direction towards the port at the other extremity it is fronted by an artificial ruin. Having called at Adolph's counting house, he gave me one of his clerks to accompany me. With him I 
went to the round tower which serves as an observatory, it has the singularity that the ascent in the interior not by means of a staircase is so gradual and at the same time so wide that a carriage can drive-up and it is said that the Czar Peter the Great actually did so, only at the highest point are a few steps. The platform on the top is protected by an iron balustrade, the prospect hence over the town, the surrounding country and the sea is of course very extensive. We went next to the Royal museum in Christianborg, several large saloons [540] are filled with collections of Egyptian, Greek and Roman antiquities, with curiosities from the East Indies, and with many other objects comparatively modern worked in Ivory, Gold, silver, precious stones and mosaic. As it always happens in such museums, the visitors, I amongst them, were hurried through the apartments much too rapidly so that little time was left to examine anything which one should like to look at attentively. Mr. Thomsen, the same whom I had seen in the Scandinavian museum, was here the head man. He requested me and the clerk to go with him up stairs where he showed us dresses of Esquimaux, and a few things from the South Sea Islands, from Mexico, from the Brazils, also lazos, Bridles, and bolas used by the Chili huasos. However the collection of curiosities from these parts of the world was hitherto insignificant, and I thought that my Peruvian antiquities would be a valuable acquisition. I might add that the other day Thomsen [_] of me a few of my coins, the remnants of those that were stolen from me [_] Rainville's hotel in Altona. Whilst at dinner in the hotel d'angleterre I was conversing freely with my neighbours, particularly with Mr. Kruger the landlord, I mentionned by chance that I was a native of Altona, whereupon a gentleman whom I had not observed hitherto inquired my name, and on giving him the desired information, he said his was Constance Von Dirkink. This was an unexpected meeting, he had been one of my play fellows in my earliest childhood. I suppose that his father, a widower who in the beginning of the century lived with his children in Altona, had been banished thither from Copenhaguen on account of some political offence. On Sunday afternoons when I by myself did not know how to while away the time, my mother used to send for the Dirkinks, Constance and his younger brother Ulisses, and hardly ever did they fail to come and play with me. Once when I was in the class Secunda in the college, Constance and I were reading Eutropius out of the same book, and he, by his continual chat and the offer of sweetmeats distracted my attention to such a degree that it was observed by our master Professor Feldmann, who to correct me, gave me a push in the back. This was the only blow ever received by me either from my teachers or my parents; and probably for this reason I have not forgotten this circumstance trifling as it is in itself. In 1844 Baron Constance Von Dirkink Holmfeld took a prominent part in the Danish German language question, and was an active 
writer on the Danish side. Shortly after dinner Adolph called upon me and together we went on board the Steamer "Hamlet" lying [541] in this harbour and bound for [Elsineur]. The dock was crowded with passengers amongst whom the three Flensburg ladies who like me had stopped at the hotel d'Angleterre. In a few minutes we were outside the strait, to our right we had the two strongly fortified Islands called "tre Kroner" and "Lynetten" and to our left the whole way down to [Elsineur] the coast of Zealand which the Danish patriot Adolph thought even prettier than the banks of the Elbe from Blankenese to Hamburg, to which however I could not agree. There were woods extending far [_] to the interior, many villages and Country houses, these last I repeat inferior to [_] Round Hamburg or Altona. Opposite on the Swedish coast the town of Landscrona was distinguishable, further on in the Sound properly called "Ore Sum" the Island of Hven well known as the dwelling place of the famous Danish astronomer Tycho-Brahe who in the year 1575 under the reign of Frederick II built there his observatory called Uraniensburg, of which the ruins still exist. Upon this Island lies the town of Saint Ibb of which I could see the church steeple. When approaching Elsineur, a whole fleet of vessels perhaps 200 in number came in sight, they were unable to proceed on their voyage owing to the strong North-west wind blowing right in their teeth, in the midst of them the Danish Guard Ship distinguished herself by her man of war build and rig. Here the Swedish coast draws so near that at the distance it appears as if the two shores joined. On the Sealand side the fortress of Kronborg shows itself, whilst Elsineur behind a small point of land, is not yet visible. We steamed on, now the narrow passage leading to the Cattegat was seen, the distance from Kronborg to Helsinborg is no more than 1800 feet. Rounding a small artificial mole, we found ourselves in the harbour of Elsineur. Mr. Adolph called my attention to the Custom house where all the vessels passing through, had to pay a toll, which toll in later years had been redeemed by all maritime powers, each paying a sum of money in proportion to the number of merchant vessels of each country which were calculated to pass annually through the "Sound"; if I remember rightly, England, Prussia and Russia contributed most. We were met by a friend of Mr. Adolph Mr. Holmblad, and a young man was instructed to accompany me to the Kronborg fortress which surrounded by a double ditch and a threefold rampart looked as if it were strong and impregnable, but I learned that this was far from being the case as it was commanded by some neighbouring hills. From the flag battery I had a pretty view over to the Swedish coast, most Northward I discerned the Kullen mountains, of which I had seen a pretty painting by Gurlitt [542] in the Christiansborg museum. Exactly opposite I saw the town of Helsingborg, further South the island of Hven, and at a distance Landscrona. we now 
entered the innermost fortification of which the sketch herewith gives an idea: e, is the gateway; a, the Church; b, a tower with its clock; c, a flat tower; $d$, a pointed tower; $\mathrm{f}$, another tower with a burning fire or light during the night. From Kronborg, my companion and I walked to the pretty garden of the Royal lodge, "Marienlyst", and returned to our inn where we supped upon excellent fish. It was past twelve when we retired to rest. In 1844 Elsineur had about seven thousand inhabitants, and Consuls of all nations resided there.

Sunday, $30^{\text {th }}$ of June 1844. After a light breakfast, Mr. Adolph, Mr. Holmblad, Mr. [J]urgensen who was another acquaintance of Adolph's and I, started for a walk; taking a Northerly direction, we passed Marienlyst, then through a wood along the beach, until turning off inland, we came to the village of Hellebek, also to the musket manufactory of Hammermöhe, further on, close to the beach to a village of fishermen Aalsgarde, and finally to a small height called Odin's höhe covered with wood. In the middle stood a monument erected in honor of Count Schimmelmann; from this elevated point, there must be a pretty view to the opposite Swedish coast when the sky is clear, this day we were not favored by the weather, it was cold and cloudy, and nothing could be distinguished at a distance. From Odin-höhe we returned to Aalsgarde where Mr. [J]urgensen treated us to an excellent dish of carp. Along the high road we returned to Elsineur. In Marienlyst garden, Mr. [J]urgensen pointed out to me a column which goes by the name of Hamlet's tomb. With him I went to the Cemetery so prettily laid out with Clipt hedges, Sepulchral monuments, trees, shrubs and flowers, that it might well answer the purpose of a pleasure ground, Mr. [J]urgensen remained in Elsineur. Mr. Adolph had ordered a half open carriage and he, Holmblad and I drove off, Adolph being kindly intent upon showing me some parts of the country in the vicinity. Not far from Elsineur to the Westward we came to a small lake called "Gurri[söe]" close to which stood the ruins of a castle which it was said dated from the time of Waldemar IV who lived in the fourteenth century. One oblong wall constructed of big unhewn stones in the inside, bricks outside, surrounds the inner building, at the four corners of which the traces of towers were distinguishable. The whole had the appearance of a modern building lately fallen in, only the trees [543] which grew upon the walls and the old age of which could not be contested, vouched for their antiquity. We continued our route over an uninteresting level piece of ground to the north of the Esrom Sö lake until we came to the wood of Gribs Skor to the westward of the lake; next to the Saxon forest, in the Duchy of Lauenburg, the most extensive forest wood in the Danish dominions. It consists mostly of beeches, also of some oaks. The road running along the beach between the wood and the lake brought us to 
the small place of Nöddebo, passing through it, we arrived between three and four in the afternoon at Fredensborg, where Holmblad left us. Adolph and I took our dinner and had a stroll through the park belonging to the Royal palace which was built in the reign of Frederick IV. Its shape is that of an octagon, a statue stands in the centre, the park is intersected by avenues which terminate at the lake. Immediately behind the palace, is an extensive lawn with a number of statues, in my opinion of little value. On another open spot in the form of an oval stand from fifty to sixty statues which represent peasants, men and women from various districts of Norway, Iceland and the Faroe islands, each in his peculiar dress worn at the time of Christian VII's reign. From Fredensborg a wide straight road, about a Danish mile long, leads to the principal gate of the Royal palace of Fredericksborg seen from a great distance. On each side of this road extends a wood so well kept, the walks in so neatly cut, as to convey the idea rather of a gentleman's park than of a Royal forest. Fredericksborg of red bricks has a peculiar fortress-like appearance, it is built not on an island, but in the lake itself, for its walls rise from the very bottom. King Frederick II laid the foundation, his successor Christian IV brought it to a conclusion, but so many were the difficulties he had to contend with, so enormous were the sums of money required, that all but the King despaired. He was blamed for his as it was thought childish obstinacy, "that he had not yet thrown off his baby shoes", was the common saying; in commemoration of the taunt the King had two big shoes represented in the formation of the wall, which are still to be seen above one of the entrances. We drove over several bridges, under as many gates through the outer yards, and stopped at a very good inn in the small place of Hellerod which adjoins Fredericksborg. From the window of our room we had before us the red looking massive pile surrounded by the now unruffled waters of the lake. The weather had changed for the better, Mr. [544] Adolph and I took a pleasant walk, on our return, tea with bread and butter and went to bed betimes.

Monday, $7^{\text {st }}$ of July 1844. Rather more than a quarter of a mile distant from Fredericksborg lay the Royal domain called Fausholm measuring 925 Tonnen, a Danish Tonne equal to 56,000 feet, it was rented by Peter Limpricht, a younger brother of my brother in law Johannes Limpricht; him, I intended to visit and Mr. Adolph was good enough to accompany me. Our walk thither led over an extremely level piece of ground with not a single tree visible, neither close by, nor at a distance. On reaching the estate, we entered a large open place surrounded by many low white painted buildings, all so alike each other, that it was impossible to say which was the dwelling house, nevertheless observing at an open door of one of them, a stout Gentleman who was smoking his cigar, we went up to him, and on approaching, I recognized Peter Limpricht's features; 
he did not know me, but on my handing him my card, he gave me a most hearty welcome, and made us walk in. The room to which he showed us was in a frightful disorder. On every chair lay some apparels or other, and Limpricht thought proper to make a kind of excuse, saying that on the previous evening they had returned from a short journey, and that the next room was being painted. He had become extremely stout, was dressed in very common clothes like a farmer, and suffered from a nasty cough, which made him expectorate incessantly. His lady, a Hamburgher by birth, had nothing engaging about her, his two eldest children, son and daughter were absent, the former on an estate in Jutland, there to learn husbandry. A younger daughter was about going to school, and the two last girls when ordered in actually displeased me, the one so bashful, that she did not even lift up her head, and was playing all the while with a trifle which she held in her hand, the other ugly, with a mouth from ear to ear. The Danish Governess did not open her mouth, the servant girl who was busy cleaning the room was crooked, and the only one with whom I found pleasure to converse a few words, was a young lady rather good looking [_] Wittrock (whose parents resided on an estate between Kiel and Eckernförde) and whose brother was engaged to Limpricht's eldest daughter. Limpricht himself was friendly and good natured. He invited me to remain the whole day with him, which of course I could not do. When Mr. Adolph had left, we conversed on many subjects. He told me that at the beginning of his agri- [545] cultural career, he had encountered much trouble and many difficulties, now he was in a fair way, and satisfied with his lot. He also mentioned to me that on his estate, there did not grow a single tree, only a few bushes in the garden behind the dwelling house. I breakfasted with him, and returned to Hilleröd. During my absence Mr. Adolph had arranged a party to visit Fredericksborg, the admittance fee for twelve persons or less was one and a half species, we only mustered five, viz: Mr. Adolph, his aunt Mrs. King, her son, her daughter engaged to Mr. William Hesse (her other daughter was Mr. Otto Donner's wife) and I. On leaving hilleröd we passed over a bridge through a narrow passage formed by low buildings on each side, over another bridge and under a gate adorned with a particularly elegant steeple, and came to the outer yard. To the left was a large gate leading to Fredensburg, in front another opening into the inner quadrangular yard, surrounded by the castle itself. I may repeat that the whole edifice commencing from the first bridge on coming from Hilleröd is built in the very lake. The foundation is either granite or sand stone, the walls above the surface of the water are of red brick, their thickness about eight feet. To give a correct description of the Castle would be difficult, if possible at all. I will therefore confine myself to a few particulars; the church is a pretty building well adorned, in the interior a gallery runs round the walls, two sides of which 
are hung with the coats of arms of all such as had received the grand Cross of the Order of Danebrog, the third wall with the escutcheons of those on whom the Order of the Elephant had been conferred amongst which latter I noted nearly all the Sovereigns of Europe, also the Duke of Wellington, and Count von Blucher Altona. This gallery is connected with the castle wither we went. We were shown through many apartments well fitted up and furnished. In one of them the unfortunate queen Caroline Mathilde was imprisoned after her arrest on the $16^{\text {th }}$ of January 1772 , and previous to her banishment to Celle; on a window pane she had cut with a diamond the following words, which I myself read. "O God keep me innocent, rather than [_]", they were in English, for everybody knows that queen Caroline was a Sister of King George III of England. A very long suite of rooms was filled with the portraits of queens and Kings, and many of the members of the Royal family of Denmark amongst which that of Christian V the builder of the castle was frequently repeated, also of some Swedish Kings amongst whom Charles XII distinguished himself, by his iron looks [546] and uncommonly high forehead, further, of many Princes, Princes of German ducal-houses of Brandenburg, Saxony, Hesse, etc. etc. Another room was dedicated exclusively to the portraits of Foreign Ambassadors who had resided in Copenhagen at a certain period. The portrait of Struensee is likewise shown, he is a handsome man, with blue and clear eyes and an aquiline nose. Various passages which lead from one apartment to the others are hung with the portraits of renowned Danish heroes amongst whom I noted particularly the daring physiognomy of Torden-Skjold. The Saloon in which the Kings of Denmark are crowned, and which goes by the name of the "Ritter Saal" is large and spacious, perhaps somewhat too low for its size. The ceiling is beautifully carved and gaudily painted, the floor is inlaid with marble slabs, the walls hung with portraits of European potentates. From the Ritter saal we descended to other rooms the walls of which were covered with the coats of arms painted on tin, of all the deceased members of the order of the Elephant and Grand-Crosses of the Dannebrog, those seen above, were the escutcheons of all such as were still alive in 1844. In the last mentioned room we remained for some time and willingly would I have stopped still longer, for I was much interested in examining the coats of arms and reading the mottos around them. One of them said "Gratia Regis, Sola Salus". I regret that my original diary does not give the name of the nobleman who could choose such a servile sentiment for his device. Mr. Thomsen observed to me on the following day, that it had struck him as worth noticing, that all those Danish noble men who had taken an active part in the fall of Struensee, were created grandcrosses of the Dannebrog on the $18^{\text {th }}$ of January 1772 whilst the arrest of the 
queen and of Struensee took place on the night of the $16^{\text {th }}$. Mr. Adolph went to dine, I preferred accompanying young Mr. King to the top of a windmill close bye on a hill. The sky was pretty clear and I distinctly saw the mountains of Kullen and Sweden, at our feet the castle of Fredericksborg, and the village of Hilleröd. At about 3 p.m. together with Mr. King, we drove back to Copenhague, on leaving Hilleröd, we passed through a pretty wood the Store-Dyr-Have, next over some level land, till we reached another small village called Rudersdal, where we got off to take some Coffee. The Flensburg ladies whom I had seen on board the Steamer and with whom I had exchanged a few words in Fredericksborg were again here. They were pleasant ladies, the more I saw of them, the better I [547] liked them. On the other side of Rudersdal, we had to our right or Westward, the lake of Fure-So' near which the brother of Senator Jenisch of Hamburg possessed an estate, called Dronnings-gaard. Now instead of following the high road, we turned off to the left, and came to a lovely little spot called Brede, in the neighbourhood of which were papermills and cloth factories. Further on in the same direction, we reached the Dyr-Have which I much admired. It is a large park full of trees of all descriptions, with fine meadows and a great number of deer running about everywhere, and so tame that they did not even move on the approach of our carriage. In the middle of this park lies the Royal hunting lodge called the "Ermitage". On approaching the Capital we stopped for a few minutes at an inn Klampenborg, for the purpose of looking at an extremely old Oak-tree. It is of inconsiderable height, but of a great thickness, the trunk hollowed, a door opening into it. We left our carriage, walked to a wood, and emerged on an open spot occupied by booths like an English fair. There were Equestrian performers, fortune-tellers, taverns, pastry cooks, stalls covered with all kinds of Nick-nacks, Railroads on a small scale, wild beasts, a tremenduously big pig, and I do not know what else. We returned to Klampenborg, took tea, remounted our carriage, and continued our drive close to the beach, left charlottenlund to our right, and entered Copenhague from the same quarter as I had come on the other day with the Zarthmann's through the Oster port or East gate, outside of which Mr. Adolph called my attention to a large reservoir which provides the town with water. It was half past ten when I alighted at the Hotel d' Angleterre, took a light supper, and in bed read for sometime my sister Maria's letters, and description of a journey to Harz in June 1818 which, as well as my letters written to her from South America, Limpricht had given me, when I saw him in Eutin.

Tuesday, $2^{\text {nd }}$ of July 1844 . I stayed at home the whole day. In the afternoon several Gentlemen called upon me, amongst whom Mr. Thomsen who took away with him the box with Peruvian antiquities. At dinner, the Flensburg 
ladies whose names was Andersen and I were on very good terms and conversed pleasantly. In the Evening till a late hour I wrote letters to Vicente Gonzalez, to my wife, and Enriqueta.

Wednesday, $3^{\text {rd }}$ of July 1844 . This day was devoted to a visit to the Royal dock yard, but though I did my best to impress on my mind all that I saw, I fear [548] that some inaccuracy or other will slip into the following account. Accompanied by Mr. Rothe Lieutenant in the Royal Navy who called on me by Mr. Zahrtmann's order, we walked down the Amalien-Gade and I learned that many of the handsome edifices on both sides of the street are public buildings such as Prince Frederick's Palace, Glasens library, the public hospital, the laying-in Hospital etc. At the end of Amalien-Gade on the right side a gateway opens into a piece of ground occupied by alm-houses called: little Copenhagen. In Brede-gade a pretty Roman Catholic chapel was about being concluded. In Copenhagen only the Churches of the Lutheran and Calvinist religion are allowed to have steeples. Near the Custom house which lies on the Kjöbenhavn's side at the Northern extremity of the port a wooden bridge leads over to the Nyholm (holm in Danish means literally an Island but in Copenhagen with holm the Dock yard is meant, and ny, in English is new). This wooden bridge may be considered as the termination of the harbour. In the middle it can be opened and during the day time it always stands open. At the moment we were there a fine large vessel went out, Lieutenant Rothe and I were rowed over, but though he was in his uniform, he had to apply to three different Superior Officers before permission was given me to visit the dock yard. The Nyholm is the most northern of 5 islands which jointly with Christianshavn form the island of Amager, close to the Western side of the Nyholm and the adjoining Fredericksholm immediately to the South of the wooden bridge, is that part of the port where the Royal navy is moored. On the northern extremity of the Nyholm is the Sextus battery with a flagstaff and a man continually on the look out. The Lieutenant and I clearly could see from here the two fortified islands of "Lynnetton" and "tre Kroner" in the Sund, and the fort of Frederickshavn on the mainland. In the Nyholm, large quantities of timber, each piece [_] rked with its respective size and quality lay piled-up under sheds. Three vessels were on the [slip], a Corvette, a line of battle ship, and a man of war steamer. This latter though built so as to serve in war time, was to run for the present as a packet between Copenhague and Stettin on account of the Danish and Prussian Governments under Danish Colors, and commanded by a Danish Naval Officer. Her power was to be of 160 horses; from 150 to 200 men were daily working at her, but just when we were there, they had gone to take their breakfast, the half hour between 11 and $111 / 2$ being allowed them for this purpose. The work commenced at 5 a.m. and lasted till 4 p.m. Two men of war 
were lying in the harbour whilst the third had gone to Morocco to settle there the questions [549] about the tribute hitherto paid by Denmark to the Emperor of Marocco, to which humiliating exaction the King had determined no more to submit. In a building which we entered I observed that the even floor (a wooden one) of a large saloon was covered with a number of black lines which appeared to me complicated and confused. On inquiry Lieutenant Rohte informed me that for a number of years probably since 1807 when at the time of the bombardment by the English everything was destroyed here, the plan of every man of war which is to be built is previously drawn on this floor in large dimensions with Indian ink, and as these plans are not effaced it is very natural that the lines intersect each other in every direction, and present an apparent confusion to unpractised eyes. The drawing of a vessel to be built for the Royal Navy is firstly made on a small scale in the Admiralty office, thence greatly enlarged it is carried over to this floor, and from this latter plan the dimensions are taken for the timber required. In another apartment an extremely pretty model of a ship of the line carrying eighty guns called the "Juliana Maria", and built about eighty years ago, was shown to us. A small wooden bridge over a narrow canal connects the Nyholm with Christiansholm also called Den Lang-Øe, or long Island. Not more than forty years ago this island consisted of two narrow tracts of land, between them a wide shallow canal which has been filled-up and produces at present excellent grass. On Christianholm are the stores for ropes, here also gun boats are kept under sheds. At the time there were sixty five of them in existence, each carrying two cannons, one at each end, a few with mortars. In the last war against England when the whole fleet had been delivered-up to the English they were sometimes of service in a dead calm when they could overpower a hostile frigate or Corvette. Since the introduction of steam, they have gone out of use, and have been always very expensive, they are mainly impelled by rowing, are manned by sixty men and five officers, have fifteen benches each one for two rowers; on extraordinary occasions when great celerity is required two men work at each oar. On another small island "Ankor Øe" anchors and chains are lying about in the open air, a school house stands here for young men and boys who whish to serve in the Danish Navy, now, all were at sea. Two large models of men of war provided with masts, sails and rigging, serve for teaching the pupils the different names and their respective use. Outside the School house masts, beanes, poles, Ropes, etc. serve for Gymnastic exercise. On Christianholm I saw the boring of an Artesian [450] well which had reached the depth of 589 feet. Of course there exists no iron bar of such length, thus one bar is fastened to the other by means of bolts and the lowest one is provided at its point with a small steel chisel or borer which is let down, and is put in motion by means of a wheel at which five 
or six men were at work. After this first borer has made some impression on the ground at the bottom, it is lifted-up, and another borer of larger dimensions is placed in its stead, after sometime this again is removed and a third borer still larger is fastened, then when the little or no resistance which the borers encounter shows that the ground is smashed or broken to pieces, a small oblong iron box with a spiral screw inside is let down. By turning the screw, the box becomes filled with the smashed stones or earth, it is lifted up and emptied, now if we consider that this process is applied to a profundity of nearly six hundred feet, the little progress which they were making say one inch and a half per diem is not to be wondered at. After having penetrated to the depth of forty three feet, alternate strata of chalk and flint had been found regularly, the former twelve inches, the latter from twelve to fourteen inches thick. Upon the fourth island Arsenal-holm several large buildings have been constructed for storing the arms which are used on board the Royal Navy. The Ground floors are occupied by the gun-carriages, those of each vessel kept separately. Alongside the walls are placed the cartridges, some containing a certain number of small bullets, others containing bullets of various sizes, nails, and bits of iron all mixed-up together. Up-stairs, arms of various descriptions, such as muskets, Pistols, swords, pikes and hatchets all arranged with order and symmetry. Again another bridge connects Arsenal holm with Christians holm where balls and bombs are piled up and the cannons themselves lay on the ground in long lines. If I were inclined to institute a comparison between the Copenhague and the Chatham dock-yards, I should say that the former is more extensive but dead and lifeless, whilst in the latter, the area of which is smaller, all is life and activity. Lieutenant Rohte and I were now rowed over to the Gammel or Old-Holm on the Kjobehavn side. This is much less extensive, here is the smithy which appeared to me uncommonly small; boats are kept under sheds. The rope yard we did not enter, nor the building which contains the models of men of war, it being already locked-up. My companion and I finished our this day's round with paying a visit to the charts-archive's office in which department Lieutenant Rohte and his superior Von Zahrtmann were specially employed. The manner in which charts are printed was shown and explained to me. [551] On a well polished copper plate, the lines of the charts are engraved, the copper plate is rubbed over with a certain description of printing ink which of course fills up the lines, the other part of the blacking is carefully wiped off, then a Sheet of paper moistened and prepared in a particular manner is placed upon the plate. This, covered over with a woollen cloth is by means of a wheel slowly and gradually pulled under a tightly fitting cylinder, and naturally the black lines on the copper plate leave their impression on the white paper. I had now to run for my dinner at the hotel, the Flensburg ladies had left for Roskilde. 
Dinner dispatched, I determined upon making on foot the circuit of Copenhagen, accordingly I walked down Amalien-Gade till I came to the Custom-house where turning off to the left I found myself vis-a-vis the fort of Frederickshavn which on showing a card of admittance procured me by the owner of the hotel, I was allowed to enter. The wall along the sea is called the "Lange Lime" or the long line, this I followed to its other extremity whence continuing my walk under gates, over bridges, and through pretty avenues I reentered the town by Oster port, there I ascended the wall and round the same I first came to the Norre Port or gate, next to Vester-Port or Western gate and finally to Lange-Bro or Long bridge. The walls are planted all along with two rows of fine trees, but are by no means so tastefully laid out as those of Hamburg. The Copenhagen walls are still those of a fortified town, whilst those of Hamburg are turned into pleasure walks. I crossed Lange-Bro, once more ascended the wall and reached amager gate where turning to the left, I walked through Christianshavn. The houses in this part of the town are inferior to those on the other side of the port, and over Knippel-bro, came to Adolph's house, with whom and his nice little wife, I took tea and spent the evening.

Thursday, $4^{\text {th }}$ of July 1844. I spent the forenoon in those apartments in Christiansborgin which Thorwaldsen'sstatueswere deposited until the museum which was about being built for them would be ready for their reception. I am no "connaisseur" or judge of statuary as little as of painting; there is however one difference. With the former I can occupy myself with pleasure for a long while whilst I soon get tired in a picture gallery. On the spot I noted down what pleased me best, and of this memoranda the following is a transcript with some trifling alterations; Minerva adjudging to Ulises the shield of Achilles; the Genius of poetry, being part of the monument erected in honor of Lord Byron, the drapery which covers the legs falls in wonderfully light and elegant folds; [552] the bust of Baron Schubart, the forehead is uncommonly high round the mouth plays a benevolent smile; the plaster model of the far famed Lion cut in the rock near Lucerne in commemoration of the Swiss guards of Louis XVI who died in defence of the Tuilleries against the Parisian mob on the $10^{\text {th }}$ of august 1792, the noble animal deadly wounded is expiring, its paw still rests upon the shield of France with the Bourbon fleur de Lys, bravely, but vainly defended; a plaster cast of the bust of Napoleon sustained by an Eagle, his is a handsome face with a particularly winning smile, the brow between the eyes a little contracted; the genius of death represented by a winged youth asleep sitting on a rock, a wreath of flowers in one hand, an inverted and extinguished torch leaning against his other side; round the wall in bas relief, a copy of the marble bas relief in the villa of Somma Riva on the Como lake, representing Alexander's triumphal entrance into Babylon, he himself rides his war horse, 
warriors on theirs steeds follow him, there are tigers and Lions fettered and led along, a Camel with a child on its neck, endeavouring to climb-up the hump, many women strewing roses on alexander's path, other persons offering him presents, flocks of sheep, a man rowing over a river in a boat, and a great number of other figures; a plaster cast of Saint John the baptist preaching in the desert, many people around him listening with great attention, all in different attitudes, the original exists in our Lady's Church in Copenhagen; the four Seasons in marble, a Lion with an Amor several times repeated; in plaster the colossal statue of Guttemberg, the original of which exists in Mayence; further, in plaster, of our Saviour of more than human size with nine of his Apostles, this is considered one of the Chef d'oeuvres of Thorwaldsen, the original is in the "Our Lady's church" of Copenhagen. I need hardly say that all the preceding are Thorwaldsen's works. Here are also some antiques, a few Originals, the greater part copies in plaster. I noted a fine drawing of P. Lutz, a stout warrior in his cuirass, bearded, and with a noble mien, also the picture of a Roman woman by Richter, another by B. Möller representing Christ blessing the four Evangelists. From Christiansborg, I went to see the museum which as already said was about being built for the reception of Thorwaldsen's works. It is of an oblong shape with a yard in the centre round which runs a portico; it is two stories high, but the vestibule or vaulted hall at the entrance, to which a flight of steps leads, rises through both stories. The hall at the other extremity, I could not enter, it being locked up. Both the ground floor and the upper story are [553] divided into small rooms, these do not look well, but as Mr. Thomsen told me, their object is to obtain a number of side walls against which the statues can be placed and the pictures hung because both show to greater advantage if the light falls upon them sideways, not straight in front. My next visit was to the Museum of natural history which I did not much admire. There were many birds and snakes, but few other animals. I dined at Mr. Adolph's with himself, his wife, his mother, two clerks and a Mr. Boysen, a pleasant young man now clerk at C. J. Hambro and Son in Copenhagen, formerly at Lucas Willink's in Altona. At five oclock I ran to Mr. Thomsen's house, who accompanied two young Gentlemen and myself to the King's palace in Amalienborg. We were shown to the majesty's private apartment which he inhabited when here, a carpet was wanting, otherwise it was well furnished. In the middle stood his writing table with a pretty ink stand, round the walls mahogany cup-boards with glass windows containing for the greater part Antique Etruscan vases, also a few Peruvian huacas, the presses in which the collection of medals and coins was kept were locked. The greater part of the books of his library treated on Numismatics, some chess men stood on the table, a Malay waved sword hung against the wall, the Glass windows were prettily painted. One with another, 
the whole apartment was exactly such a one as a well educated Gentleman of fortune might have for his private use. The Council room was hung with portraits of the Royal family, the table in the middle was covered with baize; under a canopy stood the Royal Chair or throne, only used on occasions of solemn audiences. From the Palace I hurried back to Adolph's, where he and the two ladies Old, and young Mrs. Adolph were waiting for me. Together we walked to Wester-Port, thence drove in a Droshka to Fredericksberg where we promenaded a considerable while in the beautiful avenues of the park. I was much pleased with my female companions, they put up with my bad Danish, and frequently corrected me. On our return home through the splendid walks which surround Copenhagen, we met Mr. Boysen and a young Mr. King of the family already mentionned when in Fredericksborg, who was mate of a merchant vessel. We returned to Adolph's where we concluded the day with tea, Bread, butter, and cold meat. I also showed them my drawings of the Lima costumes; whilst endeavouring to give an explanation of them, I [_] how often I was at a loss for a Danish word. [554]

Friday, $5^{\text {th }}$ of July 1844. Rosensborg palace stands on the Western side of Kron Princess's gade which street has been taken off from the garden which surrounds the Palace, and this garden notwithstanding the diminition is still of considerable extent, and is adorned with many fine avenues. Rosensborg, like Fredericksborg owes its existence to the magnificience of Christian the IV, one of the most active of the Danish Souvereigns of the Oldenburg line, the style in which both palaces (of red bricks) are built show that they date from the same period and that the same will directed their construction. Rosensborg is not inhabited by any member of the Royal family; it serves as a deposit for the reminiscences of the reigns of the various Oldenburg Danish rulers, to each of which one or more apartments are allotted. The admittance card for a party of twelve persons or less costs one and a half Species, but thanks to the kindness of justiz-Rath Thomsen, he brought together as many as five persons, so that the share which each had to pay was but small, we were: a clergyman from Falster, a Gentleman from Jutland; a musical student from Upsala in Sweden; a young jew Loria, nephew of C. H. Donner's Old correspondant Herz Isaac Loria, and Myself. When we had finished, we all confessed that we had been well pleased, but agreed at the same time that too many objects had been placed before us in too short a time, so that the impression made by the one was quickly effaced by the next, and at the end, little if anything remained fixed on one's mind. Here follows what I recollected after a lapse of less than twenty four hours and what I was able to put on paper with the assistance of a small description of Rosensborg then bought, since lost. The first thing which was shown to us was the so-called Oldenburg 
drinking horn of great size, made of silver and beautifully ornamented. It was worked in Oldenburg either 1470 or 1475 and brought to Copenhague in the $17^{\text {th }}$ century. Upon the panels of one of the apartments are painted the portraits of Christian IV's mistresses with red powder in their hair which must have been the fashion at that period. Christian IV's motto was M. H. z. G. A. which means: Meine Hoffnung zu Gott allein (My hope in God alone). It is strange that a Danish King should have his motto in German which seems to prove that the German language must have been prevalent at the court of Christian IV. These initials M. H. z. G. A. are engraved on many articles of the King's daily use, for instance, on his hunting knife, on his hanger etc., on the back of a small looking glass is his cypher in Gold, and round [555] it, the following thus: dirige [c]or meum. We were containing an iron rule or measure, compasses, a pair of small scales, put together it says: Jehova likewise shown a cane a ship compass, a pair of and similar instruments, also a stamp for stamping instead of writing his signature, further two flutes made of bone turned by himself; his own ship lantern of silver; on an almanach were painted some soap bubbles and a candle burnt out with these words: "als [Belben] Roock [verdvignt] des menssen Leeven Oock" which being Dutch means in English "like bubble and smoke vanish men's lives also". In a drawer are kept some of the clothes worn by Christian IV in the Naval action fought near Feehmern against the Swedes in 1644 in which he lost his right eye, the shirt collar, the shirt's cuffs, the ruffles still showed the blood spots. Christian IV's contemporary was Gustavus Adolphus of Sweden (Walter Scott's Bulwark of the Protestant faith) the sword worn by him in the thirty years war is preserved here. On the blade the following mottoes are engraved, on one side: "Soli deo Gloria; si Deus pro nobis; qui contra nos; fide, sed cui, vide." on the other side: "Spes mea est Deo; vincere aut mori". From the period of Frederick III's reign the objects morst remarkable to me were: the portrait of a clergyman painted on wood by the King himself when archbishop of Bremen; a miniature portrait of Christina of Sweden, very plain and fair; a large picture badly done, a faithful representation of the introduction of absolute Government in Denmark (Souveraine[tet]'s) [Ju]dförsel paa SlotPladsen e Kjobenhavn, the whole ceremony, the costumes, the buildings, all is depicted with the greatest accuracy; another painting is that of a white horse "Cranach", the mane of which reaches to the ground and the tail's length measures three times the horse's height; it was Frederick III who ordered the making of the chairs in which the Kings and queens of Denmark have been crowned since then. The frame work is made of the Narwhale's horn, the seat of the Kings chair of gold brocade, of the queen's, of silver 
brocade. There exists in one of the apartments which refer to the time of Christian V, his portrait embroidered in silk by Christian IV's natural daughter Eleonora Christina Munk. This lady born in 1621 in Fredericksborg, married Count Uhfeld who rose high in Frederick III's favor; afterwards, he fell into disgrace, and was condemned as a traitor, he lost his life drowned on passing the Rhine. Christina Munk arrested in England was carried to Copenhagen where for twenty three years she was imprisonned in the blue tower, recovered her liberty at the death of Sophia [556] Amalia Queen of Frederick III and lived till the age of seventy seven, when she died in Mariboe Castle in 1698. In the frame of the portrait (Frederick III's), the following verse of which Christina Munk is the authoress, is embroidered by her own hand.

"See her en Konge god en Engle Sj[œ]le mand,

Den i Gods-fr[y]gt med Ret regj[œ]rer Folk og Land

See her en stor Monark hvis hoved v[œ]rdig v[œ]r

at han i tusind Aar al Vardens Kroner bar."

Anglicé: "See here a good King, a man with an angelic soul, who in the fear of God with justice rules the people and the land; see here a g[_] monarch whose head deserves to wear for a thousand of years the crowns of the whole world". In the same apartment are some vases of silver filigree work; also a large tumbler of the red glass like the Bohemian glass at present so much esteemed; a small anchor requires a particular notice: it is said that when King Christian V was on board of a vessel near Bornholm and in danger of being wrecked upon a lee shore, none of the anchors held on, except this small one thrown out by the King himself which accordingly is preserved; to it are affixed the following verse by Bishop Kingo: "Gu[d] holdt paa mig og jeg holdt Christian den Femte; Da en fortvivlet storm i Østersoen han klemte, to Rigers Liv og Dod paa to Jernhage la[v]e. Jeg derfor her skal til it evigt Minde Staae". Anglicé: God held fast upon me, and I held Christian V when a frightful storm pinched him in the Baltic, life and death of two Kingdoms bestrode two iron hooks, therefore shall I stand here, for eternal remembrance. We now come to Frederick IV's time, the baptismal font silver gilt in which all the Royal children are christened, is a beautiful piece of workmanship; a large drinking cup of glass with a lid, of which Charles XII of Sweden made a present to King Frederick IV of Denmark, is an evident proof of the former's pride and haughtiness. On one side, his c[i] pher is engraved, on the other, a Hercules a club in his hand, between two columns, above whom these words: non hoec ultima meta laborum, below: XII labores Hercules; around, the names of twelve places near which Charles had gained great victories even over Danish armies. A sword preserved in the same apartment is a proof that Charles XII was also capable of noble feelings. 
It was presented by him to a Norwegian Coronel Krüse in acknowledgement to his extreme valour when defending himself with 150 Dragoons against 600 Swedish Soldiers commanded by Charles himself. After Krüse's death, his children sent it to the King Frederick IV. A blue and white porcelain jug and six cups and saucers of China ware silvered inside are only in so far remarkable as they were brought to Copenhague by the first Danish vessel which returned from China. An oil painting representing field Marshal Count [557] Steenbock (the same who ordered the burning of Altona) with a paper in his hand upon which these words: "Herr lass Deinen Gefangenen loss" (Sire let loose thy prisonner) was painted by himself whilst in prison in Tonningen, he sent it to the King then in Schleswig. Steenbock was afterwards carried to the fort of Frederickshavn in Copenhagen in which he died a prisoner in the year 1716. The looking glass cabinet makes a strange impression, the ceiling, the walls, with the exception of a small door which opens into it are covered with mirrors even the floor consists partly of a large mirror, and thus not only the persons who stand in this cabinet, but also some objects in the adjoining garden whither a window opens, are reflected "ad infinitum"; the glass cabinet contains a collection of scarce and costly curiosities made of glass in the manufactory of Murano near Venice, purchased by Frederick IV himself when there. The Rittersaal in the upper story occupies the whole length and breadth of the Palace. Of Christian VI's time, I only recollected the antler of a stag killed by the queen, in commemoration of which feat the Palace of Hirsch (Stag) Holm, since demolished, was built. Of Frederick V's time, nothing struck me as worth noticing. On reference to the Rosemborg guide above alluded to, I saw that the King's first and second wives, the former Louisa daughter of George II of England, the latter, Juliana Maria, daughter of Albert Duke of Brunswick [_]büttel, who was the irreconciliable ennemy of Carolina Mathilda, were both adepts in the art of turning. Christian VII who became crazy in after life, must have been a man of some knowledge in his younger days, at least if we may judge by the diplomas of Doctor which both Universities of Oxford and Cambridge bestowed upon him when in England. These two diplomas are kept here as well as another from the wardens of the Goldsmith's Guild in London, admitting him as one of their members. Of Frederick VI's period various crosses worn by him, and not returned at his death because the orders to which they belonged had become extinct, interested me most. There was that of "Le Saint Esprit", abolished in France since the Revolution of July 1830, those of the "La Legion d'honneur" of Napoleon I and of Luis King of Holland, the latter had this motto: "Doe Good en zi[e] dick niet om". ("Do good and [558] don't look back). I learnt here a strange custom, namely: that the Coronation robe of each King of Denmark (Red velvet embroidered with Gold crowns and 
lined with ermine) after it has covered the Corpse whilst lieing in parade, is interred in the same tamb with the Royal wearer. Before we left our attention was called to a great variety of Royal dresses stiff with Gold and Silver, and other precious stuffs, likewise to a speaking trumpet which measures in length one hundred and fifty five feet, and reaches from the most Northern saloon in the first story piercing the wall through the cellar in the most Southern extremity of the building. Our next visit was to Charlottemborg where a well instructed servant showed us round, and explained what we wished to know: here were the plaster casts of some antiques, and of nearly all Thorwaldsen's works amongst which I discovered those of the three graces and the shepherd boy, the originals in the possession of C. H. Donner of Altona; a colossal Hercules was the last statue sculptured by Thorwaldsen. I had still time to go to the Royal collection of copper plates. The first small apartment was hung around with wood-cuts which give an idea of the progress gradual of this art; the first a German one from the fifteenth century, shows it in its very infancy, one from the Netherlands of the same period, is somewhat neater; a woodcut by Albrecht Durer, of Ulrich Varnbullen is already a great improvement, it shows life and power, another woodcut by antonio Raimundi representing six witches riding on goats and skeletons is fanciful and curious. Henry Goltzius' own portrait though worked still in coarse lines, is nevertheless well finished; Jonas Snyderhof's woodcut which represents the moment when the various plenipotentiairies assembled in Münster for concluding the treaty of peace in 1648 take their oaths, is very scarce. The Catholics lift up their fingers in the sign of the cross, the protestants place theirs upon the holy Bible; next follow some small engravings of Netherlandish artists. In other apartments the engravings which form the bulk of the collection are preserved; these the visitors are not allowed to enter, but a Gentleman who attends for the purpose hands to them all such as they may ask for, an index of all lying on the table, I asked for some English engravings by Boydell also for some German ones, and was much surprised to find how much inferior those of the last century are to those of the present day. I found some amusement in noting down the devices round the arms of noble English families. That of the Earl of Devonshire is: Cavendo tutus.

that of the Earl of Brite is: Avito verit honore. [559]

that of Sir Laurence Dundas, Baronet: Essayez.

that of Duke of Mahrlborough: Dieu defend le droit.

that of Earl of Besborough: Pro lege, Rege, Grege.

that of Earl of Coventry: Spectamur agendo.

that of Earl of Chesterfield: A Deo et Rege.

that of Sir Robert Uldney: all my hope is God. 
that of Lord Travers: Vestigia nulla retrorsum.

that of Earl of Lincoln: Loyauté n'a houte.

that of Earl of Exeter: Cor umum via una.

Joseph Parrocel "peintre de batailles" has in his arms three darts thus: of these I probably took note, because in my own fancy arms I likewise introduced these darts (see page 450 and appendix in $\mathrm{N}^{\circ} 9$ of this volume). After dinner and a Siesta, I went to Tivoli, there were many people, and the weather was fair. I returned to my hotel at half past eleven.

Saturday, $6^{\text {th }}$ of July 1844. The weather was cloudy, thermometer (windows shut) R. $13=61$ Fahrenheit. Mr. Adolph having expressed the wish to be made Peruvian Consul in Copenhague, I drew out for him a representation to this effect in Spanish, which he signed. In course of time, that is to say after my return to Peru, I obtained for him this situation. At a later hour I made another visit to the Royal museum where I had been on Saturday last. Mr. Thomsen was particularly polite towards me, and to the Swedish student whose acquaintance I had made on the preceding day, his explanations were extremely interesting; he seemed to be acquainted with everything, and took a lively interest in imparting his knowledge to the visitors. He showed us snow shoes from Norway, boats filled with air from Lapland, drums used by the Finnish wizards, feather dresses from the Brazils, a Hammock from Mexico etc., etc. After dinner I went to Adolph's and accompanied the ladies as far as the Lange-Bro where I turned off to the right, came to a timber yard, and crossing the ditch which encircles copenhagen emerged over Wester-Bro into the high road from Copenhague to Roeskilde. Here in an open place stands a stone obelisk erected in memory of the laws given in 1782 and the following years which secured civil liberties to the peasants of Denmark and Norway. The inscription of the obelisk, I was unable to read, but the words on the two sides of the pedestal I could decipher, they were: "Grudstenen lagt af Fredrick Kögen's son, folkets Ven 1792". "foundation stone laid by Frederick the King's son the people's friend in 1792" and "For Christian VII [de] Danskes og Norskes [560] Konge af enige og tagneimnelige Borgere" (for Christian King of the Danes and Norwegians from united and grateful citizens). On my return to the hotel, I noted a great crowd in the street caused by three rat-catchers, probably Germans who in their coarse white linen frocks, tight long pantaloons, broad brimmed hats, and traps in their hands attracted the attention of young and Old, high, and low. At seven o'clock I went to the theatre; it is a small building, the interior neatly painted; it was badly lighted-up, only one chandelier with two rows of lamps hung over the pit, and as soon as the curtain rose one of these two rows was darkened, so that I could not even read the play bill. The 
piece performed was the maid of Lyons translated from English into Danish, having seen it in Edinburgh not many months back I could understand the meaning pretty well, and the performers, not the Royal actors, were far above mediocrity. The vandeville, "One evening in Tivoli", written expressly for the Copenhagen audience was unintelligible for me as far as the dialogue went, the meaning I could guess.

Sunday, $7^{\text {th }}$ of July 1844 . Where the two open places Kongen Ny torv and Kongen Gammel torv join, stands the town house, a plain building, its façade which is adorned with six pillars has this inscription "med lov skal man land Bygge" which may be given thus: "Law sustains the Country", its literal translation is: "with law shall one build the land". When promenading in the streets of Copenhague I made two remarks: the one that the number of good looking females is uncommonly great; the other, that amongst both men and women, many have dark hair and a complexion which if not decidedly obscure, can certainly not be called fair either. Etath rath Hvidt having invited me to spend this day at his Country house near Vedbeck, by land two miles and a quarter distant from Copenhague, I embarked at seven oclock at Nyhavn or New-port on board the Steamer "Hamlet" which Bound for Elsineur on her way down the coast of Sealand touched at various ports. Though the weather was by no means favourable, the deck was crowded, some passengers went on shore at Dyr-have, others, I of the number at Vedbeck. There were two peasant girls who otherwise dressed as town ladies in dark colored fine woolen gowns distinguished themselves by their expensive and peculiar head gear consisting of caps, the back part of which was richly embroidered the one with Gold the other with Silver thread, broad red coloured silk ribbons were tied over their simply but neatly parted hair, and fell far down both behind and before. One wore a fine woolen shawl [561] the other one was "en taille", both with gloves and fine white handkerchiefs bordered with lace in their hands; the shoes and stockings I could not see, owing to the length of their dresses. Mr. Hvidt, an elderly Gentleman, two orders on the breast received me very cordially and introduced me to his family which consisted of his wife, a lady from Königsberg who with a bad leg was unable to walk, and occupied herself all the time I was there with knitting; three daughters, Charlotte the Eldest unmarried, rather plain but very agreeable; the second, who stout and plain married in Künigsberg, was with her two little girls on a visit to her parents; and the third Theresa married to a Mr. Saga, a baker; besides these, there were Mr. Saga, Mr. Ehlers, a Doctor Lorck and myself. The conversation was for the greater part carried on in German, perhaps on my account. all Spoke this language extremely well, except Mr. Saga who was not so proficient as the others. I learnt 
the next day from Mrs. Adolph that the whole family belonged in politics to the ultra patriot or anti German party, the baker above all. Nevertheless he took such a liking to me, that he invited me to dine with him on the following day, which invitation I was obliged to decline having previously promised Mr. Adolph to spend the day with him. Mr. Ehlers, a nice young man, had been employed in the Altona Custom-House, and had now a situation in the Royal Musket Manufactory in Fredericksborg. Doctor Lorck had been on the west coast on board the Danish man of war "Bellona". Hardly had I entered when I was offered a cup of coffee, at noon lunch was placed on the table and at four oclock we sat down to a good though plain dinner, afterwards coffee, and finally tea. The time passed away pleasantly enough, I conversed a good deal with the ladies. We Gentlemen walked about in the Garden and in the neighbourhood, enjoyed the prospect over the Sund, the island of Hven, to the Swedish coast and talked on many topics mostly on [_] German-Danish question. At 8 p.m. Mrs. Ehlers and Lorck went in a boat on [_] the Steamer to return to Copenhague. The Baker, Mr. Hvidt, and I accompanied them to the beach, and on our return found two visitors: they were noble [_]amsels of the family of Sehstedt-Gylvestjern, the younger of whom was soon to be raised to the post of Maid of honor to the Russian Princess Alexandra (See P. 535 of this volume). A little later Mr. Hvidt drove me home in his gig through the Dyr Have, it was a pleasant drive though rather chilly. Mr. Hvidt was taciturn. The road was covered with carriages. The Copenhaguen people appeared to me a merry set, fond of amusements somewhat like the Vienna people, more jovial, less serious than the Hamburghers and Altonaers. I [562] learnt this day that the noble Danish family of Daneskjold Samsoe, derives its origin from Christian V and Amalia Moht, his physician's daughter; also that at this time say in 1844 when Frederick William IV was King of Prussia, the following adage was much in vogue in that country: "Er trinkt sie hinkt, des land sinkt". English: he (the King) drinks; she (the queen) limps, the country sinks.

Monday, $8^{\text {th }}$ of July 1844. I went to the Steamer's office to secure a berth for Christiania, and was much annoyed when I was told that I could have only a second class one, which I had even to divide with another passenger; a meeting of Naturalists to be held in Christiania was the cause to this great conflux of travellers. Next I paid a long visit to Mr. Garlieb to whom I delivered an extract of an abstract made by me of Chevaliers pamphlet on the possibility of cutting a canal through the ithsmus of Panama. It was now twelve oclock; with Mr. Adolph I went to our Saviour's church. In the interior I observed nothing which requires particular notice; we ascended a number of steps which brought us to a gallery (provided with a very high iron railing) round the bases of the steeple. Hence the prospect over Copenhagen and the surrounding country is of course very 
extensive. I however on account of my nervousness of which I have spoken on a previous occasion, though I knew there was not the slightest danger, could not make-up my mind to approach the balustrade, and still less to look down into the street. From this gallery, a stair outside the steeple winds up spirally to the summit which, notwithstanding this my nervousness, I determined to ascend. I clung against the wall, whilst Adolph walked by my side close to the railing; to me it was a real sacrifice, but I was decided to conquer myself. When this stair, about six feet from the top became too narrow for two persons abreast, then I had to give it up, and we commenced [_] descent. "Richard was himself again", when we had reached the Warders [_] [?] I breathed freely. Having dined at Adolph's, we, that is to say he, his wife, his mother in law, the nurse, Adolph's little boy and I, drove out together along the beach to Clampenborg where we took Coffee, the sky cleared up a little, and with the help of my glass, I could distinguish the houses in Lanscrona two and a quarter miles distant across the Sund. Adolph and I walked through the beautiful wood to the prettily situated dwelling of the Verderer. In one direction, a vista is cut through the trees, at the extremity of [563] which the Hermitage is visible, in the other direction, the eye wanders over fields, woods and houses to the distant Copenhague. We remounted our carriage and soon reached a village called Longbye close to which is the Royal Country seat "Sorgenfrei" (without care, Sans-Souci) where the King and Queen resided at the time. The ladies alighted I likewise, and for a considerable time we promenaded in the beautiful park belonging to this Palace. It was kept in excellent order, I admired the splendid groups of stately trees, and was much pleased with the Queen's private garden, a wilderness of Roses. All together, I thought this to be the prettiest Royal residence I had hitherto seen. Over a well kept chausée, lined with trees, and through many fine avenues which, as mentioned before surround Copenhague. We reentered the Capital through Norre-Port, and were home at ten o'clock, when we took the usual supper of tea, bread, butter, and cheese. Outside the town not far from Norre-Port Mrs. Adolph made me observe a monument erected in honor of Count Bernstorff by the peasants on his estates, he having been one of the first of the Danish landed proprietors who gave liberty to his serfs.

Tuesday, $9^{\text {th }}$ of July 1844 . At nine oclock I paid a farewell visit to "Justiz Rath" Thomsen, he was as friendly as he had been always towards me during my stay in Copenhague, and requested me particularly to send him Peruvian antiquities (curiosities) as many as I could, after my return to Lima. Having said adieux to the two Mrs. Adolph, accompanied by Mr. Adolph and Mr. King, whom I mentioned on the $4^{\text {th }}$ instant, I went to one of the most interesting buildings in Copenhague, namely to our lady's church. The old church of this name was destroyed by the English in the bombardment of 1807 . The new one has no 
steeple, merely a square tower; its outward appearance is by no means striking notwithstanding its being ornamented with two bas-reliefs by Thorwaldsen; the one in plaster, the other in terra-cotta. The interior, a handsome vaulted hall, is fit for a Pagan temple not for a Christian Church, this was at least the impression which it made upon me. It contains the Chef d'oeuvre of Thorwaldsen on each side, in the centre of the Church stand six Colossal statues eight feet high, each on a pedestal representing the twelve Apostles, Judas Iscariot excepted, whose place is filled by Saint Paul, the expression of the faces, always varied, is serious, at the same time benevolent, their attitudes, their hands, arms, legs, feet, in short, every part of the body which is uncovered is life-like, the garments hang down in easy, soft, and sweeping folds so natural that one can hardly bring oneself to believe that [564] what one sees is marble. St. John's countenance is called angelic, I confess it pleased me least. Ten of these statues are of unpolished marble, two of plaster, the originals as yet in Rome were shortly expected. The statue of the Christ of the same material, unpolished marble, twelve feet high, weighing as I was informed nearly four tons is placed at the end, in a gilt niche, altogether contrary to the wish of Thorwaldsen who was so much opposed to this being done, that he refused to put his finishing hand to this statue. According to him, it should have stood free in the air, like the twelve apostles, it was old architect Hansen who carried this point in opposition to Thorwaldsen's desire. Christ stands with his outspread hands in the act of blessing the Congregation. The expression of his face is that of manliness, seriousness and kindness. Before the altar knells the figure of an angel of marble of course the baptismal font in her or his hands, to judge from the extreme loveliness of the face I should say the statue was meant to be a female, though of stone, one could feel inclined to kiss the half open pouting lips. The kneeling attitude, the spread-out wings, everything is beautiful in the extreme. That part of the Church where the altar stands is rounded off so as to form a half circle; round the cornice runs a bas relief six feet high, representing Christ on his way to Golgotha, many figures precede and follow him. The elevation at which it is placed from the ground is such, that I could hardly distinguish it, notwithstanding its great size. In the vestry is another Bas relief representing the Lord's supper, not in the usual manner, Christ and the apostles sitting round the table; here he stands upright, and the disciples throng towards him, only Judas Iscariot at one extremity turns his face away with an angry demeanour. This tableau is remarkable for a particular circumstance: in the course of the preceding winter, Throwaldsen commenced to correct some trifling blemishes which he had discovered, but the cold was too severe to allow him to proceed, meanwhile death overtook him, and thus 
the rough marks of the Chisel used by this great man for the last time remain visible. Finally we were shown Thorwaldsen's Coffin; the outer one of oak was adorned with many garlands, it was to be removed to the museum which bears his name, and there to be placed in a vault in the centre of the building. To this museum we now wended our way, that part which I had not entered on the fourth instant was opened to us at Mr. Adolph's request. Here also stand many statues of Thorwaldsen amongst which a Ganymede giving the Eagle to drink and a large couching [565] Lion which was to be placed upon Thorwaldsen's tomb. Highly pleased with all I had seen in the morning, I separated from Mr. Adolph in the street, and vainly insisted upon repaying to him the heavy expenses which he had incurred on my account, both on our excursions in the country and in the churches and museums in Copenhague, he would not accept a cent. I returned to my hotel where, whilst taking lunch, I was joined by the Gentleman who was to occupy in the Steamer, the same berth with me; he was a Clergyman from Bremen, a pleasant, merry man. With him were his sister, extremely ugly, and I suppose for that reason very anxious to make herself agreable and eager to enter into conversation, and his wife, better looking but less talkative. It was now time to go on board. I took with me my trunk and a hat box, my portemanteau and some maps which I had brought, I left at Adolph's. The deck was crowded, my berth as already said of the second class was in the forecabin and very small. At three o'clock the Steamer "Christiania" got under weigh. This was the third time that I steamed along the coast of Sealand and for the third time under a cloudy sky, certainly an unfavorable circumstance for a just appreciation of its scenery so much lauded by the Danish patriots. I had been in Copenhague and its environs more than a fortnight, and all this while though in the midst of summer I had hardly had a single day with really warm weather and an unclouded brilliant sun. Elsineur, Cronborg and Elsimborg forming apparently a bay without an outlet pleased me this time quite as much as they had done on my first trip on the $29^{\text {th }}$ of June last, then, the great many vessels waiting there for a favourable wind had been to me a cause of wonder, this day there were but a few. More passengers cameoff from the first named place, so that our number exceeded a hundred. On, we steamed; Cronborg astern of us remained a long time visible. At 7 p.m., we were opposite the Kullen mountains in Sweden with a light house on the top of them. Soon after, the Sealand coast on the larboard side disappeared whilst on the Starboard side the Swedish Coast continued in sight. The motion of the Steamer was so trifling that nobody suffered from sea sickness. At a later hour, tea with lobsters and other good things were served in the State cabin, of which I partook heartily. The evening was cool, not to say cold. Towards eleven oclock, 
all retired to rest, but only few to bed. I, wrapped in my big cloak, lay down upon a bench on deck but soon felt so chilly that I got up to look out for another resting [566] place, when I came to a small office built on deck where several Gentlemen were sitting, the greater part asleep, one of them addressing me in French offered me his place, he having a berth below, for himself. I accepted his offer though his seat near the door was one of the coldest. However, resting my head on the table, I soon fell asleep. I awoke at half past two, when I went below with the intention to call up the Bremen Clergyman, and to take his place, but the floor in the State cabin was so completely occupied by sleepers that it was impossible for me to reach my berth. I therefore returned on deck, took my former place and again slept till 6 oclock. I must still say a few words about the passengers, of whom many were naturalists, such as professor Forchhammer, an Englishman with whom I conversed a few words; Professor Eschricht who was accompanied by his wife; Professor Chaufepié (a distant relation of Mrs. Lilie of Kiel) with his wife, these two very nice people; Doctor Lorck whom I had seen at Hvidt's, here on board not over polite towards me; also a Mr. Hambro from Bergen to whom Lorck introduced me; Mr. Movinckel from the same place; a young Engineer Mr. Lehmann. All these spoke German, and I made their acquaintance as well as that of a bearded Italian and a Frenchman, which two gentlemen as is generally the case with all Southern Europeans seemed to take it for granted that every well educated Gentleman must speak and understand French. Of the ladies on board I noticed two actresses Mrs. Petersen young and very good looking, Mrs. Nielsen of a more advanced age with her husband; two misses Lange from Hamburg who went as Governesses to Christiania, rather handsome; and a miss Möller, daughter of a military man, actually beautiful. A baron Sekendorff, and a Count Von-Raben, kept rather aloof from the plebeian crowd.

Wednesday, $10^{\text {th }}$ of July 1844. At six o'clock I stepped on deck and saw that we were in a small bay called "Sk[joe]rer-Gaard" completely surrounded by low greyish-looking rocks. It is well known that the small rocks, cliffs, and islands which surround the Norwegian and Swedish Coasts, and the navigation through the midst of which is extremely difficult and dangerous, are named "Skjoerer", in German "Scheren". Gaard is the Danish for yard. To our left we had on a rock, a battery Ny-Elfs-Borg. Slowly we steamed on, at a distance the steeple of a Gothenborg came in sight, gradually some verdure covered the hitherto barren rocks, there were the huts of pilots and fishermen, a tele[_], [567] some store houses, a pretty country house built on the top of a hill. At 7 oclock we came to an anchor, and as the Captain told us that he intended to remain till ten oclock several passengers went up to Gothenborg in a boat, a few, I amongst them, on foot. The road was lined on both sides with wooden 
houses, and this one long uninterrupted Sreet went by three different names, first "Klippan" (or the Cliff), next "Majorna", and finally Masthuggot, perhaps these two names being Swedish, which language I do not understand, are spelt incorrectly. To my left I had the bay, on the other side of which small cultivated plains rising gradually into hills with high mountains in the background, to my right timber yards, behind them corn fields. Having walked on for about three quarters of a mile, a small hill lay before me, from the summit of which I saw the town of Gothenborg. I passed a square tower with loopholes, the remnants of former fortifications, from which point a low ridge of hills with pretty houses on its brow stretches inland, to my left the bay was again in sight, here at its Eastern extremity some vessels, also a Steamer were at anchor. I entered the town between two strong stone walls without a gate. The appearance of Gothenborg pleased me, it is intersected by one large and many small canals, all spanned over by granite bridges with iron banisters; the Streets cut each other at right angles, many of the houses built of brick, some stuccoed, are of considerable size. The principal Church, a pretty building stands in an open place, the town house and the guard-house in the market place which was covered with people, and where I noted as a peculiarity, that the meat was sold from the low carts on which it had been brought to Market. Having seen all I could in this short time, I returned in a boat on board the Steamer together with some other passengers. At ten oclock, the anchor was weighed, and we continued our voyage. At about half past eleven we were again in the open Sea, our course was N.N.W., the Swedish coast continuing in sight, the steeple of Marstrand showed itself. At two oclock we went below to dine, I sat between Mr. Chaufepié, and Mr. Professor Forchhammner, which latter and I took a bottle of Madeira together. From him I learned that beeches grow in Norway in no higher latitude than the province of Lauervig, Firs and Tines grow intermingled with ash-trees and birches, of which four descriptions of trees ash trees require the warmest temperature and consequently the most Southern latitude, whilst birches though becoming small, crippled, and dwarfish [568] are found further North than firs, or pines. At dinner no lady made her appearance, all were more or less sea-sick. We returned on deck, the sun came out and it grew warm. I commenced reading Jones history of the seven years war and fell soon asleep. The young men under the direction of Lorck amused themselves with singing comic songs, some of which entirely, others partly German; so much for their Danish nationality! At eight p.m. I saw first the Norwegian Coast, soon after, the first rocky islet in Christiania sund became visible. At ten we came to an anchor in Sandoe Sund so narrow that our Steamer and another nearly filled up its entire width. To the latter Steamer "Prindsen Carl" such passengers as were bound for the West Coast of 
Norway were transhipped. On the beach of Sandoe island stood a few stone houses surrounded by hills in a half circle; they put me in mind of Balsas on the river Marañon (See page 683, first Volume of these extracts) though certainly in America, the beach was considerably larger and the mountains infinitely higher. At 10 1/2 I turned in and fortunately had no companion, the Bremen Clergyman had gone on shore at Gothenborg, and a servant man who was to share my berth had thought proper to stay away. At $21 / 2$ I was awakened by the renewed motion of the Steamer. When I went on deck at 4 a.m., it was filled with the male part of our party; the ladies were still dressing; the counsumption of coffee was extraordinary.

Thursday, $11^{\text {th }}$ of July 1844. We had just passed the town of Walloe on the Western shore of the "fjord", and I could still distinguish a large red roofed shed which I was told belonged to an establishment for extracting salt from the sea water. Bye and bye the fjord became narrower, the rocky shores slanted gradually down to the water's edge, they were covered with fir trees interspersed with cultivated fields, and wooden red roofed houses peeping through. At $5^{1 / 2}$ we were opposite a small bay at the Eastern end of which lies the town of Moss with a steepled Church, and neat bathing houses. In front of the town, the dark fir forest which encompassed it behind and on both sides was cleared away, making room for a cheerful looking green meadow. Now the ladies joined us. A little further on the same side, we passed a Gentleman's Country house situated on the summit of a hill, the owner had hoisted the Nor[w]egian flag which was saluted by the firing off of the small gun we had on board, and this Salute was returned from on shore. The Fjord widened, [569] the Sky became overcast and the prospect was less pleasing, though occasionally the cheerful houses shone through the surrounding dense dark trees. At Horten on the Western shore, we stopped again. The fir forest continued to form the background, opposite Horten lies Droback where we stopped for the last time before reaching Christiania. No variation in the scenery, always the Grey rocks covered with the sombre looking firs and pines. At nine oclock, the first houses of Christiania appeared, all the passengers thronged to the forecastle, when the wife of Professor Eschricht who had learned my name from Mr. Chaufepié came-up to me and said her maiden name was Petit of Altona, and that she was a particular friend of Mrs. Teresa Siveking, now also her husband was more polite towards me. He promised to introduce me in Christiania to the meetings and to the dinner parties to be given in the Freemason's hall by the united naturalists, and begged me to send him from Peru some Indian mummies, but the promise was forgotten by him the same as his request by me. It was the suburb of Pipervigen between the new palace and the fort of [agerhuus] which we had before us, and steaming round the point of a small peninsula we came 
to an anchor close to Christiania itself. Of the situation of this town the sketch herewith will give an idea, see page 573. All the luggage, my trunk of course amongst it was left piled up on deck, and the passengers went on shore in several boats. I had no money of the country in my pocket, when a Gentleman of whom I knew nothing, on observing the dilemma in which I was, paid the fare for me. It was to be sure a mere trifle, two Norwegian Shillings, less than an English penny. Nevertheless it was always an attention on his part. A porter who carried my carpet bag showed me to the Hotel du Nord where I took a bed room, and immediately went to the Custom-house where I had to wait a long while before the luggage was brought from the Steamer. The scanting was very slight and superficial. I returned to the hotel; shaved, changed my dress, and started afresh for the purpose of delivering my letters of introduction, one from Henry Siveking to his correspondent, an agent Mr. Tiedemann, the other from C. H. Donner to F. J. Heftye \& son, the first mercantile firm in Christiania. Mr. Tiedemann was not at home, one of the partners of Heftye received me with great politeness and had even the attention to accompany me to a seller of Gigs, in Danish Carriolle, which kind of carriage is indispensably necessary for travelling in Norway. The following description of the "Carriolle" is taken from H. F. Fozer's travel in Norway: "the carriolle is the nearest possible approach to a skeleton [570] carriage; in few words, it is composed of two long shafts, two large wheels, a little seat, and a little splash-board. The shafts are the great feature, as they support the body of the carriage, and being made of very strong ash-wood and thin in proportion to their length, they yield with the motion of the vehicle, and render springs unnecessary. The wheels are behind the seat, and just behind them again, is a board on which the luggage is placed, on the top of which sits the boy who looks after the horse, and takes it back to the stage left behind. The seat is extremely small, the sides are about nine inches high, the back about eighteen. Between this and the splash-board is a narrow bottom where a Knapsack or a porte-manteau will conveniently stand, and attached to the splash-board is an apron which together with a mackintosh will enable you almost to defy rain. There are no traces but the horse draw by thongs attaching the collar to the forepart of the shafts. Your feet rest on either side of the splash board against a cross-bar, which supports the front of the carriage; and as the seat is very low, so that your legs are at right angles to your body and there is hardly any support for the back, it is hard to see on what principles mechanical or anatomical it can possibly be comfortable, but it is so notwithstanding and you may travel in this way for whole days without being fatigued at all". At 2 p.m. I took my seat at a long "table-d'hôte"; opposite to me sat Mr. Dahl from Copenhagen, bookseller in Christiania, and his lady, a German by birth, very fair, but without the slightest expression in her features, 
before her marriage she had been a professional Singer, with both I soon entered into conversation. Dinner was very poor: watery soup, bad beef, bad mutton, roasted fowl of which nothing came to me, pods of pease swimming in a sea of gravy and pudding with sweet sauce formed our bill of fare. For me I ordered some bread and cheese. I now took, as is my custom in every strange place, a long walk by myself. Christiania is regularly built, the streets run at right angles, there are many large buildings, such at the theatre, the University, the Elementary School, the Freemason's hall, the Custom-house, the Savings bank, the meat market, and others. Many of the private houses, all of brick, some stuccoed, are also of considerable size. Outside the town I had to my right the Agger Eh rushing downwards like a mountain torrent forming cascades, putting saw-mills in motion close to which heaps of timber were piled-up. The country round Christiania [571] pleased me more than the environs of Copenhague, the beauties of which good Mr. Adolph had taken so much pains to point out to me. Here I had green hills and valleys dotted over with solitary houses, the summit of the hills covered with wood, and the Elv dashing through the midst of them. I returned by another road, from which I had a very different prospect over the town, the bend of the bay, and across the small peninsula to the Fjord itself. I entered the Church yard very neatly kept, passed several country houses and at about 5 1/2 delivered my letter of introduction to Mr. Tiedemann who being very busy at the moment requested me to return at a later hour which I did at seven oclock, when he received me with great kindness. He was a Mecklemburgher by birth, unmarried, about forty five years of age with grey hair, and of a merry disposition. After having conversed a little we walked out together through the suburb of Pepervigen to the new Palace of Kongens gaard which though a large building with many windows had nothing Royal in its appearance. Close-by, the new university was about being built, at a short distance thence we came to a public house kept by a Swiss, much frequented by the Christiania people, Mr. Tiedemann ordered a cold supper and a bottle of porter, we were joined by a Ship broker and a Captain, a bottle of Champaign was put on the table and I wonder I did not take too much. Mr. Tiedmann told me that King Oscar was much beloved, more so however in Norway than in Sweden. He had introduced many reforms, and given the Norwegians a National flag which last measure had raised their love for him to the highest pitch. It was twelve oclock when I reached my Hotel.

Friday, $12^{\text {th }}$ of July 1844 . The greater part of the morning I was at home waiting for Mr. Tiedmann who had promised to take a drive with me but had been prevented from keeping his appointment. The weather was cloudy thermometer R. $141 / 2=65$ F. At 2 p.m. I went to dine with Tiedemann. Besides the host and myself there were four Gentlemen, all Germans, two whose name 
I did not learn, the third a Mr. Dubourg, once a great merchant in Christiania, the fourth Mr. hansen a violin player. Dinner was very good; we commenced with herrings and Bologna sausages to whet the appetite, Strawberries with milk were served before the roasted fowl, wines were excellent Champaign in abundance, Tiedemann gave many toasts, and all were gay and merry. Coffee being handed round, the two N. N. left, and after a long discussion Messrs. Tiedemann and Duboug settled the [572] route of my future journey through Norway. We then went to look at my gig, and it being approved of Tiedemann thought I ought to make my first trial in driving: one of his horses which was harnessed to my gig was so well broken-in, that I had not the slightest trouble with it though now and then I drove over a stone or a trunk which ought to have been avoided. Tiedemann, Dubourg and I, each in his gig by himself, now took a ride through the very pretty environs of Christiania, the horses went at a good rate, fast down hill, slow up hill; hills and valleys, dark forests and cultivated fields alternate, solitary houses with their red roofs in every direction, now and then a look to the Fjord apparently land locked like a lake, with an islet, a peninsula, then the opposite shore; this is the General character of the Country. We drove to and round a small peninsula called Lagaards Øe, the greater part of which had been purchased by the late King, it was supposed the present King Oscar would have a country seat erected there for him. Mr. Tiedemann had also some property in this neighbourhood where he was building a wooden house. From a small eminence we had a view of Christiania gilt by the last Rays of the setting sun, on the one side the dark forest, on the other the placid waters of the Fjord, it was beautiful indeed. We reached Tiedemann's house by ten oclock, and in my hotel, I was busy until one oclock in the morning before I had everything ready for my Journey. The Norwegian money which Tiedemann had furnished me with, consisted of dirty nastily smelling paper.

Saturday, $13^{\text {th }}$ of July 1844 . At six oclock I was on the point of starting when it was found that a bit for my horse was wanting, this had to be sent for and thus a Count Goltz who had expressed a wish to keep company with me for some stages as far as his and my road were the same (his destination was Bergen) went on by himself, and I followed him about twenty minutes later. As long as I remained in the town, I begged the postillion called in Norwegian "Skyds" to take the reins; when outside I took them in my own hands and managed to drive pretty well. To forward the traveller by means of a "Skyds" is called at "Skydse", and the post master "Skydsskaffer" (Postillion Procurer). For a short distance until the point where the road turns-off to Lagaards Øe, I drove the same way as that which I had come last night with Messrs. Tiedemann and Dubourg, then keeping to the left I followed the Fjord which frequently came in sight, whilst [573] (From page 569 line 18) 


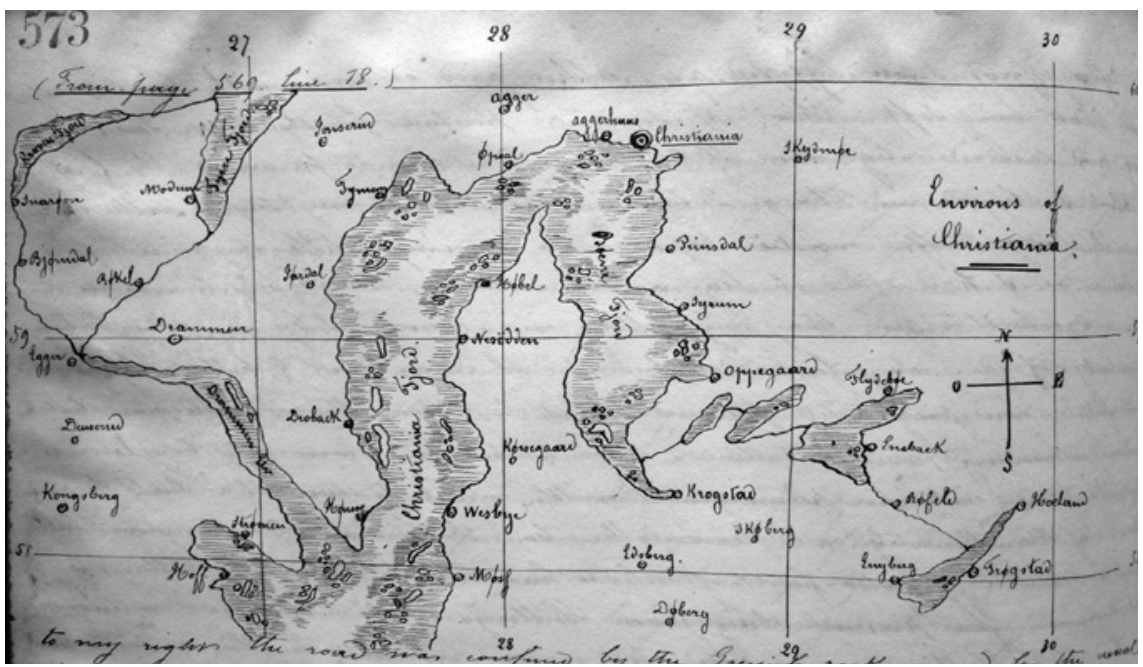

to my right the road was confined by the Greyish rock covered by the usual Norwegian Vegetation which once for all, consists almost exclusively of firs and pines, birches are also indigenous whilst ash-trees, Elms, maples, though they prosper well in this vicinity, are brought from warmer climes. A small torrent tumbling down into the ford, a few red roofed houses, a patient angler sitting on the rock, all this surrounded by rocks and trees, would, I thought by myself, have afforded a peaceful Norwegian Landscape for a skilful painter but such scenery presented itself so frequently in the course of my journey, that it ceased to impress my mind so vividly as it had done in the outset. My today's journey put me in mind of my last travels in the North of Peru in the year 1842; there I sat on a mule, here in a gig, which latter way of travelling is much more convenient than the former, but both have in my opinion, in which I fear, few will coincide with me, the advantage over the conveyance by "diligence" or Railroad, that on the mule or in the Gig, the mind is continually employed. You must necessarily be on the "qui vive" always looking round, and nothing escapes your attention, whilst especially on Railroads, you are forwarded like a bale of merchandize, you are whirled along, and when you arrive at your destination, few, faint and confused impressions of what you have seen remain on your mind. Both Peru and Norway are mountanious, but the mountains which I saw this day in Norway are mole-hills compared with the Peruvian. On the other hand, the Norwegian are picturesque whilst the gigantic masses of [574] the Andes if not snow capped, are either arid or covered with mere grass, some short and soft when it serves as pasture for the sheep, sometimes long and so coarse that even the Llamas disdain to feed on it. The first stage at which I stopped and changed my horse as well as my skyes called St[a]beck, where the skydskaffer insisted upon my paying treble the usual fare, the same as I had 
done on leaving Christiania. This I believed was an imposition but I had to give way, travelling in Norway is by no means cheap, particularly if you employ a "Forbud", as I did on my first trip. By forbud is meant a messenger who is sent ahead to inform the Post-master that a traveller is coming, and that at a certain hour, the horse and the Skyds must be ready. The horse costs per Norwegian mile, equal to one and a half Danish mile (the Danish mile, a trifle smaller than the German), 24 Norwegian Shillings and four Shillings as a fee to the Postmaster. The same 28 Shillings to the Forbud, making thus: $5^{6}$ Norwegian Shillings or 28 Shillings Currency (= to two English Shillings). They even made me pay for the gig of the Forbud, and twice Ferry-fare. From Habeck to Jonsrad the road offers little variety, it runs between rocks and trees, and where the one or the other recedes a little, the eye rests with pleasure upon green fields and meadows inclosed with boards slantingly placed, and upon solitary houses sprinkled over the whole country. Their outside is not always painted, sometimes they are roughly finished. My Skydskaffer at Jonsrad was a respectable Old woman whose Danish, or Norwegian (for these two languages differ hardly at all) I understood pretty well. Two young ladies in a vehicle similar to mine, "the Carriole", one of them holding the reins, the Skyd setting behind on a board, started a few minutes before me, and remained always ahead, until we arrived at the next stage Sundervold. The road thither leads over a very hilly country, and through a dense forest. Robbers nobody dreams of; aproof of the Security of the land, is this travelling of two young ladies without male protection. From the summit of the descent through a narrow vista formed by Rocks and trees on both sides of the road, I saw before me a smooth and quiet lake divided into several parts by islands and Peninsulas. It was a fine prospect, and is much thought of in Norway. It has however in my opinion a great defect, it has no back ground, so that the eye wanders over the lake and the surrounding place without having something to rest upon at the distance. Hardly had I alighted at [575] Sunderwold when count Goltz accosted me with the question, whether I had seen the two famous views above, the one called Kongen (the King) the other Dronnignen (the Queen), on my answering in the negative, he advised me not to continue my journey without seeing them, and up I ran again the ascent which I had just driven down; it was in the middle of the day and the heat was excessive. At the top of the ascent stands an inn called "Kongleven", where I obtained a guide to show me to the two points. From that to the left, Kongen, the prospect is similar to that which I had had from the top of the descent, from the Dronningen to the right, half an hour's walk distant, through a thick fir wood, the prospect is more extensive than either from Kongen, or from the other point. Far off, some snowy mountains tops were distinguishable. To give an idea how a professional writer 
can enlarge and embelish such a poor description as the preceding one, I will insert here two extracts translated by me from Mygge's work on Norway. "The Ravine of Kongleven steep and Romantic in its wildness with its precipices descending into frightful depths, its mountain torrents, and perpendicular Rocky walls rising high into strange configurations presents an extraordinary phenomenon to the Geologist, here, he finds Porphyry lying hundreds of feet high upon sandstone; 'Eurit Porphyre' upon the purest granulated sandstone!! a fact which overthrows all the theories of the formation of the Earth, and precipitates the learned men into a sea of doubts." Further on, when speaking of the prospect from Kongen, he expresses himself thus: "At first the beholder is dazzled, the eye distinguishes but a few solitary points in the dizzy Panorama far below (Mygge himself confesses that the height is no more than 1500 feet, and I myself, did not feel the slightest giddiness), then you go in search of a place for resting, and find at the utmost point a small bench cramped in between two trees (that is true), in the clear distance, the mountains and dark forest are discernible, behind them, still higher peaks shrouded in an azure veil which dissolves when looking at with a steady gaze. This is the 'Gausta', there lies 'Tillemarken', but soon the sight turns towards the valley and plain where it is rivetted by thousands of beauties. The mirror of the Fyrra Fyord glitters under a brilliant sun. Over the bridge and along the road you see carriages and horsemen so small and diminutive as if the whole were [Nuremberg] toys put up for our pass time, numerous farms are dotted over the plain, at the foot of the mountains, on the islands, on the Fjord, and around its picturesque bays, the black shadows of the rocks, and their bold [576] forms alternate with the cheerful light green of the corn, and as far as the eye reaches, it sees a continual variety of loveliness and strength, of Romantic Wildness and soft fertility; there the glowing of the snow on the far horizon, here the Emerald green of the valley, hugged by the crystalline waters of the Lake." My guide who was a very sensible man told me that the lake below was divided into three parts Stens-Øe, Holt Fjord, and [F]yrre-Fjord which latter is the only name I found on the map. He also pointed out to me the Church of Bynsdsnæs which according to tradition was built by Saint Olaff, who once finding himself in great danger made the vow to erect a church if he were saved, and being saved, he did so accordingly, Saint Olaff flourished in the beginning of the eleventh Century. From Dronningen, my guide and I hastened back to Kongleven as fast as our legs could carry us, thence I ran down to Sundervold, for I feared I might come too late, it being the rule in Norwegian post-houses that the skyds and the horse are not obliged to wait longer than three hours after the time fixed by the traveller for his arrival. For the two first hours they receive no extra remuneration, but for the third and any following hour which they may think 
proper to wait, six Norwegian Shillings per mile extra. I was still in time, and ordered a breakfast to my taste, viz.: a large bowl of milk with a little brandy for I was in a frightful state of perspiration, brown bread (white wheaten bread was not to be had), butter, and cheese with cummin Seeds. I now started and had to pass over an artificial dyke which separates Stens Øe from Holt Fjord, the country in this neibourghood which goes by the name of Ringerigge level if compared to the previous part of my this day's journey, mountainous if compared to the flats of Fyen and Sealand. Firs no more lined the road, but at short distances clumps of them were visible. My two young ladies had again started before me, but on this level ground I soon overtook and passed them. The following legend taken from Mygge's work which in some measures refers to the Ringerigge and the [T]yrre-Fjord may perhaps here not be out of place. "King Halfdan the black came from a feast in Hadaland, his way went over the lake, round which, it being winter time, holes had been hewn in the ice for the cattle to drink. It was thawing weather, the ice broke under the King, and he was drowned together with many of his suite. This happened in 1093, he had been much beloved in the whole country, so much so, that the [577] other Norwegians would not allow that the people of Ringerigge should posses his entire Corpse. It was therefore divided into four parts, and the principal men of $\mathrm{Ra}[\mathrm{n}]$ maricke, West[fold], and Heidemark carried away each one part; but the head was burried in Ringerigge under a stone near the '[F]yrre-Fjord', and as under Halfdan's Government the years had been very fertile, it was believed that each part of his body would fertilize the land where it was buried." Honefossen which I next came to, was the first agglomeration of houses, and might be called a village. I crossed here a river, the Store Elv which unites the Ransdes Fjord with the [F]yrre Fjord, over a long wooden bridge: a little higher up, the river forms a water fall, not high, but wide, the entire river, a mass of foam throws itself down a ridge of black rocks divided by a small islet into two unequal parts, on the other side is the post house where I met two of my companions from on board the Steamer: Count Raben who had come to Norway for the pleasure of bear hunting, and the other's position in life my skyds described in a few forcible words "Han er-[In]tet", "han er faillit", "han er bankrupt". I returned over the bridge to the left side of the river and continued my journey on the Western shore of the [F]yrre Fjord sometimes visible, sometimes concealed by intervening trees. I passed the Stages of Egge and Hong and reached Vigersund on the Southern extremity of the Ran-des-Fjord. Here for the first time I could not make out the long harange of the Skydskaffer. A Gentleman from Copenhague who stood by, either could or would not render me any assistance, he excused himself saying he was a stranger, then a notary was called in whose distinct and slow pronunciation I understood pretty well. 
At Vigersund I had again to cross the Store Elv, where the Ran des Fjord disemboques itself into it, over a long bridge, and following the river shore on its Eastern bank I soon came to a ferry near Omodsund. Here I had once more to pass over to the Western side and came to a few houses called Kongs hagen (the Kings blessing), a little further on a small river, the Sim Elv joins the Store Elv near Skartum. Not far from Kongshagen I reached a few houses where Mr. Gustavus Beneke from Berlin lived, who was the Director of the Modum works in which a blue substance called Zaffar is extracted from the Cobalt ore found in the adjoining [_]. Arnemann of Altona had given me a letter of introduction to him. He, his wife and daughter were playing at whist, the two latter disappeared, and he showed me to the house of an inspector close by [578] whose duty it was to accommodate strangers. A large room was given to me, and having taken my supper of tea, cold meat, bread and butter, I went to bed at twelve oclock, much fatigued, and fell asleep instantaneously. Before proceeding, I will note a few peculiarities which have come to my knowledge, partly by personnal observation, partly by oral information. Villages are scarce in Norway, the peasants live generally in solitary houses, gaards or farms, at no great distance from each other. These houses are invariably built of wood, sometimes painted, sometimes left in a rather unfinished state. The stores or pantries are not built close upon the Ground, they are raised above the same, and rest upon short posts, also the steps which lead up to them stand a little separate, thus: the object of the one and the other is to prevent rats, mice, and other vermin from having access

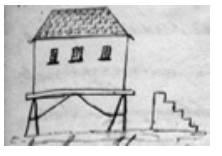
to the building. There are "Herre-Gaard" (Gentlemen's) farms, "Bonde gaards" (Peasants farms), but of the latter, by far the greater number, in fact it may be said that the whole country of Norway is owned by Peasants. They also preponderate in the Storting or Congress, and their opinion there generally prevails. The Nobility will soon be extinct, perhaps it is already in 1869 , nobody born after 1821 is considered noble, and all noble families naturally die-out. If I am not mistaken that of "Wedel-Tarls-berg" is the last. Jews were not admitted in Norway, if they are at present 1869 I do not know. Along the road I noted not far from each other high poles on which were written a certain name and number, on inquiry I was told that the high roads are originally constructed by the Government, and their cost is distributed over the whole community; but when once made, then the farmers have to attend to the necessary repairs, and the poles which I noted assigned the number of Ells of the road which each farmer had to keep in good condition. I also noted large wooden frames in this shape: standing along the road. They are called snow ploughs and serve for conveying merchandize over snow and ice during the winter season. Little peasant boys along the road 
offered to me choice Strawberries in small saucers made of bark, their taste was excellent, their cost a mere nothing, the same little fellows also begged me to allow them to advise the next Skyd Skaffer of my speedy arrival, for which service of course they expected and received a Small remuneration. [579]

Sunday, $14^{\text {th }}$ of July 1844. It was seven oclock when I had taken my coffee, I then went out to pay Mr. Benecke a visit, and found him waiting for me in the garden. He was a very plain man, his mouth all one side, and his cheek swollen, also in his dress he was negligent. To me he was very attentive. I learned from him that as long as Norway was united to Denmark, these Modum works and mines belonged to the crown, but after the cession of Norway to Sweden, the Government preferred disposing of them as well as of Fosumgaard which is the name given to the neighbouring ground where the different houses are built. They were bought by a Company formed in Berlin, some of the Share holders had died, others had sold out, and thus in 1844 the sole proprietors were Consul Wegner in Christiania, Mr. Benecke of Groditzberg (Gustavus Benecke's uncle) and this Gustavus Benecke himself, which latter had at all events a very small interest in the Concern, perhaps only a salary. He proposed to show me the factory which I readily acceded to, though it being Sunday the labourers were not at work. It lies on the other side of the Simøe Elv which is as already said an affluent of the Stor-Elv. When standing on the bridge which spans it, I already saw the spray, the foam, and froth of the water fall which is the great beauty of this little valley. Having crossed over, I had a distinct view of it, and was lost in admiration. The river, from forty to fifty feet wide, meets in its rapid course high and steep rocks, some of such elevation as not to be covered by the water, whilst the greater part is completely hidden, and now the river rushes down a white mass into a depth of fifty or sixty feet; where I stood, the spray wetted me, and formed a kind of haze which concealed the objects on the opposite bank. A few yards higher up than the fall wooden canals or gutters lead the waters off, partly for the purpose of putting in motion the wheels of the works, partly for flooding timber down the river which in the fall would be dashed to pieces. The Cobalt ore is crushed, then placed on an inclined plane over which water is allowed to flow, and it being continually stirred, the earthy particles are carried-off, whilst the heavier ore remains. This is now calcined in an oven, and in the Calcined state mixed, with sand and potash, when the whole mass is called Schlisch, which being melted and cooled, produces the g[_]y substance known in commerce by the name of Zaffar it is sold in large quantities for the English markets. At the time, Mr. Benecke of Goditzberg had made a contract wih some English firm [580] and had to place it free of expense in the port of Drammen. The Zaffar according to the description of the Ore and the sand, of course turns out of different qualities, and each quality is again divided into 
two kinds of which the paler and finer is named Esckels. The zaffars when crushed and sifted give the color called "Cobalt blue", which is much esteemed and serves for many purposes. The vapors which arise from the calcining oven pass through a very long chimney or tube to the sides of which they adhere in the shape of arsenic. Twice a year the chimney is cleaned out, of course a very unhealthy task, and the arsenic is deposited in stores, in 1844 large quantities of this deadly poison had accumulated, for no remunerating price could be obtained for it. Mr. Beneke and I climbed up a small eminence, on the summit of which stands a high iron cross erected in memory of a brother of his who had died there. The view from this elevation upon the lovely little dale below is exceedingly pretty. I dined with Mr. Benecke, wife, and daughter, all Prussians. Both the Elder lady who did not please me much, and her daughter, a nice young girl complained bitterly of the solitary life they led, and found fault with everything Norwegian, above all, they said the winter was not to be borne, whilst Mr. Benecke assured me, and I do believe him that even when the ground, the houses, the trees every thing is covered with snow and ice, there is something sublime in the motionless and rigid grandeur of nature. Dinner was fair, and I believe that all three in their solitude regretted the shortness of my visit. The road from Modum to Kongsberg runs as far as Donsernd on the western or right side of the Drammom, which river flows out of the [F]yrre Fjord. The country is rather level, neither woody nor picturesque. The three intervening stages were [Refsachl], Storm-øen, and Langebro. At Domsernd the Drammon takes a slight bend Eastward whilst the road to Kongsberg turns a little to the west. On approaching the town I met many peasants in theirs gigs all dressed in black swallow tail coats quite "a la Française". The situation of Kongsberg put me in mind of that of Cajamarca on a small scale to be sure. Here as well as there the town lies in the centre of a well cultivated plain encircled by mountains, Kongsberg is divided by the river "Long" into two halves. A bridge spans the river which both above and below forms a number of pretty cascades. I met a military band playing the tattoo, which made my horse [_] a little, observing which, the Drum-major ordered silence, certainly very polite. [581] I put up at the Hotel of Larsen, where I had an excellent room and was well treated. I went out to deliver a few introductory lines, which Mr. Benecke had given me for Mr. Bøbert the Director of the Kongsberg Silver mines, not finding him at home, I returned to my hotel and went to bed. Kongsberg is a small place, but the houses built of wood are large, the Church has a neat appearance. There is also a musket factory of which however I knew nothing at the time.

Monday, $15^{\text {th }}$ of July 1844 . Mr. Böbert accompanied me to the mint which offered nothing of interest. I learned that the coinage was carried on not on 
account of the Norwegian Government, but on account of the bank of Norway which has its principal establishment in Trondhjem. From the mint I drove to the silver mines three quarters of a Norwegian mile distant where the Foreman to which Mr. Böbert had given me a few lines of introduction was ready to show me round. The adit which we entered runs horizontally; its length was $2400 \mathrm{lbs}$, each of two feet, its height twelve, and its width six feet. For the greater part the ground was boarded so that it was far from muddy though rather moist. The summit of the mountain is seven hundred feet above the adit, whilst from the adit downwards, mines had been dug to a depth of likewise seven hundred feet. The descent was easy and safe; ladders of different lengths more than fourty in number, firmly placed, lead from one landing place to the other, and these landing places left in the rock are of a fair size and provided with seats whereupon to rest. I descended five hundred and fifty feet to the Kongen's mine where miners were busy at work. They broke the ore by blasting or by manual labour with heavy crow-bars. The broken ore placed on a small truck, is brought to the surface by means of a water-wheel. My ascent was not so easy, I had to climb up five hundred and fifty feet which though without the slightest danger was however a fatiguing job. Close to the mine stands the stamping mill where the ore is crushed and stamped, and then transported to the smelting office in which by means of rushing water, the earthy particles are separated. In the Kongsberg mine five sixths of the silver is found in a pure state and only one sixth mixed up with heterogeneous particles. In 1844, the amount of silver extracted did not surpass the small sum of 100,000 species net, the Government, I do not know for what reason, being opposed to the mine being worked with greater activity. A Norwegian species like the Danish is equal to sixty Shillings Hamburg currency [582] or about four Shillings, three pence, English. Mygge gives the following account of the Kongsberg silver mines: "In the year 1623, a peasant boy Jacob Grosvold discovered by chance a silver vein; Saxon miners were engaged, King Christian IV came over from Denmark, ordered the town of Kongsberg to be built, and looked upon the mines as being his property. For a long time the mines paid well, but towards the beginning of the present century, there was a great falling off, in 1803, the loss incurred amounted to 232,98 Rbs dollars, in 1804 the working ceased; in 1814 the Storting directed their attention to these mines, their working was recommenced but once more without a favorable result. In 1830 the debt on the mines had run up to 80,000 species, now it was decided that the mines with lands and woods should be sold. The Government asked 75,000 Sh, Mr. Benecke of Modum made an offer, but when the Government deliberated whether they should accept it, news came that a new rich vein had been discovered, one blast gave 
21,253 marks, pure silver. All thoughts of selling were now abandonned. In $183^{2}$ 19,032 marks were extracted, in 1840, 30,485. 40,000 marks annually could have been furthered to light, but Government preferred to limit the working to the extent of 20,000 marks so that the mines might not be exhausted too soon, and something might remain for future years, the expenses amount to from six to Eight thousands marks annually, and the net produce is 200,000 species." So far Mÿggeh, but these last numbers are all wrong: there was not a single individual in Norway to whom I spoke on the subject and who knew something about it, who calculated the net product at more than 100,000 Sh, and even by Mÿgge's own statement if the mines give annually 20,000 marks, and the expenses are seven thousand there remain net 13,000 at ten Species a mark, make at the utmost 130,000 Species and not 200,000 as he says. On my return from the mines to the town of Kongsberg, I observed a small monument to the memory of Moritz Christopher Hansen, a townsman and author. My dinner consisted of boiled salmon, a pudding, and strawberries with milk. I wrote my memoranda, slept a short siesta and continued my journey at half past six, as far as Langebro the same way which I had come on the preceding evening, there I crossed the Drammon to the left bank, and followed its course, along its flat shores [583] large rafts of timber, the principal export article of Norway floatted down. Once more I crossed the river, drove through [F]anger and Strons Oe, and for the third time passing it, over a long bridge which in the middle could be hoisted and lowered, entered the long street in Brøgernoess where at half past eleven I stopped at the door of the Hotel d'angleterre, of course all in the house were asleep, I roused them up, obtained a room and went to bed. [F]anger, Strongs-øe, and Brøgernoes jointly form the town of Drammen.

Tuesday, $16^{\text {th }}$ of July 1844. It was a rainy morning, I drove through the street of Drammen; when outside, I walked up a small hill called paradise height, whence on a clear day, the town is seen at ones feet, this day a heavy fog hung over it. I continued my journey, firs and pines became scarcer, whilst in the same proportion, other descriptions of trees took their stead. Without stopping at Gyellebeck, I drove on at once with the same Skyds and horse to Arker, a small place consisting of a church and a few houses, and then passing right through the stage of Stebeck I reached Christiania where I alighted again at the "hotel du Nord". The room given me was still more uncomfortable than that which I had previously had, also the dinner at "table d'hote" was nothing better than the first time. On the previous day the united Naturalists had made a tour on the Fjord on board of the Steamer Prindsen Carl, to which professor Eschricht had had the attention to send me an invitation. Owing no doubt to the negligence of the pilot, the Steamer had struck on a hidden rock, and stuck fast. All the passengers had been saved, but not without having run some 
danger. After dinner Mr. Tiedemann accompanied me to the small exchange room where a public sale was being held, thence to the building appropriated to the Sessions of the Storting, or Norwegian Congress. The Storting which numbers in all about one hundred members is divided into two chambers, the "Odelsting", and the "Lagting", both meet in two adjoining rooms, their respective Presidents sitting at a small table in front of the members who are ranged on several rows of benches placed in a half circle. The members are chosen by electors and these again are elected by the nation. None, but such as are Norwegian by birth, are twenty five years of age, and have resided five years in the country are entitled to a vote. The voters must firstly be, or have been [584] "Embedo mœnd", that is to say employed by the Government. Secondly if living in the country, they must be either proprietors of land, or have it rented for more than five years, and thirdly if living in towns they must be either citizens of the same, or posses some property to the value of one hundred and fifty species. The requisites for a deputy are: the age of at least thirty and a residence of at least ten years in the Country. Deputies are paid for their travelling expenses, also for their maintenance whilst sitting in the Storting. Every three years the ordinary Storting meets, but the King has the right to convoke extraordinary Stortings when he thinks proper. The deputies themselves choose from their body one fourth which forms the "Lagting", the remaining three fourth constitutes the "Odelsting". The Storting gives laws, decrees loans, duties, sums required for the expenses of the Country, for the civil list, etc., etc. All laws emanate in the Odelsting, where they are proposed by a minister of the Government or by a deputy; if approved of by the majority, the bill passes to the Lagting, if the Lagting agrees to it, it is sent up to the Government; if twice rejected by the Lagting, both Tings united assemble as storting, where two thirds of the votes decide the question. If the King sanctions the bill sent-up to him, it becomes the law of the Country, if he objects to it, and if nevertheless three successive ordinary Stortings insist on the bill without any alteration, then it also becomes the law of the Country; in other words the King has no absolute veto. The Norwegian constitution was planned by a certain Falsen, and accepted on the $17^{\text {th }}$ of may 1814 in Eidswold near the Mjøsen-lake by one hundred and twelve individuals called together for the purpose by Prince Christian Fredrick of Denmark, who at the death of Frederick VI ascended the Danish throne as Christian VIII. On the $19^{\text {th }}$ of may 1814, he accepted the Crown of Norway, and subscribed the constitution. This however was not in accordance with the views of the great powers who had determined upon Norway being ceded to Sweden, accordingly, the crown Prince of Sweden Charles John which was the name adopted by Bernadotte Prince of Ponte-Corvo, invaded Norway; no blood was shed. On the $14^{\text {th }}$ of 
august Christian Frederick resigned the crown at Moss and an extraordinary Storting having declared their willingness to unite with Sweden, Charles XIV King of this latter country subscribed to the Norwegian Constitution for himself and his successors, on the [585] ninth of November 1814. Afterwards when in Bergen, I learned from Charles Konow that one point on which the Norwegians and their King Charles XIV formerly Bernadotte could never agree was the date on which the constitution was dated, they insisted upon its being dated on $17^{\text {th }}$ of may, he (the King) the $19^{\text {th }}$ of November 1814. After Mr. Tiedemann and I had returned from the Congress hall, he procured me two men who rowed me over to the island called Lange-Øen where my mother's cousin Lucas Willink resided, and of whom I had given a short account (Vol. I, page $374 / 75$ of these extracts). In 1844, he was 58 years of age, hale, strong, and very active. He took a pleasure in leading me over his rocky domain where he ran and jumped from stone to stone like a youth. His features had of course become more marked, and his head a little balder during the twenty one years which had elapsed since I saw him last in 1823, otherwise he was not much altered; he had the same round smiling face, and red cheeks. In his talk he was lively, abrupt, and positive, just as in former days. In his dress, he was shabby, even dirty, I believe he chewed tobacco, and I thought that without passing the rules of strict economy which he had laid down for himself, he might well have kept up a somewhat more respectable outward appearance, as far as I could judge, he was satisfied with his present lot. The island was not without its attractions, though upon the whole, the soil was rocky, yet it had its kitchen garden, some trees, wild strawberries and a variety of wild flowers which as Lucas rightly observed contrasted prettily with the Grey barren rocks. The shores of the Fjord as well as the island called Hoved-Øen where two powder magazines stood, could be seen from Lange-Øen. The long winter evenings Lucas said he passed reading for the Christiania Library furnished him with all the books which he wanted, and studying Geology, a very interesting science. Here he was at least his own master whilst in Altona he felt himself dependant upon his brother in law Donner or his mother in law Mrs. Siveking which must certainly be very irksome to a man of his age. He offered me a cup of Coffee, went himself to fetch the wood, lighted the fire, made the water boil, and prepared the Coffee. He told me that he had made about 2500 species, but as I learned on a later occasion not on his present pursuit, but when he acted as assistant to a soap boiler in Christiania, these 2500 species he had invested in a factory of Cement in which [586] he and his partner Mr. Aubert were engaged. He also occupied himself with breaking stones for the building of houses in Christiania, and one with another, he had about fifty men at work daily. If he 
could gain 2000 species more, he said he would retire from business, of course this was all idle talk; firstly what would he do with such a paltry sum ? as 4500 species; and secondly what chance had he of ever recovering the 2500 species he had laid out ? his partner Aubert, being as poorly off as he himself. The building in which the making of cement was carried on looked very descent, whilst his dwelling house and rooms with a miserable bed looked wretched, and not fit to receive his wife and two daughters, whom I have often mentionned in the beginning of this year as living in affluence with old Mrs. Siveking. I will anticipate here what became of Lucas in later times: without having done any good for himself he returned to Altona, reconciled himself with all the members of his family and lived quietly and happily with his wife Ernestine. The last news I have received of him now in 1869 is that he is in excellent health, though eighty three years old, but that he is rapidly loosing his sight. I was rowed back to Christiania, called upon Tiedemann, went to my hotel, and made the necessary preparations for my next day's journey to Trondjheim.

Wednesday, $17^{\text {th }}$ of July 1844. I had gone to bed as late as two, at five I rose, at six oclock I sat in my gig. When outside the town I looked back upon it from a small eminence, there lay Christiania, behind it the Fjord, to the right, the cultivated plain dotted with houses. It was a pretty landscape, though seen at an unfavorable moment, for the sky was clouded, and the weather raw and rainy. The country through which I passed in the beginning of this day's journey was hilly, not mountainous, the ridge of hills covered with trees gradually drew nearer, and from the first stage Bønde Kald onwards, the road was confined on both sides by an undulating plain stretching out before me, divided into patches of all colors, brown, dark green, light green, and white, the latter produced by innumerable daisies which covered the meadows. A small river, not noted on my map wound its way through it. I crossed the same, and arrived at the next stage, Skrimstad. On the road I had met many carts laden with timber. In the middle of the load, a board was fastened and placed in a slanting direction upwards, no doubt for the driver to lean against. On the [587] other side of Skrimstad, I had again Rocks and trees, they gradually receeded, and I drove across cornfields and pasture grounds to the third stage Møe, thence through a similar country to Frøgstad. To my left the firs woods were at no great distance, whilst to my right the hills covered with this same vegetation were further off, the intervening space partly filled up with cultivated fields sprinkled over with solitary ho[_] and clumps of trees. At Frøgstadt I made my breakfast on brown bread, excellent butter, and Goats milk. The SK is pronounced in Norway as the English Sh, thus Skydsen sound like Shysen and 
the first words which the traveller pronounces when arriving in the Post house yard (Skyds-huset) are "Er Skydsen her"? (is the Postillion here?) whereupon he is shown to a room, probably the best in the house, where a book called "LagBog" is laid before him, in which he has to inscribe his name, his destination, and the number of horses which he employs. One column is destined for the complaints which he may have to make; he finds printed in it the distance to the next stage, also the laws respecting the Post master, the Post-boy, and the Posting, "Skydskaffer" "Skyds" and "Skydse". From Frogstadt to Raahold, it was a long stage, but as the sun came out, its rays tempered the cold and disagreeable wind, and contributed to my enjoyment. The country around was also such as to please a not over fastidious traveller. There was a great variety, here forests of pines and firs intermixed with birches, there patches of land where the trunks of trees were cut off, and only the blakened stumps remained, then rocks with the same description of trees, cornfields, pasture grounds enamelled by all kinds of wild flowers, red, purple, yellow, green, and white, sometimes a very confined horizon, sometimes a distant prospect. From Raahald to Minde I felt sleepy, and nooded too often to mind much the objects around me. At the foot of a small descent lay Minde where I arrived at half past two, and as the Skyds was not ordered until four oclock, I availed myself of the time to make a good dinner, on soup with bread dumplings, and hashed meat. The Postmaster's wife, a good woman, kept me company, and talked all the while. Twice a week, she told me, a Steamer left Minde for Lillehammer and as often arrived thence. After a short siesta, I started again at four p.m. The Vormen Elv, a rather broad river falls into the [_] [Hjoven] lake, I passed in a ferry which [588] was violently rocked by the waves agitated by a strong wind. I had now to my left the mjøsen lake, and close by to my right high hills covered up to the very top with pines and firs, so the road continually ascending and descending brought me to Morstue, and next to Kørsedegaard where I put up for the night. The Sun was just setting Westward of the Mjøsen lake, and its last rays illumined the summit of the hills. This [_] to my recollection many a similar scene in South America where the sun fast disappearing gave a rosy tinge to the far distant snowy Cordillera. Dinner had been ordered by Tiedemann when he sent the Forbud-zedder (Postillion ticket) which one Post master had to forward to the next and which answered the same purpose as the Forbud's, but was of course much cheaper. The dinner that expected me consisted of excellent boiled fish, indifferent Roasted pork, and a glass of beer. I was sleepy, it is true, and went to bed, but cannot say that my limbs were fatigued, though the Carriole does not rest on springs, yet it has an elastic motion owing to its thin long shafts resting in the leather thongs, which on both sides hang down from the horses back. 
Thursday, $18^{\text {th }}$ of July 1844 . I slept soundly in my confortable bed, down above and below me. At half past five I rose, and was off by six oclock. As far as Nøkleby the road is uninteresting being lined on both sides with underwood; further on it improves a little, it is level, and well cultivated. I had an occasional glimpse of the Mjøsen lake, at the stage called Frøgner I enjoyed a fine view over it to the opposite shore. After leaving this Gaard, the road for a few minutes touches the very lake, then it turns off again to the right, and continues as far as Hoff between its usual Boundaries, woods and hills. In Hoff I breakfasted on brown bread, cheese, and milk brought in on a wooden tray. Here for the first time the Skyds expressed his thanks for the fee I gave him, and shook hands with me. Four Norwegian Shillings they put into their pocket without saying a single word, but two Shillings more made them invariably grateful. To Fønberget I had a pleasant drive, the weather was fine, and the sun out. When approaching this stage the rocks to my right were steep and high, to my left, a cultivated field stretched towards the lake, as far as the next stage Möe I had a great variety of Norwegian scenery, sufficient to make the fortune of any other country less rich in Natural beauties than Norway. Mountains to[_] [589] were a new feature in the landscape, the sun burnt fiercely, and I arrived at Møe rather tired, however started again without a moment's detention. Till Freng I had a delightful drive, the heat of the sun decreased. To my left I had the lake and a view to the opposite shore, to my right abrupt rocks with Pines and birches up to the summit. One particular spot struck me as South-american-like: the rocks were completely arid, without the slightest vegetation, large stones had tumbled down and lay on the road. After Freng I passed through a thick pine wood, when emerging from it, the rocks gradually slanted down into hills well cultivated and doted with houses, also with an occasionnal church always built in the form of a Greeck cross, the steeple placed in the middle where the two arms of the Cross intersect each other. I met many people on the road, of course much more than in South America, where you can ride many leagues without seeing a single human being, but even more than in Holstein, and it was difficult for me to conceive that the population of one Town, London, was half as numerous again as that of the whole country of Norway. Both, men and women are fair; they are tall and well made, I believe I did not see a single man who was fat. The women were hard featured and very, very few could be called handsome; in their dress there was nothing particular: the women had invariably a large handkerchief tied round their heads, the men seemed to be very fond of black swallow-tail coats. The children's hair might be called white, on my whole journey, only once a little fellow asked for alms, and on my giving him a Norwegian Shilling, he held out his little hand and placed it 
into mine. Lille-Hammer my next stage might be called a town, houses stood in uninterrupted rows, there were shops, a church, and a church-yard. Here the Mjøsen lake is extremely narrow, and the Løsne Elf falls into it immediately above the town which lies on its Eastern side and opposite on a small peninsula a few houses go by the name of [Vingnoes]. Whilst dinner was getting ready, I laid down on a sofa, and got rid of an abominable head-ache probably caused by the burning sun to which I had been exposed. Dinner was first rate, it consisted of boiled fresh Salmon, fried potatoes, brown bread, cheese, and butter. After dinner I took a walk to the beach; troops in blue uniform with red cuffs and facings landed, as a review of them was to be held; on hearing the roar of a water fall I inquired for it and was told to proceed out of town in a Northern direction. Following this advise I soon [590] came to the Misna Elv spanned over by a stone bridge, above the same it forms a fall, broad, but no high, below the bridge another, violently roaring and foaming. This latter I could approach very near, and standing upon a stone which jutted-out into the river, I remained a long while admiring the spectacle before me. The noise of rushing waters led me further-on, and ere long was I well rewarded for my trouble: the Misna Elv compressed between its Rocky shores, at the same time divided by several rocks which lie in its course, forms four cascades in one line. That nearest to the right bank comes gently down in three or four different leaps, the second rushes in one bound forming a smooth arch of foam into a depth of from twenty to thirty feet, it is undoubtedly the most beautiful, the third, less majestic than its neighbour, frets and foams and froths, as if chafing against the obstacles which it finds in its way, the fourth nearest the left bank, can hardly be called a cascade, the water flows down in tiny rills. Higher-up there is another fall, broad but low. I sat down, and looked at it, I do not know how long. Still further up I could distinguish some foam, indicating more falls, but I had enough of them for the present. It was a pleasant evening, I returned to the Hotel at Lille-Hammer, and soon went to bed.

Friday, $19^{\text {th }}$ ofJuly 1844 . After an excellent night's rest, I rose without headache, at six oclock I was again on the move. As soon as I left Lille-Hammer, I found myself in Gylbransdalen, a very extensive province. The country through which I drove as far as Elstad, passing in my way thither through the Stages of Møshjem, Holmen, and Løsnoes, can easily be described. The road leads Northwards with a slight inclination to the Westward, to my left I had the placid waters of the Løsne Elv of a somewhat greenish color, on the other side of which gentle hills slant downwards towards the river covered with trees, and sprinkled with Gaards. To my right sometimes similar hills, sometimes steep rocks, even so abrupt that the firs could not find a footing upon them, now and then a mountain torrent rushes down and finds its way into the Elv, but upon 
the whole, the landscape around me presented the image of the most complete tranquility, and I could not but compare in my mind the loveliness of nature, to the uproarious turbulence of a meeting of Radicals in Covent-Garden theatre (See page 154) or to the artificial splendor of a Ball at Hesse's (See page 399/401). Between Lillehammer [591] and Møshjem the Løsne Elv forms a cascade, not high, but pretty, owing to its great width, it is called the Hynerfoss; headlands, and islands give some variety to the otherwise monotonous course of the river. On some low lands, rich pasture grew, probably to be overflown when the waters would rise, birches and alder trees became more frequent, the former distinguishing themselves by their white bark and light green leaves. It is also interesting to observe how the firs and pines clasp the arid rocks with theirs tough roots to enable them to withstand the strong winds which often sweep over the country. Frequently the wood is cleared away, and makes room for cornfields, Rye and Barley are mostly cultivated in these high latitudes, some stood in ears, others still green; everywhere peasants were busy haying. From Møshjem onwards, I observed that the men wore red woollen bonnets instead of cloth caps with leather fronts as hitherto. When approaching Elstad, I saw right before me mountains with patches of snow, and though I inquired from various persons what mountains they were, I received no satisfactory reply. On the other side of Elstad I passed two rivers, affluents of the Løsne Elv which takes here a decided bend to the Westward. The road ascends considerably. The Stage or Skyds-huset which on my map is still marked as Hundarep, was transferred to Øden; before reaching this last named gaard I passed a neat Church built of brick, and white washed, of an octagonal form, with a steeple called Fruens-kirke (Our Lady's Church). On the road to the last stage of this day (Møe) three things struck me: firstly a woman walking along, knitting and carrying her baby slung on her back like the Indian women in South America; secondly, a boat placed on a cart; and thirdly a foot path leading up one of the rocks, the first I had seen on my journey. In Møe I was kindly received with a welcome, and well treated. I had for supper salt fish with potatoes, brown bread, butter, and two bowls of milk. It was still early in the evening and till half past ten oclock I occupied myself with writing. My landlord a peasant and his wife, passably good looking, were pleasant folks, and I attempted to converse with them, but did not succeed over well. The room in which I sat was large, square and rather low; the floor, painted yellow and black, looked as if it were inlaid, the ceilings and walls were of course of wood, and both neatly painted, the latter blue, and adorned with two small looking glasses, a lackered tin plate tray, a likeness of the Crown-Prince and some wretched German prints, the three windows of the room had their curtains. The furniture [592] consisted of two bed-steads, upon one of which the clean bed linen had been spread out 
for me, a sofa covered with some woollen stuff, four ordinary wooden tables of different sizes, one of them with an old gilt edge, a chest of drawers, a white painted cup-board in a corner with some earthenware, a dozen of wooden chairs, the seat painted brown, the back and legs black, five wooden yellow painted chairs, an old wooden arm-chair upon which was placed a tin basin with water to serve for my ablutions, in other gaards I have found the luxury of wash-hand stands, and even of perfumed soap, an oven with four high candle sticks (metal ones) with tallow candles, and finally a box to keep the fuel. The window panes were here of good white glass, in other Gaards they were of a green glass not much better than that of which ordinary bottles are made. In Christiania it was prohibited to build wooden houses, but all over the country, this is the only material used for the purpose. The houses are however not made of thin boards as they are in Islay (Peru) through which the heat easily passes, and renders them sometimes excessively hot, but of thick substantial beams, even trunks; the interstices between them are filled up with moss inside, they are always boarded sometimes also outside, and whitewashed which is the height of elegance. As the houses are often built upon uneven ground, this inequality is remedied by stones being piled up to the height required, upon them the ground beams rest, others are placed across, and the floor is formed. In the neighbourhood of Christiania the roofs of the farm-houses or gaards consist of red tiles, further North, I found them to be of slates and even of boards covered with a thick layer of earth upon which grass grew.

Saturday, $20^{\text {th }}$ of July 1844 . This morning it was as late as seven oclock when I started, for though I rose early as was my custom, I was detained by repacking my trunk, the contents of which, books and clothes had suffered by the motion of the Gig. As far as Viig and Sølhjem, which last named place was the Skydshudes where I stopped instead of Breiden noted down on my route; the country was similar to that through which I passed on in the previous evening, on the left or eastern side of the Løsne Elv after Sølhjem the valley becomes much narrower, a river joins the Løsne Elv from the West, whilst from the Eastward a mountain-torrent forming a water fall, the Ura-foss, precipitates itself into it. A little further on, there is much swampy ground on both sides of the Løsne Elv, but wheresoever a little solid [593] ground could be found, surely it was cultivated, also on the sides of the hills and rocks, not an inch of good soil was lost; potatoes, barley, and rye were mostly produced, the lower lying lands being used for pasture. There was a visible falling off in the height of the trees, which upon the hills and rocks were exposed to the winds, whilst alongside of the road, where they were more sheltered, birches and alders grew more freely. Between Viig and Sølhjem I had a Skyds whom I understood pretty well, and 
with whom I therefore conversed all the while. He had been seventeen years servant to Count Fritz Baudissin with whom he had travelled all over Europe. Probably his living so long amongst Foreigners, made him pronounce his own language more clearly than he would have done, had he never left Norway. Nearly all the peasants, he told me, except the wealthiest, spin their own woollen yarn, and wave their cloth, the tailors cut and sew the cloths. The stockings are knit of the same woollen yarn, whilst the shirts are made of home spun and home woven hemp. The Government appoints the Clergymen (it is well known that Norwegian like the Swedes are Orthodox-Lutherans) and the peasants pay them. The Parish Clergyman of Fruens-Kirke received two thousands species annually; he had several assistants partly paid by him, partly by the peasants, every third Sunday as well as on holidays, Divine Service was held in Fruens-Kirke. On the other side of Sølhjem close to the road side, stands a small wooden pillar to which a white board is affixed, and upon this board a verse is written which celebrates the prowess of the Norwegians, who defeated here on the $24^{\text {th }}$ of august 1612 , nine hundred Scotch soldiers, who, commanded by (Gorgen von-Zinclair) George Sinclair, had landed in Runsdalen and came as far as here to the assistance of the Swedes; under the verse stand a few words to the effect that the said verse had originally been engraved on medals distributed by Frederick IV amongst his Norwegian subjects in the year 1704. Then it is said, that this pillar was erected to the honor of Christian VII, when he came this way (year not mentionned); and finally, these words: "Aar $1612 \mathrm{dem}$ 24 august ble[s] her 900 [nidend] Scotter Slagne af et mindre tal 300 bønder af Loesø Vaage trøen og ringeboe Søgner". Anglice: in the year 1612 on the $24^{\text {th }}$ of August, goo Scots were beaten here by the smaller number, 300 peasants from the parishes of Løesø etc. In the Gaard of Kringølen where the defeat actually took place, a short distance from the high road, a few trophies, some muskets, two daggers, a drum, and [594] a small strong box were still preserved, and I of course went to have a look at them. Just before the twenty seventh and a half mile stone from Christiania, stones and blocks of rock of enormous size seem to have fallen down from the mountains on the east side of the road, the whole space between their bases and the river was filled up with them, they lay there pell-mell, piled up the one upon the other, only where the road passes, they had been cleared away. Soon after I crossed over to the Elv's, right, or western side. In Lunegaard, the next stage, the Skydskaffer was a good kind of woman who for the first time addressed me with the familiar "du, or thou", hitherto the polite de or you had been used; henceforth han or he, du or thou. Bread as thin as a wafer and very crisp, made of barley and Rye, called flade Brøde, butter and cheese constituted my lunch. From Lunegaard onwards, the valley changes 
into a gulley, rocks high and generally barren to the right, then the road broad enough for two gigs to pass each other, rocks down to the Elv, now a torrent always heard, not always seen, and rocks again on the other side, here and there a tree. The ascent becomes very perceptible, thus the road continues as far as Hongen, next to Tøfte where the Gulley widens again, firs and birches grow in greater abundance, also the snow, of which I had only seen a patch here and there, lies in larger masses. Through a gap in the mountains to the west I saw at some distance a peak covered with snow, which my Skyds called Jynda-Fjild, and right ahead of me the snowy ridge of Dovre-Fjeld came in sight. I crossed the river to its left bank, passed the Church of Dovre, and reached the stage of Lie, where I left the Løsne Elf, my faithful companion ever since Lille-Hammer and turned to the right, no doubt with the object of avoiding the snowy heights in front of me. A road to theleft leads to [Runsdalen], I in Gyldbrau[_] continued my gradual ascent, and find myself on a snow covered wild looking plain with firs, big stones and stumps of trees. Further on the firs cease; only dwarfish birches, tall heath and a low grass or moss grow; high wooden crosses are put up to point out the road in the winter season when every tack is lost in the deep snow. I passed a brook where a small heap of snow was lying undisturbed since last winter, and likely to remain undisturbed till next winter. I was on a high table land which [_] in the same relation to the still higher ridge of the Dovre-Fjeld [595] as the "Jalca" or "Puna" of Peru stands to the Cordilleras. To the Westward I saw still higher mountains, the ridge to the Eastward did not appear to me of a greater elevation than the highland over which I drove; but both Eastward and westward, as well as before me to the North, large masses of snow covered the ground. It was a cloudy disagreeable day, I felt cold, and the more so, as my skyds who rode an excellent little horse of his own, of which he took great care, would not allow me to drive fast. To warm myself, I got off, and on foot reached the next stage called Føgstuen. I may mention that almost all the horses were of small size, but strong, active, and capable of much work, down hill they sometimes gallop, though not at such a tearing rate as the "Huasos" used to do on the "cuestas" between Valparaiso and Santiago (see $1^{\text {st }}$ Vol., Page 808). Between Lie and Føgstuen, there was not a single gaard or farm-house, as little as between Føgstuen and Jerkind which latter post-hose is situated at the very foot of the Dover Chain, and this scarcity of farms, a wonder in Norway is a clear proof of the wretchedness of this region. After leaving Føgstuen the country is for a short distance as dreary as previously, then the road descends a trifle into a little hollow which may be called a valley, where the surrounding hills must, I suppose, be somewhat lower, for I observed less snow. The road skirts a lake, which it passes over a bridge, follows the course of the Folda Elv which joins 
the lake just mentionned with another lake, and then continues Eastward watering Østerdalen, until it falls into the Glommen river; again the country is as wretched as already described. Now I had fortunately an excellent Skyds who permitted my driving on as far as I could and nevertheless it was as late as half past ten when I reached Jerkin. On my alighting I was accosted by Doctor Petit, brother of him who disappointed me so often in Hamburg with his promises to give me lessons in Italian, which he never did. The Gentleman was here botanizing in company with several naturalists. I supped on fried fish, roasted potatoes, and a glass of beer, then wrote my memoranda till one in the morning when the day dawned; even at midnight it was not dark. Thermometer in my room, windows shut, Reaumur $9=5^{2}$ Fahrenheit.

Sunday, $27^{\text {st }}$ of July 1844. In the Dag-bog which as above said [...] before me in every Skyds gaard, I observed for the third time some [_] [596] written in pretty fair French by two M[essrs.] Hutchinson, to the effect that they believed they had been overcharged by the Skydskaffer, and that they had not been treated with sufficient civility. Of want of civility I could not complain, and as regards the charges, it may well be that foreigners must pay something more than the natives, but this is the way all over the world, and moreover it ought not to be forgotten that we are here in out of the way places, where we must be satisfied if we get anything at all. At a little past six a.m. I was on the move. When outside the Gaard, I might well have thought myself amongst the Peruvian Andes. Clouds were hanging upon, and drifting along the snowy mountaintops, no vegetation but grass, moss and heath, the sky of a grey color, the wind cold; to the Eastward not far off I saw the Snow-capped Sne haetten the highest mountain in Norway, 7845 feet above the level of the Sea. The descent commenced and very soon did I come to a gateway made in a rough manner by two upright poles and another put across. This my map calls Porten or the gate, and it is the boundary between Trondhjem Stift, and Christiania Stift. The provinces of the latter Stift through which I had passed were Fiswolden (?), the most southern as far as Minde; from this town to Lille-Hammer, Hedemarken, thence to the gate, Gyldbransdalen. I must now have passed the water shed, for a brook alongside of the road flowed Northward. This brook increasing in size by the rills of water which joined it from both sides, became a torrent, and in its headlong course formed more than one pretty cascade. As far as Kongsrold the first stage in Trondhjem Stift, I had the same dreary country around me. At first, no trees; bye and bye the crooked birches reappeared, also wild flowers amongst which I recognized "hearts case", and "forget me nots", behind Drierstuen vegetation increased, and Dovre-Fjeld was left behind. The river called the Driv Elv was now my companion; there were still rocks with snow on the top but firs again showed themselves, then the 
well known wooden-houses, and finally, the gradual descent continuing, also barley fields. The Snow ploughs which I noted on my first trip to Kongsberg (See page 578) I saw frequently placed alongside the road, neither did the simple acqueducts used in Norway escape my attention; they consist of trunks of firs or pines scroped out, fitting the one into the other; through these simple canals [597] the water is conducted to great distances. The drive from Ruse the third Stage in Trondhjem stift, till Ovnet was a very agreeable one, the weather was fine, and the hour being about the middle of the day, I had not to complain of Cold. The Vinstra-Elv falls into the Driva, which latter flows to the North West through Runsdalen into the sea, whilst my route to Trondhjem was to the North East. In Ovnet, the Skydskaffer, a respectable looking old woman, received me in a very decent room, the floor covered with a woollen carpet; she gave me for lunch two large bowls of milk, smoked salmon, cummin cheese, another description of cheese very strong made of sour milk, called GammelOst, and Flade-Brøde, for which I had to pay only ten Norwegian Shillings, less than five pence English money. I suppose [Mrs.] Hutchinson could not have found fault with this charge. [_] Stuen, Sundset, and part of the way to Birkager, the country is level, and presents nothing of particular interest. Travellers are in the habit of speaking of the sombre appearance of a fir forest; generally speaking I believe they are right, however at this season of the year, the new light green shoots relieve in a great measure the otherwise dark green color of the tree. Before reaching Birkager, the road descends to the Orke-Elv, to my right rose steep rocks, to my left, more gentle hills, both the one and the other covered with pines, before me the river winding its courses through green fields of barley and pasture grounds, on the other side of the river, hills of small height, partly wood covered, partly cultivated, with an occasional solitary gaard. The two last stages of my this day's journey were Garlec and Hov. It was a beautiful evening; wood all around me with a few houses, picturresque bridges, mountain-torrents, a wide river, a placid brook so quiet that the surrounding objects were distinctly reflected by it; the sun slowly setting in the North-west for a long while lighted-up with its last rays a solitary house on the summit of a mountain, whilst everything around lay in the shade. When the sun was gone, I could not even see the spot where the house stood, all was lost in darkness. In my original diary I found here a comparison made, which I copy as it appears to me by no means inappropriate: A man of low extraction and little capacity rises high at court, by Royal favor; he shines, and is looked-up to (like the hut on the mountain) as long as the smiles of Royalty (the rays of the Sun) are reflected on his contenance; they are withdrawn, and he [598] relapses into obscurity, not even the place which he occupied can be traced. My room in Hov was neatly furnished, and on the walls hung good engravings 
of Luther, Melanchthon, John the Evangelist with the Eagle, Christ breaking the bread, and several others. For Supper, I had Salmon, potatoes, bread, butter, and cheese, at half past ten it was still day-light, but I was too sleepy to write, and went to bed.

Monday, $22^{\text {nd }}$ of July 1844. On this, the last day of my journey to Trondhjem I was favored by the weather, the temperature was warm, the sky clear - to give a description of the country is needless, as it would be merely a repetition of what I have so often said. The men whom I met began to wear Jackets instead of swallow tail coats as hitherto, leather pantaloons formed sometimes part of their dress, the one or the other wore a knife in a leather sheath, whilst the red bonnets continued. The women's head dress underwent some change; no more did they tie a large handkerchief round their head, a small cap covered the back part, and held-up the braids, whilst over the forehead, the hair was simply parted. On the previous day, Sunday, I saw many peasants in their Galadress going to Church; this day I met young men and women walking separately, prayer book in hand, going to the Clergyman to be confirmed. Hops are grown, in this neighbourhood. Carts laden with birch-bark were on their way to Trondhjem. Since Hov I had followed the course of the Søgnøe Elv which near Søgnøes flows into the Gurra Elv, and the country hitherto called Søgnøesdalen, now goes by the name of Gurradalen as far as Trondhjem, near which place the Gurra Elv disembogues into the Oyal Fjord. The three next stages were:Valland, Leer, and Melhraus, in the last Skyse-Gaard, the room to which I was shown was stylishly furnished, with looking-glasses, sofas, a round marble table, etc. For the first time the horse was not ready for me, but was brought in after half an hour's delay. The last stage before reaching Trondjheim is called Oust; here a traveller gave me the advice to put-up in Trondjheim at Mrs. Holberg's, not at the hotel d'angleterre as had been recommended to me. The road was now again more lined with trees than it had been the case for the last three or four stages; but I was surprised on my approaching the Northern Capital of Norway, to see neither Country houses, nor a greater influx of carts as I had observed in the neighbourhood of Christiania. From a small eminence I saw Trond hjem with its [599] red roofed houses prettily situated close to the Fjord, on the other side of which the mountains were clearly visible; in the Fjord itself, the island with the fortress of Munkholm, and to the right of the town, where the wood had been cleared away, hills well cultivated, with a few houses and trees. The grass in Norway is extremely soft and smooth similar to that on the lawns in the English parks, the meadows I have already had occasion to observe, are enamelled with thousands of wild flowers of various colors. I drove straight down to the sea, when turning off to the right, I passed two or three bridges over as many ditches which I suppose were once filled with water, now grass 
grew in them, and people were busy with haying, which perhaps erronously I look upon as one of the Idyllic occupations in a peasant's life. I entered the town through a gateway between two low walls; upon that to my left towards the sea waved the National flag which had been hoisted up for the first time on the previous day with great solemnity, and amidst loud acclamations. It was two oclock when I alighted at Mrs. Holberg's whose house was a corner house, not far from the Fjord, where two wide streets cut each other. She was an elderly lady, spoke a little English, and gave up to me her two daughters bed-room, all the other apartments in the house being occupied by strangers. The stairs were like a ladder. I had a good dinner in Mrs. Holberg's bed room, the curtains of her bed had been drawn of course, excellent haddock, meat meant to be beefsteak, potatoes, bread, butter, and cheese, and beer. A waiter accompanied me to Messrs. Jensen \& Co. and to Mr. Consul Knudtson to whom I had letters of recommendation, to the former from Messrs. Mathiessen \& Co., to the latter from Theodore Arnemann. Jensen \& Co. were not at home; Knudtson, an elderly Gentleman and widower, received me in a very polite manner, he spoke German. Both these firms had their establishments in a street called Kjøbmaends-Gade, which seemed to be the principal one of the place, it runs parallel to the Nid-Elv which to the Eastward of the town falls into the Fjord. The street has on its Western side a row of large houses amongst which the bank of Norway, on its Eastern side a row of stores behind which the Elv filled with vessels. All the houses in the town are large, by far the greater part built of wood, even the palace or rather the "Stift amts-[maends]-huset", or residence of the first magistrate in the Stift or province of Trondhjem, was built of this same material. Brick-houses there were but few, and a few more in progress of construction. The streets [6oo] are wide, some not paved, others badly paved, they cut each other at right angles. Some narrow lanes lead from the principal streets to the Fjord. The Churches are: the Cathedral, and Fruens Kirke. A street similar to the Kjøbmoends-Gade runs along the Fjord, it was not completed and stores were about being built. I walked down this street until I came to the Wall where the flagstaff stood, here I lay down for a considerable while, on the softest grass imaginable, enjoying the beautiful weather, I thence strolled out of town through a long avenue of birches, and returned to Mrs. Holberg's, fatigued, it is true, but much pleased with what I had seen. I went to bed when it was still day light, and when I awoked at midnight I could distinguish the numbers of the dial of my watch, though the moon did not shine. The sketch herewith shows the situation of Trondhjeim on a peninsula formed by the Fjord and the Nid-Elv. In the appendix under $\mathrm{N}^{\circ} 18$ will be found a note of my expenses, on my journey from Christiania to Trondjheim. 


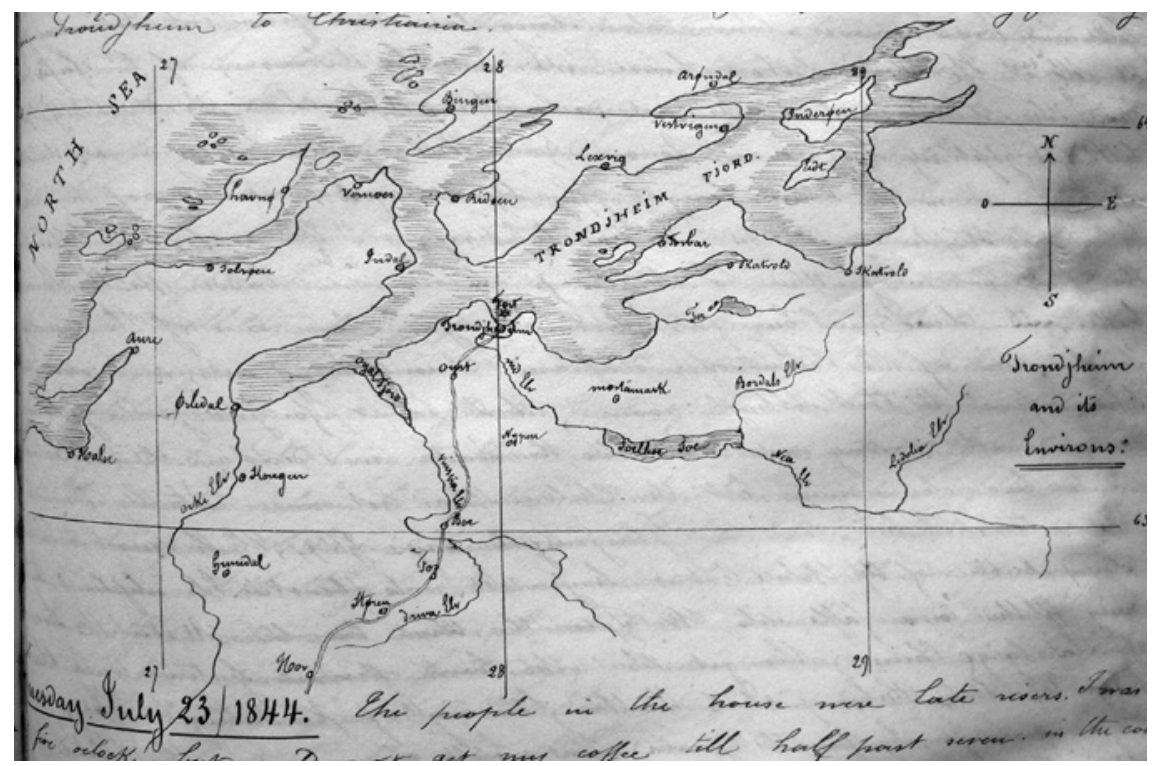

Tuesday, $23^{\text {rd }}$ of July 1844 . The people in the house were late raisers. I was up by five oclock, but could not get my coffee till half past seven. In the course of the day I visited the Cathedral and the school for the deaf and Dumb. The Cathedral dedicated to Saint Olaf is said to have been founded as far back as the year 802. Once it has been destroyed by fire, and tradition [601] says: that this fire was caused by a Stork carrying a burning stick to its nest on the roof of the Church; the second time it suffered much when besieged by the Swedes, in what year, I was not informed. Thus in 1844 it stood partly in ruins, and the repairs of later years massive and heavy, were by no means in accordance with the graceful and light style of the original structure. Of the original slender pillars there still existed a few, some in the interior of the Church, some outside, the remnants of what once was a handsome portico which in olden times ran round the entire building. The altar was surrounded by the statues of the twelve apostles, Saint Paul taking the place of Judas Iscariot, the Statue of Christ upon the altar itself, they are all made of plaster or Gypsum. Our saviour's statue is an exact copy of the original in our lady's church in Copenhagen (see page 564 ), whilst the twelve others which are the work of a disciple of Thorwaldsen differ from those in the Danish Capital. In an apartment where fuel was kept, stood a wooden triangular box of an extraordinary size, the object of which I did not learn. It went by the name of St. Olaf's hat box, on the top of it these words were cut: "for alder jeg aeres 1304" (on account of my age, I am honoured). A Well, now dried up is called St. Olaff's Well, a winding stair case of grey stone, leads up to the roof where there being no steeple on this side I had to pass, over 
the roof, to the steeple on the other extremity, where I climbed-up a common ladder, to the summit. Hence, the weather being fine, I had a good clear view of the country around. The Director of the school for deaf and Dumb being out, a servant girl showed me to the school-room, where about forty boys and girls were occupied with writing on slates; also the master was deaf and Dumb, he appeared to be a clever man, but the Children had certainly not made as much progress as those I had seen in Glasgow (See page 249/51). The master was employed with one of the cleverest boys who was about to be confirmed, before being placed as an apprentice with some artisan or other. Under the heading of "Aarsay" (Cause) the master wrote down several sentences on a black board to which the pupil under the heading of "Vierkning" (Effect) gave the answers; for instance, (Cause) the scissors are much used, (Effect) the scissors do not cut. This the boy did readily, but when I asked him a simple question, he seemed at a loss, and consulted first with the master by means of his fingers representing letters, the master replied in the same [602] manner, but before the answer to my question could be given, the Clergyman of the establishment entered, and interrupted us. This Gentleman told me, that several Gentlemen were at the time travelling in Germany on account of the Government, to acquaint themselves with the different manners in which deaf and dumb are taught in that country; I may say, that this establishment disappointed me. In 1854 I visited the Berlin deaf and dumb institution, there the teacher went upon an altogether different principle. It is known as a fact that the deaf and dumb are not actually dumb, for they can shriek and wail but that they do not pronounce articulate sounds, because they have never heard them, to remedy this defect the sense of sight is called in to supply the way of hearing. The teacher pronounces a letter, and calls the pupils attention to the manner in which the mouth is open, how the lips move, how the tongue is compressed against the teeth or palate, how the throat swells, and so on. Then the letter is written down, and the pupil notes how the sound of the letter is produced; in this manner, he is taught the whole alphabet. Next the letters are joined, so as to form a word, for instance book; the book is shown, and the pupil has learned that the mouth being opened in a certain manner, the sounds of certain letters are produced, and these letters being joined formed a certain word, this word means a certain object. Thus, by merely looking at the speaker without hearing the sound, the well taught pupil understands him. The Berlin deaf and dumb having progressed so far as to understand, though not to hear what was spoken, the last and most difficult part of the teaching was still to be accomplished, that of teaching to them how to speak; some, by careful attention to the master when he spoke, and by close imitation of the manner in which he opened his mouth, moved his lips etc., succeeded 
in producing articulate words which they pronounced distinctly, but uttered apparently with a violent effort and with a loud, harsh, and dissonant voice. Mr. Knusdtson pointed out to me various buildings, the one used at present by the Government as a store-house called Kongens-Gaard was many centuries back the palace of such of Norwegian Kings as resided in Trondhjeim, another the Convent in which poor females of respectable families obtained a domicile and third, the Exchange, to the reading-room of which strangers were admitted. Mr. Knudtson proposed to introduce me, but as my stay in [603] Trondhjem was a very short one, I declined his kind offer. I dined at home in company with a Swiss Gentleman who was travelling-clerk for some manufacturer or other. He tried to dissuade me from going by land from Bergen to Christiania, and advised me to take the steamer which goes from the one place to the other; for the visiting of the many ports of the coast was, he assured me very interesting. The result was, that I remained undecided what route to take. At a later hour Mr. Knudtson again called upon me, we took a short walk together out of town, and returned along the Elv, passing the marine establishment where every gun boat was kept under a separate shed. The females of the lower classes when walking in the streets, were rather better looking than the peasant-women in the Country, their features were less marked, and less harsh, which they owed to their having less hard work to do, and their being less exposed to the severe climate of these Northern Latitudes, Trondhjem lies in $631 / 2$ North. The ladies of the higher classes were of course dressed in the usual French fashion. At Mr. Knudtson's in whose house I supped, I met an elderly lady related to him, his daughter with her husband, a young girl, and a Mr. Bagger born in Norway, established in Stettin. The rooms were not carpeted, but otherwise prettily furnished. As soon as I entered, Porter, Wine, Brandy, together with bread, butter, cheese, and smoked Salmon were presented to me for the purpose of giving an appetite, at nine oclock we sat down to a cold Supper, claret was the only wine put on the table. The conversation not particularly interesting was carried-on partly in German, partly in Danish, the ladies did not open their mouths. I learnt here that the ore in the Copper mines of Rø[_] aas contained generally no more than six or seven per cent pure Copper, and that even three per cent paid, they produced annually about 2000 Schtt. of $280 \mathrm{lbs}$ each, pure copper, the Schtt. worth sixty species each.

Wednesday, $24^{\text {th }}$ of July 1844. In mistress Holberg's bed-room stood a French clock which she much prized, it being a present made her by Louis Philippe who for sometime lived in her house when he at the close of the last, or in the beginning of this century resided in Trondhjeim and at the time Duke of Orleans, gained his livelihood under a feigned name as teacher of mathematics; in the year 1841/42 when he, then King of France, dispatched a scientific 
expedition to Iceland, the Capn. [604] was ordered to touch at Trondhjem and to deliver this clock to Mrs. Holberg as a token of his gratitude. The weather was beautiful, the sky without a cloud, and the heat almost oppressive; at seven o'clock thermometer stood in my room at $191 / 2$ Reaumur $=76$ fahrenheit four hours later at 21 Reaumur $=79$ Fahrenheit. In the steamer's office, I took my passage per steamer "Nord Cape" to Bergen which cost for myself 12 Sps 25 Sh, for my gig 8-17, fees $16 \mathrm{Sh}$, total 20 Species 58 Shillings. From Jensen \& Co. on whom I had my letter of credit I drew fifty Species. Before dinner, though the heat was great, I took a walk, crossed a bridge over the Nid Elv to its right bank and ascending a little, came to a low eminence on the top of which stood a small fort called Christiansteen; its walls, three and a half yards thick with many [lient] bastions and constructed of large stones, though dismanteled since the union of Norway with Sweden, were kept in good repair. A building in the interior served at present as a look-out for conflagrations. Two other hills close by had also their fortifications once the outworks of the fort, at present fallen into decay. The prospect from this point, westward over the town and the Fjord to the opposite mountainous shores, to the Eastward inland over a hilly well cultivated country with a few houses pleased me well. I descended, made my way through bushes and across corn fields, and emerged at the Eastern end of a street called Baglandet which runs along the Nid Elv. This brought me again to the bridge, and thence home. It is a pleasure to see how in this far-North, people seem to be fond of flowers; in every respectable house which fronted the South I was certain to find flower pots placed on the window sills. I dined with my Swiss acquaintance of yesterday and with a young Norwegian just returned from his grand tour on the Continent. At a later hour Mr. Jensen accompanied by a young Spaniard from Barcelona, called upon me in his carriage for a drive to the two water falls called Leeren Foss. The country through which we passed was undulating and cultivated, Country houses here and there, when looking back, the splendid Fjord; all this shone upon by a bright sun, and I myself in good spirits, the great requisite to enjoy travelling. The falls are formed by the Nid Elv, the lower is the smaller of the two; that higher up, the more imposing, we only saw from a distance, for Mr. Jensen, rather a stout [605] man was not inclined to walk so far under the boiling sun. Thus I had to content myself with the lower fall. A little higher-up the current of the Elv is imperceptible, its waters of a greenish color almost immovable are like a mirror, the smooth expanse of which is not broken by the slightest ripple, but all on a sudden the whole river divided in its entire width by a rock nearer to the left side, rushes downwards, and though the height is not great, becomes at once one mass of foam, froth and spray out of which arise millions of diminutive particles which in the shape of a transparent whitish 
gauze envelope the whole. Again a few yards farther down the river flows as gently as if it had met nowhere an impediment in its course. Between the two falls on the left side thick fir woods reached to the waters edge, whilst on the opposite bank stood various factories the machinery of which was put in motion by the Elv, their director was Mr. Strohmeyer, a German. In one of them the beautiful yellow color called Chrome yellow was produced, the mineral which gives this color was found in the Røraas mines whence it was brought to the factory, there ground, crushed, and cleared of its earthy particles, which being done it was mixed with potash, boiled, and the water having run-off, the remaining mass saturated with sulphuric acid and allowed to cool, formed the beautiful red crystal [...] hich gives the chrome yellow, worth at the time eight shillings Banco the [_]. In the second factory, Sulphuric acid was produced; this is easily done, gra[_] small stones containing sulphur are toasted, the vapours which rise from them united with those of nitrate of Soda, condensed, give the acid. In a third edifice, the copper bars brought from Røraas were remelted and when red hot placed under different cylinders through which they were passed consecutively until reduced to the thinness of copper sheathing. Our drive home was again very agreeable, at Mr. Jensen's whither we went, a small party had assembled, Mr. Jensen, his wife, a nice woman, his brother in Law, his son, the already mentionned Spaniard, a Miss Richter, Mr. F[ie]chs from Vienna, agent for the Globe insurance Company in London, talkative, rather consequential but not disagreeable, several Gentlemen whose name I did not become acquainted with and myself. When I entered, the usual whetters of appetite were presented to me; then we conversed, I distinguishing myself by being able to speak five different languages, Danish of course very badly, German, English, French, and Spanish. At ten oclock we sat down to a very good Supper [6o6] excellent lobster of which I ate rather too much, warm meat which I did not touch. Many toasts were given, and we broke up at 11 1/2, I having spent a very agreable evening. It was a beautiful night, if night could be called where there was no darkness. I took out of my pocket an old press copy and read it easily. In the North West of the cloudless sky, the rosy tints produced by the rays of setting sun mingled with those which preceded the rising sun of the next day; there was no interval between the evening twilight and the morning dawn.

Thursday, $25^{\text {th }}$ of July 1844. I was up before four oclock, it was a beautiful morning, about an hour later Mr. Augustus Konow a young Gentleman from Bergen whose acquaintance I had made, and I, went on board of the Steamer. Mr. F[ie]chs and the Spaniard I was surprised to see had taken a second class passage, to be sure it cost only half of the first class, but there the society was much mixed. Mr. Konow as he told me had been brought up for an agricultural 
life and he was now looking out for an estate to purchase. He resided with his father and mother in law near Bergen, besides him, I soon became acquainted with a Mr. Dahl (Charles) and his lady not pretty, very sickly; both agreable people with whom I remained on excellent terms during the whole passage. There was also on board an Italian who gained his livelihood by showing himself as a Giant; he was certainly tall, but his enormous high boot-heels contributed not a little to his apparent height, he had with him his wife, a tall elderly woman from Stockholm, besides there were on board some people belonging to Gauthier's Equestrian establishment who carried with them an Eagle and a Lion in separate cages, a woman of easy virtue and some others who may perhaps turn-up by and by in the course of my narration. We weighed anchor and Steamed off. To our left we had wood covered mountains, here and there small patches of Barley surrounding solitary houses; next, passing the mouth of the Orke Fjord, snow capped peaks were seen at the Southern extremity, to our right or north a pretty green shore with a few houses, Stalbøg, a little further-on we stopped for a few moments at Røedeborg, and then steaming through flakke Fjord found ourselves at a quarter to nine in front of the Churches of Øreland and Østerraard situated on a level low land. At $101 / 2$ we were out of the Fjord and stopped again at Hovnøe on an Island on the [607] starboard side. Here we overtook many vessels bound from Norlandet to Bergen, laden with fish, they are generally without a deck, have one mast with one sail, they are broad and high, fore and aft, which in the middle the fish lay piled up to a considerable height, this fish is either Stock fish or Clip fish; when fresh it is called cod, being differently dressed it receives then different denominations. The first operation is to clean out the intestines which being done the Clip fish most consumed in Spain is cut open, salted and spread for drying on the Cliffs, whence its name; the Stock fish, which is sent to the Italian markets is left entire in its round state, and without being salted is merely dried in the open air. We dined at one oclock; four ladies, four gentlemen, Lieutenant Möller a nice young man presiding, the Captain was very civil to all. Dinner was fair, at half past two, we returned on deck. To the South for a short time our larboard side we had now steep, high, barren rocks, and these continued more or less until we reached Bergen, here and there a small cultivated spot, and wheresoever there was an opening through the mountains, snowy mountains at a distance, by and bye the deck became empty for the burning sun drove all below, only I remained. A very narrow passage, so narrow that it would have been utterly impossible for another vessel to pass us, brought us to a circular basin formed by three Islands; that to the N.W. God-mad-Landet, joined by a neck of land to Kirke Landet, to the S.W. Norlandet to the N.E., divided by a 
sound from the Sydlandet to the S.E. The town of Christiansund is built upon all four, opposite to where we entered is a similar narrow exit. This port must necessarily be very safe, however sailing vessels do not venture into these narrow intricated passages. At Kirkelandet the principal of the four islands, the Giant landed to show himself, a few passengers remained on board, Mr. F[ie]chs and I went on shore together. Mr. F[ie]chs went to bathe, I ran up the hills behind the town and for sometime rested on a stone and looked around, the houses were upon the whole a poor appearance; here and there a larger one formed an exception, all were made of wood; to the East I saw the red roofed houses all round the basin, to the North the narrow passage through which we had come, to the West and South, the open sea. This island is upon the whole barren, small patches are cultivated, where barley or grass is grown. It was now the season for haying. I [608] ascended a little higher, and then descended a narrow rocky ravine to the very waters-edge, a spot hardly ever visited by strangers. Here I bathed, then running up ascents, down descents, I came to a solitary house which served as a look out for a custom house officer with whom I entered into conversation, he told me amongst others things that the sea in this neighbourhood never freezes-up, which by the bye is also the case in Trondhjem fjord. On a sudden I observed that I had forgotten my watch in the cave where I had been bathing, its situation I did my best to describe to the Custom-house officer, and accompanied by him I started off. It was a mad career we ran and jumped from rock to rock, up and down without taking breath for a moment and had the good luck to find the spot, and my watch of course. We returned more quietly, my spectacles had fallenoff without my perceiving it, I was in a frightful perspiration, I had become somewhat hoarse. When we reached the house, I rested a little, my companion gave me some milk and water, I him a half Specie, we parted excellent friends. I then walked leisurely down to the town and was rowed on board. There were only as yet Konau, Mrs. Dahl, and a Clergyman whose name was Norneaned. This Gentleman had lived for a long time in a place called Borge in Latitude $681 / 2$ North, where in the winter season, daylight lasts not above one hour, he now to his great delight was to take possession of a more Southern curacy. This night was as beautiful as the preceding one, at half past eleven I laid down on a Sofa made up as a bed in the State cabin.

Friday, $26^{\text {th }}$ of July 1844. I was up at half past five, at six a gun was fired, and we steamed through a passage to the South of Christiansund which was somewhat wider than that through which we had entered. When we were outside, we had to our right the open sea in consequence of which the motion of the Steamer increased a little, to the left on a low shore, we distinguished 
the Churches of Bok and of Bentad, and snowy mountains in the distance. Soon after, we again had to thread our way between rocks and islets. At eleven oclock, the snow capped peaks of Rumsdal fjeld were in front of us, and it seemed as if we were steaming right up to them. When approaching the town of Mølde, a not inconsiderable place for it numbered as many as from five [6og] to six thousand inhabitants, the rocks were less barren they were covered with firs. We passed a hospital and stopped in front of the town. The bay was so completely locked-in that no outlet was to be seen by my inexperienced eye, the Sea here was of a beautiful blue green color. Some passengers went on shore, more came on board amongst whom some ladies carrying fine nosegays, also a young Mr. Schroeder, son of Schroeder of Schroeder and Eiffe of Hamburg, in whose business he was travelling in Norway. At dinner, he, a pleasant young man, Konau and I sat at the head of the table near the Lieutenant; after dinner we repaired on deck, the heat was great, I lay down on some boxes, and slept a good siesta. At half past four we were opposite Aalesumd a town of less extent and population, but doing more business than Mølde, some houses including a church built along the bay open to the $\mathrm{N}$. West constituted the town, the population of which numbered from eleven to twelve hundred souls, immediately behind rose the rocky mountains. Many passengers came on board, ladies with parasols, however at five oclock when we started afresh, some had returned on shore. Amongst those who remained were a merchant Dahl from Bergen, and a Chef de bureau in a Government office who was returning from Lapland and Finland whither he had been sent on a special mission. With both these I became acquainted and found them to be well informed agreeable Gentlemen. A thick fog bank rose before us, we passed through it, but the cold drove us below. At seven oclock we returned on deck and were now at Ulfsteen where the good Clergyman from Borge went on shore to take care of his new flock. A few houses round the Church on a small green patch of land between the rocks and Sea formed the town; there was not a tree to be seen, on the whole coast trees are very scarce. South of us lay the island of Gurskøe. For the night we came to an anchor in the port of [Hevskøe] a very small island with a church, a few houses and staff with the union flag, I counted seventeen boats, some rowed by women; the men continued to wear the red woollen bonnets above spoken of. A proof of the dangerous nature of the navigation along this Coast is, that even Steamers did not venture to proceed at night. Konau with his dog, Schroeder and I went on shore, we climbed about on the rocks of this small island and to be sure wheresoever a little grass grew, it was as soft and smooth as [610] as I have noted it to be all over the Country. The configuration of this coast is certainly wonderful, violent must have been the convulsions of nature which have torn it into thousands 
of pieces of all sizes and shapes. When on board we sat down to Supper. Cold meat, Salmon, Gammel-Ost etc., all very nice, in fact too many good things. I became acquainted with another Gentleman, Mr. Beraas from Tromsoe who travelled for the firm of Jansen \& Co. of Hamburg. Laplanders and fins he told me, were originally the same people; at present such as lived inland and who are nomades, go by the former name whilst Fins are those who have fixed abodes along the shore. Both the one and the other are of small stature. Reindeer form the whole fortune of the Laplanders, their dress is made of their skins, with the hair inside to answer the purpose of shirts. Reindeer meat is very tender, and tastes well, the "quarners" who have emigrated from Russian Finland are a different nation, they are taller, and speak a different language. Mr. Beraas had a particular skill in cutting figures out of paper, he gave me several of these figures representing Laplanders, and Fins, theirs huts, snow shoes, Reindeer, etc., which will be found in the appendix under Number 15.

Saturday, $27^{\text {th }}$ of July 1844. After a good night's rest, though I had had to share my large Cabin with Konow, Schroeder and Beraas I went on deck at six oclock, the fog which surrounded us was so thick that the Captain did not venture to move on till nine. About three quarters of an hour later when I was conversing with one of the passengers, the vessel struck suddenly, the shock was severe, he with whom I spoke jumped up and took hold of my arm, I did not say a word, but my heart beat quicker than usually. All the ladies came from below, many with dishevelled hair, some screams resounded from the second class passengers. For a moment, all was confusion, the Captain halloed out: "Ingen fare" (no danger) though at the moment he could not know if there was danger or not, some splinters of wood floated by, it was part of the false keel which had been knocked-off. The pumps were tried immediately, fortunately they drew no water, all was safe. Cautiously we steamed on in the thick fog, but merely moved backwards and forwards [_] at about one oclock when the sun came out and we shaped our course for the island of [611] flaaven not on my map. Whilst we were at dinner we anchored near this island. Schroeder, Beraas, Konau and I were rowed on shore. Flaaven is the smallest island imaginable, there is nothing but a rock, some soft grass, a little barley not yet ripe, five or six houses and a few boats, all the property of one merchant. After having run and jumped about to our heart's content, we returned to the Steamer and played at whist for the greater part of the evening till it was time to retire to rest, when it was so dark, (for the first time after so many days) at this hour that a lighted candle was required to go to bed.

Sunday, $28^{\text {th }}$ of July 1844. At half past three, the report of the Cannon fired on board awakened us, and by the motion of the Steamer we could judge that we were steaming on rapidly. At seven oclock when I made my appearance on 
deck, we were in the open Sea opposite to the peninsula of Stadtland, again we entered between the small islands through a passage quite as narrow as the entrance into Christiansund. The weather was cold and raw. To the right we had a miserable Church or Chapel of Capel. Further-on upon the same island the pretty looking houses of Vagøe, here and there a small barley field, but not a tree on the rocky shore. After having stopped a few minutes at the island of Moløe to take off some passengers, we once more passed through a "sund", narrow beyond conception. We kept of course in the middle, and I am certain that the distance from the Steamer to the shore on each side, taken jointly was not greater than the breadth of the Steamer. At half past nine we were opposite the mountains of Hornølen in the island of Bremanger, famed all over norway I suppose not on account of its elevation for I should hardly think it more than three thousand feet high. The lower part the base of which is washed by the waters of the sea has the usual conical shape of a common hill, but then the rock consisting mostly of slate rises abrupt and steep like the wall of a house, and terminates in several rugged points. Hornøelen was saluted by two cannon shots, the echo of which rolled loud and long between the surrounding mountains. Tradition says that Saint Olaf the famous Norwegian King, ascended to the very top, but if he did so, he must have found a path on the landside, for from the sea side it is utterly impossible. We steamed on, the islands of Froe-søe, and Turn-sund present the same grey rocks sometimes covered with soft grass. We stopped at the small [612] island of Swan-øe, with two or three red roofed-houses, again at Save-Sund where passengers came off, amongst whom a Mr. Nicolaissen of the firm of Nicolaissen \& Co. of Bergen to whom I had a letter of introduction from Arnemann. I was introduced to him by Mr. Konau. After a short stoppage at [Stoherje]havn, and a passage through a sound as narrow as any of those previously described, we arrived without anything occurring worth notice, in the port of Bergen at eleven p.m. It was so dark that I could not see anything of the amphiteatrical situation of this town of which some of my fellow passengers had spoken to me in high terms. The society on board had been very pleasant and on separating, I exchanged cards with many of the Gentlemen, whose acquaintance I had made. There was the usual hubbub, everybody looking for his own luggage, which fortunately was not subject to the searching of Custom house officers. Schroeder and I took one of the many boats laying round the Steamer, he returned on board. I went to the house of Mrs. Sontum, close to the landing place and was received with the words: "no rooms empty", but on my mentioning that Mr. Bagger whom I had seen in Trondhjem had recommended me to her, a room in the loft was got ready for me, the bed was spread on the floor. Mrs. Sontum was an agreable lady of nearly sixty, with several good looking grown-up daughters. 
Monday, $29^{\text {th }}$ of July 1844. After a fair night's rest I was up at an early hour and at half past six on board of the Steamer to bring my gig on shore, somewhat later, young Master Sontum showed me to the different houses to whom I had letters of introduction. The streets were well filled with people mostly of the lower classes, sailors, fishermen, peasants and peasant women. I noticed particularly the head dress of some of the latter, the married women wore a kind of white night cap, which stuck-out behind in an extraordinary broad triangular form thus while the unmarried girls had theirs braids placed round the head like a wreath, tied all over with red ribbons, those who had arranged their hair in this manner were without exception extremely fair, and their faces square shaped. I met Mr. Nicolaissen in the street, he took me to his Country-house in the Street called [Torvet], or market, introduced me to his younger brother, and invited me to spend the evening with him. Mr. Gade, the same, who on the Easter [613] Monday had been one of the party from Altona to Nienstadten (see page 426) gave me a very friendly welcome, introduced me to his wife, and delivered to me a number of letters from South America, England, Altona and Eutin. This Gentleman was the most extensive dealer in Bergen in dry goods, both by wholesale and retail. Mr. Stei[negke] to whom I had a few lines from Mr. Mathiessen \& Co. was by no means to my taste, I thought him a bit of a fool, the letter to Holtelmann from Sieveking's I did not deliver. The weather being fine, I started for a long walk, which on the sketch herewith is marked by dots, and looking round me attentively, I was able to form a correct idea of the situation of the town of Bergen. Bergen is situated partly on the Northern shore of the Byenn's Fjord, partly on a piece of land, which were it not for a short ithsmus, which connects it with the main, would be an island, the name of the fjords which surround this quasi island, are given in the sketch (see page 619). To the Westward another island called Stridshavn protects the town, and harbour, against the violence of the western winds and waves, two passages, one to the North, the other to the South of Stridshavn, lead to the port. We in the Steamer "Nord-Cap" entered through the Northern passage. Of the two fords, the Byen Fjord is the harbour most frequented by vessels, during my short residence in Bergen it was well filled with vessels. The houses were upon the whole large, the generality built of wood, brick houses forming the exception, the front of some was stuccoed. The suburb to the North of Pydde Fjord was an agglomeration of miserable buildings inhabited by the lower classes of the population. The Strande-Gade along the Southern bank of the Byen Fjord is the principal street, next to it ranks Torvet or the market, which running across the neck of land, cuts Strande-Gade at right angles, in it stands the bank of Norway. Opposite Strande-Gade along the Northern Shore of the Byens Fjord is Tydzke Brygge (German Bridge) where the large 
store houses resembled the gabled houses many storeys high in the old part of Hamburg. They date from the time that Bergen belonged to Hanseatic League and was the Emporium for the Northern trade of this great commercial Confederation. To the Northwards the ground rises gradually into hills, then into mountains, the lower part of which is carefully cultivated and dotted over with Country houses and clumps of trees. Starting from Mrs. Sontum's I walked down Strande-Gaden as far as Torvet, where I turned off to the right, and after a glimpse at the suburb, reached the Langaards vand, across the pretty [614] country which, with pleasure grounds, Cottages and Country houses fills-up the eastern part of the Island, there I crossed in a boat to the other side, and through a similar pretty Country reentered the town under a gateway, passed the Cathedral, a public School house, the Sailors Alm-house, then along Tydske Brygge, reached the fortress of Bergen huus, which I was allowed to enter, again took boat, and was back at Mrs. Sontum's in time for dinner. To this crossing in a boat from one side to the other, the Bergen people gives the technical name of Flyttes which literally means "to be removed". Along Tydskke Brygge Stock fish and Clip fish, just landed from the vessels moored to the query, lay piled up in high heaps; besides these two descriptions of fish, there is another inferior kind, called See, which is mostly exported to Sweden, Cod liver oil, and herrings, are others articles of export from Norway. The former extracted from the liver of the Cod is used as an excellent remedy agst. pulmonary diseases. Of the latter, there are two classes, the better which caught along the Coast between Trondhjem and Stadtland goes mostly to the markets of Prussia and Mecklemburg, the inferior class caught between Stadtlanden and Bergen is shipped to Russia and Poland. The dinner which I took with Mrs. Sontum, her two daughters, her son, and two Danish Gentlemen was plain and good. At five oclock I went to Mr. Nicolaissen's dwelling house, where I met a small party amongst whom two brothers of the host, a professor Otto from Copenhagen, with his wife and niece, which latter recognized me as having been a fellow passenger on board of the Steamer Christiania, another professor, and perhaps one or two more persons. After tea had been served we took a drive, professor Otto, the ladies, in a more capacious four wheeled carriage, Mr. Nicolaissen and I in one, one of his brothers, and the professor in another gig. We drove along the shores of the Fjords, more or less the same road I had walked in the morning, only a little further; on our return, we found a very nice cold supper waiting for us, to which every body helped himself as he pleased without setting down round the table. The Conversation was generally carried on Norwegian, or more properly speaking, in Danish with an occasional slight difference in the pronunciation, nevertheless I found it more difficult to understand, than 
the pure Danish spoken [615] in Copenhagen. With professor Otto I had a long talk in German, also with his niece, a nice and pretty young girl, we walked home together for they lived like myself at Mrs. Sontum's.

Tuesday, $30^{\text {th }}$ of July 1844 . Early in the morning Professor Otto and family left, and went on board the Steamer, which skirted the whole coast as far as Christiania. After having taken my coffee, and written some letters, young master Sontum took me to an Optician's where I replaced the Spectacles lost on the $25^{\text {th }}$ instant on Kirkelandet, next to a bookseller's where I bought some miserable woodcuts, representing the various costumes of the peasants in the different provinces of Norway. I have them still in my possession (1869) and preserve them with many other engravings in my large portfolio. Close to Mrs. Sontum's house, at the western extremity of Bergen, lies a small fort on an eminence called Fredericksberg. On the Exchange, which is nothing but an open square on the quay, I met Mr. Steinecke, Mr. Dahl the merchant from on board the Steamer, and an old Mr. Storjohann who had been in my fathers Counting house, when I had not yet reached my second year. Having still some time to spare before dinner, I went accompanied by Gade's son, a boy of ten or twelve years of age, to another fortification, a considerable distance up the mountain behind Tydske Brygge; thence, we walked along the brow of the ridge of hills to a pretty wood called "Kong-Swarre-Skov" where this King Svarre who flourished about the end of the twelfth century and who was the founder of Bergen, is said to be buried. From every elevated point, the town of Bergen presents a pretty view, itself forms the Kernel incircled by the Fjords, these surrounded by green fields, which are confined by the mountains; only towards the South, the Country is more open. At 2 p.m. I was back at Mr. Gade's where a few friends sat down to enjoy an excellent dinner, the dinner service was elegant, and the wines, Claret, Sherry, port, madeira, and Champagne were excellent. I, as the most honored guest, had to take Mrs. Gade to the table, and sat to her left. We were all in good spirits, many toasts were given, however I once more experienced that my imperfect knowledge of the language of the Country, was a great drawback to the pleasure which I should otherwise have derived from the various convivial parties, at which I was present during my stay in Norway. After dinner, we drove out in several Gigs, one [616] was occupied by a Mr. Fischer, who had lived in Altona, and was well acquainted with my nephew Charles Ropsy and myself. The road we took was the same which I had taken on the previous day in Mr. Nicolaissen's company; we stopped for sometime at the country house which one of the guests, Mr. Friller was about building, and in the construction of which he displayed much good taste, amongst other things, he showed us a plaster cast of the famous antique group 
of Lascoon and his sons, but to my surprise, few of the party were acquainted with the subject, which it represented. It was a rainy evening. Having returned to Gade's we took tea and I left at half past ten, but at home instead of going to bed, I amused myself with one of the daughters of the land lady, who was very anxious to hear something of South America, and whose curiosity I satisfied as well as I could in my broken Danish.

Wednesday, $33^{\text {st }}$ of July 1844. All in the house rose late; by eight oclock I was at the "Torvet" where I witnessed a lively interesting scene. It was the purchase of fish: a number of small vessels filled with fish were lieing close to the query, and from above, the purchasers, all women, leaning over the wooden balustrades, haggled and wrangled, with the fishermen below, screaming at the top of their voices, whilst these latter remained impassible, and allowed themselves to be called ten times or more before they vouchsafed to answer. When a bargain was struck, the money was first handed down, then the fish hoisted-up by means of a birch-twig stuck into its jaw; the only word I could make out, was the word "Fiscar". The fish were of course all alive, and kicked about in fine style, whilst laying on the ground; they were extremely cheap, I saw eight fish with whose quality and names I was not acquainted, sold for thirty Norwegian Shillings, about two pence English. Under $\mathrm{N}^{\circ} 16$ a sketch of the fish market, will be found in the appendix. In the course of the forenoon, I bade good bye to Mr. and Mrs. Nicolaissen, and to Mr. and Mrs. Gade. Mr. Gade gave me a very exact itinerary of the route, which I was to follow to Christiania. At two oclock I went to dine with Mr. Steinecke; he, a tremendous proser, sat at the head of the table, I to his left, next to me, old Mr. Storjohann and three Gentlemen, opposite to me Mr. Malling, a Dane, and four other Gentlemen, at the foot of the table Mrs. Steinecke, and the widow of Steinecke's brother. [617] I was much displeased with the little attention which [_] shown to the ladies. When we went to the dinning room, I asked Mr. Steinecke, "and the ladies?" - "Well they'll come by themselves", and so they did, the Gentlemen walked in first, they followed. Dinner was good, but not so genteel as at Gade's, toasts were given, and we broke up with Storjohann's "Tak for mad" (thanks for the meal) certainly a custom not to be admired. At five oclock I drove in my gig to Mr. Charles Konau's dwelling house, he was a gentleman of about forty, in his younger days he had been in a counting house in London, and well received by Mr. Diedrich Willink, as whose nephew I had introduced myself to him on the preceding day. He was now a married man, and lived in a genteel Country house to the North of the town, between the village of Sonviig and the so often mentionned grey barren rocks which apparently barred here every further progress. $\mathrm{Mr}$. Konaw was Spanish Consul, his wife's name was Modesta, his brother Wallace, who came in, was married to a daughter of Professor Oehlenschläger, the well 
known Danish author. Charles Konaw was fond of speaking of his residence in England, where he had made the acquaintance of the Marquis of Waterford and of the Duke of Rutland. For sometime he had resided with the latter, in his Ducal castle of Belvoir, where at the celebration of the Duke's birthday, he had had the honor to sit at the same table with the Duke of Wellington, and Prince Esterhazy, he also showed me a certificate signed by the said Duke of Rutland and Lord Forrester acknowledging Konaw to be a keen Sportsman. He finally gave me a letter to a friend of his, Mr. Francis Scott M.P. who on account of the sickly state of his wife's health, had of late removed to Madeira. This letter, he requested me to deliver in person, when on my return to South America, the Steamer would touch at this island, and to give him from Lima the details of his friend's health. I promised to do so, but as it will be seen in the course of these my extracts, was unable to keep my word, because when in 1845 I touched at Madeira, the Portuguese authorities would not allow me to land under pretence that the Steamer was infected by the measles, from Konaw's I drove home under a heavy rain, and was occupied till a late hour with getting everything ready for my departure on the following day.

Thursday, $7^{\text {st }}$ of August 1844. I was up at half past two, when it was still so dark that I had to ask for a lighted candle; what a change since [618] last [...] Trondhjem, when hardly an hour, and this hour not one of actual darkness separated the evenings twilight from the next day's dawn. At three oclock a.m., my good Landlady joined me, but as the Skyds did not come until half past four I whiled away the time conversing with her. She related to me what had happened to Konaw's friend, the Marques of Waterford when on a visit in Bergen: one night he took into his head to indulge in a suburb in one of those boisterous frolics to which he had accustomed himself in his native Isle, the Bergen watchmen however not liking such an unusual playfulness tried to put a stop to it, and our Marques attempting to resist belaboured him so soundly with their sticks, that he was laid-up at Mrs. Sountum's for many weeks. All in town were asleep, not a single human being was stirring, it appeared to me as if I, the only living creature, drove through a city of the dead. As far as a few houses which I have noted down in my Sketch to the North of Lungaards-vand, and which were the most eastern point on my walk on the $29^{\text {th }}$ and of my drive on the $30^{\text {th }}$ and $31^{\text {st }}$ of last month the road was well known to me, then I turned to the North-East, now the Country houses which numerous when nearer to town, had gradually become scarcer, were left behind. Cultivation decressed visibly and rapidly, and the barren grey rocks, the firs and pines, the solitary houses, surrounded by a small green field of Barley or of grass again made their appearance. I passed the stage of Honge without stopping, and all on a sudden came to a Fjord of the sea called Arnegoven, which name is not 
given on my map. I embarked at Garnøes round which place the ground was a little cultivated, otherwise the same rocks with a little grass here and there encircled the Fjord. The boatmen, barelegged with short leather breeches were good fellows, for my conveyance, they had thrown some hay into the boat, upon which I lay down, and soon tired of the grey walls around me fell asleep, and slept the greater part of my passage on the Fjord, two and a half Norwegian miles, as far as Dalaveaagen where I landed. Thence to Dalsested, the distance was no more than five eighths of a mile. In the scenery, not the slightest change. My Skyds, a strapping young fellow barelegged and barefooted, sometimes ran along the gig, sometimes jumped up behind on my trunk. At Dalsested I had to embark on the Balstaldern Fjord surrounded by rocks, if possible still steeper and still more barren than any which I had hitherto seen. At Bolstadens where I landed things had a rather civilized appearance, some [619] crafts and boats were anchored along the shore, there were two pack-houses and a few well dressed young ladies sat outside of a white washed house, in the room where I had to enter my name in the Dag bog, I found on the table a Danish translation of a French Novel (not "Les mystères de Paris"). For my lunch, I took some brown bread, butter and a tumbler of milk. The distance from Bolstadøn to Vands-Enden along the Bølstadten Elv was short, the masses of stones and rocks sticking out like buttresses were actually terrific, I crossed the Elv in a boat, and stepped on shore at Evanger, the boatmen wore again the eternal red bonnets. From this Place to Flagge I had a pleasant drive to the right side of the Elv, which sometimes dashed furiously along as if nothing could withstand its thundering course, sometimes it glided so smoothly as if unable to overcome any impediment, the rocks which confined the valley were covered with firs, up to the top; snowy mountains became visible, the road to Vossevangen continues on the right side of the Elv, roaring mountain-torrents each of which I had to pass over a bridge, rushing down the rocks precipitated themselves into the river. Further up, the river widens, the rocks hitherto steep like walls, slant down into mountains, and recede on both sides leaving sufficient space for a small well cultivated plain, with a gaard here and there. Vossevangen though not entitled to the name of a village, I do not know for what reason, was an agglomeration of houses, more numerous than usual in Norway, cloistered round a church. Here I was recommended to the "Gjoast-giver" (Inn keeper) whose name was Slambush; he was very polite, but went to bed so soon after my arrival, that I had no time to obtain any information from him, relative to my intended trip to Eidefjord, he only told me that there was no necessity of sending a Forbud. I dined, and was so sleepy, that I went to bed without loss of time. 
Friday, $2^{\text {nd }}$ of August 1844. How tired must I have been that I did not awake until half past five in the morning. When I was called, the temperature was cool and pleasant. trunk taking the gig. I had Elv which tore bridges were on both sides resembled so metime

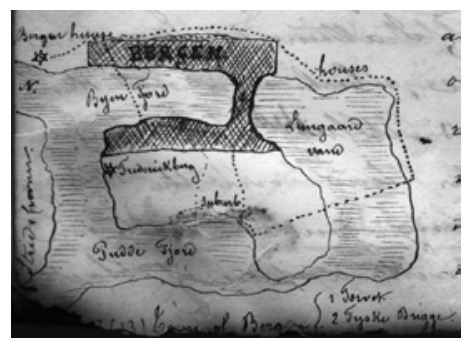
With Slambush I left my only my cloak with me in to cross and recross the along at a rapid rate, both covered over and closed in with boards, so that they two long square tubes, for I drove through a pretty wood; then emerging [620] from the same I had to my right mountains, not very high, covered with firs and pines, to my left the Elv deep below, on the other side of which gentle \{see\} hills with the usual cultivation, confined further to the Eastward by a ridge of snowy mountains. I entered again into a wood, dark and dense, firs and pines, birches, alders and aspen-trees extended high-up, the mountains steep, bold, and rugged; mountain-torrents were heard, not seen. At Eight oclock when we had reached a small extent of flat land, of course surrounded by mountains called Flatlands Møe I stopped for a short time, to rest my horse. When starting afresh, we crossed a stone bridge, which divides the district of Vossevangen whence we came, from that of Hardanger wither we went. Further on, we drove down a newly made excellent winding road which did honor to the Engineer who planned and executed it. On crossing another bridge, I had close by to my left a water fall, called Skiervenfoss divided by a rock into two parts, the volume of water was not great, but the height whence it rushed down considerable, the principal fall was again broken into seven or eight different smaller cascades. My Skyds told me that Bergen people did sometimes come as far as here, only to see this fall. The Country hereabouts was really beautiful, a valley bound by mountains, within the valley, hills, these covered with the green or yellow fields of barley, the mountains with firs and with the soft Norwegian grass. Here and there they had commenced cutting the barley, which being cut is piled-up round a pole. At a short distance I passed another water fall, not so high as Skierven-foss but which pleased me quite as well, for it plunged down in one unbroken bound. At Vads-End, I left my gig with the Skyds Skaffer, and was rowed over a fjord to Graven on the other side, which consists of a few houses with a Church, close by is a quiet lake, so quiet, that it reflected with the greatest distinctness all the objects around, mostly trees. My boatmen took me to a peasants house, the owner of which was a respectably looking old man, only a few white hairs were left upon his otherwise bold head. The various members of his family 
were very fair, and their hair of an extremely light color, I attempted to converse with them, and took particular notice of the children, which it is well known is the easiest way to gain the good will of the parents. Ullviig is one and a quarter mile distant from Graven, the road thither leads over the Ullviig fjeld, which short distance I determined to walk, my guide was the son of one of my boatmen, he carried my big cloak with a piece of black [621] bread stuck into it, and off we started at half past nine, the sun shone and the day was warm, at first the ascent was fatiguing, by and bye the road always ascending was convenient, we passed a small beautifully Crystaline lake surrounded by trees, which covered the whole mountain. Higher up, the forest became less dense, and towards the top birches predominated, two or three solitary gaards lay on our way. Hardly had we commenced descending, when Ulviig fjord came in sight, presenting the usual scenery which though so often seen by me, I never got tired-of; there was the quiet Fjord, there were the tree covered-hills, interspersed with merry looking red roofed houses, there was here and there a narrow beach and in the back ground the screen of snow-capped mountains. The last descent to Ulviig was a counterpart to the ascent from Graven, Ulviig consisted of a rather considerable number of Gaards at a short distance from each other with a Church in the centre. The Clergyman, "Praesten" as the Danes or Norwegian call him, resided here, one Sunday he had to preach in Graven, the next at Ulviig, the third in Eids Fjord. On my walk through this village I was pleased with observing a variety of fruit-trees, apples, pears, Cherries and Plums, which I had but seldom noticed in Norway. On reaching the Skyds Skaffer's house on the beach, it was locked-up, but a little boy to whom I told what I wanted, ran away, and was back in about half an hour accompanied by two boatmen, meanwhile I sat down on the beach, and slept a little. As soon as the boat was ready, and some hay placed into it, we rowed off, for sometime the objects round me were those seen from Ulviig fjield, but by degrees, the houses, the Green fields, finally the trees were left behind, and I was encompassed by black and grey naked rocks, without a blade of grass, which rose straight and steep from the very bottom of the Fjord which in the middle, my boatmen assured me, was of an unfathomable depth, they also pointed out to me a spot, where a Captain unable to witness any longer the licentious conduct of his daughter, had drowned himself - thus vice finds its way into the most retired spots on the Globe, where I had expected that the manners of the people would have preserved their primitive simplicity. A bluff Rock separates this fjord from Osa Fjord which runs Eastward. We were now close to Bangnaes fjord which remained to our left and entered Eids Fjord unvariably surrounded by the same steep barren rocks. The Sun shone warm, whilst at the same time the snowy tops of distant mountains [622] were reflected in the water. At half 
past five I landed at the Southern extremity of Eidsfjord where stood a Gaard, consisting of a few houses called Vigegrund, owned by a certain Magnus Warberg, who as well as his wife gave me a friendly welcome. Both were dressed with red jackets without sleeves peculiar to this part of the Country. The h[air] of Mrs. Warberg was arranged in a strange manner, a white handkerchief was tied over a large broad comb, stuck into the hair, near the forehead, not behind as is usually done. Mr. Warberg was not a poor man, he did business with the merchant Dahl in Bergen - both were joint owners of a vessel in which Warberg went every year in the herring fishery, he agreed to accompany me on the next day to Vørings-fossen, the goal of my this out of the way excursion; my supper was very plain, placed on the table without a table-cloth, nothing but Salt Salmon, instead of potatoes, black bread, and beer, nevertheless homely as it was, I enjoyed it, and felt quite happy. In the dag-bog I observed some complaints about high charges. In twelve months, only fifteen travellers had visited this place, the two Mrss. Hutchinson which name I again found, had as Warberg told me, left him without paying their bill. At seven p.m. the sun was still high in the heavens, whilst I was standing at the window looking upon the fjord apparently locked in, its rays fell upon the paper lying before me, the ceiling of the room was cracked, the walls were partly white washed, partly painted yellow. The oven had been taken down for the summer season, there were an ordinary table, three or four ordinary chairs, a bench, and a box painted green, two bedsteads, an ordinary chamber-pot, and a very small looking glass, this constituted the furniture. Having still some time to spare, I took a walk. This small spot is bound towards the North by the Eid-Elv which flows into the fjord, on the other side of which Elv, the never

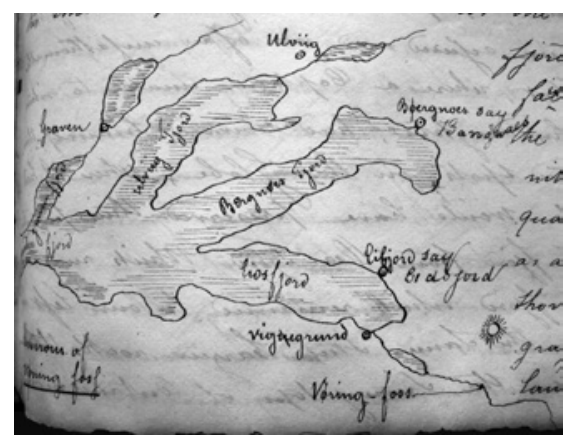
failing mountains, to the west by the fjord, to the South again by mountains, these covered with snow. Eastwards it extends for about a quarter of a mile over a level ground as far as a lake out of which the Eid Elv flows. The short distance was carefully cultivated and produced grass, Barley, and potatoes. On my return, the landlord showed me a pair of Skjœr or Snow- [623] shoes which are made of two narrow pieces of wood, each six or Eight feet long, turned up at the fore end to shove the snow away, about the middle a piece of ordinary rope is fastened, through which the foot is put by means of this apparatus, unwieldy as it appeared to me, the natives Mr. Warberg assured me could move over the snow with great rapidity. 
Saturday, $3^{\text {rd }}$ of August 1844. I awoke very early, rose and dressed, but as nobody was stirring, I again lay down till six oclock, when I went outside to fetch some water for my ablutions, Mrs. Warberg made her appearance still rubbing her eyes, she gave me a cup of Coffee with sugar without milk and some very ordinary "Zwiebak". At half past six, her husband and I started on our walk to Vørings-foss, Vigegrund is as already stated surrounded by mountains, the fjord and the Eid Elf on the North, South, and West, thus we had necessarily to direct our steps to the Eastward along the left bank of the Elv; we passed another gaard, a church, and reached a lake called Eiffjord Vand encircled by rocks, quite as steep and high as any of those seen on the previous day. Warberg and I entered a boat so leaky, that he had to bale out the water, which he did with his shoe. The rowing over to the other side took us full an hour; where we landed we had to our left the Vørrings Elv, to the right another small Elv both which disembogue into the lake. Right before us, that is to say, to the Eastward, mountains, which apparently blocked-up the road. When I stepped on shore a peasant who no doubt had received previous advice from my guide, presented to me a small saddled horse, which I mounted, its bridle was of a very simple make, a small bolt of iron with an iron ring on each side was placed in the horses' mouth, two strings were fastened to these rings, the one, the longer, held by the rider, answered the purpose both of rein and whip, whilst the shorter, fastened to both rings, passing behind the horses ears, formed what is called the head piece. We continued our way, Mr. Warberg on foot, having reached a gaard called Garathum, we turned to the left, following the course of the Vørring-Elv which coming from the North, makes here a small bend. Now I might have thought myself back in one of my Peruvian travels so bad and steep was the path, in this narrow gulley, on both sides confined by mountains from which it was clearly visible, that the large blocks of rock which lay in the way, had tumbled down. All the while the Vørings Elv, a mountain torrent in every respect, thundered downwards its head long course. Nevertheless the difference which exists between the mountainous regions in Peru and [624] and those in Norway, are too palpable to be overlooked. In the former country situated between the tropics, their elevation above the level of the Sea is such that they are either without vegetation, or the vegetation is confined to a grass at times coarse and long, at times very short, when it serves for pasture. In Norway, situated in a high Northern Latitude, the mountains which compared to the South American Giants may be called low, are capable of cultivation, even on the rock if not of too hard a nature, the soft grass is sure to creep forth. In Peru no tree is to be seen in the Cordilleras, as little as on the high table-lands called in the North "Jalca", in the South "Puna"; in Norway on high mountain ridges, though not on the very highest point, birches manage to 
extract nourishment from the soil. In Peru the traveller may journey leagues and leagues, without meeting a miserable hut; in Norway a wooden red roofed house greets his eye when least expected. Such, or similar thoughts, occupied my mind when toiling up the ravine, I also drew a comparison between the small Norwegian pony which I bestroded and the Peruvian mules, which in former years had carried me hundreds, nay thousands of leagues, all over the Country, and I came to the conclusion, that my little Bucephalus, though unable to stand so much fatigue as his American half Brethren, was by no means their inferior as regards sure footedness. We reached the Summit of the gulley in about an hour and a half, when the Elf, which we had crossed twice over bridges, making another bend, was lost to our sight, whilst we found ourselves at the foot of the ascent up the fjeld. Before proceeding, the bridges which we had passed merit a short description, on each side of the bank of the Elv, at a considerable height above its bed, several beams were placed close to each other. On the one end, they were securely fastened in the ground, at the other end, they protruded far beyond the bank, but were not of sufficient length to meet in the middle. On one side these beams were supported by posts fixed in the bottom of the river, on the other side, they were without support, the extremities of the beams which as already said did not meet, were joined by a few short pieces of wood laid across. Upon these, boards were placed, which were kept down and prevented from being blown-off by heavy stones put on them \{see at the foot of page 626\}, when walking upon this [?] part, the entire structure tremored quite as much as the far famed swinging rope bridges in Peru, the latter have at all events a rope [625] fastened alongside which serves as a banister, but the Norwegian were even without this convenience, nevertheless I do not consider that there was any danger in crossing them, for they were of considerable width. A fall would of course have been fatal, the depth being great and the bottom of the Elv full of stones; nobody passed these bridges on horseback, I also dismounted, and my horse was led over. The ascent which we now had before us was quite as steep, bad, and stony as the worst which I ever had to climb up, either in Bolivia, or in Peru. For sometime I rode, but when the crupper broke I had to alight, and trust to my feet, which in all probability I should also have done, even if this little accident had not occurred. The bridle path was nothing but a continuation of high, irregular steps formed by nature in the rock, where even the most surefooted beast might easily have slipt. At last Warbeck, a peasant who had joined us, and I reached the field. We threw ourselves down on the ground, and rested a considerable time, refreshing ourselves with a dark blue berry called "Krakling", which grows here in abundance. It resembles the bilberry, but is less juicy - Bilberries and Moltberries, these latter peculiar to Norway, thrive better 
on moister ground; here they were scarce. I remounted, and rode along the fjield over a moory soil, not without a little grass and some birches, passed over a ridge of rocks, which runs across the field and came to a few houses, where I engaged a boy for an Ost or twenty four Norwegian Shillings to show me down the fjield on the other side, to the very nearest point, where I might well see the fall; Warberg went with us. The descent which lasted an hour was fatiguing and troublesome, but not dangerous, road or path, of course there was none. For a considerable while, the ground was covered with a thick moist moss, here and there, a birch grew which served as a support to us climbers, further down nothing but loose stones and rocks through and over which I scrambled and crept as well as I could. At last we reached the bottom and were close to the fall, which being the whole volume of the Vørring Elv rushes down the height of about one hundred and fifty feet, in one unbroken gush, only at the top it is divided by a small rock, which is but seldom covered by the water, it is one mass of foam. But as two projecting rocks prevented us from seeing the bottom into which it falls, I was rather disappointed. Then we again climbed-up, and again took a little rest regaling ourselves with eating a plant which grows here wild and which the outer covering being torn off, tastes very much like English lettuce, the male of this vegetable, the [626] Norwegians call "Quan-[?]" the female "Qrian". Next I had to see the fall from above, Warberg took me to a spot where I had to approach so near a precipice that I could with difficulty conquer my nervousness and always kept fast hold of my companion; from here the upper part was concealed, whilst I enjoyed the spectacle of the Seething Cauldron below whence the Spray rose as high, as the level of the field. From the third point, to which my guide conducted me, I had a really splendid view, leaning against a slender birch, I saw the entire cascade before me, from top to bottom one unbroken mass of foam, measuring about one hundred and fifty feet as already said. For sometime I stood here rivetted, unable to tear myself away, until Warberg called my attention to another most beautiful sight, the spray shone upon by the sun formed a rainbow of the most brilliant colors, which reached from below to the summit of the mountain, and through it, like a transparent veil the black rock behind was seen. I rode back to the already mentionned houses in one of which I obtained a plate full of excellent sour milk, which being dispatched, I remounted my horse, and continued my ride, with the Halling fjield always in sight, as far as where the descent commenced. This, I managed to get down as well as I could, it was no easy job, however, though less difficult than the ascent had been. Thence Warberg and I returned the same way which we had come in the morning; when we reached Vigegrund, I was so fatigued, that I went to bed without loss of time. During my absence the Curate had arrived from Ulviig in a prettily painted boat, which his 
Parishonners kept for his exclusive use. I observed several young girls neatly dressed directing their steps to the dwelling of this worthy man, who instructed them in the principles of the Protestant faith, and prepared them for their Confirmation, which was to take place within a few months. The sketch herewith gives an idea of the bridges above spoken-off. (See below)

Sunday, $4^{\text {th }}$ of August 1844. At 6 a.m. a boat was ready, hay was thrown into it upon which I stretched myself and slept for a considerable while; I awoke when we were on the spot where the Eifjord, Bergnoes fjord, Ulvig fjord and Ossa fjord meet and join the Samlem Fjord. The Ossa fjord with the high VadsFjerna in front presented a wild aspect, whilst the Ulviig fjord on approaching Ulviig, is of a milder nature. Here the waters of the fjord were uncommonly quiet and clear, they reflected many objects, I saw the veins in the rocks, the people walking in the shore water with their head downwards, [...] [627] a vessel apparently resting on its inverted Keel, everything given back with the utmost distinctness as if by a mirror. On my landing in Ulviig, the boy whom I had ordered to wait for me was on the spot and we set-off without delay, he like Jenny Deans on her way to London took off his shoes and stockings which he seemed to have for show not for actual use. We passed Ulviig-field under a boiling sun. I perspired awfully and refreshed myself by taking copious draughts from a spring of cold water; in order to get at it, I had to lay down flat on the ground, in doing which I followed my little guide's example; fortunately this imprudence had not bad consequence. In Graven, I soon got a boat, and was rowed over to Vads-Enden. My boatman told me, that in august of the previous year, two landscape painters had lived with him for a forthnight, the one Gade, from Hallug Dalen, the other Lese, a German, who had taken several views of the Country in the neighbourhood. At Vads-Enden as above said, I had left my gig. I now remounted it, and accompanied by my skyds, started at half past one. Hardly were we outside of the place, when it began to thunder and rain; I ran the gig against a big stone and upset it, suffered some dammage, however neither the Skyds who had taken a seat behind, nor I was injured. As soon as I arrived at Vossvangen, I had my gig repaired. It was a beautiful evening, I was up writing my memoranda till half past nine, when it grew dark and I went to bed, I observed here some strange varieties in the language, thus for instance, they said: Wicken for Ugen (the week) Wetterin for veiren the weather, appler for abler (apples); my guide from Ulvig sang a song in which I observed the word Nieman, in German Niemand instead of ingen (nobody), thus mixing-up English and German with true Danish.

Monday, $5^{\text {th }}$ of August 1844. I was up at as early an hour as five Oclock, breakfasted, wrote, and read. At eleven oclock my skyds, this time a little boy, made his appearance. He was of opinion that some thongs were wanting to the 
harness, and when I went to look for them in the shed where they had been kept, Slambush of whom from the beginning I had had a bad opinion, showed his true character. He became sulky and disagreable. Page 622 I said that Mrs. Warberg of Vigegrund had a large broad Comb stuck into the hair near the forehead, whilst I noted that other women stuck it behind, which with the white handkerchief tied over it, gave it the triangular shape mentioned page 612. All the men here abouts, and [628] as far as Vorings-fossen wore two large metal buttons in their shirt collars and below in the shirt a similar large metal brooch. When I left, the sun was out, the weather warm almost too much so, my road lay along the Ving-Elv which comes from the North, and the Country was once more of that description which though uniform, I so much admired, Rocks and trees, grass as smooth as a carpet, green fields and solitary gaards. At the first stage which they call here Skifte, or as the Norwegian pronounce it, Schifte (does it not put you in mind of the English verb to shift?) called Tvinde, a water fall comes down from a great height, not in one gush, but in several breaks which are against the strict rules of cataract beauty. From Tvinde to Vinge, the next stage, the country continues more or less the same, on approaching the latter place the mountains decrease in height, and leave more space for cultivation. I crossed another Elv, Mørke-Dalen-Elv or the river of the dark valley, and on looking up the gully whence the river came, it certainly merited its name, though perhaps at the moment the darkness was mostly caused by the black clouds which hung over it. Vinge, though no village, for it consists merely of several Gaards built at no great distance from each other, has a church. On the other side of Vinge, I had to my right a lake confined by a strongly built stone-quay over which the road leads, I next passed Opheim, further on large blocks of rock lay about, and one, which had not yet tumbled down, protruded so far and so low above the road, that the traveller must take great care not to knock his head against it. Having left the lake behind, I passed on the same side a pretty little hollow, extremely well cultivated, through which a gentle brook wound its way certainly a scarcity as far as I can judge in Norway, for hitherto I had only seen rivers and torrents dashing and tearing along, never gently meandering as this little brook did. On reaching Stalheim, my next stage, it began to rain, and as my Forbuds ticket and I arrived at the same time, of course neither horse nor skyds was ready. The room into which I was shown to write my name in the Dag-Bog was very small. There stood only a table and a chair, and it smelt much of cheese and milk, in fact it was the dairy. The Skydskaffer was a fair young woman, very merry; she called me: "men friska carl" (my gay fellow) and had a baby in her arms, who to judge by her bust was not likely to die of starvation. After a little wrangling, she allowed [629] my Skyds and horse from Vinge to go on to the next stage; it now 
rained in earnest. At a very short distance after leaving Stalheim I came to an extremely steep descent, of which Gade in the instructions which he had given me, had taken a particular notice; I alighted and walked, for to drive down was an utter impossibility, the more so, as a new road was being made, the old one was entirely neglected and some labourers of the new road, by order of the Government had to render their assistance to the skyds of every traveller, to mine of course likewise, in carrying down the gig. I conversed a few words with the Overseer who superintended the new road, which when finished, will be a master piece, it was to have eight turnings, so as to render both ascent and descent perfectly easy. The Engineer who directed the work was Captain Finne of the Norwegian Infantry, they had been at work fourteen weeks; and on an average, two hundred and forty men had been employed daily. The entire distance from Stalheim to Gudsvangen, the road which I had to follow runs through a narrow gully alongside a headlong river, the Nyren Elv, high mountain ridges with scanty vegetation from the boundaries. In the bottom of the Gully, a few firs grow, but even in the midst of such bareness, nature has its beauties, and plays its freaks, at the top of the steep ascent spoken of, two fine water falls, one on each side of the road, precipitate themselves into the Gully, and mix theirs waters with those of the Elv. Further on the mountain chain on the left terminates on a sudden, with a rock of a whitish color, and of conical shape, which on the three sides where it is not joined to the ridge, rises abruptly from the very bottom. My skyds whom I found great difficulty in understanding called it Jordals-Mohe. Opposite the same on the right side, stands a mass of high block rocks, as steep and precipitous as the walls of a house, nowhere in my many travels through the mountainous regions of Peru did I meet with anything like it. Now the Gully continued as before, until we came to a spot, where the road was strewn with a number of large stones fallen down from the mountains, as late as August of the preceding year, when a peasant and his horse, who accidentally passed-by, were killed by the same. On my arrival at Gudsvangen at six oclock, I was rather wet, it had not ceased raining for the last few hours; the inn-keeper gave me a nice sitting-room and good bed room, a convinience which I had not enjoyed since I gave up my lodgings in Rainvilles hotel in Altona. [630] For supper I had a stewed fowl, vegetables, bread, butter, cheese, and three tumblers of beer. The weather cleared up, it was a beautiful evening, looking out of the window I saw over the way four or five houses close behind which high mountains with patches of snow, and small rills of water running down their sides. Between them and the houses, hidden from my view, flows the Nyren Elv which disembogues into the Nyren or Gudvangen Fjord, through a small piece of cultivated land. Immediately behind the house in which I had alighted there were similar mountains, and between the two 
ridges, the distance was not over a quarter of an English mile. I went to bed when it was still daylight, I had risen early, and on the following day I had again to get up betimes.

Tuesday, $6^{\text {th }}$ of August 1844. I awoke during the night, and looking at my watch, could not see what oclock it was; this had not happened to me for some weeks past, and proved how rapidly the days shortened. At four oclock I was up, but my boatmen, five in number, one of whom being a volunteer I did not pay, were not ready till half past five. My gig in the same manner as had been done on previous occasions was taken to pieces, that is to say: the wheels were taken off, it was put into the boat, so was my luggage and some hay in the stern for me to lie down upon. When we started the temperature was somewhat cold, and remained so, till about half past seven, when the sun was high enough on the horizon for its rays to reach these waters, surrounded on all sides by high mountains; till eleven oclock the warmth was agreeable, but from that hour, the heat was oppressive, until clouds drew up and overcast the sun. It was a long passage, I paid for five and a half Norwegian miles, and as not a breath of wind blew, the boatmen did not hoist their sail; they had to row the whole distance. There was nothing of interest to call my attention, for by this time I had seen more than enough of grey and black rocks, rising from the very waters edge, hardly ever with a vestige of cultivation, and presenting only here and there a little grass, with a few trees. To while away the time, I slept, but mostly read; finished, and reperused Jones' account of the Seven years war written very partially in favor of Frederick the great. It will be seen by the map, that I was rowed down Nyren Fjord in a North Easterly direction, then up Urlands fjord to the N.W., again [_] [631] N. East through another fjord without name on my map, called by my boatmen Leersdalen fjord which under the same name turns finally to the South-East. At its extremity lies the village of Leersdalen Oern. At Eleven oclock my boatmen had stopped for a few moments at a place called Frenege (not on the map) consisting of two or three houses; timber lay piled up and a small vessel was at anchor, a long [Seine] was stretched out in the water, for the purpose of catching salmon. I stepped on shore at Leersdalen Oern, a place of some importance for it had a church, and as many as four hundred inhabitants; the inn to which I went was very fair, the inn-keeper shook hands with me, the first time I had received such welcome from an Gjoest-giver. To the shaking of hands on the part of the Skyds' and the servants and to their "mangeta" skal du har (many thanks shall thou have) on receiving their drin[_] m[_] ey, I had already accustomed myself; even the shoemaker in Voss[eva]nge[n] who repaired my gig (a queer thing that a shoemaker should answer the purpose of a wheelwright) did not fail to hold out his paw to me. I had for breakfast wheaten bread, butter, two kinds of cheese, and a jug of milk, 
I then started afresh. Leersdal-Oern lies surrounded by mountains and the only outlet is where the Leerdalen Elv which flows into the ford comes from the South East. Along this river runs an excellent level road, on which I drove along high, barren, uninteresting mountains on both sides; gradually they change their character into formidable rocks and stones whick broken loose, heaven knows when, lie upon their sides. On the road I noted particularly two, each at least twenty feet high between which there was just space enough for the gig to pass. No doubt, this narrow passage had been made by blasting. I passed Lysne gaard with a fine water fall, and stopped for the night at Husum, where Mr. Gade had warned me that I might expect the worst quarters, during my whole journey, nevertheless, the room to which I was shown, was not so very bad, it was boarded all round; there were three bedsteads, one of which I was to occupy, an old table, a cupboard, three wooden and a leathern chair. Barley boiled in milk with a little pounded Sugar Candy, which was quite to my taste, flade brøde made of barley, thin as a wafer, excellent butter and cheese, which are found all over the country were given me for supper. It grew dark at $81 / 2$, and I went to bed. [632]

Wednesday, $7^{\text {th }}$ of August 1844. I was up at four Oclock, had for breakfast the cold barley and milk of last night, and started at five precisely, the road was like yesterday along the Elv and the mountains. Erelong I came upon a new road recently constructed under the direction of Captain Finne, Civil Engineer, Professor Otto, who mentionned it to me when I saw him in Bergen compared it, though of course on a small scale to the famous road across the mount Cenis, finished under the reign of Napoleon I. In seven turnings it gently ascends to the summit of the mountain, and is walled up by rocks and stones, at the end of each turning is a small piece of flat ground for the horses to rest. I arrived at the next stage called Høeg before the appointed time, and had to wait till half past seven, when the Skyds and horse appeared. At a short distance from Høeg the old road follows the course of the Elv, whilst the new road which I took, turns to the right. It is kept in excellent repair, and gradually ascends a gulley [_] Dalen through the middle of which a mountain torrent rushes; on one side the road is lined with huge stones, high poles between them to mark the way in the winter time, though they are twelve feet high, my skyds told me that in the preceding winter they had been covered with snow up to the top. It was the Hemsedal fjeld which I had before me. On the map I find it Called [Halrieeler-Jubs] fjeld, higher and higher I drove, the cold wind blew the rain into my face, to keep myself warm, I got off and walked, but notwithstanding my heavy big cloak in which I was wrapped up, my arms and legs got wet through. On the summit of the fjeld there were no trees, but some good pasture ground for horned cattle and sheep, on the other side, of the fjeld stands a solitary house Bjøberg, 
where men and beasts are in the habit of resting for a short time, I put on another pair of pantaloons, dried myself as well as I could, and made my lunch on hard brown biscuit, butter, cheese, and milk. The Hemsedalen Elv, which takes its origin in a lake upon the fjeld, was now my companion, my guide told me that it flows into the Drammen. Birches were the first trees which showed themselves, next firs, then pines, the country gradually improved; the more we descended the more was the land cultivated, the more frequent became the woods and houses. However, as far as I could judge, gaards in Bergen Stift [633] lie at greater distances from each other, consequently the population is more scanty than in Christiania or in Trondhjem Stift. In Hemsendalen in which I now was, the men no more wore the red bonnets, nor the women the strange head gear, which I have previously noted. The weather continued very unpleasant, the clouds hung so low as to cover the mountain tops, and the rain hardly ceased for a moment until I arrived at the last stage of this day's journey called Naes. The intervening stages had been Tufte, Dabrust, Rae, and Haltørn. A few moments after I had taken possession of my room, another traveller arrived from the opposite direction, Christiania; he was an agreable gentleman, a Dane, by name Mr. Grinsund, who travelled for the firm of S. L. Behrens \& Co. of Hamburg, and spoke German perfectly well. We supped together upon fresh Salmon with potatoes, he took out from his Knapsack some Bologna sausage and a bottle of Port-wine of which I willingly partook. Though my Forbud ticket had not arrived, I was promised a horse for the next morning at five o'clock. When I was in bed, I heard the wind blow violently and rejoiced that I was under shelter.

Thursday, $8^{\text {th }}$ of August 1844. I was the first to rise as I always did, G[_] and I had our coffee without anything to eat, to break our fast, he went on his road to Bergen, I, on my to Christiania. This day, it was the hallingdalen-Elv the course of which I was to follow, it flows parallel and more to the Eastward than the Hemsedalen Elf, and falls likewise into the Drammon River. The Skyds who accompanied me from Naes to Søevre was an extraordinary creature, his small humpbacked body was stuck upon a pair of long shanks out of all proportion, his face wore no other expression but that of utter stupidity, his nose was very big and its extremity of a suspicious red color, his hair light and lank, stuck out under a red woollen bonnet; his dress consisted of a green jacket, and red waistcoat, both adorned with many brass bottons, a blue handkerchief slovenly tied round his neck, a pair of dirty leather breeches open at the knees, instead of stockings, dirty white woollen hose, reaching as far down as the instep, which was left bare, a pair of old leather Shoes completed his attire. I myself was poorly, owing perhaps to my having indulged too freely on the previous evening, in my companion's wine, perhaps also owing to the wine's 
bad quality. I did not feel well until I had cleared out my stomach by vomiting repeatedly. I had also the mishap to loose my umbrella [634] which fell from the gig without I or my skyds observing it. From Naes to Søevre, one and a half, from Søevre to Fostern one three eights, from Fostern to Gaburg one and a half miles, the country was in every respect similar to that which I have so often and detailedly described; a good road, a torrent foaming and fretting in its rocky bed, and mountains high, steep, and naked. When I arrived at Gubviig fully an hour after the time laid down by Gade in his Itinerary (it was eleven instead of ten oclock), the rain which had threatened the whole morning, came down in good earnest, and after the loss of my umbrella I should certainly have been badly off if I had not had my big cloack with me. The road now turns off from the Elv and enters a dense forest, there are continual ascents and descents, and as my horse was by no means so active and strong as it should have been, I reached Sorteberg long after the time fixed in the Forbuds ticket, consequently the Skydskaffer, though I endeavoured to propitiate him by praising his house which was in reality very descent, insisted upon my paying him [...] or waiting money. I resisted, throwing all the blame upon my bad horse for it had taken me not less than three hours and a half to [_] two Norwegian miles - but my representations were of no avail, [...] had to pay the money - which after all was no more than nine [...]. In Gubvig I got a splendid horse, and was thus enabled to gallop on a tremendous rate, for I was anxious to make up for lost time. I crossed the Elv which here of a considerable width, takes the name of Krøven Fjord; on the other, the Eastern side, lies the next stage Green, the Country gradually looses its mountainous character, mountains to be sure are seen still, but they are of less height, the distances between them are greater, and the land, more level, is better cultivated than hitherto. Oppegaard was the next station, a respectable looking house, there is no doubt that the more I travelled Southward, the more neat and comfortable were the houses, both inside and outside. When I left this Stage, it commenced raining. I had an excellent horse, but my skyds a tall strapping fellow in a swallow tail coat was by no means to my liking, he would not allow me to whip the horse and when I did so, he had the satisfaction that my arm got wet and that the horse did not move the quicker for it, whilst when he liked, he could put it to a fine trot by means of a few encouraging words which however he did not vouchsafe to utter more than once or twice. As the rain [635] had poured down in torrents, it is easy to conceive that I was in very bad humour, and thus having reached the next stage Bractum, I gave the skyds a tremendous blowing-up which he comprehended perfectly well for he made a long reply completely lost upon me, for I did not understand a single word of it. The sun had set, the long twilight commenced, I changed my horse at Verne, and soon after falling in with the road which 
I had taken when going to Fossum, I crossed the lakes of which I gave long details (page 574 and following) and arrived at Sund-Volden at half past ten. Here night quarters and supper, which had been ordered before hand were waiting for me. The landlords daughter, a nice looking young girl received me very cordially, whilst the supper was being placed on the table, I washed myself all over with brandy, for I was completely drenched, and feared to catch cold, the supper was very nice, trout with potatoes, a large bowl of milk, and brown bread. I was much fatigued and hastened to bed.

Friday, $9^{\text {th }}$ of August 1844. After an excellent nights rest in a very good bed and room, I rose at 6 oclock and started at seven. I walked up the hill to Kongleven. It soon began to rain and continued so for the greater part of my way to Christiania, though not so intensily and incessantly as it had done on the previous evening. I obtained a fine horse and could thus drive on at full speed, up hill and down hill through the forests and along the muddy road. The next stage was Jonserud, the second Støbeck, and I reached Christiania at $111 / 2$. Twice I had passed over the last part of the road, once on going to and again on coming from Kongsberg (see P. 572 and following and 583.) I will therefore merely say that on approaching the town, I observed many pretty Country houses, also that the buildings in the vicinity of Kongens Gaard, some concluded, others about being finished, were tastefully constructed, my journey had lasted twenty three days, and had in every thing just not merely answered, but surpassed my expectations (under $\mathrm{N}^{\circ} 17$ will be found a note of my expenses from Bergen to Christiania). I took up my quarters at the Scandinavian Hotel, which Grinsund had recommenced to me. At all events the room which I occupied was more decent than that I had had at the "Hotel du Nord". I called upon Mr. Tiedemann, he introduced me to Gustavus Sieveking who was about setting out on a journey through Norway, in the business of his father Edward, established in London, cousin of Henry in Altona. I did not much admire him, he appeared to [636] me purse proud and self sufficient. I sold my gig to the same saddler, from whom I had bought it with a [loss] of twelve Norwegian Dollars, and purchased Jacob Aals "Norske Erindringer" a book recommended to me by Mr. Charles Konau of Bergen, and took out my ticket for the next day's Steamer to Copenhagen. I dined in my room, and though it rained, took a long walk through the town. Opposite to my hotel was the meat market. Aggerhuus, the fortress is surrounded by a wall with several bastions, on which the soldiers were practising, I did not think much of it, they did not actually fire, but went through the Exercise, as if they were loading, firing and cleaning their muskets. At half past seven, I was again at Mr. Tiedemann's, he, Gustavus Sieveking and I drove out together to visit that quarter of the town with which we two [_] were not yet acquainted, it is called "Opslaw", and, now inhabited by the 
lower classes, is that part of Christiania, which was built first. A little outside the town, we come to a hill "Egebiergen", part of which we ascended, but as it became too dark to enjoy any view, we returned, and drove to the Botanical Garden, which is laid out with some taste, we passed a monument erected in honor of a certain Knudsen who had distinguished himself as a deputy to the Storting, and were back at [T]iedemann's at ten, where we took tea, with lobster and cold meat. [T]iedemann pleased me much, he was very agreable, and said to be worth at least $\$ 100,000$ (Norwegian). I was at home at eleven oclock, wrote my memoranda till midnight and went to bed.

Saturday, $10^{\text {th }}$ of August 1844. Last night I fell asleep, as late as half past one. I awoke at half past two, when the day was dawning, and as soon as it was light enough to read, I amused myself with "Aals Erindringer" until it was time to rise. I took a cup of coffee, paid my bill, and went on board the steamer "Christiania", laying close to the Custom-house. At six oclock we steamed off, saying adieu to the prettily situated town of Christiania, to its handsome villas, to old Aggerhuus, to its beautiful bay with its many islands. We were about fifty passengers, amongst whom Old Mrs. Chaufepié by herself, her husband having preceded her to Copenhague, as soon as I recognized her, I accosted her, she was a very pleasant lady, and we kept on good terms during the few days of our passage. At nine, we stopped for a few minutes at Drøback, this place on the left side, when going down the fjord, is situated [637] along the beach and surrounded by mountains, thickly covered with woods interspersed with barren rocks [_] goes over to the other side, which is equally woody. Amongst the passengers I noted the actors who had been my companions when coming from Copenhagen, Mr. and Mrs. Nielsen and the very pretty Miss Petersen. Whilst I was sitting by myself reading, a gentleman came up to me, and addressed me in German with these words: "I heard you speak German, and by your excellent pronunciation I believe you must be a countryman of mine". This was no doubt an arrogant way of introducing oneself; he however turned out to be an agreeable companion, and I had much conversation with him, whilst we were on board together. He lived in Posen, and was an Employé of the Government, he had [_] himself of a leave of absence to make a journey through Norway; he did not speak a single word of Danish, as little as my old acquaintance Fuchs, whom I again saw amongst the $2^{\text {nd }}$ class passengers. I now felt so sleepy that I had necessarily to lie down in my berth which was an upper one, meanwhile we passed Holmstrand. When I returned on deck we were opposite Hørten on the Western side of the fjord, the red roofs of the marine establishment and the tree covered hills slanting gently towards the beach pleased me well. Passengers went, and came, also peasant women offering cherries for sale. At 11 1/2 we were at Moss which place on account of its 
extremely pretty situation, struck me quite as much as on my first arrival. The projecting mole was covered with people, again passengers went, and came; the Steamer "Carl Johann" arrived from Christiansund, we steamed on, stopped at Walløe, where I recognized its salt-works, at two p.m. we went below to dine. We had good fish, bad meat, and indifferent cakes, I sat near Mrs. Chaufepié. After dinner, I made the acquaintance of the actor Mr. Nielsen and of a bookseller of Copenhague a Mr. Høst, both agreeable gentlemen, spoke German as well as I. At half past four we were off a few houses in the Eastern side of the bay, the union flag waving in the midst of them, behind a few masts. A little further down on the opposite side some houses, more in number than on the Eastern side, came in sight, we were at Frederickshavn, and let the anchor go, alongside of us lan[_] Government Steamer "Prinds Carl", which had brought pas [...] the west coast, also a small Steamer the "Hardy" belonging to a private Gentleman, with which latter vessel, we exchanged salutes. The gentleman [638] from Posen, Fuchs and I went on shore in one of the many boats which had come off. We landed $[\ldots]$ part of the town, which lying westward of the fjord, is the most considerable, and climbed up a rock immediately behind, whence we had an extensive view; just before us, I suppose to the East, or South East, lay the small place itself with the arsenal and the Marine establishment, then the sea, with the Steamers, the smallest of which was already far away to the Westward. Islets and rocks forming a small circular harbour, where four small men of war were at anchor, each under a red roof, and once more the sea bounded by rocky islands perhaps the coast of the main land; to the South and West the unbounded Ocean, turning round, small green fields, behind which mountains close the prospect. We remained here a considerable while, having descended I met a Dane, accompanied by whom I passed over a bridge to the fortifications, garnished with big guns. In the same way as in Copenhagen and in Trondhjem, a number of gun boats were kept here under shed. As soon as the Steamer left Frederickshavn, we found ourselves in the open sea, the waves were long and like those of the Atlantic - I enjoyed this view for some time until sea sickness overcame me, and I hastened to my berth where after having freed my stomach of its inopportune load I fell asleep. More than once I awoke during the night; before I had sufficiently [...] myself I felt as if I was lying on the brink of a precipice, which painful dreams were no doubt caused by the great height of my berth above the floor.

Sunday, $17^{\text {th }}$ of August 1844. I rose as late as half past eight and when I stepped on deck I saw that we were already far up the Gottemburg fjord. To our left we had the small fort of Ny-Elfsborg. A steamer with the Swedish union flag passed us, ten minutes later we had houses on both sides, a telegraph, a large white building with a steeple, the object of which I did not learn, a second Telegraph, 
more houses, vessels at anchor, a third telegraph, and the Steamer "Christiania" let go the anchor. The greater part of the passengers went up to Gottemburg in a sailing boat, I was rowed to the mole close by, and walked to the town. In Klippan the streets were thronged, mainly with sea faring people, who cleanly dressed in their holi- [...] their way to Church, which I likewise entered and was pleased with its neat, plain, and decent appearance. I continued my way but instead of entering the town at once as I had done the first time [639] I made a long circuit round the same, through fine avenues, which in some places are separated from the walls by a low moat, this I had to cross over a bridge, and was highly pleased with the regular appearance of the town, the wide streets, large houses, many canals, and strong bridges with iron railings. Church service being over, many well dressed people promenaded in the avenues outside of the town, and I walked here and there, as chance directed me. When I thought it was time, I returned, took a boat at Klippan and was one of the first on board of the Steamer, by and bye others passengers came, also new ones amongst whom Mr. Witt from Bahia, with whom I renewed acquaintance, and Mr. Schäffer of Hamburg, the grand son of my uncle Hugues great friend J. P. Schaffer who died shortly after the second occupation of Hamburg by the French, and as it was said at the time, in consequence of the great loss which he had experienced by the French seizing the Hamburg Bank, in which he had placed the greater part of his fortune. At half past four we got under weigh, the weather was fine, but I, afraid of getting again seasick, turned in an hour later.

Monday, $12^{\text {th }}$ of August 1844. I rose at five oclock, and whilst I was dressing, the Steamer stopped for a few minutes at Elsineur, when I made again my appearance on deck, the Steamer was in motion, and I threw a farewell look on the just mentioned town, and the castle of Kronborg. The weather continued as pleasant as on the preceding day. Now the Sealand shore along the Sound seen by me for the first time under the influence of a bright sun, wore a very different aspect from what it had done in former occasions when every time I passed, the dark heavy clouds had thrown their gloomy shadow upon Sea and Land. As soon as the Steamer "Christiania" had anchored close to the Custom house in Copenhague I took my luggage on board the Sr. Christian VIII which lay alongside and was to leave on the same evening for Kiel. I secured my berth and hastened to the Hotel d'angleterre where I found M[essrs]. Witt and Schäfer breakfasting. I followed their example and then set out to bid good-bye to my Copenhagen acquaintances. At Zahrtmann's I found nobody; Mrs. Zahrtmann with her daughters had not yet returned from her visit to Altona and Mr. Z. was absent accompanying the King on his customary annual bathing excursion to the island of Föhr. Mr. and Mrs. Adolph were quite as kind and friendly as they had been at the time of my first visit, Profesor Otto, [...] 
Mrs. Eschricht received with great politeness, the former, whose wife [640] and niece I had not the pleasure of seeing, when shaking hands with me placed his finger in such a particular manner upon the artery of my wrist, that I felt convinced this was a sign of freemasonry, which I of course could not return. Mrs. Eschricht who apparently lived in a comfortable manner instructed her servant to show me to her husband whom I found in the midst of his museum, surrounded by reptiles preserved in spirits, and skeletons of human beings and animals. There were skeletons of a cocodrile, of a horse, of a Rhenociros, and of a whale, the latter of an extraordinary size, more than fifty feet in length, and ten in height, the two jaws, the upper and the lower one, are enormous masses of bones. In an embryo which had been cut out of the womb of a whale, the professor pointed out to me the extremely narrow throat owing to which great narrowness, whales it is well known can only swallow the very smallest fish. Of human skeletons the professor possessed an entire series from an embryo up to an old man; of skulls his collection was complete, there were skulls of the human beings of the various races on the earth, and the differences between them were remarkable, Mr. Eschricht called the skull of a Spaniard, a noble skull so perfect was it in its construction. My last visits were to the widow of the late Commodore Donner who, as well as her niece, a noble miss Von-Brockdorff were both agreable ladies, and to Mrs. Sager, Etats Rath Hvidt's daughter, who, of all whom I had seen this day, pleased me least. I had still time to take a walk over the ramparts, fetched the remainder of my luggage from Adolphs and went on board, soon after the Steamer left. For a long time Copenhagen remained in sight, among the passengers were Mr. and Mrs. Chaufepié and a apothecary from Christiania. At eight oclock we had tea, anchovies, and cold meat. The Gentlemen ordered their beds to be made; I had a little humpbacked fellow from the Duchy of Oldemburg in a berth above mine. At eleven p.m. we passed the island of Møen and at four in the morning that of Falster.

Tuesday, $13^{\text {th }}$ of August 1844. At about seven oclock I went on deck when we were between the islands of Fehmern and Laaland, both visible at a distance. At about nine that part of Holstein where the Estate of Panker lies, could be distinguished. I went below, ate a hearty lunch, and amused myself with reading some of Oehlenschläger's novels written in Danish which I had bought in Copenhagen. When I returned on deck we were just entering the bay of Kiel and with great pleasure did I greet as old acquain- [641] tances Fredricks Ort, Holtenau, Dusternbrock, the villas, bathing houses, etc., until we came to an anchor close to the pier. A small bridge was thrown over, and a porter carrying my luggage I went to Brandts hotel. Having engaged a seat in tomorrow's coach for Altona, I dined at old Mrs. Lilie with her son, Dr. Baumgarten, and another Gentleman; my dear "Mame" and I then drove to Stift. Old Mr. Willink 
was in the fields, superintending the thrashing of rape seed, he told me that he was by no means satisfied with this year's harvest, for the Rapeseed had only given fifty fold, that is to say three tonne of weight, from one Tonne land measurement. This grain (rape seed) in not thrashed in the barns like wheat, Rye, etc., but in the open air upon a large sail cloth, and is covered over as soon as rain threatens. It is sieved and separated on the spot from the large particles of straw and dirt with which it is mixed-up, at home it is again sieved and perfectly cleaned. For sometime I amused myself with looking on at the thrashing, returned to the dwelling house, and after some conversation with old Mr. and Mrs. Willink and Mr. Feddersen who had joined us (his wife being indisposed did not make her appearance), Mrs. Lilie and I drove back to Kiel. The evening I spent with Professor Pelt and his wife, who (the lady) pleased me vastly. A Professor Christiansen came-in, and inquired about Doctor Simon his brother in law, whom I had known in Lima.

Wednesday, $14^{\text {th }}$ of August 1844. At six Oclock I started from Kiel in the stage coach, the principal one being filled, three passengers and I occupied a second carriage; the three were: the land steward on C. H. Donner's Holstein estates (Retwish and Breden-Ecken) who was a rational conservative man, the little humpbacked fellow from on board the Steamer, and an Altonaer who for more than seven years had resided in Copenhagen, these two latter, were by no means to my liking. The road from Kiel to Altona is rather uninteresting, particularly the middle part, where it runs over a high ridge of land barren and very little cultivated, which separates the Eastern from the western half of Holstein; near Kiel and near Altona, the country is more fertile. Shortly after having left Kiel we crossed the railway and I learned that as far as Neumünster various trials trips had been made from Altona with a great number of passengers, which had given general satisfaction. It had been calculated that by the twentieth or the 21. of august, the Railroad would have been thrown open to the public, but recently a swamp or morass had been discovered close to Kiel, which the Kiel people said was bottom- [642] less and which they thought would be an impediment to the Railway's speedy conclusion. However when I arrived in Altona, the Directors considered it of little importance, and were certain that they could quickly fill it up with sand and stones, and so I believe it actually turned-out. We changed horses and carriage at Bordesholm where we were at eight oclock, at Neumunster at nine, at Barmstedt at eleven, at Quickborn a cheerful looking place at half past one, at Langefelde at three. We passed the well known pond, the "Diebsteich", entered Altona through Johannes Strasse, and stopped at the post office in the "Rath-haus mark", the luggage from Altona was thrown out, for the coach had to go on to Hamburg. I engaged a Droshka which passed-by and drove to Semper's. 


\section{Residence in Altona, from $14^{\text {th }}$ of August, till $3^{\text {rd }}$ of September 1844.}

Wednesday, $14^{\text {th }}$ of August 1844. (Continuation of) Semper, his wife, and his two eldest boys were absent. However, as I had been expected, Miss Emily, the Governess, showed me up-stairs to my former apartment, the large saloon with the beautiful view over the Elbe. Sieveking called. At six oclock I drove to the Saint Petersburg Hotel in the "Jungfernstieg" in Hamburg where I inquired for the Willinks from St. Thomas, they were: Charles, the younger brother of Hermann, partner of Schön of Saint Thomas, a tall, good looking young man, and his wife, a native from Saint Croix, with two little Children and a black nurse; both were pleasant people. Our conversation was carried on in English for at the time, Mrs. Willink hardly knew a word of German. I remained with them more than two hours, and should willingly have stayed longer, but as I saw that they were busy preparing for their journey on the following day to Stift, I thought prudent to leave. I next called upon Johannes Limpricht who was not visible, his wife was out; then I looked in at the Kramer's but did not find them, they being absent from Hamburg on a tour through Germany. I supped in altona with old Mrs. Sieveking.

The few weeks of my present residence in Altona were spent by me quite as pleasantly as I had passed the five or six months in the beginning of the year, my friends and acquaintances did not slacken in their kindness and attentions towards me. Old Mrs. Sieveking, as I have had [643] occasion to observe, treated me as her son; the numerous family of the Reincke's including even Mr. Lübbes, Old Mr. Raincke's brother in law, looked upon me, as if I was one of theirs, the Baur's though I was less intimate with them, were extremely polite and agreable. In Hamburg my cousin Nelly and her husband Dr. Kramer, Johannes Limpricht and the two Schmidts, my very good friends, were exactly the same as they always had been. It is not my intention to give an account of my way of living, of all the visits which I had to pay, of the dinner and evening parties at which I was present, for this would be a mere repetition of what I have so often and minutely described in the previous pages, I shall therefore confine myself to make some extracts, instead of giving an uninterrupted daily narrative.

It always has been, and will probably continue to be the custom of the wealthier classes of the inhabitants of Hamburg and Altona to make excursions to the more southern parts of Germany during the Summer months, some only for pleasure sake, others visit the watering places or spaas which abound in Germany, with the object of recruiting their health. Thus, as already said on my arrival, Semper and wife were still absent; Mrs. Teresa Sieveking returned the next day after my arrival, from Ems, where she had resided a few weeks, without however having derived any benefit from it, for she looked as delicate 
as ever; Mr. and Mrs. Kramer were also travelling about as above mentionned. Mrs. Arnemann and the Lawyer Lübbes had come back from their most distant tour for which they had set out before I left for Norway; Mrs. Gustavus Schmidt was still at Heligoland; Mr. C. H. Donner with the King of Denmark at "föehr". From Mr. Daniel Schutte who was on his commercial journey I received a letter in which he requested me to point out a place where we might see each other before I returned to South America, he also expressed the wish though not in clear terms that hereafter we might do some business together. I will say here in anticipation, that after I was back in Lima he made me one consignment on joint account upon which we lost so considerably that we felt both no inclination to repeat the experiment. The Knauers, who had not stirred, lived altogether at their country seat in Eppendorf. In this manner everybody enjoyed as well as he could the fine summer season. The weather was extremely changeable, on the $16^{\text {th }}$ my original diary says: it was a lovely morning, the thermometer on the balcony in the shade $201 / 2 \mathrm{R} .=78 \mathrm{~F}$., on the $18^{\text {th }}$, the weather was shockingly bad, a Storm blew from the West and the Steamer for Heligoland did not venture out, on the $19^{\text {th }} 8$ p.m., thermometer in my room, doors and windows shut, $14=63$, on the $21^{\text {st }}$ at 9 a.m. thermometer in the open air $121 / 2=60$, on $24^{\text {th }}$ at $81 / 2$ p.m. a violent thunder storm burst forth, two hours later thermr. stood at $16=68$, on the $26^{\text {th }}$ at 7 p.m. $13=61$, on the $28^{\text {th }}$ at 8 a.m. $141 / 2=64$, on the $30^{\text {th }}$ the weather was most beautiful at $61 / 2$ a.m. $141 / 4=64$, at 12 therm. in the shade $19=75$, on the $2^{\text {nd }}$ of September [644] windows shut, sky cloudy 14 1/2 $=64$.

As long as Mr. and Mrs. Semper were absent I dined with Siveking. On the $16^{\text {th }}$ I took a walk with him to see how the Railroad work had progressed during my absence, and was really astonished to see how much had been done in such a short time. The giving way of the hill which looked so threatening when I left, was completely repaired, and put a stop to, by two enormous walls over which a stone bridge was laid, under this bridge the inclined plain extended from the Western extremity of the Pailmaille to the beach of the Elb. For the Locomotives, the Directors Arnemann and Semper had made a contract with two factories in England, in the one they cost $£ 1405$ in the others $1410 £$ Sterling each. For this price the locomotives had to be placed in Altona terminus, some English machinists had to come with them, whose expenses were included in the said sum. Several trial trips were also to be made, and when everything turned out to the complete satisfaction of the Directors, then, and not before then the money was paid. On Saturday the $17^{\text {th }}$ I drove out to Knauers in Eppendorff, and remained there till next day, they having placed a small bed room at my disposal. On Sunday morning early, I took a short walk by myself, there were several pretty country houses, but the country level and upon the whole sandy. 
A bridge leads over the Alster, where it is narrow before it widens into the large basin called the outer-Alster, to the village of Winterhude of little importance, and with equally sandy environs. After we had breakfasted, taken a promenade through the garden, and visited the hot houses, Mr. and Mrs. Knauer proposed we should be rowed over to the other side of the Alster, the party consisted of the father and mother, Maria, George, William, Julia, (Emilia was indisposed), Johannes Reincke and myself, the young men rowed. For a few minutes we stopped at David Knauers Country-house in Harvstehude and then rowed over to the other side [645] into a small creek at the extremity of which stood a few houses called Isabella, Uhlenhorst another small village we had left to our right. When it was time to return, the wind which blew from the west, right into the creek, had increased to such a degree, that the two young men Johannes and William found it impossible to stem its violence and to make any head way. Thus not only George and the father, but even Maria had to lend them assistance whilst I was completely useless, for I had never managed an oar in all my life time. Great exertions were required, and a long while elapsed before we got out of the creek, into the open Alster. I did not remain with the Knauers but dined at Old Mrs. Sieveking's. Doctor Tschudi, whom I had known in Lima as a very unskilful medical man, but who I believe was a clever zoologist, called upon me on the $25^{\text {th }}$, and I returned his visit on the $28^{\text {th }}$. He told me that he was occupied with a work called "La Fauna Peruana", in which he gave an account of the animals of Peru in general, and a more particular one accompanied by Lithographs of those animals which hitherto unknown, had first been seen by him and of each description of which, he had shot a specimen and carried it with him to Europe. He made me a present of the introduction to this work which he called "Physiognomick of Peru", and which I have found to be very interesting and correct. He said that he was a very great friend of Prince Canino, Lucian Bonaparte's son, a great naturalist, showed me some manuscripts which Alexander Von-Humboldt had made him a present of, as well as a Gold medal awarded him by the King of Prussia. On the $25^{\text {th }}$ I was present at the celebration of Edward Reincke's birthday who completed his fourty fourth year. Nearly all the family was invited by the Knauers to their Country seat in Eppendorff; Dr. Kriechauf, Dr. Callisen, Charles Willink from San Thomas, two clercks from Knauers, and myself, were the only ones not related to them. Dinner was excellent as always, particularly the turtle-soup, with Punch, the vegetables and the wines. It rained continually which prevented our going to the garden, however with playing at billiards of which I know nothing, with conversing of which I gradually became an adept, and with playing a few rubbers at whist, to please old Mr. Reincke, the evening passed away pleasantly, till it was time to drive home. On Wednesday $28^{\text {th }} \mathrm{I}$ 
dined at Johannes Limpricht's with his nearest relations, all particularly agreeable people, his wife Carolina D'albert; his brother in law, the Senator Henry Gossler, his wife, the other sister Emma; Dr. Löhrs and his wife, the third sister [646] Helena, and old Mrs. d'Albert the mother of the three married sisters. Dinner was very nice, conversation agreeable, everything as it should be, at 8 p.m. when I thought of leaving, Johannes took me to his private room, and gave me a detailed account of the difference which had arisen between him and his old friend Warnholtz, with whom he was now on bad terms. The case was the following: Seven years back, Warnholtz had introduced his brother in law Knauer to Johannes Limpricht, in consequence of which introduction Knauer had done with the firm of Limprichts brothers of Rio-Janeiro considerable business, and Johannes had agreed to allow Warnholtz one fifth of the comission which they might earn on Knauer's business, amounting in the seven years to $1500 \mathrm{BM}$. Of late Knauer had insisted upon a reduction being made to him in the rate of commission hitherto charged. Bernhard, the brother of Johannes, and his partner in Rio, had resisted this reduction on the plea of the large allowance made to Warnholtz, which being again communicated to Knauer, he had persisted in his demand, and declared that he should break off the connection, if the Limprichts did not give way. Now of course Johannes had told Warnholtz, that he could no longer make him the previous allowance in which I think Johannes was quite right, but warnholtz was of a different opinion. Johannes added that in the previous year his and his brother's clear commissions had amounted to about 80,00o CM. It was half past nine before I could be at Mr. George Baur's, where a nice little party was assembled, some played at whist, others, I amongst them conversed, and after a light genteel supper, the party broke up at eleven oclock. On Friday the $30^{\text {th }}$ I dined with the Kramers, after dinner my dear cousin requested me to accompany her to the Calvinists burial ground, where some of her nearest relations were interred. I was unable to make out whether real feeling or affectation of feeling was the motive of the frequent visits which Nelly was fond of paying to this sombre spot, as soon as we were out of the Damm-Thor we turned to the left, and followed a path which through green fields brought us to the said Cemetery. Here my uncle Hugues, his wife, his son Anton, his grand daughter Cornelia Kramer, and his faithful clerk Wersang, had found their last resting place. Thence we continued our walk outside of the town where new houses were springing up in every direction, as far as the Millern gate where we separated, my cousin returned to her home, I hastened to mine. In the evening at Theodore Reincke's, the Railway was the engrossing theme [647] of conversation, the impediment of the morass was overcome, the road concluded, satisfactory trips had been made from Kiel to Altona, the distance 14 1/2 German miles, in 
two hours and a half, and the road was shortly to be thrown open to the public. On Saturday the $30^{\text {th }}$ I accompanied my Cousin Nelly to the theatre to see a performance of the French actors from Berlin; they gave a drama written by Alexander Dumas "Mademoiselle de Belle Isle" and a vaudeville "Le Muet de Saint Malo", we took our seats in the stalls on the second row from the stage; when at the rising of the curtain, Melle. de Belle-Isle (Melle. Duchesne) with her chambermaid (Mademoiselle Deschamps) appeared on the stage in the background. I confess that I did not understand a single word or to speak more correctly, I was unable to catch a single sound, however when they came nearer, and I listened attentively, I understood them perfectly, as well as the other actors, till the end of the play. The performance was far above mediocrity; in one or two scenes between Madeelle. de Belle Isle and her Lover (Monsieur Armand) my Cousin and another lady on the same bench drew their handkerchiefs to wipe their tears. The scene was laid in Chantilly on the $25^{\text {th }}$ of June 1726; all, ladies and gentlemen were dressed in the costumes of those times, all had powder on their hair, the former wore hoops, the latter silk-coats, long waistcoats, knee-breeches, etc. At the conclusion, Mr. Pecherne (who acted the part of the "Duke of Richelieu"), Mademoiselle Duchesne (Madelle. de Belle-isle) and her lover (Mr. Armand) were called under thundering applause. The vaudeville was a stupid farce. On the $r^{\text {st }}$ of September I being invited by Mr. Fritz Baur's to dine with him in blankenese, I thought I might as well walk thither, instead of taking a droshka; however before reaching Flottbeck a sudden shower of rain obliged me to take refuge in the public house of Richard's on the road side. When the rain had ceased, I continued my walk and entered Arnemann's Country house in Nienstadten, where the lady of the house with her sparkling black eyes and her rather unusual off-handedness was very polite and agreeable. Bye and bye some Gentlemen whom they had invited to dinner came in such as the [Heflies] from Christiania, Benecke from Gotizberg, the principal owners of the Modum works (see Page 579), "EtatsRath" Francke from Copenhague and a few others. I then left, and Sieveking with Stuhlmann who passed by took me-up in their droshka. It is almost superflous to say that in the house of Mr. Fritz Baur, everything bore the impress of wealth and good taste, the floors were rubbed with wax which I have seen here [648] in the North in very few houses. The party was small, of those who did not belong to the family I will only mention: an Englishman Mr. Lindley who, as civil Engineer superintended the construction of the Sewers about being made in Hamburg. At dinner one of Baur's daughters, Victorina, married to von Reder of Kiel, was my neighbour, she was rather plain but agreeable and I talked a good deal with her. Coffee was served in one of the Summer houses where we formed ourselves in two parties, those of a more 
advanced age round Mr. Fritz Baur, the younger men amongst whom Sieveking and I round the son, Mr. Gge. Baur. When we were tired of sitting, we walked about in the beautiful park till it grew dark. Within doors we joined the ladies, had tea, and I drove back to Altona with Sieveking and Stuhlmann, having spent a very pleasant day. On Monday $2^{\text {nd }}$ of September once more a dinner party, this day at Mrs. Dankerts, the mother of Mrs. Fischer and Geffcken, the ladies were all Hamburghers, and as far as I could judge belonged more or less to the family of Merck, at least a lady to my right was his ward, the young lady to my left, his daughter. Of the Gentlemen I knew Mr. Schütt, Mr. Stuhlmann both tremendous prosers, Etats-Rath Francke, very agreable, Fisher, Clergyman Geffcken, etc. Though we were a long time at dinner, time passed away quickly. Also at tea I found pleasant people to talk with. Finally the two brothers in law Fischer and Geffcken persuaded me to accompany them on the following day to "Alexis-Bad" where they intended to fetch their wives. Thus after leaving Mrs. Dankerts I had to run to Sievekings to arrange with him, about the money which I required on my journey. In the course of these three weeks I made an attempt to be named Consul in Lima for the united Kingdom of Sweden and Norway. For this purpose I addressed myself to the Swedish Consul and to the Swedish Charge d'affaires resident in Hamburg to whom Sieveking introduced me. One of them, if I remember well, the Consul, swindled me out of some money and the representation which I drew out for the Swedish Government, was I believe never forwarded, consequently the whole affair fell to the ground. Kedemburg tried hard to induce me to consign to his Valparaiso house a cargo of crushed sugar from Hamburg or Amsterdam, which he was certain would leave an excellent profit. I however was wise enough to keep aloof from a connection with this house which some years later suspended its payments. The most important political event about this time was the war between [649] France and Morocco: on the $6^{\text {th }}$ of August the french fleet under the Prince of Joinville commenced the bombardment of [_], and succeeded in silencing the enemy's batteries within two hours time. On the $10^{\text {th }}$ of August died the Princess Alexandra, daughter of Nicolas I Emperor of Russia, who was married to Prince Fredrick Wihelm Duke of Hesse-Cassel, and presumptive heir to the crown of Denmark (see page 537); just before her death she had given birth to a boy, christened William, who also died. These two ends put an end to the apprehensions entertained by some people, that denmark in course of time if this Prince of Hesse Cassel was to succeed to the throne, would become more or less a vassal of the Russian Empire. On the $26^{\text {th }}$ of July, Mehemet-Ali, the famous pasha of Egypt abdicated in favor of his eldest son Ibrahim Pasha, and left Cairo for Mecca, where he intended to spend the remainder of his days as Hadje (or Pilgrim). Mügge in his work previously referred to states that the 
revenue of Denmark in 1842 amounted to $15,949,361$ R.B.D., the expenses to $16,193,620$ leaving a deficit of 247,258 . The budget for 1843 showed a revenue of 15,847,800, Expenses 15,617,292 (one seventh of which were caused by the Kings Civil list), surplus 208,508. My reading was multifarious as it has always been the case whilst my sight was unimpaired, amongst others books which fell into my hands, I perused a novel written by Adolph Görling called the "Victualian Brü[der]" or the Victualling brothers, which though not particularly interesting gives a clear idea of the origin of these famous pirates. The following is a succ[_]ct account: in the year 1362 Magnus King of Sweden came to a solemn engagement with the powerful Dukes of Holstein, Klaus and Heinrich to marry his son, Hakkon King of Norway to their sister Elisabeth, and in case he should breakhis word, he confinedhimself in the loss of this Kingdom. Notwithstanding this agreement Hakkon espoused Margaret daughter of Waldemar King of Denmark. The Holstein Dukes transferred their claim to the Kingdom of Norway founded upon the non-fulfilment of King Magnus's solemn engagement to their brother in law Albert Duke of Mecklembourg, whose wife was King Magnus's sister. This Duke Albert had three sons, one of whom, again named Albert, the Swedish Council of State (who had guaranteed the fulfilment of King Magnus's promise), raised to the Swedish throne (having previously depos [...] Magnus). In a few years the new King by an unpolitic preference shown to his Countrymen and by many harsh measures, made himself [650] so unpopular that the nation rose to throw off his yoke and called to their assistance [_] Danish queen Margaret. War ensued, Albert was defeated in 1388 and [_] with his son Eric made prisonners were carried to the fortress of Lintholm where they were kept seven years. The whole country acknowledged Margaret as their Sovereign, Stockholm excepted, which held out for their captive King. The Danes invested the Capital from all sides and put it to great straits, the Dukes of Holstein and the Duke of Mecklemburg (John), King Alberts nephews took his part. They gave letters of marque to all such as would carry provisions (Victuals) to Stockholm against all vessels under Danish, Swedish, and Norwegian colors, and allowed them to carry their prizes for sale to the Mecklemburg ports of Wismar and Rostock. Numberless adventures availed themselves of this offer, and erelong the German Sea and the Baltic swarmed with armed vessels, instead of contending themselves with cruising against the vessels of the three named Kingdoms, they soon turned pirates, and without distinguishing friend or foe, did immense damage to the trade in the Northern seas. They called themselves "Victualian-Brüder" because their original object was to carry Victuals to Stockholm, also, "Likedeelers" or holders of equal share and "Lidekeelers" (cut-throats). Micael Godeke and Sigismond 
Von Clossen surnamed Stortebecker which may be given by "Gulp the Goblet" were two of theirs most renowned leaders. At last their depredations became intolerable, all the Northern maritime powers united, the pirates were overcome, and the last of them Godeke and Stortebecker were beheaded on the Brook near Hamburg.

Journey from Altona to Alexis-bad, L[_]psic, and Berlin; and back to Altona, from the $3^{\text {rd }}$ of September to the $16^{\text {th }}$ of the same month 1844 .

Tuesday, $3^{\text {rd }}$ of September 1844. By five Oclock I was up and dressed, and long before Mr. and Mrs. Semper made their appearance at our early breakfast at eight Oclock, I had finished all the little arrangements which I required for this day's journey, so suddenly resolved upon. After breakfast I hastened to Hamburg, called upon Mr. Kedimburg and my cousin Nelly. To the latter I merely said good bye. The former had wished to speak to me about my projected Sugar consignement to his Valparaiso firm, which [651] as said before at last came to nothing, I then made the best of my way back to altona, received in Sieveking's Counting house the money which I required, Prussian dollars and Prussian paper money, also a letter of credit on Schickler brothers of Berlin. At eleven oclock, the appointed hour, I was in Fischer's house. Hence we two, the clergyman Geffcken, our fellow traveller, and Sieveking, drove to the suburb of Saint Pauli where the Steamer "Primus" was ready to take in passengers for Haarburg. Sieveking left us, we three stepped on board, and off we steamed. Of the passage across the Elbe to Haarburg as well as of this place itself, I gave a description on the $12^{\text {th }}$ of May (see pages $45^{2}$ and 453 to which I refer). In Haarburg our luggage was searched, we breakfasted, I had to pay for my seat in the diligence or stage-coach, Geffcken and Fischer had previously secured the best seats, Number one and two but also my number ten was not a bad one. I sat in the Coupé of the second carriage, between a gentleman from Gottingen in the prime of his life and his very pretty and very young wife. He was the first who broke the silence with a trivial observation and thus having once commenced, we talked a good deal during the time that we were together. The lady however, though I addressed her frequently was very reserved, and little inclined to enter into conversation. We started at two o'clock, drove along a turnpike road well kept and lined with trees, the country was very uninteresting, it was the well know Luneburg heath, very level and little cultivated, which extends for many miles (I now speak of German miles) to the south of the Elbe, here and there a little corn grew, but its scantiness, its little height, and the smallness of its ears, gave clear evidence of the poorness 
of the soil; in some places, turf cut into pieces of the shape and size of large bricks, stood piled-up close to the hole, out of which it had been dug, and which had filled-up with water. We changed horses at Neundorff where we arrived at a quarter past three, again at Welle where we were at five, and had a few minutes leisure to swallow a glass of Seltzer water to refresh ourselves, for the heat had been oppressive, now the temperature became cooler, in the small place called Soltau, we were allowed thirty five minutes to take our supper. All the travellers, sixteen or eighteen in number, amongst whom various ladies, sat down together. When we remounted it was dark, my Gottingen Friends and I now occupied the body of the coach, and as the lady preferred sitting near her husband, I took the corner seat and slept soundly awaking now and then until we reached Celle at two in the morning. [652]

Wednesday, $4^{\text {th }}$ of September 1844 . Sleeping in a stage coach does not refresh, at least so it was the case with me on this occasion, it was a fine moonlight night, everyone awoke; I exchanged a few words with my Gottingen lady, but erelong we were again in the arms of Morpheus. We stopped a few moments at Bergen, and arrived at Schillershage at half past four, this is the last stage before Hanover, it was broad daylight. Had we continued in the diligence to this Capital, we should have arrived past five oclock, that is to say, a few minutes after the time fixed for the trains departure for Brunswick. Bearing this in mind, Geffcken, Fischer, and I left the diligence at Schillershage, engaged a post chaise (which is called in German "to take extra post") and ordering the postillion to tear along at full speed which he did, for we drove the one and a half German mile to Leerte in one hour. We were just in time at this latter place, two miles and a quarter from Hanover, and hardly had our tickets been paid for, when the snorting of the iron monster was heard, it stopped one or two minutes, we took our second class seats, and on, we steamed, at half past five. The Railway stations between Leerte and Brunswick were Hamlerwald, three and half miles, Peine four and three quarters, and Fehrte, four miles. We arrived at the Brunswick station at seven oclock, the fog which hitherto had concealed every object around, changed into a heavy rain, thus we had nothing better to do, but to take our breakfast which was very indifferent, and to look on, whilst our luggage was searched and marked Halberstadt. At a quarter to Eight we were again on the move, at a short distance out of town, we had to our left a Ducal country-seat prettily situated, and surrounded by a wood. I need hardly say that Brunswick lies on the Oker, and that the plain through which we steamed, is watered by this river. In about twenty minutes we reached the Wolfenbuttel terminus, the town itself with its many steeples lay to our left, a little further on, to the right, a turn-pike road, of course little used, leads to 
Gosslar, a town which if I am not much mistaken dates from the time of Henry I, Emperor of Germany, surnamed the Fowler, also the founder of cities, because it was he, who commanded his people who hitherto had been living in the open country, where they had been exposed to the ravages of the Hungarians, and other Barbarians, to take shelter in towns surrounded by walls. In the middle ages the town of Gosslar acted a conspicuous part in history, and it is famous (in modern times) as [653] being the birth place of the Marchal de Saxe, son of Augustus II King of Poland, Elector of Saxony and of the beautiful Countess Aurora von Köningsmark. Between the Chausseé and the railroad on which we were, runs another line to Hartzburg, thus: In the same direction, that is to say to the South, the horizon was confined by the Unterberg, or lower mountains, on which thick clouds rested; in clear weather, the Brocken, the highest mountain in the North of Germany 3600 feet above the level of the sea, not a pointed peak, but of a cupola shape, is visible from here. At half past eight we arrived at the station of Shöppenstedt, a town which has an unenviable reputation in Germany, for every action distinguished by an extraordinary stupidity is called in common parlance a "Shoppenstedt trick", next at Gerrsheim at half past nine, at Wagersleben at a quarter to ten, at Oschersleben at half past ten, where the buildings belonging to the Railway had a stately appearance, the trunk road goes-on to Magdeburg, thence to Berlin, whilst we, changing our carriages took that which turns off to Halberstadt. At a quarter past five we were at the town of Wienhaguen and a few minutes later, at that of Halberstadt, where we got out, and in a carriage belonging to the Hotel de Prusse, drove to the town which is at some distance. We alighted in the said hotel, and having washed, shaved, and dressed, had an excellent over abundant dinner. Before we started afresh, we paid a visit to the Cathedral, a beautiful specimen of Gothic architecture, rather in a bad state of preservation. I admired above all the height and gracefulness of the thin stone pillars, which sustain the roof. In a shop where Fischer and I bought some gloves, the shop woman, a Jewess recommended her articles to our particular attention and begged us to favor her with a call on our return from our Hartz's trip, a pretty idea indeed to expect us to buy French fancy goods in such an out of the way place as Halberstadt. Here we took extrapost, and through a level country drove on to Quedlinburg on the Bode, which town with its twelve steeples seven gates, and 13,800 inhabitants (these particulars I take from Gortshalk's description of the Hartz) is first seen from a hill, at a short distance from it. This town has a most antiquated appearance, the streets are narrow and crooked, the houses are high and gable ended, the upper Story protrudes above the lower ones. It likewise owes its origin to 
the Emperor Henry I, and in the time of the Hanseatic league, when it was one of its members, it was powerful enough to withstand Emperors and princes (see Goltschalk's). On a rock close [654] by lies the Castle, a prominent feature in the landscape. From Quedlinburg to Gernrode extends a well cultivated plain, fruit, mostly Cherry trees line the Chaussée, the Corn was partly cut, to the left we saw two isolated rocks called the twins, passed an old look out tower, and then had before us the small place of Gernrode prettily situated in the midst of the trees. It has two thousand inhabitants and belonged in 1844 to the Duke of Anhalt-Bernberg. Since we left Altona we had passed through six different dominions, namely: Denmark, Hamburg, Hanover, Brunswick, Prussia and Anhalt-Bernburg. On the other side of Gernrode the road ascends, we alighted and walked up the hill, on the top of which stood an inn, the prospect from this point is very extensive. As far as the eye reaches I saw nothing but the well cultivated plain dotted over with villages, but without any rock, mountain, or river to give some variety to its uniform character. It is true the quedlinburg castle is seen, but it is insignificant, and is lost in the wide spreading level land around. We continued our ascent and on the summit remounted the carriage, now we drove down hill over a most lovely road, woods on both sides. Before us we saw a few houses called the "MädchensSprung", or the maidens-leap where the Duke has an iron foundry on his own account, before reaching the same we passed an iron obelisk fifty eight feet high, the first evercast in Germany; it was erected in 1812 by the Duke Alexius to the memory of his father (Alexius died in 1834). Close to this monument is a mountain the "madschin-trappe" or "maiden's-foot steps": the legend says that a Giantess jumped from this spot to the Ram-mountain one mile-off, and left the impression of her feet in the ground, whence the name. I wished to climb-up, but my companions were so anxious to see their wives, that they would not listen to any delay, particularly Geffcken, the pastor, as we call the Clergymen in Germany, looked out every where for his better half, who he thought must necessarily come to meet him. From the maidens-leap where the Selke, a small river coming from alexis-bad takes a sudden turn to the East, the road to the bathing place itself is extremely pretty. On both sides it is confined by mountains perhaps not over three hundred feet high covered with trees; to the very top, winding foot paths lead, rustic seats are placed around the trees, a barren rock intervenes here and there, a chapel comes in sight, further on, a mill close to which my companions had been certain to find their wives. Again they were disappointed. This scenery cannot be compared in grandeur and wildness with the mountains, rocks, forests, torrents and cata[_] [655] of Norway, but in its kind it was charming indeed. A little further on the valley widens so as to leave room for several large houses which constitute Alexisbad. 
Some ladies and Gentlemen were standing here in a group, two of whom, Mrs. Fischer and Geffcken, as soon as they distinguished the carriage came running, and it was really a pleasure to see how they embraced and kissed their husbands, how fond they seemed to be of each other. I remained in the carriage till the first effusions were over, then alighted, and was introduced to several persons, amongst whom to the Physician of the establishment, a Dr. Zeigler, and to a widow Mrs. Steinert, with her two daughters, Maria and Ana. I was arranging my traps in my bedroom when I was called to take a walk, which summons I willingly obeyed. We were the two couples, little Theresa Geffcken, Mrs. Steinhert, very conversative and talkative, almost too much so, with whom I soon found myself on excellent terms, and her two insignificant daughters. The ladies showed the way, and led us on to many pretty spots on this mountains and through these woods, the views, everywhere confined, nowhere grand or extensive, were always pretty. It was a lovely evening, and we remained in the open air until the heavy dew drove the ladies in. We supped together, Dr. Ziegler joined us, and I learned from him, that Miss Ernestine von Selenhorst who was educated with my sisters at Mrs. Wolstein's, and had been a particular friend of my sister Maria, had lately in her fiftieth year married her first love Mr. Knoch, a military man, with whom she now lived happyly and contentedly in Detmold. On one of the Spots which we visited in our this evenings walk stood a cast iron cross, ten feet high, erected in the autumn of 1819 by Prince Frederick of Prussia and his spouse, a princess of Anhalt Bernburg, to the memory of Prince Alexius, who first opened these baths on the $1^{\text {st }}$ of June 1811 and who ordered the construction of the necessary buildings, such as: two houses for lodging the Guests, the hotel, the bathing house, the Dining room, the ball room, the Gambling saloon, and the Ducal Palace. The season during which this watering place is much frequented, commences on the first of June and closes on the $31^{\text {st }}$ of August, thus now in September, few people were left. We also had a look at the Alexius fountain, where the mineral water containing many iron particles, rises to a considerable height, then having fallen into a basin the greater part is conducted under ground to the Bathing house, where it is heated and principally used for bathing when it is sometimes mixed with the waters of a neighbouring salt water Spring; for Drinking it is seldom [656] used. The Duke who reigned over the Duchy of Anhalt Bernburg in 1844 was of a very weak intellect, almost an idiot, his Duchess was a sister of the Duke of Glüksburg who resided in Kiel.

Thursday, $5^{\text {th }}$ of September. When I rose at half past five it was a very foggy morning, nevertheless in hopes that the weather might clear-up our party including Mrs. Steinert and daughters, started at half past eight in two carriages, on a drive through the environs. When we had reached the maidens leap, 
instead of following the road which we had come yesterday from Gernrod we turned off Eastward along the rivulet called the Selke, which is so shallow that several times we crossed it in our carriages, it is bordered on both sides, by green meadows and corn fields, now yellow, ready for the sickle. These are hemmed in by ridges of tree-covered low mountains, the whole very similar to that which we had seen yesterday, with the only difference that the Selke Thursday $5^{\text {th }}$ of September 1844. valley is somewhat wider. Mrs. Steinert talkative as she was, had some favorite ephitets, sweet, nice, enchanting, charming, Divine, or rather their equivalents in German, which she lavished on every object we saw, I actually got sick of her incessant raptures which I will do her the justice to believe were veritable, not affected; however also we others the sober minded, were obliged to confess that more than once this Selke valley deserved the encomiums which our more enthusiastic companion passed so continually on its natural beauties. The fog partly cleared away and rested on the top of the mountains, through the same the ruins of the Castle of Falkenstein were dimly visible. We left our carriages below and ascending a convenient path through a wood consisting of all descriptions of trees, Birches, oaks, beeches, ash-trees, etc., we came to this ruin which as Gortschalk says is not more than two hundred feet above the level of the valley. We entered the Castle under a narrow open gateway over which, cut in the stone, "Falcons", the arms of the original proprietor were visible. Whilst the remainder of our party took possession of a small balcony where they rested, I by myself examined the entire ruin. Three rows of walls, one behind the other, leaving a space between each two, occupied the whole circumference of the rock or mountain. The ground work of these walls was still in good repair for it consisted of solid rock and stone, held together by cement. The upper part had fallen into decay, but some loop-holes could yet be traced in the same, only the centre part forming an irregular square with a deep well in the middle, was in [657] a good state of preservation. The intervening space between the walls was partly overgrown with grass and weeds, partly made use of as a kitchen garden, outside the walls, on the side of the mountain or hill if you like to call it, potatoes had been planted, and some villagers were now busy gathering them. I see from Gortschalk that this castle dates as far back as the $12^{\text {th }}$ Century. The last of the Falkenstein died in the year 1332, he bequeathed it to the Chapter of Halberstadt, which corporation sold it in 1396 to the Von-Asseborg, now Von-Asseburg, one of whose descendants still owned it in 1844. Upon a wall of the inmost yard, I observed in large Gothic letters the inscription of Bernard Von Asseborg 1491. Part of this yard was occupied by a thick-walled round tower, no doubt the original keep or donjon, from the top of the same to which I climbed, I saw 
eastward an extensive well cultivated plain with two small villages, the names of which I did not learn, towards the three other quarters of the horizon, the views was confined by the surrounding wooded hills. The Present owner, a Von-Asseburg, was represented to us, as a second Henry VIII. His two first wives, he had killed by ill treatment, from the third he had been divorced, but the fourth, a Berlin Court lady, another "Catherine Parr" had known how to tame him. Notwithstanding this bad repute in which he was held, the King of Prussia, the King of Hanovre and other great personnages had not disdained to pay him a visit in this castle, and their signatures on the wall of a saloon to which we were shown were still preserved under a glass frame. Having dined in the Ritter-Saal or Knight's saloon, a large low whitewashed room, on the walls of which hung some old, hardly recognizable portraits, a servant girl showed us all over the place some parts of which the owner had made inhabitable and decently furnished. A passage was adorned with the horns of the stags killed in the neighbourhood, below each of which were written the names of the fortunate Huntsman, the name of the spot, and the date when and where the stag had been killed. In one saloon the horns of an Elk were fastened against the wall, and in another the portrait of a man in armour. Having leisurely reviewed the whole castle, we returned to our carriages, and whilst these were getting ready I found leisure to look into a paper mill close by. We drove on, and soon the hilly woody country was left behind, we found ourselves on the plain, passed the Estate of Meisdorf which belonged to the same Count Von Asseburg who also was the owner of Falkeinstein, and reached Ballenstadt which place alternately with Bernburg is the residence of the Duke reigning. I may say "en [658] passant" that whilst the chaussées in Anhalt Bernburg and in Prussia were excellent, the roads in the Domains of the Count Von Asseburg, which lie in Prussia were shockingly bad. Ballenstedt is divided into two parts, the aristocratic and the plebeian part, each with its church, the former consists of a long avenue, houses on each side, which leads-up to the Castle. We left our carriage at an inn, then took a walk through the Ducal Palaces Garden, which full of flowers, has nothing of particular interest, as little as the exterior of the Castle, a large irregular building. From the terrace we had again before us the wide plain, with Quedlinburg in the middle just as we had seen it, on the previous day from the hill, on the other side of Gernrode. We now paid a visit to Doctor Ziegler, who with his wife and sister in law, lived in a large, neatly furnished house. He showed us to the garden full of flowers, close behind which a number of labourers, men and women, were singing harmoniously whilst gathering poppy seeds, out of which oil was made, and this oil to my great surprise I learned was to be used for salads and other purposes; I thought 
that its narcotic property would have been injurious to the health of human beings. Another thing new to me, at the time, was the sugar made of beet root, which in small cubes, two hundred to the pound, was placed on the Doctors tea-table. It is well known that the making of beet-root sugar which now in 1869 gives employment to large Capitals, and to thousands of people, owes its origin to the protracted war between England and France in the beginning of the present Century. About the year 1806 or somewhat later, when owing to the famous Berlin and Milan Decrees, which prohibited every vessel sailing under English Colors or having touched at an English Port from entering any port on the continent in the dominions of the Allies and friends of Napoleon and when owing to the equally famous British orders in Council which in retaliation declared all the ports on the continent under blockade, the legitimate maritime trade was destroyed totally. Importations of English manufactured goods and Colonial produce into France and Germany, the two countries upon which Napoleon's rule pressed more directly than upon theirs neighbours may be said to have ceased; it is true a few articles still found their way into the one or the other French and German market, either by contraband or for instance through the ports of Gottenburg and Tönningen, or by a round about route such as through Constantinople up the Danube into the [659] Austrian dominions, or finally in virtue of special licenses which at high prices and under certain conditions Napoleon conceded to some favored French merchants; but these imports were so trifling, and bore such an infinitely small proportion to the demand and to the consumption, that erelong an excessive scarcity was felt, and prices rose to an exorbitant height. Then it was that chicory was first made use off instead of Coffee, sloe leaves instead of tea, and that to supply the most necessary of these articles, sugar, somebody, I do not know whether French or German, had the fortunate idea to make sugar out of beet root. The first experiments turned out so well, that erelong beet root sugar houses were established all over France and Germany, and this substitute, for at the beginning it was nothing better, has stood its ground so well that at present (1869) it does successfully compete with the true cane-sugar, though it cannot be denied that the beet root sugar does not sweeten quite as well as that made of sugar cane. After having spent with the family Ziegler one hour or so in the most agreeable manner, we bade them good bye, the ladies with tears in their eyes, walked back to the inn, and drove home to Alexis-Bad through a very pretty Country, first through the park surrounding the Castle, then through another pleasure ground belonging to it, which goes by the name of the Thiergarten, finally over a Chaussée which brought us to the maidens-leap, then to Alexis-Bad. I took my supper with the Gentlemen, and hastened to bed. 


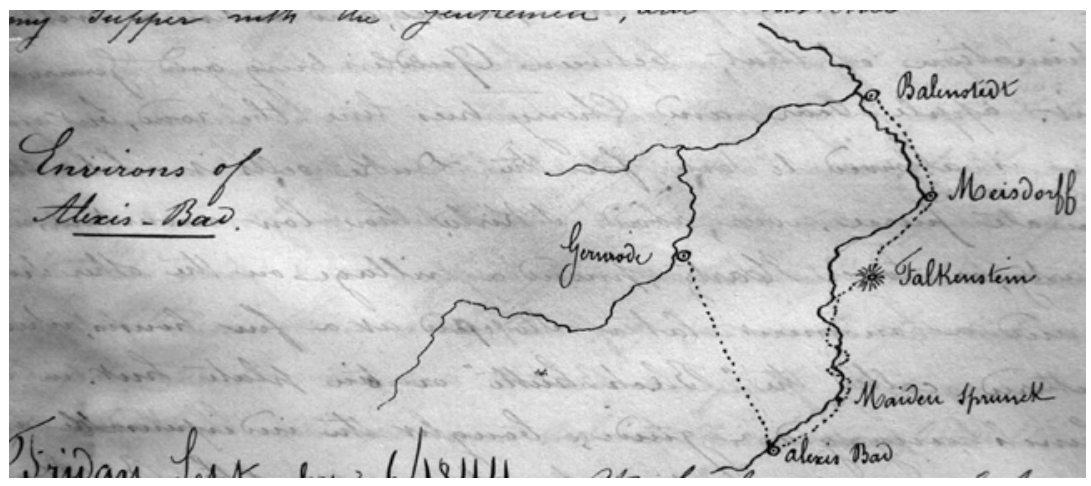

Friday, $6^{\text {th }}$ of September 1844. At half past six I looked out of my window, the fog which lay in the valley gradually disappeared, whilst the sun rose slowly over the woody heights to the Eastward. It was a lovely morning, thermometer with windows open stood at $111 / 2 \mathrm{R} .=58 \mathrm{~F}$. I packed-up, took coffee with the ladies and whilst they were getting ready, I had just time to look in at the bathing house, to cross the little bridge over the Selke and [_] a farewell look upon those pretty walks probably never to be seen again by me. We started [66o] in three carriages Fischer and I on a jolting Stuhlwagen upon which the luggage was placed drove in the direction of the maidens leap and before reaching it, turned-off to the left over a country road through a pretty wood. Gradually ascending we came to the Victors height, on our way thither we passed a heap of stones which the country people called the Devil's mill and of which the legend says, that a miller who once resided there made a compact with the evil one, and he, the miller, not complying with the conditions which he had taken upon himself to fulfil, the Devil caused the mill top blow-up, and the stones of which the walls consisted were scattered about. On the summit of the Victors height 2000 feet above the level of the sea a scaffolding was erected, up to which we gentlemen ascended, the prospect thence was very extensive. At our feet we had the wood and with the help of a Telescope I distinguished in one direction the house on the Brocken, in another the Josephs height where also a scaffolding stands, in the shape of a cross, here on the victors height, in the shape of a tower, in the third direction I saw the ruins of the Castle of Kieffhauser, likewise on the summit of a mountain, and in the plain the Ballenstedt Castle. We continued driving for sometime through the wood till we reached the Chausée between the maidens-leap and Gernrode which last named prettily situated little place we passed, and entered a well cultivated plain the continuation of that between Quedlinburg and Gernrode, rich in corn and fruit; apple, Pear, and Cherry trees line the road, but none of the fruit the traveller is allowed to taste, for the Duke sells it whilst still on the tree for his 
private purse. Our road skirted those low mountains which are called the VorHartz, or lower Hartz, passed a village on the other side of the river Bode, and a moment later stopped at a few houses, where tin plates were manufactured called the "Blech-hütte" or tin plate hut. In an inn we took our lunch, engaged a guide, bought the indispensable walking sticks and put ourselves in motion for the ascent of the Ross-trappe or Horses foot-step. At first the ladies accompanied us. We crossed a small bridge safe and provided with a banister over the Bode, then walked up a narrow very picturesque gulley, the path ascending and descending winds along the river which, though a mountain torrent, was at this season of the year shallow [_] gentle. Our guide told us that in the months of march and april when the snow in the mountains melts, it rises to a conside- [661] rable height. Trees of all kinds gave an agreeable shade, and though it was rather warm [_] walk was extremely pleasant, the mountains on both sides were covered with woods up to the summit, except where they were so rugged and pointed that no tree could possibly take root, some of these rocks were curiously shaped, so much so, that lively imaginations had been able to discover ressemblances between them and other objects, even with human beings. To one rock for instance the name of Bishop had been given, but do what I would, I could not find out the likeness. Nearly half way up the gulley stood an inn called the wald-kater or, the forest-cat, close to it on the Bodes right side many steps cut into the mountain lead-up to a spot where the trees are cleared away named the "Tanz-Platz" or dancing Place. Soon after the ladies determined upon returning, but not before our guide had treated us with a narration, next with a ridiculous declamation meant to be pathetic of the story which has given its name to the ross-strappe, it runs as follows: The Princess Brunhilde became enamoured of a poor knight, with him she escaped from her father's court, and having reached the "Tanz-Platz" they stopped there, danced and rejoiced. A giant was sent in pursuit of them, on his approach they mounted their horse and cleared the distance to the ross-strappe, where the impression of their horse's feet is still to be seen, the giant tried the same leap but fell into the Bode and was drowned. We crossed and recrossed the river, the second time over a bridge to which the ominous name of the Devils bridge is given, and reached the cauldron where the river boiling and foaming forms a fall of about five feet high. The Cauldron according to the guide's account is fathomless, probably an exageration. Here the mountains, some tree covered, some barren and rugged, form a circle apparently precluding every egress, and the whole, though on a small scale looks wild and romantic. We refreshed ourselves with a bottle of the fermented sap of the birch, a beverage which has a pleasant taste, and then commenced our ascent to the Ross-strappe, the height of which is differently stated at from five to six hundred to Eight 
hundred feet above the level of the Valley. In the middle of the day and under a bright sun, it was rather fatiguing to climb-up eleven or more hundred steps, having reached the summit, we were well rewarded for our trouble, for a wide plain in which we could distinguish Quedlinburg, Thale, and other villages lay spread out before us lighted-up by a brilliant sun, except here and there where a few clouds cast their shadows upon it. Turning round to whence we had come and standing on a projecting rock we looked into the Gulley [662] below, and to the opposite mountain ridge. Few steps further a cross is cut into the rock to mark the spot where in 1819 a young girl from Q[_]d[_]urg whom her mother would not allow to marry a young man whom she loved, threw herself down and of course was killed on the spot, her prayer book she had left open at the hymn which begins with the words "Jesus my reliance". Our guide added that her lover married afterwards her mother, and that since this couple had led a most wretched life. From the Ross-Strappe our guide conducted us to the Eggerts height, where sitting under the shade of some trees, the inn-keeper regaled us with bitter-beer. The view over the plain was similar to that from the Ross-Strappe but as Doctor Geffcken remarked, set in a different frame; next it was the Bulow's height whither our guide took us, a high rugged solitary rock, on the top a wooden scaffolding surrounded by a railing, from this point the view is still more extensive, but the charm of novelty was gone; from the Bulow height, the path winds gradually down the mountain and thus we easily reached the Blech-Hutte in less than twenty minutes. We took an indifferent dinner, and remounting our carriages Mrs. Steinert and daughters in one, Geffcken and Fischer in the Jolting Stuhlwagen, and I with the ladies, we drove homeward. At Quedlinburg the old fashioned town with crooked streets, and gable-ended houses we did not stop a moment. When the sun had set, it was a beautiful starlight night. Mrs. fischer had been ailing the whole day, for sometime Mrs. Geffcken and I kept up the conversation, by and by it dropped, both became silent, and we all rejoiced when at nine o'clock we arrived at the Hotel de Prusse in Halberstadt. I may say here that I was well pleased with my companions, even the misses Steinert improved on closer acquaintance.

Saturday, $7^{\text {th }}$ of September 1844. This day we made much progress in our journey, it was the never tiring steam-power which hurried us on over a level well cultivated country; we saw many villages and towns, some far-off, others close-by, but until we arrived at Leipsic, not one town did we enter except Magdeburg, for as it is well known the terminii, generally tasteful buildings stand always outside of the town, sometimes at a considerable distance from the same. Thus the result of a rapid Railway journey is the knowledge of a confused mass of names, the dim recollection of many objects hurridly seen and not one single clear and distinct idea. This may well answer the 
purpose of a courier, and of all those to whom time is mo[_], [663] but not of those that are desirous to derive some practical benefit from their travels. At all events Railway travelling is or at least was cheap in Germany in 1844, per second class we paid from Halberstadt to Magdeburg (seven and three quarters German miles) no more than one Prussian dollar each, the $2^{\text {nd }}$ class carriages in Germany are very good, quite equal to those of the first class in England, they have glass windows, stuffed seats, and stuffed backs. Therefore few travellers make use of the first class which only differ from the second in being the first compartment of each carriage which is called "Coupé" with windows on each side, and also in front. The motion of the train was generally smooth, seldom swinging or jolting, the Employés were dressed in uniform, none of them was allowed to take a fee. Already in 1844 a custom prevailed in the German Railways which was imitated many years later in England, namely that of giving to the traveller a ticket for his luggage, on this ticket numbers were written, corresponding to those which, printed on a bit of paper, were glued on the packages, these were only delivered to the person who presented the ticket. Thus the traveller on arriving at his destination, had merely to hand his ticket to a Railway porter who, for a trifling remuneration delivered the luggage safely in the Hotel pointed out to him. At Halberstadt we separated from Mrs. Steinert and daughters who with little Therese Geffcken returned direct to Hamburg, whilst the remainder of our party continued our journey to Leipsic. At half past eight we left the Halberstadt terminus, it was a fine day, soon however it became very warm, the sun shining clear from an unclouded sky, at nine oclock we were at Nienhaguen, at half past nine at Oschersleben, at which place three lines meet, the one from Brunswick, the second from Halberstadt, and the third from Magdeburg. We took some lemonade in an elegant Hotel, and at forty minutes past nine continued our route. Within three minutes we reached Hetmannsleben, at a quarter past ten we were at Langen Weddingen and at ten minutes to Eleven at Magdeburg. The steeple of the Cathedral of this town was seen by us a long distance off, the train running between the Elbe and the walls of the town passed this church, and on its arrival at the terminus vomited forth numbers of passengers. My companions remained in a handsome coffee-house till half past eleven, and I availed myself of this short time to run through the neighbouring streets. I did not go far, lest I might lose my way. The streets are not wide, and the foot pavements narrow but there [664] are many large respectable looking houses, and much commercial activity about the river; packages were landed and the sheds under which they were stored were extensive. The "Packhaus" which perhaps answers the purpose of a bounded ware-house was of a considerable size. Magdebourg is a very strong fortress which accounts for the many military men in Prussian 
uniform whom I met, without exception they had a martial appearance. From the wall I had a view over the river to its right bank and to the bridge which we did not cross, for our way lay along the Elbe's left or Western side. At ten minutes to twelve we stopped at Schönbeck where we noted many high and Smoking chimneys belonging to the Royal Chemical factories. At twenty minutes past twelve, we were at Halle on the Saale. Soon after crossing this river, the road ran for sometime upon a Viaduct or arches, and the Prussian Colors, white and black, with which hitherto the posts had been painted, now made way for white and green the Colors of the Duchy of Anhalt-Köthen. At one oclock we stopped at Köthen, at one twenty five minutes at Stumsdorff, in this neibourghood I observed an extraordinary quantity of the flowers called "girasols" which if I may believe Mr. Fischer, are cultivated for the sake of theirs seeds, said to be of some value. At ten minutes to two we were at the station of Halle, the university, nothing but the steeples were visible, this town is again Prussian, as well as Scheuditz where we were at twenty minutes past two. Then we entered the territory of Saxony, the Colors of which are green and white, and erelong arrived at Leipsic where we took up our quarters at the Hotel de Rome close to the terminus. It was three Oclock, we dined together, not at table d'hote, but à la carte, which means that every one chooses what he likes best from a list of dishes with the prices affixed. The ladies with Geffcken remained at home, Fischer and I went out together, but he having some commercial visits to pay, I remained alone and strolled about; however, as darkness was fast setting-in, I distinguished but little, I merely remarked that the town was lighted up with Gas and that fine wide avenues lined with stately buildings amongst which the terminus and our Hotel encircled the town.

Sunday, $8^{\text {th }}$ of September 1844. As our departure was fixed for an early hour say at half past ten, I had much to do during the short time which I had at my disposal in order to form some idea of Leipsic, though of course it could only be a very superficial one. The inner town was built in the [665] old fashioned style, the houses had narrow fronts, were high and gable-ended, amongst them some of a more modern appearance were interspersed, the market place and the houses round it were probably the very same which they had been centuries back. In the "Koenigs'-Platz" stood a statue of Frederick Augustus it was he, who, the grandfather of the King reigning in 1844, lost half of his Kingdom to Prussia by the peace of 1815 . The suburbs which comprise the fine avenues of which I had a glance on the preceding evening, owed their existence to the last twenty, or at the utmost thirty years, there are many handsome and tasteful buildings, and an open place, in the "Grimma" suburb, surrounded by the splendid post office, the Augustium or university, a church, and private-houses amongst which a handsome Coffee-house, may challenge comparison with 
many similar public places in other towns. Two monuments called my attention, the one a plain bronze column on one side of which the poet Gellert's bust in haut relief, on the other side these words: "Memoriae Gillerti Sacrum", the other of a square shape with the following inscription: C. W. Müller von den Dankbaren Burgern Leipzic's Geb. 15 Sept. 1728, Gest. 28 Feby. 1802, on the fourth side, his head in haut relief; who this Müller was, I do not know. The Pleisse which flows at a short distance outside the town throws itself into the Elster, is a miserable ditch-like river. I crossed it over a small bridge, and on paying four $\mathrm{S}$. Groshen admittance, entered a public garden owned by a certain Gerhard. The principal attraction was a room in which a few things were preserved as reminiscences of Prince Poniatowski, who I need hardly remind the reader, was drowned in the Elster on the $19^{\text {th }}$ of October 1813 , a day ever memorable in German history. There was a small plaster cast of Poniatowski's equestrian statue, the original of which Thorwaldsen had sculptured for the city of Warsaw, the saddle which he mounted on that fatal day, one of his horse pistols found in the river. On the walls hung the well known French engraving representing the scene of his death at the moment when he spurred his horse into the Elster, also some other engravings of this unfortunate hero. On the table lay two books one into which visitors were requested to write their names, the other commenced with Poniatowski's biography written in French, by a countryman of his, then followed many verses and poems written by Russians, Poles, and French, in which these various nationalities had given vent to their political opinions, those in Russian and Polish, of course I could not understand, but those in French I read with great interest. In the same garden stood a monument erected to the memory of Prince Poniatowski, also a stone is shown which denotes [666] the spot whence he took the desperate leap, and on my looking at the Elster, it seemed to me such a gentle and insignificant river, that I could not conceive how a good rider as Poniatowski no doubt was, did not make his horse swim across, we must however bear in mind that he had been previously wounded. He was born in 1763 , his father andrew was a lieutenant in the Austrian Artillery, his mother a Bohemian Princess Kinsky. The Cemetery in the Grimma suburb interested me much, it was crowded with tombs, vaults and sepulchral monuments. On the walls of the hospital church close to the Cemetery I observed various inscriptions dating as far back as the $17^{\text {th }}$ century. The sexton with whom I talked a few words told me, that he had served in the Saxon army, and that on the $18^{\text {th }}$ of October 1813 , he had been one of the first soldiers who left the French files and passed over to the allies, which sudden defection contributed in a great measure to the issue of the battle so disastrous to the French arms. In the terminus we separated from the Geffckens; they went south to Bohemia, Fischer, his wife and I northward to Berlin. We left at a 
quarter to eleven by Railroad, and as far as Köthen had to follow the same way which we had come. One of our fellow passengers pointed out to us in the neibourghood of halle, a small height, the Petersberg much frequented by the students of that university; at twenty five minutes past twelve, we reached the Köthen terminus, where we had to wait one hour and five minutes till the train started afresh. It was a fine day, we like many other travellers amongst whom not a few well dressed ladies sat in the open air taking refreshments, all were in the alert, some came, others went, the whole was a very animated scene. I met here the Frenchman with whom I had dined at the table d'hote at the Hotel d'Angleterre in Copenhague. At two Oclock we reached the Dessau terminus, the Duchess of Anhalt-Dessau who had been in the train without our knowing about it alighted here, many courtiers, courtcarriages and military escort were waiting to accompany her to her Ducal residence. On the other side of Dessau we crossed the Mulde, an affluent of the Elbe, then the Elbe itself, and at ten minutes past two, were in the Rosslau terminus, at two and forty at Cossing, at 3 at Wittenberg, a town never to be forgotten, for it was here that Luther taught, and burnt the Papal bull of excommunication and the Papal Decretal in the public square on the $10^{\text {th }}$ of October 1520, which step, as is well known, separated him and his followers for ever from the Church of Rome. Hereabouts the road passed through some fir woods, and various heights were distinguishable in the distance. At 3.40 reached Zahna, at 4.15 Jütterbock, at 4.25 Luckenwalde, and [667] at a quarter past six, the Berlin terminus. On our approach to this last named place, we passed the battle field of Gross Beeren where on the $23^{\text {rd }}$ of August 1813 the French army under the command of Marshal Oudinot was defeated by the Northern army of the allies led by Bernadotte, then Crown Prince of Sweden. A Droshka conveyed us from the terminus through several long, broad, and straight streets, to the hotel du Nord which recently concluded was at the time one of the most fashionable hotels in the city of Berlin, it stood and still stands in 1869 on the South side towards the Eastern extremity of the street called "unter den Linden", or under the lime-trees, a street which enjoys an European reputation, quite as much as the boulevards of Paris, or Regent street in London. It runs from East to West, in the middle four rows of beautiful Horse-Chesnut and Lime-trees form a splendid avenue for foot passengers only, one wide walk in the center, on each side a narrower one, then follow the wide carriage road, the broad foot pavement or trottoir and a row of buildings consisting partly of Palaces and public edifices, partly of private houses including Hotels and Coffee-houses, all large and constructed in a regular and uniform manner. In the hotel, Mr. and Mrs. Fischer obtained a room on the second floor; I, for this day on the $1^{\text {st }}$ floor a sitting, and a bedroom elegantly furnished, kept in 
readiness for some great personage expected the next day from Paris. We had to wait an hour till the porter Brought our luggage from the Railway terminus, meanwhile I amused myself standing at the door and looking at the great many people, amongst whom, not a few genteely dressed ladies, who passed to and fro, also at the uninterrupted file of carriages, private and public, which rolled along incessantly. The Droshka drivers in Berlin wear a particular kind of low round hat, with a plume attached to it; they are obliged to hand to every person who employs them a piece of paper on which their fares are printed, which useful precaution prevails their overcharging. At a later hour, Fischer, his wife, and I drove through the Brandenburg gate to Thier Garten, thence to a public garden of great repute, called Krolls' establishment. The Brandenburg gate was built in the reign of Frederick William II in 1789, its cost was half a million of Prussian Dollars, the architect was Langhans. The Propylæum of the Acropolis of Athens was taken for model, and this gate has certainly a noble and chaste appearance. It measures 174 feet in breadth, 64 feet in height, its five passages are formed by columns, one passage on each side for foot passengers, three for carriages, of which the middle one is the widest, on the [668] top stands a car drawn by for horses, in it a Victoria upright holding the reins. This group, which is cast in brass, was carried off by Napoleon to Paris, at the time of his occupation of Berlin in 1806, it was returned in 1814, after the first peace of Paris, and replaced on its old site. This Gate is separated from the Western extremity of the Linden avenue, by an open place, the Pariser Platz and outside the same, commences the Their-garten, a large park or wood similar to the Bois de Boulogne of Paris, but in 1844 it was not kept in such excellent order, was not so much frequented, nor did it present so much variety as the Bois de boulogne did in 1863 when I last was there. A high road runs through the ThierGarten in a straight line to the Royal Palace of Charlottemburg; on each side of this high road, narrower carriage-roads and foot paths intersect the wood. Krolls establishment is to the right on coming from the town, the admittance was ten Silver Groshen (thirty Silver Groshen make a Prussian dollar). This night a concert was being performed, of which we, being too late, heard only the conclusion. The Garden round the house is small, but when entering the saloon upstairs I was struck with its enormous size, with the splendid manner in which it was lighted and with the elegance of the fitting up. The Lustre which hung from the ceiling was immense, creepers wound round it, the Saloon was but partly filled, some of the ladies were busy knitting, rather a queer way of passing the time in a place of public resort, where one would suppose all who go, do so for the purpose of enjoying themselves, and laying aside for the time at least their daily occupations. On our return to the Hotel; Mr. and Mrs. Fischer and I supped together; they went to bed, I amused myself 
for half an hour or so with walking up and down under "Den Linden", many people did the same, and the rolling of the Droshkas did not cease, I heard them rattling till twelve when I felt asleep and again on

Monday, $9^{\text {th }}$ of September 1844 when I awoke. The weather was fine, the thermometer with the windows shut, stood at $18 \mathrm{R} .=73 \mathrm{~F}$. Ever since my arrival in Europe, it had been my custom to rise early, and to dedicate the first hours of the morning to the writing of my memoranda or diary, for otherwise it would have been impossible for me to keep it up to the day, of course [...] dable habit I did not discontinue in Berlin. Hardly had I brought to paper what I thought necessary, and taken my Coffee with two excellent small loans called here milk lo[_] when I received warning to leave my splendid apartment and to remove to the third floor, where I got a room fairly furnished, with windows towards den Linden [669] but such was their height above the street, that owing to my unconquerable nervousness of which I have spoken more than once, not one single time did I venture to go near them, and to look down. At half past nine I went to the Counting house of [Messrs.] Schicklers in the Gertruden Strasse, on the other side of the Spree, a small river which flows right through the town, and joins the Havel near Spandau. I delivered my letter of introduction and credit, and was told by the head of the house, a polite little man, that there were no letters for me. Next I accompanied Mr. and Mrs. Fischer to the public exhibition of articles of German industry held in the Arsenal, a very extensive massive quadrangular building with an inner yard. It is quite out of the question to give the slightest idea of the 1000 and thousands of objects exposed here to the view, not to the touch, for touching [_] was strictly prohibited, and many officials were there to enforce exact obedience to this mandate. I purchased the Catalogue, but unfortunately now in 1869 it is no more in my possession. An impenetrable cuirasse was particularly interesting to me. I was assured that a musket ball fired at it from a distance of fifty feet had made a deeper impression than that fired at twenty feet. The number of people who crowded every saloon, every room, every passage, was immense. I remained from half past ten till half past three oclock, when I was so thoroughly fatigued, that I could hardly move a limb. After dinner Mr., Mrs. Fischer and myself walked to the Koenigstadt theatre, which the "Guide of Berlin" praises as being a Chef d'oeuvre of architecture, whilst I could not discover any beauty, either in the interior, or in the Exterior, three Comedies or rather "petites pieces" were given, the principal point of two of which consisted in the successful imitation of the bad pronunciation of the lower classes of the inhabitants of Berlin, as well as of the shocking grammatical errors committed by them. These farces never afford me any pleasure; whilst in the theatre, I seldom enjoy the jokes, and at home I feel annoyed that nothing has remained in my mind worth 
remembering. The play was over at half past eight, I went to a coffee house and regaled myself with a glass of iced Punch, and read the Hamburg newspapers in which I saw that Mehemut-Ali, viceroy of Egypt, had resumed the reins of his Government, that the French had bombarded Mogador, made themselves masters of an island opposite this place and gained the battle called that of Isly; also that the majority of the judicial members in the house of Lords, has declared that the verdict of the Irish tribunal against O'Connell and his accomplices $[\ldots]$ was illegal in consequence of which the accused were immediately set at liberty - but they did not say that O'Connell and [670] his accomplices were not guilty. The appearance of Berlin, at least of the part westward of the Spree, imposes upon the stranger it is that of a large town and of a Royal residence. It is true there is no palace or grand as Christianborg in Copenhague, but on the other hand, the number of Palaces and public buildings, of Barracks, of Churches, of handsome Hotels, and of stately and large dwelling houses is such, that Berlin well merits the high reputation which as regards architectural beauty, it enjoys amongst the Capitals of Europe. Thursday $11^{\text {th }}$ of Augt. 1869 I have lying before me a map of Berlin, which shows the great improvements about being carried into effect, the natural consequence of the considerable increase in the population which has taken place in the course of the last three or four years, at present the number of the inhabitants coming up to 800,00o. I of course shall try to give a faint idea of what it was in 1844. Opposite to the hotel du Nord, where we lodged, on the Northern side of the "den Linden" Strasse, stands the academy, behind which another house with a Telegraph on the top, the University Street separates the Academy from the extensive University buildings, the last on that side parallel with the avenue. Next follows in the same direction, that is to say, to the East, the extremely handsome main guard-house, in front of which, in Carrara marble the Statues of Generals Sharnhorst, and von B[ellow] Donewitz, both sculptured by Rauch, and erected in the reign of Frederick William III in 1823, between the guard-house and the Arsenal, stand some trophies from the French wars, namely one gun and two mortars; then the Arsenal, at the time as already said, made use of for the General exhibition. The space between the Arsenal and the Spree, was taken up in 1844 by an exhibition of flowers; on the same side with the hotel du Nord the Palace of the Crown Prince of Prussia is the last unter den Linden, a wide street separates it from the spot where the New opera house, burnt down on the $18^{\text {th }}$ of August 1843, was about being rebuilt. Close to it is a bronze column of Prince Blucher Von Waldstadt, which including the pedestal, measures twenty six feet; it was modelled by Rauch cast by Lequi[h]e and chiselled by Vasserelli; next came the two uninhabited palaces; Frederick William III used to live in the one; the Princess of L[ae ]gnitz 
to whom after the death of Queen Luisa he was united by a left handed or Morganatic marriage, in the other, these two palaces were joined by a passage which when I first saw it, put me in mind of the ligament with which the Siamese twins are bound together. The edifices hitherto mentionned stood [671] round an open place quite as much frequented as the Linden. A bridge very short but solidly built of stone, provided with an iron bannister called Schloss Brüke, leads over the Spree, and we had now to our right the Royal Palace, residence of King Frederick William IV. It is an immense pile, opposite is the "Lustgarten", a garden with a fountain in the middle I believe excellent for Royal use, behind the same, the museum, next the Cathedral, again we have reached the Spree, which makes here a curve, we cross it over the long-bridge, adorned with a splendid Brass statue of the great Elector modelled by Schlüter, cast by Jacobi, solemnly inaugurated by the Elector's son King Frederick I. in 1703 , on the anniversary of his (the King's) birthday. The cost of this Statue was about $\$ 60,000$ Prussian dollars. To the Eastward of the long bridge, lies the old part of the town, on two islands formed by the Spree, and by a wet ditch, it bears still its original name, Köhln, a mutilation of the Latin word Colonia. Its appearance it is not so antiquated as that of ancient Imperial towns, such as Quedlinburg for instance, but on the other hand, it cannot be compared to the modern and fashionable part of the town to the West, built under the reign of Frederick II. In 1844 besides the owner of the Hotel du nord, many other hotel keepers, had chosen the "under den Linden" as the fittest street for their calling, there were San Petersburg, Meinhardts hotel, British hotel, Hotel de Rome, also elegant Coffee Rooms and Confectionners-shops, of the former Cafe Royal, Cafe National, of the latter Kränzlers and Fuchs. A few historical notes may perhaps not be out of place. The great Elector was a nice and prudent ruler; it was he who laid the foundation of the greatness of the house of Hohenzollern; his son, a vain, humpbacked little fellow, exchanged the title of Elector of Brandenburg for that of King of Prussia. On the $8^{\text {th }}$ of January 1701 he was crowned as Frederick I. His son, Frederick William I, the Giant fancier, the beer bibber, the tobacco smoker, was coarse and brutal; he ill treated and beat his children, nevertheless on his death, he left a flourishing country, well regulated finances, a filled treasury, and an excellent army. His son and successor was Frederick II, called the great, the sagacious King, the consummate statesman, the hero of the seven years war, the participator in the first partition of Poland, the Philosopher, the scoffer at religion, and the vain French versifier. At his death 1786 Prussia occupied a high place amongst the European powers; his nephew Fredk. William II goes by the epithet of the fat, a clear proof that not much good can be [672] said of him, his reign corresponds to the first years of the French revolution. His son and successor Frederick William III was a man 
of upright intentions, the husband of the beautiful and accomplished Queen Louisa and contemporary of Napoleon I. The loss of the battle of Jena 14 of October 1806, reduced him to be a vassal of the French conqueror, his country an appendage of the French Empire, but the victories of Leipsic, and Waterloo, respectively seven and nine years later, paved the way to his twofold entry into the Capital of his enemy. After the peace, he did not fulfil the promises which he had given to his people in the hour of peril. At the [_]ssion of his son and successor Frederick William IV in 1840, great expectations were entertained, and though in 1848 his soldiers gave a bloody account of the Berlin liberals, it must not be forgotten that he was the first who convoked the Prussian parliament. During the last years of his reign he was only known as the Champaign loving King. His brother who succeeded him first as regent, then as King in 1861, by the name of William I is not a man of shining intellect but of a steady will, and thanks to his prime Minister von Bismark and to the successful campaign of 1866, Prussia as the leader of the North German Confederation, is now at all events the third Continental power, and perhaps even single handed need not fear either of its mighty neighbours, the one to the East, the other to the West. Prince Blucher's military career is well known, after the defeat of Jena, he saved a small body of troops, threw himself into Lübeck and was beaten by Bernadotte on the $6^{\text {th }}$ of November 1806 (see page 377). During the time of Prussia's degradation nothing was heard of him, but in 1813, he again entered the service, though at the time seventy years of age, commanded a Prusso-Russian Corps and on the $13^{\text {th }}$ of August gained a great victory over the French under Marshal Mac Donald, near the river Katsbach in Silesia, on the $19^{\text {th }}$ of October, he was in time to take a share in the victory of Leipsic. On the $31^{\text {st }}$ of December 1813 he passed the Rhine at the head of his army, but in the first months of 1814 his imprudent courage and head long valor, were not a match for the strategy of Napoleon. He attempted to advance to Paris, but was repeatedly routed, and only entered the Capital after the abdication of Napoleon in Fontainebleau. In 1815 the old hero Marshal Vorwärts or "go ahead" as he was nicknamed, was beaten on the $16^{\text {th }}$ of June near Ligny but his timely appearance on the field of battle [_] [673] the $18^{\text {th }}$ at Waterloo contributed if not to the decision of the battle, for this is a point which will for ever remain controverted, at all events to the complete rout of the French. He again entered the French Capital, and insisted upon the bridge of Jena being blown up for it reminded the Prussians of their shame, happily for the fame of the allies, this idea was not carried out. Scharnhorst though of less renown than Blücher, contributed vastly to the emancipation of Prussia from the French yoke. To him is mainly due the reorganization of the Army; one of the Conditions of the peace of Tilsit did not allow the Prussian Monarchy to keep under arms 
more than a certain number, believe 30,000 soldiers; Scharnhorst complied with this condition to the letter, but evaded it in reality by sending to their home the 30,000 men and calling other 30,000 ; thus in 1812 , when the war again broke-out, a great part of the male population of Prussia knew how to manage their muskets, and swords. Scharnhorst died 1813 in Prague in consequence of a wound, received on the $2^{\text {nd }}$ of may at the battle of Lützen; he was then on his way to Vienna to induce the Emperor of Austria to join the allies. Von Bulows Donewitz received this title in consequence of the victory gained on the $6^{\text {th }}$ of September 1813 near the village of Denewitz against the French, commanded by Marschal Ney who threatened Berlin.

Tuesday, $10^{\text {th }}$ of September 1844. At an early hour troops passed the Hotel, Cavalry and artillery, each brass gun drawn by six horses; they however did not $\mathrm{a}\left[\_\right]$the slightest attention, for military men of all descriptions were so common in the streets of Berlin, that nobody took notice of them. Fischer's plans how to spend this day being different from mine, I walked out by myself down the Linden as far as the Frederick strasse, one of the many streets with which this Capital abounds, long, straight, broad, and little frequented, the houses in it, including several barracks, would be considered of an excessive size in any other town but Berlin, where it is the Custom for many families to live in the same house, each occupying a separate floor. The Frederick Strasse crosses the Spree over a small bridge called the "Weidendammer", similar to the Castle bridge. The river was filled with small vessels, the greater part laden with wood, their tillers reaching half their length. Continuing in the same direction, I came to a small market place of triangular shape, where the Frederick strasse, the Oranienburg strasse and the [Linien] strasse meet. I choose the latter, which is not one of the principal thoroughfares, and entered the Institution for the Deaf and Dumb [674] founded in 1798, which was open to strangers on Tuesday's. Here the method for teaching these unfortunate beings differs from those adopted in Glasgow and Trondhjem (see what I said on the subject pages 602, and 249 of this volume) in the two latter places they are taught to make themselves understood by means of signs, which some certainly learn to great perfection, but they can only converse with such as know the meaning of these signs, whilst in Berlin the exertions of the teachers were directed to make the pupils speak. With some this object was partially obtained, and these were then able to converse with all who spoke the German tongue. In the first room in which I entered the teacher was occupied with making the Children utter articulate sounds, he wrote a letter upon a slate, pointed this out to the pupil, and then pronounced the letter himself, very slowly and distinctly, so that the pupil paying great attention, could see how the teacher had to open his mouth, to move the jaws, the tongue, etc. in order 
to produce the same sound. The teacher had also in his hand a small piece of thin iron, with which he gently pressed the child's tongue against the teeth or the Palate, or directed it in any other way to assist him in uttering the sound required. In the second room, the teacher himself was deaf and Dumb, but could speak a little. He taught the children writing and the conjugation of verbs, a little clever looking girl showed me her slate filled with irregular verbs, in the present, the participle and the past tense, in which I found but few mistakes. In a third room the head master was occupied with seven or eight boys and girls who had made most progress; he dictated to them something about religion, he pronounced slowly and clearly, the children by merely looking at him comprehended, and wrote down what he said, in which they made but few mistakes either in Grammar or Orthography. When I spoke to them they understood me imperfectly, not so when the teacher repeated my words. Every human being has a different way of pronouncing, thus it is very natural that the Deaf and Dumb take sometime before they can understand and get accostumed to the different ways of speaking. The master asked one boy, what color is your coat? ans.: my coat is brown. - and the table? ans.: the table is also brown. - Query: both are of the same Color? - no my Coat is darker than the table. A girl when writing a certain sentence made use very correctly of the future tense of the verb "to be" (Werd, Sein), whilst we, in common parlance, would have made use of the present tense "Ist". To [675] a boy the master dictated neither by speaking nor by spelling each word by means of the letters which the fingers placed in a certain position represent but by signs made with the hands, for instance: one sign meant "this Gentleman has been in England", another meant "Spain", and a third "Russia" etc. Much pleased with what I had seen here, I left the establishment, and returned the same way which I had come, walked to the open square before the Brandenburg gate called the Pariser Platz, then through the thier-garten, passed "Krölls" Establishment along the bank of the Spree filled with small craft to the Bellevue Palace, an insignificant summer residence of the King; further on I reached the small place of Charlottenburg, two rows of houses each on one side of the broad high road; the Palace of Charlottenburg still more to the Westward is an extensive Royal building. I had to apply to the porter in order to obtain admittance to the mausoleum which, a short distance off, surrounded by trees amongst which weeping willows, was erected by the late King Frederick William III, and contains his mortal remains as well as those of queen Louisa Princess of Mecklemburg Strelitz. She died in 1810, he on the 12 of June 1840. A few steps lead up to a handsome porch formed by four granite columns, in front is the vault in which stand two coffins which enclose within their narrow 
boards all that is left on earth of the noble minded beautiful woman, and of the well intentioned good natured man; it is secured by iron railing, the keys to which the present King keeps himself and confides to nobody. On each side of the vault, a low flight of stairs ascends to the vestibule, the ceiling of which is sustained by four columns of variegated marble dark blue [...] of the same material support the Chapel itself. In the centre stand the two Cenotaphs, upon that to the left lies the statue of the queen, her eyes closed in a sleeping attitude said to be an excellent likeness, Rauch is the Sculptor, upon that to the right lies the Statue of the King, in 1844 only the Cenotaph and the Statue of the queen were of white Carrara marble, those of the King, as yet of plaster to be exchanged for marble as soon as concluded. In 1854 when I again visited this Mausoleum, this was done. Behind the Cenotaphs stands an altar in a niche where on particular occasions Divine Service is performed. The window above the entrance is of a blue Glass, thus the light which falls into the Chapel throws upon the white stone a soft and mellow Color, every traveller who visits Berlin should devote an hour or so to this Mausoleum, in my opinion the most interesting of the many objects which this Capital [676] presents to the curious. Two young men whom I had met in the garden and I engaged a droshka in which we returned to the Brandenburg gate, instead of entering the town I walked round the same through the streets in no way inferior to those already described, until I reached the Potsdam gate, which I entered, and found myself in the Leipsic square, an open place with handsome buildings around. The Leipsic Strasse, then the Wilhelms-Strasse took me to the Belle Alliance Platz inside the Halle Gate which does not equal either the "Leipsic" or the "Pariser" Squares. In the Centre stands a brass Column of the Corinthian order, fifty feet high, on a marble pedestal surrounded by a granite Basin without water. On the top of the Column lies a gilt ball upon which a Victoria, a wreath in her hand, this Column was erected to celebrate the Victory of Waterloo called by the Prussians, of "La belle Alliance". Its first stone was laid on $18^{\text {th }}$ of June 1839 by Frederick William III, the architect was Cantari, the inauguration took place on the $3^{\text {rd }}$ of August 1843. At a short distance outside of the Halle gate I came to a low hill, called the Kreutz-berg, or Cross-mountain, the greatest height in the flat environs of Berlin. On the summit of which a monument of cast iron in the Gothic Style, surrounded by an iron railing has been erected to commemorate the Victories gained by the Prussians in the last wars of 1813, 1814, and 1815 over the French. This monument in the shape of a cross, thus was modelled by Schinckel. On the salient sides A., B., C., D. the name of the place where the battle was fought is inscribed in gold, inside where I have made the dots, in black letters thus: to the right 


\begin{tabular}{|c|c|}
\hline Gross Beeren & $\left(23^{\text {rd }}\right.$ of august 1813$)$ \\
\hline Katz-bach & $\left(26^{\text {th }}\right.$ of august 1813$)$ \\
\hline Gross-Gorshen & $\left(2^{\text {nd }}\right.$ of May 1813$)$ \\
\hline Culm & $\left(3^{\text {th }}\right.$ of August 1813$)$ \\
\hline Dennewitz & (6 $6^{\text {th }}$ of September 1813 ) \\
\hline Leipsic & $\left(18^{\text {th }}\right.$ of October 1813$)$ \\
\hline Wartemburg & $\left(23^{\text {rd }}\right.$ of October 1813$)$ \\
\hline La Rothiere & $\left(23^{\text {rd }}\right.$ of October 1813$)$ \\
\hline Bar Sur Aube & $\left(27^{\text {th }}\right.$ February 1814$)$ \\
\hline Laon & (9 of March 1815) \\
\hline Paris & $\left(30^{\text {th }}\right.$ march 1814$)$ \\
\hline Belle Alliance & (18 th of June 1815$)$ \\
\hline
\end{tabular}

[677] Above [_]h name stands an allegorical figure in a niche with a cross on the top, each side finishes in a point, the centre into another point higher than the four which surround it, the whole surmounted by a cross (a large one). The allegorical figure above the name of Paris bears in its hand a miniature Copy of the Group which stands upon the Brandenburg gate. From the head of the figure above Leipsic, emanate a number of Rays forming an aureola. Below Gross-Gorshen is the following inscription in gothic letters: "Der Konig dem Volke das auf seinem Ruf hochherzig Gut und Blut dem Vaterlande darbrachte, den Gefallenen zum Gedächtnisse, den Lebenden zur anerkennung, den künftigen Geschlechtern zur Nacheiferung" which may be rendered in English thus: "the King to the people, who magnanimously sacrificed to the fatherland their property and their lives, the deeds of the dead, be they remembered, acknowledged by the living, imitated by future generations". Close to the "Kroetz-berg" was a public garden, the Tivoli, where I took a cup of coffee, and listened to some fair instrumental music, also hither the fair Berlin ladies had taken their knitting, it seems that they cannot go anywhere without this accompaniment. The garden itself was very poor, but what can be expected of the sandy soil which encircles this Capital? On my way home, I had a look at the six statues which adorn the Wilhem's Platz, they are so far remarkable as they represent the heroes of the seven years war. Viz: Prince of Anhalt Desau, the old Dessauer as he was called, and the tune of the dessauer march is still remembered in 1869; General von Zeithen the famous leader of Huzzars of whom the followed anecdote is related: in his old age when sitting at the King's table he fell asleep; a courtier wanted to awake him, but was rebuked by Frederick II with these words: "do not awake him, many a time has he watched for us when we slept"; Field Marshal Von Schwerin who died in 1757 when leading his soldiers to the assault of the battlements of Prague; Von Vinderfeld; 
Von Seidlitz, the renowned Cavalry General, and Keith the noble Scotchman who lost his life in october $175^{8}$, by a cannon ball at the unfortunate affair of Hochkirken. The evening I spent with Mr. and Mrs. Fischer at a Mr. Pabst, a high titled personnage. The party was very pleasant, there was amongst others, an old Gentleman in the Hessian Service who had been in the French Army in the peninsula war against the English and Spaniards, and had fallen into the hands of the latter at the storming of Badajoz. We had tea, cakes, and cold meat, and broke up at midnight. [678]

Wednesday, $17^{\text {th }}$ of September 1844 . Mr. Fischer went to an exhibition, I accompanied Mrs. Fischer, who pleased me the more the better I became acquainted with her, to the Royal Manufactory and ware-house of Porcelain which in quality, and exquisite finish of the paintings is equal to any other China ware in Europe. We remained sometime examining everything with great attention, and I made a small purchase of some cups and saucers. On our walk thence to the Royal library in the Opera place, we passed the GendarmesPlatz, the three sides of which are occupied by the new church, the French church, and the theatre, which three buildings, though their object is so very different, have an extraordinary similitude in their exterior appearance. All three are surrounded by colonnades, the two churches have a steeple, the theatre not. The library was about being repaired and rearranged, for which reason the public in general were not admitted, with us strangers, an exception was made. It however afforded no great pleasure to walk up and down the larg saloons where the 600,000 books and 5000 manuscripts were being put in order. The latter were not shown to me, of the former I opened the one or the other, and read titles of many. I now left Mrs. Fischer in the hotel and directed my steps to the museum in front of which stands an enormous basin of beautifully polished granite placed there in 1827. It is cut out of one block which weighing 15,000 cwt was found lying on the summit of the mountains near Furstenwalde. Its weight in its present state is 1500 cwts, its diameter 22 feet. Immediately behind this basin a flight of stairs leads up to the vestibule of the museum, sustained by eighteen pillars. The rotunda adjoins the vestibule, it receives its light from above. In the centre stands a vase presented by the Emperor of Russia, made of a green mineral called Malachite, which (1844) was as yet little known. Round the walls of the rotunda stand Eighteen statues. At a considerable height above the floor, a gallery runs round the interior likewise adorned with eighteen statues of a smaller size than those below. Whilst I was in this rotunda it appeared to me as if I heard at a distance the sounds of various well tunned instruments and I was not a little surprised to learn that these sounds came from the mouth of a man who stood in the gallery, and that its reproduction and its loudness were solely owing to the perfect circular form of the building, 
and to the extraordinary attention which in its construction had been paid to the nicest principles of acoustics. From the Rotunda an entrance leads to two large Saloons occupied by antique Statues, [679] some perfect, some repaired, others mutilated. I feel great pleasure when examining statues, much more so than paintings, but on this occasion the want of a catalogue which I could not obtain, was a great drawback for of course I, as everybody else wish to know the meaning of what we see. From one of the saloons a number of steps ascends to the already mentionned gallery which communicates with other saloons filled with a larger collection of paintings, arranged according to the different schools. I bear in mind the promise made by me page 185 of these extracts, and will only say, that I was a sufficient judge to appreciate the beauty of a painting by Mengs, representing the Holy family. Several artists were occupied copying some of the masterpieces. I dined at table-d'hôte in the hotel. Dinner was indifferent and what was worse, knives and forks were not changed at every course, or if they were taken away, they were only wiped and returned quite in the same state as they had been before. Towards the evening I accompanied Fischer and wife through the Brandenburg gate to the ThierGarten where keeping a little to the left we came to a public garden called "Kempers-hof". The principal attraction was a numerous orchestra directed by a Hungarian. The admittance cost no more than two and a half silver Groshens, nevertheless the Company consisting mainly of the middle Classes, looked very respectable. Some took beer, others Coffee, we followed their example, and walked home as soon as the cool of the evening did not allow us to remain any longer in the open air.

Thursday, $12^{\text {th }}$ of September 1844. Two hours I spent with the Fischers in the exhibition, then took a droshka, and was just in time at the terminus whence at eleven oclock the train started for Potsdam; it runs through a level, uninteresting country. We reached the Station in Potsdam three and a half German miles from Berlin, in half an hour. On my arrival there I had to cross the river Havel over the Feltau or long bridge; when on the other side I had to my right the Royal Palace, an immense building, my visit to which I postponed till another day, to the left was the Lustgarten, or Garden belonging to the Palace. In a public house where I breakfasted, I made the acquaintance of a bearded young man, whom I afterwards found to be a native of Mecklemburg, and an employé of the Government. He like myself wanted to see the curiosities of Potsdam, thus we made common cause. We walked through the streets of this town, once the favorite residence of Frederick II, now very quiet, and little frequented. Here the same as in Berlin is a [680] gate called the Brandenburg. A few steps outside the same, we came to an obelisk, its four sides covered with Hieroglyphs not engraved in, but raised upon the superficies. It stands at 
the commencement of the principal avenue of the garden of the country seat of Sans-souci. Walking down this fine avenue, we came to a pond with gold fish, then turning to the right and ascending some terraces, stood before a low, long building containing the picture gallery, which like the whole of Sans-souci owed its existence to King Frederick II. The floor was of marble, the ceiling beautifully gilt, here and there stands a statue, but the pictures themselves did not answer my expectations. I cannot bear the naked, round, fat and fair female figures which Rubens is so fond of portraying, and in which this gallery abounds. We promenaded through the beautiful park, and reached the small palace of Sans-souci, where a very decent female showed us round; she pointed out to us a narrow passage where Frederick the great was in the habit of walking-up and down; the room where he used to work; his writing desk with inkstand; his arm chair; the room in which he gave audience; the room and arm chair in which he breathed his last; the cushion and counterpane which he was in the habit of using. In all these apartments the old furniture was religiously preserved, but some modern had been added, in one apartment for instance, were two chinese vases, and a china Cup-board just arrived from England which the present King had not yet seen. Our guide conducted us to a suite of rooms occupied by the King and Queen when on visit here; also to their joint bed room, all furnished in a pretty comfortable, not in an extravagant manner. In the Concert room stood an elegant Grand-Piano. These different apartments in a long row look into the garden, the last of them Voltaire occupied when he was on a visit to his Royal friend, it was in 1841 occasionnally made use of by the queen, as her dressing room. Also here the old small silk covered arm-chairs which date from the time of the great King are preserved. Before we left, our attention was called to some flag stones under which a few favorite dogs of Frederick the great lay buried. At the other extremity of Sans-souci is the new Palace commenced by Frederick II after the Hubertsburg peace in 1763 , it was finished in 1796, its cost was: 3,000,00o Prussian dollars. Its façade towards the Garden measures 680 feet, in my opinion, a great blemish is that it is not stuccoed over, so that [681] the red bricks of which it is constructed are seen. Before we entered the Palace the Castellan led us to queen Luisa's mausoleum, where her statue very similar to that which I had seen in Charlottenburg (perhaps it may be an exact copy) lay extended on her couch. She is represented as if asleep, her face is beautiful, she wears a diadem on her forehead; the folds of the gown, the sheet, also the pillows on which she rests her head, are natural in the extreme, it is really wonderful how a great sculptor as Rauch, in this instance has taken from the marble all its hardness and rigidity. In the Palace our conductor was a female; she like all such guides hurried us too rapidly through the large apartments, the walls of which were covered by pictures; two 
by Guido Rene, the one Lucrecia on the point of stabbing herself, were in my poor opinion superior to all the rest. One of the Saloons goes by the name of the Shell saloon, its walls are incrusted not only with shells of all descriptions, but also with valuable stones, other walls imitate Stalactites. Close by is the marble gallery, above which the dining-hall, adjoining the same, the marble saloon which is one hundred feet long, sixty feet wide. Both, the walls and floor are covered with variegated marble, a passage leads to the small theatre, other rooms which Frederick II occupied, are left in the same state as they then were. His library here, as well as in Sans-Souci consists exclusively of French works, an atlas used by him, a manuscript of his, a printed copy, of some of his own French verses in which Voltaire in his hand writing has altered the words "Chiche de mots" into "avare de mots", and finally a portrait of Voltaire rather in caricature drawn in pencil by Frederick the Great are shown to the curious visitor. As I wanted to see in Berlin the performance of the midsummer nights dream, translated into German, the time was too short to allow me to visit Charlotten[_]. My Mecklemburg companion and myself hurried through the splendid garden, had a look at the fountain which in one straight jet rises to the height of perhaps fifty feet, the frothy water in its descent I could compare to nothing better than to the white drooping plumage of a general's hat. It was the first time I saw such a fountain. We took a droshka, and hastened to the terminus. Our companions in the carriage, second class of course, were two ladies, they had their commissionaire with them, and I suppose were of a certain rank in society, but [...] surprised how readily they entered into conversation with a stranger as [682] I was to them. They mentioned that like myself they intended to see the performance of the midsummer night's dream, I endeavoured to keep company with them, in which however I did not succeed. In the theatre, that situated on the "Gendarmes Platz", I was much disappointed, for when I had taken my seat and opened the play bill, I found that instead of the play advertised, a comedy and a ballet were to be given, the former full of loyal and patriotic sentiments, the latter very stupid indeed. The last scene represented a great skating match, there were sledges with horses, snow balls were thrown, and the curtain fell when one of the performers broke through the ice that is to say fell into a trap-door. In my hotel I sat down to supper with various new guests amongst whom two ladies from Saxony, one of whom glittered with diamonds. I observed that it was the custom to address all ladies with the words of "Gnedige frau" or gracious lady. A row which had taken place in Krolls establishment was the theme of conversation, he had given a great entertainment, and the populace had broken through the railing, and committed other mischief. 
Friday, $13^{\text {th }}$ of September 1844. In the exhibition I had noted an imitation of wax made of tallow not of stearine, by a certain Mr. Schopp living in the Vasser-Gasse, and I thought if it were a cheap article, a small consignment of it to the Lima market might answer. I therefore went to his establishment which I found out with difficulty in that part of the town to the East of the Spree, very different from the aristocratic quarter to the west from this river. Mr. Schopp asked 13 Silver groschen per lbb, a price which I deemed much too high, I therefore abandoned the idea of speculating in this article. At the Confectionners Fuchs I purchased a lot of dry sweetmeats (bombons), which I destined for the little Sievekings, Sempers and Knauers of Altona, then accompanied Mrs. Fischer to the Antiquarium, or collection of antiquities, which occupied several saloons in the museum. We saw here Roman coins and medals, vases and urns, and many other articles used by the Romans in their every day life, such as: pots, Lumps, Scissors, Locks, Keys, etc., etc. There was likewise a great number of Etruscan and greek vases, made of clay, many of which of a very tasteful shape, their ground colour was generally light brown, or yellow, on which grotesque figures were painted in black. Mrs. Fischer went home, I, at her recommendation, to another collection, which goes by the name of Kunst-Kammer, literally: the Chamber of art. There were several articles of Ivory and wood of exquisite, delicate workmanship, amongst them some master- [683] pieces by Albrecht Dürer, also models of Churches done in Ivory, wood, and Cork; weapons from the South Sea islands, curiosities from China, some trifles from Mexico, but nothing from the Republics on the West coast of South america. Historical reminiscences interested me most, as they always do, for instance: a large drinking glass used by Luther - a field chair of Gustavus Adolphus of Sweden - two cannon balls which at the Siege of magdeburg by Tilly in may 1631 met each other in the air, and the one broke the other - a Sword of Charles XII - a big tankard out of which Peter the great, Emperor of all the Russians and Frederick I of Prussia are said to have drunk, pledging themselves to everlasting brotherhood - a small wind-mill made by the former - the Cap used by the great Elector at the battle of Fehrbellin showing the impression made upon it by a musket ball, it is of great weight made of iron and leather - an effigy in wax of the same Elector, another of his son King Frederick I, they sit near each other, and are dressed in the customes of the periods in which they lived - respectively the musket ball said to have touched Frederick II's at the battle of Torgau, but which did not injure him having struck against a small gold "etui", which he had in his waistcoat pocket - an extremely natural figure of Frederick the great made of wax, sitting in an arm-chair, the same in which he is said to have died, though a duplicate 
chair was shown to me on the preceding day in Sans-Souci, this figure is dressed in the original suit of clothes which he was in the habit of wearing, his boots, hat, crutch, or rather big stick, a flute lying before him on a music desk - the wooden statue of a grenadier in the time of Frederick the great in the uniform then worn - a cast in wax of Frederick II's face taken after his death - the same of queen Luisa - Napoleon's hat and all his orders taken in his travelling carriage after the battle of Waterloo, the carriage itself, it will be remembered was shown at Madame Tussauds wax-works exhibition in London (see page 145 of this Volume) - a dress of Murat more proper for a theatrical performer, than for a brave General as he was - finally several Gala suits of late Kings of Prussia, and many other things more which I do not recollect, and which probably were not worth recollecting. At dinner I had to my right Mrs. Fischer, to my left the two ladies whose acquaintance I had made yesterday in the train from Potsdam, they were the one the wife of General Schmidt from Cologne, the other her sister Miss Hastock from Darmstadt. They were travelling by themselves and their intention was to [684] to perambulate Saxon Switzerland on foot. I commenced paying some attentions to them, when Mrs. Fischer called me, and obliged me to converse with her thus I had to neglect my new acquaintances for my old friend. After dinner Mr. Fischer and I drove to the Zoological garden in the Thier-Garten which is prettily situated and tastefully laid out. The buildings in which the beasts are kept, or to speak more properly, will be kept, are spacious and solid as yet there were but few animals, those worth noticing were four or five brown bears. We walked back, the evening was very pleasant, and I concluded the day at Kranzlers pastry cook shop, with taking a glass of iced punch and with the perusal of news-papers.

Saturday, $14^{\text {th }}$ of September 1844. During the whole time of our stay in Berlin not a drop of rain fell. This day at 8 a.m. windows open thermometer stood at 14 Reaumur $=66 \mathrm{~F}$., the same as in the evening at 11 p.m. windows shut. At ten oclock I went with Mr. and Mrs. Fischer to Kulms exhibition of articles of art, where I was particularly pleased with the imitation and explanation of the atmospheric Railroad between Kingston and Dalkey in Ireland, as well as of the so called Montagnes Russes, on which according to theory, he who makes the experiment is carried along with such velocity, that on one spot he goes with head downwards without falling-off the car, which extraordinary feat I confess I do not believe until I see it. Paintings, engravings, and statues were likewise shown to the visitor. In a Diorama I saw the interior of the church of San Francis of Assissi, also the exterior of the Cupola of Saint Peter's in Rome lighted-up at night, both were pretty views, but more proper for Children than for grown-up people. I next visited the garden of the Royal residence "Mon Bijou" at the end of the Oranienburg Strasse close to the Spree of which I have 
nothing else to say, but that there are many fine trees, as little does a Cementery outside the Brandenburg gate, require a particular description. The Frederick Strasse, from the Linden to the Belle Alliance Platz measures, calculating nine of my steps equal to six and a half yards, about 2780 yards. Walking leisurely it took me twenty eight minutes. Mr. and Mrs. Fischer were not at table d'hôte, being invited to dine at Mr. Pabst, the titled Gentleman in whose house I took tea on the $10^{\text {th }}$ instant. The two ladies, Mrs. General Schmidtt and her sister sat opposite to me, they were not handsome but very clever and agreeable, both had beautiful teeth, and were much admired by the Gentlemen. In the [685] Königstedter theatre I was present at the performance of a new opera by Nicolai "Il Templario" founded upon Walter Scott's novel "Ivanhoe". The house was filled, and the singing was very good, but the overpowering noise made by the trumpets was by no means to my liking. Ivanhoe, the tenor was sung by Borini, the Templar (barytone) by Medrowitch, (the bass) by Raimundi, Rovenna (soprano) by one of the Prima Donnas Miss Remorini, and Rebecca (Soprano) by the other Prima Donna, Mrs. Schiavoni, this last one, rather a little woman and of no prepossessing exterior, I preferred to the rest; though she was not so good looking as the Rossi of Lima, she put me in mind of her.

Sunday, $15^{\text {th }}$ of September 1844. In 1844 the Railway between Berlin and Hamburg did not yet exist, thus the promptest way to return was by rail to Magdeburg thence by Steamer to Hamburg; accordingly we chose this route. It was still dusk when I rose at half past five. I had to pack-up, shave, breakfast and pay my bill, was ready in good time, and at half past six drove with Mr. and Mrs. Fischer to the terminus where I took a through ticket to Hamburg, second class by rail, first class cabin on board the Steamer. I had my luggage weighed, saw it labelled, paid for some overweight, and having for the first time myself attended to these trifles, which hitherto Fischer or Geffcken had been good enough to take-off my hands, hastened to the train, and took my seat in the same carriage with my two companions. Amongst our fellow travellers was a young girl of about fifteen years of age, who by herself, without any further protection went as far as Köthen; her Berlin friends had accompanied her to the train, and her Köthen friends received her on her arrival. This is nothing particular to be sure; I merely mention it to give an idea of the ease and safety of Railway travelling. In Köthen we had to wait for about half an hour, took our lunch in the open air, started afresh, and reached Magdeburg by two oclock. Here we had to walk through the dry, sunny and dusty streets to the Steamer "Albrecht-Fredrick" moored in the river, we went on board, and at about half past three steamed-off. For a considerable while the steeples of Magdeburg remained in sight, in about two hours those of Burg showed themselves, we passed many places on both sides of the river, the names of which can 
be found on every good map and especially on that in my possession of the Elbe from Magdeburg to Cuxhaven, I will therefore not enumerate them, and confine myself to saying that the shores are flat and altogether void of interest. Tangermunde on the left side makes an exception, being prettily situated. The water in the river was very low owing to [686] the late prevalence of Easterly winds, consequently though the Steamer did not draw more than two and a half feet of water, once or twice on our way to Hamburg we touched the bottom, or at all events just separated over it. Two men at the bows were continually sounding with long poles, there was no compass, probably because when navigating a river with so many windings and turnings as the Elbe, the Helmsman must be guided by the landmarks on shore. Bye and by I became acquainted with some of the passengers, amongst whom I will only mention a Mr. Stegemann, Prussian Consul in Hamburg with a ribbon in his button hole, partner of Oswald \& Co., and Mr. Jung, a linen manufacturer in Billefeld; with these two Fischer and I playd whist till half past ten, when it was time to retire to bed, but as I heard some of my companions say, that the berths were dirty, and hot owing to the vecinity of the funnel, I followed their example, merely loosened my braces, covered myself with my big cloak, and laid down on a sofa. At Wittemberge on the right side about half way, passengers came on board, and on account of the darkness of the night, we remained here till three o'clock in the morning, when we again moved-on.

Monday, $16^{\text {th }}$ of September 1844 . At six I awoke and went on deck, but the rain which came pouring down drove me back to the Cabin. Gradually all rose, the ladies came from their berths, and the demand for Coffee was great. The rain continued, we had to remain below, and in the course of conversation Fischer and a Mr. [Hundeicker], a gentleman who had resided many years in Mexico touched on apoint regarding which their opinions were diametrically opposed to each other. Recently the Hanoverian Government had altered and in a great measure lowered the Stade duties, the Governments of Prussia and of Austria and, as Fischer pretended, also that of Denmark, had concluded treaties with Hanover in which they acceeded to these new duties. The Senate of Hamburg had done the same but the Corporation of Citizens "Die Erbgesessene Bürgerschaft" had differed from the Senate; in such cases the Hamburg constitution required that a commission formed by some Senators, and some chosen by the corporation of Citizens should discuss the point in dispute, and the decision which the majority might take, the executive had to submit to. Fischer was of opinion that it was in the interest of the Hamburghers to follow the example given them by their neighbours, for if they did not, the Altonaers who paid the lower duties would have a decided advantage over them. 
Hundeiker denied that this would be the conse- [687] quence, and added that even if this were the case, the Hamburghers ought not to give way, because by doing so, they would recognize the right which the Hanoverian Government pretended to have to fix these duties which right they, the Hamburghers, had disputed until then. I knew too little of the matter to decide who was right or wrong, but Hundeicker no doubt spoke with more earnestness and in a more intelligible manner than Fischer who made use of very fine expressions, but whose arguing I could not always understand. I learned that the Stade duties had originally been instituted for the purpose of defraying the expenses incurred in rebuilding the Hamburg "Dom", or Cathedral, and that in course of time it had become part of the revenue of the Kingdom of Hanover, also that the property belonging "Bonâ fide" to Hamburg citizens was free of this duty, that the inhabitants of Saint Paoli enjoyed the same privilege, those of Saint George not. I suppose that now in 1869 all this has been altered or done away with; at all events, these are interesting relics from former times. The weather cleared up, we were now fast approaching Hamburg, both to the right and to the left the dykes which protect the low lying land against the waters of the Elbe came in sight. On the right bank I noted a few houses called the "Zollenspicker" opposite the Kranz, here was the usual passage of merchandize from Hamburg to the opposite side, but this likewise has undergone some change since the construction of the Railway from Haarburg to Hanover. A little further down the river we passed the fertile Vierlanden, and at ten minutes to three stopped at the Grassbrook. Our journey from Berlin to Hamburg had lasted nearly thirty three hours, whilst in later years, by rail the journey takes exactly seven hours. A bridge was thrown over to the shore, and in a few moments all had dispersed, each went his way, Fischers and I took a droshka; when driving through the old part of Hamburg not destroyed by the great fire of 1842 we could not help being struck by the appearance of the narrow and tortuous streets, of the high, old fashionned houses, in a few minutes we emerged into the open place where the new Nicolai's church was to be built, then turning to the left we came to the two Steinwige streets which though pretty wide are generally dirty and filthy, being infested for the greater part by the low Jewish population of Hamburg. We crossed the suburb of Saint Paoli and on entering Altona were forced to acknowledge the insignificance of my dear native place, but also admired as every body does, the fine-trees and the splendid foliage of the Pall- [688] maille. I alighted at Sempers, and was shown to my old apartment, the large saloon up stairs. I add a sketch of my preceding journey. The Railways then in existence, are marked with uninterrupted, those constructed since, with broken lines, my journey with red dots. 


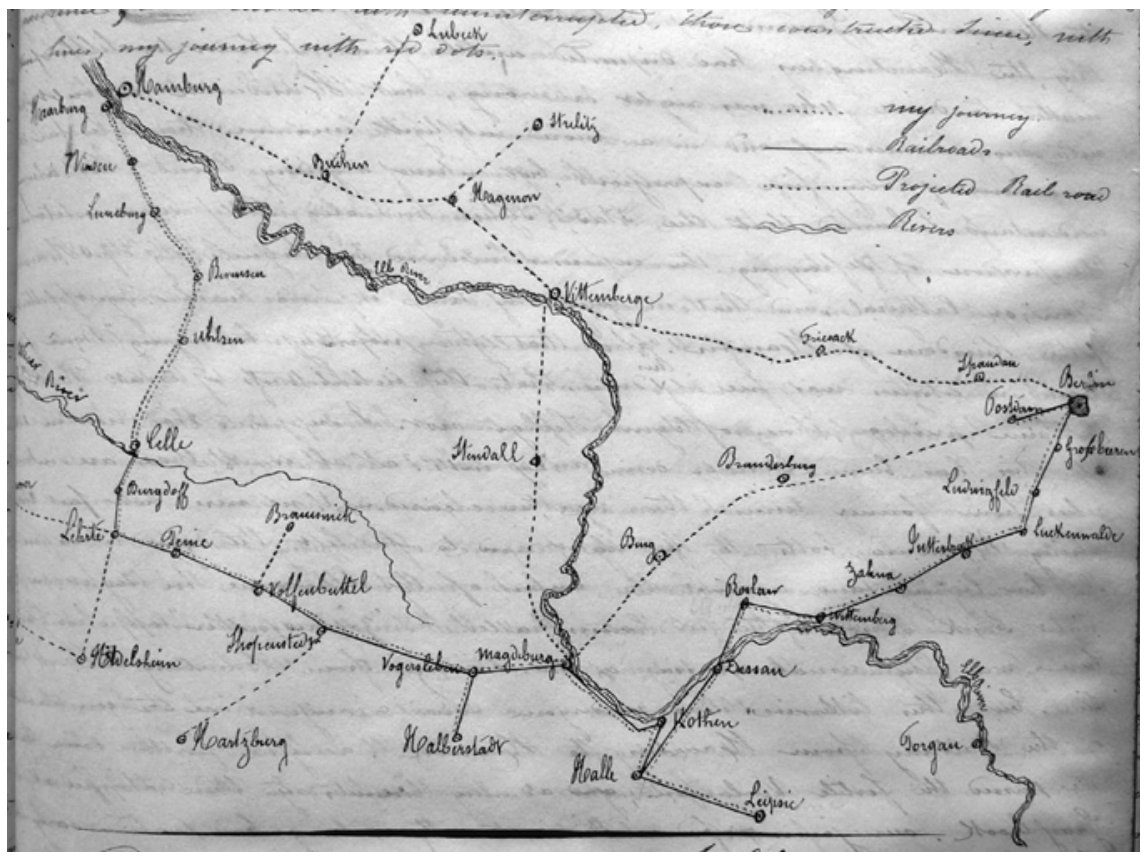

Residence in Altona from $16^{\text {th }}$ to the $29^{\text {th }}$ of September 1844 .

Continuation of Monday, $16^{\text {th }}$ of September 1844. Mrs. Semper gave me some dinner, Semper and Sieveking came, the latter brought me various letters. Gibbs' in London had not been able to purchase any goods on my account, owing to a sudden rise of manufactured articles. Mr. William Gibbs was in Switzerland, and his firm could not fix a place where I might meet him. Mr. Daniel Schutte expressed a wish that we should see each other in Brussels. My friend Sieveking was much opposed to my entering into any mercantile connection with him. At eight oclock I went below to the drawing room, where I found some of the family, [689] viz: Old Mr. Reincke, his excellent daughter Wilhelmina, the lawyer Lübbes and his pretty wife. To please the old gentleman we played a few games at whist, had a nice supper, and separated early. Nothing else was spoken of, but the Altona-Kiel Railway. The trains had already commenced running, however the solemn inauguration was to take place on the $18^{\text {th }}$ instant, the King's birthday. His majesty had excused himself, but this place would be taken by the younger brother of his wife, the governor of Schleswig and of Holstein. The distance from Altona to Kiel is $131 / 2$ German miles, the train runs it in three hours and a half, the fare was $1^{\text {st }}, 2^{\text {nd }}$ and $3^{\text {rd }}$ class $\mathrm{CM} 7.08$, [5], and 3.12 respectively. In order to defray the daily expenses including of course all Salaries and an interest of $4 \%$ annually 
on the Capital invested, it was calculated that the daily earnings must not fall short of 15 to $1600 \mathrm{CM}$. Within the last few days, they had fluctuated between 12 to $2100 \mathrm{CM}$ on each trip. The engine driver who received $1200 \mathrm{CM}$ annually, the conductor and a subaltern attending to each carriage, accompanied the train. 130 men were constantly employed merely for the purpose of keeping the road in repair, and of cleaning away every obstruction which might impede the trains rapid progress. It was the intention of the Directors that the small vessels which brought the Coal from England should sail up the Stör, and then the Brahme, an affluent of the Stör, and deliver their cargoes in a Railroad station close bye, where the coal was to be burned into coke for the use of the engines.

This time my stay in Altona did not exceed a fortnight, during these few days, the kindness and affection shown me by my friends and relations, were the same as on previous occasions. I received many invitations to dinner and evening parties, sometimes two for the same day, when of course, I was under necessity of declining the one. The meetings at the Old Papa Johann Julius's were again more numerous, for the absentees had returned from their Summer excursions, only the Knauers who had not yet come from their country residence, and Edward who walked out to them every evening, as well as the three brothers Hermann, Ferdinand, and Julius who were far off in Foreign climes, in Lima, Montevideo, and England respectively, were wanting to complete the Reincke family circle. Semper had every [_] evening a small reunion, whose members were no doubt more intell [...] folks in the other house, but in neither of the two [...] active part in the conversation as I should have liked to have done, for local interests and of late, the all absorbing Railway, were the topics generally [69o] treated of. On the $23^{\text {rd }}$ of September I received letters from Lima of $7^{\text {th }}$ and $8^{\text {th }}$ of June. The question between Castilla and Vivanco had not yet been decided the latter was retreating before the former in the direction of Arequipa near which place, his strong hold, it was expected he would give battle. Christian Hellmann had been attacked and wounded by highway men on the Lima Callao road. Doña Berna, my wife's aunt, had gained $\$ 500$ in the lottery of which she has presented my wife with $\$ 400$. Mariquita informed me that in about two years John Hayne would leave Gibbs' establishment in Lima, and it was generally reported that the London House was dissatisfied with him, because it was he who had entered on their account in the Huano business; even at the time (1844) I was convinced that these were false reports, for already then Gibbs' must have foreseen that the huano business would leave them great profits, though they could not have dreamed of the enormous proportions which it took in after times. My wife also wrote me that Consul Generals in Peru were allowed to introduce their furniture duty 
free, in this, she was wrong. However, I recommenced my negociations for the Consulate General of Sweden and Norway in Peru, which at the end, led not to result whatever. On Tuesday $18^{\text {th }}$ I dined at henry Sieveking's, this being the $13^{\text {th }}$ anniversary of his wedding-day. On the $19^{\text {th }}$ I supped at Old Mrs. Semper with the family, to celebrate the birth-day of Miss Elisa. The $18^{\text {th }}$ was a grand day, it was the King's birth-day being fixed upon as already said for the solemn inauguration of the Altona-Kiel Railway. Already at $61 / 2$ when I went below, Semper and his wife had left for the terminus where a considerable number of persons met, the Governor of Schleswig and of Holstein, the members of the Directory, of the Comittee and others, both Hamburghers and Altonaers who were invited together with their wives. Arnemann as President of the Directory made a speech to which the Governor replied praising the great efforts and perseverance of all who had had any share in the enterprise, and decorated Arnemann with a Cross of the Knights of Dannebrog. Then the train started; at every station it was received with great rejoicings, on its arrival in Kiel, carriages were ready to convey [...] quay, thence boats across the bay to Dusternbrook, where a sump [...] laid out for them, which being over, the party returned to [...] same manner they had come, they arrived at about 6 p.m. but were received very coolly for as the invitations had necessarily been limited, all not invited were dissatisfied, and this dissatisfaction which prevailed most[_] [691] amongst the lower classes increased, when it became known that Arnemann had taken with him his brother in law and his children. The Directory had employed a Hamburg Hotel Keeper, hamburg upholsterers and Hamburg Musicians; this preference shown to the rival town gave rise to many angry remarks whilst the directory defended themselves saying that they had employed those who worked best and cheapest. An hour was allowed to make toilet and at 7 p.m. the entire party, about 350 in number, again assembled in one of the Saloons in the terminus, where they partook of a splendid banquet, at which as might have been expected many speeches were made and toasts drank, and at about eleven o'clock the party broke up. For this evening Messaw, the owner of the Rainville's hotel had placed his garden at the disposal of the two Altona Lidertafel, or clubs of young men, not professional singers. The entire back façade of the Hotel and the Pavilions were illuminated; there was a pyramid of variegated lamps, and the King's cypher C. R. in transparency. The upper part of the garden was crowded, all the tables and seats were occupied, and as the weather though a little cool was agreeable, a great many persons were walking up and down. The two clubs sang alternately, and the tout ensemble was very pretty. Sieveking having given me a ticket, which was his right as member though not an active one, of one of the Clubs, I was admitted and was well pleased with what I saw and heard. I had dined with Henry 
Sieveking and at the time the train was expected back from Kiel I accompanied the two daughters of Ernestina and a Miss Löhmann to a meadow close to a terminus. Several carriages of the train were adorned with garlands. In the course of the day, I also paid a visit to Clauss Witt, once my fellow clerk at C. H. Donner's see page 514 Volume $1^{\text {st }}$ of these extracts what I said about him. Friday the $21^{\text {st }}$ was fixed upon by Knauer for the launch of a new bark of his called the "Emily". A great many of his friends were invited to be present, I of course of the number, and at half past ten, together with Semper and his wife went to the wharf in the Elbe Strasse where the vessel was on the slip. All the shores were gradually knocked away, but the vessel did not move, Knauer had already told the ladies that they might go home, for nothing $[. .$.$] done this day,$ when all of a sudden the vessel first shook, then slowly and Majestically with all her masts set, slid into the river amidst the loud huzzaing of the multitude. A launch was just passing by, and it was a wonder she was not run down or at least swamped. Next we walked [692] up stairs to a small room in the ship wright's house where Knauer had prepared an abundant lunch. At 7 p.m. in the clear moonlight night I drove with Knauer and several young men, his clerks and friends of his sons, to his Country house in Eppendorff, where Mrs. Knauer, her daughters, and a young friend of theirs, Miss Clara Thompson were expecting [_]. Having taken tea, all the young men, Knauer with a big speaking trumpet in his hand, and a little tinman playing on the mainchord at the head, I bringing up the rear, paid our respects to Knauer's mother, a lady of about eighty years of age, who lived close by. On our return a cold supper with a bowl of hot punch stood on the table. I had my seat between Mrs. Knauer and her daughter Emily. The young people commenced singing, papa Knauer with a stentorian voice and an unmusical ear chiming-in with the chorus. All were in excellent spirits, and I regretted when Mrs. Knauer and Edward insisted upon our breaking up before midnight. For the young men, mattresses were spread on the floor in the dining saloon, I had a small confortable bedroom for myself. The news of the conclusion of the war between France and Marocco was received today. I also read in an Altona paper (the Mercury) that the gross amount of duties levied by the German "Zoll-Verein" (Custom house league) in the three first mths. of 1843 came to 4,373,249 Prussian dollars, in the next three months say April, May and June to 7,161,045 total gross amount for the first six months of 1843, 71,534,294 net. 10,417,879 Pn. Dolrs. In 1844 the duties for January, February, March came to 4,626,041, April, may, June to 7,150,769 total for the six months 11,776,816 net 10,647,482 Pn. Dollrs.

Sunday, $22^{\text {nd }}$ I rose at 6 oclock the windows of my room looked to the East and I saw the Sun rise like a ball of fire, I went to the garden where it was actually cold, dense white vapours ascended from the Alster and from the 
meadow between this river and the Garden. After breakfast, we all started for a long walk to Neudorff, Colla[u], and Lokstedt, villages which lying at a short distance inland from the Alster, and lacking the prospect upon the river, have a less cheerful appearance, than those which extend along the banks of either the Elbe or the Alster. The country houses here, for country-houses there are in every direction round Hamburg, are less elegant, less sought after, but also less expensive, than those in preferable situations. Mrs. Knauer called me to her, I offered her my arm, and we headed the party - after us walked Mr. Knauer by himself, then Edward Reincke with Miss Molly Kelinghausen [693] and the four other young ladies, viz: the Younger Miss Kelinghausen, miss Thompson and the two misses Knauer soon found their partners. Of course I knew George and William Knauer, by and bye I became acquainted with Eckmann, clerck of Knauer, Franck, who was at Warnholtz's, Paulsen's at Gayen's, another Paulsen, a broker, and a few others whose names escape my memory. Mrs. Knauer and I conversed on many subjects, there existed really between her and myself much mutual confidence, of which the following may give an idea. She told me that her husband had in his business B. Mk. 200,000 from his mother at $4 \%$ annual interest, that besides his tobacco manufactory, in which his younger brother Henry was interested with him, he traded mostly in Colonial produce from the Brazils and the west Indies, that he allowed her for house-keeping expenses five hundred Mk. currency monthly out of which she had to defray the cost of her daughters' education, as well as of hers and her Children's clothes, but that all such extras as fuel, wine, tea, Coffee, Candles, etc. as well as an extra silk gown for herself, new suits of clothes for her husband and eldest sons, were paid by Knauer; also that the considerable Christmas presents, came out of his pocket. We were home by half past eleven, an hour later some of us walked, others drove to the Country-house of Mr. David, George Knauer's younger brother, a wine merchant in Harvestehude who had invited us to see from his house some regattas which were to come off on the large expanse of water called the Outer-Alster, a lighter lay in the river behind the garden, on it stood a table covered with many things for lunch. Old Mistress Knauer and several young men who worked in David's business were already there; shortly after, the merchant Stuhlmann, Mr. Lubbes, Caroline Tesdorff, a Miss Osenbrug, daughter of one of Knauers sisters, and some other friends joined us. As soon as we were all seated, the lighter moved a little further out, so that we had an excellent view of the races and of all the surrounding country, the banks of the Alster were alive with spectators, particularly great was the crowd round the public house in Uhlenhorst. The first match was rowed by the members of the Hamburg and of the English rowing clubs in six oared wherries, boats long, narrow [...]; contrary to the general expectation, the Hamburghers gained, 
seven to one having been bet upon the English. There were several other matches, but this was the most interesting. We returned to David Knauers before all was over, for the cold made itself felt. Miss Tesdorff was dressed in silk, the [694] two Misses Knauer in plain white "mouseline" but notwithstanding the French education and the polite air of the former, she was entirely neglected; the two Knauers particularly Emily looked lovely, and it was impossible not to be pleased with them. Emily, her mother told me, was more clever than her elder sister, to me she appeared to be a little devil. Soon after we had reached Knauers house in Eppendorff, dinner was announced, and we went up-stairs to the Dining saloon, only George Knauer the master of the house was wanting, for he had driven to Altona to fetch one of his clerks, Ditmar, who had been working all day. This to be sure was a proof of Knauers good heartedness, and the kindness with which he treated everybody, even his inferiors. At dinner I sat between Mrs. Knauer and the younger Miss Kelinghausen, who very naturally preferred the conversation of her younger neighbour to her left to that of the Elderly Gentleman to her right. After dinner I went for a short time to my room, and again joined the young folks, whom I found dancing, though they had no other music than the manichord of the musical tinman, they were all in high spirits and enjoyed themselves famously; when they stood-up for the Cotillion, Mrs. Knauer requested me to be her partner, and I went on very well, as long as the music played the tune of the waltz of my former days, but when the polka and other new steps were to be danced then I had to give it up, I discovered that I no more belonged to the young world. At half past nine dancing was over, a few songs were sung and at $101 / 2$ Knauer told the young men, that the carriage was ready to take them to Altona. Edward and I accompanied Miss Molly, the two Knauers, the younger Miss Kelinghausen to their house not far off in Eppendorff. When Edward and I returned, the family had gone to their bed rooms; we did the same - I learned a few words of my Italian vocabulary and soon fell asleep. On Monday after breakfast all except Mrs. Knauer had to go to Altona - the two young Knauers rode, whilst Mr. Knauer, his daughters including little Julia, Edward, and I, drove in his carriage. In the course of this week I had to make many calls, to bid good-bye to my friends, for I had fixed upon the ensuing Sunday for my departure for Amsterdam. The weather was very changeable, one night, it was said that the thermometer had stood as low as freezing point, at C. H. Donners and at Mrs. Elmenhorst I already found the fire lighted, in the Chimney place. Now and then in the evening when we had time, Semper and I who were equally matched played a game at Chess. From Gibbs of London, I [695] received advise that they had made some purchases of manufactured goods for me, and that they were about sending them via Liverpool for sale on my 
account to their Lima firm. Kedenbug was unable to purchase the crushed sugar at my limit, which I was glad of. On wednesday $26^{\text {th }}$ I was at a dinner party given by old Mrs. Elmenhorst who for the greater part had invited the members of hers and the Donner's family. There were the old Gentleman, Conrad Henrich, his daughter with her husband Vn. Zahrtmann, the Lieutenant Otto Donner with his Danish wife, a miss King, extremely fair and rather insignificant, Otto's youngest brother Arthur, their sister Betty with her husband Gossler, their mother the widow, also Bernhard, C. H. Donner's son, and Theodore Elmenhorst. Of the other grand section of the Altona world the Reincke's, there were only Knauer, Warnholtz and his wife. I led to the dinner table Mrs. Otto Donner, on my left sat Mrs. von Zarthmann. Everything went on in the manner I have so often described, there was the usual smoking, Cardplaying, tea, and conversation with the ladies, I fetched the drawings of my Lima Costumes, which afforded some amusement, and we broke-up at about midnight. The next day, thursday, Warnholtz and Theodore Elmenhorst, who it will be remembered were partners under the firm of Elmenhorst brothers, had invited a Mr. Wilson and his wife from Hull, who passed by through Altona on their returning from Germany to England, to dine with them at Rainville's hotel, and had begged me to join them. Conversation was carried on exclusively in English, which language Mrs. Warnholtz understood fairly, but did not venture to speak. I was surprised at the fluency with which Warnholtz expressed himself for he had never made any long stay in England, Theodore and Constance his wife who had resided several years in London spoke of course very fairly. I myself made two mistakes I said Victory's char instead of Car, and exposed, instead of subject to sea-sickness. Mrs. Wilson observed that I pronounced the Th, badly saying $\mathrm{D}$, instead of $\mathrm{Th}$, but in this I know she was wrong. Saturday I again dined out, though it was only pot-luck which I took with Gustavus Schmidt and wife. Sunday early in the morning I accompanied Semper to the terminus to see the trains start for Kiel, there were not less than seventeen wagons, each with six coaches, and each coach with an average of ten passengers; consequently there were from Eight to goo passengers. At 11 oclock another Sunday extra train was to start, by which Johannes Reincke, George and William Knauer thought of going to Kiel for a dance. Thus [696] there seemed to be no doubt, but that this Railroad would pay well. The weather was foggy, it cleared up by and by, and we had a finer day, thermometer at 10 a.m. 13 R. $=60$ F. The whole forenoon was taken up by a great many calls which I made in Hamburg and in Altona. From the music master Reinecke I fetched a diary kept by Charles Ropsy whilst travelling in Italy which I thought might be useful to me when visiting that country. For dinner the Lawyer Stuhlmann had embargoed me; the party assembled numbered no more than 
twelve persons, but everything was nice, without extravagance. I was requested to lead Mrs. Stuhlmann at the dinner-table, which meant to say that I was the most honoured guest. I met there my old fellow Collegian Otto Lange, also a brother of Stuhlmann's, Conrad, who lived as a private Gentleman in Hamburg, further a young Mr. Kock, a handsome young man with an aquiline nose, mustachios, and a pointed beard. As merchant he had not succeeded, and nature having gifted him with a splendid Bass-voice, the Directors of the French opera had, he told us, offered him a large salary if he would go on the stage; but this he said, he could not think of doing, as long as his mother was alive, who was decidedly opposed to it. He and Miss Tesdorff sang together, accompanied on the piano by Mr. Marxen, the music master. I played whist till nine, then I bade them good-bye, they all wished me a happy journey, and I hastened to Sieveking with whom and family I partook of a fruit soup. He accompanied me to Sempers where I had still to pack-up some trifles. I bade farewell to my kind hosts and with Sieveking and his porter who carried my luggage walked down van der Smissens Alleé, to the Elbe Strasse, where close to the quay a boat was waiting for me - I suppose it was now about ten oclock. I stepped in, and commenced "mon grand tour".

\section{Voyage fm. Altona to Amsterdam, and journey through Holland, Belgium} up the Rhine, through Zwitzerland to Genoa; thence, by Sea to Marseilles and Algiers; back to Genoa; by Sea to Naples, to Sicily, back to Naples; through Italy, Southern-Germany, Bohemia, Silesia, Saxony, to Bremen, and finally to Altona; from $29^{\text {th }}$ of September 1844 to 15 July 1845 . [697]

Sunday, $29^{\text {th }}$ of September 1844. (Continuation of) It was a mild clear moon light night, the boatmen dipped their oars into the water and off we rowed through the midst of the vessels which filled the ports of Altona and Hamburg, there lay these huge masses, now silent and motionless, all hushed. Not a single human being seemed to be stirring, and the solemn tranquillity of the midnight hour was only interrupted by the regular splashing of the oars, and by the occasionnal sound of some English sailors' voice. We hailed the Hamburg guard-ship, told the Officer who we were, and whither we went, and without being detained reached the Dutch Steamer "Willem den Eerster" which was lying far in, amongst the numerous shipping. I stepped on board, my luggage was handed-up and I found as yet only two passengers, namely: a Jewish Gentleman, son of the rich Hamburg merchant, Moses Salomon Fränckel, and an officer in the Dutch East Indian Service, a native of Kiel, called Sehstedt, who told us that he had resided seventeen years in Java, and that of late, he had been on furlough, which would expire on the 
$1^{\text {st }}$ of October - he was a talkative Gentleman and kept me in conversation till past midnight, when I turned in, and soon sleep put an end to the many thoughts which crossed my brain.

Monday, $30^{\text {th }}$ of September 1844. At three Oclock when the Steamer got under weigh I awoke, and in a few minutes was again asleep. At 8 a.m. I went on deck; on the Holstein side we had a village with a Church steeple, the name of which I did not learn. The sun shone brightly, but the stiff wind from the west blew right into our teeth; the waters of the Elbe were of an ugly yellowish Color, and much stirred-up. At nine oclock breakfast was placed on the table, to which the Gentlemen sat down. Two ladies remained on deck, whose acquaintance I soon made; I learned that they came from Riga, travelled by themselves, and were bound for Switzerland, the Elder of the two, about forty years of age was very communicative, and rather plain, the younger one very delicate, reserved, and lady-like. At half past ten we stopped at Cuxhaven where one of the passengers who left had great difficulty to get into the boat, so violently did the waves beat. At twelve we were between the light-house and the houses of the NeuWerk on our Larboard, and the breakers of the dangerous Vogal Sand, on our Starboard side, this is a sand bank of little width from North to South, but of a considerable length from East to West. Upon the same, many a fine vessel has been wrecked, many a brave crew has been lost. At One p.m., sea-sickness got the better of me; I went below to my berth where lying down, I whiled away the time with reading [698] Coningsby, a novel by D'Israeli, which, though written for political purposes about the year 1832 at the time of the passing of the Reform bill, was nevertheless very interesting.

Tuesday, ${ }^{\text {st }}$ of October 1844. I did not rise until one oclock, when having entered the Zuyder-Sea between the islands of Terschelling and Vlieland from the latter of which a custom house officer came on board, the motion of the steamer was considerably less, and I of course had no more to suffer from the abominable sea-sickness. The weather was very disagreable, thus nearly all the passengers remained below, reading and talking until four p.m., when we sat down to a good dinner. The party was upon the whole very agreeable, we were: Mr. Bendixen, a baptised jew, established as Banker in Stockholm, with his two daughters the one married, the other single; a German Gentleman whose berth was above mine, reserved towards all, very polite towards me, a Frenchman who had travelled all over Germany without having learned a single word of the language; an officer in the Russian Service; a very gay young man from Stuttgardt, Franckel, Sehstedt, and myself. The afternoon was spent like the forenoon. I also gained some games at Chess from Franckel. At midnight we came to an anchor outside the Pampas, a mud bank just at the entrance of 
the port of Amsterdam, which vessels cannot pass at lower water, and all the passengers retired to rest.

Wednesday, $2^{\text {nd }}$ of October 1844. At Six oclock when I went on deck, the steamer lay at a short distance from the quay; it rained continually, thus the aspect which Amsterdam presented was far from cheerful. This town lies in an extensive half circle round the Southern Shore of the Y, an arm of the ZuyderSea. As soon as practicable, Fränkel and I got a boat, and having landed, we requested a porter who took charge of our luggage to show us the Hotel which was recommended to me called the Karnalen Doulen. The meaning of Doulen is the Guild, or corporation of Arches, whilst Karnalen means small craw-fish, the spot where now the hotel stands having formerly been the market place for the sale of this kind of shell fish. The room given to me was in the back part of the house, low and dark, the window of which looked on an inner yard, but was carpeted, and otherwise very convenient. Having breakfasted in Company of Fränkel, the waiter informed me that Mr. Daniel Schutte lived in the same hotel, and that he had already been inquiring for me. I went to see him, we had a long conversation on many topics, also some talk about our future mercantile plans which however led to nothing. We walked out together, I bought [699] a plan of Amsterdam and an umbrella, for it rained incessantly. We then went to the Counting house of the great commercial firm of Hope \& Co., to one of whose partners Ernest Sillem, Bernard Donner had procured me a letter of introduction from his brother, the same who some years previously had dined with me in Lima, thus his brother Ernest showed me immediately the same attention and I willingly accepted his kind invitation. At Poel \& Cos. I only found two youngsters, and left with them the letter of introduction from Sieveking. On our way to these counting-houses we passed through some of the principal streets of Amsterdam which go by the name of Grachten, a canal runs through the middle of the street spanned over by innumerable stonebridges, and lined on each side with a row of trees. Of the houses high and large, hardly a single one was stuccoed over, not a few of them were adorned with slabs of marble, the window panes frequently of thick mirror glass, are kept uncommonly clean, and thus shine with a brilliancy not met in any other town, this cleanliness distinguished even the houses of less pretension. In the streets nearer to the quay through which I came on my first landing and where both, streets and houses bore a great resemblance to the old part of Hamburg not destroyed by the fire of 1842 , I also observed that many of the small houses were not built straight; on the contrary, the upper story leaned over a little, which I was told was done purposely with the object that packages hoisted-up might not touch the lower part of the wall. With Schutte I visited an exhibition of paintings exclusively by living Dutch masters, where we saw many pretty 
things. Next we went to the provisionnal exchange opposite the Palace; it was nothing but an open place with a covered walk around, a poor concern indeed, nor was it much frequented, and even in that quarter where business was being done in public securities the Jewish brokers were the only ones who kept-up a continual noise, and gave some signs of activity. Having still some time to spare we walked on to have a look at the docks which as everybody knows, are large basins with water, but these in Amsterdam were neither filled with so many vessels, nor kept in such a good repair as those in London. Also here the houses and streets resembling the Hamburg Vor-Setzen though wider and longer were kept nearly as clean and the windows as brilliant as in the more genteel parts of the town. At five oclock Schutte and I went to Mr. Ernest Sillems dwellinghouse where a servant received us, and showed us to the drawing room. Here Mr. Sillem introduced us to his lady, to a mistress Schroeder, sister of Bernard Donner's wife, and to the Elder of the two Russian ladies whom I had seen on board the Steamer. When dinner was announced, I did not offer my arm [700] to any of the ladies present, and as will be seen by the sequel, was well rewarded for this my reserve. The drawing room was carpeted and in every respect furnished and fitted up with elegance, and in the comfortable English style. At dinner we sat as follows: Mrs. Sillem at the head of the table, to her left a Hamburgher, Mr. Albert established in Matanzas, then Mrs. Schroeder, a dutch Gentleman, Mr. Van Hammert, a vacant chair, myself, another vacant chair, Mr. Sillem at the foot of the table; to his left one of his children, Mr. Schroeder, an Englishman who spoke German fluently, a Mr. Clockman, Mr. Alberts agent, the Elder Russian lady, Schutte, and again Mrs. Sillem. Hardly had we taken our seats when the younger Russian lady came in and occupied the vacant chair to my right, she immediately recognized me, we entered into conversation, which we kept up during the whole time we were at dinner in a manner which I confess was to me very agreeable; so much was I taken up by my fair partner, that though the dinner was excellent, I hardly noticed what I ate, also the wines were first rate. I stuck to the red Champaign. Even when the remainder of the party were silent, my lady who did not exchange a single word with her neighbour to the right, and I were chatting away, and I noticed that her companion observed our quickly ripening intimacy. She told me that she was of a noble family, that her father was a Russian, her mother a German; that they resided somewhere to the South East of Moscow, but that of late she had been living for some time in Riga with her friend Mistress Pfeil. Her name was so Russian that I could not keep it in my memory. She and her friend were now on their way to Vevay in Switzerland where she was to try the grape cure, that is to say: that during the whole winter she was to live exclusively upon grapes and a little bread. She had sput blood, and was no doubt consumptive. 
I really pitied her, for more than once she put her hand upon her chest, as if the pain she felt there was not to be borne. Besides Russian she spoke German perfectly, also French fluently, she was not exactly handsome, but very fair and genteel. When we rose from the table I accompanied her to the drawing room but at Mr. Sillem's request, had to return to the dining saloon where the Gentlemen remained taking wine. Some smoked, coffee was brought-in and English and German were the languages used indescriminately. On our return to the drawing room Mrs. Sillem presided at the tea-table, I took my seat near my Russian friend who as a good patriot defended the Russian Government against the aspersions cast upon it by Mr. Custine in his recently published work. Schutte, afterwards Mr. Sillem joined us. Mrs. Pfeil told me that I might inquire for her and her companion in Frankfort [701] at her uncles who lived in the second or third house outside the Pfar Thor. The party separated at half past ten, but as it was too early to go to bed, Schutte and I promenaded the streets; they were very dirty, had no foot-pavement, nor were they lighted up with gas. The Shops which might be compared to the second class in London had gas-lights.

Thursday, $3^{\text {rd }}$ of October 1844. Through the intervention of a "valet de place" it was arranged that a Dresden Baron and his lady, my fellow passengers on board the Steamer fm. Hamburg, and I, should devote this forenoon to the new town house and the Royal Palace. The former contained but little of interest. We were shown to many saloons in which the Burgomasters, the Senators, and other high authorities of Amsterdam were in the habit of holding their meetings. The walls like those of several corridors through which we had to pass were adorned with the portraits of the members of the Archers-guild of various periods. The rooms were carpeted, in the centre stood a large table covered with green baize, upon which lay the necessary writing implements, round the table, arm chairs with thick and softly stuffed cushions, all embroidered with the Dutch arms. Up-stairs in the so called model room we saw a model of the new palace, models of cannons, some ancient armour, old muskets, two [Vasees] in the shape of small vessels which de Ruyter had carried at the mast head of his flag ship, also some house breaking instruments and a ladder used by a notorious burglar who lived about a century back, as well as the instruments with which he was tortured at his execution. Certainly all this was not much worth seeing. The present Palace was originally the old town house, Louis Napoleon was the first who resided in it, and after the peace of 1815, the town of Amsterdam presented it to their King William I, since when it has continued to serve the purpose of a Royal residence. It is built upon 13,857 piles driven into the marshy ground upon which the whole town of Amsterdam stands, and there is not one house in this place which does not rest in a similar 
manner upon a foundation of piles. The Palace which was commenced being built about the year 1648 and concluded in 1664 is in my opinion a handsome solid somewhat heavy edifice, though "la revue des Deux mondes" as the "Manuel des Etrangers" observe, has declared that it has the appearance of a barrack. For a detailed description of it I refer to this guide book (Le manuel des Etrangers) and will confine myself to a few particulars. In a Vestibule stood a Statue of Ignacio de Loyola, to find here this statue caused me some surprise, for every body knows what misery those who thought like him have brought over the united provinces [702] under the reign of Philippe II. We were conducted through a number of apartments, carpeted, well furnished and of an extraordinary height. The stupendous height of the principal saloon has a striking effect upon the beholder, it is not so tastefully adorned as the marble saloon in the Postsdam Palace, but in size it still surpasses it, it measures one hundred feet in height, one hundred and twenty feet in length, Eighty in width. The floor is of marble, then boarded and covered with a carpet. The furniture and window curtains required being renewed, and here as well as in the other rooms through which we passed not one of the many mirrors was of an entire piece, all consisted of two or three pieces put together. On one of the walls hung a large painting representing the heroic dead of a Dutch Naval officer Van Spyke who during the last war, when the French besieged Antwerp, which was defended by the Brave Chassé, set fire to the powder magazine of his vessel, and blew himself up together with a number of Belgians. We ascended to the Cupola on the top of the Palace whence notwithstanding the foggy weather, we had a pretty extensive view. The rain however drove us soon below. Thence the Baron, his lady, and I, went to an Oyster-shop, where we regaled ourselves with Oysters and Porter, whereupon we separated. By myself I called at the country house of Poel \& Cos., where I was told that Mr. Poel was unwell and could not be seen. On my letter of credit I took fifty florins. Next, accompanied by Daniel Schutte, I paid a visit to the picture gallery belonging to a Mr. Van der Hoop for which Mr. Ernest Sillem had procured us a ticket. The splendid extensive house of this very wealthy Gentleman seemed to be unoccupied, and the collection of paintings of ancient Dutch masters was undoubtedly superior to that which we had seen on the preceding day. Even the unexperienced eyes of Schutte and myself could discern the difference. At half past four table d'hote was ready in the Hotel to which fourteen Gentlemen and two ladies sat down; German and French were the languages spoken. Dinner was abundant, we had a great variety of meat including game, no fish. Schutte kept me company in my room till near eight oclock when we went to the Dutch theatre "des Varietés", a small house, the audience far from select. The admittance cost no more than seventy five cents of a florn., for which a ticket was given which entitled the holder to a 
glass of refreshment. A drama and a farce were performed but my knowledge of the Ducth was so limited, that I could not make out the meaning of them. I merely guessed that the polka was the theme of the latter. I was in bed before eleven oclock. [703]

Friday, $4^{\text {th }}$ of October 1844. This day I again spent with Baron and Baroness Haugk with whom and a valet de Place I walked passing through the handsome street called Heeren-Gracht to the western dock which serves for vessels of smaller size than those which fill the Eastern dock visited by Schuttte and me on the previous day. At this Western dock we took a boat and were rowed across the $\mathrm{Y}$ to its northern bank, and landed close to the mouth of the large Canal which I see by the map connects the Y in one direction with the Zuydersea near the town of Hoorn, in the other, passing the town of Alkmaar, with the North sea near Nieu we Diep opposite the Island of Texel. I was told that its construction had cost fourteen millions of Florins, that it was twenty five feet deep, that even men of war could pass through it and that its principal object was to avoid the mud-bank called the Pampas in front of the harbour. My valet de place said, but this information I give for what it may be worth, that this canal is raised eight feet above the low land which lies on the other side of the Dyke, while the level of the sea is again at an elevation of eight feet above the Canal. As soon as we had stepped on shore, we engaged a coach for the day which cost us ten florins besides one florin to the Coachman. We drove along on the dyke having the canal to our left, on the other side of which the richest meadows imaginable afforded excellent pasture to large numbers of grazing horned cattle and sheep. After a short while we came to Buicksloot, nearly all the houses of which village were painted green, and the streets were paved with yellow bricks. Here we had to pass a canal over a bridge, and then continued our drive over a similar dyke as far as the village of Brook. On our way thither our Valet de place made us observe that the many wind mills which we saw in the low laying meadows served for raising the water from the Canals which intersect and drain the land and to throw the water into other canals which disembogue into the trunk canal. Upon this latter I saw for the first time the Trek Schuyten, the well known travelling conveyances in Holland; long boats with a cabin in the middle for passengers, drawn by horses which trot along on the shore. Other vessels were pulled in the same manner. The village of Broek is famous for its extraordinary, I may well call it extreme and ridiculous, cleanliness. The houses are not all built according to the same pattern, but the general rule was that the street door was only used on extraordinary occasions such as marriages, christenings and funerals. I even observed a few doors which though some feet above the [704] level of the ground, were without steps leading up to them, a clear proof that they were only for show, and that the side 
doors were those for actual use. Besides the yellow bricks which intermixed with bricks of other Colors formed very pretty patterns in the pavement of the streets, other characteristics of this strange place are: flower-gardens, stiff clipped hedges, narrow canals with equally short stone-bridges, and the custom of the inhabitants, who are said to be very rich and to number about one thousand, to sit in their rooms behind their clean cotton curtains peeping at the strangers who pass by. At one window we saw the Burgomaster and his wife indulging in this innocent pass-time; the lady had her head adorned in a peculiar manner, both temples were covered each with a piece of leaf gold hanging down from the hair to which it was fastened some way or other. On a placard I read that before sunrise and after sunset smoking in the streets was prohibited, also that the smokers in the day time must have their pipes well shut-up with a lid; finally, that everybody who comes to Broek on horseback must alight, and lead his horse through the place. The Canal widens here considerably; close to it lies the garden of a Mr. Van den Beck which in its kind is a curiosity. It is kept in excellent order, has a hot house with some exotics, but what most calls the visitors attention are a small summer house with a wooden figure representing a clergyman, another cottage with a wooden huntsman, a pond with a wooden Swan and a wooden Triton, a small bridge made of roughly hewn trunks meant to imitate a Swiss scenery, a small cottage said to resemble the houses in which the people of Broeck lived and made their fortunes one hundred and fifty or two hundred years back. In the same you see on entering two wooden figures badly carved, in the dress then used, before them a spinning wheel, a common table with some earthenware upon it, an imitation of black bread, of a cheese, and of a prayer book or Bible, also a little dog alongside, all made of wood. A machine was wound-up, the wheel moved and the dog barked. Having seen all what was worth seeing in that queer place, we remounted our carriage. On our return to "Buiksloot", our Valet de place requested us to alight at a common farm for the purpose of showing us the extraordinary cleanliness which prevailed in the whole establishment, in the Cow-house, in the dairy, in the sitting room, in the bed room, etc., in short every where. The floor of the Cow-house where the cattle lay down when coming in from the field was strewn with pretty small shells, their tails were then tied-up that they might not trail on the ground [705] and get soiled. Some metal pots and spoons which stood on the shelves were so bright that it seemed as if they stood there for show rather than for use. We continued our drive on the dyke till we reached Zaardam a place with 10 thousand inhabitants, distinguishable from a considerable distance on account of the many wind mills, my guide book says three hundred and fifty eight, which surround the same, and which mainly serve for grinding rape seed and extracting the oil. 
Zaardam ressembles Broek, there are in both places stiff flower gardens and many small canals with bridges across them, but at Zaardam the cleanliness is at all events not carried to such a ridiculous pitch as it is in Broek, here was activity and life in the streets, whilst in Broek there was neither the one nor the other. A canal with several locks connects the Zaar with the Y. The greatest curiosity in Zaardam is a small wooden hut, which the Czar Peter the Great inhabited in the year 1697 for ten months, when he was working here as a common ship Carpenter under the name of Peter Baas; plain as it is, the walls are now covered with innumerable names. The wooden table and three wooden chairs which the Czar used, also the alcove in which he slept are still preserved. Inside hangs on the wall a full size portrait of the Czar in his carpenter's dress presented by Mr. Van der Hoop, partner of Hope \& Co, who I may say "en passant" was in 1844 a great horse fancier, whose horses had gained many a prizes. Outside, on the walls of a vestibule built of course since the hut served as the residence of the great reformer, are inscribed in gold letters the names of many members of his posterity who within the last thirty years had visited this spot. Our valet de place related as a fact that when Napoleon I came thither he refused to enter, saying that this was not a place fit for an Emperor. In an inn called the Otter we had a good dinner, [Bucht], in German bütt, boiled in water with bread and butter in the Dutch style, beefsteaks, veal cutlets with vegetables, also preserved ginger, a bottle of good wine and Coffee. The Baron and Baroness observed that the forks, knives, and plates were not quite clean, and I believe they were right. Looking out of the window we had before us a landscape which a dutch painter would have delighted in drawing; close to the quay upon which workmen were putting up booths for a fair to be held within a day or two, small vessels were at anchor, other vessels sailed about on the quiet expanse of the $\mathrm{Y}$, and at a distance a narrow neck of land with houses and wind-mills was distinguishable. It was now about six oclock, we drove back to the same spot where we had landed in the morning, and were rowed over to the [706] Amsterdam side. On our walk home, we passed through the streets called Den Nieuwe Dyk and Den Kalber Straat, both my companions and I were well pleased with the handsome shops, lit-up with gas. Settling our account with the valet de place was not an easy matter and cost us dear. I bade good by to Daniel Schutte who at eight oclock went on board the Steamer for Hamburg, the Russian ladies had left in the morning for Franckfort.

Saturday, $5^{\text {th }}$ of October 1844. At half past five I rose by candle light, at half past six the Stuttgard Gentleman, one of my companions on board the steamer from Hamburg, and myself, drove in a small carriage to an omnibus which conveyed us and other passengers through the whole length of Amsterdam to the Railway terminus, a plain brick building. My want of knowledge of the language was a 
great inconvenience, and though I made myself pretty well understood with German and French, these languages did not carry me through everywhere, and I was very thankful to my Stuttgard friend, who knew a little of Dutch, for the assistance he rendered me. Here, the same as in Germany, tickets were given for the luggage, I took my seat in a second class carriage called "char a banes", much inferior to the same class in the neighbouring country. The seats were mere wooden benches, the backs, leather straps, there were glass-windows but on the other hand, though smoking was prohibited everybody smoked. On leaving Amsterdam I noted the many wind-mills in its vicinity. The country through which we steamed had the usual Dutch Character, rich low l[y]ing pasture-land intersected by Canals, and covered with horned cattle and sheep. Haarlem is situated due west from Amsterdam. On our way thither we had to our right the $Y$, to our left a canal then the Haarlem lake. This canal continues as far as Leyden, crosses there a branch of the Rhine and joins the Meuse near Schliedam. Hardly had I alighted at the terminus in Haarlem, when a number of little black guards offered theirs services. I chose one of them to serve me as a guide, with him I walked through the town much resembling Amsterdam. There are canals and bridges, foot pavements of yellow bricks, not separated by gutters from the carriage-road, and many old fashioned houses with gables in this shape $\Omega^{2}$ : invariably with brilliantly shining windows, the same as in Amsterdam the servant girls are continually scrubbing and cleaning, one may say that they live in the water, for which reason I suppose, they, as well as the men, women and children [707] of the lower classes wear big clumsy wooden shoes. Close to the principal church stands a monument erected in memory of Laurence Koster whom the Dutch look upon as the inventor of the art of printing in 1423 , contrary to the general opinion that this invention is due to Guttemberg. In a dense wood mostly of beech trees called Het-hout a little out of town which incloses a park and Royal residence a pretty small building, another monument is erected to the same Koster. The country houses round Haarlem are small and insignificant. This town it will be remembered was during the last century celebrated for the splendid tulips reared here, which fetched enormous prices all over Europe; recollecting the great reputation of former times, I entered the garden of a florist Messrs. Eiden \& Co., but found here nothing worth noticing unless it be the great politeness of the man who showed me round, and who spoke a little german. Round the walls of the town runs a ditch spanned over many bridges. My little conductor took me this way till I came to the Buiten Sparren, a small river near the Railway terminus which provides the ditch with the water. Along the Buiten Sparren I continued my walk through Boulevards laid out in a manner similar to the promenades on the Hamburg ramparts, and waited in a Coffee-house until half past ten when 
another train arrived from Amsterdam in which I continued my journey to Leyden. The country which we traversed did not present the slightest variety except a few sandy downs which I noted about half way towards the sea-side. The terminus in Leyden lies outside the town, I took a guide and requested him to show me to the principal streets which are again more or less the counter part of those in Amsterdam. It being saturday, market day, there was much activity especially in a street called Buisten Markt, the canals were filled with vessels, and a large bridge over the principal canal, most likely a branch of the Rhine which finds here its way into the German Ocean, was pointed out to me as the Corn exchange. I also observed many handsome shops, where manufactured articles were exposed for sale. Leyden which is famous for its University, has two museums, the one quite unique, at least so it was in 1844, was that of a Mr. Von Sieboldt which contained exclusively Japanese curiosities, mongst others, a small domestic Altar upon which stood four tablets inscribed with gilt Japanese Characters, exactly similar to that which I had seen in Lima in 1842 (see page 786 of $1^{\text {st }}$ Volume) with the only exception that these in Leyden were smaller. The other museum, that of natural history is if I mistake not the largest in Europe. There are immense saloons filled with skeletons, stuffed animals of all descrip- [708] tions, quadrupedes and Bipeds, with minerals, shells, etc. I remained so long in examining the skeletons, that I had hardly leisure to throw a hasty look upon the remainder, by far the greater part of the collection and had to make the best of my way to the terminus where I arrived just in time for the train which at half past two started for the Hague. Again we had the same country, and the Hague though the Royal residence was in noway different from the towns hitherto visited by me in Holland. I took up my quarters in the hotel called the "Boschsche Veerhuis" where at four oclock I sat down at table d'hote, good and nice in every respect. My neighbour was a Gentleman from Tunis who spoke French, next to him sat Captain Sehstadt from on board the Steamer from Hamburg, then Baron and Baroness Haugk, opposite a young Dutch Gentleman who spoke French, thus at all events, I could converse a little and learn what was going on in the world. At a later hour I went to the theatre, a small but very neat house. At the recommendation of the young Dutchman I took my seat in the "Baignovies", the name given to the boxes on the same level with the pit. These I was told were only frequented by females of easy virtue. However, three ladies genteelly and decently dressed who took their seats near me did evidently not belong to this class; I more than once attempted to enter into conversation with them, but they were so reserved, and answered so dryly, that I soon gave it up as a bad job. When the Queen entered the Royal box, there was some clapping of hands, I could not distinguish her features, but I saw that her face was pale and her hair black. A small opera "La Sirene", words 
by Scribe, music by Aubert, was performed, but did not please me; there was a great deal of speaking, little singing, and the instrumental music as far as I could judge, indifferent. Madame Flamand, "La Sirene", I liked best when I did not see but heard her sing behind the stage. It was over at ten oclock, and it rained fast when I walked home, I read the papers in the general room, and went to bed at eleven Oclock.

Sunday, $6^{\text {th }}$ of October 1844. Baron Haugk came to my room, and we arranged a joint excursion for the day. We, together with the Baronness, drove first to the Bazaar, a beautiful shop filled with fancy articles and knick-knacks, which though this day was Sunday, was open to us as strangers. The girl who showed us round, though not pretty, was pleasant, and we understood each other, she speaking Dutch, I German. The Baron bought nothing, I a very neat small case of thin marble with gilt ornaments, for which I paid six guilders. I will say in anticipation [709] that it broke to pieces before reaching Altona. A fine avenue leads from the Hague to the village of Scheveningen on the sea-shore. We drove thither, and having alighted at the bathing establishment where we took some Chocolate. We walked to the beach which stretches as far as the eye reaches from North to South and along its whole extent the German Ocean breaks in one long uninterrupted line of surf. Accustomed as I am to the sea and sea scenery I never get tired of the rolling waves, and I can look at them for hours and hours; so they have rolled for thousands and thousands of years, so they will roll to eternity. The Baroness who never before had seen the wide Ocean for I believe during our passage from Hamburg she never left her berth was highly delighted as may well be conceived. Having collected some shells for our fair companion, we climbed up one of the downs, a mere sand hill covered with a coarse grass; several small vessels were lying high and dry on the beach. We returned by another road along a canal whose waters like those of many others which I had seen of late, covered with a nasty green slimy matter stood very high only half a foot, or at the utmost a foot lower than its banks, and came to Het-Boss, an extensive wood kept in good order. Many people were promenading, mostly of the middle class. Of the females hardly one could be called good looking. A military band was playing, and having listened to the music for a short while my companions and I went to have a look at a small Royal hunting lodge which lies in the middle of this wood. Its outward appearance is plain, also the apartments through which we were shown present nothing of interest, they were neatly and tastefully furnished, by no means with Royal splendor, all were carpeted, the curtains in many instances of China embroidered silk and the covers of sofas and chairs were of the same stuff. A circular room with a cupola, the walls hung with paintings partly allegorical, partly representing scenes in which the Princes of the house 
of Orange have distinguished themselves, is the handsomest apartment, and is called the Orange saloon. Another spacious room is hung with the portraits of the same family. We were back at our hotel in time for dinner, and at half past six, we, that is to say the Baron, Baroness, and I, started afresh, this time not by Rail but in a carriage drawn by horses which conveyed us to Rotterdam. Darkness had set in, thus little was to be seen, but what I could distinguish, was a level land with an occasional glimpse of a canal. We alighted in a hotel, the Adler; my companions retired to rest, but I, not yet inclined to go to bed [710] took a stroll through the streets lighted up with Gas. In the principal street called the Hoog-straat in which the hotel was situated, there was little life, all was quiet and decent, but walking to the end of it, and turning to the right I came to a very Sodom and Gommorra, sailors and public girls held here their undisturbed sway, seven or eight of them singing or rather Bawling aloud, arm in arm, took up the whole width of the street. From a number of public places such as the London-tavern, the London-Packet, etc., music, laughter, and all kinds of merriment resounded. A mere cotton curtain concealed the unhallowed scenes within from the public gaze, and I for a certainty did not venture to lift-up this curtain. I walked back, took a light supper, and turned in.

Monday, $7^{\text {th }}$ of October 1844. At an early hour the Baron, the Baroness, and I, drove to the quay where we went on board of a very small steamer. We three were the only first class passengers; the lady remained below, the Baron and I notwithstanding the rainy and foggy weather stayed on deck. Our course was Eastward up the Meuse, the banks of which river, extremely flat and low, were covered with long coarse grass reeds, and trees down to the very waters edge. At some distance inland many wind-mills were distinguishable; to our right we had the Island of Isselmonde, to our left various small places where vessels were being repaired; their names are Nieuwe Lekkerland, Kinderdyck and others. A narrow strait of the river running to the South East brought us to the town of Dordrecht just in front, where we went on shore. This town, which lies on a small Island formed in 1421 by an inundation which destroyed seventy two villages, and one hundred thousand of their inhabitants, is famous on account of the Synod of Protestants which met here in 1618, the resolutions of which still constitute the laws of the present Ducth reformed Church. We entered the town under an old fashionned gate-way, with a round tower on the top, walked through several streets in which great tranquility prevailed. Many houses like those in Amsterdam were built in such a manner as not to stand quite perpendicularly. We returned to our steamboat, and continuing our course to the South East emerged erelong in an open expanse of water, perhaps as wide as the Elb between Hamburg and Haarburg, one of the many branches of the 
Rhine which where it disembogues into the North-Sea, is called the Flakke. Generally the helmsmen are prohibited from conversing with the passengers on board, less by doing so their [_]tion might be distracted, the phlegmatic Dutchman who was at the helm of our steamer, quitely smoking his pipe, made an exception to the General [711] rule, he answered freely to every question which I asked him. We landed at a small village called Moerdyck, where a diligence awaited us; we drove on through a level uninteresting country, by and bye however we descried corn fields. Hitherto in my whole journey though Holland I had seen nothing but pastures lands and kitchen-gardens. At 12 1/2 we arrived at Breda, an extremely strong fortress which since the sixteenth century has undergone many a long and hard siege; the walls are low, but the wet ditch round the same very wide. We had to cross several bridges before entering the town, where we dined at the Zwaan's logement, the inn at which the diligence stopped. Having a few minutes to spare, I took a quick run through some of the streets, and up the ramparts where I was overtaken by a violent shower of rain which detained me so long in a rope-walk where I took refuge, that I nearly missed the conveyance which took us to the diligence expected from Amsterdam. This conveyance was an extraordinary vehicle, a kind of gig, covered over, which rested upon two wheels, and had two seats; the hind one occupied by the Baron and his lady, the fore-one by the driver and myself, the covering, open in front, was made of a coarse white stiffened linen with one window on each side and one behind. The driver in his blue frock coat (the French blouse) was quite an original and afforded us much amusement. In a pot-house alongside the turn-pike road, we had to wait till half past three oclock when the diligence made its appearance; there was no room in the coupé, and also in the body of the coach there were only three seats empty, for my companions and myself. Henceforward it was a very dull drive though the level country, not a single object called my attention, and on my arrival in Antwerp I recollected nothing whatever of this part of my journey. The last place in the kingdom of Holland through which we passed is called Groot-Zunder; the name of the first in the Belgian territory has escaped my memory. Here we had to alight and present our passports; mine which I had brought from Altona and which was signed by Count Blücher, had no "signalment", which struck the official as rather unusual, but when I translated the document to him, and came to the words "Consul du Denmark au Peru" he very politely observed: "Monsieur, vous etes exempt". Also when our luggage was searched, mine was looked at superficially, that of the Baron and Baroness more carefully. It soon grew dark, and sometimes dozing, sometimes sleeping, I concluded this day, until we reached Antwerpt, where we put-up at the hotel d'Angleterre, and separated for the night. [712] 
Tuesday, $8^{\text {th }}$ of October 1844. I had with me two letters of introduction, one from Mr. Bosch, Belgian chargé in Lima, to his brother Mr. Prosper Bosch, the other from miss Bertrand, the companion of mistress Bauer, the widow in Altona, to her brother, clerk in the commercial firm of Ellermann \& Co.; unfortunately neither the one nor the other was of use to me. Mr. Prosper Bosch had removed from Antwerp to Ghent, Mr. Bertrand was absent on a visit to Rotterdam. On a circular letter of credit from C. H. Donner stood the name of Kervanger \& Co. of Antwerp; to their counting house I went, and was received very politely by the head of the Establishment who took me to his private room, and conversed with me on various subjects. I gave a receipt for two hundred francs for which I received one hundred and ninety Eight fr., the commission of $1 \%$ being deducted at once. Having returned to the hotel, the Baron, the Baronness and I with a Valet de Place started for the cu[_] round through a strange place. Our valet conducted us through several of the principal streets, which are wide, and in which I observed many handsome houses, none however comparable to those in the new parts of Hamburg. Of course, there are likewise tortuous and narrow streets which probably date from the middle ages, but not one house did I see which leaned over as in Amsterdam, or which like those in the old towns of Germany finished in queerly shaped Gables, or had one story protruding over the other. There are three open places in Antwerp; in the principal one of an irregular shape stands the town house, a very antiquated edifice, built about the year 1560 , and another house seven storys high, with extremely small and narrow windows, which once the palace of Charles V, was in 1844 the ware-house of Krelinger \& Co. The second, called the Green place, is planted with a few trees and has in the middle a bronze statue of Rubens on a marble Pedestal; the parents of this painter were Antwerp people, but owing to some political disturbances in their native place emigrated to Cologne where their son was born who in after life acquired such a great reputation. The place called that of Mier is the longest and the largest of the three. The exchange was an open quadrangular round the four sides of which ran a covered walk. The docks owe their existence to Napoleon I, who when Antwerp belonged to the French Empire looked upon this port as of the greatest importance for the navy which he considered indispensable to the "grandeur" of his rule, and if he could [...] have conquered his pride as to cede this place to the allies at the time of the negociation at Chatillon, he would probably have remained on his throne. [713] The docks are said to have cost fcs. 13,000,000; they are built of large sand-stones with great care and solidity. There are two of them, the outer or smaller one, which by means of a lock communicates with the Escaut or Schelde, and the inner or larger one, connected with the outer Basin by means of another lock. The bridges which 
spanned these locks are not draw-bridges but opened by moving on hinges. Some vessels were lying in the larger dock amongst which a large Government steamer the "British Queen" which as a packet had made several trips to Newyork, but which the Government was now desirous to sell; they asked for her 500,000 francs, but no more than 170,000 had been offered. We wished to go on board but were not allowed, an [...] having come down from Brussels, which prohibited the admittance of strangers. Of the three Entrepôts, handsome buildings with vaults underground in the vecinity of the docks, the foundation was laid under the reign of the dutch King William I. They were concluded after the separation of Belgium from Holland. Another entrepôt expressly for the trade with Cologne was in progress of construction at the time of this my visit to Antwerp. Here about the Hanse towns possess a house which till goes by the name of the Hanseatic-house, and was let in 1844 by the Hanseatic Consul as a ware-house. There was some bustle and activity, goods were being landed and embarked, which operations were facilitated by means of a moveable crane drawn by horses, from one place to the other. I observed large quantities of hides, tallow, potash, flax, and big cases with raw sugar. Enormous waggons laden with the one or the other of these articles, stood upon the rails which encircled part of these docks. On the walls of some stores the words Ship, Chandler, Biscuit, baker, etc., were written in English, in large letters. On the quay along the river, which though thirteen leagues from the sea is here of a considerable width, rows of trees are planted. Opposite lies a village called la "tete de Flandres"; there on the left bank of the Escaut is Flandres, here on the right side, we are in Brabant. Not only these docks communicate with the Schelde, also various canals run from this river into the town; they get dry at low water. The first church which we visited was that of Saint-Paul, whose interior like all Catholic Churches was richly adorned. The most remarkable thing in it is an exact imitation of the holy Sepulchre in Jerusalem. [_] next we went to the Cathedral, a beautiful edifice in the Gothic style of archi- [714] tecture; it has but one steeple, but it was easy to see that there would have been two, if the original plan had been carried out. The interior has an imposing effect, there is the nave on each side of which three aisles, altogether contrary to the General rule, churches having almost invariably no more than two aisles, very seldom four; perhaps this Cathedral is the only one which has six. In the centre is a square tower, similar to that I so much admired in the York Minster (see page 297 of this volume), its slender and graceful columns which rise to a great height sustain an inner roof adorned with a painting which I was unable to distinguish. In this church is the descent from the cross which is looked upon as the master-piece of Rubens, and of course it must be an excellent painting, because all connoisseurs say so. I who am [_] connoisseur, am no 
friend to his style of painting; in my opinion [_] colouring, though natural, is coarse; all his human figures, particularly the females have a vulgar look about them; his great delight was the portraying of naked woman, and a Virgin as well as a Venus looks like a fishwoman. Close to the descent from the Cross hangs a Saint-Francis by Murillo and a head of Christ by Leonardo da Vinci, which I much preferred to Rubens descent from the Cross. The choir was about being adorned with carved wood-work, and it was also the plan to place here the statues of the twelve apostles, some of which had already been finished by an Antwerp Sculptor, called de Kuyper. The third church which we entered was that of Saint Jaques in the adorning of which marble is profusely used. In it Rubens and his family lie buried, and in a painting this painter had introduced the likenesses of himself and of the members of his family. Of Van Dyk there is a splendid Christ on the cross, an emaciated figure without any of the muscular robustness always found in the creations of Ruben's fancy. At the Valet de place's earnest request we finally directed our steps to a collection, the property of madame Herry, consisting of Pictures, Etruscan vases, Roman lamps, Egyptian antiquities, medals and Cameos, amongst which there was as far as I could judge nothing of great value. We were back in time for the table-d'hote which was served at four Oclock, and at which besides ourselves, three English and three Belgian Gentlemen sat down. The Conversation was carried on in French; dinner was abundant but without fish or pudding, neither were forks and knives changed at every course, this observation I previously have already had occasion to make. At half past six I went to the theatre and took my seat which [_] [715] three francs in the stalls which nearest to the stage consist of commodious stuffed arm-chairs. Behind the stalls follows the parquet, files of wooden benches without divisions, behind the parquet is the parterre nearest to the entrance, without seats; there was one tier of boxes on the same level with the stalls, parquet, and parterre, above the same two tiers of boxes and the Gallery. The interior was neatly painted, and well lighted up with gas, but the audience was scanty, and the vaudevilles which were represented were certainly insignificant. The first "La maitresse des Langues" was a stupid thing indeed, of which the hissing heard when the curtain fell gave evident proof. The second, the "Chalet", not so bad as the first, but also insipid, the third "ma maitresse et ma femme", a little piquant, was no doubt the best.

Wednesday, $9^{\text {th }}$ of October 1844 . The Baron came to my room to inform me that he and his lady intended leaving Antwerp by an early train for Brussels, and expressed a hope that I would accompany them. In reply I regretted that I could not have this pleasure because I was desirous to see a little more of Antwerp and its environs. Accordingly as soon as I had taken my breakfast, Coffee, bread, and butter I went out by myself; without difficulty did I find 
my way to the docks, thence I directed my steps to the Ramparts into which to my astonishment in two or three places large openings had been made; through one of them passed a Railway, which, commencing at the docks, and afterwards crossing the ditch which surrounds the walls, continued towards Ghent. The fortifications of Antwerp were once of considerable strentgh but in my opinion it is always a difficult matter to defend effectually and for any length of time such an extensive and populous place as this. To make a complete circuit round the walls was utterly impossible, for I had not only to descend at these openings but also at the different gates. At one of them I saw the Baron and Baronness driving in a cab to the terminus. From another I walked out into the Country under the shade of trees between Kitchen Gardens, and passing Country houses of little beauty. I returned through another gate where I again ascended the walls, and finally reached the river some distance further up than from where I had started. Here is the citadel which the sentry would not allow me to enter without a card of admittance which I had not. Still higher up is the Royal wharf; I, walking down the river came to the Arsenal, then along the quay lined with trees, cafés, estaminets, and Hotels, to the Canals already mentioned. Turning off to the right I [716] passed through the old part of the town with high and old fashionned houses. Girls of the lowest class were standing at the doors, and looking out of the windows. At about one oclock I was back at the Hotel d'angleterre, lunched on mutton chops, made the acquaintance of the three Englishmen whom I had seen on the previous day at the table d'hote, and at half past two drove together with them to the terminus where we took our seats in the second class or "char a banes"; the first class is called diligence, the third vagons. The Country between Antwerp and Brussels is level, partly woody, well cultivated, there were villages and farms, there were corn fields and pasture land, peasants ploughing and sowing on the former, cattle grazing on the latter. The terminus at Malines or Mechiln is of importance for here four lines meet, from Brussels, Liege, Antwerp, and Ostend, by the last one my English acquaintances left en route for England. On approaching Brussels, I noted pretty country-houses, and the first appearance of this Capital, part of which is built on the summit of, the other part leaning against a hill is very picturesque. At the terminus I engaged a cab which put me down at the hotel de Flandres situated in the upper part of the town in "la place Royale" between the hotel de Bellevue, and the Church of "Saint-Jacques de Candemburg". Having taken possession of my room, which was carpeted, I went in search of the Post Office in "la rue de l'Erique", in the lower part of the town, which I found with difficulty after many inquiries, and where several letters were waiting for me. I ascended the street called "La Rue de la Magdeleine" full of handsome shops lighted-up with gas, 
to la Place Royale, in the vicinity of which, the west end of Brussels, the houses are large, the streets wide, the foot pavement commodious and broad. Outside "La Porte de Namur" in the Rue de la Pepiniere lived at the time the widow of the elder Ropsy, my brother in law's brother, with her daughter. I found them at home, the mother an old, the daughter an elderly woman. To judge from the small room which they occupied, from the scanty furniture, in short from the whole appearance, I clearly saw that they were in poor circumstances. When I told them who I was, they gave me a cordial welcome, and the daughter was ready to show me to her brother Victor, for whom I had a letter from my nephew Charles, Victor's cousin. I offered my arm to my guide, and brushing up my French, managed to converse with her. I learned that her father had served as a Dragoon in the armies of the French Republic, very different from his younger brother, my brother in law, who, a Royalist to the backbones, had in his youth carried arms against his native country in the Corps of immigrants commanded by the Prince de Conde. Monsieur Victor lived in a very small house, in a very small street, $\mathrm{N}^{\circ}$ 4[_] [717] Petite [_] de Francard Grande rue de Francard, Chaussee d'Iterbeck, Chaussee d' [Exellos]. Also here I saw at a look, [_] the inmates were not well off in the world. Mr. Victor was not at home, his wife was, who, when Miss Ropsy was gone, told me that she was an English woman and of course we then conversed in English. She, not handsome, stout and apparently good natured, was nursing her Babe Elisa, three months old; her boy Louis was twenty months of age. Surely this must have been a lovematch. I accepted her invitation to breakfast with her on the next day, bade her good bye, and returned to my hotel, where having taken a beefsteack, and learned my vocabulary (Italian) as I was in the habit of doing, I went to bed.

Thursday, $10^{\text {th }}$ of October 1844. At eight oclock precisely, I was at Ropsy's, Monsieur Victor made his appearance, he was a plain looking man marked by small pox; and as during the few days of my stay in Brussels I was a great deal in his company, I was enabled to form an opinion of him. He had learnt little of other countries besides his own, Belgium; he hardly knew anything, and as ignorant people frequently are, in Politics, he was a radical, violently opposed to the Clerical party, to the Jesuits and to the influence which they, being favored by the queen, exercised in 1844 over the whole country. Both the King and the queen were much beloved by their subjects, but according to Monsieur Victor, the leaning of the queen towards the ultramontane party could not otherwise but in some measure diminish the affection born to her. A thorough good Catholic in this Kingdom never eats meat on fridays the whole year round, and not a few extend their abstinence even to Saturdays. Mrs. Ropsy now seen by day light pleased me less than she had done on the previous evening. I thought her to be a vulgar English woman. With the 
breakfast though plain, I found no fault, the Coffee, bread and butter were good, and the host and hostess did all they could to please me. The table cloth, clean, was a little torn. A Monsieur Duverger whose wife was a daughter of old Mrs. Ropsy's brother came in, and with him and Victor I went to his house, larger and more comfortable than those of the Ropsy's. He, a clerk in the Bank of Brussels introduced me to his wife, who when he insisting upon my [_] his Madeira broke some wine Glasses which stood on a sideboard, [?] him [...] in my presence, which no well bred lady would have done. Monsieur Victor, "Controleur" or "revisor" of the accounts of the Municipal Treasury, took me [...] in the town-house, an ancient venerable [_] [built] in the Gothic style, $[\ldots]$ in the "Grande place" which serves as the market place. Monsieur Victor showed me to the large saloon where the members of the town council [718] were in the habit of meeting, but knew nothing of another saloon, in which as I afterwards read in "Los viajes de fray Jerundio", the Emperor Charles V in 1555 ceded to his son Philippe II part of his vast dominions; round the "Grand place" stand many ancient buildings which in former times belonged to the various corporations of the town, another opposite the town-house was until the year 1440 the property of the municipality of Brussels; the following words were inscribed on its walls in large letters: "A peste, fame et Bello, libera nos Maria pacis. Hoc votum pacis publicae Elisabeth consacrat". They were placed there by order of the enfanta Doña Isabel daughter of Philippe II, as an expression of her gratitude to the Virgen of peace for having delivered Brussels from the three plagues mentionned in the inscription. The lower part of the town where we now were, is inhabited almost exclusively by the lower and working classes of the population, whose languages are the Flemish and the Walloon. The streets were thronged with carriages and foot passengers, in the upper, the Aristocratic part of Brussels, only French is spoken, and the wide streets are less frequented. Mr. Victor conducted me to several other open places in the lower part: La place de la monnaie with the Mint, Le grand Theatre, and several coffee-houses of which the Café des mil Colonnes and Le café des trois Suisses were much in vogue. La grande et la petite place des sablons and La place des Martyrs in which latter many of the Belgians who were killed in the four glorious days of September $23^{\text {rd }}$ to $26^{\text {th }} 1830$, when fighting for their separation from Holland which they obtained thanks to the interference of the great powers, lie interred, a grass plot covers their remains, in the centre, a statue of liberty is erected to their memory. We descended a few steps to a circular passage round the Statue, all along the sides of this passage stand iron tablets upon which are inscribed in Gilt letters, the names which were known of those who fell on these days, as well as their native places, highest in rank amongst them was the Prince de Merode who was 
killed at Berhem near Malin[_] in October 1830 when the Belgians pursued the Dutch troops commanded by Frederick second, son of the then reigning King of Holland. Monsieur Viend told me that he who in 1844 sat on the throne of Holland, was still beloved by the Belgians. He also made me enter a large Hospital "l'hospice des [_]" where seven hundred people of both sexes were being taken care $[\ldots]$ as they enjoy good health, they dine and sleep in large saloons, [_] men and women separately. But when they fall ill, each poor sick person had [_] [719] or her private apartment. Their bed steads were of iron, their bed linen, of excellent quality, and I was actually surprised at the fineness of their shirts, night-caps, sheets, towels etc., also thin cloth clothes, were very good. They have here yards, gardens, and covered corridors in which to take exercise in good and bad weather. We went to the kitchen where the provisions which were being cooked emitted a nice odour. Having looked in at one or two Estaminets, coffee-houses where smoking is allowed, and where the society is far from select, we paid our last visit to the principal church dedicated Saint Gudule which, a very fine building renowned on account of its stained window glasses is however inferior to the Cathedral of Antwerp. In it the Prince de Merode has a monument erected to commemorate his glorious death, then we ascended a wide street, the Boulevard du jardin Botanique which takes its name from the Botanical garden which lies on its left side, whilst to the right a large new hospital had just been concluded. This ascent Brought us to La place Royale, whence leaving the small but pretty park to our right, we followed the long and broad street La Rue Royale to the gate of Sharebeck, called upon Mrs. old Ropsy, and went to dine at Monsieur Duverger's, where besides the host and hostess, we found only Mr. Jean, an old Dutch gentleman. The dinner was plain, but good; we had bordeaux wine and excellent Burgundy. With my French I got on better than I had expected. After dinner we walked through the dark and the mud, for it had been raining the whole day long, to the small park theatre, the interior of which being lately refitted looked very neat; my companions had taken a box in the third tier - only the gallery above us, but as I cannot bear looking down from such a height I soon left them and got a seat in the parquet. The play performed was Don Cesar de Bazan. We came too late to see the first act, which I much regretted, for the play interested me and the actors played well. Of the vaudeville "Carabins y Carabines" I did not understand anything.

Friday, $11^{\text {th }}$ of October 1844. My bed was excellent; for breakfast I had coffee, Bread, butter, good and abundant. At the early hour of half past eight I was in the house of Monsieur Adolphe Bosch, Greffier de la Cour militaire, who lived in La Rue Royale, for whom I had a letter from his brother in Lima. He was a man of about forty years of age, three years younger than his brother whom he 
much resembled. He was very polite and extremely communicative, much more so than I should have been inclined to be towards him. He [...] amongst other things, that he was tired of a bachelor's life and [720] that he thought of getting soon married, this afforded him an opportunity for showing me all over his house, which was large and well furnished. His parents, eighty years of age still lived in Maestricht, for three years he had been on bad terms with his brother in Lima, who had in his younger days been involved in mercantile transactions by which he had lost much money. The husband of his wife's sister a Monsieur Leroy had cost him not less than forty thousands francs. All these and many other things he related to me without the least reserve. He had also a high opinion of himself: "Je suis le cadet, mais pour ma tête Je suis l'ainé, toute ma famille le sait". Hitherto I had not been in the park, now I promenaded in the same for a short while and entered the Belgian Congress-house called here la "Chambre des Deputés", also "Le Palais de la Nation", it stands on one side of the park, opposite on the other side the Royal Palace. In the Vestibule of "La Chambre des Deputés" stood leaning against the walls, two handsome historical paintings, the one by Keyders representing la bataille des Eperons, which battle was fought on the $16^{\text {th }}$ of August 1513, when the Stout Burghers of Ghent routed completely a chosen body of French chivalry and nobility, who, as the saying went, on this occasion made better use of their spurs to escape from the lances of their enemies, than of theirs swords to meet them. The other painting by Gustavus Wapper portrayed a scene from the glorious days of September 1830. The main group consists of a young man expiring, his father holding his son's hand in his own, his mother looking up to him, and endeavouring to stanch with her handkerchief the blood which flows from the death wound. Two broad flight of stairs lead up to the first story where besides several smaller rooms, are the two principal saloons, the one for the deputies, the other for the Senate. In the latter the president sits in an arm-chair, and the senators speak from their seats, whilst with the deputies it was the custom, that the orators ascended a "Rostrum", whence they delivered their speeches, which Rostrum is just below "La tribune" occupied by the President. On the $22^{\text {nd }}$ instant the settings were to be opened. On the left side of the Rue Royale going down from the gate stands a statue of General Count Belliard, a Frenchman by birth, with this inscription: "il fut a Castiglione, a Heliopolis, a Austerlitz, a la Moscowa; il consacra ses jours a la belgique. 1832". From the Place Royale I now descended slowly and leisurely, the "Rues de la montagne, and de la Magdeleine", called upon Victor Ropsy in his office in the town house who was kind enough to accompany me, on a short stroll [...] [721] lower part of the town, he showed me a fountain in the shape of a bronze statue of a boy who makes water, of which statue, called in Brussels the "Mannequin", I find an 
interesting account in "Los viajes de Fray Gerundio" already referred to, of which the following is a translation. "Once (the year not given) the son of one of the Dukes of Brabant, seven years of age, escaped from his father's Palace; search was made for him every where and at last he was found on the spot where now the fountain stands, quietly employed in the manner as there represented. His parents full of joy, and as a proof of their gratitude, ordered a statue to be erected on the very place and to be an exact 'fac-simile' of their son in the very attitude in which he had been found. Since then the statue became an object of veneration to the inhabitants of this Capital, they call him their first citizen, their welfare was believed to be connected with him, they looked upon him as their Palladium. The statue was originally of stone, afterwards it was cast in bronze, modelled by the famous sculptor Duquemoy. In the year 1817 , it suddenly disappeared, but was found again in the house of a certain Lucas, a Galley-slave who had been set at liberty, but had not renounced to his old habits. In 1818 the statue was replaced with great solemnity, various potentates have made presents to the 'manequin'. An Elector of Bavaria presented him with an exquisite wardrobe, together with a Valet de Chambre to dress him. Luis XV to make amends for the insults offered to the Mannequin by some French Grenadiers, made him a Knight of all his orders, and gave him an entire suit of Clothes with a plumed hat, and a sword. Before the revolution of 1830 it was the Custom to dress the 'Manequin' in the suit of clothes presented him by Luis XV on Kermisse day, a great holiday in Brussels which falls in the month of July, but since the separation of Holland the preference has been given to the uniform of a soldier of the National Guard." From the fountain we walked to the markets for wood, Fish and Poultry. Then by myself I found my way to the Canal which connects the Senne, a very small river near Brussels, with the Escaut at Antwerp; it traverses the town in a straight line until where outside it meets "lalleé verte", there it turns to the right, and in the angle here formed, a new Entrepot or Custom house store was about being constructed. "L'allé Verte" is an avenue of very great length, on the one side it has the Canal, on the other the town. At its extremity I came to a recently made chaussée, which turning to the right and crossing two railways, the one for goods, the other for passengers, to [...] brought me to the boulevards, which encircle the town. At four [722] o'clock I took a plain dinner at Victor Ropsy's, with his wife, Monsieur Duverger and Monsieur Jean, the Dutchman whose acquaintance I had made on the previous day; the Burgundy was again excellent. Somewhat later the host, hostess, and I walked to the "grand Theatre" to see Miss Fanny Elssler dance. A long "queue" was waiting at the entrance, without much squeezing we made our way into the pit where we obtained seats on the first row of benches. I have kept the play bill which will be found in the appendix 
under Number 19. The house, large and dirty, was filled, but not crowded. The first, a comedy "Le Manteau", appeared to me to be well acted but I did not understand a word of it, for the sound did not reach me, and Monsieur Victor assured that it was the same with him. In "Le delire d'un Peintre", Fanny Elssler made her appearance and was received of course with great applause. She was about thirty years of age: tall, thin, with a rather large mouth; her movements and her attitudes were more graceful than anything I had seen before; especially when she curtsied in acknowledgement of the plaudits, and of the garlands and bouquets which were showered upon her from both, boxes and pit, the grace which she displayed was admirable. To see her walking on the point of her great toes was wonderful, and she was charming beyond description when leaning over her lover, resting upon one leg, stretching the other high into the air. She "pirouetted, as all dancers do, but in doing so, her petticoats did not whirl round, and fly so high-up as those of mademoiselle Augusta y Melle. Honoré, also very good dancers, though much inferior to Fanny Elssler. She and Monsieur Page danced a Spanish danse with Castagnets, which I did not think much of, though it was well received by the spectators. Between the acts we had some good playing on the violin, as well as singing by Mademoiselle Rounay and Madame Laborde. In "La Laitiere Suisse" the Elssler acted with great naiveté, her dancing was again splendid, I however gave the preference to the "Le delire d'un peintre"; it was over at ten Oclock, when we walked home.

Saturday, $12^{\text {th }}$ of October 1844 . The sky was cloudy but it did not rain thermer. windows shut $121 / 2$ Reaumur, equal to 60 Fahrenheit. I was in my room the greater part of the forenoon, wrote a long letter to my wife till half past one, when I started for a walk. From an open place in "La Rue Royale", one has a pretty view over the lower part of the town towards the country. I entered the Botanical garden which gently descending forms one [723] side of the "Boulevard" of the same name, it is laid out with great taste. The hot houses are particularly handsome, the centre part finishes in a cupola, passages connect the same with the side wings in the shape of temples surrounded with Colonnades, the materials employed in their construction are mostly iron and glass. Next I crossed and recrossed the town in all directions in order to form some correct idea of the same. The lower part, abounding in hotels, Cafés, and Estaminets, was dirty, many of the streets tortuous, the houses old fashioned, many of them empty, were to be let whilst in the upper, as already said the aristocratic, part, new houses, some palace like were springing up everywhere. I observed small carts filled with meat, or with vegetables drawn by big dogs, which also kept strict watch over them in absence of their owners. The enormous tall cart horses which every stranger admires in London must, I should think, have been brought over from Flanders or Brabant, for in Antwerp, 
and in Brussels I saw the same description of horses, though of a somewhat smaller size. No doubt in England great care has been bestowed upon improving their strength and size. Servants in Brussels are generally Flemish or Wallons; I was told that the former whose language is a corruption of the Dutch, easily learn French whilst the Wallons whose language is a patois of the French, with difficulty learn Flemish. I waited in my hotel till half past four, when Mr. Bosch called upon me in his carriage, he drove me a short distance out of town, and being a tremendous Belgian patriot, did not fail to make me observe the great improvements that were in progress, and certainly many fine houses were about being built in the new quarters of the town, called Boulevard Leopold and Boulevard Luise, the names of the present King and the Queen. Monsieur Bosch and I dined by ourselves upon a very poor dinner, his coachman and a little boy, both in livery, attending. We had two classes of Bordeaux wine, and half a bottle of Champagne the other half he carefully kept, though every body knows that kept Champagne is good for nothing. The bottle always stood within his reach, and he poured out to me only when he thought proper. The dining room, the sitting room, and the Study were all lighted-up by a single lamp, so that when he went away to fetch something, he took the lamp with him, and I had necessarily to follow in order not to be left in the dark. It was as impossible for him to conceal his closeness, as his conceitedness. He called himself a great "Industri[el]", had written several pamphlets on various subjects, copies of which he presented to me, he showed me a copy of a letter which in march 1830 shortly before the Revolution, he had written [724] to King William of Holland, giving him much good advice. He wore the orders of l'independence, and of Leopold, in short he was a great man, at least in his own opinion, though I must do him the justice to say, that he was certainly very clever. At a booksellers Langlet and Prudhomme 87 "Rue de la Magdeleine" and $\mathrm{N}^{\mathrm{o}} 3$ Caes do Sodre at Lisbon, I purchased "Le mie Prig[_]" by Silvio Pellico.

Sunday, $13^{\text {th }}$ of October 1844. Monsieur Victor was good enough to accompany me on this day on an excursion to the immediate environs of Brussels, but in the course of our long walk he was unable to point out to me a single really pretty rural Landscape; only the town which, as already said on the first day of my arrival, is picturesquely situated on and against a hill, presented occasionally a pleasant prospect. Before starting, we first entered the Church of Saint Jaques de [Candemburg], where a Sermon was being preached; as far as I could judge of its architecture, it seemed to me built in the new temple style. In 1851, when I again visited Brussels, an equestrian statue of Godefroy de Bouillon and Boulogne, Conqueror and first Latin King of Jerusalem stood in the centre of "La Place Royale", in 1844 I made no mention of it, and as it is not likely that I should have overlooked such a prominent object, the statue must have been 
erected between the years 1844 and 1851 . Next we went to the church of "Sainte Gudule", on the "Place de la monnaie", the congregation among which many men of the lower classes in their blue blouses attended high mass with great devotion, the mass was accompanied by excellent music. The women were not dressed in black, nor did they kneel and squat down on the floor as at that time it was still the custom in Peru; they wore their usual dresses, and sat or knelt on very low chairs called "Prie-Dieu". In an omnibus we drove to the village of Lacken at some distance north from Brussels, where the King had his palace and park, both closed to the public, also here the fashionable world of Brussels have their residences, the living their country-houses, the dead their graves. The Cemetery is filled with Sepulchral monuments of the first Belgian families. In the outer walls of a few of these monuments, a very small cavity was left, into which a lock of the hair of him or her who rested below was preserved, and this cavity was covered either with very thick glass or with a strong ironwire, so that the lock could be seen from without. The famous singer madame Malibran (see what I say about her Page 205 of this volume) lies interred here, here statue stands [725] within the Chapel erected on her tomb. On leaving lacken, we walked in a South Westerly direction till we reached a populous suburb called "Malebeck Sain [...] ean faubourg de Flandres", mostly inhabited by weavers. Further on we approached a boulevard and the Canal which comes from Charleroi, then we had to our right "l'abattoir", or General slaughterhouse. Crossing one or two Railroads we reached what was once the gate of Halle which for many years back had served as a prison but which now having undergone some repairs was to be converted into an Armoury. Here we left the Boulevards and cut right through the town to the Place Royale, had a look at the Palace which under the Dutch rule belonged to the Princes of Orange; then called upon the two Mrs. Ropsy to whom I bade good-bye, and returned to the Hotel where I had invited monsieur Victor to dine with me at table d'hote which was well filled. Dinner consisted of an abundance of small dishes cooked in the French style, I ordered a bottle of "Vin de Beaunce" of excellent quality which we finished amongst us. At a later hour, we went to the bookseller's with whom I had been on the previous evening, I now purchased the Complete works of Walter Scott; the prose edition of Galignani, the poetry edition of Baudry, for ninety francs without further discount, placed in Antwerp, the Freight from Antwerp to Altona had to be paid by me. Having still time to spare we paid a visit to the two coffee-houses "des mille Colonnes" and "des trois Suisses", in both were separate saloons frequented by ladies in which smoking was prohibited. In an estaminet monsieur Victor was quite at home, here, he said, he used to spend every evening drinking his glass of beer, the usual manner in which the Brussels people of his rank in life passed their leisure hours, of 
course leaving their wives at home by themselves, a habit not to be admired, nor to be imitated. Finally my companion took me to a guinguette, a place where the lower class of people meet and amuse themselves with dancing. There were weavers, artisans of various descriptions, peasants etc.; the fair sex was represented by s[eam]stresses, Milliners, some female servants, and the like, amongst whom I noted many a pretty face. The men danced with their hats on, smoking occasionally, the general beverage was beer. However, everything went on decently, both men and women behaved very properly. The dances were quadrilles, Spanish Contradanzas with easy figures, and waltzes. Sometimes two men, sometimes two women waltzed together. They had a particular way [726] of waltzing, they pirouetted and whirled round without moving from the spot. I was much pleased with what I saw here, and returned to my hotel at past ten oclock where I packed-up and got ready for my departure on the following day.

Monday, $14^{\text {th }}$ of October 1844. I rose by candlelight at half past five oclock, breakfasted, paid my bill, and was ready long before the omnibus came at half past six. We called at various other hotels, but no passengers joined me, having waited a considerable while at the terminus, the same at which I had arrived on coming from Antwerp, I left by second class or Char á banes at half past seven. As far as Malines the road was known to me; but here instead of taking the Northern line I continued my journey to Liege in a South Easterly direction; the Country though which I now passed was similar to that which I had hitherto seen in Belgium. Every piece of land was carefully cultivated, again peasants were ploughing and sowing, others were haying, or gathering potatoes, however the Country was rather more hilly, the Railway passed now and then through deep cuttings with high embankments on each side. At half past Eight we were at Tirlemont; at five minutes to ten, at Lauderns where a line branches off to Saint Trond. From Ans a large coal-depôt, onwards, I noted along the rails a rope running upon wheels. I understood that as the road descends here considerably, the train is not pulled along by a locomotive, but a stationary steam Engine placed alongside the road draws the trains up, and lets them down by means of this rope. The Country was more "accidentee" as the French would say, on both sides were hills and dales. The last Station before Liege is called Haut Pré; we arrived here at half past Eleven. In the Liege terminus my trunk could not be found, the luggage master had to be called and after a good deal of searching, it was discovered in the wrong "Van", where it had been stowed away. I left it at the terminus, and walked the short distance to the town, prettily situated on the Meuse, which divides it into two parts. The first thing which struck me was a large placard stating: "Eglise à Vendre, meme à démoler." I had the river to my right, crossed and recrossed the town just as 
chance directed me, and came to streets so narrow, that two carriages could not possibly pass each other, to lanes and alleys narrower than the narrowest closes in Edinburgh or "Gänge" in Hamburg, further on, to another [727] place with two large edifices, the one the "Conservatoire Royal de musique", the other probably the University with this inscription on the wall "Universis disciplinis"; in the centre stood a bronze statue upon a marble pedestal of which the name of Gretry 1813, he, a celebrated composer of music was born in Liege in 1741 and died in 1813. I passed the Meuse over a high arched bridge, then another river, probably L'Ourthe, an affluent of the Meuse, over two small bridges, and found myself in the open country. I ascended a small eminence and looked around: just behind me a factory with chimneys, at my feet a carriage road, the space between which and the river was taken up by a small richly cultivated plain dotted over with houses and trees, and intersected by hedges. On the other side of the river stood a long row of houses and factories behind which the ground rose rather abruptly into a ridge of heights, which well cultivated extended to the left so as to confine the horizon, whilst the town of Liege occupied the level ground in that direction. To my right the Country was undulating, otherwise similar to the small plain already referred to between the road and the River. I returned to town, and feeling somewhat fatigued entered an omnibus which drove through a part of Liege where the streets were wider and the houses looked more respectable than where I had been before, and put me down at the terminus. French is the language generally spoken here. Many shops had a sign above the door such as the Manteau d'or, le Cheval d'or, le Canon d'or, etc., cakes in the shape of saints were being sold, this is all I know of Liege. The country between Liege and Verviers is extremely pretty, the Railway passes over viaducts, through long tunnels and deep open cuttings, the hills on both sides are of considerable height, the Valleys deep in proportion. In the Verviers terminus we had to wait full an hour and a half, of which leisure time the travellers by first and second class, I one of them availed themselves to take their dinner. French was still spoken but when paying my bill, Prussian money was given to me in exchange for the five francs pieces. When at six oclock we left Verviers it was dark, immediately outside the town I saw several large factories lighted-up with gas from top to Bottom. As far as I could judge, the road was exactly like that from Liege to Verviers, the same deep cuttings, the same viaducts, the same tunnels. The recollection of the smoke circling in wreaths round the train lighted up by the fire, of the sparks flying about, and of the red cinders marking our way whilst we steamed along, and of the shadow of the train on the walls [728] of the tunnels, all which little noted by those who are accostumed to Railway travelling by night, then seen by me for the first time remain fresh in my memory even now, twenty five years later, when in 
September 1869 I dictate these lines. At Herberstahl the first Prussian station, our passports were taken from us, in Aix la Chapelle's terminus we arrived at a little past eight, after a slight searching of our luggage, an omnibus conveyed me and many fellow travellers to Nuellens Hotel where I obtained a room high up in the second or third story, little to my liking. I walked out for a moment, but as the weather was unpleasant, and the streets rather dark, for the Gas lamps were placed at great distances from each other, I quickly returned and made my supper upon a pair of excellent field-fares, French "Grives", German Krammetsvögel. The appearance of Krammetsvögel on the table is always the evident sign of the approach of autumn; only in the fall of the year these small and delicate birds are caught, generally by snares. The Sorbs (Vögel Berry) which they feed upon are frequently found in their stomach, the only part of their little body, which besides the point of their beak is not eaten.

Tuesday, $15^{\text {th }}$ of October 1844. In Aix la Chapelle which it will be remembered is situated in the Prussian Rhenish Provinces, German is the language spoken by every body. To me the "patois" of the lower classes was nearly unintelligible, occasionally but seldom French is heard. When I rose at half past six, the weather was disagreeable and rainy, thermometer 12 Reaumur $=59$ Fahrenheit. I took my coffee in the General room below and left at half past eight for a tour through this old town, one of Charlemagne's favorite residences. The Valet de place accompanied me to the Cathedral, a very ancient building. The foundation was laid under the reign of Charlemagne in the year 796, the Choir and that part of the Church where the altar now stands were added by the Emperor Otto III whose remains it is said are enclosed in a marble Coffin which stands below the high altar. On a black marble slab on the floor is a Latin inscription in honor of the Emperor, a white slab has these words engraved upon it: Carlo Magno. Frederick Barbarossa discovered the tomb of his renowned predecessor which contained a marble Sarcophagus upon which stood a marble chair, on this was found in a sitting posture, the great Emperor in his Imperial Robes. The sarcophagus according to the Sexton who showed me round, dates from the period of Augustus the Roman Emperor, and strange as this may sound, it does not appear to me incredible, for the bas relief [729] sculptured on one of its sides represents a well known fable from the ancient Roman Mythology, namely: the Rape of Proserpine. The first who was crowned on the marble chair taken out of the tomb, was Frederick Barbarossa, after him thirty six German Emperors were crowned on the same chair. The Chapel which goes by the name of Charlemagne's chapel was under repair at the time of my visit, and the workmen were replacing thirty two pillars, partly marble, partly granite which when Aix la Chapelle belonged to the French Empire, had been carried off to Paris by order of Napoleon I, but had been returned after 
the peace of Paris. The pulpit of massive silver gilt as well as other treasures and many relics escaped the same fate owing to the precaution of the authorities of Aix la Chapelle, who when the French army approached, took care to send them to Paderborn where they remained concealed until Germany was delivered of its oppressors. From the ceiling of this chapel hangs a lustre of gilt copper for sixty eight candles, a present of Frederick Barbarossa. From the Cathedral we went to the town-house, likewise a building of great antiquity, one of its walls is still the same as it was in the time of the Romans. The three stories of this edifice have the peculiarity that the ceiling of each of them is vaulted. On the wall of one of the principal saloons hangs a large painting which represents the various Embassadors who were present at the conclusion of the peace, which in Octobre 1748 put an end to the war of the Austrian succession. In the same saloon hang full length portraits of Napoleon I and of the Empress Josephine, otherwise it contains nothing of interest. Its ceiling is uncommonly low, in order to restore it to its original height and width the King of Prussia had assigned a certain sum of money. In an office, of which of course there are many in this building, a portrait of Charlemagne is preserved. His bronze statue stands in the market place on the fountain, on each side a Bronze Eagle, the arms of a Aix la Chapelle, as long as it was a free Imperial town. The Saint Nicholas church which we entered presented nothing worth my attention, except the pews, the first which I saw in a Catholic Church. Aix la Chapelle is much frequented by sick people who go thither for the use of its mineral waters impregnated mostly with sulphur, one of the establishments for the purpose of bathing is an Hotel called the Emperor's bath. Opposite Nuellens Hotel is "Elisen-Brunnen" or Elisa's-well, where the mineral water flowing out of a spout in the wall is collected in a stone-basin, where everybody may go and drink it gratis, its taste is disagreable like that of rotten eggs. The theatre, a modern building, stands on a spot former- [730] ly occupied by a Convent, its back part is turned towards a street called the Frederick William's place, whilst its façade looks towards one equally handsome, the theatre street, whence another similar street turns off to the terminus. I returned to my hotel, but started afresh after having rested a short while for it being the birthday of King Frederick William IV I was anxious to see what was going on in celebration of the same. For the parade, I came too late, but not so for the festivity prepared in honor of this day upon a small eminence out of town called Adalberts height. Upon it stands a small niche of polished granite, on its outside were sculptured in bas relief the portraits of the three sovereigns Alexander I of Russia, Francis I of Austria, and Frederick William III of Prussia who met in Aix la Chapelle at the Congress of 1818. This small niche is called the alliancechapel. Inside was placed on this day the bust of the present King, adorned 
with many flowers. At 11 1/2 some infantry in blue frock-coats with red facings and grey pantaloons arrived, they were ranged on each side of the Chapel, then gradually came the civic authorities and big wigs of the town, after they had taken their respective places, the populace, of which I formed a part, was allowed to approach. An appropiate speech was delivered by a catholic clergyman, several others were given for the King and the Queen and the solemnity concluded with the anthem played to the tune of God save the King. My next visit was to the Gambling saloon in the so called "Lur[_]haus" a building never wanting in any of the German bathing places. Roulette was being played, but few were trying their luck, many Gentlemen were reading the papers and I followed their example; at half past one all left. I went out into the country, and had the good luck to find my way to some heights which the Valet de place had recommended to me, the one is called the Calvary hill with a small Church, the other the Louis-hill with a nice public-house where I took some refreshment. My valet de place had not exaggerated when he extolled to me the beauty of the view from these hills very different from that which I had had on the small eminence near Liege. Here to be sure a wide river like the Meuse was wanting, here the horizon was not bounded by a ridge of hills, on the contrary as far as the eye could reach it roamed over a wide well cultivated plain clothed in many colors, from the light green of the young winter-corn, a few inches above the ground, to the yellow and brown of the [sere]-leaf, ready to drop at the first atumnal blast. There lay the town of Aix la Chapelle, a mere speck in this vast panorama, [731] there were numerous Villages, factories with their high chimneys, solitary houses, there were woods and single trees, there were stately avenues and lonly hedges, also small ponds glittering like Gems in the rays of an unclouded sun, this time at least the reality did not fall short of my expectations. I continued my walk in the shade of the trees, round the walls of the town, in which I observed at certain distances big round towers, perhaps Roman Structures, and came to the town of Burscheid at a very short distance $\mathrm{fm}$. Aix la Chapelle of which it almost forms an integral part. It is crowded with manufactories, and the sulphurous waters bubble up in the middle of the Streets where they are collected in small basins surrounded by stone enclosures. The road to Bursheid passes under a beautiful viaduct upon which runs the Railway from Aix la Chapelle to Cologne. I obtained my passport from the Police office, and at half past seven went to the theatre. The interior of it lighted up with gas, was neat and clean, the prologue in honor of the King was spoken by a lady dressed in a white gown with black trimmings, she wore a cuirass and a helmet with black and white plumes, the scarf and the Banner she held in her left hand were all of the same, the Prussian colors. The Templar and jewess, an opera by Marischner was represented, which though founded on the same 
novel as Il Templario by Nicolai was however brought on the stage in a different manner; the fool and friar Tuck, personages introduced in the Templar and Jewess are wanting in Il Templario. Mrs. Eschborn as Rebecca, Mr. Cohen as Bryan pleased me best. In my hotel I again supped upon field-fare and had to write for several hours in order to keep-up my diary, before I went to bed.

Wednesday, $16^{\text {th }}$ of October 1844 . For the first time I found the servants fees included in my bill; this custom which since then has become general was in 1844 adopted by very few hotel keepers. For attendance during two nights and two breakfasts and two suppers I was charged twenty Silver Groschen. In the same manner as hitherto I took my seat in the second class still called Char à banes which since I was in Prussia, had no more glass windows but curtains instead. Thus, as the weather though clear was rather cold, my big cloak was of much use to me, on the right side my fellow travellers kept the curtains shut, on my left side I opened it, and had a pretty view over the Country; hills and fields, woods and villages. Several carriages of the train were filled with recruits who gave vent to their exuberant spirits by continual huzzaing, [732] almost all wore the blue blouses, the usual dress of the peasants and artisans. At twenty minutes to Eight we arrived at Eschweiler where still more recruits joined us, quite as obstreperous in their mirth as their companions. When we passed through tunnels of which there were several on this part of the road, they did all in their power, though in vain, to drown by their shouts and yells the shrill whistle of the steam-pipe. At $81 / 2$ we were at Düren the principal place between Cologne and Aix la Chapelle, on the other side of Düren we passed a tunnel which took us three minutes and a half. The Country in this neighbourhood a fellow passenger told me is extremely fertile, Rye and Barley are grown alternately, no field is ever allowed to lie fallow; this, he added is also the case in Holland. At $101 / 2$ we arrived at the Cologne station outside the town whence an omnibus took several travellers, me amongst them, along the strong walls which surround the town, over bridges, under gates, through many narrow tortuous streets to the Hotel called the Rhenish Court in the Hay-market. At twelve oclock I went to the house of Messrs. Clement Schmidt \& Co. to whose chief, Mr. W. Meurer, Fischer of Altona had given me a letter of introduction. This gentleman received me politely in his office without inviting me to his dwelling-house. At one oclock table d'hôte was served in the Hotel to which but few guests sat down. After dinner I walked out by myself, the houses in the intricate and narrow streets are very high and old fashionned, some have gables queerly shaped, others small turrets like pepper boxes and still others with the upper story not only protruding over the lower one as I had seen in other towns, but projecting in such a manner as to require being supported by Columns which form a kind of Portico. The 
Country round Cologne is extremely level; near the walls I saw only Kitchen gardens, further out I came to one of the twelve fortifications which were about being constructed round Cologne. This, Number 7 , was concluded, and appeared to me of great strength, the walls were built in many salient angles furnished with innumerable embrasures for the Cannons. The ditch was dry, inside the fort were four pumps. The soldiers had their lodgings underground, vaulted and bomb-proof. I returned to the town, crossed it, and came to the banks of the Rhine. Here are several custom-house stores, some small vessels were at anchor, people were busy landing and shipping goods. I passed the river, of considerable width, and with a slow current, over a floating bridge consisting of a number of shallow boats fastened together and boarded over, [733] which opened in the middle to allow vessels to pass. On the other, the right side lies the small place of Deutz where a fair was being held, there were 2 rows of miserable booths for the sale of cakes and ginger-bread there were equestrian performers, wild-men, snake-tamers, punch and Judies, etc. In the large hotel called Prindz-carl a band of music was playing, I passed through the saloon and through the garden to a large apartment where a few of the good Burghers of Cologne and Deutz were taking their bottle of Moselle wine, I was the only one who ordered tea. Then I wrote in rough a letter to Mr. William Gibbs, walked back to my hotel, and went to bed at half past ten.

Thursday, $17^{\text {th }}$ of October 1844 . This morning a valet de place whom in my original diary I call a necessary evil, accompanied me in order to show me in as short a time as possible the various interesting buildings which are worth the traveller's attention in this ancient Archiepiscopal town. Until 1844 a Coffeehouse in the street called the hay-market had answered the purpose of an exchange to the merchants of Cologne but as their trade was rapidly increasing they had considered necessary to have their own exchange as it is the Custom in all commercial towns; accordingly a short time previously, they had purchased a building said to be the oldest in the place, once the property of the Knights Templars, it had now been renovated in its original style, and its innumerable small arched windows seemed to me to be its greatest peculiarity. The town-house is likewise an extremely ancient building; the niches in its walls stood empty, they had once been occupied each by an image of a saint, but these had been destroyed by the French at the time of their republican anti-religious frenzy, the Engraving in appendix Number 20 gives an excellent idea of this town house, so does $\mathrm{N}^{\circ} 21$ of the choir, seen from behind, the only part which in 1844 was finished of this Cathedral or dome, which when concluded was expected to be one of the most beautiful, if not the most beautiful, Specimen of Gothic architecture on earth. Its cost was calculated would amount to four and a half millions of Prussian dollars, the Prussian 
Government contributed annually 6o,0oo dollars to its construction and collections were made for the same purpose all over the globe. Hewn white sand-stones was the material exclusively used. The choir itself is as large as a church, its exterior walls are crowned with pinnacles or small turrets which encircle the roof. In the interior the slender graceful pillars which sustain the roof rise to the height of one hundred and eighty five Rhenish feet. The wall between the two pillars is painted al fresco, up to a certain height. Upon the wall [734] rests an arch, another arch upon the lower one, and between the two arches a gallery runs round the interior, whilst another gallery, provided with a high stone balustrade, encompasses the roof. We ascended as high as the outer gallery, two hundred and sixty five steps from the ground. About the time when the turrets already mentioned were near their conclusion, the Empress of Russia, the spouse of Nicolas I, gave an entertainment upon the scaffolding where the select party amused themselves with singing and dancing. The windows of the Choir are stained and of extreme beauty, many relics and treasure are shown here. Also for a considerable fee the monument which is said to contain the remains of the three Kings who paid their homage to Jesus Christ eighteen centuries back is opened to the curious visitor, my curiosity however did not go so far, and I saw neither the relics nor the bones, the authority of which being very apocryphal. A church which was to be pulled down as soon as the Cathedral were finished connected the Choir with the entrance of the arched gate-way in the middle, only an idea could be formed of the tower, on one side the foundation had just been laid whilst that on the other side was about half finished, and on its top stood a crane employed for lifting up the stones, which for many years, whilst the Cathedral was building, formed a prominent feature in all the views taken of Cologne at that period. The Theatre, the Government-house, and the edifice containing the Courts of justice are modern. In the street called the Skinnen-Gasse my valet de place pointed out to me a house owned in 1844 by a merchant Wagner in which the painter Rubens was born in 1577, and in which Maria de Medici died in 1642 (she was the widow of Henry IV of France), further particulars are given on two stone tablets placed in the wall of the house. Of less interest to me was an old Roman tower with a modern structure on the top; "the Gürzenich", with the meaning of which word I am not acquainted, is likewise many centuries old. The Panorama of the Rhine which is in my possession gives a small engraving of this edifice; in the first Story is a Saloon of an immense size which serves for balls, concerts and similar festivities. The Church Saint Mary of the Capitol is of great antiquity, it is held together or at all events its walls are encircled by an enormous iron hoop. The Church of the apostles (see in the appendix under $\mathrm{N}^{\mathrm{o}} 22$ ) has a cheerful appearance, it stands in the parade; behind it is an old 
house remarkable on account of the story told [735] regarding two wooden horse-heaves which look out of the [_] side the fourth floor, my valet de place narrated it to me, and Oehlenschläger had made use of it for a pretty novel which I read on board the Steamer on my late passage from Copenhague to Kiel. The legend says: A Burgomasters wife having died, or at least, being supposed to have died, the Sexton coventing a valuable ring which she wore on one of her fingers tried to pull it off. She merely being in a trance awoke, the Sexton frightened ran off, while she in her winding sheet arose from her grave and walked to her husbands house where she rang the bell and the burgomaster himself opening the door told him who she was, to which he incredulously replied, that he as little believed her to be his wife as he would believe if anybody were to tell him that his best horses were at the moment in his drawing room. Whether the horses walked up stairs, my informant could not tell, but he knew that the wife was admitted and lived happily with her husband seven years more. I paid my valet de place, probably half a Prussian Dollar (a Prussian dollar being the fee for a whole day), then took a beefsteack in the Cafe de la Bourse for 6 Sgr., whilst for a dinner with wine at table d'hôte I should have had to pay twenty seven silver Groschen, in this manner a Gentleman travelling by himself can, if he likes, economize a good deal, which he cannot, if he travels with his family as I did on my later visits to Europe. At half past two I left by rail for Bonn in the second class, no more the disagreable Char á banes, but convenient carriages like those already described when travelling in Prussia proper and Saxony. The principal town between Cologne and Bonn is Brühl on the right side, my fellow travellers told me that it is a very pretty place, and that it is much frequented by the Cologne people in the Summer Season. The palace, formerly the property of the Archbishops of Cologne, stands close to the Railway. When approaching Bonn the country is hilly and woody, towards the Rhine it is very flat. On the other side of the river I distinguished Das "Sieben Geberge", or the seven mountains, also on a hill a large white building, an asylum for lunatics. In Bonn I took-up my quarters in the star hotel in the market-place, and without delay started for one of my habitual walks, leaving to the left the large university buildings, and walking through one of the Gardens I found myself unexpectadly upon a terrace which over [736] [...] two or three nice servant girls who attended on some little children willingly answered my questions, and gave me much information regarding the many objects around me. The spot where we stood called the "Alte-Zoller", Old Balcony which Kramer of Hamburg who had lived as Student in this place, had particularly recommended to me. Opposite on the right bank of the Rhine lies the small town of Beul, a single row of houses interspersed with trees and bushes, at the northern extremity of which stands a church, whence a small 
wood extends as far as the river, just behind Beul, I saw the white houses of Siegburg; to the South of Beul the ground rises gradually to the height of the Seven mountains, the Drachenfels or rock of the Dragon is known by a ruin, the Petersberg or Peter mountain by a public house on its top. A short distance up the river its progress seems to be stopped by the apparent meeting of the two shores, a delusion caused by the small bend which the Rhine makes here to the Eastward. On the Bonn or left side, the most striking object was the Godesberg. To the South of the terrace were some gardens, Northward the houses of Bonn and a windmill. I remained here some time until the rays of the setting sun, which illumined the summit of the Seven mountains whilst the rest of the landscape lay in the shade, reminded me that it was time to leave. A fine avenue of Horse chestnut trees brought me to the village of Popelsdorf, where in a house called the palace a museum containing objects of natural history is shown to the stranger. It was fast getting dark, thus I could only hurry through it, observed however that the collection of butterflies and beetles was here more complete than that of the same kind in the far famed Leyden museum. I hastened through the village of Popelsdorf and ascended the Kreutzberg, or cross mountain, but it was now so dark that I had nothing better to do than to return to Bonn, which I did by a road different from that which I had come. It was a beautiful evening, I walked along merrily. In my hotel, I took a light supper, in bed I read "Le mie Prigioni", and was soon fast asleep. I saw in Galignani's messenger, that the sum required for building thirty one Railways in England for which licences had been given by the parliament in 1844, would require $£ 11,874,921$; from the Catholic almanch for 1845 , I made an extract, of which the following is a translation: even the most pureblind eye cannot con- [737] found the Catholic religion with those dissenting cre[_], of the features which characterize it, one recognizes it to be the only religion of Jesus Christ, one sees that it is not the Child of man, that it derives its origin from Heaven. Credat Indans apella.

Friday, $18^{\text {th }}$ of October 1844. This was the anniversary of the battle of Leipsic, not celebrated in Bonn. When in Hamburg, Kramer had furnished me with some notes relative to my Rhine tour; with reference to them, with the advices given by my landlord and with the assistance of Reishards guide book in German, and the manual des Voyageurs in French I was able to plan my todays excursion into the environs of Bonn without guide or Companion, and this excursion turned out to be a very pleasant one, for the weather was fine and I being by myself could stop where I liked and go on just as it suited my convenience. Leaving the town at 9 o'clock I started due west and came soon to a well kept chaussée lined with poplars, which crossing the Railway from Cologne, and leading through Kitchen gardens and orchards, took me to the village of Enderich. To 
my left I had the Kreutzberg, to my right the hilly country, the same which I had noted on the previous day when approaching Bonn. Turning to the left a gentle ascent through vineyards, the vines propped up with poles, though bearing hardly any grapes, probably on account of the cold Summer, brought me to the summit of the Kreutzberg, where I found somebody who opened the Church, a convent in former times. We descended to the vault where twenty five open coffins each with the Corpse of a monk were ranged in rows. This vault has the peculiar property, that corpses deposited in it, do not putrify, but dry-up. Some of the bodies which have stood here for more than two centuries were, it is true, reduced to mere skeletons, however the skin, hard as parchment still covered their bones, others which dated only a hundred years back were comparatively speaking well preserved. The skin to be sure was dry, but some of the features could be recognized, and the shoes, hair, and beard still existed. There was no disagreeable smell neither did I feel any disgust whilst examining these corpses. The thought that crossed my brains was that before the lapse of many years my dear wife and myself would be like those now lying before me. From the steeple, the view extended Northward as far as Bonn over a well cultivated plain sprinkled over with villages. To the Eastward flows the Rhine, on the other side of which again villages, and the Seven mountains, [738] whilst to the east and west the horizon was confined by wooded heights. From the Kreutzberg I cut right across fields and vineyards to the village of Kesenich; everywhere peasants were busy mostly with digging potatoes. The road from Kessenich to Dottendorf was pretty, on both sides I had green meadows, rich in fruit trees, those to the right bounded by hills covered with trees of various descriptions now in their autumnal Garb. I passed through Friesdorff in the neibourhood of which are important alum works, and reached the village of Gödesberg. All these village though small, had a steepled church, the children were generally fair, I saw one woman with a goitre. At Dreitsch close to Godesberg where the keys of the ruined castle of this name were kept, an old woman insisted upon my tasting the mineral waters which bubble here out of the ground, they are pleasing to the palate, much like the Selzer water; my guide book says that their ingredients are: Carbonic acid Gas, Chalk, magnesia, iron, and salt, of which the latter, the salt, I did not observe the slightest taste. The old woman accompanied me to the mountain. She opened the gate of a round-tower, well preserved, we ascended first a convenient stair-case, then a number of steps, cut into the wall, nine and a half feet thick, finally a ladder, which brought us to the top, lately covered with copper sheathing. The view hence is similar to that from the Kreutzberg, perhaps a little more extensive for here I could distinguish at the utmost verge of the horizon, the Cathedral of Cologne, also at the foot of the Seven mountains, the hamlet of Konigswinter, 
both which I had not been able to see from Kreutzberg. My guide informed me that the door through which we entered and the convenient stair-case had been made in later times. In the middle ages, the only entrance to the tower at a considerable height above the ground, was by means of a ladder which the inmates let out, and pulled-in again, whilst the lower part occupied now by the stair-case was the Dungeon into which prisoners were let down from above by means of a cable, and air was admitted into it through narrow openings in the enormously thick wall. This tower most have been the innermost part, or the Stronghold of the Castle, the ruins of the outer walls the one within and at a short distance from the other, can still be seen, also those of a corner tower, and of another tower somewhat lower down from, [_] object of which probably was to defend the entrance to the principal arched gateway of which some vestiges are still visible. Gebhardt, the famous [739] Archbishop of Cologne who married the beautiful Agnes de Mansfeld and turned protestant, was besieged in this Castle by his enemies, my guide told me, they were Dutch, my guide book Bavarians, at all events there is no doubt that the Castle was blown up by Ernest, Archbishop of Cologne, and Gebhardts successor. From the Godesberg a beautiful Chaussée between vineyards and Corn fields lined with poplars and lime trees leads to Bonn. On one side of this Chaussée stands a monument called the high Cross (see appendix under Number 23) it has a cross on the top and a niche on each of its four sides, two of these stood empty, the statues in the two others were without heads. On approaching Bonn pretty Country houses formed on each side an almost uninterrupted row. In the handsome hotel de Bellevue, I took a beefsteack, and after having rested a little, was rowed over to Beuel on the right side of the Rhine, passed the Village of Pützchen with a Church disproportionately large for the small size of the place, and intended to walk as far as Ranedorff, but as darkness was coming on, I was obliged to retrace my steps before reaching this village and to return to Bonn. Now I crossed the river by means of a flying bridge, that is to say by a [_] ferry which moved along several small boats anchored in the river. [...] Steamer office, I took a ticket for my passage up to Mayence, [_]lid for one month with permission to go, and to remain on shore where and whensoever I liked during this time.

Saturday, $19^{\text {th }}$ of October 1844. It was a clear, rather cool morning, thermometer in my room, windows shut 11 Reaumur $=57$ Fahrenheit, in the open air $5=41$. The greater part of the forenoon I whiled away the time with walking about in the town and in the fine avenues outside the same, with paying another visit to the Alte Zoller, with purchasing Victor Hugo's Notre dame de Paris in order to have something to read on board, and with looking at the Students, some of whom with great self sufficiency strutted up and down the streets 
smoking their long pipes, all wore caps, and frock-coats, Blouses continued to be the dress of the peasants and artisans, the peasant women had a large handkerchief tied round their head the ends of which hung gracefully behind down their neck. At half past two the Steamer from Cologne arrived. On board I made the acquaintance of a young Russian who spoke English fairly; he told me that he had been educated in England and been in Hamburg in the Counting house of a certain Mr. Bottomley whose son I remembered having seen in Lima [740] several years previously. Having left Bonn we steamed up the river; the panorama of the Rhine gives the names of the various villages which we passed on both sides, and shows how a narrow belt of level land, well cultivated, extends between the waters edge, and the base of the gently rising wooded heights. The village of Ober-Cassel on the right side is remarkable in as far as it is for some distance up and down the Rhine the only village which has a protestant church. I landed at Königswinter, left my luggage in the Hotel called the "Berlin Court", and without further delay started for my ascent of the Drachenfels. An old man was my guide, who I soon discovered could not keep-up with my quick walk, on level ground I was in the habit of making six hundred and sixty paces in five minutes. The Seven mountains have the following names: the Oelberg 1475, Löwemberg 1414, Nonnenstromberg 1066, Drachenfels 1026, Volkemburg 1050, Petersberg 1053, and Hemmerick 960 Parisian feet above the level, I suppose, of the Rhine; the most southern is the Drachenfels, the ascent to which is easy and gentle, the road winding-up first through vineyards, further up through a wood. On the summit stands an inn which I did not enter. At the very highest point, the ruins of an old tower are still to be seen, as [...] mass of stones, the remnants of a monument erected here in 18 [...] Prussian Landwehr, but which was demolished on account of its unsafe $[\ldots]$. The prospect from this elevation is very extensive, I was much favored by the clear weather, though at the verge of the horizon, the air was somewhat hazed. At my feet I had the Rhine, a trifle up the River, the two small islands of Nonnenwerth and Graffenwerth. On the opposite shore, far to the North, I could distinguish the Cathedral of Cologne, a good deal nearer Bonn and its church. Somewhat inland the godesberg mountain with the villages of Godesberg and Krüngdorff, close to the shore the village of Petersburg, and followg. the course of the river upwards on the same, the left side, upon a rock, a beautiful arch, all that had remained of the Castle of Rolandseck, close to it the villages of Mehlem and Rolandswerth; the steeples of the Church on the Apolinaris-mountain, and the town of Remagen were the very last objects in that direction, the whole landscape being bounded by the distant tree-covered hills which form the back ground. Northwards of the Drachenfels lie the six other mountains of the Sieben Geberge, they, drawing to the East, thence 
further to the South make a half circle occupied by various villages, Rönsdorff at the very foot of [741] the Drachenfels, Honness, and others whilst to the Northward lies Pützchen, Königswinter and Rainsdorff. I remained here a long while, not tired of looking round and round and should have remained still longer had not my guide pointed to the sun, only a few degrees above the horizon. The descent from the Drachenfels down one of its tree clad sides, as well as a similar ascent up the Lowemburg was to me quite as easy as the ascent to the first of these mountain had been. Between the two, not in a straight line, lies the Wolkanburg; when passing it I saw workmen busy with cutting out of the rock sandstones sent to Cologne, Dusseldorf, even to Holland. The Summit of the Löwemburg is covered with birches which preclude of course every distant view, but even without this impediment, twilight was so fast deepening into night, that close by I could merely distinguish some ruins, probably of an ancient castle below, the Rhine gl[immer]ing under the rays of the moon, now in her second quarter, and opposite, lights glittering in the houses along the shore. It was a delightful moment, I did not feel solitary, I felt happy, my thoughts wandered to the banks of the Elbe and of the Rimac. When descending, I met my guide still toiling-up. We passed through Rönsdorf, then skirted the foot of the Drachenfels, walked along the quiet Rhine, and reached Königswinter at seven p.m. In the General dining room of my Hotel some burghers of the place were playing cards. I took my supper and made the acquaintance of a Gentleman and his wife from Dusseldorf, very nice people with whom I conversed till 10 1/2. My bedroom looked upon the Rhine, now so pale in the moonshine, the lights opposite were extinguished, only one lantern was burning on this side upon the flying bridge. About midnight I heard some stir below caused by the arrival of the Steamer fm. Cologne.

Sunday, $20^{\text {th }}$ of October 1844. It was a fair clear morning. Before seven oclock, accompanied by the son of my last night's guide, a fine active lad, I was on my way up the Petersberg, the lower part of which is covered with vineyards, the higher part with birches. The road which leads-up to the summit where the Saint Peters Chapel stands is lined with many crosses, also with seven images of the Virgin mary, at the foot of which the Catholics when during Lent they make their p[i]lgrimages to the Chapel, kneel and recite their prayers, "andan las Estaciones" as they say in Peru. It is well known that the custom of saying prayers seven times at seven different places or altars, is founded upon the legend, I say legend, because [742] the Bible does not mention it, that Christ when carrying his cross to Golgotha stumbled seven times under the weight of his load. From the top of the Petersberg the prospect is similar to that of the Drachenfels some parts of the landscape were illumined by the rising sun, others still lay in the shade. We descended, and my guide, well acquainted 
with the where-abouts led me through the wet high grass and underwood where there was no road nor paths to the ruins of the Abbey of Husterbach which together with the land belonging to it was owned by a Count Von der Lippe, who had surrounded his property with a stone-wall. At the entrance stood the images of two saints, Saint Benedict and Saint Bernard. The ruin is modern, for the Abbey was destroyed towards the end of the last century by the French army during the wars of the Revolution, only the back part of the choir still remains, two parallel half circular walls forming a passage, the exterior with arched windows, the interior with several slight elegant pillars. Not far from the ruins is the tomb of the father of the present Count; it is a vault under an artificial mound shaded by trees, resembling that of the Count von Holstein (see page 488 of this volume), also the burial place of General Stobe, his wife and daughter, and the monument erected to their memory in 1825 by the officers of the $25^{\text {th }}$ Division of the Prussian army. On our return to Königswinter through woods and vineyards I by chance plucked a grape, when my guide observed to me that if I had been caught in this act of delinquency by the Rural guard I should without fail have been arrested, he also told me that the blue grapes ripen earlier in the season than the white ones. In the hotel the waiter mentioned to me that on the preceding evening, when I had gone up-stairs, a Russian who had been listening to a conversation between an elderly gentleman and myself (the Gentleman from Silesia) had addressed this latter in harsh terms, and taken him to account for some remarks made by him, unfavorable to the Russian Government. This, I thought by myself, shall be a lesson to me, not to speak of politics in public. At half past nine the Steamer passed-by and I went on board; we steamed between the island of Nonnenwerth, and the left bank, then on my turning back I saw before me the Drachenfels with its ruins, the large hotel on the island, and the arch of Rolandseck upon a rock, of which the engraving $\mathrm{N}^{\circ} 24$ in the appendix gives a very good idea. A little further up the river I landed at Unkel on the right side, where I left my luggage [743] in Classens public-house, for having forgotten my view of the Rhine in the Königswinter hotel, I determined upon returning thither to fetch them. I was ferried over to the opposite side; the weather being pleasant as already said, I had a delightful walk, first through the Vineyards on the hill, then descending to the Chaussée, I passed the miserable village of Oberwinter and a few houses which go by the name of Rolandswerth, ascended the rock of the Rolandseck to have a look at the fine arch, all that remained of the Castle or Convent which once crowned the height, whence I scrambled down a path quite as steep and rugged as any which had turned up hitherto in my many mountain-excursions. Being again on safe ground I took a boat in which I was rowed over to Nonnenwerth. I recollected the praises 
which the Baron de Winterfield whom I have mentionned on page 366 of the $1^{\text {st }}$ volume of these extracts bestowed on the beauties of this island, which however pretty as the walks are did not answer the expectations raised by his glowing descriptions. The large hotel has centuries back been a monastery of which the vaulted passages round the same give evident proof. I crossed over, and choosing foot-path instead of following the high road reached the point where the flying bridge forms a communication with the other side. More than once I met teams of eight or nine powerful horses which walking the one before the other were harnessed to a rope fastened to heavily laden vessels, which in this manner were pulled up the river. The boats used here are in construction similar to the whale boats which I had seen on the west coast; I engaged one of them, and the boatmen had to use all their efforts to prevent being carried away by the current which here runs faster and stronger than further down. In Königswinter I found my engravings; having now time to spare I walked leisurely, not by the high road, but on foot-paths nearer the Rhine, through vineyards, Cornfields, and Kitchen gardens, passed the villages of Honness, Donsdorf, Rheinbreitsbach, and Scheuren, and reached Unkel an hour and a half after I had left Königswinter. In Classens public house I dined upon beefsteak, potatoes and a glass of wine, and continued my journey by the next steamer. The width of the Rhine diminishes gradually. The heights on both sides are covered with vines from top to bottom. At Remagen, a small town of the left bank, I again went on shore, and took my lodgings in the hotel called the King of Prussia. Close by on a hill called the Apolinariosberg the Count of Furstemberg was in 1844 building an extremely tasteful Church of granite and Sandstone, in the form of a cross. Its exterior was nearly concluded, it had four steeples, many small turrets, and various niches in [744] which statues of saints were to be placed, on the outer-wall of the Choir, the arms of the Count were hewn in stone, the vaults beneath were not yet finished. The interior was filled with scaffolding, and several painters were employed (this day being sunday they were of course at rest) in adorning the inner wall with fresco-paintings, copies of the frescos of Saint Peters at Rome. A small garden is attached to this church, from the same I had a pretty view over the Rhine to the two villages of Heister and Erpel, the Drachenfels and the Rolandseck were still visible. The evening was pleasant, though cold. I loitered about in the streets of Remagen which place, small and insignificant as it is, is surrounded by a ruinous wall with a dilapidated tower. In a corner many children were playing in the Streets, girls walking arm in arm, Burghers smoking their pipes, all enjoying the fine weather and the leisure of a Sunday evening. In this ultra Catholic country Crucifixes and Crosses in great number stand on the road side. I even met 
a man walking along with a hat and a Rosary in his hand repeating his AveMarias and Pater nosters, whilst a woman behind him, said the responses.

Monday, $27^{\text {st }}$ of October 1844. The weather continued to favor me, the sky was clear, the temperature cool; my todays excursion was due west, up the valley of the Ahr, a small river which takes its origin in the Hündsruck and falls into the Rhine a little South of Remagen. Accompanied by a guide whom the landlord had procured me for the first part of the road, where I might possibly lose my way, I started by seven oclock and was soon joined by a Government officer, inspector of the Chausseés, or turn pike roads. As soon as we had left Remagen, we had to ascend, and walked for a considerable while through underwood, Hazel, and similar bushes, under the shade of Birches, oaks, and other trees. The Apolinariosberg we had left behind to the right, whilst to the left the ruins of the Castle of Olbruck or Ulbruck, situated as usually on the summit of a mountain, came in sight. I looked round, could distinguish the Rhine and on the opposite shore, upon which still rested the morning vapours, the villages of Heister and Erpel whence the church bells sounded merrily across the water. My guide left me, when a short descent brought me to the Village of Gemmingen prettily situated in a hollow or "Kettle" surrounded by the neighbouring heights covered with vines and trees. We passed the foot of a mountain crowned with the ruins of Landscron, skirted the village of Keppingen which is well known in the vicinity [745] for the mineral waters found close-by, and shortly after reached a well kept chaussée, here also the Inspector said good-bye, and I continued my walk by myself. This chaussée leads in a straight line to Ahrweiler passing through Vandenheim and Hennessen, to the left lies Bachheim. The houses in all these villages are built of stones and clay, none of brick, and though they are pretty to look at from a distance, when entering them, the illusion is soon dispelled, they are dirty and miserable. On both sides of the Chaussée as far as the ridge of hills which confine this valley the land is well cultivated, vines grow, both upon the hills, and in the plain, but not in great abundance. The town of Ahrweiler is surrounded by a dilapidated wall, there are still the remnants of one or two towers, and the ruinous gate. It is paved to be sure, but even the pavement was out of repair. At half past nine I was on the other side of this place; to the left I had now a small eminence, the Calvary mountain, upon which a church was being built, the valley becomes more and more narrow, the hills are cut into terraces, and the vines, each propped-up by a pole draw their nourishment from a generally stony soil. The Chaussée was lined with vines, and the vines I even found in the streets of the next village called Walporzheim. I observed that upon the wall of the first house on both extremities of each village, its name is written in large letters, for instance: Walporzheim, Landwehr, Regiment 22, [_]allion 2, (Kreis Ahrweiler, 
Regierungs-Bezirk Coblentz). The Ahr, a river which has a considerable fall, though it cannot be called a mountain torrent, was now to my left, to my right were abrupt and craggy rocks, part of which must have been blasted away in order to make room for the Chaussée, these rocks break easily into slabs as if they were slate but whether they are really slate, my want of Geological knowledge prevented me from deciding. I passed the villages of Mari[e]nthal and Danau, and was told that on this day the vintage commenced. It is true, I saw some peasants gathering grapes, I saw also one or two carts upon which stood tubs filled with grapes, but upon the whole peasants were more occupied with tilling the Soil, with manuring and taking potatoes out of the ground than with attending to the Vines. I crossed the Ahr from the left to its right side, all along the road I had seen many crosses, Crucifixes, and images, but this bridge was graced with a Saint of a most forbidding aspect with a cross in his arms. Here lies a small village Bech, almost hidden in a nook [_] prettily situated, as can well [746] be imagined; it was now eleven o'clock, and the villagers were no doubt getting ready their dinner, for I saw the smoke curling up from theor chimneys, on my accosting one of them, he told me I had gone wrong for I should have remained on the other side, and pointed out to me a pretty foot path which gradually ascending through the Vineyards brought me to the top of a low hill, where I sat down, rested a few moments, and enjoyed the pretty view before me. I descended, recrossed the Ahr, continued my walk on the Chaussée cut through the rock to the Laach-mill, and passed the village of the same name as well as that of Reimerzhagen. Troops of little children ran after me crying: (Shank me was) English: "make me present of some thing". The wine clad hills were no more hills, they had changed into steep, abrupt rocks, high and so near each other that the rays of the sun though it had reached its zenith, did not reach me in this narrow cleft. I came to the Durchbruck, or break through, a splendid vaulted tunnel about forty five yards long with a deep open cut at each of its two extremities. The ruins of the castle of Altenahr and the village of the same name follow next. In a public house kept by a certain Uhlrich I took a glass of Beer, bread and butter, having rested for about half an hour, still proceeded on my walk, I passed the villages of Altemburg and Kreutzberg, came to a modern building with green Venetian blinds which together with the adjoining ruined tower and wall was the property of a certain Mr. Von Bosslaer of Bonn; it lies on an eminence, surrounded by hills of still greater height. Having come so far, I should willingly, if it had been possible, have continued my walk in the same direction to find out whither it would lead me, but this of course was a momentary thought abandoned as soon as formed; on the contrary it was high time for me to return without loitering on the way. I started from Mr. Bosslaers Property at half past one, reached 
Altemberg in ten minutes, Altenahr in twelve, Reinershagen in fourteen, Laach in Eight, Mayrschafs, which I did not pass through on my going, having by mistake crossed over to the right side, in eleven, Bech in twenty two, Danau in twenty three, Marienthal in seventeen, Walporzheim in fifteen, Arweit in Eighteen, through this town in Eight, Hennessen in twenty, Wadenhe[_] in fifteen, Heppengen in thirty seven, Gummingen in ten, to the hotel of the King of Prussia in Remagen in [_] minutes; altogether in four hours and fifteen [747] minutes without stopping. For the last hour, after the sun had set I had found my way with the help of the light of the moon; though as the sky had become overcast, it was not so clear and bright as it had been on the previous evening. My Landlord said that I had walked as great a distance as Eight post miles, Bosslaers property being four Post-miles distant from Remagen. Perhaps there was some exaggeration in this. At all events I was not over fatigued, though hastened to bed as soon as I had taken my supper in company with the landlord and three Remagen burghers.

Tuesday, $22^{\text {nd }}$ of October 1844. At ten oclock I said good-bye to my landlord Mr. Hoffmann and went on board of the steamer, which this time struck me on account of her great length and narrow width. Vessels of this build are calculated upon going more easily through the water than those which are short and broad. The engine was made in the factory of Cokerill near Liege. We had a cold wind blowing right into our teeth, and I was only kept on deck by the beauty of the Scenery. The river grows narrower, the vine clad hills, except at the mouth of the Ahr, where the shore is low, increase in height, and towns and villages along the banks, ruins on the summits of the mountains follow each other in rapid succession. My Panoramic view gives their names, I will only mention on the left side the latterly repaired ruins of Rheineck, the village of Bröhl and the town of Andernach where I landed. It is as the manuel des voyaguers says the most ancient town on the Rhine, it was built by the Romans and was of great importance as far back as the year 309 of our era. I entered it under a low gateway, and walking up a long very narrow street came to the Lily hotel where I took-up my quarters. My this days excursion to the Laacher lake was similar to that on the previous day, but much shorter; the aa in Laach is pronounced by the people of the country very much like Danish aa, and judging from the similarity of the words, I should not wonder if Laach means lake. As soon as I was outside of the town I had to ascend and found myself erelong on a rather extensive plain at a considerable elevation above the level of the Rhine, the greater part was under cultivation, the remainder was pasture land on which sheep were grazing, and some villages lay sprinkled over its area. To the left a road turns-off to Ober and Nieder Mending in the neighbourhood of which places are stone-quarries. The mill stones cut there 
are forwarded to andernach for shipment. My road which inclined to the right avoided all those villages and after skirting a [748] wood for some time brought me to the Laacher lake, which excepting on the side whence I came, is surrounded by dense masses of beeches and oak trees, now alas in their autumnal garb. I kept on the south side of the lake and came to a building with a church attached to it, formerly a convent. Also to a public house with a pretty garden, which inhabited and frequented in the Summer season, now stood empty, and was closed. Thence I continued my walk along the western shore between the wood and the lake, the trees extending hardly ever to the waters edge. All was quiet, nay gloomy, I alone in the solitude, gradually a sadness to which fortunately I was but seldom subject at that period of my life crept over me; what was the cause? I could not tell, whether it was the melancholy of the scenery, or a reaction consequent upon the over joyousness of the preceding day, or the apprehension of an unknown impeding evil? I knew not. At all events it lasted long before I could shake it off. Opposite the convent on the Northern side of the lake stood a hunting lodge which I discerned at a distance making my way right through the wood, then following a gently ascending carriage road, I again came to the previously mentionned high laying plain. To my left I saw the village of Wattenach situated in a hollow, thither went my way, I passed through it and had now to my right the cultivated fields above spoken of, to my left woody hills, the boundaries of the plain. It was a very pretty road, much prettier than that which I had come. Continuing my descent I passed a Church in ruins, and on my asking a passer-by, when, and by whom it had been destroyed, I received the usual answer; by the French in the time of the revolutionary wars. Further on I came to the prettily situated village of Tonnesstein, and was shown to a well where the mineral water which is exported hence to Foreign Countries gushes out of the earth. Its taste is sourish, very agreeable, hundreds of stone bottles lay piled-up on the ground. Under a shed round a table sat three prussian officers who invited me to join them which I did, and was much pleased with their polite demeanor; they had visited the Ruin of Olbruch and intended to return to Amdernach by the nearest way, I took the road more to the left down the Picturesque Bröhl Valley very narrow, wood covered hills on both sides, [_] the Bröhl, a small rivulet which finds its way into the Rhine, putting in motion several mills in which the valuable stone found in the quarries of these hills, and which goes by the name of Luffs stone, i[_] [749] crushed; when crushed it is called "Drass", and mixed with Chalk forms a Cement indissoluble when used in masonry works under water. I recollected that in January of this year, when I visited with Messrs. Willink, father and son, the Knoop Lock (see page 370 of this Volume) which was then under repair, they spoke to me of such indistructible cement, may 
that not have been the same as this from the Bröhl Valley? On my approaching the Village of Bröhl situated close to the Rhine, I left the high road, and took a foot path which running behind the place brought me to a paper mill, the "Concordia", next to the Chaussée along the Rhine. To my left was the Reineck castle hardly a quarter of an hours walk distant, but though the moon shone, it was too late to go thither, and I returned straight home to Andernach. In the Lily hotel I ordered my supper, whilst it was getting ready, the landlord and the landlady, nice people in their way, kept me company. Up-stairs in my bedroom, it was so cold that I ordered the fire to be lighted in the stove.

Wednesday, $23^{\text {rd }}$ of October 1844 . When I rose at half past six, it was so dark that I had to call for a lighted candle, the rain came pouring down, I thought of giving-up my visit to the Rheineck, but on my landlord's assuring me that the rain was a mere fog, that the barometer was rising and that the weather would certainly clear-up, I ordered a carriage which put me down at the foot of the mountain. I ascended a path strewn with yellow and brown leaves through underwood and trees, when on the summit I applied for admittance and received for answer that, as the owner of the Castle, Professor Bethmann, was residing here with his family, visitors could only see a small part of the building. Accompanied by a servant I went to a tower attached to the main edifice, and ascending a few stone-steps, came to an extremely neat, even elegant Chapel, it was of a circular shape, vaulted, the ceiling sky blue studded with Golden Stars, along the walls, painted al fresco except where the altar stood with a crucifix upon it, were ranged benches, before each of which a desk on which prayer books were lying. We came to an apartment which might be called a boudoir, exactly above and of the same size as the Chapel, the furniture was of Rose wood, the Chairs and sofas with light blue silk seats and backs. On a table stood a small bronze statue, also the busts of the King and the Queen of Prussia, and a large vase of marble exquisitely sculptured, mirrors occupied two sides of the wall, whilst from the two other sides, windows looked upon the beautiful [750] landscape around, a bell rang and my conductor the servant left me by myself. I descended and went to another tower separated from the castle. A winding stair-case brought me to the top covered with asphalt, surrounded by a battlemented parapet, though the sky was somewhat cloudy, the prospect was delightful, over so many villages, hills, and ruins on both sides of the Rhine, whilst Westward the view was confined by more heights. Well pleased with this my short visit to the Rheineck castle, see [_] in the appendix, I drove back to Andernach, and noted close to the gate two apparently very ancient towers, the one with a "crane" on the top also of them an engraving will be found under $\mathrm{N}^{\circ} 26$ (in appendix). The ruined walls, another tower near the church, the crooked streets, the many antiquated houses; all, one with another 
was very interesting, and speaks of the old age of this town of Andernach. In good time I was at the place of embarcation. When the Steamers arrive, no time is lost, in a minute or two passengers leave and go on board, and they continue their course. On the right side we passed a place which I did not find on the map, also a modern ruin called the Devils house, with the Origin of which I am not acquainted, and before I was aware of it, we stopped again at Neuwied, where I went to a large Hotel close to the shore; this was again what might be called an hotel, whilst in Remagen and Andernarch the houses in which I had put up, though I had been well pleased with the accommodations they afforded, had been miserable looking and dingy. Sayn, a little inland, was the goal of my this day's walk, a few steps brought me to the open Country, for a short while I followed a chaussée which lined with fruit trees runs through a fertile, well cultivated plain where corn, potatoes, and other vegetables, but no vines grow. In the distance, hills with villages are seen, instead of continuing on the chaussée which would have taken me to Engers, I turned off to the left, and through by-roads rather muddy I reached the village of Sayn, prettily situated at the foot of the hills just mentionned. Everywhere peasants were at work, I also observed heaps of a stone found in this neighbourhood, which resembles pumice stone, when underground is so soft that it can easily be cut into the shape of bricks, when exposed to the air it hardens, and here abouts it is much used for partition walls in the construction of houses. I entered a public house where I ordered some coffee, bread and butter to be brought to the garden where I sat down, and enjoyed [751] the beautiful weather, at my feet murmured the Sayn rivulet, on the other side of which cattle were grazing on rich meadows, further on, on a mountain, the ruins of the Sayn castle, and all round, trees through the foliage of which houses were peeping. I next went to a royal iron foundry, the man whose duty it is to show strangers round being absent, a Gentleman who was busy in his office, immediately rose, when I mentionned to him my name, and my desire to see the establishment, he himself accompanied me for some time and handed me over to a young man who calling himself an expectant, was learning here as apprentice. This foundry was much smaller than that of Low-Moor near Halifax (see page 316 of this Volume) but everything was neat and kept in excellent order. The main shade, under the cover of which the furnaces stand and the greater part of the men were a work, rests upon two high and strong cast iron pillars. I saw the molten iron run in streams out of one furnace into iron pots in which it is carried to another place where it is poured into moulds made of moist sand where it cools in the shape of Bars, which bars are remelted in two different kinds of furnaces, the one (Reverbere ofen) heated by Coal in which the bars are melted by the mere heat of the flame, the other (Hock ofen) where the 
bars and coke are put in alternate layers into the furnace, and are melted by the fire itself. The apparatus for boring is very interesting; the borer otherwise unmoveable turns round on its own axis whilst the object to be bored is forced upon it, thus the aperture is made. I was shown an English made iron planing machine also the apparatus by which the air is created which fans the flame in the "Reverbere Ofen". The moving power in this establishment is water, not steam. I thanked my guide for the trouble he had taken in showing and explaining everything to me and then wended my way to the park or wood belonging to the Count von Boss which covers the sides of the Sayn mountain, a servant opened the gate, commodious walks lead-up, I passed numberless ruins, and on reaching the summit, I had a view which though I do not find its praises sung in any handbook surpassed in my opinion at least all I had hitherto had from Drachenfels, the Rheineck or any other elevated point. There I had the Rhine immediately below me, here I had at my feet the pretty village of Sayn with its slate covered roofs whence a rich plain dotted over with villages extends as far as the river, green meadows through which wind small rivulets like as many silvery ribbons, Cornfields intersected by roads alive with peasant men and women, with carts and [752] horses, across the Rhine tree and vine covered hills, behind which the sun gradually setting shedding its last rays over the whole landscape. I remained here a long while till the shade of the evening warned me that it was high time to return which I did by the same way I had come, the distance being one and three quarters of an hour's walk. In the Neuwied hotel I amused myself at supper with the perusal of a paper in which I found the prophecy, that erelong the trade of Hamburg would be annihilated by the growing commerce of Haarburg, Gluckstadt, and Antwerp.

Thursday, $24^{\text {th }}$ of October 1844 . As early as possible I crossed over by means of a flying bridge, and walking a short distance up the Rhine came to the monument which by "l'armée de Sambre et meuse" had been erected in honor of their Commander in chief Hoche. It consists of a short sandstone obelisk on a granite pedestal, and has this simple inscription "L'armée de Sambre y meuse á son General en chef", year not given. It stands upon a small Eminence, a vault below which was closed with an iron railing. Between this monument and the Rhine lies the small village of Weissenstein or white stone which probably owes its name to an ancient white and quadrangular tower in its immediate vicinity. On my return to Neuwied I engaged a Valet de place. Neuvied is in every respect different from Andernach, comparatively speaking it is modern, the streets are wide and cut each other at right angles, the houses, large, low and built in the new style of architecture. It belongs to the Prussian Rhenish provinces, but the Prince Hermann of Neuvied was still allowed to play the Sovereign. He had his palace, and his out houses for his suite and retinue; an aunt and 
two uncles of his lived with him, one of whom was Prince Maximilian whose name is well known in the scientific world by the publication of his journey in the Brasils. This prince has formed several Collections, to which I of course paid a visit, though a very cursory one. The one consists of stuffed animals, especially of such as are found in the Brazils, amongst which a gigantic turtle was a real monster, the second of Roman antiquities, nearly all dug out in the neighbourhood of Neuvied, near a place called Niederbiber, the third of Roman coins which would have been very interesting to me if I had had time to devote some hours to their examination which I could not. With regard to religious persuasions, a great variety existed amongst the Neuvied inhabitants, there were Calvinists, the most numerous, Lutherans, [753] English Episcopalians, Quakers, Moravian brethren or Hernhutters, Catholics and Jews. I entered the Church of the Moravian brethren which was a very plain unadorned building with an organ but without pulpit. The preacher was in the habit of addressing the congregation, men and women sitting separately, from a common chair placed in front of them, the large Saloon in which they meet in the morning and in the evening for saying their prayers is equally plain. Several streets are exclusively occupied by members of this sect. As long as they are unmarried, the young people live each sex by itself in separate large buildings, where the young men as well as the young women slept and took theirs meals in spacious saloons. As soon as they marry they leave, and each couple lives alone. The greater part of them are Artisans; what they make is sold for the benefit of the community, and the proceeds are taken care of and distributed by the elders. I was assured that in the schools kept here by the Moravian teachers not only children of their own sect, but also of other persuasions are educated. Soon after my return to the Hotel, the Steamer made her appearance, there were few people on board, the sky was overcast, the temperature pleasant. For a short time the banks of the river were flatter than they had hitherto been, gradually they resumed their previous character. Having passed Engers in the vicinity of which place are many iron foundries, we had to our left of course on the right side of the Rhine the frowning Ehrenbreitstein, opposite the pretty Moselle bridge. Coblenz in ancient time Confluentia derives its name from the conflux of the Moselle with the Rhine, it lies on the left side of the latter, to the South of the former river. The Steamer stopped here, and I went to the Giant's Hotel, the size of which corresponds to its name, and was just in time for table d'hôte at which from thirty to forty persons sat down. The dinner was excellent, nay too good. I then went in search of a Mr. Bohn at Jobst \& Cos. to whom Fischer had given me a letter of introduction, but had the mortification to learn that he was absent. I had counted upon his company and advice, now forced to do without him, I walked by myself through the Mayence gate along 
a well kept chaussée between the Rhine to my left and the Vine clad hills to my right to the Stolzenfels or "proud rock" about three quarters of a mile distant. I ascended a con- [754] venient carriage road, crossed a massive stone bridge of five arches over a gulley through which an insignificant brook flows to the Rhine, and came to the gate not of a ruin, but of an ancient castle the exterior of which had lately been repaired and rebuilt exactly as it had been originally; the King of Prussia who was the owner took a particular interest in having this reconstruction made completely and correct in all its details. Zwirn, the architect of the Cologne Cathedral, was also the architect of the Stolzenfels Castle. I passed the gate, a draw bridge, and at the guard house where a Sergeant and three soldiers kept watch, a card was handed to me provided with which I was shown over the Castle as soon as another party consisting of Prussian officers was despatched. The apartments which the King and queen inhabit when they come hither on a visit, which they do occasionally (two years back they had been here for the last time) were tastefully fitted-up; all the furniture was of oak wood, so was the wainscoting. In the Rittersaal which answers the purpose of a dining saloon, very large Goblets used centuries ago, were shown to me, also a red crystal basin once the property of Charles $\mathrm{V}$, a gold or gilt ewer which had served at the coronation of many Emperors. Against the walls were ranged a number of arms amongst which a dagger of Wallemstein and swords of many renowned warriors such as: one of Napoleon's found in his carriage after the battle of Waterloo, one of Prince Murat's, one of Poniatowski's, of Sobiesky, of Alba, of Tilly, the swords of the two last are straight ones whilst those of the others are more or less curved, Tilly's is uncommonly long. Though it was getting dark, I still ascended higher, for Stolzenfels stands not on the summit but on the side of the rock, the prospect from this more elevated point was however hardly more extensive than from the lower one. Opposite I saw the river Lahn flowing into the Rhine, the ruin of Lahneck, and the two villages of upper and lower Lahnstein. I returned to Coblentz in a beautiful moonlight, but on approaching the town lost my way, I kept too near the river, and for some time walked outside the high wall which surrounds the town, I had to retrace my steps, reentered through the Mayence gate [755] passed an open place with avenues, and reached my Hotel not without trouble and inquiries.

Friday, $25^{\text {th }}$ of October 1844. Before six oclock I wended my way through the dark streets of Coblentz to the Post office where the officials with lighted candles and fire in the stoves were busy dispatching the mail coach which at a little past six started for Wiesbaden. I took my seat as far as Ems. My companions were a French man, his lady, and two Germans. With one of them I entered into conversation; he appeared to be a well instructed Gentleman and he told me in the course of the day that his name was Moenster, that he was an 
Apothecary by profession, connected with a pharmaceutic establishment in Königsberg, or rather with a manufactory of mineral waters; he was now on a journey to the principal bathing places in Germany for the purpose of analyzing their waters on the spot. It was a disagreable morning, and even when it got daylight I could see but little of the Country, on the one side where the window was open, as much as fitted into the square space of the window frame, whilst we were driving-by, nothing on the other side, where the window was drawn-up, for the breath of the passengers adhered to the inside of the glass-pane owing to the cold exterior atmosphere, and rendered it impossible to look through it, thus I can only say that we passed the Rhine over a long bridge of boats, that on the right side of the Rhine we drove to the [_]ward through the villages of Pfaffendorf and Nieder Lahnstein close to the [_] of the Lahn into the Rhine, then followed the course [_] river, and reached Ems, a bathing place of great repute where the Frenchman, his lady, Mr. Möenster and I alighted. Ems consists of the village, of many Hotels, Bathing houses, and the never failing "Kur-Saal" which during the Season answers the purpose of Dining Hall, Ballroom and mainly of Gambling Saloon. Mr. Möenster and I took some refreshments, then went out for the purpose of seeing what was worth seeing, every thing being shut up at this season of the year when no visitors are expected, it lasted long before we could hunt out the proper person to show us round. The "Kur-Saal" is not particularly large but its interior is tastefully decorated, pillars, some of marble, others imitation of marble, form five arches along each side of the four inside walls, [756] these arches at the height of the floor of the first story support a gallery which runs round the whole interior, whilst in the middle the height of the Kur Saal reaches-up to the ceiling of the second story, both from the ground floor and from the gallery, doors open into many adjoining rooms. The three principals springs or wells are called the Krahn chen (the small crone), the Fürsten-Brunnen (Prince's well) and the Kessel Brunnen (cauldron well), their respective temperatures are 22, 27, 37 ${ }^{\circ}$ Reaumur. Springs of the mineral water abound in the vicinity, some are even to be found in the bed of the Lahn. A few have a temperature as high as 40 Reaumur, these are cooled in reservoirs before being used for bathing purposes. Another spring goes by the name of Lebens quelle, or life spring, where the water is forced-up by means of a pump and falls down in a fountain under which women who suffer from sterility place themselves. Large quantities of the Ems water are exported all over the globe in stone bottles which are filed in the months of February till June. Its taste is indifferent, by no means so pleasant as the waters of Draitsch, and those of Tonneistein, see page 738 and 748 of this volume. Though I asked Mr. Möenster more than once, what the ingredients were, I could not obtain from him a satisfactory reply. We also entered the 
bathing houses where the rooms and the baths are of different sizes and the rooms more or less elegantly furnished so as to suit the taste and the purse of the different bathers. In the season of 1844 five thousand guests had visited Ems. Whilst Mr. Moenster and I were looking at, and examining these various [_] the Frenchman and his lady accosted me, and asked if I understood [_], on my answering in the affirmative, they begged me to interpret for [_]. In the course of conversation, I found them to be very agreable people, and thus whilst Mr. Moenster absented himself to analyze the water, we three together promenaded the pretty walks along the Lahn, passed over a bridge to the left side of the river, where we ascended a small eminence. Looking back we saw below us, Ems prettily situated occupying a narrow space between the Lahn and a ridge of hills covered with trees in all the various hues of their autumnal foliage. When we returned to the hotel, we found Moenster who had just finished his experiments; he and I dined together, whilst the French people said that they preferred taking their dinner in a pavilion which we could distinguish from below situated on a height. Moenster [757] and I thought of following them, but missed our way, and came to the summit of another mountain considerably higher whilst behind us to the Northward rose another ridge of hills of still greater elevation. As it was yet early in the day, we resolved upon paying a visit to the small place of Nassau, regarding the situation of which to the South East of Ems, we had previously obtained the necessary information. About half way we passed another small place called Dassenau with some ancient towers and walls; on the other side we emerged upon a fine chaussée, and reached Nassau after a walk of about two hours. Nassau is insignificant in every respect; the only remarkable house in the place is that which belongs to the family of Von Stein, in which the Baron of this name, the Patriotic and energetic Prussian Minister, lived for some time in banishment at the period when Prussia groaned under the French yoke. On the other, the left side of the Lahn, we discerned a mountain with some ruins, part on its side, part on its summit; on inquiry we learned that the former were those of the Von Stein castle, the latter those of the Nassau Castle. Having still time to spare we went thither over an iron chain bridge which here spans the Lahn, as this was the first bridge of this description which I had seen, I give in my original diary the following description: at each extremity, two massive and strong stone pillars are erected distant from each other the width of the bridge. Between the two pillars opposite to each other, one on each side of the river, hangs a massive iron chain, which passes over the top of the pillars and is securely fastened in the ground below. From these two chains, parallel to each other, are suspended a number of smaller and thinner chains, each with a hook at the bottom. Into these hooks on each side a beam, whether iron or wood I do 
not know, is placed, of such length as to reach from the one shore to the other. Across these two, other beams are placed, which again are covered over with boards lengthways, and the bridge is constructed. The hill or mountain if you like to call it so, was but a short distance from the bridge, it was covered with wood, and a gently ascending path brought us first to the lower lying ruin, then to the other on the summit. We passed under the dilapidated gateways, into the outer one of which were cut the arms of the Nassau family with two Lions as supporters, above the words: Gemeinschaftliche Stamm Burg Nassau, English: "Castle, the origin of both families Nassau", and came, within gates, to $[\ldots]$ which still $[\ldots]$ of a round tower. The Von Stein date their genea- [758] logy as far back as the year 1000, the Nassau family derives its origin from Otto of Lauremburg, brother of the Emperor Conrad I, who lived in the $10^{\text {th }}$ Century, in 1255 they divided into two branches, the elder from the Elder brother Walram, the younger from the younger brother Otto. From Walram descend the Dukes of Nassau who in 1844, still sovereign princes of the German confederation, lost their land in 1866 when it was incorporated with Prussia. The younger line, the descendants of which still fill the throne of Holland, has been rich in illustrious men of whom I need only mention William of Orange, the founder of the Dutch commonwealth, and William III, the founder of Constitutional Liberty in England both animated by an implacable hatred, the one of the bigoted despotism of Philippe of Spain, the other of the insatiable ambition of Luis of France. Looking down from where we stood, we had before us a pretty but confined view. Nassau and another equally insignificant place surrounded by some cultivation as far as the limited level ground would allow in the midst of many wooded hills, between which the Lahn and another small river wound their way. We hastened back to Nassau, took our seats in the coach which passed at half past three and drove back through Dassenau, Ems, under Lahnstein, Pfaffendorf, and over the bridge of boats to Coblentz. Mr. Moenster and I had our seats in the Coupe. As it was still daylight, and the weather fine, we were much pleased with the road between hills along the Lahn and the Rhine; Vines do not grow in this vicinity. Without loss of time we went to the theatre where the Opera Romeo and Giulietta was performed, but with the exception of the Tenor Thibaullt, the other singers were by far inferior to those to whom I had so often listened in Lima. The old Capulet was abominable, he, Thibault and the chorus stuck fast in the beginning of the opera, and had to recommence. Giulietta was sung by a young girl whose voice was by no means so powerful as that of the Rossi, and still less could the lady, a guest from Mayence who represented Romeo, be compared to the Pantanelli, nevertheless applause was not wanting. 
Saturday, $26^{\text {th }}$ of October 1844 . This was the first day, that owing to the decrease of the traffic on the Rhine in the present season, the number of the Steamers which run up and down the river, was diminished, and the hours of their arrival and departure were altered; of this of course I could not be aware, and consequently missed the Steamer which touched Coblentz at 9 a.m., and was [759] obliged to remain one day longer than it had been my original intention; after all, I did not regret that it turned out so, for now I had leisure to walk about the environs of the town and to visit the Ehrenbreinstein fortress, which otherwise I should not have done. In an open place stands a fountain with this inscription "AD - MDCCCXII memorable pour La campagne contre la Russie, sous la Prefecture de Jules Doazan". Below these words: "Vu et approuvé par [notre] Commandant Russe à Coblentz le $1^{\mathrm{er}}$ Janvier 1814". The first part was cut into the stone at the time when Napoleon collected his until then invincible legions for the invasion of Russia, the second part, about eighteen months later when the invencible army was annihilated and when the victors had entered the French territory; for Coblentz at that time formed part of the French Empire. In my opinion it is one of the prettiest official rebukes of official boastfulness. It must be borne in mind that "vu et approuvé", is the formula of approbation used by the French authorities. The "mannuel des voyageurs" says that the Russian Commander's name was Josephowitch. From this open place I walked through some narrow streets forming the old part of Coblentz and crossed the moselle over a handsome bridge which rests upon several arches, when on the other side I soon turned-off to the right, that is to say towards the Rhine, and made the entire circuit of an extensive fortification called fort Francis. Soldiers were practising here, on inquiring I was told that they were recruits, all young men, not much above twenty years of age, who it was calculated would be sufficiently drilled in the course of eight weeks, and would then join the army about Christmas. This fort Frances occupies the Petersberg, where before the fortifications were constructed stood a monument erected in memory of the French General Marceau. This monument had not been destroyed, but carefully preserved and removed to the plain below, where it now stands, and where I saw it; it is in the shape of a low sandstone Pyramid, its four sides are covered with inscriptions which have become rather illegible. One of them however I deciphered, it runs as follows: "Marceau né a Chartres, Eure et Loire, soldat à 17 ans, general à 22, mort en combattant pour sa patrie le dernier jour de l'an IV de la Republique Française, qui que tu sois, ami or ennemi de ce jeune héros respecte ses cendres". Not far from Fort Francis lay a small outwork called moselle Flasche or moselle Flask. Walking about here I adddressed a young man in uniform, polite as all the Prussian officers whom I met, [_] [76o] pointed 
out to me on the opposite bank three strong forts commanding Coblentz, they are called: Forts Wellington, Alexander, and Constantine, the two latter on the hill, the Carthause (Carthusian monastery), no doubt once occupied by such a convent. Having descended from the eminence upon which the Mosell Flaske is constructed I continued my walk for some time along a Chaussée, then keeping closer to the Moselle through foot paths with vine covered hills to my right, passed an ammonia manufactory, and reached the small town of Güls with two hotels and two churches. Here I took a boat and was rowed over to the Coblentz side where I landed at the miserable village of Moselwiess whence an uninteresting chaussée leads through a cultivated plain right to Coblentz, this I did not follow, but turned off to the right through fields, to the foot of a steep hill which I climbed up; when on the summit, I found myself upon the Carthuse in an avenue of poplars which took me to fort Alexander, built, as the inscription over the gate says, in the years 1817 to 1821 . At each side of the gate a colossal dragon of Bronze in bas relief is fixed against the wall. The sentry allowed me to enter, and well might he do so, for inside, there was nothing remarkable to be seen, an open place, a round tower, and bomb proof vaults below the walls. On descending from Fort Alexander I passed somewhat further down fort Constantine, and came to a chaussée which brought me to Coblentz where I entered a small public house and took some bread, butter and half a bottle of wine, cost of the latter two and a half Silver groshen, in the hotel they charged me 10 Sg. for a bottle, exactly double. I was now in the new part of the town in the Klemnitz Platz, and Parade Platz, large open places with fine buildings. Having obtained without difficulty at the Governor's a ticket of admittance to the fortress of Ehrenbreinstein, I walked thither across the bridge of boats through one or two streets which form the small town of Ehrenbreinstein, and entered the fortress of the same name. A carriage road gradually winds up to the summit. I had to cross Bridge after bridge and pass under as many gates, I did not count them, there were so many of them. Walls rise upon walls, cut into the rock, perforated by embrasures with Cannons and loop-holes for muskets. When near the summit, I passed under a long vault, then came to an open place, and had to apply to the guard-house for a guide. [761] The room was vaulted and white washed; the inmates, some Sergeants and Soldiers were occupied in various ways, reading, eating, smoking, sleeping. After having waited a short time a young Sergeant came to accompany me, but in fact he showed me nothing, merely conducted me to the highest point on the wall whence he pointed out to me the various places which could be seen thence. My conductor told me, that he was a bookbinder by trade, a native of Coblentz, that he had been obliged to return from Trieste where he was following his trade in order to serve his time in the army. I also learnt from him that there 
are many subterranean passages in this fortress, that they keep provisions for fifteen years which I suppose must be an exaggeration, that they get their water from the Rhine by means of pumps, that one pump already existed and that another well was about being dug, the pump of which was to be in the shape of a monument with the bust of the late king. My manuel des voyageurs says that the height of the Ehrenbreinstein is eight hundred feet above the level of the Rhine. An iron cannon, once of great renown was preserved here, it was know by the name of Vogel-Greiff or bird Griffon cast in Franckfurt in the year 1528 , it could throw a ball weighing one hundred and sixty pounds, my guide said, as far as Andernach, my manuel des voyageurs says sixteen miles, which latter statement is arrant nonsense. When I returned to Coblentz, the bridge was just opened to let a Steamer pass through, which put the water in such a motion, that the bridge shook and trembled. I was in my hotel by five oclock, wrote, supped and read the "Mie priggioni" by Silvio Pellico. The author Pellico was arrested in 1820 by the Austrian authorities in Milan, being suspected as an Italian Carbonaro or Republican, and carried to Spielberg in Moravia, where he was kept in prison till 1830. Of this long imprisonment, he gives a plain and interesting account.

Sunday, $27^{\text {th }}$ of October 1844. I was fast asleep when I was called at five oclock, rose immediately, and before six was below in the General room where some Gentlemen were swallowing their Coffee, and settling their bills which two waiters were employed in making out. The charges in this Hotel were the following and more or less they were the same all along the Rhine in 1844 . Dinner with half bottle of common Rhenish or moselle wine twenty Silver Groshen, [_]fast seven, room and bed, per day fifteen, the cheapest wine was ten silver gro- $[762]$ shen per bottle. In my original diary I expressed my surprise, that so many hotels, for there were several besides the Giant, existed in Coblentz, a town of no more than 20,000 inhabitants including the garrison, and that all did a good business, whilst in Altona with 30,00o inhabitants there was not one single respectable Hotel. I ought to have borne in mind that close to Altona lies Hamburg, a large town with two excellent theatres and all kinds of amusements, whilst altona is in want of both, thus strangers of course give the preference to the former place. On the other hand Coblentz is situated on the Rhine, in the centre of a beautiful Country which for many months during the fine Season is visited by thousands of wealthy travellers. At half past six, the Steamer on her way up the Rhine arrived at Coblentz, and I went on board. It was a cold, rainy, disagreable morning, one of the passengers accosted me, it was the Castellan of Stolzenfels; with him I had some conversation, he told me that in the Duchy of Nassau, silver and lead mines are worked; that compared to the extent of the Duchy, the quantity of wine produced in the 
same was small; that the blue grapes must ferment before they are pressed, in order to give the red color of the wine, otherwise their juice is of a very pale red, and that in the Ahr-valley, the red wine still goes by the name of Bleichart, from the German Bleich or pale, because formerly they did not allow the blue grapes to ferment and obtained a pale reddish wine, which name has been preserved though the color of the wine has changed; from the residue of the pressed grapes, Brandy is distilled, finally, what still remains, is burnt and makes an excellent potash. The Castellan pointed out to me on the right side close to the ruin of Laneck, a villa belonging to the Banker Mendelssohm of Berlin with whose children if I remember correctly, Bobertag had lived here for some time as their Governor. Of this Mendelssohn an anecdote is related: he complained to a friend of his, that he was known in the world not as the Banker Mendelssohn, but either as the Son of the Philosopher, or as the father of the Composer of the same name. On the left bank just before Stolzenfels lies a small place Capellen, where the Castellan went on shore. Upon the walls of Stolzenfels Castle I saw a large painting which I could not distinguish, but those who had better eyes than I, said that it represented the Coronation of Emperor Otto I. On the same side, a little higher up, I observed a small building resting upon arches, outside some steps [763] leading up to the summit. It was called the King's chair, and had recently been erected by the King of Prussia, the old one having been destroyed by the French towards the close of the last century; upon this chair in ancient times some of the German Emperors were placed when elected, also placed there when deposed. This latter happened to Emperor Wenzel, who after his deposal built a chapel exactly opposite on the right bank, still in existence. The Rhine narrows considerably; the hills, some covered with wood, others with vines reach almost to the edge of the water, and the scenery, extremely pretty, may be called grand and beautiful by such persons as have never before seen mountain scenery, but upon me it made no great impression for I had lately been travelling in the picturesque mountains of Norway, and two years back I had spent many days, nay many weeks surrounded by the immense masses of the Peruvian cordilleras. I will not enumerate all the places which we passed, my map gives their names. Close to Branbach stands on a hill the fort called Marksburg in the Duchy of Nassau, which serves as a prison for political offenders, at present, it stood empty. At Boppard on the left bank several ladies and Gentlemen came on board; they were English and French as far as I could judge. Further up, the two mountains called the two brothers came in sight, the one with the ruined castle of Sternberg, the other with the ruined castle of Liebeinstein; further up the ruins of the Maus and opposite those of Rheinfels castle. We stopped at Saint Goar on the left side where I landed and went to the Lily Hotel, of a class similar to 
the Hotels in Remagen and Andernach; without loss of time I called for the landlord and made him give me the necessary information regarding the environs, which being obtained, I put myself "in march" for the Rheinfels, a trifle down the Rhine. It lies on the hill close to the river and is an extensive, interesting ruin, which had of late been purchased for $\$ 2000$ Prussian dollars by Prince William, brother of the King, now in 1869 Sovereign of Prussia. This has not been a castle belonging to the Knights of the middle age, but a modern, strong fortress; it was valiently and successfully defended by the Hessian troops against the French commanded by Marshall Tallard, in 1692, exactly a century later it was abandoned by its Governor an old man, whether a traitor or a coward, history does not tell, whereupon the French took possession of it, and blew it up. I ascended still higher, came to a plain, then to a small village Biberheim, remarkable for its execrable, beyond measure dirty streets and descended again a slippery path which brought me [764] back to Saint Goar, in which place there were a catholic and a Protestant Church. The weather had improved, and I now walked up the Rhine for about half an hour. On this my excursion, by ignorance or imprudence, I exposed myself to a great danger; a vessel heavily laden was pulled up the Rhine by eight powerful horses, which walked along the shore, and to which two or three cables were attached. I stepped over these cables so that I found myself between them and the river. This made a sudden curve, thus the cables, a minute before stretched over the beach, now were stretched over the water and would have swept off everything in their way. I escaped by throwing myself flat on the ground and allowing the cables to pass over me. The Lurley rock lies opposite and has as great a reputation on the Rhine, as the Hornølen rock in Norway (see page 611 of this Volume), it is steep and rugged and the scenery is certainly picturesque. The Rhine is here so tortuous that it seems to be completely landlocked and has the appearance of a lake. At the foot of the Lurley a man takes his station, who for a small remuneration blows the horn, and fires off a musket. The sound of the horn is clearly echoed more than once and the report of the musket runs along the mountains like loud thunder. I returned to Saint Goar and was in time for a good dinner to which the landlord, a young gentleman from Hesse-Cassel, another from Elberfield whose acquaintance I had already made on board, and I sat down. At half past two I was rowed over to Saint Goarshausen in the Duchy of Nassau; the Colors of Nassau are brown and blue. A little higher up the river lay on a hill the ruins of the Castle "the Cat", the entrance to which being locked, I ascended to the summit whence I had a good view all over the Country. Inland I saw a village which I knew was called Budersberg, and I thought I might as well walk thither. In order to reach it I had first to descend into a narrow gulley which on account of its miniature wildness, and because 
a small rivulet which they call here a mountain torrent rushes over some big stones, goes by the name of the Swiss valley. A steep ascent brought me to the plain upon which Budersberg lies, and in whose vicinity flare is grown. Further on, I came to another village Reichemberg situated in a hollow close to which is a fine ruin consisting of two towers, the one was locked, the other open, but the winding stair which I had a great mind to climb up looked so dilapidated, that I thought prudent not to run the risk. A little tale which I once had read in an English magazine came to my mind: two young ladies travelling on the Rhine came to a ruin [765] similar to that which now stood before me, they, more venturous than I, climbed up, when they had reached the top, the stairs gave way, fell in, and thus, they, deprived of the means of descending, died a miserable death from starvation, for the shrieks for assistance were not heard. For the truth of this story, I do not vouch. I returned to Saint Goar, in my room in the Hotel I wrote till the cold drove me below where I found in the dining room some burghers taking their wine. With two of them and the young man from Hesse Cassel, I played whist at 2 pf. the point, supped and went to bed at half past ten.

Monday, $28^{\text {th }}$ of October 1844 . Early in the morning, a thick fog lay upon the Rhine concealing all the objects around. At ten o'clock the Steamer made her appearance, many passengers were on board, the greater part genteel looking, with none did I become acquainted. Gradually the fog cleared away and the sun shone out, which was fortunate, for this part of the Rhine is considered the most beautiful. The narrow river, the vine clad mountains still higher than hitherto, many towns along the shore, some surrounded by dilapidated walls, and ruin after ruin following each other rapidly, pass-by as if in a moving diorama and keep the travellers attention continually on the "qui vive". It is worth noticing that very few mediæval castles of which now only the ruins remain had been constructed on the summit of the mountains, they stand almost invariably on the mountains side, so that they were commanded by higher eminencies, but as in those times Gun-powder was not yet invented, it was indifferent to the Knightly robber, whether another mountain overlooked his misdeeds or not. Fine times must those have been, when from each of these strong holds, an armed band used to sally forth, to plunder the wayfaring merchant; what would these Knights say if they could resuscitate, and were to see their castles where they held such a despotic, not to say, barbarous sway, lying in ruins, the plains covered with Corn-fields, the hills with vineyards, prosperous villages, hamlets, and towns along the banks; the inhabitants living securely under a well regulated Government, smoking vessels without sails making their way against wind and current, and all these changes brought about in the course of less than four centuries. Ober[v]esel is full of ancient 
masonry, at one extremity of the place, quite detached, stands the pretty church of the Virgin Mary see $\mathrm{N}^{\circ} 27$ in the appendix, not far off the picturesque ruin of Schönberg Castle, upon an island the old castle of Pfals rather in good repair, with several small corner turrets in the shape of pepper boxes. At one or the other of its [766] miserable windows I saw a curtain and other signs of its being inhabited, in appendix $\mathrm{N}^{\circ} 28 \mathrm{I}$ affix an engraving of this Castle, of the ruin of Guttenfels, and the town of Caub on the right bank of the river. It is well known that Pfals is a corruption of the Latin Palatium or Palace and that the first German Emperors particularly Charlemagne, who had no fixed residence but were always on the move, had many places in all parts of Germany; perhaps the Castle of Pfals was also once a residence of the great Emperor. On the same side as Caub lie the ruins of Castel Waldeck, whence in all probability the Princes of this name draw their origin, opposite the Sonneck ruin beautifully situated on the summit of a steep rock. Just before coming to Bingen we passed the mäusethurm or mice tower, an old decayed building on an island, from its walls floated the Prussian standard, white with a black double eagle. I went on shore in Bingen, a town belonging to the Grand Duchy of Hesse Darmstadt, the colors of which are red and white. It is situated on the left side of the Rhine, to the South of the Nahe river, in a corner exactly similar to that formed by the Moselle and the Rhine in which Coblentz lies. I took up my quarters in the white horse Hotel, dined by myself, for the table d'hote would have detained me too long, and took a boat in which I was rowed down the river to the Castle of Rheinstein, which, the property of Prince Frederick, the King of Prussia's cousin, had been renovated, and lost its original appearance; I was shown through the apartments, by no means elegantly fitted-up, on the contrary the furniture was antique, plain, and little convenient. The hill upon which this castle stands being surrounded by others of greater height, the view is confined, and solely open towards the Rhine and the opposite shore. Some curiosities were shown here such as: the iron glove for the left hand of the famous Suabian Knight Götz von Berlichingen who flourished in the $16^{\text {th }}$ century, his right hand which he had lost in his youth by some accident was substituted in after times, by a hand made of iron; also a suit of blue armour once worn by Albrecht the Bear, the ancestor of Prince Fredericks wife, who was the sister of the then reigning Duke of Anhalt Bernburg; a portrait of Luthers wife, Catherine Von Bora, who as is well known had been a nun; a portrait of the first of the Hohenzollern etc. From th[_] Rheinstein, I was rowed over to the right side, and landed near Asmanshausen [_] [767] the Duchy of Nassau; I knew that further up lay Rüdesheim, Geisenheim and [_]annisberg to which places I thought I might find the way by myself, but was induced by a peasant whom I met, to take his little son as a guide. By him I was conducted through the midst 
of vineyards where many people were busy gathering the blue grapes in small vats, to some buildings on the summit of a rather steep hill whose owner was Count von Basseinstein, married to a Princess Von Wallenstein, who himself residing in Munich, had considerable property in this neighbourhood. My little guide called a woman under whose charge I had to place myself, for it was to the Zauber-Höle, or bewitching cavern to which I was to be shown, a subterranean passage leads to a grotto, on a sudden the woman threw open three windows, from each of which I had a different view, a vista was cut in each direction through the thick wood which covers the brow of these heights; at the extremity of one vista, I saw the ruin of Falkenberg; at the end of the other, the castle of Rheinstein, and at the third the pavilion belonging to Rheinstein. No doubt it was a pretty surprise, but was not such as to warrant the high sounding name bestowed by the Count upon this grotto. We continued our walk to the ruin of Ehrenfels on the side of a hill, on the top stood a tower built in later times, we ascended and from the same the prospect was really beautiful; I do not speak of the Rhine and its banks but turning my looks in another direction inland, as far as my eye could reach, I saw an extensive extremely fertile plain covered with Corn-fields and Vineyards. This was the well known Rheingau which, as I learned on the next day from a Gentleman, my companion from Bieberich to Wiesbaden, Extends northward as far as Lorch, Southwards to Wölsst, he added, that of old the Rheingau had been closed in by a thick hedge, and by a ditch, which, well defended in the thirty years war, had for some time obstructed the victorious career of the Swedish Conqueror. The correctness of this statement, I am inclined to doubt. Bingen lay southward from where we stood, behind the hills which surrounded this town I descried another extensive plain, Pfalz Baier[n], that part of Bavaria called the Palatinate, and in the far west the Mount Tonnerre, and the Vosges, were distinguishable. The woman and the boy left me, but meanwhile a very decent young man had joined me. He was acquainted with the paths through this wood, and pleasantly conversing, we reached the pavilion constructed at its extremity, here we sat down, and rested a little, thirteen [768] villages did I count in the plain. Through the midst of vineyards we descended to Rudesheim close to the river, where we took a boat and were rowed over to Bingen; Geisenheim and the Johannisberg lay still further up, my visit to which two places I postponed till the following morning. Notwithstanding the proximity of these various villages to each other, their wines differ in quality, and each quality goes by the name of the village in whose vecinity it grows, thus: the one is called Asmanshäuser, the other Rüdeisheimer, etc. The village Hochheim round which a particularly good quality is produced, had enriched the English language with the word Hoch, the Generic name for all kinds of Rhenish wines, 
taken from the first syllable of Hoch-Heim. The hills behind Bingen produce the Scharlechberger or wine from the Scarlet mountains. Reichard in his handbook classifies the different Rhenish wines in the following manner: the Laubenheimer, the Bleichheimer, and the Asmanshauser are he says considered the most pleasant. The Hochheimer, the Johannisberger and the Geisenheimer the most aromatic; the Neireinsteiner, the Markebruner and the Rüdesheimer the hottest. In Bingen I separated from my companion, took a stroll over the bridge to the other bank of the Nahe, had a look at the quays and some bathing establishments, and went back to my hotel, where I remained for some time in my room, occupied with writing; the cold was such, that I had the fire lighted in the stove.

Tuesday, $29^{\text {th }}$ of October 1844. I rose in particularly good health and light spirits, which I attributed to my having gone to bed last night supperless. Before Eight oclock I was again on the other side in Rudesheim, passed through this village, and following the Chaussée along the Rhine which leads not through vineyards but through potatoe, cabbage, and turnip fields, reached Geisenheim which place distinguishes itself from its neighbours by a few large and respectable looking buildings. On the other side I again took [_] Chaussée, turned off to the left, and after long detours through many bye-roads and vineyards, where now in the vintage season the passages were often closed, reached the summit of the Johannisberg where the mansion of Prince Metternich stands. It is a plain building consisting of the main body, two wings and the out-houses. On my return I made almost the entire circuit of the hill upon which grows the wine called Schloss Joannisberger, or wine from the Castle of Joannisberg, which, the first of all [769] Rhenish wine, is the exclusive property of the Prince, and never falls into the hands of wine merchants. The Johannisberger which grows below in the plain round the village of the same name, is also a very good Rhenish wine, but inferior to that of the castle. Walking back from Geseinheim to Rudesheim, I saw to my right the heights of the Taunus chain, which extends on the right bank of the main, Eastward from the Rhine. I saw a little girl who carefully collected in a basket the recently fallen horse dung; on my asking her what she meant to do with it, she told me that she intended to sell it, a proof that manure must be scarce and valuable in this neighbourhood. The use of Peruvian huano commenced to be known in England about this time 1844, whilst in Germany, nobody was as yet acquainted with it. In 1869 the Rhenish provinces consume annually 22,000 tons, the whole of Germany, those provinces included, 70,000 tons Peruvian Huano. I was back in Bingen in time for the Steamer which arrived somewhat past eleven o'clock. In the neighbourhood of this town are the Castle of Klopp and the Saint Rock Chapel, which are considered to be of interest to tourists. I however did not visit them. 
On the other side of the Bingen, up the Rhine, the high rather steep hills which have confined the narrow bed of the river ever since the seven mountains, are no more seen, on the right side, they gradually slant down, and lose themselves in the plain, whilst on the left Bank, they are suddenly cut-off as with a knife. The land, low and level close to the shore, rises gently into undulating plains, and far inland, hills of moderate height are visible. Many passengers, I amongst them landed at Bieberich, the residence of the Duke of Nassau, I took my luggage to the Railway terminus, and having about two hours at my disposal, I walked about in the very pretty Ducal Park which is laid out which much taste. There are walks, smooth and kept in good order, fine avenues of horse Chestnuts trees, Lawns, ponds with swans and Ducks, also a fountain, and the Castle, a faithful imitation though on a smaller scale, of the ancient castles of the middle ages. The palace is a large building of red sandstone which stands on a low terrace, close to the river, it consists of the main body with two wings. The train which left Bieberich at 4 p.m. was very short, carried few passengers, and was drawn by horses. A Gentleman informed me, it was the same, who gave the information about the Reingaw see Page 767 of this volume, that the Taunus Railway shares, which cost originally 250 francs each, stood at the time at 370, though they had hitherto given a dividend of no more than $6 \%$ annually. At a place [770] called Massbach, we had to wait until the Mayence train arrived; this was drawn by a locomotive and now of course we steamed on, as usual. On one side along the Railway I observed high poles with one or two copper wires fastened to them at some distance above the ground. This was an apparatus for the conveying of messages by means of electricity, in 1844 it was a new invention, and the apparatus in Nassau was, at least so they told me, an improvement upon that from London to the Slough station, and from Fenchurch street station in London to Black wall. From the Wiesbaden terminus, a droshka conveyed me to the post, also called: the Adler or Eagle Hotel in the old part of the town, which had been particularly recommended to me. As it was still daylight I went out for a stroll, and was surprised to find what great changes had been made in this place since I was here last in 1823 with my good friend Jean Elmenhorst, Alas! dead long ago, then the only thing we noted was the extraordinary number of wine shops with these words over the doors: "Hier schenkt man wein un Brandt wein". English: here wine and Brandy are sold. Now in 1844 wide streets and fine large houses constituted the new part of the town; no house was more than three storeys high, and several, in order to have an uninterrupted suite of rooms, had their main entrance or gate way, not in the house itself, but separate, at the one extremity. Darkness soon drove me home; I ate an excellent supper, wrote, read Notre Dame de Paris, and was asleep before ten Oclock. 
Wednesday, $30^{\text {th }}$ of October 1844. I engaged a valet de place for the purpose of pointing out to me the principal buildings in Wiesbaden. The Ducal Palace has nothing striking in its exterior appearance; it consists of two large houses which might as well for their simplicity belong to a private Gentleman. On the other hand, the building which contains the offices of the various ministers, the mint, the Barrack, the public schools, the Hospital, and the Kur-saal, here called the Conservatory see appendix Number 29, are very handsome and tasteful structures. The "Kur-saal" is larger than that in Ems, it is oblong, whilst that in Ems is square; otherwise there is not much difference in the interior of the two - also here the roof is sustained by marble pillars, a gallery runs round for the musicians, and along the walls are niches with statues. During the season a ball is given every wednesday in this Kursaal, the other days of the week, gambling is carried on to a considerable extent, which the Duke permits, for the Bankers pay him a handsome sum for the [771] permission, but to his subjects, he prohibits gambling under severe penalties. Large apartments amongst which the dining-hall adjoin the Kur-saal a.a. represents the front of the Conservatory with the entrance $\mathrm{H}$; in front of it a large open place with avenues g.g.; on each side a colonnade b.b., and a row of shops now for the greater part shut up x.x., the Nassau Hotel D, the two theatres c.c.; Behind the conservatory a pond with swans F; a palace for the Duchess Dowager in progress of construction J;

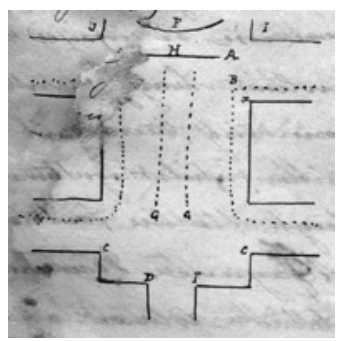
and private houses occupied by English families I.I. Of the population of Wiesbaden, two thirds were protestants, one third Catholics. A church fallen in in 1831 when near its conclusion, was now about being rebuilt; in an open place, not that in front of the conservatory, a well of the mineral waters which attract so many sicks to Wiesbaden, bubbles out of the ground, and emits large masses of vapour. Its heat is $54^{\circ}$ Reaumur, it is carried in tubes below ground to the large hotels which surround the place, and in each of which are the necessary bathing rooms; also in the Eagle hotel where I had put up, a spring bubbles out, and answers the same purpose as in the other hotels. I tasted the water, its taste is exactly like that of weak broth, greasy particles float on the surface, like cream on milk. I dispatched my valet de place who was satisfied with the remuneration of thirty Kreutzers, equal to about eleven Shillings currency. I then started by myself on one of my customary excursions through the Country. At a short distance out of town I came to a hill the gaisberg, or goat mountain on which vines grew; this vineyard was divided into compartments, in each stood a high pole to which was fastened a label informing the visitor that in this compartment the vines were allowed to creep 
along the ground, in the second, that the vines were trained over low stakes, in a third over stakes considerably higher, in a fourth over stakes of uneven height, some high, some low, a fifth over railings, and so on, each compartment showing the different manner in which vines were cultivated in the different wine producing parts of Germany. A little further on I turned to the right and came to a wide carriage road which leads to Limburg, and which gradually ascending, a dense wood on each side, took me to a height upon which stands a Ducal hunting lodge called Die Platte. It is a pretty building, more or less in the style of the villas along the road from Altona to Flottbeck, for instance like that of [772] Salomon Hayne. At the entrance of the gate are two bronze stags in a couching posture, extremely well done. It was a beautiful day, the temperature rather cool, therefore the better, for sharp exercise. I enjoyed the walk vastly, and though the atmosphere was somewhat hazy, nevertheless from the height of the Platte, looking over the surrounding trees, I saw a cultivated plain which extends to the Rhine clearly visible, whilst Southward of the Maine, I only saw here and there a small streak, to the Southwest I could distinguish Castel, and even the Steeples of Mayence. I returned part of the way which I had come, then turning to the left took a path through the wood, and emerged at the village of Sonnenberg, where I entered a public house, took a tumbler of cider, brown bread made of Rye and barley and butter, and had a long talk with the landlord; but the only thing worth noticing which I learned $\mathrm{fm}$. him was that the Cattle hereabouts are so dainty, that they cannot eat the Straw of Rye and wheat, but only that of Barley and oats. On an eminence close to Sonnenberg stands a pretty ruin whence several walks winding along a rivulet, then encircling the pond terminate at the conservatory. They, the trees, benches placed here and there, all were in an excellent state of preservation as if even the lowest classes of society, generally so prone to destroy, here refrained from indulging in this propensity, for they could not fail to understand that these improvements were made for the convenience of strangers, that without strangers, Wiesbaden would be a deserted place, that strangers put money into circulation, and that, though the mineral waters bring them to Wiesbaden, the pretty Country, the beautiful environs, convenient accommodations, make them prolong their stay, and thus, that to injure and damage the plantations, would be doing a serious harm to the interest of the Wiesbaden Commonwealth. I hurried back to the Eagle, took a droshka, and was just in time for the train which left Wiesbaden at 2 1/2. In a quarter of an hour we reached Castel where an omnibus was waiting for the travellers and in it we drove over the long floating bridge across the Rhine to Mayence, a strong confederate fortress. I alighted in the Rhine Hotel where I obtained a small room looking towards the river. Without loss of time I went into the streets for one of my usual 
peregrinations. A great part of Mayence is very closely and irregularly built, there are however several open places, in one of them, which my "manuel des voyaguers" calls La Place de la bonne Montagne, stands a bronze monument of Guttemberg, the [773] famous inventor of the art of printing, whose name has given rise to the ridiculous mistake in the "Manuel des Voyageurs". The Statue was modelled by Thorwaldsen, it has the following inscription: Johannen Gensfleish de Guttemberg patricium Maguntinum ære per totam Europam Collato posuerunt cives MDCCCXXXVII. Close-by another open place, stands the Cathedral built of red sandstone, see Number 30 in the appendix. The door being open, I entered, and amused myself a considerable while with looking at the many altars with which the interior is filled. The "Manuel" says that they are fourteen of them, twenty lateral Chapels, twenty two Epitaphia of archbishops Fastrada, one of Charlemagne's wife, for if I mistake not, he was married many times, is buried here, also the minstrel "Minnesänger" Frederick Frauenlob. In no other town had I met so many soldiers as I did here; there were Austrians in their white uniform, Prussians in Blue, Darmstadters dressed like the Prussians, all three forming the garrison of this fortress. The uniform of the Nassau soldiers was brown with orange. At night the town was poorly lighted-up, not with Gas. The cold had now set in, it was such that I required a fire in my stove.

Thursday, $3^{\text {st }}$ of October 1844 . Having engaged a valet de Place, I, accompanied by him, walked up the street along the river in which the Rhine Hotel stood, passed several extensive Hotels, then the arsenal in front of which heaps of cannon balls were piled-up, the Hessian Palace, in which once the property of the Teutonic order, high personages who visited Mayence were in the habit of taking-up their residence, further on the old Electoral Palace - these three last named were heavy massive edifices of red sandstone, a material abundant in the neighbourhood. In an open place called the Parade Platz, Prussian Soldiers were exercising - on one side stands the pretty church of Saint Peter and Saint Paul, with two slender elegant steeples, opposite workmen building a barrack and a hospital. From this place "Die Gross Bleich", the longest, widest, and handsomest street in Mayence turns off, here again I noted two barracks, opposite to each other, the one for Prussian, the other for austrian troops. At the Extremity of Die Grosse Bleich, I came to another open place adorned with a handsome fountain in the centre (see appendix $\mathrm{N}^{\circ}{ }_{31}$ ). Here is also the public library, which contains an extraordinary clock the most wonderful work of human ingenuity and perseverance; the maker was a friar Nicolaus Alexius Johann, who having been occupied [774] twenty years with planning, two years with executing the same, concluded it in 1807, and died in 1826. Another clever watch maker endeavoured to imitate this intricate and complicated machinery, but not succeeding in the attempt he turned crazy. The clock is wound-up 
weekly, indicates the hours of the day like every other watch, the days of the month, and the months of the year; also the number of the year, which is done by means of four dials. The one destined for the thousands, the second for the Hundreds the third for the tens, the fourth of the units, thus for instance in 1844 when I was there the hand on the first dial pointed to one, that of the second to Eight, that of the third to four, that of the fourth to four. At the end of 1844 the hand of the unit's dial would move to the five; at the beginning of 1850 the hand on the tens dial, to five; at the end of this Century that on the hundred's dial, to nine; and on the first of January 2000 that on the thousand's dial, to two. Also the planets of which I only saw six, namely: Mercury, Venus, the Earth, Mars, Jupiter, and Saturn describe their orbit round the sun, each in its own time, as is seen in other orrerys. Thus for instance, the earth in 365 days, Saturn in 29 years, and so on; the Earth shows also its daily rotation round its axis; the moon round the earth in the course of the Lunar month; every eclipse of the Sun and the Moon is shown at the exact time when it really occurs. Over another Dial, or more properly speaking over a yellow disk, another black disk gradually moves, so as to cover and uncover the yellow one, representing in this manner the phases of the Moon. In the same library, a model of a wooden bridge which Napoleon intended to build across the Rhine at Mayence, and the cost of which was at the time estimated at 26,000,000 francs was shown to me. The idea of constructing a solid bridge was not abandoned in 1844, then it was intended to substitute iron for wood, later in 1869 a lasting communication between Mayence and Castel has been established by means of a stone bridge. A stone tablet in the wall of an inn of little repute called the "Hof zum Junge" commemorates, that here John Guttemberg by himself, afterwards in conjunction with Faust and Peter Schoffer, put up his first printing press. In the garden of an inn called the Hof zum Guttemberg stands Guttemberg's statue, and an inscription in the garden wall makes known, that he was born in this house. The theatre in the Guttemberg Platz, the hall of justice which contains the various tribunals, and the Frucht Hall or fruit hall, where on market days Corn is sold, are other remarkable [775] buildings, which my valet de place did not fail to point out to me. He also obtained for me from the Governor a ticket of admittance to the citadel garrisonned by Austrian and Prussian troops, some companies of the one and the other were exercising. Upon a salient angle stands an ancient tower which dates from the time of the Romans called the tower of Drusus, and the Eichelstein, or acorn stone. Inside is a modern winding stair-case. I climbed-up, and had from the top an extensive view over the surrounding country. The manner in which the citadel is constructed is very peculiar; the walls are not raised above the ground as is generally the case, but the earth outside of them is dug away, so that the level of the wall is but a 
trifle higher than the ground upon which the town is built, they are I may say a fleur de terre. We returned to the Hotel where I paid off my valet de place. It was now half past ten, the weather being pleasant, the temperature cool and the sky clear, I determined upon taking a long walk, in the shape of a wide half circle round Mayence, which I calculated, I might easily accomplish by commencing at a short distance south of the town, then turning inland and keeping always to the right in a curved line; I was certain that I should again come upon the Rhine, and so of course it actually turned out. I walked up the river, passed some ancient gates, walls, and towers, then strong modern fortifications not yet concluded, and came to a park or garden called the new plantation at the extremity of which stood a public house, closed at present. Towards the river was a terrace exactly opposite to where the Main mixes its reddish waters with the yellow colored waters of the Rhine; just at the mouth of the former river on its Northern bank lies a small place Russelheim, opposite on its Southern side a fort, a little inland on the same side in the plain another small village Flörsh, and looking down the Rhine, Mayence, lay clearly before me, opposite Castel, and behind Castel, the mountain chains of the Taunus. I left this terrace, and followed a chaussée up the Rhine, which brought me to the Village of Weissenau, then keeping off from the river, I soon reached Laubenheim. From Laubenheim I turned to the right, ascended a hill covered with vines, and found myself on a plain where corn was grown; in some fields the young green corn was just above ground, in others peasants were still ploughing. From this high plain the Platte where I had been out on the preceding day was clearly distinguishable, also numberless Villages on both sides of the Main. Continuing my way always in the same [776] direction across fields through by roads and foot paths, I reached Hechtsheim, a village rather more considerable than the previous ones, and came suddenly upon one of the isolated forts which surround Mayence, next to Zahlbach, near which place are some ancient Roman ruins, worth noticing. They consist of one row of pillars standing separately, of various heights, just as they have been able to withstand more or less the influence of time and the destruction by human hands, some may be twenty feet high. At their base they measure respectively Eight, ten, and twelve feet square, they are made of small stones held together by Cement, become as hard as stone, the entire row measures in length more than five hundred yards. The careful examination of these ruins detained me a considerable while, I had to make up for it, and to accelerate my pace. Another fortress stood before me, I passed it, as well as the next village Gonsenheim, and continuing my walk as chance directed me through many kitchen gardens, I reached the public house of Hartmichlen and finally though no doubt by many round about ways, I obtained my object and emerged in an open avenue 
of poplars along the banks of the Rhine which brought me straight upon the town. This I entered by a gate exactly opposite to that I had started from, six hours and a half before. In my hotel I took a beefsteak, and had to wait for the omnibus which came long after its time. When we were upon the bridge, a vessel was passing which detained us, thus I arrived at the terminus long after half past six, the hour fixed for the train's departure, it had merely waited for the arrival of the Omnibus. My luggage was thrown into the van, no ticket given, I myself shoved into a second class carriage, where quite in the dark I obtained a seat next to a young lady who spoke French. I entered into conversation with her, found her very agreable, talkative, not too much so. When the train stopped, I had an opportunity to look at her features by the light of the lanterns; she was pale with beautiful black eyes and eye-brows, I should have taken her to be a french woman, if she had not told me that she was a German, but that from her Childhood she had been accostumed to speak French, I also exchanged some words with her father who sat opposite, he told me that they had been bathing in Ostende, had spent twelve days in London, and were now on their way home; but where their home was, he did not tell me. They recommended [777] me to go in Frankfort to the Hotel d'angleterre which I decided upon doing, for I thought I should then have an opportunity of meeting again with these pleasant people. I wondered not to see them in the omnibus which took the travellers from the terminus to the different Hotels, but when on inquiring who they were, I was told that the Gentleman was Prince Von-Wittgeinstein, the eldest son of the Russian General well known in the last Wars of 1813 and 1814, and the young lady his daughter, I no more wondered at their not having availed themselves of such a common conveyance as the omnibus and at the same time was gratified with having made the experience, that high personages when they come in contact with strangers are not always haughty, stiff and reserved, but the very reverse, as these had been towards me, during the short time we were together in the train.

Friday, $7^{\text {st }}$ of November 1844. When I rose at seven O'clock the thermometer which I had placed inside, close to the shut window, stood as low as $5^{\circ} \mathrm{R} .=43^{\circ}$ F. As soon as I was ready after breakfast, I went to the Counting house of the firm of B. Metzler to whom my letter of credit fm. C. H. Donner was directed, I conversed a few words with one of the heads of the house, a pleasant young man who delivered to me a parcel of letters which had accumulated here for me, two were from Charles Ropsy in Heidelberg, who expressed his surprise at not having heard from me for some time; very nice letters from Bobertag and Elisabeth; business letters from Gibbs \& Co. of London, and Gibbs of Lima which latter handed me some trifling account sales, finally various letters from my family in Lima containing some political news, which I intend to 
include in my next account of Peruvian Politics. From B. Metzler's, I walked to Mr. Jonase Mylius in the high street; this Gentleman, a widower in 1844 had been established about twenty years previously as a merchant in Hamburg where he had married a highly accomplished young lady Mine Souchey of Lübeck, daughter of Cornelia, the sister of my uncle Hughes, of whom I gave an account in the previous volume Page 378. Mrs. Mylius still in the prime of life died of Dropsy, leaving no family; whereupon here husband returned to Francfort, his native place. He of course was and looked much older than when I had seen him last, nevertheless I think I should have recognized him. He on the contrary did not know me at first sight, though in the course of the day, my features became again familiar to him. He was particularly kind, and made immediately a plan, how we should spend the day. He [778] called upon me in the Hotel, whilst I was still reading my letters, and together we went to the post office, where we were just in time for the diligence to Homburg, a bathing place a short distance to the North of Franckfort, belonging to the Landgrave of Hesse. Sitting inside of a coach it is impossible to see much of the surrounding Country; as far as I could judge, the country through which we drove was level and carefully cultivated, the Taunus chain visible at a distance; we passed through several villages, and different territories, and reached Homburg in an hour and a half. It was a cool clear day which would have suited me for a long walk, but Mr. Mylius older than I, was chilly, and did not like to stir, thus I saw but little of the place, not even the bathing establishment and the mineral springs; of course there were many handsome hotels and the Kur-saal richly, almost gaudily decorated; the gallery occupies only three sides of the interior, two for the musicians, a third for the Landgrave, up stairs is an elegant dining hall. The Kur-Saal with all its furniture and rich fittings had been constructed at the expense of a French Company, who not only paid to the Landgrave a large sum annually for the permission to keep the gambling tables, but had also come under the obligation to cede to him the said Kur-saal and all belonging to it, after a lapse of thirty years. This arrangement can give an idea of the enormous annual profits made by the persons who keep this bank. In 1844 Naples and Homburg were the only places in Europe were gambling was allowed to be carried on publicly the whole year round. In the latter place in order to impede the indiscriminate influx of all descriptions of people, only such were allowed to enter the saloon, who presented a ticket, but as this ticket was easily to be got by everyone who had a decent coat on his back, the object which the Landgrave had had in view was not attained. Mr. Mylius did not apply for the ticket, consequently I did not see the gambling, at one o'clock we sat down to table d'hote in the Hotel de Hesse, Mylius paid for everything, also ordered a bottle of Champagne. Thence we removed to the Kur-saal where we 
were joined by a Mr. Müller. I had to relate much about South-america, and here we remained till five Oclock, when the diligence returned to Franckfort; thus this day I may say, was nearly lost to me. In my room I ordered tea, had a fire lighted, and wrote several letters till it was time to go to bed. [779]

Saturday, $2^{\text {nd }}$ of November 1844 . It was a disagreable, rainy morning, the cold less severe than on the previous day; Mr. Mylius procured me a ticket for admittance to the Deaf and Dumb institution at the head of which stood a Mr. Kersel who was extremely attentive and took a great interest in explaining everything to me. He had at the time only five boys and six girls under his charge, all apparently lively and quick Children. The system which he pursued was the same as that which I had admired in Berlin, the pupils were taught to speak, and one little boy had succeeded so far as to be able to articulate very clearly. As the Deaf and Dumb cannot hear, they understand what is said only by looking at the speaker; therefore in speaking to them, it is necessary to pronounce very slowly; every time that a sound is uttered, a vibration is produced in the throat, a letter is pronounced, they observe the vibration, they see in what manner the mouth is placed, how the tongue is moved etc., then the letter pronounced is shown to them, both written and printed, and they comprehend that, by imitating the motion of the mouth, of the tongue, of the teeth, etc., and by pushing out a sound which produces the vibrations in the throat, they have articulated the letter which they see before them; perhaps the preceding differs but slightly from what I have said on the same subject on previous occasions (see pages 601 and 673 of this Volume) however even if this is the case, I do not erase them, because I will rather make myself guilty of a repetition, than of an omission. These present extracts I intend to be an exact reproduction in an improved form, as to style and correctness, of all I saw and heard, of all I thought and felt at the time of my writing my original memoranda. The pupils communicate also with each other and with their teacher by means of signs, and when they are able to speak they are allowed to accompany their words by signs; but are prohibited to make use of signs without speaking. The plan adopted in Glasgow of speaking by means of letters made with the fingers was unknown here. In German Geography, all the pupils were well versed, nearly all had a great talent for drawing, some were Lithographers, others modelled in Gypsum. The girls occupied themselves with needle work. I also saw some of their compositions in writing, which were very fair. Sometimes Mr. Kersel used to take a walk in the Country with the Children, and on their return each of them had to bring to paper and give a description of what they had seen, certainly a good [780] plan which might well be pursued with all children whether Deaf and Dumb or not. All boys and girls were taught Gymnastics and dined together, of course slept separately each sex, in a large 
saloon. Mr. Kersel told me that deaf and Dumb suffer from Scrofula, for which reason the Children under his charge were obliged to take Cod liver oil, the best, if not the only remedy against this nasty disease. A young fellow born deaf and dumb, partly cured, who at the time was working in the atelier of Sculptor Launitz, the disciple of Thorwaldsen, accompanied me to Bethman's museum situated in one of the many fine avenues which encircle the town. At the entrance lie two colossal stone Lions; in the interior are many casts of renowned antique statues, but the great attraction is "ariadne", sitting on a Panther of Carrara marble by Dannecker, the entire body, the arms, the thighs, the legs, the feet, every part is exquisitely shaped. It is admirable to see how a clever sculptor can give to the hard marble, the soft and round contours of a beautiful woman, her bosom is fuller than those of Thorwaldsen's graces, her look bold and commanding, also the Panther is a splendid life like animal. The dinner hour in the Hotel was very inconvenient say one o'clock, and I had to hasten home, in order not to be too late, the dinner was good, but I knew nobody, and did not speak one word, there was no Prince von Wittgeinstein nor his daughter. After dinner, in a disagreable rain, I walked to the new cemetery outside of town, concluded in 1827 , where I was shown the arrangement made to prevent the possibility of any human creature being buried alive, at least if the survivors are willing to take the precautions which are placed within their reach. The corpse in an open Coffin standing on a bier, is deposited in a large room. On each of the ten fingers a small metal thimble is placed to which a wire is attached; these wires communicate each with a bell, in an adjoining room where a guard keeps watch, and the bells are fixed in such a manner as to sound at the slightest motion; in order to have a check on the watchfulness of the guard, in the room where he watches, a clock is placed which has this particular contrivance: that close to each of the twelve numbers on the Dial is a small black hole. The Guard must wind up the Clock every hour; by doing so, a white line becomes visible in the black hole; thus if the clock is not wound up in due time, the entire hole remains black, and the Overseer who makes his rounds regularly, sees at once at what hour the Clock has not been wound up, and when the Guard was asleep, for which neglect he is severely [781] punished. A very decent girl who showed me round, told me that few people had availed themselves of this excellent precaution to secure their relatives against the fearful possibility of being buried alive, also that in the course of the sixteen years that this establishment existed, there had not been a single case of a supposed dead person having returned to life. At my request, she showed me to the family vault of the Bethmann's, its exterior is adorned with first rate bas reliefs sculptured in marble by Thorwaldsen, they are divided into four compartments, three below in a row, the fourth above 
with a bust of Mr. Bethmann Holwig, the father having been a Bethmann, the mother Holwig. The first of the three compartments to the left, represents the mother and two sisters of the deceased, in the deepest affliction; the middle compartment represents another Bethmann in a sitting posture; he is expiring and has hardly strength enough to stretch out his arm and to take hold of a garland which an angel presents to him, the difference between the dying man and the angel in the full enjoyment of health and vigor is remarkable and executed in a masterly style. On the other side of the former stands an angel of death holding a torch downwards. This Bethmann Holwig died in Italy from a cold caught in consequence of having saved a child on the point of drowning in the river Arno. The third compartment shows the river God Arno turning his looks to the second compartment, and a muse noting down the deed on her tablet. In this Cemetery are other sepulchral monuments, some by Launitz, some by Zwercher, but one whose sculptor's name I do not know pleased me most by its simplicity; it is [_] sandstone upon which the figure of the deceased in his winding sheet is represented in a lying posture. The expression of the face and the smile on the lips are admirable for their softness and sweetness. The entire inscription escaped my memory, I only remembered part which says: "Optimo patri, lugens et grata filia Maria", very pretty for its simplicity. Outside of one of the gates of Franckfort is a monument erected by William II of Prussia in honor of some Hessian troops, who fell here in 1792, when fighting against the French, when I was there in 1844 it was about being repaired by King Frederick William IV. Having still time to spare, and the weather having improved a little, I went in search of the Pfeils, outside of the Pfar-thor at whose residence my Russian acquaintances from Amsterdam had directed me to inquire for them. As I had apprehended, they had already left for Vevay, but a young Mr. Pfeil, cousin of the elder lady entrusted [782] me with a brooch which he requested me to deliver to the ladies, who were to be found in Vevay at Madame Bonchenay. I learned fm. him that the name of the young invalid was Miss Swetschin. Willingly did I take charge of the brooch, though until then it had not been my intention to visit Vevay. The street which runs along the Main is lined with handsome houses. The public librairy is also a tasteful building. Across the river a solid bridge upon which stands a statue of Charlemagne leads to the suburb of Saxonhausen which place no doubt owes its orig [...] this Emperor, who after his victory over the Saxons, transplanted [_] of them into Franconia. In my hotel I spent the evening quietly in my room with a good fire lighted in my stove.

Sunday, $3^{\text {rd }}$ of November 1844. Mr. Mylius proposed to me to make an excursion into the environs of Franckfort to which kind offer I did not accede on account of the gloomy state of the weather, we merely took a walk together. We passed 
the Main over the stone bridge, then through Saxonhausen, and continued for a considerable distance outside the town in a Southerly direction on the high road which gradually ascends, and whence if the weather had been clear, I might have had a pretty view over the lower lieing Frankfort which the dark state of the atmosphere now rendered impossible. In Saxonhausen Mr. Mylius pointed out to me a very ancient building which in former times owned by the Teutonic Order, was in 1844 the propriety of the Austrian Government. Not far from the hotel in which I lived, on the Ross markt, or horse Market, in an avenue which [_] the town stands the Bronze colossal statue of Göthe, cast by Sch[_], which had been inaugurated on the $22^{\text {nd }}$ of October with great solemnity. A few granite steps lead up to a bronze pedestal, the four sides of which are adorned with allegorical bas-reliefs upon the pedestal stands the statue, the whole measuring twenty nine feet in height. At one o'clock at which early hour it was still the custom in Frankfort to sit down to dinner, I went to partake of this meal with the family of the younger brother of Jonas Mylius, him whom we used to call in Hamburg the red Mylius, on account of his red hair. The party assembled consisted of the two Messrs. Mylius already mentionned, the red Mylius' wife [_] Aubin, young and pretty good looking, whom I had to lead to the table; a female cousin of his, Alexandrina, rather plain; two young [783] male relations, one of whom a military man; Mr. Beyerbach, brother of him in Valparaiso and his wife, rather pretty, and myself. Everything was very nice; both, ladies and Gentlemen were polite and attentive towards me; but as the conversation was general and ran on topics of which I knew little, and in which I took still less interest, the pleasure which I derived from this party was not great, all left when it grew dark. Mr. Jonas Mylius introduced me to the casino, where I read the English newspapers, all of which were in extacies at the unparalleled duration of the Soult-Guizot Ministry, which had stood its ground for four years, and still existed, a thing unheard of in Paris, since the July revolution of 1830 had placed Louis Philippe on the Throne.

Monday, $4^{\text {th }}$ of November 1844. At eleven O'clock young Mr. Pfeil called and accompanied me to the Städel collection of paintings, he being a connoisseur, not only pointed out to me the master pieces, but also called my attention to the beauties of each particular painting, thus for the first time two hours or more spent by me in a museum of paintings not only slipped away quickly, but actually afforded me pleasure. For this reason I shall also on this occasion break through the rule laid down by me page 184 of this volume, and endeavour to give an idea, though an imperfect one of the one or the other of the paintings. By a painter called Lessing, "Esseling in Prison", two friars are trying to convince him of his religious errors, the one in brown as if despairing to convince the heretic turns away, and places his hand upon the arm of his 
companion in white, who holding-up a Crucifix still addresses Ezzelin, his face expressing mildness and kindness, on the other hand, Ezzelins looks are bold and determined, he will not give in, his closed fist lies upon a block to which he himself is attached by a chain. Opposite to this picture hangs another likewise by Lessing, "Huss defending himself before the Comité of Constance", the great unsuccessful reformer, emaciated, upon his sickly looking face the prominent veins clearly visible, is intent upon convincing his audience whom he addresses with the greatest earnestness. There are three Cardinals, the youngest of whom listens with great attention, another, old and white bearded seems to think: "say what you like, I have made up my mind", the Pope's legate, dressed in violet, puts forward his head with eager looks, one of the Bishops present holds in his hand the Emperor's safe conduct, which as every body knows was so shamefully broken. On a Sea-piece by Archesback, the froth and the foam of waves tossed about by a violent storm are done in [784] a masterly style. A Roman peasant woman sitting with her two children near the sea-shore, was the painting which pleased me best, the youngest child a babe, a pretty little urchin is asleep on her lap, another boy somewhat taller is stretched on the ground on the point of falling asleep, and the mother herself is near following his example. The rays of the sun fall obliquely upon this group, imitating reality in such an extraordinary manner, that I looked out of the window to convince myself that the sun did not shine upon the picture, but outside the sky was cloudy and no sun visible. A little child sitting before a low table, occupied with playthings, by Rubens, is the first painting by this master which I had as yet seen to my liking. The child is not pretty, it has drooping cheeks, but his eyes glitter like sparks, and the little mouth just open displays a row of teeth like pearls. A scene in Hungary represents an enormous waggon drawn by Oxen and horses it has stuck fast in a muddy road and a number of men are trying hard to make it move. The "temptation" by Oppenheim is very pretty, a fair smiling lovely girl presents a goblet with wine to a little musulman negro, not black, but dark brown, who clearly shows by his looks, that if the temptress insists, he cannot help himself, but must yield. A pencil copy of an oil painting in the "Ludwig Kirke" or Louis church in Munich representing the last judgement, by Cornelius, a good painter, who strict catholic as he was, had placed Luther in the habit of an Augustin friar amongst the damned. I was at table d'hôte in the hotel at one o'clock but rose after the two first courses, for I hate these long sittings if one has no agreable neighbour with whom to converse and while away the time. The weather was very bad, it rained hard, nevertheless I found my way to Mr. Von Pechlin who represented the King of Denmark as Duke of Holstein at the German Diet assembled in Frankfort. He being absent I was shown to the secretary of Legation Baron von Tünen 
Adlerflycht, who, though he was at dinner, rose to receive me and acceded to my request to forward a Consular Dispatch to Copenhague, begging me only to fold it in a different manner. In my hotel I made this alteration, and when I returned to the Baron's, I was invited to walk-in, and to take a seat near the lady of the house. They were at the dessert, the health of my wife and family was drunk, and I returned the compliment to the lady, whose birthday they were celebrating. When I left, I was invited to dine with them [785] on the following day, which to my regret I was obliged to refuse, having already written to Charles Ropsy, that to morrow he might expect me in Heidelberg. In my hotel Mylius and Pfeil called to bid me good-bye. At half past six I returned to the Baron's for the purpose of showing to him, his family and some friends a Hungarian Colonel, a count and Countess who had been purposely called in, my drawings of Lima Costumes which amused them vastly. In my hotel I read, wrote, and made my preparations for my departure on the next morning. During my stay in francfort I had been occupied with much correspondance which had been the cause of my not visiting the new exchange, the Library in which several of the first printed books are preserved, and the Römer or town house which was undergoing some repairs, in it many Emperors of Germany have been crowned. The principal street in Frankfort is called the Zeile, some of the shops were at night time lighted up with gas, the streets were not.

Tuesday, $5^{\text {th }}$ of November 1844. At seven oclock the stage coach or diligence for Heidelberg left the Post Office situated in the Zeile, besides myself five other Gentlemen occupied the body of the Coach, and as none seemed inclined to be the first to break silence not a single word was spoken until we reached Darmstadt where we arrived at a quarter to ten. The road to this Capital of the grand Duchy of Hesse-Darmstadt leads through an extensive plain covered with corn-fields and vineyards, and woods. We passed through many villages with the names of which I did not become acquainted. In Lagnen about half way we changed horses. Darmstadt is very regularly built, the streets are out of proportion wide, this is all I can say of this town, for without the least delay I had to reenter the stage, and to continue my journey. My taciturn companions were all gone, instead of them, my only fellow traveller was now a nice young woman belonging to the middle class of society. She was acquainted with every spot on the road, and willing to give me all the information which I asked for. I on my part related to her much of what I had seen on my travels, thus the two hours which we were together, we conversed continually. I regretted when she left at Bensheim, her native place, and I was certain she would speak to her friends of the agreeable elderly Gentleman who had been her companion. Soon after leaving Darmstadt, hills gradually rising into mountains, the highest of which, the Melopocus with a tower on the summit show themselves on the 
left or Eastern side of the road known by the name of Berg Strasse or mountain road. These mountains are the commencement of the Odenwald, they are covered with woods and at their foot lay several Ducal palaces [786] and villages, such as: Yungeinheim, Seehem and others. We passed Bieckenbach, Zwielberg, Auerbach with a ruin on a neighbouring mountain, and reached Bensheim where as already said my agreeable Companion left me. I was now by myself in the carriage which was very tedious. The weather meanwhile had cleared-up, it had ceased raining and the sun peeped through occasionally. Eppenheim with a handsome ruin close by, called the Storkemburg is the last village in the Grand Duchy of Hesse Darmstadt. The first in the grand Duchy of Baden is Weinheim with the ruin of Windeck, here existed at the time a cold water cure or Hydropathic establishment. The Country remains the same as before. To the right the plain, to the left, the mountain-ridge, sometimes closebye, sometimes at a distance. I passed one or two more villages until at Neuenheim the road turns suddenly round the mountain, and Heidelberg, famous for its picturesque situation lay before me. It affords a pretty prospect which however did not come up to my expectations raised too high by the many glowing descriptions which I had heard of this town and its environs, the murky state of the weather and the late season of the year were other circumstances unfavorable to the just appreciation of the beauties of nature. In the foreground I saw the Necker spanned over by a bridge of several arches, then the town; behind the town upon an eminence the ruins of the Castle, all surrounded by wood clad hills. The stage coach stopped at the post office, and on my alighting I saw a young man walking up and down with a yellow handkerchief in his hand, and as this was the sign by which Ropsy had written me that I should recognize him, I accosted him, and certainly it was he. When I left altona in 1823 he was no more than two years and a half old, and of course in 1844 we could not know each other. In the $1^{\text {st }}$ volume of these extracts, page 584 I speak of his birth on the first of July 1820 , page 588 , of his Christening on the $2^{\text {nd }}$ of August of the same year, now he was twenty four years old, rather thin, delicate and with a tendency to Consumption, of which disease he died several years later. His mouth was very prominent, when he spoke he showed his large teeth, but as he kept them very clean this feature did not render him so plain as my cousin Nelly, always fond of exaggerating, had presented him to me. In appendix under Number 32 I affix a very good likeness of him. He embraced me, and gave me a kiss with which mark of his affection I would willingly have dispensed. I took up my quarters [787] in the Prindz Carl Hotel in the "Korn markt" about the centre of the town and as it was but half past two in the afternoon, Ropsy insisted upon our walking without delay to the Ruins of the Castle, the greatest attraction in Heidelberg, it lies on a hill on the left 
bank of the Necker immediately behind the town, and has been the residence of the Electors of the Palatinate till 1720, Charles Felix, the grand father of the King Luis of Bavaria having been the last who inhabited this castle, which very extensive when entire, is now an extensive beautiful ruin. The buildings which surround the central yard are extremely irregular, each in accordance with the style of architecture which was in vogue at the time of its construction. The most ancient part was built under the reign of Elector Rudolph; after him Rupert, Otto Henry, Ludwig V, Fredrick the Victorious, Fredrick IV, Fredrick V, son in law of James I of England, the unfortunate King of Bohemia, have each contributed their share. The part built by this last, named the English Structure, as well as that by Frederick IV is of red Sandstone curiously ornamented, and with many niches, each occupied by an allegorical figure. The entrance to the yard leads under a well preserved quadrangular tower called the bell tower in which a picture gallery, not worth visiting, is preserved. To the right of the Bell tower stands a big round tower which the French when in 1692 they devastated the entire Palatinate made an attempt to blow-up, but owing to the thickness of the walls of sixteen feet, only succeeded in destroying a part which fell into the Garden, where it still lies an everlasting memorial of the ruthless manner in which "Le Grand Monarque", his clever minister of War Louvois, and the renowned Turenne, were in the habit of carrying on war. After this tower, now a beautiful ruin, follows the Library tower, the Octogon tower, and finally the thick tower which well deserves its name for the walls are twenty four feet thick. All these towers as well as the walls which connect them are more or less in a dilapidated state. In a cellar is the Heidelberg Fass or Barrel known all over Europe for its enormous size, the present one was made under the reign of the last Elector Charles Theodore, previously there had been two barrels of smaller dimensions. The present one measures twenty four feet in diametre, thirty three feet in Length, and is capable of holding 283,200 Common bottles of wine. In 1844 it was empty. On both sides steps lead-up, and it is said that a quadrille has been danced on the top. Close-by stands a wooden figure of Clement the Court-fool who had the unenviable fame of surpassing all his contemporaries in the quantity of Wine which he could imbibe at one [788] sitting, also a sham clock out of which, on a wire being pulled, a long fox tail springs-up, which invariably makes the visitor start, and the conductor grin. Various points in the Garden or park belonging to the Castle afford pretty views; upon the bridge, the town, the Necker, the opposite side with the Village of Neuenheim, and the wooded hills behind. Up the river these hills draw nearer forming a narrow valley, whilst in the opposite direction westward, the river widens, on its northern bank the Chain of hills breaks-off abruptly, on its left bank, they gradually slant down and further on on both sides a plain 
extends as far as the Rhine, visible like a white streak. On the other side of this river the mountains in Rhenish Bavaria are distinguishable, also the steeples of Mannheim situated at the junction of the Neckar with the Rhine. On our return to the hotel, we dined together, and retired to my room where we had the fire lighted and were soon joined by Cesar Hesse, the youngest, the most agreeable, and the least Jewish looking of the sons of Old Isaac. We conversed, and the hours passed pleasantly till it was time to go to bed. I was much pleased with Charles Ropsy; he was well instructed, modest, by no means conceited, he studied law, not with the object of becoming a lawyer but in expectation of obtaining some day or other a situation under Government in which he succeeded a few years later in the Kingdom of Wurtemberg.

Wednesday, $6^{\text {th }}$ of November 1844 . The temperature had become milder, the thermomether in my room with windows shut stood at $10^{\circ}$ Reaumur $=54^{\circ}$ Fahrenheit; for some hours the rain kept me within doors, and until Ropsy called, I was busy writing, amongst others a letter to J. J. Mayer - fils of Saint Gallen whom I informed of my intention to pay him a visit. At a few minutes to ten I went with my nephew to the University to hear Professor von Vangerow lecture on civil law; about two hundred students amongst whom not a few good looking young men, were assembled in a large white washed room. The Professor spoke slowly, in a clear intelligible voice, his delivery was energetic, and though the subject on which he treated was a dry one in itself, yet he knew how to render it very interesting, and I listened to him with pleasure. Ropsy told me that he received from each student who attended to his three lectures weekly, thirty florins every six months. The rain having ceased, Ropsy was of course anxious to show me something more of the environs; we crossed [789] the bridge, ascended the hills on the right bank, returned, and then climbed-up the point where tradition says a Roman castle had once stood. Ropsy left me, for his weak chest did not allow his taking any violent exercise, by myself I continued the ascent until I reached the very highest point called the "Kaisers Stuhl" or Emperor's chair 1900 feet above the level of the Sea, and 1600 above that of the neckar. Here a round tower has been erected bearing this inscription: "Dem Genusse Der schönen Natur, der gross herzog Leopold, Die Bewohner Heiderbergs und Freunde Von Nah und fern 1832 a 1835". English: to the enjoyment of beautiful nature the grand Duke Leopold, the inhabitants of Heidelberg and friends from near and far $183^{2}$ a 1835. Inside is a winding stone staircase 140 steps high which brought me to a platform on the top, whence the prospect is of course very extensive. To the North and West it differed but little from that which I had from the Castle whilst towards the East from the greater elevation on which I stood my eyes could roam over the undulating mountains 
of the Odenwald, and distinguish the villages here and there interspersed between them. To the South West, I discerned the spires of the Old Imperial town of Speier, and occasionally when the sun broke through the heavy clouds which overhung the whole landscape, the distant Rhine gleamed under its rays like a ribbon of pale gold. On my descent I remained for some time examining all the nooks and corners of the castle, some were covered with the thickest Ivy I had ever seen. At four oclock I was back at the hotel, and accompanied Charles to the same large room in the University where we had been in the morning; now it was the turn of Professor Gervasius, one of the seven Professors who several years previously were banished from Gottingen on account of their ultra liberalism. His lecture treated on German literature, he spoke in a low voice, his periods were interminable, his delivery was indistinct, and his subject as treated by him uninteresting, nevertheless the auditory was very numerous. When he had finished, Professor Mittersmeyer took his place, Criminal law was the subject on which he expatiated, and though he did not speak so well as Von Vangerow, yet the subject itself was much more interesting. He gave several examples of the difficulties under which the Criminal judge labours, sometimes the Criminal is not known, and sometimes it is uncertain that a crime has actually been committed though the probabilities are, that it has been. The three Professors at whose lectures I had been present were men who enjoyed a great reputation all over Germany, and who attracted many students to [790] Heidelberg, of whom there were seven hundred in 1844. Charles and I dined together like yesterday, young Hesse called and took us to the museum or Club-house, where I made the acquaintance of Rodrick, a fine young man, son of Doctor Stintzing of Altona. In a paper I read an amusing letter written by a soi-disant Catholic who addressed himself to Dr. Arnoldi, the Bishop of Treves, and exhibitor of the holy vesture of Christ, and showed the horrible wickedness of this ridiculous and absurd comedy.

Thursday, $7^{\text {th }}$ of November 1844. The weather having changed for the better, Charles and I availed ourselves of it, to take a long very pleasant walk, and now the natural beauties of Heidelberg which hitherto I had not been able to value as they deserved, showed themselves to great advantage under the influence of a clear sunny sky. We walked up the river on its left, the Heidelberg side, were rowed over to the opposite shore and then passing the bridge without crossing it, came as far as Neuenheim, where we again took a boat, had a look at the Railway terminus, and were back in town just in time to attend to the lecture of Professor Noegele, on [manniednifery], which was by no means void of interest. It lasted from four to five. We dined, called upon Rodrick Stintzing and finished the day in the Club room where I played a game at chess with 
Cesar Hesse, which lasted two hours and which I ought to have lost, for at one time he had a decided advantage over me, fortunately I retrieved the loss, and finally came off victorious. When we walked home, it was a cool starlight night.

Friday, $8^{\text {th }}$ of November 1844. At Seven O'clock the omnibus called, which was to convey me to the Railway terminus. At another hotel a party in deep mourning stepped-in, consisting of an elderly lady, with an expression of sadness on her countenance, a younger lady who vainly endeavoured to conceal her rushing tears, and two little girls apparently unconcious of the loss which they had suffered. The deep grief of the mother who I supposed had been bereaved of her husband, made me forget that they were complete strangers to me, I was desirous to learn something of their past history, and of their future prospects, and after all in less than a quarter of an hour, for it took no longer to reach the terminus, I lost sight of them and never did I see nor hear anything more about them. Ropsy joined me, for a short time he was to be my companion, and of course whilst he was with me I defrayed all his expenses. We took our seats in the Second class carriages, quite as good [_] [791] convenient as those which I described page 666 of this volume. The doors were locked as is always the case, but here, in a small glass box, the key was kept, so that in case of accident, the passengers could open them from inside, a precautionary measure which in my opinion ought to be adopted on all Railways. Our only companion was a genteel young man elegantly and richly dressed, whom we believed to be a Scion of Nobility and with whom we had some agreeable conversation. We left Heidelberg at five minutes to Eight; at half past nine reached Bruchsal, a place of some importance; next we came to Durlach close to which town we observed on a mountain an old look out tower, then through Guttesaw, the artillery barracks, through Carlsruhe, the Capital of the Grand Duchy of Baden, of which various places I only learned the names; but what they were like, whether old or modern, whether large or small, whether they deserved the Epithet of beautiful or not, of all this I knew as little as if I had remained hundreds of leagues off, the natural consequence of Railway travelling, where the human being is forwarded from stage to stage like a bale of merchandize, and when arriving at his destination, he is but little [_] than when he started. The Country through which we steamed differed in nothing from that to the North of Heidelberg, to the right or Westward extends the well cultivated plain to the Rhine, to the left the Odenwald which gradually decreases in height. About Durlach another ridge of hills forms its connection with the black forest, so called on account of the dark appearance of the pines and firs, the only trees of which this extensive forest consists; it commences about Ettlingen. Further on, we passed Rastadt on the Ming, a town well known in history for it was here where from 1797 to 1799 a Congress was held by the great powers then at 
war. It led to nothing, and concluded with a great crime, for on the $28^{\text {th }}$ of April 1799, the French Plenipotentiaries on their way home were attacked at a short distance out of town by persons dressed as Austrian Hussars, they were robbed of their papers, and two of them were murdered, the perpetrators were never discovered. At Oos, a village to the South of Rastadt our journey by Rail ceased for the present. The Railway was to be continued to Baden-Baden, but in the year 1844 the work had not yet begun. Charles, an agreeable companion, made me observe, that in the South of Germany the properties of different farmers are not separated from each other in a visible manner, so that from a distance, they present the aspect of one [792] uninterrupted plain, whilst in the North, they are divided, in Holstein for instance by hedges in other parts by stone walls. From Oos we drove in an omnibus through a narrow valley, through which the rivulet called the Oos flows, and which on both sides is confined by hills covered with firs and Pines, to the famous bathing place of Baden-Baden which lies in a plain open to the westward towards Oos, otherwise hemmed in by the spurs of the black forest mountains. In 1844 there existed still narrow and tortuous Streets, which in 1863 when I again was in Baden-Baden were no more. At both periods, handsome and large hotels abounded. Ropsy and I alighted at the Sun hotel, and after a light dinner started at one oclock, Ropsy who had been here before, serving as my cicerone. We first directed our steps to the Kursaal, which workmen were employed in repairing, fitting-up afresh, and cleaning out, so that I was unable to form an opinion of how it would look in the season; probably it would not differ much from the Kursaals in Ems, Wiesbaden, and Homburg. The new Trink Halle, or Drinking-hall, where the bathing guests after having drunk their mineral waters are in the habit of taking exercise early in the morning, when the state of the weather does not allow doing so in the open air, is a handsome building with a fine colonnade. The Old Trink-Halle on a hill rather out of the way was no more used; Roman antiquities found in the neighbourhood, of which the most remarkable was an altar believed to have been dedicated to Mercury, were preserved in this building. We returned to the Hotel, and Charles, mounted on a donkey for he had necessarily to take a great care of himself, and I on foot ascended a neighbouring hill, or mountain as they say here, upon which stands the new Castle, a modern building owned by an old Grand Duchess of Baden. Higher up, the way leading through a pretty wood mainly of firs and pines intermixed with a few beeches, we came to the Old castle, a beautiful ruin much less extensive, but far more picturesque than that of Heidelberg Castle: gate succeeds gate, battlement rises above battlement, we climbed up pretty high but not to the very highest point. When standing here, the sun broke through the heavy clouds which had hitherto overcast the sky and by fits and starts 
lighted up now one part, then another part of the landscape. At our feet we had the dilapidated walls of the Castle, round the ruins the dense trees which cover the sides of the hill; below, the town of Baden-Baden [793] and the rivulet Oos finding its way through $[. .$.$] to the Murg, up this valley more mountains, then$ directing our [_] a little more to the right over other hills, we saw at the verge of the horizon, the Vosges hardly perceptible, nearer, the Rhine with all its windings, between this river and the Black Forest, a rich plain through which flows the Murg, and which is covered with woods, villages and towns amongst which Rastadt in the foreground, and Carlsruhe in the distance can easily be distinguished. Behind us, still higher mountains closed us in. We ascended them, came to a spot where the trees were cleared away and following a path which was pointed out by a sign post with the indication "aux rochers" reached a point really wild and picturesque. There were no cataracts to be sure, but grey rocks, Big stones, beautiful trees, wooden bridges, rugged paths, all thrown together in the most admirable confusion. Whilst we were here a thick fog drew up, covered the whole valley, a sudden gust of wind swept it away, for a moment the beautiful country was again visible, again it was hidden to our sight, and thus we remained here much longer than we had intended to do. It grew late, and we had to give-up our visit to another, the Eh[_] Castle, which we were told overlooks the Murg valley. We returned, were overtaken by a heavy shower of rain when in the Lichtemberg Avenue, and reached our Hotel in time for the omnibus which took us in the dark to the village of Oos, whence by rail we arrived at Kehl at about nine in the evening. I intended to write, but was too sleepy, and after eating a pancake, went to [_].

Saturday, $9^{\text {th }}$ of November 1844. Kehl, the frontier town of the Grand Duchy of Baden is a miserable place, at least in 1844, it consisted of nothing, but one long street with poor small houses amongst which an out of proportions great number of Cigar and Tobacco shops, for the smuggling of these articles into France where tobaccos of all descriptions are subject to a very high duty is a lucrative, though of course perilous trade. At the western extremity stands a very large Custom house built of red sandstone. The Rhine is here wide, its current strong, we crossed it over a floating bridge about half way on the first bridge, for the river is divided by an island situated nearer to the left shore, we passed a French sentry, dressed in a grey surtout coat, and red pantaloons. The island is small and low, across it leads a chaussée, extremely muddy, when we were there, lined by two rows [794] of trees, then [...] floating bridge much shorter than the previous one, another [...], and under three successive gates we [_] red the citadel of little extent, surrounded by high walls. On the other, the western side there were once more two gates, and a short distance further, we entered the town of Strasbourg. This town is walled round, but, as far as 
I could judge, its fortifications cannot avail much. Of late I had seen many large towns, but I must confess that of all which I had seen, Strasbourg was decidedly that which pleased me least. I did not observe one single straight regular street, one single large handsome house. One of the streets, probably the principal, has a canal in the middle, perhaps it may be the river Bursche, spanned over by many small bridges, but even these were made of wood, not of stone. Above all its insignificance and lowness, rises the Cathedral or "Dom", built on the true style of undefiled Gothic architecture. It has only one steeple, but this one steeple is famous all over Europe for its beauty; it is light, elegant, I may say aerial; that it was originally the intention to built a second steeple is clearly seen by the open place left on the roof for that purpose. The exterior of the walls is ornamented with numberless statues and [...] were in the hands of the Sculptors; for as the Verger told us, not a few had been destroyed at the time of the French revolution of 1789 . The interior pleased me extremely, and is of a noble simplicity; it consists, as nearly all churches do, of one wide middle passage, the Nave; of two lateral, passages, the aisles; at the Eastern extremity the transept, and behind the transept the Choir. Charles complained of the nakedness of the walls, I was not of his opinion, though no doubt compared with what I had seen in the other churches, here were but few Chapels, altars, and monuments. The centre part of the Cathedral was built in the Eleventh century by the famous architect Ervin von Steinbach when Werner was Bishop. The part with the steeple owes its existence to an Austrian Noble Conrad von Lichtemberg, who flourished in the $13^{\text {th }}$ Century. Of the former, Bishop Werner, there is a statue, of the latter, Von Lichtemberg, his tomb and monument. Even I who knew nothing of architecture, was able to observe the difference between the pillars constructed in the $11^{\text {th }}$ and those of the $13^{\text {th }}$ Century. The Choir was originally built under the reign of Charlemagne, under Luis XV it was rebuilt in the Style of architecture then in fashion, and in 1844, the [795] intention was to restore it to its pristine beauty; meanwhile it was of wood. The Organ is considered to be one of the best in Europe, and the Clock perhaps surpasses even that of Mayence which I had thought to be the "Non plus ultra" (see page 674 of this volume), thus for instance the Strasbourg clock indicates the movable Catholic festivals, also midday and midnight in all the principal Capitals on the Globe, both which the Mayence clock does not indicate. In Strasburg the full hours are struck by the figure of time with a small hammer on a bell, holding a scythe in the other hand, at the same moment the figure of an angel reverts an hour glass. The first quarter of the hours are struck in the same manner by a Child, the half hours by that of a youth, the three quarters by that of a man, the cock crowing three times. Charles and I ascended the winding stair case 205 steps high, landed on a platform from which rise four 
pillars which sustain the steeple. In the walls of the apartment formed by the four pillars are cut the names of several distinguished persons: Göthe, Herder, Schlosser, Engel, Roederer and others, Charles and I did not climb-up higher, we contented ourselves with the view which we had from here over the neighbouring country, uninteresting and very level. From the Cathedral, Charles and I went to the Church of Saint Thomas in which church the most remarkable monument is that of the "Marechal de Saxe" who was born in Gosslar (see page 653 of this Volume) in the year 1696, and acquired his great renown mainly by the Victory gained over the allies at Fontenoy on the $11^{\text {th }}$ of may 1745 . I bought a small pamphlet which gave a good description of this monument, as well as of several others in the same church, to which I referred in my original diary, but unfortunately it is no more in my possession. I found this pamphlet in march 18 and affixed it [...] In the market place stands a bronze statue of Guttemberg; the statue of General Kleber we did not see. We hastened back to Kehl and were in time for the omnibus which at half past two put us down at the terminus, our today's destination being Carlsrhue. We had a fine weather the whole day long, and towards the evening the black forest mountains to our right, some fantastically shaped, occasionally a ruin on the summit, villages between them, villages at their base, were beautifully illumined by the rays of the gradually setting sun. For a short time we had a fellow traveller, whose exterior though he was dressed like everybody else struck me at the first glance. His complexion was rather dark, his eye-brows beautifully arched, he wore mustach[_] [796] and was lively in his conversation, he spoke French and German fairly; we took him to be an Asiatic, who in the capacity of a Russian courier might have travelled all over Europe. At six o'clock we arrived in Carlsruhe, where we alighted at the Zehringer Hof. This town, the Capital of the Grand Duchy of Baden is of modern date, it was founded in 1715; in the centre is an open place where the Palace stands disfigured by a heavy colonnade in front, behind a park and a wood. From this centre diverge nine streets at an equal distance from each other like the radii of a circle, then terminate in a long street which forms the outer circle whilst they are intersected by other shorter parallel circles, but as the town was originally planned on too large a scale, only one fourth has been concluded, moreover the small size and the mean appearance of the greater part, not of all the houses do not correspond with the wideness of the streets. The gate through which we entered when coming from the terminus is a handsome structure, inside the gate on an open place stands an obelisk called the "Constitution pillar". The sides of another open place are occupied by the Catholic church with a Colonnade, and by one of the Ministerial buildings, in the centre a pyramid erected in memory of one of the Margraves of former times. On our return to the hotel, we had a visit 
from a young man Spangenhaguen a relation of the Bocklemann's and friend of Ropsy. He was studying architecture in Carlsruhe. At supper I ate frog legs for the first and last time in my life, they were dressed with a sourish sauce, and tasted like chicken.

Sunday, $10^{\text {th }}$ of November 1844 . We rose so late that we had not even time to breakfast, merely to throw ourselves with our luggage into an omnibus which answering the purpose of a Stage Coach, conveyed us to Stuttgard at the cost of three florins each. Our fellow travellers to judge from their exterior were of the lowest classes of society; neither Charles nor I entered into Conversation with them, and as regards myself I slept many hours in the course of my this day's journey. At Durlach we crossed the Railway, a little further on in a small country place we had time to take a cup of Coffee, and passing through a great number of Villages reached Pforzheim, a town of some importance where we changed horses. Pforzheim is well known for its Gold ornaments such bracelets, ear- [797] rings, Brooches, necklaces, etc., which are worked here with much taste and great delicacy, but are at the same time very thin and fragile, moreover they are made of a gold of much lower standard than that generally used by Goldsmiths, so that he who has once been induced to make a purchase of Pforzheim Gold articles by their exquisite workmanship, and comparative Cheapness, is not likely to make a second purchase on account of their utter want of durability. Between Pforzheim and Veiningen where we dined and remained till two oclock, we passed the frontier between the Grand Duchy of Baden and the Kingdom of Würtemberg, the colors of the former country are red and yellow; those of the latter, Red and black. The road which we followed during the day, was a well kept chaussée partly lined with poplars, partly with fruit trees, the country was undulating, covered with cornfields and vineyards, occasionally woody hills at a smaller or greater distance. When approaching Stuttgart, the Enz, an affluent of the Neckar, came in sight, at half past six we stopped at the adler or Eagle hotel in the Capital which as far as I could judge of it in the darkness, had a Capital-like appearance. The peasants of Wurtemberg, part of the ancient Suabia have preserved a peculiar dress; they wear big boots up to the knees, leather breeches, frequently a red waistcoat with large metal buttons, a thick surtout coat, and a three cornered hat. When in undress, they doff the big coat and the three cornered hat, and content themselves with a Jacket and a Cap. The blue blouses the use of which I observed first in Belgium, are still worn; here not by peasants and artisans but by Carters and Coachmen. The German spoken by the Wurtembergers in the lower classes of society grated on my ears. Charles told me that there are several dialects, but the peculiarity which I mostly observed was their dropping the "N" at the end of a word for instance: instead of Kommen, English: to come they 
say comme; instead of Essen, to eat, they say Esse which certainly sounds very badly. Charles and I went to the theatre to hear the Opera, Nabucodonosor, music by Giuseppe Verdi, and took our seats in the parquet. Since I had left Lima, I had not heard such a good singing; the Baritone Mr. Fischer who sang Nabucodonosor was superb, the prima Dona with a Soprano voice who sang Abigail, was also first rate, the Chorus excellent, the decorations pretty and adequate, the ballet above mediocricy.

Monday, $11^{\text {th }}$ of November 1844. It was past nine O'clock, when Charles and [798] I were ready to start for the customary perambulation through a town new to me. The market place where the Eagle Hotel stands is irregular, surrounded by old fashionned houses. The Königstrasse or King Street is wide and straight, there are many large and handsome houses, also a few smaller ones. The Old Castle is a building from former times, as its names denotes. Close to it stands a bronze statue of Schiller, born in Marbach, a small town two or three miles distant from Stuttgard; though this statue was modelled by Thorwaldsen, I could not admire it, the expression of the countenance is sombre, and the folds of the cloak are stiff, this at least is my opinion, though very likely I may be in the wrong. Somewhat further on, we came to the new palace, a large building consisting of the main body and two wings, with an extraordinary number of windows, seen from behind it differs but little from the front view, and neither side is remarkable for its architectural beauty, as little does the exterior of the theatre require any particular notice. Behind the Palace is a large pond upon which Swans and Ducks were disporting; from this pond a wide gravel road for foot passengers with a carriage road on each side leads to the neighbouring town of Canstatt, and as the weather was fine, we determined upon going thither on foot, which walk took us about an hour. When approaching Canstatt, we saw the Royal Palace of Ros[ein]stein on the summit of a hill, and many workmen employed at the railroad and at a Tunnel which was to perforate this hill, and to pass nearly under the Palace itself. We crossed the Neckar to our right over a wooden bridge, came to a small island, and another small bridge brought us to the modern part of Canstatt with wide streets and many fine houses amongst which the Hermann Hotel distinguished itself. The Cursaal was an unpretending building; it being locked up, we entered through an open window, and convinced ourselves that the interior was nothing better than a long low room; both in front and behind the Cursaal are two large basins filled with mineral water which I tasted. It has a sourish sulphuric taste, and effervesces a little, which is a proof of its being impregnated with Oxygen. We continued our walk through the old ugly part of Canstatt, recrossed the Neckar over a handsome bridge, but slightly arched, which is considered one of the perfections of bridge architecture (at least when 
Waterloo bridge in London was about being built, I remember that it was [799] much entolled, because it was very straight, and on a level with the two banks of the Thames), and came again to the neighbourhood of Roseinstein where a covered passage was pointed out to us, which leads from the Palace to the Canstatt theatre. Here workmen were as busy at the railway and at the Tunnel as on the other side. We returned to Stuttgard, dined at table d'hôte, and at a quarter to two, entered an omnibus which conveyed us to Esslingen, once a free town of the Empire, where Charles had some intimate acquaintances, to whom he was desirous to introduce me. As long as we were in town we drove through the Neckar strasse, a fine wide street with handsome houses amongst which that inhabited by the mistress of the King was the most remarkable. When outside the town, we found ourselves in the Valley of the Neckar in an avenue of fruit-trees between fields, further on between hills, we passed many villages, crossed the river over a bridge, and reached our destination at half past three oclock, where having secured a large bed room in the Eagle Hotel we did not lose a moment's time, for in November the days are short, to see what was worth seeing. The town house is a wonderfully antique looking building. Of late it had been abandonned on account of its inconvenience, and a new one been built; the steeple of the Church, Charles assured me was one of the best specimens of Gothic architecture all over Germany. At a short distance from the town we ascended a hill from which we had a very pretty view over the Neckar valley in which Esslingen lies. Towards the East we saw the Suabian alps, an extensive ridge of mountains which encircles a great part of the horizon. When it grew dark, we went to Charles friends; they were a widowed lady, Mrs. Dr. Rössler and her daughter Lotte about twenty years of age, not pretty, but as agreeable as her mother. Charles was quite at home, the twin sister of Lotte, Pauline, was absent in Stuttgard, and an elder sister had died in Kiel exactly a year previously, when they were there on a visit. A young Baron employed under Government in a judicial capacity joined us. We had Tea, bread, and butter, and spent a pleasant evening till nine O'clock, when we walked back to our Hotel. Charles told me that his intention was to undergo his examination on Easter of the ensuing year, when he was in hopes of soon obtaining the situation of a Referendarius. Whether Charles was examined on Easter? whether he obtained the situation? what the duties of Referendarius were? and whether it was perhaps an affair [80o] of the heart which made him so desirous to settle down in Esslingen? of all this, I was, and have ever remained ignorant.

Tuesday, $12^{\text {th }}$ of November 1844. I may observe that the bedclothes in the greater part of the German Hotels were linen, very clean and of very good quality, here in Esslingen they were particularly fine. Before returning to 
Stuttgard, Charles looked in at Rosslaers before Eight in the morning, a proof that he must have been very intimate with the family. As soon as we were back in Stuttgard we went out for the purpose of seeing the Museum, which contains a collection of paintings, another of plaster casts of antique and modern statues of great renown. I have made the promise not to inflict the tedium of a description of pictures upon my readers, should these extracts ever find any, but this my promise does not extend to statues in which I take a great interest, and I will therefore give an account, adding perhaps a few details of those which I saw here. The group of the Niobides, the Original of which dug out in 1583 near La Porta Lateraniensis in Rome exists in Florence, was new to me. Niobe, it will be remembered being mother of seven sons and seven daughters, prided herself on her superiority to Latona who had only one son and one daughter, Apollo and Diana. To punish her for her boastfulness, Latona ordered her children to destroy Niobe's progeny. The group represents Niobe with her Children, the youngest clinging to her mother's breast, some struck or about being struck by the unerring shafts of the Deities and endeavoring to avert their inevitable doom, consequently a similitude in their different attitudes could not be avoided, however there are no two figures completely alike, there is always some difference between them. The sons, one of whom lies dead with a wide gaping wound in the breast, are only partly covered, from which I drew the conclusion, that one of the smaller figures dressed like a Persian, does not belong to the same group, and I am glad to find in a North American Encyclopedia, that wiser men than I are of the same opinion. Some call this statue the Pedagogue, others think that it represents Amphion, Niobe's husband, and the guide who showed us round named it the "Haus-hof-meister" or the Governor of Niobe's household surely a queer expression which did not give me a high idea of the intellect of him who made use of it, for, to apply a term arising from our modern Customs and civilisation to a myth of ancient Greek Polytheism, [801] is surely a ludicrous anachronism. It has been supposed by an English architect Cockerell, and in my opinion with great show of reason, that these statues served originally as an ornament for the façade of a Temple standing in one line in the shape of a Pyramid of which the largest statue Niobe was the Apex, whilst the other statues diminishing in size, formed the two sides, the attitudes of all are as if tending to a common centre, moreover their back is imperfectly worked as if they were only to be seen in front. In the same appartment are the casts of the bas-reliefs in bronze of the doors of the "Battisterio" in Florence, they represent scenes taken from the Bible; Lorenzo Ghiberti was the author. To me they seemed very confused, however, there can be no doubt of their extraordinary beauty, for Micael-angelo is said to have called these doors, "the gates of Paradise"; also the well know Borghese 
Gladiator. The second saloon contained statues with the Originals or copies of which I was already acquainted such as: the beautiful group of Lascoon and his sons; the antinous and Apollo of Belvedere Adonis; Selenus with the little Bacchus in his arms; a favorite of mine, the Medicean Venus considered to personnify Celestial love; the boy who extracts a thorn from his foot. New to me were: a majestic Jupiter's head; the drunk Faun; the Keeping Hermaphrodite; the Venus Calypigus, the meaning of which is the Venus with a beautiful posterior, the Original in Naples, the perfection of this statue struck me, Charles told me that it is considered to be a master piece. I recognized the head of Nero when a boy with the ominous contraction of the eyebrows above the nose, the original of which I had seen in Berlin. In a third a room is the group of the Æginates, the Original, now in possession of the King of Bavaria, adorned in ancient time the Eastern and Western front of a temple erected at the expense of all the Grecian States, toJupiter Panhellenius in the island of Aegina. In my original diary I find the following remark: "these status are of great interest as showing Grecian Sculpture before it had reached its last stage of perfection; the least exercised eye can see their inferiority which shows itself in a particular stiffness and ungracefulness". The North american Encyclopedia above mentioned says about them: "they were probably sculptured between the Sixtieth and the Eightieth Olympiad which corresponds to the years 536 to 456 B.C., there are seventeen of them, Minerva, a trifle above the other sixteen, a little below human size. [_] may be divided [802] into four classes; firstly, upright, clothed and female - secondly, advancing or fighting combatants - thirdly, kneeling or archers - fourthly, lying or wounded. Excepting their heads, their bodies are close imitations of nature, without the slightest attempt at ideal, the figures are slender, rather small at the hips, and the legs remarkably long. There is much life in the attitudes though they are not altogether free from a certain stiffness. The heads seem to belong to an earlier epoch of art; the eyes project, and are lengthened somewhat in the Chinese fashion; the mouth has prominent lips with well marked edges, the corners in some are turned-up; the nose is rather small; the ears finished with the greatest care; the Chin is full and generally too large, they all look alike and exhibit not the slightest expression of Passion; between conquerors and conquered, Gods and men, there is not the least difference. The appearance of the hair is not natural, but stiff and conventional, the arms are rather short, the hands natural to deception, not a wrinkle of the hair is forgotten, the legs are well shaped; the knees masterly, the feet elegant, and the toes which are rather too long, run out parallel. The drapery is close to the body with folds artificially arranged. Though the style is hard, the execution is tasteful and elaborate. Not one of them has any support, 
and they are equally finished on all sides. In all probability this group is meant to represent one of the fights of the Æacides or Sons of Æacus, King of Æginæ, in the Trojan war under the protection of Minerva". In the same room with Æginates stood the cast of the Capitolian Venus personnifying terrestrial love, rounder, more voluptuous in her countenance than the Medicean Venus - the Conquering Venus, Venere Vencitrice - A Diana going to hunt accompanied by a stag - Il Torso, or the Trunk of a man without head, legs, or arms, the original in Rome with the studying of which tradition says Michel Angelo was occupied seven years - the Colossal head of a horse, the original of which in bronze is in Naples. In the fourth and fifth apartments, I met old friends, they were master pieces of Thorwaldsen, viz:: Christ, of more than human size and four apostles, which casts give no idea of the beauty of the Originals in our Lady's church in Copenhague - a lovely Amor and Psyche - C. H. Donner's Pastor boy, the little [_] on a marble vase, and the three graces, the latter in bas relieff [803] do not render the slightest justice to the Originals. Further, the Bas-relief of Guttemberg's statue in mayence and the famous entrance of Alexander into Babylone, a copy of which I had seen in Copenhague. New to me were: night and morning - the four seasons - a venus ordered for an English Lord, the vessel in which the Original was shipped, was wrecked, the statue went to the bottom of the sea, but was again brought-up - a Mercury lulling Argus to sleep by playing on the so called Pan's pipes, is on the point of drawing his sword to sever Argus's head, and his looks indicate that he is anxiously watching the moment when he can with safety give the fatal blow. Charles and I passed rapidly through the collection of paintings, as little did we remain long in the Royal stables where the King's best horses were kept. We hastened to our hotel, dined, and continued our journey, this day's destination being Tübingen the University, on the Neckar, South West from Stuttgard. Hardly were we out of town when the road wound up gradually to a slight eminence whence looking back I saw Stuttgard lying in a hollow surrounded by a low vine clad hills. Alternately ascending and descending, through Cornfields and Vineyards, we reached Waldbuch about half way, where horses where changed. The weather had been cold and rainy the whole day long, now the sun set, I wrapped myself up in my big cloak [nasconded] myself in a corner of the Coach, and slept until our arrival in Tübingen. Once or twice I awoke momentarily, when as far as the Obscurity would allow me to see, it seemed to me that we were driving through an uninterrupted wood which closed us in on both sides. The coach stopped at the Post Office, I took a room in a Hotel, and went with Charles to his lodgings which were convenient and neatly furnished. He gave me tea and we spent a quiet, agreeable evening, conversing mostly on the journey I intended to make through Italy, which Country Charles had recently visited. 
Wednesday, $13^{\text {th }}$ of November 1844. I spent this day in a very quiet manner, more so than I had spent any other day since I landed in Amsterdam on the second of Octobre. The weather which was unfavorable, kept me within doors; I wrote and read a good deal, and noted down Charles' instructions relative to my future travels. He introduced me to a friend of his, Feuerbach, who was employed in a Court of law. We dined at table d'hote, and by four O'clock, I by myself went to see a Mrs. Mayer whose maiden name was Elfriede Dede, a native of Altona. When she and I were children, I, ten or eleven years of age, she perhaps one year younger, she was a pretty little girl, I was very fond of her, and tried hard to persuade myself that I loved her. These boyish illusions soon vanished, and the next thirteen years [804] till I left my native place in 1823 I saw little of her. However, having heard that she resided here in Tübingen I thought I might as well pay her a visit, and I did not repent of having done so. Her beauty if ever she had had any pretentions to it, which I doubt, was gone; she spoke German with the broad Hamburg accent as if she had been born and bred in this town, whilst until she removed to Tübingen, she had always lived in Altona where better German is spoken than in the neighbouring place. Her education seemed to have been somewhat neglected, but on the other hand, she was very kind, seemed good natured, and expressed a great desire to return to Altona which she had left more than seventeen years ago. Her husband "Ober-Justiz-Rath" or member of the Superior Court of justice had lost his reason and was under medical treatment in a Lunatic asylum near Baden-Baden. She had four Children, of whom the eldest, a girl of sixteen, was absent on a visit to Stuttgard. I remained with her for more than two hours. We took tea together and remembered many of our mutual friends in Altona. From the windows of her house we could see the Neckar, and at a distance the Suabian Alps, probably a pretty view on a sunny day, not so this day when the sky was cloudy and all nature wore a sombre appearance. I finished the day in Charles' Company.

Thursday, $14^{\text {th }}$ of November 1844 . Several hours of this day I was occupied with writing, amongst others, I dispatched a letter to Mr. W. Gibbs of London, of which I had made a rough draft in Cologne, in it I expressed my wish to reenter his establishment in Lima. At about noon, the weather having improved I took a walk with Charles. Tübingen is a miserably looking place. I think I did not see a single house which looked somewhat respectable. In some parts the Dunghills lay in the streets, nothing better than in a dirty village in the Country, on the other hand, nature is never without its charms and so it was in the environs of this place which lie partly in the Valley of the Neckar, partly on the side and upon the saddle of a chain of low hills which separates this valley from that of the Ammer, a small river, and affluent of the Neckar. From this ridge we 
had a pretty view to both valleys. Here also stands a Castle, interesting for its great antiquity, and its peculiar construction, it contains a library, and plaster casts of a few statues. The Neckar valley is joined by another, that of Steinlach, extremely narrow, which is inhabited by the descendants of some Swedes who formed there a Colony at the time of the thirty [805] years war, and they, the descendants have preserved up to this day their peculiar and neat dress. In a large building called the Stift, one hundred and twenty poor young men who study divinity, live, board and frequent the lectures in the University gratis, all expenses being paid by the Government. Charles assured me, that many renowned Theologians and Philosophers in Germany have sprung from this institution. After dinner say at four oclock, I by myself went to the house of Professor Theodore Hepp of whom and whose family I have said a few words in the previous Volume of these extracts page ${ }_{526-532}$, his mother and elder sister Emily stood at the top of the staircase when I entered the house, they did not recognize me, and I was obliged to mention my name. It was the same with Theodore, whom I of course addressed with the familiar "Thou" of former years; in the first volume I qualified him somewhere as a dry stick, and surely he had not improved since then. Though we had not seen each other for a quarter of a century, he allowed himself easily to be persuaded by me, not to deviate from his daily routine, and to take his usual walk which he did, as if I were a mere common acquaintance. I thus remained with the two ladies, of whom Miss Emily was the more agreeable, the mother fell into the extreme of garrulity, Theodore on his return, into that of Taciturnity. I took tea with them, the ladies were not at all pleased with Tübingen life, they said that men looked here upon their wives as mere drudges whose only duty was to attend to housekeeping, they in the day time attended to their avocations, and in the evening went to the Beer house, leaving the poor wives most of the day by themselves. Theodore, who in the university lectured on Criminal Jurisprudence, was a widower, and had two boys, whose Suabian German I was hardly able to understand. As long as his wife lived, he had seen much Company, but now his mother and sister complained he had withdrawn from all society. I was about an hour with them and though Theodore on my taking leave favored me with a Kiss, I was not highly pleased with the reception he had given me. Next I went with Charles to pay a visit to some friend of his, the family of Baron Von Wachter, his lady, a Baronness in her own right, and who had to be addressed with "Gnädige Frau" (Gracious Lady) received me very kindly, at the same time, in a manner which showed that she was "du bon ton". Two ladies, the one the wife of a professor, the other Mrs. Doctor Wallatti sister of Dr. Heise, married to Miss Emily Henckel (of Hamburg) joined us, also the Baron came in. We had 
tea and spent the time agreeably [8o6] till Eight oclock, thence we repaired to Mr. Feuerbach where I took tea for the third time and remained till midnight.

Friday, $15^{\text {th }}$ of November 1844. At two oclock a.m., the Stage Coach was to start for Schaffhausen, consequently I did not go to bed but remained with Charles in his room till near this hour, when he accompanied me to the Post office. Here we separated and I have not seen him again; thus my acquaintance with him was very short, however I liked him well and if God had spared his life, I am confident he would have become a useful member of society. Of course it was pitch dark when we left, I had three Companions in the coach, two Gentlemen opposite, one female alongside of me. With the latter I entered into conversation, she spoke the true patois of the Country, was a rather insignificant woman and I did not regret the want of her society when she left us in the course of the day. Hechingen, the Capital of Hohenzollern-Hechingen was the first place where we stopped. I wrote a few words to Charles requesting him to send after me my spectacles which I had forgotten in his room. At seven Oclock it became daylight, the sky was cloudy and the weather disagreeable. Our road led over a well kept Chaussée between two rows of trees, we had mountains covered with firs on the one, then on both sides. They were the last spurs of the black forest which gradually slanting down, lost themselves in the plain, at theirs bases lay many villages, others in our route. It one it struck me as strange, to see all the women wear scarlet stockings. Of the two Gentlemen, the one left, the other, from his furred cloack, fur cap, and big mustachios I believed to be a Pole or a Turk; however when I became acquainted with him, he turned out to be a Genoese of German extraction named C. C. Schmidt, Prussian Consul in Genoa, and by trade a Druggist. He had been on a visit to Mr. Jobst, the famous quinine manufacturer in Stuttgard, and was now on his way back to Genoa, where he had said he shd. be very glad to see me, for which purpose he handed me his card. Tuttlingen is the frontier town in the Kingdom of Wurtemberg where we arrived at $121 / 2$ and dined; close-by upon a hill, I observed an old Castle, and was rather surprised to be told when I inquired what river it was which we had crossed over a bridge, that it was the Danube. A little further west lay Donaushingen where this mighty river has its source. From Tuttlingen we drove in a South Easterly direction [807] and arrived at four oclock at Stockach in the Grand Duchy of Baden. Here the two roads for Schaffhausen and Constance separate; Mr. Schmidt took the latter, I the former. As the Coach was not to start before six Oclock, I had time to spare and took a stroll in the environs which I enjoyed the more, as the weather had changed for the better, and it was now a beautiful afternoon. Stockach is prettily situated in the midst of hills, here and there covered with wood. At a distance I observed 
three high, not snow covered mountains, on inquiry I learnt that one of them was the "hoch Santis" at the Southern extremity of the Canton of Appenzzel in Switzerland. At six o'clock I continued my journey, the moon in her first quarter shed a mellow light over the country, it was a delightful drive. My companions were a gentleman and his lady who he said, was his wife, though I have my reasons for believing that they were not married. They could speak German, but preferred French. He was a Swiss established in England whither he intended to return after leaving the lady with her parents in Neuchatel. It was eleven Oclock when we alighted at the hotel du Rhone in Schaffhausen. I wrote a few words to Mr. Mayer in Saint-Gall, informing him of my arrival in this place, and went to bed at midnight.

Saturday, $16^{\text {th }}$ of November 1844. The usual breakfast consisting of Coffee, bread, and butter was brought to my room. I bade good-bye to my acquaintances of the previous evening, and then walked out by myself. At a very trifling distance to the Eastward of the Hotel, a few stone steps lead-up to a tower surmounted by a Steeple of little height, and erected on an extremely solid vaulted foundation of Roman origin. The view which I had from the top gave me a correct idea of the situation of Schaffhausen. It lies on the right bank of the Rhine in a hollow, like Stuttgard, the surrounding hills, there clad with vines, were here covered with wood, from them several roads descended into the town. I crossed the moat over a bridge, and found myself in the open Country. I wandered about, as chance directed me, up hill, and down dale, and keeping always to the left or Westward, came to a narrow valley called the Michlenthal. The hills on both sides, not of great height, are steep and rocky, here and there with a few trees, leafless of course in this season. A small rivulet which I had to cross many times moves the wheels of a water mill. I ascended this Valley, the hills draw so near each other as to form a gulley, leaving only room for the rivulet, now a torrent and a well kept gravel path. My guide book written by Walcher, lavishes upon this Mühllenthal the epithet of wild and [808] romantic which "en miniature" it well deserves. On my inquiring for my way to the Hanethal I was told that I had to climb-up the range of heights to my left, which I did and descending on the other side was once more in a valley, this time so narrow as to resemble a mere cleft in the mountains; following the same I emerged on a wide well kept chaussée, again confined by wood clad hills on both sides. This I ascended for a considerable distance in hopes of meeting a road or path, which turning off to the left would bring me back to the western extremity of Schaffhausen, but being disappointed in this expectation, I returned, and when close to the town the path of which I had so long been in search, presented itself. It took me to a hill for the greater part covered with firs, where they were cleared away I had a pretty view over the town, the 
Rhine and the surrounding Country. I descended, entered Schaffhausen by its western gate, and reached my hotel at $121 / 2$, in time for dinner; many of the houses in this town are disfigured by balconies shaped as pepper-boxes, and provided with windows, the walls of a few houses were painted. I observed one in particular, which, covered all over with paintings, represented, as far as I could distinguish the confused mass, our first parents in Paradise, at all events, there were some naked figures which I took to be Adam and Eve. Carts steered, on "terra firma" by means of a rudder are surely strange contrivances, two wheels before and two behind connected by an extremely long arch-tree upon which the trunks of firs are placed, and in order to keep these unwieldly machines steady, and to prevent their moving from one side to the other, a short pole is fastened to the hind wheels, which pole drags along the ground, to this again a solid handle is fastened which is held by a man who follows the cart, and who actually steers it. On the walk, of which in the preceding lines I endeavoured to give an idea, I for the first time had a glimpse of the Suiss Alps, "the Jungfrau", the "Finsteraarhorn", the "Schreckhorn", the Mönch, etc., all between twelve and thirteen thousand feet above the level of the sea, isolated snow peaks grouped together, not extending in a long uninterrupted chain like the Peruvian Andes as I saw them on the $18^{\text {th }}$ of December 1826 on my way from Puno to La Paz, see Volume the $1^{\text {st }}$, page 156 , and again on the $12^{\text {th }}$ of July 1842 when near Recuay (see same Volume page 540). A small hill on the other side of the Rhine concealed the continuation of these mountains to the [809] Eastward, but where this impediment ceased, I distinguished other mountains at a considerably greater distance than the previous one. They were the Alpes of the Vor Arlberg. At dinner I was the first who broke the ice of a general reservedness. I made the acquaintance of a German architect, an agreeable well instructed young man, in his political opinions an ultra Napoleonist; also of a Gentleman and lady, French Swiss proprietors of a manufact[uror]y of window Glass at Rosemberg near Ulm; with them I arranged to pay jointly a visit to the famous water-fall, and accordingly after dinner we crossed the bridge to the opposite, the left side of the River, where we took a boat, a miserable small skiff in which we floated down, for the current was so strong as to preclude the necessity of rowing. The roar of the fall sounded into our ears like the report of a distant artillery. We landed on the same side, a little higher-up the river than the Castle of Laufen, which stands exactly opposite the fall, I understood that the owner of the Castle had let it to the present lessee for twenty years. The apartments through which we were conducted were tastefully fitted up, the walls hung with pictures. In one apartment Guide-books, engravings, wooden models of the Swiss Chalets, and other similar curiosities were exposed for sale, I bought a pretty lithography engraving still in my possession representing 
in the centre the Schaffhausen Cataract, around the different Costumes of the peasant women in the various cantons of Switzerland. The first view which we had of the fall was from a balcony, and I must confess that I was disappointed. I had expected something more grand, more sublime. The Rhine of considerable width precipitates itself over a ridge of rocks, seventy feet deep as the guide book asserts, it is divided by two rocks into three different falls of which that nearest the left side is the widest, equalling, I should think, the Løren foss near Trondjheim, see page 604 of this Volume. From the balcony, we were led to a small pavilion, the windows of which are differently colored, red and yellow, and of course nobody ever omits to have [_] them a look at the falls. Lastly we went to a gallery which [_] above the water, and approaches [_] near that when standing up there, we were continually wetted by the sp [...] [810] rushed and roared, whirled and tossed, foamed and frothed, incessantly and ever lastingly, so it had done for centuries past, and would continue to do for centuries to come. We again took a boat, were rowed over to the opposite side, and landed not far from the splendid and large Weber Hotel prettily situated on the top of a hill. We passed the village of Neuhausen and reached Schaffhausen at about five O'clock. I secured a seat for Constance on tomorrow's coach, and spent the evening in my room, occupied with writing.

Sunday, $17^{\text {th }}$ of November 1844. At eight Oclock I was in the Post office, about an hour later, the diligence which was to convey me to Constance, arrived from Basle, my companions in the Coach were uninteresting people, and I took not the slightest notice of them, the weather was delightful, the sky clear, the temperature mild, and I much enjoyed this day's journey. At about ten oclock we stopped for a quarter of an hour whilst black bread was given to the horses in a suburb of the town of Stein, still in the Canton of Schaffhausen. On the right side of the river lies the town itself, connected by a stone-bridge with the suburb, also on the same side is the ruined castle of Steinklinge on the summit of a mountain. Here the Rhine widens and takes the name of Untersee, or lower lake, as soon as it narrows again, it resumes its own name. Shortly after leaving Stein, we crossed the Northern extremity of the Canton of Zurich, and entered the Canton of Thurgau which extends to the very gate of Constance, in German Köstnitz, belonging to the grand Duchy of Baden. About half way between Stein and Constance lies Stockborn where horses were changed. The entire distance from Schaffhausen to Constance we drove on the left Bank of the Rhine, sometimes close to it, sometimes at a small distance from the same. On the opposite bank, a ridge of hills gradually rising into mountains runs parallel with the river, along this ridge, as well as on the sides of the mountains lie isolated farm-houses, villages, and towns prettily to be looked at, when shone upon by a cloudless sun. Also to our right we 
had a similar continuation of heights, and the level ground was occupied by Cornfields and vineyards, Kitchen gardens, fruit tress and other descriptions of trees interspersed with merrily looking white painted farm houses. The greater part of the vines lay on the ground, and were carefully covered with straw to protect them from the cold during the [_]. I observed that the arms of the Canton of Thurgau are two [...] Constance where my luggage was searched by the Custom house Officers. [...] ent to the nearest hotel, [811] the Adler, and was just in time for table d'hôte. The dinner was fair, only the vines were bad, the same as in Schaffhausen. Here for the first time I experienced a marked want of politeness, a Gentleman near me carried on the conversation in an overbearing manner with his acquaintances, and when I tried to put in a word, no notice was taken of me, whereupon I rose before the dessert was brought in. It was now about three oclock and the weather as fine as it had been in the forenoon. I walked towards the lake, the Bodensee as every body knows, when a Steamer was just leaving, two other Steamers were at anchor protected against the waters of the Rhine which disembogues here from the lake, by a long, somewhat curved stone mole, at the extremity of which stood a tower, probably a light house. Towards the South I saw the snowy alps but regretted that I had nobody near me who could tell me the names of the different peaks. I entered several Churches, which I supposed were partly protestant, partly Catholic. My opinion that some of the inhabitants of Constance were Protestants founded itself upon a trifling circumstance, namely the similitude which I noted between the black bound books which some females carried in theirs hands and the Protestants hymn books universally used in the North of Germany. I crossed the bridge to the town of Petershausen, on the Northern part of the River, and followed a chaussée for sometime, but as this afforded nothing of interest, I returned, crossed the town sauntered about in the fields and reentered through the Paul Strasse, one of the principal streets; near one of the gates is a miserable wretched house where Huss was apprehended; his name and the year 1414 are inscribed over the door. Constance is irregularly built, there is no foot pavement, its appearance however is not so antiquated as that of Schaffhausen, nor so decidedly ugly as that of Tübingen, the Post-Office and the Cow-market are the only buildings which distinguished themselves from the rest. In the centre of an open square in front of the principal Catholic Church stands a Column upon two pedestals with the Statue of the Virgin Mary on the top, I copied the inscriptions, which I should say give a very poor opinion of the intellect of the Constance people; on the one side of the upper pedestal, you read as follows: Sanctæ Mariæ Dominæ Angelorum; on the second side: Mariæ terrori infernorum; on the third: Mariæ refugio pecatorum; on the fourth: Mariæ patronæ mortalium. Below each respectively: Deo, ter, 
opt, max. Upon the lower pedestal on one side: Virgini sine labe conceptæ, Cœli terræque reginæ, hoc perenne ad posteres monumentum pos[_] ecclesia Co[_] MDCLXXXIII. On the second side: Mariæ matre [812] misericordiæ urbis Constantiensis protectrice potentisimæ. On the third: Mariæ Virginum Virgini, Ecclesiæ Cathedr[a]lis domine Clementissimæ, and on the fourth: Mariæ matre ter admirabili Diocesis Constantiensis patroneæ augustissimæ. Having returned to my hotel and retired to my room, I was on the point of going to bed at an early hour because I did not feel quite well, when I heard suddenly the sound of a music, my curiosity was roused, I looked put of my room, and saw that a large Saloon fitted up for a ball, was fast filling with the "Beau monde" of Constance. Whilst they enjoyed themselves on the light fantastic toe I was quietly in my bed, reading notre Dame de Paris, and soon fell asleep, the tunes of waltzes ringing in my ears.

Monday, $18^{\text {th }}$ of November 1844. At about four o'clock I heard a gruff voice calling out that there was no steamer from Constance to Rorschach, and that a Bavarian Steamer would touch at a place close by, but I, not thinking that this advice was meant for me, remained in bed, and when at 5 oclock I woke the dozing boots, I certainly received for answer that there was no conveyance for Saint Gall until the afternoon, thus I had to resign myself to one days longer stay in Constance. On referring to my guide book, I found that a spot called Hohenrain was recommended for its commanding situation and beautiful prospect, without difficulty did I find my way thither; I had merely to follow a chaussée which parallel with, but a little to the South of the high road from Schaffhausen ran right through the Country yesterday seen and described by me. The sky was cloudy and the weather less agreable than on the previous day; yet I was in high spirits for not only my yesterday's indisposition was gone, but above all I found myself in Switzerland, the Country which since my earliest youth I had been so desirous to visit. I passed through the village of Kreutzlingen, Ennenshofen, and Tägerwylen, also two public houses with true Swiss names, the one Wilhelm Tell; the other Zum schnapsle (to the Small Dram), and emerged in the high road. Again I had to turn off to the left, to ascend and to cross a pine wood before I reached the Village of Waldi; then a few houses, the Hohenrain, close to which stood a Scaffolding like that on the Victors height near Alexis Bad see, page 660 of this Volume, but meanwhile a dense fog had drawn up which envelopped and concealed every object, so it would have been [813] useless to climb-up. I retraced my steps as far as the high road which took me in a straight line to the gate of Constance, to my left the Untersee and the Rhine were always in sight, to my right I had a ridge of woody hills, the continuation of those upon which Waldi and Hohenrain are situated. At table d'hote, I kept a sullen silence like yesterday. The man whose 
uncourteous manners I had noted, was the owner of the Hotel who did not address a word to me, and I of course did not speak to him, I ate my share and rose. The council-room in which Huss was condemned remained to be seen. Near the landing place stands an ancient building which dates from the year 1348 , it is called the town-house, but is used for storing merchandize; a broad stair-case leads to a long, wide, and very low saloon which notwithstanding its large size could never have held the five thousands persons more or less who as history informs us constituted this famous Council, which convoked by the Emperor Sigismond, sat here from 1414 to 1418. It sentenced to the flames John Huss and his friend Jerome of Prague, the former was burnt in July 1415, the latter in May 1416. This council likewise ordered that the bones of Wicliffe who had been dead thirty years should be desinterred and thrown into the flames. Having committed these deeds of excerable wickedness, it deposed the three popes, John the XXII, Gregory XII, and Benedict XIII, and elected another Martin V, of the family of the Colonna, who soon after his election left for Italy, and dissolved the Council, so that the principal object the Emperor had had in view when convoking this Council, viz.: the reform of the many abuses which had crept into the Catholic church, was not obtained, and he remained for ever with the indeleble stain upon his otherwise fair character of having broken the safe conduct given to the Huss under his Imperial seal and hand. The following curiosities were shown here: the identical Chairs used by the Emperor and the Pope Martin during the Council; a gilt wooden box in which the Cardinals threw their votes when condemning Huss and Jerome; a very small narrow wooden cell, an exact facsimile of that in which Huss was kept prisoner for three months; also a stone German idol dug out in the Vecinity, representing on one side a dog, on the other the God of war. As the stage coach for Saint Gallen did not start till four Oclock I whiled away the time by walking up and down the diverted streets of Constance. My fellow traveller in the Coupe was a deaf and a dumb Lithographic artist, further on, another Gentleman joined us. However, as the weather was extre- [814] mely foggy, and it soon got dark, I slept the whole way until at half past nine, when the coach stopped at the Post office in Saint-Gall. Hardly had I alighted when a Gentleman addressed me in German with "are you in good health Mr. Witt from Hamburg of course," this was Mr. Mayer, who gave me a very hearty welcome. He introduced me to his two sons who were at work at the Counting house, then to the female part of his family in the dwelling house, a short distance out of town; they were: his wife, an elderly sickly, very agreable lady, his daughters Mary, Rosalie and Hedwig, the last on the point of being married to a merchant of Messina, all three very good looking, and two younger ones, Jenny and Gertrude, one of whom had returned from an institution in the neighbourhood of Canstadt, where she had 
been a considerable time for the cure of a weakness in the spine. All were very kind to me. We had a nice supper, I had to sit on the Sofa, the seat of honor. Mr. Mayer joked a great deal with his daughters but whether he did so merely because I was present, and to give me an idea of his affection for his children, or whether it was his usual habit, is more than I can say. Everything in the house was neat and genteel, nothing splendid nor extravagant. I had for myself a bed room, and a sitting room, very pretty and convenient.

Tuesday, $19^{\text {th }}$ of November 1844 . Before proceeding with my diary I will say who Mr. Mayer was, and how I became acquainted with him. He was not a manufacturer, but one of the first merchants of Saint Gallen, he purchased $\mathrm{fm}$. the small manufactories in the neighbourhood as well as from the Country people who weave and work in their own houses white Cambric and muslin articles, plain and embroidered, in his own store he gave them the last finish, assorted, and packed them, then either sold or sent them on his own account to foreign markets. One of such consignments he had made about the year 1830 to the firm of Huth Grunning \& Co. of Lima, managed at the time by a Mr. Bartholomew Browne. This firm had not given him satisfaction, and as far as I could learn, his complaints were well founded. At that period duties could be paid in the Peruvian Custom houses with a certain description of documents called "abonos" of which I gave an explanation (page 324, 32[?] of these extracts, Volme. I), and which could be bought at a considerable discount, whilst the duties paid [815] in this manner were debited in full to the owners of the Goods. Mr. Browne in order to secure to his house this profit, had dispatched all the goods belonging to Mr. mayer, which he then found much difficulty to dispose of. Mr. Mayer gave orders that they should be reshipped to other markets, or returned to him, the Reply given was: that his wish could not be complied with, because the articles existed duty paid in the stores of the Lima house, whereupon Mr. Mayer came out to Lima, either in the year 1834 or 1835 , and took his property out of the hands of Huth and placed it into those of Gibbs, who, notwithstanding all the exertions of Mr. Pflucker, the salesman, were unable to save him from a heavy loss on this speculation. Mr. C. W. Schutte, then on a visit to Lima, Mayer, Pflucker, and I used to play at whist in Pflucker's house, and thus I made the acquaintance of Mr. mayer. I breakfasted with the ladies, for the Gentlemen had already gone to town to attend to their business. At a later hour I called upon Mr. Mayer in his Counting house, where he tried to induce me to make a purchase of some of his Cambric articles, and to send them on my account to the Lima market. Some of the samples which he showed me were very pretty, nevertheless I, remembering how badly he himself had fared with his consignment in former years, was little inclined to act up to his wishes. Meanwhile, the weather had 
become beautiful, the fog had fallen, and the sun shone from a cloudless sky. One of Mr. mayer's sons William, at his fathers request accompanied me on a walk out of town. We ascended a range of hills to the South, and from its Eastern extremity, "the Strangers mountains", had a very pretty view. Saint Gallen lay at our feet in a narrow valley formed by the heights upon which we stood on the one, and a similar range on the opposite, the Northern side, the houses almost all painted white had a cheerful appearance, shone upon by a bright sun. Turning back we saw the Appenzel mountains, to the right of which another snowy chain, whilst to the Eastward in the direction of the Constance lake, the whole valley was covered by a fog so dense and compact as I never had seen before, nor have ever seen since then, it seemed as if one layer of thick vapours had been pressed upon the other, the uppermost had the appearance of one gigantic white fleece, or of a sandy plain seen at a distance, the surface of which had been shaped into billows by the action of the Wind. This thickness remained unmoveable, now and then some hazy light vapours [816] detached themselves, as if making an attempt to envelope the town itself within its folds but they quickly disappeared being drunk up by the rays of the sun. This spectacle was quite new to me, Cooper, the North American novelist, in the third Chapter of his two Admirals describes a fog exactly similar. At the other extremity of the town some thin transparent clouds floated about in the otherwise serene and azure sky. We returned by a road different from that which we had come, between hills along a rivulet, the Steinach, which put in motion several manufactories, an iron foundry, a manufacture of machinery, and a manufacture of Cotton-thread, came to a suburb called Saint George, and finally to Mr. Mayer's dwelling house. Besides the family and myself, a Mr. Hellersberger, Danish Consul in Rio Grande in the Brazils sat down to dinner, which was good and abundant. We had wine of the Country, and a glass of Bordeaux to wind up with. The attendance however might have been better, for the daughters had to rise every moment to take away the plates, and to bring in the dishes, neither were knives and forks changed at every course. After Coffee, Mr. Mayer and I went out together. We now ascended the other range of hills to the North of the town, where we stood the sun shone out brightly, also the Southern ridge with many villages and farm houses lay before us in the bright sunshine, whilst in the valley the fog had increased in density, and extending to the town now concealed it from our view. Further East than the Constance lake we could discern some mountains in Wurtemberg. On our return home we had to pass through the fog palpable, I may say "cutable". Mr. Mayer had to attend to his business, and left me at the Casino, where I read in the newspapers that General Castilla had gained a Victory over General Vivanco, the details were not given, but these news must of course, have referred to the battle of Carmen 
Alto, near Arequipa. A clerk showed me my way to the dwelling house where I took tea, and spent the evening with the ladies till half past ten, when the Gentlemen came from their work, we conversed a few words, then everybody retired to his bed-room.

Wednesday, $20^{\text {th }}$ of November 1844 . At six Oclock I was called by the eldest son James with whom on the previous day, I had arranged to take a walk to the Ebenberg, a mountain in the Canton of Appenzel. A Cup of Coffee, bread, and butter sufficied for our breakfast, at seven Oclock, just about Sunrise the temperature was cool, but erelong the highest mountain [_] [817] then the lower hills and finally the whole country were lighted-up by the rays of the sun, not a single cloud was to be seen, and during the whole day we had the finest weather imaginable. James and I ascended the heights South of Saint-Gallen, where I had been on the previous day with his brother, but instead of keeping to the left towards the strangers mountain, we climbed-up a point considerably higher on the Western extremity called the Schafeck (sheep corner); a beautiful panorama lay round in, close-by hills, woods, and pasture land, villages, and farm houses, whilst towards the Constance lake, the thick dense fog of yesterday had not moved an inch, there it lay as if it intended to remain for ever. Further on in the same direction the high lands of Wurtemberg, Baden, and Bavaria could be seen, a little more to the right, but at a still greater distance, the snowy Tyrolese Alps were distinguishable. Considerably nearer we had the Appenzel mountains amongst which the Old man and the high Saentis; then further in the back ground, more or less to the South, the mountains of Glarus, and in the foreground these of Saint Gallen, the Speer and the Sieben Curfürsten (the Spear and the Seven Electors), the circle closing with the Fockenburg mountains considerably lower than the rest. We descended from this eminence and about half way down came to the village of Teuffen in the Canton of Appenzel, it is but a small plain, but never before or after, have I seen a village with such decided well to do appearance; there was not a single dwelling which deserved the epithet of wretched or miserable, all the houses were in good repair, to the height of four feet they are built of stones, upon which rests a structure of wood and a roof of shingles. From Teuffen we continued our descent, again ascended and came to a plateau dotted over with isolated houses. We stopped at one of them, James entering into conversation with the inmates, who requested us to enter. We found here in a clean room, an elderly woman with four daughters between ten and eighteen years of age, all five employed at their frame embroidering white mousseline. They worked fourteen hours a day, of which at the present season, the last four from six to ten with candle light, for which they were placed at the rate of twenty five Kreutzers per head daily; others capable of doing finer work, James told me, 
received as much as a Florin each. The white mousseline with the pattern printed in black upon it, and the cotton thread, were given them by their employers; the girls though not exactly pretty were good looking, they as well as [818] their mother had a neat, healthy and conten[d]ed appearance. Each of the girls wore a ring upon one of their pretty little fingers. James talked to them in the patois of the country, which I could not make out whilst they understood all I said; their pronunciation was abominable, thus for instance to the $\mathrm{K}$, they gave the sound of the German $\mathrm{Ch}$, instead of kalk (chalk) they said shalk, instead of köhchin (cook) they said "chochin". The family belonged to the Catholic persuasion, the protestant inhabitants extended no further than to a short distance south of Teuffen. From the plateau, we again descended, crossed a small eminence, and came to a level road which brought us to Appenzel, the capital of Canton. Just before entering this town we saw on the summit of a mountain the ruins of the Castle of Clanks where in those times when Switzerland formed part of the possession of the Arch $\mathrm{Du}[\mathrm{kean}]$ of Austria, the Lieutenants well known by the name of Vogt dominered [_] all the neighbourhood. The character of the country between the plateau and Appenzel was neither grand nor majestic, it was pretty and picturesque with an occasional dash of the wild. The road lead us over an undulating ground, across rivulets and torrents spanned by long bridges completely covered over, alongside a craggy and barren rock, a foaming cascade, or through a narrow and sombre gulley. Of the town of Appenzel I saw but little, we walked rapidly through it, and I merely noted the unusual site of the Church at the edge of a rock, part surrounded by a wooden gallery from which one looks down, to be sure no great height, into a small river, the Six which to the North west of Appenzel falls into the Sitter, the Sitter joins the Thur, and this again disembogues into the Rhine. Appenzel is strict Catholic, which if I may believe my companion James, was the cause of its not being such a thriving place as the Protestant Teufen. After leaving Appenzel, we continued on a level road, until we reached a large public house Blaichbad, much frequented in the summer season for the whey-cure, we met many of the Appenzel peasantry; the men generally not tall, but robust, and broad chested, wore without exception a very short white linen jacket open in front with embroideries red and yellow on both sides, terminating in the shape of a heart, the women of whom the young ones were generally good looking, did not distinguish themselves by any particularity in their dress, they wore a cotton gown with long sleeves and an apron, their caps with streamers red ribbons. Though this Wednesday was a common [819] working day, all looked very tidy, even the Children running about on the high road, clean and neat, on the other hand I must not conceal that more than once we were asked for alms, and that on the 
road side like in other Catholic Countries, there stood Crosses and Crucifixes, little Chapels and images of Saints and of the Virgen Mary. The usual salutation is Gott Grüss, "God be with you". In the Bleichbad we took our dinner in a very clean room provided with an immense stove. Two peasants came in, one of whom, Hubert, who was to serve as our guide, walked up to us and shook hands; we then started, it was about noon. As soon as we had left the Bleichbad a steep ascent commenced, at first the ground was covered with a beautiful smooth pasture intermixed with many pretty Alpine flowers, some of which my guide culled and presented them to me with much natural politeness; further on, moss took the place of pasture, and still higher up even the pines grew no more. We had now a wall of decayed limestone before us, parts of which had broken-off and strew our path which for some time skirted the basis of this natural wall, then gradually rising ran along its side, where it was made by human hands, long beams provided with a Bannister connecting here and there one projecting point with the other. Next we passed through a Cavern called the Wild Church in which stood an altar, and where, as James told me, once a year mass was said; on emerging from this cave, we saw deep below us a small lake, the See-alp, wonderfully pellucid, and reflecting the surrounding objects with such a distinctness, that it was impossible for me to distinguish the line of demarcation between its waters and the banks which inclose them. We entered another cave in which a wooden trough filled the place, which the altar occupied in the previous one, and into this trough filtred from above from the caves Vault, the best and purest water, which I have ever tasted. From its extremity a dark stony subterraneous passage brought us to a small piece of level ground and thence, the last ascent to the summit of the Ebenberg, 4500 feet above the level of the sea. I turned my looks towards the Bleichbad and the way which we had come, the houses sprinkled over the mountains sides appeared of the size of big stones. Towards the lake of Constance, the fog which lay there in the morning, continued to conceal every object, from the lake to the right, that is to say to the North East, East and South East we saw the entire range of mountains, which is the main feature of this prospect, first most to [820] the left those of Bregenz, far behind those of Tyrol, then quite in the fore ground the Kamm, der Hohe Kasten (the high box), die Kegel Alp (the cone-alp), die maus (the mouse), these two latter particularly steep, and various other peaks, all belonging to the ridges of the Cantons of Saint Gallen and Appenzell of which "der alte mann" and der Saentis, situated at the Western extremity, both snow capped, are the highest, between these two and where we stood lie der Hohe Schäffler which may perhaps mean the high sheep mountain, and the Ziesler, meaning unknown to me, covered with firs and pines. It was about half past two oclock, high time to return. We retraced 
our steps, stopped for a moment at the Bleichbad merely for the purpose of exchanging our long Alpine sticks with iron points, for our usual walking-sticks which we had left here, and rested for a quarter of an hour or so in a public house in Appenzel where in a large, low, hot room, many men of the lower classes were drinking, smoking and playing cards. We were shown to a private room where coffee bread and honey were placed before us, and the hostess, to see whom had been the only reason for our entering this house, kept us company. She was perhaps thirty two years of age, and suffering from a disease in the throat; but her fine black eyes, white teeth, well shaped nose, and other regular features, gave evidence of her beauty in younger years. She might still be called a handsome woman. By this time the sun had set, and though we had moonlight, yet as our way lay often under trees, it was not an easy matter to avoid stumbling. We stopped for a few moments at the house of our females friends of the morning, they were still at work, now of course with Candlelight. We shook hands with all of them and willingly would I have kissed the pretty little hands of the fair embroiderers. We passed Teufen, and when at the foot of the Schaffeck, did not cross it but followed the high road, an excellent Chaussée, then turning off to the right skirted a hill the Born Eck (the fountain corner) and reached Mr. Mayers Counting house at Eight Oclock. He succeeded in persuading me to purchase two cases containing each one hundred dozen white mousseline handkerchiefs printed in fast colors which I requested him to forward on my account to Messrs. Gibbs Crawley \& Co. of Lima, I also took some money fm. him for my draft of twenty pounds on Gibbs of London. James accompanied me to the dwelling house, where [821] the amiable mother and the lovely daughters were waiting for us with tea and supper. It was Hedwig's birth-day, and of course I had to drink her health. At half past ten we separated.

Thursday, $2{ }^{\text {st }}$ of November 1844. After having breakfasted with the ladies and received from Mrs. Meyer a letter of recommendation to her daughter Gertrud married to Mr. Jaranso of Messina, also being charged with her compliments for a Mr. Schnars of Naples, the eldest daughter Mary accompanied me to her father's Counting-house, whence Mr. Mayer himself was my guide to the Post Office, during these few minutes, the last which we were together, he bewailed the preponderance which the Catholic party was fast gaining over the Liberal Protestants in the town of Saint Gallen, one of the latter, an enlightened teacher having found that the former made this place too hot for him, had decided upon departing, and Mr. Mayer intended to give him on the evening of this day, a farewell party. I obtained a seat in the Coupé, and had for my Companions an elderly Lady with her daughter with whom as it was my habit I entered into conversation, though I had great difficulty to understand their bad German. About half an hours distance from Saint-Gallen we passed the Sitter over a fine 
bridge resting upon two arches. The valley of the Sitter is pretty, but upon the whole this days drive over an excellent chaussée with many ups and downs did not afford me much pleasure, a small map printed on my diligence ticket and which I have affixed in appendix under number 33 shows the different places through which we passed. Gossan, Flawyl, and Wyll, at which latter place we stopped for dinner, lie in the Canton of Saint-Gallen. We then entered that of Thurgau, and arrived at four Oclock in Winterthur, a considerable place. We drove through its long street and remained about a quarter of an hour in the post-house. My female Companions had gone, some Gentlemen taking their place, with whom I did not exchange a word. We passed the river [_] an affluent of the Rhine over a bridge, which, completely covered over, looked like a long narrow box, the weather, cloudy in the morning, had much improved by this time, but as it soon grew dark, I wrapped myself up in my cloak, and slept soundly till we arrived at the post office in Zurich close to which stands the large and handsome Hotel Bauer in which, though the owner had failed, the business continued to be carried on and strangers had not the slightest reason to complain of any want of Convenience. I supped in the general room, and for many hours [822] before going to bed, was employed in bringing-up my diary.

Friday, $22^{\text {nd }}$ of November 1844 . In Switzerland, honey is generally added to the plain breakfast of Coffee, bread, and butter, I liked it well and thought it a great improvement. With a certain Hermann Scherer I made an agreement to serve me as a guide to the Wetteberg the Albis and the Riggi for a remuneration of thirteen francs, which I afterwards discovered was somewhat more than the usual tariff, but otherwise I had every reason to be satisfied with him. It was Eight oclock when we started, the first thing we did was to take my luggage to the Post Office to be forwarded to Lucerne, "Poste restante". A few paces from the hotel we came to a bridge over the Limath, next to a large building, the "Corn-Market", where, this day being market-day, much activity prevailed, and many bags of grain lay piled-up; further on, the so called port where the Limath flows out of the Lake, and finally to many handsome edifices, such as the Public or Canton-School, the institutions for blind, and deaf and dumb, the hospital with sufficient room for five hundred sick persons, the anatomical institution, and the Arsenal. The arsenal was the only one which we entered, and though Mr. Maxwell in his recollections calls it contemptible compared to the tower of London, yet it was interesting to me for the historical reminiscences which it contained. Here are preserved Charles the Bold's musket taken at Grandson on the $3^{\text {rd }}$ of March 1476, his blue steel Cuirass, Tell's cross bow, Zwingle's banner etc., Tell's bow alas! is apocryphal, for modern historical critics are far from giving complete credence to the pretty story of the apple shot by the father, from his son's head, and they found their doubts on various circumstances. 
Firstly, that exactly the same story is related of a Danish patriot called Palnatoke several centuries previously to the period in which William Tell lived; secondly, the Chronicles who give an account of the rising of the Swiss against the Austrian Arch-Dukes make no mention of the apple story; thirdly, the first who introduced it as a fact in a Swiss history was Tschudi, a Swiss who wrote the history of his fatherland some centuries after the time that the event is said to have occured. My guide and I returned to the Hotel through the old part of Zurich with many narrow and tortuous streets, had to cross another bridge, upon which [823] the fruit and vegetable market was held, passed the town-house, and I having settled my bill, departed afresh on our along walk. The library I did not visit. Mr. Maxwell says that it consists of 45,000 volumes, and also some original letters written by Lady Jane Grey. As soon as we were in the open Country, we had to cross the river Sihl wich taking its origin in the Canton of Glarus flows for some time parallel with and to the Westward of the Zurich lake, at the northern extremity of which it falls into the Limath. The bridge over this river was under repair, the long beams lengthways were laid, but the boards cross-ways were still wanting, and it was a ticklish matter to cross it, walking along the beams, an open space being left between each two. However I accomplished it without any accident. When on the other side, we immediately commenced ascending the Wettiberg, the road led us through a wood, leafless of course in this season of the year; about half way-up, we came to a monument erected to the memory of a young man who, descending a path by no means dangerous, fell, and broke his neck, it bears this inscription: Hier stürtzte hinab und starb Friedrich von Dürler den 8 Marz 1840, 26 Jahre alt, treue freunde setzten diesen Stein. English: here fell from the mountain's height and died Frederick von Dürler on the $26^{\text {th }}$ of March 1840 , sincere friends placed this stone. Just when we had reached the summit 2500 feet above the level of the sea, a thick fog came rapidly sweeping down from the North and every distant prospect being for the moment rendered impossible, we entered an inn where I ordered some bread and wine, and amused myself with looking over the Strangers book which was crammed with nonsense, I found however one verse which did not displease me and which I copy:

"Ver Epfel schält und sie nicht isst

Beim mädchen sitzt und sie nicht Küsst

Beim Weine sitzt und schenkt nicht ein

Der muss ein rechter Schaafskopf sein."

English:

"Who apples peels and does not eat,

Sits near his girl, and does not kiss,

has wine at hand, and does not drink

must be an idiot, I should think." 
Meanwhile, the fog had partly cleared away, we again went into the open air, and though the sky was cloudy, yet the fitful changes of light [824] and dark, sun, and the fog striving for the ma[_] contributed to the beauty of the scenery. To the Eastward close by, we saw the white houses of Zurich crowded together at the northern extremity of the lake, and many country houses lining its borders, immediately behind, a low range of hills whence Massena in September 1799 Bombarded the town of Zurich, and gained a Victory over the Russian General Korsakow; far behind, the black forest could be distinguished, heavy clouds resting on the range of mountains, thence to the left, the Vosges also far off came in sight, somewhat at a less distance the Jura stretching Southward, and still nearer we could see the Lindenberg, much lower than the rest, at the foot of which gleamed when the sun's rays occasionally fell upon it, a large white building, the Muri Convent; there also flowed the Reuss hid from our view, and between the Lindenberg and the Wettiberg, the space was occupied by hills and dales in charming variety. From the Wettiberg, the northern extremity of the Albis range, we descended a little, and continued our walk along this ridge through a pretty wood consisting mostly of firs. To our right we had the just mentioned hills and dales, to our left, the Zurich lake between which and ourselves the richly cultivated valley of the Sihl. In the lake itself I noted two islets in one of which called the Ufuan, the famous Ulrich von Hutten lies buried, and on the same side where we were, the town of Rapperswyl with a bridge across the lake. Turning back, the Wettiberg remained as a kind of landmark, to its left, the Lagernberg ridge branches off, the town of Baden to the North West can be seen, and near Solothurm or Soleure my guide pointed out to me some of the highest mountains of the Jura, the Weisseinstein, and some partial streaks of the Reuss glittered through here and there. When we were near the extremity of the Albi's, the pretty, small Turler lake came to view, also the narrow and long expanse of the Zug lake, thus here we saw three lakes at one glance, for the zurich lake was not yet left behind. Having descended from the Albis we came to the high road from Zurich, an excellent Chaussée with fir-clad hills on both sides which we followed, we passed the village of Hausen where, the same as in the vicinity, the people of the Country gain their livelihood by weaving silk articles. Further on stands a monument erected in memory of Zwinglis heroic death [825] who fell here at the head of a small band of Protestants followers, in a skirmish against his Catholic enemies. The monument is nothing but a plain granite block with two inscriptions, a German on the one, a Latin on the other side. The Latin says that Zwingli and Luther jointly were the founders of the liberty of the Christian Church; of the German the following is a copy: 
"Den Leib Können sie Tödten,

Nicht aber die Seele

So spracht an dieser Stätte

Ulrich Zwingli

Für Wahrheit

Der Christlichen Kirche

Fetchtendt

Den Heldentod Sterbend

den 11 October 1531."

English: "The body they may kill, but not the Soul, thus spoke on this spot Ulrich Zwingli fighting for the truth of the Christian Church and dying the death of a hero on the $11^{\text {th }}$ of October 1531 ". How beautiful in its noble simplicity! Kappel was the next village which lay in our way, in its vicinity some ordinary wine is grown; we struck off from the high road, and through paths and by roads, and over the small river Lortzee which flows into the Zug lake, we again emerged into the same and reached the town of Zug. The Riggi was clearly seen before us; to the left two high peaks, the one, the Mythen in the Canton of Schwyz, and far behind the Glarish in the Canton of Glarus, whilst to the right of the Riggi, we discerned the Pilatus, on the other side of the lake of the four cantons, in German: "Wierwaldstädter-see", and between the Pilatus and the Riggi, quite in the back ground, the Alps of the Bernese Oberland can be seen on a clear day; this day, they could not. In Zug we walked through its long street; Sherer dined in a public house with the family, I contented myself with a glass of wine, and read the Swiss papers, in one of which I observed an excellent law just passed in the Canton of Saint Gallen which says that if a merchant fails, and if his assets do not suffice to pay half of what he owes and the judicial expenses, he loses his right [_] voting at the elections and for two years is not allowed to enter a [826] public house; if a stranger, he may be sent out of the Canton. A brother of the host showed us to the Churchyard filled with Crosses, the tablets fixed to these crosses, on which the names of the dead are inscribed were all gilt which pretty Custom I had previously observed in other church yards. He made us also enter the Charnel house, and told us that it was the Custom after a certain number of years to desinterre the dead when the Skull of each with the name affixed and a few bones of the Corpse are ranged on shelves which run along the interior walls of the building, close-by is the Chapel where once a year mass is said, and where I saw two individuals kneeling, probably praying for the soul of a dear deceased. Not far off a house was pointed out to me which for sometime during the first French Revolution had been inhabited by Louis Philippe and his sister Adelaide. It grew dark, but 
Scherer and I, though we had already walked many a mile in the course of the day, stepped out bravely on the Chaussée which runs between the lake on the one, and rows of hills on the other side, we passed the Villages of Oberwyll, Otterwyll, and Walchwyll and reached the Adler public house in Art, in the Canton of Schwyz full two hours after our leaving Zug. In many houses I still saw light, and on inquiring what the inmates were doing at such a late hour, my guide told me that they were occupied with spinning flax and hemp for their own use. The houses almost without exception of a comfortable appearance were built of wood, upon a ground wall of stone, not only the roofs, but also small sheds from the lower storeys project for the purpose of protecting the Windows, frequently double, against the beating of the rain. In the Adler, two peasant women who were on their way to the holy shrine of Einsiedlen were at supper with their two male servants; they the old mother and her daughter were richly dressed, they wore massive silver and gilt chains over their silk velvet jackets. I also took my supper and went to bed at nine Oclock, really tired.

Saturday, $23^{\text {rd }}$ of November 1844 . At six oclock I rose and took my breakfast, a very good one (honey, I will say once for all, is always placed on a Swiss breakfast table) in Company with the peasant pilgrims of last night whose bad [_] I had to my regret much difficulty to understand. [827] At seven Oclock Sherer and I started for our ascent of the Riggi. It was a cool clear morning, the sun just rising behind the Schwytz mountains, to the South East of us. A convenient path leads up through the midst of trees; from an open place where the wood did not impede the prospect, I turned back and certainly one of the most beautiful landscapes, beautiful even in this unfavorable season lay spread out before me; to the left the Zug lake in the shape of an e[_]t, 1320 feet above the level of the sea, as quiet and motionless as a mirror surrounded by hills of inconsiderable height gradually slanting down towards the water; behind the lake of Zug, that of Zurich presenting a more cheerful appearance owing to the many towns, houses, and villages which line its banks. From the Village of Art where I had spent the night, and which lies at the Southern end of the Zug lake, a pretty little valley covered with trees extends in a South Easterly direction to the Lowertz lake, at present of small dimensions for on the $6^{\text {th }}$ of September 1806, a large mass of earth and stone detached itself from the Rossberg, filled-up a great part of the lake and buried completely the villages of Röthern, Busingen and Goldau, partly that of Lowertz, together with six hundred inhabitants. Goldau and Lowertz have been rebuilt. In the Lowertz lake lies the small island of Schwanau, and on its Western bank the chain of the Schwytz mountains partly covered with Snow amongst which the two Mythenhorns, particularly the higher one ( 5870 feet) raising its needle like a point straight and perpendicular into the clear sky, are the most remarkable. Whilst 
I was enjoying this fine prospect the Church bells sounded merrily across from Art and from Goldau, it was a delightful moment, I felt happy indeed, and satisfied with myself and the whole world. Scherer and I continued our ascent, firs grew here and there, occasionally a barren grey rock stuck out, a torrent rushed by, now and then, forming a cascade, we reached the first house, in French: the "Refuge", in Swiss German "das unter Tächli" or lower small roof, one third way-up the mountain, next the upper Tächli. Here abouts, the ground commenced being covered with hoar-frost, also the firs were clad in white, further-up, snow lay on the ground and icicles hung down on the sides of the tiny rills. We passed several Chapels, a huntsman who no doubt had said his prayers came out of one of them, then we met the "Wald-Bruder" (Brother of the forest) or soi disant Hermit who lived on the island of Schwanau. Still higher-up we came to the Klosterle or small convent dedicated to Maria, in the [_] some houses [828] are built round it, those which serve for the purpose of inns were shut up, only one was open, inhabited by the two Capuchins friars. We entered the Church, which considering its out of the way situation, might be called richly adorned, in the Vestibule many small votive tablets hung against the walls; strict Catholics are in the habit of presenting such tablets to the Virgin or to a certain saint after having escaped from eminent peril or recovered from a severe illness, which escape or recovery they attribute to the intercession of the Virgin, or of the Saint; thus a tablet had been presented because the donor had got rid of a severe pain in the thigh, a second because having partly lost his reason, he had recovered it, a third, because being knocked down by a bull, he had escaped uninjured, a fourth, a woman, because having been brought to bed, of two still-born children consecutively, a third Child had been a live one, and so on, "ad infinitum", all of course due to the special protection of the Virgin on the Riggi. On leaving the Klösterle a fog began to form itself, the higher we ascended, the thicker it became, occasionally the rays of the sun pierced through, when we flattered ourselves with the hope that the sun would conquer, but it was not to be. We passed various solitary houses inhabited in summer by herdsmen, now they stood empty, on the $30^{\text {th }}$ of September it is the Custom to drive the cattle further down the mountains. We came to the Hotel or "Pension du Riggi Staffel", where the barking of a dog gave evidence of its not being shut-up, and in an half an hour from the Staffel, the ground, be it borne in mind, covered with snow and ice, we reached the highest point, the Riggi Kulin $555^{\circ}$ feet above the level of the sea, the ascent had taken us three hours. The fog had increased in density, it was like a wall, we entered an inn, the owner of which was the first whom I met, to whom my good German was unintelligible. We remained till one o'clock in hopes that the fog might Clear away, but hoped in vain. I ordered some butter, bread and 
wine, and looked over the Strangers book commenced in April of this year, I found here amongst others the name of a certain Guillermo Espinosa from Venezuela, whose name I had previously seen in the book kept in the Castle near the Schaffausen Cascade, also the effusions of many travellers who like myself had been disappointed by the unfavorable state of the weather. One, probably a yankee, had brought his complaint [829] to paper in the following energetic lines:

"I have climbed-up this darnation place,

To see the sun arising;

The critter will not show his face,

And I'm as mad as pison." (means I suppose poison)

Jack Downing.

I added an account of my ill-luck in Spanish. My guide told me of a verse which he had read in the Strangers book at the Grimsel which pleased me, owing to the strange idea of making four languages contribute each one line.

"In questa casa troverete,

Toutes les choses que vous souhaitez,

Vinum, panem, pisces, Carnes,

Horses, Coaches, Mules, and Harness."

The last visitor who had been here before me was Monsieur Charles de Billecourt de Marenne Sur Ley, Marne, France, on the first of November he had been so fortunate as to have a fair view of the whole chain of the Alps, but not of the Valley. We commenced our descent as already said at one oclock, as far as the Staffel the same way which we had come, then turning off to the right, the path was sometimes rather steep and at a certain point, I had some difficulty in getting over the clear slippery ice. The fog and the snow covered ground kept us company for two thirds of the descent, hardly ever did the sun break through, but when we were out of the fog, and at the same time on turfy ground, I saw before me the lake of the four Cantons with Küssnacht at its North Eastern extremity, the Zug lake and the town of Jonensee, between which town and Kussnacht a pretty little plain, hardly a quarter of an English mile wide. Instead of following the path which leads to the Kussnacht, we steered our way to the Hohle-Gasse (hollow road) - Classic ground - and over hedges, across fields, through paths and bye-roads, we emerged at Tells Chapel on the outer wall of which is painted the assassination of Gessler by William Tell with these words below:

Gessler's Hochmuth Tell Erschossen, und des Schweyzer freiheit antprossen,

Wielange wurd aber selbe Währen, [830]

Noch lange venn vir die Alten wären. 
English: Gessler's pride shot dead by Tell,

And Swiss liberty arisen well;

how long will this freedom hold?

Still long, of were we the men of old.

At the Chapel, I paid off my guide Scherer, and added in his pocket book my testimonial of his good behaviour, to the many, which it already contained. By myself, I walked along the Chaussée, passed through the Hohle Gasse (the hollow Road), not particularly hollow, and certainly not such a deep cut as the descent into Rainbeck from the other side of the Bille (see page 444 of this Volume) but the Hohle Gasse is well known in German Literature, for, who is ignorant of Tells beautiful monologue in Schillers Wilhelm Tell which begins with these words:

Durch diese hohly Gasse muss Er Kommen.

English: Through this hollow road must he Come.

Then continued my walk; to my left lay the lake of the four Cantons, on the opposite side of which I discerned a ridge of mountains slanting down towards the lake covered with verdure, and studded with isolated houses behind which a chain of snow capped mountains, to my right ran a similar ridge of hills. My spirits were good as long as daylight lasted but when darkness came on, and with the darkness rain began pouring down, to protect me against which I had fortunately my umbrella with me, other thoughts came into my head: what strange creatures are we, said I to myself; in Lima I have my comfortable home, in Altona many friends are ready to give me a kind reception, and here I prefer walking by myself in the dark, in the rain, on a road with which I am not acquainted to a place where nobody knows me, nobody cares for me, were I to drop down dead who would mind the stranger's corpse! No mishap heaven be praised befell me, and safely did I reach Lucerne. As soon as I entered the gate a church yard stretched out before me, there is I should think, no other town on the Globe, which receives the way farer in such a sombre manner. Having crossed the churchyard I saw before me a big dark hole into which I did not venture myself, not knowing what it might be, some persons [831] passed who told me, that this was the entrance to one of those long bridges all covered over, of which I have already spoken, it crossed a branch of the Lake; when at the other extremity I stood before the Swan Hotel whence with a porter I hastened over another similar bridge to the Post office and fetched my luggage. Whilst the fire was being lighted in my room, I remained in the dining saloon, and listened to the conversation of an Englishman and an Englishwoman, who appeared to me so vulgar that I immediately thought of an expression of Mr. Mylius in Franckfort: "Since I have been in England, it seems to me that all the English who travel on the Continent are tailors and shoemakers"; on referring 
to the strangers book I found that they were Mr. and Mrs. Hopkins from Manchester, what gentility could be expected from such a common name.

Sunday, $24^{\text {th }}$ of November 1844. I had a comfortable room with a pretty view over the lake, upon its green borders, and the white houses on the opposite side, behind which at a small distance snow covered mountains. Breakfasts in Switzerland are invariably good. After having despatched mine, and written my memoranda I engaged a guide Francis Küttel for twenty franc to accompany me through the Bernese oberland, as far as the snow would allow us, I then went out for a stroll, crossed the bridge which was covered over, and between whose rafters, pictures representing scenes from Swiss history were painted, below each picture were written a few words in Rhyme, corresponding to the miserable execution of the paintings, here follows one of these verses:

Vierzig mann acht darunder,

Von Lucern als Helden-Vunder,

Schlagen runter auf einmal,

Drei mal Hundert an der Zahl.

English: Before forty, heroes all,

Eight of whom were of Lucerne,

Three hundred Knights did quickly fall,

Valient though they were, and stern.

From this bridge I could see where the Reuss flows out of the Lake; the Reuss joins the Aar at Brugg in the Canton of Aargau and this latter river falls into the Rhine. I passed the new theatre, a [_] formerly belonging to the Jesuits, a large building also once the property of this order [832] now used for Government Offices, the Post office, and through the narrow and tortuous streets, found my way to the Cathedral as well as to the Churchyard which I had crossed on the previous evening. It is surrounded by a portico paved with large tombstones, the walls of which are covered with sepulchral inscriptions referring to those who have found here their last resting place, to each was affixed a small stone basin filled with holy water with which an old woman sprinkled the pavement. At twelve o'clock I was back in my hotel whence Kuttel accompanied me a short distance out of town to where the famous dying Lion is sculptured out of a sandstone rock in commemoration of the fidelity of the French Swiss guards on the fatal days of $10^{\text {th }}$ of August, $2^{\text {nd }}$ and $3^{\text {rd }}$ of September 1792. It lies in a niche, its back is pierced by a dart or spear not withdrawn, its right paw rests upon a shield with the French fleur de Lys, close-bye stands another shield inclined, with a cross, the Swiss arms; the left paw hangs down without strength or power, the expression of the Lion's face shows that he is in his last agonies, a broken spear on the ground indicates that he is vanquished. The Lion measures twenty eight feet in length, and from the extremity of the left 
paw to the utmost point of the body, eighteen feet in height. A small limped pond at the foot, reflecting the whole with great distinctness. The monument has these inscriptions: above:

Helvetiorum fidei et virtuti

below: die X Augusti II et III Septembris

MDCCLXXXXII

Haec sunt nomina quorum qui, ne sacramenti fidem fallerent,

Fortissimo[æ] pugnantes ceciderunt.

Here follow the names of 26 officers and 760 soldiers.

Solerti amicorum Cura

Cladi superfueront.

Here follow the names of thirteen officers and 350 Soldiers.

Hujus Rei gestae cives [aere] Collato perenne monumentum posuere.

Studio: Pfyffer. Arte: Thorwaldsen. Opera: Ahorn.

Kuttel having left me, I took by myself a very pleasant walk, I ascended the hills close to the Lion's monument, descended on the other side into a Chaussée which leads to Baumgarten, but instead of following it, I crossed it, entered a pine forest, and came to the banks of a [833] small lake, the Rothsee prettily situated and surrounded by meadows. Towards the North East, where a small rivulet flows into it, the valley loses itself in gradually rising hills, whilst in the opposite direction high snowy mountains, the usual feature of a Swiss landscape, raise their lofty heads. I crossed this rivulet, made my way through pine woods and fields, passed many a pretty farm-house and peasant's cottage and came out into a Chaussée, which brought me back to Lucerne from another side where it is defended by a wall and by towers. I entered the Church above mentioned, whose inside was prettily adorned, a preacher had just finished his sermon, vespers were sung, and the Congregation, mostly peasants, men and women, each with a rosary in their hand, gradually retired; I remained to the very last, in order to obtain a clear idea of the dress of the latter, dark hues decidedly preponderated in their attire, their petticoats and aprons were either black or dark brown, their jackets of the same colors, sometimes dark green; the sleeves long, reaching to the waist, only in a few instances they were cut off at the shoulders, perhaps for the purpose of making a Show of the dazzling white of their shirt sleeves. In front, the jackets were wide open, scantily land across, displaying a Chemise of black silk velvet richly embroidered with Gold and Silver. A dark neck handkerchief below the Chemise worn by the one or the other seemed to be optional, the same might be said of a white Ruff round the neck, whilst hardly a single one of the many peasant women whom in the course of the day I had met in the streets and who had crowded the church, was without a silver chain to which a large Silver 
Cross was suspended, hanging over their bosom. Their caps were small with a neat black frill encircling the face, the hair fell down behind in long braids to which black ribbons were attached nearly touching the ground, only one woman did I see, and she was from the Canton of Unterwalden who had her hair tied up with a red Ribbon intertwined, and her Chemise of bright and gay Colors, both the ground and the embroidery. At six Oclock I repaired to the theatre which being recently finished, had a very clean and neat appearance, the lustre hanging over a pit was very poor, consisting of no more than $t$ [_] oil lamps. At six, the play was to have commenced; all waited patiently till $S$ [even] when the manager appeared on the stage, begging the audience [834] to excuse the delay. The book containing the play had only just been returned from the Censor who had given leave that it might be acted, whereupon the performance commenced, the play represented was "Das Turnier von Kirnstain" or "Die Drei Wahrzeichen"; Engh., the tournament of von Kirnstain, or the three forebodings, one of those dramas in which the Knights and high born damsels move always on the Cothurn, and which upon the whole are by no means to my taste. However the performers acted fairly, and Mrs. Von Seele, the heroine, might be called pretty, if it had not been for her large mouth. The play was over by nine o'clock. I returned to the hotel, supped, retired to my room and wrote more than an hour before going to bed. I learned in the Course of the day that the Government of the Canton was anxious to reintroduce the order of the Jesuits, but the Communalty strenuously opposed to this measure, had given in their veto, and that for the present the said order had little chance of returning.

Monday, $25^{\text {th }}$ of November 1844. The repeated ringing of a bell on board the steamer whose Captain lived in the hotel prevented my sleeping soundly, and long before boots came to call me, I was up, dressing by the uncertain light of the setting moon, breakfasting, packing-up, and taking my luggage to the Post Office, thence to be forwarded to Berne poste restante occupied my time till seven Oclock, when I started with my guide Kuttel; we passed the already mentioned public buildings, and when out of town walked in a southerly direction towards the Lake. I subjoin a small sketch of the lake of the four Cantons and its environs, for its shape is so irregular, that without this assistance, the many windings of my route during these few days will not easily be understood (see next page). The weather was beautiful, the day clear, not a cloud visible, the temperature cold, the air bracing, and rapidly did we stride along over the hard and frozen ground. To the right we had the Pilatus ( 6725 feet), whilst to our left the sun was just rising behind the rugged snow capped Schwyz mountains. This being Saint Catherine's day, the saint of unmarried girls, we met many peasant women in their gay holiday dress, none passed without 
saluting. We walked across the village of Horn and reached a few houses close to the lake called Winkel (the Corner), where we embarked in a small boat; white vapours hung over the surface of the Lake, its borders were [835]

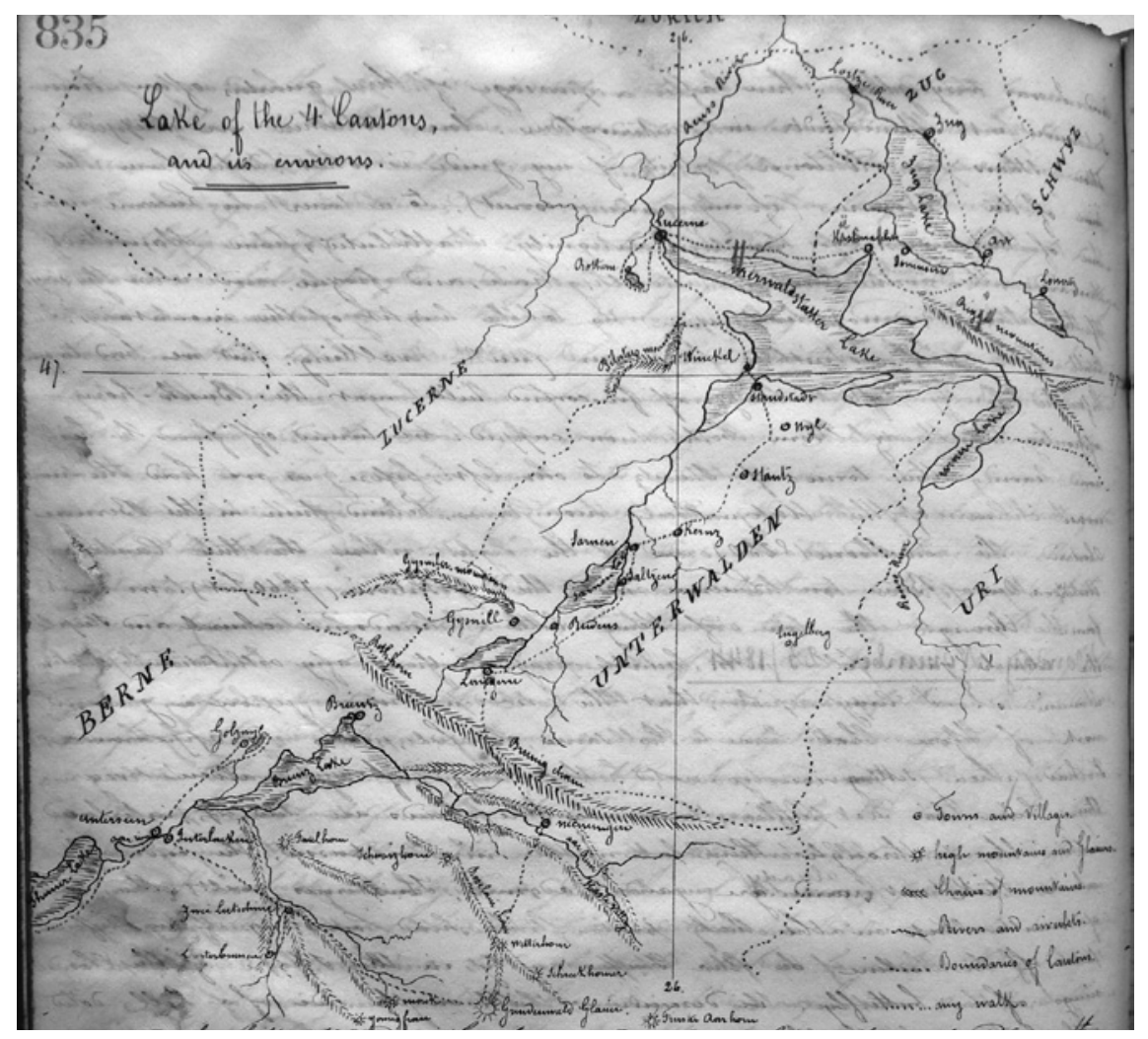

encircled by hills studded with farms and villages, behind them the Pilatus, the Unterwalden mountain, the Riggi and the Schyss chain occupied more than half the horizon, I distinguished the inn on the top of the Riggi and it may well be conceived how vexed I was when I considered that, had I put off the ascent of Riggi till this day, I should have had a beautiful view, whilst on the day I was there I saw nothing, but an impenetrable fog. The boatmen rowed standing up, on the Norwegian fjords they rowed sitting, there I understood but little of their Norwegian Danish, here their Swiss-German was almost equally unintelligible to me. Meanwhile the sun had risen over the mountains, nevertheless the temperature continued cold, [836] and I was very glad when after a passage of three quarters of an hour I landed at Standstadt in Unterwalden. Close to where we stepped on shore stands an old tower which if my guide is correct, dates from the time of the Romans, to a tower in Lucerne near one of the bridges a similar antiquity is attributed. From Standtstadt 
onwards, the road continued level, hard, and frozen, and where the rays of the sun did not reach us, owing to the height of the mountains, I still felt cold notwithstanding our quick walking. First we had to our left the Burgenstock, a ridge of fir-covered hills, next the Busch-horn, opposite the Stantz Horn both snow capped. We turned off from the high road leaving the tower of Stantz to our left, before us we had the snow covered chain of Unterwalden mountains, behind them in the Bernese Oberland the Faulhorn (8250) and to the right where the three Cantons of Unterwalden, Berne and Lucerne meet the Rothhorn (726o feet). We next came through the town of Kernz with a handsome church and steeple, the Church-yard filled with humble crosses without any ostentations sepulchral monuments. I may repeat, that the wooden houses, upon a ground work of stone had here the same cheerful, well to do appearance, as I had already previously noted. The women of Unterwalden wear their hair in a peculiar manner; the braids are tied-up, interlaced with ribbons; through them, a metal wire is passed, the ends of which stick out, and are gaudily adorned, sometimes gilt; others wear a small cap on the back part of the head consisting of two stiffened pieces of mousseline or other stuff, exactly in the shape of the Closed wings of a butterfly. We descended a little on the side of a low hill doted with houses; to the left we had a deep dark gulley, with a roaring mountain torrent, a village came in view, it was Sarnere on the lake of the same name, the arsenal occupied now the place where once stood the Castle of Vogt Landenberg the fierce friend of the cruel Gessler, we crossed a small river the Melchen, which has its origin in the Melcha-Alps and had now a very agreable walk between the lake on the one and the covered hills on the other side. We passed the village of Saltzen, at the extremity of the lake the wild aar, came to Gyswyl [...] pointed Gyswilstock (570o feet) behind the village. The Rothhorn [_] had straight before us, whilst the Wetterhorn, with two high sn[_] [837] peaks far in the background, for the first time came in sight. The road gently ascending lead us through a now leafless wood, where we met [_] peasant women, whom by the red handkerchiefs tied round their heads, Kuttel knew to be from the Häsle valley, the one was elderly, the other young and pretty; they asked alms, and I gave something to the latter; "human nature", as old Tom says in Marryats novel "Jacob faithful". Further on we met a clergyman and two Capuchin friars, one of whom grey bearded, who at the rate they walked, were likely soon to overtake the two peasant women, and who knows if "Human nature" would not then play one of her tricks? By this time, we had reached a spot called the "Kaisersthul" (or Emperor's chair) surrounded on all sides by higher mountains; thence a short distance brought us to the pretty dark green Lungern lake, the surface of whose waters is from sixty to Eighty 
feet below the level of the road; formerly, they stood nearly as high, but in order to gain land, some years ago, a large hole, which is still visible, was dug into the bank of the lake, and through the same about half of its contents emptied themselves into the lake of the four Cantons. Now where once the water was, houses stand, and the ground is under cultivation. The two Schrekhorner in the Bernese oberland came into view a little before we reached the village of Lungern lying at the South East extremity of the Lake. Here we rested for a short time in a public house where I ordered an Egg cake which was excellent, everything in the house was so neat and clean, that I was put in mind of my Norwegian trip. Instead of the salutation common in the Cantons of Appenzel and Zurich of Gott Grüss, here the Country people said good evening immediately after noon. On the wall of the Lungern church I saw a painting representing Christ descending from the Cross, and throwing himself into the arms of a friar dressed in black, probably an Augustin monk; on the other side of this village, a few steps cut into the rock brought us to the highest point, called Saint Jame's Chapel, whence a valley of little length, wild and beautiful, ascending and descending, overgrown with firs, strewn with big stones, and confined by high mountains, took us to the boundaries of the Canton of Berne, indicated by the outlines of a Bear roughly cutted into a large stone. We were now in the famous Bernese Oberland, and a little further on, reached the summit of the [838] Brünig (3590), overgrown with firs, strewn with big stones and confined by high mountains whence we rapidly descended a rugged path; occasionally we had a glimpse of the Brunz Lake. We passed a pine forest, to our left the Grimsel appeared, for a moment the Engehorner, two separate peaks rising from one mountain stem thus: was setting, the moon had not yet risen, the evening and pleasant. We walked along the sides of a hill, The sun

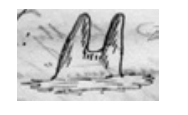
was cool passed many spots whence Rocks and stones had fallen into the lower lying Hasle valley which for many hours extends in an uninterrupted plain to the Brientz Lake. On the other side, this valley through which the Aar flows is confined by a ridge of lofty mountains amongst which the Faulhorn, the Olschhorn 8220 feet, and the Schwartzhorn (8650) are the most remarkable. At half past five we arrived at the town of Meiringen, in the Hasle valley; I was perfectly well and did not feel any fatigue, whilst my guide, not such a man as Sherer, was knocked up, and complained of blisters on the soles of his feet, and of pains in his thighs. We had walked full six German miles in the course of the day. In an inn where we put up for the night, I obtained a good room, had a fire lighted, ordered a cup of Coffee and wrote my memoranda, which being done, I was utterly at a loss how to employ my time. The Swiss guide by Walcher, the 
only book I had with me, was excessively dry reading; the servant girl would not listen to the Compliments which I paid her on her good looks, and thus sheer "ennui" drove me to bed at the early hour of [_].

Tuesday, $26^{\text {th }}$ of November 1844. I was awake by half past six but as I knew that nobody in the house would be stirring at this early hour, I did not rise till half past seven. The Coffee was indifferent, otherwise the breakfast good. The following are the Charges which in 1844 were customary in all Swiss Hotels: bed and room two francs daily, breakfast one franc and a half, dinner three francs without wine, fire one franc. It was half past eight when Kuttell and I put ourselves in motion, the morning was exactly like that of the previous day, the sun had not yet risen above the mountains which, upon the whole barren, form the limits of the Hasle valley. We immediately began the ascent of the ridge to the south, and turning off to the right, reached in about an hours time the cascade formed by the [839] Reichenback. In Norway I had seen so many splendid cataracts, that I thought but little of that now before me, this is its shape: the upper part is concealed with which the water but when standing in front of the lower part, by the Rock, and so insignificant is the force rushes down, that the froth and spray caused by its touching the ground, rise but a few feet, whilst at Vorring Fossen, they rose one hundred and fifty feet, as high up as the level of the mountain (see page 625 of this volume). A young Chamois which a peasant attempted to domesticate was shown to me. We continued our ascent, Kuttel pointed out a narrow gulley between the mountains, a continuation of the Valley called [Imgrunde] separated from the Hasle valley by a hill, the Kirch[s]t through which the road leads which those travellers have to take who cross the Saint Gotthard on their way to Italy. We passed the Reichenback over a bridge, heard its roar, but did not see it. Through an opening in the mountains the Pyramidal form of the "Well-horn" (11,450 feet) stood distinctly before us in the clear unclouded sky, more to the right equally distant, the Wetterhorn (950o feet), higher and higher we climbed, the Reichenback to our left, to our right the frozen waters of the Sielbach, now Wellhorn was nearest, further off the Wetterhorn, furthest the Eiger (12,220 feet) all snow covered. We were in the Roselaui valley through which the Reichenback flows, and which may more properly be called a high plain narrowed in by mountains on either side. Hitherto we frequently walked over patches of ice, now our path barely visible lay over an uninterrupted expanse of frozen snow, the Valley changes into a gulley, and the Roselaui glacier ( $465^{\circ}$ feet) stood before us. It is well known, that by the word "Glaciers", are understood large masses of ice which extend from the top of mountains, frequently between two of them, far into the valley, lower down than the snow line; their color is near the surface of a greenish, towards the bottom of a bluish 
tinge. At their basis, where the heat of the sun, and the warm temperature in summer act upon them, they gradually, though very slowly melt away and consequently a rivulet invariably flows at the bottom, but more or less in the same proportion as the ice melts away below, above on the summit it increases by freezing, and thus the entire stupendous mass is continually moving downwards, but with great slowness. The beauty of these glaciers consists in the Contrast which during the summer months [840] they present between their eternal mass of ice and the green vegetation on their borders, on the mountains sides moss, pasture and trees, in the valley frequently flowers. This contrast does not exist in the winter Season, when all around, if not actually covered with snow and ice, wears at all events a cold and rigid aspect. We reached the Roselaui public house at the foot of the Wellhorn, kept open at this season by a female servant who had three little girls under her charge, what a desolate forlorn situation! This house stands at the very foot of the Well-horn, whose summit has, I believe, never yet been trodden by human foot, and surrounded by other mountains equally high, equally snow covered, perhaps equally inaccessible. A Protestant Catechism, for since we passed the Brunig the population is mostly Protestant, lay on the table. I made the eldest of the girls read which she did pretty fluently, but with a disagriable Swiss accent. I ordered half a bottle of wine, and after a short rest started afresh. We passed through a small pine forest, the dark color of whose trees contrasted prettily with the white snow which when at about noon the sun had risen above the mountains, glittered like diamonds dazzling the sight. We sat down for a few moments on a small spot of green pasture free from ice and snow suddenly I heard a great noise, my guide told me that it was the roar of an avalanche, however on turning round, all I saw was a small quantity of snow falling down from the top of a mountain. At one Oclock we had reached the summit of the Scheydeck (Separation Corner), the public house was empty, I took my seat on the trunk of a tree, and noted a few words in my pocket book. Before me was the Eiger, (the monk 12,86o feet) and the Blumli Alp, around me everything covered with snow, nevertheless, so hot shone the sun, that I actually perspired. Here trees had ceased to grow, but under the snow, the ground was covered with Grass. From the Schaideck we rapidly descended its South Western slope where owing to the influence of the sun, both snow and ice had melted away, a few fir-trees reappeared, we were in the Grindelwald; to our left we had the upper Grindelwald Glacier between the Wetternhorn and the Mittenberg, behind the Glaciers, probably at a considerable distance, the Schreck-horner. Kuttel and I approached this Glacier, he remained above, [841] but I descended to its very base where a mountain torrent, an affluent of the Lutschine, too broad to allow my jumping over, separated me from the [icy] mass, however I 
was near enough to knock off a pine with my stick. To climb up to where my guide waited for me, was no easy matter. Again we heard the roar of an avalanche, and again I was disappointed, however, insignificant as the mass of snow was, which fell down, it was a pretty spectacle; numberless small snowy particles preceded the fall and glittered in the rays of the sun. Another fearful noise resounded, Kuttel told me that this arose from the cracking in the Interior of the Glacier, outside nothing was to be observed. On our further descent "the Chalets" small miserable wooden buildings which had hitherto stood empty were again inhabited, also other trees besides firs greeted our sight. To our left was the Mittenberg, to the right other mountains of less fame. The second, the lower Grindelwald Glacier, next reverted my attention, it is not quite so large as the upper one, otherwise similar to it. A few steps further on, we reached the village of Grindelwald and entered a friendly looking public-house, where I was shown to a Comfortable room of a pleasant temperature, for in the same, delicate plants were being preserved during the winter season, and of course, they required a certain degree of heat. From the windows I looked upon the glacier, the Mittenberg to the right, the Eiger to the left. For dinner I ordered some ham, a bottle of wine, and an Egg cake, made an agreement with my guide to take me on the following day for an extra five francs through the Vergis Valley over the Wenger Alp to Lauterbrunnen, a road seldom undertaken by travellers in this wintery season. Then having written my memoranda I found myself exactly in the same predicament as on the previous evening at Meiringen. I requested my landlady to lend me some book or other, she sent me a novel written by Johanna von Schoppenhauer quite as uninteresting as Walchers guide [to] Switzerland. I really did not know what to do with myself, for it was still too early to go to bed, when the servant woman, neither young nor pretty, whose looks already whilst I took my dinner seemed to have some particular meaning, came in, to keep me Company, she was very different from the Good Girl of Meiringen, we were soon on very good terms, and I am ashamed to confess it, she promised to pay me a visit [842] at the dead of night but did not come. Of course I slept little and when I rose in the morning of

Wednesday, $27^{\text {th }}$ of November 1844, I was out of humour with myself, not inclined to undergo the fatigue of the passage over the Wenger Alp, I therefore abandoned the plan which I had formed on the previous day, but have ever after regretted, that I did not carry it into effect. At half past seven, the weather favoring me quite as much as on the previous two days Kuttel and I left the Grindelwald public house and rapidly descended the Lutschine Valley. The sun had risen above the horizon, but its rays reached as yet only the summits of the mountains which form the boundary of the valley. In some places, these mountains are steep and abrupt, from their sides hung thousands of icicles, 
rivulets and streamlets, pretty rills of limpid water in the summer, were frozen over. I turned back to have a last look of the lower Glacier, there it lay like a mass of frozen waves, full of holes and crevices. Behind it I saw for the first time the Finster Aarhorn, the highest of all the alps in the German Switzerland $(13,820$ feet). We walked on, the Lutschine gradually increases to the size of a river, houses stand here and there along its banks, for the greater part neatly built; a few the reverse, even without a Chimney. Some of the Country people were cutting, what to me appeared common stone, Kuttel assured me it was marble, though of an ordinary quality. To the left, the Silver-horn came in view, of the Jungfrau (12,827 feet) I had but a momentary glimpse. At about two we had reached the Valley where at the conflux of the two Lutschine, the one, the course of which we had followed from the Grindelwald, the other of the same name which comes from the Lauterbrunnen valley, a few houses are built, which go by the name of the Zwei Lutschin (two Lutchin). Crossing a bridge, we struck off into the Lauterbrunnen valley which bears great ressemblance to that which we had come down from the Grindelwald, with the only exception that its ascent is much more gentle. Here we met an empty carriage and learned from the driver that he had just left two English travellers at Lauterbrunnen whose intention was to ascend the Wenger Alp. On our proceeding a little further, I actually [843] saw these two Gentlemen on their way up, and it may easily be imagined that I felt not a little annoyed at my want of resolution on the morning of this day, for the meeting of venturous Climbers, two ascending, one descending upon a Swiss mountain at this unreasonable time of the year, would have been a not every days occurrence, and well have merited a conspicuous place in my diary. We had before us the Breithorn 11,690 feet, the Silverhorn 10,620 feet, and the Jungfrau, the summit of the former of these last two, which forms part of the latter, is pointed, that of the Jungfrau round. The Staubach which may be translated the "dust fall" came into view (Lord Byron calls it somewhere, the tail of Mephistopheles, a fameful expression to be sure, but to understand its appropriateness is beyond my intellect), from the top of the mountain down to its base (80o feet high), shone upon by the midday sun, it presented a pretty view, but when I placed myself in front of the fall, the small volume of water showed to great disadvantage, from the summit of a black rock two separate narrow sheets of water precipitate themselves. At first they are compact, but soon dissolve into froth, so thin and transparent that through it like a veil, the black rock here and there encrusted with ice was clearly seen, moreover, the real fall is not high, for the water soon touches the rock which protrudes a little; thence it drizzles along its side until it reaches the bottom, where in the present cold season, it formed a complete bed of ice. I rejoined my guide, who, whilst I had taken a 
close view of the Cascade had ensconced himself in the "Capricorn" public house at Lauterbrunnen and at half past twelve we retraced our steps as far as the "Zwei-Lutchin" where instead of turning off to the Grindelwald whence we had come, we followed the level road to Interlacken along the Lutschine and between mountains which gradually decrease in height. The Country people were everywhere at work, some felling wood, mostly pine, threw it down the mountains, others were sawing wood for the houses which they were building, others were manuring the fields, others cutting stone and slate, and so on. In the Bernese oberland the peasants, both men and women, are dressed in a thick cloth, home-woven, of a light brown color, the cut of their clothes has nothing particular. We passed several villages, on the summit of a hill a ruin of a castle called Unspunnen and arrived at about three Oclock at the place of Interlacken which, as well as its neigbour of less renown, [844] Untterseen, derives its name from its situation between two lakes, that of Thu[nn], and that of Breintz; these are connected by the Aar, and a bridge across leads from Interlacken, situated to the East, close to the Breinz lake, to Unterseen to the west, near the Thu[nn] lake. Interlacken is one of the prettiest spots on the globe, of course it did not appear to me so delightful in the winter of 1844 as when I again visited it in the Summer of 1855 , but even in 1844 I could form an idea of what it must be in the fine season. It lies in a valley of no great extent, well cultivated, rich in trees, surrounded by mountains, and consists almost exclusively of genteel, not splendid Hotels and "Pensions", which now were for the greater part shut up. In the direction of Unterseen, the Niesen 7270 and the Stockhorn $(6625 \mathrm{f})$ are in view. In fact this day the atmosphere was so clear that every peak, every summit of the many mountains all around the horizon was distinguishable. I obtained a comfortable room in the hotel of Interlacken, and after a few moments rest, started again on a walk. I went in the direction of the Breintz lake, and having crossed the Aar, ascended a small hill on the northern side of this lake on the summit of which stands a small ruin, the "Golzwyl", its high tower well preserved looked beautiful standing out distinctly against the serene evening sky. The sun was still above the horizon, but it gradually disappeared behind the western mountains whilst the tops of the Eastern ridges remained long illumined by its last rays. From this hill I saw the Thum and the Brienz lakes surrounded by the often mentioned snowy mountains, these clearly reflected in the limpid waters of both lakes as well as in those of the small Golzwyl lake which lies much higher than either of the two, and which is said to be unfathomable. I made my way across fields and came to another Village, Riggenberg; the Church in the churchyard, to which two flights of stairs lead, stands considerably higher than the Breintz lake, the foundations are laved by its waters. I was back by five Oclock, had an 
excellent dinner, conversed with the waiter, then went to bed. I learned that in the summer season, for a single Gentleman who remains for some time in the Hotel, living what is called "[_] [845] pension", the Charges were: six francs a day, for which he had a bedroom by himself, and excellent living, besides the use of the general sitting-room for conversation. During the season, three Clergymen, the one a Lutheran or Calvinist, the other a Catholick, the third of the Anglican Church, take up their abode in Interlacken for the purpose of administring to the spiritual wants of the many strangers who throng thither from all parts of the Globe.

Thursday, $28^{\text {th }}$ of November 1844. It was as late as half past seven when I rose, the fog which on the previous evening when standing in the Riggenberg Churchyard I had seen gathering about the Thum lake, had increased and extended, and though both my guide and the waiter prophesied that the sun would dispel these vapours, and that we should have a clear day like the previous ones, unfortunately it did not turn out so; the fog rose, took the shape of clouds, and these again hanging down into the valley deprived me of the beautiful prospects which I had hitherto enjoyed. My guide Kuttel bade me good-bye, and willingly did I augment the many certificates which he had, of his good conduct by a few words which I wrote to the same effect. At my request the waiter accompanied me to several of the Hotels and pensions, which did not answer my expectations. The rooms were upon the whole low, their furniture decent, not elegant, the Hotel which had been finished in the preceding year, and which had been inhabited by the King of Wurtemberg during the last season made the only exception. The Saloon was large, the rooms of a fair height were all tastefully fitted up, decorated, and furnished. Immediately after leaving Interlacken I passed through Unterseen, a sombre looking place, crossed several small inlets of the Thu[nn] lake over bridges, and then followed a fine chaussée which leads straight to Thum, between the lake to the right, and a continuation of hills to the left. Generally the chaussée runs close to the border of the Lake, sometimes it recedes from the same, leaving sufficient space for rich pasture land or for small heights. On a clear day, it must be a very pretty walk, this day however as already said, the fog was much against me, and but seldom had I a momentary glimpse of some white buildings on the opposite shore. I passed various villages amongst which one called Spiez is very prettily situated on a peninsula projecting into [846] the lake. Just before reaching Thu[nn], I had to cross the small river Kander which coming from the south flows into the Lake at its western extremity, it is spanned over by a handsome new stone bridge of one arch, workmen were still busy, finishing its stone balustrade. A little further up was the old wooden bridge, where the river at a considerable depth has worked its way through 
steep rocks. Here and there fir trees grow on its banks. On the western side of the Kander the hills withdraw far in the background, so as to leave space for a small plain upon which Thu[nn] is built at the Western end of the lake; the Aar which flows out of this lake and continuing its course towards Berne divides the town into two unequal halves. In the smaller part stood the post Office, and the Hotel called "zum freien Hof", in the former I secured my seat in the stage coach for Berne, in the latter, I took a good dinner, and then went out to see what was worth seeing, nothing of great importance, to be sure. The appearance of Thu[nn] is old fashionned, several streets are disfigured by low, heavy, massive porticoes which go by the name of "Lauben", anglice "Arbours", and which serve as basements for the upper stories of houses. The principal street has another peculiarity, the foot pavements are at an elevation of three to five feet above the carriage road. The Churchyard lies very high, a number of steps lead[s] up to it and on a fine day the prospect thence is very extensive; I could see nothing and amused myself for sometime with reading the epitaphs on the tombstones. In the hotel I whiled away an hour or so with Washington Irving's sketch book till 5 p.m., when the Post omnibus for Berne left. It was a disagreeable drive, I felt cold for I was without my big cloak which I had sent with my luggage from Lucerne to Berne, the cold prevented me from sleeping, the darkness did not allow me even to see anything of the Country, and the curt replies of a pretty young French girl to whom I addressed a few words, were such as not to warrant my keeping up the conversation. I see by the map, that we had the Aar to our left. At eight Oclock we arrived at the Post Office in Berne. As soon as I obtained my luggage from the "Poste restante" office, which lasted a considerable while, I went to the Hotel de Berne, where I took up my quarters for the night. [847] The streets were lighted up with Gas. In the Hotel as well as in the Post office French and German were spoken.

Friday, $29^{\text {th }}$ of November 1844. Last night, the reading of Eugene Sue's interesting novel Mathilde kept me awake until a late hour, the consequence of which was, that I did not rise till eight, and was not ready until nine oclock for my customary peregrination in a strange place. Berne is built upon a peninsula formed by the river Aar, it is surrounded by hills, not within the peninsula, but outside the river. The principal streets which have a considerable fall to the Eastward, run towards the point of the peninsula; they have low clumsy porticoes similar to those which I had noted in Thum. These porticoes are without exception occupied by shops filled with articles of every description to such an extent, that I could not help asking myself where the purchasers were to come from, when all are sellers. I first directed my steps to the peninsula's point where I crossed the Aar over a handsome recently concluded bridge. Upon the same, still stood a wooden arch decorated with fir branches, which 
had been constructed to congratulate the builders on the completion of the work. This, the Nideck bridge consists of one wide arch in the middle and a smaller one on each side. Having crossed the Bridge, I ascended the range of hills on that side called the Altemberg, or Old mountain, convenient roads or paths lead up. A Latin inscription cut into a stone commemorates the immense labour employed in the making of these roads; another plain monument is erected in honor of a certain Von Werdt, who fell here on the third of September 1802 in the defense of his Country. I reentered the town over the Old bridge which, further down the river, spans the same at a considerable less height above its bed than the Nideck bridge. The Cathedral is built on a platform or Terrace which rests partly upon solid walls, partly upon a ridge of rock, its steeple is flat at the top and defaced by three or four large doors painted red, the one above the other. The platform protected all round by a parapet is at such an elevation above the streets below that I could not look down without shuddering, the height is said to be one hundred and fifty feet, and no stranger comes to Berne without the following story being related to him. On the $25^{\text {th }}$ of may 1654 , a student named Weinzapfli [848] rode on this terrace, his fellow students molested the horse, which shied in consequence, and jumped over the parapet, at the time not so high as it is at present, down into the street. The animal was killed on the spot, the rider escaped with his life, but had his two legs broken. From the Cathedral, I walked westward where the peninsula widens, the streets are broader, and the houses built in a more modern style than in other parts of the town. Here are various public buildings, the hospital, the Custom-house, and the house of correction. An easy ascent brought me to the summit of another ridge of hills, the continuation of the Altemberg. I descended near the Aarberger gate, and returned to the hotel. Close to the road side, two deep holes are dug into the ground, they are laid out with flag stones and in them at the expense of the Government, three or four large bears are kept; I am not exactly acquainted with the object and meaning of these animals, but I have no doubt that there is some connection between them and the arms of the Canton of Berne. The black lace caps which I had already noted as being worn in the Bernese Oberland, are also used by the lower classes of the Bernese women, in some instances they were of such an excessive size as to become real scare crows. At eleven o'clock I left Berne in the diligence for Freiberg, my guide book says that the road is uninteresting, I did not think so, for there are many pretty views on both sides, over hill and dales, we passed more than one pine wood and stopped for a few minutes at Neueneck on the river Sense, which separates the Canton of Berne from that of Freiberg, which latter, we were now entering. The sky which had been cloudy the whole morning, cleared up. To my left I saw for the last time, the many snow capped 
points and peaks of the Alps in the Bernese Oberland, my companions in the Coach were unable to give me the name of a single one of them; to my right was another lower chain of mountains, probably the Jura. We passed a wonderful Chain-bridge, and found ourselves in the town of Freiberg of which Alexander Dumas says that only an architect who was half seas-over could have planned and built a town so irregular, even so shapeless. Having secured a comfortable room in the excellent hotel the Zehringer Hof I sallied forth. I crossed the Chain bridge over which I had just driven into town; it is constructed in the same manner as all chain [849] bridges (or suspension bridges) are, and of which I gave an account page 757 of this Volume, it is remarkable however not so much for its length of nine hundred feet, as for its great elevation above the level of the river, the Sarine, which flows below at a depth of one hundred and seventy feet. As soon as I was on the other side of the bridge, I found myself on a chaussée confined by steep sand stone rocks, this I followed for a short distance, and came to another chain bridge similar to the previous one, six hundred feet long, and Two hundred eighty feet above the romantic Galtern or Goltern valley. From a low hill, at the bridges other extremity, I had a pretty view over the town which is in fact in such a strange and unusual manner on the summits of hills, and in the narrow valleys between them, that, at one moment one has a mind to subscribe Dumas's above given verdict, whilst at the other moment one feels so delighted with its peculiar and picturesque situation that one does not hesitate to affirm that one might well make a long journey for the sole purpose of visiting Freiberg. From this height I descended to the banks of the Sarine which I recrossed this time over a low bridge called that of Saint-John. Before reaching the hotel which I did past five oclock more than once I went into the Country and reentered the town, more than once I ascended a hill and descended into a Valley or a ravine, and when I tried to put to paper where I had been, and what I had seen, I found it impossible to bring into my description anything like order or regularity, nowhere in my original diary have I found the sentences so disconnected as on this day. The irregularity of the place seems to have affected my style, and to day after a lapse of twenty five years, I see no means of mending what I then wrote, and must reproduce the phrases abrupt disjointed as they are in the Original. Freiberg is partly surrounded by a wall. Outside of the Gate "des Etangs" I stood for sometime upon a small bridge which crosses a rivulet, the connecting link between two ponds, and was lost in admiration at the beautiful spectacle which the setting sun afforded; the western sky looked a sea of blood. The Jesuits College is an extensive, rather handsome edifice, when I passed it, I heard the voices of young people resounding from an adjoining yard encircled by a high wall, a 
bell rung, no doubt they were called to prayers, suddenly, all was hushed and silent. Railroads are frequently [850] spanned over by a stone bridge from the embankment on the one, to that on the other side; just in the same manner here in Freiberg, a bridge connects two streets across another deep below. A public walk named the "Court Chemin" is laid out on the roofs of a row of houses. On an open place before the Cathedral Saint Nicholas, stands a tree surrounded by a railing which my guide book calls "Le Tilleul de Morat", no doubt it must bear some reference to the victory gained by the Swiss at Morat on the $10^{\text {th }}$ of June 1476 over Charles the Bold, but of its exact signification, I am ignorant up to this day ( $28^{\text {th }}$ of Nover. 1869). The said Cathedral contains a far famed organ built by Möser; but as eleven francs were asked for playing it, I did not like to pay this sum for my sole gratification. At a later period when I again visited Freiberg in 1855 accompanied by my wife and grand daughters I had an opportunity of hearing this wonderful instrument, and of listening to its powerful and swelling tones. Having returned to the hotel I supped, wrote a long letter to Sieveking and read in bed till a late hour Eugen Sue's Mathilde.

Saturday, $30^{\text {th }}$ of November 1844. When I rose at a late hour of Eight, I saw the streets covered with a thin layer of snow which had fallen during the night, a not to be mistaken proof of the presence of winter, it reminded me of a passage in "L'histoire de la Grande armée" by Count Segur, where he says that the first flakes of snow which fell at the commencement of the retreat, were looked upon by all as a fatal omen. When I went to the Post office to leave my letter to Sieveking, I came by chance to the market place, and was much amused with the different dresses of the peasants, men and women, particularly in the head-gears, of the latter; there was a great variety, red cotton handkerchiefs tied round the head predominated, the small black lace caps worn in the Canton of Berne were still to be seen, other women wore a broad black velvet ribbon across their forehead, whilst with others this black ribbon increased to the size of a small Cap, in both instances the hair was tied up behind in a thick heavy bunch, like the fashionnable Chignon of 1869. Some women were wrapped-up in big black cloaks like those used by Friars, others wore short little Jackets with black velvet [851] facings and Collars. The Coats, Jackets, and trowsers of the men were with few exceptions made of the country woven light brown cloth. Goiters of all sizes abounded. The languages spoken in Freiberg both by the higher and lower classes are indiscriminately French and German. I saw by my guide book that the "Hermitage de Sainte Magdelaine" was worth seeing, and notwithstanding the unfavorable state of the weather, I determined upon ferreting it out by myself without a guide. Having made the necessary inquiries, I walked over the bridge, and for some distance followed the road 
which leads to Berne; then turning off to the left and passing through a village not noted on my map, called R[_] or something like it, came to the high banks of the Sahne or Sarine, wildly flowing through its rocky bed, with many trees along its sides, some black, some white, just as the snow had melted, or not. I descended to the bottom; at that very moment, it commenced snowing; nevertheless, seeing some apertures not clearly distinguishable from below, cut into the Bank, I climbed up, when at a fair height, finding no further path, I had to return to where I had come from. I renewed my attempt, and this time was more fortunate, for I landed right in front of several doors which open into various cells and a Chapel; of these, some were locked, others not, and the large dimensions of the apartments proved the perseverance of the Hermit who once occupied them, and of whom tradition says that he by himself, without any assistance, cut them out of the sandstone rock. I met here two huntsmen who were taking their plain breakfast; they told me they were in search of foxes and hares but that the weather did not favor them. The snow increased fast; I hurried back to Freiberg, and reached the Zehringer-hof, just in time for dinner. The guests spoke without exception French very fluently, German indifferently. Though my guide book praised in glowing terms the wild beauties of the Gottern valley, I did not stir, for the weather had become too bad. I amused myself with the perusal of the Lausanne newspapers which gave an interesting account of the disputes which had arisen in the Canton of the Lucerne between those in favor, and those opposed to, the readmittance of the Jesuits. At three Oclock the Coach left for Vevay, there were but three passengers besides myself, the Prefect [852] and a respectable Cheese merchant who had all the conversation to themselves, and an old women of the lower classes of society who, like myself did not say a word. The weather was in the highest degree disagreeable, snow covered the ground, fir trees lined the road; it soon grew dark, and I fell asleep. At half past six we arrived at the town of Bulle which having been completely destroyed by fire in 1805 has been rebuilt in the modern style. We drove through a wide straight street and stopped at the Post-office. After half an hour's detention I continued the journey by myself in a small carriage. It was cold, and I was very glad when at half past ten I reached Vevay, where I took up my quarters in the handsome and fashionable hotel Monnet. The bed and bed clothes were excellent, I read Mathilde till a late hour.

Sunday, $7^{\text {st }}$ of December 1844. Vevay lies close to the lake of Geneva or "Lac Leman", on its southern bank, opposite are the snowy Savoy mountains upon which I had a pretty view from my bedroom. The weather was mild and cloudy. Having taken my breakfast in the General dining room, I started for a walk in 
the environs, I left the town in an Easterly direction and soon came to a village called La Tour du Pin where I struck off to the left, that is to say inland, and ascended the ridge of hills covered with vineyards which line the high road. All these vineyards are inclosed by walls, between them the foot-path winds, following which I reached "La Terrace du Panorama", whence as its name indicates, on a fine clear day, I should have had an extensive view over the lake and the surrounding Country; but on this day, the dense state of the atmosphere prevented every distant prospect. The two Russian Ladies whose acquaintance I had made in Amsterdam, see Page 699 of this Volume, Misses Pfeil and Von Swetschin had replied to a note which I wrote them in the morning, that between twelve and one they would be glad to see me, thus it was now time to return and pay them a visit. Both received me in a very friendly manner, the younger, by far the most interesting of the two had not improved in health since I saw her last, notwithstanding her having used the grape cure for the last four weeks with such perseverance that she had been able to increase her daily allowance of Grapes to as much as Eight pounds. Miss Pfeil did not [853] displease me either, though she was rather too talkative to my taste. We agreed to take a walk together on the following day. The dinner hour at table d'hote was later than I had hitherto found it either in Germany or in Switzerland, no doubt, in order to suit several English families who appear to have taken their residence in Vevay for some weeks, if not months. This also agreed well with my own arrangement, for now I had time to make a long excursion on foot. I remained with the two ladies till half past one, then set out, and kept along the borders of the lake to the Westward until where the road to Lausanne turns off; then just as I had done in the morning, I climbed up the vine covered hills, now of course to my right, at a considerable elevation above Vevay, the fields and roads were covered with snow, whilst below hardly any snow had fallen, or if any had fallen, it had immediately melted, and then continuing my walk to the right, that is to say Eastward I came to the Village of Chacedronne, next to the road from Freiberg which I crossed, and erelong found myself on another road, that to the Chatel Saint Denis, running along the mountain-torrent "La Vevaise" which close to the town, a little to the Westward, falls into the lake. To obtain a closer view I descended a dirty slippery path and saw the torrent rush its headlong course through a wild narrow and rocky gulley. I climbed up again to the road which I had momentarily left, and continued on the same, in expectation that higher-up I might cross the Vevaise, and then return to town, but on inquiring my way from a peasant girl, she told me that for a stranger it would be difficult to avoid losing himself, particularly as it was getting dark, I therefore retraced my steps, passed through the Village of [?] ürsur, crossed 
a bridge much lower down the river Vevaise and was back in my hotel when the Bell rang for dinner. The dining saloon was neatly fitted-up, the dinner excellent, knives and forks were changed at every course, all was genteel, the whole had more the appearance of a private party, than of a hotel dinner. The greater part of the Guests spoke English, they were: a Mr. Keogh, his lady, two daughters, and Governess from Ireland, lady Glenmorris also from the Green isle, and her companion, miss Brown, who not very young, had preserved traces of great beauty, Mrs. General Dubois, a Russian lady and many others with whose name I did not become acquainted. Erelong I found myself quite at home, and spent some pleasant hours, [854] conversing sometimes with the one, sometimes with the other; at nine oclock, the whole party withdrew to the drawing room where tea was handed round. At ten I retired to my bed room, I learned that Mademoiselle Flora Tristan of Peruvian celebrity, the authoress of "Les Perigrinations d'une Paria", had died, the papers made a great fuss about her, certainly more than she deserved. Thus for instance, a French paper said: "Elle est morte a Bordeaun ou elle était retenne par une maladie inflamatorie, elle parcourait depuis quelques temps la France pour y repandre dans la classe ouvrier les doctrines socialistes a la propagation desquelles elle s'était [_]onée avec ardeur; Mademoiselle Flora Tristan descendait du [_] Vice Roi de Pérou, sa beauté egalait son éloquence, et son enthusiasme", the paper added, that she had acquired some reputation by the publication of various novels, finally that a joiner had pronounced a funeral speech on her tomb. This lady was born in France, she was the daughter of a brother of Don Domingo and of Don Pio Tristan, and in 1834 came to Peru for the purpose of claiming part of her father's inheritance, but as she could not prove the marriage of her mother, she did not succeed, and I believe contented herself with a few thousands of Dollars which Don Pio gave her to stop her mouth; the result of this visit to Perú was "Les Peregrinations d'une Paria", an amusing book for such as are acquainted with Arequipa, and its inhabitants.

Monday, $2^{\text {nd }}$ of December 1844. At half past ten I went by appointment to the lodging of misses Pfeil and von Swetschin; the latter mounted her donkey, to the former I gave my arm, and thus we three, I of course bound to attend to Miss Pfeils conversation though I should have preferred exchanging a few words with her companion, wended our way to "La terrace du Panorama", from which elevated point the weather being somewhat clearer than yesterday, we could distinguish some white houses on the opposite, the Savoy-side, "Le Chateau de Chillon" in the lake, and the town of Villeneuve at the lakes Eastern extremity. Close to the Terrace is the Chateau de Hauteville whither we went. It has pretty park-like walks, a miniature Temple, and numberless roses in blossom [855] even in the present season. The ladies had to hasten back in 
order to be in time for their early dinner. I accompanied them, then resumed my walk in the same direction, but ascended considerably higher, and came to several villages, Saint-Leger, La Chaise, chateau Blonay, then redescended to the high road along the lake and returned to town passing through the La Tour du Pin. During our walk, Miss Pfeil communicated to me some details regarding the Von Swetschin family; the father was a true Russian, the mother from Riga a Von Webel Kruger, both very handsome, they lived in the Government of Kursk where most probably the father filled some Government situation; his wife bore him several daughters, who, all handsome, contracted advantageous marriages, as soon as they grew up to womanhood, only Katiuska, the least handsome, Miss Pfeil's companion remained single. Disputes arose between father and mother, who separated, the lady died two years ago and Mr. Von Swetschin immediately married again. Kursk lies on the high way to the Caucasus, the troops sent thither, made there their halting place for a day or two, and very naturally some festivity or other was always prepared for the officers; thus the young ladies were accustomed to a life of dissipation and Miss Katiuska plunged into it with all the ardour of an admired young and pretty girl. She rode $\mathrm{h}\left[\_\right]$, danced passionately, and perhaps committed some other imprudences which had been the Cause of the disease from which she was suffering, perhaps some constitutional defect may also have been at the bottom. The two ladies intended to remain winter in Vevay and to remove next summer either to Weisbad or to Geiss near Saint Gallen to use the Whey-cure in either of the two places. At five Oclock the same party as yesterday with the addition of a few gentlemen newly arrived, sat down to dinner. My neighbourh was Mr. Keog, the Irishman with whom and his lady I was on very good terms. Lady Glenmorris lent me Lord Byron's Poem the Prisonner of Chillon written by him whilst he was detained for two days at Ouchy on the lake in consequence of the bad weather. I took tea with the party and went to my room; at ten the thermometer, no fire lighted stood at $16 \mathrm{R} .=68 \mathrm{~F}$. certainly a mild temperature for the season.

Tuesday, $3^{\text {rd }}$ of December 1844. The thermometer had fallen considerably since the previous night, it stood as low as $9^{\circ}$ Reaumur. I had devoted [856] this forenoon to a visit to the Castle of Chillon, of which it will not be amiss to say a few words: a Duke of Savoy kept prisoner in this Castle a certain Bonnevar, a reformer, for the period of six years in the beginning of the sixteenth century, the Bernese and Genevese jointly took the Castle by storm and placed Bonnevar at liberty. If Lord Byron is correct in his poem, two brothers of Bonnevar were encarcerated with him and died there. When I left Vevay at half past ten, the ground was frozen and the temperature actually cold, nevertheless I again saw roses in blossom, a proof of the General mildness of the climate of Vevay 
and its environs. Outside the town the road leads through two rows of hills covered with vines, that to the right gently sloping down towards the Lake, whilst that to the left rises to the height of snow covered mountains. Besides La Tour du Pin, I passed through several villages amongst which Clarens, where Jean Jaques Rousseau has placed the scene of his "Nouvelle Heloise". The road was alive with Carts, some drawn by a horse with a tinkling bell, others by a pair of Donkeys, also with many peasant women whose clear French I easily understood, very different from the ugly German patois spoken in many parts of Switzerland. Just before reaching Montreux, far famed for its healthy and mild climate, the hills to the left approach so near to the Lake as to leave merely room for the road, no doubt they had been blasted away and their black steep sides were beautifully covered with Ivy and other creepers. A little further on I came to the Castle which stands at the extremity of a narrow tongue of land projecting into the Lake, towards the landside it is surrounded by a dry moat over which a small wooden bridge leads. At the entrance is a guard house with this inscription in German over the door "Gott Segne den Eingang und hausgang" English: "God bless the entrance and the Exit", in which three Gendarmes kept watch, for at the time the Chateau was used as a depot for artillery, one of them came out to serve as my guide. He took me to a high, massive, arched vault just above the level of the Lake, not below as Lord Byron gives to understand in his poem. Between two pillars a beam is placed, from which it was the Custom in former times to hang such as had been condemned to death. [857] I could not distinguish the beam, such was the darkness, immediately behind, a stair case ascends to the hall improperly called the Justice hall, where the judges gave their verdicts, to be executed without a moment's delay. Opposite the stairs, a door in the thick wall opens to the lake, through it the Corpses of the Culprits if culprits can be called those who perhaps were guilty of no crime, were thrown into the Lake, but before this was done, they were stretched out on a large stone "La purre de preuve", where it was ascertained whether the vital spark was really extinct, for it was apprehended that the shock of the cold water might again bring them to life, and they effect their escape. My guide opened a door, and we entered another vault, which in former times was divided by massive walls into a number of small cells or prisons, each of which closed by a massive iron door with a small hole at the top to admit air and light. The door of Bonnevar's prison, I was told, is still preserved in one of the rooms above, at present these massive partition walls exist no more, and sufficient light and air find their way through the loop holes cut in the outer walls. Round one of the pillars, which sustain the vault, at a distance of about twelve feet, the rocky floor is somewhat worn out, which 
has been attributed to the continual pacing of the prisonner Bonnivar, but this cannot have been the case, it was the heavy iron chain twelve feet long, by which the poor prisonner was fettered for six long years and which was attached to a ring still extant in the pillar, which being incessantly dragged along the Ground, left the circular impression still visible at the present day. Up stairs are three large apartments, the one where the Tribunal held its sittings, the second, the refectory, the third, the receiving room, the walls of which are hung with the portraits of many Bernese Baillés whose descendants belong to the most respectable families of the Canton, and who no doubt took an active part in the storming of the Castle. Its outside is very irregular; it consists of several towers, Lord Byron says seven, I did not count so many, the middle one, of greater height served in 1844 as a powder-magazine. From the "Chateau de Chillon" I walked as far as Villeneuve, a place not worth any particular notice, and returned to the same way I had come. I was home at 2 p.m., dressed, and called upon the Misses Pfeil and Von Swetschin. I had taken with me my drawings of the Lima Costumes which I showed to them, and spent the time in an extremely pleasant manner, only as I have [858] already insinuated before, I should have wished Miss Pfeil to be less talkative. When I was on the point of going at 4 p.m., they entreated me to remain a little longer, even the youngest of the two said: "pray remain, Heaven knows if we shall ever meet again" and of course I did remain till five Oclock, when I had to go to dinner at my hotel. Here everything was as nice and pleasant as on the previous days, nevertheless none of the English ladies could bear the slightest comparison with the graceful Russian young lady from Kursk. At 7 p.m. I returned to take tea with her and miss Pfeil, now several Vevay ladies relations of their hostess had joined them, and I found myself under the necessity of brushing-up my French. We took tea with toasted chesnuts and preserved quinces, when I left at nine oclock I made my bow to the Vevay ladies, and shook hands with my russian friends, of whom I never heard again, probably an untimely grave has closed over Katinka Von Swetschin. Here in Vevay, the same as in Amsterdam, she frequently placed her hand upon the heart, as if she felt there a severe pain. I gave them a letter of introduction to Mr. Meyer of Saint Gallen.

Wednesday, $4^{\text {th }}$ of December 1844. Once more I sent my luggage, with the exception of my carpet bag and hat-box which I kept with me, pr. post to Martigny, there to await my arrival for I had decided upon passing over from Chamounix to Martigny on foot, notwithstanding the repeated assertions of many of my friends who knew something about travelling in Switzerland, that this passage in the winter season, was next to impracticable. At 10 1/2 I left Vevay, a place with the situation of which I had been much pleased. In the stage 
Coach or "diligence" for Lausanne, my fellow travellers were three Gentlemen and two ladies with whom I conversed freely the whole way. The road leads between the lake to the left and the frequently mentioned vine covered hills to the right. When approaching Lausanne which does not lie immediately on the borders of the lake, we turned a little inland, and arrived in this town at one oclock. I took up my quarters in the Hotel Gibbon which derives its name from the circumstance that in a neighbouring house, this great historian wrote by far the greater part of his inmortal [859] work "Decline and fall of the Roman Empire". Lausanne is built in an extremely regular manner; the houses consist generally of the ground floor and one story, plastered over and white washed. The Streets are narrow and steep descending towards the Lake. A deep gully separates the two parts of the town which are united by a splendid viaduct, two rows of arches, the one above the other, recently concluded. I passed the viaduct in search of Le bois de Sauvabelin which my guide book recommends as very pretty, but on finding it, I prolonged my walk out of town in a different direction. Ascending gradually I came to an extensive plain and passed through several villages, when at [Romanel] which, as will be seen by the map, lies at some distance, I returned. The ground was covered with ice and snow, the atmosphere thick, and the Clouds apparently pregnant with snow, hung deep and lowring upon the heights, in this state of the weather I saw of course little, if anything at all, of the Country, which slopes down fm. the high ground upon which I took my cold walk towards the Lake, and of the Lake itself. Past five I sat down to a very good dinner, besides myself, there were only a French Lady and a German Gentleman, in whose conversation I took little share, until it was time to retire to bed I remained in the dining room, occupying myself partly with writing, partly with commencing the reading of Botta's excellent history of Europe towards the end of last and the beginning of the present century written in Italian. I was interrupted for some time by an agreeable Gentleman from Geneva, with whom I conversed very pleasantly.

Thursday, $5^{\text {th }}$ of December 1844. The weather was cold and heavy as on the previous days, moreover a disagreeable wind called here "La Bise" blew from the North; having got my passport "vised" at the Sardinian Consulate, I once more set out in search of the Bois of Sauvabelin which, if my hand book is to be believed, enjoys a European reputation. This assertion I can only endorse on Trust. The sky was of a grey lead color, not a sunbeam broke through the thick clouds, my eye ranged over an expanse of snow and over the murky lake, and I walked back to Lausanne greatly disappointed. At half past ten an omnibus conveyed me to the village of Ouchy close to the Lake, which may be called Port of Lausanne. I as well as other travellers had to wait on the quay [86o] until the Steamer made her appearance; we were rowed on board, and steamed off, I 
think it was about Eleven oclock. Notwithstanding the cold weather, I managed to remain on deck, only ran down occasionally to warm myself. We kept close to the Northern shore, and though now everything was wrapped up in a snowy winding sheet, I could well form an idea, how pretty the scenery must be when shone upon by a bright summer's sun, the high land which borders the lake, gradually slanting upwards is covered with trees, with villages, houses, and towns behind which rises the long chain of the Jura mountains. The Steamer stopped at Morges, Rolle, Nyon, Coppet, and at about four oclock arrived at Geneva. At Morges, the Geneva Gentleman whose acquaintance I had made on the previous evening, came on board, which I was glad of, for now I had at least somebody with whom I could speak a few words, and who could give me some account of what I saw around me. Opposite Rolle lies a small island upon which a plain monument is erected in honor of General Laharpe, who mainly contributed to free Le pays de Vaud, from the Bernese dominion. In Coppet Mr. Neckar and madame de Staël lie buried, on the South side of the Lake some of the high mountains in Savoy were visible, but the highest, such as the mont Blanc and the Monto Rosa were enveloped in clouds. The western end of the lake where it begins to narrow from Ivoire on the Southern shore onwards is called Le petit Lac. On approaching Geneva Country houses on both sides came in sight. We stopped close to the quay lined with a row of large houses, three of which were: l'hotel des Berges, de L'Ecú d'Or, and de la Couronne. I went to the last, and having to wait for a washerwoman and a Shoemaker whose services I required, I had no time to go out before dinner, which was served at five Oclock, my sole companion was a good looking Gentleman and his son, a pretty little boy; he did not vouchsafe to take any notice of me, and of course, I did not address him either, he even rose and withdrew without the Slightest courtesy. When he was gone, I wrote and read, till I retired to my bed room.

Friday, $6^{\text {th }}$ of December 1844. Soon after breakfast that is to say at about ten O'clock I left my hotel for a short walk through the gate de la Rive, which at the South Eastern extremity of Geneva, leads [861] towards Savoy. The weather was disagreeably cold, the sky covered with heavy clouds, the ground hard and frozen, thus it was hardly possible that I could enjoy this promenade; only by dint of quick walking I got somewhat warm, I had a look over the Lake to the opposite snowy shore, all was cheerless, even the many country houses with which the environs abound, now all locked up had an uncomfortable appearance. I returned to town and at one Oclock presented myself in the Counting house of M. M. Hintach \& Co., one of the first, if not the first Banker in Geneva. I had to this firm letters of credit from Donner, Baur and Meyer from Saint Gallen, I presented the two latter, and obtained for my draft on 
Gibbs of London of $£ 20$, all charges deducted, twenty five Napoleons and Eighty five cents. Ferney lies to the North west of Geneva at the distance of seven kilometres ( 4780 metres make a French, 5280 a Swiss league), thither I now directed my steps. I passed through several villages, and at the other end of Ferney turning to the left down a short avenue, came to an old dilapidated house, in 1844 the property of the widowed Countess de Bude which for several years had been the property of Voltaire; his sitting room and bed room are preserved exactly in the same state in which they were whilst he inhabited them; however, they do not present anything of very great interest, they are furnished with the small sized old fashionned arm-chairs in use during the Reign of Louis XV, the walls of the sitting room are hung with many engravings, whilst in the bed room, they are adorned with the portraits of Voltaire when a Youth, of his mistress La Marquise de Villette, of his Chimney sweep, and his washwoman, of Catherine of Russia and Frederick of Prussia, of Milton, of the actor Quain, Washington, D'Alembert, etc., etc. The bed is also the very same in which he used to sleep, it is a common wooden bedstead, the Cotton coverlid has also been preserved. Of the green silk curtains, little remains, for they have gradually been cut off by the visitors, each of whom desirous to take away with him a bit of them as a relic. In a small receptacle which still is to be seen in the bed-room, the heart of Voltaire was originally preserved; this has been removed to the Pantheon in Paris whilst the empty receptacle remained, it is somewhat injured, for in the time of the French Revolution of 1789 sacrilegeous hands broke it open in expectation of its containing some treasure. I also strolled about in the park belonging [862] to this Chateau; then walked back to Geneva, once I lost my way and found myself at the same spot where I started from. The second time, I was more fortunate, passed the Village of Pasqui close to the Lake, then over a long draw bridge which shook at every step, over the "fossé", entered the town which I now crossed and recrossed in every direction. Besides being partly surrounded by a ditch, Geneva had once its fortifications and walls; they are now demolished, and shrubberies, lawns, and walks occupy their place. The Rhone which flows here out of the Lake divides the town into two halves, also forms an island connected with the two other parts by several bridges. Many streets are narrow and irregular; a few, wide with alphalte-footpavement. The houses are for the greater part four or five stories high. In the lake, close to the town is a small island upon which a monument is erected to the memory of Jean Jaques Rousseau. In a Coffee house, I read in the Augsburg Allgemaine Zeitung an excellent address presented by ninety nine inhabitants of Kiel to the Holstein parliament assembled in Itzehoe on the subject of a proposal made in the Roskilde parliament which recommends to the King, 
to declare the inseparability of the three duchies of Schleswig, Holstein and Lauenburg from the Danish crown. The evening I spent quietly in the Hotel, reading, writing, and taking tea.

Saturday, $7^{\text {th }}$ of December 1844. I was up by seven o'clock, got my boots back from the shoemaker who had mended them, and without having time to breakfast, hastened to the diligence office where I left my hat-box and Carpet bag to be forwarded to Martigny Poste restante, and with difficulty obtained a place in the miserable four wheeled vehicle, called here the diligence. Two men, whether they deserved the name of Gentlemen I hardly know, and a pretty little woman squeezed themselves into the seat behind, partly covered over, whilst another individual and myself took our seats next to the driver without any shelter against the inclemency of the weather, the remainder of the Carriage, wheresoever any room was left, was occupied by many packages of merchandize purchased in Geneva and destined for the Savoy markets. One horse, a fine small bell round its neck sufficied to pull along this heavy load, and as far [863] as I could judge, it did so without any particular effort. Fortunately I had my big cloak with me, but though I wrapped myself well up, my feet were as cold as ice, and I rejoiced when the driver requested us passengers to alight, which he did more than once, everytime there was a somewhat heavy ascent before him. At first it looked as if we were to have a fine day, but gradually the clouds drew up and the weather was as disagreeable as on the previous days. To our right we had the river Arve which, a little below Geneva falls into the Rhone. At Annemasse we passed the frontier of Savoy where we had to wait more than an hour, every package in the carriage was carefully and closely overhauled, nevertheless I suspected that both my fellow travellers and the driver had many small articles of Contraband about them which escaped the experienced eye of the Custom-house officers. I had to present myself at an office where my passport was vised. We continued our drive, passed through many villages, the fields, the hills on both sides sometimes at a greater, sometimes at a lesser distance, the houses, the leafless trees, all was clad in its white winter livery. I entered into conversation with the man who sat near me, and learned from him, that he was now on a tour to the small places in the neighbourhood of Geneva for the purpose of purchasing the various small pieces of which a watch is made and each particular description of which is worked in a different place, thus for instance: in the one place only the dials are to be obtained; in the Other the wheels; in another, the Chains; in the next, the hands, and so on, and then the watch makers in Geneva put them together, and finish the watch. At twelve oclock we arrived at Bonneville, a small town about half way; in a miserable inn, we got our dinner, pretty fair and very cheap, twenty five 
sous a head. Not far from Bonneville we passed through Cluses, beautifully situated, completely surrounded by rocks. In June 1844 it had been totally destroyed by fire, and some of the ruins were still visible. This French word Cluses as well as the corresponding German Klause, and the Italian Chiasa, are derived from the Latin Verb Claudo, Clausi, Clausum, Claudere, to close, to shut-up. For sometime after leaving Cluses, the gulley through which the road passes along the Arve [864] is very narrow, the rocks on both sides are high and steep, into one of them opens "la cave de Balen" frequently visited by Tourists. Gradually the rocks dwindle down into hills and the gulley again becomes a valley. We passed through Saint Martin, crossed the arve over a bridge, and arrived at Sallanches on the left side of this river; the end of my this day's journey. Monsieur Mercier, one of my Companions, apparently a hardware merchant recommended to me the hotel du Lou Leman which turned out to be a vulgar public house. I obtained a cold bed room and in the General room the tables and benches were of the most ordinary description, round them sat artisans and peasants in theirs blue blouses, again more generally worn since I found myself in Countries where French was spoken. I took a stroll through the town which presented nothing worth noting, the weather was very cold. I hastened back, took some Coffee, engaged a guide for the following day, wrote, read Botta's history, and went to bed at nine Oclock. On the $19^{\text {th }}$ of April 1840 in an hour and a quarter Sallanches was totally destroyed by fire; three hundred eighty seven houses were burnt down and Eighty persons lost their lives, since then, it has been rebuilt on a regular plan, but like Carlsrhue or Washington, on too large a scale, many streets were traced, but the houses as yet were still wanting, the population numbered about two thousand souls.

Sunday, $8^{\text {th }}$ of December 1844. It was not yet full daylight when I rose at seven Oclock; for the first time in this winter the windows of my room were frozen over, and I found ice in the water-jug. My breakfast consisted of hot milk Coffee, bread, butter and honey. At Eight o'clock I started for Chamounix accompanied by the Guide who carried my cloak; he, dressed in a blue blouse was a rational man and well acquainted with the Country through which we passed. He told me that in the fine season, he gained his livelihood as driver of char á banes, a vehicle much used in this neighbourhood, it is a four wheeled carriage drawn by one horse, one bench runs lengthways, and the passengers as well as the driver, who occupies the seat nearest the horse, sit sideways, [865] a leather cover drawn up from behind shelters them partly against sun and rain. As far as Saint Martin we retraced the same road which I had come on the previous day, there we turned off to the right or Eastward. To our right we had the swiftly flowing Arve, all round hills and mountains, some covered with snow, others not; to the left "Les arguilles de Varens" (719o feet) double 
pointed, then La Porte Lanterne (6218) also with a peculiar pointed summit came in sight. Upon neither the snow had found a resting place. We passed Passy, next, continuing as yet on the level road, we reached Chêde from which point onwards the road ascends, the hills draw nearer, and form a Gulley, the Arve roars deep below without being seen, the black firs partly snow covered, the mountains white, and here and there a black isolated peak present a landscape not without beauty, but void of life and animation. Further on to the right between the mountains lies Saint Gervais, a mineral bath much frequented in summer, the Church bells called to Mass and their sound came distinctly over to us through the clear and transparent atmosphere of a fine winter day. By this time, the sun which had conquered the fog and clouds stood so high on the horizon, that its rays could reach us - brave wayfarers. The temperature was pleasant, and I walked along in excellent spirits, pleased with myself and the whole world. Gaily did I exchange a good morning with the many peasants, men and women whom I met, neither of whom, though this day in their holiday attire distinguished themselves by any peculiarity in their dress. When we had reached a small eminence, my guide requested me to look back to the cascade of Chêde which, said to be about three hundred feet high, now a compact mass of ice, must be a superb fall, when in its liquid state, my guide made me also observe a hole at the foot of the mountains, which at present the source of a torrent which flows into the Arve, was about ten years back of the size of a lake, when it was suddenly filled-up and reduced to its present dimensions by a rush of earth from the neighbouring mountains, for though my informant spoke of an avalanche, he cannot possibly have meant an avalanche of snow, this would have melted in the water. We crossed the Torrent noir, now hardly observable, whilst in the beginning of the warm [866] season when the snow melts in the mountains it sometimes swells to such a height, as to render the passage impracticable. At about half past ten, we came to a high plateau upon which lies the village of Servoz, the church bells played a merry peal (Carrillon), very pretty and exhilarating, close bye another village Bouget, where we stopped for sometime in a public house, my guide fortifying himself with a glass of Cognac, I with a glass of wine. The road continues to rise, we crossed the Arve over the bridge of Pelissier, and a further ascent brought us to another plateau, always encircled by mountains upon which several struggling houses formed the Village of Les Ouches. The peasants came from mass, and I observed more than one pretty girl. From Les Ouches onwards, we remained about on the same level, hills and mountains in every direction, only the Mont Blanc invisible, being enveloped in fogs and clouds. To our right we had the Glacier des Buissons, an immense uninterrupted mass of ice, of the usual bluish tinge, which from the mount Blanc stretches right down into 
the Valley, a mountain on each side, its dimensions surpass those of the three glaciers which I had seen in Switzerland, the Roselaui and the two Grindelwald (see page 839/840 of this volume). Higher up, where its width may be three hundred feet, it is broader than close to the bottom, where it is narrowed-in by many bushes from which it derives its name, it finishes abruptly like a bluff headland and is split into innumerable beautiful crevices of a white Greenish color. When opposite the Glacier des buissons I had a glimpse of "La mer de glace", the far famed glacier on the other side of the Prieur of Chamoun[ix] (319o feet) where we arrived at two oclock. The snow lay here very deep, and creaked under my feet, a proof of the great cold. My guide took me to the Hotel d'Angleterre et de Londres, where no travellers being expected in this season, the landlady, a respectable widow, Madame Terrace received me in her warm comfortable room, protected against the Cold by double windows and other contrivances. The severity of the weather was such that I only ventured out doors for a few moments. With her daughter Hortense I had a long talk, engaged a guide for the next day, [867] dined, and sitting near the fire, read a life of Napoleon, very partially written in his favor, whilst the landlady, her daughter, and some female friends whose patois I could not understand, kept up a lively conversation; at nine oclock I retired to bed room.

Monday, $9^{\text {th }}$ of December 1844. On the $15^{\text {th }}$ of June 1842 when I was thrown by my mule near Cajabamba (see page 697 of the first volume) I had a narrow escape of my life. This day however I ran a more imminent risk of breaking if not my neck, at all events some of my limbs, but a kind providence watched over and saved me, for which I can never be too thankful to my Creator. After having taken the excellent Swiss breakfast I started at about nine o'clock for La mer de glace, with my guide François Coutet, fifty two years of age, a very nice fellow. He was dressed in his blue blouse, and both he and I carried in our hands, the long Alpine Stick with an iron point at the bottom, for the purpose of making an impression upon the frozen ground, my common stick I left at Madame Terrace's. Between Chamounix and the montanvert to the South East, extends a small piece of level ground now covered with frozen snow; this we crossed, then commenced the ascent, for a considerable while zig-zag up the mountain through a wood of fir trees. Erelong the snow lay ancle deep, the higher we climbed, the deeper it lay, and after a fatiguing walk of about two hours it had increased in depth to such a degree, that at every step, we sunk into it, up to our knees. When at an elevation of about 2500 feet above the level of Chamounix, the zig-zag path ceased, and we had to continue our ascent of the mountain in a slanting direction. Sometimes we had still firs on both sides, but on other spots where the trees had been kept under, and their growth prevented by the 
continual fall of avalanches, we had to make our way the best we could over a sheet of snow, sometimes soft, sometimes frozen which sloped down from the summits of the mountains uninterrupted by trees or rocks, to the very bottom, where the Arve flows. There was no path, my guide walked before me, I after him, treading in his foot steps. No doubt there was danger in these passages, however I did not think of it, but walked along bravely and merrily until we reached the Shepherd's house on the montanvert close to La mer de glace; my guide had the key, we entered; he lighted the fire, gave me a glass of rum, for several bottles stood in a locker, which I drank off, as if it were water [868] and wrapped up my feet, dreadfully cold, in a sheep-skin which was lying about; thus somewhat restored, we ventured to descend to the mer de Glace, an extraordinary glacier of which maxwell says in his rambling recollections: "the glaciers and particularity La mer de glace resemble a sea suddenly frozen in its most violent agitation over whose surface sharp and savage rocks protrude, casting on the ice a tint of variable blue." Hardly had I made a few steps, when I slipped and fell, my guide being near, took hold of me, and we continued our descent, he before me fixing his Alpine Stick into the ground, I took hold of him at every pace, and thus we reached the glacier without any accident, and for sometimes walked about upon it. We did so however with the utmost precaution, frequently, Coutet sounded with his stick to ascertain whether the spot where I had to place my foot was safe or not. "La mer de glace" is full of crevices from one to two feet wide, their depth varying from sixty to seventy feet or more, near their borders where the snow hangs over into them, and is partly frozen, the danger is greatest. My guide showed me a stone where the names of the two strangers who first visited "la mere de glace", Messrs. Pockock and Windham in the year 1741, are engraved. To the East of "La mer de Glace" I saw the high peaks of l'aiguille de Dreux $(10,727)$ and l'aiguille Verte $(12,660)$ at the foot of which in the midst of the Glacier lies "Le jardin", an oasis in this icy wilderness covered in the summer season with the richest and softest grass. To have visited it at this season would have been a useless fatigue, for being covered with snow like the rest, it would have differed in nothing from the surrounding icy masses. We returned to the Shepherd's house where I entered my name in the Stranger's book, I again found here the name of Guillermo Espinoza, also that of Ernest Mayer of Altona, that of Countess Von Brockdorff of Preetz with her Gentilhomme de Chambre Von Stumann. We began our home-march at about half past one; when passing one of those sloping fields, of which I have endeavoured to give a faint idea, my Guide who always walked before me, I in his steps, gave me the advice to fix my stick not to the right on the lower side of the slope as I had done hitherto, but to my left on the 
[869] upper side, and at the very moment that I passed my stick from the one hand to the other, I slipped, lost my stick, fell on my bottom and in the very instant commenced sliding down the slope, at first slowly, but every second the velocity increased, I did not lose my conciousness, nor my self possession. I tried to fix my hands in the ground but the snow was frozen, and I could not make any impression on it. I felt that I was utterly helpless; quicker and quicker went my downward career, when all on a sudden, I felt a severe pain. I had rushed against something, it was a large stone which raised an inch or so above the snow had stopped my downward progress and saved me. I rebounded, was thrown over the stone, and on the other side, a little further down fell upon the snow with such violence that I broke the icy crust, and there I sat. I immediately felt for my spectacles, they were still on my nose; for my money, it was in my waistcoat pocket. In a minute or two the guide was with me, I took hold of his arm and we retraced our steps more or less to the spot where I had fallen, and walked back to Chamounix. Both my courage and forces were gone; François Coutet was of opinion that I had slid about a hundred feet, and that I had rebounded about seven or Eight, and all this was done within the time of fifteen seconds more or less. The entire height down to the Averon which takes its origin in the glacier is about 2500 feet. The rivulet was full of ice, stones, and trunks, and in all probability if I had even reached the bottom alive, I could not have avoided fracturing my limbs; for a certainty it was a wonderful escape. Having reached the hotel, I took a very light dinner, and hastened to bed. I had hurt the shinbone of my right leg where I had knocked a hole through the trowsers, drawers, stockings and skin; it bled profusely, but I thought little of this wound, I felt the greatest pain in my left hip-bone which had first come in contact with the stone, less pain in the right thumb, and right ankle, but one with another, nothing in comparison with what I suffered when I fell from my mule near Cajabamba (in Peru), there I was on the point of swooning, here I was gay and in good spirits. Madame Terrace cured me with motherly care, all the injured parts were washed with lukewarm water into which salt had been dissolved, which both [870] she and my guide thought preferable to the washing with Brandy. I fell asleep at an early hour but awoke more than once during the night, and when I awoke always saw myself sliding down the icy slope. For some time after, these horrible moments were continually present to my memory.

Tuesday, $10^{\text {th }}$ of December 1844 . When I rose, my whole body felt stiff and the various parts which I had hurt on the previous day pained me more or less. Nevertheless I was able and ready to carry out my original plan of crossing over to Martigny by the pass called "la tête noire". The idea of ascending Laflegere ( 6550 feet), a beautiful pointed peak on the other side of Chaumouni opposite 
La mer de Glace, Les aiguilles Vertes and Les aiguilles de Dreux, I abandoned, partly because I was gradually gaining the Conviction that the Winter was not exactly the right season for such undertakings, partly and mainly because the day was cloudy, had the weather been as favorable as on Sunday last I should at all events have made the attempt. At nine Oclock Coutet and I left Chamounix, I, as may well be conceived, very grateful to madame Terrace for the great kindness with which she had treated me. The road lead us on the right side of the Arve, this river flowing to the South West, whilst we ascended in a North Easterly direction. To our left we had the Brevent (7210), and les aiguilles rouges (9615), to our right. After Coutet had pointed out to me the spot of my yesterday's mishap, we passed La mer de Glace, then the Glacier d'argentière. We had reached La valley d'Argentière, and a trifle further on the road divides, to the right it branches off to the Col de Bahne, to the left to La tête noire, which was our way. The ascent of the Montet (5240) commences, here and there we passed over patches of snow, but nowhere did it lie so deep as Yesterday on the Montanvert, and upon the whole the path was pretty well beaten. We came to a small village called Valencina, the greater part of which had sometime back been destroyed by an avalanche. On the other side of this village, we passed the frontier between Savoy and the bas valais, one of the Cantons of Switzerland, worked by a miserable low wall, and an equally miserable low gate called: Le fort du Chatelet. Henceforward [871] the roaring "riviere noire" was our Companion. Here Keller's map though generally very correct, is at fault, for the path which crosses "La tête noire", is not laid down. We descended to the village of Trient where we entered a public house L'hotel des Alpes and took our dinner consisting of a tumbler of hot water with wine and sugar, Broth, salt mutton, salt pork, potatoes, and black bread, all of good quality. Whilst we were there several travellers came-in, which circumstance I merely mention for the purpose of showing that though probably this road has seldom been selected in the winter, by such as I who merely travel for pleasure, yet even in this bad season, it is not altogether unfrequented by those whose business and occupations bring them to these parts. I suppose it was past two oclock, when we left Trient, we had now a high mountain the Col de Trient ( 6712 feet) before us. The ascent I achieved without particular fatigue, not so the descent which was difficult in the extreme, nay occasionally dangerous. The Villagers were in the habit of throwing from the summit down into the Valley, trunks and logs of wood, and to facilitate their descent, they poured water on the mountain side which froze, and very naturally rendered the path slippery in the extreme. This path leads through a very narrow pass between two steep and high walls of rock, with here and there a small patch of earth from which a few fir-trees draw their scanty sustenance, it keeps close to the rock, so abrupt, that in some 
places recourse has been had to Blasting, in other places a tunnel or a "gallerie" as Tunnels are called here, is cut through, more than once further progress has only been made practicable by means of beams and boards, which, well fixed and fastened, are placed across, from one projecting point to the other. To the left flows la Riviere noire at a great depth whence pines and firs rise, more or less to the level of the path on which Coutet and I strode along, Ice and snow above, below and around us. Suddenly a thick fog filled up and concealed the abyss below as suddenly it cleared away. Though I consider myself a good climber yet here more than once, I found myself obliged to take hold of my guide's arm and with his assistance reached the bottom without accident. In the Valley, no snow had fallen as yet; we crossed the river La Drause, an affluent of the Rhone, [872] passed through the Bourg of Martigny, and a quarter of an hour later arrived at Martigny, I went to the hotel du [Coygne]. It was about six oclock, I fetched my luggage from the Post office for the [?]ight of which fm. Geneva I had to pay as much as twenty one francs seventy five cents, read Botta's history and went to bed at an early hour.

Wednesday, $11^{\text {th }}$ of December 1844. Till twelve oclock when I had my dinner I remained quietly in my room resting my tired limbs and occupying myself with reading and writing. From my window, I saw the mountains of Fully on the Northern side of the road, it was a fine day, and at about one oclock I started for a walk to the well known water-fall of Pissevache. As soon as I was out of town I crossed the Drause over a bridge and found myself in the valley of the Rhone inclosed by mountains on the high road to Geneva, with the river to my right, the space between it and the road being filled-up by underwood and bushes. I crossed the small river Trient, passed the village of Vernagaz, and after about an hours walk from Martigny, reached the fall which comes down from the mountains to the left. Its height may be fifty feet, only in the middle a small quantity of water had preserved its liquid state, on both sides thick masses of ice covered the rock. In the winter, small water falls do not show to advantage; the water freezes, its volume decreases, and there can be no froth nor spray, which in great measure constitutes the beauty of a Cascade. On my return, I made an attempt to reach the banks of the Rhone, but the shrubs which covered the ground were so dense and entangled, that I could not make my way through them. In the open air my thermometer stood at one degree below zero, but notwithstanding the Cold, when repassing the Trient, I remained for a while on the bridge wondering how this small river could have broken its way through the massive black rocks before me, which I should have thought would have been an impenetrable barrier; I amused myself with looking at the logs of wood tumbling down the mountain sides, and admired the world 
of mountains around me, one of which right ahead shaped like a sugar-loaf is called La Pierre a Voie (7270). At four Oclock, I was back in my hotel [873] and in the Course of the evening wrote a long letter to Siveking. I learned that since I had left Lucerne, the two parties, the one in favor of, the other opposed to the readmittance of the Jesuits into the Canton, had come to blows; I was also told that in the beginning of the year 1844, near the small bridge over the Trient, the people of the Cantons "du haut Valais", called Aristocrats and those "du Bas Valais", liberals, nicknamed: Gripioux, or thieves had fought, in which Combat, the latter had been worsted and their leaders fined and banished. I understood that the dispute had arisen from the Liberals insisting upon the Clergy who possessed considerable landed property, paying their share of the taxes in the same proportion as everybody else, and upon their not enjoying any privileges whatever; these requests which to me seemed rational enough, were represented to the more ignorant inhabitants of the Haut Valais as abortions of Protestants and Heretics. They flew to arms to defend the supposed rights of the Clergy, and thence the war.

Thursday, $12^{\text {th }}$ of December 1844. This day I devoted to a visit to the Hospice "du Grand Saint Bernard". I ascended this mountain from the same side from which Napoleon I had achieved his famous passage in the month of may 180o, the great conqueror bent on blood and Carnage descended into the Italian plains by the valley of Aosta; I, the insignificant man of peace whose only object was to satisfy his curiosity, returned the same way I had climbed-up, back to Martigny. He, the warrior, bestrode a safe footed mule, not a spirited white Charger as he is represented in the well known engraving of "Le passage du grand Saint Bernard"; [...] traveller trusted to my own legs; he was embarassed by a numerous army, its baggages and artillery, I, had with me my walking stick, a few francs, [_] tooth brush; in 1800 there was no road up the Great Saint Bernard, in 1844 an excellent road was finished nearly up to the summit; in the moth of may, the snow fallen during the winter had hardly commenced melting, in December, no snow had as yet fallen in the valley. This in every respect except Napoleon being mounted, I on foot, the little little man in December 1844 made the ascent under much more favorable circumstances than the great great man had done it in may 1800 . I left Martigny without a guide at about Eight Oclock and as far as a stone Obelisk on the other side of the bourg of Martigny went the same way which I had come from Chamounix, here crossing the drause to its left side, I followed the road which leads to the Great Saint Bernard, whilst to the right, that to Chamou[_] [874] turns off. I walked up the Valley of the just named river, narrow and hemmed-in by high steep Rock[_] mountains. The Road was excellent, hard and frozen, here and 
there the ground was covered with hoarfrost, but nowhere did I as yet see any snow. I passed the Villages of Brocard, Vallete, and Bournier, and recrossed to the Drauses right bank. Some distance higher-up, the rock approaches so near the river that it has been necessary to cut a tunnel "La gallerie de la [Monnani]" nearly eighty yards long, through the same. On the other side of this tunnel, I reached the village of Sembranchies where two rivers join, both called Drause, the one flows west, the other due North. I took this latter, the road in excellent repair ascends gradually, the river as yet was still liquid, but along its sides enormous masses of ice had formed, and the rills along the mountain sides were all frozen into the shape of large and wonderful icicles. At $111 / 2$ I arrived at Orsières ( 3810 feet). On the other side of this village the ascent became more palpable than it had been hitherto, the road winds up, the Drause flows to my left many feet below, on this side, the mountain exposed to the midday's sun showed no traces of snow, whilst on the other, my right side it lay in pretty heavy masses, [and] completely covered the highest points. I next came to the village of Liddes, other villages were parched on the mountains-sides and summits just as I had seen them in the Peruvian Cordilleras, and at about one oclock I reached the town of the same name. In a miserable public house called L'hotel del'Union in Liddes, I took bread, Cheese and a tumbler of sour wine, and for three francs engaged a guide to the Hospice. He was a good natured willing fellow, but his French patois I had some difficulty to understand. Somewhat higher up than Liddes, lies Saint Pierre, in its neighbourhood, I observed many wooden railings upon which it is the Custom to spread horse-beans for drying. The houses used for storing Corn, built of boards, not of beams as in Norway, rest like there on foundations of stone. Having [...] Pierre, the excellent road which I had followed [...] valley ceased, a bridle path, sometimes hardly visible took its place; together with the road ceased the high wooden crosses along its side, [875] also the villagers whom I had frequently met as far as Liddes became scarce, only a few Savoyards who I understood had during the summer been working in France as masons, passed me on their way to their native Country. These of course were dressed like the labourers in France, the peasants wore long coats, not swallow tailed as in Guldbrandsdalen, the pantaloons of the younger as well as the breeches of the Older men were of an ordinary home made cloth of a reddish brown color. Many of the Girls might be called pretty. Now the Snow which had first appeared on the road on the other side of Liddes increased in depth, it lay ancle-deep. Another difficulty presented itself, the rivulets which flow down the mountain sides into the Drause were frozen over, the ice was very slippery and merely with my guides assistance could I get over them. Thus we continued our ascent until we reached a high plain or plateau where we bade good bye to the last firs, they no more grow at this elevation, the 
plateau is incircled by mountains. The Drause hitherto in the Gulley to our left, now flows on the same level with the plain, here stands a solitary public house, half way between Liddes and the Hospice; it is called "La Cantine", my guide entered and took a dram, for which I paid. My Thermometer marked Seven degrees below zero, it was half past three oclock. We drudged on over this snow covered plain for full an hour longer until we reached two habitations; the one, a burial place for such as may die in these inhospitable regions, the other, opposite, a vaulted house, the entrance to it without a door. By this time it had become dark and though we had new moon, the light it shed was little and lasted but a short while. Henceforward we had a steep ascent before us between two ridges of mountains which draw close to each other. No more did I see the Drause, it was hidden under ice and snow. The snow at first ancle-deep as already said, lay soon so high, that at every step we sunk into it, up to our knees, still higher up, my guide not being well acquainted with where the path lay, though it is marked by high poles, we fell into the snow, up to our hip-bones, I was [fatigued], every twenty steps or so, I had to lean upon my guide, [...] sat down, and finally I clinging to his arm was actually pulled-up by him; without his assistance, I [876] should never have reached the summit. I was completely knocked up, what a joyous sound the barking of the dogs of the hospice was to me, may well be imagined. Through a low passage in the building, we found our way to the kitchen, where I threw myself on a chair and asked for some Brandy, this revived me; a servant came, drew-off my boots and gave me a pair of slippers; a few minutes later one of the friars made his appearance, and in very polite terms requested me to accompany to the refectory. "Richard was himself again." It was now half past six, the cloth was being laid for supper, ten or Eleven friars sat down with me, their number is thirteen, two or three were absent. The seat which was given to me, was opposite to him whom I believed to be the superior and who before as well as after the meal said some prayers to which his companions responded. The supper was excellent, hot milk with bread for soup, Cutlets with potatoes, roasted veal with stewed pears, boiled chesnuts, walnuts, cheese and good white wine. I conversed with the friars who told me amongst other things that the road was to be continued up to the hospice in the course of the ensuing year, the expenses being defrayed half by the Government, half by the parishes (Les Communes). At half past eight, one of them showed me to my bed room, my bed had been warmed, and I soon fell asleep, highly delighted with the hospitality and kindness with which these good folks had received me.

Friday, $13^{\text {th }}$ of December 1844. I was awake long before the servant called me, at seven oclock the thermometer in my room stood above zero, in the refectory I had for breakfast hot milk, coffee and bread, the friars fasted. In the 
strangers book I again found the name of Guillermo Espinoza in the beginning of Octobre; the last date on which a visitor had entered his name was the third of November. In 1844, not less than 18,000 strangers had received hospitality in this hospice, which lies 7768 feet above the level of the sea, in the year 1843, 15,000 . The hospice was founded in 962 by a Savoyard nobleman Bernard de Menton, who lived from 923 to 1008, and whose descendants still existed in Savoy in 1844, where they possessed landed property. The friars are of the order of Saint [877] Augustin, those whom I saw, all young men, none I suppose above forty five, were natives of Entremonts as the Country between the Great Saint Bernard and Chamouni is called; they were dressed in a long tight fitting black gown with two white narrow cords which meet on the left side about the waist, hanging over their shoulders, on the head they wore a high black cap similar to those used by the Polish Jews which they did not take off at meals. In the Chapel one of the friars who showed me round pointed out to me a bas relief in white marble representing General Desaix's death in the battle of Marengo on the $14^{\text {th }}$ of June 1800 , it was put up in 1804 by order of Napoleon in the presence of General Berthier. Into a block I threw five francs piece no one of course having asked for any remuneration. The convent, though extensive, has been found insufficient for the many strangers who throng thither in the fine season, and thus an additional building has been constructed to lodge them. Just before the refectory is a large iron railing which women are not allowed to pass, therefore lady visitors take their meals in a room by themselves, even a piano is placed at their disposal, in another apartment many Roman coins and medals, Roman household Gods, and other antiquities, also modern coins and engravings, presented by various persons, form a pretty considerable collection. On the other, the Italian side of the summit stood once a temple of Jupiter, which accounts for the Roman antiquities found in the neighbourhood. The descent to Aosta is much steeper than the ascent from Martigny, and on that route lies the small fort du Bard which as everybody knows who is at all acquainted with the history of those times, had nearly proved an insuperable impediment to Napoleon's march, he himself knew of its existence, and spoke of it when in the hospice. Before leaving, I entered a room, where many people of the lower classes were assembled, ready to start; amongst them was one of the Savoyards who passed me on the previous day, and who had arrived with his toes frost bitten; to cure them, he had had to put his feet into melted snow and during the night the injured parts had been wrapped-up in raw scraped potatoes. I started at half past eight, the weather was as clear and beautiful as on the previous day, my [878] thermometer stood at Eight degrees below zero. I was accompanied by my guide to whom I paid an additional two francs, and by 
a "Marinier" with his dog, the road was extremely slippery, my two companions took hold of me under the arms each on one side and thus helped along. I reached the refuge and the burial place whence the ascent had taken me on the previous day more than an hour in little more than fifteen minutes. The marinier and his dog left us, at half past nine we were at "La Cantine", and before reaching Saint Pierre, had again to cross the slippery spots of which I spoke yesterday. One of the rivulets had become much worse during the night, it had spread all over the mountain side and covered it with an icy crust. First my guide cut out two little holes into it and passed over to the other side on his knees, but, I, mindful of the accident on the Montanvert did not venture to follow him; he came back, we then climbed up a considerable height in hopes that near its source, the rivulet might be narrower and the passage less difficult but all our searching was in vain, we had to redescend to where we had started from, then my guide with his knife cut a row of successive holes into the ice, large enough to put my heels into them, and thus, he giving me his hand, I crossed over. Thence forward nothing particular occurred, in Liddes, my guide remained, I by myself, walking very fast, reached the hotel du Cygne at Martigny at half past four, dined, and remained at home noting down what I had seen in the course of this and the preceding day.

Saturday, $14^{\text {th }}$ of December 1844. At nine Oclock I left Martigny in the diligence from the Post office, and being the last comer had the worst of the six inside seats of the carriage, namely that with the back to the horses and in the middle, one fellow passenger on each side. Thus seated, it was impossible for me to see much of the Country. We drove through the Valley of the Rhone on its Southern bank, mountains on both sides. Three of the passengers were of the lower classes of society, the fourth was a military man with a prepossessing countenance, the fifth, poorly dressed, honored me with most inquisitive looks. We passed various [879] Villages, and on the other side of Riddes, crossed over a provisional bridge to the Rhone's northern bank, that which formerly existed, having been burnt by the people of the Bas valais in the spring of the year. The person who had looked at me with such particular attention was the first to leave us, and one of the passengers informed me that he was a "monchard" or police spy, which accounts for the attention which he had thought proper to bestow upon me. I now took a seat near the window, the country however presented nothing of interest. At twelve oclock we were at Sitten or Sion where we took our dinner, abundant but second rate, only the servant girls who attended at the table were very pretty. On the other side of Sion, German again began to be spoken, but mixed up with French. Here snow lay on the Ground, and the driver of the diligence which we met, told 
us that on the other side of the Simplon till Milan, the snow fall had been very heavy, consequently I at once abandoned the Plan which I had formed to stop at Baveno and to make thence an excursion to the Boromean islands in the "Laggo Maggiore", and determined upon proceeding directly to Milan. After having driven through Siders or Sierres, we again crossed to the South of the Rhone, then through Vispe or Viege, arrived at half past seven at Brieg where we stopped for the night. In the course of the day passengers had stepped in and out. In Brieg we were four of us, an insignificant man from Domo D'Ossola, the military man whose name I now learned was Becque, and who, a native of Bas Valais in the Napolitan service as Surgeon having been on furlough, now returned to his post; a friend of his, Captain Cross, hitherto an outside passenger with his splendid dog and myself. We four, also the dog I may say, were on very good terms and supped together; at ten oclock we retired to our bed rooms.

Sunday, $15^{\text {th }}$ of December 1844. I was called at half past three oclock, rose immediately, and when going below, already found my fellow passengers assembled. We left at four precisely in a lighter and smaller carriage than that used on the previous day, for we had the Simplon and much snow before us. Hardly were we outside the town when the road commenced ascending, it was the famous road, [880] constructed in the first years of Napoleon's reign $(1801 / 6)$ and leads in a somewhat South Easterly direction, whilst the Rhone which we saw no more, comes from the North-East having its source on the Saint Gothard. The Carriage had but two wheels and four seats covered from behind, open in front, of these, the two fore seats decidedly more exposed to the Cold, were occupied by Cross and by myself; but as his dog laying upon our feet, kept them nicely warm, I did by no means suffer so much from the Cold as I had apprehended. After a short while we had to alight, the wheels were taken off and fastened behind and the carriage placed upon a sledge drawn by three horses, the one before the other. We continued ascending, it was a beautiful night and the stars gave sufficient light to enable me to see how admirably the road winds up the mountains sides. When the morning star rose, I recollected how often I had seen it on the pampa between Islay and Arequipa as the fore-runner of the anxiously expected sun. This day, the sun rose cloudless, and under its rays the snow spread far and wide, glittered and sparkled, dazzling to the sight. To the left we had still higher mountains, to the right, a deep precipice through which in all probability, torrents and rivulets find their way, not visible in this season, mountains again on the other side. Along the road, wide enough for two carriages, several solitary houses called "refuges" of which I counted nine, are built, and were inhabited at the time. At half past seven we stopped at a few houses called Persal where 
sufficient time was allowed us to take some hot Coffee, Bread and butter, I do not exactly remember whether already before reaching this small place, but at all events between the same and the summit, also on the other side, Tunnels or galleries are cut through the rock, also on those spots which are most exposed to avalanches strong walled-up vaults are constructed, at the very highest point these projecting tunnels and vaults are wanting, for which reason, if I may trust the unanimous opinion of my fellow travellers, the passing of these parts of the mountain is not without danger, for the enormous masses of snow continually pressing downwards, sometimes especially when the thaw [881] loosens their compactness, rush over the mountain-side, and the impetus increasing with their weight, overwhelm and carry with them everything in their way. Towards noon, a strong wind sprung-up, it whirled the frozen snow, and blew it into our faces pricking like needles. In some places, the snow actually lay so high as to be on a level with the top of our carriage. Les Eaux froides are on the summit of the Simplon; the map marks there a glacier of the same name; on the other side, the snow increasing continually in depth, we passed "L'hospice" a branch establishment of that on the Great Saint Bernard, "La Chapelle" and a few houses formerly the old hospice, buried in snow. At twelve o'clock we arrived at the village of Simplon (6387 feet) where we dined. French and German continued to be spoken indiscriminately; though we had only two horses, the third having been left behind, we drove down rapidly. We passed two spots where the loosely laying snow gave evidence of the recent fall of avalanches; a ditch or may be a torrent marks the frontier between Switzerland and Piemont. This water joins another torrent which flows alongside the road, and which gradually increasing takes the name of Vedra. Further down, the Vedra falls into the Toccia, and this into the Lago Maggiore. At Isella, the first Italian town, our passports were vised and our luggage searched very slightly. My books attracted the attention of the Custom-house Officier, but as he saw only my dictionnaries and guide books, Bottas history and my French novels being at the bottom of my trunk, he let them pass without any notice, and did not refuse a fee of half a franc. We continued our drive along the Vedra, mountains on both sides. We crossed it, and in the complete darkness reached d'Omo d'Ossolla, Italian is of course the language of the Country, but French is still understood. We went to a miserable house close to the post-house, the Domo-D'Ossolla man left us, Becque, Cross and I remained together, and as we had to continue our journey on the same evening, we did not go to bed, but whiled away the time sitting before the fire, conversing, taking some mulled wine and a bottle of Vino d'asti, very pleasant and effervescent. We were joined by a Sardinian officer and at 10 p.m., were requested to walk a small distance out of [882] town, because the Sledge laden with our weight; would not have 
been able to move over the stones of the streets. The Post officials attempted to put us into an open vehicle, which I decidedly resisted, and owing to my strong remonstrances, obtained the same carriage in which we had come from Brieg. It struck twelve when we arrived at a place the name of which has escaped my memory, and where our Sledge was exchanged for a four wheeled carriage completely covered.

Monday, $16^{\text {th }}$ of December 1844 . Whilst the carriage and the horses were getting ready, we had to enter the Stable, for at least there the temperature was milder than in the open air, and no public house was open. Becque and the Sardinian officier ceded to Cross and to me the two hind-seats which were by far the best, for they had a firm back, which the two others had not. More than once when we stopped to change horses, I awoke, also the night air which found its way through the small openings in the leather, was cold and sharp, nevertheless I slept fairly till $71 / 2$ when I opened one of the side covers, and found that we were driving along the Lago Maggiore, of the beauties of which and of its neighbourghood so far famed, I of course saw nothing, for as far as the eye reached, all was covered with snow. On the other side of the Lake I observed a Castle whose name none of my companions could tell me. Baverno we had left behind, and at ten Oclock arrived at Arona where we went to the public house in the Post-office through the kitchen, upon the door of which was painted in large letters "Cuchina", and where the cook with his white apron and white Cap, gave himself great airs, we were shown to an inner room, where I took a cup of Coffee. I ventured out to see something of the place, but the snow water rushing from the roofs, the dirty streets, and the snow blown or swept together laying in many places several feet high soon drove me back, and thus what I saw of this place, though I believe I saw the best of it, a narrow street along the Lake, gave me no great idea of the same. At noon I started afresh in a light carriage drawn by 3 horses, Becque came alongside to bid me good bye, the "Condu[_], [883] an Austrian and a pleasant fellow was my only companion. We conversed freely, every moment he came out with his true Austrian "was Schaffens". The thaw had converted the road into a bed of mud, I saw a heavily laden waggon which nine horses and mules harnessed the one before the Other, could hardly move. Our way lay along the Lago Maggiore, not always in sight of it, a wider and better beaten road turned off to the right towards Turin. When approaching Sesto Callende, we crossed the Ticcino which flows from the Lago Maggiore into the [Pó] in a ferry, and stopped for a short time in this town which is larger than Arona, the houses are built of bricks plastered over and white washed, the roofs are somewhat pointed. I had been told that at the Custom House my luggage would be exposed to an extremely strict examination, but on the contrary, nowhere did I got over this annoying 
process better than here; the officer was a hungry looking drunken fellow, I gave him a franc, he merely opened my Carpet bag and shut it again without looking into it. About the Post office, a number of hangers-on, Rugganuffins or Fachini (Porters) stood about and offered their services, a motley set they were. We continued our journey in a large four wheeled carriage drawn by six horses, of which the conductor and I occupied the Coupé, another carriage drawn by four horses followed us. We entered the extensive plains of Lombardy rich in Mulberry-trees, the leaves of which as everybody knows are the sole food of the silk worms, silk being one of the principal exports from Lombardy and from Venetia. Wine is also produced, and in the Summer season the vines hang in graceful festoons from one mulberry-tree to the other. Now in the winter, there was nothing but snow, nevertheless, it was not particularly cold, for it thawed, it ever rained occasionally, and my feet were warmed by means of a good deal of straw which I ordered to be placed into the Coupé. At a small place called La Somma, the "Conducteur" called my attention to a cypress tree of an extraordinary dimension, which no doubt must have been many many centuries old. Traditions says that once Hannibal rested under it, this is apocryphal without doubt, that Napoleon I did the same, is more certain. In Gallaretto we halted for some time; in the kitchen of a miserable inn I got some bread and Cheese over [884] the Counter which served for my dinner and supper for the day. When near Milan in the middle of the night I was awakened by the sudden stoppage of the Coach, one of the horses had dropped down and to make it rise again was found impossible, it was also observed that the additionnal carriage, had not come up with us, thus waiting for another horse and for the second carriage we remained on the road for more than an hour, at last we drove on, and made our entrance into Milan under Il Arco della Pace concluded under the Austrian Reign and commenced by Napoleon in 1804 by the name of Il arco del Sempione. From the Post office where the Conducteur gave me a receipt for my passport taken from me at Arona, a Facino, a complete blackguard to judge by his looks, showed me at my request to the Hotel Suisse Nella Contrada dei Visconti where, though it was three Oclock in the morning, I was received and got a comfortable bed room.

Tuesday, $17^{\text {th }}$ of December 1844. Honey did not form part of a breakfast in Italy as it did in Switzerland; I however obtained it, for I let the landlord know that the reason of my taking my quarters in the Hotel Suisse, was because I expected to be treated there in the same manner as I had been in the Country whose name it bore. I despatched a note to the marquis Alessandro di Litta whose acquaintance I had made in Lima, and who was my fellow passenger from Callao to Huanchaco on the 26/7 of April 1842 (see the Volume I of these extracts, page 6o9). Accompanied by a Valet de place I went to the 
Counting-house of Messrs. Henry Mylius \& Co, for whom I had letters of introduction from their firm in Hamburg, from Semper and Doctor Kramer. A number of letters had accumulated here for me, the perusal of which after my return to the hotel occupied several hours. The Lima dates were: $3^{\text {rd }}, 18^{\text {th }}$, and $19^{\text {th }}$, of August; my wife expressed a desire that I should form a commercial connection with Daniel Schutte. She and Enriqueta gave me political news: Doctor Justo Figuerola was at the time they wrote, provisional president of the Republic of Peru. Juan informed me that Dionisio Boulanger of Paita had made an arrangement with the Peruvian Government [_] [885] virtue of which he had compromised himself to despatch every fortnight a fast sailing vessel to Panama, to receive the European mails, Eldridge's vessels hitherto employed for the same purpose having turned out hardly sea-worthy. Gibbs of London had made some purchases of manufactured goods on my account. Mr. William Gibbs wrote a few polite words which I interpreted to the effect that he wished to know what it was, that I actually wanted. The Government in Copenhague asked me what advantages a Consul General enjoyed in Peru, over a Consul which former title I had solicited for me, I was at a loss what to answer to this question. Henry Sieveking wrote in as kind and friendly manner as he is always in the habit of doing and Daniel Schutte refused to reduce his Charge of Commission and garantee from seven and a half, to six per cent, as I had requested him to do; on the other hand, he offered me a share in his sugar speculation to Valparaiso, which I declined. The weather was bad, it thawed and rained, the streets were thus in a horrible state, many labourers were employed in clearing away the immense masses of Snow, I was assured that for the last one hundred and fifty years, they had not experienced in Milan such an early and heavy snow-fall as this year. I had a glimpse at the Cathedral or Il Duomo, an immense pile of marble somewhat dingy. The streets I came through were narrow, the houses high; in La Contrada degli Orifici, I noted many splendid Jewellers shops. I dined at table d'hote in my hotel, very well served and cost no more than three francs a head, without wine. The Languages spoken were German and French. I had a visit from the Marquis di Litta who was very polite, also a call from Mr. Mylius's younger son, who invited me to dine at his father's on the following day, and remained at home till bed time, when I still felt some pains resulting from my fall on the Montanvert.

Wednesday, $18^{\text {th }}$ of December 1844. As I was at present on the threshold of Italy, the Country which "par excellence" is called the cradle of the fine arts, it might be expected that I should give an account of my own proficiency in architecture and sculpture, in painting and drawing, but I must confess that of all these, I literally knew nothing, as I was not brought-up to gain my livelihood as an architect or a sculptor, it is not to be wondered at, that the rudiments of 
these arts were not [886] imparted to me, but why I was equally ignorant of painting and music, the first principles of which are taught in all schools, requires some explanation: When I was a child, I did not evince the slightest talent or inclination either for drawing or for music, for which reason my father and mother who themselves did not care much either for the one or the other, were of opinion that it would be a loss of time if I were to take lessons in these branches of education. Music was as little indigenous in the family of the Witts, as it was in that of the Willinks. My mother it is true had a good musical ear, that was all, my elder sister played on the piano with great skill, but I believe, she practised more because she considered playing on the piano an indispensable accomplishment for a young lady, than that she really enjoyed the music. My other sister was so short sighted that she had to wear spectacles, in order to distinguish the music paper, which made her give up the playing on the piano. It must not be forgotten either, that in my Childhood, Operas were not so frequently performed as they had been in later years. A visit to the theatre was also an extraordinary occurrence in our quiet family-life; in Altona, if we had any actors, they were very second rate, and to go to the Hamburg play-house was connected with difficulty and considerable expense. After the death of my parents, Theodore Elmenhorst, my Companion in Donner's Counting-house who was very fond of music, persuaded me now and then to accompany him to the Opera in Hamburg, where it is true I was pleased, but probably more owing to the presence of certain young ladies in the Box than to the Singers on the stage, or the musicians in the Orchestra. Then came my departure for South America, where both, in Arequipa and in Lima, Opera Singers were hardly known until the year 1840 when the arrival of the Le Signore Pantanelli and Rossi with their Companions, caused an extraordinary sensation in the latter place. I took a box with my wife, for nobody who had the means declined doing so, and I confess, that at that time I spent many a pleasant evening in the theatre, when the Operas Romeo and Guiletta, and La Sonnamboula were my favorites. But there also [887] an undercurrent was perhaps at work; I then was beginning to learn Italian which I studied with Great zeal, and certainly my being able to understand this language when I heard it sung gave me much satisfaction, and this contributed to my enjoyment. In this condition I found myself with regard to music at the period of my arrival in Italy. In drawing, my sisters had made fair progress, the elder drew heads in pencil, in black and in colored crayons, with great perfection, whilst the younger had turned her attention to the drawing of landscapes, especially of animals; when I was last in Rattzeburg at her daughters, the drawing room was still adorned with some of her paintings in Sepia representing groups of Cattle, very well executed. The utmost which I ever was able to produce in this line 
was a pencil copy of the Vessel called the "Vicar of Bray" (see in appendix number $4 \mathrm{C}$ ), and even there the waves are not of my doing. Nevertheless, ignorant as I was on my arrival in Italy with respect to pictures, I determined to visit every collection, Museum, and gallery which I might have an occasion of seeing in the course of my journey, for I hoped that the continual sight of works of art, the observations found sometimes in the catalogue, and the remarks which I might pick-up in conversation with "connoisseurs" would contribute to form my taste, and give me some insight into the mysteries of the art. When I left Italy, I had succeeded in making myself acquainted with the styles of some of the great masters, especially a Gui Doreni, and a Carlo Dolce, I could fix upon amongst hundred of pictures, and seldom erred, however, to distinguish a copy from an original, or to point out where the merits or the demerits of a picture lay I have never been able to accomplish. The Valet de place showed me to Il Duomo (The Cathedral) of which I have somewhere read, that in the opinion of great architects, it does not belong to any style of architecture, it is neither pure Gothic, nor Roman, nor Greek, nor Bizantine, nor anything at all. Somewhere else I have read that the Princes, Kings, and Emperors who ordered it to be built, have merely exchanged a pile of [Gold] for a pile of marble. Be that as it may, let connoisseurs disparage this wonderful edifice, it will be always admired. Its interior is very imposing, it is divided by fifty two columns, high and Colossal, not massive nor heavy, into the nave and four aisles, two on each [888] side, besides the high altar there are fourteen smaller altars, but they so entirely disappear in the immense area, that not a few have blamed the interior of this Church for its nakedness, whilst I on the contrary was pleased with its simplicity, and preferred it by far to the overloading with Chapels, altars, and all descriptions of ornaments which I have seen afterwards in other Catholic churches. Below the high altar is a subterranean Chapel where mass is sometimes said. Another Chapel, likewise underground, a few steps nearer the entrance is dedicated to San Carlos Borromeo; the Corpse of this gentleman, an archbishop of Milan who died in the year 1584, is preserved here in a coffin of rock crystal, all the ornaments are of massive silver. A winding staircase, square, not round, of granite leads up to the roof which as well as the entire building, the said stair-case excepted, is of white marble. From the centre of the roof considerable raised, stairs descend to its sides which formed of large marble slabs, are nearly flat with a trifling inclination towards the street. This roof is adorned with a countless number of pinnacles (Aiguilles as Victor Hugo would call them), and each pinnacle has on its summit a small statue, a bust, a bunch of flowers or of leaves, all of white marble of course. The Guide book states the length of this Cathedral to be four hundred fifty six feet, its breadth two hundred and seventy eight; that it was commenced under the reign of 
Prince Giovanni Galazzo di Vizconti in 1386; that the architect was Henrich Arler Von Germünd, and that it was concluded under the reign of Napoleon I in 1805 . The word concluded must not be taken in its absolute sense for though in 1855 when I was last in Milan the small statues and other ornaments spoken of above, placed and to be placed on the top of the pinnacles and in the niches at their bases, numbered already four thousand, yet still more were required, and sculptors were continually at work making them. This day the weather did not favor me in the least, it was so foggy that I could not distinguish anything from one end of the roof to the other. From Il Duomo, my guide showed me to the Palazzo di Brezz[_], [889] formerly a college of Jesuits which contains a large collection of paintings, where I remained till one oclock when the Cold (for the saloons were not heated) and an appointment with the marquis obliged me to leave. The marquis lived in the Palace of his family, Contrada della Passarella Number 469 where he inhabited two rooms, a bed room and a sitting room neatly and comfortably furnished. When I entered, he was warming himself before a blazing fire. From his journeys to the East and West, he had brought home many curiosities, thus for instance his coverlid was a Turkish Standard. I remained with him for sometime, and when leaving, he accompanied and introduced me to Club-house Societtá della Unione opposite the theatre di La Scalla, elegantly fitted-up, servants in livery. Here I amused myself with reading the Augsburg allgemeine Zeitung and the Galignanis messenger, the only two foreign newspapers which on account of their conservative tendencies, were in 1844 to be found in all the hotels and Coffeehouses in Italy. At five Oclock, I ordered my guide to show me to Henry Mylius's dwelling house, Casa di Crevelli, Dontrada di Pontaccio. This is a palace like that of the de Litta's, with the difference that the Di Litta's occupied the whole building, whilst the Mylius's rented only part of that di Crevelli. The rooms were here of immense height, twenty two or twenty feet, very cool and pleasant in summer, but difficult to be warmed when the winter is at all severe as it was the case this year. I entered at the same time with a German Gentleman whom I had seen at table d'hote, and of whom I can only say, that he was in the habit of breathing so hard as if he was on the point of suffocating; besides him and myself there was only the family. Mr. Mylius, younger than his brother Jonas, rather insignificant, his wife apparently older than he, who as I was told in the course of the evening was a relation of Obussier who married in Lima Manonga Cardenas, two daughters, the Elder one a widow with four nice little Children, both agreeable enough, and rather good looking, not to be compared however to Miss Katinka von Swetschin; and two sons, the younger who had been with me on the preceding day in his fathers counting house, the elder an Engineer. Dinner was good, not over abundant, the wine was of the Country, for me 
expressly a bottle of Foreign wine was [890] placed on the table. Knives and forks were not changed at every course. The conversation was carried on in German, though Mrs. Mylius owing to her long residence in England had acquired the habit of speaking English with her Children who also spoke this language amongst themselves. I heard Mr. Mylius say that it cost the town of Milan not less than one hundred thousand Florins to clean the streets of the masses of snow which had fallen of late, also that the value of the raw silk exported annually from Lombardy and Venetia amounts to one hundred and sixty millions of francs, and that the net revenue, all expenses deducted, which the austrian Government draws from its Italian possessions comes up to thirty millions of francs. After dinner, whilst Mrs. Mylius was nodding on the sofa and her daughters were occupied with needle work, Mr. Mylius, his eldest son, the hard breather and I played four rubbers at long whist, not very interesting. The German Gentleman and I walked home together; in bed I was foolish enough to read Eugene Sue's Mathilde till half past four in the morning. The object of the author in writing this novel was to show to the world the evils resulting from the French laws which give to the husband full, almost unlimited power over his wife, even though he be such a rascal as Mathilde's husband is represented to be.

Thursday, $19^{\text {th }}$ of December 1844. In the Course of the forenoon, the Marquis di Litta called upon me in his own carriage, and together we drove to an extensive amphitheater situated a little out of town; it is of an oval shape, and large enough it is said to hold thirty thousands persons; three entrances lead into it. At the one extremity stands a handsome Granite building for the use of the Viceroy. From the Colonnade in front of the same many rows of seats, the one rising above the other like steps, descend to the lower inner space called the Circus, destined for sports and other exhibitions; they are of granite and serve for the Viceroy himself, his family and suite, while the remainder of the seats all round the Circus which are for spectators of all classes of society, are made [891] of earth or turf, and covered with boards when used. On the same level with the Viceroyal building, avenues of trees encircle the "Arena", the lowest row of seats is separated from the Circus by a ditch filled with water, which on certain occasions when the circus is [_] converted into a lake, and rowing regattas are to be held, is [...] overflow, and gradually fills the inner space to the depth of several feet. This account I owe more to the description which the Marquis gave me, than to my own eyes, for the Amphitheatre lay buried under the deep snow, and every prospect far and near was made impossible by the dense fog. "La piazza di Armi", a large open place is surrounded by "La Arena", a ruinous fortress (Il Castello), an avenue and Il arco della Pace. To the latter the Marques and I drove; it is of white marble, in the middle is 
the principal passage, the two lateral passages are narrower. The bas-reliefs with which it is adorned are of exquisite workmanship. A winding staircase in one of the pillars, leads to the summit; we climbed up. Here stands the Goddess of Peace in a car drawn by six horses, and at each corner a Victoria on horse back, all of Bronze and of Colossal size (in appendix under $\mathrm{N}^{\circ} 35$, will be found a Lithographic engraving of this Arch). We returned to town, the Marquis left me at the Police Office where I had my passport vised for Como. The weather became worse and worse, it even rained, nevertheless I did not allow myself to be deterred from my habitual long walk which in my travels I have looked upon as a duty not to be neglected on any account when I am on my first visit to a town. With the interior of the houses, the families and their mode of living, a traveller during his short stay of a few days, at the utmost of a few weeks, has seldom an opportunity of becoming acquainted, but he may always take away with him, if he likes, a correct idea of its outward appearance and this is in my opinion, one of the advantages acquired by Travelling. Milan is surrounded by a wall which can hardly any longer serve for a fortification, for it is planted with trees, and avenues and promenades are laid out on it. In the centre, the town is irregularly built and the streets are narrow, towards the gates, they are wider, and have a more modern look, all are well paved, the foot pavement consists of flag stones which are not separated by gutters from [892] the Carriage road. The houses consist generally of the ground floor and three storeys, but in height they surpass five storied houses in other towns. With few exceptions they are plastered over and white washed, many of them have iron balconies, and in grand mansions (Palazzi), a porter lodge is never wanting. I noted [_] extensive hospital with a fine Colonnade in front, $\mathrm{b}$ [...] stone, came to two open places, each with a column in [...] dle, the one surmounted by a female figure with a cross in her hand representing probably the Christian religion, the other with a Stone Lion on the top; also to a "Passage", such as in England is called "Arcade" with shops, not of great elegance on each side. I finished my round with a visit to the Church dedicated to Saint Stephen the Protomartyr, on which I have no particular observation to make; probably some feast had been lately celebrated, for the interior was still decked out of with Crimson gold fringed Damask. Hot potatoes and toasted Chesnuts were being sold at the corners of the streets, the latter we also had for dessert at our table d'hote in the Hotel, the male Chesnuts, French "marons" are considered more agreable to the palate than the females, French, "Chataignes". The Streets swarmed with Austrian soldiers in undress, who, to judge from their language, were almost exclusively from the German provinces of the Austrian Empire, but also without taking the soldiers into account, next to Italian, the language which most struck my ear was German, not French. Of female dwarfs, 
I observed an extremely great number, goiters were much more frequent than in any other large town hitherto visited by me. Amongst the higher classes I saw many a pretty female face; in the lower classes, hardly a single one. After having dined at table d'hote with a few Gentlemen I went in the evening to the small theatre "di Re", where I amused myself extremely well, the Comic opera Don Pasquale, music by Gaettano Donizetti was performed, the actors were without exception under twenty years of age, the eldest from sixteen to seventeen I suppose, the servants and the notary were acted by Children about ten years of age; it was really wonderful [893] to see how well they knew theirs parts and how appropriate were their gestures, their slim and small figures were dressed in the antiquated style of Louis XIV's times, their hair powdered and their youthful faces daubed over with red and white paint.

Friday, $20^{\text {th }}$ of December 1844 . At half past nine, the Marquis de Litta called in his carriage, and we drove to the Railway Station where he took first class seats and paid for them. In about twenty minutes we arrived at Monza, three leagues distant. An electric Telegraph, well known in 1869 when I dictate these lines but as yet in its infancy in 1844, ran alongside the Railway, and, the Marquis informed me, answered well. In Monza, we went at once to the Cathedral, the exterior of which is strange and unusual, I refer to the engraving in the appendix under number 36 . The interior presents nothing particularly striking, on the contrary the pillars which sustain the vault, are short and clumsy. The Marques requested that the treasures of the Church might be shown to us, for which he of course had to pay a gratification. They consisted of the Imperial mantle which was worn by the Emperor Ferdinand at his coronation, it is made of black velvet with extremely rich Golden embroidery and is of such a weight, that the Emperor who is small and delicate could not support it without its being sustained by several pages; next the Pyx which means a small box in which on certain solemn occasions, the host is presented to the faithful, it is of silver, gilt and adorned with numberless precious stones and pearls; also a massive Gold goblet used by the Lombardo queen [...] Theodorinda, foundress of this Cathedral; an imitation of the iron crown, the original of which can only be seen by special license, this imitation consists of a broad golden circle inclosing an iron ring which in the original, is said to be made of one of the nails used in the cross on which Christ was crucified; many Kings of Lombardy have been crowned with this crown, amongst whom I will only mention Charlemagne, Charles V, Napoleon I and Ferdinand I. Maxwell in his rambling recollections speaks of two other relics preserved here which I did not see, viz: a large gilt cross, which has in its centre a crystal containing a portion of the sponge saturated with the identical Vinegar presented to our saviour while crucified, and by him rejected, and a [...] [894] vial containing 
a small quantity of the blood that flowed from the redeemer's side. The Palace inhabited sometimes in the Summer season by the Viceroy Reiner, uncle of the Emperor, I had no inclination to visit, for nothing is more tedious than to be hurried through a number of large splendidly furnished apartments which differ but little from those already seen in other Palaces. In the garden and Park, we walked about a little as far as the snow which was rapidly melting away, would permit us; when the Season is favorable, it must be a pretty spot, of the many hot houses, only few required to be heated by fire, though the plants are exotics, the heat produced by the reflection of the Sun's rays upon the glasses sufficed for the greater part of them. It was time for the Marquis to return to Milan, and as soon as he was gone, I went to a Coffee-House which, though it may be well frequented in summer, was now a wretched place, and for the first time since I am in Italy, the cup in which my Coffee was served, gave evidence of Italian filth, of which so much is said in Northern Europe. I whiled away the time with reading an Italian Journal, and had nearly lost my seat in the diligence, for whilst I was waiting at the door of the Coach for Lecco, that for Como was fast filling. Fortunately I observed my mistake in time, and was the last to make up the number of Six in a coach destined for four only. We were actually wedged the one into the other, and to move a limb was utterly impossible, but my Companions, all Italians, of whose language, the Milanese, I could not understand a word, took it in good part, they joked and laughed, whilst, had they been English, they would for a certainty, had they been German they would probably, have grumbled and stormed. We drove through a level Country with leafless muhlberry-trees, all snow covered. At Mariano, half way, we changed horses. Shortly after, it grew dark, I [_] asleep and did not awake until we drove over the streets in a suburb of Como, Il Burgo di Vico, we passed under a gate [...] few minutes later stopped at l'Albergo dell Angelo, [895] recommended to me by the Marquis. No fire was lighted either in my bed-room, or in the General dining room, to warm myself, I had to go to the Kitchen; my supper was very bad, boiled meat, an Omelette, and sour wine. Though it was still early, having nothing better to do, I went to bed.

Saturday, $27^{\text {st }}$ of December 1844. Having broken my fast with a cup of Coffee and a very small loaf, I sallied forth. At the door of the hotel stood a fellow whom I engaged to show me to the Church, the Cathedral, by no means so large as Il duomo in Milan, not in any other way remarkable. Nevertheless when I entered the same, it made a deep religious impression upon me, attributable not to the building itself, but to the light or rather to the want of light in which I saw it. It was just eight Oclock, a gloom pervaded the entire Church, everywhere men and women were kneeling before the altars, many masses were being said at the same time but in such a low voice, that the one did not interfere with the other, 
and at the Confessionaries women were kneeling pouring an account of their sins into another sinner's ears. This Church built in the shape of a Latin Cross is divided into the nave, and two lateral aisles; there are nine altars: the high altar, two lateral, and six smaller ones. Having left this church, my guide showed me the new Theatre into which the old Castle has been transformed. In an open place stands the Statue of Alessandro Volta, who, born in Como in 1745, has acquired an everlasting renown by various discoveries in the Physical sciences, and above all by the invention of the Galvanic battery, called the Voltaire pile; he died in 1827 . I gave my guide half a franc for his trouble, with which he was well satisfied, then by myself took a stroll out of town. The weather was fast improving, and the snow melting away. I walked through Il Burgo di Vico, filled with Country houses, then struck off into a narrow path which ascended, and on which I met many Country people. I returned by the high road, and was back exactly at eleven oclock, when I had been told on the previous evening that the steamer was to leave, but learned to my great annoyance, that its departure was put off till one p.m. Como lies at the South Western extremity of the Lake to which it gives its name, it is surrounded by hills which extending to the right and to the left encircle the whole lake; only their summits were [896] still covered with snow, on their sides the green grass and the brown earth reappeared, and upon them stood many pretty looking villas or Countryhouses. Close to the hotel is the port which, this day being market day, was filled with covered boats bringing provisions to the town, the streets of which are upon the whole narrow. I did my best to discover something outlandish or particular in the dress and appearance of the Country people, but in vain. It is true I saw many black eyes and much black hair; some girls with naked legs and high heeled wooden sandals tied with leather straps; breeches worn by the men of the lower classes; hats of this shape $\neg$; and a queer head gear of the women, many of whom pass through their plaids behind large metal needles in the shape of half a circle and another one horizontally, so as to imitate a Comb, thus:_. But all this jointly wore by no means such a decidedly Southern aspect; the features of the men were not so marked, their looks not so banditti like, the women were not so beautiful nor interesting, the attire of both sexes was not so fanciful; in one word: everything to the South of the Alps was not so completely different from what I had been accostumed to see to the North of the same mountains, as we North Germans had been taught to believe in the days of our childhood, led astray in our opinion about Italy by what we saw represented on the stage or delineated in a picture, or what we read in novels.

For Continuation, See $3^{\text {rd }}$ Volume. 
Index

\begin{tabular}{|c|c|c|c|}
\hline & & $\begin{array}{l}\text { Continuation of Voyage from Callao to Chile } \\
\text { and back along the Coast including a journey to } \\
\text { Arequipa and Orcopampa }\end{array}$ & $2-48$ \\
\hline \multicolumn{4}{|l|}{1843} \\
\hline \multirow[t]{2}{*}{ Jany. } & 24 to 29 & Journey to Orcopampa & $2-10$ \\
\hline & 29 to & Stay in Orcopampa & \\
\hline \multirow[t]{2}{*}{ Feb. } & 4 & & $10-15$ \\
\hline & & State of C. W. Schutte's affairs & $14-15$ \\
\hline \multirow[t]{2}{*}{ Feby. } & 4 to 8 & Return to Arequipa and & $15^{-20}$ \\
\hline & & stay in Arequipa & $20-27$ \\
\hline \multirow[t]{3}{*}{ Feby. } & 8 to 20 & Outbreak of the revolution in favour of & \\
\hline & & M. J. Vivanco & 20 \\
\hline & & J. M. and Ml. Costas & 20,22 \\
\hline Feby. & 20 & Mrs. Wents death & 27 \\
\hline Feby. & 20 to 22 & Journey to Islay & $27-28$ \\
\hline \multirow[t]{2}{*}{ Feby. } & $23-26$ & Voyage to Callao & $28-29$ \\
\hline & 26 & Arrival in Lima & 29 \\
\hline 1843 & & Connecting Narrative from 26. Feby. to 17. May & $30-48$ \\
\hline 1843 & & New and Old Acquaintances in Lima & $31-32$ \\
\hline \multirow[t]{3}{*}{1843} & & Baths of Altazar & $33-34$ \\
\hline & & G. Candamo & $34-35$ \\
\hline & & Chorillos & $35-37$ \\
\hline Feby. & 27 to & Carnaval & \\
\hline Mch. & 1 & & $37-38$ \\
\hline March & 2 & Comet & 38 \\
\hline Ap. & {$[-]$} & Procession Palm Sunday & 38,32 \\
\hline Ap. & {$[-]$} & Holy Thursday & $39-40$ \\
\hline Ap. & 27 & Death and Funeral of Thos. Greene & $40-41$ \\
\hline \multirow[t]{3}{*}{ May } & 3 and 5 & Archbishop of Lima, death and burial & 41 \\
\hline & & Chas. Pflückers mines of Copper and silver & $42-43$ \\
\hline & & Political news from Afghanistan and China & 43 \\
\hline \multicolumn{4}{|l|}{$[898]$} \\
\hline \multicolumn{4}{|l|}{1843} \\
\hline \multirow[t]{2}{*}{ March } & & Fire in Valparaiso & 43 \\
\hline & & Progress and success of Vivancos revolution & $43-48$ \\
\hline
\end{tabular}


Voyage from Callao to Europe - Journeys

through England, Ireland and Scotland and

voyage across the German Sea to Altona

$48-328$

Capt. Geo. Seymour 48-49,

54

50

May $\quad 18 \quad$ Departure from Lima

Vicente Gonzalez

50, 70-71

Island of Diego Ramirez

61

First sight of Icefields

61

Falkland Isles

62-[?]

Problematical Island Isla de Grande

66

Variation of the Compas - Aberration and dip 68-69

July $\quad 27$

Trinidad and Martin Vasrock

69-70

Gulf Stream

74-75

Great Britain Iron Steamer

75

Saragossa or Weedy Sea

81

Cape Verde Islands

80

Horse Latitudes

83

Azores

$84-88$

Description of watching a dolphins death

Watches on board ship

88

18

In the Chops of the Channel

93

Rennets Current

Espartero

93-9[_]

94-[_]

Intended monument for Herman the German

hero

95

Transference to Pilot Boat Agnes

96

Scilly Islands

[899]

1843

Septr. $\quad 23 / 43$

Penzance

99-104

Septr. 24

Journey from Penzance to Exeter

104-107

Septr. 25

Exeter

107-113

Septr. $\quad 26$

Travelling p. rail (first time) Exeter to London

114-117

Septr. $\quad 26$ to

Residence in London

Oct. $\quad 29$

Political news from Perú

117-197

127 ,

191-192,

230

Drury Lane Theatre

128-129 


Tower
Mrs. Grautoff
Astley's Amphitheatre
Bernard Charlton
Surrey Zoological Gardens
Madme. Tussaud's Wax work
Zoological Gardens - Regents' Park
Windsor
Public meeting in Covent Garden
Visit to Chatham and Robertsons
Chinese Exhibition
West India Docks
Thames Tunnel
Greenwich
Henry Marriott - Hampton Court
Haymarket Theatre
Polytechnic Institution

132-134

134-135

137-138

138-139

140-141

142-145

145-148

148-151

154-155

155-172

175-176

177-178

178-179

179-181

182-185

189-19o

192-195

Birmingham

198

Octr. $\quad 29$ to Liverpool

198-211,

Novr. $\quad 16$

Manchester

$230-238$

Octr. $\quad 31$

Manchester

201-205

Novr. $\quad 5$ to $12^{\text {th }} \quad$ Sea Point nr. Bray, and Seymour

214-221,

227-230

Novr. $\quad 7^{\text {to }} 9^{\text {th }} \quad$ Dublin

221-227

$\begin{array}{llll}\text { Novr. } & 17 & \text { Greenock } & 236-237\end{array}$

Novr. $\quad 17$ to $25^{\text {th }} \quad$ Glasgow and Alexander family $\quad 237-257$

$\begin{array}{lll}\text { Novr. } & 25 \text { to } 29 \text { Edinburgh } 258-278\end{array}$

Novr. $\quad 29$ to Bridgelands nr. Selkirk - family of Rodger,

Decr. $\quad 7^{\text {th }} \quad$ Abbotsford, etc.

279-292

Dec. $\quad 7^{\text {to }} 8^{\text {th }} \quad$ Newcastle-on-Tyne $293-296$

[900]

1843

Decbr. $\quad 8$ to $9^{\text {th }} \quad$ York

297-301

Decbr. 10 and $18^{\text {th }}$ Leeds

301 ,

323-324

Decbr. $\quad 10$ to $11^{\text {th }} \quad$ Bingley - Hardon Grange - Betty Wall

301-306

Decbr. 11 to $18^{\text {th }} \quad$ Halifax - Pie Nest - Craven Lodge - the

Edwards

306-323

Decbr. $\quad 19^{\text {th }} \quad$ Hull

325-326

Decbr. 19 to $21^{\text {st }} \quad$ Voyage to Altona

326-328 
Residence in Altona including a trip to Kiel,

Eutin and back

$329-465$

1843

Decemb. $21^{\text {st }}$

1844

January $1^{\text {st }}$

[901]

1844

Jany. $\quad 17$

Dinner party to celebrate the bethothal of Löhmann and Sophia Willink

329-332

Henry Sieveking, and family

$33[?]-$

Hambg.

$3[?]-339$

340-345

(343-345)

Christmas-eve at Siveckings, Warnholtz's,

Raincke's, G. Knauer's and Semper's

$343-345$

G. Knauer's country-Seat in Eppendorff

346

Christmas presents at Old Mrss. Elmenhorst

3[?]-347

Families of C. Gräpel, and J. C. Donner's

347

$3[?]-351$

Renewal of old acquaintances (348-351)

$3[?]-354$

352

George Baur - Kedenburg - A. Schmidt

C. A. Nopitch - Lübbes - Fritz

Baur - C. H. Donner - Bocklemann - Henry

Baur - Stuhlmann - Warnholtz

353-354

Dor. Kramer - Mr. And Mrss. Gossler - Otto

Heyne

$355^{-356}$

Dr. Stuhlmann, and familiy - dinner party at

Mrss. Baur

Profr. Klausen - Nelly Kramer and

$357-35^{8}$

family - Henry Schaar - Hermann Dryer

359-36o

Altona-Theater, and "tableaux vivants"

362-363

Christmas presents, at Kramers

363

Journey from Altona to Kiel - Kiel - Mrss. Lilie and Son

365-368

Farm Stifft - Hermann Willink, and famly.

369-[-]

Luis Pelt, and Wife - Preetz - Ploën - Eutin

$371-[-]$

Limpricht's, and Bobertag's families

373

Mrss. Tramm, and Misses Willink 
19 Return to Hamburg Via Lubeck

$377-378$

22/23 Railway-ball - my removal to Rainville, fm.

Siveking's

379-381

February 5

Family of the Mathiessens - Mr. Schutt

18

Dinner party at Johannes Limpricht's, and

388-391

Guests

393

$28 \quad$ Ball at Senator Isaac Hesse's

399-401

March $\quad 16$

My dinner party

27

Examination of the pupils of the Altona

408-410

Gymnasium - Thalia Theater in Hamburg

$415-416$

Farewell speeches of Altona Collegian

416-417

31

Saint Chatherine's Church, in Hamburg

418-419

April 5

Walk by myself to Blankenese

420-424

Walk to Nienstadten, with the Raincke family

426-427

Description of Hamburg - battle of

Bornhoved

$431-433$

Peruvian Politics

434

Theft of my Coins and medals - Presents

made to Count and Countess Von Blucher

Altona

28

Christening of Semper's Child, Richard

$437-438$

$5^{0^{\text {th }}}$ anniversary of the Wedding of Ct. and

May $\quad 1^{\text {st }}$

Cess. Von Blucher

439-442

Excursion to Rainbeck, with the Kramer's

$443-445$

A Small dinner party given by me

446-447

Semper's dyed Woolen yarn manufactory

My birth-day celebrated at old Mrss. Siveking's 449-451

Excursion to Haarburg, and the Sch[w]

artzberg with the Kramer's, and the Bobertag's

$45^{2-454}$

Hamburg Joanneum - C. H. Donner's Country

Seat

454-455

14

Excursion to Blankenese, with Kramer's and

Bobertag's

$456-457$

Day spent with the family of Joes. Limpricht's, and the Bobertag's

$457-45^{8}$

Laying of the foundation-Stone of the Altona

Railway terminus

460

19

Removal from Rainville's to

Semper's - Semper's family

$460-461$ 
[902]

1844

May $\quad 28^{\text {th }} \quad$ Journey to Lubeck

$29^{\text {th }} \quad$ Lubeck - Cathedral (466) - St. Mary's Church (468-469) - Travemunde (470-471)

$30^{\text {th }}$ to Eutin, its environs (471-475) - Bossau (476)Ploen (479) and environs (473) - 2 evening parties (479) -

June $\quad 5^{\text {th }}$

$5^{\text {th }}$ to $8^{\text {th }} \quad$ Walk fm. Eutin to Frederickshoff (481-483)Frederickshoff - Hesenstein (483), on estate of Panker (484) - Hermn. Willink - environs of Frederickshoff (485) - something about farming (486) - Condemnation of OConnel (486)

$8^{\text {th }} \quad$ Walk from Frederickshoff to Kiel

$9^{\text {th }}$ to $13^{\text {th }}$ Kiel - Clergyman Harms (492) - Stifft and environs (493-495) - families Willink and of Federsen (493-494) - cousins Willink (494) Mrss. Pelt, Ernest Lilie and his mother (498) Lectures in the university to Students (498) $14^{\text {th }} \quad$ Voyage $\mathrm{fm}$. Kiel to Flensburg (500-502) - drive to Obdrup (502) - Fritz Wall and family $15^{\text {th }}$ to $16^{\text {th }}$ Something about the dairy $(502)-$ Customs in Angln (503) - Edlefsens (504), and Mrss. Blüme in Satrup (505)

$17^{\text {th }} \quad$ Drive from Obdrup to Gravenstein - Glucksburg (505-506) - Hølness (507-508)

$18^{\text {th }} \quad$ Gravenstein (510) - Sunderburg (511-512) Castle of Augustemburg, and Boyden (512-513) $491-498$

466-642 466-467 $467-471$ $471-480$ 481-489 $489-491$ 498-502 $[-]-505$ 505-509 $510-513$ 
$19^{\text {th }}$ to $21^{\text {st }}$ Faaburg - J. Plough and family $(514-516)-$ King Valdemar the Conqueror (516) - Schleswig and Holstein politics (519) - Hwedholm, property of Count Bille-Brahe (518) - Horne (519) Swanige (520) - Brahe Trolleberg (522) $22^{\text {nd }}-23^{\text {rd }}$ Journey to Odensee - Odensee (523-525) $24^{\text {th }} \quad$ Journey $\mathrm{fm}$. Odensee to Roskilde

$25^{\text {th }} \quad$ Roskilde - Cathedral (528-530) - Journey to 526 Copenhagen (531) $26^{\text {th }}$ to $29^{\text {th }}$ Copenhagen - Zarthmann's $(534-535)$ - Adolphe's (535) - Exchange (536) Christiansborg (536) - Garlieb (537) Thomsen (538) - museum for Northern antiquities - Port of Copenhague (539) - audience from King Christian VIII (539) - round tower (539) - Royal museum (540) Constant Von Dirkink

June $29^{\text {th }}-30^{\text {th }} \quad$ Passage to Elsineur - Elsineur (542) Fredensburg (543) - Fredericksburg (545-546) - Peter Limpricht and family (546)

July Copenhagen - Dock-yard, or Holm (547-551) walk round the ramparts (551) - Thorwaldsen's statues in Christianborg (551-552) - museum built for their reception (553, 563) - Royal Palace in Amalianborg (553) - Rosemborg Palace (554-556) - Charlottemborg (557-559) - Collection of Copper-plates - Theatre (560) - visit to L. N. Hvidt (560-561) - Vedbeck - our Saviour's church $(562)$ - Sorgenfries (563) Our Lady's church - the 12 apostles and Christ by Thorwaldsen (563)

$9^{\text {th }}$ to $11^{\text {th }} \quad$ Voyage from Copenhaguen to Christiania Gottemburg (567)

$11^{\text {th }}$ to $12^{\text {th }}$ Christiania and environs - Mr. Feedemann (570-572) $569-572$ 
$13^{\text {th }}$ to $16^{\text {th }}$ Journey to Kongsberg, and back to Christiania prospect from Kongen and Dronningen (575) Modum zaffar works (577-580) - Kongsberg (580) and Silver mines (582) - Drammon (583) 572-583

$16^{\text {th }} \quad$ Christiania $\left(583^{-584}\right)-$ Stortings - Lucas Willink (585) 5 $53^{8-585}$

$17^{\text {th }}$ to $22^{\text {nd }}$ Journey to Drondheim - mjøsen lake $(587)-$ Lille-Hammer (588) - Dorre-Fjield (594-596) 586-599 $22^{\text {nd }}$ to $24^{\text {th }}$ Trondjheim - Cathedral $(601)-$ institution for deaf and dumb (601-602)

$25^{\text {th }}$ to $28^{\text {th }}$ Voyage $\mathrm{fm}$. Trondjheim to Bergen - loss and recovery of my watch in Kirkelanded island (6o7-6o8) - the Steamer Struck (610) Hornølen rock (611)

$29^{\text {th }}$ to $31^{\text {st }}$ Bergen

August $1^{\text {st }}$ to $9^{\text {th }} \quad$ Journey from Bergen to Christiania - Voring Fossen (625) - Helmsdallen Fjield, or Halmeller jab Fjield (632)

$9^{\text {th }} \quad$ Christiania $635-636$

$10^{\text {th }}-12^{\text {th }} \quad$ Voyage from Christiania to Copenhague Fredrickshawn (637) - Gottemborg (638-639) 636-639 $12^{\text {th }} \quad$ Copenhaguen - Professor Eschricht's museum (640) 639-640

$13^{\text {th }}$ to $14^{\text {th }}$ Voyage from Copenhague to Kiel, and Journey to Altona

Residence in Altona from 14 of August to $3^{\text {rd }}$ of September 1844

Augt. $\quad 14^{\text {th }} \quad$ Charles Willink and family

1844

August $\quad 24^{\text {th }} \quad$ Doctor Tschudi - Edward Raincke's birth-day $\quad 645^{-646}$ $25^{\text {th }} \quad$ Dinner parties at Mr. Fritz Bauers and at Mrss.

Dankert's $647-648$

War between France and Marrocco - Death of Russn. Princess Alejandra - Orijin of Victualian-Brüder 
Journey fm. Altona to Alexisbad, Leipsic, and

Berlin, and back to Altona from $3^{\text {rd }}$ to $16^{\text {th }}$ of

Septb. 1844

$650-696$

September $3 / 4^{\text {th }} \quad$ Passage from Altona to Haarburg, thence by

Stage coach to Leerte

650-655

$4^{\text {th }} \quad$ Journey per rail fm. Leerte to Halberstadt, by

Post chaise to Alexisbad

$65^{2-655}$

$5^{\text {th }} \quad$ Excursion through the Selke Valley (656-657)

- Falkemstein Castle (657) - Ballenstedt (658)

- Beet-root Sugar (658-659)

$656-659$

$6^{\text {th }} \quad$ Excursion to the Bode Valley $\left(659^{-660}\right)$ - Ross-

trappe (660) to Haberstadt (661)

659-662

$7^{\text {th }} \quad$ Journey fm. Halberstadt to Leipsic - RWay

travellg. (663) - Magdeburg (664)

$662-664$

$8^{\text {th }} \quad$ Leipsic - Poniatowski (664) - Journey to

Berlin

664-668

$8^{\text {th }}$ to $14^{\text {th }}$ Berlin - Brandenburg gate (666) -

Thiergarten - Krolls establisht. (667) -

Exhibition (669) - Konigstadter theater (669) - Description of Berlin (670-671) historical notes $(671-672)$ - Deaf and Dumb establishment (673-674) - mausoleum in Charlottenburg $(675)$ - Belle alliance Platz (676) - Kreutzberg $(676)$ - heroes of the seven years war (677) - museum (678-679)

- Potzdam (679) - San-souci (680) - queen

Luisa's mausoleum (681) - New-Palace (681) antiquarium (682) - Kunts Kammer (683-684)

- Il Templario in the Königstadter Theatre (685)

$668-685$

$15^{\text {th }}$ to $16^{\text {th }}$ Journey per rail to Magdeburg, thence by Steamer to Hamburg

$685-686$

Residence in Altona, from $16^{\text {th }}$ to $29^{\text {th }}$ of

September 1844

688-996

Altona-Kiel Railway

689

$18^{\text {th }} \quad$ Inauguration of Altona-Kiel Railway

$23^{\text {rd }} \quad$ Peruvian Politics - Lima-news (689-69o)

689-69o

691 
$21^{\text {st }} \quad$ Launch of Knauer's vessel "Emily" (691-692) Peace between France and Marrocco (693-694) - German Custom House league revenue (692)

$2^{\text {nd }} \quad$ Walk and dinner at Knauers in Eppendorf (692) - rega[tt]as on Alster

[905]

1844

September $25^{-2} 6^{\text {th }}$ $29^{\text {th }}$

Septembr. 29 to

October $\quad 2^{\text {nd }}$

Dinner at Old Mrss. Elmenhorst - dinner given by Theodore Elmenhorst and Warnholtz Dinner party at Lawyer Stuhlmann's 695 696

Voyage from Altona to Amsterdam, and journey through Holland, Belgium, up the Rhine, through Switzerland till Como. From $29^{\text {th }}$ September to $27^{\text {st }}$ December 1844 $696-896$ Passage from Hamburg to Amsterdam - Amsterdam and environs - Diel. Schutte (698) - dinner party a Ernest Sillem's (699) - the new town-house (701) - the Palace (702) - excursion to Brock (704) and Zaardam (705)

696-706

$5^{\text {th }} \quad$ Harlem $(706)-$ Leyden $(707-708)-$ The Hague (708) 706-708 $6^{\text {th }} \quad$ The Hague - Schevelingen (709) - the Royal Palace in Het Bosch (709-710) - Rotterdam 708-710 $7^{\text {th }} \quad$ Journey to Antwerp (710-711) - Dordrecht (710) - Breda (711) $8^{\text {th }} / 9^{\text {th }} \quad$ Antwerp - Docks (713) - Cathedral (714) Saint Jaques Church (714) - Theatre (715) Walls (715)

$9^{\text {th }} \quad$ Journey to Brussels - the family Ropsy 712-716 716 Brussels - Victor Ropsy and wife (717) Town-house (717) - Place des Martyrs (718) - Hospital (718) - Church Ste. Gudule (719) dinner at Duvergers (719) - Royal park Theatre (719)

${ }_{11}{ }^{\text {th }} \quad$ Adolphe Bosch (719) - Chambre des Deputes (720) - Le mannequin (721) - Le Grand Theatre (721) - Fanny Elssler (722) 


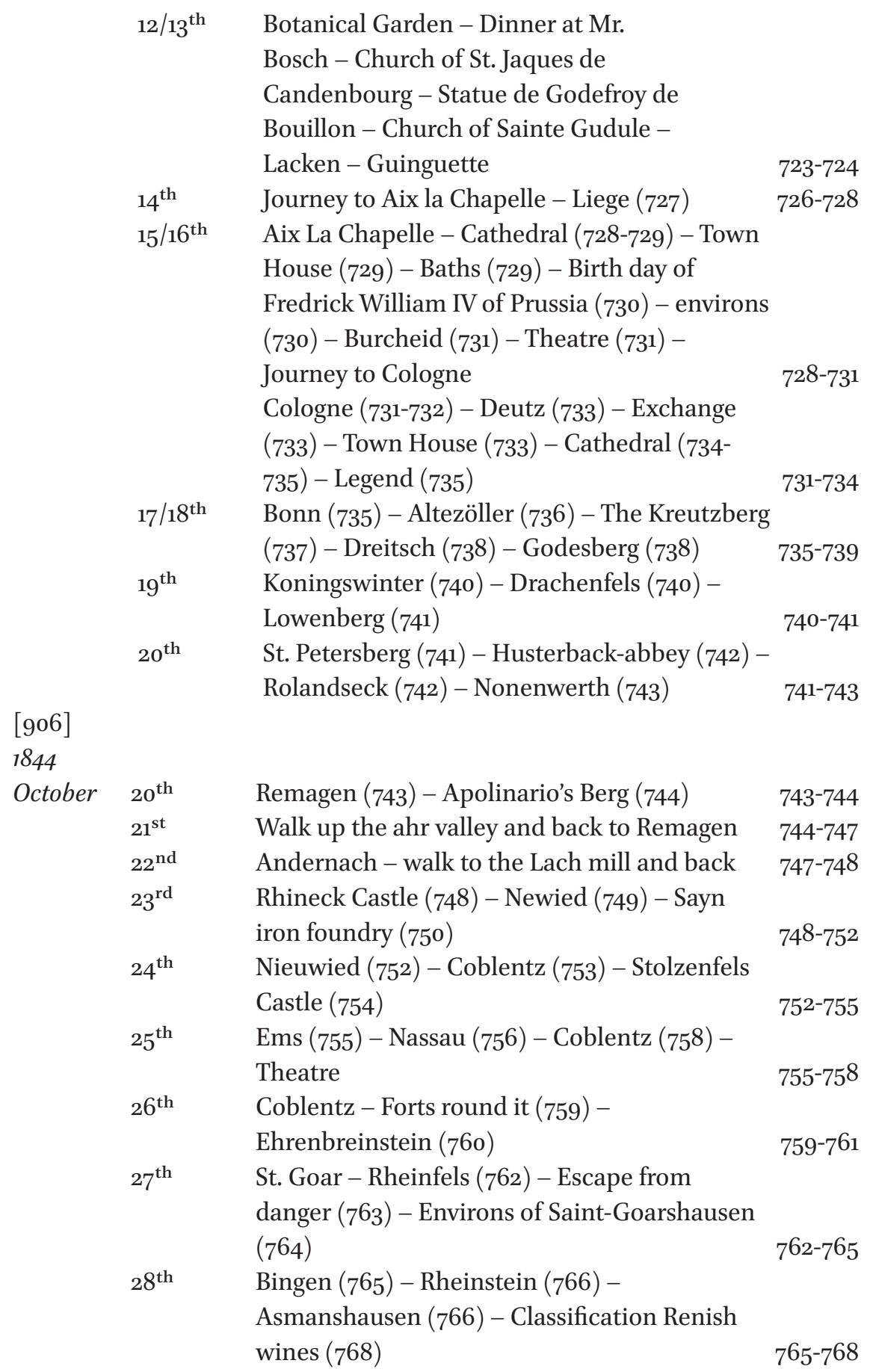




\begin{tabular}{|c|c|c|c|}
\hline & $29^{\text {th }}$ & $\begin{array}{l}\text { Rudesheim }(768) \text { - Geissenheim }(769) \\
\text { - Johannisberg }(769) \text { - Bieberich }(769)-\end{array}$ & \\
\hline & & Wiesbaden (770) & $768-770$ \\
\hline & $30^{\text {th }}$ & Wiesbaden (770) and its environs (771) - & \\
\hline & & Mayence (772) & $770-772$ \\
\hline & $3^{1^{\text {st }}}$ & Mayence - Wonderful Clock - Walk round the & \\
\hline & & town - Prince Witgenstein and daughter & $773-777$ \\
\hline Novembr. & $1^{\text {st }}$ to $4^{\text {th }}$ & Francfort on the Main - Jonas Mylius (778) - & \\
\hline & & Homburg (778) - Deaf and dumb institution & \\
\hline & & (779) - Dannecker's Ariadne (78o) - & \\
\hline & & Cementery (78o) - Pfeils - Dinner at Mylius's & \\
\hline & & $(782)$ - Städtel's museum $(783-784)-$ Baron & \\
\hline & & Von Tiennen adlerflicht (784) & $777-785$ \\
\hline & $5^{\text {th }}$ & Journey to Heidelberg passing through & \\
\hline & & $\operatorname{Dar}[\mathrm{m}] \mathrm{stadt}$ & $785-787$ \\
\hline & $5^{\text {th }}$ to $7^{\text {th }}$ & Heidelberg (787) - Charles Ropsy (788) & \\
\hline & & - Ruins of Castle (787) - Lectures in the & \\
\hline & & university (788-789) - Kaiser's stuhl (789) & $787-790$ \\
\hline & $8^{\text {th }}$ & Journey to Baden-Baden (790-791) - & \\
\hline & & Baden-Baden (791) - Old Castle (792) - drive & \\
\hline & & to $\operatorname{Kehl}(793)$ & $790-793$ \\
\hline & $9^{\text {th }}$ & Strasbourg (793) - Cathedral (794) - Journey & \\
\hline & & to Carlsrhue $(795)$ - Carlsrhue $(796)$ & $793-796$ \\
\hline & $10^{\text {th }}$ & Drive to Stuttgard (796) - Pforzheim (797) - & \\
\hline & & Stuttgard (797) - Theatre (797) & $796-797$ \\
\hline & $11^{\text {th }}$ & Stuttgard (798) - Canstadt (798) - Esslingen & \\
\hline & & (799) - Family Roessler (799) & $797-800$ \\
\hline & $12^{\text {th }}$ & Museum (800-802) - Niobites and & \\
\hline & & Eaginates - Journey to Tubingen & $800-803$ \\
\hline & $13^{\text {th }}$ to $14^{\text {th }}$ & Tubingen - Mrss. Mayer, formerly Alfrede & \\
\hline & & Dede (804) - Theodre. Hepp and family (804) & \\
\hline & & - Baron and Baronness von Wehrter (805) & $803-806$ \\
\hline & $15^{\text {th }}$ & Drive to Schaffhausen & $806-807$ \\
\hline & $16^{\text {th }}$ & $\begin{array}{l}\text { Shaffhausen }(807) \text { - Walk }(808) \text { - Water fall } \\
(800-810)\end{array}$ & $807-810$ \\
\hline & & $(809-810)$ & $807-810$ \\
\hline & $17^{\text {th }}$ & Journey to Constance - Constance & $810-812$ \\
\hline & $18^{\text {th }}$ & Constance - walk to Hohenrain (812) & \\
\hline & & - Council-room (813) - account of its & \\
\hline & & proceedings (813) - Saint-Gallen (814) - G. G. & \\
\hline & & Mayer (814) & $Q_{1}$ \\
\hline
\end{tabular}


[907]

1844

Novemb. $19^{\text {th }}$ to $20^{\text {th }}$ Saint Gallen and environs - Excursion to the

Ebernberg, through Appenzell and back to

Saint Gallen $\quad 814-821$

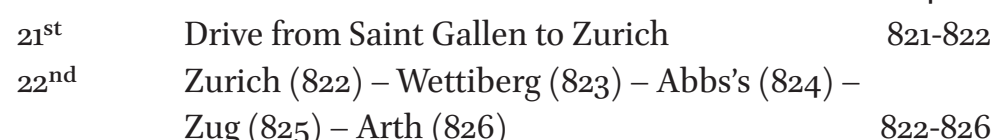

$23^{\text {rd }}$ to $24^{\text {th }}$ Ascent of the Riggi $(827)-$ Descent to Tells

Chapel (829) - Lucerne and environs $(832)$ -

The Lion Sculptured by Thorwaldsen $(832) \quad 826-834$

$25^{\text {th }} \quad$ From Lucerne to Meiringen $834-838$

$26^{\text {th }} \quad$ From Meiringen to

Grindenwaldt - Rheichenbach Cascade (839)

- Scheydeck (839) - Roselaui Glacier (840) -

upper and lower Grindenwaldt Glaciers (840)

- avalanches (841) - Grindenwaldt (841)

$27^{\text {th }} \quad$ From Grindenwaldt to Interlacken and

$838-842$

Unterseen - Staubach Cascade (843) -

Environs of Interlacken (844)

$842-845$

$28^{\text {th }} \quad$ Interlacken $(845)$ - walk to Thunn $(845)-$

Thunn (846) - drive to Berne (846)

$845^{-8}-87$

$29^{\text {th }} \quad$ Berne (847) - Drive to Fribourg (848) -

Fribourg (849-850)

$30^{\text {th }} \quad$ Environs of Fribourg (850) - Drive to Vevay

$\left(85^{-}-85^{2}\right)$

$847-850$

850-852

Decembr. $1^{\text {st }} \quad$ Environs de Vevay $(852)-$ dinner party $(853)-$

Flora Tristan $(854)$

$85^{2-854}$

$2^{\text {nd }}$ to $3^{\text {rd }}$ Misses Pfeil, and Von Swetschin - Castle of

Chillon (856-857) - misses Pfeil, and Von

Swetschin

$855-858$

$4^{\text {th }} \quad$ Drive to Lausanne - Lausanne and its environs $858-859$

$5^{\text {th }} \quad$ Ouchy (859) - Passage to Geneva (860) $\quad 859-860$

$6^{\text {th }} \quad$ Fernay (661) - Geneva (662) 860-862

$7^{\text {th }} \quad$ Drive from Geneva to Salanches $\quad 862-864$

$8^{\text {th }} \quad$ Walk from Salanches to Chamounix $\quad 864-867$

$9^{\text {th }} \quad$ Walk to La mer de glace, and back to

Chamounix - my fall, imminent danger, and

Escape (869)

$867-870$ 


\begin{tabular}{|c|c|c|}
\hline $10^{\text {th }}$ & $\begin{array}{l}\text { From Chamounix to Martigny, across La tête } \\
\text { noire }\end{array}$ & $870-872$ \\
\hline $11^{\text {th }}$ & Martigny - Water fall of Pissevache & $872-873$ \\
\hline $12^{\text {th }}$ & $\begin{array}{l}\text { Ascent from Martigni to the "Hospice du great } \\
\text { St. Bernard" }\end{array}$ & $873-876$ \\
\hline $13^{\text {th }}$ & $\begin{array}{l}\text { Hospice on the Great St. Bernard - descent to } \\
\text { Martigny }\end{array}$ & $876-878$ \\
\hline $14^{\text {th }}$ & Drive by diligence fm. Martigny to Brieg & $878-879$ \\
\hline $15^{\text {th }}$ & $\begin{array}{l}\text { Drive by diligence from Brieg to D'Omo } \\
\text { d'Ossola, includg. passage of the Simplon (881) }\end{array}$ & $879-882$ \\
\hline $16^{\text {th }}$ & $\begin{array}{l}\text { Drive by diligence from D'omo d'Ossola to } \\
\text { Milan }\end{array}$ & $882-884$ \\
\hline $17^{\text {th }}$ to $19^{\text {th }}$ & $\begin{array}{l}\text { Milan - Marquis Alessandro di } \\
\text { Litta - Il Duomo - dinner at Henry } \\
\text { Mylius's - La Arena - Arco della Pace - Teatro } \\
\text { di Ré }\end{array}$ & $884-893$ \\
\hline $20^{\text {th }}$ & $\begin{array}{l}\text { Cathedral of Monza (893) - Drive to Como } \\
(894-895)\end{array}$ & $893-895$ \\
\hline $21^{\text {st }}$ & Town of Como & $895-89$ \\
\hline
\end{tabular}




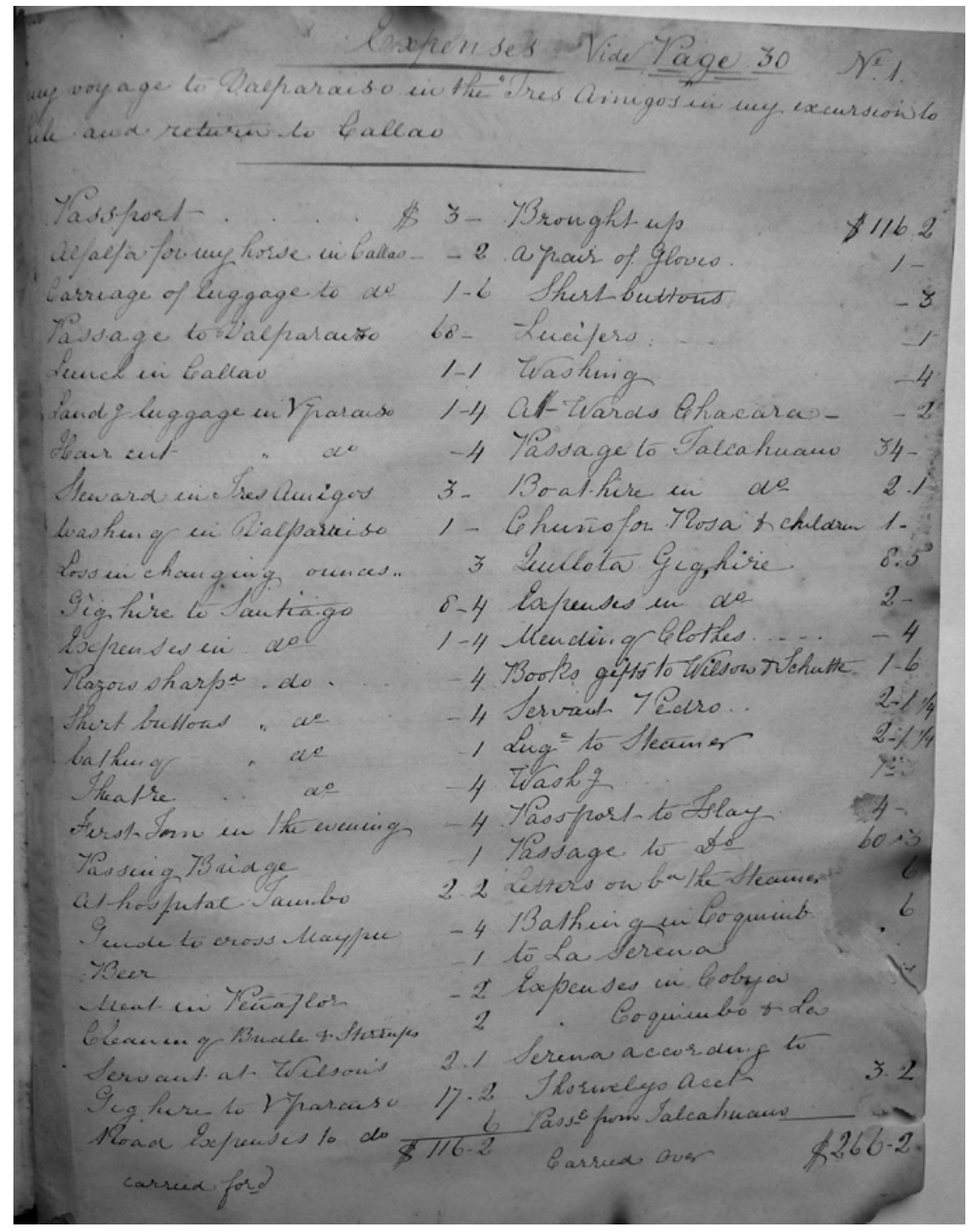

A-2-1. OA-2-1-1 
Sroughl forward

doothat cardes on bes themer

dentlire Hayme.

to Serst on foc Stecemer

A bouk of thang do belet un Yronchofordo sops at the Gan bo - Tral slay to arequipa To. Tasas luck ones afras of thoes un Areg a 1 tb of Grerew Gaudes do - Mendur of Glotites Areopanpar Ghicha

$$
\text { " Towl }
$$$$
\text { Yhosur of trahts. }
$$

frovarde un levllu.ce

$$
\begin{aligned}
& \begin{array}{l}
\text { Gurde } \\
\text {-un Ghachecary : : }
\end{array} \\
& \text { * Arriero }
\end{aligned}
$$$$
\text { to }
$$$$
\text { ter }
$$

Takras to Tosta.

viesdes for the chacrea.

1\%ryellow ileves

Carruage of bove to Silay

lostal. Tikot.

nkendur of thoes
2662 YBrought up \$334-

2- Degoshorselot.m. Dlay 10.

- I ly horses and astew

2 Q diais to Solay Deargo

2 - unles thomozo 2 .

- 2 lo olago x traje un Areg 4 .

$1 / 2$ Manilewance of Sor

I hove ui Areqa

19. unerden of fiolanas

-5 Lopos un the Caubo $5 \mathrm{l1} / 2$

$1-3^{2}$ Pificha

8- hant of Sugathosde

- 6 unidolay- Guremlo I

2 Dupowher ca cerai 6

- 11/2 Lug eseafsyar Slecuerer 1-4

-4 " 10 av 2-2

- 6 to relurenges. Dlecuner I

-4 Yasonge to halcav sel 34-

-4. .. Aocencera 34-

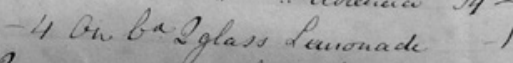

"... bol Skesy I

1-2 Landz un Gacas 2

12. Gargados no 1 -

2- Uacleage av 5

-4 Carrange do Leura S5.

- 4 An Govraxivite

3 -4 Yorlac

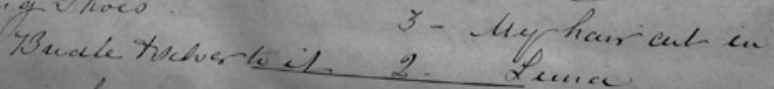

carred for 1

A-2-2. OA-2-1-2 


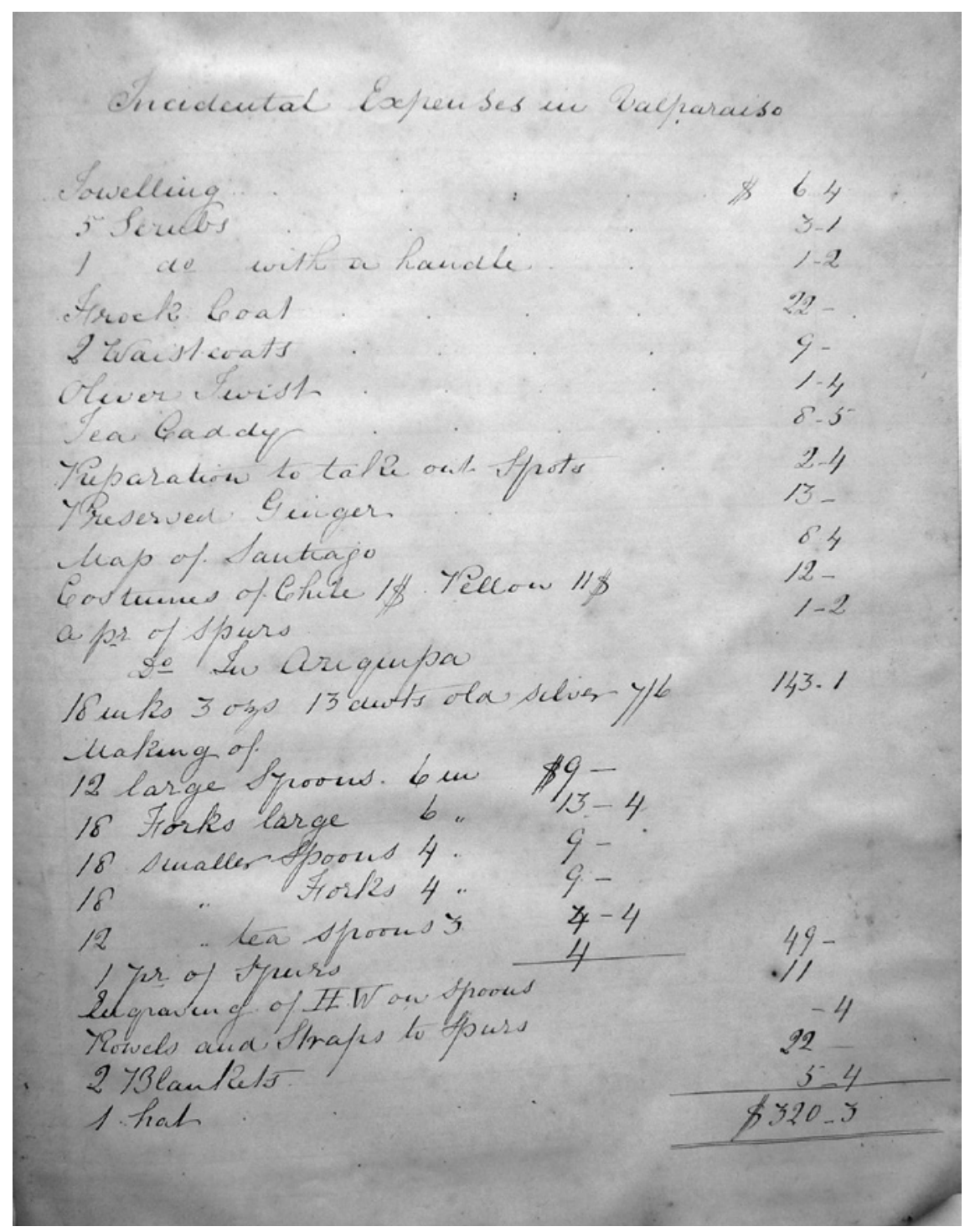

A-2-3. OA-2-1-3 


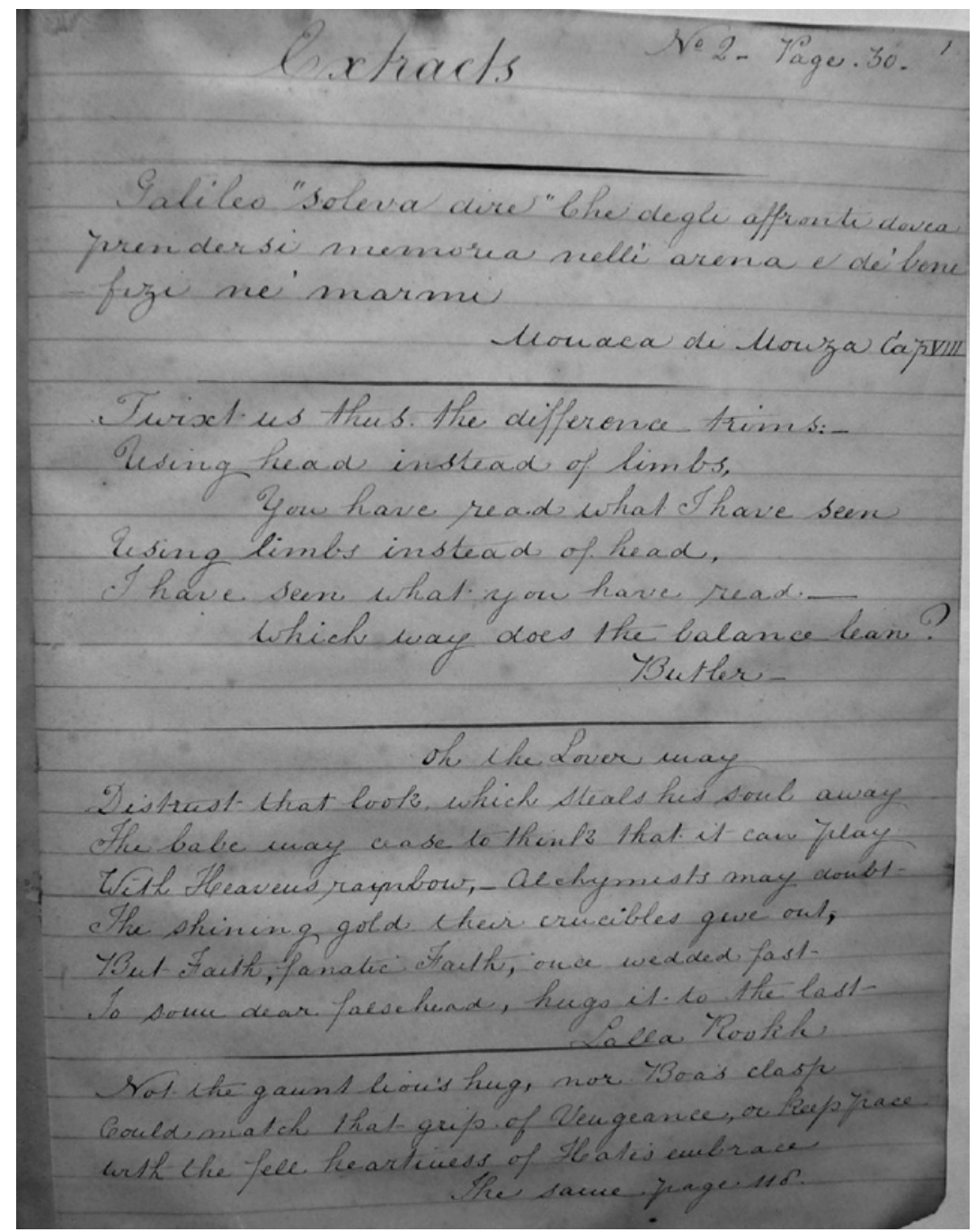

A-2-4. OA-2-2-1 


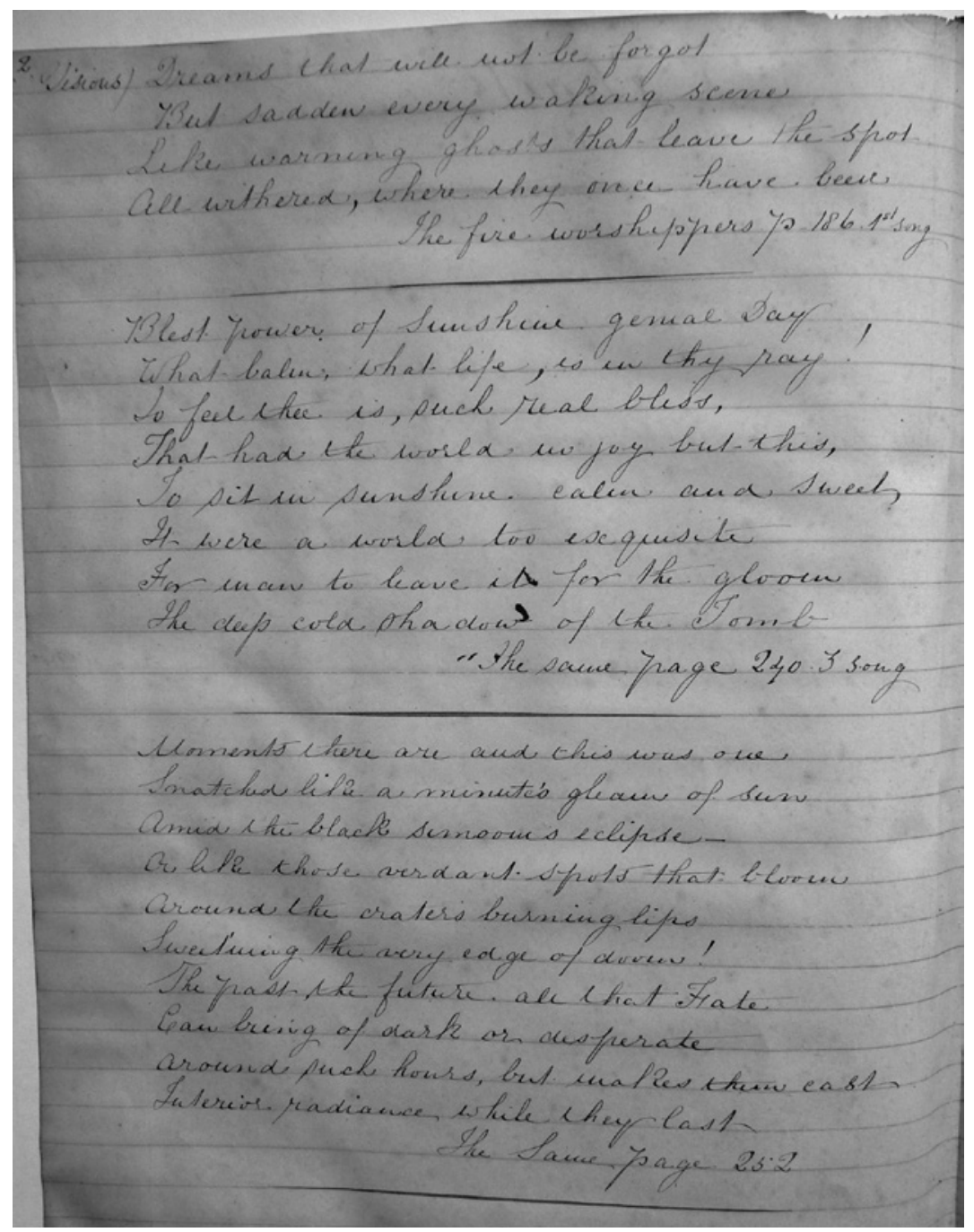

A-2-5. OA-2-2-2 


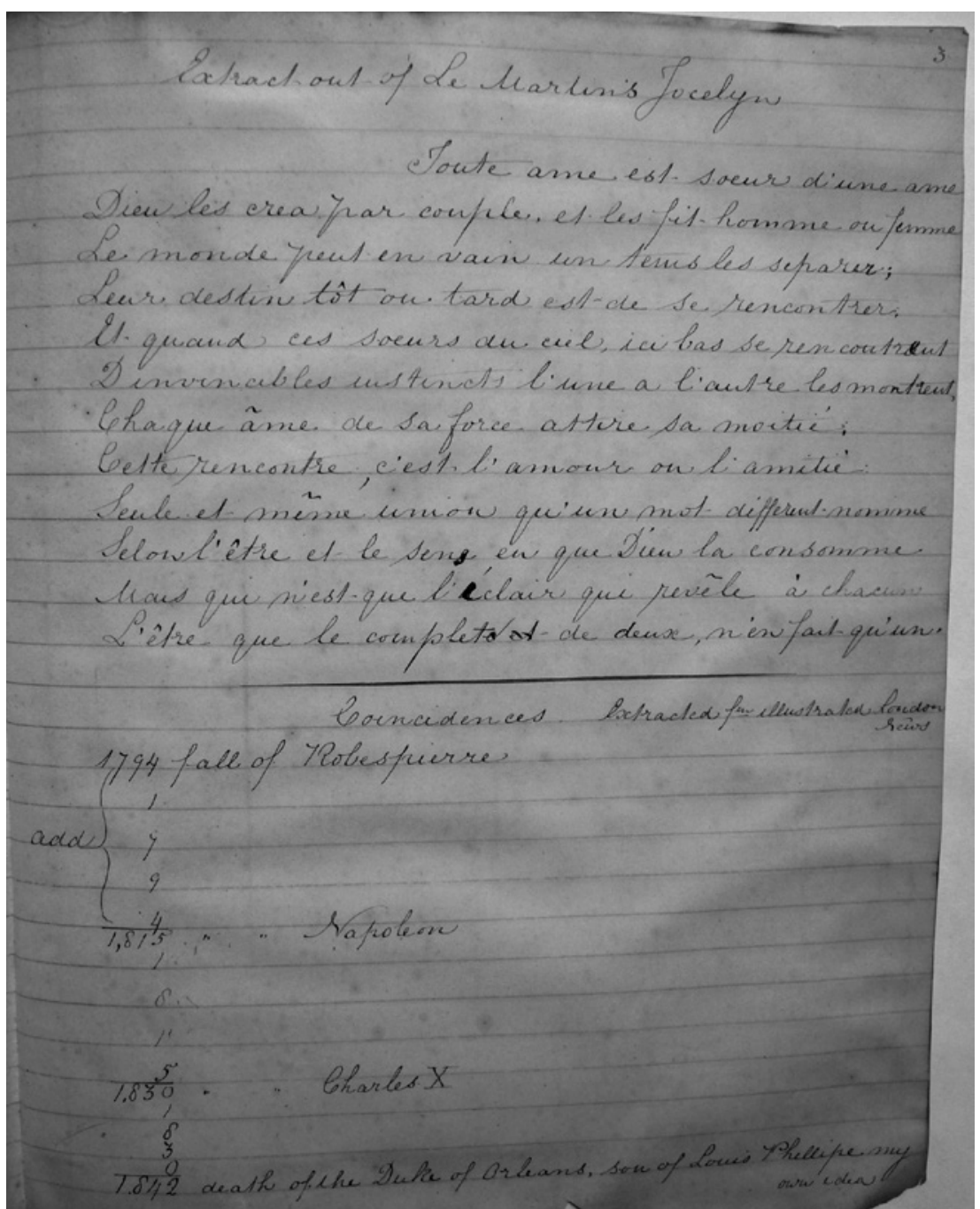

A-2-6. OA-2-2-3 


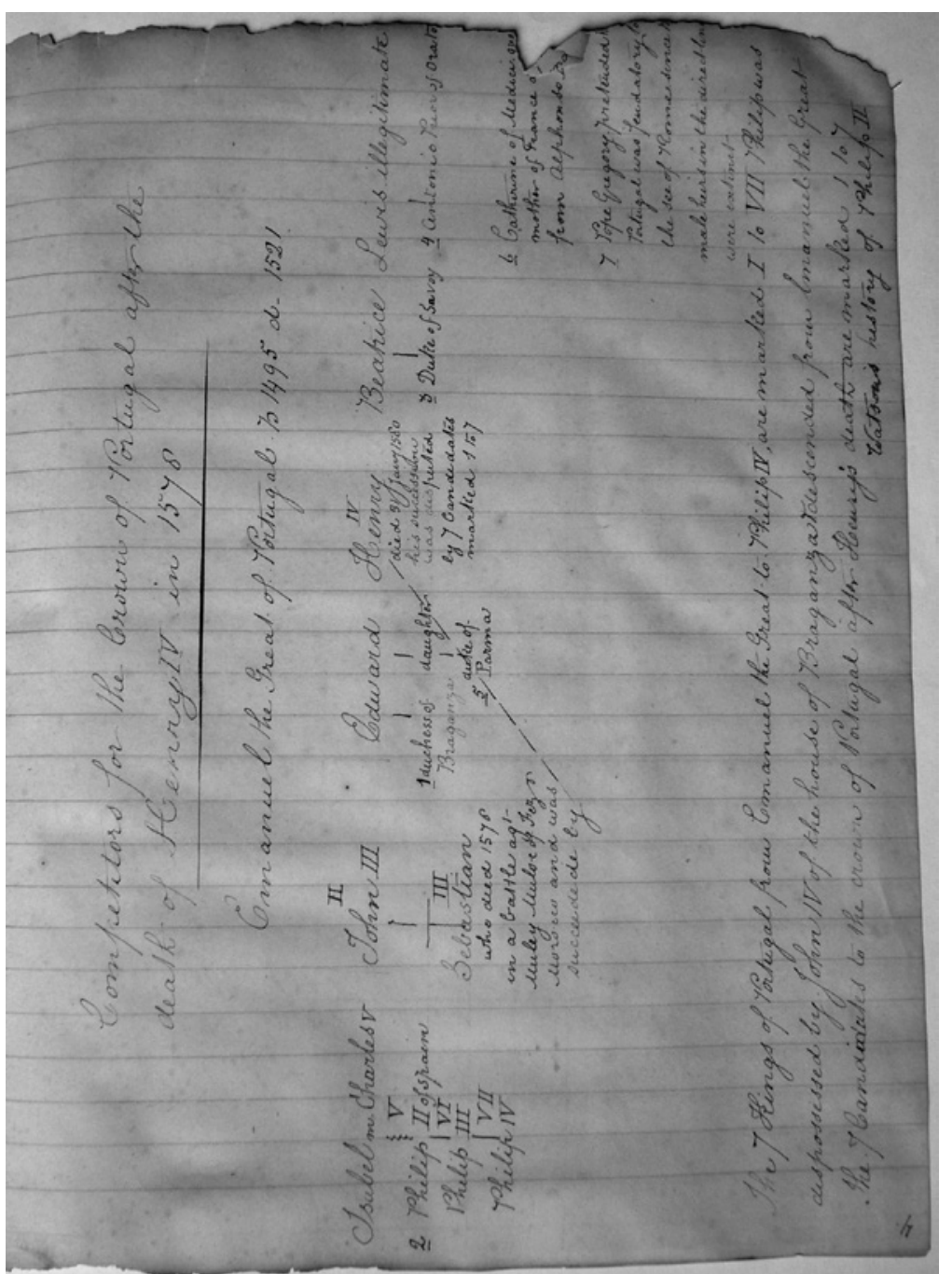

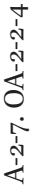




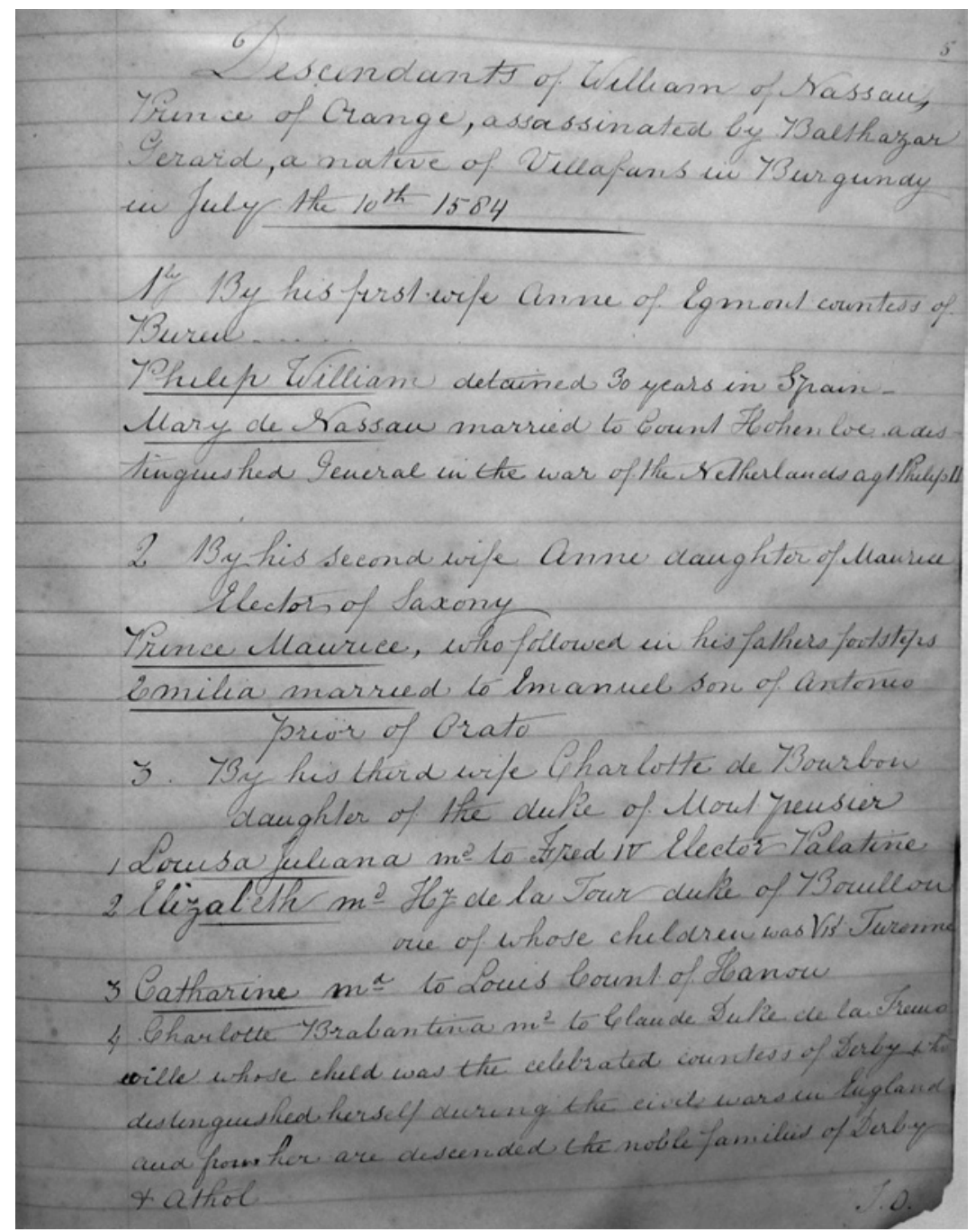

A-2-8. OA-2-2-5 


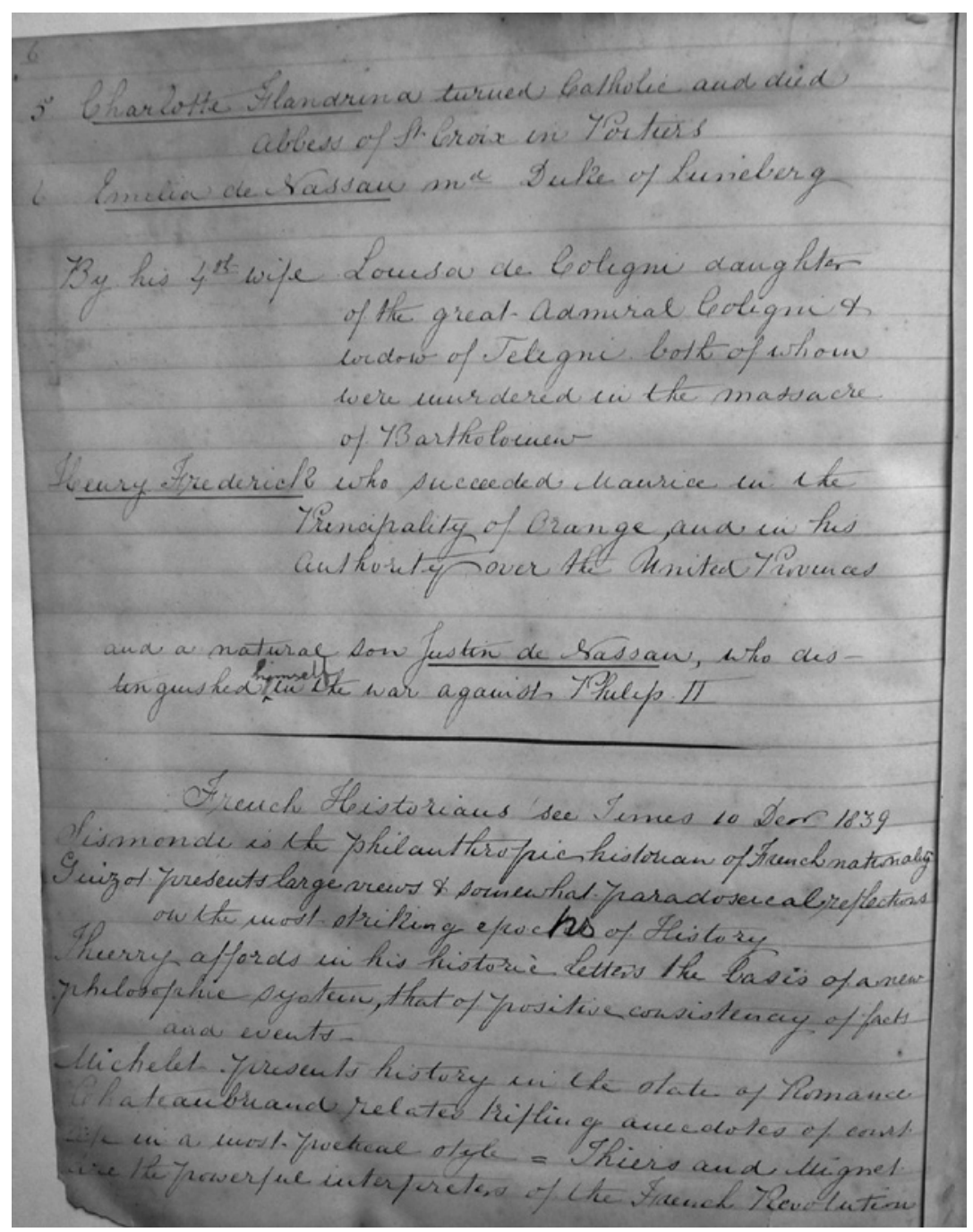

A-2-9. OA-2-2-6 


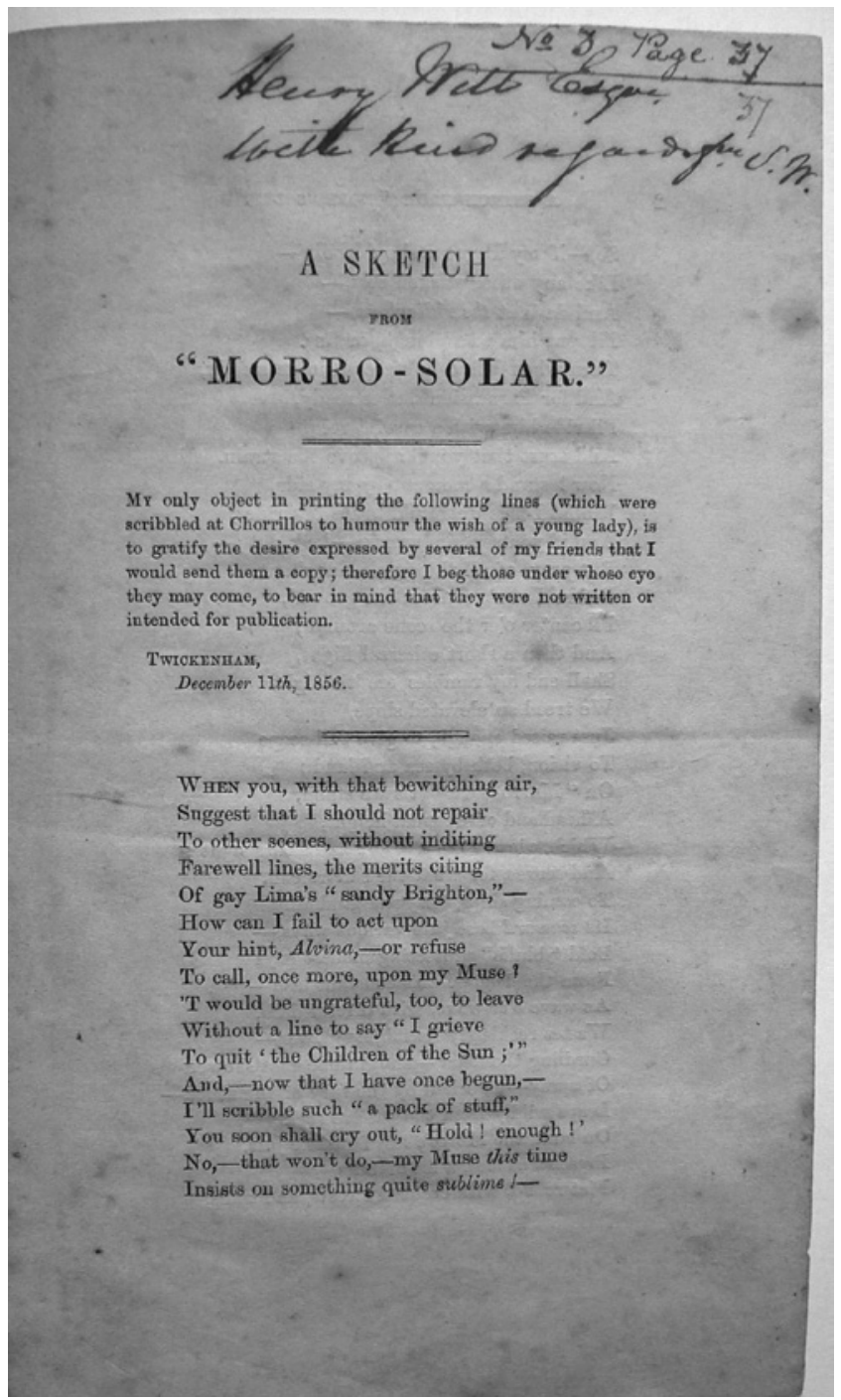

A-2-10. OA-2-3-1 


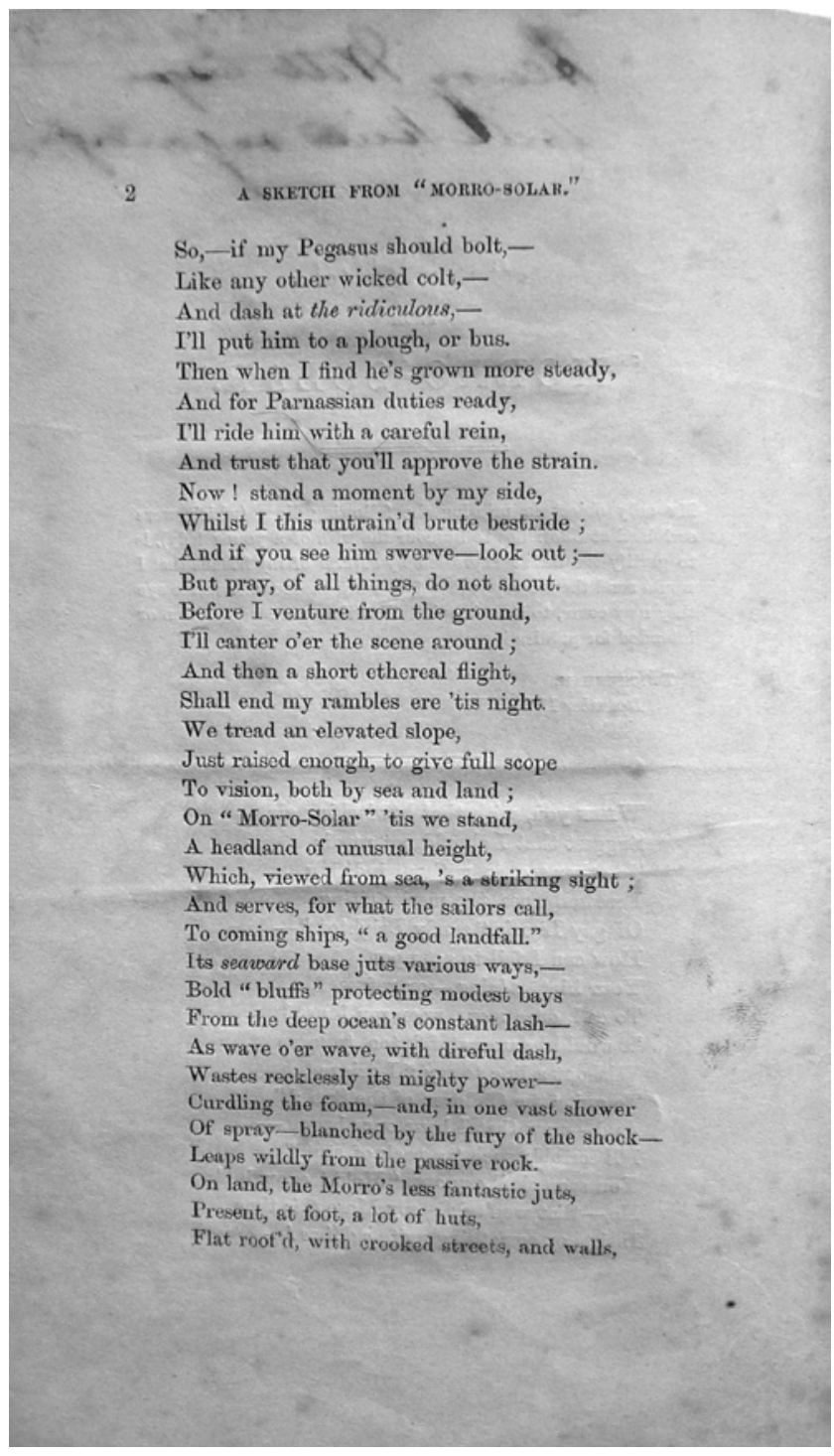

A-2-11. OA-2-3-2 


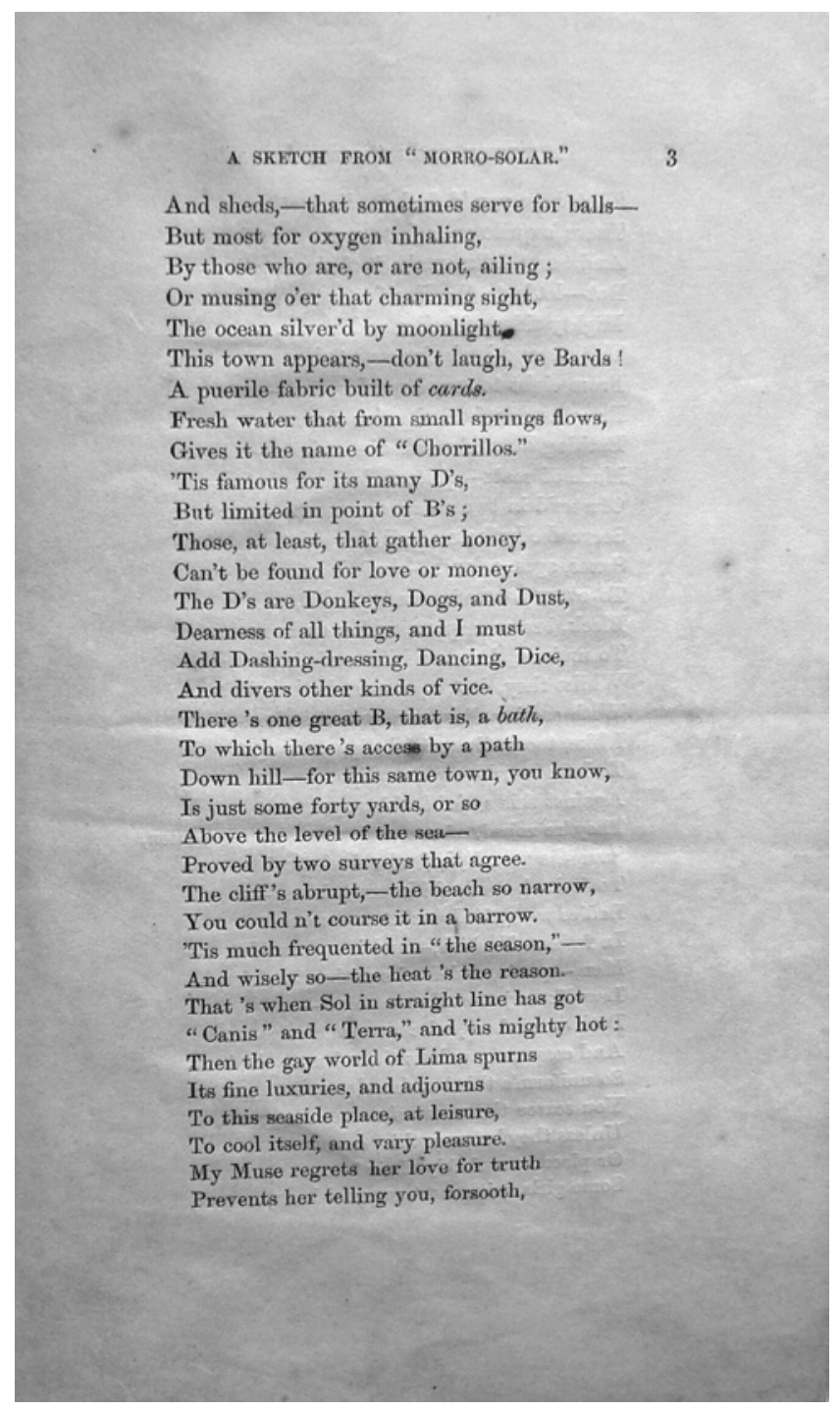

A-2-12. OA-2-3-3 
That here you 'd find no dissipation.

There 's quite enough to serve a nation, And, some folks, make it their devotionBut-let's to the Pacific Ocean.

Mighty tides of belles and beaux,

Thither and back, incessant flow,

From eight to ten, a.m., I mean-

From two to four, they 're also seen.

Bathing huts of small dimensions-

Made of mats-quite rude inventions-

Cluster'd in two compact masses-

Serve the bathers of all classes,

Sexes, ages, colours-shaded

To every tone of pure, or faded,

Black, brown, copper, white, and rose,

To undress, dress, and leave their clothes,

Whilst they, in troops, refresh their limbs,

With cooling dips, or pleasant swims.-

I like, too well, a soeial dip,

To let a word escape my lip

Against this social bathing system.-

They 're robed, of course, both men and women,

Save the 'small firy,' who don't profess

To feel ashamed of Nature's dress.-

Ladies wear frocks and trowsers too,

In fashion Turkish, - and in colour blue :-

Mon,-pants, and frocks without a skirt,-

Less like a jacket than a shirt.-

Both wear shoes, of canvasfmade,

And coarse straw hats their face to shade.-

So uniform's this bathing dress,

You scarce the wearers' names can guess,

Unless they 're very thin, or fat,

Or place remarkably their hat.

Some girls, with most eoquettish air,

A-2-13. OA-2-3-4 
Do this, setting off their silken hair, So famed, for length and rich profusion, I can't omit this slight allusion.

These bathing robes were not invented By the Nympls, - who were contented To paddle, just as Nature made 'em, At the margin of some stream,- -but then Those beauties always bathed alone,-

At least on canvas so they 're shown,

And in some calm, secluded spot,

Where, for the world, man's eye was not

Allow'd to pierce the sylvan screen

That grew around so richly green,

Unless 'twere in the cause of art-

But-this is quite a point apart,

Our theme is now of Lima graces,

With tiny feet and pretty faces,

For whom, and whose express convenience,

A General, at his own expense,

Placed at this bath some wooden stairs,

By which these beauties cun, in pairs,

Glide up and down; for they are made

Full wide, with double bahustrade.

O'Brien, is the donor's name,-

An officer of happy fame,

For gallant deeds, in fights so many,

I will not pause to record any,

Save that at Maypu-where "At any cost

"A charge, my chief,-or all is lost !"

"Twas thus to San Martin he cried,-

"Charge them!" that chief at once replied,

"Charge ! charge ! my boys, tis glorious fun,"

O'Brien shouts-the Spaniards run ;-

And who can donbt that this grand stroke

Freed Chili from the Spanish yoke?

A-2-14. OA-2-3-5 
Again reverting to the bathing throng,Til not detain you very long :

Some hurry in, and swim about, And when they 're tired, hurry out. The rest,- - at least a few of these,Conscious of their power to please,Even in robes withont a bustle, Have, as 'twere, a gentle tuss With their courage ere they get it Bland enough to let them wet it. Now one appears, with modest air, Stepping, as though her only care Were to elnde the vulgar gaze,Acting the part, beyond all praise,But,- -ere she trkes the "briny tide" She turns, and looks from side to side, As if a phantom from "the deep," At which she dare not even peep,-

Had suddenly just stepp'd between

Her and the sea, exclaiming - "Queen

"Of beauty, stay thy onward course !-

Think! if this cold should make thee hoarse !"

A graceful motion of her head,-

Not quite "a toss" - she 's too well bred

For that-hurls all warning to the skies,

And every form on earth defies.

Then, changing, she, to winning airs,

To take a plunge, as 'twere, prepares,-

Adjusting first, her hair and dress,-

And then,- with visage of distress,

Trying the water with her toe,-

Recedes, and cries demurely-" $\mathrm{Oh}$

"Say! you who look so very bold,

"How is it you endure the cold?

"Well-I declare, I can't proceed :-

A-2-15. OA-2-3-6 
"'T will be my death-it will indeed!

"I 've lost my breath beyond redeeming!"

She then belies herself, by screaming.

All this-you see-is mere invention,

Just enough to call attention

From her admiring beaux,

Of whom she has some score or so.

You 'd forgive this affectation,

And lend yourself to admiration,

Could you behold, as I have done,

Some of these "daughters of the Sun,"-

Of whom there are, I say, a few,

So very beautiful to view !

There's the small foot, and taper hand,

The fawn-like tread upon the strand,

The form, the carriage, and the style

Of every step they take the while,-

Artistic eyes delight to trace

Their ever varying lines of grace.

Adieu ! fair " daughters of the Sun,"

I see that orb, himself, has run

His daily course, and, sinking in the West,

Suggests that I should, likewise, rest ;-

But ere my Pegasus is stall'd

I am in painful duty call'd

To say a parting word or two,

For soon I leave thee-Oh Peru !

Scene of my labours, joys, and tears,

For something more than thirty years.

The while I breathed thy balmy air,

And never lack'd the tenderest care

Of thy kind people, who " in need"

Have ever proved my "friends indeed."

Many dear friends have sunk to rest,

For ever be their memory blest !

A-2-16. OA-2-3-7 
A SKETCH FROM " MORRO-SOLAR.",

Those that romain will ever find I hold them gratefully in mind ;-

And if I had the power at will, I'd steer them clear of every ill, And make their life a happy lot, From palace down to humble cot.

To all thy worthy sons, Peru, A long-perhaps, a last, adieu! Where'er I go, whate'er my fate, My sympathies shall ne'er abate. I wish thee, truly, from my heart, Soon to acquire the happy art Of governing thy favour'd land; So the "Tree of Liberty" shall stand, And flourish, spreading, great and free, Its shade from Tumbes to Iquique, From Yungas to the great Pacific: In fruits-oh ! may it be prolificAnd that thou mayest reap its fruits, With Huano, pray, don't burn its roots Choose for its culture men most skill'd, In whom virtues are instill'd.

Each man labour, patient in his sphere,

Nor seek to hasten his career

By selfish means or artful ways ;

Which, in the long run, much delays

One 's individual progress,

And the general welfare no less. 


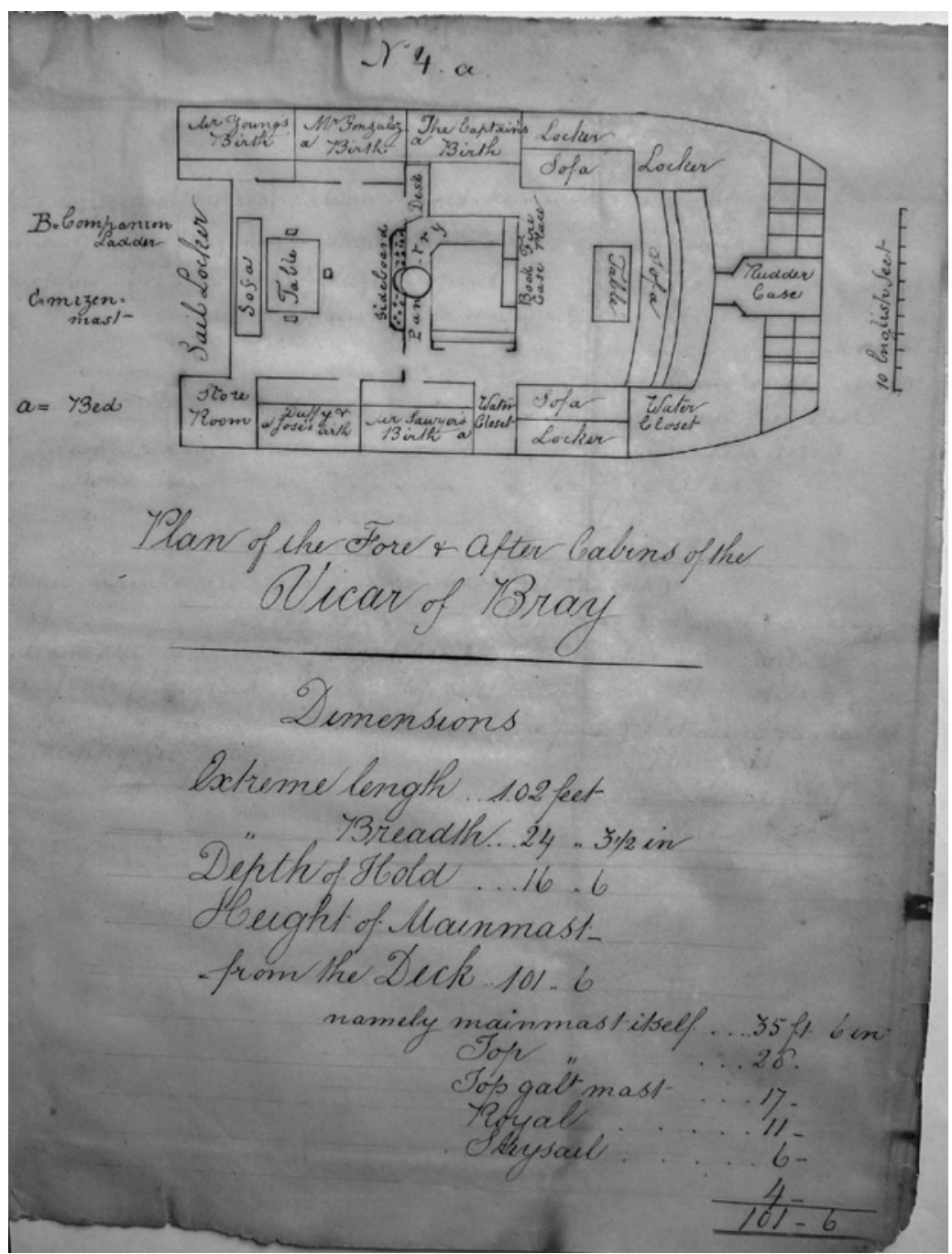

A-2-18. OA-2-4a-1 


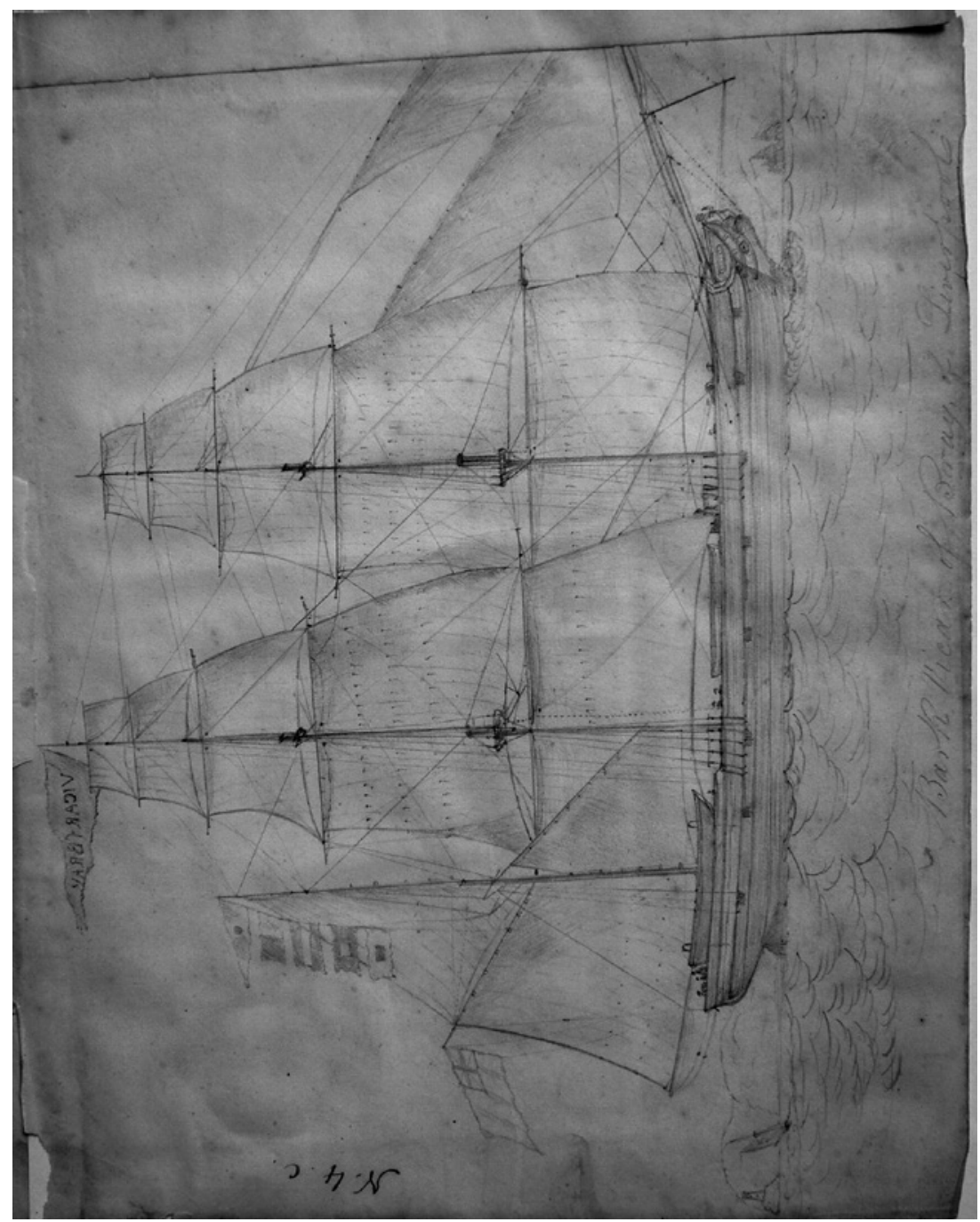

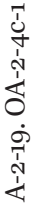




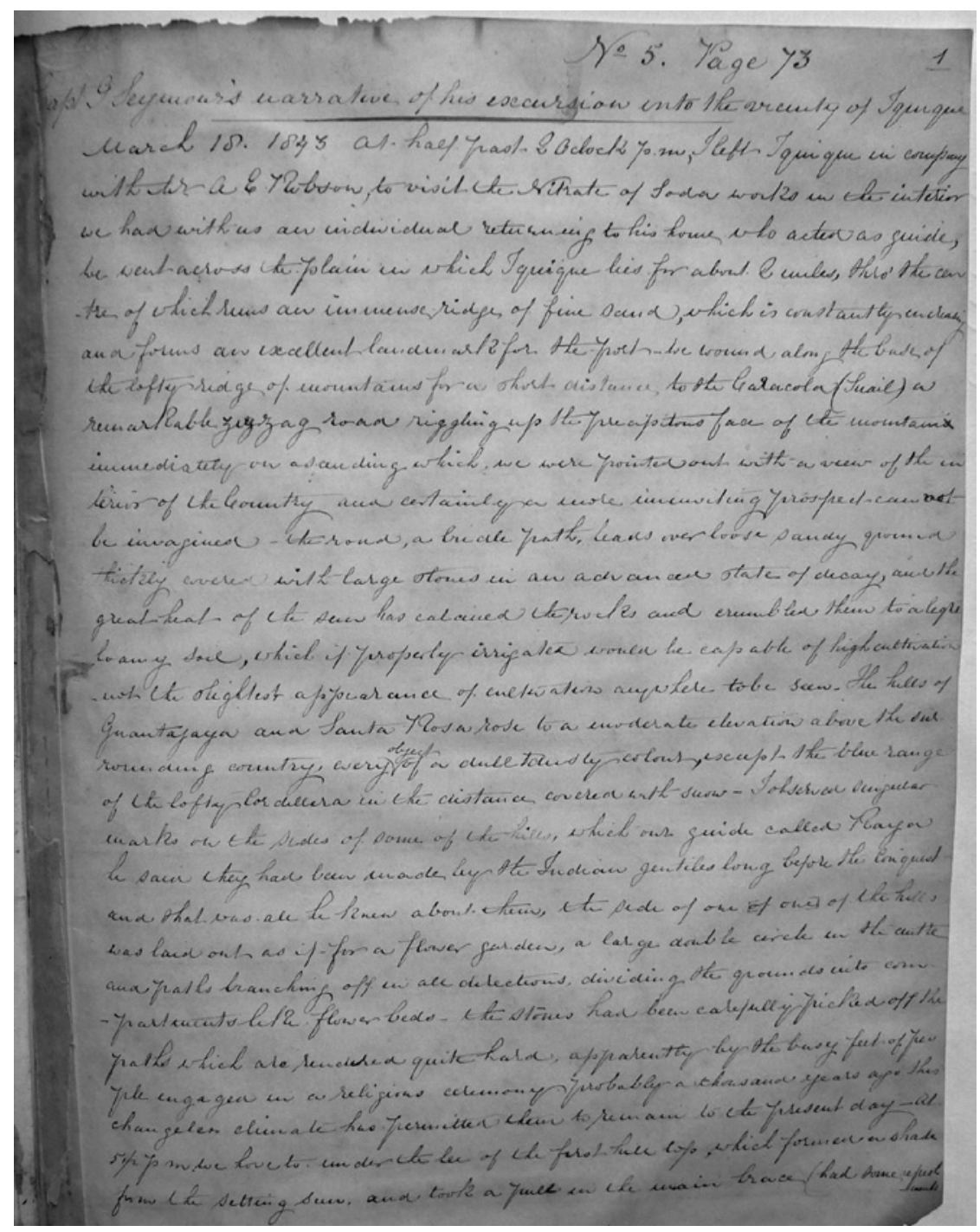

A-2-20. OA-2-5-1 


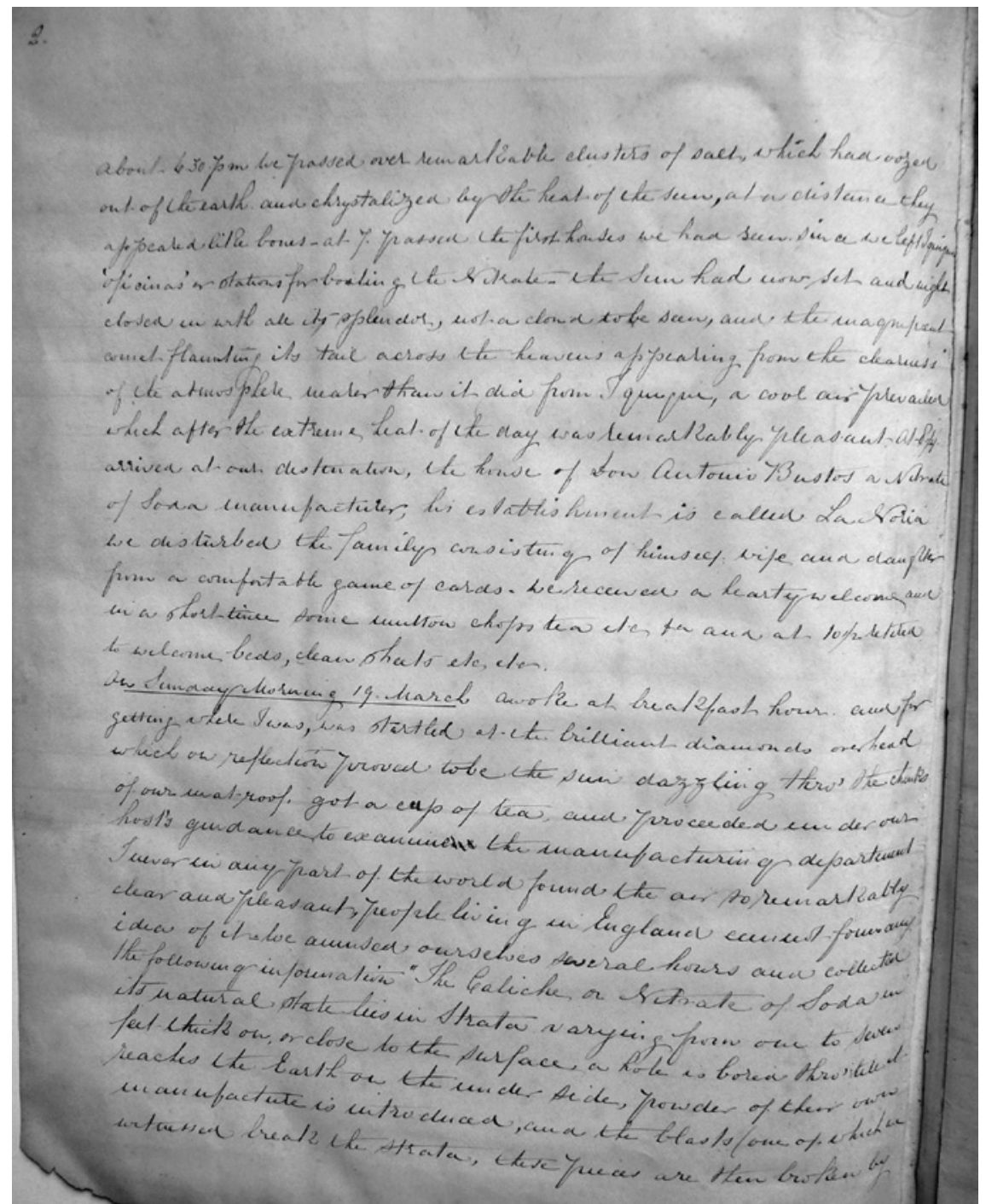

A-2-21. OA-2-5-2 


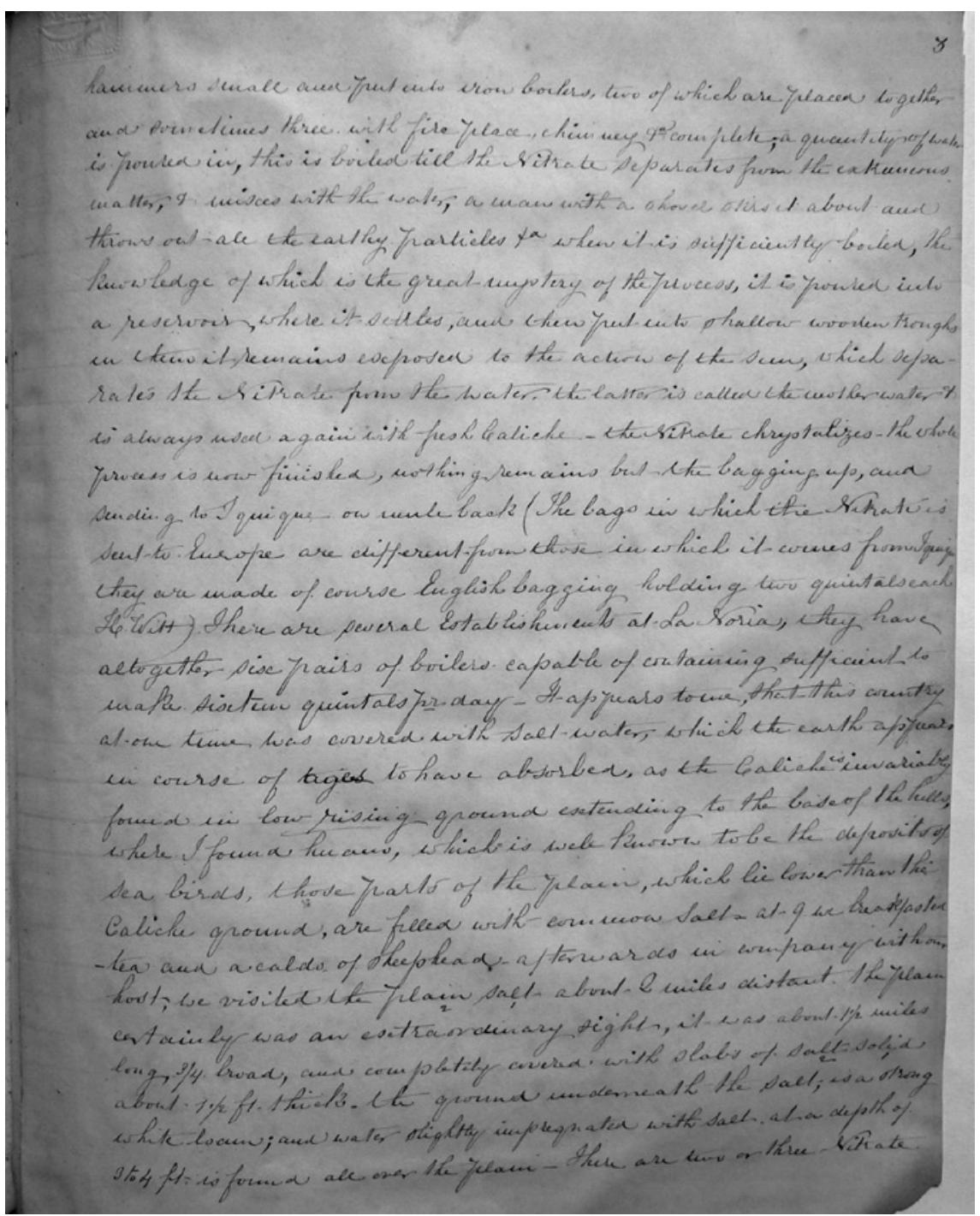

$\mathrm{A}-2-22 . \mathrm{OA}-2-5-3$ 


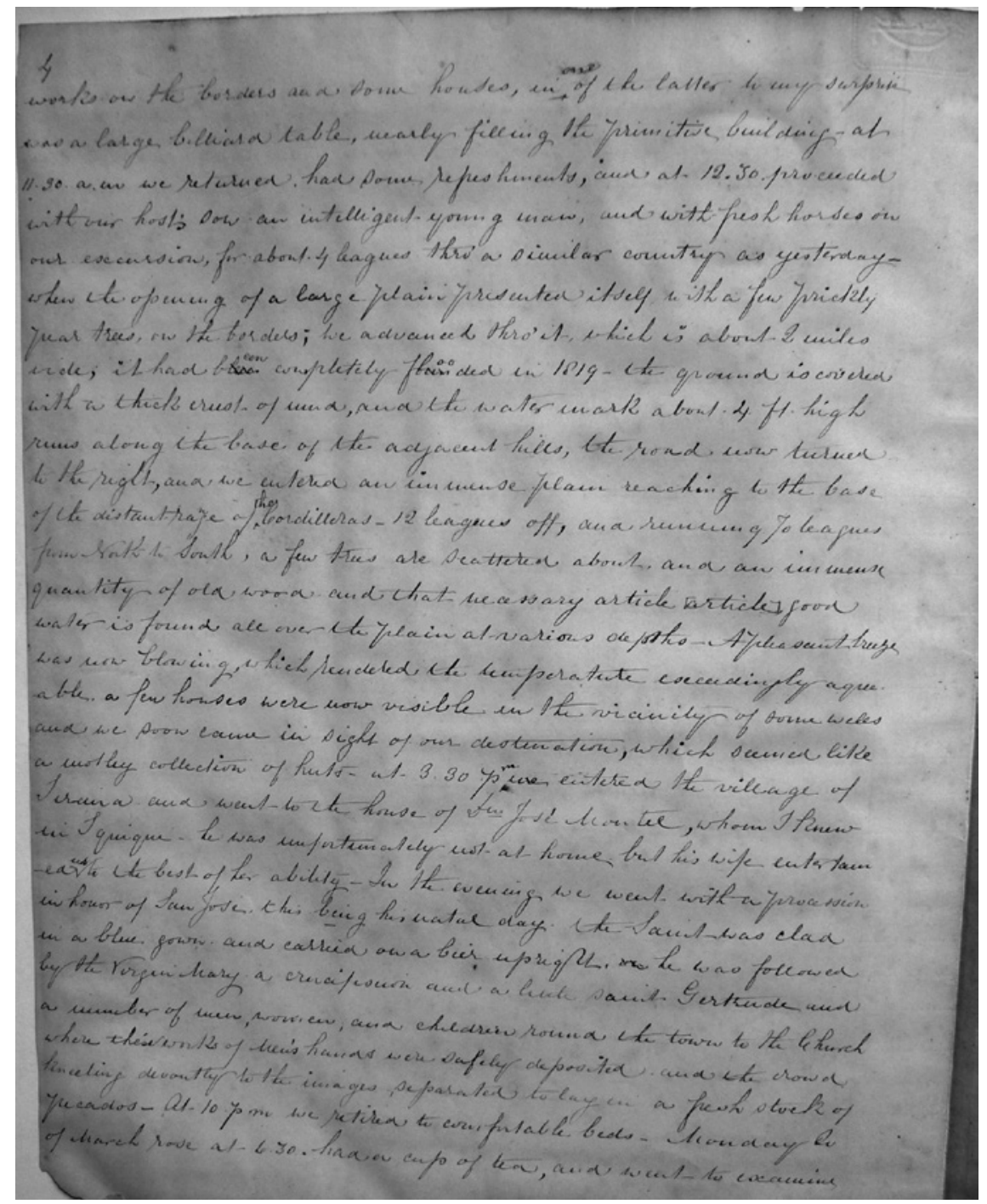

A-2-23. OA-2-5-4 


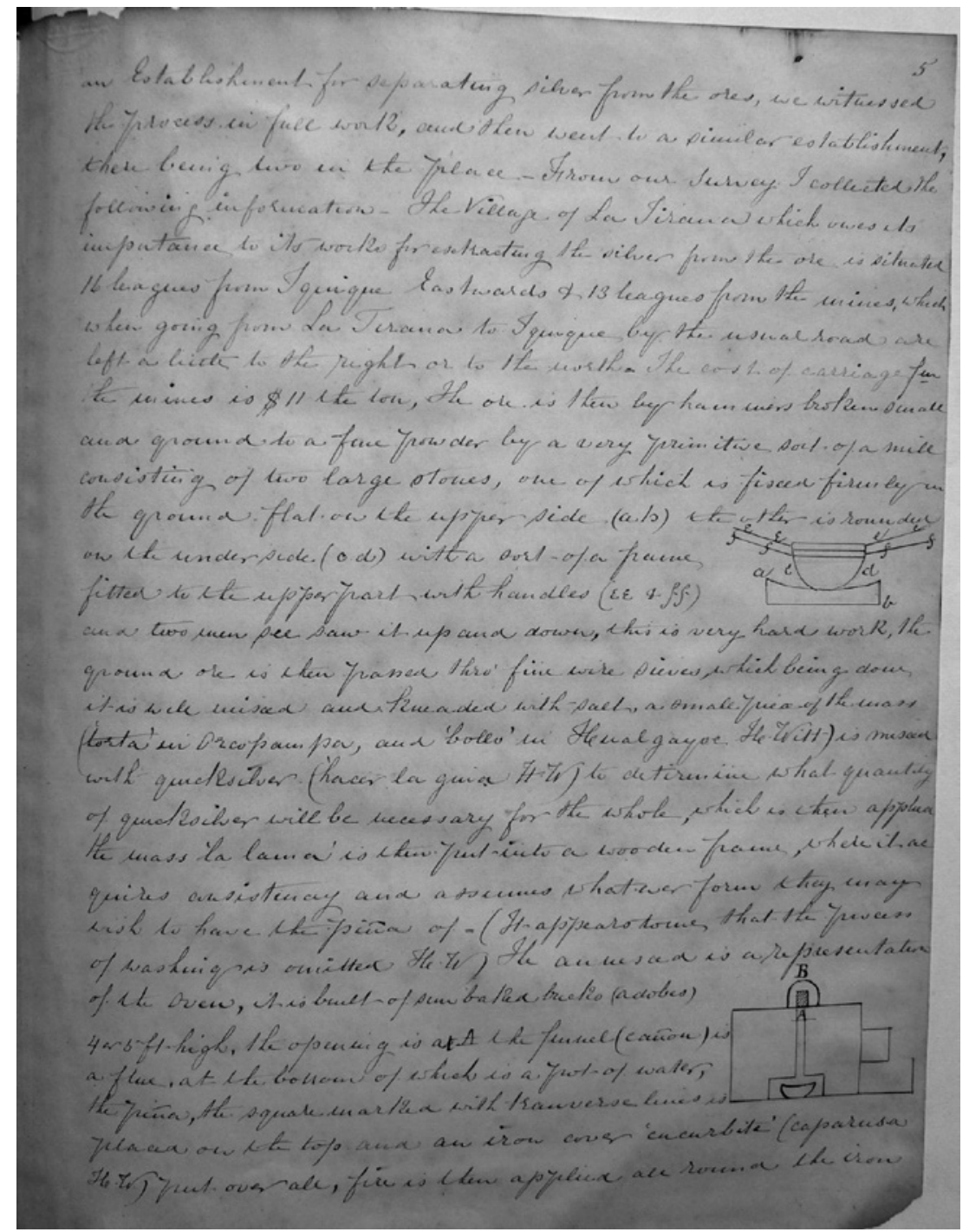

$\mathrm{A}-2-24 . \mathrm{OA}-2-5-5$ 


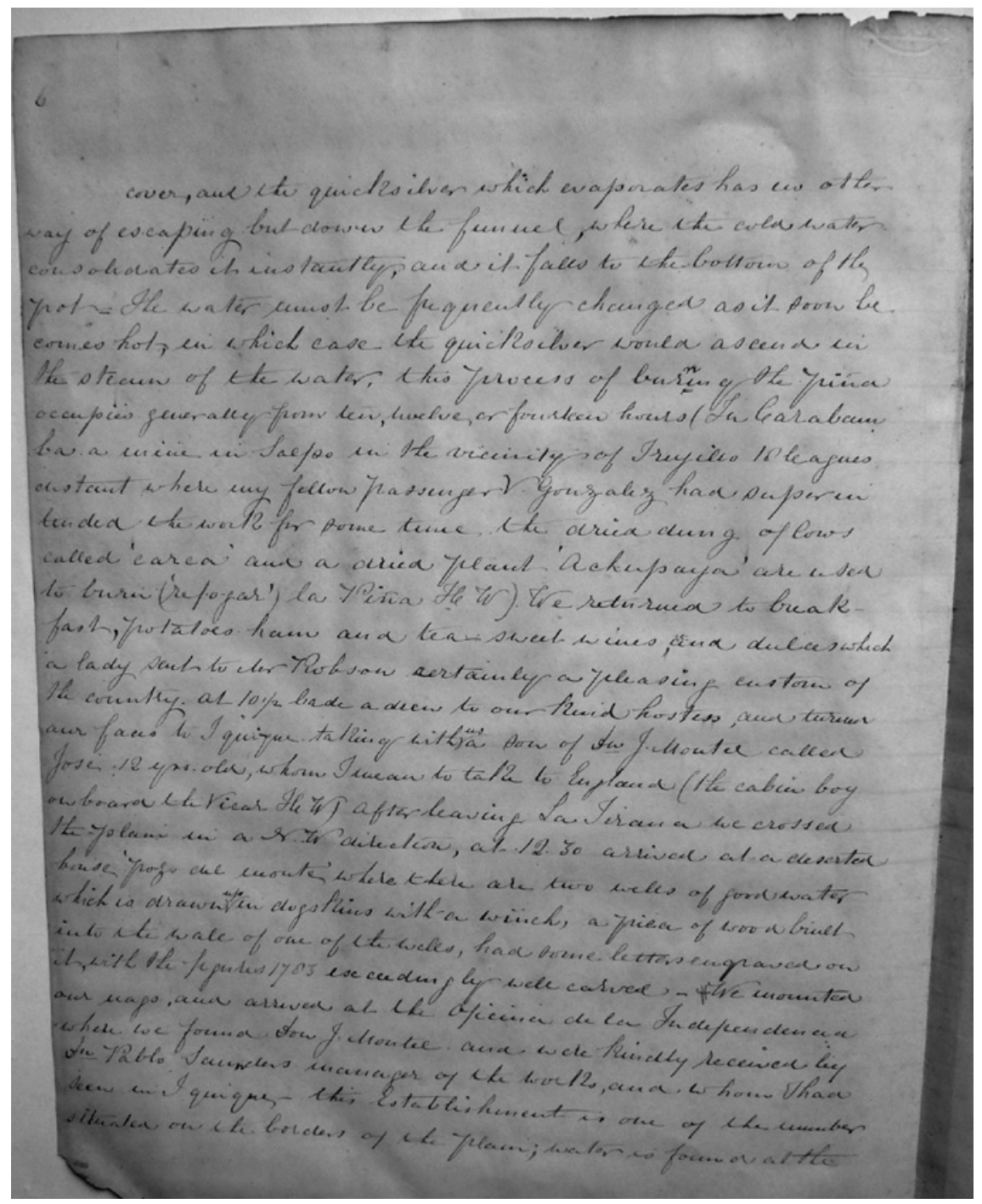

A-2-25. OA-2-5-6 


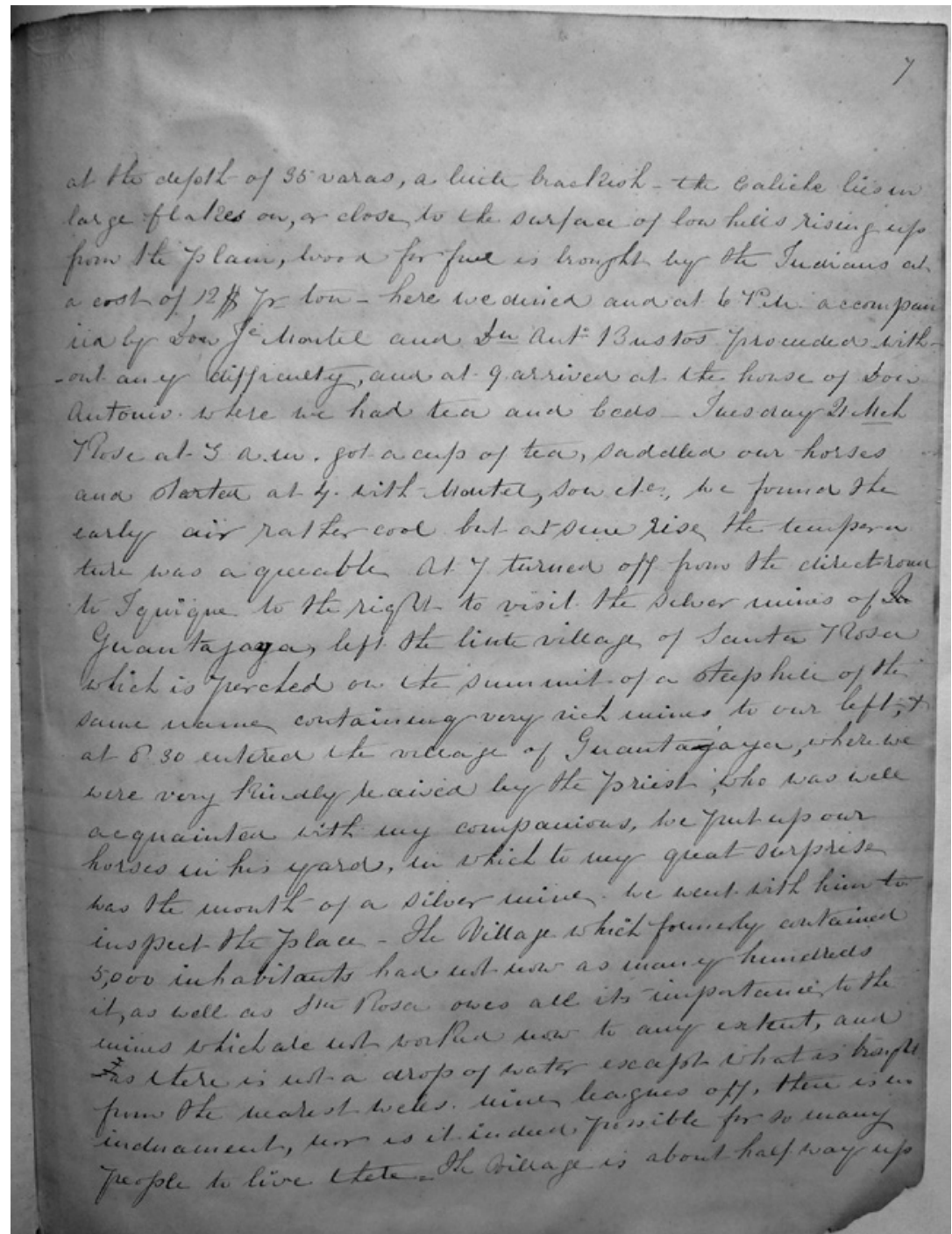

A-2-26. OA-2-5-7 


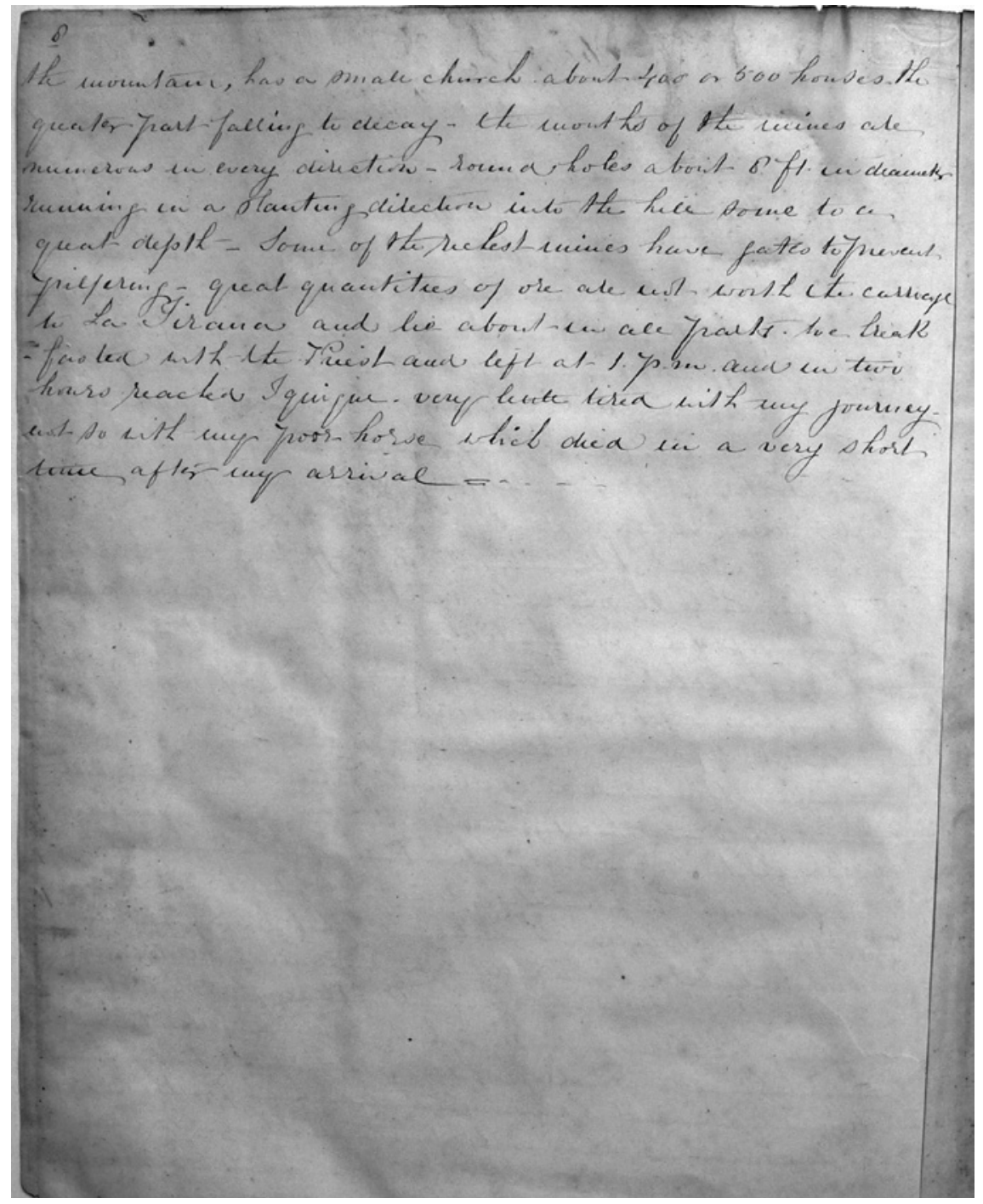

A-2-27. OA-2-5-8 


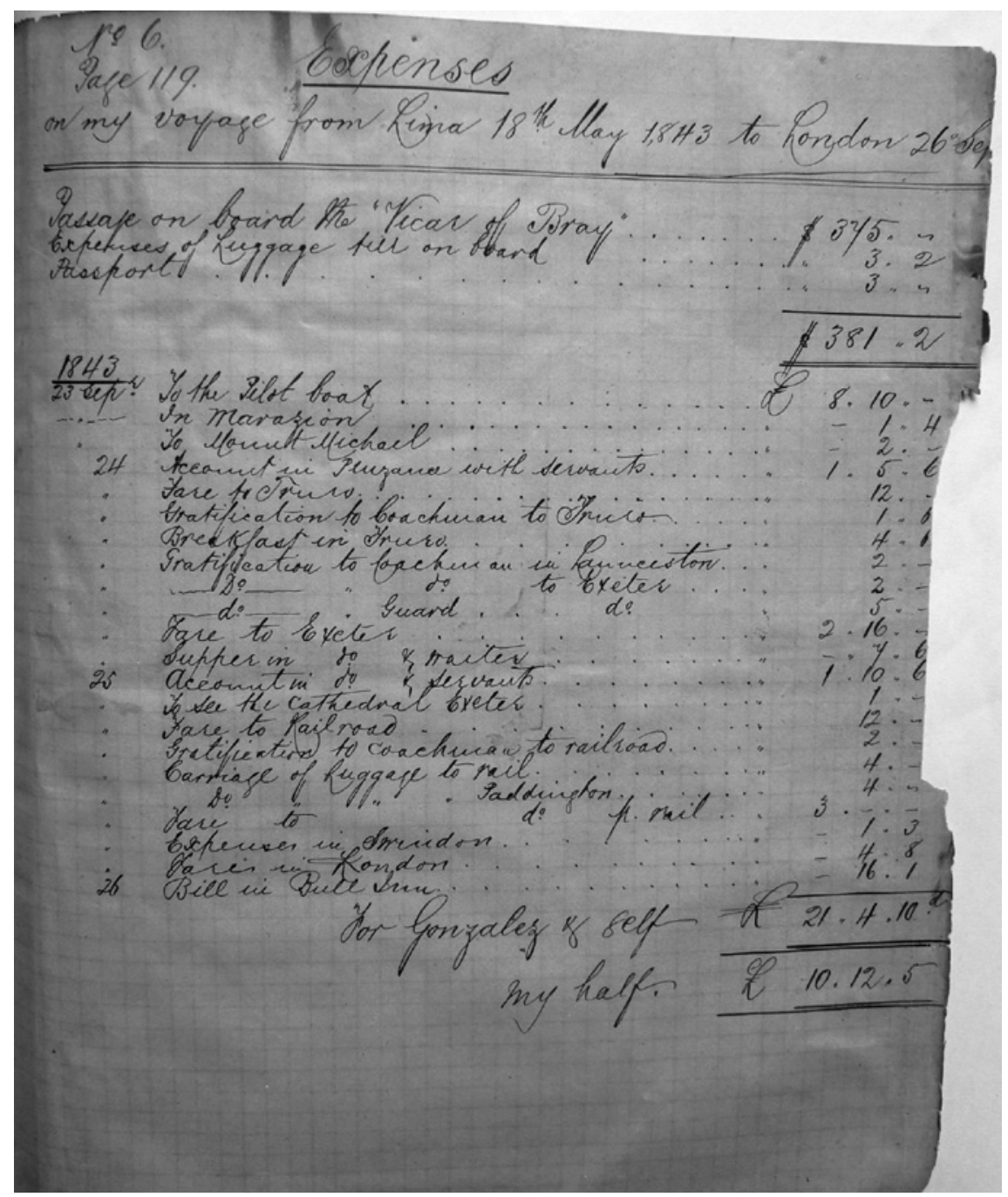

A-2-28. OA-2-6-1 


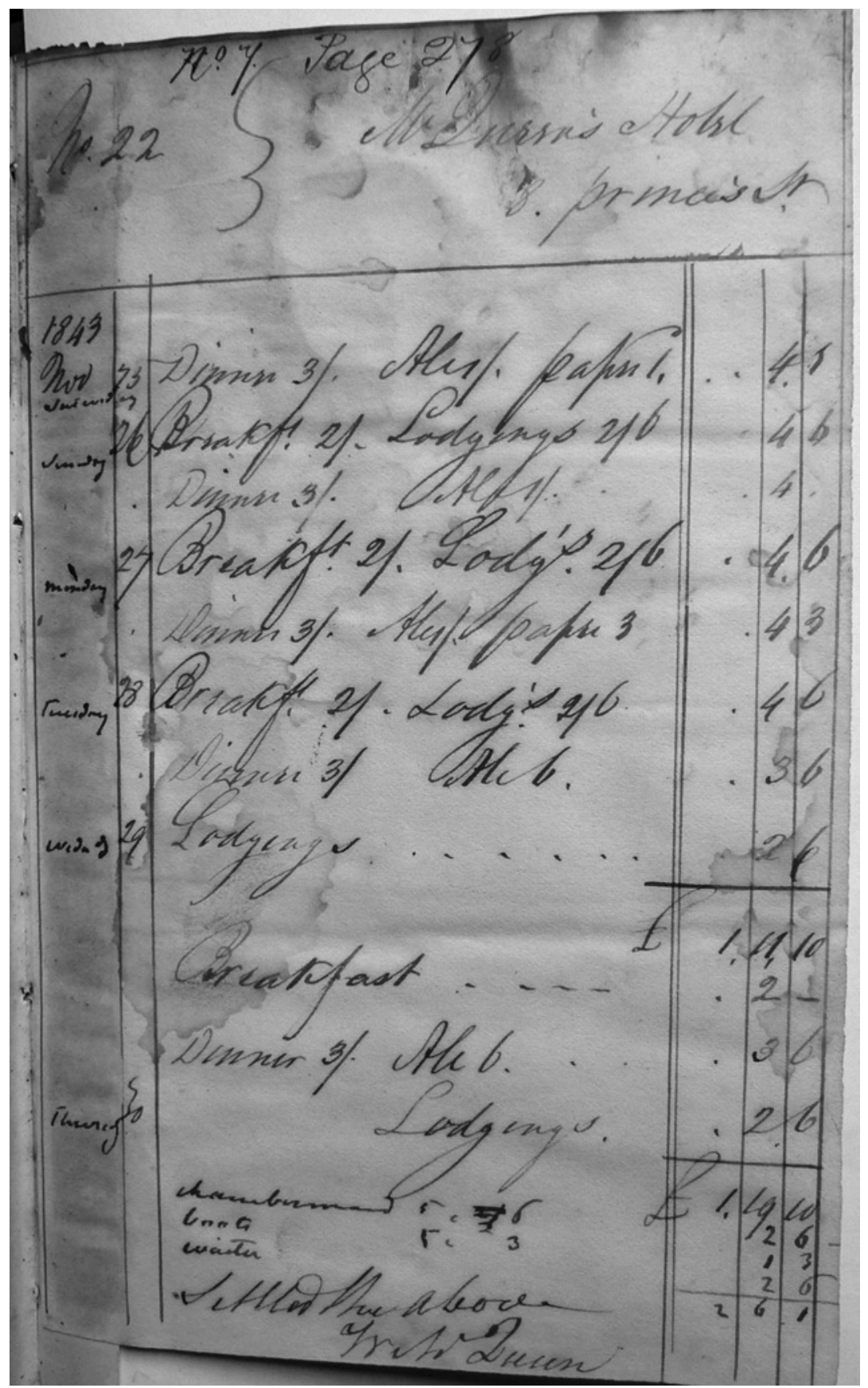

A-2-29. OA-2-7-1 


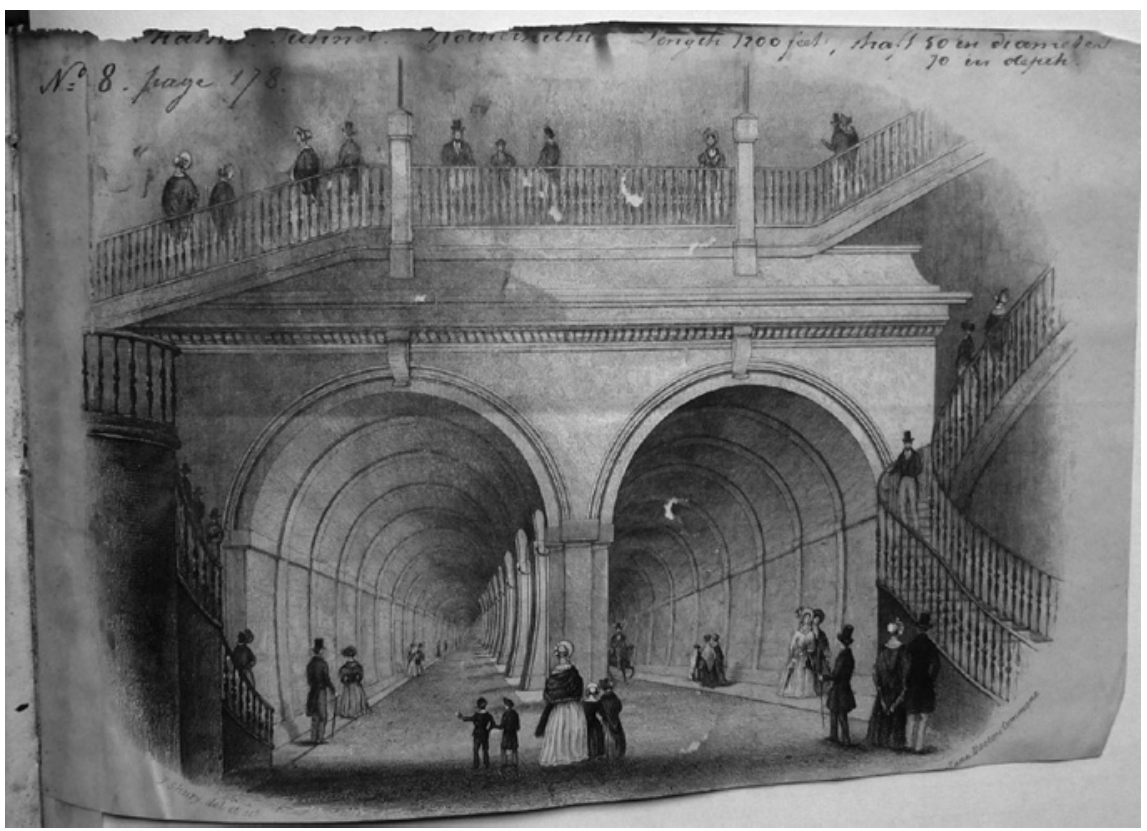

A-2.30. OA-2-8-1 


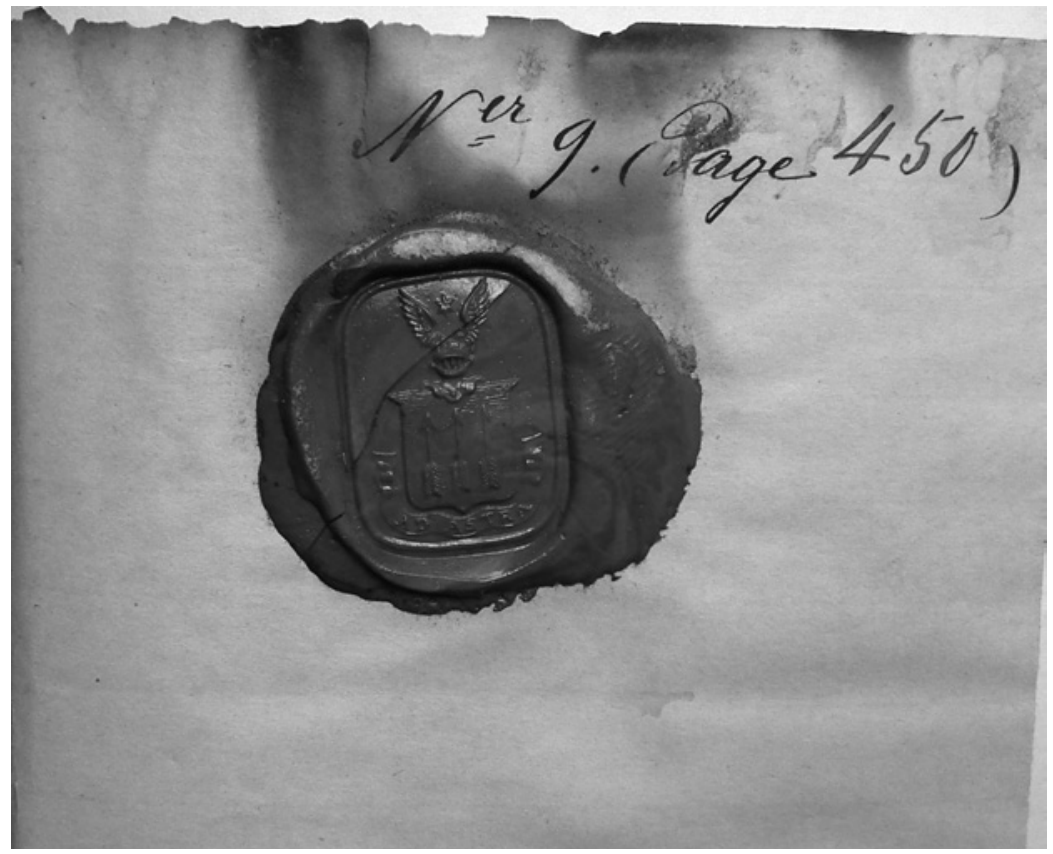

A-2-31. OA-2-9-1 


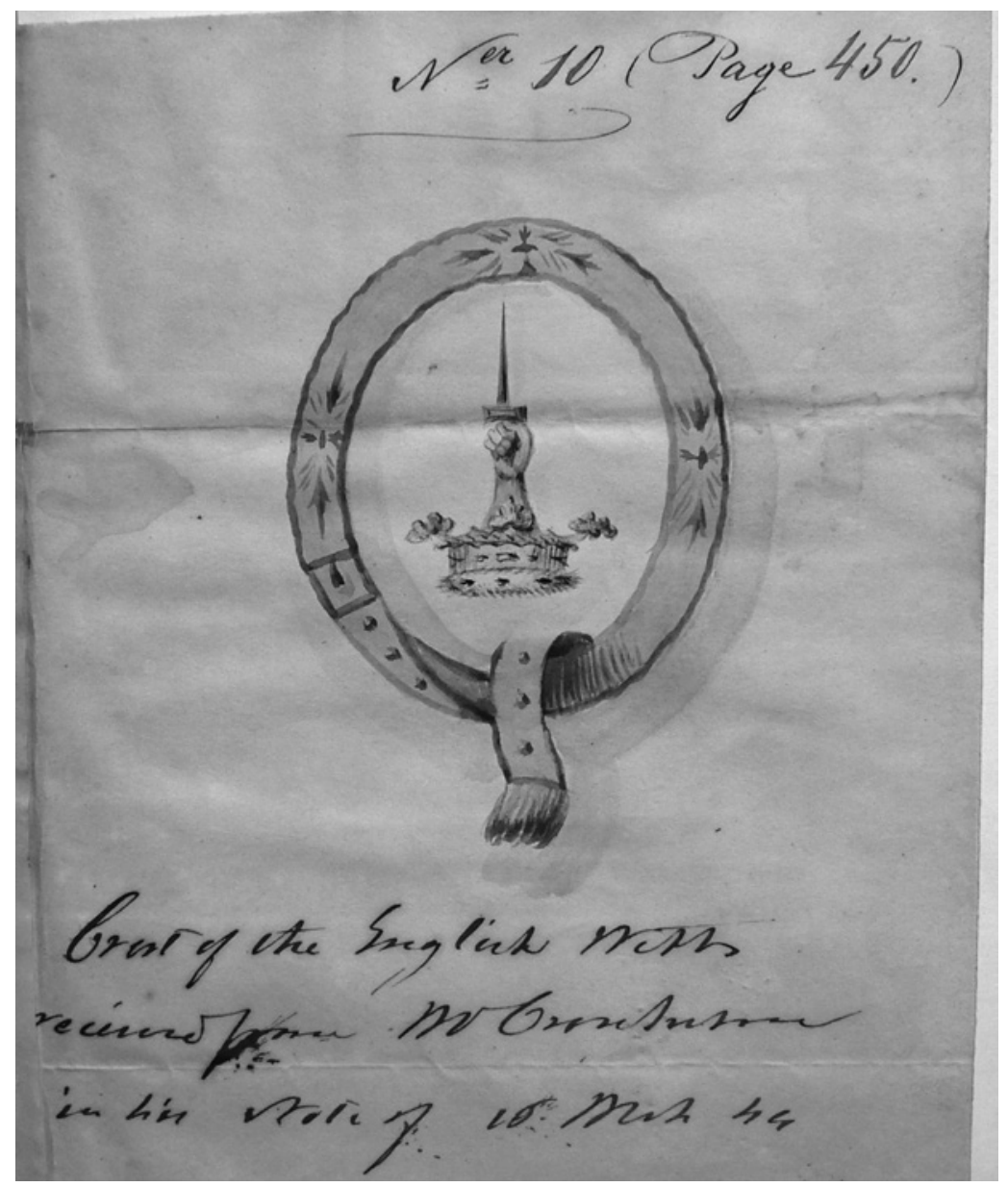

A-2-32. OA-2-10-1 


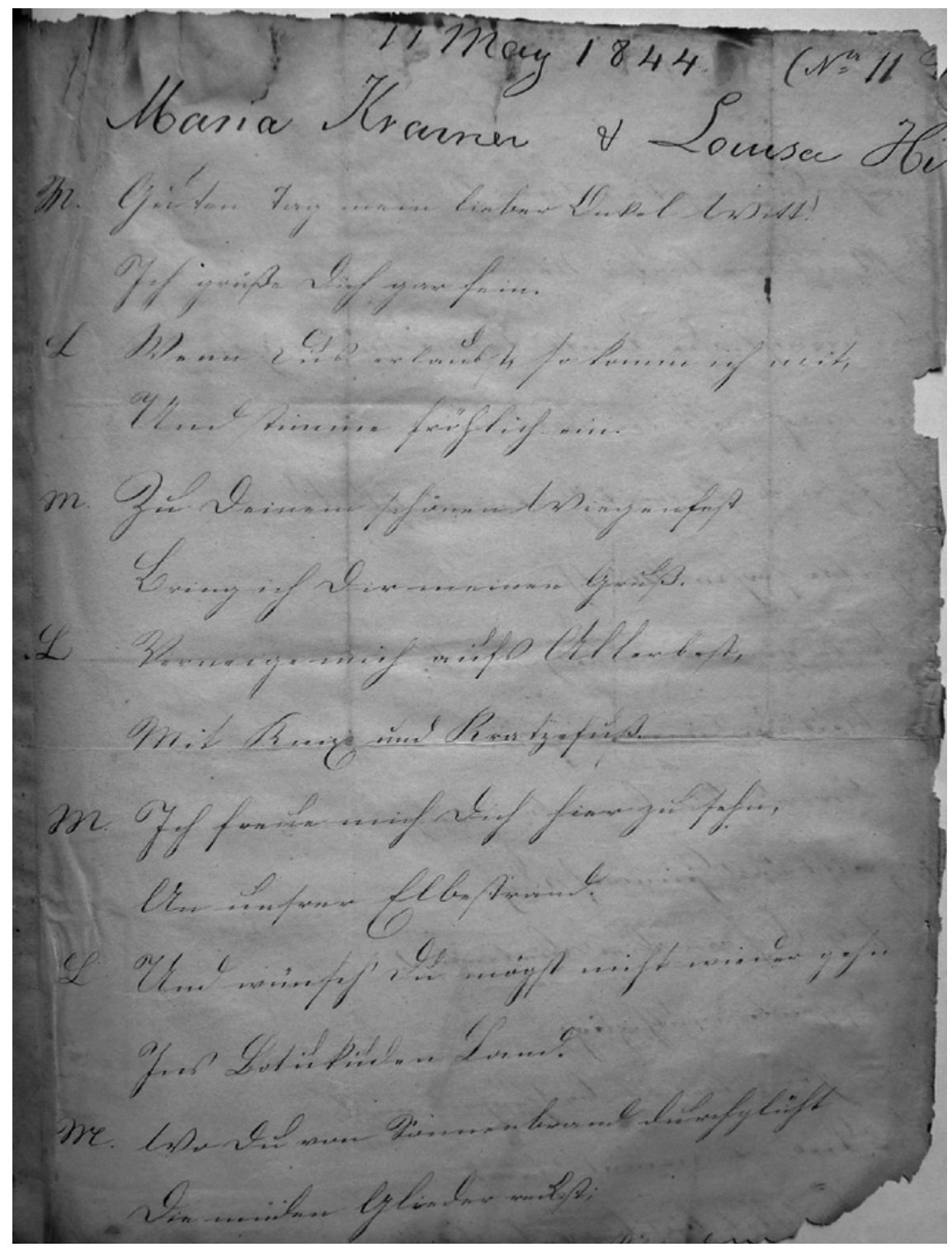

A-2-33. OA-2-11-1 


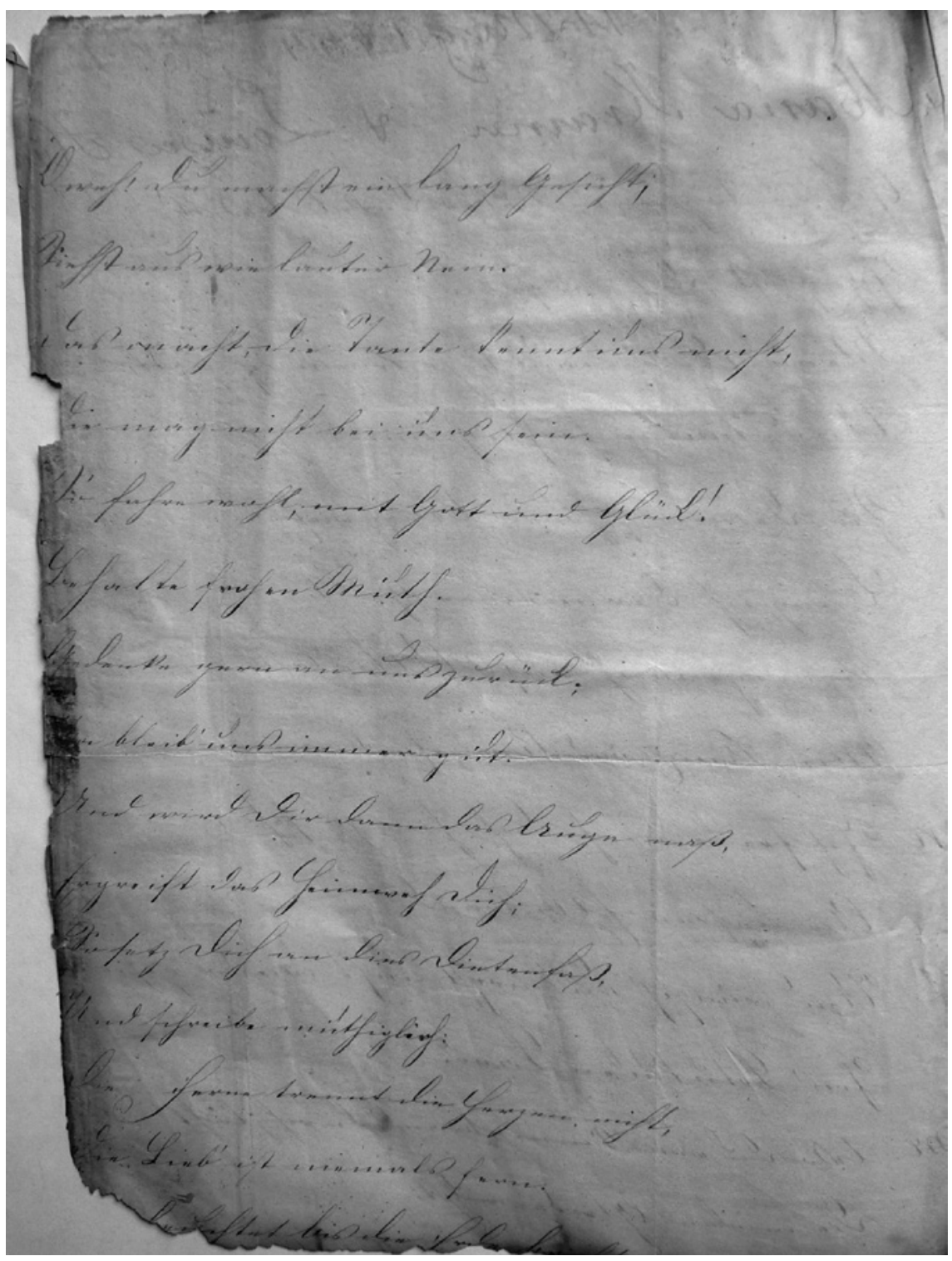

A-2-34. OA-2-11-2 


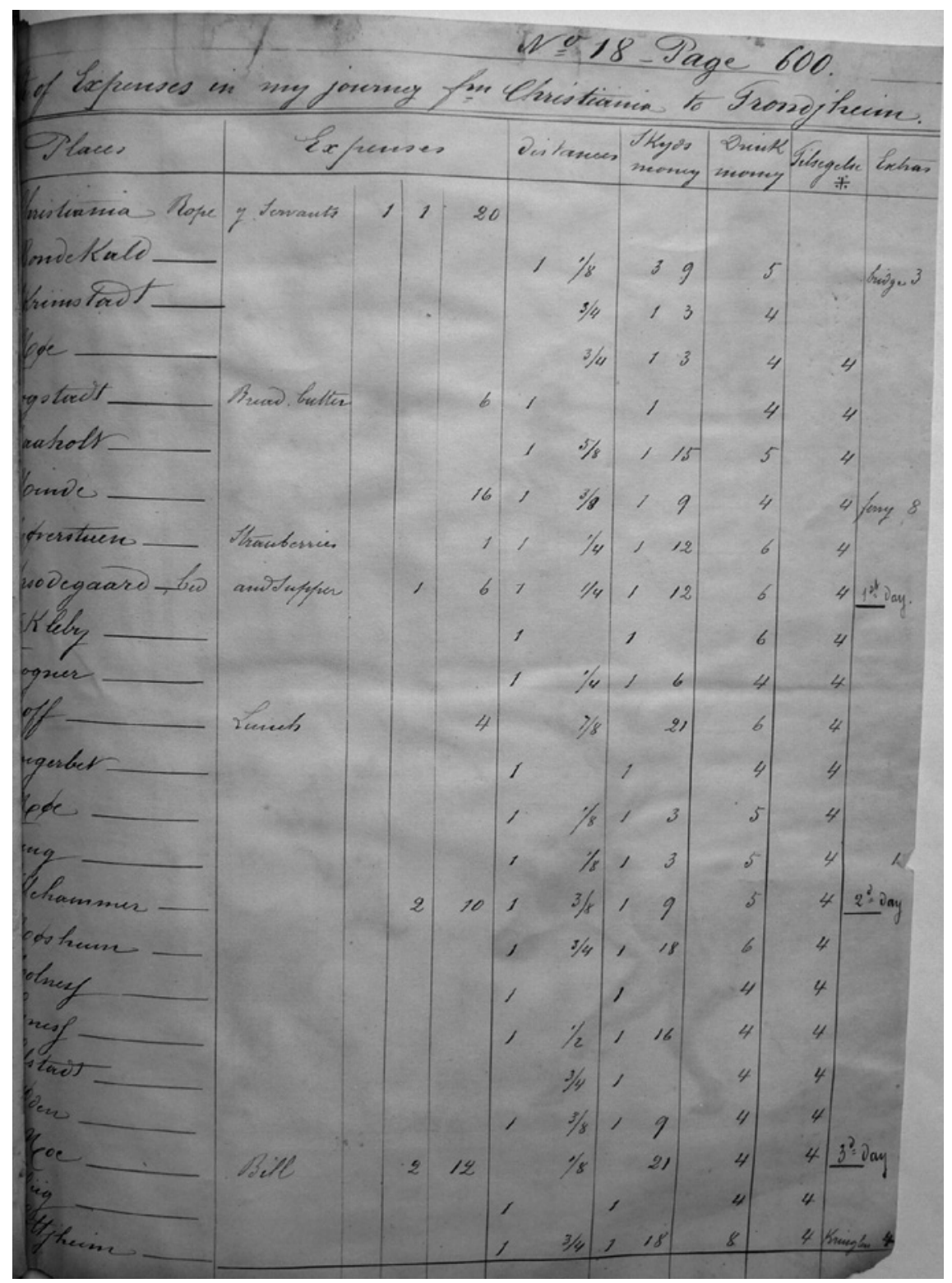

A-2-35. OA-2-18-1 


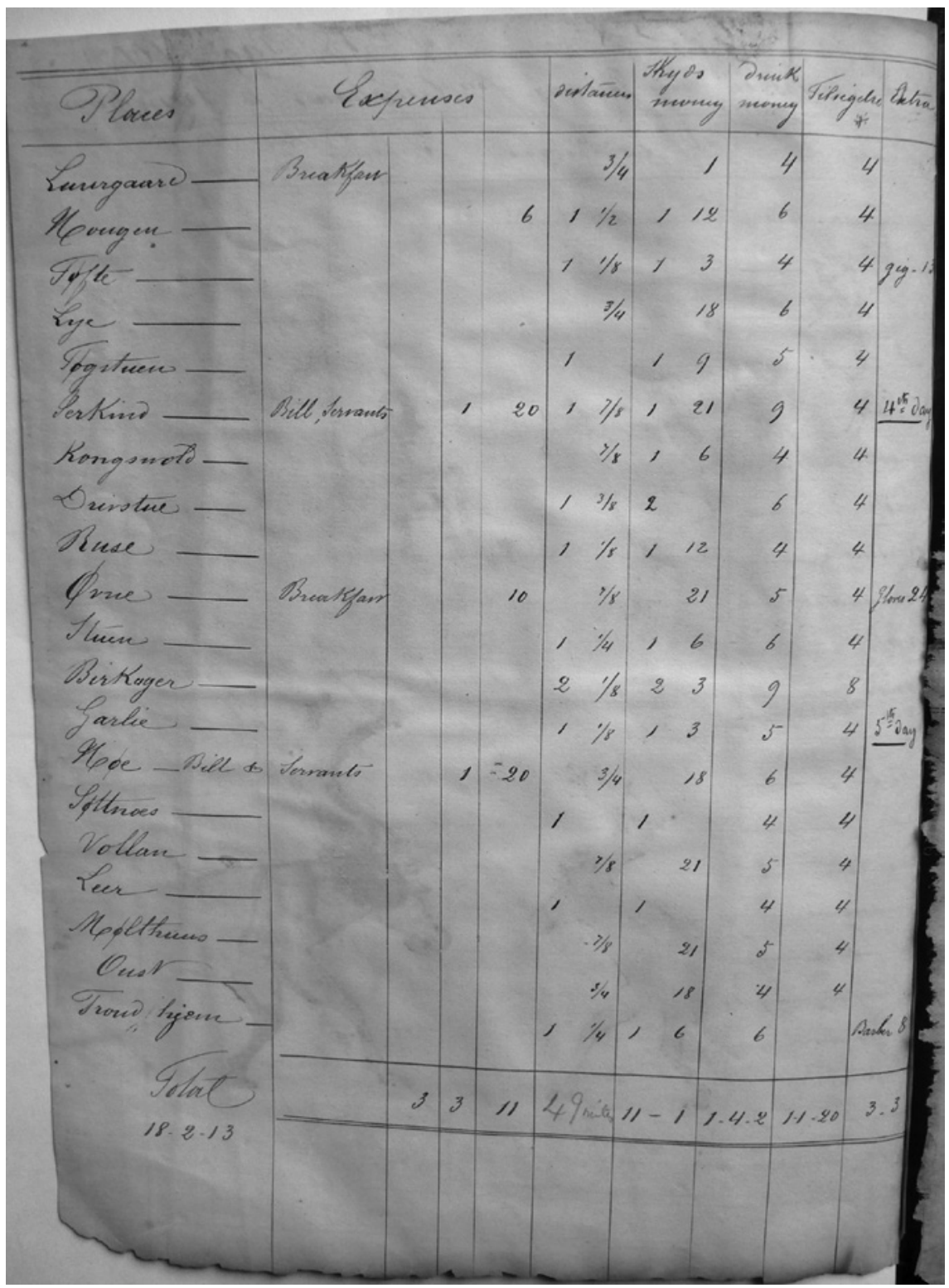

A-2-36. OA-2-18-2 


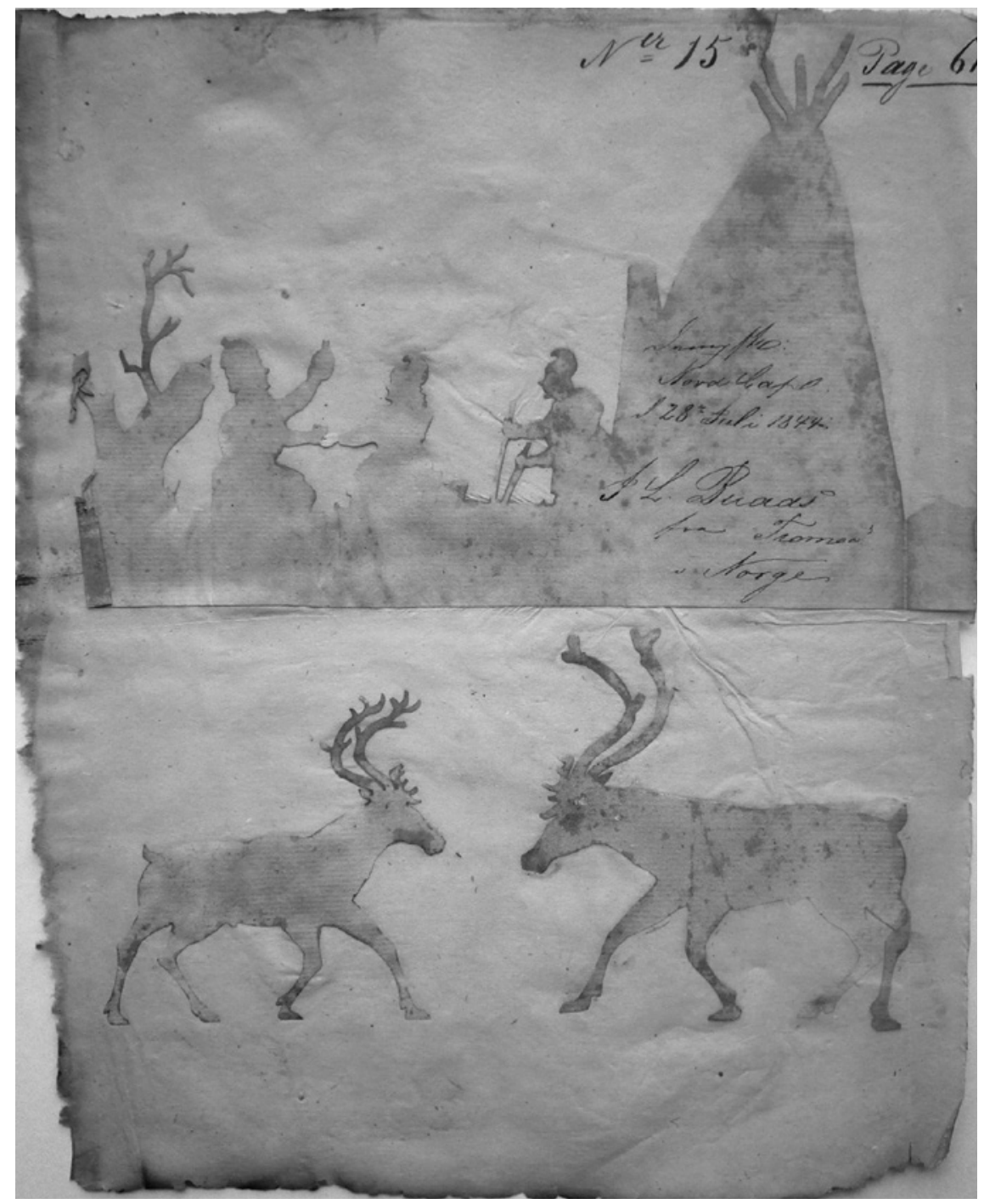

$\mathrm{A}-2-37 \cdot \mathrm{OA}-2-15-1$ 


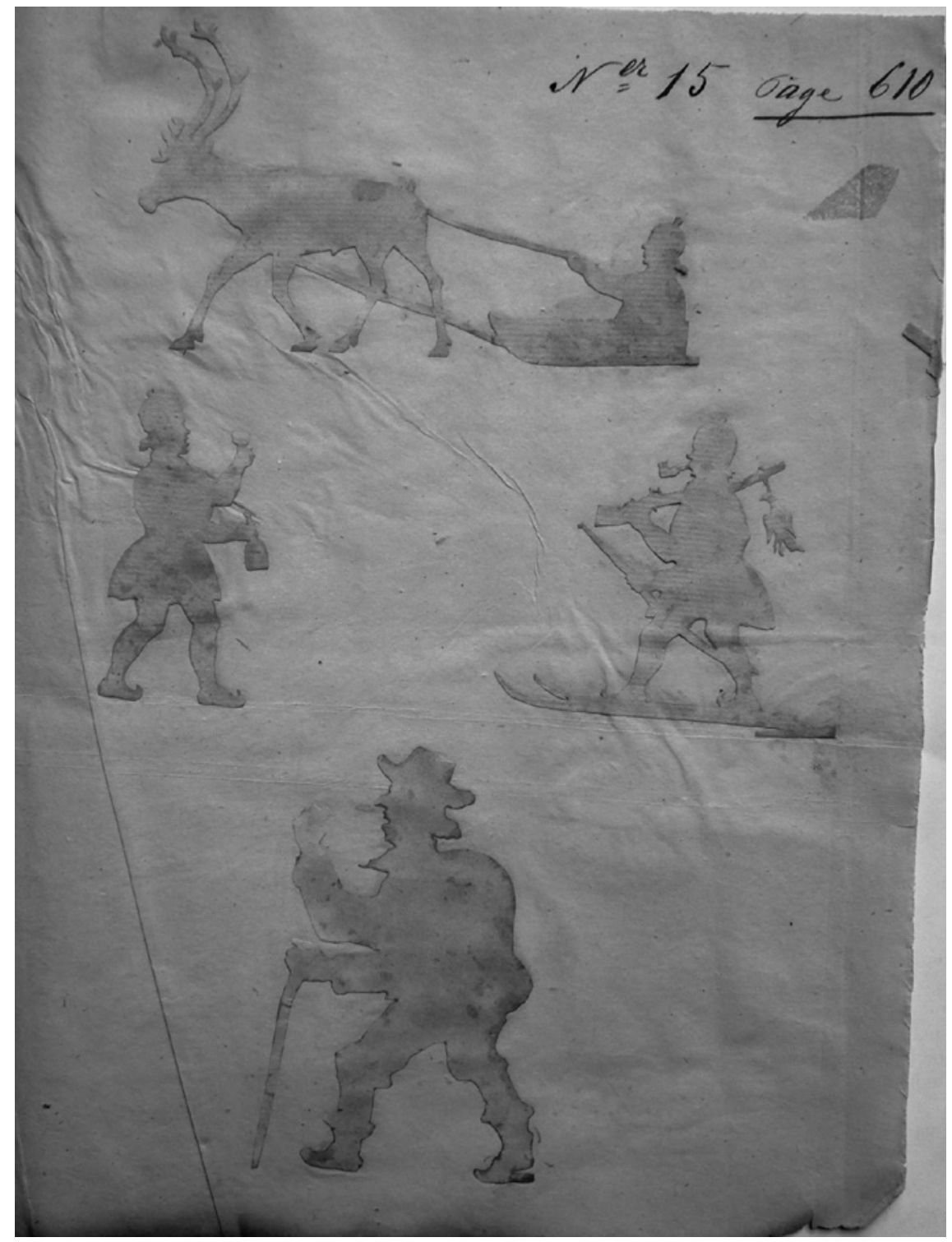

A-2-38. OA-2-15-2 


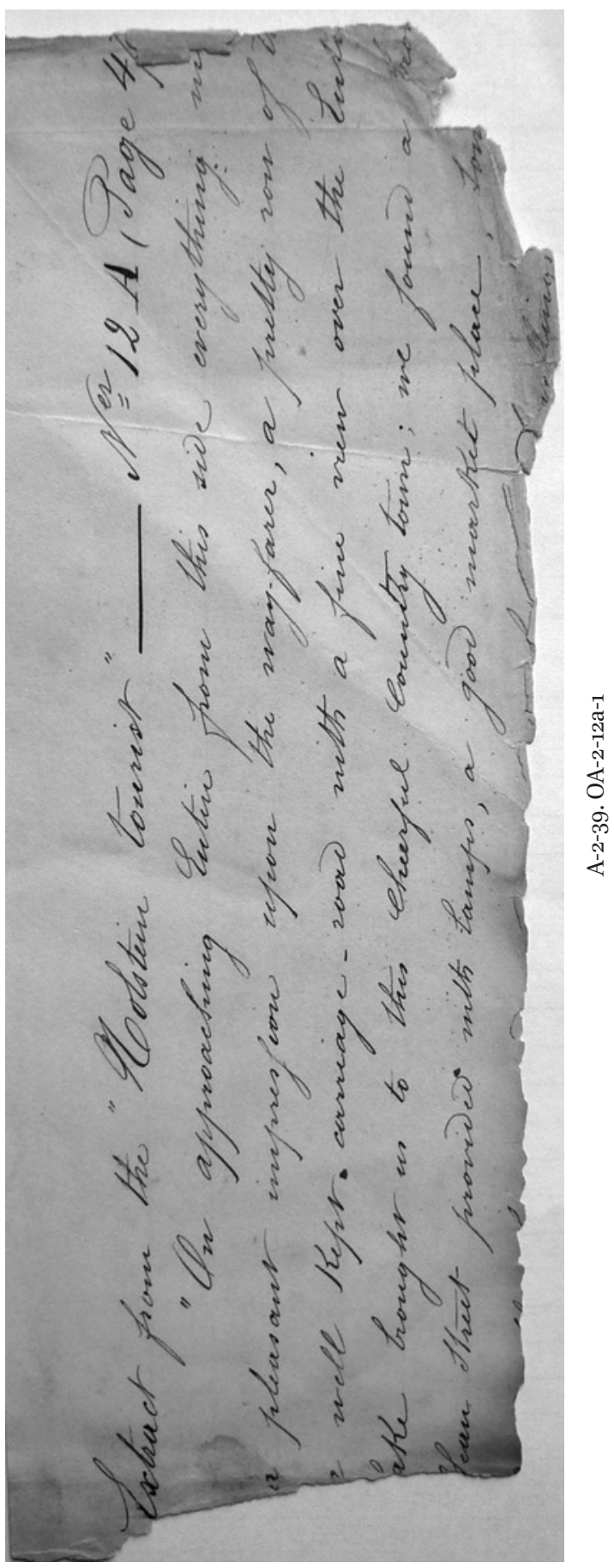




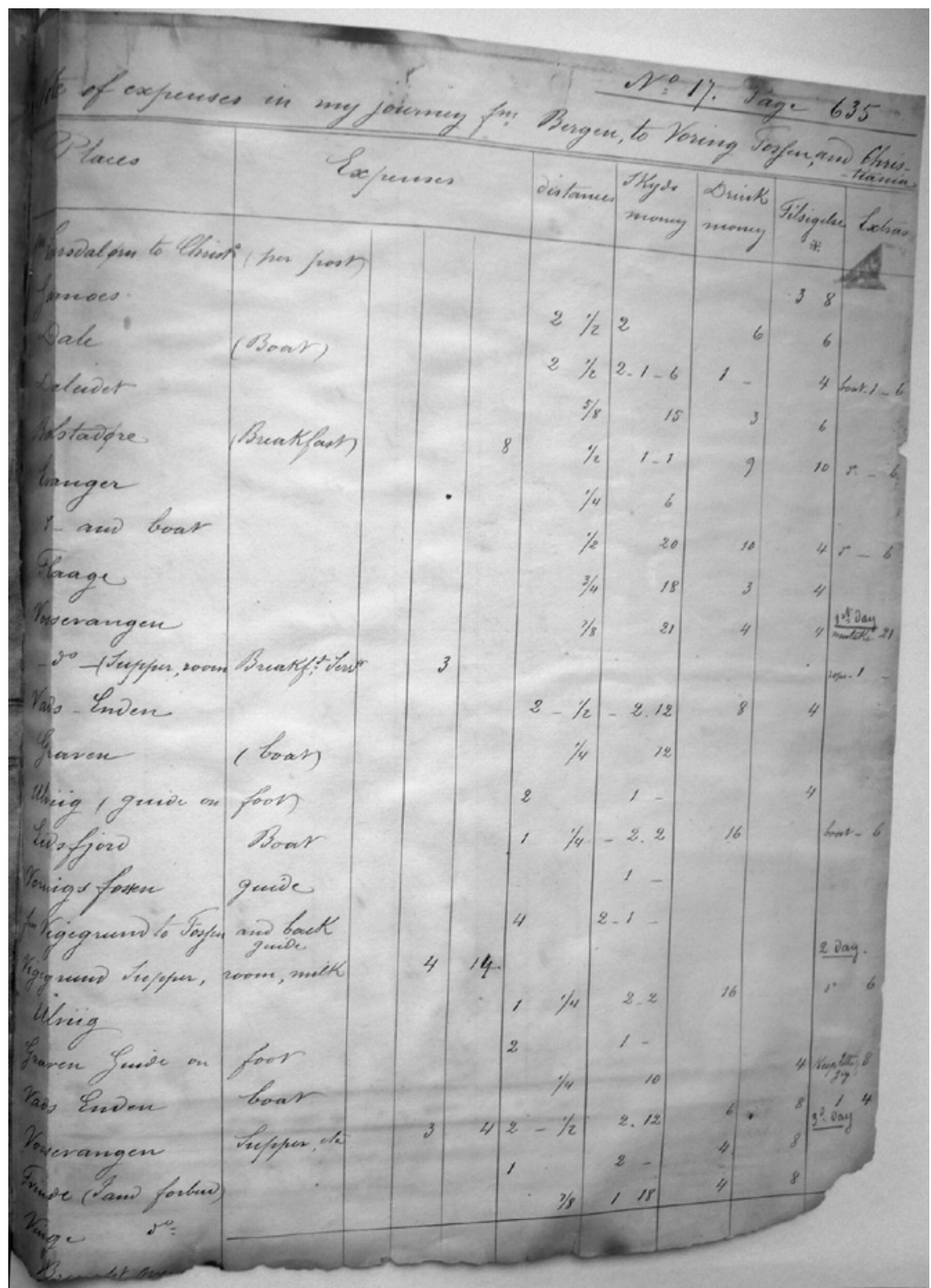

A-2-40. OA-2-17-1 


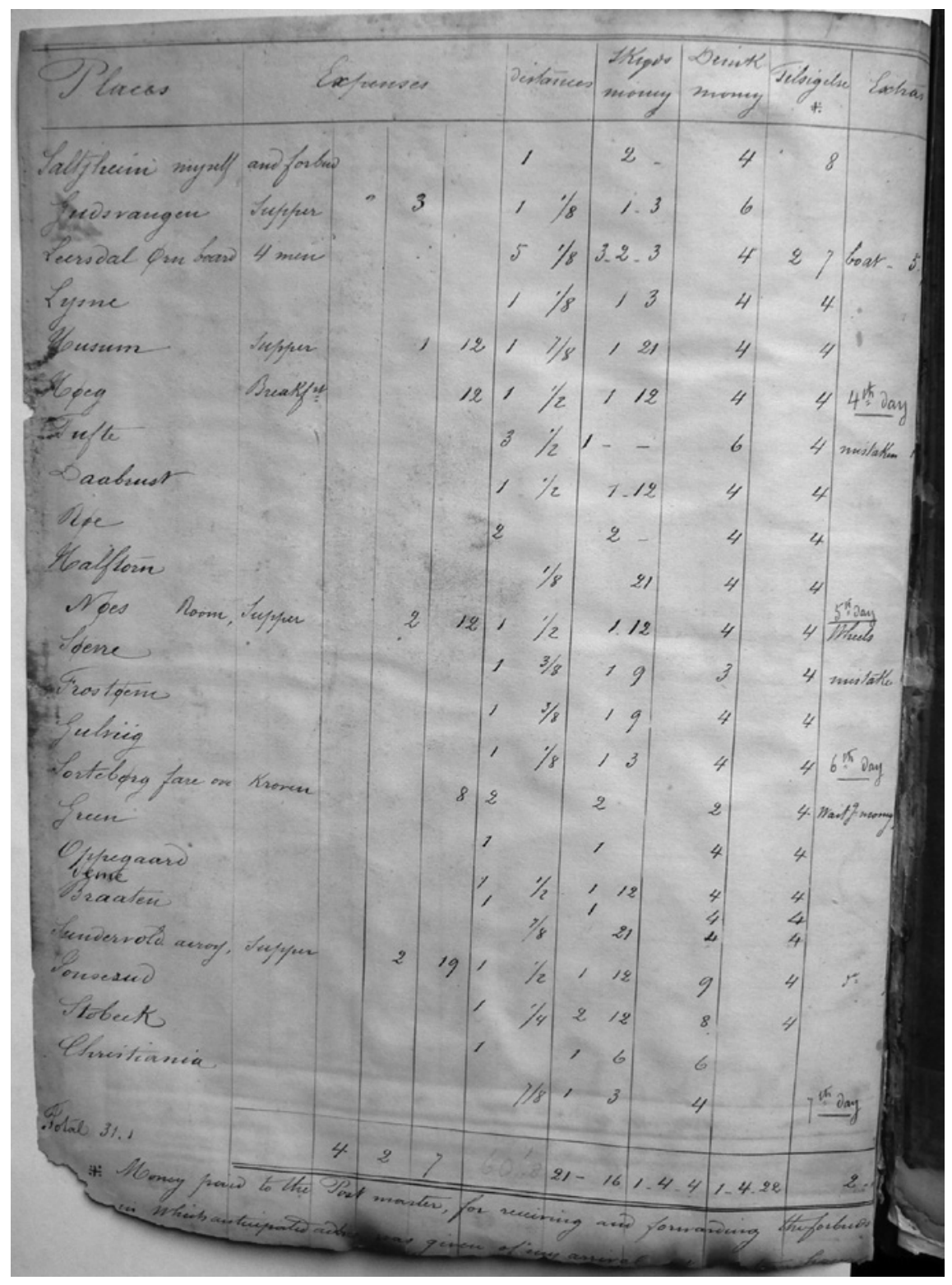

A-2-41. OA-2-17-2 


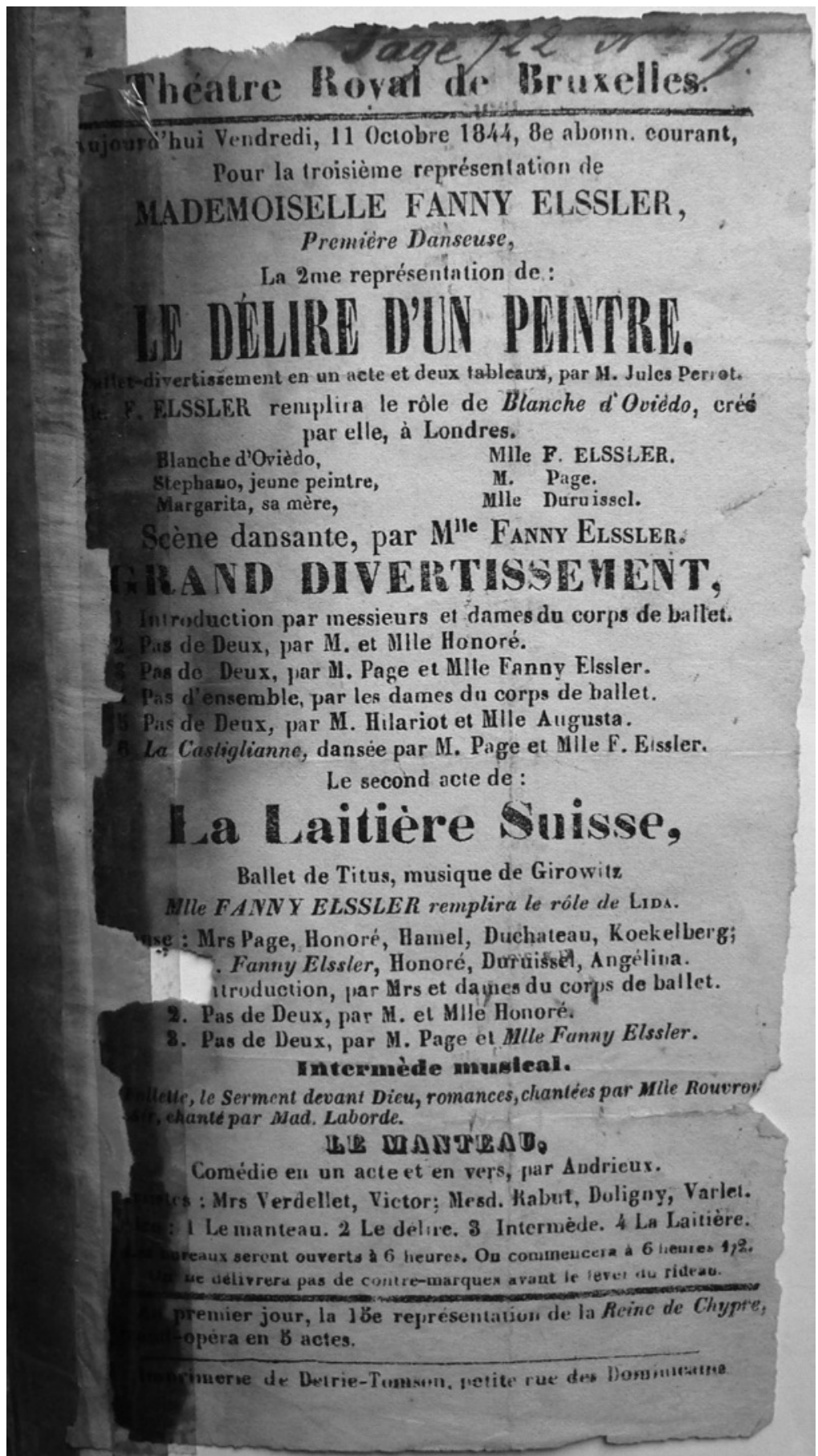

A-2-42. OA-2-19-1 


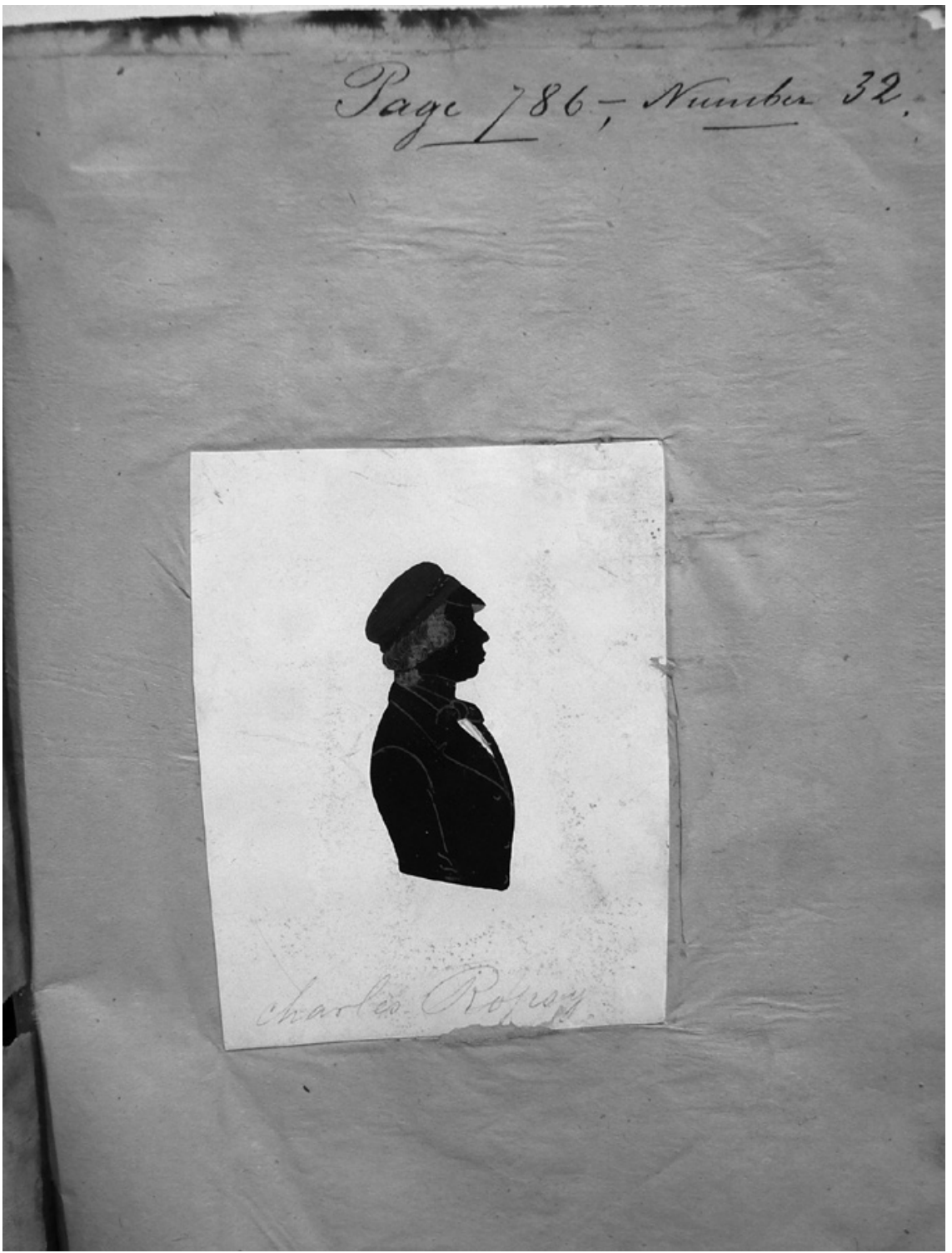

A-2-43. OA-2-32-1 


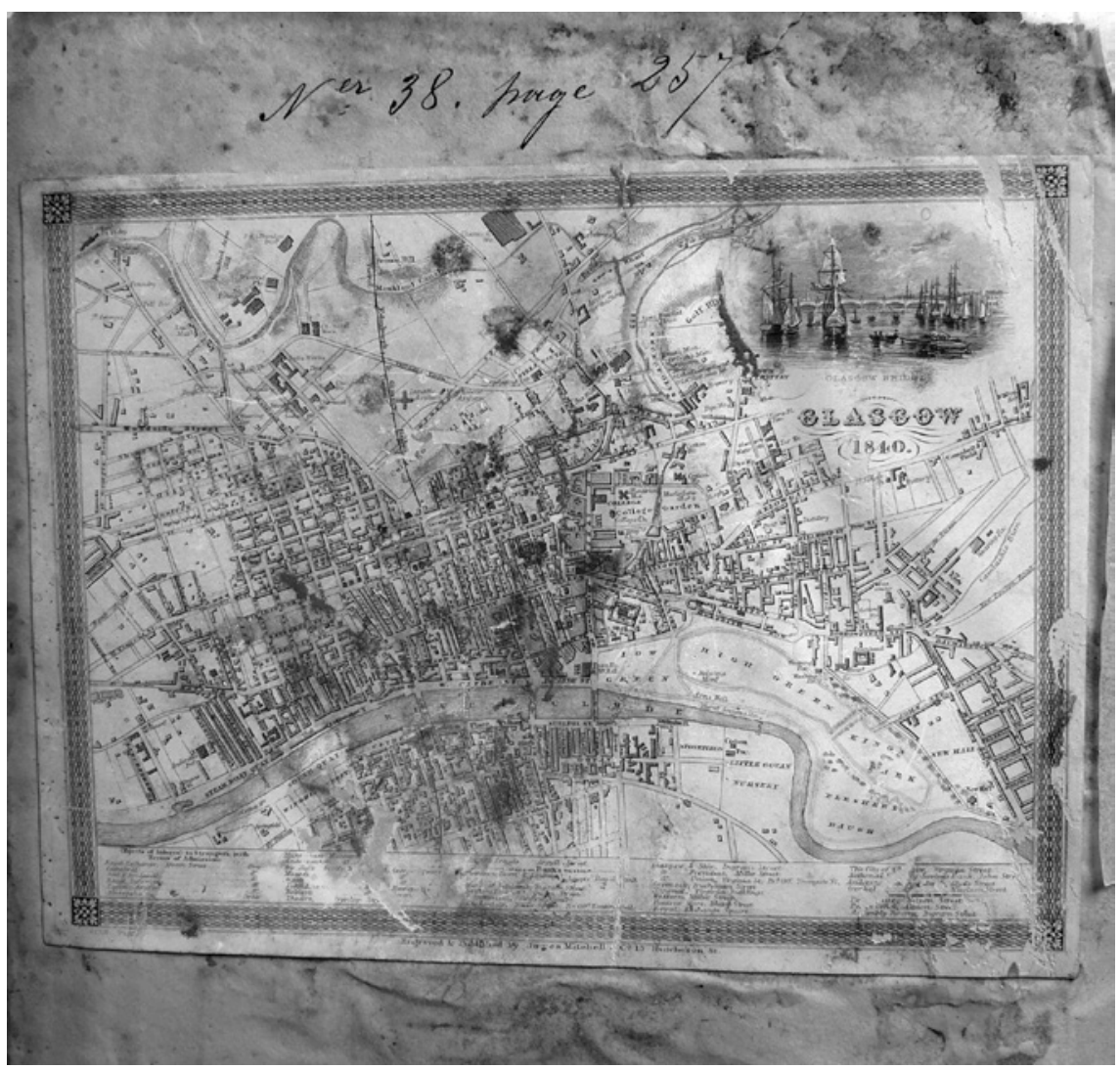

A-2-44. OA-2-38-1 


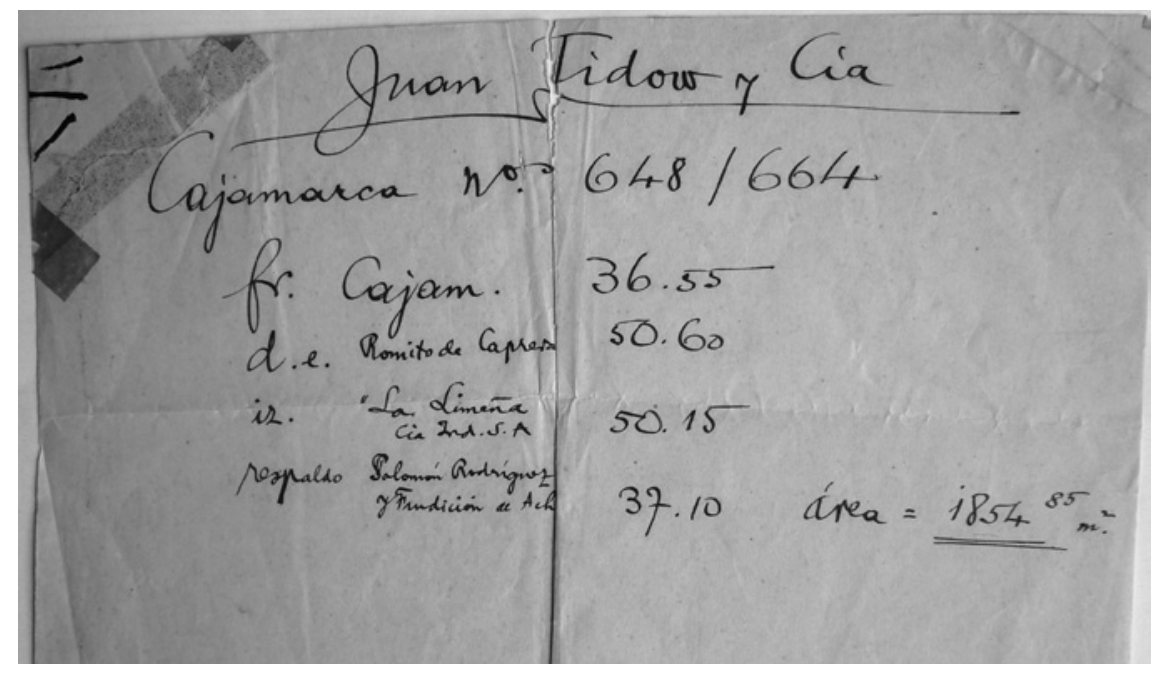

A-2-45. OA-2-unknown 